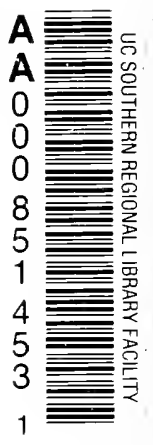




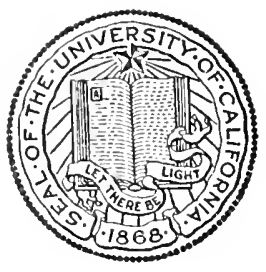

\section{THE LIBRARY \\ OF}

THE UNIVERSITY

OF CALIFORNIA

LOS ANGELES

SCHOOL OF LAW 




\section{A}

PRACTICAL TREATISE

ON

A B STR A C TS

AND

\section{EXAMINATIONS OF TITLE}

TO

\section{REAL PROPERTY.}

BY

GEORGE W. WARVELIE, LL.D.,

AUTHOR OF A TREATISE ON VENDOR AND PURCHASER, PRINCIPLES OF THE IAW OF REAL PROPERTX, ETC.

\section{THIRD EDITION.}

CH I C $\triangle$ GO:

CALLAGHANAND COMPANY.

1907. 


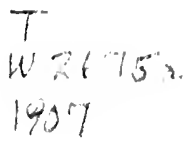

Entered According to Act of Congress, in the year 188\%, By GEORGE W. WARVELLE,

In the Office of the Librarian of Congress, at Washington.

Entered According to Act of Congress, in the year 1892 , By GEORGE W. WARVELLE,

In the Office of the Librarian of Congress, at Washington.

Copyright, 1907, BY GEORGE W. WARVELLE 


\section{IION. JOSEPH V. QUARLES,}

\section{OF MILWAUKEE, WIS.,}

ONE OF THE JUDGES OF TIE DISTRICT COURT OF TIE UNITED FTATES, TIIS VOLUME IS INSCRIBED, AS A

TRIBUTE OF RESPECT BY

THE AUTHOR.

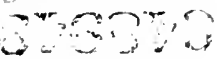





\section{PREFACE.}

In presenting a third edition of this work $I$ have made no change in either the method of arrangement or general treatment of the subject pursued in the first edition. The text has been enlarged by the introduction of new topies and a more extended discussion of old ones, and a number of additional practical forms have been incorporated. I have not attempted to compile a work on Real Property, nor even upon the Title to Real Property, and rotwithstanding that this latter topic receives constant mention throughout the volume it is yet but an incident to my main purpose. My object has been the furnishing of practical aids and suggestions to those who prepare and examine abstracts of title, and to this end I have devoted much space to what may be regarded as the mere mechanical execution of the work. The statements of law are necessarily brief, and, for the most part, elementary.

It is now about twenty-five years since the first edition appeared. The uniform favor with which successive editions have been receiver by the profession emboldens me to hope hope that this revision will be equally acceptable, and that in the practical work of the demonstration of land titles it may be found a helpful assistant.

Chicago, Oct. 1, 1907.

$$
\text { G. W. W. }
$$





\section{PREFACE TO FIRST EDITION.}

I have no apology to make for the appearance of this book, but a word or two of explanation may be in order.

The subject which I have here undertaken to elaborate, is new to the legal literature of the United States, although abstracts of title have long been employed by the profession in all matters pertaining to title of real property. But with each successive year it has assumed raster proportions, and, as the country continued steadily to develop, it has gradually been shaping itself into a distinct branch of legal seience, that calls for a high degree of technical skill and special learning. And this has reference both to conveyancers and lawers; the one to properly and systematically compile, and the other to interpret, the evidences of title which go to support claims of ownership in land.

No American author has heretofore seen fit to epitomize, for the special use of conveyancers and the legal profession, the questions of law which arise during the perusal of an abstract, or to direct the attention of either class toward a srstematic method of presenting those questions. Eminent writers on real property have passed the subject in silence, and the few American writers on converancing who have heretofore ventured to touch upon it, have dismissed it with the fewest possible words, and, as a rule, whatever remarks they may have made were ustally but servile echoes of English writers.

Several works, of more than ordinary merit, have appeared in England, in which the subject, from an English standpoint, is very thoroughly and ably disenssed, but the irreeoneilable differences in our laws and institutions have rendered them comparatively worthess to the American practitioner, and they are rarely met with on this side of the Atlantic. The vii 
mothods of Fnglish conveyaneers and solicitors, while admirably adipted to the exigencies of their own laws and enstoms, and highly eonducive to the end desired, are but ill suited to our wants amd furnish little assistance in tracing the devious courses of an Ameriean title.

In view, threfore, of the constantly increasing importance of abstracts of title, and the present inadequate means of information concerning the same, I have been prompted to write this look. It combines, not only the result of my own experience, both in the preparation of abstracts and in passing titles therein presented, but also the experience of a number of eminent conveyanecrs and lawyers whom I have freely consulted during its preparation.

I have endearored to give a general outline of what I consider the best methods of compiling the abstract so as to insure the most satisfactory results; a general system for the arrangement of the several parts and formal divisions; and the latest approved plans for presenting the essential matter of deeds, instruments and proceedings affeeting title necessary to be shown. I have further made a few suggestions relative to laying out and keeping a set of abstract indices, the great ntility of which must be apparent without comment. To reduce the work within the smallest allowable space, as well as to prevent confusion, I have made but few allusions to local statutes, while the statements of law have been confined mainly to broad and commonly accepted doctrines. It is expected that the careful practitioner will be fully posted on the lavs of his own State relative to deseent, purchase, etc., and hence the rules here given are of general application only. As this book is intended for the use of conveyaneers, as well as for the legal profession, it has been decmed best, in many instances, to elncidate only those principles which are elementary in their nature, and to avoid subtilties or extended discussions.

Though this work is entirely the result of my own personal labor, I am under many obligations to gentlemen of the har for alvice and suggestion, and particularly would I express my thanks to S. MI. Ilenderson, Esq., and Messrs. Haddock, Val- 
lette \& Rickeords, of Chicago, for the very valuable assistance rendered in the preparation of many of the forms.

I trust that my work may mect the faror of the profession, and be of real utility and assistance to them; that it may serve to assist in creating a better understanding between conveyaneer and counsel, by acquainting each with the methods of the other; and that it may be instrumental in building up a symmetrical system of title abstracts in this country.

G. W. W.

Chicago, Sept. 1, 1883. 



\title{
ANALYSIS OF CONTENTS.
}

\author{
CHAPTER I. \\ PRELIMINART OBSERVATIONS.
}

SEC.

PAGE.

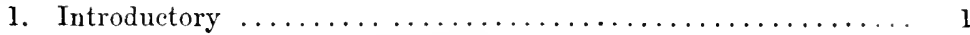

purport of the work................. 1

2. Abstracts defined.......................... 2

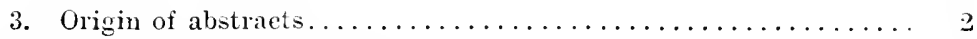

4. Essentials of the abstract......................... 3

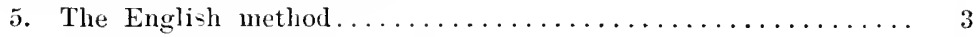

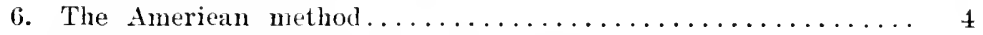

7. Abstraets and examinations distinguished............. 5

8. Qualifications of the examiner.................... 6

9. Examiner's liability for error.................. 7

implied skill and knowledge.............. $\mathrm{s}$

necessary conditions to fix liability.......... 8

10. Character of examiner's Jiability ................ 11

11. Duty of furnishing abstract.................... 11

vesdor to furnish when ................ 12

eustody and ownership of ................ 13

12. Taxation of abstract books.................... 13

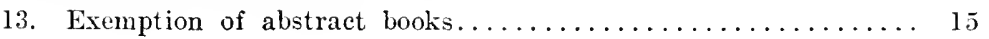

CHAPTER II.

TITLE TO REAL PBOPERTY.

14. Property and title distinguished $\ldots \ldots \ldots \ldots \ldots \ldots \ldots \ldots \ldots \ldots$

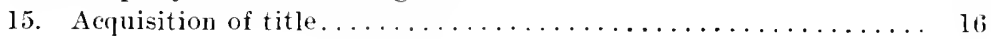

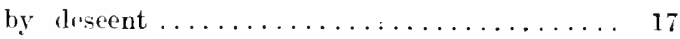

by purchase ................... 17

other distinctions................ 17

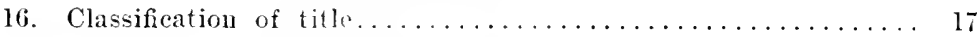

Blackstone's divisions............... 17

American divisions ................... 17

barl. dombtful and perfect............. 1s

logal and equitable.................. 1s

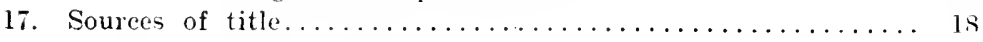

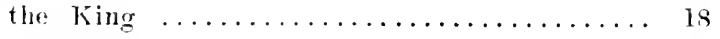

the State ................... 19 
SEC.

18. Nature of title in the United States................ 19

all lanel held in allodium............... 20

submission to legislative control.......... 20

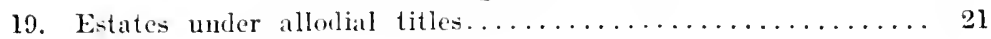

fee simple $\ldots \ldots \ldots \ldots \ldots \ldots \ldots \ldots \ldots \ldots \ldots \ldots \ldots \ldots \ldots \ldots \ldots$

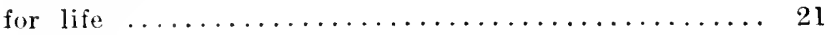

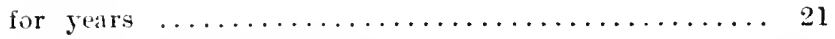

possession and expectancy............... 22

reversions and contingencies............... 22

20. Usiss and trusts........................... 22

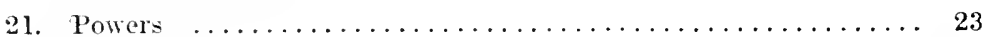

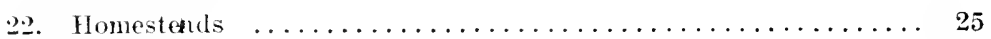

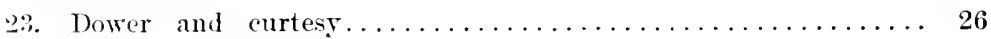

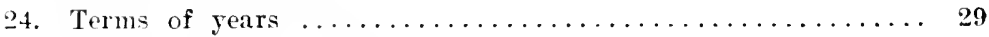

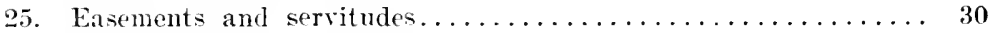

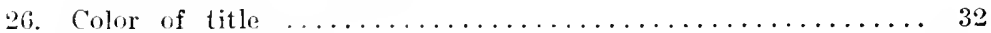

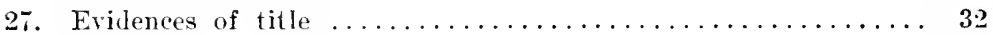

28. Alienation and descent......................... 33

\section{CHAPTER III.}

TITLE IYY DESCENT.

29. Nature of the title...................... 35

30. Rules of descent... . . . . . . . . . . . . . . . 36

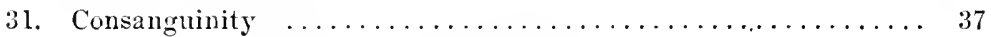

methods of computation............. 37

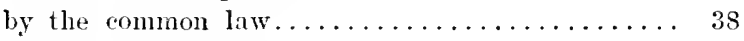

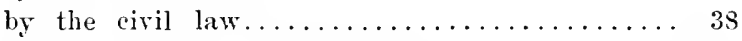

table of degrees of consanguinity . . . . . . . 40

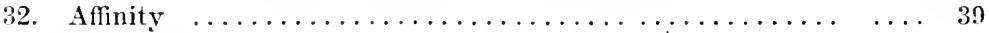

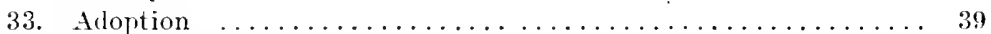

34. Proof of heirship....................... 41

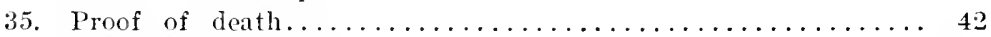

36. Conveyances by heirs.......................... 42

\section{CHAPTER IV.}

TITLE BY PLRCHASE.

37. Nature of the title...................... 44

methods of purchase............. 44

39. Deed .................................... 4.5

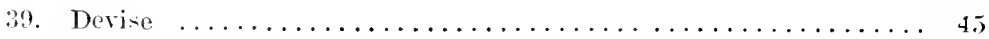

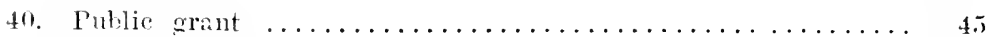

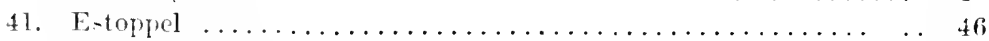

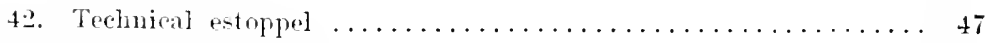

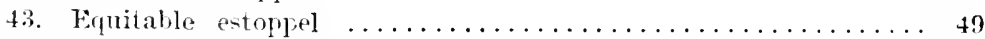

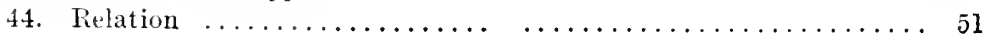


SEC.

PAGE.

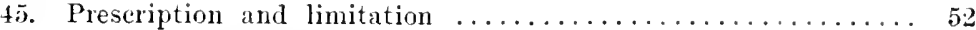

46. Accretion and reliction......................... 53

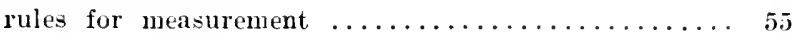

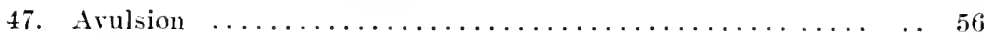

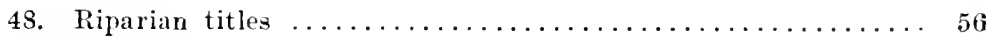

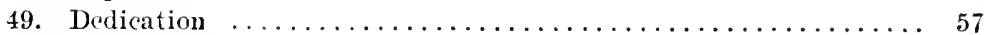

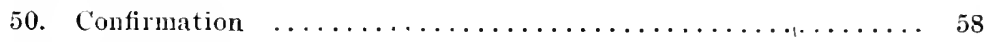

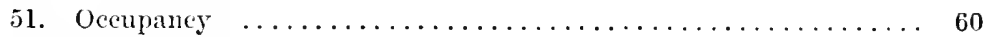

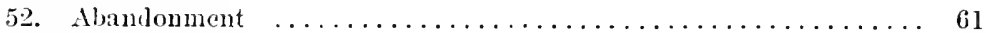

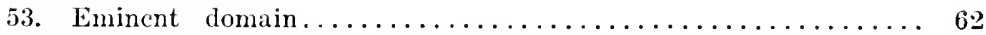

54. Title acquired by eminent domain................ 63

55. Escheat ............................. 64

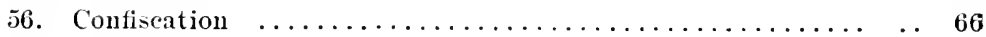

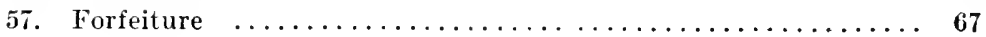

CHAPTER V.

SOURCES OF INFORMATION.

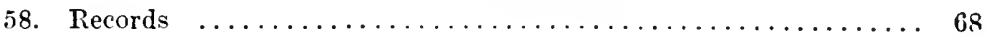

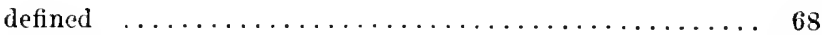

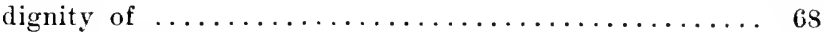

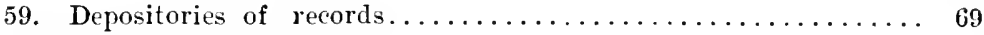

60. The right of inspection of records................. 69

61. Doctrine of notice....................... 74

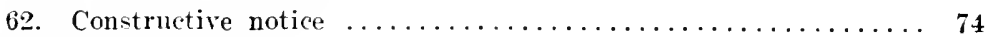

63. Actual notice ......................... 76

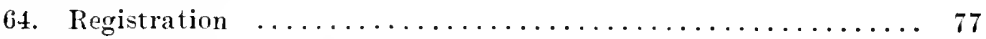

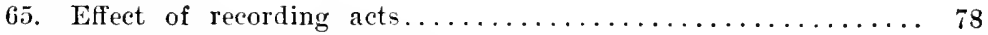

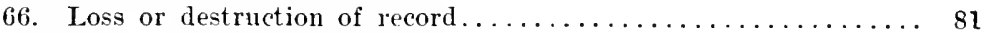

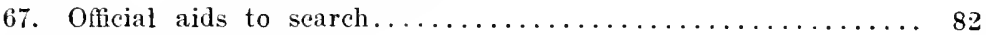

6s. Grantor and grantee indexes................... 82

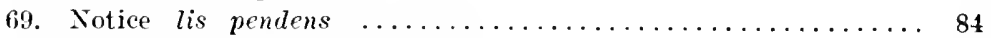

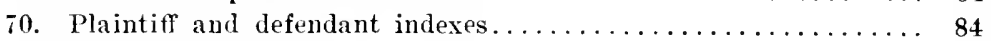

71. Tax records $\ldots \ldots \ldots \ldots \ldots \ldots \ldots \ldots \ldots \ldots \ldots \ldots . \ldots \ldots \ldots$

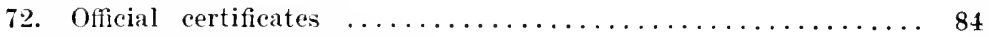

73. Church and parish records $\ldots \ldots \ldots \ldots \ldots \ldots \ldots \ldots \ldots \ldots . \ldots \ldots$

CHAPTER VI.

INDICES AND REFERENCES.

74. Importance of indexes..................... 86

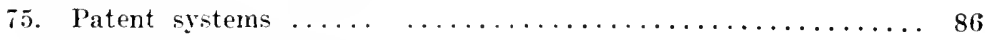

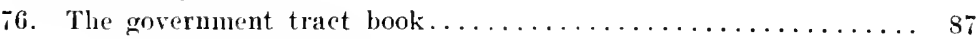

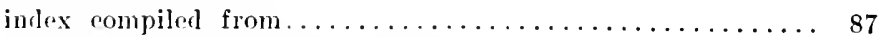

77. Field notes of government survers............... 88

uses of in abstracting .............. 88 
SEC.

PAGE.

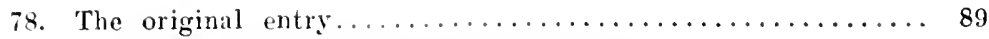

methoul of arranging books........... 89

illustration of sample page............. 90

methol of compilation............... 90

79. Doeument number inlex....................... 91

method of compilation........... 91

illustration of sample page......... 91

So. Long form entries.............................. 91

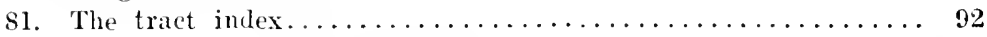

how compiled $\ldots \ldots \ldots \ldots \ldots \ldots \ldots \ldots \ldots \ldots, 92$

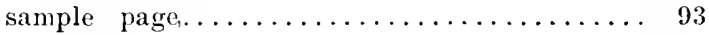

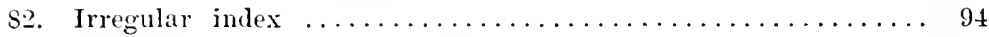

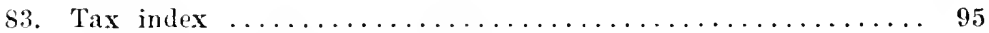

methor of compilation................ 95

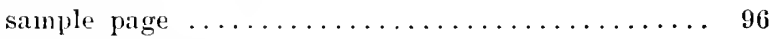

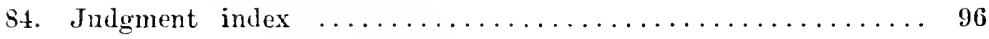

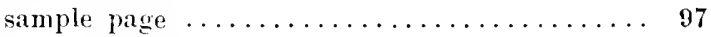

85. Deerees and sales in chancery ................. 97

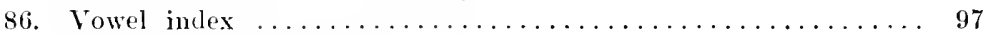

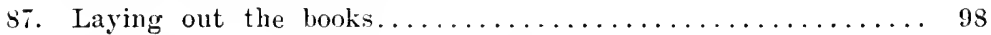

seale for indexing................. 99

88. Resume ................................ 99

\section{CHAPTER VII.}

\section{COMPILING THE ABSTRACT.}

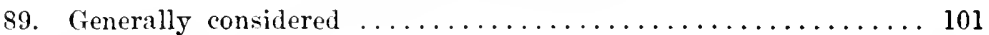

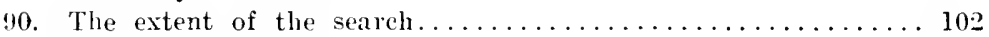

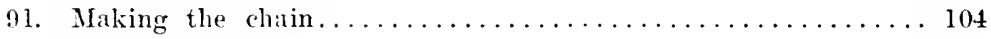

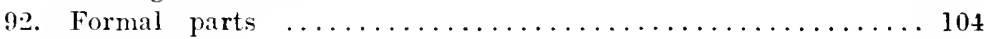

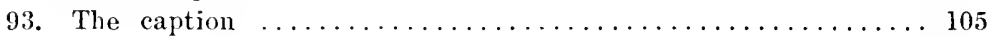

for general examination................ 105

for assumption of title.............. 108

for special examination.............. 108

for tax abstract................... 109

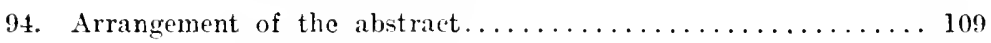

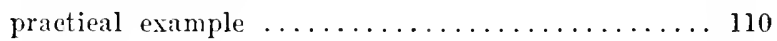

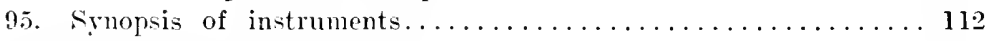

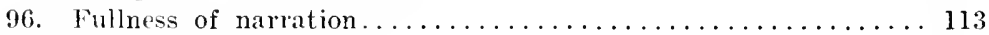

97 . Instrmments shown for reference.................. 114

98. Examiners' notes........................... 115

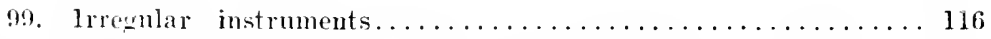

100. Peference to original instruments and private memoranda..... 116

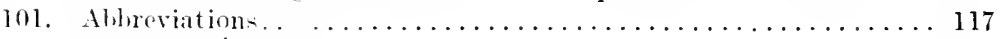

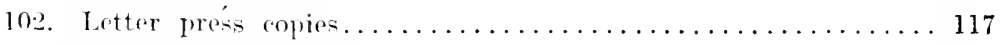

103. Coneluding certificate....................... 118

practical example.................. 119

order for examination................. 118 


\section{CHAPTER VIII.}

IXCEPTION OF TITLE.

SEC.

PAGE.

104. Preliminary stages of title..................... 124

105. Inceptive measures unter the U. S. land laws ........... 125

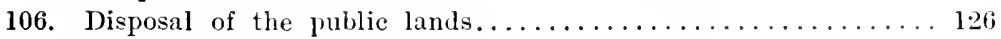

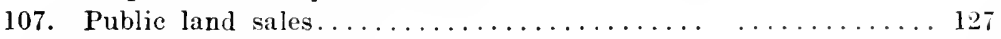

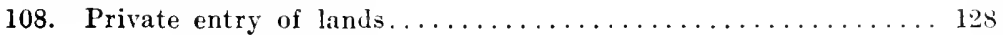

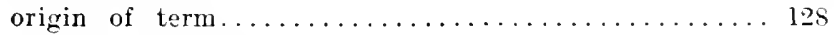

entry, how made.......................

109. Nature of the title conferred by entry . . . . . . . . . . . 129

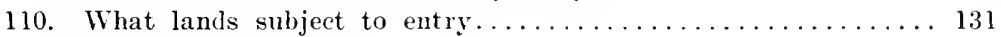

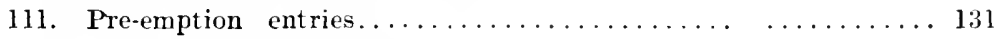

112. Nature of pre-emption rights.................. 133

113. Conveyances before entry . . . . . . . . . . . . . . . . . 135

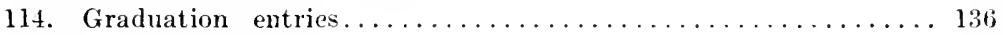

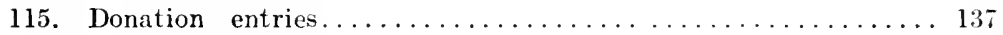

116. Homestead entries................................ 13s

117. Rights acquired under homestead acts.............. 140

118. Desert land entries.......................... 140

119. Tree clains................................ $1+1$

120. Location by military warrants................ 14:

121. Land serip............................... 143

Virginia military serip.................. 143

Indian or half-breed serip................. 143

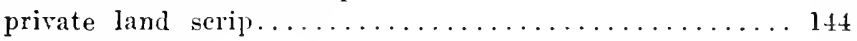

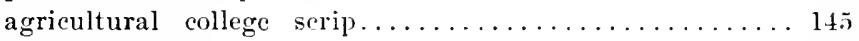

122. Swamp land grants........................ 145

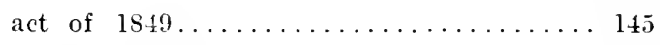

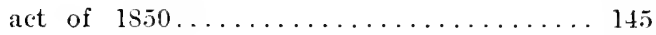

123. School lands.............................. 147

124. Internal improvement grants.................... 148

125. Land grants to railroads.......................... 149

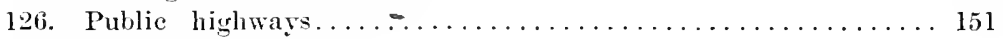

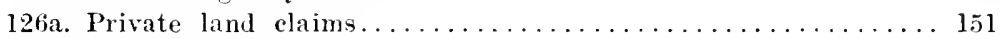

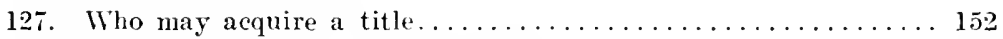

128. Inceptive measures in the abstract.............. 153

\section{CHAPTER IX.}

INITIAL STATEMENTS.

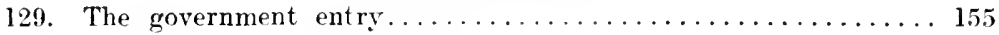

practical form.................. 155

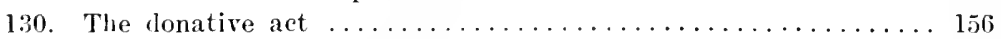

practical form................. 157

131. Continued, section sixteen....................

practical form.................... 158

practical form for lieu land.............. 158 
SEC.

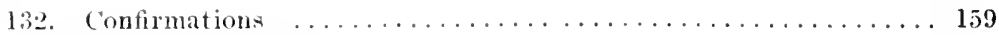

13:. Town site entries ......................... 161

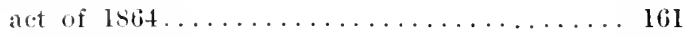

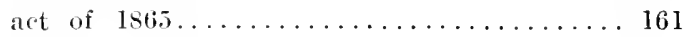

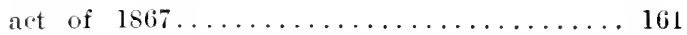

13. The receiver's receipt......................... 163

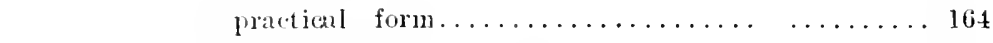

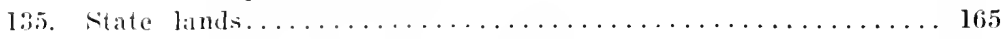

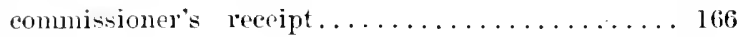

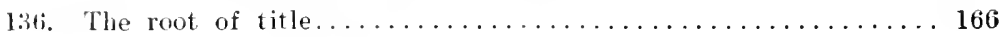

\section{CHAPTER X.}

CONgRESSIONAL AND LEgISLATIVE GRANTS.

137. Legislative grants generally consilered............. 168

138. Nature and effect......................... 168

from the United States............. 168

from the State................. 169

139. Construction of legislative grants............... 170

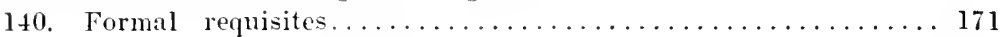

practical form............... 172

\section{CHAPTER XI.}

P.TEXTS.

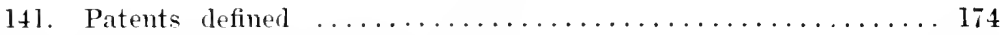

149. Patents from the United States ................. 174

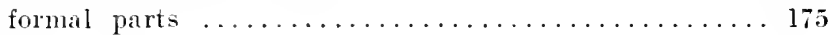

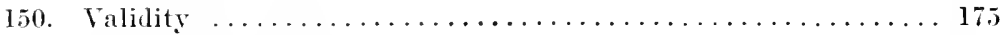

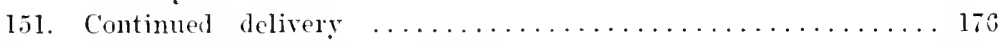

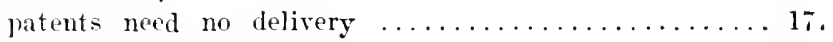

take effect by registration .................

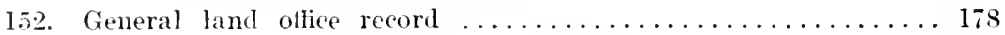

its object and purport ........... 179

153. Operation and effect of patents ................ 180

its evidence of governmental action .... 180

when operating only as a quit-elaim ...... 181

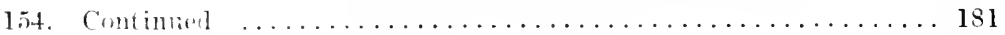

ly what laws patents construed $\ldots \ldots \ldots \ldots \ldots \ldots \ldots$ 182

pinchaser need not look behind patent ........... 1s2

but is chargeable with defects upon its face ........ 182

15.5. Construction .......................... 182

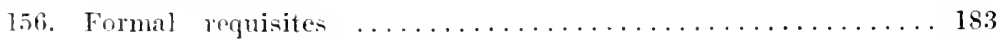

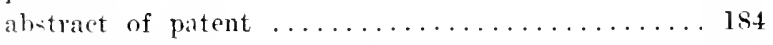

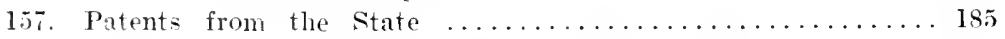

classification of State lands ......... 185

history of State titles ........... 185

to what State patents ronfer title ..... 186 
15s. State patents, continued .................... 187

155). Formal requisites of State patents ................ 187

by whom issued ................ 188

\section{C'HIAP'TER XII.}

SURVEYS, PLATS AXD SUBDIVISIONS.

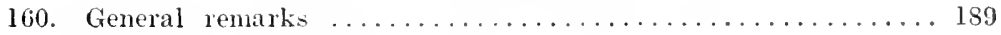

161. Divisions of the public domain $\ldots \ldots \ldots \ldots \ldots \ldots \ldots \ldots \ldots$

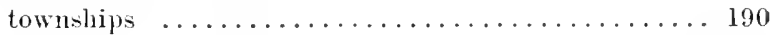

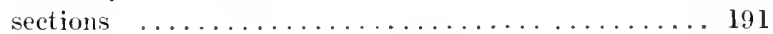

plan of township, numbers and base lines ........ 191

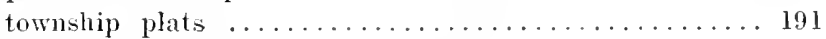

163. Subdivision of sections ..................... 192

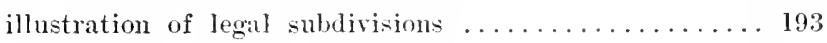

illustration of fractional section ............ 194

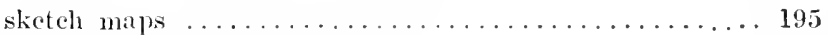

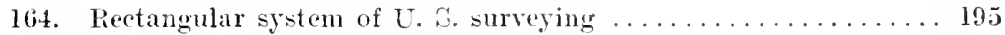

pincipal base line and meridian ...... 196

165. Meander lines ............................. 197

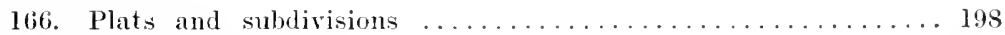

167. Formal requisites. . . . . . . . . . . . . . . . . . . . . 199

abstract of subdivision ............... 200

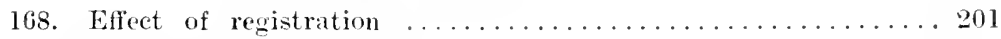

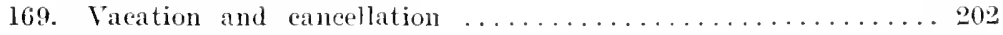

abstract of racation ......................... 203

170. Dedication by plat ........................... 204

distinguished from rescrvation ..............205

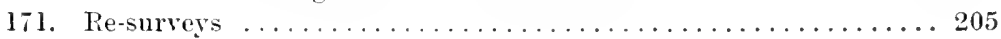

\section{CHAPTER XIII.}

FORMAL PARTS OF DEEDS.

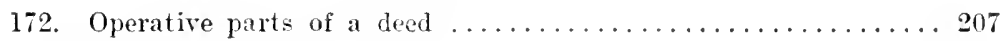

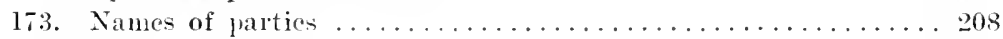

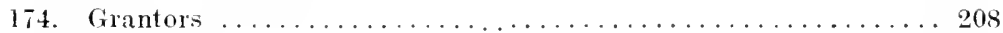

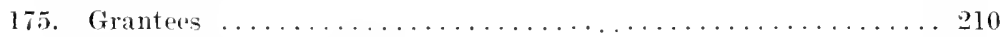

176. Nature of the instrument ................... 212

177. Date of instrument.................................. 212

178. Registration ............................ 214

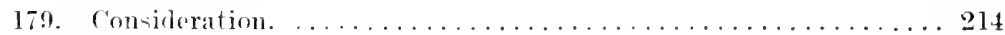

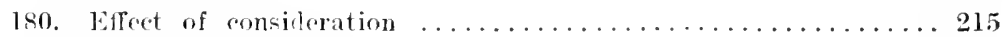

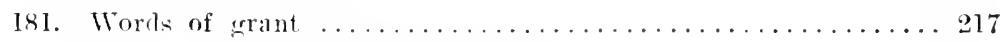

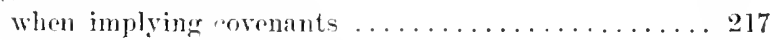

18. Words of purchase aur linitation ................ 218

rule in Sluelly's rase ............... 218

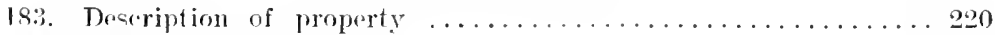

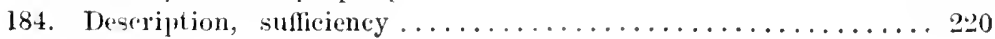


SEC.

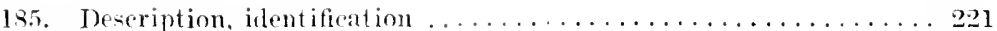

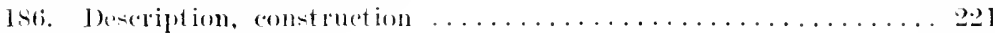

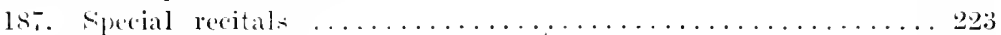

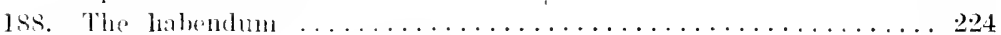

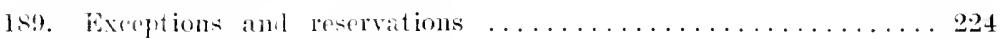

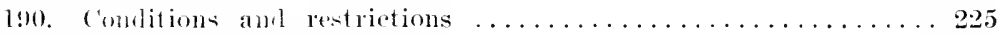

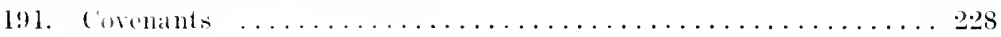

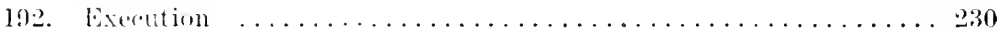

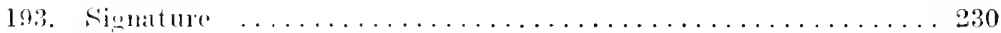

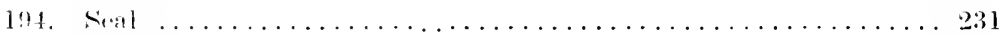

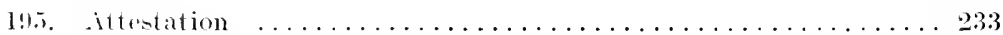

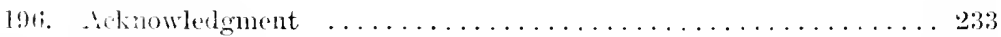

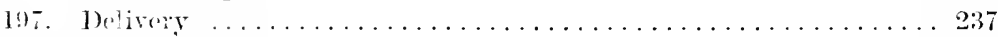

19s. Anvient teeds . . . . . . . . . . . . . . . . . . . 240

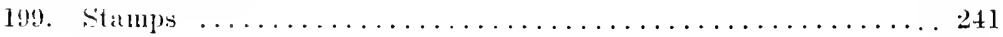

\section{CHAPTER NIY.}

ERRORS, OMISSIONS AND DEFECTS.

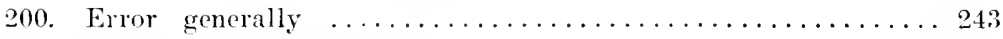

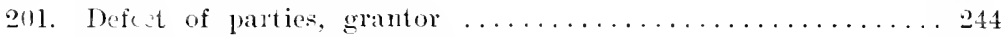

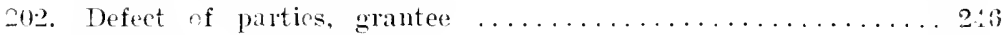

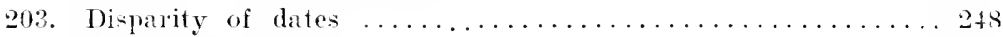

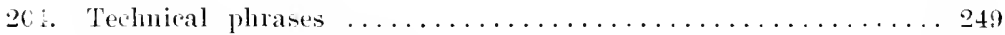

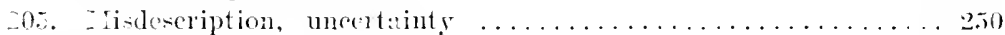

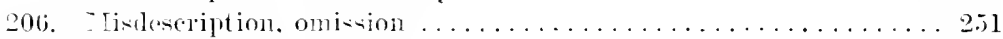

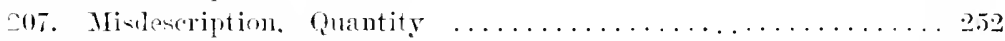

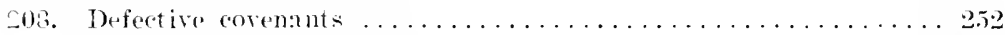

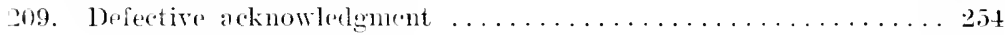

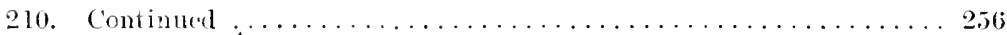

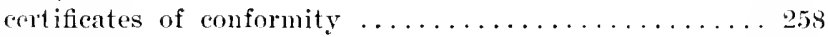

211. Repugnancy. ............................ 260

\section{CHAPTER XV.}

\section{CONIEYANCES LY INDIVIDUALS.}

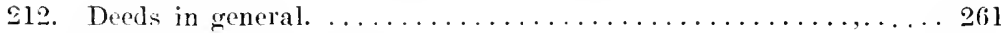

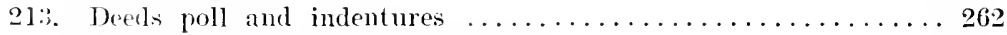

214. Construction and effect of deeds ................. 214

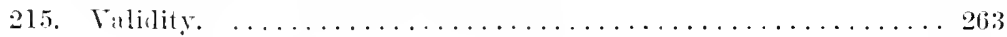

roid and voidable distinguished $\ldots \ldots \ldots \ldots \ldots \ldots \ldots 216$

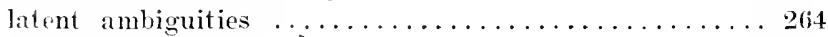

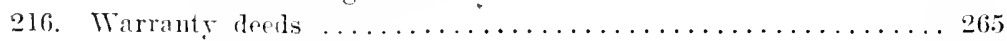

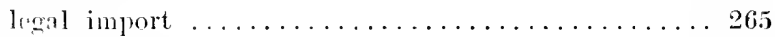

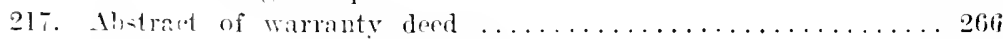

practical example $\ldots \ldots \ldots \ldots \ldots \ldots \ldots 266$

218. Notes. . . . . . . . . . . . . . . . . . . . . . . . . . 267 
219. Quit-claim deeds

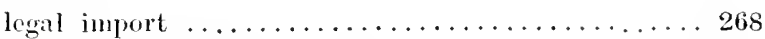

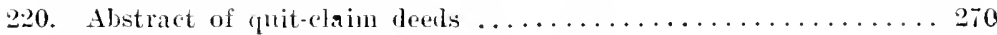

221 . Eflect of covenants in quit-claim deeds $\ldots \ldots \ldots \ldots \ldots \ldots \ldots \ldots$

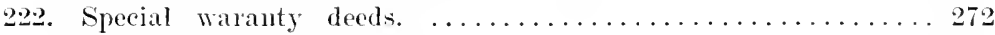

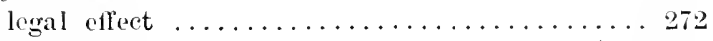

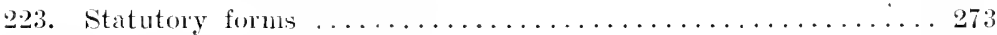

224. Common law conveyances ...................

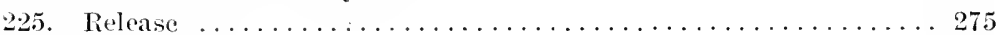

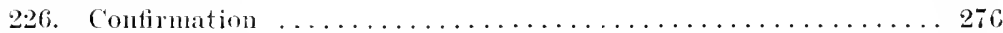

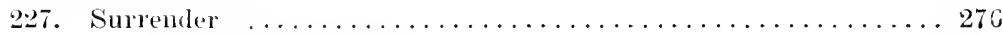

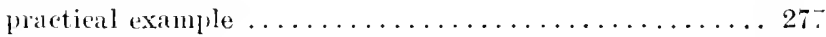

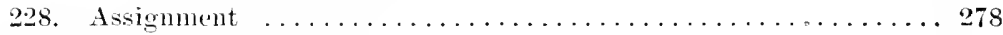

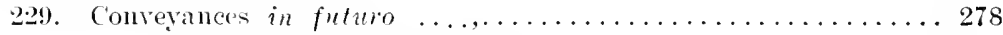

practical example ................. 280

230. Conveyane of special interests and estates ..........281

231. Continued, instances .................... 283

practical example ................. 285

232. Restrictive and conditional conveyances . . . . . . . . . 285

933. Prolibited conveyances, adverse seizin ............ 288

234. Continued, fiandulent conveyanees ............... 289

235. Conveyanees subject to incumbance ................ 289

236. Dedication by doed ...................... $29 \mathrm{I}$

237 . Resulting trusts ......................292

238. Re-records and diplicates ................... 293

practical cxample ................ 293

249. Corrected records . . . . . . . . . . . . . . . . . 294

\section{CIAPTER XTI.}

\section{SPECIAI, CLASSES OF INDIVIDUAL CONVEYANCES.}

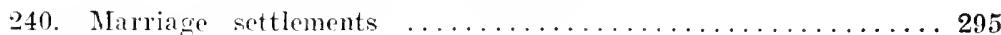

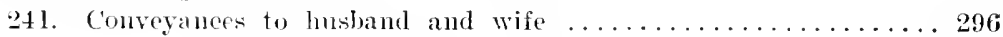

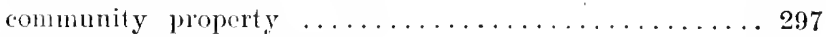

242. Converances between hushand and wife. ............. 299

243. Convegances by matried woman................. 300

244. Ellect of wife's conveyance .................. 302

245. Continued acknowledement ................. 302

246. Release of dower. . . . . . . . . . . . . . . . . . 304

practical example ...................... 305

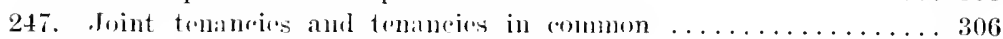

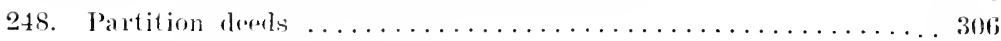

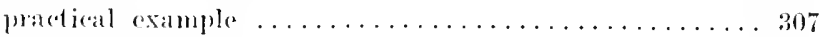

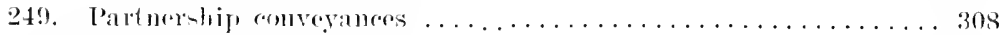

2.50. Corjorate ronveyances . . . . . . . . . . . . . . . 310

251. Stafutros of mortmain . . . . . .

252. Power of acquisition; user ................... 
SEC.

PAGE.

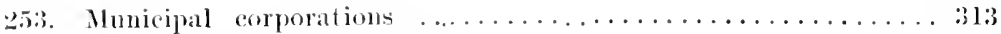

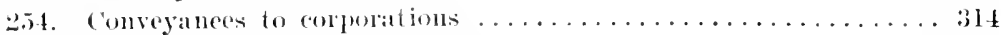

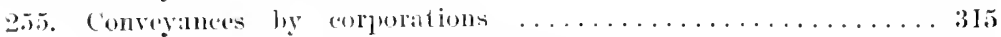

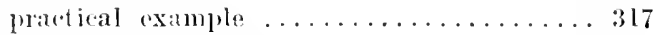

256 . Continued; expeution, acknowledgurent ............ 318

practical example ............ 319

257. Acts of ollicers in excessi of chanter powers. . . . . . . . . 321

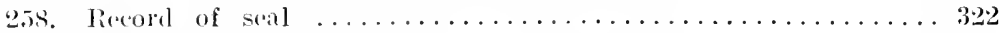

259. Corveyanes by incorporated religious societies.......... 323

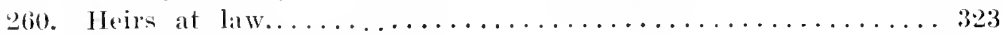

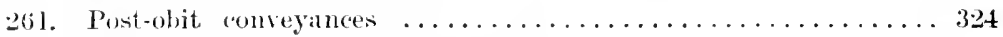

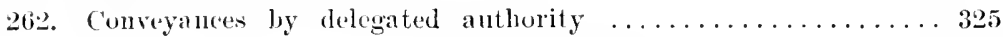

practical example ............ 325

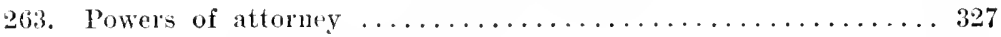

practical example .................. 329

264. Revocations .......................... 330

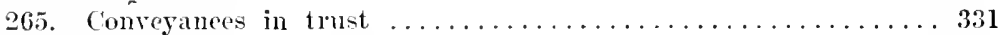

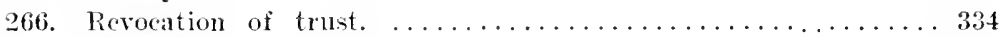

267. Declarations of trust $\ldots \ldots \ldots \ldots \ldots \ldots \ldots \ldots \ldots \ldots \ldots$

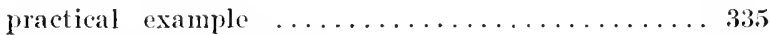

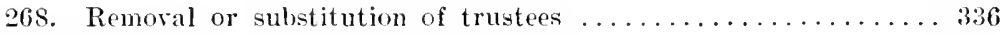

269. Resignation, refusal to act $\ldots \ldots \ldots \ldots \ldots \ldots \ldots \ldots \ldots \ldots$

\section{CIIAPTER XVII.}

OFFICIAL CONVEYANCES.

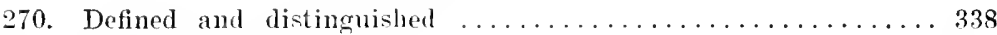

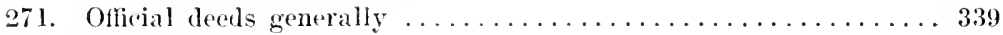

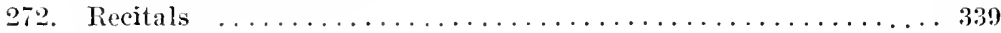

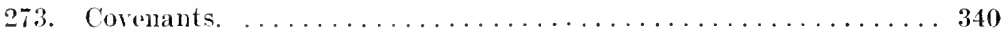

274. Sheriff's deed; on exceution ................... 340

275. Continued; acknowled mment . . . . . . . . . . . . . 342

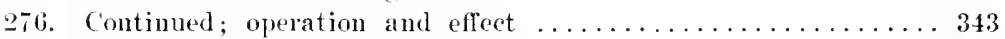

277. Contiuned; imperfect description ............... 344

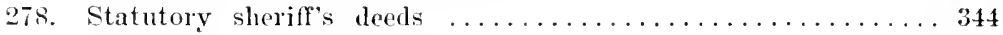

practical example ..................... 345

279. Sheriff's deed; under decree .................. 346

280. Master's, commissioner's and referee's leeds ............ 3i6

practical example ................... 347

281. Trustees ................................... 347

28.3. Trancfors of the legal estate by trustees . . . . . . . . . 349

2s.). Power of sale and trut of sale distinguished . . . . . . . 350

284. Trustere's deeds . . . . . . . . . . . . . . . . . 352

praetieal example ................... 353

24.) Nortuagee's deeds . . . . . . . . . . . . . . . . . . 356

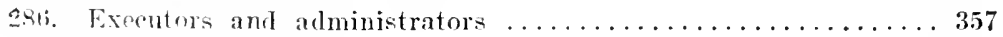

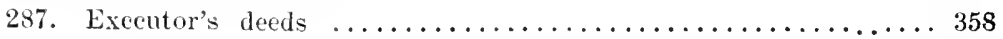


2iss. Administrator's deeds . . . . . . . . . . . . . . . . . 359

practical example ................ 361

289. Administrator with will annexed ................ $36: 3$

290. Guardian's deeds ....................... 364

291. Trustees can not become purchasers . . . . . . . . . . . 365

292 . Continued; exceptions and qualifications ............ 366

\section{CiIA PTER IVIII.}

\section{ASSIGNMENTS, INSOLVEXCY AND BANKRUPTCY.}

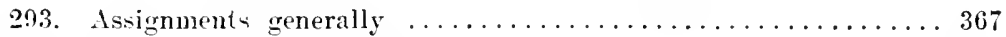

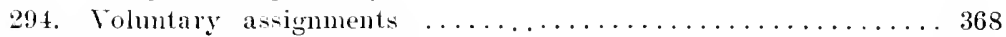

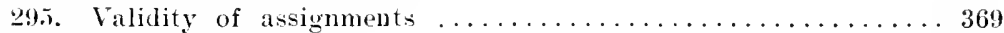

296. Formal requisites ........................ 369

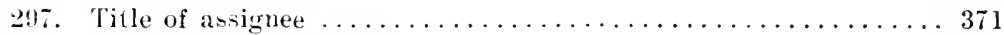

298. Construction and effect ....................... 372

299. Contliet of laws; foreign assignments ............. 372

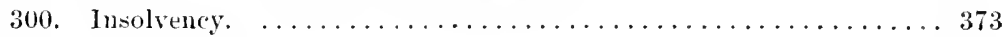

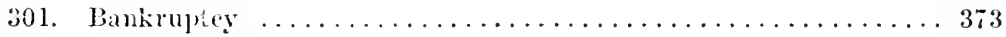

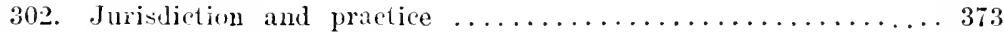

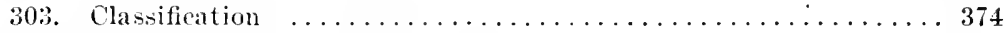

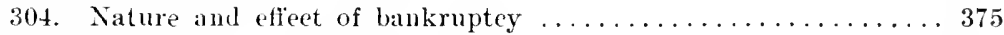

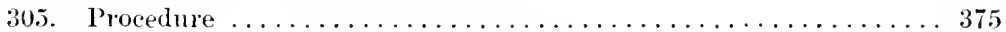

306. Bankruptey proceedings; how shown.............. 376

practical example .................. 376

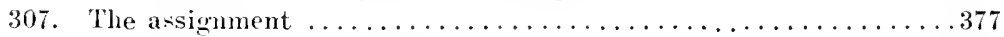

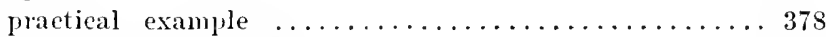

308. Assignee's or Trustee's cieed ........................ 379

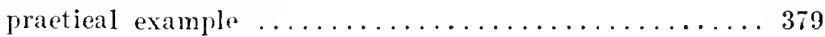

309. Discharge in bankruptcy ............................. 381

practical example ................ 38.2

\section{CHAPTER XIX.}

\section{AGREEMENTS FOR CONVEYANCE.}

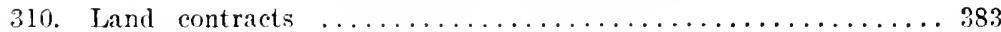

311. Relation of parties under land contracts .............. 384

312. Eflect and operation of the contract............... 384

313. Nature and requisites . . . . . . . . .

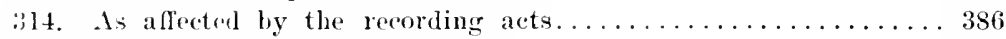

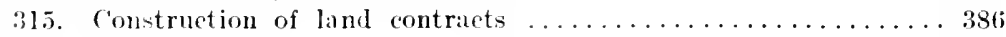

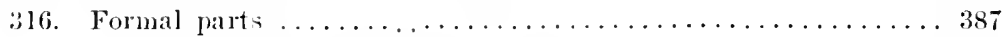

abstract of agreement to deed $\ldots \ldots \ldots \ldots \ldots \ldots \ldots \ldots . \ldots \ldots$

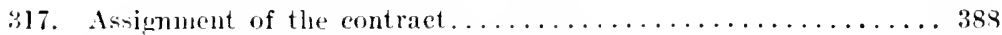

318. Prrormance; sufficiency of deed and title............. 389

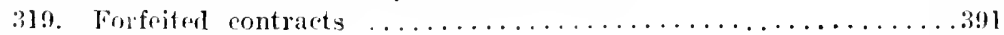

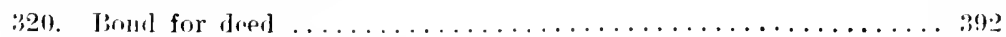

practical illustration $\ldots \ldots \ldots \ldots \ldots \ldots \ldots \ldots \ldots \ldots \ldots$

321. Agreements for conveyance by will ................... 393 


\section{CH.APTEL XX.}

LEASES.

SEC

PAGE.

32.2. Nature and requisites . . . . . . . . . . . . .

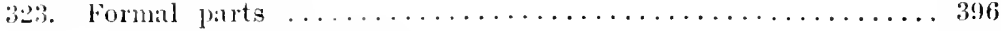

abstract of lease .......................... 397

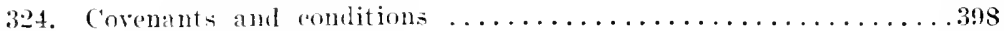

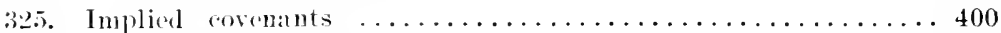

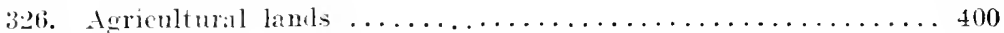

3.7. Assignment of lease $\ldots \ldots \ldots \ldots \ldots \ldots \ldots \ldots \ldots \ldots \ldots \ldots \ldots \ldots$

\section{CIIAPTER XXI.}

MISCELLANEOT'S EVIDENCE OF AND AFFECTING TITLE.

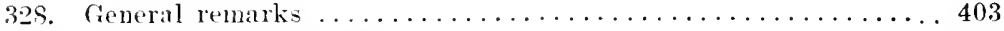

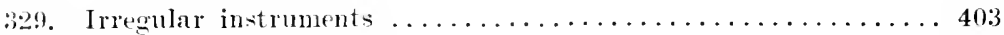

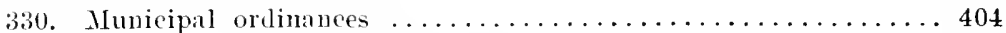

practical example ................ 40 s

3.1. Exeeutive approral of ordinanees................. 407

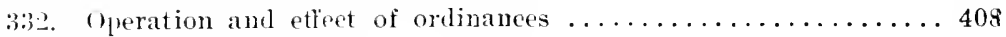

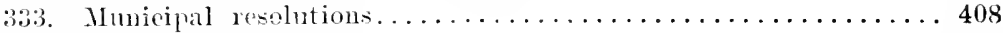

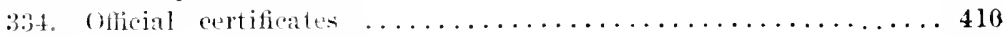

practiral example .................. 411

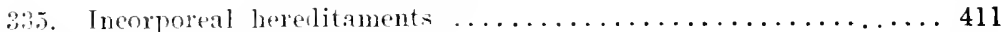

306. Easments and servitules .................... 412

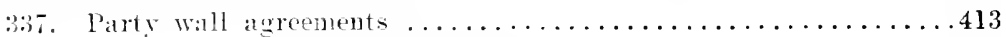

practical example $\ldots \ldots \ldots \ldots \ldots \ldots \ldots \ldots \ldots 414$

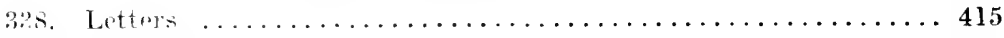

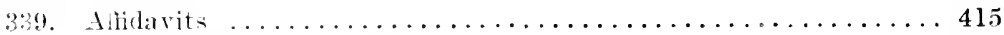

practical example ......................

3 to. Contimed; general requisites; sufficieney............ 417

341. Lnrecorded evidence ....................... 417

\section{CHAPTER XXII.}

MIORTGAGES.

342. Nature of mortgages . . . . . . . . . . . . . . . . . 419

343. Different kinds of mortgages $\ldots \ldots \ldots \ldots \ldots \ldots \ldots \ldots \ldots \ldots . \ldots \ldots 20$

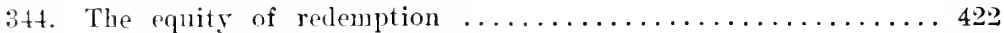

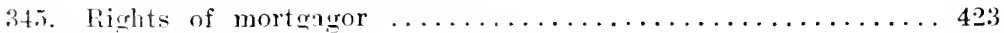

346 . Mortgages as affected by estoppel ............... 423

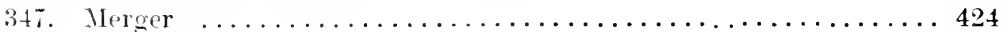

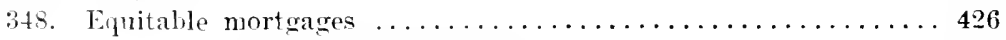

rules for determining $\ldots \ldots \ldots \ldots \ldots \ldots \ldots \ldots \ldots, 426$

import and effect .................... 427

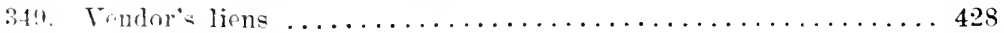

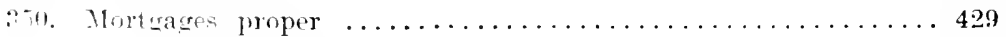

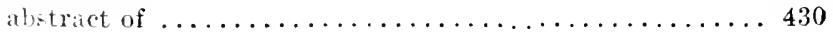




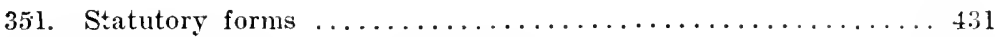

352. Uncertainty or error of description $\ldots \ldots \ldots \ldots \ldots \ldots \ldots \ldots \ldots 2$

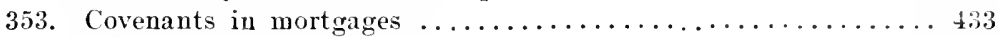

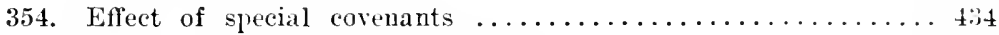

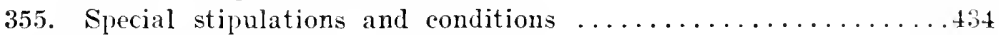

356. Effect of informality ........................ 435

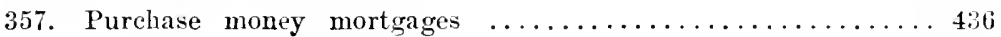

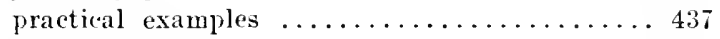

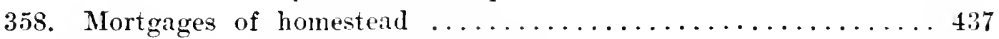

359. Mortgage of after-acquired property $\ldots \ldots \ldots \ldots \ldots \ldots \ldots \ldots 438$

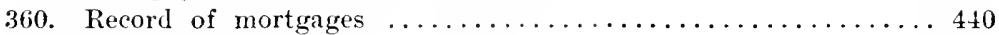

361. Notice imparted from possession ................ 441

362. Re-records ............................ $4+1$

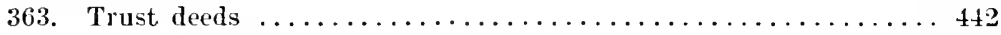

practical example .................... 443

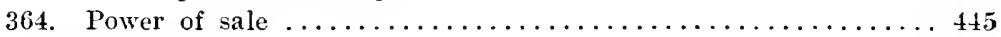

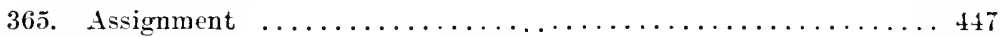

366. Operation and effect of assignments $\ldots \ldots \ldots \ldots \ldots \ldots \ldots 448$

367. Formal requisites of assignments ................ 449

368. Release and satisfaction ..................... 450

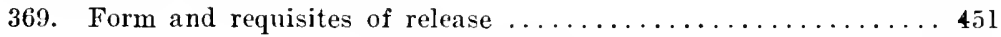

practical example ............... 452

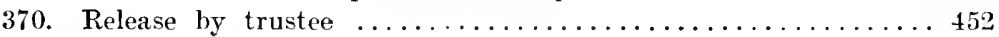

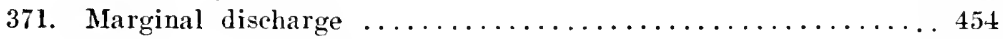

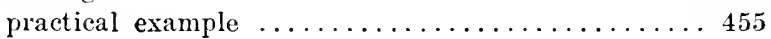

372. Foreclosure .............................. 456

373. Proof of title under foreclosure. $\ldots \ldots \ldots \ldots \ldots \ldots \ldots \ldots \ldots 56$

\section{CHAPTER XXIII.}

\section{WTLLS.}

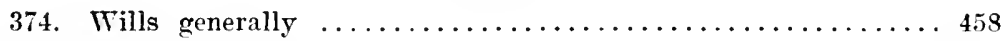

375. Nuncupative wills . . . . . . . . . . . . . . . 459

376. Nature of testamentary titles . . . . . . . . . . . 459

377. Devises .................................. 460

378. Operation and effect of devises $\ldots \ldots \ldots \ldots \ldots \ldots \ldots \ldots \ldots+\ldots \ldots$

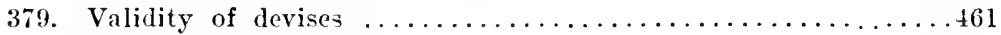

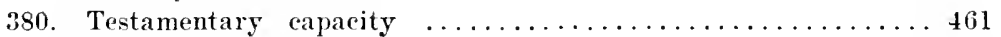

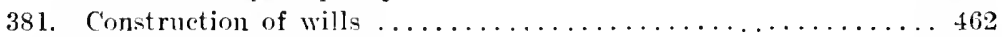

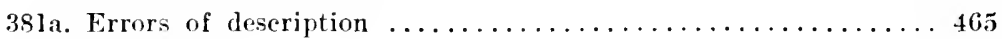

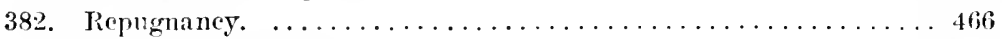

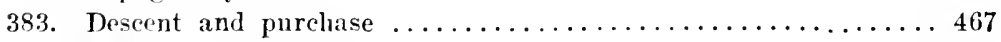

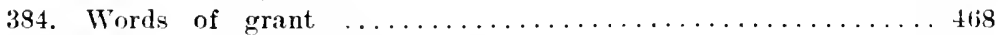

38.5. Words of purchase and limitation $\ldots \ldots \ldots \ldots \ldots \ldots \ldots \ldots 468$

386. Rule in Shelly's case ...................... 470

397. Interpretation of particular worls and phrases..........4 4 l

388. Words which pass real estate $\ldots \ldots \ldots \ldots \ldots \ldots \ldots \ldots \ldots \ldots . \ldots \ldots$ 
SEC,

PAGE.

389. Limitatious and remainders $\ldots \ldots \ldots \ldots \ldots \ldots \ldots \ldots \ldots \ldots . \ldots \ldots$

390. Devise to a cliss ............................

391. Gift of the income of realty $\ldots \ldots \ldots \ldots \ldots \ldots \ldots \ldots \ldots \ldots 476$

392. Devise with power of disposition................ 477

393. Indeterminate devise . . . . . . . . . . . . . . 480

394. Devise on condition precedent................. 481

395. Conditional devise; marriage .................. 482

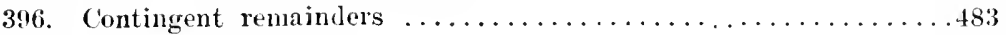

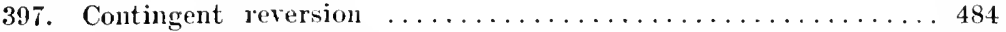

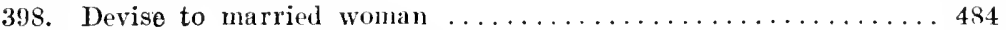

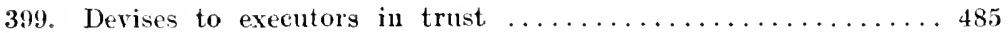

400. Bequest to the devise by deseription $\ldots \ldots \ldots \ldots \ldots \ldots \ldots 487$

401. Precatory trusts ........................ 488

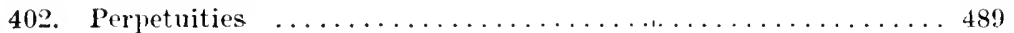

403. Lapsed devise $\ldots \ldots \ldots \ldots \ldots \ldots \ldots \ldots \ldots \ldots \ldots \ldots \ldots \ldots \ldots \ldots$

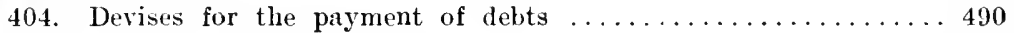

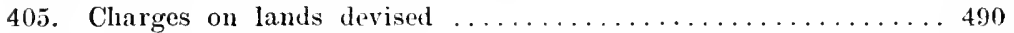

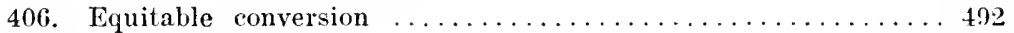

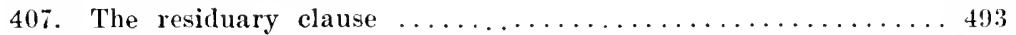

40s. Codicils ................................. 494

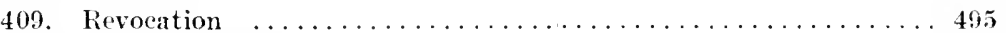

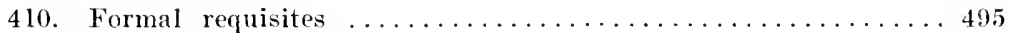

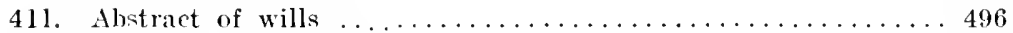

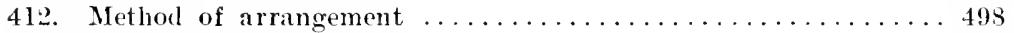

413. Practical examples ........................ 498

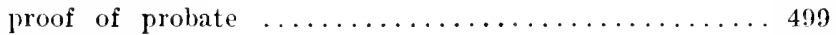

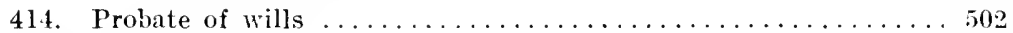

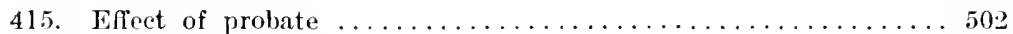

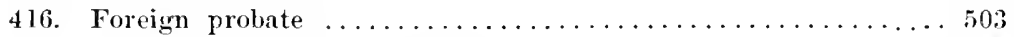

417. Abstract of probate proceedings .................. 504

practical examples .............. 506

\section{CHAPTER XXIV.}

LiENS, CIARGES AND INCUMBRANCES.

418. Liens generally . . . . . . . . . . . . . . . . . 509

419. How ereated ........................... 510

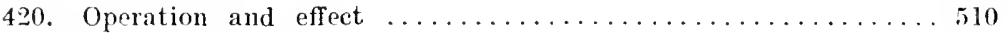

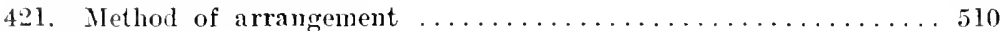

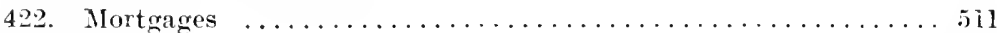

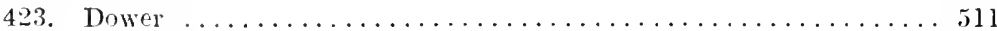

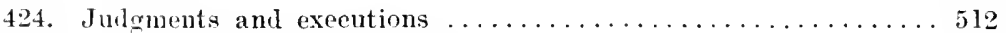

425. Judicial and execution sales .................. 512

426. Lis pondens and attachment ................. 512

427. Decerlent's dehts. . .

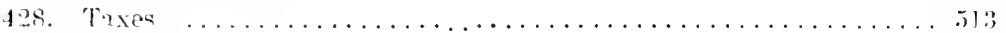

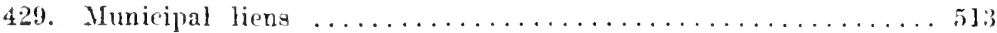




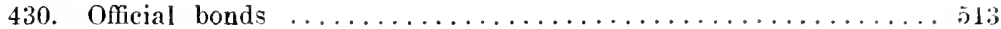

431. Leases . . . . . . . . . . . . . . . . . . . . . 514

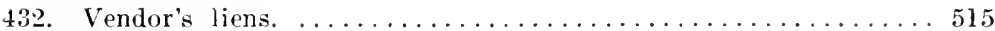

433. Mechanic's lien ....................... 516

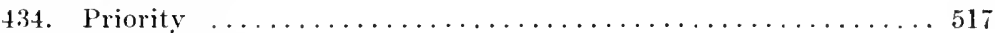

435. Estate to which lien attaches ................517

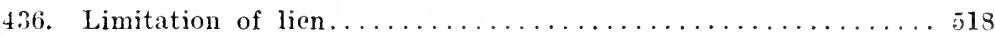

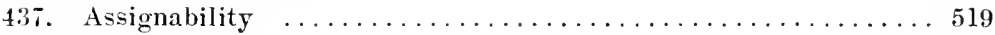

438. Foreclosure of lien $\ldots \ldots \ldots \ldots \ldots \ldots \ldots \ldots \ldots \ldots \ldots$

CHAPTER XXV.

LIS PENDENS AND ATTACHMENT.

439. Doctrine of lis pendens ....................... 521

440. Requisites of lis pendens ..................... 522

441. Continued; effect of dismissal ................. 523

442. Notice lis pendens ......................... 523

practical example ................... 524

443. Property drawn incidentally in question $\ldots \ldots \ldots \ldots \ldots \ldots \ldots . \ldots 25$

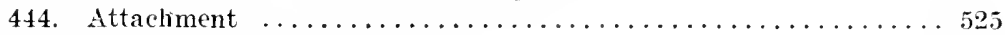

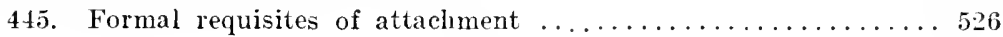

practical example $\ldots \ldots \ldots \ldots \ldots, 527$

\section{CHAPTER XXVI.}

JUDGMENTS AND DECREES.

446. Judgments and decrees; defined and distinguished.........529

447. Operation and effect of judgments ................ 530

448. Lien of judrments ......................... 530

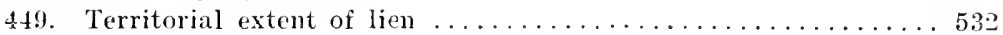

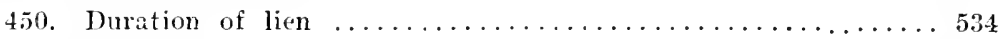

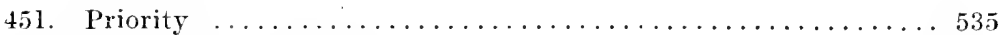

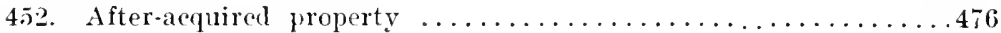

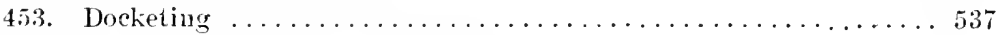

454. Formal requisites of judgments ................ 538

practical example ............ 539

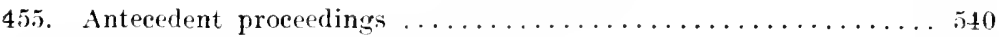

456. Judgments against a deceased person ............... 541

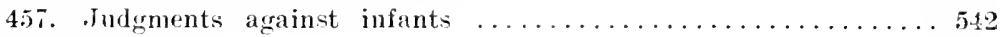

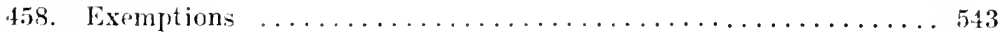

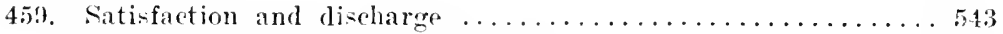

460. Decrees elassified and distinguished ................ $5 ! 1$

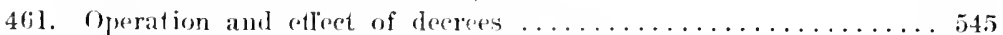

462. Decrees rendered on constructive notice ............ $5+6$

46:3. Lien of derrees . . . . . . . . . . . . . . . . . . 547

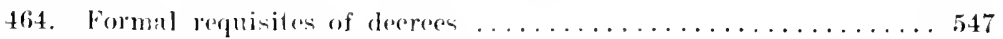

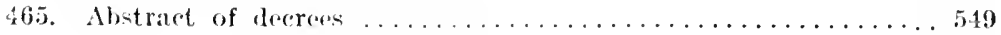

practical example .................. 549 
SEC.

466. Errors and defects

467. Continned; middle names ................... 55:

468. Continuel; initials; idem sonans $\ldots \ldots \ldots \ldots \ldots \ldots \ldots \ldots \ldots \ldots$

469. Operation and eflect of probate decrees $\ldots \ldots \ldots \ldots \ldots \ldots \ldots \ldots .5 .5$

470. Foreign judgments and decrees $\ldots \ldots \ldots \ldots \ldots \ldots \ldots \ldots \ldots \ldots$

\section{CHAPTER XXVII.}

\section{JUDICIAL AND EXECUTION SALES.}

471. Judicial and execution sales; defined and distinguished ..... 557

472. Execution sales; validity and effect. .............. 558

473. Title under execution sale ................. 560

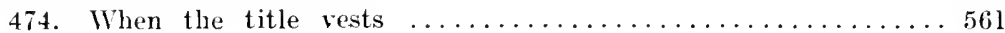

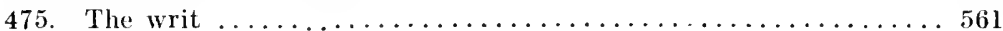

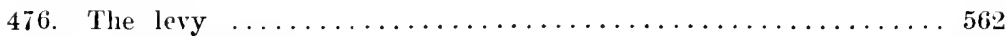

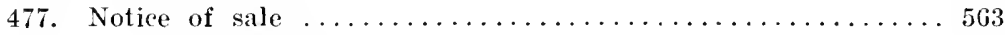

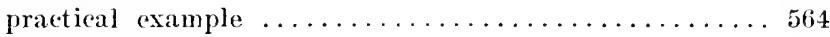

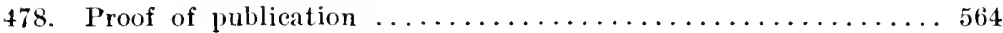

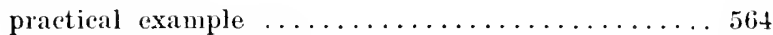

479. Execution sale as affected by death $\ldots \ldots \ldots \ldots \ldots \ldots \ldots 60 \ldots$

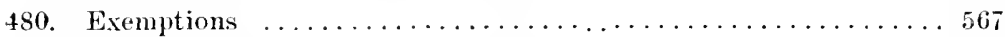

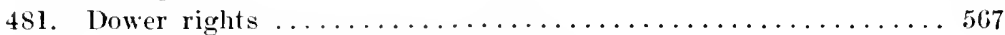

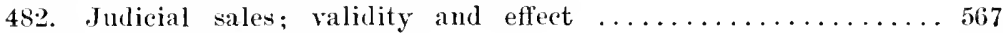

483. Title under judicial sales $\ldots \ldots \ldots \ldots \ldots \ldots \ldots \ldots \ldots \ldots \ldots \ldots . \ldots 69$

484. Rights of purchaser ........................ 570

485. Compelling purchaser to take title .............. 570

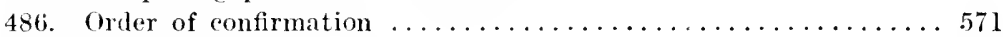

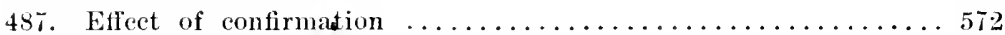

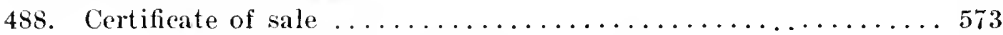

practical example; by sheriff ............ 575

practical example: by master ............ 576

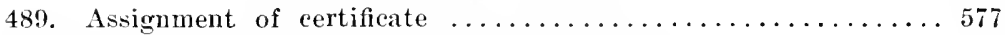

400. Proof of title under judicial and execution sales . . . . . . 577

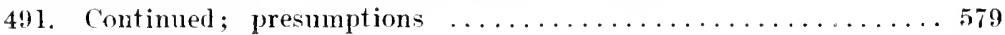

492. Probate sales . . . . . . . . . . . . . . . . . . 580

493. Nature and requisites of probate sales $\ldots \ldots \ldots \ldots \ldots \ldots \ldots . \ldots 52$

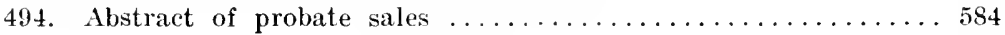

practical example ............. 585

\section{CHAPTER XXVIII.}

ACTIONS AND PROCEEDINGS.

495. Chancery proceedings generally ................ 587

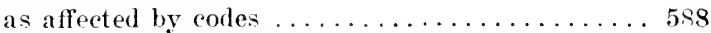

496. Authority and jurisdiction of chancery conrts . . . . . . . 58 s

497. Authority and jurisdiction of probate rourts . . . . . . . 589

498. Aotions and proceedings to be noticed.............. 590

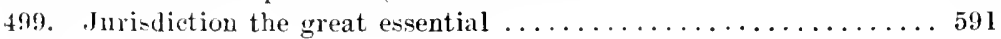


500. Notice afforded by chancery records ............... 592

501 Process ............................ 593

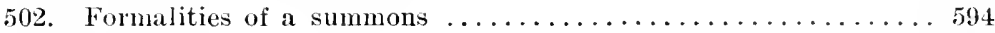

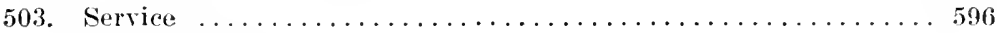

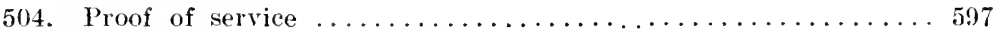

505. Affidavit and order of publication $\ldots \ldots \ldots \ldots \ldots \ldots \ldots \ldots \ldots$

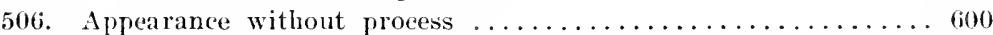

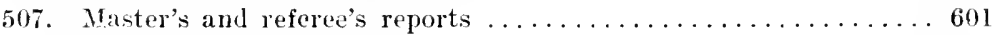

508. Verdicts .............................601

509. Abstract of chancery proceedings ... . . . . . . . . . . 602

practical example $\ldots \ldots \ldots \ldots \ldots \ldots \ldots \ldots \ldots$

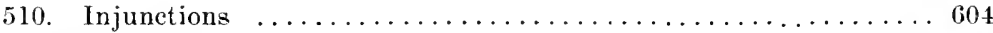

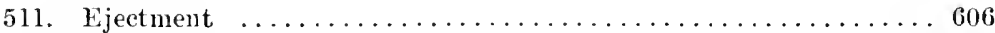

512. Quia timet ...........................608

513. Partition .............................609

practical example $\ldots \ldots \ldots \ldots \ldots \ldots \ldots \ldots \ldots \ldots \ldots$

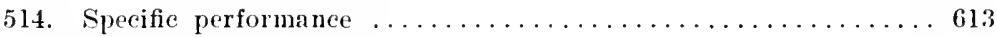

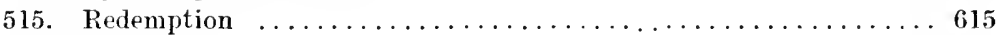

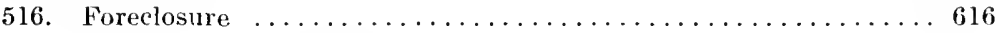

enumeration of methods ..............616

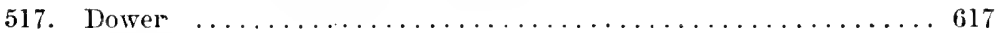

518. Divorce ..........................618

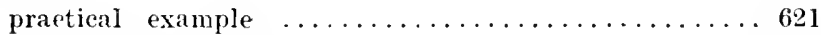

519. Right of eminent domain ..................622

520. Proceedings for condemnation and assessment $\ldots \ldots \ldots \ldots \ldots 23$

521 . Construction of wills .................... 626

\section{CHAPTER XXIX.}

TAXES AND TAX TITLES.

522. Definition; nature and scope of the taxing power $\ldots \ldots \ldots \ldots 27$

523. Subjects of taxation $\ldots \ldots \ldots \ldots \ldots \ldots \ldots \ldots \ldots \ldots \ldots$

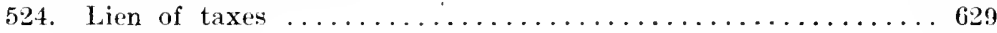

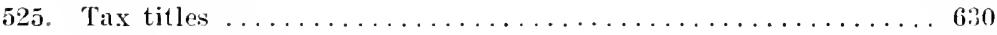

requisites and effect $\ldots \ldots \ldots \ldots \ldots \ldots \ldots \ldots \ldots \ldots \ldots$

526. Nature of tax titles; dependent or independent ........632

527. Proceedings ineident to taxation $\ldots \ldots \ldots \ldots \ldots \ldots \ldots$

528. Deseription of land; assessor's plats .............6.

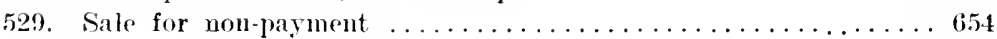

practical examples ................6635

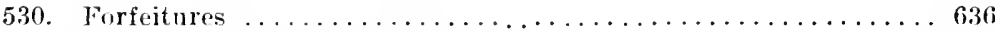

5.31. Tax sales; tax payer as purchaser . . . . . . . . . . . 637

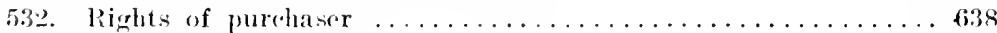

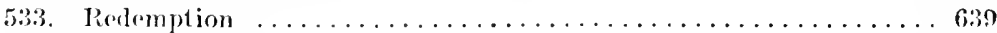

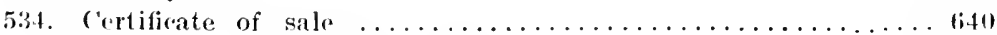

practicil example .................645

535. Tax deeds $\ldots \ldots \ldots \ldots \ldots \ldots \ldots \ldots \ldots \ldots \ldots \ldots \ldots \ldots \ldots$ 
536. Continuel; statutory modifications of common law rules ..... 64:

537 . Formal parts......................... 643

practical examples.............6645

5:8. Effert of dend as evidence ................... 646

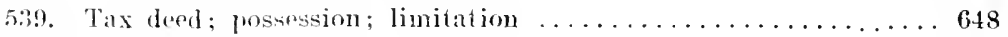

540. l'ax abstracts . . . . . . . . . . . . . . . . . . .

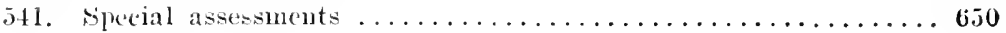

\section{CHAPTER XXX.}

\section{DESCENTS.}

542 Title by descent . . . . . . . . . . . . . . . . . . 651

543. Nature, operation and ineidents of title ...........652

54t. Inheritance as dependent upon seizin .............663

545. Heirship; its rights and privileges $\ldots \ldots \ldots \ldots \ldots \ldots \ldots \ldots$

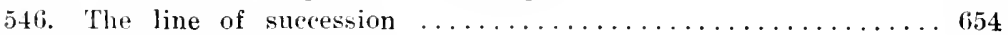

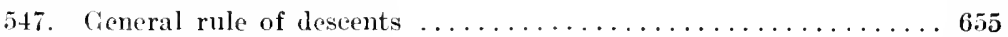

548. The right of representation $\ldots \ldots \ldots \ldots \ldots \ldots \ldots \ldots \ldots \ldots$

549. Preferences $\ldots \ldots \ldots \ldots \ldots \ldots \ldots \ldots \ldots \ldots \ldots \ldots \ldots \ldots \ldots$

550. Who may take by descent; aliens $\ldots \ldots \ldots \ldots \ldots \ldots \ldots \ldots \ldots$

551. Continued; adoptive heirs .................. 658

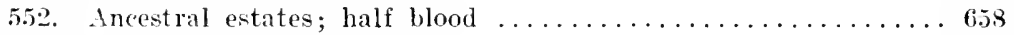

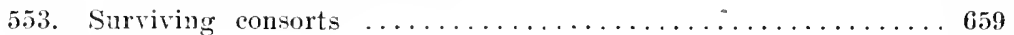

554. Coparceners ......................... 660

5.55. What descends .........................660

556. Jow affected by ancestral corenants ...............660

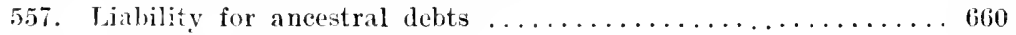

558. Creditor's liens ........................661

559. Equitahle conversion $\ldots \ldots \ldots \ldots \ldots \ldots \ldots \ldots \ldots \ldots \ldots \ldots \ldots \ldots$

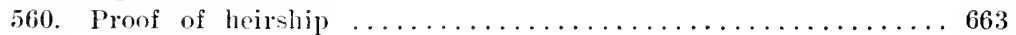

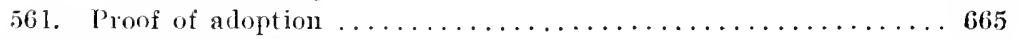

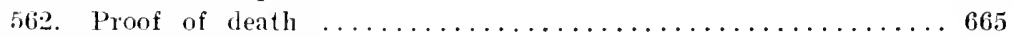

563. Continued; official registration .................669

practicable example .............669

564. Continued; probate of death ..................670

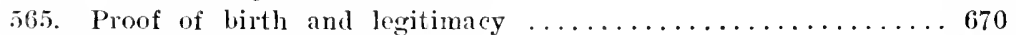

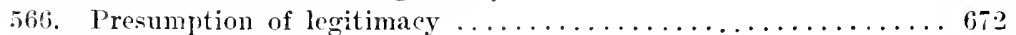

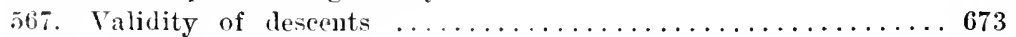

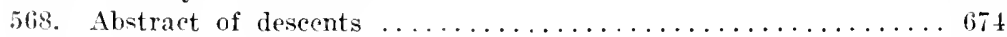

example of pedigree .............6. 675

569. Continued; probate proceedings ...............675

practical example ...........6 676

570. Settlement without administration $\ldots \ldots \ldots \ldots \ldots \ldots \ldots \ldots 7$

571. Escheat ........................... 678 


\section{CHAPTER XXXI.}

\section{ADVERSE TITLE.}

SEC.

PAGE,

572 . Adverse title, generally considered $\ldots \ldots \ldots \ldots \ldots \ldots \ldots . \ldots 69$

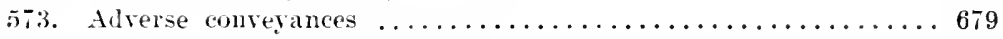

practical examples .................6. 681

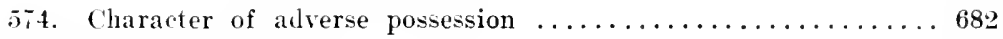

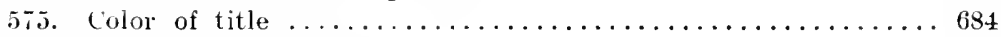

$5 \%$ (j. Adverse possession under color of title $\ldots \ldots \ldots \ldots \ldots \ldots \ldots 66$

57. . Constructive possession ........................687

578 . Adverse possession from user $\ldots \ldots \ldots \ldots \ldots \ldots \ldots \ldots \ldots \ldots 67$

579. Naked possession without elaim $\ldots \ldots \ldots \ldots \ldots \ldots \ldots \ldots \ldots 8 . \ldots \ldots$

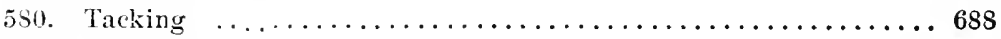

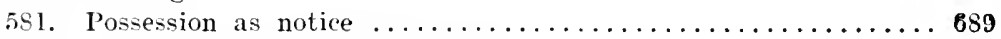

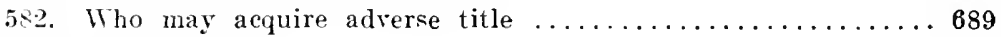

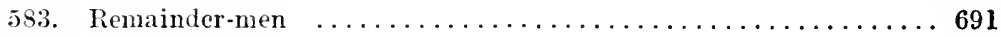

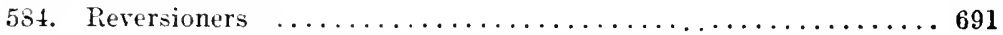

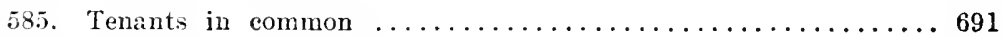

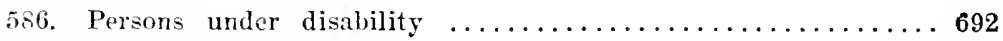

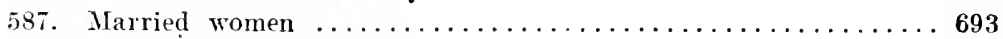

58s. Adverse rights as against the State $\ldots \ldots \ldots \ldots \ldots \ldots \ldots 6 . \ldots \ldots 3$

589. Effect of adverse possession . . . . . . . . . . . . . 694

590. Proofs to support title by adverse possession ...........695

\section{CHAPTER XXXII.}

\section{OPINIONS OF TITLE.}

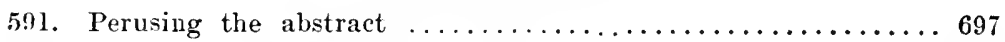

Mr. Sugden's views................6697

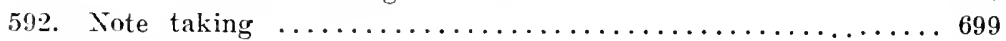

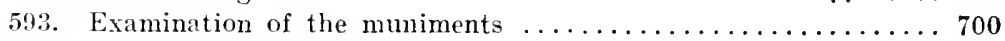

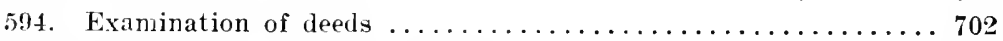

595. Examination of legal proceedings and judgments $\ldots \ldots \ldots \ldots 704$

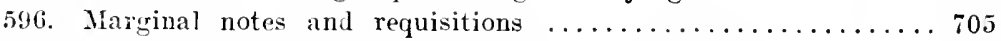

597. Continued; English and American Methods compared........ 706

example of requisitions .................. 707

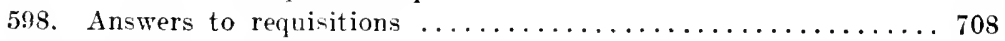

599. Affidavits of perligree ........................ 709

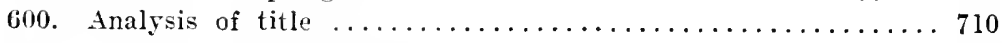

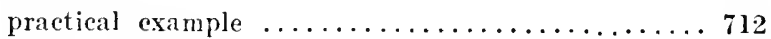

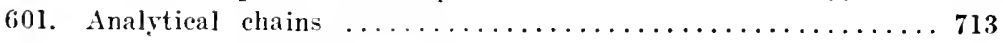

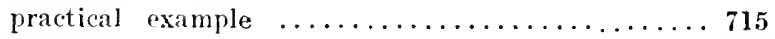

602. Sketch maps ............................ 714

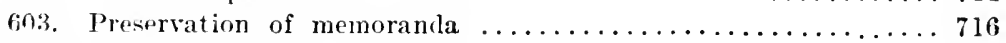

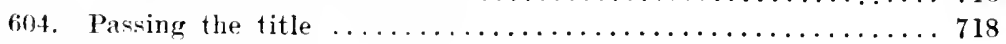

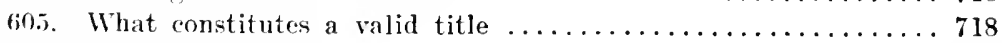

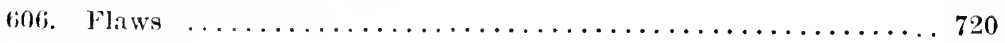

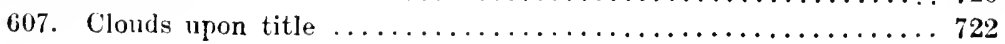


SEC.

PAGE.

608. Inquiries in pais .........................

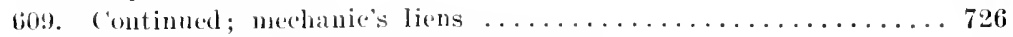

6]0. Continued; easements and servitudes .............. 726

611. Continuted homesteads ................... 728

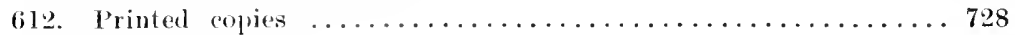

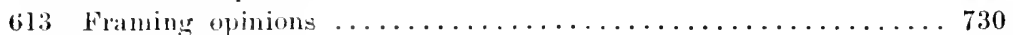

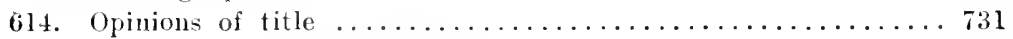

practical examples ............... 732

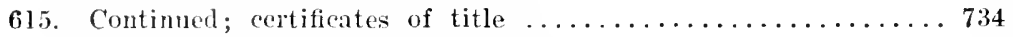

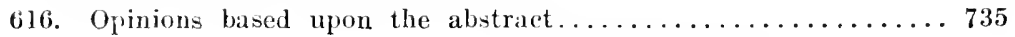

practical example ........ 737

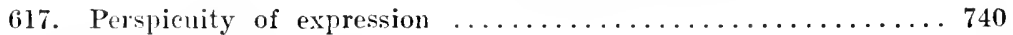

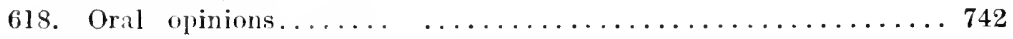

619. Liability for erroneous opinions................ 743

APPENDIX.

620. Conclusion $\ldots \ldots \ldots \ldots \ldots \ldots \ldots \ldots \ldots \ldots \ldots \ldots \ldots \ldots$

New England abstracts..................... 747

English analysis of abstract ................. 748

Tables of land measures..... . . . . . . . . . . . 750

Spanish-French land measures $\ldots \ldots \ldots \ldots \ldots \ldots \ldots \ldots \ldots \ldots$

Spanish-Mexican land measures................. 755

Texas land measures ...................... 758 


\section{TABLE OF CASES.}

THE REFERENCE IS TO PAGES.

Abbot v. Wilbur, 46.

Abbott v. Holway, Adm'r, 279, 280, 281.

Abbott v. Semple, 598.

Abbott v. Doling, 633, 635, 645 .

Abell v. Lathrop, 26.

Abererombie v. Abereromie, 463.

Acr v. Westcott, 74, 223.

Actor v. Hoyt, 511.

Adam v. Norris, 181.

Adams v. Morse, 224.

Adams v. Buehanan, 342.

Adams v. Jones, 666.

Adams v. Frothingham, 54.

Adams v. Adams, 590.

Adams v. Cowles, 597.

- dington v. Hefner, 451.

Adrain v. Shaw, 26.

Aetna Ins. Co. v. Hesser, 537, 555.

Agricultural Ass'n v. Neill, 242.

Agricultural Society v. Paddock, 316.

Aiken v. R. R. Co., 425.

Aiken v. Morse, 663.

Akers v. Akers, 471.

Akers v. Clark, 467.

Albee v. Ward, 578.

Alexander v. Stewart. 689.

Alexander v. State, 51.

Allaire v. Allaire, 503, 505.

Allard v. Lane, 451.

Allen v. Hawley, 26.

Allen v. Bates, 221.

Allen v. Holton, 271.

Allen v. Sales, 341.

Allen v. Woodruff, 389 .

Allen v. Culver, 399.
Allen v. Loring, 515.

Allen v. Morris, 522.

Allen v. Cole, 564.

Allen v. Poole, 661.

Allen r. McGaughey, 559.

Allen v. Smith, 606.

Allen v. Armstrong, 642, 643.

Alexander v. Alexander, 238.

Alexander v. Tolleston Club, 31s.

Allie v. Sehmitz, 610.

Allison v. Hunter, 164.

Allman v. Taylor, 568, 570.

Almy v. Hunt, 513.

Almond v. Almond, 525.

Alt v. Banholzer, 621 .

Altes v. Hinckler, 630.

Alton v. Transportation Co., 263.

Alton Ins. Co. v. Buekmaster, 608.

Allwood v. Mansfield, 522.

Am. Bible Socicty v. Sherwood, 315.

Am. Emigrant Co. v. Clark, 218.

Ambrose v. Raley, 683.

Amesti v. Castro, 59, 607, 608 .

Amphlet $r$. Hibbard, 436, 438.

Anderson v. Merowan, 363.

Anderson v. Cublert, 438.

Anderson v. Grable, 489.

Anderson v. Domnell, 516.

Anderson v. Arnotte, 598.

Anderson v. Tuek, 536.

Anderson v. Kerns Draining Co., 627.

Annan v. Baker, 645, 647.

Anthony v. Bank, 318.

Apperson v. Burgett, 535.

Applegate v. Elwards, 534.

Aquire $\forall$. Alexander, 692. 
Arbuckle r. Ward, 692.

Armstrong v. Ross, 301.

Armstrong r. Lear, 502 .

Armentrout's Exr, v. Gibbons, 428, $4: 9$.

Arnold v. Arnold, 297.

Arnold r. Chesebrough, 672.

Arnold v. Nye, 541 .

Arthur v. Anderson, 246.

Arthur v. Cole, 483.

Arthur v. Webster, 210, 309.

Ankew v. Dupree, 672.

Aston r. Galloway, 491.

Astor r. Hoyt, 420.

Astrom v. Hammond, 130.

Atherton $v$. Fowler, 132.

Atkins $v$. Kinman, 339, 644.

Atkins v. Hinman, $341,630$.

tikins v. Horde, 607 .

Atlanta Mlills v. Mason, 31.

Atlanta Dock Co. v. Leavitt, 227.

$\therefore$ ittorney General v. Garrison, 336.

Attorney General v. Plankroad Co., 628.

Atrood v. Wright, 560 .

Augustine r. Doud, 567.

Aultman v. Obermeyer, 300.

Austin v. Cambridgeport, 401, 484.

Austin v. Bainter, 602 .

Austin v. Wohler, 726.

Austin v. Bailey, 654.

Austin v. Downer, 428.

Aven v. Beckom, 340.

Avery v. Babcock, 538.

Ayer v. Ayer, 477.

Ayers v. Hays, 448, 455.

Ayling v. Kramer, 227.

Babbit v. Bowen, 677.

Babcock v. Jones, 537.

Bachman v. Sepulveda, 549 .

Bacon v. Van Schoonhover, 448.

Badger v. Daniel, 523.

Bangel v. Brodrick, 33, 34, 129, 163, 164.

Bailey v. Kilburn, 210.

Bailey v. Litten, 304.

Bailey v. Doolittle, 637.
Bailey v. Smith, 448.

Bailey v. Bailey, 336.

Baird v. Wolf, 129, 164 .

Baker v. Stewart, 299.

Laker v. Bartlett, 525.

Baker v. Brilge, 481.

Baker v. Chandler, 532.

Baker v. Hale, 688 .

Baker v. Il unt, 254.

Baker v. Scott, 470.

Baker v. Swan, 685.

Baker v. Neff, 313, 315.

Balcum v. Wood, 26, 437, 438.

Baldwin v. Sager, 448.

Baldwin v. Pool, 384.

Bales v. Perry, 353.

Ballou v. Lucas, 269.

Ballame r. Forspthe, 637.

Ballance v. Tesson, 169.

Bank v. Abstract Co., 15.

Tank v. Mathews, 313.

Bank v. Schott, 321.

Bank v. Sherman, 376.

Bank v. Bankon, 441.

Bank v. Anderson, 448.

Bank v. Stone, 381.

Bank v. Drummond, 428.

Bank v. Clapp, 390, 439.

Bank v. Green, 26.

Bank v. Humpliress, 572.

Bank v. Kortright, 317.

Bank v. Lanaham, 421.

Bank v. Jrons, 26.

Bank r. Rice, 245.

Bank v. Ward, 8, 9, 732, 734,745 .

Bank v. Willis, 368.

Banker v. Caldwell, 7 .

Bankers, etc. Co. v. Blair, 551.

Barber v. Roarbeck, 2.5.

Barber v. Harris, 283.

Barber v. Guaranty Co., 73.

Barbour v. Mtg. Co., 453.

Barbour v. Gates, 242.

Barclay v. Plant. 299.

Bardsley r. Hines. 597.

Barling v. Peters, 572.

Barleydt v. Barheylt. 481.

Barker v. Ry. Co., 220. 
Barker v. Barker, 580, 590.

Barker v. Comins, 502.

Barker v. Dayton, 20.

Barker v. Ins. Co., 596.

Barlow v. Stanford, 570.

Barnard v. Campan, 75, 79. Barnhizel v. Ferrell, 41.

Barnet v. Mendenhall, 26.

Barnet v. Proskatuer, 234.

Barnet v. Lachman, 210, 309.

Barnet r. Newark, 404.

Barney v. Keokuk, 5i, 186.

Barney v. Little, 83.

Barrett v. Messner, 25.

Barron v. Mullin, 560.

Barron v. Robbins, 608.

Barry v. Gamble, 18:.

Barter v. Greenleaf, 216.

Bartlett v. King, 466,467 .

Barton v. Moss, 637.

Bass v. Estill, 80.

Bassett v. Bassett, 216.

Bassett v. Budlong, 260.

Bassett v. Lockhard, 560 .

Batchelder v. Keniston, 55 .

Bates v. Noreross, 49.

Bates v. Spooner, 545.

Bates v. State Bank, 551, 555.

Bates v. Shrader, 65̃4.

Bates v. Ableman, 370 .

Bates v. Seely, 298.

Batesville Inst. v. Kauffman, 336.

Bauer v. Gattmanhausen, 89.

Baugher v. Merryman, 428.

Baxter v. Arnold, 199.

Bayliss v. Williams, 216.

Beacroft v. Strawn, 475.

Beach v. Beston, 367.

Beall v. White, 440.

Beal v. Blair, 252.

Bean v. People, 70, 72.

Bearss v. Ford, 420, 427.

Beatty v. Kurtz, 204.

Beatty v. Mason, 682.

Beatly v. Dixon. 589.

Braufort r. Dunean, 408.

Berker v. Howard, 639.

Bedell v. Shaw, 683.
Beebe v. Morrell, 81.

Beecher v. Hieks, 218, 284.

Beekman v. Frost, 440.

Beekman v. Bingham, $64 \pi$.

Beleher v. Braneh, 363.

Belden v. Meeker, 42, 503, 548.

Bell v. Dunean, 18:.

Bell v. Hearne, 113 .

Bell v. Boston, 254.

Bell v. Twilight, 271.

Bell v. Humphrey, 463.

Bell v. Simpson, 447 .

Bell v. Farmers' Bank, 238.

Bell v. Longworth, 685.

Bellows v. Todd, 131, 164.

Belslay v. Engle, 219.

Belt v. Abstraet Co., 71.

Beman v. Green, 387.

Bemis v. Beeker, 385.

Benkert v. Jacoby, 477.

Bennett v. Saloman, 449 .

Bennett v. State, 554 .

Bennett v. Whitman, 590 .

Bennett v. Nichols, 599 .

Bennett v. McFadden, 589.

Bennett v. Waller, 614.

Bennett v. Williams, 592.

Benoist v. Carondelet, 318.

Benson v. Morrow, 53, 186.

Benson v. Humphreys, 249.

Bently v. Deforest, 278.

Bergan v. Cahill, 462.

Berger v. Bennett, 446 .

Bergman's Appeal, 553.

Berlin v. Melhorn, 569, 571, 572.

Bernhart v. Brown, 319, 537.

Berry v. Derwart, 220.

Bertles v. Nunan, 297, 298.

Besore v. Dosh, 640.

Bessemer v. People, 594.

Best v. Gholson, 438.

Bethel v. Bethel, 34, 266, 567, 573.

Betsey v. Torrance, 288.

Bet inger r. Cliapman. 671 .

Beverly r. Jirooke, 685.

Beygeh v. Chieago, 565.

Bicknell v. Bickmell. :s9.

Diedler v. Biedler, 467 . 
Biglow v. Forest, 66.

Biglow v. Wilkon, $5 \geq 6$

Bill $r$ Mason, 516.

J3:llinges y. Stirk, 239.

Jinglanton Jirilge ease, 170.

Binkert v. Wabush Ry, 634.

Jirisill v. Hewlett, 490, 491.

Birdsall v. Russell, $75,77$.

Biscoe v. Coulter, 643 .

Bishop r. OConnor, 339, 362, 661.

IBishop v. Morgan, 221.

Pishop v. Schneider, s0, 83.

livard v. Walker, 238.

Jlack v. Gregg, 436.

Blackwell v. Barnett, 450.

Blacklurn v. Crawford's Lessee, 670,709 .

Islackwood v. Van Vliet, 632.

Slacklaws v. Milne, 663.

Blair v. Osborne, 212.

Blair v. Vanblareum, 284, 484.

Blair v. Ostrander, 533.

Blake v. Williams, 447.

Blake v. Shaw, 526 .

Blake v. Stone, 470 。

Blake v. Fish, 213.

Blakely v. Bestor, 644, 647.

Blagge v. Miles, 480.

Blanehard v. Ware, 592 .

Blanchard v. Strait, 524.

Blanchard v. Maynard, 463.

Blanchard v. Bissell, 408.

Planchard v. Brooks, 271, 272.

Jland v. Mumeaster, 568.

Blanvelt v. Ackerman, 324.

Blayton v. Merett, 330 .

Blatch v. Johnson, 552.

Bliss v. .Johnson, 684.

Blodget v. Hitt, 563, 565 .

Jlood v. Bloor, 80.

Plood v. Light, 559.

Blommfield R. R. Co. v. Burgess, 551.

Poardman v. Bourne, 643.

Boardman v. Riced, 183.

Bonline v. Artlur, 284.

Boerum v. Schenek, 365, 366.

Bolin v. Barrett's Exr., 488.
Bogardus v. Trinity Ch., 687.

Bogert v. Elizabeth, 723.

Bogy v. Shoab, 27 l.

Bohn v. Barrett's Exrs. 468.

Bohon v. Bohon, 325.

Bonewits v. Wygaınt, 56.

Bonnell v. Holt, 516.

Booker v. Warrill, 299.

Boorman v. Sunnucks, 56, 197.

Boon v. Pierpont, 432.

Booth v. Cook, 235.

Booth v. Small, 682.

Boothroyd v. Engle, 231.

Boreel v. Lawton, 400.

Borders v. Murphy, 596.

Borland v. Walrath, 237.

Bostick v. Blarles, 483.

Bostwiek v. Powers, 83.

Bottineau v. Ins. Co., 565.

Botsford v. Wilson, 269.

Botsford v. O'Comnor, 583, 584, 596.

Bourland v. Peoria, 76 .

Botsford v. Wilson, 269.

Bowden v. Henderson, 666.

Bowers v. Oyster, 389.

Bowers v. Kuscher, 134.

Bowers v. Andrews, 251.

Bowen v. Wiekersham, 549.

Bowen v. Bond, $5 \mathrm{~S} 1$.

Bowen v. Preston, 610.

Bowen v, Bommer, 562.

Bowen v. Thrall, 271.

Bowin v. Sutherland, 598.

Bowlin v. Pearson, 515.

Bowman v. Davis, 340.

Bowman v. Lee, 688.

Bowman v. Thompson, 631.

Bowman v. Pcople, 561.

Bowman v. Cockerill, 644.

Boyd v. Slaylack, 298.

Boylan v. Warren, 69, 70.

Boyland v. Boylamd, 596 .

Boynton v. IIubatrd, 325.

Boyuton v. Rees, 216.

Bozza v. Rowe. 574.

Brackett v. Gilmore, 641.

Brarlbury v. Falmouth, 7 \%

Bradford v. Howell, 210. 
Bradstreet v. Clark, 2si, 466.

Bradshaw v. Bradshaw, $2 \notin 9$.

Bradshaw r. Bradbury, 2.22.

Brady v. Spruck, 263.

Brain v. Renshaw, 250.

Bramberry's appeal, 298 .

Brame v. Craig, 25.

Branch v. Lowery, 533.

Brannan v. Brannan, 260.

Brannan r. May. 659.

Branger $\therefore$ Luey, 661.

Brantly $v$. Cheeley, 366.

Brashear v. Connor, 677.

Brattle Sq. Ch. v. Grant, 401.

Bray v. Adams, 223.

Braxton v. Bressler, 54.

Breckenriage $\mathrm{v}$. Tood, 213, 240.

Bree v. Bree, 556.

Brennan v. Wilson, 349, 372.

Brewer v. State, 671.

Brewer v. Watson, 69, 70.

Brewster v. Hardy, 279.

Brewster v. Madden, 134.

Brewton v. Watson, 218.

Brice's Estate, 671.

Bridge $v$. Wellington, 21s, 266.

Briggs v. Davis, 372.

Brightman v. Briglitman, 525.

Brine v. Ins. Co., 34.

Brinkerhoff v. Lansing. 605.

Britton v. Lorentz, 370.

Broek v. Frank, 504.

Brolasky v. Furey, 239.

Bromley v. Goodrich, 264.

Bronson v. Kukuk, 129.

Bronson v. Kinzie, 34.

Brodie v. Watkins, 217, 265.

Brown r. Sims, 9.

Brown r. Renshaw, 250.

Brown v. Farran. 257.

Brown v. Atwater, 280.

Brown v. Dean, 427.

Brown v. Goodwin, 523.

Prowu v. Pierce. 533.

Brown v. Gilmor, 572.

Jiown ve Delaney. 447.

Brnwn v. Thorndikm. 468.

Brown v. Jewett, 666 .
Brown v. Cockerill, 6s4.

Brown v. Coble, tis6.

Brown v. Brown, 264, 483.

Brown v. Smith, 520.

Brown v. Phil. Bank, 235.

Brown v. Parker, 54*, 566, 595.

Brown v. Rose, 695.

Brown v. Thompson, 242.

Brown v. Coal Oil Co., 268.

Brown v. Pforr, 328.

Brown v. Brown, 483.

Brown v. Throckmorton, 133.

Brown v. United States, 66.

Brown v. Chamberlin, 3il.

Brown v. Jackson, 2il.

Brown r. Manter, 217, 218.

Browne v. Ferrea, 559.

Browning r. Howard, 570.

Browning v. Harris, 437.

Brownfield v. Wilson, 463, 472 .

Brownfield v. Dyer, 596.

Brookbank v. Kernard, 299.

Brooks v. Bruyu, 65.5. 656, 687.

Brooks v. Rooney, 563.

Brooks v. Curtiss, 31.

Brooks r. Chappel, 590.

Broome v. Momek, 385.

Bruce r. Luke, 49.

Brunswick v. Crossman, 480.

Brush v. Ware, 75.

Brush v. Beecher, 399.

Bryant v. Christian, 478.

Bryan v. Ramirez, 236, 258.

Brybe v. Norchouse, 22:3.

Buchan r. Hart, 336.

Buehanan v. Curtis, 53.

Bucher v. Wetherhy, 148.

Buck v. Collins, 47, 70,72 .

Buckner v. Street, 273.

Buckingham $r$. Jacques, 37, 659.

Buckingham v. Wesson, 359.

Buckley r. Gray, it6.

Buekmaster v. Rỵder, 608.

Buckner v. Street, 273.

Buffalo v. Welster, 405.

Pull v. Willard, 383.

Bull v. Bull, 486 .

Bullork $v$. Battenhousen, 432, 440 . 
Bulleck v. Wilnou, 129.

Buncer. lieed, 566.

Bunch r. llardy. 2st.

Bundy v. Ophir iron Co., 2:38.

Bunker v. Green, 242.

Burch v. Carter, 5l.s.

Bureh v. Burch, 460.

Burdens r. Amperse, 296.

Burdick v. Wentworth, 130.

Burdick r. Brigge, 129, 621.

Eurgess v. Gray. 133.

Burgetit v. Paxton, 532.

Burke v. Stokely, 5+2.

Burkholder v. Cased, 2:38.

Burlen v. Shannon, 47 .

Burleigh v. Clough, 24, 475, 477.

Burlington Lniversity v. Barrett, 496.

Burnet v. Pratt, 306.

Burnet v. Burnet, 493.

Burnside v. Merrick, 309.

Burr v. Borten, 56t.

Burr v. Mueller, 306.

Burrows v. Bailey, 365.

Burton v. LeRoy, 232.

Burton v. Tuite, 72, 73.

Burtners v. Keran, 48 .

Burwell v. Jackson, 390.

Buseh v. Donohue, 133, 170.

Buseh v. Huston, 637.

Bush v. Scott, 543.

Bush v. Stevens, 216.

Bussey r. Hardin, 572.

Bushnell v. IIarford, 605.

Bustamete r. Bescher, 598.

Butcher v. Rogers, 217.

Butler's Appeal, 629.

Butler v. Lee, 545.

Butler v. Haynes, 56:.

Butler v. Fitzgerald. 567.

Butler r. Roys, 306.

Butler r. Huestic, 219, 462, 463, 472.

Butterfield v. Haskins, 476, 4iT.

Butterworth v. Crawforl, T:-

Button v. Am. Tract Society, 497.

Button r. Sehroger, 384.
Byars v. Spencer, 238.

Byrne v. Roberts, 597.

C. P. R. R. Co. v. Beal, 249 .

Caal v. Higgins, 21, 719.

Cabeen v. Breekenridge, 76 .

Cable's Appeal, 488, 491.

Caday r. l'urser, 79.

Caday v. Eighmey, 135.

Cady r. Shepard, 309.

Cabill v. Palmer, 682, 683.

Cahoon v. Coe, 634.

Calaman r. Iturley, 643.

Calcord v. Alexander, 251.

Calder v. Chapman, 103.

Callwell v. Caldwell, 463.

Callwcll v. Laminer, 519.

Calhoun v. Cook, 682.

Callins v. Lavelle, 218, 250, 263, 283.

Callanan v. Votruba, 537, 538.

Callaway r. Fash, 236, 259.

Calumet Co. v. Russell, 294, 254.

Cambridge Bank v. Delano, 74,76 .

Cameron v. Supervisors, 63.

Cameron v. Logan, 560.

Camp r. Smith, 135.

Camp v. Bates, 605.

Campbell v. Gas Co., 54.

Camphell r. Johnson, 252.

Camplell v. Camplell, 292, 459.

Campbell v. McCahn, 591.

Campbell v. Hall, 607.

Camplell r. Ware, 659.

Campbell r. Wiggins, 468.

Campbell v. Wilson, 671.

Canal Commissioners r. People, 57.

Canfield v. Bostwiek, 461.

Cannon v. Brame, 545.

Cappock r. Smith, 41 .

Capehart v. Dowery, 569, 571.

Carbine v. Morris, 311 .

Carbine v. Pringle, 75.

Cardell v. Rịder, 299.

Carluart v. Harshaw, 26.

Cary v. Whitney. 384.

Carev v. Rae, 30, 31. 
Carlisle v. United Statcs, 20.

Carman v. Johnson, 1:6.

Carow, In re, 375.

Carpenter v. Snelling, 242.

Carpenter v. Underwood, 370.

Carpenter v. Dexter, 254.

Carpenter v. Sherfy, 340, 533.

Carpenter v. Browning, 464.

Carpenter v. Bowen, 420, $5 \mathrm{il}$.

Carpenter v. Mitchell, 515.

Carpenter v. Denoon, 691.

Carpentier v. Williamson, 268.

Carr v. Rising, 26.

Carr v. Ellison, 399.

Carr v. Carr, 426.

Carrington v. Manning's Heirs, 499.

Carroll v. Safford, 130.

Carroll v. E. St. Louis, 310.

Carroll v. Carroll, 503, 505.

Carroll v. Gillion, 682.

Carson v. Murray, 28.

Carter v. Day, 611.

Carter v. Hawkins, 75.

Carter v. Rodewold, 599.

Carter v. Wise, 268.

Carver v. Louthain, 274.

Cary v. Whitney, 384.

Case v. Codding, 292.

Casebolt v. Donaldson, 25.

Cassell v. Cook, 257.

Cate v. Craynor, 464, 474.

Catlin v. Ware, 217.

Catlino v. Decker, 690.

Caranaugh v. Peterson, 441.

Cemetery v. R. F. Co., 63.

Chadlourne v. Mason, 562.

Challis v. R. R. Co., 64, 623.

Challefoux v. Ducharme, 46, 59, $129,156,169$.

Chambers Re 73.

Chambers v. Jones, 360 .

Chambers v. St. Louis, 277.

Chambers v. Cox, 438.

Chamberlain v. Bell, 76 .

Champaign v. Harmon, 314.

Champlin v. IIaiglit, 350.

Chandler v. Chandler, 279.
Chandler v. Spear, 630, 643.

Chandler v. Cheney, 297.

Chapin v. Gilbert, 488.

Chapin v. Curtenius, 364.

Chapman v. Lee, 13.

Chapman v. Templeton, 649.

Charles River Bridge v. Warren Briche, 622.

Charles v. Wangh, 630, 634 .

Chartiers Etc. Co. v. MeNamara, 242.

Chase v. Ross, 363.

Chase v. Heaney, S, 745.

Chase v. Whiting, 340 .

Chase r. Peck, 389.

Chase v. Chase, 620.

Chatard v. Pope, 128.

Chatham v. Bradford, 83.

Cheever v. Perley, 450.

Cheney v. Cook, 614.

Chicago v. Vulean Iron Works, 288.

Chicago v. Larned, 62, 629.

Chicago, ete., R. R. Co. v. Joliet, 58.

Chicago, etc., R. R. v. Kennedy, 74.

Childs v. Lanterman, 543.

Chiles v. Conley's Heirs, 218.

Chiniquy v. Catholic Bishop, 247, $258,606$.

Chope v. Lorman, 47.

Chouteau v. Eckhart, 168.

Christian v. Newherry, 425\%

Christie v. Gage, 691.

Christy v. Dana, 136.

Christy v. Fisher, 637.

Chubb v. Johnson, 35.

Church v. Gilman, 177.

Church v. Furniss, 599.

Church v. Smith, 384.

Church v. Hoboken, 58.

Clunreh v. Crossman, 538.

Churehill v. Reamer, 263.

Cineinnati v. White, $\mathbf{5 8}$.

Clader v. Thomas, 79.

Claflin v. Dunne, 542.

Clargett v. Conlee, 685.

Claiborne v. Ifolmes, 80.

Claps v. Stomghton, 484.

Clapp r. Bromagham, 692. 
Clark r. Bomman's Ex'r, 470.

Clark r. Commer, (643.

Clark v. Bosworth, 725.

Clark v. Temnison, 455, 483.

Clark v. Marshall, S, Tt5.

Clark v. Graham. 34, 217, 327.

Clark v. Baker, 48, 49, 136, 439 .

Clark r. Collidge, 50.

Clark $x$. Wuthy, 202.

Clark v. Hillis, 547 .

Clak v. Thompson, 583.

Clark v. Hall, 130.

Clark v. Clark, 298, 348.

Clark v. Manfg. ('o, 318 .

Clark v. Sawyer, 341.

Clark v. Henry, 4: $\bar{\tau}$.

Clark v. Martin, 227, 286.

Clarke v. Clarke, 348 .

Clarke r. Rowan, 634.

Clark v. Boorman's Ex'rs, 470.

Clark v. Huges, 691.

Clarkson v. Stinchfield, 60 万.

Claunch v. Allen, 273.

Clayton v. Wardell, 6il.

Clements v. Lamkin. 682.

Clery v. Himman. 636.

Close v. Samm, 686.

Coa! Co. v. Barber, 536.

Coats v. Taft, 220, 251.

Cobble v. Tomlinson, 309.

Coburir v. Ames, 186.

Coburn v. Ellenwood, 171.

Cuckerel v. Coleman, 654.

C ffee v. Sil $n, 579$.

Cum rom Taylor, 449.

Cofran $r$. Cofran. 362.

Cohea v. Nemingway, 359.

Cohen v. Shard, 723.

Colby v. MieOmber, 257.

Cole v. Kimball, 229.

Colts r. Mithers, 429.

Colesburg v. D.rt. 328.

C. 'eman v. Allen, 133.

Coleman v. F. R. Co.. 311.

Coleman r. Billings, 686.

roleman v. Improvement Co., $2 \mathbf{2} 1$, 2023.

Coleman v. McAnulty, 542.
Collame v. Langdon, 422.

Collins v. Bartlett, 175.

Collins v. Marey, 286.

Collins v. Warren, 309.

Collins $r$. Megraw, 518.

Collins v. Collins, 608.

Collins v. Lymch, 693.

Collamore v. Wilder, 663.

Collier. v. Va in, 564.

Collier v. Grimsey, 477.

Collier's Case, 481.

Colson v. Thompson, 614.

Comer v. Baldwin, 238.

Commonwealth v. Alger, 19, 20.

Commonwealth v. Jackson, 238.

Commonwealth v. Andre, 51.

Commonwealth r. Stump, 6il.

Commissioners v. Rush, 205.

Commissioners v. Brackenridge, 629.

Comstock v. Crawford, 42.

Comstoek v. Smith, 268, 271.

Conboy v. Ior a City, 404.

Congregational Society v. Stark, 315.

Conklin v. Foster, 567.

Conn. Ins. Co. v. Smith, 313.

Comnard $v$ Colgan, 238.

Connor v. Banks, 447.

Connor v. Whitmore. 449.

Conover v. Musgrave, 573.

Conover v. Warren, 510.

Conrad v. Ins Co., 53l.

Comroy v. Perry, 519.

Cook v. Sinnamon, 247.

Cook v. So. Pk. Com'rs, 63.

Cook v. Barr, 334, 335.

Cook v. Clark, 435 .

Cook v. Holmes, 466, 481.

Cooley r. Scarlett, 548.

Coolilge v. Learned, 53.

Coons v. Throckmorton, 597.

Cooper v. Ord. 32. 655.

Conper v. Reynolds, 592.

Cooper v. Willer, 142.

Conper v. Roberts, 148, 158.

Cooper v. MreBrile, 688.

Cooper v. Cooper, 298, 666. 
Corbin v. Healy, 224.

Corbin v. Sullivan, 79.

Corbitt v. Timmerman, 601.

Corficld v. Corgell, 658.

Cormack v. Wulcott, 70, 72.

Corning $\mathrm{r} . \operatorname{Trc}:$ Factory, $68 \mathrm{~s}$.

Corning $\because$ Gould, 61 .

Corning r. Troy, etc., Factory, 604.

Cori. 1 v. Merritt, 360.

Cor.vith v. Bank, 562 .

Cos r. Estes, 242.

Cost v. Rose, 596.

Costigan r. Gould, 213.

Costly v. Driver, 595.

Coursey v. Daris, 284.

Cover v. Manallay, 256.

Corenhoren v. Shuler, 466.

Covington v. Stewart, 694.

Cowan r. Foster, 581.

Cowell v. Col, Spring:s Co., 227, 286.

Cowles v. Rickett, 367 .

Cowles $r$ : : Tarble, 419, 422.

Cowley i. iulsifer, 74 .

Cowl v. Varnum, 516.

Cox v. Steru, 227.

Cu: v. James, 199.

Cos v. Cor, $\mathrm{C} 56$.

Co: v. Halsted, 564.

Coyce v. Stovell, 537.

Coyc r. Leach, 668.

Craddock v. Stewart's Adm'r, 340 .

Craig v. Radford, 657 .

Craig v. Leslie, 490.

Craig v. Dimock, 2.?‥

Craig r. Swincrton, 5ls.

Craig r. R. R. Co., 63.

Craig v. Wells, 2si.

Cram v. Cotting, 631.

Cramer's Appeal, 37, 659.

Crane v. Reeder, 288.

Crane v. Turner, 449.

r'ranton v. Crane, 445.

Crary v. Goodman, 68., 687.

Crawforl v. Richeson, 514.

Crawford v. Speneer, 211.

rerelle r. Hays, 221, 223.

Crispen v. Hannavan, 32, 684, 687.
Crittenden v. Fairchild, 352.

Crittenden v. Leitensdorfer, 561.

Croade v. Ingiaham, 28 .

Crockett $r$ Mclinire, i5.

Croeker $\checkmark$ Pierce, 5:6.

Croeker v. Dallangee, 264.

Croft r. Bunster, $216,420,447$.

Croker v. Gilbert, 216.

Cromwell v. Ins. Cc., 388.

Cronise r. Harct, 359.

Crooker v. Crooker, 84.

Crooke v. Andrews, 722.

Crook r. Lumsford, 26.

Crosby v. Dowd, 556.

Crosby v. Parker, 249.

Cross $r$. Cross, 672.

Crouse v. Murphy, 553.

Crowell r. Johnson, 573.

Cruger v. Mrilliday, 337 .

Crump v. Fancett, 656 .

Cryder's Appeal, 350.

Cuendet v. Lohmer, 368.

Culver v. Pliclps, 595.

Cummings v. Rogers, 392.

Cummings v. Cummings, 5S0.

Cummings v. Plnmmer, 472.

Cunningham v. Pattee, 75.

Crimningham v. MeCollum, 344.

Cunningham v. Curtis, 221.

Cumningham v. Ashley, 130.

Curd r. Lackland, 559 .

Curren v. Taylor, 37, 659.

Clury v. Hinmail, 5!s.

Cirry v. Speneer, 627.

Curtis v. Ifunting, 179.

Curtis v. Flynn, 432.

Curtis v. Root, 536, 571.

Curt is r. Smith, $396,349,638$.

Curtis v. Lyman. 83.

Cuchamun v. Glover, 320 .

Cutler v. Darenport, 372, 449.

Cutler v. Tufít, 260 .

Cutright r. Stalıford, 661 .

Dismond v. Dubose, 242.

Dailey v. Titrhfolll, 13.

Da!e v. Tinolu, 211, 239.

Dale v. Shively, 229. 
Dalton v. Lanburth, 605.

Dalton v. Jurats, 647, 648, 649.

Dimon v Bibben, 474.

Danforth v. Lowry, 332.

Daniel v. Purris, 169.

Daniel v. Leitch, 291.

Daniel v. Hodges, 525.

Daniel v. Whartenby, 469 .

Darst v. Baltes, 213.

Dirt v. Woodhouse, 14.

Dartmouth College v. Woodward, 170 .

Dal vemport v. Whistler, 2:38, 383.

Davemport v. Young, 359.

Dadidson v. Secrist, 15.

Davidson v. Seegar, 723.

Daridson v. Van Pelt, 390, 719.

Davie v. Briggs, 666.

Davis v. Hollingsworth, 210.

Davis v. Burton, 233.

Davis v. R. R. Co., 321 .

Davis v. Steeps, 537, 553.

Davis v. McDonald, 304.

Davis v, Savings Bank, 330.

Davis v. Alvord, 517, 519.

Davis v. Life Ins. Co., 523.

Daris v. Hamilton, 428, 535.

Davis v. Ransom, 562.

Davis v. Henderson. 390, 719 .

Davis' Heirs v. Tanl, 490.

Day v. Brenton, 453.

Day v. Wilder, 689.

Day v. Micom, 66.

Dayton v. Corser, 567 .

Dayton v. Mintzer, 580, $58 \mathrm{I}$.

De Camp r. Dobbins, 313.

De Graw v. King, 235.

De Wolf v. Hayden, 49, 270.

Dean v. Bittner, 16s, 169.

Deerfield v. Arns, 54, 55.

Deford v. Deford, 461.

Deininger v. MeConnell, 232, 239.

De Kay v. Irving, 463.

Delancy v. Ganong, 399.

Delaney r. Brunette, 450.

Delano $v$. Bennett. 449.

Delaumay v. Burmett, 134

De Laureal v. Kemper, 455.
Delevan r. Duncan, 390, 391, 719.

Dement v. 'Thompson, 56i2.

Dennett v. Dennett, 472.

Den v. Taylor, 341 .

Den v. Messenger, 481.

Den v. Troutman, 452.

Den v. Despreaux, 341 .

Dennis v. Maynard, 513 .

De Pauw v. New Albany, 627.

Dequindre v. Williams, 52.

Dew v. Dellinger, 384 .

Dewey v. McLain, 66.

Devries v. Haywood, 50.

Dexter v. Nanley, 400.

Deyer v. Homer, 289.

Dibrell v. Carlisle, 545.

Dickle v. Abstract Co., 9.

Dickenson v. Breedan, 645.

Dickson v. Randal, 299.

Dickson v. Rawson, 367.

Dickson v. Todd, 522.

Dickins v. Barnes, 251.

Dikes v. Mliller, 61 .

Dill v. Wisner, 490.

Dills v. Jasper, 571.

Dills v. Hubbard, 687.

Dillman v. Hoffman, 30, 727.

Dillon v. Brown, 309.

Dillingham v. Fisher, 132.

Dillingham v. Brown, 649.

Dingley v. Bank, 428.

Dingley v. Boston, 64.

Dingman v. People, 170.

Dinkins v. Bowers, 516, 519.

Disque v. Wright, 432, 440.

Diversy v. Jolinson, 585.

Dix v. Palmer, 59 s.

Dixon v. Dixon, 532.

Dixon v. Merritt, 48.

Dixon v. Cook, 682, 683.

Dobbins v. Wilson, 531.

Dodd v. Williams, 49, 102, 103. 734, 743.

Dodge v. Hopkins, 32?

Dodge v. Beeler, 6.56. 6.59.

Dodge's Appeal. 65.

Doe v. Hardy, 358.

Doe v. Governeur, 657. 
Doe v. Jackson, 364.

Doe v. Eslava, 687.

Dugan r. Griflin, 631.

Dolde r. Vodicka, 199.

Dole v. Thurlow, 233, 236.

Donaldson v. Holmes, 518.

Donaldson v. Hibner, 50.

Donahue v. Chase, 357.

Donnelly r. Turner, 414.

Donlin v. Hettinger, 585.

Doolan v. Carr, 176 .

Dooly v. Waleott, 77.

Doolittle v. Jenkins, 516.

Doran v. Mullen, 231.

Dorr v. Harrahan, 227.

Dorland v. Magilton, 690.

Dorsey v. Kendall, 568.

Dorsey v. R. R. Co., 413 .

Douglass v. Blackford, 464.

Donglass v. Dangerfield, 637.

Durette v. Briggs, 340 .

Douseman v. Hooe, 169, 548.

Douthitt r. Stinson, 208, 210.

Dow v. Lewis, 218.

Dow v. Dow, 460.

Dow v. McKemnedy, 605.

Downer v. R. R. Co., 58.

Downey v. Borden, 477.

Downing v. Marshall, 351.

Drake v. Kinsell, 25.

Drayton v. Marshall, 420.

Draper v. Bryson, 343.

Dressel v. Jordan, 256.

Drew v. Smith, 222.

Drisadow v. Wilde, 477.

Drỵlen v. Hanway, 292.

Dublin r. Chadbourn, 503.

Dueat v. Chicago, 310.

Ducker v. Burnham, 492, 532.

Dulley v. Sumner, 395.

Duff v. Beaucliamp, 298.

Duffy r. Holson, 242.

Dugan v. Follett, 593, 691.

Dunean v. Dumcan, 672.

Dunlre Mtg. Co. v. Huges, 8, 743, 745 .

Dunklin r. Wilson, 545.

Dunklee $v$. Crane, 517, 726.
Dugan v. Follett, 5i0.

Dunlap v. Gallatin Co., 513, 630, $631,634$.

Dunlap v. Bullard, 402.

Dunlap v. Dunlap, 289, 461.

Dunleith v. Reynolds, 628.

Dunn v. Ketehum, 416.

Dumn v. Snell, 637.

Dunn v. Gaines, $2 \pm 4$.

Dumning v. Ocean Nat. Bank, 363.

Dunning v. Van Dusen, 479, 480, 701.

Duplessis v. Kennedy, 667.

Dupont v. Daris, 221.

Dupuy v. Leavenworth, 309.

Durant v. Comegys, 538.

Durett v. Briggs, $3 \pm 0$.

Durfree v. Paritt, 292.

Durham v. Heaton, 566.

Duryea v. New York, 198.

Dutton v. Simmons, 552.

Dwight v. Overton, 372.

Dwight v. Packard, 220.

Djer v. Clark, 309.

Eames v. Turnverein, 547:

Earl v. Rowe, 477.

Easterly v. Goodwin, 596.

Eastman v. Porter, 530, 545.

Eaton v. Trowbridge, 240.

Eaton v. Simmonds, 291.

Eaton v. Brran, 663.

Eaton r. Ryan, 559.

Eaton r. White, 573.

Edgerton v. Bird, 32, 685.

Edwards v. Bibh, 463, 472.

Edwards v. Rays, 288 .

Edwards v. Ralley, 176.

Edwards v. Thompson, 725.

Erwarls r. Trumbull, 427.

Edwards v. Barnard, 469.

Fidenmilter v. Wyandotte City, 63.

Fitlen v. Fillen, 609.

Fiscley v. Spooner, 218.

Fisenmenger v. Murphy, 543.

Egery v. Woodard, 238.

Elilritge v. Pierce, 25.

Elitred v. Sexton, 131. 
Elker v. Derloy, 424.

Elmlorf r. Lockwiot , 27, 29, 305. Ellis v. R. R. Co.. 443 .

Elliott v. Sleeper, 245.

Elliott v. Armstrongr, 334.

Elliott v. Wood, 445.

Elliott v. Mlorris, 334.

Elliott v. Pearle, ts6.

Ellixon v. Wilson, 74 .

Ellison v. Daniels, 449.

Ellsworth v. R. R., 239.

Ellwell v. Shaw, 326.

Ely r. Wileox, 102, 103.

Emmerson v. White, 664.

Emmison v. Whitlesey, 484.

Emory v. Keighan, 450.

Enfield v. Permit, 51.

Equitable Trust Co. v. Fisher, 443.

Errissmann v. Errissmann, 619.

Erskine v. Daris, 244.

Eshelman's Estate, 656.

Espy v. Anderson, 13.

Ethell v. Nichols, 583.

Evans v. Davis, 563.

Evans v. Asliley, 344, 549, 573.

Evans v. Edwards, 210.

Evans v. Hudson, 466.

Evertson v. Sawyer, 561, 574.

Ewins v. Gordon, 387, 393.

Fairman v. Beal, 478.

Falkner v. Guild, 581.

Fallon v. Clindester, 503.

Faloon v. Simshauser, 283.

Fannin Co. v. Riddle, $5 \mathrm{I}$.

Farrington v. Wilson, 581.

Fairman v. Beal, 478.

Faris v. Dumn, 334.

Parish v. Coon, 185, 687.

Farish v. Cook, 474, 475.

Farmers' Bank v. Haight, 232.

Farmers' Bank v. Merehant, 512.

Farmers' Bank v. Peters, 571.

Farnham v. Hildreth, 550, 551.

Farnsworth v. Cole, 617.

Farnum v. Peterson, 298.

Farrington v. Wilson, 581.

Farwell v. Rogers, 288.
Fast v. McPherson, 334.

Faulke v. Bond, 692.

Fearing v. Swift, 469.

Feaster v. Fleming, 561.

Fehrle v. Turner, 605.

Feit v. Vannata, 472.

Felino v. Lumber Co., 435.

Fell v. Young, 240, 360.

Fellows v. Heermans, 333.

Feltman v. Butts, 463.

Fenn v. 1Iolmes, 33, 182.

Femner v. Tucker, 5́tit.

Fenton v. Reed, 67l.

Fergus v. Woodward, 561.

Fergusen v. Miles, 343.

Fergusen v. Jones, 665.

Fergusen v. Craw ford, 541.

Fergnsen v. Scott, 60:.

Ferris v. Crow, 595.

Ferry's Appeal, 463.

Fetrow v. Merriweather, 216.

Fiege v. Garvey, 26.

Field v. Seabury, 169.

Final v. Backus, 257.

Finley v. Brown, 644.

Finley v. Steele, 265.

Finley v. Boyd, 530.

Fire Ins. Co. v. Doll, 327.

Fire Ins. Co. v. Loomis, 574.

Fischer v. Eslaman, 306, 341.

Fisher v. Fields, 23, 333.

Fisher v. Hall, 238.

Fisher v. Forbes, 292.

Fisher v. Provin, 297.

Fisher v. Beckwith, 237.

Fisher v. Buteher, 239, 254.

Fish v. Lightner, 530, 545.

Fisluback v. Weaver, $546,570$.

Fisk v. Flores, 223, 340.

Fiske v. Kellogg, 583, 584.

Fiske v. Tolman, 289.

Fissler's Appeal, 593.

Fitch v. Boyer, 578, 579.

Firtlı v. Lawrenee, $\mathbf{4} 15$.

Fitzgerald v. Spain, 637.

Fitzgerald v. Glaney, 662 .

Fitzgibbon v. Iake, 364.

Fitzhuglı v. Maxwell, 384. 
Flening v. McHale, 292.

Fleming v. Johuson, כॅ

Flemming v. Griswold, 693.

Fletcher v. Tyler, 2st.

Fletcher v. Holmes, 420, 436, 437, $438,511$.

Fletcher v. Peck, 60.

Flinn v. Owen, 672.

Flint v. Clinton Co., 317, 409.

Florence v. Hopkins, 692 .

Florence v. Paschal, $7 \geq 3$.

Flowery Mining Co. v. Bonanza Co., 232.

Floyl v. Herring, 360.

Fogal v. Perro, 691.

Fogg v. Clark, 473.

Foley v. Harrison, 156.

Foley v. McDonald, 360, 555.

Foltz v. Prouse, 654.

Fonda 7 . Sage, $7 \geq 23$.

Fontaine v. Sarings Bank, 239.

Fotte v. Bryant, 292.

Forbes v. Scannell, 371.

Ford v. Unity Church, 102, 103.

Ford v. Wilson, 686.

Ford v. Doyle, 551.

Ford v. Marshall, 691.

Forstll v. Preer, 433.

Forsyth v. Small, 57.

Forrest v. Jackson, 219.

Foshier v. Narver, 551.

Foster v. Shreve, 219.

Foster v. Richard Busteed, 530, 545.

Foster v. Waterman, 635.

Foster v. Evans, 607.

Foster v. Young. 48.

Fouly v. Fouby, „2ib.

Foulks v. Pegg, 526.

Fowle v. Nerrill, 357.

Fowler v. Shearer, 326.

Fowler v. Merrill, 357.

Fowler v. Dorle, 539.

Fox v. Phelns, 131.

Fox v. Turtle. 56.5. 560.

Fox v. Burke, 36.

Frakes v. Brown. 6000.

Frazer v. Peoria Co., 284, 484.
Frazer v. Lee, 366.

Frazer v. Thatcher, 532.

Frances' Estate, 463, 472.

France-Texan Land Co. v. MicCormick, 311, 321, 322.

Franklin Co. v. Salvings Inst., 313.

Franklin v. Talmadge, 244 .

Franklyn v. Hayward, 42.5.

Fratt v. Woodward, 22.2.

Frederick v. Haas, 292.

Frederick v. Pacquette, 580.

Freedman v. Goodwin, 185.

Fremont v. Flower, 180.

French v. Croshy, 28.

French v. Wade, 66.

French v. Edwards, 340.

French v. Burns, 421.

Frink v. Darst, 270.

Frink v. Le Roy, 425.

Frisbie v. Whitney, 133.

Froneberger v. Lewis, 366.

Frost v. Beekman, 76, 79 .

Frost v. Dcering, 304.

Frost $\vee$ Bank, 560.

Fugate v. Pierce, 683, 684, 686, $68 s$.

Fuller v. Eddy, 420.

Fuller v. Shedd, 618.

Fuller v. Carr, 252.

Fuller v. Jillett, 2.29.

Fuller v. Feilows, 252.

Fulton v. Hill, 466 .

Fulton v. Moore, 574.

Funk v. Eggleston, 479, 481, 492, 701.

Furgeson v. Jones, 665.

Furgusen v. Mason, 279.

Furnas v, Durgin, 290.

G. B. \& M. C. Co. v. Groat, 339.

Gadherry v. Sheppird, 287.

Gage v. Reil, 64s.

Gage v. Schroder, 586.

Gaines v. Hnle, 130.

Gairity v. Ruasoll, 605.

Galawiy v. Nalchon, 440.

Gale v. Kinzie. $54,56$.

Gale v. Wilson, 290. 
Gallagher's Appeal, 491.

Galaway v. Malchon, 4:20.

Galloway v. Finley, 18:.

Galpin v. Abbott, 80.

Galpin v. Page, 541, 600.

Galt v. Galloway, 18:.

Gammon v. llodges, sl.

Gambert v. Hairt, 743,744 .

Gans v. Renshaw, 719.

Gardener r. Moore, 436.

Gardiner v. Niller, 53, 693.

Gardner v. Com. Nat. Bk., 369, 372.

Gardner v. Jaques, 34t.

Gardner v. Eberlart, 341, 57t, 577.

Gardner r. Gramnis, 240.

Gardner v. Gardner, 350.

Gardner v. Heyer, 487 .

Garland v. Britton, 5.4.

Garner v. Jones, 297.

Gamett v. Garnett, 208.

Garnsey r. Rogers, 291, 435.

Garret v. Moss, 209.

Garrett v. Lynch, 5.58.

Garrison v. Rudd, 412.

Gas Co. v. San Franciseo, 408.

Gashwiler v. Willis, 316.

Gaskill v. Balge, 79.

Gates v. Labeaume, 369.

Gates v. Caldwell, 2as.

Gates r. Preston, 530.

Gault v. Woodlirige, 562.

Gay r. Walker, 225.

Gayetty r. liethune, 52.

Gaylord v. Dodge, 27.

Gavin v. Shuman, 647 .

Geary r. Simmons, 530, 545.

Geary v. City of Kansas, 236.

Gebhart v. Reeres, $40 \mathrm{~s}$.

Gebhard v. Sattler, 686 .

Gee v. Minore, 271.

Grekie r. Kirly Co., 648.

Geer v. Mlining Co., Sl.

Georce v. Kimbll, 289.

(ierman lns. Dk. v. Nunes, 369.

Gernet v. Lymn, 472, 101.

Geyer v. Wintzel, 460 .

Gibbs v. Thayer, $272,273$.
Gibbons v. Hoag, 375, 433.

Gibson v. Chouteau, 52, 53, 693.

Gíbson v. Warden, 309.

Giesy r. R. R. Co., 64.

Gilford v. Choate, 477 .

Gigos v. Cochran, 386, 614.

Gilbert v. Claapin, 468.

Gilbert v. Holmes, 328.

Gilbert v. How, 328 .

Gilchrist v. Rea, 363.

Giles v. Lyon, 588.

Gill v. Wood, 299.

Gill v. Hoblitt, 595.

Gillett v. Gafrney, 79.

Gillett v. Neaganza, 606.

Gillilan v. Swift, 305.

Gillham v. Mustin, 496.

Gilkey v. llamilton, 358, 359 。

Gilmore v. Sapp, 177, 179.

Gilpin v. Hollingsworth, 468.

Gissey v. R. R. Co., 64.

Given v. Marr, 621.

Gierstadengen v. Van Duzen, 140.

Glading v. Frick, 83.

Gladsen v. Whaley, 602.

Gittens v. Lowry, 685.

Gleney v. Elliott, 637.

Glass v. Hurlbut, 725.

Glover v. Payn, 428.

Goddard v. Perkins, 526.

Godfrey v. Bralley, 149.

Godfrey v. Valentine, 599.

Godfrey v. Alton, 204.

Golder v. Brewster, 345.

Goodel ₹. Hibbard, 22.

Goodrich v. Lambert, 470.

Goodman v. Randall, 230.

Goodspeed v. Fuller, 215.

Goodwin v. Goodwin, 366.

Goodwin v. Baldwin, 450.

Gorham v. Arnold, 5ll.

Gorman v. Stanton, 213.

Gossard v. Fergusen, 574.

Gossett v. Kent, 210, :09.

Gossom v. Donaldson, 561.

Fondy v. Hall, 581.

Gould v. Mather, 349.

Gould v. Sternberg, 608. 
Gould v. Day, 239, 637.

Gould v. Hendrickson, 343 .

Gowan $\mathrm{r}$. Jones, 572.

Graff v. Middleton, $26 \mathrm{~s}$.

Graham v. Bleakie, 5 1.

Graham v. Graham, 49.

Grandin v. Hernandez, 232.

Granger v. Avery, 54.

Grant v. Davenport, 408.

Grant v. Fowler, 686 .

Grantern v. Rosecierrance, 598.

Gray v. Pingree, 46.

Gray v. Ulrich, 234, 236.

Gray v. Hayes, 283.

Gray v. Blanchard, 252.

Gray v. Brignardello, 568 .

Gray v. Gray, $61 \mathrm{~s}$.

Grayson v. Wedlle, 513.

Graves v. Buren, 643.

Graves v. Graves, 215.

Graves v. Coutant, 515.

Grebbin v. Davis, 545.

Green v. Liter, 179.

Green v. Blanchard, 17, 286 .

Green v. Myers, 555.

Green v. Marks, 543.

Green v. Holway, 242.

Green v. Irving, 694.

Green v. Slayter, 521, 525.

Green v. Pulsford, 708 .

Green v. Garrington, 83.

Green Bay Co. v. Hewitt, 260.

Greenby v. Kellogg, 229.

Greene v. Dickson, 25.

Greene v. Lunt, 633.

Greenleaf v. Bebee, 461.

Greenwood v. Murray, 503.

Greer v. Higgins, 76.

Grey v. Tubbs, 392.

Gridley v. Hopkins, 205.

Gridley v. Watson, 360, 534.

Gridley v. Gridley, 490.

Fridley v. Philips, 360 .

Griffin v. Ranney, 242.

Griffin v. Rogers, 367.

Giriffin v. Proctor, 332.

Griflin v. Sheffirld, 236, 258.

Griffin v. Page, 579.
Grifith v. Harvester Co., 54l.

Grignon's Lessee v. Astor, 129, 169, 583.

Grimes v. Orrand, 210, 248.

Grimstone v. Carter, 428.

Griswold v. Smith, 725.

Griswold v. Fuller, 723.

Grogan v. San Francisco, 170.

Groner v. Smith, 232.

Girout v. Townsend, 216.

Grove $v$. Cather, 518.

Grover v. llale, 348, 349, 353.

Groves v. Webler, 527.

Grube v. Wells, 683, 687.

Cirumley v. Webb, 365.

Grundies $r$ Reid, 550.

Guidry v. Woods, 136.

Guild v. Richards, 226.

Guild v. Hall, 476.

Guilford v. Love, 579.

Guion r. Pickett, 25, 333, 336.

Guiteau v. Wisely, 535.

Gulden v. O'Bryne, 387.

Gulf R. R. Co. v. Owen, 696.

Gunton v. Zantzinger, 569.

Guyer v. Wookey, 606.

Gusnn v. McCauley, 569.

Grynne v. Neiswanger, 642.

Haekett $v$. Callander, 72.5 .

Hadden v. Shoutz, 263.

Haddock v. Haddock, 608.

Hagne v. Hague, 284.

Hague v. West Hoboken, 423.

Hahn v. Kelly, 541, 579.

Hairston v. Jandon, 385.

Haldeman v. R. R. Co., 64.

Hale v. Woods, 326.

Haley r. Boston, 471.

Halifax v. Stark, 224.

Hall v. Aslıby, 288.

Hall v. Jarvis, 46, 156, 169.

Hall v. Leonard, 210, 248.

Hall v. Bumpstead, 254.

Hall v. Chapman, 583.

Hall v. Hall, 460, 503.

Hall v. Dennison, 371.

Ifall v. Gould, 512. 
Hall v. Mooring, $6 \mathrm{~S} 4$.

Hall v. MeDuff, 389.

Hall v. Law, 685.

Hall's Lessee v. Ashby, 275.

Hallahan v. Jerbert, 518.

Halloran v. Whitcomb, 50.

Halleck v. Guy, 574.

Hallett v. Wylie, 397, 399.

Hallyburton v. Carson, 494.

Hallas v. Bell, 687.

Hamelnan v. Mounto, 217.

Hamilton v. Lubkee, 357.

Hamilton v. Doolittle, 268.

Hamilton v. Valiant, 639.

Hamilton v. Wright, 400, 685, $6 \mathrm{ss}$.

Hamilton v. Boggess, 685.

Hamilton v. Porter, 460.

Hamlin v. Express Co., 466, 467 .

Hilnmond v. Gordon, 258.

Hammond v. Wells, 519.

Hancock v. Wentworth, 30 .

Hand v. Winn, 301.

Handley v. Wrightson, 473.

Hanford v. Blessing, 428.

Hannahs v. Felt, 526.

Hansen v. Eiehstaedt, 73.

Ilanson v. Armstrong, 606, 607.

Hanson v. Vernon, 627.

Happin v. Dotr, 725.

Haraden v. Larrabee, 473.

Harbeck v. Harbeck, 672.

Hardin v. Crate, 213, 239.

Hardin v. Osborne, 239, 381.

Hardin v. Jones, 608.

Hardin v. Governeuer, 6st

Harding v. Hale, 291.

Harding v. Strong, 608.

Harland v. Eastman, 671, 709.

Harlowe v. Hudgins, 278 .

Harman v. Oberdorfer, 239.

Harnage r. Berry, 695.

Harper v. Rowe, 578.

Iarpham r. Little, 560.

Harrer v. Waldner, 298, 622.

Harris Case, 291.

IInrris Estate, 656.

Ilarris v. Glem, 26.

Harris v. Lester, 417, 584.
Harris v. Douglas, 499.

Harris v. HeGovern, 695.

Harris v. Fly, 490.

Harrington v. Fish, 117, 234, 254.

Harrington v. Fortner, 436.

Harrington r. Wofford, 598.

Harrison v. Boring, 205.

Harrison v. Phillips' Acalemy, 213.

Harrison v. Simmons, 245.

Harriman v. Gray, 268.

Harryman v. Star, 569.

Harshaw v. MeKesson, 616.

Harshbarger v. Foreman, 515.

Hart v. Stone, 469.

Hart v. Chalker, 440.

Hart v. Lindsey, $5 \tilde{3} 3$.

Hart v. Smith, 643.

Hart v. Lyon, 413.

Hart v. Gregg, 325.

Hartford Ore Co. v. Miller, 306.

Harthill, In re, 375.

Hartsliorn v. Dawson, 254 .

Harrey r. Lebetter, 292.

Harvey v. Varnes, 289.

Harvey v. Sullen's Heirs, 462.

Haskill v. Serier, 436.

Hastings r. Johnson, 561.

Hastings v. Cutler, 80.

Hatch v. R. P. Co., 62, 63.

Hatch v. Hateh, 177 .

Hatch v. Bates, 217.

Hatch v. Kelly, 602.

Hatch v. Buffalo, 723.

Hatch v. Bullock, 690.

Haughwout v. Murphy, 5ะ2.

Havens v. Sherman, 558.

Haverstick's Appeal, 473.

Hawk v. MeCullough, 217, 265.

Hawkins v. Champion, 218.

Hawkins v. Hawkins, 573.

Haworth v. Huling, $54 \mathrm{~S}$.

Haworth v. Taylor, 90.

Hawley v. Northampton, 489.

Hawley v. Morse, 76.

Hayden v. Bucklin. 521, 523, 593.

Hayden v. Stoughton, 461.

Haydock v. Stow, 385.

Hayes v. Livingston, 50. 
Hayes v. Shaw, $5+2$.

Hayes v. Stiger, 5$\rceil l$.

Hajes v. Fessenden, 518.

Haynes v. Bourn, 21, 653.

Haynes v. Boardman, 689.

Hays v. Russell, 57\%.

Hayward v. Ormsbee, 126, 129.

Hayward v. Daridson, 3I3.

Hayward v. Cain, 342.

Haywood v. Collins, 526, 596.

Haworth r. Huling, 548.

Haxton v. Corse, $65 t$.

Hazel v. Hagan, 478.

Headley v. Gaundry, $45 \mathrm{l}$.

Heaton v. Fryberger, 209.

Heath v. Heath, 210.

Hect v. Spear's, 516.

Hedriek v. Hughes, I58, 694.

Heil's Appeal, 554.

Heinlen v. Heilborn, 175.

Hellreigil v. Manning, 247, 720 .

Hemingway v. Scales, 297.

Hemphill v. Davies, 133.

Hemstreet v. Burdick, 328.

Henderson v. Ford, 330.

Henderson v. Whitinger, 362.

Henderson v. Dorrning, 369.

Hendrick v. Cleveland, 589.

Hendley v. Baccus, 596.

Henly v. Hotaling, 428.

Henning v. Paschke, 248.

Henning v. Punnet, 570.

Henning v. Varner, 466.

Hensley v. Baker, 560.

Herman v. Deming, 432, 440.

Herndon v. Reed, 257.

Herrick v. Morill, $22 \mathrm{I}$.

Herrington v. Williams, 609.

Herrington v. MeCollum, 523.

Herrington v. Herrington, 522.

Hertig v. People, 417.

Hersey v. Turbett, 592.

Hess v. Voss, 591.

Hetzel v. Barber, 25.

Henser v. Harris, 472.

Heust is v. Johnson, 590.

Hewes v. Reis, 633.

Hewitt v. Week, 83.
Hewitt r. Morgan, 235.

Heyward v. New York, 64, 623.

Hickman v. Quimn, 283.

Hickox v. Greenwood, 518.

Hicks v. Skinner, 560.

Hickman v. Quinn, 283.

Hickman v. Perrin, 440.

Higbee $v$. Rice, is.

Hightower v. Rigsby, 516 .

Hightower $r$. Haudlin, 501 .

Hillreth v. Thompson, 562 .

Hiles v. Atlee, s3.

Hill v. Franklyn, 25.

Hill v. Treat, 42, 460, 513.

Hill $\checkmark$ Epley, 74.

Hill r. Miller, 17.5.

Hill v. Reynolds, 342.

Hill v. Wall, 5.56.

Hillis r. Hillis, 493.

Hilton v. Asher, 230 .

Himes v. Keighblinger, 238.

Hines v. Perkin=, 429.

Hinkley v. Greene, 32, 686.

Himman $r$. Warren, Ist.

Hinsdale r. Thornton, 342 .

Hinson v. Adrian. 617.

Hinton $\mathrm{v}$. Milburn, 473.

Hiss v. MeCahe, 256.

Hitcheock v. Merrick, 449.

Hoadley v. Stephens, 34.

Hoard v. Hoard, 583.

Hobson v. Ewan, 561.

Hoehlander v. Hoehlander, 596.

Hodgen v. Guttery, 594.

Hoffman r. Mackall, 372.

Hoftman v. Stigers, 298.

Hoffman v. Felt, 390.

Hogans v. Carrutl, 234.

Hogue v. Corbit, 559.

Holbrook v. Dickinson, 631, 635.

Holbrook v. Debo, 27I, 272, 273.

Holder v. Mount, 660.

Holdane v. Cold Spring, 291.

Holloway r. Gallway, $4 \mathrm{ce}$.

Holland v. Kreider, 26.

Holland v. Fuller, 309.

Holland v. Ilolmes, 390, 719.

Hollman v. DeNyze, 301. 
Holm v. Wust, 13.

Holman v. Gill, 341,345 .

Holmes v. Seely, 31 .

Holmes v. R. R. Co., $6 \mathrm{I}$.

Holnes v. Jarret Moon, 284.

Holmes v. Johnson, 505.

Holmes v. Carondolet, 607.

Holmes v. Sharer, 568.

Holmes v. MeGinty, 447.

Holnes v. Erans, 386.

Holmes v. Mead, 485, 487.

Hooker r. De Palos, 614.

Hooper v. Scheimer, I29, 164.

Hope v. Sawyer, 257.

Hope v. Blair, 268, 562.

Hopper's Will, 496.

Hopping v. Burnham, 562, 563.

Hopkins v. MeCann, 651 .

Hopkins v. Medley, 591.

Hoppin v. Doty, 689, 725.

Hoppough v. Struble, 461.

Hopson v. Commonwealth, 472.

Hornbeck v. Westlrook, 212.

Horner v. Zimmerman, 289.

Hosmer v. Wallace, I64.

Hosmer v. Campbell, 357.

Hot Springs Cases, 131.

Hotehkiss v. Cutting, 573, 595

IIonck v. Yates, 197.

Hongh v. Land Co., 313, 315.

Houghton r. Kendall, 472.

Houghton r. Hardenburg, 178.

Houseman v. Girard Loan Ass'n, 8, 743.

Honsley v. Lindsay, 569.

Houston v. Blackman, 217.

Honx v. Batteen, 231.

Howard v. Kennedy, 592.

Howe v. Thayer, 83, 554.

Howe v. Williams, 252.

Howe v. Hutchinson, 13.

Howe v. Howe, 288.

Howland $v$. Blake, 237.

Howland r. Cemetery Assoc'n, 695.

Howland r. Shurtleff, 450.

Ilowerter v. Kelly, 59こ.

Hoy v. Allen, 236.

Hoyt v. Kimball, 226, 287.
Hoyt v. Jaques, 328.

Hoyt v. Swar, 300.

Huber v. Huber, 299.

Huber v. Gazley, 204.

Hubbard v. Bell, 54.

Hudson v. Putney, 688.

Hudson v. Poindexter, 232.

Huebsch v. Schell, 216.

Huftalin v. Misner, 577.

Hughes v. Tabb, 350.

Hughes v. Washington, 359 .

Hughes v. Watt, 579.

Hulett r. Inlow, 297.

Huls v. Bunten, 686 .

Humbert v. Trinity Ch., 683, 687.

Hungerford's Appeal, 545.

Hunnicut v. Peyton, 686.

Hunt v. Rowley, 89.

Hunt v. Hunt, 53, 473.

Hunt v. Johnson, 216, 299.

Hunt v. Amidon, 228.

Hunt v. Bridge Co., 312.

Hunt v. Chosen Friends, 85, 671.

Hunt v. White, 463.

Hunt v. Haven, 592.

Huntt v. Townsend, 348, 352.

Hunter v. Watson, 210, 248.

Hunter v. Vaughn, 336.

Hunter v. Buckner, 441.

Hunting v. Walter, 346, 570.

Hunton v. Nichols, 695.

Hurd v. Brisner, 643.

Hurley v. Estes, 421.

Husbands v. Jones, 5⒍

Huston v. Seeley, 302.

Hutchens v. Doe, 561.

Hutchings v. Low, 130.

Hutchins v. Carleton, 266.

Hutchins v. Kimmell, 672.

Hutchinson v. R. R. Co., 265.

Hutchinson's Appeal, 554.

Hutton v. Williams, 574.

Hyam v. Edwards, 667.

Hyde v. Olds, 371.

Hyde v. Tanner, 662.

Hyde v. Warren, 447.

Hyde Park v. Borden, 408.

Hydraulic Co. v. Loughry, 532, 535. 
Ill. Land \& Loan C'o. v. Pouner, Jackson v. Leek, 215. 671.

Illinois, etc., R. R. v. Johnson, 323 .

Imp. Fire Ins. Co. v. Gumning, 589.

Ingals v. Plamondon, 728 .

In re MeLean, 7:2.

In re Fox, 490.

In re Chambers, 73.

In re Caswell's request, 73.

In re Phillips, 235.

In re Harthill, 375.

In re Lewis, 368.

In re Muller, 375.

In re Carow, 375.

In re Sands Brewing Co., 434.

Indianapolis R. R. Co. v. Ross, 688.

Ingle v. Jones, 363.

Ingle v. Culbertson, 421.

Ingraham v. Grigg, 370.

Ins. Co. v. Dake, S3.

Ins. Co. v. Walsh, 287.

Ins. Co. v. Scales, 641.

Ins. Co. v. Eldridge, 452.

Ins. Co. v. Stewart, 2S9.

International Bank r. Sherman, 376.

Irvine v. Marshall, 125.

Irving v. Brownell, 258, 683.

Irwin v. Dixon, 204.

Isett v. Stuart, 594.

Isham v. Bennington Co., 318.

Ishmeal v. Parker, 614.

Isler v. Brown, 525.

Israel v. Arthur, 583.

Ivy v. Clawson. 602 .

Jacks v. State, 350.

Jacks v. Dyer, 638.

Jackson v. Ingraham, 19.

Jackson v. Hart, 19.

Jackson v. Veeder, 25.

Jackson v. Vandorheyden, 28.

Jackson v. Alston, 77.

Jackson v. Warren, 84 .

Jarkson v. Cary, 212, 250.

Jackson v. Schoommaker, 213.

Jackson v. Bard, 213.

Jackson v. Dillon, 216 .

Jackson v. Mleyers, 218, 263.

Jackson v. Perkinis, 2:38.

Jackson v. Hudson, 268.

Jackson r. Rosvelt, 263.

Jackson v. Sisson, 284.

Jackson v. 1lenry, 289.

Jacksom v. Camploll, 316.

Jackison v. Bush, 343.

Jackion v. Hagaman, 343.

Jackson r. Jelancey, 344.

Jackon v. Merrill, 481.

Jackson $v$. Andrews, 521.

Jackson v. liobinson, 583.

Jackson r. Spink, 562.

Jackson $v$. Toung, 56:3.

Jackson v. Ifendricks, 653.

Jackion v. Biromer, fi l.

Jackson v. Berner, 6s?.

Jackson v. Woodrufi, 686.

Jackoon v. Wheat, 687.

Jackson v. Johnoron, 1989.

Jackson v. Monre, (69:3.

Jackson r. Boneham, 667.

Jackson v. Harsen, 395.

Jackson v. Delecroix, 396.

Jackion v. Allen, 396.

Jackson v. Bull, 424, 481 .

Jackion v. Roberts, 42t.

Jackson r. Deritt, 4:5.

Jackson v. Mcchenney, 428.

Jackson $v$ Robhins, 477.

Jackion v. Esty, 6tt.

Jackson v. Mlorse, 642.

Jackson v. littel. 433, 434.

Jackson v. Wnol, 450.

Jackson v. Fousel, 473.

Jackson v. IIarris, 481.

Jackson v. Jackson, 496.

Jackson v. Warren, 592.

Jackson v. Anterson, 560.

Jaekson v. Gireen, 657.

Jakkson v. Winslow, 268.

Jacoluns $v$ Sulth, 573.

James v. Moore, 17.

James v. Stiles, 244.

Janes v. Jantes, 461. 
James v. Morey, 424. Jamieson v. Hay, 476. Jamison v. Fopiana, 409. Jamison $r$. Perry, 690. Janes v. Williams, 503. Janvrin v. Fogg, 242. Jarvis v. Peck, 630. Jassey v. White, 478, 479, 701. Jecks r. Tonsing, 21. Jefferis v. Land Co., 53 Jeffers $v$. Radelifi, 4 ?. Jelks v. Barrett, 359. Jemison v. Bank, 322. Jenkins $v$. Yoltz, 25. Jenkins r. Rosenburg, 427. Jennings v. Simpson, 542. Johnson v. McIntosh, 60. Johnson v. United States, 51. Johnson v. Bantock, 217. Johnson v. Shaw, 240. Johnson r. NfeGraw, $36 \pi$. Johnson v. Montgomery, 304. .Johnson r. Corlhett, 449, 663. Johnson v. Bush, 319. Johnson v. Hubbell, 394. Johnson v. Ilouston, 420. Johnson v. Stagg, 428, 440. Jolunson r. Carpenter, 448. Johnson r. Dodge, 614. Johnson v. R. R. Co., 62. Johnson $v$ Q Quarles, 292. Johnson v. Johuson, 476. Johnson v. Schloesser. 537, 538. Johnson v. Baker, 571, 578. Johnston v. Haines, 257. Johnston v. Geisriter, 375 . Johmston v. Miendenhall, 390. Johnston v. Smith, 637. John Haneock ete., Co. v. Moore, $66 \mathrm{~s}$.

Jolliff v. Jolliff, 619. Jones v. Johnson, 55. Tones v. Roberts, 80. Jones v. Meyers, 131, 136, 164. Jones v. Martin, 258. Innes v. R. R. Co., 201. Jones v. Franklin, 229. Jones v. Monroe, 211.
Jones v. Clifton, 296.

Jones v. Carter, 326.

Jones v. Scott, 339, 341 .

Jones v. Wood, 383, 480.

Jones v. Brewer, 388.

Jones v. Bacon, 477.

Jones $\because$. Doss, 515.

Jones r. Lapham, 517.

Jones r. Porter, 550.

Jones r. Patterson, 695.

Jones v. Gardner, 719.

Jones $v$. Jenkins, 727.

Jones v. Devore, 631.

Jones' Estate, 553.

Jordan v. Bradshaw, $3 \notin 1$.

Josepli r. Biglow, 213.

Joy v. Berdell, 606.

Jumel v. Jumel, 291.

Kane v. Whittick, 544.

Kansas v. R. R. Co., 321.

Karnes v. Harper, 547.

Kaufman v. Whitney, 299.

Kayser v. Heavenrich, 369.

Kean v. Ash, 605.

Kearney v. Vaughn, 264.

Kearney v. Post, 401.

Keating v. Keating, 319 .

Keegan v. Geraghty, 39, 41, 658, 665.

Keeler v. Keeler, 590.

Keemle v. Conrad, 550.

Keen v. Preston, 367.

Keith v. Keith, 341.

Kelley v. Bourne, 211.

Kelly v. Hendricks, 50.

Kelly v. McGuire, 671.

Kelly v. Transportation Co., 315.

Keller v. Brickey, 169.

Kellett v. Shepard, 407 .

Kellogg v. Hale, 332.

Kemp v. Cook, 543.

Kenredy v. Municipality No. 2, 56.

Kennedy r. Kennedy, 473.

Kennedrs v. Penple. 595.

Kennedy v. Taines, 364.

Kent v. Teleh, 228.

Kent $\nabla$. Cantrall, 274. 
Kent v. Itlantic DeLaine Co., 279, 281.

Kenyou v. See, 2:2.

Kenzie r. lirleson, 4 lit.

Kerfoot v. Cronin, 114, 224.

Kerr v. Doumherty, 461.

Kerr v. Birnie, 2:39.

Kerr v. Hitt, 695.

Kerr r. Agrart, 42t.

Ketehmm v. R. R. Co., 336.

Kidler v. Abolt\%, 518.

Kille v. Jyye, 2239.

Kimball v. Blaisde!l, 273.

Kimm v. Weipurt, 296.

Kincial v. Dormey, 89.

Kincaid v. Tutt, 5\%:.

King r. Rea, 219, 302.

King v. Whiton, $3: 39$.

King v. Ruckinam, 384, 387.

King v. Y. M. Ass'll, 515.

King v. Kent's heirs, 581.

King v. Llood, 595.

King v. Goodwin, 560.

Kingman v. Barton, $37 \mathrm{I}$.

Kinsley v. Ames, 446.

Kinsman v. Loonis, 268.

Kirlyy v. Runits, 540, 547.

Kirk v. Burlioltz, 218.

Kirk v. Vanber. 343.

Tirkaldie r. Larrabee, 48.

Kirkland r. Cox, 392. 334.

Kirkpatrick v. Chestnut, 491.

Kirtz r. Belrensmeyer, 554.

Kister v. Reeser, 224.

Kleppner r. Laverty, 472.

Knapp v. Brown, 518.

Kneeland v. Van Valkenburgh, 249.

Knight v. Waterman, 370.

Knight v. Wahoney, 483.

Knotts v. Stearns, 570.

Knox v. Prady, 302.

Knox v, Leidgen, 691.

Knox v. Cleveland, 647, 649.

Knox v. Baton Rouge. 605.

Knox v. Jones, 48.

Knehler v. Boll, 568. 573.

Koelle v. Kneeht, 412.
Korn v. Cutler, 473.

Kostenboder v. Spotts, 571 .

Krant v. Crawford, 53.

Kreichbaum v. Netton, 433.

Kruger v. Knob, 6;13.

Kruse v. Wilson, 22:3, 260, 342, $341,685$.

Kruse v. Scrips, 89.

Frunou v. Kruson, 605.

Kurtz v. Hibner, 464.

Kurtz r. Sponable, 447.

Kyle v. Kavanagh, 389.

La Framboise r. Crow, 28, 305.

La Plante v. Lee, 362.

Laberee v. Carleton, :216.

Lateey v. Daris, 643.

Ladd v. Inarrey, 460.

La Plante v. Lee, 362.

Laird v. Boyle, 399.

Lake v. Gray, 64l.

Lallerstedt v. Jemning, 460.

Iamar Co. r. C'Iments, 204.

Lamar v. Turner, 224, 340.

Lambert v. Livingston, 546 .

Lametti r. Anderson, 399.

Lammers v. Nissc11, 53, 54, 197.

Lamb v. Davemort, 135.

Laml) r. Wakefeld, 229, 283.

Lambert r. Smith, 217.

Lampman v. Milks, 727.

Lamprey v. State, 197.

Lancaster v. Wilson, 592.

Land $r$. Keirn, 471, 4SI.

Landts v. Brant, 343.

Lane v. Soulard, 209.

Lane v. Debenham, 349.

Lane r. (ionll, 686 .

Lanfair v. Lanfair, $4: 28$.

Lang v. Phillips, 5:36.

Langdon v. New York, 183.

Langsdale v. Mills, 567 .

Langdean v. IIanes, 169, 161, 169.

Lain v. Cook, 64t.

Lanier v. Toochl, 30.

Lansing $v$. Smith, 187.

Laramore v. Minish, 682. 
Large v. Fisher, 644.

Lassell v. Powell, 558, 556.

Lash v. Hardick, 535.

Lash v. Lash, 622.

Latham v. Smith, 242.

Lathrop v. Brown, 532.

Lawe $\checkmark$. Hyde, 212.

Lathrop v. Am. Emig. Co., 545.

Latta v. Tutton, $5+1$.

Lattin v. Gillette, $8,10$.

Laughlin v. Fream, 217.

Laverty v. Noore, 687 .

Lawe v. Hyde, 212.

Lawrence's Will, 496.

Lawrence v. Farley, 238.

Lawrenee v. Ball, 450.

Lawrence v. Belger, 532.

Lawrence v. Fast, 538.

Lawrence v. Englesby, 555.

Learned v. Welton, 349.

Leavell v. Poore, 5:3.

Leazure v. Hillegas, 313.

Le Beau v. Armitage, 59.

Lee v. Ruggles, 609.

Leeming v. Sheratt, $4 \mathbf{i 6}$.

Leese v. Clark, 181.

Leferre v. Leferre. 487, 488.

Legget v. Doremus, 24 .

Leitch r. Wells, 84, 521, 5!2, 593.

Leiter $\because$. Sheppard, 22.

Leland v. Wilson, 339, 341.

Lenox v. Clark. 341, 579.

Leonard v. Diamond, 334.

Le Frane v. Richmond, 232.

LeRoy v. Jamison, 175, 178, 180.

Leupold v. Kruse, 26.

Levi $\vee$. Thompson, 155.

Lery v. Levr, 657.

Levy v. Griffiths, 478.

Lewis v. Aylott, 459.

Lewis v. Owen, 549.

Lewis $v$ Marshall, 85, 667.

Lewis $v$. Darling, 491.

Lewis r. Overby, 232.

Lewis' Appeal, 47.

Jiddel v. MeVickar. 662.

Life Ass'n of Ameriea v. Fassett, 542.
Life Ins. Co. v. Norton, 67.

Life Ins. Co. v. Smith, 315.

Life Ins Co. v. White, 321.

Lick v. Ray, 724 .

Light v. West, 640 .

Liles v. Woods. 598.

Lindsey v. Bates, 516.

Lindsey v. Thompson, 47.

Lines $v$. Lines, 334.

Linker v. Long, 278 .

Lillard $v$. Ruckers, 283.

Lilly v. Palmer, 425.

Lirette v. Carrane, 538.

Litehfield v. Burwell. 597.

Little v. Harrey, 534.

Little v. Paddelford, 13.

Littlejohn v. Egerton, 24.

Littleton v. Giddings, 74 .

Liringstone r. MeDonald, 257.

Lloyd r. Bunce, 22.2.

Locke r. Caldwell, 450.

Lockett $v$. James, 28.

Lockwood v. R. R. Co., 54.

Lockwood r. Sturderant, 360

Logan r. Steel, 49.

Logansport v. Dunn, 204.

Lombard v. Culbertstand, 83.

Lombard v. Sinai Congregation, 323.

Long v. Hewitt, 39.

Long $\mathrm{v}$. IVagoner, 220 .

Long v. Shelby Co., 404.

Long v. Mostrn, 438.

Long v. Weller, 5il.

Long v. Barker, 589.

Long v. Linn, 608.

Long v. Burnett, 644.

Loomis v. Piler, 593.

Looney r. Adamson, 303.

Lorrillard r. Conter. 489.

Loughridge v. Bowland, so.

Loving v. Paire, 372.

Lovering $v$. Allen, 493.

Lovingston $v$. St. Clair Co., 54.

Low v. Graff, 247 .

Lowry r. Davis. 440.

Loyless v. Blackshear. 283.

Lucas v. Harris, 451. 
Luce v. Durham, 463.

Lum v. MeCarty, 69, 73.

Luppie v. Winans, titis.

Lupton v. Lupton, 491.

Lyon v. Vannatta, 364.

Lyon v. Ifunt, 64:2.

Lyon v. Marsh, 478.

Lyon v, Kiain, 244, 5.54, 652.

Lytle r. Arkanmas, $13 \mathrm{I}$.

Lytle v. Beveridge, 462 .

McAlister v. Iutterfield, 463.

McAllister v. Plant, 446.

McAllister v. McAllister, 487.

McArthur v. Browler, 18\%.

MeAusland v. Pundt, 558.

McBane v. Wilson, 532.

MeCabe v. Ramey, 50.

MeCabee r. Mazzuchelli. 188.

McCall v. Niely, (65:)

MeCardia v. Billines, 254, 256.

McCartrey v. Kittrell, 539.

MeCarty v. Carter, 518.

McCartney v. King, 560 .

Mechesney v. Brown's Heirs, 296.

McCready r. Sexton, tit3, 64\%.

Mclean r. Mr'Be:n, 660.

NeClellan v. Darrah, 614.

McClellan v. Kellogr. 683.

McClintic v. Ocheltree, 296.

NaClintock v. Rogers, 89.

McClure v. Burris, 448.

McClurg v. Phillips, 436.

McClurken v. Logan, 519.

MeClurken v. Detrich, 614.

MeCombie v. Daris. 519.

McConnell v. Smith, 362, 470.

MeConville v. Howell, 657 .

McCoraher v. Commonwealth, 119.

MeCormick v. Sullivant, 34 .

NeCormack v. Patchin, 628.

McCormick v. Huse, 198.

MeCowan v. Foster, 581.

MeCoy v. Norrow, 662 .

McCracken v. San Francisco, 409.

MeCraney v. McCraney, 304.

MeCurdy v. Canning, 297 .

McDermid v. Russell, 595.
McDonald $v$ Gregory, 48.

McDonald v. Life lns. ( $0 . .570$.

McDonald v. Edmonds, 164.

AcDonald v. liear liver Co., 326.

McDonald v. Smalley, Is:.

McDurf v. Beauchamp, 297, 298.

MeFarland v. Febiger, 304.

Mcllany v. Schenk, 572.

Nctian v. OXeil, 602.

McGarrahan v. Mining Co., 175, 179.

Mcrinty ve MeGints, 334.

McGoon v. Scales, 34.

McGowan v. Mlerowan, 366.

Medraw v. Bayart, 59 I.

Mefirew v. Mecirty, 518.

Medinie v. Tan Pelt, 447.

Moruire $r$. Stevens, 356.

MeIntyre v. Storey, 58.

MeIntyre v. Mintyre. 605.

MeIntire v. Benson, 370.

Melver v. Walker, 183.

MeKinney r. Stewart, 39.

NeKinney v. Settles, 218.

McKinzic v. Steele, 50.

Mclane r. Bo:ce. 130.

McLangan v. Brown, 5\%0.

MeLanghlin v. MeLauglhlin, 496.

MeLaughlin v. McCroby, 597.

MeLaughlin $\mathrm{v}$. Thompon, $63 \mathrm{l}$.

MeLaughlin r. Ilmsen, 441.

MeLaurie 8 Partlow, 334.

McLean $\mathrm{r}$. In re, 7.2 .

MeLean v. MeBean, 661.

McLouth v. Hart, 79.

MeMicken v. L. S., 125.

Mc.Millan v. Warner, 26.

Medillan v. Eilwards, 344.

McMullen v. Lank, 348.

McNab v. Young, 720.

MeNeil v. Kendall, 402.

McPherson v. Rollins, 453.

MeQuidiy v. Ware, 692.

MeQuie r. Pcaș, 436.

MeVey v. MeQuality, 324, 427.

MeWhorter v. MeMahon, 386 .

Mabury v. Ruiz, 617.

Nachemer, Estate of, 492. 
Mack v. Brown, 596.

Mack v. Wetzler, $4 \geq 0,449$.

Mackay v. Bloodgood, 233.

Mackie v. Cairns, 369.

Mackie v. Story, 463.

Madden v. Barnes, 515.

Magee v. Mellon, 340 .

Maghee v. Robinson, 725.

Magruder v. Esmay, 130.

Magness v. Arnold, 256.

Magill v. Hinsdale, 326.

Magnolia v. Marshall, 54.

Magruder v. Esmay, 130, 163.

Mahar v. O'Hara, 460.

Mahoney v. Middleton, 607.

Main v. Cumston, 413.

Mandeville v. Welch, 386.

Marcom v. Allen, 435.

Mallory v. Fergusen, 11 .

Miallory v. Mallory, 292.

Mallony v. Horan, 28, 50, 304.

Manderschid v. Dubnque, 204 .

Mangold v. Barlow, 79.

Mangue v. Mangue, 672 .

Mann v. Best, 269.

Manley v. Gibson, 205.

Mansfield v. Moaglind, 561.

Mapes v. Seott, I65.

Marden v. Chase, $26 s$.

Markwell v. Thorne, 504.

Mirkoe v. Anrlias, 510.

Marling v. Marling, 6It.

Marsh v. Chestnut, 635 .

Marsh v. Griffin, 689.

Miarshall v. Narshall, 602.

Marshall v. Roberts, 268.

Narshall v. Rose, 651.

Marshman v. Conklin, 549.

Martin v. Ry. Co., 286, 321.

Martin v. Wyneoop, 366.

Martin v. Martin, 292.

Martin v. Beasley, 360.

Nartin v. Kirby, 476.

Martin v. Dryden, 512.

Mlartin v. Williams, 555.

Martin v. Juld, 719.

Martin v. Zellerhaeh, 50.

Martindale v. R. R. Co., 313.
Martinez v.' Vives Succession, 665.

Marvin v. Smith, 28, 305, 334.

Marvin v. Dutcher, 602.

Marx v. Hawthorn, 6+2.

Matney v. Graham, 343.

Matthews v. Skimner, 310.

Matthews v. Eddy, 573.

Matthews v. Demerritt, 726 .

Mattis v. Robinson, 600 .

Mattocks v. Brown, 279.

Mattox v. Hightshue, 50, 306.

Mash v. Russell, 438.

Mason v. Osgood, 363.

Mason v. Gray, 422.

Mason v. Ainswortl, 449.

Mason v. Brock, 209, 258.

Mason v. Jones, 463.

Massie v. Watts, 608.

Massingill v. Downs, 533, 535.

Masterson v. Cheek, 239.

Mastin v. Halley, 254.

Maunday v. Vail, $546,549$.

Manl v. Rider, 79.

Maurior v. Coon, 343.

Maurr v. Parish, 58I.

Maxwell v. Hartman, 83.

Maxwell v. Jonesbro, 404.

Maxwell v. Stewart, 538.

May v. Baker, 526.

Maxbury v. Ruiz, 617.

Mayo v. Libby, 46, I69.

Mayo v. Wood, 48.

Mayo v. Foley, 341.

Meade v. Jeunings, 472.

Meach v. Fowler, 213.

Meaeham v. Steele, 569.

Meachan v. Williams, 76 .

Meader v. Norton, 59.

Meagher v. Thompson, 327.

Mears v. Howarth, 589.

Meehanics Bld. Assn. v. Whitacre, 8.

M. E. Church v. Hoboken, 57.

Methodist Church v. Chicago, 634.

Meek v. Bunker, 562.

Meeker v. Meeker, $2 \mathbf{I} 5$.

Meetze v. Padgett, 576.

Mehan v. Williams, 517, 726. 
Megerle v. Ashe, 133, 157.

Melia v. Simmons, 582.

Melvin v. Waddel, 69t.

Melvin v. Clark, 596.

Melvin v. Whiting, 53, 692 .

Menage v. Burke, 211.

Mendenlall v. Treadway, 458.

Meredith v. Little, 546.

Merriam v. Dovey, 643.

Merrick v. Mlerrick, 466 .

Merrick v. Hutt, 526 .

Merrill v. Bickford, 491.

Merrill v. Emery, 478.

Merrill v. Burbank, 216.

Merrill v. Burbank, 409.

Merrill v. Hutchinson, 268, 269.

Merrill v. Montgomery, 316, 597 .

Merritt v. Merritt, 25.

Merritt v. Disney, 218.

Merritt v. Brantly, 481 .

Messerschmidt v. Baker, 577.

Metcalfe v. Brandon, 239.

Mejer v. Graeber, 435.

Meyer v. Fegaly, 553, 554.

Meyer v. MeDougal, 662.

Meyers v. Buchanan, SI.

Meyers v. Croft, 130, I31.

Meyers v. Ladd, 223.

Meyers v. Reed, 297.

Meyers v. Anderson, 469.

Meyers v. Rasback, 588.

Meyers v. Tyson, 535.

Middleton v. Smith, 219.

Middleton v. Findla, 231.

Middleton Sav. Bk. v. Bacharaeh, $560,637,638$.

Milford v. Worcester, 669 .

Millard v. MeMullen, 692.

Miller v. Bledsoe, 654, 660.

Miller v. Mills, 596.

Miller v. Ruble, 230.

Miller v. Ware, 264.

Miller v. Thompson, 290.

Miller v. Corey, 384.

Niller v. Flournoy, 466.

Miller v. Ilandy, 578, 594.

Miller v. Sherry, 521, 523, 525.

Nliller v. Aldrich, 434.
Miller v. Wilson, 343, 560.

Miller v. Ewing, 268.

Miller v. Marx, 26.

Miller v. Lapham, 31.

Miller v. IVilliams, 36 .

Mliller v. Hepburn, 55.

Millett v. Pease, 596, 597.

Millikan v. Patterson, 643.

Mills v. Hoag, 544.

Niltmore v. Miltmore, 621.

Miner v. Brown, 299.

Miners Ditch Co. v. Zellerbach, 316.

Mines v. Mines, 79.

Mining Co. v. Herkimer, 312.

Minnesota, ete., Co. v. MeCrossen, $3: 8$.

Minot v. R. R. Co., 629 .

Mirfitt v. Jessop, 469.

Mitchell v. Pettee, 49.

Mitchell v. Mitchell, 279.

Mitehell v. Schoonover, 536.

Mitchell v. Haven, 340.

Mitchell v. Burnham, 448.

Mitchell v. Wood, 531.

Mitchell v. Robertson, 607 .

Mitehell v. Nilliams, 627 .

Mitchell r. Bartlett, 237.

Mix r. French, 66I.

Moffat v. Carrow, 4\%2.

Moffitt v. Moffit, 581, 583.

Mohr v. Tulip, 5s1, 584.

Moiston v. Hobbs, 229.

Moingona Coal Co. v. Blair, 695.

Monaghan v. Small, 571.

Momroe v. Jones, 473.

Montague r. Dawes, 356, 446.

Montgomery v. Johnson, 222, 581.

Montgomery v. Dorion, 326 .

Montz v. Iloflman, 299.

Moody v. Fislar, 515.

Moody v. Moody, 683.

Mooers v. White, 494.

Mooney v. Cooledge, 225.

Noore v. Jordan, 134.

Noore v. Wilkinson, 160.

Noore v. Robins, 175.

Nonre v. Moore, 242.

Noore v. Simmons, 284. 
Moore v. Pickett, 415.

Moore v. Wade, 426.

Moore v. Cornell, 447

Moore v. Neil, 56j.

Moore v. Alderman, 623.

Moore v. Burrows, 663.

Moore v. Chandler, 652.

Noore v. Lyons, 476.

Moore v. Giles, 238.

Moore v. Snow, 180.

Moran v. Dillehay, 462, 472.

Moran v. Palmer, 179.

Morano v. Shaw, 8.

Moreland $v$. Lawrence, 590.

Morgan v. Curtenius, 134.

Morgan v. Clayton, 228, 267.

Morgan v. Bergen, 385.

Morgan v. Pope, 477.

Morgan v. Bause, 560.

Morgan v. Hammett, 425.

Morice v. Bishop of Durham, 486.

Morley v. Daniel, 279.

Morrill v. Chapman, 130.

Morrill v. Noyes, 439.

Morrill v. Graham, 744.

Norris v. Candle, 210.

Morris v. McMorris, 242.

Morris v. State, 417.

Morris v. Robey, 559.

Morris v. Halbert, 677.

Morris v. Turnpike Road, 63.

Morris v. Hogle, 571, 583.

Morrison v. Caldwell, 48, 213.

Morrison v. Rossignol, 399.

Morrison v. Kelly, 74.

Morrison v. Seybold, 298.

Morrison v. King, 727 .

Morrison v. Silverburgh, 595.

Morrow v. Weed, 581.

Norrow v. Whitney, 59, 161.

Morton v. Greene, 606.

Moseley v. Mastin, I17.

Mosley v. Wingo, $50 \mathrm{I}$.

Moss v. Atkinson, 385.

Moughon v. Masterson, 437.

Moulton v. Macarty, 551.

Mounce v. Beyers, 389.
Mount Pleasant v. Breese, 404.

Mountour v. Purdy, 563.

Mowry v. Crocker, 373.

Mulford v. Beveridge, 364 .

Mulford v. Peterson, 447.

Mullanphy Savgs. Bank v. Schott, 321.

Mullins v. Aiken, 570 .

Mullins v. Sparks, 596.

Mumford v. Whitney, 32.

Munday v. Vail, 546.

Mundorf v. Howard, 394.

Murdock v. Ward, 473.

Murfree v. Carmack, 536.

Murphy v. Mayor, ete., 722.

Murphy v. McGrath, 417.

Murplyy v. Hendricks, 432.

Murry v. Blackledge, 211.

Murry v. Lyburn, 522.

Musgrove v. Bonser, 80 .

Nushlitt v. Silverman, 516, 519.

Musick v. Barney, 80.

Musser v. Hershey, 186.

Myler v. Hughes, $5 \mathbf{4 5}$.

Myer v. Ladd, 223.

Nash v. Towne, 291.

National Bank v. Jaggers, 551.

Neal v. Nelson, 248.

Neal v. Speigle, 516.

Negbauer v. Smith, 222.

Neff v. Pennoyer, 579.

Neiswanger v. Gwyne, 632

Nellis v. Lathrop, 690.

Nelson v. Ferris, 447.

Nevius v. Gourley, 4SI.

Newell v. Nichols, 668.

Newcomb v. Presbrey, 228.

Newcomer v. Wallace, 360.

Newman v. Jenkins, 666.

Newman v. Fisher, 374.

Newman v. Willetts, 504.

Newton v. Fisher, 73.

Newton v. MeKay, 211, 212.

Newsom $v$. Thompson, 283.

Neufville v. Stewart, 415.

Nichols v. Nichols, 143. 
Nichols v. Postlethwaite, 491.

Nichols v Mitcheil, 581.

Nicholson v. Caresis, 217, 208.

Nicol v. R. R. Co., 623 .

Niles v. Sprague, $669,671$.

Nixon v. Downey, 598.

Noland v. Barrett, 568 .

North v. Belden, 440.

North v. Knowiton, 440.

Norton v. Kearney, 370.

Norton v. Reardon, 568.

Norton v. Dow, 595.

Norris' Case, 374.

Norris v. Thompson's Heirs, 486.

Nowlin v. Reynolds, 685.

N. W. Iron Co. v. Mead, 614.

Oakes v. Williams, 531.

Oaksmith v. Johnson, 694.

Oates v. Beckworth, 693.

O'Brien v. Perry, 129.

O'Brien v. Gaslin, 573.

Ochoa v. Miller, 343, 502.

Ochiltree v. MeClurg, 215.

Odd Fellow's Bank v. Banton, 441.

Odiorne v. Wade, 5:.

Odell v. Montross, 422, 426, 511.

Odle v. Odle, 593.

O'Gara v. Eisenlohr, 666.

Ogden v. Jennings, 31 .

Ogden v. Walters, 255.

Ogden v. Walkers, $44 \mathrm{I}$.

Okeson's Appeal, 490.

Oleott v. Rohinson, 563.

Olds v. Cunmings, 448, 449.

Oliver v. Crosswell, 614 .

Oliver v. Robinson, 630.

Oliver v. Pratt, 268.

Oliver v. Craswell, 614.

Olney v. Hall, 484.

Olson v. Merrill, 54.

Ommanny v. Butcher, 486.

Or. \& Wash. Trust Co. v. Shaw, 426.

Orendorff v. Stanberry, 595.

Ormshy v. Terry. 570.

ORourke v. O'commer, (699.

Orrick v. Bochm, 492, 493.
Orr v. O'Brien, 503.

Osborn v. Adams, 34.

Ostrom v. Curtis, 390.

Osterberg v. Lnion Trust Co., 63I.

Osguod r. Blackmore, 564.

Osgood v. Abbott, 226.

Oswald v. Gilfert, 399.

Ottawat r. Spencer, 623.

Overseers v, Sears, 315.

Owen v. Baker, 257.

Owen v. Williams, 279 .

Owen r. Reed, 352.

Owen r. Narasota, 559.

Owens v. Mins. Soc., 487.

Oxley v. Lane, 466.

Oxnard r. Blake, 238.

Packard r. Ames, 226.

Padgett $r$. Lawrence, 211.

Page v. Rogers, 33.

Page v. Palmer, 226.

Page v. Greely, 391.

Page v. Trutch, 744.

Paige v. Chapman, 449.

Paige v. Foust, 474.

I'almer v. Palmer. 289.

Palmer v. Ford, 2287.

Panmyra v. Morton, 405.

Panola Co. Silp. v. Gillen, 5ls.

Parion v. Drire, 596.

Paris v. Mason, 63.

Parish r. Ward, 657.

Park Comm ira v. Armstrong, 64.

Parker v. Foy, 216.

Parker v. Scxton, 633.

Parker v. Parker, 466.

Parker v. Parulee, 390.

Parklurst v. Race, 592.

Parks v. Irall, 422.

Parks v. P'arks, 463.

Parks r. Jackion, 525.

Parkinton v. Trousdale, 523.

Parmley v. Buckley, ass.

Tarrat r. Noligh, 5ti9.

Pilredt v. Slathlut, 80, 233.

Pursel r. Stryker, 400.

Jatusell v. Thityer, $4+1$.

Parsley r. Nielıolson, 549. 
Parsons v. Noggle, 423, 511.

Parsons v. Wells, 615.

Parsons v. Hoyt, 522.

Parsons v. Commissioners, 146.

Passmore's Appeal, 476.

Pateh v. White, 466.

Pate v. Bushong, 22, 465.

Patterson v. Swallow, 493.

Payson v. Hadduck, 661.

Peabody v. Hewitt, 245.

Peabody v. Brown, 211.

Peak v. Wendel, 129.

Peak v. Ligon, 546.

Pearse v. Pearse, 708.

Pearson v. Bradley, 565.

Pearsons v. Tueker, 519.

Pease v. Pilot Ínob I. Co., 701.

Peay v. Little Rock, 628.

Peck v. Arehart, 264.

Peck v. Clapp, 725 .

Peckham v. Haddlock, 263, 472.

Pegues v. Warley, 689.

Peine v. Weber, 310.

Pendleton v. Button, 236, 258.

Pennock's Estate, 488.

Pensonneau v. Bleakler, 326.

People v. R. R. Co., 54.

People v. Lineolı Pk. Comrs., 187.

People v. Marshall, 627.

People v. Bradley, 628.

People v. Biggins, 634, 635 .

People v. Snyder, 237, 239.

People v. Gates, 242.

People v. Herbel, 276.

People v. Livingstone, 19.

People v. Conklin, 65.

People v. Ferry Co., 186.

People v. Morrill, 186.

People v. Brislin, 545.

People v. Manran, 623.

People v. Gillert, 693.

People v. Reat, 634.

People v. Berval, 596.

People v. Riehards, 69, 73.

People v. Circuit Judge, 364.

Peoria r. Darst, 263.

Pepper v. O'Dowd, 687.

Perkins v. Dibble, 341.
Perkins v. Pitts, 451.

Perkins v. Swank, 689, 725.

Perry v. Big Rapids, 14.

Peter's v. Spillman, 461 .

Peters v. Phillips, 386.

Petition of Bateman, 303.

Petersine v. Thomas, 545.

Peterson v. Clark, 428.

Pettibone v. Griswold, 432.

Pettibone v. Hamilton, 605 .

Pettit v. Black, 502.

Pettit v. Cooper, 545.

Peugh v. Davis, 420, 427.

Peyton v. Jefiries, 29.

Phelps r. Simons, 298.

Phelps v. Curtis, 369.

Phillips v. Stevens, 397.

Phillipsburgh v. Bureh, 461.

Pick v. Strong, 505.

Pickering v. Langdon, 466.

Piel v. Brayer, 559.

Pieree v. Milwaukee, 439.

Pierre Mutelle ease, 178.

Pike v. Galvin, 423.

Pike v. Brown, 290, 395.

Pike v. Wassell, 66.

Pillsubury r. Mitelell, 229.

Pillsbury v. Kingon, 368.

Pingree v. MeDuffe, 30, 727.

Pingree v. Watkins, 267.

Pinney r. Fellows, 689, 725.

Pitts v. Singleton, 358.

Pitts v. Mesler, 502.

Plater v. Cunningham, 400.

Plumb v. Tubls, 286.

Poe v. Hardie, 25.

Pollock v. Buie, 555.

Pollock v. Maison, 450.

Pollard v. Hogan, 185.

Pomeroy v. Stevens, 77, 725.

Pool v. Potter, 328.

Pope r. Cutler, 503.

Poplin v. Mundell, 90.

Port v. Port, 672.

Porter v. Snllivan, 272.

Porter v. Purdy, 5s:.

Porterfield v. Taliaferro, 661.

Post v. Kearney, 399. 
Potter v. Stevens, 447.

Potts v. Dalvellport, 26, 577.

Powell v. Smith, 4.25.

Powell v. Knox, 53:3.

Powell v. Rogers, j‡6, 561.

Power v. Cassidy, 486.

Powers v. Jackson, 199.

Powder Co. v. Loomis, 517.

Pratt v. Pratt, 423.

Prescott v. Morse, 363.

Preston v. Morris Case Co., 447.

Preston v. Van Gorder, 631.

Prettyman v. Barnard, 548.

Prettyman v. Wilkey, 265.

Pribble v. Hall, 303.

Price v. Osborn, 302.

Prim v. Rabateau, 589.

Pringle v. Dunn, 83, 236.

Pritchard v. Brown, 724,726 .

Proctor v. Bigelow, $67 \mathbf{l}$.

Prouty v. Nather, 340.

Provenchere's Appeal, 473.

Providence $v$. Adams, 48 .

Pronst r. Meadows, 589, 590.

l'ryor v. Downes, 583.

l'ugh v. llolt, 42.2, 4.28.

Pullan v. R. R. Co., 310.

Putnam v. Bicknell, 211, 296.

Pryor v. Downes, 583.

Pynchon v. Sterus, 260.

Quimby v. Conlan, 602.

Quinn v. Kenyon, 134.

Quinn v. Rawson, 416.

Racine v. Emerson, 206.

Raines v. Walker, 239.

Raley r. Guinn, 643.

Ramsdell v. Ramsdell, 477.

Pand v. Sanger, 475.

liand v. Meir, 477 .

Randall v. Edert, 164.

Randall v. Songer, 599.

Randolph v. Land Co., 333.

Randolph v. Carlton, 526 .

Randolph v. Metcalf, 538 .

Randolph r. State, 70 .

Rankin v. Miller, 364.
Rannels v. Rannels, 68T.

Rathgerber v. Dupy. 392.

Rawles v. Jackson, 562 .

Rawson r. Fux, 686 .

Ray v. Thompson, 534.

Rayburn v. Kuhl, 643.

Raymond $v$. Halder, 691.

Read v. Cather, 488.

Reasoner v. Markley, 439 .

Redden v. Miller, 6S9, 724 .

Reddick v. Bank, 599.

Redfield Mfg. Co. v. Dysart, 217.

Reed r. Ash, 305.

Reed v. Jones, $38 \vec{r}$.

Reed v. Dradley, 317.

Reed v. Pelletier, 369.

Reed r. Lukens, 384.

Reed r. Reed, 476, 489.

Reed's Appeal, 531.

Rees v. Chicago, 204.

Reeves v. Kimball, 388.

Reid ғ. Heasley, 343.

Reid v. Shergold, 701 .

Reinders v. Kappelmann, 4 .

Reinhast v. Schuyler, 634.

Remington $v$. Lintlicum, 574.

Rhienstrom v. Cone, 242.

Rex v. Matherseal, 502.

Reynolds v. Harris, 577.

Reynolds v. Schmidt, 5SI.

Reynolds r. Scott, 42l.

Rice v. R. R. Co., 170.

Rice $r$. Kelso, 440 .

Rice v. Bunce, 50.

Rice v. Lumles, 621.

Rich v. Doane, 422.

Richards v. Green, 26.

Richards v. Miller, 468, 472.

Richards v. Bent, 229 .

Richards v. Crawford, 427.

Richardson v. Thompson, 595.

Richardson v. Clow, 216.

Richardson r. Wicker, 559.

Richeson v. Craw ford. 514.

Richmond v, Gray, 17.

Riddle v. Bush, 341, 562.

Ridgeway v. Holliday, 690. 
Ridgeway's Appeal, 553.

Rigg v. Fuller, 692.

Riggin v. Love, 224, 2283.

Riggs v. Boylan, 81 .

Rigney v. Chicago, 62.

Rigor v. Frye, 32.

Rindge v. Baker, 41:.

Rines v. Mannfield, 260.

Ringhonse r. Keever, 659.

Ripley v. Harris, 441.

Ripley r. Gage Co., 518.

Ritchie v. Griffiths, 83.

Rivard v. Gardner, 548.

Rivers v. Thompson, 630, 635 .

Rix v. Smith, 55.5.

Roane v. Baker, 536.

Rolins v. Bunn, 135.

Roherts v. Clelland, 57.

Roberts v. Roberts, 366 .

Roberts r. Bassett, 390, 719 .

Roberts v. Stowers, 598.

Robertion v. Wellsville, 58.

Robertson v. Guerin, 340.

Robertson v. State, 6r2.

Robinion v. Douthitt, 48.

Robinson v. Swift, 590 .

Rohin-on v. Je Grand, 468.

Robinson v. Bates. 2S.

Rohinonon v. Payne, 224.

Robinson v. Eagle. $297,298$.

Rockwond v. Darenport, 537, 538.

Roche v. Ullmann, $413,414$.

Roderigas v. Sarings Institution, 582.

Rodgers v. Bell, 607.

Rodgers v. Bomner, 533.

Pogan v. Walker, 226.

Rogers v. Clemmans, 134.

Pogers $\checkmark$ Green. 595.

Rogers r. Sinsheimer, 413.

Pogers v. Renslaw, 26.

Rollin v. Cross, 5l9.

Follin v. Pickett, 2.51, 263.

Rooker r. Perkins, 53.

Rnce $v$. Talunton, 217.

Rosebonm v. Masher. 370 .

Roseboom r. Rocelonom, 477.

Rosenthal r. Renick, 513.
Rosenthal v. Maylughh, 325.

Ross v. Ross, 41.

Ross v. Sadgbeer, 216.

Ross v. Faust, 54.

Ross v. Barclay, 363.

Ross v. Worthington, 233.

Ross v. Barland, 632.

Roth v. Michalis, 332.

Tiotligerber v. Dupy, 516, 519.

Rowe r. Becker, 228, 267.

Rowley v. Beerin, 257.

Rowley v. James, 519.

Rowlings v. MeRoberts, 281.

R. R. Co. v. Ragsdale, 50.

R. R. Co. v. Schurmeir, 57.

R. R. Co. v. R. R. Co., 171.

R. R. Co. v. Beal, 249.

R. R. Co. v. Burkett, 622.

R. R. Co. v. R. R. Co., 149.

R. R. Co. v. Litchfield, 171.

R. R. Co. v. Joliet, 205.

R. R. Co. v. Schuyler, $7 £ 3$.

R. R. Co. v. Maguire, 633.

R. R. Co. v. Kennedy, 223.

Rucker v. Decker, 561.

Rucker v. Dooles, 608.

Ruckle v. Barbour, 573.

Rudolph v. Rudolph, 476.

Rufner v. MeConnell, 253.

Rugg v. Hoover, 519.

Puigo v. Rotau, 169.

Rusling v. Rusling, 602.

Pusslin v. Shield, 238.

Russ $v$. Wingate, 257.

Russell v. Abstract Co., 10, 11.

Russell v. Ransom, 726 .

Russell v. Hart, 504.

Russell v. Tackson, 676 .

Russell v. Sweezy, 725.

Russell v. Place, 5:30.

Russell v. Brown, 251.

Ruscell v. Whitehead, 154.

Russell v. Mandell, 81 .

Ruston v. Ruton, 467.

Rutgers v. HIunter, 899.

Ruth v. King. 2If6.

Rutherford v. Tracy, 199.

Ruttenberg r. Main, 386. 
Runyan v. Messerean, 4 fi?

liyan $v$ Andrews, 37.

Ryan v. Ciller, 160.

liyan v. (arr, 34.).

Ryan v. Duncan, 360.

Ryan v. Killpatrick, 695.

Ryder v. Flanders, 364.

liyder v. Rush, 379.

Salmon r. Vallejo, 229.

Sammons v. Ilalloway, 242.

Samuels v. Shelton, 34:.

Sanlorn v. Robinson, 4:36.

Sauborn v. C'hambrlin, 574 .

Sanders v. Eldridge, 221.

Sands v. Davis, 179.

Sands v. Lynham, 6.5.

Sands v. Hughes, 686.

Sanger v. Craigul, 76.

Sansberry v. McElroy, 652.

Sanxay v. Hunger, 72:3.

Sapp v. Wightman, 622.

Sargent v. Howe, 337.

Saunders v. Hart, 51.

Saunders v. Hanes, 2l8, 263, 283.

Saunders v. Sehmaelzle, 22I.

Sawyer v. Cox, 89, 192, 319.

Sayler v. Plaine, 23.

Scammon v. Chicago, 565.

Scammon v. Swartwout, 566 .

Scanlan v. Wright, 211.

Searborough r. Snith, 609.

Scarlett v. Gorham, 52.2.

Schade v. Gehmer, 8, 9.

Schaeffer r. People, 631.

Scharfenburg v. Bishop, 254, 255.

Schettler v. Snith, 489.

Schmedding v. May, 74.

Schmeling v. Kriesel, 614.

Schmucker $\checkmark$. Sibert, 290.

Schnee r. Schnee, 182.

Schneider v. Botsch, 694.

Schneider v. Hutchinson, 694.

Schofer v. Reilly, 449.

Schofield v. Honested Co., 229.

School Distriet v. Taylor, 441.

School District v. Werner, 531.

Schoot's Estate, 463, 466.
Scluoeder v. Gurner, 609.

Sclumenberg v. Harriman, 149.

schumucker v. silert, 290.

Schumpert v. Dillard, 234.

Schurmier v. R. R. Co., 54.

Scofield v. Jennings, 244.

Scofield v. Olcott, 492 .

Scoffin v. Grandstaff, 48 .

Scott r. Rand, 336 .

seott v. Mann, 366.

Scott r. Simpson, 391, 719.

Scott v. Moore, 589.

Scott r. Bruyn, 686.

Scott r. Elkins, 686.

Scovill \&. Griffith, 588.

Seoville v. Hilliard, 610.

Sechler $r$ Delfs, 449.

Security Co. v. Longacre, 8.

Seigneuret v. Fahey, 32.

Seigwald v. Seigwald, 477.

Sellers v. Corwin, 533, 535.

Semple v. Bank, 33.

Sewal v. Roberts, 6.58.

Sevler v. Carson, 264.

Sevier v. Gordon, 663.

Shackelford v. Todhunter, 26.

Shackleton $r$. Siebree, 279.

Shanks v. Klein, 309.

Shannon v. Hall, 441.

Shattuch r. Hastings, 226.

Sharp v. Spear, 63.

Shaw r. Nilliams, 56.5.

Shan v. Clnambers, 588.

Shays v. Norton, 421.

Sheaf v. Wait, 632.

Shear v. Stothart, 58.

Shearer v. Shearer, 309.

Shearer v. Weaver, 665.

Shetdon v. Rice, 366.

shepard r. Howard, 304.

Shepard v. Shepard, 441.

Shepardson v. Rowland, 306.

Sheppard v. Thomas, 226.

Sheridan v. Andrews, 608.

Sherlock v. Winnetka, 62s.

Sherman v. Abbott, 615 .

Sherman v. Hogland, 211, 299.

Sherman v. Kane, 690, 694, 720. 
Sherrid v. Southwick, 438.

Sherwood v. Wilson, 456.

Sherwood v. Sherwood, 463.

Shields v. Miller, 343.

Shields v. Roberts, 682.

Shirk v. Gravel Road Co., 560.

Shivley v. Parker, 1 S6.

Shivers v. Simmons, 302

Shoat v. Walker, 649.

Short v. Conlee, 258.

Shreve's Case, 471.

Shrew v. Jones, 533, 535.

Shriver v. Shriver, 247,720 .

Shriver's Lessee v. Lynn, 573.

Shuffleton v. Nelson, 689.

Shumaker v. Johnson, 49.

Shumway v. IIolhrook, 502.

Skinner v. Wood, 359.

Skinner v. Fulton, $673,676$.

Sibley v. Waffle, 584.

Sibley r. Smith, 643.

Siceloff v. Redman, 466.

Sickmon v. Wood, 252.

Sidener v. White, 605.

Sigourney v. Larned, 80.

Sillers v. Lester, 439.

Silliman v. Cummings, 303.

Sillyman v. King, 130.

Simmons v. Fuller, 432, 440.

Simmons v. Wagner, 130.

Simmons v. Thomas, 299.

Simnett v. Cralle, 558.

Simpson v. Pearson, 47, 50.

Simpson v. Neil, 186.

Simpson v. Blaisdell, 221.

Sims v. Rickets, 296.

Sims v. Hammond, 449.

Skillen v. Wallace, 743, 744.

Skinner v. Wood, 359.

Slater v. Breese, 252, 432.

Slewers v. Commonwealth, 9.

Sloan v. Lawrence Furnace Co., 225.

Sloan v. Sloan, 723.

Slocum v. Slocum, 591.

Slosson v. Jynch, 659.

Small v. Slocumb, 242.

Small v. Field, 257.
Small v. Stagg, 516.

Smiles v. Hastings, 412.

Smiley v. Bailey, 476.

Smith v. Holmes, 8.

Smith r. Chenault, 539.

Smith v. Colvin, 561.

Smith v. Block, 219.

Snith v. Crawford, 221, 251, 610.

Smitlı v. Garden, 236, 259.

Smith v. Van Gilder, 260.

Smith r. Dall, 235.

Smith v. Jewett, 287.

Smith v. Hutchinson, 474.

Smith v. Rice, 580.

Smith r. Sheely, 313, 315.

Smith v. Bell, 477.

Smith v. Rowland, 515.

Smith v. Bradstreet, 526.

Snith v. Richardson, 602.

Smith v. Bangs, 605.

Sinith v. Sherwood, 607.

Smith v. Wood, 614.

Smith v. Messer, 630.

Smith v. Lewis, 639.

Snith v. McConnell, 360, 652.

Smith v. Smith, 663, 666.

Smith v. Robertson, 719.

Smith v. Granberry, 366.

Smith v. Wilcox, 565.

Smithdeal v. Smith, 459.

Smyth v. Taylor, 472.

Snapp v. Pierce, 52.

Snell v. Ins. Co., 383.

Snydacker v. Brown, 597.

Snyder v. Palmer, 49.

Sœns v. Racine, 628.

Sohier v. Coffin, 288.

Solomon's Lodge v. Montmallin, $317,319$.

Sonfield v. Thompson, 235, 258.

Soulard $v$. United States, 152.

Soule v. Barlow, 684, 695.

South Fort Canal Co. v. Gordon, 558.

Southern Cal. Coll. Assc. v. Bustamete, 318.

Southern Bank v. Humphreys, 547, 599. 
Southern Pac. R. R. v. Dull, 151.

Sower v. Philadelphia, 408.

Spackman v. Ott, 421.

Spangler v. Sellers, 744.

Spangler v. Brown, 744.

Sparhawk v. Buell, 555.

Sparrow v. Hovey, 683.

Spaulding v. Gregg, 279.

Speakman v. Forepaugh, 719.

Speck v. Pullman Co., 572, 573.

Spence v. Armour, 571.

Spencer v. Dearth, 530.

Sperry v. Pound, 286.

Spight v. Waldron, 609.

Splahn v. Gillespie, 341, 579.

Sprig v. Moale, 666.

Springer v. Brattle, 268.

Springer $v$. Shavender, 582.

Spurlock r. Allen, 645.

Staak v. Sigelow, 211.

Stadler v. Allen, 532.

Stanelifts v. Norton, 435.

Standen v. Standen, 480.

Standish v. Lawrence, 413

Stanley v. Risse, 602.

Stark v. Mather, 130.

Stark v. Brown, 695.

Stark v. Starrs, 126, 130, 164, 685, 690.

Starkweather v. Martin, 232.

Starkweather v. Bible Soe., 464 .

Starry v. Jolinson, 532.

State v. Meagher, 360.

State v. MeGlynn, 503.

State v. Ramsburg, 545.

State v. Pepper, 47.

State v. Bradisli, 49, 102, 103.

State v. Laverack, 63.

State v. Jennings, 326 .

State v. Jersey City, 408.

State v. Fosdiek, 310.

State v. Leffingrell, 312.

State v. Rachac, 73.

State v. Roanoke Nar. Co., 569.

State v. Wallace, f66.

State v. Potter, 669, 671.

State v. Williams, 671.

State v. Orwig, 607.
State v. Goodrich, 671.

State v. Armington, 671.

State v. Ames, 678.

St. Clair Co. v. Livingstone, 54.

Steel v. Kurtz, 39.

Steel v. St. Louis Smelting Co., 176.

Steele v. Boone, 81.

Steeple r. Downing, 632, 643.

Steere r. Steere, 334.

Stein v. Sullivan, 448.

Stelz v. Shreek, 298, 622.

Stephens v. Reynolds, 394, 401.

Stephens v. Williams, 235.

Stephens v. Evans, 489.

Stephens v. Holmes, 641.

Stephenson v. Wilson, 143.

Steplenson v. Thompson, 342.

St. Paul r. Ry. Co., 694.

Sterns v. Swift, 304.

Sterens r. West, 211 .

Sterens r. Bond, 564.

Stevens v. Brooka, 684, 686.

Stevens v. Raimwater, 516.

Stevens v. Harrow, 289.

Stevens v. Hampton, 236 .

Stewart v. Stewart, 465, 684.

Stewart v. Pettigrew, $5 \overline{5} 9$.

Stewart v. Garvin, 505.

Stewart v. Barrow, 420, 449.

Stewart v. Mesweeny, $28 s$.

Stewartson r. Stewartson, 619.

Stickle's Appeal, 466.

Stiles r. Brown, 237.

Stillwell r. Swarthaut, 558.

Stinehfield r. Little, $3 \geq 6$.

Stinson v. Ross, 342.

Stoddard v. Burton, 48.

Stoddard v. Chambers, 175.

Stoffel v. Schroeder, 268.

Stone v. Sleilge, 245.

Stow v. Yarwood, 381.

Stow v. Steele, 339.

Strauss" Apleal, 399.

Streeper r. Williams, 392.

Streeter v. Streeter, 400.

Stricklaud v. Draugham, 222.

Strickland v. Kirk, 384. 
Stringer v. Young, 175, 180.

Strong v. Lehmer, 175.

Strong v. Converse, 290 .

Strother v. Lucas, 168, 169.

Strother v. Law, 447.

Stuart v. Harrison, 516.

Stuart v. Walker, 478.

Stuart v. Allen, 360.

Stubbs v. Sargon, 456.

Stuller v. Link, 236.

Stuphen v. Ellis, 503.

Sturderant v. Mather, 638 .

Styles r. Probst, 301.

Suecession of Bogere, 661 .

Sullivan v. Sullivan, 609.

Summer v. MitchelI, 254.

Sumner v. Parker, 580.

Sumner v. Williams, 228, 340.

Surgi v. Colmer, 559.

Sutherland v. Goodnow, 399.

Sutton r. Schonwald, 570.

Suydam v. Thayer, 473.

Swan v. Benson, 515.

Swan v. Yaple, 449.

Swamn v. Lindsey, 149, 168, 169.

Swartz v. Leist, 448.

Sweat v. Corcoran, 175.

Sweet v. Mitchell, 421 .

Swegle v. Wells, 602.

Swink v. Thompson, 577.

Sydnor v. Palmer, 49.

Sykes v. Sykes, 304, 305.

Taft v. Kessell, 390, 719 .

Taggart v. Risley, 48, 217.

Taggart v. Murray, 466.

Talbott v. R. R. Co., 291.

Talbot v. Hudson, 63.

Talbot v. Todd, 545.

"Tankard v. Tankard, 77.

Tapley r. Wright, 9.

Tatum v. MeClellan, 469.

Taylor v. Wright, 643.

Taylor v. Watkins, 53.

Taylor v. Weston, 136.

Taylor v. Merrill, 614.

Taylor v. R. R. Co., 643.

Taylor v. Preston 228.
Taylor v. Boyd, 546.

Taylor v. Reed, 544.

Taylor v. Dodd, 488, 491.

Taylor v. King, 452.

Taylor v. Sutton, 287.

Taylor v. Brown, 130.

Taylor v. Gilpin, 346.

Taylor v. Phillips, 677.

Tatum v. MeClellan, 469.

Teabout v. Daniels, 685 .

Teft v. Munson, 423, 424.

Terrell v. Andrew Co., 79, 81.

Terrell v. Weymouth, 613.

Terrett v. Taylor, 168.

Terry v. Wiggins, 475, 478.

Terry v. Sisson, 5.5.

Terwilliger v. Brown, 348.

Teschenacher v. Thomson, 181.

Teutonia, etc., Co. v. Turrell, 237.

Texas Land Co. v. Williams, 235.

Thaley, in re, 6r2.

Thatcher v. St. Andrews Ch., 237.

Thatcher v. Candee, 337.

Thateher v. Howland, 304.

Thatcher v. People, 633.

Thayer v. Torry, 251, 389.

Thaxter v. Williams, 518.

Thielman v. Carr, 517, 726.

Third Ave R. R. Co. v. Mayor, 589.

Thomas v. Clark, 369.

Thomas r. Wyatt, 182.

Thomas v. Bartow, 388 .

Thomas v. Goodwin, 368 .

Thomas v. Babb, 688 .

Thomas v. Industrial University, 518.

Thomas v. Desney, 5.50, 551.

Thomas v. Stickle, 633.

Thomas v. People, 676.

Thomas v. Chicago, 263.

Thompson v. Gregory, 32 .

Thompson v. Prince, 156, 169.

Thompson v. Thompson, 213.

Thompson v. Lorrein, 245.

Thompson r. Lambart, 313.

Thompson v. Ludington, 484 .

Thompson v. Lee, 552. 
Thompson v. Craighead, 5169.

Thompson v. Ware, 1543.

Thompson r. l'ioclse, 684, 688.

Thompson v. Dearborn, 239, 290.

Thompson v. Lyman, 435.

Thompson v. Sehuyler, bot6.

Thompson v. Felton, 653.

Thompson v. Burhans, 726.

Thompson v. Curtis, 4l3.

Thompson $v$. Iligrginlotham, 417 .

Thorn v. Ingram, $3633,572,573$.

Thorntou v. Grant, 55.

Thornton v. Irwin, 45l.

Thorp v. Keokuk Coul Co., 230, 269.

Thrasher v. Ingram, 466 .

Thrasher v, Bentley, 37.2 .

Throckmorten r. price, 79.

Thuleman v. Jones, 537.

Thurman v. Cameron, 326.

Tibbs r. Allen, 597.

Tibbitts v. Tilton, 580.

Tidd v. Rines, 129.

Tilles v. Brilges, 569.

Tillman v. Davis, 473, 659 .

Tilton v. Hunter, 75 .

Tilton v. R. R. Co., 724.

Timanus v. Dugan, 469.

Tisdale v. Ins. Co., 668.

Tobey v. Tilunton, 48.

Todd v. Philhour, 341 .

Tollenson v. Gunderson, 252.

Tolman v. Emmerson, 644.

Tomlin v. MeChord, 391.

Tomlinson v. Hatthews, 302, 368.

Thompkins v. Fonda, 2s.

Thompkins v. Seely, 388.

Thomkins v. Wiltberger, 597, 599.

Tone v. Wilson, 229.

Torrey v. Dearitt, 448, 455.

Torrey v. Cook, $35 \overline{\text {. }}$.

Tower v. Divine, 425.

Towles v. Fisher, 480.

Townsend v. Corning, 327 .

Townsend v. llubbard, $326,327$.

Townsend v. Tallant, 573 .

Townsend v. Radelitl. 473, 659.

Townsend v. Reg. of N. I., 73.
Traey v. Kilborn, 481.

Tracey v. Rogers, 518.

Traynor r. l'almer, 253.

Treadwell v. Iitynold , 239.

Treusch r. Shyrock, 519.

Trim v, Marnl, 449.

Tritt v. Joberte, isto.

Troost v. Davis, 588 .

Troy v. R. R. (o., 64, 623.

Trutehart $r$. Price. 605.

Trunt co. v. Penple, 65.

Truet co. r. Shaw, 448 .

Trustees vo Beale, 437.

Tru-tees r. Horeg, 514.

Truntees $v$. snell, 5fit.

Truntees r. Grily, 605.

Tubls v. Gatewook, 234, 260.

Tucker v. Field, 2.j.

Turker $r$. Whitehearl, 503.

Tufts $\therefore$ Kine, 77 .

Turner $\checkmark$ s. suith, 631.

Turner v. Yeoman, 643.

Turner v. Kerr, 4?o.

Turner r. Ivie, 283.

Turner r. Hoỵle, 350.

Turner $r$. Scott, $4 ! 96$.

Turner v. Jenkins, 5\$8, 599.

Turner v. Watkins, 372,421 .

Turney r. Chamberlain, 683.

Turpin r. Railroad Co., 412, 417.

Tustin r. Faught, 231.

Tuttle v. Churehman, 76, 77.

Twichell v. Years, 291.

Tyler v. Coulthard. 15.

Tyler v. Reynolds, 39, 655, 665.

Lfford r. Wilkins, 252.

Union Mill Co. r. Ferriss, 182.

Union College v. Wheeler, 448.

Union Trust Co. v. Weber, 629.

United States v. Jones, $62,63$.

United States v. Brooks, 152.

Lnited States v. Land Grant Co., 182.

United States v. Fox, 461.

Lnited Stutes r. New Orleans, 628.

United States v. Fitzgerald, 129.

United States r. Hoar, 693. 
United States v. King, 125.

United States v. Perchman, 152.

United States v. Stone, 175.

United States v. Schurz, 33, 178.

Updike v. Tompkins, 461.

Ury v. Houston, 363.

Utz, Estate of, 471 .

Van Aken v. Gileason, 440, 441.

Van Antwelp, In re, 5.5.

Van Cleaf r. Burns, 621 .

Van Cott r. Prentice, 334.

Van Courtlandt v. Kip, 494.

Van Dusen v. People, 595.

Yan Honwwek v. Wiese, 496.

Van Keuren v. R. R. Co., 77, 690.

Van Keuren v. McLaughlin, 372.

Van Meter v. McFadden, 389.

Van Nostrand v. Moore, 466 .

Van Ransell:r v. Smith, 19.

Van Ransslær v. R. R. Co., 30.

Van Rensselær v. Hays, 396.

Tan Ransselier v. Gullup, 401.

Van Ransselær v. Pennimar, 399.

Van Riswick v. Goodhue, 436.

Tan Scliaac v. Robbins, $26 !$

Van Wickle v. Calvin, 358.

Van Wickle v. Landry, 437.

Vail v. Vail, 485 .

Vail v. Inglehart, 578 .

Valentine v. Rawson, 519.

Valle v. Fleming, 572.

Vallette v. Tedens. 10.

Vallejo Land Ass'n r. Viera, 434.

Vandall v. Dock Co., 310.

Vandever v. Freeman, 608.

Vandiver v. Roberts, 596.

Vammatta v. Brewer, 397.

Vancycle v. Richardson, 36, 513, $654,662$.

Vanzant v. Tanzant, 523, 618.

Vacon v. Ball, 420, 511.

Yass v. Johnson, 559.

Vascault v. Elwards, 387, 393.

Vauglen $\because$. Punch, 495.

Vangluan v. Fily, 512, 561, 574.

Vanghan $v$. Greer, 290.

Ventress v. Cobb, 352, 356, 446.
Verdin v. Slocum, 23.

Verges v. Giboney, 456.

Vernon v. Morton, 369.

Vernon v. Police Board, 352.

Vernon $v$. Vernon, 464, 474.

Videan v. Griffin, 327.

Viele v. Judson, 448.

Vipond v. Hurlbut, 229, 270.

Virden v. Needles, 547.

Voorhees $v$. Frisbie, 374.

Voris v. Renshaw, 226.

Wacek v. Frink, 8 .

Wade r. Lindsey, 288.

Wade v. Deray, 223, 260, 611.

Waggoner L HcLoughlin, 637.

Wainwright v. Tuckerman, 495.

Wait r. Bulling, 481.

Wait v. Smith, 79, 320.

Wakefield v. Brown, $2 \pm 6$.

Wakefield r. Tan Tasse!l, 286.

Wakefield $v$. Bonton, 602.

Wakefield v. Chowen, S, 10, 102.

Walbridge r. Day, 35.

Waldron v. Tuttle, 671 .

Wales r. Dogue, 537.

Wallie v. IIoody, 560.

Walker v. Matthers, 510.

Walker v. Smallwood, 351.

Waiker v. Cary, 548.

Walker r. Goodman, 74t.

Walker v. Dement, 419.

Walker v. Craig, 358, 360.

Thalker v. Miller, 381.

Walker v. Summers, 423.

Walker v. Cockey, 435.

Walker v. Denni-on, 329, 330.

Wall v. Mall, 496.

Wallace $v$. Berdell, 238.

Tallace v. Harmstad, 19, 20, 66, 653.

Wallace v. Wilson, 130, 439.

Wallace v. Monroe. 532.

Tallace v. Marris. 216.

Wallach r. Tan Riswick, 66.

Mallbridge v. Dar, fist.

Waller r. Aruold, 354.

Wallington v. Taylor, 491. 
Wallingford v. Allen, 296.

Walsh $\therefore$. 11ill, 657 .

Walsh r. Kirkpatrick, 551.

Walter r. Armold, 44.5.

Walter's Appeal, 45s, 491.

Walton v. Hargloses, 515.

Walton v. Cody, 420, 427.

Wambough v. Schenk, 666.

Wangelin v. Gioe, 605.

Ward v. Mulford, 155, 196.

Ward v. Lumber Co., 3it, 409.

Ward v. Amory, 478.

Ward v. Oates, 503.

Warder v. Cornell, 392.

Ware v. Johnson, 34t.

Ware v. Wisner, 503.

Warehouse Co. v. Terrill, 5it.

Warfield v. Brand, 358.

Warneke v. Lembea, 35 s.

Warner v. Bull, 288.

Warner v. Bemett, 2s7.

Warner $\checkmark$ Bates, 489.

Warner v. Everett, 526.

Warnoek v. Flarlon, 525.

Warren v. Richmond, 725.

Warren v. Lynch, 231.

Warren v. Blake, 31.

Warren v. Levitt, $17 \%$.

Warren v. Chambers, 56 .

Washburn v. Cutler, 649, 687.

Washburn v. Burnham, so.

Washburn v. Burns, 297.

Washburn v. Fleteher, 386.

Washington r. Hasp, $6+3$.

Waterloo Bank v. Elmore, 425.

Waterman v. Smith, 180.

Waters v. Bush, 130, 143, 164.

Waters r. Jones, 451.

Watkins v. Hall, 255.

Watkins v. Specht, 318 .

Watkins v. Rogers, 359.

Watson v. Water Co., 311.

Watson v. Riskuire, 299.

Watson v. Atwood, 643.

Watson $v$. Tindal, 666.

Watson v. Muirhead, 743.

Watson v. P. R. Co., 623.

Watson v. Hoy, 569.
Watson v. Blackmood, $\frac{4}{2} 66$.

Watson $v$. Sherman, 327.

Watrons v. Morrison, s?.

Watrous $v$. Allen, 22\%.

Watt r. MeGalliard, 564.

Weaver r. Peasley, 562.

Welh v. Yeale, 216.

Webb v. Richardson, 686.

Webber v. Townley, 72.

Weber $r$ Anderson, 689.

Web-ter v. Conley, 340.

Weckles r. Bank, 311.

Viedge v. Moore, 291.

Wecks v. Milwatuee, 628 .

Weekit $v$. Dowing. 117.

Weidersum v. Naunann, 591.

Weir r. Lumber co., 7.t.

Weis r. Aarm, 542.

Weleh v. 1i. R. Co., 42.

Welch $v$. Dutton, 5:, 391.

Welch v. P'riest, 410.

Welch v. Plillips, 422.

Welch r. Sicket, 235.

Wells v. Bailey, 54.

Wells r. Pemington Co., 151.

Wells v. Atkin=011, 234, 2.59.

Wells v. Jackson Nifg. Co., 6S7.

Wells v. Wells, 299.

Wells r. Stumph, 596.

Welsh v. Joy, 342.

Welsh r. Huse, 462.

Welsh v. Phillips, 449.

Welseh r. Savings Bk., 467, 479.

Welton v. Atkinson, 235.

Wentworth v. Wentworth, 666 .

Westlake v. Westlake, 302.

West Point Iron Co. v. Reymert, 225.

Wetmore v. Parker, 456.

Wetmore v. Laird, 234.

Wetmore v. Wetmore, 620 .

Wetter v. Walker, 469.

Wickle v. Calvin, 358.

Willer v. East St. Louis, 627.

Wier v. Simmons, 226.

Wisenor $v$. Lindsay, 364 .

Veisner V. Zaun, 48. 
Wiggins liery Co. v. R. li. Co., Wilson r. Carrice, 279. $28: 2,287$.

Wilder v. Brooks, 299.

Wilson r. Spring, 337.

Wilcox r. Jackson, $3 \frac{1}{4}, 126,144$, 182.

Wilcox v. Bates, 426.

Wilcoxon r. O-burn, 2.56.

Wiley v. Sirdorus, $2 \cdot 5$.

Wiley v. Williamson, 448.

Wilkes r. Back, 326 .

Wilks r. Burns, 701.

Wilkius r. Tourtellott, 37s, 381.

Wilkinion v. Elliott, 6.2.

Willamette Co. r. Gordon, 502.

Willamette Co. v. Hendrix, 541.

Willard r. Cramer, 236, 258.

Williams v. Baker, 237.

Williams v. Winnor, 373.

Williams v. Merritt, 875.

Williams v. Teachey, 450.

Williams v. Jacksou. 45:3.

Williams r. Williams, 48, 6.2.

Williams v. Chıtpman, 517 .

Willianss r. Jolmson. 541, 601.

Williams v. Amory, 560. 654.

Williauns r. Valkenbure, 59s.

Williams r. Downes. 596.

Williams v. Townsend, 638.

Williams v. Kirkland, 64:3.

Williams v. Ewing, 661 .

IVilliams y. Augueta, 404.

Williams v. Wallace, 682.

Williams v. Rhodes, 366.

Williams Estate, 666.

Williams, In re, 503.

Williamson v. Derry, 568, 572.

Williamson v. Jones, 569.

Villiamson v. Russell, 637

Willis v. Nicholson, 57?.

Willot. $ง$ Sanford, 170.

Wills v. Chandler, 573.

Wilson r. Spring, 337 .

Wilson v. Owen, 595.

Wilson v. James, 690.

Wilson v. Reuter, 436.

Wilson v. Wilson, 36. 287, 619.

Wilson r. Thraup. 48.

Wilson v. White. 247 .

Wilson v. Mckemna, 242.

Wilson v. Lyon, 515.

Wilson v. Hunter, it.

Wilson v. King, 49.

Wilson r. Sexton, 58.

II ilson's Exrs. r. Viin Leer, 496.

Winans v. Cheney, 2.2.2.

Wing v. Dodge, 559, 581 .

Wing r. Hall, 64t?.

Wing v. Cooper, 421.

Wing r. Railey, 287.

Wingate r. Pool, 360.

Winkler r. Miller, 269.

Winslow v. Winslow, 210, 248.

Winslow r. Goodwin, 22.2.

Winter v. Stock, 210, 309.

Winter v. Crommelin, 175.

Winter v. Jones, 170.

Winthrop v. Fairbanks, $224,225$.

Wisenor v. Linliay, 364.

Witham r. Brooner, 332.

Wittenl,rock v. Wheaton, 133, 135.

Wheaton r. Andress, 473.

Wheaton $v$. Sexton, 56 ?

Wheeler v. Smith, 485.

Wheeler r. Hartshorn, 463.

Wheeler r. Śpinola, 57.

Wheeler r. Wheeler, 659.

Wheeler v. Clutterbuck, 659.

theeler v. Schad, 229.

Wheeler v. Willard, 447.

Whelan r. Sullivan, 386.

Whetstone v. Ottawa Lniversity, 312.

Whitaker v. Miller, 208, 213, 220, $237,248$.

Whitcomb r. Rodman, 465 .

White v. Whitney, 228, 343.

White v. Hopkins, 279.

White r. Clover, 358.

White r. Clawson, 364, 693.

White r. Rittenmeser, 422, 511.

White v. Patton, 424.

White r. Foster. 200.

White v. Luning. 222, 338.

White v. Davis, 343. 
White v. Hampton, 8.3.

White v. Carpenter. 350.

White v. Hermann, 38ti.

White $r$.ldiarry, 440.

White $r$. White, $\bar{T} \bar{T}$, 691 .

White r. Fuller, 726.

Whitehall v. Gottwal, 270.

Whiteman r. Whiteman, 466.

Whiting v. Nicholl, 6itis.

Whiting r. Butler, 343.

Whitmore v. Larned, $6: 30$.

Whitman v. Fisher, 359.

Whitman v. Hennebery, 239, 240, 611.

Whitmore v. Larned, 630.

Whitney v. French, 450.

Whitney v. Roberts, 589.

Whitney v. Rr. Co., 200.

Whitney v. Whitney, 531.

Whitridge $v$ Taylor, 374.

Whitsell v. Nills, 304.

Wool v. Croodridge, 327 .

Wood v. Sampson, 460, 491.

ITood v. Bank, 68\%.

Wood v. Beach, 216.

Wood v. Morehonse, 559.

Wood v. Myrick, 5s0.

Wood v. Young, 535.

Ilood v. Hurd, 58.

Wood v. Griffin, 489.

Woodley v. Gilliam, 562.

Woods v. Monroe, 581, 586.

Woods v. Hildebrand, 420, 511.

Woodbury v. Dorman, 439.

Woodfin v. Anderson, 661.

Woodman v. Clapp, 644.

Woodward v. Roberts, 242.

Woodward v. MeRernolds, 133.
Woodward v. Harris, 614.

Woodworth v. Payne, 237.

Woodworth v. Raymond, 30.

Wooliseroft r. Norton, 229.

Wuoters r. Joseph, 562 .

Word $v$. Douthett, $5: 88$.

Work v. Welland, t23.

Worth r. Branson, 129, 131.

Worrall v. Munn, 326.

Wright $r$ sperry, 22e?.

Wright v. Tinsley, 394.

Wright $\therefore$ Dufield, 303.

Wright v. llowell, 289.

Wright v. Marsh, 610 .

Wright v. Walker, 638.

Wright $r$ Young, 5l2.

Wright $r$ Day, 197.

Wright $v$ Dunn, 467.

Wylly v. Gazan, 249.

Wrman $x$. Farrer, 2.25.

Yackle v. Wightman, 547.

Tahoola Mining Co. v. Irbs, 324.

rale r. Flanders: 233.

Yaple $v$. Titus, 542.

Yard v. Murry, 493.

Yarnall's Appeal, 471.

York v. Crawford, 596.

Yosemite Valley ease, 133.

Young v. Gailbeau, 237.

Young $v$. Clippinger, 270.

Young v. Young, 296, 493.

Youse r. Forman, 495.

Zeigler v. Hughes, 436.

Zahnn v. Haller, 231.

Zirkle v. McCue, 580. 



\section{ABSTRAC'TS}

ANI

\section{EXAMINATIONS OF TITLE.}

CIIAPTER I.

PRELIMINART OBSERTITIONS.

§ 1. Introductory.

2. Abstracts defined.

3. Origin of abstracts.

4. Essentials of the abstract.

5. The English method.

6. The American method.

7. Abstracts and examinations distinguished.
§. Qualifications of the examiner.

9. Examiner's lialility for error.

10. Character of eximiner's liability.

11. Duty of furnishing abstract. 12. Taxation of abstrict books.

1:. Exemption of abstract books.

§ 1. Introductory. Within comparatively recent rears the business of furnishing abstracts of title to real property has grown to enormons proportions in the United States, calling for a class of highly skilled converancers with special training and qualifications for the work, while the examination of titles has practically created a new department of legal labor. To assist, in an humble way, this large and constantly increasing class of practitioners, by a statement of the most approved methods of compiling and arranging the ab-tract, the sources of information and the aids derived from indices and references, together with a brief review of the general principles of law applicable to the examination of titles, will be the object of this work. In the latter respect it is necessarily brief, and con- 
sequently elementary, and is intended rather as a series of hints and suggestions that mas incite the examiner to more extended inquiry, than as a full elucidation of the law on the subjects discussed.

s. A Astracts Defined. An abstract may be defined as a condensed history of the title to land, consisting of a synopsis or summary of the material or operative portion of all of the rarious instruments of conreyance which in any manner affect said land, or the title thereto, or any estate or interest therein, together with a statement of all liens, charges or liabilities to which the same may be subject, and of which it is in any way material for purchasers to be apprised. It is usnally arranged in chronological order and is intended to show the origin, course and incidents of the title without the necessity of referring to the original sources of information.

$\S$ 3. Origin of Abstracts. Although the use of abstracts of title has now become universal, where free alienation of land is permitted and property rights are recognized, but little can be said as to the origin of the practice. The earliest English works on the subject, published during the first lalf of the last century, treat of the abstract as an established fact, but make no mention of the period at which it first began to be used.

During the earlier rears of the United States, but little attention was paid to title in purchases of real property. Ordinarily the buyer was fully satisfied with the rendor's "warrantee" deed, the corenants thereof being taken as conclusive eridence of all they recited. No inquiry was made with respect to the past, present possession being considered a sufficient guarantee of ownership, and no thought was taken as to the future. Transfers of land were frequently accompanied by the rendor's purchase deeds and other mumiments upon which the title was bascd, and such may still be the custom in some parts of the country. But, with the flood of years, the increasing commereial activity of the age, the remoral of property disqualifications and other impediments to alienation, has come a rast accumulation of evilences of title, frequently involving conplex interests that call for a high degree of skill to arrange and 
classify, as well as to interpret and adjust. Land, too, in many focalities has actuired an almot fabulous ralue and purchas. er's now part warily with their money and only on strong assur. ance of title. It is no longer practical, save in rare instances, tn examine title by specific inspection of the original documents, were such always available, or to laboriously follow on the records the rarious mutations through which it lias passed. Yet, as purchasers take at their peril, sare as they may find protection in the covenants of their deerls, it is necessary that they should be apprised of whaterer may affect the ralidity of the title or estate they take, of which the law rharges them with actual or constructire notice. To sati:fy this demand has been developed the modern abstract of title, together with its incident, the examiner.

$\S$ t. Essentials of the Abstract. Without going into detail at this time it may be stated generally, that the abstract should furnish all the matrial information contained in the original documents and records from which it is compiled, and that, as fully and completely as if they had been specifically inspected. It should show, when from the somrce of title, the inceptire measures; the foundation of title; the derolution of same to date of examination, inclnding all transfers of any and every interest; the incitents of the land itself, divisions and subdivisions; any and all adverse titles or claims; all liens or charges, howerer created, including judgments against the person during the period the law makes them a lien on land; taxes, special assesments, and statutory liens; and every other matter or thing appearing of record that may affect, implicate or impair the title. To these, in proper cases, may be added any matter in pais, that to the examiner may seem pertinent or material.

$\S 5$. Whe Fuglish Methoul. According to Preston, ${ }^{1}$ it is the custom in England when land, or other property which does not pass by mere delivery but is held by a title depending on documental evidence, is sold, for the solicitor for the vendor

11 Preston on Abstracts, 1. 
to prepare an abstract of the title, and the solicitor for the purchaser to compare the abstract so furnished, with the decds, wills, ete., that constitute the chain, to sce that it contains a correct and faithful statement of all circumstances disclosed by them relevant to the title, or depending on extraneous facts; as marriages, burials, baptisms, desecnts, ete. The abstract is prepared from the original documents, and is delivered to the prorchaser who founds on it such "requisitions" by way of further inquiry or objection as he thinks proper; the purchaser must then send in his objections and queries within a limited time from the date of delivery of the abstract, and in default of such requisitions or objections he will be deemed to have accepted the title. The objections and queries, when made, are answered by statements and observations, signed by the solicitor or party making them, and form a part of the abstract. ${ }^{2}$ The method of abstracting the instruments and arranging the chain, differs in no material respect from that now commonly cmployed in the United States.

$\$ 6$. The American Wethod. Asicle from an arrangement of indexes and references, there is no system of title abstracts that can be said to be distinctively American, the methods varying somewhat in different sections, thoughis preserving a general similitude. The spirit and operation of our laws preclude the adoption of the English methods to any appreciable extent, although it would seem that the abstract makers of the Eastern States still follow as closely as possible in the footsteps of their English predecessors, and their work is usually constructed upon the regulation English model. In the Midhle and Western States, the operation of the United States land laws, the later methods of survey and subdivision, and the almost total ammihilation of many of the old common-law rules relative to the acquisition and transfer of estates in land, have canson a wile departure from the conventional system expoumled ly Preston, Moore and other English writers, as well as that now, or formerly, nsed in the Colonial States. The

2 Deane's Conveyancing, 325; Lee on Abstracts, 20. 
American alstract is not frepared from the original documents, but from recorded evidenees thereof found in the ofiness of reegistration, courts, and other legal depositories, and, as a mle, shows only such title as is deducible of record. It is not identical with the English "abstract," as will be seen, and by way of distinction is frecpuently termed an "examination." Iroth terms, howerer, are ued interehangeably by the profession and are practically synonymous.

In compiling an abstract, the examine simply collects, condenses and arranges the information foumel of record, withont any expression as to the rights of any of the parties named therein. The work is then turned orer to comusel, who critically examines each instrument shown, or statement made; decides upon the sufficiency and legal effect of the conveyances, noting any defects or irregularities therein, or in any of the proceedings necessary to divest or aequire title; determines the relative rights and legal relations of the parties to the land in question and to each other; and finally formulates his views in a written opinion which is annexed to the abstract, and on the strength of which future sales or other dispositions of the property are usually made.

\& 7. Abstracts and Examinations Bistinguished. As before stated the terms abstract and cormination in their ordinary acceptation are smonymous, but for the purpose of defin. ing the broad scope of their inquirr, as compared with the narrowness and singleness of the English method, Anerican abstract makers frequently prefer the latter term to designate their work. The English abstract is largely personal in its object. That is, it seeks to show only the title of some particular individual, rather than the general condition of the title and is usually expressed in the caption to be, "An abstract of the title of John Doe, Esq., to that certain messuage," etc. The nature of English land tenures and the peruliar conditions attending the ownership of real property in that country preclude a showing of the origin or course of title for any considerable period, nor would that, perhaps, be necessary. An English abstract generally commences with some specitic document, as a deed 
or will, or frequently with a descent, and from this point, called the "root of title," and, covering a period of at least sixty year's, shows the successive links that connect the present title of the person proposed with the "root." 3 Obvionsly, such an abstract, however well it might serve the purpose in England, would be most inarlequate in the United States, where several persons frequently claim title throngh different chamels from the same source, not to mention the many adverse titles springing from independent sources. "A perfect abstract of title," says Preston, "means a perfect title in the rendor," and "a condition that vendor shall deliver an abstract of title, means," says Suglen, "the delivery of an abstract showing a good title." 4 The American abstract, thongh confined, as a rule, to matters of record, presents a far willer range. While intended primarily to show the present state of the vendor's title, it does not in terms purport such purpose, lut is a gencral inquiry into every matter or thing in any way affecting title to the land, in whomsocver it may rest and howerer arising or acquired. A "perfect abstract," as that term is unlerstood in the United States, shows the true state of the title, even though it defeats that of the vendor, and one that is defective in any of the particulars heretofore noted is not "perfect" even though it may show "a perfect title in the vendor." The caption of the American abstract expresses its true purpose: "an examination of title to the $\mathrm{N}$. E. $1 / 1$, , ete. It has none of the personal features that characterize the English abstract, and is decidedly an examination in rem.

$\S$ s. Qualifications of the Examiner. In a recent Minnesota case, Flandran, J., reviewing the labor and skill necessarily displayed in the compilation of an abstract, says: "That the making of a perfect abstract of title to a piece of land, with all the incumbrances which affect it, involves a great exercise of legal learning and careful researeh, no one will dispute. The jereon preparing such an abstract must understand fully all the laws on the subject of conveyancing, descent and inher-

3 Deane's Conveyancing, 325; 142 Sugd. V. \& P. 27.

Preston on Abstracts, 5. 
itances, nees and truntin, devises, and in falet every brancle of the law that can alferet real estate, in its rarions mutations from owner to owner, sonetines by operation of law, and agalin by act of the parties." " Should the ab-tract maker, or als we may term hin for short, the "eximiner," posess the varied aceomplishments enumerated by the larned judge, he will find it much to his arlyantage in the proeecution of lis work, yet it by no means follows that he may not beeme proticient while lacking many of the esentials above lescriber. The abstract maker is, in the full sonse of the worl, a converancer, equally with him who dranghts and prepares the original instrunents. The difference is in legree, not in kind. The same laws which control and direct the converaneer in the preparation of the originals, operate with equal effecet in the compilation of the abstract, and a gencral knowletge of ench laws and their applieation is an indispensalle requicite, ats are also the pinciples of survering and platting. The efiect of laws relative to conveyaneing, the transfor of estates, the devolution of titles, and the manifold and perplexing questions eonreruing the rights and interests of parties that may arice under them, are subjects which shonld properly be left to comsel who is to examine the abstract and pass an opinion upon the title. Occasionally the same person fills both offices, thongh this is rare save in smaller places or sparsely settled districts, and, as a rule, the union is not productive of good restlts.

s 9. Examiner's Liability for Error. The degree of intelligenee and skill required of a man by the law, depends much upon his ealling. A professional man must be specially educated or fitted for the duties of his rocation, and in arklition to the requisite technical knowledge must have reasonable skill in its application. So the understanding implied from persons engaged in the busines of searching the public records, examining titles to real property, and making abstracts thereof for eompensation is, that they are poescesel of the requisite knowledge and skill and will exercise due and ordinary care in

5 Banker $v$. Caldwell, 3 Minn. 94. 
the performance of their duties. ${ }^{6}$ For a failure in either of these respects, resulting in damages, the party injured is entitled to recover. $^{7}$ Nor ean the examiner limit his liability by a clause in the certificate appended to the abstract without specially ealling his elient's attention to it. ${ }^{8}$ It does not seem, however, that the emplorment inrolves any elements of guaranty or indemnity further than that raised by the undertaking to bring to the discharge of the duty reasonable skill and diligence. ${ }^{9}$ Thus, he should make a full and true seareh; should examine the record of every matter shown upon his own or the public indices which affects the land in question; should accurately abstract or digest every instrument or other matter so found and should supplement his seareh by an explicit statement or certificate of all matters corered by it. He has no right to rely upon index entries or marginal references, but should inspect the record itself, and should he assume the information furnished by index entries or marginal references to be correct he does so at his peril. ${ }^{10}$

But to fix the liability of the examiner there must, as a rule, be privity of contract with the injured party, for he ean be held answerable for his errors only to the person who has employed him, ${ }^{11}$ and where, in the absence of fraud, collusion or falschood, the examiner has made an erroneous certificate, upon the strength of which a third person has loaned and lost money, or suffered other injury, no liability will attach, not-

6 Chase $x$. Heaney, 70 Ill. 268; Lattiu $r$. Gillette, 95 Cal. 317.

i So held where the examiner had omitted to note on the abstract a judgment against the property for taxes, and its subsequent sale to satisfy same: Chase $r$. Heaney, 70 Ill. 26s; and where a pending attachment suit, which afterward culminited in a julgment, was omitted: Security Co. $r$. Longacre, 56 Neb. 469 ; and see, Clark $v$. Marshall, it Mo. 429: Bank $v$. Ward, 100 U. S. 195 ; Wakefield $v$. Chowen,
26 Minn. 379 ; Smith $v$. Holmes, 54 Mich. 104.

8 Chase $r$. Heaney, 70 Ill. 268.

9 Dundee Mtg. Co. $v$. Hughes, 20 Fed. Rep. 39; Housentan $v$. Girard Loan Ass'n, 81 Pa. St. 256; Schade $r$. Gehner, 133 Mo. 252.

10 Wacek $r$. Frink, 51 Minn. 282. 11 Savings Bank $v$. Ward, $100 \mathrm{U}$. S. 195; Dundee Mtg. Co. $v$. Hughes, 20 Fed. Rep. 39 ; Mechanies' Bldg. Ass'n $v$. Whitaere, 92 Ind. 547; Houseman v. Bldg. Ass'n, 81 Pa. St. 257; Morano $v$. Sliaw, 23 L. A. Ann. 379. 
withstanding the faret thest the noney was athaneed on the as-

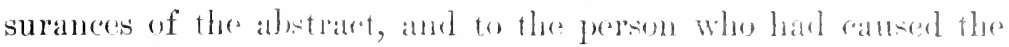
same to be made." (On the othere hamel, the owner of land seldom incurs the expense of procming an atstract of title except for the purpose of therely furnishing intormation to some thind person who is to be influenced lyy the information thens provided. Ilenee, it is contenderl, if the abstraet maker shall in all wates be lack responsible only to the person meler whose enplorment he performs the service it is manitest that the loses if any, occasioned thereby, must, in many awes, be withont remesly. Acting upon this line of reasoning we maly observe a tendency in sone of the cases to exteml the abstracter"s liability and to give to anyone, who in good faith relise upon the statements of the abstract, a remedy against him for any loss that may have resulted from his errors or omissions. ${ }^{13}$ The general rule, however, and that sustained by the weight of anthority, is as first stated, and in most of the cases that may seem to militate against it there are special circumstances tending to create privity, or such other relation as gives to the injured third party a right of rectress. ${ }^{14}$

Where a canse of action is pernitted to lie against an ab-

12 Savings Bank $t$. Ward, $100 \mathrm{U}$. S. 195; Talpey $v$. Wright, 61 Ark. 275 ; Sehade $v$. Gehner, 133 Mo. 252. In this latter case the examination having been made for a purchaser, and under cmployment by him, it was held that a right of action for such negligence did not exist in faror of the purchaser's widow and sole devisee and legatee. The court, referring to cases cited in support of a contrary view, said that they would be found to hold that the particular circumstanees of those cases brought the party injured, though not the party directly employing the abstracter, into privity with his contract, and created a duty to him as well as to his immediate employer.
13 Dickle $r$. Abstract Co., 89 Tenn. 43I.

14 is where a lender, before making a loan, informs the abstract maker that he will rely upon the abstract, and is told by the latter that he may. Brown v. Sims, 22 Ind. App. 317; and see Slewers $v$. Commonwealth, 87 Pa. St. 15 , where it was said that for the accuracy and truthfulness of his scarch and certifieate a prothonotary was responsible to the percons who employed him to renter the service, and not to others; yet where the certifieate was given to the horrower, but the agent of the lender, not being satisfied, to ascertain whether the eertificate was correct asked the prothonotary whether 
stracter who has furnished an erroneous search or giren a wrong eertifieate of title, the right accrues at the time of the delivery of the abstract and not at the time the negligence is discorered or the consequential damages may arise. ${ }^{15}$ Hence, it would seem that the statute of limitations may be pleaded in defense when the statutory bar has interrened.

It has further been held, that the examiner is under no obligation to show anything not arising within the dates of his examination, even though it be at the time a valid and subsisting lien upon the land; nor is he bound to inquire or state whether the title rested in any grantee during the period covered by his examination was affected by any prior conveyance, or any estoppel growing out of any corenants therein. ${ }^{16}$

As a general proposition, it may be said that the relation of confidence which subsists between parties engaged in the business of making abstracts of title and those who employ them is not unlike that existing between attornes and client, and they are equally held to a strict responsibility in the exercise of the trust and confidence which are reposed in them. ${ }^{17}$

With respect to this branch of our subject a distinction must further be kept in mind between persons engaged in the business of compiling abstracts as an ordinary occupation and publie officers who furnish same as a part of their official duty. Abstracts are frequently made by recorders, clerks and prothon-

it was correct, and the latter replied that it was, and took the certificate, and again made the search, and returned the certificate to said agent, saying that it was correct, and that there were no other judgments, and the agent then, relying on the certificate, lent the money, it was held that this was a republication of the certificate, a renewal and delivery thereof to the lender, and that the officer was liable for his negligence in the search.

15 Lattin $v$. Gillette, 95 Cal. 317, and see, Russell $v$. Abstract Co., $8 \pi$ Iowa, 233.

16 Wakefield $v$. Chowen, 26 Minn. 379. In this case the examiner failed to show a judgment rendered against one who at the time (prior to the commencement of the examination) had no interest in the subject of the examination, but who subsequently, and during the period covered by the search, acquired title to the same.

1 i Vallette $v$. Tedens, 122 Ill. 607. With respect to the liability of attorneys for erroneous opinions, see Chap. XXXII, post. 
otaries, and in sone states their liability is proseriberl and

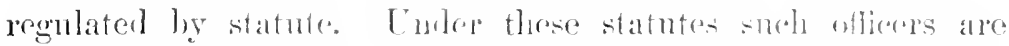
often declared lialile for all hos or damage which may hapen

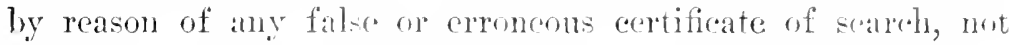
only to the person ol pereme te, for, or unom whowe order the said certifieate was mate or given, lunt also to any person claining title through, from or under them, or who may suffer loces by reason of the making of such false or erronenus cortificate. But where an ufficrer is not bonml to make scarches of the records of his ottice lis liability wronld scem to be measured by

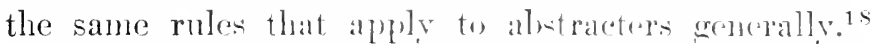

$\$ 10$. Character of Examiner"s Liability. There exists some confusion with respect to the chararter of the liability of an examiner who las made an croments starch resulting in injury to the client, as well as to the rementice that may be resorted to in such a ease. The better opinion, howerer, and that which seems to be supported by legal reaton, is that such liability is strictly contractmal, and, notwithisuming that the examiner may have violated a duty which he owed to the client, and that such violation was an act of culpalile neglect, ret such neglected duty was alone imposed by the contract and does not. involve a tort in the proper interpretation of that term. Epon an undertaking of this kind the examiner owes 10 duty to the client apart from the contract, and the fact that the contractual act has been negligently performed does not change the situation or alter the relation of the parties. ${ }^{19}$

$\S$ 11. Duty of Furnishing Alstract. In England a purchaser may, it scems, require to be furnished with an abstract of the seller's title, even though he may have already agreed

18 Thus, a clerk of court, not being bound to make searclies of the records of his office for liens, is not liable to one who purchased land on the faith of his certificate erroneonsly stating that thore were no liens against it. Mallory $v$. Ferguson, $50 \mathrm{Kan} .685$.

19 Russell $v$. Abstract Co., 87
Iowa, 233, and see, Thomas $v$. Carson, 46 Neb. 765 , where it is held, that an abstracter who gives an abstract which recites that the abstracter has carefully examined the records of the offices of the county clerk, the clerk of the district court, and the county treasurer, and that there were of record in said offices 
to accept the same, and he may retain such abstract during the negotiations upon, and even after rejection of, the proficred title, until the dispute is finally settled, for the purpose of showing the grounds of such rejection. ${ }^{20}$ It will be remembered, however, that an English abstract is gencrally only a digest of the title deeds and numiments relied on by the vendor to establish his claim, and which invariably accompany the abstract for examination and comparison. The abstract so furnished, therefore, is rather in the nature of a well-arranged index to accompany documents, and is prepared primarily for their more convenient and strstematic perusal. An American abstract, on tho contrary, is intended to furnish within itself a full exposition of title, and to obriate the necessity of referring to the original sources of information. In the former case the deeds and muniments are in the hands or under the control of the vendor, and the reason of the English rule is obrions from this fact alone. But in the United States the changed conditions of the evidences of title, the system of registration, the actual and constructive notice imparted thereby, and the access which the purchaser has to information concerning the title, would secm to render inoperative the English rule by remoring the reason which occasioned it; and, while it is customary in this country, as in England, for the rendor to prepare and furnish an abstract of title, either pending or after consummation of the sale, it does not appear that this can be demanded as a matter of right, but is rather the result of the contract or conditions of sale.

In England, where titles are not registered, ${ }^{21}$ the vendor, in

no liens on the property exeept as mentioned in the abstract, is not liable on his bond because of the onision from the abstraet of a prior mortage of reeord in the oflice of the register of deeds, thrugh the omission was the result of a conspiracy to defrand between the ab-tracter, the mortgagor, and the prior mortgagee.
20 See 2 Sugd. Vend. “39; Dart. Vend. (Am. Ed.) 130 .

21 Certain kinds of deeds, as a bargain and sale, were by an early statute required to be "enrolled." Of late years registration has become more general but there is no system in rogue in that country which corresponds with that observed in the United States. 
order to show performanere or an offere to perform on lis.s part, whether in an aretion at law for the purchase money or a suit

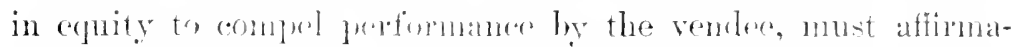
tively fore lis title. In this conntry, where titles are matters of record, and at all times open for inspection, a different rinle prevalis. This dostrine has often lwam amonned in aletions

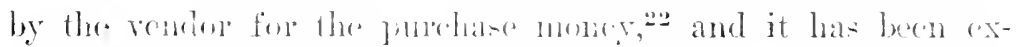

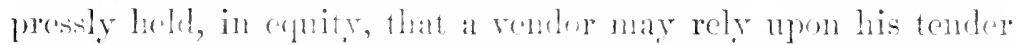

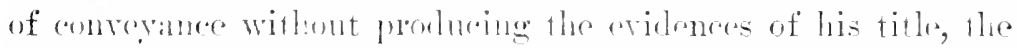

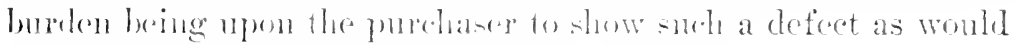

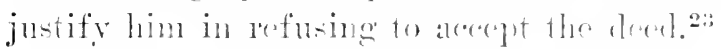

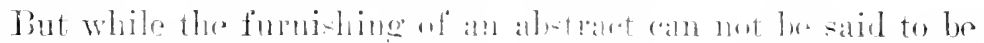

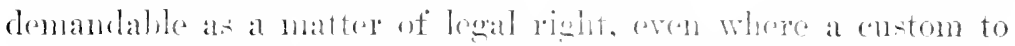

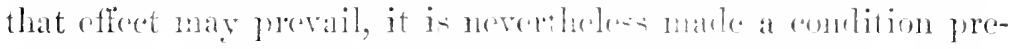

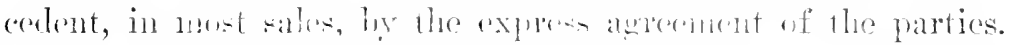
Where parties nualie a contract for the sale or exchange of lands which provites for the exhibition of an alletrat showing title in the proposing parties by a day nandel, this is a condition preceslent to be performed before either party in ase of an exchange, or the remtor in care of sale, can call upon the other to prerform the agrement; and, if the abetraet is not satisfactory or fails to show the title awreed to brom mate, the other may elect to consiler the contract at an end.: ${ }^{2}$

If, on the sale of land, it devolves on the vendor to furnich an abstract, on the delivery and aceeptance of the deed it becomes the property of the purchaser, ${ }^{25}$ and so, where the owner of land, about to execute a mortgage, delivers to the mortgagee an abstract of title to the prenises, it becomes part of the security for the loan, and the mortgagor is not entitled to the possession of it until the mortgage is paicl or discharged. ${ }^{21}$

$\S$ 12. Taxation of Abstract Books. Ale the indices, and other books of the examiner, employed by him in the prep167 .

22 Little $v$. Paddleford, 13 N. II.

23 Espy r. Anderson, 14 Pa. St. 308; Daily $v$. Litchfield, 10 Mich. 38.
24 Howe $v$. IIutchison, 105 Ill. 501.

25 Chapman $v$. Lee, 5j Ala. 616. 2 flolm $v$. Wust, 11 Ab. Pr. (N. Y.) N. S. 113. 
aration of abstraets, subject to taxation? Unfortunately, the question has not received a uniform answer from the several courts to which it has been presented. There is no dispute with respect to the general proposition that umpublished mannscripts are not subject to taxation, but the difficulty seems to lie in the character to be accorded to such manuscripts. The statute, generally, requires that all property shall be returned and assessed at its fair eash value, except in the case of specific exemptions. Abstract books are certainly property. But, it is said, the provision of the statute means, not only a thing that may be put to valuable uscs, but that which has a recognizable pecuniary value inherent in itself, which is not enhanced or diminished according to the person who owns or uses it. Hence, it is contended, abstract books have no intrinsic value. They are valuable only for the information they contain, which is conveyed by consultation or by extracts, and such value is maintained only by their completeness and continued correetion. Indeed, except as they are used they have no value. ${ }^{27}$ It is further held, that they resemble in their nature the books which are consulted by any person who makes an income from his acquired knowledge, as a surveyor's notes, a lawyer's briefs, a druggist's recipes, and many analogous things. Therefore, while ther may be, and are, very serviceable, yet they are not things which the law makes subject to seizure or asscssment. ${ }^{28}$

On the other hand, we find cases which hold that notwithstanding abstract books are manuscripts and are not made for publication in the general sense, and which concede that such publication would defeat the very purpose of their production, yet maintain that they are the means, in a sense the instruments, for carrying on a business; that they have a commereial value, and that where a commercial value attaches to an object it becomes property; that being property they come within the terms of the statute, and, like other property not specifically exempt are subject to the burdens of taxation. ${ }^{2}$ 146.

27 Perry v. Big Rapids, 67 Mich.

28 Dart $v$. Woodhouse, 40 Mich.
399 ; Perry v. Big Rapids, 67 Mich. 146.

29 Leon Loan, etc., Co. v. Equali- 
It will ler sorn, llwerefore, that the question is one of doubt, to besolved by keal peliey or positive law.

1\%. Exemption of Alstract Books. Analogous to the fuestion discused in the last palragraph is the further question: To what extent, if any, are the looks used by an examiner of titles in his businesis exempt from forect sale on execution? To this question no decisive answer can be given. It is entirely a mattre of local law and statutory construction. In those States where the statute exempts the necessary tools and instruments of "any lerson," used in his trade or business, or by other general terns inchules all kinds of oceupations and the means whereby snch ocenpations are pursued, the books of an abstract maker will be exempt. ${ }^{3 \prime}$ On the other hand, in those States where the exemption privilege is specifically confinerl to certain classes of oecupations, mulese the business of abstract making distinctly falls within one of the enmmerated classes the books used in such business are not distinguishable from other non-exempt froperty, and may be seized and sold to satisfy a judgment against the owner. ${ }^{31}$

zation Board, S6 Iowa, 127; Booth $r$. Phe!ps. 8 Wash. 549.

30 Davidson $r$. Sechrist, 28 Kan.
31 See, Tyler $r$. Coulthard, 95 Iowa, 705; Bank $v$. Abstract Co., 15 Wash. 487. 324. 


\section{CHAPTER II.}

TITLE TO REAL PROPERTY.

\begin{tabular}{|c|c|c|c|}
\hline 14. & $\begin{array}{l}\text { Estate and title distin. } \\
\text { guished. }\end{array}$ & & $\begin{array}{l}\text { Powers. } \\
\text { Homesteads. }\end{array}$ \\
\hline 15. & Acquisition of title. & & Dower and eurtesy. \\
\hline & Classification of title. & & Terms of years. \\
\hline & Sources of title. & 2.5. & Easements and servitudes. \\
\hline 18. & $\begin{array}{l}\text { Nature of title in the Cnited } \\
\text { States. }\end{array}$ & & $\begin{array}{l}\text { Color of title. } \\
\text { Evidence of title. }\end{array}$ \\
\hline & Estates under allodial titles. & & Alienation and descent. \\
\hline
\end{tabular}

20. Uses and trusts.

$\$ 1$ t. Estate and Title Distinguished. A rell defined and strongly marked distinction has been made by the elementary writers, between the property or interest which one has in lands, tenements and hereditaments, and the authority whereby same are hell, or the mode by which they are acquired. This property or specific degree of interest in lands, of whaterer kind or nature, is described in the comprehensive term estate. The method of aequiring and right of holding same is denominated title. The subject of estates, with their quantities, qualities, extent and other attributes, belongs to a treatise on real property, and will be allnded to in this work only as they incidentally occur in treating of the manner by which such estates are acquired or held.

In the paragraphs immediately following a brief mention will be made of the fundamental principles and broad specialized rules which affect the transfer of proprietary rights in land and the devolution of title thereto, and which are incidentally involved in the compilation of abstracts and examination of titles.

\$ 15. Acquisition of Title. It may be stated as an elementary proposition, to which all writers and jurists agree, that there exist but two modes of acquiring title to real property: 
namely, by deseent and by purchase, the latter torm incluidise every legal nethed of acquisition, exeept that by which an heir, on the death of an ancestor, sucereds to the extate of the latter by operation of law. ${ }^{1}$ The common law estates of dower and eurtesy have been regarded by some writers as property coming within the dowtrine of deserente, while others malso a distinction, in respect to estates acquired by purchase, betwern titles rreated hy act of the law, and those created by act of the parties. ${ }^{3}$

$\$ 16$. Classification of Title. Plarkstone makes an elaborate division of title considered in relation to its progresive derelopment, and formulates the following stages: Xaked possession; right of possescion; right of property without possession, and right of property united with posacsion. ${ }^{4}$ This classification, which has been followed and aptrowed by nost English and many American writers, seems necdlessly prolix and a trifle confusing. Jurge Walker in alluling to it save: "Such refinements serve to perplex rather than inform the mind. The truth is, title means the sane thing as ownership. A man may be in possession of a thing which he does not own, and he may own a thing of which he is not in possesion," and draws the inference "that the perfeetion of title consists in the union of possession, with the right of possession." 5

For purposes of comparison only, titles are sometimes classified as bad, doubtful, good and perfeet; the latter being also known as a marketable title, or one which a court of equity considers so clear that it will enforce its acceptance by a purchaser. A doubtful title on the contrary being one that the court will not go so far as to declare invalid, but only that it is subject to so much doubt that a purchaser onght not to be compelled to accept it. ${ }^{6}$ The doctrine of marketable titles is

12 Blk. Com. 24l; James $v$. Moore, 2 Cow. 290; Green $r$. Blanchar, 40 Cal. 194.

23 Cruise Dig. 31 .

3 See 3 Wash. Real Prop. 4; War. velle, Real Prop. 130.
42 Blk. Com. 195.

5 Walker's Am. Law, 317.

62 Boul. Law Dict. 596; Richmond $v$. Gray, 3 Allen, 25. 
purely equitable and of modern origin; at law, every tithe not incurably defective is marketable. It must be distinetly understood, however, that the foregoing classification represents merely convenient colloquialisms. The law knows nothing of "good" or "bad" titles. In fact, they camot be said to have any legal existence. Title is simply title. A person is without title or he has title. IIis title may be perfect or impaired, but "bad" title is merely a rulgarism. The fact that many lawyers employ the tem does not make it any the less a vulgarism. Nor are there any degrees of comparison in titles, for "good" title suggests a "better," or, possilly, a "best."

A more pronounced distinction is made in the case of legal and equitable titles, and their application to estates is of frequent occurrence in actual practice. Though originally applied only to estates in land, the terms are now extensively used to designate the manner of acquiring and holding same as well. The equitable title usually carries with it the beneficial interest in the land, togother with the incidents of ownership, the legal title being held as a mere naked trust, and is illnstrated in the relations of the govemment and a purchaser of public land before patent issnes: a grantee under a land contract after payment made and before execution of deed. Where a trust imposes active duties on the trustee he takes the entire interest in the land and the beneficiary has no title of any kind. The abstract, as a rule, shows only the legal title, unless an equitable title appears from the recitals of the instruments or is plainly deducible from facts appearing on their face.

$\$ 17$. Sources of Title. By a fiction of the English law, the king, as the hearl and sorereign representative of the nation, is regarded as the original proprietor, or lord paramount of all the land in the kingdom, and the true and only source of title. ${ }^{7}$ From lim all the lands in the realm are held, either mediately or immediately, by a tenure, of which fealty is the great characteristic. Under the feudal system this element of fealty was inseparably incident to the reversion, which could never be lost to the ultimate lord.

氵 3 Kent Com. 487; 2 Blacks. Com. 51. 
The foudal sytem contrmplated a prine - the sovercign, and the people:- the suljects, lut with the assmuption of

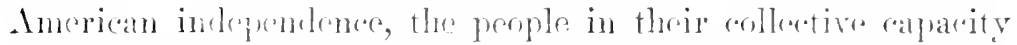

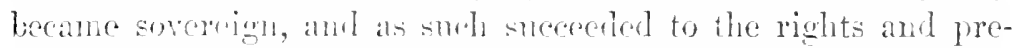
rogations formerly guscesed by the king. As a consequence all valid indiridual title to land in the Cnited States is dro rived only irm the grant of the Ferleral govermment, in the case of pullic lands; from the State governments of such of the States as entered the Lnion as sorepeign lwalies possessed of lands; or, from foreign jowers frior to the Rerolution, or the subseruent acquisition of the teritury by the government, the vested rights of the lant owner being recognized in the latter case by treaty stipulations at the time of the cescinn, or by subsequent confirmation. She king not only possessed the original but alon the ultimate title, an asumption that has never been made by the Iederal govermment, which parts with all its title by its grant or patent. The people of the States, however, in their sovereign capacity, are declared to posess the ultimate property in and to all lands within the juriediotion of the State, the title to which shall fail from defect of heirs, though the character in which the sitate takes is not properly that of a reversioner but rather that of a statutnry heir, who succeeds to the property on defanlt of known kindred of the decedent. $^{10}$

S 18. Nature of Tive in the Cuited states. Then by the Revolution, the domination of the mother enuntry was thrown off, the State, in its sovereign capacity, succeeded to the titles of the king and becane the proprietor of all the lands. ${ }^{11}$ But instead of lending then like a furtal lord to an enslared tenantry, it sold then for the bet price they wonld bring, or, with more than princely generosity, conferest then upon its citizens as a reward for inlustry and conrage in the develop-

83 Kent Com. 498; Jackon $r$. Ingraham, 4 Johns. 1183; Jackson $v$. Hart, 1.2 Johns. T.

93 Kent Com. 488; People v. Livingston, 8 Ijarly. 253.
10 Wallace $\vartheta$. Tarmstad, $44 \mathrm{~Pa}$ St. 402.

11 Commonwealth $r$. Alger, Cush. 82: Juhnon $t$. McIntosh, 8 Wheat. $58+$. 
ment and settlement of the country, or in recognition of valor and patriotic derotion in its defense. Its patents all acknowledge a pecuniare or valuable consideration, and stipulate for no fealty or other feudal ineident. "The State is lord paramount, as to no man's land." 12 Though here, as in England, indiridual ownership in lands can be deduced only from the sorereign - the Crown, the ante-revolutionary, United States, or State governments, - yet, when so acquired it is held in pure and free allodium, being the most ample and perfect interest that ean be obtained in land and denoting a full and absolute ownership; ${ }^{13}$ "a time in the land withont end" 14 with no duties to a superior lord, or services or fealty incident thereto. The allegiance which the citizen owes to the State is frequently spoken of as fealty, ${ }^{15}$ but this is an obligation arising from political status, and is as binding on him who orms no land as on him who eounts his aeres br the thousands. It is an obligation, reciprocal to protection, resulting from our political relations, and in no way affects the title to land more than to chattels. ${ }^{16}$

It is, lowerer, a well-settled principle, growing out of the nature of well-ordered ciril society, that every holder of property, however ahsolute and unqualified may be his title, holds it under the implied liability, that its use mar be controlled and regulated by the State in such a manner as not to interfere with the equal enjorment by others of their properts, nor be injurious to the rights of the communits, ${ }^{17}$ and subject to such laws as the legislature mar enact to regulate the mode of converance, descent, right of dower or other rights growing out of the domestic relations. ${ }^{18}$ All property is held subject to

12 Wallace $r$. Harmstad, 44 Penn. St. 49:- Van Tansellær $v$. Smith, 27 Rarb. $15 \%$.

131 Bou. Law Dict. 115; 1 Wash. Real Prop. 16.

14 Plowlen. 5.5.

152 Bou. Law Dict., 585 Art., "Tenure."
16 Trallace $r$. Harmstad, 44 Penn. St. 492; Carlisle $v$. United States, 16 Wall. 146.

17 Commonwealth $v$. Alger, 7 Cush. 53; Commonwealth $v$. Tewkesburs, 11 Met. 55.

is Barker $v$. Dayton, 28 Wis. 367 . 
those ganeral lowalations astablished by law, which are neros-

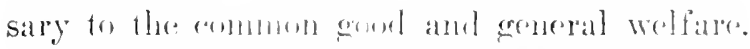

§ 19. Estates under Allodial Titles. The highest estate held by an allowid tillo is donominated a fee simple; a nano bormwed from the land syetren of Cireat Britain, Imt of far greatre import lueve than therr. It sienilies an alsonlute estate of inleritanere, rear of any lestrictions to particular heirs, and is the lareset estate and most gemeral interest that can be onjoved in land, Ixing tho ontire property therein, and confors an mulimited jower of aliemation. ${ }^{19}$

Though usually desoribul as above, tho estate is comprised in the wort "foe," the allition of the word "simple" arlding nothing to the foree and comprehencivenes af the term. ${ }^{20}$ A sale of the foe does not inelute, in the term itsolf, al sale free from incumbrances, but denubes only the natmere of the estate as distinguished from a lessm or lostricted one, amd land may be solel in fee subject to incmubrances, the expression involsing no incomsistere $\mathrm{r}^{21}$

The fine distinctions of the English law in respert to estates have little application in the Lnited States, and the American doctrines on this subject, though regulated by statute in the different States and hence differing some in detail, are comparatively simple. In addition to the fee, or inheritance, we have estates for life, for years, at will and br sufferance. The estate in fee tail is practically abolished, the entail being limited to the first taker, while the remainder carries the fee. Estates of inheritance and for life are generally denominated freeholds; estate for vears, chattels real.

With respect to the time of their enjorment, they are further divited into estates in possession and in expectancy; the latter being again divided into estates commencing at a future day, called future estates, and reversions. A future estate is one limited to commence in possession at a future day, either witl or without the intervention of a precedent estate, or on

19 Haynes $v$. Bourn, 42 Vt. 686; Warvelle, Real Prop. 70.

20 Jecks $v$. Toussing, 45 Mo. 167.
21 Caal $v$. Higgins, 23 N. J. Eq. 308. 
the determination, $l_{y}$ lapse of time or otherwise, of a precedent estate, created at the same time. When preceded by a particular estate they are generally known as remainders.

A reversion is the resilue of an estate left in the grantor or his lieirs, or in the heirs of a testator, commencing in possession on the determination of a particular estate granted or devised.

Future estates, or remainder', are also classed as vested or contingeni. They are vested when there is a person in being who would have an immediate right to the possession of the lands, upon the ceasing of the intermediate or precedent estate. They are contingent while the person to whom or the event upon which they are limited to take effect, remains nucertain. As a general rule contingent interests are assignable, devisable and descendible the sane as rested interests. ${ }^{22}$

In respect to the number and connection of their owners, estates are divided into estates in severulty, in joint tenancy and in common. ${ }^{23}$ The estate in joint tenancy has now hecome very infrequent and is generally confined to interests held by a number of persons as trustres. It may still be ereated, however, by the employment of apt words.

As a rule, every conveyance or devise of lands is to be deemed a fee simple, if a less estate is not limited by express words, or does not appear otherwise by construction or operation of law, ${ }^{24}$ and future estates are alienalile in the same nunner as estates in possession, by deed of bargain and sale withont covenants. ${ }^{25}$

$\S 20$. Uses and 'rusts. The ancient doctrine of uses and trusts prevails to a limited extent in the United States, though its effect is by no means miform. I majority of the States,

22 Kenyon $v$. See, 94 N. Y. 563 ; Winslow $v$. Goodwin, 7 Met. (Hass.) 363.

23 Estates, in the United States, are essentially creations of the statute, preserving a general harmony in all tlie States, but frequently widely divergent in detail. The statute should always be consulted in eonstruing them.
24 Leiter $v$. Sheppard, 85 Ill. 242. This is the general statutory rule but in a few States the old eommonlaw ideas seem to have been retained and a grant or devise withont words of inheritance ereates only a life estate in the grantee. Sce, Pate v. Bushong, 161 Ind. 533. 25 Goodel $v$. IIibbard, 32 Mich. 47 ; Kenyon $v$. Sce, 94 N. Y. 563. 


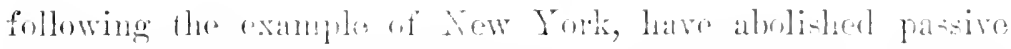

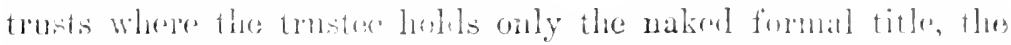

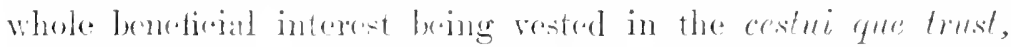
the statule, in such rase, confimning to the beneficiary a legal cstate therein of the sune (puality and luration, and subjort to

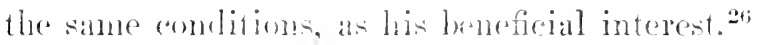

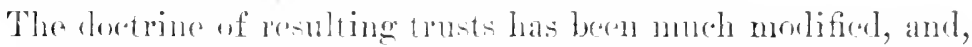
as a rule, no implied or resulting trust is ceffectual to nofeat or prejuries the tithe of a purchaser for a valuable eonsideration, and without notices of surh trust.

Express truste are nsually rombuted hy statute, and are reated for the sale of lanel tor the benetit of eroutitors, legat tees, cte. or for the purpose of satiefying any charge thereon; for the collowion and application the routs and profits of land; and for the benctivial interests of any preom or persons, when such trust is fully expressed and relearly defined upon the face of the instrmunt. Whore the clasede of express trusts are specifically cummerated by statute, the creation, for any purpose, of any trust not so enumerater vests no estate in the truster, though if valid as a jower the lands to which the trust relates remain $i_{i}$ or descend to the persoss otherwise entitled, subject to the execution of the tinst as a power. So particular form of words is necessary to create a trust, and effect will always be given to the intention of the panties. 27

\$21. Powers. Closely allied to trusts, and partaking somewhat of their nature, are pouers, the creation, construction and execution of which, are, in a majority of the States, governed by express statutors provisions. A power, as defined, is an authority to do some act in relation to lands, or the creation of estates therein, or of charges thereon, which the owner granting or reserving such power might limself lawfully perform, and no person is capable, in law, of granting a power,

26 The above statements are substantially true of all the States whose procelure is the same as, or similar to, the N. Y. Revision, and conveyances to use are generally abolished in all the States: 4 Kent's Com. 30s; Verdin $v$. Slocum, $71 \mathrm{~N}$. Y. 345 .

27 Fisher v. Fields, 10 Johns, 495; Saylor $v$. Plaine, $31 \mathrm{Md} .158$. 
who is not at the same time capable of alienating some interests in the lands to which the power relates. Powers are general or special, and beneficial or in trust. ${ }^{28}$

A power is general when it authorizes the alienation in fee, by deed, will, or charge of the lands embraced in the power, to any alience whatever; and is a simple form of familiar oecurrence. It is special, when the appointee is designated; or where it authorizes a conveyance of a particular estate or interest less than a fee. A general or special power is beneficial, when no person other than the grantce, has, by the terms of its creation, any interest in its execution. A general power is in trust, when any person, other than the grantee, is designated as entitled to the proceeds, or other benefits to arise from the alienation of the lands. A special power is in trust, when the disposition which it authorizes is limited to be made to any particular persons other than the grantee; or when any class of persons, other than the grantee, is entitled to any benefit from the disposition or charge authorized by the power.

A porrer may be granted by a suitable elause contained in the instrument of conveyance of some estate in the lands to which same relates, or by derise contained in a last will and testament, and may be vested in any person eapable in law of holding lands, but can not be exeeuted by a person not capable of alienating lands holden by such person.

A power, technically speaking, is not an estate, but is a mere authority, enabling a person, through the medium of the statute, to dispose of an interest in real property, vested either in himself or in another person, ${ }^{29}$ and where a power is executed, the person taking under it takes under him who ereated the power, and not under him who executes it. ${ }^{30}$

A power to sell land can only be exereised in the manner and

2s Kent Com. 319; 2 Bou. Law Dict. 356. The classification above given is that which is now generally oiserved in this country, though it dillers somewhat from the common law classification.
29 Burleigh $v$. Cloughs, $52 \mathrm{~N}$. H. $268 ; 2$ Prest. Abstracts, 275 . 30 Legget $v$. Doremus, $25 \mathrm{~N}$. J. Eq. 122. 
for the presise purpese drelared and intruded lye the lonor, and when the purpese berones whelly wattainathe, the powere ceases. ${ }^{31}$ In the construction of powers, the intention of the partios, if conpatible with law, must govern; and the intention is to be detemined from the instrmment creating the power. ${ }^{32}$

$\$ 22$. Homesteads. The statutes of all thre States have injected into the law of real property, as applierl in this country, a new quality, unknown to thr (ommon law, denominated "homestearls." The homestearl is unully a constitutionally guaranteed right ammexed to land, wherethe the same is exempted from sale muler exention for lobs. No uniform rule ean be given for its ascertainment, it being varionsly measured either by a definite money value, ur a specitic alpuropriation of land. Nor can any general definition of its character be given other than the abore, as the anthorities are by no means harmonious in prescribing its limit, or dofining its efferet.

In some of the States the homesteal is an estate, 33 limited only as to its value, and not by any specific degree of interest or character of title in the particular property to which it attaches, and when the worth of the property does not exeed the statutory raluation, the estate cmbraces the entire title and interest of the householder therein, laving no separate interest in him to which liens can attach or which he can alien distinet from the estate of homestead. ${ }^{34}$ Such estate has also been regarded as a determinable fee. ${ }^{35}$

The right of homestear, in a majority of the States, is held to be but a privilege of occupancy against creditors, ${ }^{36}$ the continuance of which depends upon the continuance of preseribed conditions. ${ }^{37}$ When once aequired it is a rested right, ${ }^{38}$ though

31 Hetzel $v$. Barber, 69 N. Y. 1. Haslam $v$. Campbell, 60 Ga. 650.

32 Guion $v$. Pickett, 42 Miss. 77; 36 Brame $r$. Craig, 12 Bush Jackson $v$. Veeder, 11 Johns. 169.

33 Littlejohn $v$. Egerton, 77 N. C. 379 ; Eldridge $v$. Pierce, 90 Ill. 474 ; Jenkins $v$. Volz, 54 Tex. 636. 34 Merritt v. Merritt, 97 Ill. 243. 35 Poe $v$. Hardie, 65 N. C. 447 ; (Kr.), 404; Casebolt $r$. Donaldson, 67 No. 308; Drake $v$. Kinsell, 38 Mich. 232.

$3 \pi$ Hill $r$. Franklin, 54 Miss. 632. 38 Barret $v$. Mcssner, 30 Tex. 604; Barber $v$. Roarbeck, 36 Mich. 399 . 
it seems it may be impaired by subsequent legislation, ${ }^{39}$ and can be lost only by abandomment. ${ }^{40}$ The homestead law does not vest in the owner any new rights of property but simply inposes restrictions on the creditor in seeking satisfaction for lis debt, ${ }^{41}$ and the protection afforded by it attaches to an exnitable title with the same force as to the legal title. ${ }^{42}$ Where there is an abandonment, with a fixed intention not to return, the homestead may be subjected to the demands of creditors, but the question is almost exclusively one of intent, and absence for an indefinite period is not sufficient to establish the fact of an abandonment, muless accompanied with proof of intent not to return. ${ }^{43}$

In every State special restrictions have been placed on the alienation of the homestead, it being in contemplation of law the last retreat and shelter of the family; and though its sale is permitted the voluntary act of either husband or wife, or both, would be ineffectual for that purpose, except in the manner provided by statute, ${ }^{44}$ and, as a rule, the alienation of homestead property by either spouse without consent of the other is an absolute nullity, the purchaser acquiring no title whatever. ${ }^{45}$ When a party derives title to property in good faith, and in the prescribed methods, through one who has a homestead right therein, he will, it seems, snceed to his grantor's rights, and take the property exempt from his grantor's debts. $^{46}$ In many examinations the questions raised with respect to homesteads are very important.

$\$ 29$. Dower and Curtesy. One of the common law in-

39 Harris $v$. Glenn, 56 Ga. 94.

40 Carr $v$. Rising, 62 IIl. 14; Crook $v$. Lunsford, 2 Sea (Tenn.) 237.

41 Bank $v$. Green, 78 N. C. 247.

42 Allen $x$. Hawley, 66 Ill. 164; Smith $v$. Chenault, 48 Tex. 455. 43 MeMillan $v$. Warner, 38 Tex. 410; Potts $v$. Davenport, 79 Ill. 455. 44 Fiege $v$. Garrey, 47 Cal. 371 ; Balkum $r$. Wood, is Ala. 642. \$5 Rogers $r$. Ronshaw, 37 Tex.
625; Abell $v$. Lathrop, 47 Vt. 375; Barnett $v$. Mendenhall, 42 Iowa, 296; Richards $v$. Green, 73 Ill. 54; Bank $v$. Lyons, 52 Miss. 181; Miller $v$. Marx, 55 Ala. 322.

46 Shackelford $v$. Todhunter, 4

Ill. App. 271 ; Adrian $v$. Shaw, 82 N. C. 474; Leupold $v$. Kruse, 95 Ill. 440; Carhart $v$. Harshaw, 45 Wis. 340 ; Holland $v$. Kreider, 86 Mo. 59. 
cidents of roat propery is dower, being that provision which

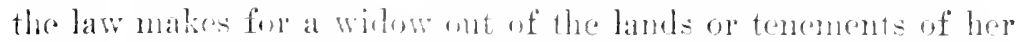

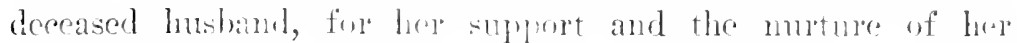

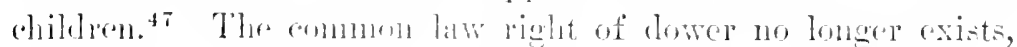
lowerer, in a majolity of the states, the rights of the smriving wife in the real retate of her drerased hmeband being those creatcel by statute alone, and gurstions arising upon them nust

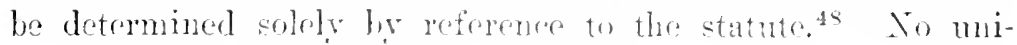
form measure, wither as to guantity ol goulity, has been

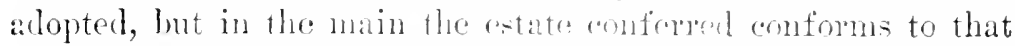
of the eommon law and romsiste of the nor by the wilow, duming her life, of one third lart of all the land- wherest her husband was seized of an estate of inheritance at any time during the nuariage.

During the lifotine of the husband, the wife has only an inchoate richt, whirh is not an estatro in thr land but a more contingent interest that attalehes to the laml as som as there

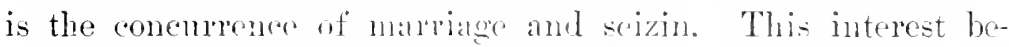
comes fixed and cortain upon the doath of the hubanel, and after the assigment of dowel derelops into a frechold rotate in land. ${ }^{49}$ During the marriage no act of the hubband alone could, at common law, har or extingnish this interest, whioh in Fngland was accomplished only by lerying a fine or suffering a common recovery" In the Lnited States a woman may be barred of her dower by jointme settled on her before marriage, or by joining with her husband in a deed of converance, properly acknowledged. ${ }^{51}$

Before dower has been assigned, it can be released only to the owner of the fee, or to some one in privity with the title by his covenants of warrantr. But where the former owner of tho fee in land in which dower rights still exist, has conveved the same with warranty, he may purchase the right for the

472 Black. Com. 130; 4 Kent ('om. 35 .

48 Gaylord $v$. Dodge, 31 Ind. 41.

49 Elmdorf $v$. Lockwood, 57 N. Y.
502 Black. Com. 137; 4 Kent's Com. 51.

514 kent Com. 60; Elmdorf $v$. Lockwood, 57 N. Y. 322. 322 . 
benefit of his grantee, however remote, and thus prevent a breach of the covenants. ${ }^{52}$

The release of dower which a married woman makes by joining with her husband in a conveyance of his land, operates against her only by estoppel, and can be taken advantage of only by those who claim under that conveyance, ${ }^{53}$ and if the conveyance is roid, or ceases to operate, she is again clothed with the right which she had released.

During coverture, the wife's inchoate right of dower is incapable of being transferred or released, except to one who has already had, or by the same instrument acquires an indepenlent interest in the estate. ${ }^{54}$ The right is not such an estate as can be leased or mortgaged, ${ }^{55}$ neither can a married woman bind herself personally by a eovenant or contract affecting her right of dower during the marriage. Hence, a deed executed by husband and wife with a covenant of warranty, does not estop the wife from setting up a subseqnently acquired title to the same lands. ${ }^{58}$ The inchoate right of dower not being the subject of conveyance in any of the usual forms by which real property is transferred, and the doctrine of estoppel by which subsequently acquired titles are made to inure to the benefit of former grantees being inapplicable, it follows that a grantee or nortgagee claiming under an instrument executed by a woman during coverture aequires no title or interest in the dower of the grantor or mortgagor when the estate becomes absolute, whether dower has been assigned or not. ${ }^{57}$ But in all cases where the wife unites with her hnsband in a conveyance, properly executed by her, which is effectual and operative against the husband and which is not superseded or set aside

52 La Framboise v. Crow, 56 Ill. 197 .

53 Malloney $v$. Horan, 49 N. Y. 111; Lockett $v$. James, 8 Busl (Ky.), 28; French $v$. Crosby, 61 Me. 502 .

54 Roljinson $v$. Bates, 3 Met. 40 ;

Tompkins $v$. Fonda, 4 Paige, 448.

55 Croade $v$. Ingrahant, 13 Pick.
56 Jackson $v$. Vanderheyden, 17 Jolnes. 167.

57 Marvin $v$. Smith, 46 N. Y. 571; Carson $v$. Muray, 3 Paire, 4s3. It will be understood that the statement of the text has no reference to lands held by a married woman in her own right. 33. 
as against him or his grantee, her right of dower is forever barred and cxtinguished, for all purposes and as to all persons. 5 .

Tenancy by the curtesy has been generally abolished and the husband takes a statutory allowance fron the deceased wife's estate, the quantity and quality varying in the different States. Tenancies in derrer or enrtesy stand, like all other estates of freehold for life, neecsarily subjected to the charges, duties and services to which the estate may be liable, in proportion to the interest therein. ${ }^{59}$ In the examination of titles dower is an important incident and always raices an inquiry in erery conveyance not of an oficial nature.

\$2t. Terms of Years. Next to a fee simple, the most common estate known to our law is an estate for years, being a right to, or eoutract for, the possession and profits of lands in consideration of a recompense, called rent. ${ }^{60}$ Estates for vears, for life, and at will or ly sufferance, are frequently called "tenancies," beeause the hollers thereof are regarded as mere occupants, while the ultimate title remains in the proprietor of the fee. This, howerer, is not strictly exact, as every owner of an estate is, in law, a tenant, that is, a holder, without reference to the quantity or quality of the interest. But in common parlance the owner of leaschold interests are generally called tenants as distinguished from owners of indeterminate interests or estates.

In estates for years, the time as well as the estate itsolf are both called a term. Such an estate is not an interest in the land, but only a right to the use and possession thereof for a definite period, hence a tenant is not said to be seized of the land, but only possessed of the term. The estate is of frequent oceurrence in the examination of titles, and often rivals in dignity and importance the fee itself. It is created by an instrument ealled a lcase, and is terminated by its own limitation; by forfeiture, in conseruence of a breach of some expless stipulation or covenant; or by operation of law termed a merger, where the tenant by any means becomes seized of the fee

58 Elmdorf $v$. Lockwood, 57 N. Y. 322.
59 Peyton $r$. Jofries, 50 Ill. 143.

$60+$ Cruine, Dig. 5l. 
of the reversion. The tenaney may also be terminated by a surrender of the lease to the landlord, or where the subject-matter of the lease wholly perishes. The tenant is never permitted, for reasons of sound pulblic policy, to controvert his landlord's title, or to set up against him a title acquired by himself during his tenaney which is hostile in its character to that which he acknowledged in accepting the demise.

\$ 25. Easements and Serritudes. An easement has been defined, as "a right in the orner of one parcel of land, by reason of surh ownership, to nse the land of another for a special purpose not inconeistent with a general property in the owner." ${ }^{1}$ This, perhaps, is as good a definition as can be framed. Easements are as rariors as the exigeneies of domestic convenience or the purposes to which buildings and land may be applied, and are created by grant, confirmation, reservation or preseripitive user. The owner in fee of land may impose upon it any burden, however injurions or destructive, not inconsistent with his general right of ownership, if such burden be not in violation of public policy and does not injuriously affect the rights or property of others. ${ }^{62}$

An easement mar be created, or reserred by an implied grant, when its existence is necessary to the enjoyment of that which is expressly granted or reserved, upon the prineiple that, where one grants anything to another, he thereby grants him the means of enjoring it, whether expressed or not, ${ }^{63}$ but easements exist as appurtenant to a grant of lands only by reason of a necessity to the full enjoyment of the property granted. ${ }^{64}$ Tothing passes by implication, or as incident or appurtenant, except such rights or privileges, as are directly necessary to the proper enjorment of the granted estate, and the necessity measures the extent and duration of the right. When the necessity ceases, the rights resulting from it cease. ${ }^{65}$

61 Wash. Real Prop. 25: Neek $r$. Breckenridge, 29 Ohio St. 642.

fo Tan Rensseler r. R. R. Co., 1 Hun (X. I. , . $50 \%$.

63 Lanier $i$. Booth. 50 Mis.. 410 ; Pingree $r$. McDuffe, 56 N. 1H. 306 ;
Dillman $r$. Hoffman, 38 Wis. 559. 64 Woodworth $v$. Raymond, 51 Conn. 70 .

65 Hancock $r$. Wentworth, 5 Met. 446 ; Cares $r$. Rae, 12 Rep. 523. 
It must be an actual and a direct necessity. A mere convenience is not snfiucient to create or convey a right or easement, or impose burdens on lands, other than those granted, as incident to the grant. ${ }^{60}$

Easements of necessity, when the title to the dominant estate and to the serrient estate mite in a common owner, are merged and lost. On separate converances of the estates by the common owner, snch eascments are not revived, nor treated as having existed during the time the two estates were in the common owner, but are re-crated by the conveyance of the estates separately, and arise from the application of the rule above stated. ${ }^{6 \tau}$

In respect to the acquisition of easements by user, no universal rule of law as to the effect of evidence of particular facts can be laid down, and when established by prescription, or inferred from nser, such easements are limited to the actual user. A right claimed by user is only co-extensive with the user. $^{\text {is }}$

Special easements are created by grant or confirmation, or may be reserved by special reservation in a converance of lands, and easements created in this manner do not cease, even though the necessity for them may have ceased. ${ }^{69}$

A license is an authority to enter upon the lands of another and do a particular act or series of acts, without possessing any interest in the land. A claim for an easement must be founded upon a grant, by deed or writing, or upon prescription which presupposes a grant, for it is a permanent interest in another's land; but a license, conveying no estate or interest, may be by parol. It is founded in personal confidence, is not assignable, and if executory is revocable at the pleasure of the grantor. The distinction, however, is quite subtle,

66 Ogden i. Jennings, 62 $\mathrm{N} . \mathrm{Y}$. 526; Holmes $r$. Seely, 19 Wend. 507 ; Warren $v$. Blake, 54 Me. 276; Carey $v$. Liae, 12 Reporter, 523.

67 Miller v. Lapham, 44 Vt. 416.
68 Brooks $v$. Curtiss, 4 Lans. (N. Y.) 283.

69 Atlanta Mills $x$. Mason, 120 Mass. 244. 
and it hecomes difficult, in many cases, to discern a substantial difference between thens. ${ }^{\text {io }}$

In the cxaniuation of titles easements of record are readily ascertained, but, as an easement may exist withont an express grant, the attention of clients should always be directed to the incidents, sitnation and condition of the land, and particularly to the rights of persons in possession or exereising acts of ownership.

$\$ 26$. Color of Title. A title may be actual or merely colorable. A person is properly said to lave color of title to lanıls when he has an apparent thongh not a real title to the same, founded upon a deed which purports to eonvey them to him, ${ }^{71}$ and a claim to real property under such a converance, however inadequate it may be to carry the true title, or however incompetent the grantor nnay be to convey such title, is strictly a claim under color of title. ${ }^{2}$ Possession under color of title for the periot of statutory limitation, confers upon the holder a perfect title in law, and where one takes possession under a deed giving eolor of title, his possession may be transferred to subsequent parties, and the possession of the different hollers may be mited so as to make up the statutory period, the operation being technically ealled tacking. ${ }^{i 3}$ Titles aequired in this mamer mot, however, show connecterl possestion, and a privity of grant or descent. Those who hold lands independently of previous holders, their several possessions haring no comnection, can not so tack their possession as to avail themselves of that which has gone before. ${ }^{74}$

\$ 27. Evidences of Title. There is, strictly speaking, but one species of title to lands, and that the legal title. Individuals may possess equities of recognized potency, but such equities, after all, do not constitute title, although they may carry with them the right to the title and the entire beneficial

70 Mumford $v$. Whitney, 15 Wend. 380; Thompson $r$. Gregory, 4 Johns. 31; 3 Kent Com. 452.

71 Signenret $v$. Fahey, 27 Minn. 60; ligor v. Frye, 62 Ill. 507.
72 Eugerton $r$. Bird, 6 Wis. 527; Ilinkley $r$. Greene, 52 Ill. 223. is Cooper $r$. Ord, 60 Mo. 420.

7t Crispen $r$. Ilannavan, $50 \mathrm{Mo.}$ 536. 
interest. Conrts of equity nuag grant relief to the holders of such equities, but at law the legal title must always prevail. ${ }^{5}$

A sale of real property, whether judicial or voluntary, does not pass title, but only gives a right to a converance of the land according to the terins of sale, ${ }^{\text {is }}$ and the purchaser can not be treated as the legal owner of the property, until it has becn duly transferred to him by a deed executed by proper anthority. ${ }^{77}$ The evidences of legal title consist of voluntary grants by the sovereign, or indivinal; converances resulting from judicial procecdings, or made in the exere of the taxing power of the State; deeds executed by tmistees or other ministerial officers; regular decents in the maner provided by law; or continuous possession which presupposes sone one of the other methods.

$\$$ 28. Alienation and Descent. The Constitution of the Enited States declares that Congress shall have power to dispose of and nake all needful rules and regulations respecting the territory and other property belonging to the gorernment, and under this provision the sale of the public lands has been placed by statute unler the control of the Secretary of the Interior. To aid him in the performance of this duty, a bureau has been created, at the head of which is the commissioner of the General Land Office, with many subordinates. To them, as a special tribunal, Congress has confided the execution of the laws which regulate the disposal and general care of these lands, and has also enacted a system of laws by which rights to these lands may be acquired, and the title of the government conreyed to the citizen. ${ }^{i s}$ Congress has the sole power to declare the effect and dignity of titles emanating from the United States, ${ }^{79}$ and the States can not interfere with the primary disposition of the soil by the general government. Whether a title to a tract of public land has passed from the

75 Bagnel $v$. Broderick, 13 Pet. 436 ; Fenm. $v$. Holme, 21 How. 481 .

ic Semple $v$. Bank, 5 Sawyer (C. (i.) 394 . it Page r. Rogers. 31 Cal, 294;

Smith $r$. Colvin, 17 Bark. 157.

is Cnited States $v$. Schurz, 102 U. S. 378 . 
United States, is a question depending solely upon statutes enacted by Congress.

After title has passed from the gorernment the land becomes subject to the laws of the State in which it lies, ${ }^{80}$ and to the laws of such State recourse mmst be had for the rules which govern its descent, alienation and transfer, as well as for the effect and construction of its conveyances. ${ }^{81}$ All the means by which the title to real property is transferred, whether by deed, by will, or by judicial proceeding, are subject to, and may be governed by, the legislative will of the State in which it lies, ${ }^{82}$ except where such law impairs the obligation of a contract, and all the laws of a State existing at the time a conveyance or contract is made, which affect the rights of the parties to the same, enter into and become a part of it. ${ }^{83}$ The State possesses the sole power to regulate the modes of transfer and the solemnities which accompany them, and titie can be acquired, transferred or lost only in aceorlance with such regulations, ${ }^{8 t}$ though it would scem that in the interpretation of deeds personal covenants can not be implied if not authorized by the laws of the State where the deed was made, ${ }^{\text {s }}$ while in some states the rule as above stated has been so modified by statute that lands may be as effectively conveyed by conforming to the law of the place where the deed is executed and acknowledged. ${ }^{\text {se }}$ In the latter case proof of such conformity should accompany the deed or other instrument of conveyance.

79 Bagnell $v$. Broderick, 13 Pet. (U. S.) 436.

so Wilcox v. Jackson, 13 Pet. (U. S.) 498 .

s1 McGoon $v$. Scales, 9 Wall. (U. S.) 23 ; Clark $v$. Graham, 6 Wheat. 577 ; McCormick $v$. Sullivant, 10 Wheat. (U. S.) 192. s2 Osborn $v$. Adams, 18 Pick. (Mass.) 245 .

sa Brine $v$. Ins. Co., 96 U. S. 627 ;

Bronson $v$. Kinzie, 1 How. 311. 8+ Story's Conf. Laws, 708.

s5 Bethel $r$. Bethel, 5t Ind. 428.

si Hoadley $v$. Stephens, 4 Neb. 431. 


\section{CHAPTER III.}

TITLE BY DESCENT.

§ 29. Nature of the title.

30. Rules of descent.

31. Consanguinity.

32. Affinity.
\$33. Adoption.

34. Proof of heirship.

35. Proof of death.

36. Conveyances ly heirs.

§ 29. Nature of the Title. Deseent, or hereditary succession, is the title whereby one person, upom the death of another, suceeds to or aconires the estate of the latter as heir at law, the estate so derived being called an inheritance. Though of universal ob-ervance, inheritance is not a natural right but is purely statutory, and therefore arbitrare, absolute and unconditional. 2 in heir at law is the only person who, by the common law, becomes the owner of land without his own agency or assent, the law casting the title upon him without regard to his wishes or election, and when the right of inheritance is fully established by strict empliance with the law relating to descents, proof of heirship, etce, the title thus conferred is of the highest dignity and effectual for all purposes. In the absence of probate procedings or a judicial determination of the rights of the heirs, titles depending on descent are to be viewed with jealousy and aceepted with caution, and particularly will this be the case where title is asserted through descent, by an heir in a remote degree from the intestate or common ancestor.

The title to the land of an intestate rests immediately in the heir who holds same in bis own right, but charged with the payment of the ancestor's debts, ${ }^{3}$ and until finally settled

12 Black. Con. $201 ; 4$ Kent Com. *374.

2 Tyler $v$. Reynolds, 53 Iowa, 146.

3 Walbridge $v$. Day, 31 Ill. 379 ; Chubb $v$. Johnson, 11 Tex. 469. 
in the probate court the estate is liable to bo defeated by a sale made in due conrse of administration, becoming absolute only after the debts are extinguished. ${ }^{4}$

The heirs are said to take per capita or per stirpes, that is direct, or in their own right, they standing in equal degree, and receiving equal shares; or, by right of representation, where the descendants of a decensed heir take the same share or right in the estate of another person that their ancestor would have taken if living. Posthumons chiliren are considered as living at the death of their parents and participate as such. ${ }^{5}$

Inheritance only accrues to the issue of lawful wedlock, but all the presumptions of law are in favor of legitimate birth, ${ }^{6}$ and an illegitimate child is generally concidered as the heir of its mother. ${ }^{7}$ The descent of real property and the order of succession is governed by special statutes known as "rules of descent," and which vary in every State.

$\S 30$. Bules of Descent. "The English law of descent" says Chancellor Kent, " is governed by a number of rules, or eanons of inheritance, which have been established for ages, and have regulated the transmission of the estate from the ancestor to the heir, in so clear and decided a manner, as to preclude all uncertainty as to the course which the descent is to take. But in the United States, the English common law of descents, in its most essential features has been universally rejected, and each State has established a law of descent for itself." The laws of the several States, while preserving a general agreement in their essential outlines, yet differ materially in detail, and it is doubtful if any two of them are exactly alike, a circumstance that has induced a distinguished writer on this subject to say, that " this nation may be said to have no general law of descents, which probably

4 Vancycle $v$. Richardson, 13 Ill. 171 ; Wilson $r$. Wilson, 13 Barb. 252.

54 Kent Com. 412; Morrow $v$. Scott, 7 Ga. 535 .
6 Fox $v$. Burke, 31 Minn. 319.

7 Miller $v$. Williams, 66 Ill, 92.

This matter is statutory.

84 Kent Com. ${ }^{*} 374$. 
has not fallen to the lot of any other civilized country." a No attenpt will he lope mule to summarize or explain the regulations of lesent in the varions States, but in the conrse of his investigations, the exaniner will frequently have to refer to then for astistance in mraveling knotty points or snarls in the tamblen sisuin of title.

The transinimion of property by hereditary descent, from the parent to lis clildren, is the dictate of the natural affections, and forms the first rule of inlloritance in every State, varied in sone cases, however, by the equal particination of the widow. From this point on there is no uniformity, but, as a rule, the lincal kindred take in preference to the collateral. If the descemiants all stand in the same desree of consangrinity they take equally, otherwise ly right of representation, and if there be no heirs, the property escheats to the State. The degrees of kimlred are nsually computed in the Tnited States, accorling to the rules of the civil law; and the kindred of the half-blool inherit cqually with those of the whole blood, in the sane degree, unless the inheritance be ancestral, in which case, as a general proposition, thuse who are not of the blood of such ancestor are excluded. The last mentioner rule has been enacted substantially in most of the States, but is held to refer to the immediate and not to a remote ancestor. ${ }^{10}$

$\S 31$. Consanguinity. The relation subisting among all the different persons reseending from the same stock or common ancestor, is called consanguinity, and is the medium throngh which, in the descent of ral property, the several degrees of kindled are computrd and destuced. Consangninity is lineal or collateral; the forner beiug the relation which exists among persons where one is descended from the other, as between father and son, in the tirect line of descent; the latter is the relation subsisting between persons descended from the common ancestor, but not from eacl otler, as between brother and sister. There are two methols of computing the

9 Reeve on Descent, pref.

10 Buckingham $v$. Jacques, 37

Conn. 402; Curren v. Taylor, 19
Ohio, 36; Larder $v$. Collins, 2 Pet.

58; Cramer's Appeal, 43 Wis. 167;

Ryan $v$. Andrews, 21 Mich. 229. 
degrees of consangninity, known respectively as the civil, and common law method, the latter being also the same as the canon law.

The rule of the civil law is generally used in this country, and is preferable for that it points ont the actual degree of kindred in all cases. This node of computation begins with the intestate, and ascends from him to the common ancestor, and descends from such ancestor to the next heir, reckoning a degree for each person, both ascending and descending, and the degrees ther stand from each other is the degree in which they stand related. According to this rule of computation it will be seen, the father of the intestate stands in the first degree, his brother in the second, his nephew in the third, ete.

Bo the common law method of computation, different relations may stand in the same degree, and the degrees are counted the same whether lineal or collateral. The mode of the common and canon law is to discoser the common ancestor, and beginning with him to reckon downwards, and the degree the two persons, or the more remote of them, is distant from the ancestor, is the degree of kindred subsisting letween them. ${ }^{11}$ By this means the father and brother of the intestate, or person proposed, stand in the same degree. By the ciril law the father stands in the first degree, the brother in the second. So by the comnnom law the first consin stands in the second degree; by the civil law he would stand in the fourth.

The line of ancestry is classed as ascending or descending, taking the person proposed as the unit, and is further classified as patemal or maternal, according as the examination may lead through the father or the mother. In England, a fair ability to trace genealogy is an indispensable requisite of the examiner, as, owing to the non-probate of real estate wills until very recent years, a pedigree always accompanys an abstract showing a descent. The matter is of much less importance in the Lnited States, as in all properly condneted probate procedings a table of heirship is always fomd. As an illustration of the subject under discussion, a diagram of the

111 Boll. Law Dict. 327; 2 Black. Com. 202. 


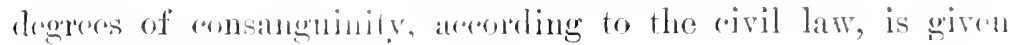

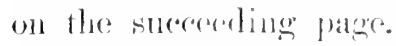

\$.). Antinity. The relationship or connection arising in consecpuence of malriage, which exists between each of the malried persons and the kindred of the other, is termed affinity, and is distingnistend tom consanguinity which is used to denote the tios of blomel. At common law the relationship of athinity is mot sulticient to olutain learal sucossion or inheritance, but by statute, in some States, the surviving husband or wife has been endowed with inhruitalo fualitios and either may take as an heir of the othere arourling to the preseribed rules of descent; and in the sesuse that an licile at law is simply one who suececds to the astate of a deroased prostl, the surviving

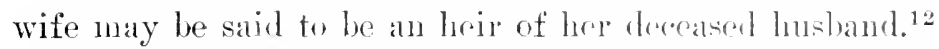

\$33. Adoption. Adoption is a jurblical aret creating bre tween two persons certain relations, purely aivil, of paternity and filiation. The leanl arleption by one person of the off:spring of another, giving hin the status of a child and hoir of the parent by arloption, was nuknown to the conmon law, although long recognized hy the civil, and is of comparatively recent date in the [nited States. The act of adoption is the creation of an artificial relation, made in conformity witl and regulated by positive statute, in the light of which the new rights and obligations thus derived are to be solely construed. ${ }^{13}$

There is a lack of miformity in the statutes enacted by the States, yet, in the main they agree in conferring on the person so adopted the rights of inheritance and succession, and other legal consequences and incidents of the natural relation of parent and child, the same as if such child had been born in lawful wedlock of such parent by arloption, but, as a rule, restrict such child from taking property expressly limited to the body or bodies of the parents by adoption, and in some instanees from taking from the lineal or collateral kindred of the

12 MeKinney $v$. Stewart, 5 Kan. 384; Steel v. Kurtz, 28 Ohio St. 192.
13 Keegan $v$. Geraghty, 101 III. 26; Long $v$. Hewitt, 44 Iowa, 363; Tyler v. Reynolds, 53 Iowa, 146. 
DEGREES OF CONSANGEISITY ACCORDIAG TO THE CIVIL IAW. (Paternal Line.)

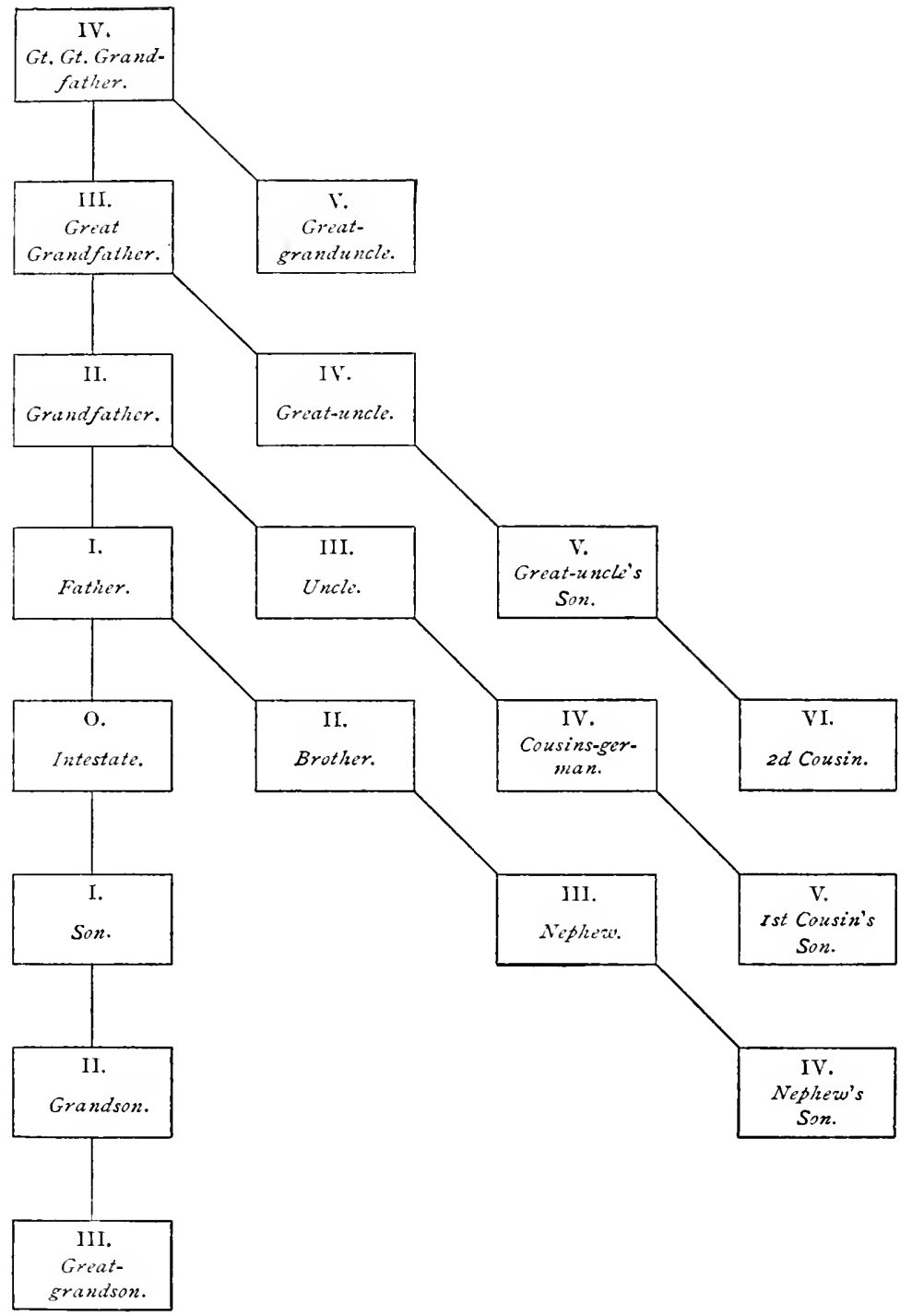


parents by right of representation. The right of inleritance thus secured is further restrieted to the adopted parent and precludes an inheritance from the actual children of such adopted parent, ${ }^{14}$ while the right of inheritance by the adoptive parents from the child is confined to such property as he had receiven through them, and, as a rule, they are expressly prohibital from inheriting any property which the child received from his own kiudred by blood. ${ }^{5}$ As against the arlopted child, the statute should be strictly constrund, being in derogation of the general law of inheritanee, which is fommled on natural relationship, and is a rule of surecsion accorling to nature, which has prevailed from time immermorial.

It will thus be seen how innentant a sncession through adoption may become in the deternination of land titles, and the strictness necessary on the part of examine and counsel in the investigation of guestions of this nature. Where title is elaimed through a descent by arloption, a general summary of the proceedings creating the relation shonld appear and the full and perfect title of the adoptive heir should be deducible of record and in strict conformity to the statute. The rights of inheritance acquired by an adopted child under the laws of a particular State are recognized and upheld in every other State, so far as they are not inconsistent with its own laws and policy, ${ }^{16}$ but in the absence of statutory directions the general rules of descent must govern as in other cases. ${ }^{17}$

$\$ 34$. Proof of Heirship. Thongh title rests in the heir by operation of law immediately on the death of the ancestor, yet purchasers desire, and shonld have, affirmative evidence that the person asserting such title is justified in so doing, and this is furnished by the proceedings of the probate court. In all abstracts the interval of title between the deed by which the decedent became seized and that which purports to be a

14 Barnhizel $v$. Ferrell, 47 Ind. 26 ; see, also, Reinders $v$. Kappel335 ; Keegan $v$. Geraghty, 101 Ill. 26. mamn, 68 Mo. 482.

15 Keegan $v$. Geraghty, 101 Ill. 16 Ross $x$. Ross, 129 Mass. 243.

iT Reinder's $v$. Kappelmann, 68 Mo. 482. 
conveyance by the heirs, should be filled by a smmary or abridgement of the proceedings in probate, showing the death of the intestate, proof of heirship by those asserting title, and a satisfactory settlement of the estate, for until all this has been accomplished the title of the heirs is liable to be defeated by a sale made by the administrator, as will also the title of one purchasing from them. ${ }^{1 \mathrm{~s}}$ This is a necessary result of the rule of law, that the intestate's property is primarily bolden for the payment of his debts, and may be sold by his administrator for that purpose. Such a sale necessarily defeats all hereditary titles.

$\$ 35$. Proof of beath. The recitals of the essential facts necessary to confer jurisdiction, in the decrees and judgments of conts of exchsive thongh of limited jurisdiction, are prima facie evidence of the facts so recited. Upon this principle it has been repeatedly declared that the grant of letters testamentary or adninistration is competent evidence of the death of the testator or intestate, ${ }^{19}$ and in support of titles elaimed by descent is of the highest character of evidence of title in the heir. Usually no other proof will be required or need be shown.

\$ 36. Conreyanees hy Heirs. Few titles are to be aecepted with greater caution, than those asserted, and purported to be conveyed, by persons claiming to be the heirs at law of the person last scizerl, in the absence of full compliance with prescribed regulations concerning the deseent and distribution of intestate estates. Too frequently, from various motives, no probate is ever had, and the ehildren, or other heirs, of the decedent unite to convey their interests describing thenselves in such conveyance as "children and heirs at law" of such decedent. In England, a pedigree would accompany a conveyance of this character, fixing, by reference to the rules of descent, the nature and extcnt of the interest owned by each heir. In the United States, the paneity of family records and the

1s Hill $v$. Treat, 67 Me. 501.

19 Comstock $v$. Crawford, 3 Wall. 396 ; Belden $v$. Meeker, 47 N. Y.
307 ; Welch $v$. R. R. Co., 53 N. Y. 610 ; Jeffers $v$. Raddliff, 10 N. H. 242 . 
methed of compriling sane, wonld renter a peeligeres of little value, eren were they in use, and the exannining annuser, if doubts arise, usually resosts to the dombtful alternative of an aftidavit to prove the faret of hrophip and bolstere ne the title, the affidarit, in many instances, Jxing entitled to less eredence than the deal it supplements. A litle resting on no lyetter foundation than a dered of this character, unless reinforeed by the statute of limitations, is entitlenl to littie consideration, and is liable to be deforited al any tine luefore the bar of the statute has interposed. Nor can the purehalser kiow, mules personally cognizant of the farets, that all the hoiph have united in the conveyance, or that they are qualifion to convery or that a widow's dower may not greatly derreciate the value of the property thus accunirect.

In this comtry, where all the heirs are allowed an equal representation, partition is frecgnently made by the hours between thenselves without the intervention of a mont, and while such partitions are regarded as valid, wot when marle of an unprobated estate confusion and muecrtainty are greatly augmented, and purchasers shomld decline the title thus derivesl as affording no noasme of safetr. Where aftidarits are resorted to to prove heirship, death of ancestor, ete., they shomld be well anthenticated as well as positive in their arements; but howerer well framed they may he, they aftord evidence of the lowest order only. Where partition is the result of a regular judicial proceeding the foregoing observations do not apply, even though there has been no probate of the ancestor's estate. In all properly conducted suits for partition a proof of heirship is recuired before division and the fact of heirship must be found by the decree entered in the suit. 


\section{CHAPTER IV.}

TITLE BY PLRCHASE.

$\S 37$. Nature of the title.

38. Deed.

:9. Derise.

$\therefore$. Public grant.

4l. Estoppel.

42. Technical estoppel.

43. Equitable estoppel.

44. Relation.

4.5. Prescription and limitation.

46. Accretion and reliction.

47. Avulsion.
\$ 48. Riparian titles.

49. Dedication.

50. Confirmation.

51. Occupancy.

52. Abandomment.

53. Eninent domain.

54. Title acquired by eminent comain.

55. Escheat.

56. Confiscation.

57. Forfeiture.

\$ 37. Nature of the Title. Purchase is a generic term which includes every mode of coming to an estate, except by inheritance, though in its more limited sense it is applied only to the acquisition of lands by way of bargain and sale for money or other consideration. Neither law witers nor courts seem to have rentured on a more extended definition, if indeed che can be frameal, and the one above given has come down unchanged from Blackstone, who in turn borrowed it from earlier writers.

There are four principal methods recognized of acquiring title by purchase, to wit: by deed, devise, prescription or limitation and escheat. To these may be added title accruing through operations of nature; as accretion, reliction and arulsion, as well as such as result from our political and civil relations; as eminent domain, confiscation and forfeiture. Some writers still farther extend the list by the addition of abantomment, occupancy and estoppel. The two former of these are not known in the United States, while the latter is not, strictly speaking, a method of acquiring title at all, but simply a recognition of existing titles. 
In the parataphe follwwing, no attempt has been made at systematic troument of the topies above mentioned, and only those greneral fratures of interest to the examiner of titles will be presentad.

S38. Heser. Title be deed is the mot common form of purchase, and that by which the great bolk of all the roal property in the comntry is dirently held. The term "deed" is very conpulansive in its signification, and denotes not only all classes of instruments for the converance of land, but any instrument in writing under seat, whether relating to land or any other matter. In its pomlan axecptation, however, it is confined to converances of land, or estates or interests therein, and is still further pestrictenl in its meaning to absolute sales, as distingnished from monteages, indieating eomlitional sales, thongh the latter are as comptially deods as the former. In its broad signification it is the highest form of expression of title known to the law.

\$39. Devise. Next to deeds, testamentary conreyances form the most common reliele for the transere of interosts or estates in land, the instrument for affecting a transfer being called a will; the subject-matter as well as the title by which same is acquired, a derise; and the recipient of the testator's bounty, a derisee. A will, which is effective as a conveyance only at the maker's death, is from its own nature anbulatory and revoeable during his life, and it is this ambulatory quality which forms the chief characteristic of wills; for thongh a disposition by deed may postpone the possession or enjoyment, or eren the resting of an estate until the death of the disposing party, yet the postponement in such cases is produced by express terms and does not renult from the nature of the instrument. Titie by derise is of the highest dignity, and effective for all pupposes, yet it may be lofeated in the same manner as a titlo ly derent, when in the comse of atministration it becones necessary to sell the testator's land for the parment of his debts.

$\$$ 40. Prbite Grant. For purpoes of emvenience a distinction is nade between conveyances by the sorereign and deeds 
of the individual. Public grants, when forming the foundation of title, are minuly claseed separately from other forms of conreyance and constitute a special department in all works treating of titles or estates. The original diresture of title by the government may be effected in a variets of ways, either of which will be sufficient for the purpose intended. The usual method is by patent isened in conformity to prescribed legal formalities, though gorernment may make a grant by a law as effectually as by a patent issned in pursuance of a law; ${ }^{1}$ and a confirmation br law of a claim of title in public lands is to all intents and purposes a grant of such lands. ${ }^{2}$ The original grant, whatever may be its form, is the first link in the chain of title, and whenever practicable should constitute the initial of the abstract, as the basis mpon which all after-acquired titles and derivative interests rest.

§ 1. Estoppel. Title by estoppel, as defined by Washburn, "is where equitr, and in some cases the law, in order to accomplish the purposes of justice which can not be otherwise reached, draws ecrtain conchusions from the acts of one party in faror of another, in respect to the ownership of lands, which it does not allow the first to controvert or deny." 3 Strictly speaking, a title is rather presumed than acquired by estoppel, which can operate neither to direst nor transfer an estate, and the parties are precluded by former acts from asserting ancthing to the detriment of the title.

Estoppels are not farored in law, for the object of the administration of justice is to discorer and apply the truth; but there are cases in which the courts are bound to sar to a litigant that he has to his own adrantage, or to the injury of his adrersary, asserted that which is false, and that, haring done so, he must be forever forbidden to unfold for his own benefit the truth of the matter. ${ }^{*}$

1 Hall $r$. Jorvis, 65 Ill, 302 : Strather $r$. Luras, 12 Pet. 411 ; Mayo $r$. Libby, 1:2 Milss. 339.

2 Challefoux $r$. Ducharme, 4 Wis. 554 . s 3 Wash. Real Prop. (4th Ed.) 70 .

4 Abbott $r$. Wilber, 22 La. Ann. 368 ; Gray $\iota$. Pingree, 17 Vt. 419. 
Mutuality is an exometial ingredient of estopleds, and it follows from the very prineiplo on which the whole doctrine rest that they operate neither in farene of nor again-t strangers, but affect only the parties, and their privine in blood, estate, or in law. A third palty derives no allantage from, nor can he be bound by an estopinal, and this rule applies equally whether the estopplat arises ly recold, dect, or matter in pais. ${ }^{5}$ Estoppels are clasitient, areording to their nature, as technical, or by record or deed, and cruituble, or in mis. Courts at the present day incline to restrict the dextrine of technical estoppel, and to farou" and extend conitable estoppel."

\$ 42. Technical Extoysel. The cotopuel arising from deeds and recerts is that which direetly onneerns an examiner of titles, and is really the only question of this nature on which he can be called to pase. Matters in pais, fron their nature, are not presunted to hinn, nor are they effective in questions of title milil presented for doternination to some competent tribunal, when they beeome matters of record and operative, if at all, as technical estomple

Estoppel by record is based upon the rulings and determinations of the conts, and proeeding - had therein, which are comsidered at length in other portions of the work. Verdicts and judgments are conchusive by way of ratoppel, only as to facts without the proof or admission of which they conld not have been rendered, ${ }^{7}$ or of matters material to the decision of the cause, and which the parties might have harl decided, although not actually litigated, ${ }^{8}$ but not as to facts not essential to, althongh consistent with the general rerdict or decree entered in the case. ${ }^{9}$ The estoppel of a judgment extends only to the question directly involved in the issue, not to any incidental or collateral matters, althongh they may have arisen and been passed on, ${ }^{10}$ and is effective only as between the orig-

5 Chope $v$. Lorman, 20 Mich. 327 ; Simpson $v$. Pearson, 31 Ind. 1; McDonald $v$. Gregory, 41 Iowa, 513.

6 State $r$. Pepper, 31 Ind. 76.

7 Burlen $v$. Shannon, 99 Mass. 200. s Lindsley $r$. Thompson, 1 Tenn. Ch. 272; Buck $v$. Collins, 69 Me. 445 .

9 Burlen $v$. Shannon, 99 Mass. 200.

10 Lewis' Appeal, 67 Penn. St. 
inal parties thereto or their privies. ${ }^{11}$ It must equally estop both partics thereto, or it ean not be set up by either, ${ }^{12}$ and is not available for or against a stranger. ${ }^{13}$ The reversal of a judgment destroys its efficaey as an estoppel. ${ }^{14}$

Estoppel by deed arises from the provisions contained in instruments for the conveyanee of land, either by recital, admission, corenant or otherwise, whether in express temis or by necessary implieation, and parties giving and reeeiving such deeds, together with their privies, are estopned from denying the operation thereof aceording to the manifest intent. ${ }^{15}$ In controversies concerning the title to land the question of estoppel arises most frequently in construing the effect of covenants. Thus, if a person having no title to land convers the same with a general warranty and afterward acquires title, such acquisition will inure to the benefit of the grantee, because the grantor is estopred to deny, against the terms of his own warranty, that he had the title in question. ${ }^{16}$ The miscliief of the rule is where a grantor who has convered without haring title subsequently aequin's same and then convers to a third party. Usually, such third party would look no farther than the acquisition of title by his grantor, and, relying on such fact, would pay the purchase price and take a deed. Yet, the deed, in such a case, woulh convey no title, if the prior deed of his grantor was then of record, for, by the rule of estoppel, the title passed, or inured, to the first grantee the moment the grantor became clothed therewith. ${ }^{1 \tau}$ Dut this effect does not extend to any other covenants than that of warranty. The other covenants

153; Dixon $v$. Merritt, 21 Minn. 196 ; Providence $v$. Adams, 11 R. 1. 190.

$11 \mathrm{McD}$ onald $v$. Gregory, 41 Iowa, 513.

12 Stoddard $r$. Burton, 41 lowa, 582.

13 Mayo v. Wood, 50 Cal. 171.

14 Smith $v$. Frankfield, $77 \mathrm{~N}$. Y. 414.

15 Taggart $v$. Risley, 4 Oreg. 235 ; Toley $\because$. Taunton, 119 Mass. 404;
Atlantic Dock Co, $v$. Leavitt, $54 \mathrm{~N}$. I. 35; Foster $v$. Young, 35 Iowa, 27; Scoffin $v$. Grandstaff, 12 Kan. 467 .

16 Burtners v. Keran, 24 Gratt. (Va.) 43 ; Wiesuer $r$. Zaun, 39 Wis. 18s: Clark v. Baker, 14 Cal. 612; Robinson $r$. Douthitt, 64 Tex. 101. $1 \tau$ Morrison $r$. Caldwell, 5 T. $B$. Mon. (Kr.) 426; Wilson v. Thraup, 2 Cow. (N. Y.) 195; Kirkaldie $v$. Larrabee, 31 Cal. 455. See the re- 
are personal only. Tor does the rule extend to covenants by a married woman, execpt in States where married women laive been expressly enabled by statute to enter into covenants. ${ }^{1 .}$

Although a grantor can not set up a hostile title existing at the time of his conveyance, because he is estopped by his covenants, yet if the deed be a mere quitelaim, without corenants, and purports to eonvey nothing but the present interest of the grantor in the premises, whatever that interest may be, without defining the chanracter of the interest, or affirming that he has an interest in the premines, he is not debarred from subsequently acquiring, and setting up, any other title, whether existing at the time of lis conveyance or sulsequently created. ${ }^{19}$ It has been held, in a late case, that the doctrine of evenants for title, inuring on principles of estnpel in favor of a subsequent grantee, is not to be carried so far as to charge a purchaser, or his attorney examining title for him, with constructive notice of deeds recorded before the vemlur las any record title, and that such purchaser, finding an apparent title of record, may rely upon it, and is not required or expected to look further, ${ }^{20}$ yet such decision seems to be foumled on doubtful authority and is opposed to the great bulk of American cases on the subject. ${ }^{21}$

\& 43. Equitable Estoppel. An estoppel in pais rests upon the principle that a party lias misled another to his prejudice, under such cireumstances that it would be a fraud for him to assert what may be the trutl. Ifence, to raise an estoppel from former declarations or admissions by a party to prevent him from setting up his title to property, the facts

marks of Mr. Rawle in opposition to the doctrine. Rawle on Couts. (5th Ed.), § 259.

18 Wilson $v$. King, 23 N. J. Eq. 150.

19 Bruce $v$. Luke, 9 Kan. 201; Read $v$. Whittemore, 60 Me. 479; Sydnor $v$. Palmer, 29 Wis. 229; Sliumaker $v$. Johnson, 35 Ind. 33; Graham $v$. Graham, 55 Ind. 23.
20 Dodd $x$. Williams, 3 Mo. App. 278 ; see also State 1 . Bradish, 14 Mass. 296.

21 Logan $v$. Steel, 4 Mon. 433; Mitchell $x$. Pettee, 2 W. Va. 470; Bates $v$. Norcross, 17 Pick. 14; Clark $v$. Baker, 14 Cal. 612; DeWolf $v$. Hayden, 24 Ill. 525. 
must show: (1.) That when making the statements or admission relied upon he was apprised of the true state of his own title. (2.) That he made the statement or admission with the express intention to deceive, or with such careless or culpable negligence as to amount to constructive fraud. That the other party had neither knowledge of the true state of the title nor convenient means of acquiring such knowledge. by the use of ordinary diligence. (4.) That he relied upon such statement or admission, and will be injured by allowing its truth to be disproved. ${ }^{22}$ It will be seen that the important and primary ground of estoppel in pais is, that it would be a fraud in a party to assert what his previons conduct had denied, when on the faith of that denial others have acted, ${ }^{23}$ but no man can set up another's act or declaration as the ground of an estoppel, unless he has himself been deceived by it, ${ }^{24}$ and a party can nerer be estopped by an act that is illegal and void. ${ }^{25}$

An estoppel in pais, mlike that by deed, operates only on existing rights. Thus a person who, while having no title in hiniself, induces another to purchase land at a sheriff's sale, by his representations that an unimpeachable title will pass by such sale, is not precluded from setting up afterward an adverse title in himself. ${ }^{26}$

At law, the doctrine of equitable estoppel can not be applied to work a transfer of property, which, by the statute of frauds, ean be effeeted only by a writing, and the legal title must always prevail, ${ }^{2 \pi}$ yet, although a party can not divest himself of an estate by parol, he may, without writing so conduct himself

22 Martin $r$. Zellerbach, 38 Cal. 300 ; Mc Cabe $v$. Raney, 32 Ind. 309; Nugent $v$. Cincinnati, etc., R. R. Co., 2 Dinsey (Ohio), 302; HalInran $v$. Whitcomb, $43 \mathrm{Vt}$. 306 ; Horn v. Cole, 51 N. H. 287 : Clark r. Coolidge, 8 Kan. 189; Mallony $r$. Horan, 49 N. Y. 111.

23 lice $r$. Bunce, 49 Mo. 231. $2+$ Simpson 1 . Pearson, 31 Ind. 1;
McKinzie $v$. Steele, 18 Ohio St. 38; Derries $r$. Haywood, $6+$ N. C. 83. 25 Lattox $v$. Hightslue, 39 Ind. 95.

26 Donaldson $v$. Hibner, 55 Mo. 492.

$2 \pi$ Kelly $v$. Hendricks, 57 Ala. 193; Hayes $v$. Livingston, 34 Mich. 384. 
with reference to it that he will he estopped afterwalel to a - icent a clain thereto; and this principle is applied withont referentee to the statute of frambls. 25

The doctrine of estoppel does not ordinarily apply to a State as it does to individuals. The soreroign power is lont a trustee for the poople. It acts by its acrents and the poople shembl not be bound by any statement of farts made by those agrents. For their benefit the truth may always be slown, notwithstanding any former statement to the eontrary. ${ }^{29}$ This principle rests, in part at loast, mpon the erencit doctrine that the State can not part with its title to land except by srant or other record evidence.: 10 apparme cxeoption his been said to arise in those cases in which the act songlit to le nuale binding was done in its sorereign capacity hy legislative mactment or resolution, 31 but this is not so much an exceution to the general doctrine of estoplyel, by acruiesecnee in an anthorized act of a mere snbordinate agent, as it is an origrinal bindiug athimative act on the part of the State itself, made in the most solemn manner in which it can give expression to the sorereign will. ${ }^{2}$

$\$ 44$. Relation. The dortrine of relation is applies in conveyances of land to equitahle tities which subsequently mature, either by operation of law or act of the parties, into legar titles, and where several acts concur to make a converance, estate, or other thing, the original act will be preferred, and to this the other acts will he said to have pelation.

The fiction of relation is, that the intermediate bona fide alienee of the incipient interest may claim that the grant inmes to his benefit by an cx post facto operation. In this way he receives the same protection at law that a cont of equity conld afford him. Thus, the assignee of a certificate of the purchase of school land, the purchase money being all paid, conreyed the 200.

28 R. R. Co. $v$. Ragsdale, 54 Miss.

29 Fannin Co. $v$. Riddle, $5 l$ Tex. 360 ; Farish r. Coon, to Cal. 50; Johnson v. U. S., 5 Mason C. C. 425.
30 Saunders v. Hart, 57 Tex. 8.

31 Alexanler $\%$ State, 56 Ga. 486 ;

Enfield $r$. Permit, 5 N. H. 285;

commonwealth $r$. Andre, 3 Pick. 224.

32 Simulers r. Hart, 57 Tex. 8. 
premises by quitclaim deed; a few days afterward he received the patent, and it was held that the legal title passed to his grantee. So, where a deed is made in pursuance of a recorded land contract, it relates back to the date of the contract, and conveys the title as it stood at the time the contract was recorded. ${ }^{33}$ The same doctrine also applies to grants of unlocated land, the subsequent location operating by relation to the original grant. ${ }^{34}$

The doctrine of relation is a fiction of law adopted by the courts, solely for the purpose of justice, where several proceedings are required to perfect a conveyance of land; it is only applied for the security and protection of persons who stand in some privity with the party that initiated the proceedings and acquired the equitable claim or right to the title. It does not affect strangers not connecting themselves with the equitable claim or right by any valid transfer from the original or any subsequent holder. ${ }^{35}$

$\S$ 45. Prescription and Limitation. Prescription is that title which arises from long and continued possession of property, and is founded upon the presumption that the party in possession would not have been allowed by other clainants to hold same without a just and paramount right. Prescription, in the ancient sense of the word, rests upon the supposition of a grant, and the nse or possession on which such title is founded must be minterrupted and adverse, or of a nature to indicate that it is claimed as a right, and not the effect of indulgenee, or of any compact short of a grant. ${ }^{36}$ Presumptions of this nature are adopted from the general infirmity of human nature, the difficulty of preserving mumiments of title, and the public policy of supporting long and minterrupted possessions. They are founded upon the consideration that the facts are such as could not, according to the ordinary course of hmman affairs, occur, muless there was a transmutation of title to, or

33 Welch v. Dutton. 79 Ill. 465;

Snapp $v$. Pierce, 24 Ill. 156.

$3+$ Dequindre $v$. Williams, 31 Ind. 444.
35 Gibson $v$. Chouteau, 13 Wall 92.

36 Gayetty $l$. Bethune, 14 Mass. 49 ; Odiorne $v$. Wade, 5 Pick. 421. 
an andinimion of an existing adverse title in, the party in possession. $: 37$

The period of leoul memory, or prescription, does not, at common law, extenl farther back than sixty years,"3s while forty years is usually a sufficient length of time to cotablish a preseriptive tille, ${ }^{\prime}$ and, in eneral, it is the polier of the consts to limit the presumption of grants to periods analogous to those of the statute of limitations, in cases where the statrete itself does mot apply. ${ }^{40}$ I title fommled mpon prescription or limitation, accompanied by an adrerse user or (mjorment, is lecognized as vilid and substantial, as against all save the sovereign power, ${ }^{41}$ and in the older States of the Cnion, where it is often difficult to trace title to its somree, property is freely conveyel on the assurance furnished ly time and the statute of limitations.

Twenty years is the period ordinarily fixed by the statute in which to perfect an adrerse possession of lands, while in case the occupant claims a title exchusive of any other right, founding such claim upon some written instrumcnt, judgnent or decree, ten years is frequently sufficient, and in some States even a shorter period. ${ }^{42}$

$\S 46$. Accretion and Reliction. Accretion is the increase of land, caused by the addition made by the washing of the sea, a narigable river, or other water course to which the land is contiguous, whenerer the increase is so gradual that it can not be perceived at any one moment of time. ${ }^{43}$

37 Gayetty $r$. Betlune, 14 Mass. 49 ; Rooker $x$. Perkins, 14 Wis. 79 ; Taylor $v$. Watkins, 26 Tex. 688.

3s Coolidge $v$. Learned, 8 Pick. 504; Odiorne $v$. Walle, 5 Pick. 421. 39 Melvin $v$. Whiting, 10 Pick. 295.

40 Hunt $v$. Hunt, 3 Met. 175.

41 Gardiner $v$. Miller, 47 Cal. 570. 42 Consult local statutes for the periods of limitation, and the character of the occupancy necessary to perfect title.
43 Lovingston $t$. St. Clair Co., 64 III. 56 ; Krant $r$. Crawford, 18 Iowa, 554 ; Benson $r$. Morrow, 61 Mo. 252. This definition has its origin in the Institutes of Justinian, see Lib. II, Tit. I, Sec. 20, and has been followed by courts and writers ever since. See, Lammers $v$. Nissen, 4 Neb. 245; St. Louis, etc., Ry. Co. $v$. Ramsey, 53 Ark. 314; Jefferis v. Land Co., 134 U. S. 178. 
The increase or deposit obtained by accetion is technically called allurion, and whether produced by natural or artificial causes inures to the benefit of the adjacent territory. ${ }^{4 t}$ It is held by the same title, and under the same grant, as the land which it arljoins, and is smbject to the same liens and benefited by the same incidents that appertain to such adjacent land. ${ }^{45}$ Cpon all rivers not navigable ly common law the owner of the land adjoining is prima facic owner of the soil to the central line or thread of the stream subject to the public right of narigation. ${ }^{46}$ The presumption will prevail in all cases in faror of the riparian proprietor, unless controlled by some express words of description which exchule the bet of the river, and in all cases where the river itself is used as a boundary, the law will expound the grant as extending to the center or thread. ${ }^{47}$

Tpon navigable lakes and rivers, where the public easement is not intermpted, the question of navigability, as at common law, does not arise, and the riparian proprietor will still be entitled to all accretions without regalrd to navigability. ${ }^{48}$

The general rule ahove stated applies as well to land which by erosion becomes riparian, and where through the gradual washing away of intervening land an originally remote tract becomes riparian all of the rights of aceretion will at once attach thereto. ${ }^{48}$ :

In applying the principle that land formed by alluvion is the property of the adjoining owner, it is quite immaterial, on non-navigable streams, whether this alluvion forms at or against the shore so as to eause an extension of the bank, or in the bed of the stream and becomes an island, ${ }^{49}$ and where an

44 St. Clair Co. $v$. Lovingston, 23 Wall. (C. S.) 46 , afirming Gt Ill. 56 ; Adams $x$. Frothingham, 3 Mass. 35; Penple r. R. R. Co.. 42 N. I. 315: Lockwood v. R. R. Co.. 37 Conn. 387: Lammers $r$. Nissin, 4 Neb. 245.

45 Campbell $r$. Gas Co., S4 Mo. 352; Gale $r$. Kinzie, So Inl. 132. 46 Hubbard $r$. Bell, 54 Ill. 110: Olson $r$. Merrill, 42 Wis. 203.
At common law only tide waters are navigable.

47 Liraxon $r$. Bressler, 64 Ill. 158; Ross r. Faust, 54 Ind. 47.

1 Loringston $r$. St. Clatir Co., 64 III. 56 ; Schumeir $r$. R. R. Co., 10 Minn. So: Magnolia $r$. Marshall, 39 Miss. 111.

$45^{*}$ Wells $x$. Bailey, 55 Conn. 292. 49 Deerfield $r$. Arms, 17 Pick 41 ; Granger $\imath$. Avery, 64 Me. 292. 
island is so formerl in the led as to divide the rebamel and form partly on areh side of the therad, the opposite sides helong to the different propriofors and the island should be divided aceording to the original therad.

The incrase on strants, rivers and water fronts should be divided breweren the omenes of the shore, aceording to their respective frontage, so as to serure to each the benefits which his original froutage wave hin, and for this purpose the following rule may bre (2mployert:

Measure the whole extent of the ancient line on the rivel and ascertain how many foet, rouls, efe., ealch proprietor owned on the line; divide the newly fommer line inte equal parts and appropriate to each properictor as many jortioms of this now river line as he owned foet on the olil. Then to complete the division, lines are to be drawn from the parts at which the proprietors respectively boumdert on the old, to the points thins determined as the new points of division on the newly fomed shore. The new lines, thus formed, it is obrions, will be either. parallel, divergent or comvergent, acoorling as the new shore line of the river equals, exceods or falls slort of the old.5 This mode of clistribution secures to anch riparian proprietor the benefit of continuing to lold to the river shore whatever ehanges may take place in the condition of the river or the aceretion. The rule will require modifieation under particular circumstances, as for instance, if the aneient margin has deep indentations or sharp projections the general available line on the river ought to be taken, and not the actual length of the margin as thus elongated by the indentations or projections.

A more familiar rule, and one of general application in the West, is to extend the original water frontage of the respective parcels of land, as nearly as practicable at right angles with the original shore line, or with the conse of the river to the thread of the strean1. 51

5n Deerfield $v$. Arms, 17 Pick. 41; 477; Jones $v$. Johnson, 18 How. Batchelder $v$. Keniston, $51 \mathrm{~N}$. H. 150.

496; Thornton $v$. Grant, 10 R. I. 51 Miller $v$. Hepourn, 8 Bush (Kу.), 326. 
The usual ineidents of title attend property acquired by accretion. ${ }^{52}$ The right to allurial formation is a rested one, inherent in the property itself, and forms an essential attribute of it in consequence of the local situation of the land. ${ }^{53} R e$ liction differs from aceretion only in that it results from the gradual subsidence of waters, the effect being the same. ${ }^{5 t}$ Aceretion or reliction follows the title of the land contiguous to the allurion, but will appear of record only when surveys or divisions have been made in the manner above indicated.

$\$ 47$. Arulsion. Avulsion is the reverse of accretion, being the sudden remoral or deposit of land by the pereeptible action of water; and the ter'm is also applied to the derelict left by the sudden subsidence of water on the seashore or on navigable rivers. The authorities are not altogether harmonions, but the majority, following the common law, place the title to such derelict in the sovereign. ${ }^{55}$ In the ease of inland navigable streans, the title depends upon local laws, some States claiming the title of the bed of the stream, while others concede it to the riparian proprietor, subject only to the public right of navigation. When title extends to the middle of the stream the boundary remains as it was, irrespective of changes in the channel. ${ }^{56}$

$\S 48$. Riparian Titles. By the eommon law of England the title to land under water, as well as the shore below ordinary high water mark in navigable rivers and arms of the sea, is rested in the sorereign for the public use. But as the rivers of England were comparatively small, tide waters only were regarded as navigable, and the confusion of narigable with tide waters, found in the monments of the common law, long prevailed in this country, notwithstanding the broad differences existing between the extent and topography of the

52 Gale $v$. Kinzie, 80 Ill. 132. 53 Kennerly $r$. Municipality No. 2 , 10 La. Ann. 54; St. Clair Co. $v$. Lovingston, 23 Wall. (U. S.) 46.

54 Warren $v$. Chambers, 25 Ark. 120; Boorman $v$. Sunnuchs, 42 Wis. 235.
552 Black. Com. 262; Dikes $v$. Miller, 24 Tex. 417.

56 St. Louis $v$. Rutz, $138 \mathrm{U}$. S. 226 ; Bonewits $v$. Wygant, 75 Ind. 41. 
American continent and the briti-h islands. ('ongeres, by the

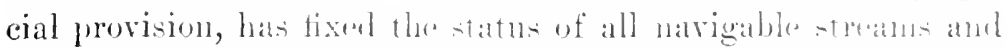
water ways in what was formerly a jortion of the pablic do-

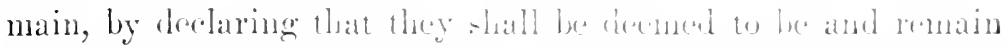

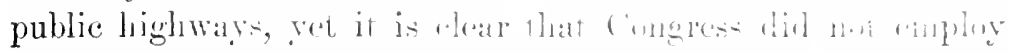
the words navigable or non-navigable in the sence of bing affected by the elub or thow of the tide. On the contrary, it is obvious that the wrels were emploverl without respect to the tide, and were applicel to territory situatul far above tide waters, and in which there wore no salt watrestreans. Tiewerl

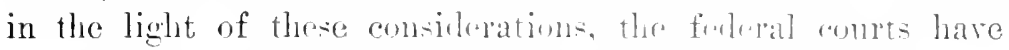
adopted the rule that proprietors, muler titlus derived from the

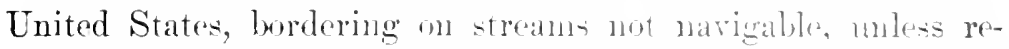
stricted by the terms of the grant, lold to the conter of the stream, white in case of navigalle rivers the title of the riparian proprietor stops at the streann.

Nor will the common law apply to our ereat fresh water lakes, for here there is neither flow of the tide nor thread of the strean, and local law appears to have a-rigned the shores down to ordinary low water mark as the boundary of the riparian proprietor. ${ }^{5 s}$

$\$ 49$. Dedication. I derlication is an appropriation of land to public use; 59 the public and not nerely a public corporation must be the chief benefieciar, and properly speaking, there can be no defication to peirate n-e ${ }^{61}$ Thalication is express, as when mate by deed or ther unequirocal act or

57 R. R. Co. $\%$, Schummeir. T Wall. (U. S.) 272; Forsyth r. Small, Biss (C. Ct.) 201; Barney $r$. Keokuk, 4 Otto (U. S.), 32:.

58 Wheeler $r$. Spinola, $54 \mathrm{X}$. $\mathrm{Y}$. 377 ; Canal Commrs. $r$. People, 5 Wend. (X. Y.) 423. Riparian rights upon the great lakes have been held to be, in theory, the sam as upon navigable streams, and are not governed by any such proprietary divisions as high and low water mark. The submerged lands are appurtenant to the upland, so far as their limits can be reasonably identifial. Lincoln $r$. Daris, 53 Mich. 35.5.

591 Bon. Law Dict. 443.

60 Todd $r$. R. R. Co., 19 Ohio St. 514 .

61 M. E. Church r. Hoboken, 33 1. J. L. 13. But reservations for livate use may be male, which confer much the same rights upon the beneficiaries as do dedications upon the putblic generally. 
declaration; or, implied, or presumed from an acquiescence in the public use. $^{62}$ The law requires no particular form or solemnity to constitute a valid dedication, the intention of the owner being the rital principle, and this may be evidenced by the owner's acts or declarations and the circumstances under which the user has been permitted. ${ }^{63}$

The question of dedication arises most frequently, in the examination of titles, in the construction of plats and subdivisions, and must be determined by reference to local law, as the common law dedication has in many of the States been supplemented by statute which vests the legal title to the dedicated tract in the municipality. ${ }^{64}$ At common law, when the right of the public to the use of land rests upon no other foundation than a dedication to public uses, the easement rests in the public while the fee remains in the original owner, and may be conveyed by hin to third persons; but, in such case, the right of the public to the use is paramount to the title of the owner of the fee, and does not require the fee for its protection. ${ }^{65}$

$\$ 50$. Confirmation. Confirmation, at common law, is a species of conveyance wherebr an estate which was voidable or inchoate is made valid and certain, or where a particular interest is increased. It is not an original method of passing title, and only operates on an existing estate or right in lands by strengthening the title of one who already has, or claims, some right or interest therein.

Thongh deeds of confirmation are in use between individuals, the term, as indicative of a form of title, is usually applied to those confirmatory acts of government whereby inchoate or uncertain rights derived from the national government or from foreign powers, are ratified and approved, and relates to the origin of title. From the earliest period in the history of

6. Robertson $v$. Wellsville, I Bond, 81.

63 Hood $v$ Hurd, 34 N. J. L. 87; Buchanan v. Curtis, 25 Wis. 99; MeIntyre $v$. Storey, 80 Ill. 127; Shear $r$. Stothart, 29 La. Ann. 630. 64 Chicago, etc., R. R. v. Joliet,
79 Ill. 25; Downer v. R. R. Co., 22 Minn. 251.

65 M. E. Church $v$. Hoboken, 33 N. J. L. 13 ; Cincinnati $v$. White, 6 Pet. (U. S.) 431 ; compare Wilson $v$. Sexton, 27 Iowa, 15 . 


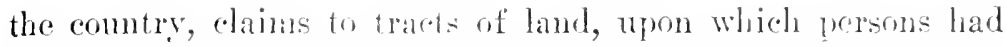
settled and made improvements in adrance of the public surveys and before the lands land been offered for sale, sonnetiones upon the respless invitation of the pulblir authorities and sonentimes upon theil supposed acquiesence, have been presented for the cepitable consideration of the goverument. Such claims, in great numbers, lave also arisen under other governments from which we have arepried troritory, with treaty stipulations for their protection. Sometimes sull clams have been submitted to formels of commisimers for approval or rejection; sometimes they have bern rofered to tho judicial tribunals for determination, and sometimes they lave been directly aroted upon by Congress. I contimation can not strengthen a void title, but only one that is virlable, and is conclusive only as between the Governunent and the confinnee.

Confimation, as a basis of title, lolates mainly to imperfect grants of the French, Spanish or Mexican Governments, made prior to the annexation of the territory to the Lnited States, and may consist of the judgment or defermination of a board of commissioners organized for that purpose, a judgment or decree of the federal courts, or a special act of Congress. Though it has been held, that a confirmation by law of a claim of title in public lands is to all intents and purposes a grant of such lands, "ir yet it seems that the legal title to lands confirmed to a private person by act of Congress, or by action of Government tribunals, remains in the Cnited States until a patent has issued therefor, and, until then, the confirmee lias only an equitable title. ${ }^{6 s}$ 442.

66 Meader $v$. Norton, 11 Wall.

\section{Challefoux $v$. Ducharme, 4} Wis. 554 .

68 LeBean $x$. Armitage, 47 Mo. 138; Amesti $v$. Castro, 49 Cal. 328. In the settlement of these claims the law has generally provided that a patent of the United States should be issued to the claimant when his claim should have been recognized as valid and entitled to confirmation, ret the patent, in such cases, is only documentary evidence of the existence of the title, or of such equities respecting the claim as to justify recognition and confirmation. Morrow $r$. Whitney, 5 Otto (U. S.), 5.5l; Langdeau $v$. Hanes, 21 Wall. (U.S.) 5.1. 
\$ 51. Oceupancy. Title by occupancy forms a sub-head in Mr. Washburn's admirable work on real property, ${ }^{69}$ but this method of acquisition does not now seem to be recognized in the United States, if inleed it ever existed. In its broad sense, it is the right or title derired from an original state of nature; hence the American Indian holds the use and enjoyment of his lands by occupancy, and though this title is respected br the courts until legitimately extinguished, it does not extend to property in the soil and can not be made the subject of transfer, while the Govermment has ever reserved the exchusive right to extinguish this title by purchase or conquest. ${ }^{\text {io }}$ In its technical sense it was applied to a method of acquisition once in rogue in Englasd, where one was tenant for the life of another who outlived him. The estate being a free hold did not go to his personal representatires, but not being an inheritance could not go to his heirs; and, as a consequence, no one having a legal right to the remmant of the estate, whoever first ocempind it acquired such a title by possession and occupancy that no one could dispossess him. This

693 Wash. Real Frop. (4th Ed.) 50.

"Wohnon $r$. Meintosh, 8 wheat. 543: Fleteher 1 . Peck, 6 Cranch. 87. Immediately after the inauguration of Prenident Washington, he laid before Congess a repurt from the Sectetary of War. acknowledging the Indian right of occupancy, and recognizing the principle of acquiring their claims by purchase for specific consideration according to the "practice of the late English colonies and government in purchasing the Indian claim.." and the rule in that respect laid down in the proclamation of Oct. 7,1763 . by the King of Great Britain, interdicting purchases of land by private individuals from Indians and declaring that "if at any time any of the said Indians should be inclind to di-pose of said lands," the same "shall be purchased only" for the Crown, the ultimate dominion and sovereignty being held to reside in the dincoverer colonizing upon the continent. In accordance with this principle, beginning with the treaty of 1795 , at Greenville, the Indian title of occupancy has been gradually extinguihed by the Cnited States in all of the States east of the Mississippi, and in nearly all of the States and Territories west of same, leaving, in some cases. remmants of tribes. Who have been invested by Congress with allodial titles. 
was a title by ocempang. it Provision is made in most of the States for an merererency of this kind.

\$ 52. Abandonment and Pelinquishment. 'This method of acquiring or losing title may be fommel noted in neally all works on rual property, ret it seems to oceupy a most uncertain and indistinct prition. Easements and incorporeal rights annexed to land, nua lu lost by abandomment. So may a homestead. So may an incipient right to lamel, as a location and surrey, or other merely quitable title not perfected into a grant or vested by deerl, but legal righte, when once vesterl, must be dirested accorting to law. ". "Yot," says one authority, "if a person having the disposing power absolutely, does an act sutheient in itself, legally to divest his title with the express intention of relinguishing and abancloming the property, it is not casy to pereeive why he may not do so. Abandomment, it is said, is the relinquisliment of a rient: the giving ul something to which one is cntitled. If the owner sees proper to abandion his property, and eridences his intention by an act legally suthicient to rest or divest ownership, why may he not do so in the case of land, as well as of a chattel? It might go to the Goremment instead of the first ocenpant, upon the principle upon which land escheated or became derelict." It has been observed, that a man shall be held to intend what necessarily results from his own acts. Consegrently, when property is abandoned under such circmustances as to loave no doubt of the fact, no one who has taken possession of it can be required to relinquish it: but abandomment is a question of fact for which no rule can be fommulated, and must be dreided by the circumstances of each case. ${ }^{i t}$ It would secm that there is nothing in principle to prevent the orrner from abandoning his right of property in land, provided the intention to do so be evidenced by an act or deed legally sufficient to operate a di-

713 Wash. Real Prop. (4th Ed.) In this case the owner filed a deed 50. of relinqui-hment in the General

724 Kent Com. 448; Picket $v$. Dowling, 2 Wash. (Va.) 106; Dikes v. Miller, 24 Tex. 417. i3 Dikes $t$. Niller, 24 Tex. 417 . lieg. 716 .

Land onice.

74 Corning $v$. Gould, 16 Wend. 543 ; Holmes $r$. R. R., 8 Am. Law 
vestiture of the title, yet this will so seldom occur that a discussion of it seems unnccessary. Ordinarily when title is asserted throngh this method, it will be found to depend more on long continned adrerse posscssion and rights conferred by the statute of limitations.

Examples of relinquishment may be found in the actions of Congress where property, instead of being granted, is relinquished to the donce, either with or without conditions annexed, yet all of the acts of this character which have come under the observation of the writer, may properly be classed as dedications, notwithstanding the express term "relinquishment" is used as the operative word. This is particularly true where provision is made for reverter. ${ }^{i 5}$

\$ 53. Lminent Domain. One of the sorereign attributes of the State, is the right to sulject the private property of its citizens to public nses, is but with the concurrent obligation to make just and full compensation therefor. ${ }^{i i}$ Such right is inherent in the State, thongh usually reserved as well in the organic law - the Constitution; and where it is lodged to any extent in corporations, is limited by the uses for the furtherance of which, on the ground of public polier, it is conferred. Whaterer exists, in any form, whether tangible or intangible, ${ }^{\text {is }}$ is subject to the exercise of this right including the property and franchises of ineorporated companies as well as individuals.

The exercise of the right of eminent domain is primarily and mediately the act of the State; and corporations to which it has been delegated, and by which it is immediately exercised, are but instrmmentalities of the State, althongh they may have, and generally do have, conporate interests intermingled and growing out of the exereise of this sorereign prerogative. ${ }^{79}$ Though the power can only be exereised for a public use, it has never been deemed essential that the entire community or any considerable portion, should direetly enjoy or participate in the

T5 See 19 U. S. Stat. 127.

is Cnited States $v$. Jones, $109 \mathrm{U}$. S. 5ls; Johnson $r$. R. R. Co., 23 Ill. 202. it Chicago $r$. Larned, 34 Ill. 203. is Rigney $r$. Chicago, 102 Ill. 64. io Hatch $\imath$. R. R. Co., 18 Ohio St. 92. 
benefits to be derived from the purpose for which the property is appropriated. It is cmongh if the taking tends to enlarge the resonrees, increase the industrial energies, and promote the productive power of any "onsiderable number of the inhabitants of a section of the State, or leads to the growth of towns and the creation of new channels for the employment of private capital and labor, such results contributing indirectly to the general welfare and prospority of the whole community. ${ }^{80}$ Compensation is always a condition precedent to the appropriation of the property,,$"$ and when land is accurired ly the public for one particular use no additional burden can be superadded without further compensation. ${ }^{* 2}$

\$ 54. Title Acruired by Eminent Domain. The general rule in this comtry is, that the exercise of the power of eminent domain, particularly when exerted in behalf of corporations, extends only to the use of the property appropriated, and does not include the fee. ${ }^{\mathrm{s}}$ The easenent, howerer, is usually regarded as perpetual, and as such forms the basis of compensation; but should the use be abandoned, the land, disencumbered of the easement imposed by the appropriation, will revert to the holder of the fee. It is a mindinal rule that every statute in derogation of the right of property, or that takes away the estate of a citizen, is to be construed strictly, ${ }^{84}$ and no implication can be indulged in that a greater interest or estate is taken than is absolntely necessary to satisfy the language and object of the statute making the appropriation. ${ }^{85}$

But a fee may be taken as well as a lesser right or inter'est. It is not necessary that exact or technical language should be

so Talbot $v$. Hudson, 82 Mass. 417; In Re Gas Co., 63 Barb. 437.

81 Eidemiller $v$. Wyaudotte City, 2 Dill. 376; Cameron $v$. Supervisols, 47 Miss. 264; Paris v. Mason, 37 Tex. 447; Cook v. South Park Commissioners, 61 1ll. 115. This, however, is a constitutional limitation of the righi. United States v. Jones, 109 U. S. 513.

82 State r. Jarerack, 34 N. J. L.
201: Hatch $v$. R. H. Co., 18 Ohio St. 9.2; Craig v. R. R. Co., 39 N. I. 404 .

83 Morris $v$. Turnpike Road, 6 Bush (Ky.), 671 ; R. R. Co. v. Burkett, 42 Ala. 83; Cooley's Const. Lim. 559 .

84 Sharp $v$. Spear, 4 Hill. 76.

85 Cemetery $v$. R. R. Co., $68 \mathrm{~N}$. Y. $59 \mathrm{I}$. 
used in a statute, for taking private property for public use, in order to vest the fee in the publie, but it must elearly appear that it was the intention of the Legislature, as disclosed by the act itself, to take a fee. If any remaining private ownership is inconsistent with the use for which the land is taken, and compensation is made for the fee, which is also neeessary for the full use of the property under the act, a fee will be deemed to have been taken in the absence of express words. ${ }^{86}$ In some of the States the fee passes as an ineident, ${ }^{87}$ and excludes any remaining rights in the former owmer, but usually the extent of interest, or quantity and duration of the estate aequired by the exercise of this power, is derived from the specific act of appropriation.

The power is a legislative one, subject to constitutional restrictions, and the only conditions requisite to its exereise are the needs of the public and compensation to the owner; when these conditions exist, the right of the State to withdraw propcrty from private control and subject to public nse whatever interest or estate is necessary to accomplish the intended purpose, is complete and perfect, ${ }^{88}$ and this interest, aceording as the Legislature may determine, may eonsist of an estate for years, for life, a mere easement, a conditional fee, or a fee simple absolnte. ${ }^{89}$ It would therefore appear that the act of appropriation, whenever the title has passed by the exercise of this power, together with such of the condemnatory proceedings as may be necessary to show the extent of land taken, are necessary links in the chain of title, and should be duly set forth in the abstract.

\$ 55. Rscheat. In its original aceptation, achect was the right of the lord of the fee to enter sane when it became vaeant by extinetion of the blood of the tenant. It was one of the ineidents of fendal tenme, and is still oeensionally men-

so Park Commissioners $v$. Armstrong, 45 N. Y. 234.

87 Troy $v$. R. R. Co., 42 Vt. 265 ;

Challis r. R. R. Co., 16 Kan. 117.

ss Dingley $v$. Boston, 100 Mass.
544; IIaldeman $v$. R. R. Co., 50 Pa. St. 425 ; Giesy $r$. R. R. Co., 4 Ohio St. 308 .

89 Heyward $r$. New York, 3 Seld. 314; Cooley's Const. Lim. § 558. 
tioned as marking the foudal origin of Anerinan land titles. Nothing but the nane, however, is fendal, and is only another instance in which, in our land systen, a word is applied in al sense far different from its original neaning, suggesting inleas which have long beren exploded.

Escheat, in the Linited states, depends upon positive statutes. It does not follow as a matter of riglit, but of expediency. The lord of the fee, holling the ultimate title, night with propriety assert his ownership, but no surde right can be claimed by the State, nor is the idea compatible with the full property in land held moder an allodial title. It is, however, a miversal rule of eivilized society that when the decented owner las left no heirs, his property should rout in the pullic and he at the disposal of the Govermment, ${ }^{90}$ and by threnoral rule of the common law, all real property ealpable of use and posesion, and having no other arknowlergerl owner, is in theory rested in the king as the heal and sovereign represutative of the Nation; so the State, in its right of sorereignty, is saicl to possess the ultimate property of all lands within its jurisdiction. When the owner dies intestate and lenving no inheritable blood, the lands vest immediately in the state by operation of law; ${ }^{91}$ but some proceeding is necesany on the part of State to assert the title thms acquired, which is accomplished by a procedure sometimes termed "incucst of oftice," the various steps being prescribed by statute, and culminating in a decree. $^{92}$ This aceree, together with the preliminary proceedings, forms the recort eridence of title derived in this manner. The State on taking lands by escheat, takes the sane title as the person last seized, and none other, subjert to the same trusts, incumbrances, charges and services to which the property would have been sulject had it descended to lieir. ${ }^{93}$ the State

9n Bou. Law Dict. 587; 4 Kent Com. * 425 .

91 People $v$. Conklin. 2 Hill, 67; Sinds $v$. Lynham, 27 Gratt. (Va.) 291.
92 An encheat may be asserted by an action of ejectment in the ustal form.

93 Trust Co. $v$. People, 1 Sandf. Ch. 139. 
being for this purpose a statutory heir in default of known kindred. ${ }^{94}$

§ 56. Confiscation. Closely allied to escheat, but resting. on a different foundation, is confiscation, being the right to appropriate to the use of the State, the property of alien enemies during war. Respecting this power of the Gorermment, no doubt can be entertained. That war gives to the sorereign full right to take the persons and property of the enemy whereever found is conceded. The mitigation of this rigid rule, which the humane and wise policy of modern times has introduced into practice, will more or less affect the exercise of this right, but can not impair the right itself. ${ }^{95}$ Save in a few instances, during the revolutionary period, this right has been restricted to seizure of personal property until the late civil war, when by act of Congress of July 17, 1862, the right of confiscation of real estate was again asserted. But concurrently with the passage of this act, Congress also adopted a joint resolution explanatory of it, whereby it was resolved that no punishment or proceedings under the act should be construed so as to work a forfeiture of the real estate of the offender beyond his natural life, and courts when passing upon the question have uniformly decided that confiscation proceedings in effect, reach only the life estate of the owner. ${ }^{96}$ The condemnation goes to the whole estate, however, and extinguishes all the rights possessed by the original orner, leaving in him no estate or interest of any description which he can conver by deed, and no power which he can exercise in faror of another. The forfeiture is complete as long as it lasts, and the proviso, by way of grace, gives back the land to his heirs upon his death. ${ }^{97}$

94 Wallace $v$. Harmsted, 44 Penn.

St. 492 .

95 Brown $v$. United States, 8 Cranch (U. S.), 110.

96 Biglow $v$. Forrest, 9 Wall. (U. S.) 389; Dewey v. McLain, 7 Kan. 126: Day $v$. Micon, 18 Wall. (U. S.) 156.
97 Wallach $v$. VanRiswick, 2 Otto (U. S.), 202; French $v$. Wade, 12 Otto (U. S.), 132; Pike $v$. Wassell, 94 U. S. 71l. In England attainder of treason worked corruption of blood and perpetual forfeiture of the estate of the person attained to the disinherison of his heirs. When 
\$5). Forfeibure. The term forfeiture is need, as be tween individuals, to denote the method by which an interest or estate in lands reverts to a former owner by operation of law, as by a breach of comtition in a deed or lease. Forfeitures are not favored in law, and courts eagerly seize hold of any cireminstances by which they may be defeated, and where alequate compensation can br unale, the law in many cases, and equity in all calses, elischarges the forfeiture upon such compensation being made. ${ }^{98}$

In its more common aceptation it is the means by which the property of the citizen inners to the benefit of the State through the violation of law, and in the Tnited States oceurs only in case of confiseation "1 seizure for taxes. In either case it is in the nature of a penalty, and results as a necessary incident from our reciprocal duties and obligations. Is a method of aequiring title it is ricwed with disfaror and is of doubtful effect. It is attended with greater formalities than any other form of pureliase, and the title derived through it is liable to be defeated by a rast number of contingencies. Ordinarily, titles resting solely on rights derived through forfeiture, for non-payment of taxes or othertrise, are to be viewed with suspicion and accepted with caution, experience having demonstrated in many cases their unsubstantial nature.

the Federal Constitution was formed, this was felt to be a great hardship, and even rank injustice. For this reason it was ordained that no attainder of treason should
Work corruption of blood or forfeiture of estate, except during the life of the person attained.

98 Life Ins. Co. $v$. Norton, 6 Otto (U. S.) 234 . 


\section{CHAPTER V.}

SOURCES OF INFORMATION.

\$5. Thecords.

5). Depositories of records.

60. The right of inspection of records.

61. Doctrine of notice.

62. Constructive notice.

63. Actual notice.

64. Registration.

65. Effect of recording acts.

66. Loss or destruction of records.
\& 67. Official aids to search.

68. Grantor and grantee indexes.

69. Notice lis pendens.

70. Plaintiff and defendant indexes.

71. Tax records.

72. Official certificates.

73. Church and parish records.

\$ 58. Records. An abstract of title, as compiled in the United States, is an abridgment of the public records, to which it also bears the relation of a special index, they being the great repositories of title, and the source from whence the examiner draws the greater part of his information.

A record, it has been said, is a written memorial made by a pullic officer, authorized by law to perform that function, and intended to serve as evidence of something written, said, or done. $^{1}$ The acts of Congress and of the State Legislatures are the highest types of records, while the proceedings and determinations of the courts are scarcely less in dignity, and by statutory enactment the enrollment of deeds, though made primarily to perpetuate the memory of the facts which they recite, is given the operation and effect of reeords. These records are of controlling efficacy in the State where marle, and by the Constitution of the United States it is declared that "full faith and eredit shall be given in each State to the public acts, records, and judicial proceedings of every other State." In matter's of sales and conveyances of land, records acquire a

12 Bou. Law Dict. 424. 
new importance from the peculiar American doctrine of constructive notice, which casts a knowledge of their contents and import upon subsequent purchasers, and forms one of the chief incentives to the production of abstracts.

$\S 59$. Depositories of Records. Under the general nane of records are clased all official acts of the public ofticers in relation to title; the adjudications and determinations of the courts; ministerial acts of officers in furtherance of the taxing power, and incidentally all papers, whether filed or engrossed, which affect title by relation and through the operation of law. Popularly the term is applied to the registry of deeds rather than to the other classes mentioned; but all come within its signification, so far, at least, as the purpose of abstract making is concerned, and from all of these varied sourees the examiner draws the details which go to make up a full exposition of the title. The registry of deeds furnishes the most fruitful field, and the great bulk of the examination is compiled therefrom, but recourse must also be had to the gorermment archives, the transactions of the State Legislature, the files of all the courts, State and Federal, ordinances of the mmicipality, and acts of the officers exercising the ministerial duties of taxation. Though easily enumerated, these somres cover a wide fiekl, and one which requires no ordinary ability to fully encompass.

$\S 60$. The Right of Inspection of Records. The right to inspect and copy or abstraet the public records is undonbted to those who have a direct interest therein." Not only does such a right result from the plain intendment of the reeording acts with reference to the matter of notice, but it has also been assured, in a majority of the States, by statutory enactments providing for the "free examination" of such reeords by all persons having occasion to inspect them for any lawful purpose. But until very recent years the question has usually arisen only where the right claimed was to inspeet or obtain a copy of some particular document, or of documents relating to a given transaction of title. With respect to the right of the

2 Brewer $v$. Watson, 61 Ala 310 ; People v. Richards, 99 N. Y. 620 ;
Lum r. MaCarty, 39 N. J. T. 287;

Boylan $v$. Warren, 39 Kan. 301. 
abstract maker to copy or abstract the entire records of a county for speculative purposes, the question may be considered of such modern origin as not to have been contemplated or corered by the common law authorities relating to the inspection of records; ${ }^{3}$ and, while it has been raised to some extent by recent decisions, it has not yet become shaped into any general definite rule or policy of law.

It must be remembered that the abstract maker does not ask for an inspection of a record and abstract thereof, relating to lands in which he claims to have title or interest, or concerning which he desires information in contemplation of acquiring some right or interest, either by purchase or otherwise, and, except when pursuing some special examination, he is not the agent or attorney of parties seeking information because interested or likely to become so. On the contrary, the right is based upon neither a present nor prospectire interest in lands, cither personally or as a representative of others who have, but is for his own future gain in furnishing information therefrom to third parties for a consideration. In view of these facts the rohme of authority seems to lean toward a denial of any right in the abstract maker to demand the inspection and free use of public records, holding that the statutes permitting free inspection were not designed to allow indiriduals the privilege of copring or abstracting the entire records of a pullic office in which they have no direct or special interest, or of using them continuously for the purpose of obtaining information to be used for speculation and gain in their private business. ${ }^{4}$

3 In England, the occasions which generally have required the exercise of the power of the court to enforce inspection of public documents have been those where a party has sought evidence for the prosecution or defense of his rights in pending litigation.

4 Bean v. People, 7 Colo. 200; Cormack $v$. Wolcott, 37 Kan. 391 ; Boylan $r$. Warren, 39 Kan. 301.
In Buck $v$. Collins, 51 Ga. 391. it was said, that the right to make abstracts is a perversion of the purpose for which the books are kept, and in Randolph $x$. State, 8: Ala. 527 . the comt sars, that the right of free examination is the rule, and the inhibition of the privilege when the purpose is speculative, is the exception. So in Brewer $v$. Watson, 71 Ala. 299, it is said: 
It is difficult, however, to reconcile the reasoning in some of the cases with the spirit and general policy of the law, or with the just claims of business convenience. The great utility of the professional examiner is a recognized fact, and with the constantly increasing complication of land titles his assistance in their proper adjustment has, in many localities, become an absolute necessity. The position which he oceupies in the world of commerce is second to none in importance and responsibility, and the free and unhindered inspection of the records should he aceorded him as a matter of public policy and in furtherance of great public interests, if not as a matter of legal right.

Not the least among the reasons assigned in the foregoing class of cases is solicitude for the preservation of the somrces of information. The public records, it is said, are the repositories of the rights of persons and of property, and in many cases hold the only evidence of either, and the law imposes upon courts and ministerial officer's the duty of their secure

"It is not the unqualified right of every citizen to demand access to, and inspection of the books or documents of a public office, though they are the property of the public and preserved for public uses and purposes. The riglit is subject to the same limitation and restriction as the right to an inspection of the books of a corporation, which strangers can not claim, and which is only allowed to the corporators, when a necessity for it is shown, and the purpose does not appear to be improper; *** and the individual who claims access to public records and documents can properly be required to show that he has an interest in the document which is sought, and that the inspection is for a legitimate purpose.

In other States the same general doctrine has been announced in equally emphatic terms. Thus, The Prince George's County Abstract. Company was incorporated by an act of the legislature of Maryland, which provided "that said corporation may make and may procure copies and abstracts from the public records of the State and gather information therefrom, and from other sources relating to conveyance of property, real and leasehold, make indexes of all deeds, mortgages, judgments, decrees and other records within the State of Maryland and may examine and guarantee titles to property, real and personal." Under this liberal legislation the Supreme Court of Maryland, in Belt $r$. Abstract Co., $73 \mathrm{Md}$. 289: declared that said company lad not the right to make searches and abstracts of title for their business withont payment to the clerk of his statutory fees. 
and eareful protection and preservation; a protection and preservation which might be greatly jeopardized if every citizen at his will and pleasure should be permitted to inspeet, examine and cops them in his own way." It must be admitted that the argument is weak when applied to any particular class as contradistinguished from the general public, and fanciful when applied to actual facts as they are presented in every county in the country. Mntilations of records are rare, and when instances of this kind do oceur, it will almost invariably be found that the mutilation has been accomplished by some person haring a special interest therein - in other words, by one whom the law says may inspect them. It is a significant fact that the case in which this theory was first adranced, ${ }^{6}$ and which has served as the keynote for erery subsequent decision of similar import, has since been overruled in the court where it was pronounced. ${ }^{\tau}$ As a matter of fact, no class of the community are more directly interested in the preservation and integrity of the records than the compilers of abstracts, and on more than one occasion their indices and references have been brought into requisition to protect public interests and prevent confusion of titles.

A more liberal view has been taken of this matter in some States and the rule has been announced that, as the records are public, every person has the right to inpect, examine and copy them, at all reasonable times and in a proper way; that ministerial officers charged with the custody of books and records can not deny access to their offices or the books therein

5 Webber $r$. Townler, 43 Mich. 534 ; Pean $r$. People, 7 Colo. 200 ; Cormack $r$. Wolcott, 37 Kan. 391; Buck $r$. Collins. 51 Ga. 391 ; In Re McLean, 8 Peporter 813. In the latter case the judges afterward granted, as an act of grace. what they denied the petitioner to be entitlor to as a matter of right. See, also, Re Caswell's Request, $18 \mathrm{R}$. I. \$35. 534.

6 Tebber $v$. Townley, 43 Mich.

7 Burton $r$. Tuite, is Mich. 363; 29 Am. L. Reg. 60.

8 A notable example is afforded by the great fire in Chicago, in 18:1. This conflagration entirely destroved the public records, and the ante-fire indices of the local abstract makers now furnish the only connected history of land titles in the county prior to that event. 
contained to any peran roming there at a proper time and in an orderly manner, ${ }^{9}$ and that any person so desiring las a right to examine such books and reerds without charer. wit as a privilege or faror, but as a matter of right. ${ }^{10}$ Such oftiecers should have the right to make reasonable restrictions as to the manner in which the books shall be samined, and to exercise a discretion as to the matter of the armision of persons to examine and copy when their presence, by reason of numbers. would interfere with the performance of official duties or the convenience of the general public, ${ }^{11}$ but this should be the extent of their powers of discrimination or refusal.

In some of the cases in which the right of free inspection, and privilege of copsing las bew declared, the privilege has been restricted to such persons as are employed to examine or guarantee a particular title, and while, as to such persons, the right is freely concerled it is denied to others. ${ }^{12}$

With respect to the public records of the Cnited States the necessity of interest, as at common law, has been done awar with by statute, ${ }^{13}$ and any person may examine them or take memoranda therefrom, ${ }^{14}$ while the courts of some States have made a distinction between court records and county records, holding that the judicial records of the State should alwars be accessible to the people for all proper purposes, mder reasonable restrictions as to the time and manner of examining them. ${ }^{15}$ In the absence of any statute regulating the matter, there can be no doult as to the power of a court to prevent an improper nee of its records, and hence it may dens a request to examine same from motives of mere curiosity, or to gratify spite, or for the purpose of creating public scan-

9 People $r$. Richards, $99 \mathrm{~N}$. Y. 620 ; State 2 . Rachac, 37 Minn. 372 ; Burton $v$. Tuite. is Mich. 363.

10 Lum $v$. MeCarty. 39 N. J. L. 287 ; Townshend $r$. Peg. of $\mathbf{X}$. Y., 7 How. Prac. (N. Y.) 318; Burton $v$. Tuite, 78 Mich. 363; Hansen $r$. Firhstaedt, 69 Wis. 538; Newton $r$. Fisher. 98 N. C. 20 ; and see State v. Rachac, 37 Minn. 372 .
11 People $r$. Pichards, 99 N. Y. 620 .

12 Barber $x$. Guaranty Co., 53 X.

J. Eq. 159.

139 C. S. Stat. 29?.

14 Re Chambers. 44 Fed. Rep. 796.

15 Re Caswell's request, 18 R. I. 835. 
dals:18 but when the object is legitimate and serves a proper purpose, there is no good reason for denying the right of inspection, and this is particnlarly true after the final hearing or determination of a cause. ${ }^{17}$

$\S 61$. Doctrine of Notice. The principle is well established, that a purchaser of land is chargeable with notice, by implication, of every fact affecting the title, which conld be discovered by an examination of the deeds or other muniments of title of his vendor, and of every fact, as to which the purchaser, with reasonable prudence or diligence, ought to become acquainted. If there is sufficient contained in any deed or record, which a prudent purchaser onght to examine, to induce an inquiry in the mind of an intelligent person, he is chargeable with the knowledge or notice of the facts so contained, and generally, a party in possession of certain information will be chargeable with a knowledge of all facts which an inquiry suggested by such information, diligently proscented, would have disclosed to him. ${ }^{18}$ The purchaser must be presumed to investigate the title, and to examine every deed or instrument forming a part of it, especially if recorded, ${ }^{19}$ and to make inquiries in pais as well as look at records. ${ }^{20}$

Notice is classified as either actual or constructive; but there is no difference between them in regard to the legal consequence or effect. ${ }^{21}$

$\$ 62$. Constructive Notice. It is scarcely possible to declare a priori what shall be deemed constructive notice, becanse unquestionably that which may not affect one man may be abundantly sufficient to affect another, and Sugden observes, "that every one who has attempted to define what it

16. Schmedding $r$. May, 85 Mich. 1 ; Cowley $v$. Pulsifer, 137 Mass. 392.

1i See cases last cited.

1s Cambridge Bank $v$. Delano, 48 N. Y. 326 ; Wilson $r$. Hunter, 30 Ind. 466 .

19 Acer $v$. Wescott, 46 N. Y. 384;
Chicago \& R. R. $r$. Kennedy, 70 IIl. 350 .

20 Littleton $r$. Giddings, 47 Tex. 109.

21 Hill $v$. Epley, 31 Pa. St. 335; Morrison $r$. Kelly, 22 Ill. 610; Ellison $v$. Wilson, $36 \mathrm{Vt} .67$. 
is, has declared his inability to satisfy eren himself." 22 The accepted legal definition is, that constructive notice is a legal inference from established facts. ${ }^{23}$ Where a party has actual notice of anything by which the title to property is affected, or has the means of knowing the sane, he is charged with constructive notice of facts and instruments to a knowledge of which he would have been led by inquiry, and which would have revealed the true state of the title. ${ }^{24}$ Such would also be the case when a party has designedly abstained from inquiry for the very purpose of aroiding notice; for the policy of law, and the safety of the public, forbils a person to deny knowlenge, while he is so dealing as to keep himself ignorant, and if he omit to make examination and incuiry in a proper case he is conclusively charged with negligence, and with notice of the defects in the title. ${ }^{25}$

In this country it has been uniformly held that the record of a conveyance, executed in conformity to law, operates as constructive notice to all subsequent purehasers on incumbrancers, claiming under the same grantor, of any cstate, either legal or equitable, in the same property, prorided the conveyance be one which the law requires or anthorizes to be recorded; ${ }^{26}$ and such purchaser is charged with the duty of exereising diligence in making proper examination touching the rights and equities of others, where the record shows that others have such rights, in the lands he is about to purchase. ${ }^{27}$

A subsequent purehaser is not chargeable with eonstructive notice of all instruments of recorl, by whomsocver made, but only of such as lie in the apparent chain of title, or have been made by one in some way commected with the property involved in interest, and brought to his notice. ${ }^{28}$

222 Sugden on Vendors, 570 (Am. Erl.).

23 Birdsall $r$. Russell, $29 \mathrm{~N}$. Y. 220.

24 Knap $レ$. Bailey, 79 Me. 195 ; Carter $r$. Hawkins, 62 Tex. 393.

25 Jarnard $x$. Campau, 29 Mich. 162; Cunningham $r$. Pattee, 99
Mass. 248; and see. I Warvelle on Vendors, 316, and eases cited.

24; 1 Story Eq. Jur. \$ 40:3; Tilton v. Hunter, 29 Haine, 29; Crockett r. Maruire. 10 Mo. 34. 27 Brusli r. Ware, 15 Pet. (U. S.) 110.

2s Carline $r$. Pringle, 90 Ill. 302. 
ITence he is not bound to look for conveyances by or judgments against one in whom the record shows no title.

The loctrine of constructive notice under registration laws has always been regarded as a harsh necessity, and the statutes which reate it have always been subjected to a rigid construction. ${ }^{29}$ Therefore, only the facts as they appear on the face of the record are deemed binding on subsequent purchasers, and if, from any canse, the real facts are there misstated, as if the wrong land is by mistake described, or the sum for which a mortgage is given is inadvertently omitted, a subsequent purchascr in good faith, relying upon what is shown, will not be affected by the error or omission. ${ }^{30}$

The recording acts, for the purpose of information and constructive notice, have not altered or abolished the rules of equity in relation to actual or constructive notice by other means than the recording acts. ${ }^{31}$

$\S 63$. Actual Notice. That which a person actually sees; or which is specifically brought to his attention, creates an actual notice of the fact. But the general doctrine of actual notice is much broader than this. Where a purchaser has knowledge of any fact sufficient to put a prudent man upon an inquiry, which, if prosecuted with ordinary diligence, would lead to actual notice of some right or title in conflict with that he is about to purchase, it is his duty to make the inquiry, and if he does not make it, he is guilty of bad faith or negligence to such an extent that the law will presume that he did make it, and will charge him with the actual notice he would have received if he had made it. ${ }^{32}$

Open, notorious and exclusive possession of land imparts notice of the title of the person in possession, ${ }^{33}$ and of every

29 Chamberlain $v$. Bell, 7 Cal. 292.

30 Chamberlain $r$. Bell, 7 Cal. 292: Sanger $v$. Craigul, 10 Vt. 555 : Frost $r$. Beekman, 1 Johns. Ch. (N. Y.) 288 .

31 Bourland $v$. Peoria, 16 Ill. 588.
32 Cambridge Bank $v$. Delano, 48 N. Y. 326 .

33 Greer $v$. Higgins, 20 Kan. 420 ; Mechan $v$. Williams, 48 Penn. St. 241 ; Cabeen $v$. Breckenridge, 48 Ill. 91; Tuttle $v$. Churehman, 74 Ind. 311; Hawley v. Morse, 32 Mo. 287. 
fact which the purchaser might learn by inquiry, ${ }^{34}$ lnt this rule does not apply to a rentor remaining in possession, so as to rer quire a purchaser from his grantee to inquire whether ho hats reserved any interest in the land conveyed. So far as the prirchaser is concerned, the vendor's deed is conchusive on that sulject. $^{35}$ While it is true, that the law regards the actual owenpaney of land as cquivalent to notice of the claim of the oecupant, to all persons dealing with the title, yet this is not an absolute proposition, which is to be taken as true in all possible relations, other than the one last noticed. The known circumstances may be such that the occupancy will not suggest to a purehaser an inquiry into the title or claim of the oceupant, and when the inquiry may be onitted in good faith and in the exercise of ordinary prudence, no one is bouml to make it. Possession out of the rendor and actually in another person ordinarily suggests an inquiry inte the claim of the latter, and a failure to make sueh inquiry erinces spos neglect, but the question in such cases is one of actual notice, and such notice will be imputed only where it is a reasonable and just inference from the visible facts ${ }^{36}$

As distinguished from construetive notice, actual notice consists in expres information of a fact brought home to a party, or a knowledge of circumstances which should leat him to a knowledge of such fact. Its existence is always a question of fact, open to rebuttal or explanation, while, on the other hand, constructive notice is a presumption of law which can not be rebutted. ${ }^{3 \top}$

$\S 64$. Registration. The system of registration practiced in the Lnited States is unknown to the common law and is essentially a creation of the statute. It is doubtless derived from the English statute of enrolhments, which was enarted to com-

34 Tankard $v$. Tankard, 79 N. C. 54: Pritchard $v$. Brown: 4 N. H. 397 .

35 V:an Fouren r. R. R. Co., 38 ‥ J. I. 16.j: Tuttle $r$. Churchman, it Ind. 311: rontra, White $v$. White, 8!) 111. 460 .
36 Pomeroy $v$. Stevens, 11 Met. 244; Donly $r$. Waleott, 4 Allen, 406 ; Jackion $r$. Elston, I2 Johns. 42.5 .

3i Tufts r. King, I8 Pa. St. 157; Bradbury r. Falmouth, 18 Me. 65; Birdsall $r$. Russell, 2!) N. Y. 220. 
teract the evil effects resulting from the practice of secret conveyances under the statute of uses. This statute provided that every bargain and sale of an inheritance or freehold should be by deed indented and enrolled within six lunar months from its date, either in one of the courts of Westminster, or before the justices and clerk of the peace in the county where the lands were situate. The enrolling of a deed did not make it a reeord, however, but it was recorded "to be kcpt in memory." ss

By the American system of registration, deeds of conveyance of any estate or interest in laud, when duly recorded in conformity with the law of the State where such land is situate, have the dignity and effect of records, and to them much of the stability of our land titles is attributable. Such record not only serves as a means of preservation of the muniments and evidences of title, lont also has the effect of giving to the transfer that notoriety formerly obtained by livery of seizin, to which it is made equiralent in some of the States by statute. ${ }^{39}$ The statutes of registration bear a close similitude in all the States, and provide generally for the recording of every instrument in writing, by which any estate or interest in land is ereated, aliened, mortgaged or assigned, or by which the title to land may be affected either in law or equity.

$\S 65$. Effect of Recording Acts. It is a familiar provision of the recording acts, that every conveyance which shall not be recorded as provided by law, shall be roid against any subsequent purchaser in good faith, and for a valuible consideration, of the same land, or any portion thereof, whose deed of conveyance shall be first duly recorrled; and finther, that every instrument recorded in the manner prescribed by statute, shall, from the time of filing same for record, impart notice to all persons of the contents thereof. It would seem, howerer, that the constructive notice afforded by the record of a deed, ap-

3s Tacobs Law Dict. 457: Tiffany on Registration. It will be perceived that only one class of deeds was required to be enrolled. towit: bargain and sale of an inheritance. This developed the form of conveyance by lease and release, which for many years was the popular mode of conveyance in England and which required no enrollment or other form of publicity.

39 Higbee $v$. Rice, 5 Mass. 344. 
plies only to those who are bound to search for it; as subzcruent purchasers, and all others who deal with or on the credit of the title, in the line of which the recorded deed belongs. ${ }^{40}$ That such record imparts notice, is to be mulerstood also, in the sense that the contents of the deed are correctly spread upon the record, ${ }^{41}$ for the recording acts can not be made by equitable construction to cmbrace cases not within them, or to give constructive notice of things the records do not show; and where a mistake is made in recording, a subsequent purchaser has a right, in the absence of actual motice of the mistake, to rely on the records as showing the exact facts. ${ }^{42}$ But incorrect registration can not arail a party who is not misled thereby. ${ }^{43}$

It would further seem, that instrunents to impart notice, must be recorded in the proper books. Thus, where separate books are providen for deeds and mortgages it has. in some instances, been held that a mortgage recorded in a book of deeds will not furnish constructive notice. ${ }^{44}$ So also, the registry of an instrument not required $b_{\varepsilon}$ law to be recorded is notice

40 Maul r. Fider, 59 Pa. St. 167; Corbin r. Sullivan, 47 Ind. 356 ; Gillett $r$. Gafiney, 3 Col. 3 万ิl.

41 Terrell $r$. Andrew County, 44 Mo. 309; McLonth r. Hurt, 51 Tex. 115 .

42 Frost $r$. Beekman, l John. Ch. 288; Barnard $v$. Campan, 29 Mich. 162; Wait $r$. Smith, 92 IIl. 385 ; compare Rigrs $r$. Boylan, 4 Biss. 445. As was said by the court in Terrell $v$. Andrew County, 44 MIo. 309: "A person in the examination of titles. first searches the rec. ords, and if he finds nothing there he looks to see if any instruments are filed and not recorded. If nothing is found, and he has no actual notice. so far as he is concerned the land is uninsmbered. If he finds a conveyanue, he goes no further; he never institutes an inquiry to find whether the deed is correctly recorded or the eontents literally transcribed. Indeed to attempt to prosecute such a search would be idle and nugatory. Grantees do not usually leave their deeds lying in the Recorder's office for the inspection of the public. After they are recorded they take them away and keep them in their own possession. In a large majority of cases, it would not only entail expense and tromble. but it would be useless to attempt to get access to the origrinal papers."

This is a rexed question; the text states the preponderating view but in sereral States a contrary doctrine is held. See Mangold $r$. Barlow, il Miss. 59:3: Mines $v$. Mínes, 35 Ala. 23; Throckmorton $r$ Price. „s Tex. 605; Clader $r$. Thomas. 89) Pa. St. 34:.

43 Garkill $v$. Badge, 3 Lea (Temn.), 144.

44 Cady r. l'urser, 131 Cal. 552. 
to no one, ${ }^{45}$ and, in the absence of statutory provisions to the contrary, a deet is not constructive notice, because copied into the registry, if it has not been duly executed, acknowledged or proved, so as to entitle it to registration, ${ }^{46}$ though such an instrument is effective as to all parties who have actual notice of its contents. ${ }^{47}$

Registration in legal intendment is conclusive notice to the parties to be affected by it. But notice of a prior unreeorded deed, communicated to a purchaser, will prevail over a subsequent recorled deed, ${ }^{48}$ and as between the immodiate parties no registration is necessary, an morecorded deed having the effect to carry the legal title as against all persons having aetual notice of its existence. ${ }^{49}$

It will often happen that in sparsely populated loealities a large area will be devoted to the purposes of a single county. As the comntry derelops and population inereases this area is divided into possibly several comties. In such event, unless there has ben a forvision for the transfer of records, it may become necessary to extend searches into more than one county, or into conmties other than that in which the land in question is siciate. Thi roults from the rule, now very generally obscrord, that a change of county boundaries does not impose the dinty of re-recording deeds where lands are thrown into a new or different comnty from the one of which they originally formed a part, and whore an instrument has once been properly lodged f., record in the eounty where the land is then situate, it will continue to impart constructive notice to all persous subse-

45 Galpin r. Ahbott, 6 Mich. 17; Sigourney $v$. Larmed, 10 Pick. 72.

46 Loughridge $\imath$. Bowland, 52 Mis.. 546; Pringle r. Dum, 37 Wis. 449; Blood r. Blood, 2.3 Pick. 80; Bishop $v$. Schneider, 46 Mo. 472; Parrett $r$. Shabhut, 5 Ninn. 323; Washburn $v$. Burnham, 63 N. Y. 132; Jones $r$. Rolserts, 65 Me. 273. 47 laws $r$. Fistill. 50 Miss. 300; Musick $r$. Barney, 49 Mo. 458; Musgrove $v$. Bonser, 5 Oreg. 313.
Where upon the records a defective deed is found and is seen, this must be regarded as actual notice, such as every reasonable and honest man would feel bound to act upon. Hastings $v$. Cutler, $25 \mathrm{~N}$. II. (4 Fost.) 483.

48 Claiborne $v$. Holmes, 51 Miss. 146.

49 Musgrove $v$. Bonser, 5 Oreg. 313. 
quently dealing with the land notwithstanding such land lias been attached to another eounty and no record of the conreyance has been made in snch latter eounty. ${ }^{50}$

66. Loss or Destruction of Records. The obligation of giving the notice required by law rests upon the party holding the title, and if his duty is innereetly performed, he, and not an innocent purehaser, must suffer the eonsequences; ${ }^{51}$ yet in a majority of the States that duty is effectively performed by filing the deed or instrument for record, and when this has been accomplished, the party has done all that the law requires. $^{52}$ Where a party has in all respects eomplied with the law the total or partial destruction of the record will not, it seems, impair any rights which may lave acerned thereunder nor affect the constructive notice afforded by the filing or recording of the instruments, which still remain of binding force and effect upon subsequent purchasers. ${ }^{53}$ In the event of the destruction of the record, as well as of the original instrument, an abstraet, shown to have been made in the ordinary course of business, and delivered to the parties interested in the land, is, as to such lost instrument, competent evidence of the facts therein reeited, either by comity, or, in some States, by express enactment $;^{54}$ but where such abstract is mintelligible without the aid of some proof to explain the meaning of abbreriations and initial letters used therein, unless some stipulation has been made which determines what effect shall be given to them, it would seem that the abstract is insufficient to cstablish title. ${ }^{55}$

For this reason, among many others that could be adduced, an abstract should always be so written that its contents may be read and understood by anyone. Abbreviations, as far as possible, should be avoided.

50 Geer $v$. Mining Co., 134 Mo. 85; Koerper $v$. Ry. Co., $40 \mathrm{Minn}$. 132.

51 Terrell $v$. Andrew County. 44 Mo. 309.

52 Riggs $v$. Boylan, 4 Biss. 445; Ifook $v$. Fenner, 18 Colo. 283; becbe $\mathrm{x}$. Morrell, 76 Mich. 114.

6
53 Meyers $v$. Buchanan, 46 Miss. 397; Gammon $r$. IIodgess, 73 Ill. 140; Steele $r$. Boone, 75 III. 457;

Deming $r$. Miles, $35 \mathrm{Nob} .739$.

54 linsiell $x$. Mandell, 73 Ill. 136. 55 Weeks v. Dowing, 30 Mich. 4. 
\$ 67. Official Aids to Search. No perfect abstract can be compiled without the assistance of a carefully prepared tract index, the details of which will be fully considered in another place; and should the county records be supplemented with this indispensable adjunct, the searcher will have less difficulty and experience more satisfactory results. Presuming, however, that no books of this character are provided by the public authorities, recourse must be had to such donbtful aids as by law the various officers are required to keep. These consist ordinarily of a series of alphabetically arranged indexes with brief descriptions of the property. Well kept, they will be of much assistance; if otherwise, they will prove very misleading. In all sales of real estate, where no better methods are available, these indexes should be carefully consulted and a rough chain obtained, which, by reference to the records, can be amplified into an abstract.

$\S 68$. Grantor and Grantee Indexes. The grantor and grantee indexes of the Registry of Deeds, will show the successive conveyances and ineumbrances under the names of the various parties who at different times have held the title, where there has been no break in the chain, together with the volume and page of the record on which the instruments may be found. Adverse deeds, unless within the knowledge of the examiner, can rarely be found by this method, or if found are usually the result of accident rather than design. If only an index to grantors is provided it will be almost impossible to detect adverse deeds. Should a brief description of the property be carried out, as is usually the case, ending with the section, town and range, in proper columns, these columns should always be carefully run down for any conveyances that may have escaped the searcher's attention, while going over the names.

While it may be the duty of the recorder to keep a proper index of his books of registration, so that one searching the records may easily find what is contained therein, yet a deed of converance properly filed and copied on the records is recorded within the meaning of the law, and imparts notice to subsequent 
purchasers, notwithstanding the failure of the recording officer to index it. The index is no part of the recorts. "ro

In a very fow States, porlaps, these latter statrments may not apply, for in sereal instancos it has been holet, under statntes which require the reorrer to keep indexes, that a deed camnot be considered as leablly reoreled mint the proper entries of at least its cssentials have loen mald in the general index, 57 while some decisions so so far as to declare that the index itself is an essential part of the recorel. 58

Index entries are, howerer, frequently held sufficient to charge notice," $"$ and this ton, even thorgh no description of the property is entered, hut simply the words, "see record" 60 or "certain lots of lanel; ${ }^{61}$ nor is it necessarily and essentially a prerequisite to a valid registration that the index should com. tain a description of the lands conrered, enough to put a careful aud prudent examiner on inquiry, and if, on such inquiry an artverse title would have been ascertained, the party will be held to have received notice.

56 Bishop $r$. Schneider, 46 Mo. 472; Chatham r. Bulford, 50 Ga. 327; Board of Commiswioners $r$. Babcock, 5 Oreg. 472; Ins. ('o. $r$. Dake, 87 N. Y. 257: Curtis r. Lyman, 24 Vt. 338; Glading r. Frick, $88 \mathrm{~Pa}$. St. 460 . The index is not. as a rule, marle essential ly situtute, and though the courts in some instances seem to have indicated that it is a material part of the records the reasons therefor do not seem to be sound or in consoname with the general doctrine on this subject. "The principle," sbserves White, J., "that would justify the holling the index to be asiential to the effective character of the record in the case of conveyances, woukd seem to require that the index to be kept by the rlerk should be regarded as essential to the lien of judgments; yout no one, wo suppose, would claim that the effect of a judgment was dependent on tho act or onision of the clerk in making the index." Green $r$. Garrington, 16 Ohio St. 548; but see Howe $r$. Thayer, 49 Iowa, 1.54; Lombard r. Cuilertmon, 59 Wis. 433.

so lliles $r$. Atlee, 80 Wis. 219; Hewitt $r$. Week, 59 Wis. 444; and see, Howe $r$. Thayer, 49 Iowa, I54. 5s Ritchie $t$. Grifiths, 1 Wash. 429.

5!) Pringle $t$. Jumn, 37 Wis. 449 ; Maxwell $r$. Hartman, 50 Wis. 667. bo White $r$. Hampton, I3 Iowa, 210.

"1 Bostwick v. Powers, I2 Iowa, $4: 20$.

62 Barney r. Little, 15 Iowa, 535. Local statutrs will go far in the solution of this rexerl question. In now rases where index entries are given aflext as records there will be fomml shatutes which have shaped the decisions of the courts. 
$\S$ 69. Notice Lis Pendens. As a further precaution careful seareh must always be made for notices lis pendens, and attaehments. These are usually kept in books separate from the reeords of deeds and mortgages, and very frequently are not noted on the reeeption or alphabetical indices, partieularly in smaller comties where less method is observed than in larger and more active places. When filed according to law they create liens upon the land to whieh they relate, and afford notice to all subsequent purchasers. Whoever takes a title to property in litigation will be bound by the judgment or deereo that may be rentered in the suit. ${ }^{63}$

$\S 70$. Plaintiff and Defendant Indexes. The plaintiff and defendant indexes of the eourts, when such are kept, should be further consulted for judgments against any of the parties, who at any time during the period that judgments are a lien on land, have held title to the property in question. The matter of pending suits, in which the title to land is involved, may also be ascertained from the defendant's index. Where no notices lis pendens are required to be filed with the recorder of deerls, as is the case in many States, this, perhaps, will be about the only way in which the examiner ean ascertain the facts. The index generally shows the present status of the ease and refers to other reeords or files where its history may be obtained.

These books will be found far more satisfactory in their results than the indexes of the reeorder's office, though not always available to detect adverse matters. Should these useful books not form a part of the machinery of the clerk's office, recourse must be had to the judgment docket.

\$ 71. Tax Records. $A$ further search must also be made in the records of the county elerk's or auditor's office for delinquent taxes, tax sales, forfeitures and judgments, the indices and aids by way of reference in this department being usually rery ample, and affording all the information necessary.

$\$$ 7.. Official certificates. It is frequently the custom of the raminer to append to an abstract of this character, the

63 Crosker $r$. Crooker, 57 Me. 395; Leitch $r$. Wells, 48 N. Y. 585; Jackson r. Warren, 32 Ill. 331. 
certifieates of the whicer's having the anstory of the pecords examined, yet in a majolity of cases such eertifikates do not materially enhance the value of the examination as cridenee, and mless forming a jart of their official duty create no responsibility on the part of the eartifying otherers.

\$ 73. Chureh and Parish Records. It is not customary for examiners of title to extent their inquiries beyond the public records kept pursuant to law, nor will the exigencies of many cases denand a wider scope. The admirable systen of registration which exists in every State is amply sufficient for almost every purpose connected with the development of title and the preservation of the muniments by which same is evidenced. But occasionally a mising link — birth, death, or marriage - can only be supplied by evidence aliunde the record, and to effect this, recourse nunt be had to less reliable testimony.

Church or parish records are frequently resorted to in the determination of doulteful questions of pedigree - proof of birth, or death of ancestor, as well as to settle questions of legitimacy in matters of sncession. Nor is there any good reason why a parish register should not be received and credited. It has been held that they serve a purpose cquivalent to that served by family records, and are fairly to be dealt with as equivalent to corporation records, which are gencrally taken as eridence of such matters as are recorded in the usual comrse of affairs. ${ }^{6+}$ While there is not much authority on the subject in this country, yet all the analogies and reasons which apply to other presumptively correct documents apply to these. ${ }^{65}$

64 Hunt $v$. Chosen Friends, 64 Mich. 671.

65 The question was deeided in favor of such entries in an early case in the Supreme Court of the United States, where the entries of burial in a ehurch in Philadel- phia were held admissible in a land controversy in Kentucky, tried in one of the United States Courts. It was there expressly held that they were competent testimony, Lewis $v$. Marshall, 5 Pet. (U. \&.) 470. 


\section{CHAPTER VI.}

\section{INDICES AND REFERENCES.}

$\S 7$. Importance of indexes.

75. Patent systems.

76 . The Government tract book.

i7. Field notes of Government surveys.

78. The original entry books.

79. Document number index.

80. Long form entries.

81. The tract index.
\$ 82 . The irregular index.

83. The tax index.

84. The judgment index.

85. Decrees and sales in chancery.

86. Vowel index.

87. Laying out the books.

88. Tiesume.

S 74. Importance of Indexes. In many portions of the United States no indexes are kept by the examiner of titles, who relies, in the preparation of his abstract, solely upon such meager facilities and arils as are usually afforded by the public offices, the details of which were considered in the preceding chapter. A perfect and complete abstract lowever, can be compiled only with the assistance of properly prepared indices and references. By the aid which they afford the examiner will be enabled to produce a perfect chain of recorded title, however intricate or complicated it may be, while without them diligence and learning will avail but little, and the abstract, as a necessary consequence, will be incomplete and lacking in many important particulars.

\$ 75. Patent Systems. In this age of labor-saving inventions it is not strange that many schemes should have been derised to lighten and abridge the labors of the examiner in the preparation of abstracts of title. These "systems" are usually protected by copyright or letters patent, and are warranted by their respectire originators and proprictors to be fully adequate for every purpose and equal to all the exigencies that ean possibly arise. Not infrequently some of these patent systems possess elements of merit, and, in a limited way, may encom- 
jass the end for which they are designed. Experience has not demonstrated their usefulness, however, but on the eontrary, in most cases, has shown their utter inutility. As a rule they are highly chimerical, and in practice generally prove a fraud, a delusion and a snare.

There is no royal road to abstract making, and the examiner who desires to produce only just and perfect work will derive but little assistance from any method that secks to dispense with conscientious labor or to avoid the deep and thorough investigation essentially necessary to a full and accurate development of title. An abstract prepared by any of the patent methods which have been brought to the attention of the writer, if at all complicated or involving intricacies of title, must needs be imperfect, and hence unreliable, and counsel should reject such compilations, or at most pass only a qualified opinion. The methods detailed in this volume are neither patent nor copyright systems. The are the results of years of practical experience, and are those now employed by the abstract makers of Chicago, where this seience has been more fully developed than in any other place in the world. They are freely given to the profession and may be used by any person. ${ }^{1}$

We may now direct our attention to the necessary equipment of a well appointed abstract office and the books that will be required for the proper and expeditious transaction of the business of abstract making.

\$ 76. The Govermment Tract Book. Among the permanent archives of a local government land office are a series of township plats and tract books, upon which it is the duty of the Register to note a proper entry of the fact of the sale of any land in the district. These tract books are arranged in the regular order of townships in a range, and of sections in the township, or fractional township, and afford all the necessary particulars of the method of the disposal of the land in

1 This hook is fully protected by ropyright, and no person may appropriate any part thereof without permission of the author. But the varions methods herein deseribed are given to the profession and may be used by any person. 
the district; description of land sold; name of purchaser; price paid; number of certiticate, etc. Where the land office is still in operation these particulars can be obtained from the Register, and in districts where same has been discontimed, the archives are usually deposited, in pursuance of an act of Congress, in the office of the Secretary of State, or some other designated officer of the State, in which the land office was situate. A cors, or eompilation, of the Government Land Office records forms the foundation of the examiner's indices, and will be found an invaluable adjunct, if not an indispensable requisite, to all effective examinations showing the entire course of title. This index should briefly indicate the governmental description of the land; the name of the purchaser; the character of the entry, as sale, homestead, etc.; the date of entry; number of certificate, and note of cancellation ${ }^{2}$ and re-entry, if any; and finally the issuance of patent, with date and name of patentee. Recourse for the latter information must be made to the General Land Office at Washington, if necessary, as the possession of the information is essential and will save much time, annoyance and many perplexing questions to client and counsel, owing to the nsual loose methods of early proprietors and the imperfection of county records.

$\$ 77$. Field Notes of Government Surveys. The field notes of the govermment surveyors afford the elements from which the plats and calculations in relation to the public surreys are made, and are the sonree wherefrom the description and evidence of locations and boundaries are officially deineated and set forth. They contain a minute record of all the official acts of the surveyor in relation to the measurement of the public lands, establishing of boundaries, etc., and present, as far as possible, a full and complete topographical description of the country surveyed. A copy of these notes, as well as of the official tomship plats made in connection therewith, should

2 The Commissioner of the General land Office has power, for cause, to cancel entries of public lands. See, Parsons $v$. Venzke, 4
N. Dak. 452, for a very full and lucid discussion. And see, Jones $r$. Meyers, 2 Idaho, 793. 
be found in every abstract office, for the field notes of the original survey enter into and form part of the description of land in all the certificates of entry and patents from the government, and are of controlling importance in determining the true location of public lands. ${ }^{3}$

The original monuments, as long as they can be ascertained, afford the most satisfactory if not conchusive eridence of the lines originally run, which are the true boundaries of the tract surveyed, whether they conform to the plat and field notes or not, on the principle that monmments alwass control courses, distances, quantity, etc. These monuments are regarded as facts, while the field notes and plats indicating courses, distances and quantities, are but descriptions which serve to assist in ascertaining the facts, ${ }^{4}$ yet when such monuments become lost or obliterated by time, accident or design, the notes and plats are all that remain to fix the original location of the monuments and determine true boundaries. ${ }^{5}$ To description can be more definite, certain and satisfactory than according to government survey. ${ }^{6}$

$\S$ 78. The original Entry. The books used in the business of abstract making resemble, in many particulars, those in common use in mercantile transactions, the day book and ledger of the merchant bearing a strong analogy to the original entry and index of the examiner. The series of books designated as "original entries," comprise an epitome of the transactions of the day in the rarions record oftices of the county, so far as the same may in any way affect or implicate the title to land, set forth with whaterer degree of fullness the exigencies of the oceasion will admit, or the inclination of the examiner may dictate. There is no special methor of arranging these books, the convenience of the compiler usually determining this point, the only essential being that the transactions of the

3 Hunt $v$. Rowley, 87 Ill. 491.

4 McClintock $\%$ Rogers, 11 Ill. 279 ; Watrous $v$. Morrison, 33 Fla. 261 ; Kincaid $v$. Dormey, 47 Mo. 337.
5 Sawyer r. Cox, 03 Ill. 130;

Bauer $r$ Gattmanhauken, 65 Ill. 499.

6 Kruse v. Scripps, 11 11l. 93. 
day are shown under proper chronological heads. Where the volume of business daily passing through the recorder's office is very large, only a brief note, showing the nature of the instrument, parties, date, and a condensed deseription of the property, can bo shown on the original entry, the date at the top of the page showing the date of filing for record, thus:

Nov. 29, 1882.

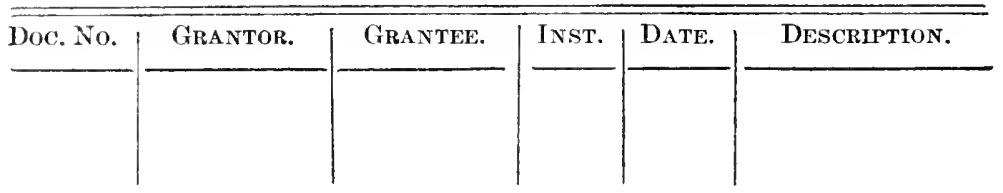

In Chicago, where from two to three hundred instruments frequently pass throngh the recorder's office in a single day, the above method is pursued, the examiner making his entries from the original instruments, the only practical system under circumstances similar to the foregoing. This information may also be obtained from the reception indexes of the recorder's office, should such books be kept, and while this might be sufficient in a majority of cases, yet oversights or omissions are liable to occur, partienlarly where the deeds are noted in alphabetical and not numerical order. The danger is apparent when it is remembered that, where a deed properly acknowledged and certified, is left for record with the reeorder, it takes effect from that date, although not entered on the receiving book until afterward. ${ }^{\top}$

It will sometimes happen that errors are made by the recording officer in transeribing. Where the examiner's entry is made from the original document these errors may be detected and corrected on the compilation of abstracts. In practice this is a circumstance of not infrequent occurrence.

Where the original instrument forms the basis of the entry a further index is necessary to furnish the book and page of

7 Poplin v. Mundell, 27 Kan. 138; and see Haworth $v$. Taylor, 108 Ill. 275 . 
the record for rearly reference in making the abstract, which is easily accomplished where the now rery common system of document numbers is employed. After the instrument has been formally filed for record the actual transcribing does not occur for several days or perhaps weeks, yet as the instrument takes effect and operates as constructive notice from the time it is filed, from obvious reasons the examiner must obtain his notes of same at that time and not wait for the uncertain contingency of actual transeription. The document number is placed on the instrument at the time of filing, and forms a portion of the original entry; it is posted as well on the tract index, and in making up the chain, as hereafter explained, furnishes a key by which the particular instrument is always identified.

§ 79. Document Number Index. As the numbers run in consecutive order, a book called the Document Number Index is provided, in which all the numbers of the series are first written or printed. At the close of business hours of each day, all the instrments which have been transcribed during the day are collected, and opposite the number of the deed in the Document Number Index, are written the book and page on which it has that day been recorded, thus furnishing a ready and easy reference to the books of the office, thus:

$$
1-100 \text {. }
$$

\begin{tabular}{c|c|c|c|c|}
\hline Doc. No. & Book. & Page. & Doc. No. & Book. \\
\hline 100 & 614 & 520 & & \\
& & & &
\end{tabular}

$\S 80$. Long Form Entries. Whenever practicable, the original entry may consist of a full abstract of every instrument. In the cities this is frequently impossible, but in sparsely setthed comties, or in places where mly a suall number of conveyances are filed daily, it can easily be accomplished, and tho 
examiner will then have, in his own possession, a complete duplicate of the material parts of all the records of the county, an acquisition that circumstances may make of inestimable value. By this method the greater portion of the abstract can be compiled withont consulting the records, thus effecting a great saring of time, labor and expense, and in many other ways it will be found equally adrantageous. It is unnecessary to dilate on the subject of care and accuracy in the compilation of these entries, or the necessity of thorough revision. When made in short form from the original documents, errors may be detected on abstracting the deed from the records, but if the long form system be used, an error perpetrated in the entries will be repeated in the indexes, and again in the abstract, furnishing endless confusion and a remote possibility of a law suit for damages.

While this method possesses obvious advantages it is not without disadrantages. In abstract is presumed to represent the actual comlition of the record and to have been compiled therefrom. The record may be erroneous, but in such case so also shonld the alstract. The examiner's entry may be a correct srnopis of the instrument, but if the abstract is made from such entry and not from the record it mas not be a true recital of the instrmment as it appears upon the record. For this reason, even when a long form of entry is used, the abstract should be compiled from the records rather than from the entries, and if divergencies appear they should be property noted. In any event, even though the abstract may be prepared from the examiner's own long form entries it should nevertheless be compared with the record before it leaves his hands.

\$ 81. The Tract Index. The Tract Index occupies much the same position in the abstract office, that the great lerlger does in the counting room. It is the receptacle for all the notes of the entry books, where the great mass of each day's transactions is separated, classified and arranged, and exhibits at a glance on its broad pages the balance sheet of all the land titles of the comnty. It is the foundation stone upon which the entire superstructure of the business rests, and the source from whence 
the examiner draws all his primary information in preparing the abstract. This index is arranged with sole reference to the land in the comnty, by sections or parts of sections in case of unsubdivided lands, and ly lots, blocks or subdivisions in respect to such as have been resurveyed and platted. For convenience it should contain, as far as practicable, all the specific allusions to particular tracts found upon the records, whether consisting of deeds, agreements, releases, attachments, sales, lis pendens, or other instruments, in any way affecting title to such tracts, or mentioning same, or any part thereof. In addition all other instruments, caluable of definite location, thongh containing no description, shoulk, as in ease of specific instruments, be posted under the particular classification to which they properly belong. For ordinary use six or eight quire demy $^{s}$ books will be found the nost serviceable, the number of volumes being regulated by the size of the county, population, prospects, ete. The books should be ruled across with heary and faint blue lines, and the page divided with red lines in the following proportions:

$$
\text { SEC. } 16-1-23 .
$$

\begin{tabular}{|c|c|c|c|c|c|c|}
\hline & & & & & $1-16-78$ & $1-25$ \\
\hline 2002 & Jno. Doe \& wf & Rich d Roe & $N\left\|\frac{1}{4} N\right\| \frac{1}{4}$ & M. & $2-10-78$ & $A-515$ \\
\hline
\end{tabular}

The forrgoing sample page would be posted from the original entries as follows: the left hand columm is filled by the document number, the second column by the grantor's name, the third by the grantec's, while the wide space next following

8 The demy page is recommended mainly on areount of its width, but cap size is more rourcuient for handling. The demy sheet is lix:21, making a page J(ix)101,2; the cap parge is $14 \times 81 / 2$. For the original entry a four quire cap is recommended. Should a double page be devoted to the tract index cap will also be formul to be the more convenicent form. 
is deroted to a briof description of the property. The nature of the instrument, indicated by the initial letter or some abbreviation, ocenpies the next space, while in the two suceeding columms much information may be condensed into little space by writing on both the heary and faint lines. Thus, in the first colnmm the upper line is intended to represent the date of the instrument; as, first month, sixteenth day, 1878, the lower line in like namner representing the date of record. So, in the last column, the upper line will reprosent the book and rage of the entry, which, if writen in extenso will be the only reference needed on making the chain, the entry supplying all the desired information that conld be afforded by the record; the lower line of this columm represents the book and page of the record. Should the examiner so desire, another colum may be added, in which are noted "remarks," notes of reference, satisfactions, re-records, ete., all of which will be found to greatly enhance the value of the volume.

In posting these books, ceonomy of space should always he kept in riew, otherwise they will soou become numerous and cumbersome, greatly retarding the examiner's labors. The faint lines should always be used in case of long descriptions, and the poster is allowed considerable latitude in the matter of abbreviation and condensation. So long as the identity of the parcel is preserved the description used in this book is of little moment; for it will be remembered this is but an index to the place where the full and original description may be found. For example: I deseription commences at the northeast corner of the northeast quarter of a stated section, town and range, and describes in a lengthy manner, by metes and bounds, an irregular shaped tract which contains eleven acres, the deseription cnding at the place of beginning. It will save time and space, and be just as correct as an index, to post the parcel as "11 ac. in N. E. cor. N. E. 1/4."

\& 82. Trregular 直dex. This index is dosigned as a receptacle for all matters, except judsments, that from their nature do not admit of specifie poting in the tract indiecs. Of this nature are gencral powers of attorney, unless the examiner 
sces fit to keep a separate book for same; releases and satisfaction pieces, which describe no property and are incapable of definite location; general confirmations, assignments, affidavits, etc. The index consists of two bonks, arranged alphabetically, by grantors and grantees, and is used, in compiling the chain, in exactly the same mauner as the judgment indices. It is posted in the same manner as the tract index, except that in place of the deseription of the property is noted a brief statement of the subject-matter of the instrument, the other details being the same. In all compilations this index should be carefully searched for the names of all partics, grantor and grantee, who at any time during the period covered by the examination have held title to the land in question, or possessed any equities therein. In case of variance in the orthography of a name it is advisable to post it both in the category to which the spelling of the name would properly consign it, and in the section where the examiner has reason to believe it rightfully belongs. Thus should the name as found be "Lauson" and the examiner from other indicia have reason to believe the name is "Slauson," the two names, to insure accuracy, should be noted on the index, the latter being identified by any system of marks the examiner may adopt to show that it is a substitute.

§ 83. Tax Index. With the exception of sales for taxes, everything capable of such treatment should be posted in the tract index. Tax sales, howerer, ean best be handled in a separate volume, and as a large portion are followed by redemption much dead matter will thus be kept off those books. This index is posted after every sale, and should be arranged to show: the description of the property; the name of the person against whom the tax is assessed; the nature of the tax for which the sale was made, as general, special, state, county, municipal, speeial assessment, and the like; the amount of the tax; the year for which it was levied; the date of sale; and if desired the name of the purehaser. On the right hand margin of the page a space should be left on which may be entered the fart of redemption. At the top of the page the section or subdi- 
vision is written, as in the tract index. In compiling the chain of title this book is consulted in the same manner as the tract index, and a list of all the sales, forfeitures, etc., taken off, which is then sent to the office of the custodian of the tax records and rerified by his books. All the redemptions are stricken from the chain, and existing liens shown as hercafter directed. I note of all the redemptions is then made in the index, thus:

SEC. $10-12-14$.

S W I/4 S W T/4 Thos. Higgins

Should circumstances permit the examiner to procure a daily list of redemptions, this indes would be much more servicable, and considerable labor would be saved in preparing the abstract. Such a courec, however, is rarely practicable, and the method above indicated is that usually followed.

It has now become a common practice for examiners of titlo to show special assessments and impositions of like character. When this is done the better way is to keep a special index to all confirmed special assessments and where inheritance taxes are levied on the estates of decedents a further index covering this matters should also be provided. Confirmed special asscssments may be noted on the general tract index and inheritance taxes might be posted in the irregular index, but the better plan, and that which is conducive to the best results in abstract making, is to keep special indices in both cases.

S St. Judgment Index. The Judgment Index consists simply of an alphabetically arranged index of names, taken from the court files exery day, and shows: the name of the jurgment debtor: the plaintiff or judgment ereditor; the court in which the judgment is docketed: the general number of the ease; the time of rendition or docketing; the amount of the julgment and costs, and the fact of satisfaction in the same 
manner as tax liens. In practice this book is used the same as the tax index. The following will be found a suitable form for the page:

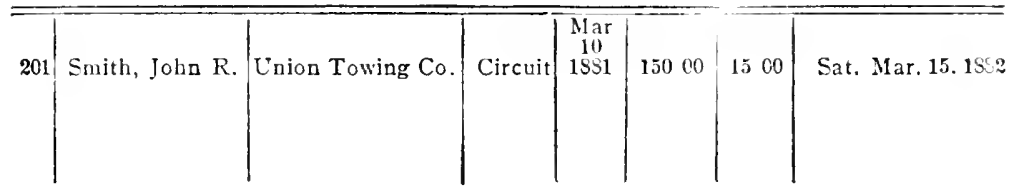

If desired, a further column may be added, showing the nature of the suit. This book is used only for money judgments, or such as create a lien on land. Decrees in chancery, or actions and proceedings directly involving the title to land, are posted in the general tract indices.

$\$ 85$. Decrees and Sales in Chancery. No separate index need be kept for proceedings in court of an equitable nature. For pending suits a note of the lis pendens or attachment as found in the registry of deeds is sufticient. For decrees, orders or sales made in pursuance thereof an original entry should be kept as in ease of deeds, ete., showing as fully as may be the entire transaction, and posted as other instruments are in the general tract index. These procedings have all the stability of conreyances between individuals, and form permanent mumiments of title. Exceution sales may be noted in like mamer.

For greater convenience many examiners keep special indices of decedents' estates, as well as of the estates of minor's and other persons under disability. Where this can be done the practice is recommended. In large and populons counties some such a course becomes almost a necessity.

$\S 86$. Towel Index. In addition to the books descriled in the foregoing paragraphs, all of which are inclispensable in a properly equipperl alstract office, there are a number of supplemental volumes that may be used to arlvantage. Chici anong these supplemental books may lo mentimed an index to grantecs arranged alphabetically, and, for the purpose of more ready reference, by vowel sounds. In this book are writ- 
ten the names of all grantees, and after same the book and page of the record where the name appears and a reference to the book and page of the original entry of the examiner. The name is written but once, all subsequent transfer's being posted opposite same by simple reference to book and page. A form for this book will readily suggest itself.

The primary object of this index is to furnish a ready means of ascertaining the present or past interests of any individual who at any time has held the legal title to lands in the county, and to facilitate search for real estate standing in the name of judgunent debtor's.

s si. Laying out the Books. Considerable judgment must be exercised in laying out a set of abstract books, not so much for economy in material, though this may be an object, but for economy of time in their nse, which is a very important consideration. The aim of the examiner should be to have his indices preserve such a correspondence in all their parts that posting shall cease in every division of the work at about the same time. To attain this end, where a section or subdivision is thickly populated and sales are frequent, considerable space, should be deroted to it, and, if necessary for greater convenience, the land may be indexed by half or quarter sections instead of sections. In less active localities, the index may be by sections and less space should be used. In a new county this question must be determined by geographical considerations, present location of towns, railroads, water ways, etc. In older places the experience of the past will usually furnish a safe guide in this respect for the future.

Alphabetical indexes are laid out on technical and arbitrary principles based upon experience in the distribution of initial letters in names. Thus it is found that certain letters occur much more frequently than others in the commencement of names, and space must be given accordingly. The table on the opposite page will be found a safe guide:

Thus it will be seen, in a book containing thirty pages one page will be sufficient for names beginning with the letter "A." Names begimning with the letter " B" are much more frequent, 


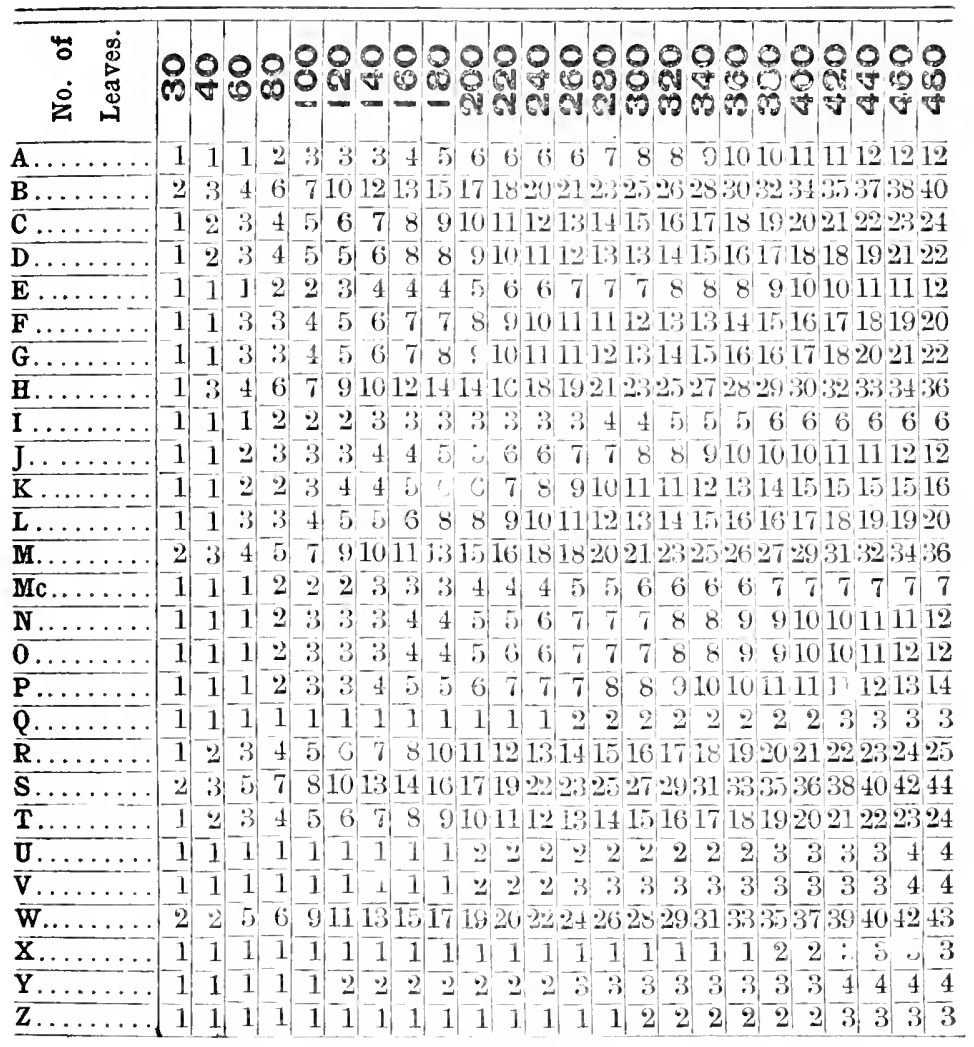

and hence two pages shomld be kerotrd to these names. And so the number of pages for each letter will be proportionately increased with the increasing size of the book, so that if it contains 480 pages, forty of then may properly be set aside for the letter "B."

\$ 88. Resume. The foregoing brief sketch, it is hoped, will furnish sufficient hints to enable one with wo previons experience to lay out and kecp, a set of abstraet bouks in a nothodical and intelligible manner. Neatuess is a prime neessity in compiling the books. Chirography should be plain and distinct. Only the very best writing fluid should be nsed. Nemoranda, 
not of a permanent character, should be made with a hard lead pencil, and as little as possible should be made. When the memoranda has answered its purpose it should be erased. For their better preservation books should be eneased in canvas covers and a fire-proof receptaele should be their abiding place at all times when not in actual use. Many things will suggest themselves to the examiner, arising from local causes, while his own ingenuity will enable him to improve on the forms here giren. Having then started the books, the next thing in order is to prepare an abstract from them, and this will form the subject of the next chapter. 


\section{CHAPTER VII.}

\section{COMPILING TIE ABSTRACT.}

§ 89. Generally considered.

90. Extent of the search.

91. Making the chain.

92. Formal parts.

93. 'The caption.

94. Arrangement of the abstract.

95. Synopsis of instruments.

96. Fullness of narration.

97. Instruments shown for reference.
§ 9S. Examiner's notes.

99. Irregular instruments.

100. Reference to original instruments and private memoranda.

101. Abbreriations.

102. Letter press copies.

103. Concluding certificate.

\& 59. Generally considered. Examinations of title in the United States, which are usually prepared by professional examiners, do not, as a rule, disclose, except inferentially, any matter or thing affecting title save what appears of record, and searches are mainly restricted to the public records of the county. Ordinarily this is sufficient, and a careful search will reseal all that is necessary to a proper estimate of the title, and fully protect intending purchasers. In England, where the abstract is prepared from original documents, it is customary to give a far wider range to the examiner's efforts and to include not only the material parts of deeds, wills, ete., but of records and private acts of Parliament, and even of public acts passed for private purposes, which might in any wise implicate or affect the title; and to these are added such facts as fill up the interval of title, as descents, deaths, marriages, births, burials and other cireumstances generally called matters in pais, ${ }^{1}$ and when it is necessary to prove a pedigree, as where a descent occurs in the course of the abstract, in the absence of better evidence the examiner has recourse to wills of relatives, extracts from parish books, from family bibles, and even from tomb-

11 Prest. on Abstracts, 43. 
stones. ${ }^{2}$ Onr sytem of registration, of probate proceedings, and of julicial incuiry and letermination, and the legal effect thereof, renters the English exaniner's methods useless to a lanere axtent in the Inited States, yet it can not be denied that coppormitice frequently oecm for a judicious breach of the conventional observance of record evidence only, and for the introrluction of what may properly be ealled matter's in pais. A number of instances of this kind will be found noted on the succeeding pages of this bonk.

$\$ 90$. Wxtent of the Search. An examination, upon its face, purports to show the course of title from a definite date to another definite date, and the fair and reasonable import of the mudertaking is, that the exaniner has made a full and true search relative to the title during that period and has noted on the abstract erery transfer, or other matter, affecting the same, actually made and entered of record between those dates. Ite is mider no duty, howerer, to inquire into the existence of any judgments entered, or conveyances recorded, prior to the date mentioned as the commencement of the search, neither is he required to ascertain or ecrtify as to any lien arising under any such prior judgment, although the same may have first attached and beeone operative after that time by reason of the fact that the judgment debtor then first acquired title to the premises; nor is he bound to inquire or state whether the title vested in any grantec, luring the period covered by the examination, was affected by any prior conreyance or any estoppel growing ont of any corenants therein. ${ }^{3}$

It must be obvions, howerer, that an examination made in strict conformity to the foregoing will in many instanees defeat the rery object of the seareh, and henee it is customary to show -nbisting tax and judgment liens, even thoneh aecruing prior to the date of the enmmeneement of the examination, and, ex-

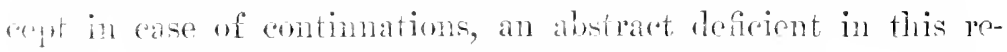
freet should be rejectert by comed, as un afo npinion can ho

2 Trumb't Tom Dict. 5.

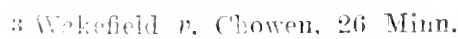
379 ; Dodd $r$. Williams, 3 Mo. App.
278: and see, Ely r. Wilcox, 20 Wis.

523 ; State 1 . Bradish, 14 Mrass. 296 ;

Ford $r$. Unity Church, $1 \geq 0$ Mo. 498. 
Jredicated upon it. In all cases where a lien tirst attaches during the period covered by the examination, it should be shown, whatever may have bern its inception, and any departure from this rule is to rob the abstract of its character of a trustworthy guide and reduce, if not vitiate, its value as an evidence of the true state of the title.

In many localities it is or has been customary to dispense with a formal abstract, and in its stead the examiner merely "certifies the title," as being "good," "bad" or "doubtful," in an indivirhal named, basing his certificate upon his personal examination of the records. This is merely an opinion of title, and its worth depends wholly upon the learning, ability, and financial responsibility of the individual rendering it.

Again, while the examiner may present a symopsis of the deeds, etc., it is simply for the purpose of showing, like the English abstract, the present title of some specified person, the chain commencing at some given point as the root. In a case of this kind unusnal care is required, lest a prior conveyance operating by way of estoppel, may not defeat the title shown. It is customary, in an examination similar to the one under consideration, to commence with a deed showing title in vendor or his grantor, and thence continuing down to the date of the certificate. There is not wanting authority to support an examination of this character, and it has been held that a deed recorded before the grantor has any record title may be safely disregarded in examination of title, muler the system of registration and notice adopted in the different States of the Union; that such a deed would not be constructive notice to any innocent purchaser; ${ }^{4}$ and further, that a purchaser finding an apparently valid title of record, is not expected to look behind it. ${ }^{5}$ The rule, however, is unsafe and does not prevail generally, ${ }^{6}$ and counsel before passing on an examina-

4 Dodd $v$. Williams, 3 Mo. App. 278; and see, Ford $v$ Unity Church, 120 Mo. 498; Calder v. Chapman, 52 Pa. St. 359 ; State $v$. Bradish,
14 Mass. 296; Ely $v$. Wilcox, 20 Wis. 52?.

5 State v. Bradish, 14 Mass. 296.

"See "Estoppel," "Notice" and "Registration." 
tion purporting to show no more than above stated, should have satisfactory assurance that no prior deeds exist of record, or his opinion should indicate the possible defeets of title resulting therefrom.

If the examiner is directed to commence his search at a given period, or with a specifie event in the devolution of title, he will, of course, discharge his whole duty by a true showing of what has transpired since that time or event, but a purchaser will thereby assume a risk.

$\$$ 91. Making the Chain. Pefore commencing the formal abstract a preliminary sketch should first be mads from all the indices. This sketch, called the "chain," is simply a series of brief notes of all conveyances, incumbrances and liens affecting the property under consideration, as shown by the tract index, and, where the original cntry is meager, the examiner uses these references in making full abstracts of the instruments from the records. It also shows what instruments are associated with the names of those whom the tract index invests with title, that appear upon the irregular index; the names of all persons who at any time have held title which are found upon the judgment index; and all tax sales or forfeitures of the land in question as shown by the tax index. These latter are then verified by comparison with the records, and all satisfactions or redemptions stricken from the sketch. The instruments, proceedings, ete., are then numbered and arranged in the order in which the abstract should be written, and furnish a reference guide for this portion of the work.

$\S$ 92. Formal Parts. The abstract should be prepared in a neat and orderly manner, and so disposed as to facilitate the labor of comsel in passing on the title. A formal caption should apprise the reader at the ontset of the subject of the examination, while the different searches shonld be arranged under classified heads, and for purposes of convenient reference the various converances and statements should be numbered consecutively from the beginning. The result of the search shoulk be recapitulated at the conclusion by a certificate covering all the essential features of the examination. The formal 
parts should be brief, yet explicit, and drawn with great care, particularly the examiner's certificate, for it is this which imparts to the abstract its vahe as evidence.

$\S 93$. The Caption. The object of the caption is to definitely describe the sulject of the examination. It would seem to be the practice of Eastem abstract makers, following the English precedents, to insert here the name of the person for whom the search is made, and frequently, to describe the abr stract itself as the exemplification of the title of some particular individual. ${ }^{7}$ But this is usurping the province of the examining counsel, who alone shonld say where and in whom the title rests, and that only after a careful and diligent inquiry into all the questions raised by the abstract, betll directly and inferentially. The work of the examiner is to present to counsel all that appears of record concerning a specified tract of land; no more. The comsel must say in whom, under the application of legal rules and principles, the title rests, or is vested. The caption, therefore, should comsist of a full deseription of the parcel or pareels of land under exanination, and the time from which the scarch is made. The following is the form of an ordinary caption:

\section{EXAMINATION OF TITLE ${ }^{\mathrm{s}}$}

to

Lot Five (5) of Block Four (4) of Bond's Subdirision of the North East quarter of Section Twenty-Three (28) Town Thirty-Seven (37) North, Range Thirteen (13) East of the Third Principal Meridian; except the South one hundred acres, and also one acre, in the North. West corner of East one half (1/2) of said quarter section, deeded to the school Commissioners.

Deseriptions of platted lands are frequently confined to the record title of the plat, which fails to provide a full designa-

7 Sce Curwen on Abstracts, 38; Willard on conveyancing, 551.

8 If desired the word "abstract" may be employed instead of " exam- ination." The former is the Englinh metherl, the latter more fully expressict the idea involved and is in common use in this country. 
tion, and the rescription thus employed in the deects is also used in the cartion of the abstract. When such is the case it is a goom phlan to further indicate the location of the property with reference to the original division, thus:

Shb-Block Three (3) of Block (4) of Sheffeld's Addition to Chicago, Cook County, Ills.

The premises in question are located upon the North half of the North East quarter of Section 3.9, Tou'n 40 North, Range 14. East of the $3 d$ Principal Meridian.

So also, it may happen that a sublivision is laid out on several parcels, in which case it may be deemed desirable to show the particular parcel in which the lots under examination are lorated. The caption would therefore vary a little from that last shown. As for example:

Lot (4) in Block (Q) in Pockwell's Addilion to Chicago, Cook County. Ills.

Said addition is laid out on the West Half of the North West quarter of Section 1S, Town 39 North, Range 14 East of the 3 d Principal Meridian, and the North East quarler of Section 13, Toun 39 North, Range 13 East of the $3 d$ Principal Meridian.

The Lot in question falls within. the North East quarter of section 18 aforesaid.

When the early stages of title, prior to the subdivision, are shown, the foregoing method often becomes a great help to counsel in examining the abstract.

Should the examination be a continuation of a former search, the words "Continuation of" may be placed at the lerginning of the caption, preceding the word "Examination." If desired the word "Abstract" may be employed instead of "Examination." This is the English style and many examiners prefer it.

Where the examination commences at the source of title, 
as where a devolution from the United States is shown, no announcenent of the time from which the search dates is neeessary, but when any intromediate point is selected, it is customary to indicalte sane. This is acomplished by a simple statement of the fact immediately following the description, and neatly scparated from what precedes and follows by dashes, thus:

Commencing this examination Oct. 9, $18 \% 1$.

The certificate, when properly drawn, will always show the respective dates covered by the eximination, but many examiners prefer to indieate these facts in arlvance, and when such is the case, the time clanse should read so as to show the temmination as well as the commencenent of the search. When the examination is partial, and does not come down to include present time, this method is strongly recommended. In such a case the time clause might read as follows:

Commencing this examination Oct. 9, 1871, and bringing the same down to include Sept. 7,$18 ; 4$.

Where the examination includes several distinet parcels, and the search does not cover the same period of time as to all of the parcels, this fact should be indicated at the start; thus:

As to Lots 13 to 16 inclusive, in Block 5, we bring our cxamination dow'n to include Varch 3, 1856.

As to the remainder of said premises we bring our cxamination down to include the date hereof.

In ease of a continuation of a former search the time elause should read somewhat as follows:

Last examination made by us dated March 8, $18 \% 9$. 
or should the seareh bave been made by a different examiner,

Last cxamination made by Handy, Simmons \& Co., dated June 7, $18 S 0$.

It may be that the examination is designed to show only a particular title antedating the actual time of the search. In such casse some initial statement disclosing the fact is necessary to avoid confusion, and this may be accomplished by some such statement as the following:

We bring our examination down to include the title to said premises acquired by Delbert A. Clithero by the deeds to him herein shown.

It sometimes happens that the client desires a search only from some particular time, and selects some particular instrument as the basis of his title. In this case, the instrument selected should form the initial number of the abstract, and the time clanse should read substantially as follows:

We assume, by direction, that John Smith acquired title to the fee of the land described in the caption hereto, on the 10th day of April, 1S\%3, by the instrument shown as number one of this examination.

Frequently the examiner will be called upon for partial, or special examinations, either of land or concerning individuals, in which case the caption should explicitly state all the points covered by the examination, and, if necessary for greater certainty, negative such as are not; as

\section{Special Examination}

for

Judgments and Pending Suits in the Circuit and Superior Courts of Cook County, Illinois, against George P. Will- 
iams and John R. Smith. Judgments against John Smith disregarded.

Examinations for special conveyances, for real estate standing in the name of judgment debtors, for taxes, ete., should be treated in the sane general manner.

Where the examination is confined to the elucilation of a single issue, it becomes more properly an abstract of the particular point under consideration, and is so denominated; as,

\section{Abstract}

$$
\text { of }
$$

A Tax Title to in-lot twenty-four, of the original plat of the village of Edgerton, Green county, Wisconsin, acquired under and by virtue of a sale made May 10,15\%9, for the taxes of $18 \%$.

$\S 94$. Arrangement of the $\mathbb{A}$ bstract. The different conveyances and stages of title are usually shown in chronological order so as to present, as far as possible, a connected chain, and are numbered scriatim from the beginning. Many examiners show the deeds and grants collectively, while the mortgages and liens are grouped together in the same manner under a classified head. This arrangement, thongh widely used, is inconvenient and frequently distracting to comsel. The liens and incumbrances when connecting title should be set forth in regular chronological order in conjunction with other instruments, and releases or discharges should immediately follow the incumbrance or lien which they purport to affect, irrespective of the time they bear date. The ain of the examiner should be to present, so far as may be, the course of title in umbroken sequence throngh whatever forms or instmmentalities it may pass. Judgments against the person, mechanic's liens, taxes and tax sales, may be shown after the course of title has been traced, in the shape of appendices and under apmropriate heads. Decrees, judgments, orders affect- 
ing the land, and tax deeds, of course appear in regivlar order in the body of the abstract. Official deeds, resulting from execution or judicial sales, shonld be preceded in the former case by the jutgment, in the latter by the special proceedings and decrees mon which they are founded.

As a further aid in effecting a correct and systematic arrangement of the instruments shown in an examination, an illustration in the form of a chain is herewith given. This title, while it would present but fow difficulties, is yet sufficiently intricate to explain the method.

\section{ETAMINATION OH TITLE}

to

The N. E. $1 / 1$ Sec. 10, T. 1 N., R. 2.3 E.

\begin{tabular}{|c|c|c|c|c|}
\hline 1. U.S. to $A .^{9}$ & Patent & All & $A u g$. & 1,1839 \\
\hline 2. A. to $B$. & Deed & All & Dee. & $15,1839$. \\
\hline 3. B. to $C$. & Deed & $A 7 l$ & Inne & 10,1845 \\
\hline 4. C. to D. & Deed & $A\rceil l$ & May & $3,1 S 50$ \\
\hline 5. D. to $G$. & Deed & $1 \%$ & $.7 m$ me & 1,1550 \\
\hline 6. G. to $H$. & Deed & $1 / 2$ & ipril & $11,1855$. \\
\hline y. D. to E. & Deed & $1 / 2$ & July & $\stackrel{2}{N} 1852$. \\
\hline S. E. to F. & Deed & $1 \%$ & Sept. & $12,1853$. \\
\hline 9. F. to $H$. & Deed & $1 \%$ & Amil & $11,1859$. \\
\hline 10. H. to $M$. & Deed & $A / l$ & oct. & $8,185 \%$ \\
\hline 11. State to $I$. & Tar Deed & .177 & Mroth & $1.185 \%$ \\
\hline 13. I. to J. & Quit CTaim & All &.$J a n$ & 2.1851. \\
\hline 1.). J. to $K$. & Deed & All & Way & $15,1851$. \\
\hline 1.t. K. to $L$. & Deed & All & $T \cdot b$. & $20.195 \%$ \\
\hline 15. L. to $\mathrm{M}$. & Deed & All & Ort. & $\mathcal{S}, 1859$ \\
\hline
\end{tabular}

8 The above illustration is for arrangement only; of course, in compiling the abstraet, a full synopsis of every instrument and proceeding must be given. 
16. M. to $N$.

Deed

All Nov.

1,1860 .

Judgments.

Tax Sales.

Examiner's Cerlificate of Search.

The foregoing sketch, though brief, conveys, in some measure, an idea of the arrangement of a chain of title. From Nos. 1 to $t$ the divestiture of the title from the govermment and its devolution through mesne eonveyances is regular and withont interruption. At No. 5 the ownership of the land changes from sereralty to common, an undivided one half being vested by No. 6 in II. As H, in the devolution of title, subsequently becomes invested with the remaining one half, a stop should be made at this point and the title to such remaining one half traced until it again becomes merged in $\mathrm{H}$. This is accomplished in No. 9. The remited title should then bo distinguished from what has preceded by a short dash, and the next eonveranee, No. 10, should form another initial point, from which, if no other obstacle intervened, the ehain would be continued. But during the devolution of the original title a tax title has been ereated by a grant from the State. This title is independent and adverse, and if there should be no subsequent merger would be properly shown after the original title had been fully traced. In the illustration this title is afterward acquired by $\mathrm{M}$, therefore, as he now owns the original title, such tax title should at this point be traced to him. A broad dash should therefore separate the chain and the course of the tax title should be followed until $\mathrm{M}$ receives the investure, which is aceomplished in No. 15. ITere the broad dash is again employed to separate the tax title from the original, and the full and remited course is continued in the deed from $\mathrm{M}$ to $\mathrm{N}$. The jurlgments and tax sales, if any, follow as special appendiees.

An abstract thus arranged greatly lessens the labors of coun- 
sel in preparing an analysis, ${ }^{10}$ and by reason of its coherency presents most, if not all, of its salient features on first perusal.

\$ 9\%. Synopsis of the Instruments. In England, abstracts are prepared after a uniform system which has long been observed by the conveyancers of that country, and the impress of which is plainly discernible in many portions of the Vnited States. It is rery methodical and precise, and in view of the differences in the sources of information, as well as the information itself, and of the effect which many of the matters there required to be shown have upon title, is perhaps highly conducive to the end desired, yet after all it is more a matter of precedent and the observance of established forms than of real utility. Should the taste of the examiner so incline, or counsel so direct, the instruments may be displayed after the English model, which is, briefly, as follows:

The abstract is usually written on "brief" paper, which is divided by three real or inaginary longitudinal lines, thus leaving a page with four divisions which are technically known as "margins." The outer, or left hand margin, is left clear for the person investigating the title to insert any note or intended inquiry which may suggest itself during the perusal of the abstract, or it may sometimes be used by the abstract maker for the iusertion of a note or statement necessary to a proper display of the title. The caption is written from the third margin. The description of the parties, as well as the testatum, is nsually written from the outer margin. The parcels, that is the descriptions of the property, are invariably set out from the third inner margin. The habendum is most frequently written from the second inner margin, while the recitals are almost invariably written from the first inner margin. ${ }^{11}$ This method undoubtedly possesses some advantages, the chief merits being, that it cnables counsel at a glance to

10 As an instance, an analysis of the title shown by the above abstract is given in Chap. XXXII of this work.

11 Seaborne on Vendors, 4 et seq.
As this matter receives frequent allusions in different parts of this work, an example illustrating the methods will be found in the appendix. 
refer to any portion of an instrument withont having his attention diverted to other parts, and the facility it affords for the comparison of instruments and the determination of their operation and effect when construed in relation to each other; but aside from this it is difficult to perceive any partienlar inducement for the adoption of the marginal system.

The form of synopsis recommenterl by the writer, and of which the succeeling illustrations afford mmerous examples, is exceedingly simple and martificial. It consists merely of an arrangement not unlike that nsed in preparing the pleadings in a law suit; that is, a caption reciting the parties to the transactir: or the nature of the transaction itself in practicable cases, followed by a plain narration of whaterer matter may be deemed essential. The caption, for greater ease in rerusing and comparing, is placed at the left hand side of the page and united with a bracket, or, if desired, may be written over and across the narration which follows. All the recitals are written across the entire page and not otherwise distinguished from each other than by being thrown into paragraphs. In case of notes a slight indentation is desirable to more fully distinguish them from other matter, but with this exception all writing had better be made from the mled margin of the sheet, ordinary legal cap being used for the purpose. This mothod has long been pursued by the abstract makers of the West, where it is conceded the most perfect and finished abstracts are now produced, and has met the general approbation of the legal profession.

$\S 96$. Fullness of Narration. From what has been said, it will appear that a full and complete narration of every instrument, proceeding or act, shown in the abstract, is necessary to a complete and perfect examination. A thing of no sceming moment to the examiner, may, to the trained eye of connsel, be a circumstance of vital importance. While the abstract is not intended to be a copy of what is shown it should yot $l_{r}$ sufficient to impart all the essential information that might be obtained from a perusal of the original documents. It is not necessary, save in exceptional cases, that it should be 
a literal transeript of erery point or matter deemed material or essential, for, on the contrary, the majority of these matters will be more clcarly and pertinently presented by a brief and suceinct statement that shall fully cover the particular point, livested of its redundancy and umecessary verbiage. The object of the abstract is to economize time, and to enable the reader to survey the entire course of title, comparatively, at a glance. Hence, long aud technical provisions should, whenever practicable, be digested so as to show their pith and substance, which, in many instances, may be done withont in any manner impairing their significance. The faculty of condensation should be cultivated by all who would aspire to excellence in the preparation of abstracts, for nothing more distinguishes the accomplished and expert examiner, and the work is always duly recognized and appreciated by comsel.

These remarks, however, apply mainly to the general and not to the speeial incidents of instruments, for these latter, as a rule, can best be presented in the language of the originalis, and to aroid error or omission should be so shown. Thus, a general recital is far better presented as a terse and suceinet statement, but provisions peeuliar to the instrument must be fully stated or literally copied, for it must erer be borne in mind, that where one is chargeable with the notice of the record of an instrument, he is equally affeeted with notice of all material matters contained in snch instrument. ${ }^{12}$

\& 97. Instruments Shown for Reference. While the primary purpose of an abstract is to show only the course of title to a specitied tract, yet, in order more fully to illustrate such title, or to enable comsel to obtain better views with respect thereto, it is not an infrequent practice to exhibit, for the purpose of referenee, instruments which connect with the title collaterally. The practice is fully sanctioned hy the usage of the best examiners and such collateral matters are often of high importance considered in comnection with the title shown. Whenever it may be deemed desirable or experlient to show such instruments they shonld immediately follow the 12 Kerfoot $r$. Cronin, 105 Ill. 609. 
deeds they affect or explain and should be preceded by the following note:

The following deed is shown for mference only.

It is well, also, when reference deets are shown, to append a note in proper cases showing that the subsequent development of the title thereloy conveyed is not eontemplated, thus:

Note.-Title of John Smith and his grantees not followed out.

$\S$ 98. Examiner's Notes. The examples in the preeding paragrapl are notes of explanation. It is the custom of many examiners to freely intersperse throngh the examination their own comments and observations relative to matters therein stated. When properly inserted these notes are of much arvantage in arriving at a proper estimate of the instruments shown, and in determining their character and the degree of importance to be attached to them. From his peculiar position, knowledge of the reeords, and control of indices and references, the examiner is frequently in possession of information, which, though not strictly essential to the abstract, and in a certain sense aliunde, is yet a valuahle contribution and mas obviate many perplexing questions that might otherwise arise on its perusal by comsel. This information should be appended in the shape of explanatory notes. They should be bricf, eoneise, and confined strictly to a statement of facts. Querios, save in rare instances, opinions, and desultory suggestions, only serve to confuse and distract. When alluding to any particular instrument or proceeding, they shoulk, when practicable, intmediately follow the particular convevanee roforresl to, or should this be modesirable, may be placed at the end of the alstract, inmediately lofore the certifieate, by way of appendix. It is not a good plan to encmulker the albstract with a profusion of notes, yot in un case where the matter stated is important, ar neersially to a better mulerstanding of what has preceded or may follow, shombl they loe mitted, and 
when doubtful as to the propriety of their insertion, it is better to err on the side of safety, even at the cost of being prolix.

$\S 99$. Irregular Instruments. In compiling the abstract the irregular index should be as carefully consulted as the index of lands, and not only should this index show every independent instrument of an irregular character, but also references to other instruments duly posted in the tract index, when by reason of anything therein contained or appended thereto, light may be shed upon examinations in which they do not properly appear. Thus, an affidarit of pedigree, domestic condition, ete., may be appended to a deed of specifie lands which is duly posted in the tract index, but as this affidavit may have an equally important bearing upon the title to other lands, it must also be posted in the irregular index for easy reference.

\section{$\$ 100$. Reference to Original Instruments and Priv-} ate Memoranda. An abstract is compiled, in the usual course, from the face of the record, and purports to show all essential facts thereby disclosed. If incorrect statements appear upon the record they must also appear upon the abstract. The examiner should not assume to correct the record. But, as will often be the case, if the examiner is satisfied that a misstatement has been made, or that the recording officer has failed to properly transcribe the contents of a document left with him for record, it is the duty of the examiner to apprise his client of such error, and that too upon the face of the abstract he has compiled. This will, in some instances, necessitate a reference to the original instrument and when the fact of an error lies within the examiner's knowledge this is a proper way of presenting it.

The usual and better way to show a matter of this kind is by a note appended to the abstract of the erroneous document in this manner:

Note.-The original document, now in our hands, which is recorded as above in Book 512 of Records, page 197, show's the signature of said grantor as "Harriet Jones" and not "Harict Janes." 
So, too, if the original entry books, made from the original doeuments as they were filed, shows a difference in names or description a reference thereto, in the same manner as the foregoing, is proper.

$\$$ 101. Abbreviations. In preparing his notes and arranging his books, the examiner will find his labors greatly accelerated by the use of abbreviations. These may include not only the commonly aecepted initials for the points of the compass, different elasses of conveyances, governmental divisions of land, etc., but all such abbreviated forms or contractions as to himself may have a definite meaning. In the abstraet, however, everything should be written out in full, for it can not be known into whose hands it may eome, and arbitrary forms and abbreviations that to the examiner appear extremely lueid may cause much annoyance and ineonvenience both to counsel and non-professional readers. On the other hand, the examiner should never attempt to supply the deficiencies of the conveyancer by writing out in the abstract his abbreviations in the deed, but whenever such occur the better way is to make a literal transeription of the abbreviated words or passages, and certify same with quotation marks thus: "Sec. 14, T. 39, Range 13 E." The question of interpretation will then rest where it rightfully belongs - with counsel who is to pass on the title. A deed is not invalid beeause of the description of the lands being in figures or well understood abbreviations, ${ }^{13}$ but abstracts which are mintelligible without the aid of some proof to explain the meaning of abbreviations and initials used in them, when permitted to be used as evidence, are insufficient in themselves to establish title. ${ }^{14}$.

$\$ 102$. Letter Press Copies. No abstract or examination should be permitted to leave the maker's hands until a duplicate letter press copy, or its equivalent, has first been obtained. The examiner should always have in lis own possession the verification of his work as a matter of self-protection, while in case the volume of business passing through the offices of regis- 
tration is snch as to prechude making full minutes in the first instance, the copiso thus obtained will supply the deficiency, and be arailable for future examinations of the same property, withont the lnbor of again referring to the records. This may for acomplished by noting on the tract index opposite the referen of the instrument in question the volume and page of the apr book on which the full abstract is preserved.

s 10:) Comclnding certificate. The result of the examiner's labors should be summed nir in conclusion, by a brief recapitulatory and explanatory certificate, embodring the essential features of the search. Its extent is optional with the examiner, but it should, to give stability to the abstract, cover his searches in the offices of registration, the courts, and depositorios of records relative to taxation, these three sources of information fumishing nearly all the exidence required in passing on the suficiency of the title. It should be certain in its statements, leaving nothing to implication, and contain no more than is developed hy actual investigation. If the examination is marle from the records it shonld so state, enumerating the different classes examined, or describing the offices or lepositories from which the information was obtained, but where it is male from indices, kept by the examiner, it is usmal to certify from such inclices, ${ }^{15}$ which is a much safer plan than to certify from the recolds. It should be signed by the examiner and dated, such date being nsually the date of the examination. The amnexed form of certificate will cover the points investigated in an ordinary search:

15 As a further precaution the dient is usually required to make a specific order, stating his desires,

of which the following, taken from actual practice, is an example:

No $\ldots \ldots \ldots \ldots \ldots \ldots$

ORDER FOR ENAMINATION OF TITLE.

Cintcago,...............

HADDOCK. TALLETTE \& RICKCORDS,

Make an exanination, according to your Indexes to the Records in Cook county, Illinois, of deeds, judgments and tax sales, of the title to the following deseribed land, in Cook County. Illinois:

(Iiere invert the description of the 
II have examined our Inderes to records in Cook rounty, Illinois; and find:

Ko conceyaness of the land described in the caption hereto. reccuted by any of the parties named herein as grantor or granter, shown thereby to hare been recorded in the Recolder's office of soill Cook county, Illinois, since January 25, 1875, and prov to this date. and no procecdings affecting the title to said pemises had in any of the courts of record of said county, execpt as show' on the ton (10) preceding sheets. ${ }^{16}$

To judgments rendered in any court of record in said Cook county. Illinois, against John M. Smith since October 25, $182^{17}$ and prior to March $2,1880^{18}$ nor against William Thompson since Ortober. 25, 1S22, and prior to this date, which are a lien on said premises [or which we consider liens on said premises].

Note- No examination made for judgments against John Smith, nor against. John Smith with middle initial other than " $M$."

No taxes, or tax sales, or forfeitures of said premises, remaining unredecmed or uncanceled of record (except as shoun). Haddock, Tallette d: Rickicords,

Examiners.

Chicago, October 25,1882 .

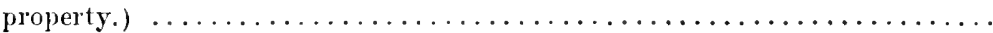

(Signed)

No........................

16. Although the examiner may only eertify that he finds no conveyances, yet this is equivalent to a statement that none exist. McCorahes $r$. Commonwealth, 5 IVatts \& S. (Pa.) 21.

17 This date has reference only to the tine from which a persomal judgment is a lien on real estate and not to the commeneonent of the examination. In Illinois the lien only exists for seven years, hence, with reference to the date of the certifieate, October 25, 1875 . would have been a proper date from which to certify judgments, but in a nujority of the States the period is ten years, which corresponds to the illustration above given.

18 This would be the date when John M. Sunith disposed of the tille, and hence no examination 
If the examination commences with the assumption of title in a given person, the certificate should, for the better protection of the examiner, specify such person by name and the statement of conveyances might read something like the following:

No conveyances of the land described in the caption hereto, executed by John M. Smith, shown lhereby to have been recorded in the recorder's office of scid Cook county, Illinois, since Jan. 25, $1875,^{19}$ and none by those who derived title through said Smith, named in the foregoing examination as grantor or grantee, etc.

Where instruments have been shown for reference only, or where under the general caption deeds are exhibited of parcels which do not eonstitute any part of the lands in question, no necessity exists for following the title of sue? pareels or noting its subsequent devolution; as where a Railroad right of way intersects a dirision or tract of land. It is advisable, however, to call attention to this fact, either by a note following the abstract of such reeds or by a clause in the final certificate, and such mention, in either casc, may read somewhat as follows:

No examination for conveyances by or judgments against the Illinois and Wisconsin Railroad Company or its grantees.

Where, in a continuation, no enveyances are shown, there having been no ehange of title since the last examination, the statement as to conveyances may simply recite this fact, or, if desired, and this is the better way, a special certifieate may be marle with respect to the record owner of the land, as shown by the last examination, and the holders of such incumbrances as may appear thereon; thus:

wouk be made concerning him after that date. William Thompson, though only holding title a little over two years, must yet be certified, is against judgments, for a period equal to the statutory limi- tation, which, in the example, is ten years.

19 The date of the assumption of title and commencement of the search. 
No conveyances of the land described in the caption hereto executed by John Brown ${ }^{20}$ or by James Smith, ${ }^{21}$ mortgagee, shown thereby, etc.

Where two or more parcels form the subject of the examination and the caption, in technical parlance, is a "donble header," if the examination purports to be from different dates as to each parcel the fact must find appropriate mention in the certificate, as per example.

No conveyances of the land first described in the caption hereto, executed by any of the partics named herein as grantor or grantee, shown thereby to have been recorded, ctc., since June 10, 1S6S, except as noted.

No conveyances of the land secondly described in the caption hereto, executed, etc., since Harch 1, 18:0, except as noted.

In continuations, when no tax sales have occurred during the period covered by the search, say:

No tax sales had since Dec. $10,1903 .{ }^{22}$

Of late years it has become customary to certify with respect to special assessments and when the land in question is located in a city this is an important matter. When certifying special assessments at any time, say:

No confirmed special assessments remaining unpaid, which we consider liens on said premises. (Except as shou'n.)

When certifying special assessments sinee the date of the last examination, say:

20 The record owner as shown by the last examination.

21 The encumbrancer as shown by the last examination.
22 The date of the last examination. 
No special assessments confirmed since January 15, 1904, remaining mulat, which we consider liens on said premises. (Except as shown.)

In the foregoing examples the abstracts are supposed to have been compiled from the records or the examiner's indices, and sre what are termed "original examinations." Not infrequently, bowever, the examiner is alled upon to prepare compilations from former examinations, being, in effect, digests of the title to particular tracts shown in snch original examination in a general way with other lands. While the practice is not recommended there will yet be many eases in which it may be profitably followed, and, when this is done, the concluding certificate chould specifically show the course pursued and verify the correctness of the eompilation. Thus:

The foregoing Examination of Title to the land described in the caption hereto, is a compilation from the following sev eral examinations, including the land in question, heretofore made by us, riz.:

To the West half of the South East quarter of Scction Ten, Town Thirty-nine, North, Range Fifteen, East of the Third Principal Meridian, dated A pril 22, 1869.

T'o the same land dcted March 1, 1890.

And we do certify that same is a true and correct compilation from said several examinations, including all conveyances of the land described in the caption hercto, made by the parties grantors or grantees named therein and shown thereby to have been recorded in the Recorder's office of Cook county, Illinois, prior to the dates of record of the deeds by them respectivery, up to and including Warch 10, $1889 .^{23}$

In like manner the examiner may be called upon to fill a gap in the history of the title. While the caption should show this fact, in the manner heretofore indicated, the eertificate

23 This is the date to be covered by the search and from which $a$ continuation would be made. 
should also be made with special reference to it and the recitals of converances, judgments, etc., should all be qualified by the statement,

$$
\text { And prior to June 10, } 18 \text { ro, }
$$

or words of sinilar import which clearly mark the time of the termination of the search. The certificate should, of course, bear date as of the actual time it was made. 


\title{
CHAPTER VIII.
}

\author{
INCEPTION OF TITLE.
}

$\S$ 104. Preliminary stages of title.

105. Inceptive measures under the U. S. land laws.

106. Disposal of the public domain.

107. Public land sales.

108. Private entry of lands.

109. Nature of title conferred by entry.

110. What lands subject to entry.

111. Pre-emption entries.

112. Nature of pre-emption rights.

113. Conveyanees before entry.

114. Graduation entries.

115. Donation entries.

116. Homestead entries.
$\S 117$. Rights acquired under homestead acts.

118. Desert land entries.

119. Tree claims.

120. Location by military warrant.

121. Land serip.

122. Swamp land grants.

123. School lands.

124. Internal improvement grants.

125. Land grants to railroads.

126. Public highways.

126a. Private land claims.

127. Who may aequire title.

128. Inceptive measures in the abstract.

\section{$\$$ 104. Preliminary Stages of Title. All of the lands} in the National Territories, not appropriated by competent authority before they were acquired, are, in the first instance, the exchusive property of the Cnited States, to be disposed of to such persons, at such times, in such modes, and by such titles, as the Government may deem most advantageous to the public. This right has been uniformly reserved br solemn compact upon the admission of new States, and lias always been recognized and scrupulonsly respected by the States within which large portions of the public lands hare been comprised, and within which much of these lands are still remaining.

The system adopted for the disposition of the public lands embraces the interests of all the States, and proposes the equal participation therein of all the people of all the States. The system is, therefore, peculiarly and exclusirely the exercise of 
a federal power, and the morle of its accomplishment, as well as the erilences or mumiments of right which it bestows. are all the work of federal functionaries. Neither State nor Ter. ritorr can, in any manner, interfere with the primary disposal of the lands. ${ }^{1}$

Under the land system of the United States, there are a number of preliminary or inceptive stages of title before its final divesture from the Gorernment and consummation in the purchaser. They are created by the provisions of the various acts of Congress in furtherance of the derelopment of the country, ant their recital forms, or should form, the initial statements of every abstract, whenerer the examination purports to show a connected chain of title from its source, the general Gorernment. Where title, as in the East, is derived directly from the State as the original proprietor, these stages, of course, do not appear, nor are they present where title is deduced from anti-revolutionary governments. Titles derived from foreign powers prior to the acquisition of the soil by the Lnited States are respected and protected, but should be confirmed, when inchoate, lyy special act or in conformity to general laws on that subject, ${ }^{2}$ the title in such cases dating from the confirmation, though relating back to the time of the cession of the Territory to the Government, or to the original grant. 3

\section{$\$ 105$. Inceptive heasures Cnder the U. S. Land Laws.} The public lands are sold only by legal divisions, or parcels, made in conformity with the government system of surreys, and title is accuired by purchase at public sale; by ortinary " pri-

1 Irvine $v$. Marshall, 61 L. S. $(20$ How.) 5.58 .

2 Cnited States $r$. King. 3 How. 773; McMicken $r$. Lnited States, 97 U. S. (T Otto) 204 .

3The policy of the Cnited States, in the alju-tment of sich titles has been one of unexampled liberality, reserving to claimants the lands to which they asserted titles derived from the lawful authorities of governments which lield sovereignty over the territory prior to its acquisition, and crinfirmations have been extended to all claims formded on titles in form. orders of survey, and even to lands to which no written title harl been recorded, where the claimants had mate actual settlements before the change of sovereignty. 
vate entry:" anil ly the varions othor methods provided in the special enactments of Congress known as the pre-emption acts, homestead acts, ete. These laws and regulations for the disposal of the public domain apply only to individuals who take direct from the United States.

Comoress has also at different times by special legislation granted to the States, or certain of them, a portion of the pultlic lands to aid in the construction of great internal improvements; to endow schools and enconrage edncation; and for other specific purposes.

These various measures, for the most part, are inceptive and initiatory. Though creating rested interests, and granting equitable rights, ${ }^{4}$ the legal title still remains in the original grantor, ${ }^{5}$ to pass and become absolute in the grantec, only on the performance of preseribed conditions or in due course of law. A brief review of the preliminary steps to acquire title will form the subject of the succeeling paragraphs.

\$ 106. Disposal of the Public Lands. The public lands of the United States are mifomly brought into market in pursuance of a system which originated in the year $1796^{6}$ and was perfeeted about the yea: 18:0. They are divided into two classes, designated respectively, the minimum at $\$ 1.25$ per acre, and the double minimum at $\$ 2.50$ per acre, and may be purchased in tracts of from to to 610 acres, or in larger hodies if the same can be found vacant. In cases of public sale or private entry the law requires the price to be paisl in cash at the 402 .

t Stark $r$. Starre, 6 Wall, (U. S.)

5 Carman r. Johmon. 20 Mo. 108 ; layward r. Ormbee, 11 Wis. 3; Wileox r. Jackson, 13 Pet. (U. S.) 498 .

o The first treaty extinguishing the Indian title was not effected until 1795, but not a year had elapsed from the definitive treaty of pence in 1783 before the Conaress of the Confederation took the initiative for establishing a system for the disposal of the then existing western lank- and on May 20, 1785, the requisite ordinance for that pupuse was passed, by which the Bond of Treasury was anthorized to dispoe of the enreyed londs in the western territory, commeneing sales at New York or Philadelphiz, with power to adjourn to any part of the [nited States. 
time of pripchase. ${ }^{\top}$ For a pelou of twenty years, hegining with the commencenent of the last century, the lands were sold on credit, at not less than \$2.00 per acro; but the redit system not working satisfactorily, in 1820 it was abandoned and the price reduced to $\$ 1.25$ per acre. The $\$ 2.50$ per acre lands are such as lie within the linits of raiload or internal inprovenent grants. Exceptions to these rules are made nuder the pre-emption and homestead laws, which will be noticed hereafter. The lands are first requiled to be smrveyed, then advertised and exposed for sale at public acution, after which, whatever remains is subject to private entry, location, cte, at fixed prices. 8

\$ 107. Public Land Sales. The pablic sales are held in pursuance of a proclamation by the President, ${ }^{9}$ or of a public notice given in accordance with directions from the General Land Office. $^{10}$ At this sale the lands are offered at a ninimmm

7 See instructions, Secy Interior, Sept. 10, 1849; March 10, 1869 .

8 The first method of disposal was by offering at public sale for such price, above a fixed minimum, as the lands would bring, and after this to purchase by private entry, on a credit at a minimum in excess of the lowest price now admissible by law. In the progress of events the national legislature took cognizance of actual settlers, giving them precedence and preference in the purchase of the public lands, and, relieving them of the necessity of competing at public auction with ordinary purchasers, pernitted them, on very liberal terms and at the lowest price, to secure titles to actual setflements. Tlsis policy continued retrospective until after the nirration of the pre-emption law of 18:0, and its supplements, and up to the passage of the permanent prospective preremption systom by the act of Sept. 4, 1841. Congress has also dealt with lands which had been in the market ten years or longer by reducing these to actual settlers at low rates, bnt this benign policy haring led to abuse and speculation, Congress rescinded the law, yet not without indicating a continued interest in the actual settler in passing the homestead act of May 20, 1862. by which any citizen can secure a farm comparatively without cost.

9 In the early periols of the history of the country, Congress, in some cases, fixed by law the times at which public sales in particular land districts should be held, and in others directed the sales to commence at such times ats the President should fix ly proclamation. But by the alet of 1pril 24, 1820 , regulating land sales generally, it became the duty of the President to proclaim and ofler for sale all the public lands as they might be sur. reyed and prepared for market.

11) Les. Stat. U. S. $\$ 2353$ el seq. 
price, and can not be sold for less, but may be sold for as much more as any one will give. On payment of the price for which the land is sold, the Receiver of the local land office issues his receipt as in other cases and the sale is noted on the tract books of the Register. The law limits the duration of the sale to two weeks, and in case of a shorter period private entries are not permitted until the expiration of that term. Comparatively, only a small portion of the public lands are disposed of by this method.

\$ 10s. Private Entry of Lands. The term "entry," as applied to appropriations of public land, is said to have been borrowed from the State of Virginia where it has been used in that sense from a very remote period. It has now a fixed and definite signification in the legal nomenclature of the country, and means that act by which an indiridual acquires an inceptive right to a portion of the unappropriated soil of the country by filing his application for same in the ofice of the designated land agents of the Government, and is confined to the riglut of purchase at private sale. ${ }^{11}$

The entry is made by presenting to the Register of the district land office a written application describing the tract desirnd, to which the Register attaches his certificate, setting forth the fact of such tract being at the time subject to private entry and specifying the price per acre. The application is then taken to the Receiver to whom payment is made, and who in return, gives duplicate receipts, one of which is retained by the applieant, to be surrendered on receiring his patent, and the other, together with the application, is delivered to the Register, who, after placing the application on file, issues his certificate of purchase of the land. The application, accompaniml by the Register's corresponding certificate of purchase, is then forwarded to the General Land Office for official action. ${ }^{12}$

Patents do not issue in the usual course of business in the General Land Office until several years after the entry has

11 Chatard $t$. Pope, 12 Wheat. Rev. Sarat. U. S. $\$ 224$ et seq.; (L.S.) 586 . and see Cir. Gen. Land Office, Mar.

121 Lester's Land Laws, 311: 1, 1854. 
been made, though conveyanees with warranty are freely male, and the property frequently passes throngh many hands on the strength of the inchoate title conferred by entry and payment. The recital of this entry forms the first statement of the al stract of all lands acepuired in this namner, and shond be fol-

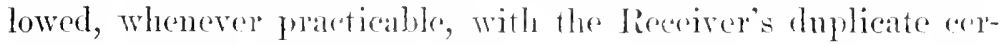
tificate of purchase and payment.

$\$ 109$. Nature of Title Conferred hy Entry. The practice of dating the legal title from the date of the entry is followed in many of the Staten, ${ }^{13}$ yet nothing passes a perfect title to public lands, with one exception, but a patent. ${ }^{14}$ The ex-

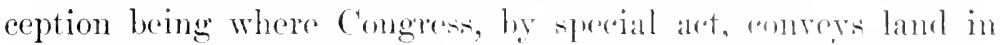
words of present grant. ${ }^{5}$ Congrese has the sole prower to make and anthorize appropriations of the publie lands ${ }^{16}$ and to declare the effect and dignity of titles emanating from the I'nited States, ${ }^{17}$ and the whole legislation of the foderal govermment in relation thereto declares the patent the superior and conchsive evidence of legal title; until it ismes the fre remains in the government. ${ }^{18}$ The entry "an only eome in aid of the Iegal title, and is no evidence of snch standing alone, when opposed to a patent for the same land. ${ }^{19}$

But a party who has compliced with all the terns and conditions which entitle hin to a patent for a particular tract acquires a vested interest therein, and is to he regartod as the equitable owner thereof, the government simply retaining the formal legal title in trust for the purchasere until the patent issues." The right to a patent once rested is equivalent, as respects the government, to a patent issued ; and

1:3 O'Brien $r$. Perry, l Black. 13: ; Tidd $v$. Rines, 20 Minm. 201 ; Bullock v. Wilson, 5 Port. (Ala.) 338; Burdick v. Briggs, ] I Wis. 126 .

143 Opinions Att'y lom. 91 ; Carman 1. Jolmson, 20 No. 118.

153 opinions Atty qen. 350: 9 do. $240 ; 11$ do. 47 ; trignon's lese soe r. A-tor, 2IJoward, 31!; ('hallefoux $r$. Dueharne, 4 Mis. 5.54.

16 United States $r$. Fitgorald, 1;5 9
Jet. 407: Farringtun $r$. Wilson, e? Wis. 383.

17 Bagnell r. Boulerick, 1;) Pet. $4: 3$.

1s Peak r. Wendel, 5 Wheat. 258; Honper $x$. Soluimer. 2:3 How. 235: Jayward $r$. Mombere, 11 Wis. 3 ; Bromson $r$. Kakuk, :3 l)ill. 490.

1! Bairal $r$. Wulf. + Melom, 5t!); Peak r. Mindel. 5 Whate 290.

20 Worth 1. Branson, 98 U. \& ( 
when the patent is issued it relates, so far as may be neeessary to cut off intervening claimants, to the inception of the right of the patentee. ${ }^{21}$. The interest thus acquired is a recognized property which courts will respect and protect, ${ }^{22}$ and has been held to be a valid subject of sale or transfer. ${ }^{23}$ In such case the assigmment of the certificate of entry passes the equitable title to the land, ${ }^{24}$ or, if intended as collateral security creates an equitable lien. ${ }^{25}$ On filing the assignment of the certificate in the General Land Office, patent will issue to the assignce with the same effect as to the original purchaser, ${ }^{26} \mathrm{or}^{\circ}$ if issued to the original purchaser he will take only as trustee for the true owner. ${ }^{27}$ Assigmments are not frequently met with on the records. As a rule, the early proprietors disposed of their interests under the entry by deed of bargain and sale, and usually with covenants of seizin and warranty. The receiver's receipt was usnally placed on reeord as the foundation of title, while the patent, in the mutations through which the property afterward passed, was often overlooked and frequently forgotten. ${ }^{28}$

The effect of location or entry in due form, is to segregate the land from the public domain and subject it to private ownership, with all the incidents and liabilities thereof. While such location is in foree no other can lawfully be made; ${ }^{29}$ the public faith has then become pledged to the locator and any subsequent grant of the same land would be void, unless the

Otto) 118; Waters $v$. Bush, 42 Iowa, 255 .

21 Stark $r$. Starrs, 6 Wall. 402 : Taylor $r$. Brown. 5 Cranch, 234; Morrill $v$. Chapman, 35 Cal. 88; Astrom $r$. Hammond, 3 MeLean, 107.

22 Gains $r$. Hale, 26 Ark. 168; MeLane $r$. Tovee, 35 Wis. 27.

s3 Carrall $r$. Safford, 3 How. 460 ; Hutehings $r$. Low, 15 Wall. 88.

24 Sillyman $r$, King, 36 Iowa, 207: Meyers $v$. Croft. 13 Wall. 291; Burdick $r$. Wentworth, 42 Iowa, 440 .
25 Wallace $v$. Wilson, 30 Mo. 335. 26 Instructions Sec'y Interior; 1 Lester's L. L. 351; Clark v. Hall, 19 Mich. 356.

$2 \tau$ Stark $r$. Mather, 1 Walker (Miss.), 181; Magruder $r$. Esmay, 35 Ohio St. 221: Cumningham $v$. Ashley, 14 How. 37\%.

2 Ilundreds of thousands of uncalled for patents are yet remaining in the files of the General and local land offices. Gen. Land Office Report, 1875.

29 Simmons $v$. Wagner, 101 U. S. 251. 
first location or entry is set aside. ${ }^{30}$ It is within the power of the Commissioner of the General Land Office, bowever, to cancel entries of public lands at any time before patent issues, on proof that the entryman has failed to comply with the law. ${ }^{31}$

$\$$ 110. What Land Subject to Entry. It is a fundamental principle, underlying the land system of the conntry, that private entries of the public lands are nerer pernitted unless Congress by special act order otherwise, until after such lands have been exposed at public auction at the price for which they are afterward subject to entre ${ }^{32}$ Irhere lands have been surveyed but not exposed at public sale they may be olitained under the provisions of the preemption law, in which manner large portions of the valuable lands in the States adnitted since 1841, have been taken up..3 Lands known as "mineral," including deposits of the precious metals, coal, and salines, are not subject to ordinary prirate entry and are disposed of in accordance with special acts, ${ }^{34}$ the general procedure, however, being the same. Nor can lands be entered which have been reserved for any purpose, or otherwise withdrawn from market. $^{35}$

$\$ 111$. Pre-emption Eutries. As has been shown, in the earlier stages of our land strstem, no right or interest could be secured by the individual in anc public land until it had been survered into legal dirisions; nor after this had been done was it subject to sale until by a proclamation of the president, it was brought into market. This proclamation always fixed a time and place when the lands within a giren distriet were offered for sale at public anction; and mutil all of them were sold, which could be sold in this manner, at prices above the minimum fixed by law, no one could make a private entry of a particular tract or establish a claim to it. The scenes of rio-

30 Worth $v$. Branson. 8 Otto, 118; Lytle $r$. Arkanials, 9 110w. 314; U.

S. $v$. Fitzgerald, is Pet, 401.

31 Jones $x$. Meyers, 2 Jlaho, 79:\%. 32 Eldred $r$. Sexton, 19 Wall. 189; do. 30 Wis. 189. See also 4 Opinions Att'y Gen. 167.
3:5 Mreyers r. Croft, 13 Wall. 291. 34 Aet, July 26tith. 1866.

:5 Hot Spring (anes, 92 U. S. (2 Otto) 69s; Bellows $r$. Todd, 39 Iowa, 209 . 
lence, fraud and oppression, and the combinations which attended these sales, as woll as the wrongs perpetrated under them, led to the law of pre-emption. It often ocenred that emigration, in arlvance of the readiness of the publie lands for these sales, harl caused hundreds and thousands to settle on them; and when they came to be sold at public anction, their value, enhanced by the houses, fences and other improvenents of the scttler, placed them beyond his reach, and they fell into the hands of heartless speculators. To remedy this state of things the pre-emption system was established. ${ }^{36}$

A "pre-emption claim" confers upon the settler the exclusive right to purchase, at a minimum price, the public land of the Lnited States upon which he has settled in conformity to the acts of Congress on that subject. ${ }^{3 \pi}$ This policy of seeuring to individuals a preference right to purchase, had its origin at about the commencement of the last century, and at first was confined to lands which had been surveyed, but gradually this was changed until in $1862 ; \% 5$ pre-emptions were allowed, muler proper restrictions, on misureyed lands as well.

The law's on this sulject are numerous, beginning as early as May 10, 1800, which allowed pre-emptions in the country northwest of the Ohio river, and were at first restricted to particular classes and localities, until the aet of September 4 , $1841,{ }^{39}$ and supplemental act of Mareh $3,1853,{ }^{40}$ which superseded all previons laws and now constitute the general preemption system. ${ }^{41}$ Under this law the settler, possessing the prescribed cualifications, who enters upon public land, making inprovements and bringing the same under cultivation,

36 Atherton $r$. Fowler, 6 Otto (U. lic lands before they had been ex. S.), 513 .

3 i Dillingham $v$. Fisher, 5 Wis. 475.

3812 Stat. at Large, 418.

395 Stat. at Large, 457.

4010 Stat. at Large, 244.

41 Prior to the year 1841 , the legislation of Congress had not encomraged settlements upon the pubposed to public sale. The enactments granting pre-emption rights, before this time, were mainly in the nature of relief laws. by which trespasses were waired, and a preference was given to those who were occupring public lands at the dates of the several laws. 
and otherwize conforming to specified requirements, acruires a prior and exchuive right to purchase, and is protecterl in the enjoyment of his claim from intrusion or trespass he whers. ${ }^{42}$ To fix these rights, he is required, where the land at the time of settlement is subject to prirate entry, to file with the Register a declaratory statement, describing the land settled upon, and reciting his intention to claim the same under the provisions of the pre-emption act, and within twelve months thereafter to make proof of settement and parment: failing in these partienlars the land so settled or improved will be subject to the entry of any other peroon. By the act of May $30,1862,{ }^{43}$ the premption claimant of unsurvered lands is required to file his declaratory statement within three months from the date of the receipt at the district land oftice of the approved plat of the towship embracing such pre-emption settlement. ${ }^{44}$

$\$ 112$. Nature of Preemption Rights. The right of pre-emption attaches only to snch public lands as are subject to the operation of the general land sretem of the comtry, and not to those which have been taken ont of the class of publie lands and appropriated to specific objects, or reserved for particular purposes. ${ }^{45}$ No title, either legal or equituble, is conferred by the pre-emption laws. They give merely a naked right to purchase and acquire title within a specificd time, on compliance with eertain conditions. ${ }^{46}$ The settler acquires, and can acquire, no vested interest in the land he ocenpies by virtue simply of settlement; ${ }^{4 i}$ the land continues subject to the absolute disposing power of Congress nntil all the necessary legal steps to perfect an entry thereof have been taken. ${ }^{4}$

42 Coleman $v$. Allen, 5 Mo. App. $12 \pi$, and see, Cir. Gen. Land Office, March 1. 1884.

4312 Stat. at Large, 418.

44 Megerle $r$. Alle, 47 Cal. 632. 453 Opinions Att'y Gien. 4.,5. 46. Woodward $\because$ MrRoyolds, 2 I'in. (Wis.) 269; Brown $r$. Throckmorton. 11 Ill. 529; Hemphill $v$. Davies, 38 Cal. 577.
47 Opinions Att'y Gen. 56; Burgess $x$. Graty, 16 How. 45.

4s Frisbie $r$. Whitney, 9 Wall. 187: Busch $r$. Donolue, 31 Mich. 452: Vosemite Valley Case, 15 Wall. 7 ; R. R. Co. $r$. Tevis. 41 Cal. 489: Wittenbrock $r$. Wheadon, 1:28 cal. 150. 
Before this the scttler has nothing but a contingent, personal privilege to beome, withont competition, the first purchaser of the property, a privilege which he may never exereise, or which he may waire or abandon. As previonsly stated, this right has been uniformly hald to confer no present title to the land, being gratuitous, prospeetive and contingent; and it is indisputable that the general proprietor, the government, has a paramomt right to reserve the land from sale, to reeall the privilege previonsly conferred, or make an absolute grant of the land to other parties, with or withont consideration. ${ }^{49}$

The interest acquired by a pre-enption right is not an estate within any drinition known to the common law, ${ }^{50}$ and at best can be regarded only as a right of occupaney with a privilege, enjoyed by no one elee, of purchasing on preseribed conditions. It can not be sold, so as to rest the purchaser with any rights in the land, and such a sale would extingnish the pre-emptor's own right. ${ }^{51}$ Teither can it be conveyed by devise. ${ }^{52}$

But shonld the pre-enptor die withont establishing his claim within the perior limited by law, his rights thms initiated are still preserved, and the title may be perfected by his personal representatives or his heirs, provided the cutry is made during the period in which the pre-emptor wonld have been entitled to do so, had he lived, and patent will be issued aceordingly. ${ }^{53}$ In such erent, howerer, while resort may be had to the laws of the State under which the descent was cast for the purpose

4911 Opinions Att'y Gen. 490.

su Delimay $r$. Bumett, 4 Gilm.

(III.) 484 .

51 Moore $x$. Jordan, 14 La. Amn. 4.14; buinn $x$. Fenyom, 38 (a). 499 : Morgan $x$. Curtenins, 4 Mr.Lean. 36t; Brewster $r$. Madden, 15 Kan. 249: but see Dlamay r. Buruett, 4 (iilm. (111.) $45 t$, Phelps $r$. Smitls. 1.) J11. 5id, where the interest is regured as property which mat pass ly deel, the purchaser being reanded as the "legal representative" of the original chimant: aloo, Bowers $r$. Kuscher, 14 Iowa, 301.
52 Rogers $v$. Clemmans, 26 Kan. 522.

5. Rev. Stat. U. S. $\S 2269$. It is imposible to state the number of entries made under the pre-emption laws, becanse the system of the General Land ofice carries them into " cash entries" aud they are therefore embraced in the annual eash receipts from sale of land under varions laws. lunt it is estimated that there has been disposed of nuder the pre-emption system, since its inauguration, about $175,000,000$ acres. 
of detemining who are the heirs, ret the heirs do not take the land by inheritance from their ancestor, but by direct conreyance from the Enited States, and the portion taken by each heir is dotemineel, not by the law of inheritance but by the terms of the converance. ${ }^{5}$

11;. Converances before Entry. The benefits of the pre-emption acts, lecing intented only for the actual settler, are perwonal in therp application, the 12 th section of the act

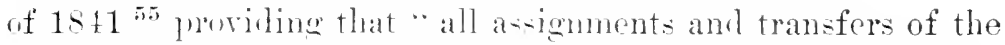
right hereley secures frior to the issming of the patent shall be mull and roil:" and to burent speculator' from aroquiring

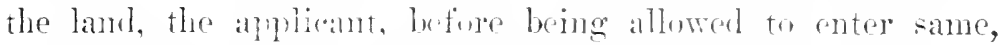
is required to sweal that he has not contracterl it away, nor settled to sell on speculation, and any grant on converance made by him befone entre is declared roid, with an exception in faror of bond fide purehasers for a valuable en-ideration. This restrietion has been held, howerer, to extend only to the right to pre-emption; that is, the preference right to purchase at a mininum price, no matter what the value might be when the time limited for perfecting the pre-emption has expired, ${ }^{56}$ leaving the pre-emptor free to sell or otherwise dispose of the land after the entry had been made."

Since the passage of the act of $18+1$, in those parts of the United States where that act applies, the right to sell has been freely expreised after the clam, has been prover up, the land paid for and the eertificate of entry received: the pre-emptor then standing in the same relation to the gorermment as other purchasers, ${ }^{58}$ and though the patent may only issue to the purcheser, it will inure to the benefit of his grantee. ${ }^{59} \mathrm{By}$ proof and parment the equities of the elaimant are matured and complete, and while the right of government to disposo of its own property is undisputed, as well to preseribe rules for the disposition of same, yet, subject to these well-known

54 Wittenbrock $r$. Wheadon. 128 ('al. 150 .

355 Stat. at Large, 457.

5is Meyers $r$. Croft, 13 Wall. 291.
5 T Robhins $r$. Bunn, 54 Ill, 48. 5 c carly $x$. Eighmey, nt Iowa, 615. 59 Camp $r$. Smith, 2 Minn. 155. 
principles, partic rightfully in possession of the soil may make valid contracts, even concerning the title, predieated upon the hypothesis that they may thereafter lawfully acquire such title, except in cases where Congress has innosed positive restrictions. ${ }^{\text {in }}$ it the same time it must ever be borne in mind that the goremment has the power to cancel all entries of public lands at any time before patent issues, ${ }^{61}$ and that the rule of reveat emptor applies with peculiar force to all purehasers of land from pre-emption entrimen. ${ }^{62}$

$\$$ 11t. Graduation Entries. In order to further facilitate settlement and coneonrage the sale of public lands to actual settlers and cultivators, Congress, by the act of August 4, 18.it, ${ }^{63}$ proviterl for a graduater scale of prices, for lands which had been in the market for ten years and npward, ranging from 1212 eents to $\$ 1,00$ per acre. This act remained in force until June 2, 1862, when it was repealed. ${ }^{64}$ In its essential features it closely resembled the preemption law, to which it was in fact an aid. The lands conld also be purchased for cash at the grathated price. Like the pre-emption law, the rights conferred by this act were personal, and because of actual settlement and cultivation, made or contem-

to Lamb r. Davenport, is Wall. 307. In California it has been held that a mortgage made hefore proof and payment, might be enforcel after entry had been perfected: Clatk $r$. Baker, 14 Cal. 612; Chrixty $x$. Dana. 34 Cal. 548. See also lieasoner $r$. Markley, 25 Kan. 63s.

"61 As where the pre-emptor has failed to comply with the requirements of law and has procured his fincl receipt or certificate on falie evidence. See, Jones $r$. Meyers, 2 liaho. 793 .

"i2 Taylor $r$. Weston, 7 Cal. 534; Giviby $r$. Woods. 19 La. 334; Hes. tres r. Breman, 50 Cal. 211.

(1:) 10 Stat. at Large, 574.

tit Thrusands of entries were made under the provisions of this act, the quantity of land sold, as shown by the reports of the Ceneral Land Office, agrregating nearly $26,000,000$ acres. It is still possible that in orme few cases patents have not been iscued on the entries made, as thore were many cases in which the required proof of settlement and eultivation was wanting, but under a confirmatory act passed Nareh 3, 1s.5. the patents were delivered, on application therefor, without the proof being required in all such enses, where the entry was allowed prior to the passage of that aet, and where it was not found to be fraululently or evasively made. Subsequent to the passage of that act, and prior to June 2, 1862, when the graduation law was repealed, 
plated. Assignments of the rights acquired under the arot: were expressly jolitited and wholly dispegarded, and the fiatents in erery instance issned to the onignal purehaser.

The method of acpuiring title muler graluation acts was substantially the same as moler the pre-emption laws, with only a slight difference in details. It is not enstonnary, mon is it necessary, to incorporate in the abstract the ineentive details prior to entry. The matter is optional with the examiner, but the entry is the first material stage.

\$ 115. Donation Entries. In a few localities initiations of title will be found under what are known as the " Donation Acts." These acts were a serios of laws designed to indnce settlenents on the public lanrls in dangerons or distant parts of the nation. They were all local in character as well as temporary in their application, and all of them lave long since expired by their own limitation. In their practical fuatures they resembled the present homestead law, of which, indeerl, they were the precursors. The first of these laws, passed in $1842,{ }^{65}$ was had in riew of the Indian ditticulties in Florida, and provicled for the donation of one quarter section of land to any person, able to bear arms, who should make an actual settlement within a certain portion of the peninsula., In $1850,{ }^{67}$ a still more liberal act was pased with special reference to the Territory of Oregon, and when in 155:; the Territorial government of Washington Territory was estallished, its terms were extended over that Territory. This act donated from a quarter to an entire section, a premimm being placed on matrimony br a double allowance to a married man, and by permitting the wife to retain the ownership of half the

a large number of entries were allowed under that law, and in the course of business thre cane to be many patents for entries so allowed, the delivery of which was suspended for the reason that the requisite proof was not fortherming. To this rass of races the (nonfirmatory prineiples of the act of
Marel 3, 1857, were made applicable by the act of Feb. 17, 1873, and the issuing of patents has since contimuert.

1;.; Stat. at Lalloge. 502.

ba This law, which was valiously amented, resulterl in the patenting of 1.317 clatus.

(;) 9 Sitat. at Jarge, 496. 
land in hel own right. ${ }^{\text {is }}$ Residenee on and cultivation of the land for four consecutive years was nocessary to insure a patent from the government.' The act expired Dec. 1, 1855. In $1854^{69}$ a similar act was passed with special reference to the Territory of New Mexico, except that the grant was restricted in quantity to 160 acres, and available only by males then residing in the Territory or who shonld remove there prior to $1858 .{ }^{i n}$

$\$$ 116. Homestead Entries. Until 1862, Congress had passed no general law offering the public domain in a limited quantity to any person who wonld cultivate and make a permanent home thereon. Pre-emption laws, securing the right to enter land by purchase at a premium priee fixed per acro had been enacted, and donation laws, applieable to particular States had been passed, hut the liberal poliey of offering homesteads had not been extended to all persons. The aet of May SOth of that year ${ }^{i 1}$ is the first homestearl law of the government, "and it would be difficult perhaps," says Dillon, J., "to point to any enactment of the Federal Congress, more wise in conception, just in policry, and benefieial in results than this." i2 By this act a quantity of land, not exceeding 160 acres, is given to any person, being the head of a family and possesing the requisite qualifications, on condition of setthement, cultivation and continuous ocenpation as a home by the settler for a periorl of five rears. ${ }^{73}$ During this period

bs Upwards of 8,000 donation certificates were iswued under this law covering alout $3,000,000$ acres.

6910 stat. at Large, 308.

io Less than 200 dertificates have been issued under this law.

71 12 Stat. at Large, 392.

is Seymour $t$. Sander's. 3 Dill. 437.

7i At the close of the civil war, the President by proclamatiou June 13. 1865, ortered the reopening of the Cnited States distriat land offices in the States of Lonisiana,
Florida, Arkansas, Mississippi, and Alabama. Congress, June 21. 1866, directed that all public lands in those States shonld be reserved for settlement under the homestead act of May 20, 1862. The obtaining of these lands by the lindlens elass of the South was enusidered essential to their future welfare and that of the Nation. Congress therefore, enaeted that they should only be entered under the homestead law, and, changing the rule, fixed the maximum acreage to be entered by a 
he is presented from alienating any part of it, or from making any actual change of resilenee, or from abandoning the land for more than six months at a time. A full compliance with all the provisions of the act, entitles him to a patent at the expiration of five years.

The law requires the land "to lo located in one body, in conformity to the legal subdivisions of the public lands, and after the same shall have been surveyed." The applicant is required to file with the Register of the district land office his application, designating the tract desined to be enteresl, together with his affilarit setting forth the facts which loring him within the requirenents of the law, ${ }^{74}$ whereupon the Receiver issues homestead duplicate receipts for each entry, one of which is delivered to the applicant, and the other returned to the General Lanr Office. is No certificate is issmerl at the time of entry, nor until the expiration of the fire yrars, except in ease of a sale for the benefit of infant heirs, or where full payment is made bofore that time as provided by the act. In case of a sale for the benefit of infant heirs, a certificate issues in the name of the purehaser, upon erilence of sale made in obedience to a decree of a court of competent jurisdiction. In case of full payment the party is required to make proof of settlement and cultivation as required by the pre-emption laws, upon which, and the surrender of the homestead duplicate, a new and original entry may be made and a pre-emption receipt will issue as in ordinary cases. ${ }^{i t}$

person at 80 acres. This law continued in force until Jume $2.2,1876$, when it was repealed amd all of the lands in the five Southern States were ordered to be liromght into market by proclamation for sale at public offering to he followed by private entry. Title to upwards of 12,000,000 aldes was intiated by hrmestead entry under the law of 1866 i.

it $A$ fee of $\$ 10$ must aliog he paid at this time, trogether with a rommission of one-half of one per cent. upon the cash value of the land applied for, based on \$1.25 per acre.

t5 Cir. Cen. Lanel Ofice, Mar. 1, 1884.

ir $\$ 2$ of act.

it Cir. Ge'n, Land Ofice, Oct. 30, 1862. From Nily 20, 1862 , the date of the law, to Jume :30, 1889, atecording to a very modent estimate, the number of patents issmed was 297,20 , cmbluaring an area of 74 ,30:2 s(platre milas, or 47,553,280 acres. Repr. Gern. Land Ollice, 1 s89. 


\section{\$11\% Rights Acquired Under Homestead Aets. PY} the prelininary procedings already moted, an inceptive right is renter in the settler, which by a fathful observance of the law in regard to settlenent and cultivation for the contimous torn of tive raars, and final proof and parment is is perfected and marle the busis of a patent or complete title. The homestead sottler's right attaches only from the date of antry, the pre-enptor's from the late of his actnal personal settlement. The title in either atse is consummated by a full complianee with the terms and eonditions impored by law. ${ }^{\text {in }}$ By the tht section of the act of 1862, lam acquired in this manner is declared to be not liable for debts contracted prior to the issming of the patent.

The sale of a lonestead dain by the settler, before completion of title, rests no title or exputies in the purchaser, and is not recognized by law, ${ }^{\text {so }}$ and, in making final proof, the settler is by daw required to swear that no part of the land has bern alinated except for church, eemetery or school pmposes, or the riglit of way of a railroad. ${ }^{\text {s1 }}$

In the event that a lomestead clainant lies before patent issnes, or before the right to demand a patent has accrued, the land does not become part of his estate. L pon his death all his rights muler the homesteal entry cease. IIis heirs thereupon become entitled to a patent, ${ }^{82}$ not because they have sncceeded to his equitable interest, howerer, but becanse the law gives them preference as new homesteaders, and allows them the benefit of the residence of their ancestor on the land. ${ }^{\mathrm{s}}$

\section{s 118. Desert Land Entries. In the western-central}

is The parment here mentioned is a commision of $1 / 2$ of one per cent. paid on the issuance of the certifirate. The fees and commissions, lowerer, vary somewhat. See Instrutctions Gen. Land Office, Oct. 30 , $156 i^{2}$.

in commisioner's Instruetions, Alig. 2.5. 1866.

sil An exception to this rule seems to have been made by the
Act of Jume 1.j, 1880 (21 Stat. at Large, § 237). This act. however, is retrospective in its operation and applicable only to peculiar cireunstances. See, Cir. Gen. Land Office Mar. 1. 1884.

s1 Rev. Stat. C.S. \$ 2288.

* 2 Rev. Stat. L. S. $\$ 2291$.

sa G.jerstadengen $r$. Van Duzen, $r$

N. Dak. 612. 
part of the [rinted States there is a vast arid region, esrimated to eontain more than seven humlred millions of acres, wherein agriculture can lwe conducted only by means of irrigation. ${ }^{\text {st }}$ These tracts hare received the name "desert lands," notwithstanding they poseses remarkable fertility when properly irrigated, and, from the experience of actual settlers, can be made to produce larger crops than those which reward the labors of the husbandman in regions subject to periodic or occasional rainfall. ${ }^{\mathrm{s}}$

In order to induce settlement on this class of lands lying west of the Missouri river, Congress, in 1 17, , sis passed what is known as the "Desert Land Act," the object of which is to effect a recianation of lands which will not, without artificial irrigation, produce any agricultural crop. This act is not a donation law, howerer, but simply a variation of the ordinary cash entry, its beneficial features being that the claimant has three rears in which to introdnce water and pay for the land. A duplicate certiticate is ismed at the time of entry, a small entre fee being paid, but final certificate of purchate is not given until proof of compliance with the terms of the act and full paynent has been marle for the land, which is usnally three vears afterward.

\$ 119. Tree Claims. To promote the growtl of timber on the treeless prairises of the West, Congress has further enacter a law, by which any person contitled to make a pre-emption or homestead entry may secure 160 acres of public land by planting, protecting and keeping in a healthy growing condition thereon, for eight rears, ten acres of tiunber. Lanels subject to entry under this act numst be composed exchusively

s4 Theos latmds lie in Nevada, New Mexico, Arizena, Colorato, Wyoning, Southeru Caljfornia, Montana,

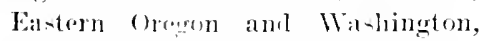
and a poltion of the We-tern part of the Dekntas. Thry are also fomml in -mell areas in other prorti of the livetrin sitater.

so feee, liepout an the Lainds of the Arid Region, ly Powell, 18is; Preliminary Report of Publie Land Commision, Issil).

sij A.t of Niareh 3, 1877. This act appline only to califmnia, Oregon, Nevalla. Wishington, Matho, Montana, Italı, Myoming, Arizona, New Mexico and Dakota. 
of prairie lands, or other lands devoid of timber. At the expiration of eight years tinal proof is made and patent issues as in other cases. Liesidence or actual settlement is not neecsary, nor will an cutry of this character prechde a simultaneons homestead or pre-entption entry, hence "tree claims" have been made on a large portion of the western lands and will form the initial stage of title to much valuable property.

If the owner of a timber claim dies before he has complied with all the conditions necessary to obtain a patent, his heirs maly complete the remaining conditions, and upon obtaining a patent they take the land in equal shares as direct grantees of the government and not by inheritance. ${ }^{87}$

$\$ 120$. Location by Military Warrants. The practice of granting bounty lind to officers and soldiers who have been engaged in the militury scrice of the Cnited States, as a public reward for derotion and patriotism, dates back to the period of the Revolution, and has formed the subject of a number of Congressional enactments since that time. ${ }^{\text {ss }}$ The warrants or certificates issued in pursuance of these acts may be located at any land office in the Inited States and must be made on lands subject to private cntry, according to the legal subdivisions and in one borly, the selection always to be in as compact a form as posible. The law expressly forbids the location of a warrant upon any lands to which there shall be a pre-emption right, or upon which there shall be an actual settlement or cultivation, or upon auy lands which are resersed or withdrawn from market for any purpose what"ver. ${ }^{\mathrm{s} 9}$ When located by the warrantee in person they are available upon any tracts of land which may be cintered under the general preemption laws, whether such land has or has not been offered at public sale. ${ }^{90}$ By act of Congress of March

si Cooper $r$. Wilder, 111 Cal. 191. s. No land hounties were given by congress for military service in the rivil war. The only privileges granted for such service, in eonnestion with the public lands, were time allowances on homestead en. tries.

s: Art Fob. 11, 1847; Act. Sept. 2s, $18 \% 0$.

90-Instructions Gen. Land Office, April 1, 1848; do. Mar. 31, 1851. 
22, 1852, certificates of location of military land warrants were marle assignable, and the interest acquired by ralid location was made to pass by deed or instrument of writing, in the form and subject to the regulations prescribed by the General Land Ottice, the assignee becoming fully rested with all the rights and property of the original owner or warrantee. ${ }^{91}$

The entry is made by application to the Register alone, who issues duplicate certificates of purchase, one of which is delivered to the purcliaser and the other transmitted to the General Land Office as in other classes of entries. If the certificate has been assigned, and such assignment has been receiver before the issue of the patent, the same will be issued in the name of the assignee. Assignments and locations, as well as deeds of land so located prior to the issue of the patent, if made before March 2.2, 1552, have been held invalid. ${ }^{92}$

$\$ 121$. Land Scrip. In 17\&t, the State of Tirginia ceded to the Enited States the largest and most valuable body of land that.ever belonged to the public domain of any State in the world. But previons to the cession the State had promised to give certain portions of it to the soldiers and sailors who had served during the Rerolutionary War in its armies and navies. The government took the land charged with this obligation to satisfy the claims of Virginia's defenders, and assumed all meatisfied outstanding military land warrants of the State, issned by proper authorities, giving in exchange therefor the land "scrip" of the Enited States. ${ }^{93}$ This scrip is receivable in parment of any lands owned by the United States, subject to sale at private entry, but can not be applied by pre-emptors.

There has also been issued under acts of Congress." and in pursuance of treaties with Indian tribes, a species of location

91 Waters $r$. Busch. 42 Iowa, 25.5; Bell $x$. Hearne, 19 How. 260. The grants for military and naval land bounties from the origin of these laws to June 30, I 893, amounted to 61,064,150 acres. liep. Pub. Land Commission, 1883.
92 Nielols, r. Nichols, 3 Pin. (Wis.) 17t: Stephenson $r$. Wilson. 37 Wis. $48 \%$.

936 Opinion: Atty. Gen. 243; 9 do. 156; Act Alug. 31, 1852.

9410 Stat, at Large, 304. 
eertificates known as Indian or Ilalf-breed scrip. It is issued to the Ifalf-bresel and ean be located only in his name, and, mike the Virginia serip, can not be treated as money, but must be locaterl acre for acre. This scrip is not assignable and transfers of same are held void. Though originally confined to rescriations, the sphere of location has ly statute been enlarred so as to comprise any other mocenpied lands subject to pre-emption or private sale. No receipt is issned to the locator, except in mavoidable cases, as where there is a small excess in the area of location over the scrip, which must be paid for and receipt issued as in bounty land warrant cases. But no eertificate of purehase is issued, as in ease of money purchases, the serip and application, instear of certificates of pur-. chase, being the instruments of title which are returned to the General Lamb Office in this class of business. ${ }^{95} \quad \Lambda$ certifieate by the commissioner of the General Land Office showing the location of the scrip, and that snch location was marle by the party authorized to do so, is competent evidence to show title in tle lncation. A eny of the scrip is not esicutial to prove title fom the govermment whenever this becomes necessary. ${ }^{96}$

Private land scrip is issned on confirmation of the claims of individualis, and is intented as a compensation to the donee for the lose of valuable estates or interests in lands. It may be atsigned, and when aswigned may be located in the name of the arigmee. It womld appear that entries made with this serip are not patentable, no provision being nate therefor, but it seems that in this ease a patent is not absolutely necestry for the full protection of claimants, inasmuch as a certifieate of entry will be full eridence of a complete relinquishnent by the Lnited states of all its interests in the land located. ${ }^{9 t}$

95 Instructions Gen. Land Office, Fih. 22, 1864; do. May 13, 1865.

: Wilcox $r$. Jackson, 109 Ill, 261. or Opinion and instruetions Secy. of Int.. Ang. 4, 1875. It is difficult to reconcile this procedure with the oft repeated decisions of courts, respecting the necessity of a patent to prove title out of the government, in actions of ejectment or other proceerlings at law to try disputed titles. 
The most important of this peenliar class of paper is that known as Agricultural College scrip. It is issued in phrsuance of an act of Congress, pased July 2, 1862, to donate a portion of the publie land to the several States and Territorics which may provide colleges for the benefit of agriculture and the mechanic arts. The anount of land donated by this act was a quantity equal to 30,000 acres for each senator and representative in Congress by the apportiomment under the census of 1860. The quantity of land to which each State was entitled was to be selected primarily from the public lank, within the limits of such State, that were sulject to sale at private entry at the minimum price, and in care of a deficiency of such lands the Secretary of the Interior was instructed to iswne land serip to the amount in acres for such deficiency of its distributive share. This serip was to be sold by the States and the proceeds applied to the uses prescribed by the act. The State is prohibited from locating the scrip within the limits of any other State, but its assignees may locate same upon any of the unappropriated lands of the Lnited States subject to sale at private entre, or in payment for pre-emptions, ${ }^{9 x}$ and in commuting homestead entries. ${ }^{99}$ The mamer of proceeding to acquire title with this elass of certificates is the same as in cash and warrant cases.

$\S$ 122. Swamp Land Grants. By aet of March 2, 1849, Congress made a grant to the State of Lonisiana of certain swamp and overflowed lands, and by act of Sept. 28, 1850, made a similar concession to the State of Arkansas "and each of the other States of the Enion in which such swamp and overfowed lands may be situated." The first act applied only to the State of Lonisiana, and rested the fee in said lands upon the approval of the selections by the Secretary of the Interior. The general law of 1550 provides that the fee shall rest in the State upon the issuing of a patent. The method of selection being left optional with the States, Michigan and

98 Instructions Gen. Land Office, July 22, 1870.

99 Instructions Gen. Land Office, 10
Feb'y 8, 1972. See also 15 Stat. at Large, 227 .

19 Stat. at Large, 519. 
Wisconsin adopted the field notes of survey as the basis of theil acceptance, while the others agreed to ascertain the lands he examination in the field. ${ }^{2}$ The grant comprised all lands which were wet and unfit for cultivation, and included also all lands which, hough dry part of the year, were subject to inumlation at the planting, growing or harresting season, so as to destroy the erop. These lands, for the most part, have since, by drainage and cultivation, becone valuable for agricultural purposes, and the title to many fine farms in the Western States is derived throngh the swamp land grants. ${ }^{3}$

Though the act provided for the issuing of a patent to vest the fee, it was it lf a present grant, wanting nothing but a definition of boundaries to make it perfect, the patent being merely in confimation of the equitable title already rested, ${ }^{*}$ ret as the fee ramained in the govermment until the issuance of the pateri, the State wonld have no power to convey a legal title or dispose of the land prior to that event." ${ }^{5}$ The complete abstract, therefore, should recite the original grant, showing the acrontance by the State, and any other necessary feature, and finally the patent from the government, as the foundation of title.

It will be observed that the provisions of this act extend to, and their benefits are conferred mpon, only "each of the other States of the Union," and it has always bion held by the General Land Office that the grant extended only to States in existence at the date of the act, and that as new States were admitted additional legislation was needed to confer the benefits of the swamp grant upon them." In this construction Congress seens to have concurred, for in 1860 we find a special statute extending the swamp grant to the States of Oregon and Minnesota, which States had been admitted subsequent to

21 Lester's L. L., 542.

$\therefore$ Since the passage of these acts and prior to June 30, 1889, there has been patented to fifteen States lands aggregating 57.099 .972 acres. Jiep. Gen. Land Oflice, 1889.
49 Opinions Atty. Gen. 253; Sterling $v$. Jackson. 69 Mich. 488.

5 Parsons $v$. Comm'rs $\mathrm{S}$. \& $\mathrm{U}$. Lands, 9 Wis. 236.

6 See Rulings Commissioner Gen. Land Oflice, Jan. 19, 1874, and May 2,1871 . 
the passage of the grant of 15.50 . This is undoubtedly correct, as all grants of the public domain are in the nature of benefits derived through the original grauting acts, designating the character and cxtent of the grants and the manner in which they are to be mate effective and secure to the grantee. Such benefits are nonally bestowed not by general, but by special legislation.

$\$$ 123. School Lands. It lats alwars been a cherished policy of the goverument to set apart and apropriate a portion of every township for the arlvancenent of education in the support of common sehools. Former? ane section only was devoted to this most landable purpose, but in the States admitted during later years two sections have been reserved, ${ }^{7}$ usually sections 16 and 36 . The practice of setting aprart section 16 is traceable to the ordinanee of 1785 , being the first enactment for the disposal by ale of lands in the Westem territory, and became a fundanental prineiple by the ordinauce of 1757, which settled terms of compact between the people and States of the Northwest Territory and the original States. One of the articles afmrming that "religion, norality and knowlexlge being necesary for good gowernment and happiness of mathind," declared that "schools and the means of education should forever he encouraged." This principle was

iTo eaeh organized Territory, after 1803, was and now is reserved the sixteenth section for school purposes, which reservation is carricd into grant and confirmation by the terms of the act of admission of the Territory or State into the Union; the State thin becoming a trustee for school purposes. These grants of land were made from the public domain, and to States only which were known as priblie-land States. Twelve States, from Marh 3, 1803, known as publie-land States, receiver the allowance of the sixteentli sertion to August 14, 1848.
In the aut for the organization of the Territory of Oregom, Angust 14, 1sts, there was in-erted an alditional grant for school purnoses of the thirty-sixth sertion in each township, with indemnity for all public-land states thereafter to be admitted, making the reservation for sobool praroves the sixteenth and thirty-sixth seretion, or $1 \cong 80$ acres in each township of six miles square rescrved in publiceland States and Torritories, and confirmest by grant in terms in the act of admission of such state or Territory into the Cuion. 
extended, first ly congressional enactment, ${ }^{8}$ and afterward in $180^{2}$, by eompact between the United States and Georgia, to the Sonthwest Territory.

'The contancy with which the government has ever allhered to this policy in the varions eompacts with the people of the newly formed States, and the eare which Congress has manifested to prevent the aecumulation of prior obligations which might interrupt it, fully display their estination of its importance and value. ${ }^{9}$ The reservation of these sections, in words of present grant, is made a part of the organie act on the admission of the State into the Union and passes to the State the title to the land withont further legislation. As the govermment extends its surveys, so that the location of the section can be ascertained, the title in the State hecomes perfect and eomplete." Where sections 16 or 36 are in whole or in part ineluded in private claims, held by titles legally eonfirmed or decided to be valid, the State may seleet their equiralent in other unreserved lands.

$\$ 124$. Interual Improvenent Grants. In arldition to the grants hereinbefore described, Congress, from time to time, has made large grants of the prbile domain to the different States, to aid in the development of the country by the build-

S I Stat. at Jarge, 550.

9 See Cooper $r$. Roberts, 18 How. (U. S.) 173 , for an elaborate review of this subject.

10 Cooper $v$. Roberts, 18 How. (U. S.) 173; Bucher $v$. Wotherly, 5 Otto (U. S.), 5l7. There has leen granted and reserved for edurational purposes, sinee the organization of the government and prior to . Tume 30,1883 , a grand total of 78.889 .839 acres. Of this amount $07,893,919$ acres have been donated for the - upport and maintenanee of the fullite or rommon schools, the balane has been valionsly given for agricultural and mechanical rolleges, seminaries or universities.
In the legislation relating to the admission of the publie-land States into the Union, from the admission of Ohio in 1802, grants of two townships of public lands, viz, 46,080 acres each, for university purposes are enmmerated. Ohio, Florida, Wisconsin, and Minnesota are the exceptions, each having more than two townships in area. These reservations in each case require a special act. All school, miversity or agricultural college lands granted are sold by the legisiatures of the severil Sitates or leased, and the proceerls of sale or lease applied to education. 
ing of railmoals, ramak, and other intemal impromements. These grants, though lowal in their nature, are all gererned by the sane general prineiples. The acts, as a rule, conver in words of presont grant which rests a fee simple title in the States to which the lands are given, ${ }^{11}$ and where, as in case of an mulocated lailuad, no specifie tracts are lesignated, they have been held to constitute a conditional grant in prosenti in the nature of a "float" which does not attach to any particular pareel of the public lands metil the necessary deterninative lines lave been fixed upmo the faec of the earth, ${ }^{12}$ but upon such definite location the title to cach particulan parcel will be as complete as if it had lexpn sranterl by name, number or deseription, ${ }^{13}$ relating back to the date of the eqrant. ${ }^{14}$ The same general rules will also aproly to special grants for State improvements.

All public grants are to be construed most strongly against the grantee, and this is specially true of legislative grants. In construing a congressional grant, it should always lo borne in mind that the act by which it is made is a law as well as a conveyance, and that such reffect must be given to it as will carry out the intent of Congress. This intent can not be defeated by applying to the grant the rules of the common law, which are properly applicable only to transfers between private partics, and to the ralidity of which there must exist a present power of identification of the land conveyed. Where no such power exists, instruments with words of present grant, are operative, if at all, only as contracts to convey, but in the grants under consideration, as in all other cases of governmental conveyances, the rules of the common law must yield to the legislative will. ${ }^{15}$

\$ 125. Land Grants to Rairoads. From the period of

11 U. S. $v$. Perchman, 7 Peters, 51 ; U. S. $r$. Brooks, 10 Howard, 442; Godfrey $v$. Bradley, 2 MeLean, 412.

128 Opinions Atty. Gen. 244.

139 Opinions Atty. Gen. 4l; R.
R. Co. $r$. United States, 92 U. S. 733.

14 Swann 2 . Lindsey, 70 Ala. 507. 15 Sehulenberg $v$. Harriman, 21 Wall. (U. S.) 60 ; R. R. Co. v. R. R. Co., 97 U. S. 491. 
the inanguration of the system of land grants in aid of internal improvements by private corporations until the year 1862, it was the invariable practice to make the grant to the State, which, in this instance, acted as a trustee or transfer agent, conveying to the corperation the fee of the land after performance of conditions. ${ }^{16}$ The charter of the Lnion Pacific R. R. offected a complete change in this respect. Here the frait wat made direct to the corporation, all intermediaries being aroided, and the precedent thus sot has been followed in a lange number of grants make since that time. ${ }^{17}$

The act of Congress granting the lands is the inceptive measure of all titles initiated in this manner, and forms the first link in the chain. The arets are nsually conched in words of present grant, as "that there be and is hereby granted," and when so worded they cousitute a converance that can only be lefeater by failure to pertom the conditions annexed to the grant. The general right to the land, subject to the exceptions contained in the act, rests at the date of the passage of the law, and, as in the case of other mlocated tracts, attaches to the specific lands at the time of filing the plat in the

16 March 2, 1833, Congress anthorized the State of lllinois to divert the canal grant of Narch 2 , 1827. and to constinct a railroad with the proceeds of said lands. This was the first Congressional enactment providing for a land grant in aid of a railroad, but was not utilized by the State.

The act of September 20, 1850, was the first railroad act of real importance, and initiated the system of grants of land for railroads by Congress which prevailed until after July 1, 1862. This grant gave the Siate of Illinois alternate sections of land (even-numbered) for six sections in width on either side of the road and branches, being a grant of specific sections. The road was to be a public highway, to be used by the Government free of toll or other charges, and the mails were to be carried at prices to be fixed by Congress. This act extended like terms and conditions to the States of Alabama and Missimippi in aid of the Mobile and Ohio road which was to connect with the Illinois Central and branches-all of which roads are now established.

17 It is estimated that if the lands embraced in limits of grants to railroads were all available, and, that the corporations, State and National, built their roads, and complied with the laws, it would require $215,000,000$ of acres of the pulblic domain to satisfy the requirements of the various laws. Actual selections, forfeitures. etc., 
General Land Office. After this has been aceomplished the title of the corporation lrecomes fully rested and complete. ${ }^{\text {s }}$

$\$ 126$. Public Highways. By act of Congress, in the year $1866,{ }^{19}$ the right of way was granted for the construction of highways over public lants not reserved for public use, and in nearly all of the States containing public land a special enactment declares that all section lines, as far as practicable, shall be and remain public ways. The effect of these laws, taken together, is to locate and dedicate, by express public grant, a strip of land along each section line for highway purposes, and subsequent settlers and purchasers acquire title subject to the public use in this particular. ${ }^{20}$ Where the land had passed into private ownership prior to the enactment of these laws their effect would be nothing more than an assertion of the right of eminent domain, and should the strip be actually taken the rule of compensation would undoubtedly apply.

$\$ 126 a$. Private Land Clains. Embraced in the accessions which at different times have been made to the National territory, are numerous individual foreign titles having their origin under the govermments preceding the United States in sorereignty. To these the name "Private Land Claims" has been assigned. They are usually founded on written grants of some kind, yet they also exist even as nascent claims resting upon actual settlement before the change of government. ${ }^{21}$

have greatly reduced this amount. See Rep. Public Land Commission, 1883.

18 South Pac. R. R. Co. r. Dull, 22 Fed. Rep. 489.

19 Sec. 2477 Rev. Stat. U. S.

20 Wells $v$. Pennington eounty, 2 S. Dak. 1 .

21 Turning to the national map it will be seen that these private claims or grants, marking the progress of early explorations and settlements on this continent, begin on the northern shores of the Michigan lower peninsula, come down to the old French settlement at and near
Detroit, pass over to Green Bay and Prairie du Chien in Wisconsin, enter into Indiana at the old Vincennes post, down the eastern side of the Mississippi, and in Illinois reach Peoria, Prairie du Rocher, and the Kaskaskias, there resting on ancient British and French grants, and all within the limits of the United States according to the treaty of limits in 1783. Thence such ancient claims are found in descending the Mississippi under other forms of grant and granting officers, to the Gulf of Mexico, extending into the southern portions of Mississippi and 
These titles have been serupulously respected by the United States and erery offort has been made to secure to individuals all their rights which originatel moler former governments. The principle has been rigoronsly mintained that though the sorereignty may change the rights of private property remain maffected, ${ }^{22}$ and in this respect no nation has shown a higher sense of justice or a more liberal spirit. Frequently these claims are confirmed by the Lnited States and thereupon patents of confirmation issue, ${ }^{23}$ but there are numerous holdings, particularly in States east of tlie Mississippi, which rest entirely on the old French and Spanish grants.

\$127. Who May Acquire Title. The policy of the general government in relation to the sale of the public lands has ever been most liberal, yet a few restrictions have been imposed in certain cases which it may be well to notice. The general land system makes little or no discrimination, but to this has been superadiled a speeifie new faet: the sale or disposal of certain lanels, in certain limited quantities, at a re-

Alabama, and scattering all over both Fast and West Florida, erossing the Min-isippi and following the shores of the Gulf, they are found thickly scattered over Lonisiana, existing in Arkansas, and in great numbers in Miscomi.

In those localities south of the thirty-first degree, east of the Mississipli, to the Perdido, and those west of the Mississippi to the present State of Missouri, inclusive, the claims are founded on Spanish and French titles, under treaty of 1803 and ancient settlements; those east of the Perdido, in the Floridas, upon Spanish titles under the treaty of 1819, and under old settlements.

In New Mexico, Colorado, Arizona, and California, as we advance wentwarl, there exist ancient Spanin th titles, municipal and rural, claimed under the treaty of 1848 with Mexico, and what is known as the Gadsden purchase of December 30,1853 . These claims are for irregular tracts, illy defined, bounded by streams or marked by headlands, or natural objects in many cases since removed. They were made for agricultures, mining, stock-raising, or colonization, in all sizes from a village lot to a million-acre tract. The records kept by the granting authorities of Spain and Mexico have been a serious hindrance in some cases toward a satisfactory solution, being frequently of doubtful meaning. See, Report Public Land Commission, 1883.

22 Lnited States $r$. Percheman, 7 Pet. (U. S.) 51 ; Soulard $r$. United States, 4 Pet. (U. S.) 511.

23 See $\S 132$ "Confirmations," post. 
duced price or on certain specific conditions, for personal use and for actual settlement and cultivation only, under a series of acts known as pre-emption, grartuation, homestead acts, cte. The benefits of these acts are designed for actual settlers and exclude all persons not sui juris, such as married women, minors, and others who are legally incapable of contracting; meaning of course married women and minors not unemancipated, and constituting nembers of the fanily of the husband or father. $^{24}$ The general law, in so far as regards the United States, undoubtedly enables aliens to purchase the public lands for cash and at the ordinary price, sulbject only to such limitation as the particular States may enact. ${ }^{25}$ The benefits of the special laws above referred to, howerer, apply only to persons who are citizens of the United States, or such as have filed their declarations to become citizens, as required by the naturalization laws. ${ }^{26}$

$\S 128$. Inceptive Measures in the Abstract. The foregoing brief and fragmentary review of the inceptive stages of title, but faintly expresses the vastness of onr public land system and conveys no adequate idea of its many intricate details produced by an almost inmmerable number of acts of local or temporary application, together with their attendant rulings, instructions and decisions by the Interior Department, and adjudicated cases. ${ }^{2 \tau} \quad A$ full and aceurate knowledge of the United States land system is of the utmost importance to both examiner and counsel, and thongh it is not usual or neeessary to ineorporate any consilerable portion of the inceptive measures in the abstract, yet when it is remembered that the validity of title to each and every tract carred from the public domain, depends upon the aceuracy with whicl the first details of transfer from the govermment to its grantee were executed, the importance of exereising eritical care at this stage of the abstract will be apparent. ${ }^{28}$

245 Stat. at Large, 458.

2510 Stat. at Large, 649 .

26 7 Opinions Att'y Gen 351.

27 See Lester's or Zabriskie's
Land Laws for a full exposition of these acts and dereinions.

2x A grant of publir lands eannot be impeached collaterally unless it 
A brief note of the entry should always form the initial statement of the abstract, or when originating in grant, a corresponding statement to that effect, the degree of fullness of narration being optional with the examiner. The various steps undel the pre-emption laws prior to entry are unimportant, and shed no light on the title after the certificate has issued. But with homestead entries it is different. Here the certificate does not issue until five years after entry and during this period eventful changes may oecur. In case the interest should be sold for the benefit of infant heirs, a certificate issnes to the purchaser, and the abstract should show substantially all the proceedings from entry to issue of certifieate. All the needed data can be procured by obtaining a transcript of the Register's tract book, something no well appointed abstract office can dispense with. The tract book, further, has all the dignity of other recorded evidence in matters affecting title. ${ }^{29}$ In titles originating in grant or confirmation and not followed by patent, much more particularity is requisite than when the patent is relied on as the foundation of title, and a corresponding fullness of narration and detail is necessary.

is void upon its face. But it may be assailed in a direct proceeding.
29 Russell $v$. Whitehead, 4 Scam. (IIl.) 7 . 


\section{CHAPTER IX.}

INITIAL STATEMENTS.

\$ 129. The government entry.

130. The donative act.

131. Continued-Section sixteen.

132. Confirmations.
\$ 133. Town site entries. 134. The Receivcr's receipt. 135. State lands. 136. The root of title.

\$ 129. The Government Futry. Whenever the abstract goes back to the foundation of the title, it should always commence with a brief note of the original entry of the land at the United States Land Office of the district in which the same is located, giving the name of the person so entering it, together with the date, and any other particulars that may appear and are pertinent. Should the entry, from any cause, have been canceled and re-cutry made, that fact should also be noticed, giving date of cancellation and re-entry. Where parties hare negligently omitted to record the Receiver's receipt or the patent, ${ }^{1}$ as is frequently the case, this forms the only item of information relative to the origin of the title, and will be of great service to counsel in his investigations, as well in determining the rights of the parties as in supplying missing links of eridence. The entry itself, if ralid, gives a right to the Register's certificate of purchase, and creates an equitable interest in the land. ${ }^{2}$ It is useful in showing the inception of title, and forms a symmetrical initial to the history which follows. No particular form is necessary so long as the facts are substantially stated, and the following example will suffice:

The northeast quarter of Section six, Town one. north. Pange twenty-thres, east of the $3 d$ Principal Meridin?. wese entered by

1 The recording laws of the States, as a general rule, do not require the recording of the Receipt, al- though provision therefor is always made.

2 Levi $v$. Thompson, 4 How. (U. 8.) 17 . 
Thomas. Jolmes, May 14, 1S39, at the Cinited States Land Office at Miluauke, Wisconsin. Certificate, No. 341. (Certificate canceled, and re-entry made, June 10, 1339 . Certificate, No. SOO.)

This, of course, applies only when the land has been entered in the nsual mamner, and never includes sections 16 or 36, or such other lauds as may have been selected by the State in lien thereof, and which are commonly known as the "school sections." Nor would lands donated for specific purposes, as to assist in the construction of internal improvements, etc., be stisceptible of this treatment. In such cases a recital of the original grant should constitute the initial statement of the abstract.

S 130. The Donative Act. When the inception of title is throngh some grant of Congress, though the immediate grants are from the State, the preliminary measures by which the State acquired its right to convey should appear upon the abstract. A. grant of public land by statute is the highest and strongest form of title known to our law, ${ }^{3}$ and vests in the grantee all the title which the United States had at the time of the grant or may afterward acquire: subject, however, to the conditions and restrictions appended thereto, and this, althongh a patent may afterward issue." The original grant, or so much thereof as may be necessary to show the eonveyance, should therefore form the initial statement of an abstract of title to land so derived. Coupled with this should appear so much of the official action of the State anthorities as will show an acceptance on their part and a compliance with such conditions as may be imposed by the granting act. These need not be set out at length; brief referenees are sufficient, provided all the essential steps are substantially noted. Public grants to States are usually of specified quantities but of mascertained

811 Opinions Atty. Gen. 47; Mall $v$. Jarvis, 65 Ill. 302; ChalleDoumman $r$. Hooe, 3 Wis. 466. foux $r$. Ducharme, 4 Wis. 554 ; but 49 Opinions Att'y Gen. 346; see Foley $r$. Harrison, 15 How. 433. Thompson $v$. Prince, 67 Ill. 281; 
location, which is determined by selection in aecordance with the termin of the grant. I statement similar to the following should preface the abstract in such cases:

Section seren, Toun thirty-nine north. Range fourteen east of the sd Principal Meridian, with other lands, was selected by the Commissionse of the Genepal Land Office, under the direction of the President. as a portion of those tracts granted by the Cnited Stutes to the State of Illinois b!y tet of Congress approved Mareh 2. 182. r. putitled "An Art to grant a quantity of land to the state of Illinois for the mupose of ciding in opening a Canal to connect the waters of the Itlinois River with those of Lake Michigan."

Selection approved by the President Ifay 21, 1830.

These statements are nsually short, from the fact that the title at this stage is usually unquestioned, and in the older States has aequired all the elements of stability and permanence from long aequiesence and the effhxion of tine. The examiner will finding no dificulty in adapting intemal improvement or railroad grants from the hints above given, and further illustrations are not deemed neepsary.

A selection by the State has the effect of an entry of the land, and withlraws the tract from further disposal, mless the selection shall be subsequently rejected, subject, of conrse, to the perfection of ans pre-existing valid pre-emption elaims: ${ }^{5}$ and when a particular parcel of land is selected by a State, through its officers or other authorized agents, as a part of a gross acreage theretrofore granted, and such selection and location are appored by the Cnited States, the title beemes perfect and attaches to the land solected. ${ }^{6}$

$\$ 131$. The Same-Section Sixteen. The imnediate titlo to section sixteen, and in States west of the Missouri river to section thirty-six as well, is derived from the State, although

5 See Instructions Commr. Gen. G Megerle $v$. Ashe, 27 Cal. 322. Land Office, Jan. 5, 1872. 
the original title romes from the Federal Government. These sections, in pursunce of the cherished policy of the government, are specifically aprepriated to the nse of common schools, which anpropriation or reservation forms a part of the compact by which the state is atmitted into the Lnion. When the lands are surveyed and marked out the possessory right of the Siate at once attaches, and, if there be no legal inpediment, becomes a legal title. ${ }^{7}$ Where such section has been sold or otherwise disposed of by the gorermment, other lands, equivalent thereto and as contiguous as may be, are granted in their strad, such selection being lnown as "lieu lands"; the act of selection of a section in lien of section sixteen, is that by which the tract becomes appropriated for school purposes. ${ }^{8}$ A formal introluction, therefore, of land in sections sixteen or thirty-six, would read somewhat as follows:

Scction sirtenn. Torn one north. Range thirty-one east of the second Principal Meridian, was granted by the Cnited States to the State of Michigan for the use of srhools, by act of Congress, Iune 2.3. 1836, providing for the admission of Michigan. as a State of the Enion, and arcepted by the State of Michigan by act of Legislature approved July 25, 1836.

Where section sixteen, as returned by the survey, is found to be occupied by pre-emption settlements made under the law permitting settlements on msurvered lands, or where the land has been otherwise disposed of, or prior rights have attached, and a solection of lien lands is made, the preliminary note must. show the facts of selection, confirmation, ete, necessary to bring it within the law vesting the title, thns:

The northeast quarter of Section seventeen, Toun ten north, Range twenty-two cast of the Fourth Principal lieridian, was selected by the serretery of the Treasury ${ }^{\text {a }}$ in lien of land in

7 Conper r. Roberts, 18 How. (TT.

S.) 173 .

s Herick $r$. Hughes. 15 Wall. (U. S.) 123. satnder the prosent practice, seIectinns from othor publie lands as indemnity for deficiencies in sertions 16 and 36 and fractional town- 
Section sixteen, by rivtue of an act of C'ongress, approved June 15, 184t, and entitled "In Act to authorize the selcction of certain school. lands in the Territories of Flovida, Ioun and ITisconsin," and was granted by the Lnited states to the Strite of II isconsin for the use of schools, by art of Congress approved August 6, 1S46, entitled "An ict to enable the people of Wisconsin Territory to form a Constitution and State government, and for the admission of such State into the Tnion," and accepted by the State of Wisconsin by the Constitution framed February 1, 1S48.

$\$ 132$. Confirmations. In the West and Southwest, the title to land rests, in many cases, upon confirmed claims of inchoate rights derired from the governments which orned the land prior to the conquest or cession, the method of confirmation differing considerably with the locality. The rights of parties elaiming under titles from the Spanish or Mexican Gorernments are determined by special enmmissions appointed for the purpose, or by the Enited States courts, and such determinations are usually followed br patent.

Mexican grants were make by the governors of the Territories in conformity with laws on that subject, and a dernment signed by the governor served as the basis of title, while maps of the lands granted and circumstantial reports were preserved in the arehives of the supreme government. A person

ships under acts of May 20, 1826, and February 26. 1859, are made by agents appointed by the respeetive States, which relections are filed in the local offices of the district in which the land is situated, and if found to be correct are certified to the General Land Office by the register of the local office where filed. If. upon examination by the Conmissioner, the same are found to inure to the State, a list is made sut aud wrtified to the Secretary of the Interior for his approval. When approved, a certified copy of the same is transmitted to the governor of the State in which the selections are made, and a copy thereof transmitted to the local office from which the selections are received, to be placed on file, and the approvals to be noted on its ree. ords. By the approval of the sor retary, the fee is passed to the State. See see. 2419 Rev. Stat., U. S.

a Ordinarily no reenrd evidence of the fact of selection is required beyont the entries in the books of the register of the loeal land office. 
daiming nnder these grants is entitled to a patent from the Unitel States whenever his claim has been confirmed by the comminimers, the District Court, or the Supreme Court, prorided his proof of confirmation is accompanied by a survey certified by the surveyor general. But neither the decree of the condt, nor the surver, nor the patent, is conclusive on anybody but the government and the patentee. The rights of third parties are expressly saved by act of Congress, and those who claim a title adrerse to the patentee have still a chance to establish it in the proper courts of the State. ${ }^{10}$ Whenever practicable, the decree of confirmation, or reference to it, together with a note of the survey and approval of the survevor general, should form the initial statement of the abstract and precede the patent.

The territory lying north of the Ohio River and west of the Alleghanies and extenling to the Mississippi, was claimed by Virginia previons to 1766 to be within its chartered limits, but was not reduced to its possession until the war of the Revolution. Previons to that time, howerer, numerous settlements had been male within that portion of the territory which at present comprises the States of Indiana and Illinois, consisting prineipally of French inhabitants from Canara, who held the lands they oceupied under concessions from French and English anthorities. The possession and titles of these people were respecterl by the State of Virginia, and on its cession of the territory to the Enited States it expressly stipulated for their confirmation, which was afterward effected by snitable legislation.

In the matter of pre-existing titles, the Lnited States has never asserted anything more than a sovereign right over the sulyject. His property rights in and to the soil have never been interfered with, and a patent adds nothing to the foree of a confirmation. ${ }^{11}$ It is of value as record erimence of the pos-

11) Sce Instructions and Opinione, Atty. Gen. Sept. 29, 1859, Nor. 9, 1sin: Mnore $r$. Wilkinson, 13 Cal. 478.
11 Langlean $r$. Hanes, 21 Wall. (L. S.) 521 ; Ryan $v$. Carter, 93 U. S. 78 . 
session and title of the ancestris, ard of the recognition and confirmation of such title l, the Tuitod States. It obviates comtroversies at law respeting the laid, and beennes an instrument of quiet and security. Fom !ce as it is upon a surpy of the government, it removes all doubts as to the houndarios of the traet, which always arises when their establishment rests on uncertain evidenee, yet it adds nothing to the interest rested by the confirmation.

In the legislation of Congress, a patent has a double operation. It is a conveyanee by the goremment when the gorernment has any interest to conver, but where it is issued upon the confirmation of a claim of previonsly existing title it is merely documentary eridence, haring the dignity of a record, of the existence of that title, or of such equities respecting the claim as justify its recognition and confirmation by the Cnited States. The instrument is not the less efficacions as evilence of previously existing right, because it also embodies words of release or transfer from the government. ${ }^{12}$

\$ 133. Town Site Entries. It frequently lappened that the advancing tide of immigration, not only pushed forwart the adventurons pioneer and agriculturist berond the line of the public surveys, but in many cases whole communities settled and formed a town or village. These settlements, sometimes on surveyed and sometimes on unsurveyed lands, have been provided for by several acts of Congress. The first act, approved July 1, $1864,{ }^{13}$ prorided for the fomling of eities or towns upon the publie domain, and for entering the land upon which eities and towns had alreary been founded. This was supplemented by the act of March 3, 180.5, which preseribed rules where the lots were of different dimensions, and not uniform. A further act approved Warch 2, 1867, anthor-

12 Langdeau v. Hanes, 21 Wall. (L. S.) 521; Morrow $v$. Whitney, 5 Otto (U. S.), 551.

$13 \Lambda$ town site law with a very restricted application was passel in 1844, but was repealed by the act ahove referred to. Ender the former system no title could be seaured in town property until the locality had been embraced by the general system of public surveys. 
ized the entry of public lands, settled upon and occupied as town sites in trust for the several use and benefit of the occupants thereof in prescribed quantities according to the number of inhabitants, respectively, in said towns. It will thus be seen that two methods exist of acquiring title to land in town sites at the inception of the town.

By the first method a privilege, both of purchase on sale and pre-emption at minimum figures, is granted, provided certain preliminary conditions are complied with. The requisites consist of filing with the recorder a plat or map of the town, describing its exterior boundaries according to the lines of the public surreys, when said surveys have been executed. The map must also exhibit the name of the city or town; the streets, squares, etc., together with the size and measurement of each municipal subdivision. The map must further be verified by the oath of the party acting for or on behalf of the town. When the town is within the limits of an organized land district, a similar copy must be filed with the Register and Receiver, and a copy must be forwarded to the General Land Office, within one month after filing with the recorder. Under the provisions of this act patents issue for all lots, the price of the lots being graded by size, location, etc. ${ }^{14}$ The second method is under the act of 1567 , which grants to the inhabitants of cities and towns on the public lands the privilege of entering the lands ocenpied as town sites at the minimm price of $\$ 1.25$ per acre. The entry is made by the corporate authorities of such towns

14 The first method limits the extent of the area of the city or town to 640 acres, to be laid off into lots, and which, after filing in the General Land Office the transeript, statement, and testimony required by law, are to be offered at public sale to the highest bidder, at a minimum of ten dollars for each lot. Lots not thus disposed of are made thereafter liable to private entry at saic minimum, or at such reasonable price as the Secretary of the
Interior may order from time to time, as the munieipal property may increase or decrease, after at least three months' notice.

A privilege, however, is granted to any actual setller upon any one lot of pre-empting that. and any additional lot on which he may have "substantial improvements," at said minimum, at any time before the day fixed for the public sale. 
and cities, or by the judges of the comnty courts acting as trustees for the occupants thereof, according to their respective interests. Either method may be resorted to, but the inhabitants are limited to one or the other of the mores preseribed.

The preliminary measures attenling the inception of the title of tow and city property when aequired under the acts above noted, should appear with reatomable degree of detail. If by the former mothod, the plat, or so much as may lue necessary to show the property in question, shonld be given. The preliminary statement in this case wonld consist, in addition to the plat, of a resume of the steps taken, with lates, ete. In the latter caso it would difter but slightly from an ordinary entry. ${ }^{15}$

$\$ 134$. The Receiver's Receint. The receipt issned by the Receiver of a district land office, though constituting no title, is evidence of an equitable interest, which, in mimy of the States, is accorded a dignity and effect equal to a complete investiture by patent. Tron the strength of this receipt large investments are frequently made and great improrements commenced, while the land often passes throngh many hands before a patent has been issued. In many cases the patent is never called for or formally delivered, the receipt being relied upon as sufficient evillence of title to warrant the largest expenditures and the most ample corenants of title. ${ }^{16}$

In a certain sense this is true: for thongh the patent is the superior and conclusive evidence of legal title, ${ }^{17}$ yct the receipt so far precludes the gorernment as to invalidate a second sale of the land, and the patent, when issued, by relation extemls back to the time of the purchase so as to cut off intervening

15 See acts above noted; 13 U.S. Stat. at Large, $34.3 ; 13$ U. S. Stat. at Large, 529; Instructions Commissioner Aug. 20, 1864; Apr. 26, 1865; Sept. 21, 186s. Consult also Lester's or Zabriskie's Land Laws. 16 A patent issued in the nume of the purchaser inures to the benefit of the srantee under a deed executed before the patent issued: Marruder $r$. Esmay, $3 . j$ Ohio St. $2 \cdot 21$.

17 Bagnell $v$. Broderick, 13 Pet. 436 . 
claimants. ${ }^{18}$ In the courts of the United States, however, an equitable title, however strong, can not be set up at law to defeat the logil title by patent, ${ }^{19}$ and an abstract which fails to diselose such instrument reveals a vital defeet that should deter a purelaser from consummating the sale until it has been remedicd. The receipt of the receiver, however, is prima facie evidence that the law has been complied with, ${ }^{20}$ and under the rulings of State courts has been held to convey the entire benoficial interest in the land, leaving nothing in the government but a naked trust of the fee, ${ }^{21}$ while it establishes in the person entitled to it a right to the possession as against one who shows no title. ${ }^{22}$ On the other hand, the doctrine of cavcat cmptor applies with peculiar force to purchasers from an entryman and the govermment always has it within its power to cancel all entries of public land at any time before patent issues tlereon. ${ }^{23}$

The instrument is very informal, and its main provisions may be shown as follows:

$\left.\begin{array}{c}\text { Receiver }{ }^{24} \\ \text { to } \\ \text { William Robinson. }\end{array}\right\} \begin{aligned} & \text { Duplicate receipt, No. 5,084. } \\ & \text { Dated Nay 1, 1889. } \\ & \text { Recorded May 31, } 1839 . \\ & \text { Tolume "A" of deeds, page } 208 .\end{aligned}$

Acknowledges payment in full (\$190.00) for the norlheast quarter of Section ten, Town one north, Range twenty-three, cast of Bd P. M., Milwaulee land district.

1s Stark $v$. Starrs, 6 Wall. 402; Magruder $v$. Esmay, 35 Ohio St. 221.

19 Baird $v$. Wolf, 4 McLean, 549 ; Hooper $v$. Scheimer, 23 How. 235; Bagnell $v$. Broderick, 13 Pet. 436.

20 Allison $v$. Hunter, 9 Mo. 402.

21 Waters $r$. Bush, 42 Iowa, 255; and see Worth $v$. Branson, $98 \mathrm{U}$. S. 118.

22 McDonald $r$. Edmonds, $44 \mathrm{Cal}$. 328 .
23 Jones $r$. Meyers, 2 Idaho, 793; Hosmer $t$. Wallace, $47^{\circ}$ Cal. 461; Randall $r$. Elert, 7 Minn. 450; Bellows $t$. Todd, 34 Iowa, 18.

24 If lesired. say "United States, to," ctc. The better practice, however, is as shown in the text, as the instrument does not purport to be anything more than an acknowledgment of the receipt of money by the person signing it. 
The foregoing statement immediately follows the note of entry, and to preserve chronological sequence, precedes the patent when that instrument is shown. In receipts and patents, no special designation of the property with reference to political divisions is made, but same is described as of a certain land district. This has been held to be a sufficient designation, the name of the county not being essential, and the land district sufficiently indicating the State. ${ }^{25}$

$\$ 135$. State Lands. Lands granted to the States for school and university purposes, as well as grants for internal improvements, are disposed of in much the same manner as the public lands of the general government. The special methor of their disposal is regulated by express statute in each State, and while the system in all the States is based upon, and closely follows that pursued by the general government, minor differences of detail preclude more than a general notice. In some States the disposal of the land is placed in the hands of the Governor and Secretary of State, who issue and sign all patents emanating from the State; in others it has been placed in the hands of a special commission, to whom is giren the power of disposal and control of the investment of the funds arising therefrom.

A certificate of sale of State lands is not sufficient to carry the fee, which, by analogy to the doctrine of sales of Federal lands, remains in the State until patent has issued. It entitles the purchaser, howerer, to the beneficial interest in the premises, and is sufficient evidence of title to rest in him the same rights of possession, enjoyment, descent, transmission and alienation of the lands therein described, and the same remedies for the protection of said rights, as against all persons except the State, that he would possess if he were the owner thereof in fee. ${ }^{26}$

The methorls of sale are ton widely divergent to inquire ints.

25. Mapes $r$. Scott, 94 Ill. 379.

26 This matter is purcly statutory. The reader, for greater certainty, will consult the statutes of his own State, both as to the legal effect of certificates of purchase, and the method of conducting sales. 
Thus, in Wirensin, sales of school lands are made by the commisioners of selued and university lands: ${ }^{2}$ in Illinois by the eonnty superintendents. ${ }^{2 s}$ Each State provides a mothod of its omn with special officers to excente the power.

A certificate of sale of State lands, like the tuplieate receipt of the receiver, is informal in substance, the main point being the execution by the proper statutery oficer. Its provisions are nenally preseribed by statute, and should consist of a description of the land soli, the smm pail, and where only a portion of the purchase money is paid the amont renaining dne thereon, the time, place and terms of pament, and that if it shall be duly diwcharged, the purehaser or his arigns will be entitled to a patent for such land. Is this matter, when followed by patent, is only introductury, the certificate nua be shown briefly as follows:

State of trisconsin to

Abraham Smith

Document, No. 300.
Commissioner's certificate, No. 104. Dated Ma!y 24. 1850. Riecorded Jume 1, 1550 . Book. " $1, "$ page 45.

A chnowledges receipt of \$26.50 in (part) payment for Lot six, in. Toun one north. Range mineteen east of the Fourth Principal Iieridinn, in the northuest quarter of Section sixteen fand thet said Abrehum Smith will be cntitled to a pat. ent therefor on payment of $\$ 230.00)$.

\$ 136. Whe Root of Title. The foregoing paragraphs have reference only to well ascertained beginnings of title, which may he traces with little difficulty from its source or fomtain hearl. In all States west of the Alleghanies, with possibly the exception of Kentucky and Temnesee, this may the casily aceomplished, and a purchaser may reasonably insist on the protuction of a chain of title from the gorernment. Such, however, is not alway done, and the cxaminer, from 
information furnished by the renlor, prepares a preliminary statement, resting mainly on tradition, in which is recited the condition and conrse of the title at some remote period, which is followed by a regular examination from that time, usually twenty years or more prior to the date of the abstract. This is following the English precedents, and is not without anthoritative usage in the Lnited States. Where information is difficult of access, or impossible of procurement from official or anthentic sources, as is often the case in the original States, snch a practice might be followed as the only available method, leaving the keemness of comnsel to detect flaws, and call for further evidence on desired points; but in the States formed from the territories where the rectangnlar system of surveying and registration of eonveyances prevails, no good reason exists why a complete abstract showing the inception of title should not be produced. Where a preliminary sketch is given as forming the root of title, the examiner should carefully speeify all his sonrees of information, and, if consisting of hearsay or tradition only, expressly disarow all responsibility for the truth of the matters therein recited. No other safe course is open, and the reader is apprised at the outset of the value to be placed upon the statement. 


\section{CHAPTER $X$.}

CONGRESSIONAL AND LEGISLATIVE GRANTS.

$\S 137$. Legislative grants generally $\S 139$. Construction of legislative considered.

138. Nature and effect. grants.

140. Formal requisites.

\section{$\S 137$. Legislative Grants Generally Considered. Not}

a few titles have their foundation in Congressional or legislative grants, or are grounded upon legislative confirmations of previously existing inchoate or equitable rights. A recurrence to these is necessary, eren though a patent may appear, as in many cases the patent is only confirmatory evidence of prior elaims and is conclusice only between the sovereign and the patentee or these in privity with him.

A grant of land by statute is the liighest and strongest form of title known to our law, and does of itself, proprio vigore, pass to the grantee all the estate of the government except what is expressly excepted. ${ }^{2}$ As a primary eonveyance, however, it is not in general use, for, as a rule, the government parts with its title only by patent, but when an act of Congress purports to eonvey land in words of present grant it is equally as effective as a patent and rests a perfect and irrevocable title. ${ }^{3}$

$\S 138$. Nature and Effect. The United States or a State may make a grant of land by a law as effectually as by a patent issued in pursuance of a law. In the former case it is the direct act of the govermment through the Legislature; in the latter it is a ministerial act under the direction of the Legislature. A confirmation by law of a claim of title in public lands

111 Opinions Att'y Gen. 47.

29 Opinions Att'y Gen. 253.

3 Strother $v$. Lucas, 12 Pet. (U.

S.) 454; Terrett $v$. Taylor, 9
Cranch (U. S.), 50; Chouteau $v$. Eckhart, 2 How. (U. S.) 372; Swann v. Lindsey, 70 Ala. 507; Dean $v$. Bittner, $7 \tau$ Mo. 101. 
is to all intents and purposes a grant of such lands, ${ }^{4}$ and where one is in possession of land, a resolve of the Legislature, releasing them to him, passes a title without any further act, except performance of the conditions, if any. ${ }^{5}$

An act of Congress, containing provisions clearly indicating an intention to pass the fee meonlitionally and absolutely, operates ipso facto, to vest the title in the grantee, but if the grant be coupled with a condition it will not operate to vest the title until such condition has been complied with. ${ }^{7}$

So, too, an act of Congress granting land to one person, is higher evidence of title than a patent of the same land subsequently issued by the officers of gorermment to another person, and can not be defeated by such subsequent patent; 8 thus, titles derived from the State, of lands selectert mider the "swamp grant," will take precelence orer patents from the United States issued subsequent to the date of the granting act. $^{9}$

Legislative grants and confirmations are usually followed by patent, the issnance of which is specially morided for in the granting act, yet the patent in most cases ards nothing to the force of the grant, but is merely confirmatory of what has preceded. If a claim be made to land with defined boundaries the legislative confirmation perfects the title to the particular traet, and a subsequent patent is only documentary evidence of that title. If the clain be to quantity, and not to a specific tract capable of identification, a segregation by surrey will be required and the confimation will then immediately attach the title to the land segregated. ${ }^{10}$

4 Challefoux $v$. Ducharme, 4 Wis. 554; Dean $v$. Bittner, 77 Mo. 101; Hall $v$. Jarvis, 65 Ill. 302 ; Langdeall $x$. Hanes, 21 Wall. 521; Strother $v$. Lneas, 12 Pet. 411; Field $v$. Seabury, 19 Ilow. 323.

5 Mayo v. Libby, 12 Mass. 339 ; Ryan $v$. Carter, 93 U. S. 78.

"Pallances $v$. Tesson, 12 Ill. 327; Grignons, Lessee, $v$. Astor, 2 How. 319. $\tau$ Thompson $v$. Prince, 67 Ill. 281.

s Doumman $v$. Ifooe, $W \mathrm{Wi}$. 466; Mezerle $r$. Ashe, $27 \mathrm{Cal}$. 82.

9 Ruigo r. Rotan, 29 Ark. 56 ; Koller $r$. Brisker, is lil. 13:i; R. R. Cо, r. Вrowm, 40 lowa, :3:3; Daniel re Purvin, 50 Mits. 201.

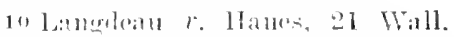
(L. S.) 5el; Swamu r. Lindisey, 70 Alı. 507; Dean r. Bittner, 77 Mo. 101. 
Analogons to the rule which obtains in case of patents, where there are two confirmations or grants of the same land, the cher must prevail, and will give the better title. ${ }^{11}$ The govermment, like an individual, has no power to withdraw or annul its grant: the first, if lawful, must stand, and the second can not operate as a consequence, for the reason that the grantor, when it was made, had no estate to conver. ${ }^{2}$

$\S 139$. Construction of Legislative Grants. A Legislative grant by the State is an executed contract, ${ }^{13}$ and as such is within the clause of the Constitution of the Cnited States which prohibits the States from passing any law impairing the obligation of contracts. It can not, therefore, be destroyed, and the estate divested by any subsequent legislative enactment. The rule applies with equal force to corporations as to indiviluals, and when the State enters into a contract with a municipal corporation, the subordinate relation of the corporation ceases, and that equity arises which exists between all contracting parties. The control of the Legislature over the corporation can be exereised only in subordination to the principle which seenres the inviolability of eontracts. ${ }^{14}$

Congressional grants are governed by the same rules, and a grant by Congress to a State can not be recalled at the will of Congress any more than a grant to an individual.15 Generally, in a conveyance by the sovereign, of property which is usually the subject of private ownership, the extent of the thing granted is to be ascertained by the rules of construction applicable to private conveyances; yet in construing a Congressional grant, it must be remembered that the act by which the grant is made is a law as well as a conveyance, and that such effect must be given to it as will carry out the intent of Congress; and that the rules of the common law must yield

11 Willot $r$. Sanford. 19 How. 79;

9 Opinions Att'y Gen. 253.

1211 Opinions Att'y Gen. 47.

13 Tlie Binghamton Bridge. 3

Wall. (U. S.) 51 ; Dartmouth College $r$. Woodward, 4 Wheat. (U.
S.) 625: Dingman v. People, 51 Ill. 267 .

14 Grogan $r$. San Franeiseo, 18 Cal. 590 .

15 Busch $r$. Donohue, 31 Mieh. 480 ; Rice $v$. R. R. Co. 1 Bl. 35 
in this, as in all other ease, to the legislative will. ${ }^{16}$. nother exception will be ob-erred in that the ordinary rule construing the grant most strongly against the grantor is hore reversed, and whatever is not giren expresiry, or very clearly implied from the words of the grant, is witheld. ${ }^{-1}$

\$ 1t0. Formal Requisites. To particular terms are necessary in a grant by Congress or the Legislature, ${ }^{18}$ which will vary with the exigencies of each particular case. In preparing a synopsis of such grants the eximial features to be observed are: the title of the act; the date of passage or approval; the subject matter, including the granting words, in the language of the act; and the conditions or restrictions, if ans, annexed to the grant. A practical example, taken from the files will better serve to illustrate the matter. Peter Poncin entered in dne form a certain tract of land. which entry was afterward canceled by the commissioner of the General Land Office, but not until Poncin hat made converances on the credit afforded by the entry. This cancellation was afterward set aside by special act of Congress and the claim of Poncin confirmed, with a further direction for a patent, which was subsequently issued. The land is now a portion of the city of St. Paul, Minn., and has become very raluable. As the inception of this title is somewhat complicated, a full detail of all the preliminary steps is important, and the abstract in this case should show: the original entry by Poncin: the subsequent cancellation: the confirmatory act of Congress; and finally the patent; the mesne converances by Poncin taking effect by relation. Examples of the entry have been given: the confirmatory act would appear much as follows:

16 R. R. Co. $v$. R. R. Co.. 97 U. S. 335; R. R. r. Litchfield, 23 How. 491.

(U. S.) 88 .

17 Mayor, ete., R. R., 26 Pa. St.

1s Coburn r. Ellenwood, i N. H. 99. 


$\left.\begin{array}{c|c}\text { United States }{ }^{13} \\ \text { to } \\ \text { Peter Poncin. }\end{array}\right\} \begin{aligned} & \text { Act of Congress, entitled "An act } \\ & \text { authorizing a patent to be issucd to } \\ & \text { Peter Poncin for certain lands therein } \\ & \text { described." } \\ & \text { Approved July } 27,1854 . \\ & \text { Recorded August 1, 1854.20 } \\ & \text { Bool. "C," page 560. }\end{aligned}$

Enarts, That the entry of Peter Poncin of the north half of the southeast quarter, and the south hatf of the northeast quarter of Section 3i, in the Stillwater land district, Minnesota, canceled by the Commissioners of the General Land Office, be and same is hereby allowed and reinstated as of the date of said entry, so that the title to said lands may inure to the benefit of his grantees as far as he may have conreyed same; Provided, that the purchase money shall be again paid at said land office, and that thereupon a patent shall issue in the name of said Peter Ponein for said lands.

Further enacts, That the Superintendent of Public Schools of Minnesota be and he is authorized to sclect other land in licu thereof.

This is one of the few species of conveyance that the examiner is justified in placing on the abstract when same does not appear of record in the county in which the land is situated; and where the records are silent, reference to other authentic sources of information must be inserted and attention drawn to the fact of non-registry. This is accomplished in the first instance by referring to the volume and page of the United States statutes, and in the latter by a foot-note, as follows:

Note.- At the date of this examination the foregoing instrument is not of record in Ramsey county, Mimnesota.

19 If desired, this may read "Confirmation by the United States," as this example is, strictly speaking, a confirmation rather than a grant.
20 These acts rarely appear of record in the county, in whieh event refer to the book and page of the U. S. Statutes. 
The foregoing example belongs to a class of private and local laws technically known as "relief" acts, of which vast numbers have been passerl at different times since the public domain has been open for sale and settlement. Is a patent usually follows all acts of this character the necessity of exhibiting them is not so great as in case of confirmations, for the latter not only serve as "acts of relief," but also operate as grants in favor of the confirmees. An abstract of a confirmation need not differ materially from the example last shown, the main object being to present all the operative parts of the law, but should the examiner desire a choice of phraseology in the arrangement of the formal parts a further illustration is herewith given.

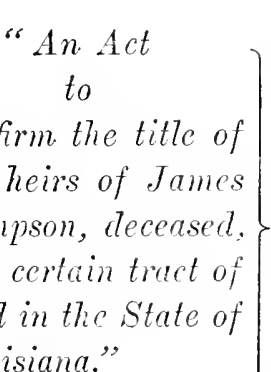

"confirm the title of "the heirs of James "Sympson, deceased. "to a certain tract of "land in the State of "Louisiana."
Act of Congress, entitled as in the margin.

Approved, Aug. 29, 1S42, Tol. 6, page $869, L$. S. Statutes at Large.

Enacts, that the heirs at law of James Sympson, deceased, late of Clarke County, Kentuchy, be and they are hereby confirmed in their title to a certain tract of land siturited at the mouth of the Atchafralaya, at its junction with the Mississippi River, containing 6.40 acres; and as surveyed and platted in the surveyor general's office at Donaldsonville, in the State of Louisiana, "ipon the survey made and returned by Charles Morgan, datcd February 11, 1S06, and executed for Andy Robinson.

Provided (it is stated) this confirmation shall only be construed as a relinquishment of the title of the United States to said land, and not to prejudice any superior or better title. 


\section{CHAPTER XI.}

PATINTS.

\$141. Definition. .

149. Patents from the United

\$ 154. Continued. States.

150. Validity.

151. Delivery.

155. Construction.

150. Formal requisites.

157. Patents from the State.

158. Continued.

152. General Land Onice record.

153. Operation and effect.

159. Formal requisites of State patents.

\$ 141. Dequition. A patent has been defined as a grant of sone privilege, property, or anthority, made by the govermment or sovereign of a country to one or more individuals, and the tem, as originally used in England, is said to have signified certain written instruments enanating from the king, and sealed with the great seal. These instruments conferred grants of linds, honors, w franchises, and wore ealled tetters patent from being delivered open, and, by way of contradistinction from instruments like the French Lettres de cachet, which went ont sealed. In the [nited States, the word is nsed to denote those instruments which secure to inventors, for a linited time, the exchuse nse of their inventions, but when nsed in connection with real property, it means the title deed by which a government, either State or Federal, conveys its lands.

\$ 149. Patents from the United States. A patent of the C'nited States is the conveyane by which the Tation passes its title to the publie domain and is the highest cridence of derivative title known to the law; it is conchnsive as against the goremment, and all persons claining nuder junior patents or titles, ${ }^{2}$ until set aside or annulled by some competent tribu12 Bou. Law Dict. 298.

2 Hooper $v$. Young, 140 Cal. 274. 
nal. When detivered to and accepted by the granter, it pasers the full legal title to the land, ${ }^{4}$ and carries with it the presumption that all the prerequisites of law have been complied with. 5 But the patent must show npon its face a regular issue, and a full compliance with the formalities of law, for a patent forms no exception to the rule, that the legal title to lands can not be conveyed except in the form provided by law. ${ }^{6}$ The principal requisites in this respect have reference mainly to execution and authentication. To conform strictly to the letter of the law, the patent must be signed in the name of the President, either by himself or his duly appointed secretary, sealed with the scal of the General Land Office, and conntersigned by the Recorder. Lntil all of these have been done, the United Sitates has not executed a patent for a grant of lands. Each and every one of the integral parts of the execntion is essential to the perfection of the patent. They are of equal importance under the law, and one ean not he dispensed with more than another. Neither is directory, but all are mandatory, and neither the signing nor the sealine, nor the countersigning, can be onitted any more than the signing or the sealing, or the acknowledgment by a grantor, or the attestation hy witnesses, when by statnte such forms are prescribed for the due execntion of deeds by private parties for the conreyance of lands. Where, howerer, the patent is regular mon its face, then a presmmption arises that it is valid and that it passes title, and it is, of itself, prima facic evidence that all the steps prescribed loy law for its proper issuance have been taken before it was executed."

$\$ 150$. Falicity. The prinary rules which control the

: Cnitid States v. Stone, 2 Wall. 5.5: Strong $v$. Lehmer, 10 Ohio st. !3; Strodard $v$. Chambers, 2 How. 284.

4 Moore 1 . Robbins, ( Ofto, 530; Jeeroy r. .Janison. :3 Sawyer, :369.

5. Sweat r. Coreoran, 37 Mist. 513; Hill r. Miller, 36 Mo. 182; Collius $r$. lartlett, 44 fal. 371;
Winter v. Crommelin, is $110 \% .87$; Stringer $r$. loung. 3 lete :30).

G NeGarahan $l$. New llia Mining Co., g( U. S. f6 Otto) 316 .

T Mefarralian $r$. Mining (o., 96 I. S. BIti.

sIleinlen $v$. Ifeilhron, 97 Cal. 10.5. 
validity of patents are not unlike those which obtain in conveyances between indiridnals. The government must possess title to that which it assmmes to convey ; the instrmment of conveyance must be in legal form, and it must have been issued by competent authority. Notwithstanding a patent may be exeented in due form its validity may yet be impeached, and at all times it is subject to inquiry as to whether the oficers who issued it had authority to make a conveyance, or whether the land which they purported to convey was within their control. If not, then the patent is absolutely void and may be attacked in any collateral proceeding. ${ }^{9}$

This follows from the fact that the true ofice of a patent, whether of a State or the Lnited States, is to pass title to lands in practically the same manner as the deed of an individual. It convers to the patentee all the interest of the govermment, whatever it may be, and, as a rule, is conclusive between them. But it does not establish the fact that the government possessed title, ${ }^{10}$ and hence is open to attack collaterally, the same as any other muniment which purports to convey possessory rights. ${ }^{11}$ Thus, it may be impeached, and its operation as a conveyance dereated, by showing that the department had no juristiction to clispose of the land; that is, that the law did not provile for its sale; or that it had been reserved from sale or dedicaterl to special purposes; or had been previously transferred to other's. In such erent the patent would be inoperative to pass title, and oljection to it conld be taken on these gromels at any time and in any form of action. ${ }^{12}$

$\$ 151$. Delivery. Tnlike conveyances between individuals, a formal delivery of a patent is not essential to its validity, nor will non-delivery thereof defeat the grant. ${ }^{13}$ The

9 Cummings $v$. Powell, $116 \mathrm{Mo}$ 473; Edwards r. Ralley, 96 Cal. 408 ; Doolan $v$. Carr. 125 L. S. 625.

10 Musser 2 . Mcliea, 38 Minn. 409.

11 Winter $v$. Jones, 10 Ga. 190.

12 Steel $r$. St. Louis Smelting Co., 106 L. S. 447.
$13 \mathrm{It}$ is the practice of the General Land Office to transmit patents, as rapidly as completed, to the various local offices for delivery on surrender of the duplicate receipt or certificates. Frequently, however, they remain uncalled for, and on the discontinuance of a 
importance attached to the delivery of deeds in modern eonveyancing aries largely from the fact that a deed has taken the place of the ancient livery of seizin, when, in order to give effect to the enfeoffment of the new tenant, the act of delivering possession in a publie and notorions manner was the essential evidence of the investure of the title to the land. This became gradually diminished in importance until the manual delivery of a piece of the turf, and many other symbolical acts, became sufficient. When all this passed away and the ereation and transfer of estates in land by a written instrument, called the act or deed of the party, became the usual norle, the instrument was at first delivered on the land in licu of livery of seizin, ${ }^{14}$ until finally any delivery of the deed, or any act which the party intended to stand for such delivery, became effectual to pass the title. ${ }^{15}$

No livery of seizin, however, was necessary of the king's grants, which were made matters of record, for when the seal was affixed to the instrument and enrollment of it was made, no higher evidence could be had, nor was any other evidence necessary of this act or deed of the king. Hence, Mr. Cruise in his digest says: "The king's letters patent need no delivery; nor his patents under the great seal of the Duchy of Lancaster; for they are sufficiently authenticated and completed by the annexing of the respective seals to them." In like manner when a patent for public lands has been made out and signed by the President, the seal of the Lnited States affixed, and the instrument countersigned by the Recorder of the Land Office and duly recorded in the reeord book kept for that purpose, it becomes a solemn public act of the government of the United States and needs no further delivery or other authentication to make it perfect and valid. ${ }^{16}$ When this has

local office all undelivered patents remaining in its files are returned to the General Land Otfice where they are assorted, filed and preserved. Sie Rep. General Land Uffice, 1875 .
14 Shep. Touch. 64; Coke on Litt. 266 b.

15 Chureh v. Gilman, 15 Wenl. 6.56; Warren v. Levit, 11 Foster (N. II.), 340; Hatch $v$. Jatch, 9 Mass. 306.

16 Gilmore $v$. Salp, 100 Ill. 297. 
been done the title to the land conveyed passes by matter of record to the grantee, and delivery, as in ease of the deeds of private individuals, is not neessary to give effect to the granting elause of the instrument. ${ }^{17}$

Theoretically, in order that the patent may take effect as a conveyance, it is essential that there be an aceptance on the part of the grantee, lnt the acts recquired to be done by him in the preparation of his claim are equivalent to a positive demand for the patent, and where the patentee does not expressly dissent, lis assent and aceeptance are always presumed from the beneficial nature of the grant. ${ }^{18}$ Some confusion has arisen as to the time when a patent takes effect, that is, when it becomes operative as a conveyance and binding upon both parties, from not distinguishing between acts which bind the govermment and acts which bind the patentee. No one can be compelled by the government, any more than by an individual, to become a purchaser, or erent to take a gift. Nor can the burdens or ardvantages of property he thrust upon him without his assent, and the patent of government, like the deed of a private person, must, in order to take effect as a conveyance and transfer title, be aceepted by the grantee; yet, as we have seen, the possession of property is so miversally considered a benefit, that, in the absence of express dissent, an acceptance is presumed whenever the conveyance is placed in condition for aceeptance, and this oceurs when the last formalities required by law of the oftien's of the government are complied with. By the execntion, scaling and recording, open and public declaration is made that, so far as the government is concerned, the title to the premises has been transferred to the grantee. The reeord stands in place of the offer for delivery in the ease of a private deed; and the instrument is theneeforth held for the grantee, who takes by matter of record. ${ }^{19}$

\section{\$ 152. General Land Orfice Recond. Patents do not}

17 United States $v$. Schurz, 102 I. S. 378; Lelioy v. Jamison, 3 Sin. 369 ; Houghton $v$. Hardenberg, 53 ('al. 181.
18 Pierre Mutelle case, 3 Op. Atty Gen. 654; LeRoy r. Jamison, 3 Saw. (C. Ct.) 369.

19 LeRoy $r$. Jamison, 3 Saw. (C. 
come within the provisions of the reending laws of the State, where the terms of the statute do not specifically include them, ${ }^{20}$ though it is menal to record them in the county where the land is situate, and snch registution, as a rule, is expressly permitted by statute. The act for the estal)limment of a General Land Office provides that all patents iswing therefrom "shall bo recorded in said office in book to be kept for the purpose," and the indorsement of such reeorel will alwars be fomd upon the patent. This indorsement should always be copied by the recording officer when presented for local registration, and a minute of same made by the examiner when prepraring the abstract. Direet and easy reference is this male to the highest source of information in case of the mutilation, loss or destruction of the original, thomgh, of course, reconrse may be had to it in other ways. This original reeord is not in itself a grant of title, but it is an evidence of equal dignity with the patent, because, like tho patent, it shows that a grant has been made.

The record called for by act of Congress is made by copying the patent to be issned into the book kept for that prupose, and such reeord, as a matter of evidenee, stands in the same position and has the same effect as the instrmment of which it purports to be a cony. ${ }^{21}$ The mblie reenels of the departments of the goverment are not, like those liept prusuant to ordinary registration lawe, intented for notice, hat for preservation of the evidence of the transactions of the department. Where the county records fail to show a patent, and no other divesture of governmental title aprears, reconve shonld be hat to the General Land Ollice, and the clamant's ti:le will be deternined, in the absence of other ciremustances, by what is there shown.

The failure to reroid the patrint lues not defeat the grant,

Ct.) 3e9; Green $v$. Liter, \& Cranch ([. S.), 247; Gilmore r. Sapp, 100

111. 297.

2" Moran v. Pámer, 13 Mich.
367 ; Curtis r. Inonting. 6 Iowa, $5: 6$.

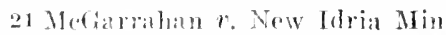
inge ('o., ti c)to, 316; Sands $v$. Balvis, 40 Mich. 14. 
but merely takes from the party one of the means of making his proof. If the patent itself can still be produced, and it is duly executed with all the formalities required by law, the patentee and his grantees may still maintain their rights under it. A perfect record of a perfect patent proves the grant, but a perfect record of an imperfect patent or an imperfect record of a perfect patent has no such effect. In such latter ease, if a perfect patent has in fact issued, it must be proved in some other way than by the record. The reeord of the patent, analogous to the doetrine of registration under State laws, is treated as presumptive evidence of its delivery to and acceptance by the grantee. ${ }^{22}$

§ 153. Operation and Efrect. A patent is a complete appropriation of the land it deseribes, ${ }^{23}$ and passes to the patentee all the interest of the United States, whatever it may be, in everything commected with the soil, or forming any portion of its bed, or fixed to its surface; in short, in everything embraced within the term "land." 24 It is conclusive evidence of the right of the patentee to the land described therein, not only as between himself and the government, but as between himself and a third person, who has not a superior title from a source of paramount proprictorship. ${ }^{25}$

When issued to a confirmee of a foreign grant, a patent operates like the deed of any other grantor, and passes only such

22 McGarrahan $r$. New Idria Min. C Co., 6 Otto, 316 ; LeRoy $v$. Jami wh, 3 Sawyer, 369.

23 Stringer's Lessee $v$. Young, 3 Pet. 320 .

24 Fremont v. Flower, 17 Cal. 199. According to the common law of England, mines of gold and silver were the exclusive property of the crown. and did not pass in a grant of the king under a general designation of lands or mines. It has sometimes been asserted that this prerogative right passed to or was inherent in the States, but this is an error. The jura relgalia which pertained to the king at conmon law, comprehended not only those rights which relate to the political character and authority of the sovereign, but also those which are incidental to his regal dignity, and may be severed at pleasure from the crown and rested in the subject. It is only to the rights of the first class that the States by virtue of their sorereignty are entitled, and mines of the precious metals belong to the second class. Moore $v$. Snow, 17 Cal. 199.

25 Waterman $r$ Snith, 13 Cal. 373. 
interest as the gorernment possessed, the deed taking effect by relation from the initiation of the series of proceedings for confirmation and of which it forms the last act. ${ }^{26}$ But as the record of the govermment of the existence and validity of the grant, it establishes the title of the patentee from the date of the grant, such title depending, up to the issuance of the patent, upon the character of the grant and the proceedings of the former government in reference to it. ${ }^{27} \mathrm{As}$ such record, with respect to the title of the patentee existing at the date of the cession of the foreign territory, it is conclusive evidence of title in the patentee at the time the jurisdiction of the subject passed from the foreign government to the United States. ${ }^{2 s}$ It is the evidence which the government furnishes the claimant of its action respecting his title. By it the sovereign power, which alone conld determine the matter, declares that the previous grant was genume; that the claim under it was valid, and entitled to recognition and confirmation by the law of nations and the stipulations of the treaty; and that the grant was located, or might have been located, by the former government, and is correctly located by the new government, so as to embrace the premises as they are survesed and described. ${ }^{29}$ A patent issued on a confirmed foreign grant, is, therefore, in the nature of a conveyance by way of quit-claim. It is conchsive only as between the parties thereto, and is evidence that as against the Cnited States, the validity of the grant has been established. ${ }^{30}$

$\S$ 154. Continued. The Government of the United States has a perfect title to the public land and an absolute and unqualified right of disposal. Neither State nor territorial legislation can in any manner modify or affect the right which the government has to a primary disposal; nor can such legislation deprive the grantees of the United States of the possession and enjoyment of the property granted by reason of any delay in

26 Yount $v$. Howell, 14 Cal. 465 ; Leese $v$. Clark, 18 Cal. 535.

$2 \tau$ Teschemacher $v$. Thompson, 18 Cal. 11. 2s Leese $v$. Clark, 20 Cal. 387.

29 Leese $v$. Clark, 20 Cal. 387.

30 Adam $v$. Norris, 103 U. S. 591. 
the trunser of the title after the initiation of procedings for its acrunition."3r Whather the title to a portion of the public lands han fureed from the Enited States depends exchsively mon the law of the Lnited States; when it has passed, it then herones suljeet to State laws. ${ }^{32}$ These statements acquire anditinal innurane from the fact that in a majority of the Westem staten the entry has, for many years, been recognized an the hasis of a legal title, and in actions of ejeetment has frequently ben received as smchl but in the federal comrts the patant is held to be the fundation of title at law, and neither party can bring his entry before the comrt. ${ }^{33}$

1 prechaser from one holding under a patent is not bound to low behind the patent to learn if it was properly issued to the ore entitlal to it, ${ }^{84}$ for the instrument is in itself presumpire evidence that all prior proceedings are logal, ${ }^{35}$ but every purchaser is prestmed to have notice of any defect of title apparent upon its face, ${ }^{3 i}$ and is chargealle with notice of whatever the patent recites. ${ }^{3 i}$

I patent issued to a fictitions person is a mullity, ${ }^{38}$ as is also a patent ismed to a person deceased, ${ }^{39}$ but the heirs of a deceased person will take a valid title to the land so conreved to a deceased aneestor ${ }^{40}$ under speeial aets of Congress. ${ }^{41}$

15.r. Construction. It is a rule of construction generally applicable to public grants, that such grants are to be con-

31 Tnion Yíll, etc., Co. $r$. Ferris. 2 Sawyer. 170: Gibson 2 . Chouteau, 13 Wall. 62 .

32 Wileox 1 . Tarksun, 13 Pet. 498. 33 MeArthur $r$. Browder. 4 Wheat. 48s; Fem r. Holmes, 21 How. 481.

34 Schnee $r$. Schnee, 293 Wis. 877. 35 Barry $r$. Gamble, 8 Mo. 88; Ninter $r$. Crommelin. 18 How. 87 : Stringer $r$. Youmer. 3 Pet. 320.

$\because$ Bell r. Duncan. 11 Ohio, 192. 3) Inited States $r$. Land Grant Co.. 21 Fed. Rep. 19.

38 Thomas $v$. Wyatt, 25 Mo. 24.
39 Galt $r$. Galloway, 4 Pet. (U. S.) 345 ; MeDonald $v$. Smalley, 6 Pet. (C. S.) 261 .

4" Calloway $r$. Finley, I2 Pet. (U. S.) 264 .

41 In 1836 Coingress passed an act to give effect to patents issued in the name of deceased persons which provides, that the title to the land dosignated in such patents shall in. ure to and become rested in the heirs, devinees or assignees of such deceased persons as if the patent had heen issued to the deceased person during life. 
stried most farorably to the public and inost strongly against the grantee; that nothing passes by such grants except what is expressed in meciuivocal language, and that whatever is not unequirocally granted is deemed to be withheld, nothing passing by implication. In late cases, however, it has been held, that this rule does not apply, at least to its full extent, to grants made upon adequate valuable onsiderations, but refers lather to gratuitous grants made by the sovereign upon the solicitation of the grintees. ${ }^{42}$

But little room for construction will ordinarily be found in patents, and when rules of construction are invoked it is usually to determine matters relating to description. In such cases it has been held that the entire description of the lands given in the gatent nunst be taken together, and the identity of the land aseertained by a reasonable construction of the language used. If, however, there be a repugnant call, which, by other calls of the patent, elearly appears to have been made through mistake, the patent will still be valid and the anbiguity or doubt which may arise may be explained in the same manner and under the same rules that obtain between privat grantors and grantees. ${ }^{43}$

\$ 156. Formal Requisites. As has been seen, less for. mality is required in grants from the sovereign than in deeds between individunls, the main essentials having reference to the facts of exeeution. The instrument usually consists of an acknowledgment of payment for the land granted, and a conreyance thereof by a description conforming to the terms of the government survey. This, with the execution, is all that is found in the average patent, particularly when issued to a purchaser in the regular course of disposition aceording to pre-

42 Langlon $v$. New York, $93 \mathrm{~N}$. Y. 12!); Charles River Britge $v$. Warren Bridge, 7 lick. (Mass.) 34t. The reason generally given for the rule is, that in a grant proceeding from the application of the sub. ject, the grantee ought to know what he asks, and if that does not appear, nothing shall pass from the sovereign by reason of the meertainty.

4:2 Boardman $r$. Reed, o Pet. (U. S.) 328 ; MoIver $x$. Walker, 9 (rinch (U. S.), 173. 
seribed legal formulas. The abstract of such an instrument is as simple as the original, and would corer all the essential points if made as follows:

\begin{tabular}{|c|c|}
\hline United States & Patent. \\
\hline & Certificate, No. 520. \\
\hline to & $\begin{array}{l}\text { Dated Feb. 1, } 1860 . \\
\text { Recorded Feb. 25, } 188 s .\end{array}$ \\
\hline Wr & Book 15, page 90 \\
\hline
\end{tabular}

Grants, The Northeast quarter of Section ten, Town two North, Range twenty-three, East of 3d P. M., Milwaukee Land District.

General Land Office, record 100,5:0.

Where the patent is issued in pursuance of a confirmation or act of Congress, the matter of inducement will nsually be found immediately preceling the granting clause, and in such case a brief recital should be made in the abstract setting out the substance or purport of the matter of inducement.

It will often happen that a patent has been duly issued and delivered to the patentee, but through neglect has not been placed on record in the registry of deeds of the county where the land is situatc. To remedy the defect of title thus produced, where the original document can not be found, it is customary to procure an exemplification of the General Land Office record and this, when recorded, practically takes the 1) lace of the original patent. In abstracting such instruments the commissioner's certificate should always be shown, and this may be done, substantially, as follows:

Appended is:

A certificate dated Dec. 2, 18si, by Jno. M. Brown, Commissioner of the General Land Office, Washington, D. C., under the seal of said office, that the "annexed" copy of Patent to Francis W. Wallier, founded on Milwaukee, Wis. cash entry No. 500, is a true and literal exemplification from the records of "this office." 
\$ 157. Patents from the State. The lands belonging to the State are distinguishable into two general classes: 1st. Those which it owus by virtue of grants from the Cnited States. 2d. Those which it owns by reason of its sorereignty. The original thirteen States and Texas entered the Union as landed proprietors. In the remaining States, with but a few exceptions, as Vermont, whose territory was claimed by Xew York and New Hampshire, etc., ${ }^{44}$ the original title to the soil was in the general govermment. The States entering the Union as sovereign proprietors, claim original and ultimate title in all their lands, while the class of lands, in States formed from the territories, belonging to the State loy reason of its sovereignty, includes only the shores of the sea, and of its bays and inlets. Snch lands, called "marsh" or "tide" lands, are such as are covered and uncovered by the ebb and flow of the tide, but are susceptible of reclamation so as to

44 Kentucky was part of Virginia, Tennessee of North Carolina, and Maine was claimed by Massachusetts. The territory "northwest of the river Ohio" was originally elaimed by Virginia, and was conreyed to the United States by the deed of cession of March 1, 1784, as a common fund for the use and benefit of all the States, "upon condition that the territory so ceded shall be laid ont and formed into States, containing a suitable extent of territory, not less than 100 , nor more than 150 miles square, or as near thereto as circumstanees will admit; and that the States so formed shall be repuhliean States and admitted members of the Federal Union, having the same rights of sovereignty, freedom and independence as the other States." The State of Georgia, hy dred of eession, dated April 24,1802 , substantially the same as the Virginia cession, conveyed the territory forming the present State of Alabama. The remaining territory was anquired by purchase and emquest. The cesions of Crenrgia and Virginia were aceepted by the Cnited states, and the mumicipal eminent domain held as a trust for the new States to be formed in conformity to the deeds of eession, the details to be regulated by the act of Congresa known as the ordinanee of 178\%. Lpon the admission of the new States nothing remained to the United States, according to the terms of the agreement, but the public lands, and upon their disposal the power of the surulal govermment over these lands, as property, also ceated, leaviner tho State in undisputerl sovereignty, including the ownership and dominion of her navigable waters and the soil under them. See Pullarl r. Hagan, 3 How. (U. S.) 212; Fredman $\%$ Goolwin, 1 MrAlister, 142; Ward v. Mulford, 32 Cal. 365; Farrish $v$. 
be male raluable for agricultural or other purposes. ${ }^{45}$ This doctrine of title by sovereignty also prevails in some of the inland States, and is applied to the submerged lands covered by narigable lakes and streams upon the borders and within the boundaries of the State. ${ }^{46}$

The State can make no disposition of the lands it holds by virtue of its sovereignty prejudicial to the rights of the public to use them for navigation and fishery, but it may dispose of them for the purpose of promoting the interests of navigation, or of reclaiming them from the sea, where it can be done without prejulice to the public right of navigation. ${ }^{47}$

The title to lands under tide waters within the realm of England was by the common law deemed to be rested in the king as a public trust to subserve and protect the public right to nse them as common highways for commerce, trade and intercourse. The king, by virtue of his proprietary interest, could grant the soil so that it should become private property, but his grant was subject to the paramount right of public use, which he could neither destroy nor abridge. The laws of most nations have sedulously guarded the public use of the narigable waters within their limits against infringement, subjecting it only to such regulation by the State, in the interest of the public, as is deence consistent with the preservation of the public right. ${ }^{48}$ The title to lands under tide waters in this country, which before the Revolution was vested in the king, becanne, upon separation of the colonies, rested in the States within which the lands are situated. The people of the State, in their right of sorereignty, succeeded to the royal title, and through the Legislature may exercise the same powers, which, previously to the Revolution, could have been

Coon, 40 Cal. 33; Barney $v$. Keokuk, 94 U. S. 336 : Shively $r$. Parker, 9 Or. 504.

45 People $v$. Morrill, 26 Cal. 336; Ward $r$. Mulford, 32 Cal. 365; Simpson $v$. Neil, 80 Pa. St. 183; Coburn $r$. Ames, 52 Cal. 385; Hinman $\because$ Warren, 6 Oreg. 408; Pol- lard $r$. Hagan, 3 How. (U. S.) 212. 46. Musser $v$. Hershey, 42 Iowa, 356 ; Barney $v$. Keokuk, 94 U. S. 324 ; Benson $v$. Morrow, 61 Mo. 345.

47 Ward $x$. Mulford, 32 Cal. 365. 48 Andrews, J., in People $v$. Ferry Co., 68 N. Y. 71 . 
exereised by the ling alone, or by him in conjunction with parlianent, subject only to thos restrictions which have been imposed by the constitntion of the State and of the Lnited States. ${ }^{49}$ A molined form of this doctrine has been alopted by States adjacent to the great lakes.

\& 15s. State Patents-Continued. It will be seen, therefore, that in the Colonial States, as well as in the State of Texas, the original and paramount sourec of title is the State. In all the States formed from national territory, except as the sovereign prerogative above mentioned has been asserted, the patent from the State is only a mesne converance of an older and pre-existent title, depending for its validity upon the preliminary steps by which the State acquired ownership to the soil. In tide water States, notably Alabama, California and Oregon, where the doetrine of original title by virtue of sorereignty has been strongly asserted, a State patent or grant may, in some cases, form the foundation of an unassailable title; but in the interior as well as in States bordering on the great lakes, where no perceptible tile is found, the State while exercising dominion wer its water ways, has usually eonceded the ownership in the soil covered therebs to the aljacent riparian proprietor, who would hold, whatever might be the mesne conreyances, from the United States in virtue of the original divesture by patent, grant, or otherwise. The rule, in this respect, is not uniform, however, and in some of the States Ladering on the great lakes, as in Illinois, while title to the bed of streams is conceded to the owner's of the banks, the land under the waters of the lakes is held by the State and the title of the riparian proprietor stops at the shore. ${ }^{50}$

$\$ 159$. Formal Requisites of State Patents. The formalities to be observed in patents emanating from the State have reference to the statutory requisites relative to issuance and execution, and while the instruments closely follow the forms adopted by the national goverument, minor differences of detail will yet be found, varying with the locality. Or-

49 Lansing $v$. Smith, 4 Wend. 9.

5o See, People v. Lineoln Park Comr., 162 Ill. 138. 
dinarily a State patent, in analogy to those issued by the gencral government, is under the hand of the chief magistrate, and authenticated by the great scal. Such a course is, homever, by no means uniform, the statute often prescribing other and different formalities. Thus, in Wisconsin, the commissioners of school and university lands are alone authorized to eonvey such lands, and that power can not be transferred to others; hence a patent issued by the Gorernor and Sceretary of State, although in conformity to the general statute regulating patents, would be coid and inoperative to pass the title to that particular class of lands. ${ }^{51}$ Thus it will be seen that in State, as in national patents, the excention, according to prescribed regulations, is after all the main point of inspection in abstracting these documents.

51 MeCabee $r$. Nazzuchelli, 13 Wis. 478. 


\section{CIIAPTER XII.}

SURVEYS, PLAT'S AND SUBIIVISIONS.

$\S 160$. General remarks.

161. Division of the public domain.

163. Subdivision of sections.

164. Rectangular surveying.

165. Meander lines.
$\S 166$. Plats and subdivisions.

167. Formal requisites.

163. Effect of registration.

169. Vacation and cancellation.

170. Dedieation hy plat.

171. Re-surveys.

$\$ 160$. General Remarks. A fair knowledge of the principles of surveying is indispensable to good work on the part of either examines or counsel. In traeing devious paths and intricate windings of the title through the media of uncertain, ambiguous or faulty descriptions, as well as where, by minute subdivisions, and irregular shaped parcels, the proper location of the land becomes a matter of careful measurement or ealculation, this knowledge will be found of the utmost importance. A knowledge of the governmental divisions of the county is also necessary to intelligent inquiry, and the same is generally true of subsequent subdivision either by publie authority, as case of torn plats, or subdivisions by individuals. Where the examination is complicated by questions arising from description, counsel should first familiarize hinself with the relative position of the land, and, when the examiner has furnished no plats, can greatly facilitate his labors by the use of sketch maps prepared by himself.

$\$$ 161. Divisions of the Public Bonain. The public lands of the United States are ordinarily surveyed into reetangular tracts bounded by lines eonforming to the cardinal points, according to the true meridian. ${ }^{1}$ The largest of these

1 This system, which is essentially American in all its details, was reported from a committee of Con- gress May 7th, 1784. Thomas Jefferson was the chairman of this committee, and to him the eredit 
divisions, called a township, is a borly six miles square, having reference to an established prineipal base line on a true parallel of latitude, and to a longitnde styled a prineipal melidim, and contains, as near as may be, 20,0 to acres. The twruships are sublivicled into thirty-six tracts, each one mile square, called scclions, and containing, als near as may be, 610 acres. The dirision is accomplished by ruming throngh the township, each way, parallel lines at the end of every mile. Iny number or series of contignons townships situate north or south of each other constitute a range.

$\Lambda$ s it is imposilble to strictly follow the letter of the law in regard to the public survers, owing to the convergency of the merilians, an inequality develops, increasing as the latitude grows higher. The excess or defieiency is added to $\mathrm{or}^{\circ}$ deducted from the westem or northern ranges of sections or half sections in each townhip according as the error may be in rmning the line from east to west or from north to south. To obriate, in sone measure, the errors that otlerwise would result from the convergency of meridians, standard parallels, or, as they are usmally temed, "correction lines," are established at stated intervals," while what are known as "guide meridians" are also surveyed at regular distances. ${ }^{3}$

The townships bear numbers in respect to the base line, either north or south of it, and the ranges bear numbers in

of its invention is usually accorded. lut beyond tive committee's report, its origin is not positively known. It is thouglit the square form of States, provided in Tirginia's decel of cen-inn of lue western territory, nay have influenced Mr. Jefierom in favor of a square form of survers, although in the colony of Georgia a sinare from of surveying had been in vogue in eleven townships for fifty years prior thereto.

2 correction lines are run east and west from the principal merid- ian and contitute special bases for town-hip lines lying north thereof. Such lines are rum and marked at vely four tuwnships, or twentyfour miles nuth of the base, and at every five townships, or thirty miles, south of same.

3 Guide meridians are surveyed at distances of every eight ranges of townships, or forty-eight miles, east and weet of the principal merilian: the grides north of the prineipal base starting either from it or from standari parallejs. 
respect to the meridian line according to their relative position to it either east or west.

The sections are the smallest tracts, the out boundaries of which the law requires $t$, be actually surveyed. Their minor subdivisions are defined by $1 \cdots, \mathrm{v}$ and are designated by imaginary lines dividing the sections into four quarters of 160 acres each, ant these an turn into quarter-quarter sections, of 40 acres each. The thirty-six sections into which a township is subdivided are numbered consecutively commencing with section one at the northeast angle and proceeding west to section six; thence proceeding east the sections number to twelve and so on alternately until the number thirty-six in the southeast angle.* The accompanying diagram will serve

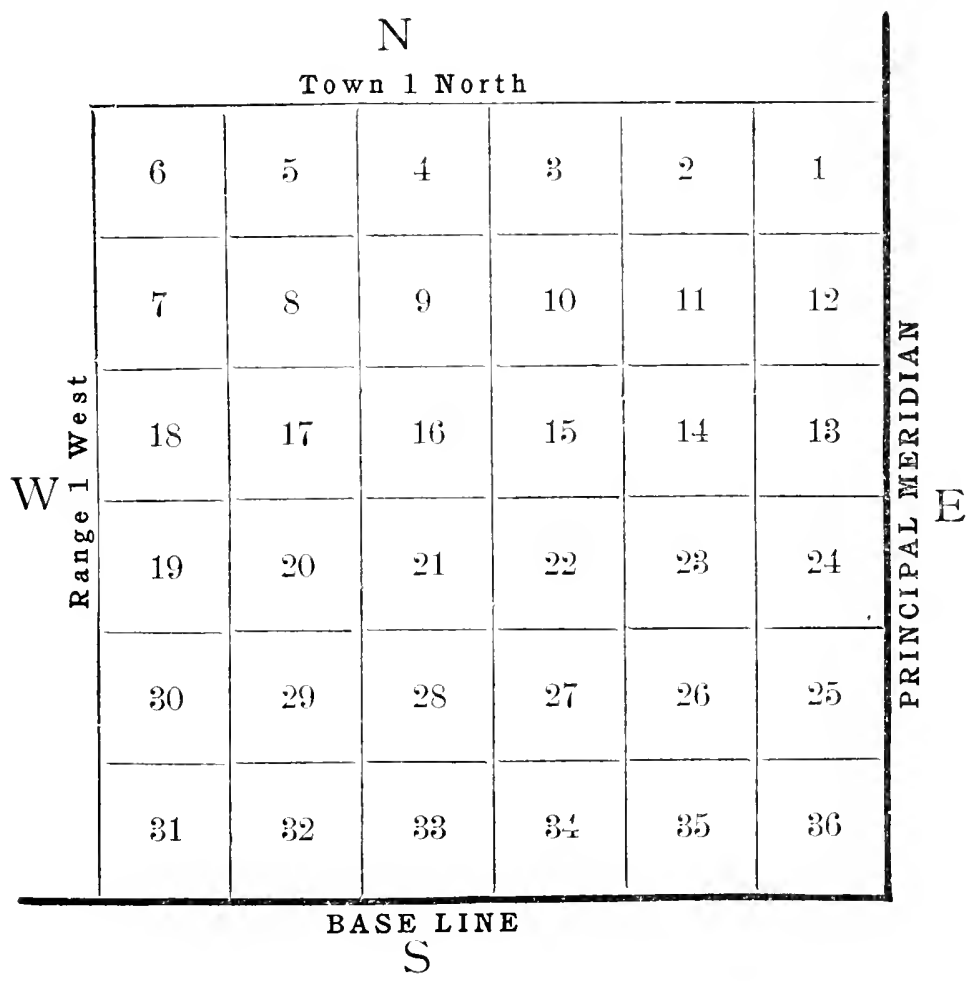

4 Sep Zabriskie's or Lester's U. S. important topies. The lines and Land Laws for full details of these corners of land established by the 
to illustrate the method of running the exterior lines of townships and sections.

The official township plats, of which mention has already been made, will furnish all the information necessary to a thorough understanding of each particular township, and show, in addition to a general topographical delineation of the surveyed territory, the exact area of each section, excesses, deficiencies, meanders of navigable streams, islands and lakes and all other details necessary for surveying or subdivision; as, wituess monuments, section and quarter section corners, etc.

$\S 163$. Subdivision of Sections. Although the section is the smallest division of public land, the lines of which are actually run by the government surveyors, smaller divisions are contemplated by law and provision is always made for their rearly ascertaimment, which is done by ruming true lines from one established point to another. These legal subdivisions vary from a quarter section, containing 160 acres, to a "quarter-quarter" section, containing but 10 acres. The shape and area of the sectional subdivisions will be better understood, perhaps, by reference to the following diagram.

The illustration contemplates only an ordinary survey, where no obstacles intervene to interrupt the symmetry of the map, or interfere with the runing of the lines, nor does it provide for deficiencies or excesses, which will usually occur in sections $1,2,3,4,5,6,7,18,19,30$ and 31 , the greatest diserepancy being found in section 6 . The section lines are surveyed from sonth to north on true meridians, and from east to west, in order to throw the excesses or deficiencies

government surveys when it was first surveyed, plattor and recorded must control, when they can be ascertained and identified; lut when such lines and comers are in doulst, and a matter of muel uncertainty and dispute, the parties may settle them and thus ond the dispute: and when they have ngreed upon the position of such boundary, and lave acted upon it as the true line, they are estopped from asserting another and a different line: Yates $r$. Shaw, 24 Ill. 367 ; Thomas $r$. Sarles, 63 I1l. 363. But parties holling simply an agreenent that might ripen into an equity can not make agreements as to surveys which will he binding on a subscquent holder of the legal title: Sawyer v. Cox, 63 Ill. 130. 


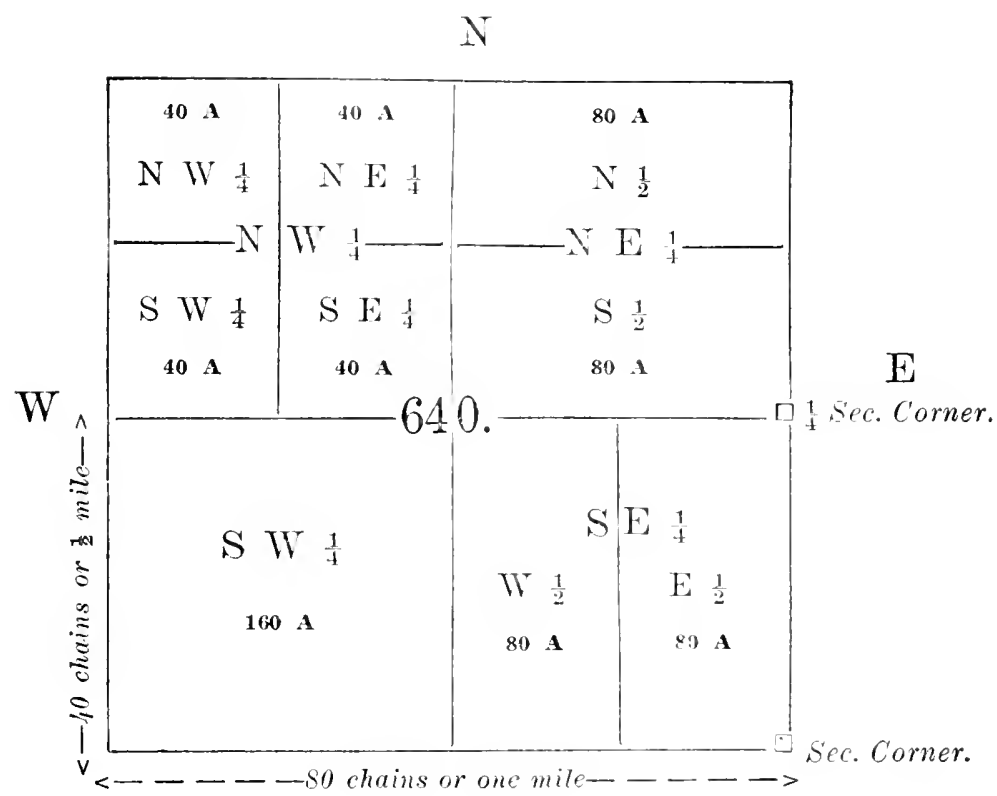

$\mathrm{S}$

in measurement on the north and west sides of the township, and, as the sphericity of the earth must nocosarily interfere with the correctness of measurements calculated for a level area, it will be found that the sections and half--ections on the northern and westem lines of a township will always vary from the prescribed legal standard. The legal presumption is, however, that the section contains 610 acres.

The section and quarter section corners are established as indicated in the diagram; the half quarter soctions are not marked in the field, but are regarded by the law as point: intermediate between the half mile, or quartor section corners."

The smallest parcel indicated on the formening map is a quarter-quarter section, with an area of 10 anpen, this being the limit of sublivision reenguized by the gerement. If required, however, this tract may be divilfed in the same man-

5 Act of April 24, 182 
ner as a section and the various parts described by the same general terms.

Where navigable lakes, streams, ete., intereept the surreys, they produce fragmentary divisions known as "fractional" sections, quarters, etc., the divisions of a fractional section being also known as "lots." Meander corner posts are established at all those points where township or section lines intersect the banks of such rivers, bayous, lakes, or islands as are by law directed to be meandered, and the courses and distances on meandered navigable streams govern the calculations wherefrom are ascertained the true areas of the tracts binding on snch streams. In the sale of such fractional tracts or lots, which always conform, as near as may be, to the size and shape of the regular subdivisions, the specific lot is sold by the acreage as returned by the gorernment surveyors, and reference is always made to the field notes and plats for certainty of deseription, boundary, etc. The ammexed diagram will serve to illustrate the subject more fully:

$\mathrm{N}$

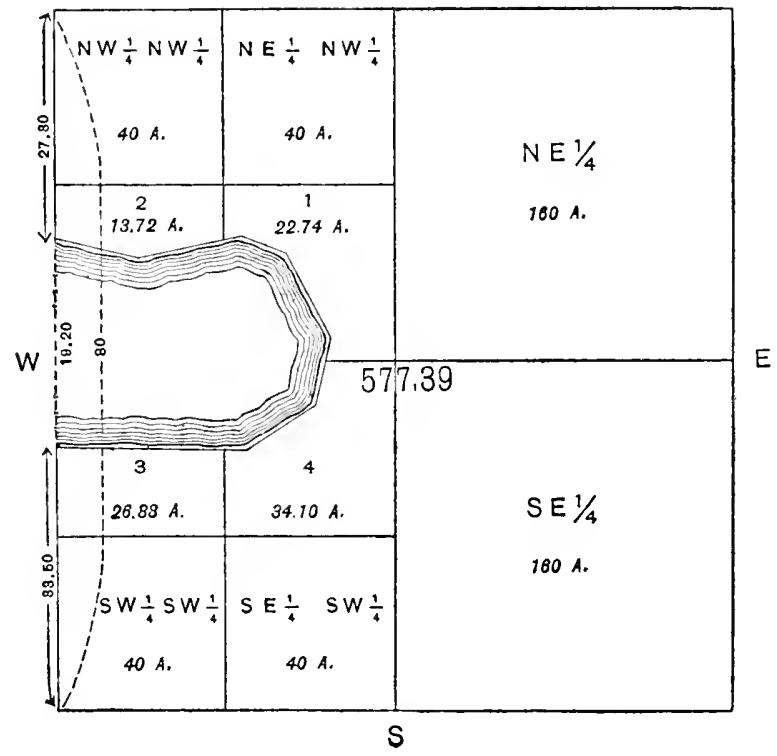


While meander lines follow, in a general way, the sinuosities of the lyank of the strean or lake, yet the linfs themselves are always straight. This is necessary for the purpose of accurate neasurement. Their only office, lowerer, is to facilitate measurement; they de not eonstitnte boundaries of the tract. The rater is always the boundary. ${ }^{6}$

Interspersed thronghont the rectangular surreys of the publie domain, are survers of nmmerons bodies of land of anomalous and irregular foms corered by titles known as "Private Land Claims," which the gevermment of the Lnited States, under treaty obligations, or from other considerations, has confirmed. These titles derive their origin from rights acquired under the sorereignty which once held dominion wer the territory now constituting part of the Lnion, and from donations under the laws of the Lnited States. The survers of snek titles are in strict accordance in measurement, form, and extent with the land system of the government from which the titles are derived.

In compiling the abstract it is advisable to prefix thereto a sketeh of the govermuent surver as shown by the official township plats, and particularly should this be done when the subject of the examination consists of a fractional section or lot. Such sketch will be of great service to comrel and serve to illustrate and define the boundaries of the land far better than any verbal description can. Where land hinds upon a navigable meandered stream or lake, aceretions and relictions will oceur, materially changing the shore line, and here the sketch will prove very serviceable in fixing the original boundaries, as well as in determining present rights.

$\S 164$. Rectangular Surveying. The rectangular system of survering abore described has now been in operation in the United States for more than one hundred years. ${ }^{\tau}$ Its arlvantages over other methods consist in its economy, simplicity

6 This is particularly true in those States where the bed of streams and lakes belongs to the State.
7 It was formally adopted May 20, 1785 . 
in the process of transfer, brevity of description in deeding the land by patents, and in the convenience of reference of the most minute lecal subdivision to the eomers and lines of sections, ${ }^{s}$ the convenient mode of sublividing sections with a view to economy and to facilitate sales of small tracts being an essentially marked feature. The prineipal base, principal meridian, standard parallels and guile meridians constitnte the framework of the rectangular system of public surveys, and there are at present permanently established twenty-three prineipai bases and thirty principal meridians, ${ }^{2}$ controlling the public surveys in the land States and territories.

As a general rule, the public survers are governed by one principal base and principal meridian, but in a few districts and on the Pacific slope, a number of different initial points are necessitated by abrupt momntains thronghout the district. The lines of public surveys over lovel ground are measured with a four-pole chain of sixty-six fect in length, ${ }^{11}$ eighty chains constituting a mile; but where the features of the comtry are broken and hilly, a two-pole chain is nsed. The lines and comers thus run are marked and perpetuated by blazing trees, stones, mounds or other momments, the witness monnments, bearings and distances being ascertained and described in the ficid notes.

The boundaries and contents of the several sections and furrter sections are ascertained in conformity to the following rules: "The boundary lines actnally rm, and marked in surveys returned, shall be established as the proper bomdary lines of the sections or subdirisions for which they were intended; and the length of sneh lines, as returned, shall be held and considered as the true length thereof; and the bound-

S See Zabriskie's Land Laws, 508; Instructions Commr. Gen. Land Office, Hay 3, 1881; Govermment Mamual of Surveying. 1883.

9 These are divided into six numerical meridians and twenty-four indenendent meridians named after the locality which they control.
10 Commonly known as a "Gunter"s chain." It is composed of one humbred links. Twenty-fire of these links make one rorl, but, in practice, rods are now seldom used, distances being talken in chains and links. See appendix for tables of measures. 
ary lime wheh shall not have been actually rmu and narked as aforesaid, shall be ascertained by ruming straight lines from the established corners to the opposite corresponding corners; but in those portions of the fractional towndhips where no such opposice correponding corners have been or ean be fixed, the said bomdary line shall be ascertained by rumning from the established corners due north and sonth or east and west lines (as the case mar be) to the water-compe or other external boundary of such fractional township." 11

\$ 16.5. Wrander lines. Neander lines are rm, in surreying fractional portions of the prblic lands bordering on navigalle rivers, not as bomlanies of the tract, but for the purpose of defining the sinnosities of the bank of the strean, and as the means of ascertaining the quantity of land in the fraetion subject to sale, and which is to be paid for by the purchaser. $^{12}$ Fractional dirisions, mate so by the interference of water, are designated and sold by the number's attached to the lots, and reference is always had to the notes of surver. The water indieated in these noter is alwars the bundary, and where there exists a difference between the meandered line as run and the existing line of the rater-comse, the latter and

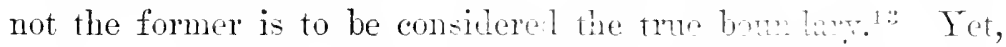
though a meandered line is generally consilerel an following the winlings of a stream, it seems the quesion whether it does so or not max alwars be determined by evidence ciliunde, and the mere fact that it is run and designated mon the plats as a meandered line is not conchusive against the goremment: thus, it has been held, that an entry of worernment land, bomicd by a meandered line, does not include land fying at the time between such meantered line and the bank of the river. ${ }^{1 t}$ So, too, while the meander line is not, in strict sense, a bomdin'y,

111 Stat. at Lorere, 440 ; 2 Stat. at Large. $73 ;$; (1). : 313 .

12 R. R. Co. R. Flumarir. T Wall. (L. S.) 272 ; Lanprey r. Stato. 52 Minn. 181.

13 Boorman $v$. Sumnucks, 42 Wis.
2.3.): Wonck r. Yatex, 8? 111. 179; Lomprey $r$ state se Mim. 191.

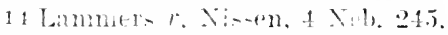
lint see Wright $r$. Day, $2: 3$ Wis. 260, and authorities last cited. 
yet if there is no body of water corresponding to the meander line, to which the ownership of arljoining lands extends, then the line limits the extent of the land conreyed. ${ }^{15}$

Where fractional pieces of land are patented, bounded in part by a stream or bayou, the original plat may be resorted to, and the lines as originally run will control. This is the rule adopted in determining controversies between contiguous proprietors of fractional lands, the patentees, and those claiming under them, being restricted to the boundaries as shown by the plats and field notes. In all cases, where land is made fractional by a narigable water-con'se, the patentee purehases by the plat, and a patent for a fractional part of a quarter section on one side of a water-course, where the area sold is noted on the plat of the fractional tract called for by the patent, will not extend his entry and purchase across the stream, so as to embrace that part of the quarter on the other side. ${ }^{16}$

$\$ 166$. Plats and subuivimionss. Agricultural lands seldom receive any other subdiriding than that afforded by the government surver, but in rities, towns and villages, the necessities of society require a most minute subdivision into what are popularly termed blocks and lots. ${ }^{1 \tau}$ Original subdivisions again become the subject of resubdivisions, and these in turn are not infrequently divided to meet the exigencies of social or busines relations. The formal act of resurveying is teehnically termed a subdirision; the result of the surver, when projected ryon paper, a plat.

$15 \mathrm{As}$ where a meandered lake had dried lip. Carr $r$. Moore, 119 Iowa, 152.

14 Mecormitk $r$. Inuse, 78 Ill. 363.

17 The term "lot" seems to be peculiar to Ameriean land pareelins. Its orignin is mknown. It does not apper to lave any allinity with the term as used in oher connections, as "a lot of goods," otc. It is said that the word, in commection with land, orjginated in the colonies and grew out of the eustom of diviling grants into parecls and then numbering each parrel. The numbers would then be plaeed in a hat, or some other receptacle, and drawn out by those among whom the lind was to be livided. Each man woukl then take the parcel eorresponiing to the nomber he had diain, and ats his land laad come to him, literally. by lot, it soon became enstomay to speak of the land as a lot, and the usage has ever continued. 
These subdivisions and plats play an important part, both in conreyancing and in the examination of titles, and upon them no small portion of the validity of land titles rests. In every community of any appreciable size, lands are conveyed and described with speeial referenee to these plats and subdivisions, the government surrey being referred to only incidentally and for the purpose of greater certainty in locating the particnlar tract which forms the subject of the plat. They form equally as important features in preparing an abstract as the title deerls there shown, and recuire the same degree of care from the examiner in their exposition. Where a deed of converance gives no other description of the land than the lot or block of a survey or sublivision, the authentic plat of such survey is as much a part of the deed as if set out in it, ${ }^{18}$ and a referenee to a plat is as effective by way of estoppel as express words of grant or eovenant. ${ }^{19}$ A reference to a plat by lot and block has usually a more controlling influence than a special description, and when a designation by lot is followed by a description by metes and bounds enbracing an area less than the lot, it has been held to import an intent of the grantor to convey the whole lot, the law presuming the addition to be merely an efiort to give a more particular deseription. ${ }^{20}$

$\S 167$. Formal Requisites. The formalities attending the platting and subdividing of land are the subject of express statutory regulation in all the States, and, unlike deeds, there are no common or uniform methods, each State providing its own system of platting and authentication. Ordinarily the plat must show the shape and extcrior boundaries of the land it is intended to represent, and of each subdivision thereof; the length and courses of all boundary lines; the monuments erected in the field; and the name of the tract so divided, as well as the streets, alleys, etc., shown thereon, together with the width of such strects, alleys, ete. Appended to the plat there must usually be a description of the land surveyed, officially certified by the surveror and a certificate of acknowledgment

18 Dolde $r$. Vodicka, 49 Mo. 100 ; Powers $r$. Jackson, 50 Cal. 429. 10 Baxter $v$. Arnold, 114 Mass.
$577 ; \operatorname{Cox} r$. James, 45 N. Y. 557. 2 " lintherford $x$. Tracy, 48 Mo. 325. 
by the owner or owners of the lant. In addition, municipal regulations sometimes require an approval by the civic authoritirs. The foregoing, or sinilar requirements, are usually made indispensable requisites to registration, and their faithful observance is necessary to give ralidity to the subdivision. As a rule, no field notes are required, the dimensions shown upon the plat being sufficient for all practical purposes.

Plats are usually recorded in the registry of deeds in special books, though this is not a uniform practice, and where no specific regulation exists they will also be found in other places. Thus, arhitrary divisions made by the assessor for the purposes of taxation will frequently be fomm in the office of the anditor or clerk of the county; plats made by the order of a court of chancery in partition, and other cases, will be found among the records and archives of the court, though these observations rather apply to what has been than to present practices. At the present time all plats, particularly in the newer States, are required to be filed with the recorder of deeds. The following will sorve as a precelent for abstracting a plat and subdivision, the minor details of which must be varied to snit the demands of loeal legislation.

$\left.\begin{array}{c}\text { Subdivision } \\ \text { Wy }\end{array}\right\} \begin{gathered}\text { Ptnt, entitled [here set out the title } \\ \text { as found on the plat, and proceed as } \\ \text { lereinafter shown]. }\end{gathered}$

Or, if desired, commence it thus:

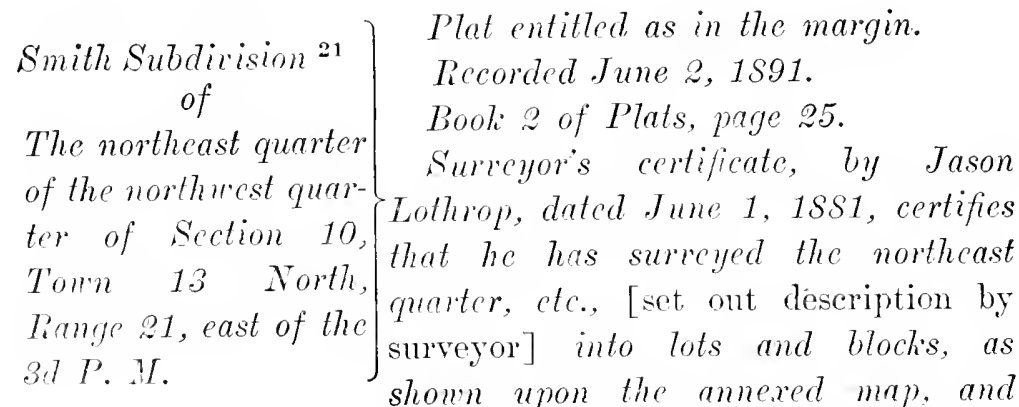
th.t s.id map is a correct representation of all the crterior

21 This is taken from the title of the plat, and should consist of a literal transcription. 


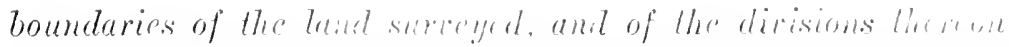
made, and further certifies that said surtey and map wess mate by the order and disection of thillinene smith, and that he has fully complied with all the procisions of law in surterying, subdividing and mapping same.

[Should notes of survey be tilent in ardition to the wap, they may be shown or not in the discretion of the examiner, or as his client may direct.]

Acknowledged by Willim smith, as omner, June 2, $18 S 1$. Said map is as follou's (or), by direction. we omit the map.

Usually, if the nuap is small, it is antmmary to insort it.

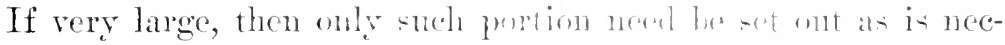

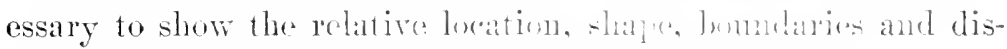
tances of the particular lot or lots muler examination.

In this event, the conchuling paragranh shonlet reat:

So much of said map as relates lo the property in question is as follows:

It is recommended that wheneres practicalle the plat or some portion of it be shown. It is nually of cmetrierable assistance to comnel, and if the examination involves niceties in measurements, or conficting clains of contignous propnietors, it is indispensable. If the law repnires attuting witnewes any defect of this nature should be noted, as also any imperfect or defective execution. Plats and sublivisions made ly executors, administrators and guardians, as well as in partitions between heirs and tenants in common are freupuntly made under the direction and sanction of a court of opuity, and in this event a general synopsis of the proceding in compt, as well as the acts of the owners or parties interested, shmlit be shown.

$\S 168$. Erfect of Registration. When duly axeroted, acknowledged and recorded, as provided by law, a certified comy of a plat and subdivision may be used in evillenee to the same extent and with like effect as in case of deeds, and by statute 
such registration and acknowledgment is usually made to operate as a conveyance in fee simple of those portions of the platted lands as are marked or noted on such plat as donated or granted to the public, or any societs, corporation or body politic, and as a general warranty against the donor, his heirs and representatives, to such donee or grantee for their use, or for the use and purposes therein named or intended, but for no other use. The parts intended for streets, alleys, ways, commons, or other public uses, are held in the corporate name of the mumicipality in trust for the uses and purposes set forth or intended. ${ }^{22}$ Selling by a plat which has not been recorded is a misdemeanor in many of the States.

$\$$ 169. Vacation and Cancellation. The making of plats and subdivisions being regulated, in the main, by statute, no uniform rules can be given as to the method of racation or cancellation, and reconrse numst be had to local law, as in the case of platting and recording. Ordinarily a plat mas be vacated by the owner of the property, at any time before he has disposed of any part thereof, by a written instrmment declaring such intention, executed, acknowledged or proved, and recorded in like mamer as leeds of land. Such a declaration, duly recorded, usually operates to destroy the force and effect of the recording of the plat so racated, and dirests all public rights in the streets, allevs, public grounds, ete., laid out or described in such plat. ${ }^{23}$ The record of the plat so vacated should also refer to the racation.

The foregoing describes the common and most simple manner of vacation. In some States, however, more formality is required, frequently rendering necessary the intervention of a court, as well to anthorize the initiation of proceedings as to approve of such as may be taken. ${ }^{24}$ Where an application is required to be made to a court, notice is also required to all whom it may concern. In the former case of vacation a syn-

22 See R. S. Ill. 1845, p. 115; do. 1874, p. 771 ; R. S. Wis. 1878, p. 645; see infra, "Dedication by Plat," page 179 .
23 R. S. Ill. 1874, Chap. 109, § 6. 24 R. S. Wis. 1878, Chap. 101, $\S 2265$. 
opsis of the instrument filed is all that is necessary in the abstract; in the latter, a resume of the steps taken as well as the judgment or order of the comrt is necessary. The effect is practically the same in wither case both as to the owners and the pulblic. When madr by a dredaratory statement, the abstract would be substantially as follows:

$$
\begin{aligned}
& \begin{array}{l|l}
\text { Vacation }^{25} & \text { Declaration of racation. } \\
\text { Datod Jan. 31, } 1883 .
\end{array} \\
& \text { of }
\end{aligned}
$$
dale, being Fred. Schmidt's subdivision of part of the who is the sole owner of all the lands south 2,300 chaius of the southeast quarter of section 3.3, town $3 \%$ north, range 14. east. Chains of the sontheast quarter of secof the $3 d P .11$. in the C'ounty of Cook, and State of Illinois, recorded June $21,18 \% 4$, in book 'y of plats, page 8.3, under the provisions of the statute, sets aside the subdivisions referred to and racates the same for the purpose of iestoring the property to its originat condition, meaning and intending to declare vacated, and does declave vacated the whole of said plat.

Acknowledged Jan. 31, 1883.

Whenever practicable, a racation should immediately follow the abstract of the subdivision and plat thereby affected. This can always be done where no conveyances have been made. Where portions of the property have heen sold and the owners join in the execution of the vacation, the dech to then will intervene in elronological order. As a rule, there can be no racation of a portion of a plat containing a dedieation of land to

25 Instead of this caption the examiner may say, "Vacation by Frederick Schmidt," and then set out the title of the plat vacated in the right-hand margin. 
a public use minless all of the owners of all lots sold with reference thereto juin in the proceeding. ${ }^{26}$

\$ 170 . Dealeation by phat. Where a dedication to publie nee is songht to be established from the acquiescence of the omner in the use of the lingrery by the public, or from acts or dechations of an equisual character, which are consistent with a delicativin to the public nee, or to the mere permissive use by the public for a temporary though indefinite perion of time, the intention of the owner in permitting such wise is mquetionably of controlling influence and importance in determining whether property has been dedicated by the omner to pubic ne or not.2 But where the dedication is elrarly manifested by imequivocal acts or declarations, upon which the public or those interesten in such dedications hare acted, the fact that the owner may have entertained a different intention from that manifested by his arts or declarations is of no consequence. ${ }^{2 s}$ Therefore, if the omer of lmal sublivides and plats the same, or lays out and establishes a town or any adlition thereto, and malies and exhibits a map or plan of such town or addition, with strects, allers, public squares, etc., and sells the lots with reference to snch map or plan, the purchascrs acquire, as appurtenant to their lots, all such rights, priviloge, easements and servitules represented by such map or plan to belong to them, or to their owners, and the sale and conveyance of lots according to such map implies a grant or covenant, for the benefit of the owners of the lots, that the streets and other public places represented by the map shall never be appropriated by the owner to a use inconsistent with that represented by the map on the faith of which the lots are sold. ${ }^{29}$

If the owner of land indicates by the map, or other un-

26 Village of Lee $\boldsymbol{v}$. Harris, 206 111. 428 .

27 Dillon Mun. Corp. § 498; Irwin $r$. Dixon, 9 How. 30; Manderschild $r$. Dubuque, 29 Iowa, 73; Godfrey $v$. City of Alton, 12 Ill. 29 ; Rees $v$. Chicago, 38 111. 322. 2s Lamar County $v$. Clements, 49 Tex. 347 .

29 Lamar County $r$. Clements, 49 Tex. 347; Huber $v$. Gazley, Is Ohio, 18; Logansport $v$. Dunn, 8 Ind. 378; Beaty $v$. Kurtz, 2 Pet. 566 . 
equirocal acts on dreclurations, that a particular lot or square is to be reserved or amplicul to a particular or specifie use, of a quasi pullic chararter, and such as to induce purchasers of contignous or neiglowing lots to give a higher price than they otherwice would, the nece to which such lot was to be appropriated would no doubt bo a reseration, and not, strictly speaking, a derication to public nee. Bnt, nevertheless, the difference, so far as the owners of lots purchasol on the faith of such reservation are concepned, is merely nominal. for the owner of the property who thus sells it is estoped from appropriating the land so reserved to a purpose inemsistent with that for which it was reserved, or he will be held by such sale to have ereated a servinule in the property reservel in faror of the dominant estate, which he has convered, which will prevent his applying the recred properts to any other purpose than that for which it was resered. ${ }^{30}$

As a general promition the fre does not pass by a derlication but remains in the original proprietor burdened with the public use; but in a statutory dedication, by making and recording a plat, the fee passes as an incident and is held by the municipality for the nee and benefit of the public. ${ }^{31}$ in immortant distinction will therefore be made between a common-law and a stctutoing dedication.

As a necesary seguence, where the title of one who makes a dedication fails, the dedication alon fails; but if the owner of the title recognizes the dedication, as where there has been a plat made by the one whose title has failed and the true owner deeds lands accolding to the plat, he will be estopped from denying the dedication. ${ }^{32}$

- \$171. Re-surveys. Occasionally re-surecs are marle, when, by reason of time or circumstance, the original surey fails to furnish the desired information. The only olject of a re-survey is to determine the lines of the oricinal. and lome

3n ITarrion $r$. Boring, 44 Tex. 25.); Com. $x$. Puhh, 14 Penn. St. 186.

31 Manly $v$. Gibson, 13 Ill. 308;
R. R. Co. r. Molint, 7) Hll. 2.5. This is statutory. Consilt lowel siatnites.

32 Gridley $\imath$. Hopkins. 84 Ill. 528. 
it will never be permitted to change or alter the lines of the old survey whenever such lines can be ascertained from monuments or other authentic data. In every instance the monuments set by the original survey and named or referred to in the plat, are the highest and best evidence from which to determine lines. If these are lacking the stakes set by the survesor may be resorted to, and, in the event that these can not be found, buildings or pemmanent ereetions shown to have been constructed according to them may themselves be considered monuments and proper eridence for locating the true lines.

The disturbance of ancient lines and boundaries is discouraged by the courts as tending to create confusioni and the unrest of titles, and this is particularly the case where, as often happens, municipal officers attempt arbitrary re-survers for the purpose of correcting or changing the lines or boundaries of a torn. ${ }^{33}$

33 See, Racine $v$. Emerson, 85 Wis. 80 . 


\section{CIIAPTER XIIT.}

FORMAL PARTS OF DEEDS.

\$ 172. Operative parts of a deed.

173. Names of the parties.

174. Grantors.

175. Cirantees.

176. Nature of the instrument.

177. Date of instrument.

178. Registration.

179. Consideration.

180. Efiert of consideration.

181. Worets of grant.

182. Word of inheritance and linitation.

183. Description of property.

184. Deseription-Sufieciency.

185. Description-Identification.

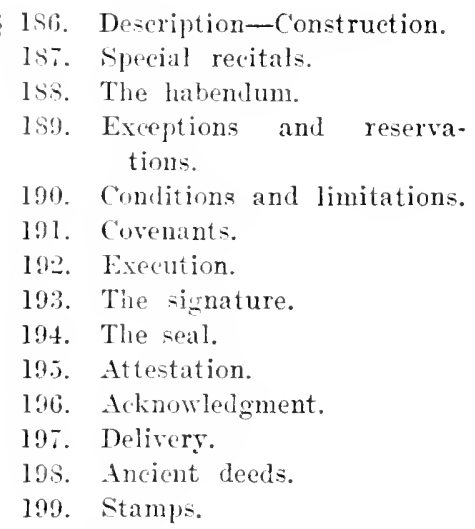

$\S 172$. Derative Parts of a Deed. In making an abstract or srnopsis of a deed of converance, the essential features which require notice on the part of the examiner are as follows :

The names of the parties, grantor and grantee respectively, with full descriptio persone, including the character in which they act.

The nature of the instrument.

The dates respectively, of execution and registration, together with the rolume and page of the registry.

The consideration, or other matter of inducenent.

The operative words of grant, inheritance and linitation.

The description of the land or property conveyed.

The habendum, whenever it assumes to limit or qualify the grant.

Reservations and exceptions from the grant.

Covenants and conditions. 
Restrictire clanses, and directions respecting the uses to which the land shall be applied.

Special recitals.

Execution and attestation.

The acknowledgment and certificate of conformitr.

A mmber of the forewoing parts nust appear in erere abstract, while a few need only be thown when they become naterial: the question of materiality to be deciled by the examiner from the circunstances dereloped in each particular case. $A$ luief review of the foregoing licals will be made in the sneceeding paragraphs and the subjects will also receive further consideration in other parts of the work treating of specific conveyances.

S 17\%. Names of the Parties. As there can be no valid decd withmt grantors to give ${ }^{1}$ and grantecs capable of taking, ${ }^{2}$ the partios to the converance form the first natural inquiry. In the alstract they shond be shown with the same certainty of ilentity as in the oriomal instruments, together with any imprect designation, coror or omission appearing on the face of the doen or lenticen inferentially from a comparison with other instmuents in the chain. Errors or onissions, howerre slict on trivinl, should alwars be mentioned in such a manner a is ?, ing them to the attention of any person who may fonce the abtract, ant, when necescary, such mention may be sumlenented by the examiner's prirate note, or by retuences to other instruments shown in the same examination. The names of the partics should form the caption to the srmonsis, and are nenally written in the style of a legal caption or entitlement in court pleadings, on the left hand marein of the shect and mited by a bracket.

\$17. Grantors. The names of the grantors appear sevcral times in a deerl. They are usually inserted among the first recitals of the premises, acempanied with a description of the peren and other particulars as to residence, marriage, capacity, ete. Frequently they again appear in the corenant

1 Whitaker $r$. Miller, 83 Ill. 381. Mon. (Ky.) 545; Douthitt $v$. Stinlett $r$. Garnett, 7 T. B. son, 63 Mo. 268 . 
elause and fually in the exeention. In abstracting a deed the names, wherever witten, shmild be carefully comprared with each other and variances in the granting or eovenanting clauses as well as in the exention and acknowledgment, properly noted. The donestic relation of either or any of the grantors, if stated, shomld always be given with the same particularity as the original.

At common law the deed of a married woman is absolutely void, ${ }^{3}$ but by liberal and progresive legishative enactment, this rigorous and sexmingly unjust rule has been practically abrogated. The examiner will therefore note the changes of the law in this respect, as applied in his own State, and carefully observe that all the recquirements of the statute, at the late of the deed, have been substantially eomplied with, as a matried woman can only be dirested of her property or interest in land in the mode which the Legislature has preseribed.

Though it is the miversal prartice of enreyancers to insert after the names, the residence and not infrequently the occupation of the parties, there appears no good reason why these matters should be transferred to the abstract. The question of alienage is set at rest in most of the States ly special legislation, while the chain of converances is usually sufficient to prove identity withont referriug to residence or occupation. Some examiners give the residence of parties only when they reside without the State, as an aid in determining their identity in the scarch for judgments, or to enable counsel to further prosecute inquiries raised by the abstract and not answered therein. The matter is optional with the cxaminer and may be omitted or not in his diseretion. Special descriptions, particularly when explanatory of the eapacity in which the parties act, ${ }^{5}$ should be giren rerbatim. This direction acquires adeli-

3 Fowler $v$. Shearer. 7 Mass. 14;

Lane $v$. Soulard, 15 Ill. 124 .

4 Mason v. Brock. 12 Ill. 2i3; Garret $v$. Moss, 22 Ill. 363; Heaton $v$. Fryberger, 38 Iowa, 185.
5 As heirs at law of a deceased person: devisee of a certain tentator; widow of a former grantor, etc. 
tional force when such descriptions indicate representative or ofticial character.

$\$ 175$. Grantees. Nost of the foregoing remarks on grantors apply with equal force to grantees, and the same care shonld be observed in reciting and describing them. The names of the grantees are found in the operative part of the premises, and occasionally are repeated in the habendum, though the references which follow are usually to "said sccond parties." Inperfect designation, errors and omissions should be treated, so far as may be, in the same general manner as in case of grantors, though these circumstances are not so apparent when applicd to grantees, and usually must be deduced inferentially or by comparison.

It is essential to the validity of a conreyance that it be to a grantce capable of taking and of proper identification; hence, a deed to one who had died prior to its execution ${ }^{6}$ or to a person not in being, ${ }^{\top}$ or to a corporation which has no legal existence, ${ }^{8}$ would be a mullity, and pass no title to any one. ${ }^{9}$ The same result would follow from a deed to the heirs of a living person named therein without giving the names of the heirs. ${ }^{10}$ So, too, a conveyance to Jno. Sinith \& Co. would, at law, ${ }^{11}$ have the effect to vest the title in Jno. Smith alone, ${ }^{12}$

6 Hunter $r$. Watson, 12 Cal. 363.

7 Morris $r$. Candle, 178 Ill. 9; Heath $v$. Heath, 114 N. C. 547; Davis $v$. Hollingsworth, 113 Ga. 210. But this, of course, refers only to a deed conveying a present estate.

8 Donthitt $r$. Stinson, 63 MIo. 268.

9 Douthitt $v$. Stinson, 63 Mo. 268 ; Hornbeck r. Westbrook, 9 Johns. (N. Y.) 73 ; but although no grantee be named, if the grant be nade for a specific use, a trust will often be ereated which a court of equity will protect, and, if neessary, appoint a trustee and compel a eonreyance to him of the legal title. Bailey $r$. Kilburn, 10 Met. (Mass.) 176.
10 Hall $r$. Leonard, 1 Pick. (Mass.) 2r; Winslow $v$. Winslow, 52 Ind. 8. In a similar ease in Tennessee, however, it was held that the word "heirs" should not be taken in its teehnical signifieation, hut to mean "ehildren," and that the deed took efiect as a present grant. See Grimes $v$. Orrand, 2 Heisk. (Tenn.) 298 .

11 The several members of a firm can not be regarded, in the view of a court of law, as holding real estate as tenants in common, amless it be conveyed to them, as such, by name.

12 Arthur $x$. Webster, 22 Mo. 378; Winter $r$. Stock, 29 Cal. 407: Gossett $v$. Kent, 19 Ark. 607; Barnett v. Lachman, 12 Nev. 361. 
a firm name not bing a sufireist naming of the grantce; yet it seems that this may le reganded as a latent ambiguity which may be explatised by pront, "while in equity, he would be

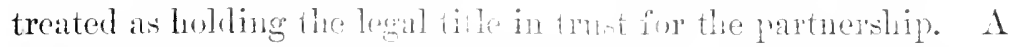
conveyance to John sinith \& wom womid be effective, lowerer, as "son" is a sultiviont worel of purcluse, and, similarly, a deed to Smith \& . Jumes of a drignater place, would be lowally sufficient to pass title to Johis Sinith and Thomas Jones, it being shown that they were engaged in business as partners at the place naned. ${ }^{14}$

An absolute conveyanee from hushand to wife. while roid, at law, will generally he uphehl in equity, and will vest the title in the wife as against the heirs of the husbanc.. ${ }^{5}$

A deed to a party by a wrong lonptisnal or Christian name will yet vest title in the intended granter, ${ }^{10}$ extrinsic evidence being admissible to explain mistakes or prove identity, ${ }^{17}$ and if upon a view of the whole instrument the grantee is pointed ont, the grant will not fail, even thongh the name of baptism be not given at all. 18

When two persons bear the same name any desiguatory quality mentioned in the deed should bu shown, as " JP.," 19 " 2 d," etc., and for the purpose of mov centain identifieation it is often well to ald the residence of the partics if given. If father and son bear the sane name, muless explaincd, the grant will be taken as one to the father. 20

13 Mury r. Blackledge, 71 X. C. and see Scanlan $r$. Wright, 13 Pick. 492.

14 Menage $r$. Turke, 4: Mimn. 211 ; and see, Kelley $r$. Bowne, 1.5 Oreg. 476.

15 Putnam $r$. Bicknell, 18 Wis. 333 ; Dale $r$. Jincoln, 62 111. 22; Sherman $v$. Ilogland, 54 Ind. 578.

16 Staak $r$. Sifolkow, 12 wic. 234; but see Crawford $t$. Spencer, 8 Cush. (Mass.) 418.

17 Peatbody $r$. Brown, 10 Graly (Mass.), 45.

1s Newton v. Mcliay, 29 Mich. I; (Mass.) 5:3.

19 The worl " $\mathrm{J}_{1}$ " " forms no part of the name of the person to whose nane it is 11 andly affixed, but is minely domintive of the person intended, and is usially adoptent to designate the son where father and son both lave the sande Christian name as woll as fomily nome. Pat gett r. Lawwerne, 10 latige (N. Y.). 170 .

20 Stevens r. Wret, if Jones (N. (.), 4!): P'aldente r. Lawrence, 10 Paige (N. Y.), 170 
No person can take a present estate under a deed unless named therein as a party, and the habendum can never introduce one who is a stranger to the premises to take as grantee, ${ }^{21}$ thongh he may take by way of remainder, but where the granteo's name has been omitted in the premises, if the habendum be to him by name, his heirs, etc., he takes as a party, and the defect is cured. ${ }^{22}$ Far less strictness is required as to capacity, etc., in grantees than is observed in case of grantors, and few of the disabilitics which encompass the latter are applicable to the former. Corerture, infancy, lunacy, etc., form no bar to the grant, but as a rule, to be valid, it must be to a corporation, or to some certain person named, who can take by force of the grant, and hold in his own right, or as trustee. ${ }^{23}$

$\S 176$. Nature of the Instrument. After the recital of the parties, the next inquiry of importance is the nature of the conveyance, which can be ascertained only from a general surrey of the entire instrument. The name of the docnment should be written on the right hand margin of the shect in the mamner hereafter shown, and should be sufficiently full to indicate its true purport. The name of the particular kind of deed has, of course, no legal efficacy or vahe, but serves as a fitting introduction to the synopsis, and apprises the reader at the ontset of its import and character. Where the deed is made with general warranty it is described in the abstract as a "Warranty Decd." This will be a sufficient reference to the covenant. So, too, if the instrument is a quit claim, and is so describer, no necessity will exist for setting ont the operative words of conveyance or other recitals. If the instrmment departs from conventional forms it may be described simply as a "Deed," and so much of the special matter shonld be giren as will enable counsel to determine its specific character and operative effect.

$\S 17$. Date of Instrument. The date of the execution

21 Slair $v$. Osborne, $84 \mathrm{~N}$. C. 417 ; Hornbeck $v$. Nestbrook, 9 Johns. 73.
22 Lawe $r$. Hyde, 39 IVis. 346.

2: Jarkson r. Cary, S Johns. 385;

Newton v. McKay, 29 Mich. 1. 
of the deed should follow next in opder, and may consiot simply of a line embodying thre tact, as,

Dated July 10, 158\%,

or, if withont date, a statement to that effect. The date is no part of the substance of a leer, $2^{+4} n o r$ is it essential to its validity, ${ }^{25}$ the converance taking elferet only from its delivery but the date may beeone impurtant in detemining questions of priority, ${ }^{27}$ or in ascertaining whether all the statutory requirements at the tinc of the excoution of the deed have been complied with. The dato of a deed, in the absence of other proof, is presumed to be the true date of its execution, ${ }^{2 b}$ as well as delivery, ${ }^{29}$ and is the time fonn which title in the grantee should, in most cases, be computed."

As deeds are now drawn, the date usually forms the initial recital of the premises, though it may frepuently be found in the testimonimm dause, and in case of discrepancy the latter should, it seems, be taken as the true date. ${ }^{31}$ Though the expressed date of a deed is immaterial to its operation and effect, ${ }^{32}$ and may under ordinary circumstances be contradicted or explained, yet when taken in comection with conditions or stipulations annexed to the grant, it may become important in fixing the time for the performance of any act by grantor or grantee, and in such case can not be varicd by panol. ${ }^{33}$ Should the instrmment be without date, the date of acknowledgment

24 Jackson $r$. Sehoonmaker, 2 Johns. 230; Meach $r$. Fowler, I4 Ark. 29; Costigan $r$. Gould, 5 Denio, 290.

25.Jackson $r$. Bard, 4 Johns, 230; Blake r. Fish, 44 Ill. 302 ; Thompson $v$. Thompson, 9 Ind. 323 .

26 Thatcher $r$. st. Andrew's Churel, 37 Mich. 26it; Whitaker $v$. Miller, 8:3 Ill. 381.

27 see title "delivery."

2s Darst $r$. Bates, 51 11l. 439; Smith $r$. Porter, 10 Gray, 66.

29 llardin $\boldsymbol{r}$. Crate, 78 Ill. 553.
30 Breckenridge $r$. Torld, 61 Am. Dee. 83.

31 Morrison $t$. Caldwell, 5 T. B. Mon. (Ky.) 436. In formally drawn deeds where the date is stated in the premises the testimonimm recital is usmally "the day and year first above written" with. out specific mention.

32 Ilarrisen $r$. Trustees of Phillips" Acaleny, 12 Milss. 456.

:3is Joseph $v$. Biglow, 4 Cush, (Mass.) S.2. 
may be presumed to be also that of execution and delivers. ${ }^{34}$

\$ 17. Fegistration. For comvenience, the particulars of registration should follow the date, though many examiners preter to insert them at the conchusion of the synopsis ats a proprer logical sequence. On the perusal of the abstract, low ever, these facts are best read together, and, to facilitate the labors of comsel, should be placed as first indicated. The only matelial facts concerning registration are, the date of record and the rolume and page on which the instrument is recorded: which should be stated briety and concisely. In case of rerecord, the date, volmue and page of the former record may be given after the synopsis as a sumplemental font-note. Is the general subject of legistration has alleady been quite fully noticul, but little need be further said at this place.

The date of record is important in passing on questions of priority, particularly when the instrument is itself withont date, and it acquires an additional impontance in those states where, by statute, it must be recorded within a specified time to secule Ireference over other conveyances or against creditors.

Whenerer puaticable, it is recommended that all information be taken direct from the records. Lnt oceasionally it will happen that through the tardiness of the enrolling ofticers, deeds, and other instruments are not actually transcribed nutil long atter they have been tiled for recond. In this event the examiner, in order to fully cover the period of his search, must have recomse to the original docmurnts, but it is further recommended that after the syopsis of all such documents, the examiner append the following:

Note. - The particulars of the foregoing conveyance taken from the originat instrument.

s 179. Cousideration. The ensideration named in the deed next follows, and whn eonsisting of the ordinary acknowl34 Gorman r. Stanton, 5 Mo. App. 585. 
edgment of the receipt of momer, may be expressed in a simple statement of the anomnt mentioned; as

Consideration, $\$ 1,000.00$.

The ronsideration recital, mer the current of modern decisions, has lost its former importance and not infrequently fails to kenote the true motive of the conveyance. When only a nominal sum is inserted, compled with other considerations not of a peemiary nature, as "lore and affection," marriage, performance of specific acts, cte., the recital shomld be giren in full, in the identical language of the instrument, and rerified by quotation marks. When the expressed consideration amounts to a condition precedent or subsequent, this may become of primary inportance, while it should always be stated with sufficient clearness to enable counsel to determine whether same is sufficient to sustain the converance. Should the instrument be without consideration, this fact should also be noted in the line,

No consideration expressed.

\$ 180. Effect of Consideration. To consideration was required in conrerances under the common law, the homage and fealty ineident thereto being deemed sufficient, but becane necessary under the statute of uses. ${ }^{35}$ As a general proposition, any raluable consideration, acknowledged or proved, is sufticient to sustain a converance of lands, ${ }^{36}$ and the acknowledgment in the deed of parment thereof is so far conchnive of the fact as to gire effect to the conreranee. ${ }^{3 i}$ A deed executed by the party in whom title is rested, and expressing a valuable consideration, nevel needs, as against him or those

35 At the present time the only practical operation of the expression of a consideration or the introduction of a clause reciting a consideration, is to prevent a resulting trust to the grantor and estop him from denying the making and effect of the deed for the uses therein de- clared. Meeker $v$. Meeker. 16 Conn. 383; Goodspeed $r$ Fuller, 46 Me. 141; Graves $v$. Graves, 29 N. H. 129.

36 Jackson $r$. Leek, 19 Went. 339. 37 Ocliiltree $v$. McClurg, $7 \mathrm{~W}$. Va. 232. 
claiming under him, or as against a stranger, to be supported by showing what other reason, in addition to the will of the party, led to its execution. ${ }^{3 s}$ Nor is it essential to the ralidity of a conveyance that the consideration should be expressed, ${ }^{39}$ and a deed, if properly dramn, will pass the title, whatever it may be, without reference to the consideration paid. ${ }^{40}$ Whero parties contract by deed, a consideration will usually be implied from the seal, ${ }^{41}$ which as a rule imports consideration, ${ }^{\mathbf{4 2}}$ and it has been held that an instrument in form a conveyance and duly signed, whether under seal or not, imports a consideration, ${ }^{43}$ while a voluntary converance, without any consideration, either good or valuable, is ralid and binding between the parties and their privies. ${ }^{44}$

As against the grantor, and those in privity with him, the acknowledgment in the deed of payment of the purchase price is his receipt or admission, which on proof of the deed will be considered as proved. ${ }^{45}$ Such acknowledgment, however, is not conchusive, being merely by way of recital, and though it affords prima facie evidence of the fact, yet, like any other receipt, it may be inquired into, ${ }^{46}$ and, for the purpose of recorering the consideration the grantor may still show that it was never, in fact, paid, ${ }^{4 \tau}$ but not to invalidate or defeat the operation of the deed. ${ }^{4}$

3 s Rockwell $v$. Brown, $54 \mathrm{~N}$. Y. 210 ; Merrill $v$. Burbank, 23 Me. 538.

39 Jackson $v$. Dillon, 2 Overt (Tenn.), 261; Wood $r$. Beach, 7 Vt. 522 ; Boynton $v$. Rees, 8 Pick. (Mass.) 329.

40 Fetrow $v$. Merriweather, 53 Ill. 278 ; Laberee $v$. Carleton, 53 Me. 211.

41 Ross $v$. Sadgbeer, 21 Wend. 166: Evans $v$. Edwards, 26 Ill. 279; Croker $v$. Gilbert, 9 Cuslı. (Mass.) 131.

42 Hunt $v$. Johnson, 19 N. Y. 279 ; Croft $v$. Bunster, 9 Wis. 503; Bush v. Stevens, 24 Wend. (N. Y.) 250.
43 Ruth $r$. King, 9 Kan. 17. This in the absence of statutory requirements to the contrary.

44 Fouby $v$. Fouby, 34 Ind. 433; Wallace $v$. Harris, 32 Mich. 380 ;

Laberee $v$. Carleton, 53 Me. 211. 45 Bayliss $v$. Williams, 6 Coldw. (Tenn.) 440 .

46 Huebsch $v$. Scheel, 81 Ill. 281; Parker $v$. Foy, 43 Miss. 260; Webb v. Peele, 7 Pick. (Mass.) 247. 47 Barter $v$. Greenleaf, 65 Me. 405; Paige $r$. Sherman, 6 Gray (Mass.), 511; Grout $v$. Townsend, 2 Hill (N. Y.) 554.

48 Bassett $v$. Bassett, 55 Me. 127 ; Newell $v$ Newell, 14 Can. 206; Richardson $v$. Clow, 8 Ill. App. 91. 
As against the creditors of the grantor such recital is but hearsay, and no evidence of the fact of payment, ${ }^{49}$ but no one except a creditor can avail himself of the objection that the deed was given without consideration.tio

$\$ 181$. Words of Grant. The operative words of grant are found in the premises and usually immediately follow the consideration recitals, in which orter they should also appear in the abstract whenever it may be desirable to set them forth fully. It is a familiar rule with converancers, that to rest a title to land the deed must contain apt words of grant, release or conveyance, ${ }^{51}$ and, so faithfully has this been followed, it is not uncommon to meet with deeds containing as many as seven or even ten operative words of grant. The effect of these words is a question of construction to be governed and decided by the law of the State in which the land is situate, ${ }^{52}$ and no general rule can be formulated for the guilance of the practictioner the laws of the different States being widely divergent. The words of grant of most frequent occurrence are "grant, ${ }^{53}$ bargain and sell." In many of the States, when not limited by express words, they are construed as covenants, ${ }^{54}$ while in other States such a conveyance, withont more, wonld be a mere quitclaim and inoperative to convey an after-acquired title, ${ }^{55}$ or warrant that conveyed. ${ }^{56}$ Where the deed is without covenants, or contains only special or limited corenants, the words of grant should be set forth inmediately preceding the description. When the usual covenants of seizin, warranty, etc., appear in the deed they are immaterial, and may be omitted.

49 Redfield Mfg. Co. v. Dysart, $62 \mathrm{~Pa}$. St. 62; Rose v. Taunton, 119 Mass. 99; Houston $v$. Blackman, 66 Ala. 559.

50 Hatch $v$. Bates, 54 Me. 136.

51 Johnson $v$. Bantock, 38 Ill. 111 ; Catlin $v$. Ware, 9 Mass. 218; Hammelman $v$. Nounto, $s i$ Ind. 178; Brown $v$. Manter, 21 N. H. 52S. 52 MeGoon $v$. Scales, 9 Wall. 23; Clark $v$. Graham, 6 Wheat. 37 . 53 The word "convey" is equiv- alent to "grant." Lambert $v$. Smith, 9 Or. 185.

54 Brodie $r$. Watkins, 31 Ark. 319; Hawk r. MaCullough, 21 Ill. 220. This construction is usually made under peeuliar statuiory provisions.

5. Butcher $r$. liogers, 60 Mo. 138 ; Nicholson r. Caresio 45 Ind. 479.

no Taggart r. Risley, 4 Oreng. 235. The worl "grive" was formerly held, in the absence of express 
Technical words of grant possess little of their former effieacy, though it is still true that to constitute a convesance there must be suffieient words showing an intention to grant an estate, ${ }^{5 \pi}$ yet every part of the instrument may be resorted to for the purpose of ascertaining its true meaning and the intention of the parties, ${ }^{58}$ and, generally, any writing that sufficiently identifies the parties, describes the land, acknowledges a sale of vendor's rights for a valuable consideration, and is signed, sealed and delivered, is a good deed of bargain and sale, ${ }^{59}$ and, if complete in other respects, has been held to constitute a valid conreyance even though all words of grant are omitted. ${ }^{60}$

$\S 182$. Words of Inheritance and Limitation. Closely allied to the foregoing are the words of inheritance and limitation, once of the very essence of the deed, ${ }^{61}$ but now, by reason of sweeping statutory ehanges, comparatively without value or legal effect. Though invariably inserted by the conveyancer, words of inheritance are no longer necessary to ereate or convey a fee, and, as a rule, every grant of lands will pass all the estate or interest of the grantor, unless a different interest shall appear by express terms or neeessary implication, ${ }^{62}$ the question of the estate transferred being determined rather by the end sought to be attained by the grantor, than by the language cmployed. ${ }^{63}$ The usual and ordinary words for conveying an estate in fee simple are "heirs," or " heirs and assigns forever."

The rule in Shelly's case, with its refinements and subtilties

coverants, to constitute a warranty during the life of the grantor. Dow $v$. Lewis, 4 Gray (Mass.), 468.

57 McKinney $v$. Settles, 31 Mo. 541 ; Brewton $v$. Watson, 67 Ala. 121; Brown $v$. Manter, 21 N. H. 528.

58 Saunders $v$. Hanes, 44 N. Y. 353 ; Callins $v$. Lavalle, 44 Vt. 230 ; American Emigrant Co. $r$. Clark, 62 Iowa, 182.

59 Chiles $v$. Conley's Heirs, 2 Dana (Ky.), 21.

jo Bridge $v$. Wellington, 1 Mass. 219. This case has been severely criticised in subsequent decisions and frequently rejected.

61 Jackson $v$. Meyers, 3 John. 388. 62 Merritt v. Disney, 48 Md. 344; Beecher $v$. Hicks, $\tau$ Lea (Tenn.) 207 ; Eiseley $v$. Spooner, 23 Neb. 470 .

63 Hawkins $v$. Champion, $36 \mathrm{Md}$. 83; Kirk v. Burkholtz, 3 Tenn. Ch. 425 ; Lehndorf $v$. Cope, 122 Ill. 317. This is now a general statutory rule. In a few States, however, the common-law rule still obtains and words of inheritance are necessary to pass a fee. 
is not recognized in some States, and has but a partial effect in others, although its influence is still manifest in nearly every State. As a wide difference of interpretation is displayed in the decided casen, it is diffieult to prescribe a definition of the rule that shall be sulficiently certain. Generally, if an estate of frechold be limiter to the ancestor for life, and the inheritance to his heirs, cither mediately or immediately, the first taker takes the whole rstate; if it be limited to the heirs of his body, he takes a fie tail; if to his heirs generally, a fee simple. The words "heirs" or" "heir's of the body" in such case, are words of limitation and not of purchase. ${ }^{64}$ The rule in Shelly's case is, howerer, at nost a technical rule of construction, and must, as a general proposition, give way to the clear intent of the lonor when that intention can be ascertamed from the instrument in which the words supposed to be of limitation are used.".5

Whenever the words of inheritance depart from the usual form for granting a fee, and seek to create a rested or contingent remainder in some person other than the grantee named, the only safe method for the examiner is to set forth the granting clanse verbatim, and as a further precaution the habendum may also be shown. To ereate an estate tail or remainder, there must be the use of technical words designating a class of heirs to take in snecession, or language di-closing a clear intent to that effect. ${ }^{66}$ The word " children," though frequently used, is usually a word of purchase, requiring strong langnage to change it into a rord of limitation. In the preparation of abstracts these questions are too frequently lost sight of by the examiner, who fails to give to them and other seemingly minor details, the attention their importance deserves.

(44 Butler $r$. Huestis, 68 Ill. 594; consult Foster $r$. Shreve, 6 Bush (Ky.), 519; Bradford $\imath$. Howell. 42 Ala. 422; Forrest v. Jackson, $56 \mathrm{~N}$. H. 357; Smith $v$. Block, 29 Ohio St. 488; King $r$. Rea, 56 Ind. 1. Entails, when permitted, are limited to the first degree only, that is, the first grantee takes an estate for life while the remainder passes in fee to the second taker. Sce, liutler $v$. Huestis, 6s Ill. 594.

tis Bulslay r. Engel, 107 Ill, 182. af Middleton $v$. Smith, 1 Coldw. (Tenn.) 144. 
$\$ 18 \%$ Description of Property. After the partics to the converance, the description of the thing or subject-matter conveyer is the great essential, ${ }^{67}$ but for convenience, and following the orderly parts of the deed, it should appear immediatcly after the words of conveyance. In abstracting a deed it is custrmary to condense the introductory sentences of the description, which allude generally to the situs of the land in a given comty and state, but from this point, or after the words "to wit," the entire description, as found in the deed, should be set forth rerbatim. It is the eustom also, of many examiners, to refer for descriptions to the eaption of the abstract, or to other instruments in the chain containing the same or substantially the sane description; a practice as slovenly as it is dangerous and one strongly to be reprehended. Both in preparing the abstract and in passing upon the title, the description shonld in every case be compared with the caption, and any deviation therefrom, cither in form or substance, carefully noted.

\$ 18:. Bescription - Sufficiency. Every deed of conveyance, in order to transfer title, must, either in terms or by reference or other designation, give such description of the subject-matter intended to be conveyed as will be sufficient to identify the same with reasonable certainty. ${ }^{68}$ If the description is too indefinite to convey anything, or too vague to permit of location, then the deed lacks one of the essential elcments of a conveyance. ${ }^{69}$ It is not essential, however, that the deed should on its face ascertain the limits or quantity of the particular tract conveyed. It will be sufficient if it refers to certain known objects or things, and provides definite means by which the land may be readily aseertained and known ; ${ }^{70}$ where words of gencral deseription only are used, oral evidence may be resorted to for the purpose of ascertaining the particular

67 Whitaker $v$. Miller, 83 Ill. 381. 68 Berry $v$. Derwart, 55 Mil. 66; Long $r$. Wagroner, 47 Mn. 178; Barker r. Ly. Co., 125 N. C. 596.
69 Barker v. Ry. Co., 125 N. C. 596.

70 Coats $r$ Taft, 12 Wis. 388 ; Dwight $r$. Packard, 49 Mich. 614. 
subject-matter to which they apply. ${ }^{\top 1}$ Any description by which the identity of the property intended to be envered is established, will be suflicient, ${ }^{\top 2}$ and a deseription not sufficiently certain in itself nuay be marle so by reference to other deeds in which it is sufficiont. ${ }^{73}$

\$ 155. Description - Identification. Defects of description are sometimes cured by the acts of the parties after the converance has ben marle. As, where the land intended to be conveyed is not ilentified in the decd the parties may afterward survey or stake ont a tract, ame, if the grantee takes possession of such tract, this, it is said, aseertains the grant and gives effect to the dect.it But surh a proceeding, as a rule, can only be slown ly matter in pais, and hence does not affect the conchnsions of the examiner deduced from an inspection of the record. Enless the parties have recorded the survey or minutes of location the examiner is moler no duty to note the fact, even though he may be cognizant of it, and the opinion of comacl should conform to the facts of record only. If parties desire to fix and perpetuate their rights in a specific parcel of land recourse shonld be harl to the courts or to the publie records.

$\S 186$. Description - Construction. It is a rule of construction as to the deceription of the land fomd in the premises of a deed, that the least certain and material parts must give way to the more certain and material. Quantity is never allowed to control courses and distances, ${ }^{i 5}$ and courses and ristances must vield to fixed monments and natural objects also referred to therein. ${ }^{76}$ But where the monuments, if once ex-

71 Coleman $r$. Inprorement Co., 94 N. Y. 229.

72 Smith r. Crawford, 81 Ill. 296 ; Allen $r$. Bates, of Pick. 460.

73 Russell r. Brown, 41 Ill. 184; Credle $r$. IIars, 88 N. C. 321 .

74 Thms, where a deed was made for "one-half acre of land near the wharf," describing the wharf, it was held that such deed was not void for uncertainty if the parties, after the conveyance, marked out a pareel of land of which the grantee took possession with the consent of the grantor. Simpson r. Plaisdell, s.; Me. 199; and see, Irerrick $r$. MIorrill, 37 Minn. 250 .

T) Bishop r. Morgan. 82 Ill. 352; Saunders $t$. Schmarlzle, 49 Cal. 59. is Dupont r. Daris, 30 Wis. 170; Sanders r. Eldridge, 46 Iowa, 34; Cumningham $r$. Curtis, $57 \mathrm{~N}$. II. 157. 
isting, are gone, and the place where they originally stood can not be ascertained, the conrses and distances, when explicit, must govern; ${ }^{i \tau}$ and where the boundaries are doubtful, quantity often becomes a controlling consideration. ${ }^{\text {is }}$ Nor will the rule that monuments, natural or arificial, rather than courses and distances, control in the construction of a conveyance, be cnforced when the instrument would therelyy be defeated, and when the rejection of a call for a momment would reconcile other parts of the description and leave enough to identify the land. ${ }^{\text {is }}$ Where a deed calls for a natural object and the line gives out bofore reaching it, the line must be extended to the natural object, ant the distance disregarded; ${ }^{\text {so }}$ but where no nonuments are referred to and none are intended to be afterward designated, the distance stated in the grant must govern the location. ${ }^{s 1}$ An erroneons description of land by numbers will not control other descriptive particulars which indicate the land with certainty. ${ }^{82}$

Where lines are rmu to fix the boundaries of a tract, with special reference to the points of the compass, they will generally be construed according to their technical significance. Thns, a line ruming "northerly" will be constmed to mean due north, and so of the other cardinal points. These terms may be controlled or qualifies ly other worls of description used in connection, but in case there is nothing to suggest a different construction they must be giren their technical meaning. ${ }^{83}$

Where, as is often the case, the converancer, from an orer anxiety to ilentify the property, makes two descriptions, the one, as it were, superadded to the other, the one deseription being complete and sufficient in itself, the other incorrect, the incorrect description, or feature, or circumstance, may be re-

Tt Drew $r$. Smith, 46 N. Y. 204; Clark $v$. Wethy, 19 Wend. 320.

78 Winans $v$. Cheny, 5.) Cal. $56 \pi$.

79 White $r$. Luning, 93 L. S. (3 Otto) 515 .

so Strickland $v$. Draughan, $88 \mathrm{~N}$. C. 315 . s1 Negbaner r. Smith, 44 N. J. I. 672 .

82 Bradshaw r. Bradbury, 64 Mo. 334; Montgomery r. Johnson, 31 Ark. 192.

ss Fratt $v$. Woodward, 32 Cal. 220 . 
jected as surplusage, and the complete and correct description allowerl to stand alone. ${ }^{84}$

It must be remembered, however, that notwithstanding the utmost liberality is allowed in the construetion of descriptions, so as, if possible, to effectuate the intention of the parties, nothing passes by a deed exeept what is deseribed in it, whatever the intention of the partien may have been, and extrinsic evidence is inadmissible to malie the dieed operate upon land not cmbraced in the deseriptive words. ${ }^{45}$

\$ 187. Special Ifeertals. Tmmediately following the description are usually found the special reeitals, reservations, exceptions, conditions, etc., thongh in forms specially prepared they may also be foumd in that palt of the deed techinically known as the redicmlum and to insure certainty all of the instrument from the habendum to the testinoninum clanse should be carefully read by the examiner when compiling the abstract. All special inatter, including recitals, refrenees, exceptions, reservations, conditions, linitations, ete, should be set forth fully in an orterly manner and, whenever practicable, in the identical language of the deed and verified by quotation marks. When not so treated, or where slight condensation nay be auvantageously employed, the matter should be preceded by a parenthetical statement, to indicate that what follows is a transcription and not an observation by the examiner, thus:

" Said grantor (it is stated) agrecs to," etc.

Recitals in deeds bind the parties thereto, and those claiming under them, ${ }^{86}$ and a grantee is chargeable with notice of facts recited in a deed which constitutes a necessary palt of his chain of title, ${ }^{s t}$ but such recitals are not evidence against one

84 Kruse $v$. Wilson, 79 III. 233: Myer $v$. Ladi, 26 IIl. 415; Wade $v$. Deray, 50 Cal. 376 ; Credle $v$. Hays, 88 N. C. 321 ; Bray $v$. Adams, 114 No. 486 .

85 Coleman $v$. Improvement Co., 94 N. Y. 229. st: Fisk $\varepsilon$. Flores, 43 Tex. 340 ;

Lamar $v$. Turner, 48 Ga. 329.

87 Pringle $r$. Dunn, 37 Wis. 449; Acer $r$. Weseott, 46 N. Y. 318; Bryne $v$. Morchouse, 22 111. 603; R. R. Co. v. Kennedy, 70 11l. 350 . 
who holds under a title emanating from an independent source. ${ }^{\text {s. }}$

$\S 18 s$. The Habendum. It is rarcly that the attention of either examiner or comsel is called to the habendum of a deed, which, unless declaring a trust, or defining the limitation of an estate, may be passed without notice in the abstract. Though formerly, like many other technical features, of great importance, it has now degenerated into a mere form, ${ }^{89}$ and in the statutory converances in use in many of the States is entirely omitted. In general the habendum refers to the premises and declares what estate the grantee shall hold. It may sometimes enlarge or diminish the grant, when showing a clear intention so to do, ${ }^{90}$ but can not perform the office of divesting the estate already rested by the premises, and is roid if repugnant thereto. ${ }^{91}$ Where the deed purports to create a rested or contingent remainder, or conveys property in trust, the habendum often beemes important, and where no estate is mentioned in the granting clanse it becomes efficient to declare the intention and rebut any implication which would otherwise arise from the omission.

189. Exceptions and Reservations. Everything that restrains, qualifies, reserves or subtracts from the grant or thing granted, should be shown on the abstract with minuteness of detail, and to that end it is desirable that ererything in the nature of an exeeption or reservation be copied rerbatim. Both a reservation and an exception must be a part, or arise out of that which is granted in the deed. The difference is that an exception is something taken back or ont of the estate then existing and clearly granted, while a reserration is something issuing out of what is granted. ${ }^{92}$ Thus, an exception is always a part of the thing granted, and of a thing in being. ${ }^{93}$

ss Lamar $r$. Turner, 48 Ga. 329 ;

Kerfoot $r$. Cronin, 105 Ill. 609.

s9 4 Kent Com. 46s: 4 Bik. Com. 298.

90 Corbin r. Healy, 20 Pick. 514. 91 Riggin $r$. Love, 72 Ill. 5.5;
Halifax $r$. Stark, 34 Vt. 243; Robinson r. Payne. 58 Miss. 690.

92 Adams $r$. Morce. 51 Me. 497; Kister $r$. Reeser, 98 Pa. St. 1.

93 Winthrop $r$. Fairbanks, $41 \mathrm{Me}$. 307 . 
A reservation is of a thing not in being, but is newly ereated out of the land or property demised. ${ }^{94}$

The usual operative worls to create an execption are, "saring and excepting," etc, but the terms indieative of either methorl are often used indiscriminately and frequently in conjunction, as "exeepting and rescring," etc., and the difference between the two is so obscure in many cases that it has not been observed.95 Although there is a terhnical distinction between the terms, yet where "roserving" is used with evident intent to ereate an exception, eflect should be given in that sense. ${ }^{96}$ $\Lambda$ reservation in a deed will mere operate to give title to a stranger, though it may, when intended by the parties as an exception, afford notice to the grantee of adverse clains in or to the thing excepted or reserved. ${ }^{9 \pi}$ I restriction may take effect as a reservation, if it dees not necesarily deprive the grantee of the essential benefits of the grant. ${ }^{98}$

The same certainty of deceription is required in an exception out of a grant as in the grant itself, as where a deed excepts out of the conveyance one acre of land, and there is nothing in the exception to locate it npon any particular part of the tract, the exception is roid for mectainty, and the grantee takes the entire tract. ${ }^{90}$ Reservations and exceptions, when expressed in a doubtful manner, are to be construed most strongly against the grantor, ${ }^{1}$ get if the intention of the parties can be fairly ascertained from the instrument, such intention will govern in its construction.2

$\$ 190$. Conditions and Restrictions. Analogous to the exceptions and reservations of a deed are the conditions qualifying the grant and the limitations or restrictions of its use, both of which demand the closest attention on the part of ex-

94 Gay $x$. Walker, 36 Me. 54. See, Warvelle, Real Property, 256. 95 Winthrop $v$. Fairbanks, 41 Me. 307 .

96 Sloan $v$. Lawrence Furnace (1). 29 Ohio St. 568.

97 West Point Iron Co. $v$. Reynert, 45 N. Y. 703. us Gay $\iota$. Walker. 36 Me. 54. 99 Hooney 2 . Cooletge, 30 Ark. 640.

1 Wyman $r$. Farme, 3i Me. 64;

Duryea $e$. Now York, 62 N. Y. 592. 2 Wiley $v$. sirdorus, 41 lowa, 224. 
amincr and counsel. As in the casc of reserrations, the conditional or restrictive clauses shonld be copied word for word, the abstract showing them to be literal quotations. Conditions frequently partake of the nature of the consideration for the conrerance, and declare its true motive, and, when such is the case, it becomes donbly important that they be correctly shown.

Conditions are divided into precedent and subsequent, the former being something which must be punctually performed before the estate can rest, and deeds containing them expressly declare that the grant is upon such condition. A condition subsequent indicates something to be performed after the estate vests, the contimuance of such estate depending upon its performance. The character of conditions, precedent or subsequent, depends upon the intention of the parties, as shown by a proper construction of the whole instrument, not upon the precise or technical words used. ${ }^{3}$ A deed upon condition subsequent conveys the fee with all its qualities of transmission. The condition has no effect to limit the title, until it becomes operative to defeat it. ${ }^{4}$

The law does not favor forfeitures, ${ }^{5}$ and conditions in aroidance of an estate are strictly construed; no language will be construed into such a condition contrary to the manifest intent of the parties, nor when any other reasonable construction can be given to it. ${ }^{6}$ Conditions of this kind will not bind the heirs or assigns unless they are expressly mentioned, ${ }^{7}$ nor will a conditional grant revert on breach, there being no clause providing for forfeiture or re-entry, ${ }^{8}$ and until defeated by an actual entry made for the purpose of claiming a forfeiture, by some one haring the right so to do, the estate continues in the grantees. ${ }^{9}$ Conditional grants, though sometimes running to individuals, are more frequently found in dedicatory conveyances,

3 Rogan $r$. Walker, 1 Wis. 527 ; Sheppard $r$. Thomas, 26 Ark. 617. 4 Shattuck $v$. Hastings, 99 Mass. 23.

5 Toris $r$. Renshaw. 49 Ill. 425 ; Hoyt $r$. Kimball, 49 N. H. 322. 8 Wier $r$. Simmons, 55 Wis. 637.
7 Page $v$. Palmer, 48 N. H. 385. This is the general rule, but local statutes may qualify or vary it.

8 Packard $v$. Ames, 82 Mass. 327.

9 Osgood $x$. Abbott, 58 Me. 73; Guild $i$. Richards, S2 Mass. 309 . 
or in deeds to religions, dharitable or educational institutions.

Restrictions on the nse of property conveyed are of more frequent oceurrence, but, mless ther are also conditions subsequent, do not work a forfeiture in their violation. They consist nsually of building regulations, suntary measures and matters inrolving the good morals of community, as probibition of the sale of intoxicating liquors on the promises, etc. They are dosigned ordinarily to prevent such use of the premises by the grantee and those claiming under him, as might tend to diminish the value of the residue of the land belonging to the grantor or impair its eligibility for particular purposes, and that such a design is a legitimate one, and mar be earried out consistently with the rules of law by reasonable and proper restrictions, can not be doubted. Every owner of property has the right to so deal with it, as to restrain its use by lis grantee within such limits as to prevent its appropriation to purposes which will impair the value or dininish the pleasure of the enjoyment of the land which he retains. ${ }^{10}$ Such restrictions are recognized and upheld by the courts, and violations thereof will be restrained by injunction. ${ }^{11}$

A condition, whether precedent or subsequent, is not bind-

10 The only restriction on this right is that it shall be exercised reasonably, with due regard to public policy, and withont ereating any unlawful restraint of trade. Nor does there seem to be any doubt that in whatever language such a restraint is couched, whether in the technical form of a condition or covenant, or of a reservation or exception, or merely by words which give to the acceptance of the deed by the grantec the force and effect of a parol agrecment; it is binding as between the immediate parties thereto, and may be enforced by or against their respective assigns. Whitney $v$. Ry. Co.,
11 Gray (Mass.), 359; Atlantic: Dock Co. v. Learitt, 54 N. Y. 35 ; Watrous $v$. Allen, 57 Mich. 396; and see Warvelle on Vendors, $\S 438$ et seq.

11 Dorr r. Harralian, 101 Mass. 53I; Cowell 4 . Col. Springs Co. 100 U. S. 55; Clark $x$. Martin, 49 Pa. St. 289. Where restrictions upon building are inserted in a deed as a part of a seheme for a plan of improvement, such restrictions, as a rule, thongh spoken of as comditions, are not to be deemed ferehniral conditions whose breach involves forfoitme. Ayling $v$. Kramer, l3: Mass. 12. 
ing after the party imposing it has rendered its perfornance inpossible or unnecessary. ${ }^{12}$

s 191. Coremants. The corenants of a deed add nothing to its efficiency as a means of converance, and a quitclaim deed will as effectually pass the title and corenants ruming with the land as a deed of bargain and sale, if no words restrict its meming. ${ }^{13}$ The corenant clause usnally immediately precedes the testimonium, and when consisting only of the conrentional assurance of seizin, right to conrey, freedom from incumbrance, quiet enjorment and warranty, may be passed with simple notice, or if the deed is in other respects regular, and is described in the abstract as a "Warranty Deed," there seems no good reason why any further mention should be made, particularly if the client knows such to be the exaniner's custom. There is no uniform rule regarding their inscrtion, and usually they are omitted. Special, or unusual corenants, or such as seek to limit the grantor's liability, should be noticed at such length as their importance seems to demand, and if necessary for a proper understanding, should be literally transcribed.

Covenants are either express or implied. Implied covenants must be consistent with, and not contrary to, the express corenants, ${ }^{14}$ and where a deed contains both, the latter qualifies and restrains the former. ${ }^{15}$ Covenants are also classified as personal and real, or those which rum with the land, though some confusion exists as to the division between them. ${ }^{16}$ No special words are needed to raise a corenant, ${ }^{1-}$ and whatever shows the intent of the parties to bind thenselves to the performance of a stipulation may be deemed a corenant without regard to the form of expression. ${ }^{18}$

The ancient common law warranty has been superseded by

12 Jones $v$. R. R. Co., 14 W. Va. 514.

13 Morgan $v$. Clayton, 61 Ill. 35; Rowe $v$. Becker, 30 Ind. 15t; Pingree $v$. Watkins, $15 \mathrm{Vt}$ t. 479 ; White $v$. Whitney, 3 Met. 81; Hunt $v$. Amidon, 4 Hill, 345 .

14 Gates $v$. Caldwell, 7 Mass. 68.
15 Kent $r$. Welch, 7 Johns. 258; Sumner $t$. Williams, 8 Mass. 201.

162 Boul. Law Dict. 327.

17 Newcomb $v$. Presbrey, 8 Met. 406.

18 Taylor $v$. Preston, $79 \mathrm{~Pa}$. St. 436. 
personal coremonts, and nerer hat any practical existence in this esuntry. The woght of American authority holds that the covenants of seizin, goml risht to convey and freedom from incumbrances, are in prescnti; that they do not run with the. land, and if broken at all, are broken at the instant of their creation. $^{20}$ The clain for damages thereby becomes personal in its nature to the granter, amel is not transferred by a conveyance to a subsepuent grantee. ${ }^{21}$ Several of the States, following the English rule, permit an action by a renote granteo in his own mame where the substantial breach of the covenant ocenrs after the assigmment, and the whole actual damages are sustained by the assignee.22 Where privity of estate exists between the partics, aud the corrumt is one abont or aftecting the land granted, and tends directly and necessarily to enhance its value, or render it more beneficial to those by whom it is owned, the corcnant is said to be incident to the lank, and may be enforced by and is binding upon, those in whom tho title subsequently vests. 23 It is a general principle that covemants which run with the land pass only with the legal title thereto. ${ }^{24}$ The covenant of warranty extends only to the right, title and interest in the lands hargained and sold by the rendor. The covenants can not enlarge the premises. ${ }^{25}$

Where a covenant is implied from statutory words, the very words of the statute must be used to raise it. ${ }^{26}$ In a conveyance in form a "Warranty Deed," but omitting any of the customary covenants, it is well to note the omission, and in such cases, where by statute covenants are implicd from specific words of grant, the operative words of conveyance as found in the deed should be inserted. 631.

19 Jones r. Franklyn, 30 Ark.

20 Tone $v$. Wilson, 81 Ill. 529; Fuller $x$. Jilkett, 9 Birs. (C. ('t.) 290.

21 Salmon $v$. Vallejo, 41 Cal. 481 ; Dale $v$. Shively, 8 Kan. 27f; Pillsbury $v$. Mitchell, 5 Wis. 17 ; Moimton v. Inohbs, 2 Mass. 433; Greenby $v$. Kellog, 2 Jolıns. 2.

22 Richard $r$. Bent, 59 Ill. 38; Schofield $r$. Homestead Co., 8: Iowa, 317 ; Cole $r$. Kimball, 52 Vt. 639. 2s Wooliscroft $r$. Nolton, 1.j Wis. 198: Wheeler $r$. Schad, 7 Nev. 204. 24 Wright $r$. Sperry, 21 Wis. 331. 25 Lamb $x$. Wakefield, l Singer, 251.

2; Vipond v. Hurlbut, 22 11l. 226. 
S 1:2. Txperition. The execution of a deed technically comprises the signing, senling and delivery 27 and in some Statco the attestation of witneses as well, but the attention of exaniner and connsel need only be dimected to the two former, and, where required by law the attestation. The laws of the various States on the subject of execution, though preserving a general harmone, are ly means uniform nor have they always been the sane during the goremmental existence. The examiner shoukl be fully posted on all the changes of the law in respect to the execution of deeds in his own State, and carefully observe and note in the abstract any defects or errors, in signatures, seals or attestation, and any non-compliance with statutory requirements. Extra rigilance will be required in the cases of deche by marricd women, converances by delegated anthority and by corporations.

\$ 193. The Signature. Sealing, not signing, was the sine qua non to the validity of the common law deed, and a signature was not considered necessary ${ }^{28}$ Sealing is now of little moment, save as a technical recuirement, while in several States it is entirely dispensed with, and the deed derives its effieacy from the signature. An unsigned deed, though duly attested, acknowledged and delirered, is a nullity. ${ }^{29}$

27 Thorp r. Keokuk Coal Co.. 48 ก. Y. 2.93.

es Coke. Lit. L. 1. C. 5. \$ 49. This was donhtess necanioned by reason of the reig general inability of the nims of the preople to read or write; see 1 Reeres" Mirt. Eng. Law, 1St, note. Enler the Saxon rule it would seem that sinning was in general use provided the parties were able to write. and whether they could write or not it was cus. tomary to afix the sign of the cross; lut on the Xorman conquest waxen seals. nswally with some sperific derion, were introluced and trok the place of the Saxm method of writing the name and making the sign of the cross. By the statute of $\approx 9$ Charles II, for the prerention of frands and perjuries, all transfers of land were required to be put in writing and signed by the parties making same and this statute is the foundation of the American laws upon the subject. In Blackstone's time signing does not appear to have been essential to validity, althongh he says (1 Com. 30.5): "It is said to be requisite that the party. whose deed it is, should seal. and now in most cases, I approluent. slonkl sign it also."

29 Cinodmen r. Pancell, 44 Conn. 325: Miller $r$. Ruble, $107 \mathrm{~Pa}$. St. 395; Hilton $\ell$. A-her, $103 \mathrm{Kg} .730$. 
The law presmues that in executing instruments, partics use their real names, and does not presume them to have different names. So, where the record of a deed purporting to have been signed by IIarmon. S. was acknowledged by Hiram S., it was held inadmissible to prore a conveyance by Hiram, ${ }^{30}$ as only the signer ean acknowledge as grantor. It is doubtful, however, whether this can be received as the accepted doetrine, the volume of anthority inclining to the contrary, and generally if the grantor's true name is recited in the body of the deed and he also acknowledges it by his true name, the fact that he signs it by a wrong nane does not invalidate the conveyance. ${ }^{31}$ All variances of this nature, being of the essence of the conveyanee, require full notice. A leed signed with a mark, if otherwise regular, may be treated as proporly executed, and such is also the eustom of examiners where the signature is in a foreign language. Where an instrmment is found with a signature affixed to it, the presumption is, that the party signing it knew its contents, and there is no distinetion in this respect between those who can and those who can not write. ${ }^{31 a}$

$\$ 194$. The Seal. In most of the States the formality of a seal is required in the excention of deeds for the conveyance of land, while in some its use has been dispensed with by statute. The common law seal has been defined as an impression upon wax or wafer or some other tenacious substance capable of being impressed, ${ }^{32}$ bnt as the record would fail to show the method

It would seem as though the statement of the text was not only in eonsonance with law but with reason as well, yet late decisions in some localities would indieate that a deed is not necessarily roid because the grantor's name is not subscribed to it, provided it is written in his own handwriting, and so placed in the body of the deed as to control the grant. The question then becomes one of intent, and, it has been held, may be considered by a jury in connection with otler circumstanees. See Saunders $v$.
Hackney, 10 Lea (Tenn.), 194. See also the topic "Defective Execution," in the succeeding chapter.

30 Boothroyd $r$. Engle, 23 Mich. 19.

31 Middleton $v$. Findla, 25 Cal. 76; Tustin $v$. Fanght, 22) Cal. 237; Zahnn $v$. Haller, 71 Ind, 136; Houx r. Batteen, 68 Mo. 84.

31a Doran $r$. Mullen, 78 Ill. 342. 32 Waren $r$. Lyneh, 5 ,Johns. ( $N$. Y.) 239. And a later decision held that the seal of a corporation or of a private intividual impressed directly upon paper without the use 
of sealing, the examiner would still be at a loss to know if the deed had been properly sealed, were this rule still in effect. In a majority of the States where seals are still required, a serawl has, by statute, the force of a seal, whenever it appears from the body of the instrument, the scrawl itself, or the place where affixed, that such seraw was intended for a seal. ${ }^{33}$ Where a scrawl is allowed for a seal, the word "seal" at the end of the maker's signature, and referred to in the testimonium clause, creates a sealed instrument; the word "seal" is equiralent to a scrawl. ${ }^{34}$ And, generally, an instrument will be treated as sealed, when the intent to aifix a seal is clear. ${ }^{35}$ It has been held that where the record was male at a time, and under a law, permitting the registration of only sealed instruments, and the instrument was in form a warranty leed, the conelusion attestation and certificate of acknowledgment, all speaking of it as under seal, it will be presumed that the original was sealed. And whether or not it was the legal duty of the recorder to indicate upon the record whether the instrument was sealed, his omission to do so will not overcome the presumption. ${ }^{36}$ Usually, if the instrument is otherwise in form, it will at least be sufficient to convey an equitable title, and therefor'e, if recorded, will affect those interested with construetive notice of its contents as fully as if sealed. ${ }^{3 i}$

If one of seceral grantors named in an instrument which purports to be sealed by all of them, neglects to affix his seal thereto, in the absence of other evidence he will be deemed to

of wax or other tenacious substance is a mullity, although holding the contrary as to seals of courts and public officers. See Farmers' Bank $r$. Haight, 3 Hill (N. Y.), 493.

38 IIudson $v$. Poindexter, 42 Miss. 304; Deininger $v$. McConnel, $41 \mathrm{Ill}$. 229. This is a general statutory rule.

34 Groner $v$. Smith, 49 Mo. 318; Lewis $v$. Overby, 28 Gratt. (Va.) 627 .
35 Burton $v$. LeRoy, 5 Sawyer, 510 ; McCarley $v$. Supervisors, 58 Miss. 749 ; Flowery Mining Co. $v$. Bonanza Co., 16 Nev. 302. 36 Starkweather $v$. Martin, $2 S$ Mich. 471; LeFrane $r$. Richmond, 5 Sawyer (C. Ct.), 601.

37 Grandin $v$. Hermandez, 29 Hun (N. Y.), 399. Local statutes prescribing requisites for registration may vary this rule. 
have adopted the sal of some one of the other signers, and will be equally bound with them." ${ }^{\circ}$

In compiling the abstract it is unnecessary to refer to the execution, or any part thereof, if in all respects regular and in conformity to law; only defects or omissions require notice, and these are best shown by a literal transeription.

\& 195. Attestation. Subscribing witnesses to a converance of land are not necessary at common law, ${ }^{39}$ nol by statute in many of the States; others require an attestation by one sub scribing witness onlr, while in a majority it is necessary that the deed be executed in the presence of two witnesses, who shall subscribe their names to same as such. As the matter of attestation is purely statutory the effect of onision in this particular is to be decided soldy by the application of local law.

The usnal and ordinary words of attestation are "signed, sealed and delivered in our presence," but the late statutory forms of conresanco have somewhat abbreviated this ancient form of expression, and the rords "in our presence." immediately following the testimonim clanse, and followed lyy the signatures of witnesses, is a good and sufficient attestation. When required at all, attestation is nsually a prepequisite to registration, and any informality in this respect deprives the instrument of its legal effect as constmctive notice. ${ }^{40}$ Then properly attested no mention of the fact scems necessary in the abstract, while omissions or defects may be indieated by some simple statement; as

No subscribing witnesses shown of record.

\$ 196. Acknowledgment. The statutes of all the States provide for a proof of execution of converances of land, ly an acknowledgment of the deed before some officer, eridenced by his certificate of authentication. Snch acknowledsment, prop-

38 Yale $r$. Flanders, 4 Wis. 96 ; Norvell r. Walker, 9 W. Va. 447; Mackay $v$. Bloodgrood, 9 .Johns. (N. Y.) 285; Daris $r$. Burton, 4 Ill. 41.

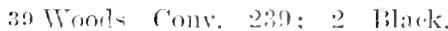
Com. 307: Dole r. Thurtow. 1.2 Mer. (Misis.) 153.

40 Parmet $r$. Shaublunt, 5 Minn. 32:3; Ross $x$. Worthington, 11 Min. 441 . 
erly certified, anthorizes the production of the instrument in avidence without other or further proof of its execution, and, in some States, is a prerequisite to registration.

The certificate of anthentication is no part of the conveyance, and is not the act of cither party to it, ${ }^{41}$ but only evidence in regard to its execution and acknowledgment, and, like all other evidence, should be reasonably considered and construed. $^{42}$ Being statutory ereations greater strictuess is necessary in their construction, yet it is a woll settled rule, that a substantial compliance with statutes prescribing the form and requisites of an official certitieate of acknowled mment, or proof of deeds, is sufficient. It is the poliey of the law to uphold such certificates whenever substance is found, and not to suffer conveyances, or proof of thom, to be defeated by technical or unsubstantial objections, and in construing them resort may be had to the deed or instrument, to which they are appended ${ }^{43}$ yet nothing will be presumed in favor of an ofticial certificate, which inust state all the facts necensary to a valid official act. ${ }^{44}$

Of course, the eertificate should be signed by the person making it. It is also enstomary for the officer to add a deseription of his office, as, "John Smith, Notary Public." But, while this is a usual and proper custom, it does not seem to be neeessary where the body of the eertificate deseribes him as a notary public and acting ofticially. In such case the omission of the name of his office after his signature will not have the effect of rendering the acknowledgment invalid. ${ }^{45}$

The official acts of a notary should be authenticated by his seal ${ }^{46}$ particularly when a non-resident of the jurisdiction

41 An acknowledgment taken by a grantee named in the deerl is void, though the deed itself will still be valid and linding as between the parties and its execution ma be established by common law evidence. Hogans $\ell$. Carruth, 18 Fla. 58T.

42 Harringt on $v$. Fish, 10 Mieh. 415 ; Gray $r$. Ulrich, 8 Kan. 112.

43 Wells $v$. Atkinson, 24 Minn.
161; Tubbs $v$. Gatewood, 26 Ark. 128; Bamet $v$. Prokkauer, 62 Ala. 486 ; Calumet Co. $v$. Ruscell, 68111. 426.

44 Wetmore $r$. Laird. 5 Bins. 160. 45 Lake Erie, etc., R. R. ('o. $v$. Whitham, 15.5 111. 514.

si The requisites of a notarial seal are determinerl by the law of the locality from which the ofincer derives his authority; or, if that be 
where the land is situatr, and nomally, in such cases, his certificate must also be aceompanied by a certificate of unasistracy and conformity made by some officer of competent authority.

The seal is prima farie evirlence that the person using it is a notary, duly commissioned, ${ }^{t i}$ ete, and its absence should be brielly noted; thus:

No notarial (or officiul) scal show of record.

As a rule, a notarial certificate from another State without a seal or certificate of confomity will be invalid; ${ }^{18}$ and, generally, where the statute requires a notary to attach his seal to certificates of his oflicial acts, a certificate unathenticater by the impression of such seat is roir. ${ }^{49}$

The law does not usually, in terms, imprse upon the recorder the duty of transeribing the official seal of the oftecr taking the acknowledgment, and many recondere simply represent it by a seroll and the words "seal " or " notarial seal; " in bint whatever the form that mar be employed to indicate the fact of sealing it should be observed by the examiner. It has been held, in several instances, that where there is a statement in the

silent on the subject, then by the rules of the common law. It is defined as an impression on the paper directly, or on wax or wafer attached thereto, made by the official as and for lis seal. In the absence of express legilation it need not contain his mame. for it is the seal, and not its composition or character of which conts take jurlicial notice. The presmuption is that a seal is the official seal of the person it purports to be, and who subscribed the jurat. In lie Plitlips, 14 Nat. Bankr. Ties. (Xo. 5) 2J!!

47 Brown $r$. Phil. Bk., 6 Serg. \& I. 484 ; Stephens $r$. Williams, 46 lowa, 540.

48 Bonth $r$. Cook, 20 I11. I29; 'Texas Land Co. $v$. Willians, jl Tex.
5I. See also the local statutory provi-ions on this subject.

49 Welton $r$. Atkinson. 53 Veb. 674; Hewitt $r$. Morgan. Ss Iowa, 46s; De Graw r. King. 23 Ninn. 118. But comprare, Sonfield $v$ Thompen, 4.2 Ark. 40.

50 In Simith r. Dal, Is Cal. 510. it was held that it in not necessary that the seal should he ropied upon the record and that it is enongly if it appears from the record that the deed oppied was undire seall. In Bucklen r. Hatatelik. Har Ill. 42:3. it was laete that the lotters" L. S." following the mame of a notary in a rertificate of ackuewledgment. als slown in an abstratet of tille. suflidiently indieate that an onireial scal was attached to such certiticalte. 
body of the certificate, that the ofticer who made it, affixed his seal of office, a presumption is raised that such was the fact, and that it is not necessary that the recorl copy should contain a fac simile of the seal, nor any indications thereof by scroll. ${ }^{51}$

But although a deed is defectively acknowledged, or even not acknowledged at all, it is good as between the parties and subsequent purchaser's with actual notice, and passes title equaliy with one duly certified. The certificate does not affect the force of the instrument. ${ }^{52}$ Acknowledgment, however, is frequently a requisite for registration, and a deed must be legally recordable to make the record thereof constructive notice. ${ }^{53}$

The certificate should state the fact of acknowledgment, and should fix the identity of the party making same, those being the great essentials of erery official authentication. ${ }^{54}$ A certificate defective in either respect does not show a substantial compliance with the requirements of law, which provide that the grantor shall be known or his identity satisfactorily proved to the certifying officer. ${ }^{55}$ When regular, the certificate is notieed at the conclusion of the synopsis by a brief mention of the fact and date, as,

Aclinowledged June 1, 1982 .

Slight defects or omissions may be shown in a descriptive way, as:

Acknowledged June 1, 18S2, by William Smith only. (or) In certificate of acknowledgment, said grantor's name is written "William Smythe."

51 Geary $v$. City of Kansas, 61 Mo. 37s; Griffin $v$. Slieflield, 38 Miss. 359.

52 Sterens $v$. Hampton, 46 Mo. 404; Gray v. Ulrich, 8 Kan. 112; Dole $v$. Thurlow, 12 Met. 157; Hoy $v$. Allen, 27 Iowa, 208.

53 Pringle $v$. Dunn, 37 Wis. 449;
Bass $x$. Estill, 50 Miss. 300; Willard $r$. Cramer, 26 Iowa, 22. 54 Bryan r. Ramirez, 8 Cal. 461 ; Pendleton r. Button, 3 Conn. 406; Short $r$. Conlee. 2 S Ill. 219.

55 Stuller l. Link, 2 Thomp. \& C. (N. Y.) 86 ; Callaway v. Fash, 50 No. 420; Smitl $v$. Garden, 28 Wis. 685 . 
Defects of form, insufficient statement, or non-compliance with the statute, will frequently require an entire or partial transcription of the certificate. The acknowledgments of married women, corporations, and persons acting by delegated power, or in an oficial capacity, should be closely scrutinized, while in several of the States the deed is ineffectual to convey the homestead estate unless the statutory l'ight is specially waived in the acknowledgment. Where the certificate omits any of the jurisdictional facts such omissions should be properly noted, as:

Certificale of arlinouledgment by James Thompson, Notary Public, Cook ('ounty. Ill., does not state that grantors were linown to him, or that they waived their homestead rights.

As between the immediate partics, the eertificate may be impeached for fraul, collusion, or inposition, but not otherwise, ${ }^{56}$ As to purchasers for a valuable consideration without notice, it is conchusive as to all matters which it is the duty of the acknowledging officer to certify if he has jurisdiction, ${ }^{57}$ and where an oficer is authorized to take acknowledgments, it will be presumed that they were taken within his jurisdiction. ${ }^{5 \mathrm{~s}}$

The subject will be further considered, with practicai examples, in treating of specific converances.

$\S 197$. Delivery. To principle is better established by the entire current of modern authority than that the delivery of a deed is essential to a transfer of the title ${ }^{59}$ It is the final act consummating and confirning the conveyance, and without which all other formalities are incffectual.;0 $A$ deed, though

56 Fitzgerald $v$. Fitzgerald, 1.00 1II. 385.

5 i Williams $v$. Baker, 71 Pa. St. 476 ; Wharton on Evid. \$ 1052: Borland $r$. Walrath, 33 Iowa, I30; Howland r. liake, 97 U.S. (7 Otto) 624.

5s People $v$. Snyder, 41 N. Y. 397; Teutonia, etc., Co. $v$. Turrell, 19
Ind. App. 469 ; Cox. r. Stern, 170 IIl. 442 .

59 Mitchell $r$. Burtledt, $51 \mathrm{~N}$. Y. 447 ; Stiles $r$. Bown, ]6 Vt. 563; Fisher v. Beckwith, :30 Wis. 5.5; Oliver ve Stome, 24 ra. 63.

(;0) Young $v$. Gailleatu, 3 Wall. 636; Whitaker $r$. Millar, 83 11 l. 381 ; Thatcher 1 . St. Andrew's Church, 37 Mich. 2064. 
duly executed and otherwise perfort, while remaining under the control of the granter passes no title. ${ }^{61}$

To constitute a sufficient delivery, the deed must not only be delivered by the grantor, but must be accepted by the seantee, ${ }^{62}$ though ordinarily a delivery of a deed implies an acceptance. ${ }^{63}$ What constitutes a valid delivery or acceptanco has been the subject of a great diversity of opinion and a vast number of reported deciwions, and is still, to some extent an open and unsettled qucstion to be letermined by the particular facts of each case under the application of local law. These questions, however important in rother respects, present but few features to the examiner, who looks only at the instruments as they appear upon the reeords, and passes un their sufficiency and legal effect from what is there show. The attestation clause usually recites that the conveyance was "signed, sealed and delivered," ete., but this has been held, not sufficient. in itself, to establish a delivery. ${ }^{64}$

The recording of a decd not only affords prime facie evidence of its delivery, ${ }^{65}$ but, when the instrument is properly executed and acknowlentgerl, raises a legal presumption of that fact, ${ }^{66}$ and, where it $i ;$ in $^{\circ}$ the grantee's advantage, of its ac-

61 Egery $r$. Woodard, 56 X[r. 45: Fisher $v$. Hall, 41 T. Y. 416 : Byar's $r$. Spencer, 101 111. 429. Thomigh it seems that a deed once delivered is not invalidated by the fact that it remains in the possesion of the grantor. Wallace $r$. Berdell, $97 \mathrm{~N}$. Y. 13.

62 C mer v. Baldwin. 16 Minn. 172; Commonwealth $v$. Jackson. 10 Bush (Ky.), 424: Welch v. Sacket, 12 Wis. 243; Oxnard $r$. Blake, 45 Nie. 602 .

6: Davemport 1 . Whistler, 46 Iowa, 287; Bundy r. Ophir 1ron Co., 38 Ohio st. 300: Bivard $r$. Walker, :9 Ill. 413. This is the general rule. and rests upon the ground that a parly is presumed to accept that which is beneficial to him, yet the presumption that a parly will acept : deed because it is beneficial to him will never be carried so far as to consider him as haring arcepted it. Bell $x$. Farmers' Bank, 11 Bush (Ky.), 34.

b4 linslin $r$. Shield, 11 Ga. 636; but see, Howe $r$. IIowe, 99 Mass. 88.

65 Himes $r$. Feighblinger, $14 \mathrm{Ill}$. 469 ; Burkholeler $r$. Calsed, 47 Ind. 418; Kille $r$. Eyc, 79 Pa. St. 15; Jackion r. Perkins. "Wend. 303 ; Latwence $r$. Farloy, 24 Irum (N. Y.), 293; Comard $r$. Colgan, 55 Iowa, 5:38: Moore $r$. Giles, 49 Conm. 570 .

6is Kille $r$. Eye, 79 Pa. St. 15; Alexander $r$. Alexander, 71 Ala. 295: hut see, Boyd $i$. Slayback, 63 Cal. 49\%. 
ceptance as well. ${ }^{67}$ Where the grantor in a deed not actually delivered causes the same to be recorded, this has been held a sufticient delivery to enalile the grantee to hrold the land as against the grautor and those claming under him. ${ }^{68}$ Generally a delivery will be presnmed, in the absence of direct evidence of the fact, from the concurrent acts of the parties recognizing a transfer of title. ${ }^{69}$

As a general rule a deed will be presumed to have been delivered on the day it bears late, "in though this presumption is not conclusive. ${ }^{71}$ It has been held that where the date of acknowledgment is subsequent to the date of the deed, there is no presmption of delivery prior to the acknowledgment. ${ }^{2}$ The volume of anthority, howerer, does not sustain this doctrine, and the date of execution, in the absence of other proof to the contrary, may still be taken as the true date of delivery, ${ }^{3}$ and not the date of acknowledgment, which, as a matter of convenience, nay well have been made afterwarl. "* So where a grantce dies between the dates of the doed and its acknowledg-

6 T Metcalfe $v$. Brandon, 60 Mirs. 685; Manterson r. Check, 23 Ill. 73. While the recording of a decel for land may atrord prima facie evidence of its delivery and acceptance, this must be umlerstood as applying to a deed simply conteying the land, and not as aplylying to a deed which imposes an obligation upon the grantee to anslume and pay a pre-existing incumbrance on the property. Thompon $v$. Dearborn, 107 Ill. 87.

68 Kerr $x$. Birnie. 2.5 trk. 20.5; Dale $v$. Lincoln, 62 Ill. 22: Palmer v. Palmer, 62 Iowa, 170.

69 Gould r. Day, 4 Otto (U. s.). 405. Thus wheres a deed hall been executed and recordend without the knowledge of the granter, who sulpsequently exeroterl a monveraner to a thisd party. this recosnition by both particis of the transfer of the title was hold to be sufficient evidence that at the time a delivery of the deed had been made. Ibid.

i" Deninuer $r$. MreConnell, 4l 111. 228; Treadwell r. Reynolds. 47 Cal. 171; Harnian $r$. Oberdorfer. 33 Grat. (Va.) 497; Raines $t$. Waiker, $77 \mathrm{Ta}, 9 \%$.

71 Whitman $r$. Heunelerry, 73 Ill. 109.

iz Fontaine $l$. Savings Institu. tion, is Mo. 553; Brolasky $r$. Furer, 1.2 Phil. (Pa.) 428. Waishburn alos amnouneses the wane prineiple. See 3 Waslı. hetil Prop. (tell Will.) 286.

72. Hardin r. C'rate, 7s 111. 553; Elhworth r. (ent. R. R., 3.1 X. I. L. 9:8; Jillings $t$, intark, to liat. $89 \%$.

it Prople r. Anyder, 41 N. Y. 402 ; fiardin $r$, (Mborme, (o) IH. 9), and see Fisher $\because$ linther, 19 Ohio, 406. 
ment, it will be presumed that the deed had been delivered in his lifetime. ${ }^{i 5}$ As a conveyance derives its effect and operation only from delivery of the deed, the cuestion of time will not infrequently form an important element in the niethods employed by comnsel in framing his opinion of the title, as well as in determining the respective rights and relations of parties who hold unrer the deeds, or who show conflicting or adverse claims. The abstract will nsually shed but little light on itself, and under ordinary circumstances it will be safe to proceed on the assumption that the date of execution is also the time at which the title to the property conreyed passed to the grantee. $^{\tau \omega}$ In case of a forged instrument, there is no presumption of delivery either at its date, or at any other time. ${ }^{77}$

$\$$ 19s. Ancient Dreds. Deeds more than thirty years old are called "ancient deeds," and are exempt from the usual tests applied to conreyances, being admitted in evidence without proof of execution, ${ }^{78}$ and where a leed wonld be evidence as an ancient deed withont proof of its execution, the power under which it puports to have been executed will be presumed. ${ }^{79}$ This rnle is not uniform, howerer, and it has been hold that a converance, thongh over thirty years old, can not be admitted as an ancient deed when purporting to be executed by one acting as atministrator in the absence of proof of his authority to make the deed. And when such authority is conferred by an onder or lecree of a conrt, the jurisdiction of the latter to grant the order or decree inust be shown on the face of the procecdings. ${ }^{80}$

Some discretion may be employed by the examiner in regard to conreyances of long standing, and under which the rights of the parties hare become fixed by continued possession and enjoynent. It will not be necessary, in many cases, to notice de-

75 Eaton $v$. Trowbridge, 38 Mich. 454 .

is Breckenridge $r$. Toss, 3 T. B. Mon. (Ky.) 150. The same doctrine is recognized and sanctioned by the English decisions under their statute's of enrollments. See also Shep. Touch. 72 .
77 Remington Pap. Co. $v$. O'Dougherty, 81 N. Y. 474.

is Whitman $\iota$. Heneberry, $73 \mathrm{Ill}$. 109; Gardner $v$. Granniss, $57 \mathrm{Ga}$. 539.

i9 Johnson $v$. Shaw, 41 Tex. 428. so Fell $v$. Young, 63 Ill. 106. 
feets that should invariably appear in the case of later deeds, particularly when rendered of no effect by curative legislative enactments.

Most of the States have enacted statutes which, in effect, eure defects and irregularities in acknowledgments of deceds made a snecified tinc prior to such enactnents. In the absence of any inhibiting constitutional limitation, and execpt as against vested rights, it would seem the legislature has power to eure, by retroactive legislation, defective acknowledgments of deeds, in all cases where the purpose of the acknowledgment is the admission of the instrument acknowledged to reeord or its use as evidenee. Where the statute enres irregularities in acknowledgment, the record of snch deet, male prior to the enactment, is also cured and rendered valid, and such record, or a copy thereof, is properly admissible in evidence. ${ }^{81}$

$\S 199$. Stamps. Br act of Congress, ${ }^{82}$. July 1, 1862, and acts amendatory thereto, ${ }^{\mathrm{s}}$ an ad valorem stamp duty was imposed on deeds of conveyance and other contracts relating to real property. The act provided that the stamps should bo affixed to the instrument and properly cancelles,${ }^{84}$ and in default thereof the instrument to be invalid. The act becane in force on and after Oct. 1, 1862, and continued for a period of ten years. ${ }^{85} \quad$ By the act of June 13,1898 , a stanp duty was again imposed, which, in varions forms, continued until July 1, 1902. On all instruments executed during these periords, the examiner will observe whether the record purports to show a stamp. If so, it should be bricfly indicated in some manner, as ;

U. S. Int. Rev. Stamps for $\$ 1.50$ affixed. or, if none;

No Int. Rev. Stamp shown of record. 179.

81 Summer $v$. Mitchell, 29 Fla.

8212 U. S. Stat. 475.

8313 U. S. Stat. 299.

S5 The duty was repealed by the act of June 6, 1872, in foree, Oct. 1, 1872. See, 17 Stat. at Larie, 256 .

8413 U. S. Stat. 293. 
The presence or absence of lle stami', however, matters little so far as the validity of the conveyance is concerned, for it is not in the constitutional power of Congress to prescribe for the States a rule for the transfer of property within them, ${ }^{86}$ nor to provide rules of evidence for the State courts, ${ }^{s 7}$ and conveyanees are not rendered roid by the omission of the prescribed stamps, ${ }^{s s}$ nor for neglect to cancel them if affixed. ${ }^{89}$ The act, so far as it prescribes a rule of eridence, is operative only in the Federal courts, and has no application to the courts of the States.90

The right of the Federal Government to collect a revenue by the imposition of stamp duties is molisputed, and penalties may be prescribed for the non-payment of such tax. But the anthorities are mited in declaring that an unstamped instrument if otherwise conforming to law, is not, for that reason, invalid. ${ }^{91}$

s6 Moore $r$. Moore, 47 N. Y. $46 \tau$; Carpenter $v$. Snelling, 97 Mass. 45: si Barbour $r$. Gates, 43 N. Y. 40 ; Craig r. Dimork. 47 Ill. 308; Green $r$. Holway, 101 Mass. 243; Griffin i. Ranney, 35 Comn. 293.

ss Janvin $r$. Fogg, 49 N. H. 340 ; Rhienstrom $v$. Cone, 26 Wis. 163 ; Brown $v$. Thompson, 59 Me. 372; Morris $t$. MeMorris, 44 Miss. 441 ; Latham $r$. Smith, 45 Ill. 29 . 89 Agricultural Awsoe. $\ell$. Neill, 31 Iowa. 95: Dtrmond $r$. Dubose, 2. La. Ann. 131. 9u Wilson $r$; McKenna, 52 Ill. 43; People 1. Gates, 43 N. Y. 40 ; Sammons $r$. Halloway, 21 Mich. 162; Woodward $r$. Roberts, 58 N. H. 503; Snall $r$. Slocumb, 112 Ga. 279; Kennedy $r$. Roundtree, $59 \mathrm{~S}$. C. 324; Cos r. Estes, 106 Tenn. 472.

91 Sammons $r$. Halloway, $21 \mathrm{Mich}$ 16:- Bunker $v$. Green, 48 Ill. 243; Duffy $r$. Hobson, 40 Cal. 240. An apparently contrary decision was reached in Chartiers, ete., Co. $v$. McNamara. 72 Pa. St, 278, but this case seems to stand alone. 


\section{CIIPTER XIV.}

ERRORS, OMISSIONS AND DEFECTS.

§ 200. Error generally.

201 . Defect of parties-Criantor.

202. Defect of parties-Crantee.

203. Disparity of dates.

204. Technical phrases.

205. Misdescription - Uncertainty.
$\S$ 206. Misdescription-Omission.

207. Misdercription-Quantity.

218. Defective arenants.

20!. Defective acknowledgment.

210. Comtinued.

211. Tiepugnancy.

§ 200. Frror Generally. Conveyaners, like other mortals, have no immunity from error. Not only do the best skilled often forget, but ignorance and carelessness, assuming the office and functions of the conveyaneer, angment their mistakes a thousand fold. Superadderl to thre, are the errors, blunders and omissions arising during the transcribing fiom the original documents to the record, all of which necessitates constant watehfuncss on the part of both examiner and counsel.

The errors most eommon are found in disparity of dates; the acknowledgment frequently antelating the execution, and occasionally the date of registration having priority of both. Diserepancies in names; a particular name appearing in the premises, another in the execution and ofttimes yet another in the acknowledgment. Manifest misdescriptions of the property intencled to be conveyed when compared with preceding conveyances; sometines glaring and obtrusive and again retiring and only discernible by close and coneentrated attention. Onissions are more frequent and palpable. They are usually the result of negligenee on the part of cither the conveyancer or recorder, or perhaps loth, and call for a corresponding degree of eare on the part of the examiner. Whe po printed forms are used in conveyaneing, blanks are frequently inproperly filled, or quite as often loft untonched. This will fre- 
quently be found to be the case in the matter of dates, personal pronouns, referenees to the parties, venue and the like. Misdescriptions of the property often ocenr where the conveyancer copies the description from some older deed in which figures, initials, words, a course or distance, or even a whole line will be omitted and pass unnoticed until detected by the examiner. These errors, appearing on the face of the recorl, it is the duty of the examiner to detect and carefully note in such a manner that the attention of counsel will be drawn to them on the perusal of the abstract.

$\S 201$. Defect of Parties-Grantor. A discrepancy will frequently be noticed between the names of the grantors in the body of the deed, usually written by the conveyancer, and those in the execution, written by the parties personally. Where the variation is slight the difference may be shown by writing the name in the caption or entitlement as it appears in the signature, and adding a statement at the conclusion of the synopsis substantially as follows:

In body of deed (and certificate of acknowledgment) said grantor's name is written "George A. Smith."

The error being indieated in both names by an underscore.

Diserepancies similar to the one just noticed are frequent, but fortunately comparatively harmless. The law knows but one Christian name, and the omission or insertion of a middle name is immaterial, ${ }^{1}$ and usually if there is a variance between the names of the grantors as they appear in the body of the deed and in the signatures, the identity of the persons will be presumed, until rebutted, where the deed has been properly acknowledged. ${ }^{2}$ In case of a radical difference in the orthography or sound, the names in the premises should form the eaption and the execution of tho deed should be set forth fully.

1 James $v$. Stiles, 14 Pet. 322; Dunn $\because$ Gaines, 1 McLean, 321; Erskine $v$. Davis, 25 Ill. 251; Scofield $v$. Jennings, 68 Ind. 232;
Franklin $v$. Talmadge, 5 Johns. (N. Y.) 84 .

2 Lyon $v$. Kain, 36 Ill. 362. 
An apparent defect of parties will sometimes appear through an error of the copyist in transcribing the original instrument to the pages of the record. Thus a deed is found from IIarry Thompson. The title of record, as shown by the previous converance, is rested in Ilarvey Thompson. Now if the original entries of the examiner disclose that the deed in question is from Harvey Thompson it may fairly be concluded that the name as recorded is an error of transcription. But the examiner must show the deed as he finds it. This he does, calling attention to the discrepancy by underscoring the erroneons part of the name and then, for the information of counsel, he should append a note something as follows:

Note.-Our books of original entry, compiled from original instruments before the same are spread of record, show the name of the grantor in the foregoing deed to be Harvey Thompson.

It sometimes happens that, through inadvertence or mistake, the name of the grantor has been entirely omitted in the body of the deed, and while it has been held, in some instances, that one who signs, seals and delirers a deed is bound by such acts as grantor, although not named as such therein, ${ }^{3}$ the current of later decisions would indicate that a deed of this kind is ineffectual to conves any interest or pass title. ${ }^{4}$ The theory upon which the first mentioned class of cases proceed seems to be, that the signing of a deed manifests the intention of the signer to be bound by it, and, hence, that courts should construe such a deed so as to give effect to the intention of the parties. But the preponderance of authority holds that the intention of parties must be derived from the language of the deed itself, and, therefore, when there is nothing in the bods of the deed to show an intention on the part of the signer therenf to conver,

3 Elliott $v$. Sleeper, 2 N. H. 525; Thompson $v$. Lovrein, $82 \mathrm{~Pa}$. St. 432 ; Armstrong $v$. Stovall, 26 Miss. 275.
4 Harrison $r$. Simmons, 55 Ala. 510; Laughlin $v$. Fream, $14 \mathrm{~W}$. Va. 322; Peabody $v$. Hewitt, 52 Me. 33; Bank $v$. Rice, 4 How. 225; Stone $v$. Sledge, 87 Tex. 49. 
his mere signature cannot he held to manifest such purpose.

Where only a portion of the grantors named in a deed sign and acknowledge same, the authorities are somewhat divided as to its effect. Some hold that where a deed shows that it was interded to be jointly execnted by all the parties, an execution and delivery by a portion only is incomplete and does not bind them; ${ }^{5}$ a majority of cases, however, favor the contrary doctrine and secm to sustain the principle, that the parties executing will be bound thereby, and the derd be suffieient to pass their interests. ${ }^{6}$

If the true owner of land conveys by any name, the conveyance, as between him and his grantee, will transfer title, and in all cases evidence aliunde is admissible to identify the actual grantor: ${ }^{7}$

$\$$ 202. Defect of Parties-Cranted. Defects, of the kind which forms the caption to this section, arises mainly from imperfect designation, misnomer and omission, and from their nature are not always susceptible of easy detection. In case of misnomer they will frequently appear only inferentially by comparison with other instruments, but when detected attention should be drawn to them. Where a deed to William Iremon is followed by a conveyance from William $J$. Hermam, there is an apparent break in the chain and the examiner should call attention thereto by an underscore, or, better still, by a row of short marks under each name, thus: Mermann. When an underatanding to that effect exists between examiner and comsel, this method of notation will also serve to signify that this is the identical mamer in which words so treated appear upon the records, and is not due to any negligence of transcription on the part of the examiner.

Defects similar to that jut consilered are latent defects and

5 Arthur $r$ Anderson, 9 S. C. 234 .

6 Story Part., \$ 119; Parcons Part. $\$ 369$.

$T$ As where a deed purports to be from John O. Black, and is signed
".. O. Black," parol evidence is armissible to show that James 0 . Black was the ilentical person who in fact exconted the deed. Wakefield $t$. Brown, 38 Minn. 361. 
susceptible of parol explanation, and where no new deels are made, affidarits showing the identity of the parties should be required by coumsel. In constming deeds of this character, $i$. $e$, where a party takes nucer a misnomer, but conveys by his proper name, courts are ever inclined to grant the widest leniency, for, in the great influx of foreign speaking population which the United States is constantly receiving, mistakes must occur in adapting to the English forms of pronunciation, foreign names and the spelling of same; hence it has been held that a deed to "Mitchell Allen," followed by a deed from "Michael Allaine," is not a fatal variance, and the parties will be presumed to be

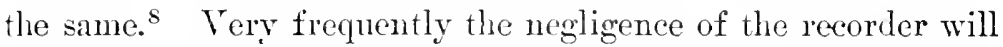
produce disparities of this kind, as where the records show a deed to "Electa Wilds" and a subsequent deed of the same property from "Electa Wilder," "Wilds" being, howerer, the true name. In every case similar to this the attorney examining the abstract should, by proper inquiries, ascertain the facts, and when the defect is wholly due to errors in transcribing, a re-record of the instrument should be had. Is a rule, defects in the record or paper title nuy be cured or removed by parol evidence. ${ }^{9}$

Grantees capable of identification, though not fully named, will nevertheless take title; thus, a deed to John Smith and the "other heirs at law" of one deceased, would convey an estate to all the heirs of such deceased person as fully as if each were specifically named; " yet where one of such "heirs" lias attempted to assert title, the abstract should show by competent evidence his right so to do. A conreyance to a person specified,

8 Chiniquy $v$. Catholic Bishop, 41 III. 148. It has been held that where a person accepts a deed of conveyance in which his name is not correctly stated or spelled, he is deemed to have adopted the erroneous name for the purpose of acquiring and holding title to the land. Blinn $v$. Chessman, $49 \mathrm{Mlinn}$.
140. And, generally, if a person is in existence a conveyance to him by a wrong name palsies title. Wilson $r$. White, 84 Cil. 2:89.

9 Hellreigil $r$. Manning, $97 \mathrm{~N}$. Y. 56 ; Shriver $r$. Shriver, $86 \mathrm{~N}$. Y. 575.

1) Cook $r$. Sinnamon, 47 Ill. 214; Jow v. Graft, 80 Ill. 360 . 
however, and the heirs of a living person would be void as to all except the person specifically named. ${ }^{11}$

$A$ deed to a dead person is, of course a nullity, ${ }^{12}$ though it scems that a conveyance to one at the time dead, "or his heirs," is good if the heirs can be identified. ${ }^{13}$ It seems almost unnecessary to remark that a deed without a grantee is absolutely void. ${ }^{14}$

But, as previously shown, it is not essential to validity that the grantee shall be speeifically named. It is enough that suffieient appears to distinguish him from the rest of mankind, and if, by proper construction, this can be done the grant will not fail. Thus, where a deed recited that the grantor in consideration of a sum of money paid by John Smith "does hereby conrey unto the said — all right, title and interest in and to "property then deseribed, the deed was held a valid conveyance to John Smith. This presents a familiar case of omission by an unskilled draughtsman. The recital that the money was paid by John Smith raises a strong but not conclusive presumption that he was intended for the grantee, but the imperfect granting clause recites that the grant is to "the said -C," clearly indicating some person theretofore named. The only persons to whom reference could be made are the grantor and John Smith, hence the court in construing the deed held that the grantee was suffieiently identified. ${ }^{15}$

$\S 203$. Disparity of Dates. A frequent defect in deeds is a disparity of dates, that is, the acknowledgment antedating the execution, ete. This is a minor defect, however, that does not go to the foundation of the deed, for the date may be disregarded in a proper case and the deed will yet stand.

In point of form the date is not essential, and is valuable chiefly as an evidence of time in passing on the rights of parties, or fixing the status of the conveyance in respect to other deeds

11 Hall $v$. Leonard, 1 Pick. 27; Winslow $v$. Winslow, 52 Ind. 8; but see Grimes $v$. Orrand, 2 Heisk. (Tenn.) 298.

12 llunter $v$. Watson, 12 Cal. 363.
13 Neal v. Nelson, 117 N. C. 393. 14 Whitaker $v$. Miller, 83 Ill. 381. 15 Henning $v$. Paschke, 9 N. Dak. 489. 
or transfers of title. For the purpose of operative converance the time of delivery is the true date, and this may alway be shown by parol. Attention is called to defects or disprarities of dates by a broad dash or underscore, as

\section{Dated June - 1883, or Dated June 13, 1883.}

In the latter case, both dates, or as many as appear irreconcilable, must be treated in this manner, and the disparity will thus be brought prominently before the notice of the person perusing the abstract.

\$ 204. Technieal Prisses. Whenever it is apparent that a grantor has used a techical word to express an idea different from its technical signification, a court will constrne it according to the manifest intention of the grantor, ${ }^{16}$ but in ascertaining such intent, where the words emplover are not technical, they must be taken in their usual acceptation. ${ }^{7}$

In conveyancing a large number of plrases have obtained currency, which, practically, neither add to nor detract from the force of that which preceles or follows, but are retained and used in much the same mannel as numerons other incidents of modem deeds, rather for their supposititious efficacy than for any real utility. Of this elass is the language "more or less," which is cxtensively used in deeds and contracts for the sale of land. This term must be understood to apply only to small excesses or deficiencies attributable to the variation of the instruments of surveyors, ete. ${ }^{1 s}$ In like manner the words "known as," in a description in a deed, is a mere formula and has no restrictive effect. ${ }^{19}$ " And all the buildings thereon," etc., have no legal signification. ${ }^{20}$ So, also, many phraves in the body of the deed are withont force;

16 C. P. R. R. Co. $v$. Beal, 47 Cal. 151.

17 Bradshaw $t$. Bradshaw, 64 Mo. 334.

18 Benson $v$. Humphreys, 75 Va. 196. It has been held, however, that a qualification of the quantity of a lot of land sold as "more or less" will eover any deficieney not so gross as to justify the suspicion of wilful deception or mistake amounting to fraud: Wylly $v$. Gazan, 69) Ga. 506.

19 Kneeland $r$ Vian Valkenburgh, 46 Wis. 434.

20 Crosby v. Parker, 4 Mass. 110. 
as, the worls "to his and their proper use and behoof," etc., following the words of limitation. These words have no particular meaning or effect in determining either the extent of the interest conveyed, or the nature and quality of the estate in tended to be rested. In deeds of bargain and sale, at the present time, they serve no office whatever. ${ }^{21}$

Words and phrases similar to the foregoing, detract nothing from the deed by their omission and do not eall for notice, but where technical words of limitation, purchase, inheritance, ete, are onitted in dcels purporting to convey only limited or special interests or estates, it will sometimes become advisable to show such omission, together with such parts of the habendum, or other operative portions of the deed, as will supply the missing words or indicate the undefined intent of the grantor. The intent, when apparent, and not repugnant to any rule of law, will always control technical terms; for the intent and not the words, is the essence of every agreement. ${ }^{22}$

§ 205. Misdescription - Uncertainty. Ambiguous and uncertain descriptions, particularly when composed of ealls for courses and distances, are among the most common defects found in modern deeds. They arise frequently from the carelessness and inattention of the conveyancer, but more often, perhaps, from a false conomy in the surver, the draughtsman computing his distances and framing his courses by reference to some former map or survey, and not by actually ruming the lines in tho field. This very convenient, but equally pernicious system, prevails to an alarming extent in modern conveyancing, and when attempted by incompetent hands, is often followed by uncertainty if not fatal error. In all cases of description by metes and bounds, the description in the deed under examination should be compared with both former and subsequent ones as given in other conveyances, and with the true description of the tract that forms the subject of the examination. This task should be performed both by the examiner and by counsel, and is a precaution never to be omitted.

21 . Jarkson v. Cary, 16 Johns. 302; Brown v. Renshaw, 57 Md. 67.

$2 *$ Callins $v$. Lavelle, $44 \mathrm{Vt} .230$. 
An imperfect or nucertain description does not, of itself, vitiate the conveyance, provided it affords definite means by which the identity of the prenises may be established; as by reference to certain known whincts or things, ${ }^{23}$ or to perfect descriptions in other deeds. ${ }^{24}$ In the absence of references, or other identifying cireminstances, if the land be so inaceurately described as to render its identity wholly uncertain, the grant is void. ${ }^{25}$ The same rule applies with equal force to exceptions and reservations from the grant, for although the grant may prevail, the exception may be voil for uncertainty. ${ }^{26}$ What is here meant, howerer, is legal invalidity, for notwithstanding that at law a deed may be roid on its face for want of a definite description of the land intended to be conveyed, $\mathrm{yc}_{\llcorner}^{2}$, in equity, it may be reformed upon proper allegations and proof of extrinsic faets. ${ }^{2 \tau}$

Imperfect descriptions creating uncertainty by reason of vagueness are common, particularly in case of tax deeds; as, "200 acs. in Sec. 2," etc.; no particular portion of the section being designated. A deed is not necessarily void for uncertainty where land is described by a general name or designation, which by extrinsic evidence can bo fully identified, ${ }^{28}$ and, as a rule, a deed will only be held void for uncertainty, where, after resort to oral proof, it still remains a matter of conjecture what was intended by the instrument. ${ }^{29}$ It will be understood, however, that this alludes only to latent ambiguity. ${ }^{30}$

$\S 206$. Mistescription - Omission. One of the principal elements of uncertainty in deseriptions is produced by omissions of essential particulars, though the effect of such omissions is not the same in all the States. The name of the comnty and State in which the land is situate usually precedes, and some-

23 Coats $v$. Taft, 12 Wis. 388; Smith $v$. Crawford, 81 11l. 296.

24 Riussell $v$. Brown, 41 Ill. 184. 25 Calrord $v$. Alexander, $67 \mathrm{Ill}$. 581; Campluell $v$. Johnson, $44 \mathrm{Mo}$. 247; Dirkins $v$. Barnes, $79 \mathrm{~N}$. C. 490; Rollin v. Pickett, 2 Ilill (N. Y.), 552 .
26 Thayer 2 . Torry, 37 N. J. I. 339.

27 Creene $r$. Dickson, 119 Ala. 346 .

28 Tuleker r. Finld, it Mist. 191.

29 Smith r. Crawforl, \& I Ill. esti.

3) Bowers 1 . Andrews, 52 Miss. 596 . 
times follows the description. Its insertion tends to greater certainty, yet the entire omission of this particular is of minor. conseninene, provided the section, town and range is correctly stated, as there can be but one locality answering that description, ${ }^{31}$ but a description giving simply the subdivision of the section, and emitting the section, town and range, wonld be so defective that it would convey nothing, ${ }^{32}$ even though the county and State were given. ${ }^{33} \Lambda$ very common omission is found in the matter of the meridian, as where lands are describer as "Section 10, Town 39, North Range 14 East." The insertion of the comnty and State will serve, in large measure, to correct the uncertainty thus created but should the county and State be also omitted the description is fatally defective unless aided by extrinsic evidence.

But, as freviously stated, a material omission will not usually invalilate an instrument, where other adequate elements of identification exist. ${ }^{34}$

\$207. Misfoscription - Quantity. A recital in a conveyance of land that the tract contains a certain number of acres, mless there is an express covenant as to quantity, will always be regarded as a part of the description merely, and if inconsistent with the calls of the deed, will be rejected as surplusage. ${ }^{35}$ Such a recital aids, but does not control, the description of the grant.

\$ 208. Defective Covenants. Defective covenants form a fruitful source of litigation, as well as of rexation and annoyance, and the examiner shonld devote especial care in abstracting this portion of the deed, to the end that throngh his negligence the intending purchaser may not also buy a lawsuit.

31 Howe $v$. Williams, 50 Mo. 252; Beal $v$. Tlair, 33 Iowa, 315 ; Slater $v$. Breese, 36 Mich. 77; Sickmon $v$. Foorl, 69 Ill. 329: compare Lloyd $r$. Bunce, 41 Iowa, 660.

s2 Tollenson r. Gunderson. 1 Wis. 113: Fnller r. Fellows, 30 Ark. 65i; hat com?nge Butler $\ell$. Daris, 5 Neb. 521.
33 Such a deed, though inoperative as a conveyance, would raise an equity in the land sought to be conveyel in faror of the grantee. Lloyl $v$. Bunce, 41 Iowa, 660.

34 Slater $t$. Breese, 36 Mich. 77. 35 Fuller v. Carr, 33 N. J. L. 157; Camplell $r$. Johnson, 44 Mo. 247; Ufford $r$. Wilkins, 33 Iowa, 110. 
The majority of these errors arise through the stupidity or carelessncss of incompetent dranghtsmen in the use of printed forms, and unless closely scrutinized they will sometimes escape the eye of even an expert examiner. 4 familiar example - one occurring more frequently, perhaps, than any other - is in the commeneement of the collective covenant clause, which reads: "And the said parties of the first part for -." Here follows, in the printed blank, a spare intended to be filled by the conveyancer, with a personal pronom descriptive of the granting party or parties. The conveyancer neglects to fill this space; and the clause eontinues, "their heirs," etc., "do corenant," ete. Here there is certainly no direct corenant on the part of the granting partics, and in a similar case in Inlnois, it was held that the legal effect of a covenant of this character is not that the grantors will defend the title, but that the same shall be defended by their heirs, etc.; that it does not give a right of action against grantors on the loss of the title, but provides a remedy against their legal and personal representatives; that it exempts the grantors from personal liability, but binds their descendants in respect of the estate that may be cast upon them; that it is not like a covenant that a person who is not a party to the deed shall warrant and defend the title, for in such case, upon the eviction of the grantec, and the failure of such third person to comply with the terms of the covenant, an action might be maintained against the grantor, on the familiar principle that what a party undertakes shall be performed by another, he must himself perform on the default of that other. Here, the covenant is that the act shall be performed by parties who can have no legal existence during the lives of the grantors, and until their decease there is no person living who can be called upon to arouch the title. 36

A covenant by the grantors - "for them - heirs," de.- has been construed, "themselves, their heirs," etc., and held to be

36 Rufner $v$. AcConnel, 14 IIl. 168; Traynor v. Palmer, 86 Ill. 477. The error above inclicated is common, and can be found in books of "practieal forms." See "New Wiscon-in Form lbok," p. 92, form No. 2. 
the enrenaut of grantors. ${ }^{37}$ If the grantors corenant for themsclves, the neglect to insert the rords "their heirs," ete, after the allusion to the grantors, is only a minor defect, and, while it ealls for notice, is attended with no evil consequences. The legal effect of the corenant would be the same if all referenee to the heirs, executors and arlministrators were omitted, ${ }^{38}$ and this applies as well to grantees as to grantors.

\$209. Defective Acknowledgment. The office of the acknowledgment is to authenticate the deed, but to bo effective for this purpose, it must conform to, or substantially follow, the directions of the statute, loth as to the certifying officer and the form and substance of the certificate. The certificate, lowerer, is no part of the deed, but only evidence of its execution, and, like all other evilence, should be reasonably considered and construed. ${ }^{39}$ A substantial compliance with the statute prescribing its form and requisites is all that is required, ${ }^{40}$ and minor defects, not going to the essence of the acknowledgment, may be disregarded.

Clerical error's aire common, and arise mainly in the use of printed forms, where blanks are improperly filled or passed orer without filling. Courts are always inclined to construe such defects liberally, ${ }^{41}$ and only purchasers for value can take advantage of a defective acknowledgment. ${ }^{2}$ Where a certifieate stated that "Personally appeared before me P. II. and E. H., his wife, who - personally known to me," ete., omitting "are" after "who," it was held that snch omission did not impair the deed, as "who" might be disregarded as superfluous, and the certifieate would then be correct. ${ }^{43}$ So where the word "appeared" was omitted after the phrase "before me person-

37 Baker $r$. Hunt, 40 Hll. 201.

3s Hall $r$. Bumstead, 20 Pick. 2; Bell $r$. Boston, 101 Mass. 506.

39 Harrington $v$. Fish, 10 Mich. 415.

40 Calumet, etc., Co. $r$. Russell, 68 III. 426; Carpenter $r$. Dexter, 8 Wall. 513; Summer v. Mitchell, 29 Fla. 179 .
41 Scharfenburo $v$. Bishop, 35 Ia. 60; Fisher $r$. Butcher, 19 Onio, 406; IfcCardia $r$. Billings, $10 \mathrm{~N}$. Dak. 373.

42 Mastin $r$. Ialley, 61 Mo. 196. 108. 
ally," the omission was held to be a elerieal error, and not fatal to the validily of the acknowledgment; ${ }^{44}$ again, a certificate that $A$ "to me well known," cte., was held to be sulstantially in the form prescriberl hy statute, viz. that 1 "known to me to be the perion whose name is subseribed to the foregoing instrument, acknowledyenl," cte., ${ }^{45}$ and, generally, when the defect can he reconciled, or does not ilefeat the acknowledgment by indefiniteness or unerertainty, it will not invalidate. ${ }^{46}$

Another common defeet, and one that raiscs a very embarrassing question, is presented in the ase of a misplaced or improper pronom. In nust printed forms the recital of acknowledgment reads, "and adknowledged that - he - signed, sealed, delivered" "te., the purpose of this "latror saving" device being, to allow the blanks before and after the word "lie" to be filled by letters that shall make the words "she" or" "they" aceording as the exigencies of the case may require. The careless or imnorant draughtsman frequently neglects to avail himself of tho device and the deed goes forth with an ambiguous recital of one of the essential facts of acknowledgment. The mistake often oceurs in the case of a joint acknowledgment by husband and wife and the effect of the eertificate, in such event, is that the parties appeared before the officer and acknowledged that "he," the husband, executer the instrument. Now it is mdoubtedly true, under the generat trend of the decisions, that obvious errors or onissions, clearly appearing upon the face of the certificate to be clerical in their nature, will not invalidate the acknowledgment, and that, before a certificate will be held fatally deficient, there must be an absence of some essential fact of a substantial character. But, is not an omission like the one now muler consideration a matter of substance? In a reeent case where the question was presented it was held that it wonld render the whole sentence useless and meaningless, so far as the wife was encernerl, to place upon it the construction that she appeared hefore the notary and

\footnotetext{
44 Scharfenburg t. Bishop, 35 Iowa, 60. 
acknowledged that her hushand executed the deed, yet that such constrnetion numst be had mless it was held that the word "lue" was not changed to "they" throngh a clerical oversight. To hold the former, it was contended, wonld be a strained and technical constrnction of the language used, and so the certificate was sustained. ${ }^{47}$

A material omission, maided by other circumstances, will vitiate the acknowledgment, as where murporting to be made by - Smith, without other designation of the person; ${ }^{48}$ but it has been held that where the certificate onits the name of grantor, if it yet shows that the party who appeared before the oficer was the grantor, and that lie, and no one else appeared and acknowledged, ${ }^{* 9}$ or if he is referred to by name in the wife's acknowledgnent, ${ }^{50}$ this will be sufficient. In all cases the crror or onission should be clearly indicated by the examiner, and in such a mamer that counsel can pass upon it with relation to the context. Hence so much of the certificate should bo presented in all cases which scem to require it, as will effectuate this end.

A defect of frequent ocemrence will be found in disparity of dates, as where the date of the deed is subsequent to the date of acknowledgment; yet this error, while it calls for notice, is of minor importance and does not constitute a ralid objection to the title. ${ }^{51}$ Such anterlating is usually the result of elerical mistake and is so constmed in the absence of any matters calculated to raise a contrary presumption, and as the officer in taking an acknowledgment is required to certify both the day and the year he will be presumed to have performed his duty and will not be supposed, withont proof, to have tal:en the acknowlerlgment before the deed was in fact executed. ${ }^{52}$

\section{§ 2. D. Defective Acknowledgment-Continued. A}

47 MeCardia $*$ Billings. $10 \mathrm{~N}$. Dak. 373; sce also, sontgonery $r$. Homberger, 16 Tex. Cir. Ар]. 29. 48 Hiss $v$. MeCabe, 45 Mra. 77. 49 Wilcoxon $\because$ Csiven: 75 Mo. 621 .
50 Magness $v$. Arnold, 31 Ark. 103 .

51 Dressel $r$. Jordan, 104 Mass. 407 .

52 Cover $v$. Manaway, 115 Pa. St. 338 . 
certificate in which the person taking the acknowledgment gives himself no official designation or title is fatally defective, for an acknowledgment or proof amounts to nothing unless it be taken by an authorized offices, and whether the person be authorized or not, is a fact which should appear in the certificate of the officer himself. ${ }^{53}$ But when it appear's from the certificate that it was taken by an authorized officer, it is not necessary, nor is it customary, for him to state in so many words, that he was authorized to take such proofs. ${ }^{54}$ If the title of an officer taking an acknowledgment is written out fully in the borly of the certificate it has been held that the omission of such title from the signature is immaterial: ${ }^{55}$ if the title of the officer is affixed to the signature, this, it seems, is suficient without mention elsewhere, ${ }^{56}$ and in some cases it has been held that the use of initials gencrally understond to stand for the title of an office will answer the same purpose as the full title. ${ }^{57}$

A question sometimes arises with respect to eapacity when the actual acknowledgment is taken by a depnty, and not by the officer in person. It is generally held, however, in the case of court officers, that where the acknowlergment purports to be taken by the clerk and is ecrtified in his name, with a seal of court attached, it will be sufficient, and that the certificate is none the less the act of the elerk beanse male by his deputy. ${ }^{\text {ss }}$ It is further held, that the seal of a court affixed to a certificate carries with it a presmmption that it was properly attached. ${ }^{59}$

The want of a seal is nsually no defeet where the land conreyed is within the enrtifying officer's jurisuliction, yet it is a general rule, that whenerer a certifying oflies is required to have a seal he mut authenticate his certificate muler his official

53 Lessee of Johnston $v$. Haines, 2 Ohio. 55; Cassell r. Conk. 11 Ohio, 610.

54 Livingstone $v$. MeDonald, 9 Ohin, 168.

ה: Colby $r$. MeOmber, 71 Iowa, 469 ; Brown $e$. Farran, 3 Ohio, 140 ; Lake Erie, ete., R. R. Co. r. Whet. hans, 155; Ill. 514 .
5 Ruse $r$. Tingerte. 30 Mirs. 440. 5 See, Rowley r. Mexrian. 12111. 19s: Ruce r. Wingute. 30 Mise. 440: Final r, Bukne, 18 Mich. 2918: Owan $r$. Riaker, I01 Mn, 407.

5. Jope r. Silwyer. 14 111. 25!:

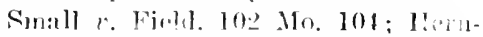
don r. Rect, s. Ter. (i17.

5o Small $r$. Field, 102 Mo. lit, 
seal, ${ }^{60}$ as well as his signature, and its presence is usually made by statute an indispensable requisite when the officer resides beyond the State. The form of the notary's seal is a matter of minor importance. The recorder is not required to make a fac simile of the impression of the seal upon his books, and generally eould not if he were; ordinarily he is permitted to show it by a scrawl, the reeord then disclosing the faet of sealing and that the seal used purported to be a seal of office. This is about all that is required and persons dealing upon the faith of the record will be proteeted by it. ${ }^{61}$

A certificate defective in venue is insufficient for failing to show the locality in which the aet is done, though this may be cured by the eertificate of eonformity, ${ }^{62}$ or even by the scal, ${ }^{63}$ when the county only has been omitted, and the officer has authority to exereise his offiee in any part of the State; but this omission has been held in Iowa to be fatally defective, and the seal inefficient to cure the defect. ${ }^{64}$ In a properly drawn certificate, the date as well as the place of aeknowledgment should appear, yet it would seem that the want of a date to a eertifieate otherwise good, will not vitiate it. ${ }^{65}$ An acknowledgment taken by the grantee is of no effect, though the deed would still be binding between the parties and their heirs. ${ }^{66}$

The main defects of substance are a failure to state the fact of acknowledgment, or to fix the identity of the parties. ${ }^{67}$ These are the two essentials and neither ean be dispensed with. The eertificate must state the faet of aeknowledgment. It is this which forever afterward binds the party, even though he may not acknowledge the instrument freely in point of faet; yet if he aeknowledges properly, he is afterward estopped to deny his act as against subsequent innocent purehasers. The

60 Mason v. Brock, 12 Ill. 273.

61 Sonfield $v$. Thompson, 42 Ark. 46; Hammond $v$. Gordon, $93 \mathrm{Mo}$. 223 ; Jones $v$. Martin, 16 Cal. 166 ; Griffin $v$. Sheffield, 38 Miss. 359.

62 Hardin v. Osborne, 60 Ill. 93. 63 Chiniquy $v$. Bishop of Chicago, 41 Ill. 148.
64 Willard $v$. Cramer, 36 Iowa, 22.

65 Irving $v$. Brownell, 11 Ill, 402. 66 Hogans $v$. Carruth, 18 Fla. 587.

i7 Bryan v. Ramirez, 8 Cal. 461; Pendleton $v$. Button, 3 Conn. 406; Short $v$. Conlee, 28 Ill. 219. 
officer is bound to know and certify the identity of the person making the acknowledgment. Such person must be known to him as the person who executed the instrument and must be so certified. I certificate deficient in this respect is fatally defective. ${ }^{68}$

The examiner will further observe, where the acknowledgment appears to have been taken in a foreign jurisdiction, that the officer's certificate conforms to local regulations, and if not, that it is accompanied by a certiticate of conformity to the law of such foreign jurisdiction, made $\mathrm{ly}$ sone competent officer. In the case of some officers, particularly those not having a seal, a certificate of magistracy must al aco acompany the certificate of acknowledgment. Should no such certificate appear, after noting the defects or divergence, the examiner will add:

No certificate of magistracy or conformity shown of record.

When accompanied by such certificate, its purport should appear, thus:

Certificate of magistracy and conformity by Jno. Smith, Clerk of the Circuit Court, Cook County, Ill., ${ }^{69}$ appended.

Sometimes the fact will appear that the officer taking the acknowledgment was authorized to take proof of deeds but there will be nothing to show that his certificate eonforms to the law of his venue, in which case say:

Certificate of magistracy, but not of conformity, by Jno. Smith, Clerk, etc.

In case of foreign notaries, and other officers, a certificate of magistracy is usually required by statute, but where the

68 Callaway $r$. Fash, 50 Mo. 420; Smith v. Garden, 28 Wis. 685.

69 Here, if desired, set out any portion of the certificate; as thist the officer's signature is genulue, etc. The unqualified and positive affirmation that the magistrate's signature to the acknowledgment is gemnine, neersarily implies, on the part of the clerk, both a knowledge of the londwriting and his belief of its gemnineness: Wells $v$. Athinoon, 24 Minu. 161. 
notary's certificate is in conformity to local law, the certificate of magistracy and conformity need not be noticed in the abstract, its main oflice being to cure defects of form. A commissioner appointed by the Gorernor of a State to take acknowlecigments of deeds in another State, is an oflicer of the State from which he derives his appointment. The courts of that State are bound to take judicial notice of his acts, and these require no other authentication than his seal of office. ${ }^{i 0}$ His certificate, however, should be in conformity with the laws of the State from which he derives his authority. ${ }^{71}$

A properly drawn notarial certificate will always disclose the officer's jurisdiction, and where a defeet of this kind occurs, as where the officer fails to state that he is a Notary Public "in and for the county and State aforesaid," it should be shown by a brief note, thus:

Certificate of aclinowledgment by "Henry Brow'n, Notaiy Public," whose venue is, "State of Illinois, County of Cook." Jurisdiction of offecr not otherwise shown.

$\$ 211$. Replignancy. Where there is a disagreement or inconsistency between two or more clanses of a deed, it is a general rule that the earlier clanse will prevail if the inconsistency be not so great as to aroil the instrument for uncertainty. ${ }^{72}$ This rule is alwars applied where an estate expressly granted is followed by a reservation, exception, or condition which destroys the grant. ${ }^{73}$ In the matter of description, where there is a clear repugnance, efiect will always be given to that which is most definite and certain, and which will carry out the erident intention of the parties. ${ }^{74}$

70 Smith $v$. Van Guilder, 26 Ark. $52 \pi$.

71 Brannon $v$. Brannon, 2 Disney (Ohio), 2.24.

72 Tubbs $v$. Gatewood, 26 Ark. 128; Green Bay, etc., Co. v. Hewitt, 55 Wis. 96.
73 Cutler v. Tufts, 3 Pick. 277; Prnchon $r$. Sterus, 11 Met. 304; Rines $r$. Mansfield, 96 Mo. 394.

it Wade $r$. Deray, 50 Cal. 376; Kruse $v$. Wilson, 79 Ill. 233; Bassett $v$. Budlong, 77 Mich. 338 . 


\section{(INATER XV.}

\section{CONYEYANCES ISF IAIIVIDUALS.}

§ 212. Deeds in general.

213. Deeds poll and indentures.

214. Construction of deeds.

215. Validity.

216. Warranty deeds.

217. Abstract of warranty deeds.

218. Notes.

219. Quitclaim deeds.

220. Alsstract of quitclaim deeds.

221. Eflect of covenants in quitclaim deeds.

222. Special warranties.

223. Statutory forms.

224. Common law conveyances.

225. Release.

226. Confirmation.

227. Surrender.

228. Assigmment.
\$ 2.29. Conveyances in futuro.

230. Conveyances of special in. terests and estates.

231. Continued - Illustrations of special cases.

232. Restrictive and conditional conveyances.

239. Prolibited conveyances Alverse seizin.

234. Continued - Frandulent conveyances.

23.5. Converances subject to incumbrance.

236. Dedication ly deed.

237. Kesulting trusts.

235. Rerecorts and duplicates. 239. Correcter Records.

\section{\$ 212. Deeds in General. In the Tnited States, the an-}

cient technical principles relating to common law conveyances seem to be in a great measure inapplicable. The tendeney of modern legislation, as well as the current of later decisions, has been to simplify the forms of conveyance and to reduce the number of the methods. The deeds conmonly in use, and by which the great bulk of real estate transactions between individuals is effeeted, are, the deed of bargain anil sale, pupularly known as "Warranty Deed" and the deel of release and quitclain, known as "Quitelaim Deed." To these may be added a third, a deed atilpted from the old deed of nomclaim, combining qualities peenliar to both of the other classes, and callerd "Special Warranty Deerl," I wherein the erantor

1 The above enumeration, though forms. is in reality hut ono kind of the conveyances assme different decul, to wit, a bargain and sale. 
covenants only against his ow acts and those who claim under under him, and not against alverse or paramount titles. They are all effectual to convey the fee, or whatever interest the grantor may possess, and will always do so mless a contrary intention is expressly manifest or clearly deducible by implication.

$\S 213$. Deeds Poll and Indentures. The operative instruments for the conveyance of land were formerly classed as "deeds poll" and "indentures," the former being where an obligation was incurred, or an estate conveyed, by only one of the parties to the transaction, the other being a mere recipient; the latter, on the other hand, contained mutual transfers or corenants, the one in exchange for the other. $\Lambda$ deed poll was a single instrument, signed by one party, and delivered to the other; an indenture consisted of two or more parts, of the same tenor, executed in duplicate by both parties, and interchangeably delivered by one to the other. The name "indenture," is said to have originated from the practice of writing both parts of the agreement upon one parchment, and then cutting them asunder in acute angles, ${ }^{2}$ the parts at the place of separation resembling teeth. Such a deed was said to bo "indented." The phrase "this indenture" still forms the initial to deeds of bargain and sale, thongh such conveyances are in effect deeds poll, and affords another instance where common-law forms of expression have been retained after their original meaning and technical significance have been lost. ${ }^{3}$

$\$ 214$. Construction and EPect of Beeds. The general construction of deeds is farorable to their validity, and al-

22 Hill Abridgment, 280; 2 Wash. Real Prop. 587; 2 Sharswood's Black Com. 291.

3 Adaptations of both forms are still in use. The deed poll always commences with a declaration to all persons, calling upon them to notice the act of the grantor. The phrase reads, "Hnow all men by these presents," ete., and the grant is usually in the first person. The
Indenture, on the other hand, is always in the third person, and commences "This Indenture witnesseth" that the grantor has conreyed, etc. In powers of attorney and similar documents the deed poll form is always preserved. In leases, dual agreements, and instruments of a bilateral character the indenture is still generally employed. 
though courts can not give effect to an instrument so as to do violence to the rules of language or of law, they will yet so construe it as to bring it as near to the actual meaning of the parties, as the words they have seen fit to employ, and the rules of law will admit. ${ }^{4}$ The intention of the parties, when it can be ascertained, will always control, if by law it may, and as between them the deed is always construed most strongly against the grantor. ${ }^{5}$ When the worts of a deed are so uncertain that the intention of the parties 'an not be discovered, the deed is void. ${ }^{6}$ In the exposition of deeds, the construction must be upon the whole instrument, and with a view to give every part of it meaning and effect, and the intent when apparent, and not repugnant to any rule of law, will control technical terms. ${ }^{7}$ Where a deed purports to convey all the interest and title of the grantor, effect will be given to it accordingly, although he actually held a greater interest than he, at the time of conveyance, supposed he owned, for a party is bound to know enough about his title, as not, by his want of knowledge, to mislead a purchaser. $^{8}$

\$215. Talidity. In all works treating on conveyancing, or the alienation of real property, the subject of validity of conveyances of land, as affected by extraneous evidence, rightly occupies a prominent position, yet in a work of this character it can receive little more than passing notice. The principal facts which tend to invalidate deeds, aside from defeets of form or substance, which appear from inspection, are: incapacity of the parties; inadequacy of consideration; fraud in the inception; and undue influences or duress in the procurement; all of which must, from their several natures, be shown by

4 Callins $v$. Lavalle, 44 Vt. 230; Churchill v. Reamer, 8 Bush (Ky.), 256; Peckham v. Haddock, 36 Ill. 38; Hadden $v$. Shoutz, 15 IIl. 581; Jackson $v$. Meyers, 3 Johns. 395.

5 City of Alton $v$. Transportation Co., 12 Ill. 38; Jackson v. Hudson, 3 Johns. 375 .
6 Rollin 2 . Pickett, 2 Hill. 522; Jackson v. Rosvelt, 13 Jolns, 97; Peoria r. Darst, 101 Ill. 671.

$\tau$ Callins $v$. Lavalle, $44 \mathrm{Vt} .230$; Saunders $v$. IJanes: 44 N. Y. 353. 8 Thomas $v$. Chicago, 55 Ill. 403. 
evidence aliunde, the deed unon its face being regular and the formalities of law having been fully complied with. ${ }^{9}$

There is an important distinction between void and voidable deeds, although the terms are often used indiscriminately. A deed absolntely void passes no title, while a deed which is voidable merely may be the foundation of an unassailable title in the hands of a subsequent purchaser without notice. ${ }^{10}$ The term "void" is seldom, unless in a very clear case, to be regarded as implying a complete nullity; but it is, in a legal sense, subject to large qualifications in view of all the circumstances calling for its application and the rights and interests to be affected in a given case. ${ }^{11}$ Statutes not infrequently declare acts void, which the tenor of their pror'sions necessarily makes voidable only. Deeds are seldom absolutely void, though they may be relatively so, and incapable of legal effect as between the parties, but in regard to the consequences to third persons the distinction is highly important. ${ }^{12}$ Matters in pais are seldom known to the exanining counsel, who is justified in pronouncing that a marketable title which appears so of record, and which in fact is such, mntil assailed or set aside by competent authority. As respects subsequent purchasers without notice, the right or title conferred by a conveyance is to be determined by the instrument of transfer as recorded, and not by facts in pais or other instruments not recorled. ${ }^{13}$

Latent ambiguities and defeets do not usually avoid a conveyance, and a deed intended to correct an error in a former deed by the same grantor, will cure snch defect, and take effect

9 A purchaser of land from a prior bona fide holder who acquired the legal title, as shown by the records, for a valuable considera. tion, without notice of any outstanding equity, will be protected against such equity, even thongh he himself had notice thereof: Peck $v$. Arelrart, 95 กl. 113.

10 Crocker $v$. Ballangee, 6 Wis.
11 Brown $v$. Brown, $50 \mathrm{~N}$. H. 538 ; Kearney $v$. Vaughn, 50 Mo, 284.

12 Bromly $v$. Goodrich, 40 Wis. 131; Seylar v. Carson, $69 \mathrm{~Pa}$. St. 81; Van Schaac $v$. Robbins, 36 Iowa, 201; Kearney $v$. Vaughn, 50 Mo. 284.

13 Miller $v$. Ware, 31 Iowa, 524; Peck v. Arehart, 95 Ill. 113. 645 . 
by relation as of the time, when the erroneous deed was giron, the same as if it had been reformed in equity. ${ }^{4}$

$\S 216$. Warranty Deeds. The most familiar form of conveyance known to our law is the deed of hargain and sale technically called a warranty deed. The legal import of a deed of this character is that of aboulute convesance of the interest intended and that there is no resulting trust in the grantor, who is estopped from erer after denying its execution for the uses and purposes mentioned in it, ${ }^{15}$ while its name is derived from the personal covenants which follow the habendum.

The operative words of converance in this chass of deeds, are "grant, bargain and sell," which in many States are allowed to operate as covenants of seizin, freedom from inembrances, and quiet enjoyment, ${ }^{16}$ mless their statutory effect is rendered nugatory or limited ly express words contained in such deed. ${ }^{17}$ It is still a common practice for the converancer to insert in warranty deels, as well as in other classes of conveyances, all the operative terms used in transferring land: as, "grant, bargain, sell, remise, release, alien, conrey and confirm," though their presence, save where they imply covenants, is no longer necessary. This was formerly done, that the instrument might take effect in one way if not in mother, and in such ease the party receiving the deed har his election which way to take it. Thus according to the words used, he might, claim either by grant, feoffment, gift, lease, confirmation $\omega^{\circ}$ surrender. The majority of the foregoing words of grant are now superfinous, execpt that in a few States the worts "grint. bargain and sell" must, muler the statute, be construed as express or implied covenants, for seizin, against incmulyanues, etc., ${ }^{18}$ yet the rule that the law of the State where the lamel lies governs the interpretation of the deed, does not warrant the

14 Hutchinson $v$. R. R. Co., 41 IIis. 541 .

15 Kimluall $v$. Walker, $30 \mathrm{Ill}, 482$.

16 Prettyman v. Wilkey, 19 Ill.
285; Mawk r. Me(u!longh, 21 Hll. 2.20 .

17 Find

1s Prodis $r$ Watkint, :3 Ark. 319 ; Finley $v$. Steele, 23 Ill. 56. 
implication of personal corenants not authorized by the law of the State where the deed was made. The question, whether the words shall import covenants, must be decided by the law of the latter State. ${ }^{19}$

It must be understood that some words evidencing an intention to transfer an estate must appear, but the conveyancer has a choice of a number, and the word "convey," which is most in use, fully expresses the intent, and is effectual for all purposes. $^{20}$

$\$ 217$. Alstract of Warranty Deed. In preparing an abridgment of an orlinary deed of bargain and sale, when drawn in the nsual manner and nnincmmbered by any unusual conditions or stipulations, only the salient features are necessary, it being understrod that the deed is in form, and that all the essential requisites have been complied with. Wre this otherwise the abstract would become unnecessarily bulky and cumbersome, and defects when shown would be less readily detected. This is the miversal custom of abstract makers, and the method seems to have met the approbation of the legal profession. In ordinary deed of converance is sufficiently presented as follows:

John Smith, and Mary B., his wife, to

Thomas L. Jones.
Warranty Deed.

Dated June 1, 1SS2.

Recorded June $2 S, 18 S \Omega$.

Tolume 2S, page 10.

Consideration $\$ 1,000.00$.

Conveys land in Racine county, Wis., described as lot fourteen, of block twenty-eight, of Rosuell's Addition to the village of Enmetsturgh, being a part of the northwest quarter of section thirty-six, town two north, range fourteen, east of the third principal meridian.

Achnowledged June 1, 1SS2."1

19 Bethel $\tau$. Bethel, 54 Ind. 428 .

20 An extremely simple form of a deed in fee is given in 4 Kent Com. 461 ; and see Hutchins $v$. Carleton,
19 N. H. 487 ; Bridge $v$. Wellington, 1 Mass. 219.

21 In the abstract of ancient conveyances it may be necessary to 
The foregoing cxample pre-supposes gool work on the part of converaneer and exannine', and that the instrument as shown of record is regular in form and properly exected and acknowledged. It further carries the presumption that no recitals appear, other than those commont to all drests of bargain and salo, and that all covenants necessary for the proper assurance of the estate conveyer are inserted. Shonld the examincr desire, however, to note the covenants, he may ald:

\section{Full covenants of seizin and wrementy.}

Defeets of form or substance, ocenrring in any part of the deed, must be suitably noticed as suggested in the preceding ehapter. In amoirnt deerls, where the premises are inperfect by reason of omission of words of inleritunce, the habenchum may be shown thus:

Habendum to heirs and assigns.

$\S$ 218. Notes. The matter of examiner's notes has already been discussed. These should tre appended, whenever practicable, immerliately after the deed to which they allurle: as, in the foregoing example, if the abstract is of the original instrument and not of the record thereof, a mention of the fact immediately follows same, thus:

Note.-The particulars of the foregoing deed taken from the original instrument.

§ 219. Quitclaim Deeds. I quitelam deed is as effeetual for transferring the title to real cstate as a deed of bargain and sale, ${ }^{22}$ and passes to the grantee all the present interest

show a trifle more than is here noted. The words of inlseritanes in the premises and habendum may be material in determining the nature of the estate convered, but as the necessity of the word "heirs" or other words of inheritance has been dispensed with in a majority of the States for upward of fifty years, their iusertion or omission in ancient grants will have but little eflect on the titles of to-day, which, tholegh dofective orierinally, have been perefeeted by the efluxion of tine..

2a Morgan v. Clayton, til IIl. 35; Rowr 2 . Perker', 30 Iml. 15t; Pingree v. Watkins, 15 Vt. 479. 
or estate of the grantor, ${ }^{23}$ together with the corenants rumning with the land, unless there are special words limiting and restricting the conveyance. ${ }^{24}$

But while a quitclaim deed is as effectual to pass title as a deed of bargain and sale, still, like all other contracts, it must be expounded and enforced according to the intention of the parties as gathered from the instrment, and if the rords used indicate a clear intention to pass only such land or interests as the grantor then owns, lands embraced in a prior valid deed have been held to be reserved from its operation, even though such prior deed remains mrecorled. ${ }^{25}$ It is a rule, however, of general application, that a quitclaim deed, when recorded, takes precedence of a prior unrecorded warranty deed from the same grantor, the purchaser under the quitclaim having no notice of the prior deed, and there being no words therein suggestive of an earlier converance. ${ }^{26}$

A quitclaim ded, though effectual as a present converance, when unaccompanied by warranty will not operate to carry a subsequently acquired title, ${ }^{2 i}$ nor $^{\circ}$ ean one who takes muder such a deed be regarded, in all respects, as a bona fide purchaser without notice of outstanding titles and equities.2 ${ }^{2}$ The authorities are not agreed, howerer, with respect to the character to be aceorded to a purchaser by quitclaim. is a general proposition he obtains just such title as the rendor had, and the laud in his hands remains subject to all the equities attaching to it in the hands of the rendor, eren though they may

23 Nicholson $v$. Caress, 45 Ind. 479 ; Carter $v$. Wise, 39 Tex. 273; Carpentier $r$. Williamson, 25 Cal. 158.

24 Brady $\imath$. Spruck, 27 Ill. 478; Marden $v$. Chase, 32 Me. 329 .

25 Hamilton $v$. Doolittle, $37 \mathrm{Ill}$. 473.

26 Brown $v$. Coal Oil Co., 97 Ill. 214; Graff $r$. Middleton, 43 Cal. 341 ; Marshall $v$. Roberts, 18 Minn. 405; Merrill $r$. Hutchinson, 45
Kan. 59; and see, Hope $v$. Blair, 105 Mo. 85.

$2 \pi$ Comstock $r$. Sinith: 13 Pick. 116; Jackson $r$. Winslow, 9 Cow. 13; Harriman $v$. Gray, 49 Me. 538; Kinsman $r$. Loomis. 11 Ohio, 475; Niller $r$. Ewing, 6 Cush. 34.

28 Stoffel $r$. Schroeder, 62 Mo. 147; Carter $r$. Wise, 39 Tex. 273; Springer $\imath$. Brattle. 46 Iowa, 68s; Oliver $t$. Piatt, 3 How. (U. S.) 363. 
be unknown to such purchaser. ${ }^{29}$ Put it would seem this harsh doctrine is not applicable in all cases. It prevails in settling conflicting titles, and is intended to protect equities as against those charged with notice of their existenee, but is never inroked to protect a frandulent grantor who, by false representations, induces a confiding purchaser to believe that he acquires an indereasible title under a quitclain deed." In the absence of framd, lowever, a party aceepting a quitelain deed takes the risk of the title, ${ }^{31}$ for where a person purchases of another who is willing to give only a quitclaim, he may properly enough be regarded as bound to inquire and ascertain at his peril what outstanding equities exist, if any. His grantor virtually declares to him that he will not warrant the title even as againat himself, and it may be presumed that the purchase price is fixed aceordingly. 32

It is generally conceded, even in those States which hold the strongest against muitclaims, that the mere form of a deed will not conchude the parties thereto nor prevent a vendee thereunder from claiming the protection giren to a purchaser in good faith. At most, a deed in this form is simply a warning; it imposes the duty of inguire, and it eharges the purchaser with notice of such ontstanding equities or interests as he night have discovered by the exereise of reasonable diligence. But where the rentee hat paid a fiar comsideration, has duly examined the public recurds, and finds what appears to be a clear right of ownership in the rendor, the preponderating rule seems to be, that he will not be affected by secret expities, liens, interests or incumbrances of which he hat no notice and concerning which no inquiry was suggested. ${ }^{33}$

The grantee of one holding under a quitclaim, when such grantee holds by a warranty deed, is presumed to be a buma fide purchaser for value. He is not affected by the more fact

29, Mann r. Wa-1, fi2 Mo, 491; May

v. Inclaire, 11 Wall. (L. S.) 217.

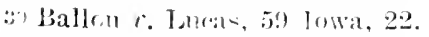

:1 Boteford v. Wilson, 75 III. 132;

Thorp $v$. Coal ro., 48 N. Y. 253.
::2 Winkler r. Miller, if Iowa, 47 it.

:3 Merrill v. IIutchinson, 45 Kan. ii). 
that he derives title through a quitclaim deed, and will take the land free from ontstauding equities of which he had no notice. It is the policy of the law that real estate titles should becons matters of certainty as far as possible, and as quitclain deeds ocen in the lives of many titles, a different pule than the one abore set forth would tend to unsettle titles, hindor and delay improvements and impair the selling value of all property so affected.

\$ 220. Alstract of Onitelaim Deeds. As in the case of simple warranty deeds, only the main features of quitelaim deeds need be shown in preparing a synopsis of same. The operative granting works of deeds of this nature are "remise, release, convey and quitclaim;" but any other words indicating conveyance will do as well and have the same effect. In the abstract it is not customary to recite these words, but the description is prefaced by the simple word "convey," the examiner indicating the nature and legal import of the instrument by its name. Should the deed contain the statutory words which raise covenants, they then become material, for the instrument in effect becomes a warranty deed, though in form a quitelaim. ${ }^{34}$ To raise a statutory eovenant the very words of the statute must be used, ${ }^{35}$ and if only a part of them appear, as "grant, sell and convey," the deed will remain a quitclaim. ${ }^{36}$

It is the eustom of eonveyaneers to insert after the words of grant, a recital of the estate or interest conveyed; as all "right, title, interest," ete, but this is the legal, as well as the statutory effect of the deed, and the omission or insertion of such words is immaterial to the dect, and consequently of no importance to the abstract, except when they clearly indicate a prior conveyance, or afford constructive or actual notice of existing equities. Where the deed contains covenants of any kind, particularly of warranty, these words beenme material,

34 DeWolf $r$. Haycien, 34 Ill. 525.

$: \pi$ Vipond $r$. Hurlbut, $2 \cdot 2$ Ill. 220.

36 Whitelall $v$. Gottwal, 3 Penn.
323; Frink $r$. Darst, 14 Ill. 304;

Joung $c$. Clippinger, 14 Kan. 148. 
however, and in some States they are of controlling efficacy, ${ }^{3 r}$ as per the succeeding paragraph.

\section{$\$ 221$. Effect of Covenants in quitclaim Deeds. Inas-} much as the particular granting words employed in deeds are now of comparatively little moment, if one conveys land with a general covenant of warranty against all lawful claims and demands, he can not be allowed to set up against his grantee, or those claiming under lim, any title subsequently acquired, either by purchase or otherwise, and snch new title will inure by the way of estoppel to the use and benefit of the grantee, his heirs and assigns. ${ }^{3 s}$ But where the deed does not on its face purport to convey an indefeasible estate, but only "the right, title and interest" of the grantor, thongh containing covenants of ownership, warranty, etc., it will, it seems, only convey such interest in the land as the grantor has at the date of the deed, ${ }^{39}$ and the covenants are to be regarded as having reference to and as being qualified and limited by the grant. ${ }^{40}$ In a like case, where the grantor agrees to warrant the title conveyed only as against all claims derived from himself, he is mulerstood to refer to existing claims and incumbrances, and not to any title he may afterward derive from a stranger: ${ }^{41}$

As quitclaim deeds are usually dram, after the words of grant are a number of words limiting or defining the estate conveyed; as "all right, title, interest, daim, demand," etc., which, in what are usually termed "straight" deeds, may be disregarded; but when followed by covenants, it is advisable. that every part of the instrument which tends to show the nature and extent of the granted estate loe set out, inchinding all the operative parts of the premises and the habendum.

37 See Ilolbrook $v$. Debo, 99 Ill. ;82.

38 Comstock $v$. Sinith, 13 Pick. 119.

3 Brown $v$. Jackson, 3 Wheat. (U. S.) 449; Bowen v. Thrall, 28 Vt. 382 ; Hlanchard $v$. Brooks, $I 2$ lick. (Mass.) 47.
4) Bell $v$. Twilight, of Foster" (x. II.), 411 ; Rawlo (ov, for 'lit. 420. 41 Jogy $r$. Ghoal, l:3 Mo. 378; Ge v. Muore, 14 Call. 471; Mllen $r$ IIolton, 20 Pirk. 4.5s; Holbrook $i$. Debo, 99 Ill. 372. 
A distinetion has been made by some courts between such deeds as quitclaim or release the land itself and such as merely release whaterer interest the grantor may have in the land, ${ }^{42}$ and thongh the distinction does not always seem to rest in sound reason, ret where such dectrine oltains, no other safe course is open to the examiner than that above indieated, and it is immatcrial whether the deed be one of the quitclaim or non-claim. ${ }^{43}$

\$ 222. Spccial Warranties. There is in common use in the Cuited States, though it would seem to he rarely employed in England, a deed of conveyaner, with a limited warrantr, varionsly known as a "special warranty" or deed of "non-claim." In its original form the non-claim was inserted immediately after the habendmm, without the usual words of erenant being prefixed, and purported to be a denial of any furthor rights in the grantor in relation to the property convered, and from which he was "utterly debarred and foreverexlund " he virtue of the instrument. ${ }^{44}$ The covenant might he gumal, hut was usually limited to the grantor and thrise chaming water lim. As now framed it is a limited fwal covenat, not as against paramoment title, but only sh far as encoms the acts of the grantor. It is a covenant of wamente the extent of its import, and differs from a goneml warenty only, in that one is a warranty against any and all paransunt titles, while the other is against the grantor him-alf, and all prereons claming by, through or under him. ${ }^{45}$ "As a general rule," says Rawle," "no distinction has in any way ben taken between such a corenant, and the ordinary covenant of warranty. Both are, in general, held to have the same operation by way of estoppel; both equally possess the eapacity of runing with the land, and confer the same rights

42 See Holbrook $v$. Deho, 99111. 372; Blanchard $r$. Brooks, 12 Pick. 46.

43 Gibbe $r$. Thayer, 6 Cush. 32.

44 See Rawle on Cov. for Title, p. $223,3 \mathrm{~d} \mathrm{Ed}$.
45 Holbrook $r$. Debo, 99 IIl. 372;

Porter $r$. Sullivan, 7 Gray, 44I;

Lathrop $x$. Snell, 11 Cush. 453.

46 Rawle on Cov. for Title, p. 223, $3 \mathrm{~d} \mathrm{Ed}$. 
as to a recovery in damages." $4 i$ Such a deed, however, can not bo extended to include a general covenant of warrunty, and, as it contains no general cormants to seeure the title, an aggrieved party ean have no remely under it on the grond of a mere failure of title, proviled there has been no fraud in the transaction. ${ }^{48}$ The deed is shown in the abstract the same as a warranty deel, except that it is called a "special warranty." The operative worts of grant, if material, $i$. e., if implying covenants, should be set out and the express covenants may be noticed as follows:

Grantor covenants against his ou'n acts, and those claiming by, through or under him only.

Tho legal effect of the deed as a conveyanco is, of course, equal to a deed of bargain and sale in any other form. Its defeets as a conveyance must be noted, as in other cases, and the remarks and suggestions heretofore made relative to deeds gnerally will apply to these and all other classes, but, to avoid prolixity, will not be further alluded to when speaking of each particular kind.

$\$ 223$. Statutory Forms. While the constant tendeney of courts and conveyanecrs has been to molify and reduee the common law forms of expression in conveyances of land, the radical hand of the legislator has further been felt of late years in the changes wronght in the form, eontents and effect of deeds and kindred instruments. Statutory forms are now preseribed, as brief and curt as those they are intended to supplant were often long and verbose. The wisdon of these forms has often been doubted, while their porerty of language has not endeared them to the eonvyancer, and as the statute has left their use optional they have not as yot, in some loealities, cone into very general use.

47 The following eases sustain the text: Kimball v. Blaisdell, 5 N. II. 533; Gibls $v$. Thayer, 6 Cush. 33 ; Clauncle $v$. Allen, i2 Niı. 163; Ben- nett $r$. Waller, 23 IHI. 97; Holbrook v. Deho, 9! 111. 372.

48 Bukner $v$. Street, 15 Fed. liep. 36.5. 
The operative words of statutory deeds purporting to conrey the fee, are "convey and warrant," which words have also the effect of express covenants of seizin, good right to convey, freedom from incumbrances, peaceable possession and warranty of title. Deeds made in conformity to statite have all the force and effect of covenants that are usually contained in the common law deeds. All the covenants mentioned in the statute are to be regarded and treated as though they were incorporated in the decd, of which they constitute a part as effectually as if they were written therein. ${ }^{49}$ The operative words of conveyances of naked interests are, "Convey and quitelaim." The operative words, in either case, should always be given in the abstract, which, in other respects, will not differ from the ordinary forms of abridgments already shown.

\$224. Common Law Conveyances. In addition to the deed of bargain aud sale, which in its three-fold form of "warranty," "quitclaim" and "non-claim" has been made a statutory conveyance in many of the States, there are a number of technical forms of conveyance derived from the land and conveyancing system of Great Britain and which are popularly known as "common law deeds." They consist primarily of the deeds of Release, Confirmation, Surrender and Assignment. 50 These deeds, as originally employed, were all highly technical, long, and verbose. They displayed to fine advantage those extremely complex but finely rounded sentences that so delighted the heart of the conveyancer of the eighteenth century and furnished so much food for disquisi-

49 Carver v. Louthain, 38 Ind. 530 ; Kent $v$. Cantrall, 44 Ind. 452 ; Lehndorf $v$. Cope, 122 I1l. 317.

50 The elementary writers elassify common law deeds as follows: Five original conveyances, to wit: Feoffment, Gift, Rent, Lease, Exchange and Partition; five derivative eonveyances, to wit: Release, confirmation. Surrender, Assignment and
Defeasance; and five conveyances derived from the statute of uses, to wit: Covenant to stand seized to uses; bargain and sale; lease and release; deed to lead or deelare the uses of other more direet conveyances; and deeds of revoca. tion of uses: Willard. Conveyancing, 419; 3 Wash. Real Prop., Chap. 5. 
tion and disputation in wonstuing sotates under the complicated English land tenures. In the United States they have lost somewhat of their dedumdane, thomgh there are not wanting to-day many forms needlestly long and uselessly prolix, while the differenee in our lond system, and estates thereunder, has robbed them of mueh of their original significance. There now exist but fow estates that can uot be arlequately conveyed by deed of barcain and sale, and in a majority of instances a "quitelaim" deed will aceomplish all that was formerly sought through the metia of the deods alove enumerated.

\$ 225. Release. The term "rolease," in its popular and limited signification, is now used to denote the instrument whereby the interest convered by a mortgage is reconvered to the owner of the fee, and it is also used generally to designate the conveyance of a right of any kind to a person in possession. In England, it obtains in a forr-fold form, and is one of the most important of the common law forms of conveyanee. ${ }^{51}$ In the Enited States, the technical principis relating to deeds of this character are wholly, or in a great measure, inapplicable, while the converane which correspond to a release at common law, is the popular quitelain deed, the operative work being the same in both deeds. If a releatse is used it is generally regarded as a substantive mode of converance. ${ }^{52}$

Where a deed remising and releasing lands contains a corenant of warranty of title, either general, or simply as against the claims of all persons daining under the grantor only, and particularly if the habendum be to the grantee, his heir:s, ete, it will not be a sineple release, but a conveyanee of the

51 Under the English system of conveyancine, reloawes are extensively employed as methols of antveranes of putules in fare lint in order to give effect to a doed of res. lease. it is first nereseary to exereme a lease (or bitrogin and salo for a year) which by forme of the statute of uspes puts the leseer or burguines in presensions, and loping thus in

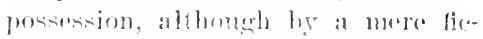

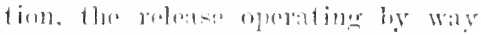

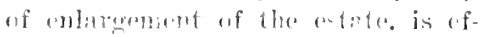
ferdlual to tratnefer the entive titke.

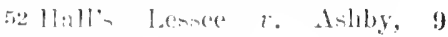
(Hine, 96. 
fee, and a title subsequently acquired by the grantor will inure the grantee, unless it is derived from a sale under an incumbrance assumed by the grantee. ${ }^{53}$

$\S 226$. Confrmation. The subject of confirmation has been sereral tines alluded to in the course of this work, but mainly in treating of confirmations by the government of previously existing but inchoate rights to what would otherwise be public land. Deeds of confirmation are also in use among individuals, and is that species of conveyance whereby an existing right or voidable estate is made sure and unavoidable, or where a particular interest is increased. The appropriate technical words of confirmation are "ratify, approve and confirm," but "grant and convey" or similar terms will have the same effect.

Deeds of confirmation are not in general use, as a "quitclaim" is effective for alnost every purpose which might be accomplished by the former. Frequently, however, recitals in deeds show that they were giren in ratification or confirmation of previous acts or to correct errors, irregularities or infirmities in former deeds, in which event they take effect by relation as of the date of the former act or deed, and the confirmatory words become material to interpret and explain the undisclosed intention or correct the irregularity of the former deed. In such case the abstract should briefly set out the confirmatory particulars, as:

This deed is given, it is stated, to correct an error in a former deed from the same parties, dated June 10, 1900, wherein the land conveyed was erroneously described as being located in Section Ten.

\$ 227. Surrender. A surrender is defined as the yielding up of an estate for life or years to him who has an immediate estate in reversion or remainder, the lesser estate being merged in the greater by mutnal agreement, ${ }^{54}$ and the term is applied both to the act and the instrument by which it is accomplished. It is directly opposite in its nature to release, which

5. People ex rel. Weber $v$. Herbel, 96 Ill. 384 .
54 2 Bou. Law Dict. 573; Coke Litt. $337 \mathrm{~b}$. 
techically operatrs by the greater estate descending upon the lesser. The operative words of a conveyance of this nature, are "surrender and yiekl up," but any form of words that indicates the intention of the parties will serve the same purpose, while a surrender is alwars implied when an estate incompatible with the existing estate is accepted.

Though books on conreyancing still contiune to give ample forms for deeds of surrender, the quitclaim deed in common use has taken its place for most purposes, but it would seem that this is still the proper instrument for the relinquishment of leasehold interests, dower, etc. In deeds of surrender the special matter of inducement nsually precedes the operative part of the deed; as in case of leaschold, a recital of the lease, etc., and an abridgment of this matter should appear in the abstract. This, and the surrender clause, constitute the essential distinctive features. An example is given of a surrender of a life estate:

William E. Chaning
to
Thomas L. Channing,
y son and heir apparent of $\left\{\begin{array}{l}\text { Surrender, } \\ \text { Dated, etc., } \\ * \text { Pecites that [here set ont } \\ \text { briefly the matter of induce- } \\ \text { ment, which would be, in this }\end{array}\right.$ case, the instrument conveying the life estate to the father and the remainder to the son]. Now this Indenture witnesseth (it is stated) that said first party in consideration of $\$ 1.00$ grants, surrenders and yields up to second party all those certain lands and tenements [describing same] and the estate for life, or life interest of said first party, in and to said premises mentioned to be hereby granted and surrendered, to the inlcnt that same may merge and become absolutely extinguished, so that said second party may be in the actual possession of said premises.

[Note covenants if any.]

Acknowledgment. 
A better idea of the aliridgments of deeds, and other instruments presented in this work, would be obtained if it were practicable to insert the original instruments in connection therewith. As it is, the reader is requested to compare same with the forms presented in any form book and to note where language can be elininated without imparing the force of the instrument, and where condensation and abbreviation can be advantageously emploved. A deed, of the character just considered is, when drawn after the regulation pattern, very long and technical. Condensation in such cases is an imperative necessity, while the spirit of the original must be preserved.

\$228. Assignment. In assignment is a mode of conveyance applicable to any estate in lands whaterer; hut the term is usually employed to express the transfer of an equitable estate or a leasehold interest, and as snch will recoive attention in another part of the work. The operative worls of conveyance are "assign, transfer and set over," hut any other words evincing an intention to make an entire transfer will be sufficient. 55

An assignment by endorsement on a deed is entirely nugatory. Such a proceeding might, perhaps, vest in the assignee a right to the paper itself, but would not affect the title to the land. At best, it might, in equity, be considered as an exceutory contract, on proof of the facts comnected with it, and as such entitle the assignee to a decree for specific performance, but it would not operate as a conveyance of the legal title. ${ }^{56}$

$\$ 229$. Conveyances in Futuro. At common law an attempt to create or comvey a freehold or estate of inheritance in futuro was a nullity, the nearest approach being a covenant to stand seized to uses, and this was only permissible when the consideration was blood on marriage, ${ }^{57}$ nor was it nutil comparatively recent rears that such concerances have been recog.

552 Hill Abridg. 31s; 4 Cruise Dig. 81 .

51) Lesace of Bently r. Deforest, 2 Ohio, 221 ; Linker 2 . Long, 64 N. C.
296. But see, Harlowe $r$. Hudgins, St Tex. 107, where a contrary rule is announced. 5.2 Black. Com. 338; Jackson $v$. 
nized in the Lnited States, unless the estate had first been filtered through the mediun of a trustee. This resulted from the principle of the old feudal law, that there must always be a known owner of every freehold estate, and that the title thereto should never be in abeyance. It followed, therefore, that a freehold to commence in the future could not be conveyed, for the reason that it would be in aberance from the time of the conreyance until the future estate of the grantee should vest. Ender the statute, however, a freehold estate in most, if not all of the States, may be created to commence in the future. The effect of such legislation has been to abrogate the common law, and the rule now scems to be well established that if a deed convers a rested right to either a present or future enjoyment of the premises it is valid. ${ }^{5 s}$

Conveyances of this kind will usually be found to take the form of a common deed of bargain and sale, with a proviso restraining the grantee from using or occupving the granted premises during the life of the grantor, ${ }^{59}$ or defining the time at which the deed shall become effective, though in this respect they are rariant, occasionally partaking of the nature of a contingent remainder. If otherwise sufficient a deed of land to take effect at a future time will vest the fee in the grantee according to its terms. ${ }^{60}$

In the abstract there should be shomn: the mords of grant, and if material the words of limitation, as tending to indicate more fully the nature of the granted estate; the proviso limiting or restricting the use of the estate or explaining its scope; the habendum, with only slight abridgment, this being one of

Mckenny, 3 Wend. 233; Prewster v. Hardy, 22 Pick. (Mass.) 3s0; Spaulding $v$. Gregg, 4 Ga. 81.

5 S Mattocks $v$. Brown, 103 Pa. St. 16; Morley $v$. Daniel, $90 \mathrm{Ga}$. 6.50; Shackelton $v$. Seloree, S6 IIl. 616; Wilson $v$. Carrico, 140 Ind. 533.

50 See Chandler $v$. Chandler, 55 Cal. 267 ; Abbott $v$. Holway, Adm'r,
72 Me. 298; Shackleton v. Sebree, 86 Ill. 616; Kent $r$. Atlantic, De Laine Co., 8 R. I. 305; Bohon $v$. Bohon, $78 \mathrm{Ky} .408$.

60 Furgusen $r$. Mason, 60 Wis. $3 \pi$; MeDaniel $v$. Johns, 45 Miss. 632; Mitchell $v$. Nitchell, 108 N. C. 542; Owen $v$. Williams, 114 Ind. 179 ; White $v$. Hopkins, $80 \mathrm{Ga}$. i54. 
the few eases in which it becomes material and important; and the covenants, or such of them as may appear material. A deed of this character, taken from the files, will serve more fully to illustrate the matter. A grantor seeks to eonvey the fee, to vest only in the event of his death before that of the grantee, as extreme a case as can be well imagined. Omitting the preliminary parts, which would be in the form already shown, except that the consideration and conveying clauses are set forth more fully, the abstract after the description would read:

Provided (it is stated) " that this deed is not to take effect and operate as a conveyance until my decease, and in case I shall survive my said wife, this deed is not to be operative as a conveyance, it being the sole purpose and object of this deed to malie a provision for the support of my said wife if she shall survive me, and if she shall survive me, then and in that event only, this deed shall be operative to convey to my said wife said premises in fee simple. Neither I, the grantor, nor Clarissa B. Abbott, shall convey the above premises while we both live, without our mutual consent. If $I$, the grantor, shall abandon or desert my said wife, then she shall have the sole use and income and control of said premises during her life."

To have and to hold, etc., "to the said Clarissa B., if she shall survive me, her heirs and assigns, to their use and behoof forever."

Said grantor covenants "that I have good right to sell and convey the same to the said Clarissa B., if she shall survive me, to hold as aforcsaid at my decease," and that he, his heirs, etc., will warrant and defend the same "to said Clarissa B. if she shall survive me."

The foregoing deed was construed and declared a valid conveyance in futuro, sutficient to vest the fee in the grantee on the happening of the contingency mentioned. ${ }^{61}$ It is doubt-

(;1 See, Abbott $v$. Holway, admr., see, also, Brown $v$. Atwater, 25 7. Me. 298, a very instructive case; Minn. 520 . 
ful, howevel, whether such an instrument would be given effect as a deed in a number of States. ${ }^{62}$

Under the statutes now in force in a majority of the States, the owner of land may convey in the mamer preseribed, any part or portion of his estate therein as ho and his grantee may agree, subject only to those restrictions which the law imposes as required by public policy, but relieved from the technical doctrines which arose out of ancient fendal tenures, and all the restrictive effect which they had upon alienations. "The mere technicalities of ancient law," says Barrows, J., "are dispensed with upon compliance with statute requirements. The acknowledgment and recorling are accepted in place of livery of seizin, and it is competent to fix such time in the future as the parties may agree npon as the time when the estate of the grantee shall commence. To more necessity for limiting one estate upon another, o $1^{\circ}$ for having an estate, of some sort, pass immediately to the grantes in opposition to the expressed intention of the parties. The feoffment is to be regarded as taking place, and the livery of seizin as oceurring, at the time fixed in the instrument, and the acknowledgment and recording are to be considered as giving the necessary publicity which was sought in the aneient ceremony." 63

$\S 230$. Conveyances of Epecial Interests and qualified Estates. The terms "warranty" and "quitclaim" are used in preparing the synopsis of deeds, only when the instruments to which they are applied purport to be absolute conveyances of the entire interest of the grantor. In the former instance, when containing covenants which rm with the land; in the latter, when conveying but a naked interest, uncoupled with covenants or conditions. In both of these eases the legal import may safely be determined ly the examiner, who may indicate same by the name he applins to the conveyance; in all other cases he should simply use the generie word "lned,"

62 Consult, Turner $v$. Srott, 51 Pa. St. 126; Rowlings v. MeRoberts, $95 \mathrm{Ky} .346$; Leaver $v$. Gauss, 62 Iowa, 314. f3 Abbotk v. Tolway, Adm'r, 72 Me. 298; Kent n. Atlantic, Delaine Co., 8 IR. 1. 305 . 
and setting ont the material and operative parts of the instrument should leare the question of their legal import and effect to comsel.

This class of conveyances comprises deeds of equitable interesis, contingent and rested remainders, reversions, all conreyances not in presenti, and may include estates for life or years, as well as ineorporeal hereditaments, ${ }^{64}$ easements and the like. Greater particularity is required in their treatment than in the other elasses of conveyances heretofore mentioned, as their validity and effeet do not depend so much on general principles, as in ease of warranties and quitelaims, as upon the application of special provisions of law to particular faets. The operative words of converance, and frequently those of purchaso or limitation, become material in determining the nature and extent of the estate granted, while the habendum, or some portion thereof, must also be resorted to to explain or further define the grant made in the premises. The conditions annexed to the grant, or restraints upon the use or enjoyment of the land must further be observed, and where corenants are inserted in a deed of this kind it is well to allude to them.

It is a generally recognized principle, that where the granting clause does not define the nature of the estate conveyed, and is not followed by language assuming to supply what is thus omitted, the estate conveyed is a fee, or whatever interest the grantor posscssed at the time, and this is the general statutory doctrine; but where the habendum describes what estate passes it becomes efficient to declare the intention, and will rebut any implieation which would otherwise arise from the omissions of the premises. The habendum, in such case,

6. A grantee may take a fee in any kind of hereditament, either corporeal or incorporeal; but there is this distinction between the two species; that a man is seized in his demesne as of a fee of a corporeal hereditament, while of an incorporeal hereditament he can only be said to be seized as of fee, and not in his demesne, which means property in the thing itself: Wiggins Ferry Co. $v$. O. \& M. Railway Co., 94 Ill. 83. This, howerer, is one of the abstractions of the medixval lawyers and the distinction may not be recognized in many States. 
does not contravene the rule that nothing can be limited thereby, nor does it contradict the language of the granting clause, but simply supplies what is there omitted, and renores all necessity for resorting to inplication to ascertain the intention of the parties." Se Seither can the corenants enlarge the grant, whatever be their tenor, ${ }^{\text {its }}$ yet they, like the habendum, may serve to nore fully explain the intention of the parties, as will be seen from some of the ramples given in this chapter, and courts are ever more inclined to look to the whole instrument for a proper construction, than to isolated and detached portions as formerly.;

\section{$\$ 231$. Continued - Hustrations of Special Cases.} It is impossible to give more than a reference to the large class of converances that come within the scope of this section, but it is believer that the examiner will realily recognize such when met with in actual practice.

A common occurrence in deeds and wills will be found in the efforts to secure to married women and their children the use and ownership of land freed from the dominion and control of the husband and father, and such conveyances give rise to many subtle questions in their construction. A conveyance of land directly to a woman and her children, without other words, she then having children, would vest the title in her and her children equally, ${ }^{\text {ss }}$ and it seems no title will vest at law in children thereatter bom, ${ }^{69}$ although the instrmnent may declare the grantor's intent that the after-horn children shall take. $^{\text {io }}$ But such children wonld take as beneficiaries under a trust by deed, ${ }^{\prime \prime}$ or will, ${ }^{2}$ and perhaps the living grantees

65 Riggin $v$. Love, 72 Ill. 553.

Ge Lamb $v$. Wakefield, 1 Sawyer

(C. Ct.) 251.

ei Saunders $r$. Hanes, $44 \mathrm{~N}$. Y. 353; Callins r. Iavelle, $44 \mathrm{Vt} .230$.

6s Hickman $r$ Q Quinn, 6 Terg. (Tenn.) 96; Loyless $r$. Black hear, 43 Fa. 327; Barber v. Jarris, 15 Wend. (N. Y.) 615.
69 Faloon $r$. Simshauser, $130 \mathrm{Ill}$. 649.

6 Lillard $r$. Tiuckers, 9 Yerg. (Tenn.) 64; Newsom $\because$. Thompson, 2 Ired. (N. C.) 277; but see, barber v. Harris, 15 Went. (N. Y.) 61.5.

71 Gray $\imath$. Jlayes, 7 Iumpls. (Temm.) is8.

72 Tumur $x$. Ivie, 5 Hleisk. (Temu.) 222. 
under such a deed expressly providing for after-born children wonld hold the legal title interest for themselves and snch dhilinen. ${ }^{\text {i3 }}$

A rery slight indication of an intention that the children shall not take jointly with the mother will suffice to give the estate to the mother for life, with remainder to the children, an well in the case of a deed ${ }^{74}$ as of a will ${ }^{i 5}$ and even though the roman should have no children then living, or if she were unmarried, there would yet be such a contingent remainder in favor of any children she might have, that she would have no power by a conveyance before issue to defeat this contingent lemainder in favor of such issue. ${ }^{\pi 6}$ There are cases which hold that a conveyance to a woman and her children will vest in the woman no more than an estate for life with remainder in fee to the children as a class, so that those in being at the date of the deed as well as those subsecnently born would be entitled to take in the distribution on the termination of the life estate. ${ }^{i 7}$ It is also a well established rule that a conveyance to a woman and the heirs of her body will pass only a life estate to the woman herself, her children, whether born before or after execution, taking a vested estate in the remainder. ${ }^{\text {is }}$ In like manner, a deed to a woman and her issue by a specified husband, will give to lier only a life estate with the remainder to her children begotten by such specified Intsband. ${ }^{79}$ If the conreyance be expressly to the mother for life, and after her death to her children, the children born during the life estate would take, the remainder vesting as they came into being, and opening to let in those bon'n afterward. ${ }^{s}$

73 Holmes $x$. Jarret Moon, 7 Heirk. (Teun.) 506; Jackson r. Sisson, 2 Johns. Cas. 321 ; Schumpert v. Dillard, 55 Miss. 438 .

it Moore $v$. Simmons, 2 Head (Tenn.), 506.

75 Bunch $x$. Hardy, 3 Lea (Tenn.), 543.

is Frazer $v$. Sup. of Peoria, 74
$7 \tau$ Coursey $v$. Daris, $46 \mathrm{~Pa}$. St. 25; Hague $v$. Hague, $161 \mathrm{~Pa}$. St. 643.

is Fletcher v. Tyler, $92 \mathrm{Ky} .145$.

5 Bodine $v$. Arthur, $91 \mathrm{Ky} .53$.

so Beecher r. Hicks, 7 Lea (Tenn.) 207; Llair $v$. Vimblarcum, ‘1 11l. 290.

III. 282. 
In all of these cases, aside from the fine points of construction to decide the ownership of the fee, collateral questions arising from the doctrine of dower and curtesy present themselves according as the statutory law of the State may be; the collateral questions being dependent on the construction of the main question of the nature and quality of the estate conveyed. The intention of the grantor being gathered from the whole instrument, it is recommended that all technical words of conreyance, limitation and definition, whether in premises, habendum or corenants, be set out fully and without reserve, and repugnancies or rariations noted as heretofore shown. In the instances above cited, and generally when the instrument purports to convey more than one estate, or where the estate conveyed is defeasible from any cause, the premises and habendum must be construed together and should be properly presented for that purpose; as, in a case where land is conveyed to $A$, to hold until his som $\mathrm{B}$ shall become of age, and then to $\mathrm{B}$ in fee; or if $\mathrm{B}$ shall die before that event, then to $\mathrm{A}$ in fee. In such a case the premises and habendum and all operative words become material and must be shown, thus:

Grants, bargains, sells and conveys to A, and his son $B$, the following described land, etc.

To have and to hold *** unto said A, for and during the minority of his son $B$, and until said $B$ shall arrive at the age of twenty-one years; and unto said B, his heirs, ctc., * * * in case he shall arrive at the full age of twentyone years; but in case the said $B$ shatl deccase before he arrives at the age of twenty-one years, then unto said $A$, his heirs, etc.

(Note covenants if material.)

As a general rule, contingent interests are ascignalule, derisable and deserndilile the same as the rested interest.."

\$ 23:2. Restrictive and Conditional converances. The subject of conditions and restrictive clanses in deeds and 81 Kenyon $v$. See, 94 X. Y. 563. 
other forms of converance has alrealy been alluded to, ant need not be extensively discussed here. As a rule, any condition which is repngnant to the estate granted will be invalid, but it has been held that the omner of property has a right to dispose of it with a limited restrietion on its use, however much the restrietion may effect its value or the nature of the estate conreyed. Repugnant conditions are those which tend to the utter subrersion of an estate; such as prohibit entirely the alienation or use of the property. Conditions which prohibit its alienation to particular persons, or for a limited period, or which provide for its subjection to particular uses, are not sulversive of the estate. They do not destroy or limit its alienable or inheritable character, and the reports are full of cases where conditions imposing restrietions upon uses to which property conveyed in fee may be subjected, have been upheld. In this way slaughter honses, soap factories, saloons, distilleries, livery stables, tameries, and machine shops have in a multitude of instances, been excluded from particular localities, which, thus freed from unpleasant sights, noxions vapors, or disturbing noises, have become desirable as places for residences of families. ${ }^{\text {s2 }}$ That sneh a purpose is a legitimate one, and may be carried ont consistently with the mules of law, by reasonable and proper covenants, conditions, or restrictions, can not be donbted.

In abstracting deeds of this character, the attention of the examiner should be particnlarly directed to the words of grant, the habendum, the conditions annexed to the grant, and the covenants. Conditions restricting the use of the premises conveyed are usually conditions subsequent, and often provide for a reversion of the title upon their breach, and upon which the grantor may recover in ejectment. ${ }^{\$ 3}$ The form for ereat-

sa rowell $r$. Colorado Springs Co., 100 U. S. 5.5; Plumb r. Tubbs, 41 N. Y. 442; Collins $r$. Marey. 25 Conn. 242; Sperry r. Pound, 5 Ohio. 189; Gray v. Blanchard, 8
Pick. 294: Clark $r$. Martin, 94 Pa. St. 289.

S3 Plumb $r$. Tubbs, 41 N. Y. 442; Wakefield $v$. Van Tassell, 202111. 41: Martin $t$. R.y. Co., 37 W. Va. 349 . 
ing a condition in a grant or deed, as laid down by the elementary writers, is " provided alwars, and this deed is upon the express condition," 84 and these expressions have always been held sufficient to create an estate upon condition, unless there is something in the deed to negative this idea. Inasmuch as estates upon condition working forfeiture are odious, ${ }^{85}$ courts have generally laid hold of any plausible feature to sustain them. Such conditions are not farored, and must be construed strictly, , and will under no circumstances, be enforced further than may be absolutely required, and so strong is this principle engrafted in the law that courts of equity will seldom lend their aid to divest an estate for breach of a condition. ${ }^{87}$

The fact that an estate is subject to condition does not in any way affect its capacity for alienation, or of being devised, or descending in the same manner as an indefeasible estate, but the purchaser, devisee, or heir, takes it suliject to whatever conditions may be annexed to it. ${ }^{s s}$ The estate so granted is sometimes called a base or qualified fee, being such as has a qualification subjoined thereto, and which must be determined whenever the qualification annexed to it is at an end. It is a fee, because it may possibly endure forever; and it is base or qualified, because its duration depends upon collateral circumstances which qualify and debase the purity of the donation. ${ }^{s 9}$ But these terms are now rarely emplored, the ideas they represent being better expressed by what is called a conditional limitation. Indeed, the ideas involved, as well as the terms in which they are expressed, are survivals of the middle

84 Kent's Com. 122; 2 Wash. Real Prop. 3.

85 Warner $v$. Bennett, 31 Comn. 478; Palmer $v$. Ford, 70 Ill. 369 ; Craig $v$. Wells, 11 N. Y. 315.

88 Gadberry $v$. Sheppard, 27 Miss. 203 ; Pradstreet $r$. Clark, 21 Pick. 389 ; Hoyt $v$. Kimball, 49 N. H. 327; 4 Kent Com. 130; Woodworth v. Paine, 74 N. Y. 196. 8i Warner $v$. Bennett, 31 Conn. 478 ; Ins. Co. $v$. Walsh, 54 Ill. 16t; Palmer $r$. Ford, 70 Ill. 369: Wing $v$. Railey, 14 Mich. 83; Smith $v$. Jewett, 40 N. H. 530.

ss Taylor r. Sutton, 1.) Ga. 103; Wilson v. Wilson, 38 Me. 18; Underhill v. R. R. Co., 20 Barb. 455. sa Wiggins Ferry Co. $v$ O. \& Mr. Ry. Co., 94 Ill. 83. 
perion of the common law, and in modem legal theories have practically lecome obsolete.

5 23\%. Prohibited Conveyances - Adverse Seizin. "From an carly date," says Washburn, "the policy of the law has not admitted of the conveyance, by any one, of a title to land which is in the adverse seizin and posscssion of another. This is cusidered, not as passing a title, but as the transfer of a right of action in violation of the early laws against champerty and maintenance, and therefore, not to be sustained by the courts." ". This doctrine was long maintained in this comntry and still prevails to a limited cxtent in some of the older States, ${ }^{91}$ but in the West it has been swept away by express statutory enactments, and no conveyance is void because at the time of its execntion or delivery, the land in question is in the possession of another who holds by a title adverse to that of the grantor. ${ }^{92}$ Where such doctrine still prevails, an entry on the land and delivery there, will evade the letter of the law and make good the deed. ${ }^{93}$ The abstract will show both titles, provided they are each deducible of record, and questions of this kind must be decided by the application of local law to the admitted or known cirenmstances. At most, the principle will apply only as to the person holding the adverse title at the tine of the exccution and delivery of the decd, or those claiming by, throngh or under him, and as to all others the deed would be valid and effectual. ${ }^{94}$

$9 \circ 3$ Wash. Real Prop. 329 (4th Ed.).

91 Sohier v. Coffin, 101 Mass. 179 ; Jones $v$. Monroe, 32 Ga. 188.

$92 \mathrm{Hall} v$. Ashby, 9 Ohio, 96; Shortall $v$. Hinkley, 31 11l. 219; Crane $r$. Reeder, 21 Mich. 82; Stewart. $r$ Mesweeney, 14 Wis. $47 \mathrm{l}$. Under these statutes any one claiming title to land althoum out of possestion, and notwithstanting there may be an actual adverse possession. may sell and convey the same as though in artual possession. and his deed will give the grantee the same right of recovery in ejectment as if the grantor had heen in the actual possession when he conveyed: Chicaso v. Vulcan Iron Works, 93 Ill. 222.

93 Farwell $r$. Rogers, 99 Mass. 36 ; Warner $v$. Bull. 13 Met. 4.

94 Edwards $v$. Rays, 18 Vt. 473 ; Wade $r$. Lindeey, 6 Met. 407 ; Betsey $r$. Torrance, 34 Miss. 138; Farnum $r$. Peterson, 111 Mass. 151. The English statutes upon which this dortrine was founded, grew ont of peculiar exigencies entirely forrign to our condition and habits. 


\section{\$23t. Continnes - Franduknt Conveyances. What} are known as "fraudulent conveyances," or such as are made with intent to hinder and delay creditors, thongh formal in all respects, and valid and effectual between the partics, are prohibited by law and void to a certain extent. ${ }^{95}$ Depending largely upon intent, the record will furnish few clues to the real character of such a deed, which will usually pass unquestioned when found upon the abstraet. Want of consideration may be sufficient to raise an inquiry, yet, as lias been seen, this of itself does not denote bad faith, nor is a consideration essential to the vesting of the title, and where the controlling motive in making the deed was to defeat creditors, a full consideration is usually expressed. The invalidity of a deed is usually the result of a decision of a court, and whatever internal evidence it may possess will rarely decide its character.

The question of fraudulent intent, as a rule, is confined to the immediate parties and does not extend to the second grantee, who, if acting in good faith and withont notice, will take the property, and the full title, purged of its former taint. ${ }^{96}$ Such a purchaser is a farorite in the eyes of a court of equity. ${ }^{97}$

§ 235. Conveyauces Subject to Incumbrance. Where land is conveyed subject to a mortgage, a promise to pay the debt thus secured can not be inferred from the mere aceeptance of the deed. ${ }^{98}$ even though made a part of the consideration. ${ }^{99}$ In the absence of other evidence, such a deed show's

They were passed at the close of revolutions, when the property of the kingdom having to a great extent changed hands, it became the interest of those who succeeded to power to place every possible obstacle in the way of the former proprietors recovering possession.

95 Dyrer $v$. Homer, 2.) Pirk. 258; Dunlap v. Dunlap, 10 Ohio 162; Harvey v. Varney, 98 Mass. 118; Ilorner v. Zimmerman, 45 11l. 14; 10
Stevens $v$. Harrow, 26 Iowa, 45 . 96 Jackson $v$. Menry, 10 Johns. 185; Wright $r$. Howell, 35 lowa, 292; 1 Story Eq. Jur. \$ 434; ( Fonrge $v$. Kimbill. 24 l'ick. 238; 4 kent ('om. (11th El.) 464.

97 I Story Eq. Jur. \$ $4: 34$.

98 Ins. Co. $v$. Stewart, 86 Pa. St. 89.

99 Fiske $v$. Tolman, 124 Mass. 254. Compare Twituhll $\%$ Mears, 8 Biss. (C. Ct.) 211. 
that the grantee merely purchased the equity of redemption. ${ }^{1}$ But if a grantee takes a deed, containing a stipulation that the land is sulject to a mortgage, which the grantec assumes or agrees to pay, a duty of payment is imposed on him by the acceptance, and the law implies a promise to perform it. ${ }^{2}$ This, of course, only applies where there has been an actual acceptance by the grantee, for the simple facts of execution, acknowledgment, and recording of a deed of incumbered property, with a clause therein that the grantce shall pay the mortgage indebtedness, is not sufficient, in itself, to ereate a personal liability on the part of such grantee unless he has assented to such clanse, yet as we have seen, by his acceptance of the deed his assent to all it contains may be inferred. ${ }^{3}$

The examiner should observe great care, therefore, in the abstracting of clauses relating to subsisting elaims or incumbrances, for the purehaser is charged with notice of all recitals of this character, and is bound thereby even though such incumbrance fails to appear of record. ${ }^{4}$ Though the conveyance of property subject to mortgage, unless expressly so provided, imposes no personal liability on the grantee, it yet raises a presumption that the purchaser buys the property to the extent stated, and takes his chances of realizing out of it enough, orer and above the mortgage, to indemnify him for his advance of purchase money. The fair inference is that the purchaser does not pay the vendor the full value of the property, but that the amount of the mortgage debt is reserved in lis hands as so much purchase money for the purpose of discharging the lien. In such case the land conveyed is as effectually charged with the amount of the mortgage as if the purchaser had expressly assumed its payment. ${ }^{5}$

As between the vendor and the purchaser of the equity of redemption, the general rule is that the land is the primary

1 Strong $r$. Converse, 8 Allen, $55 \pi$.

2 Pike v. Brown. 7 Cusl. 133;

Furnas 2 . Durgin, 119 Mass. 500: Sehumucker $v$. Sibert, 18 Kan. 104; Miller $v$. Thompson, 34 Mich. 10.
3 Thompson $v$. Dearborn, 107 Ill. 87.

4 White $r$. Foster, 102 Mass. 375;

Vaughan $v$. Greer, 38 Tex, 530.

5 Gale $v$. Wilson, 30 Gratt. (Va.) 166. 
fund for the liquilation of the incmubrance, ${ }^{6}$ but where the payment of an outstanding incumbrance, created by the grantor, expressly constitutes part of the purchitie noner, it has been held in sone cases that the law will imply an mudertaking by the purchaser to pay it, upm which the mortgagee may recover. ${ }^{7}$ Where this doctrine obtains the consideration recital becomes important and should be fully shown in the abstract.

\$ 236. Dedication by Deed. Intent, as has been stated, is the vital principle of dectication. In a calse where acts and declarations are relied on to show such intent, to be effectual they must be unmistakable in their purpose and decisive in their character; and in erery case nust be mequirocally and satisfactorily proved." Where the dead relied on is to the public direct, that is, to the State or any of its mumicipal agencies, no question as to the intent can usually arise; but when the dedicatory matter forms a recital or agreement in a deed between indiriduals, the rule above stated becomes efficient to determine its import. In ascertaining the intent of the parties in the latter case, it is a fundamental rule of construction, that the language employed is to be read in the light afforded by the subject-matter and the surrounding circumstances, ${ }^{9}$ while every part of the deed is admissible to declare the meaning of certain passages, and such construction should be put upon particular words as will best answer and effectuate the apparent general intention. ${ }^{10}$

The recitals indicative of dedication are best shown by a literal transcription, whenever the circumstances will arluit of such treatment, or a judicions condensation of the aprement, covenants and declaration of uses, may be presented when such

o Daniel v. Teitch, 13 Gratt. (Va.) 206; Jumel r. Jumel. T Paige, 595; Herlge $r$. Noore, 6 Cush. 8; Eaton $x$. Simmonda, 14 Pick. 98.

TTwitchell $v$. Mears, 8 Bise. (C. Ct.) 211; and see Garsney $r$, Rogers, 47 N. Y. 233.
S flarris case, 20 Gratt. (Va.) 833: Hollane $x$.old spring, 21 x. Y. 474; Harding r. IIale, 61 III. 192.

a Nash r. Towne. o Wall, tes?. 16 Talbott r. R. R. Co., 31 Giratt. (Va.) 68.5. 
a course may not be desirable; but, in any event, sufficient of the language employed should be given as will enable counsel to detemine whether there has been a dedication to public uses, or simply an adjustment of the conflicting claims of the parties, resulting in a common right of way to be annexed as an easement to the property for the convenience of the owners, and not for the accommodation of the public.

§ 237. Resulting Trusts. It is a general rule of equity, that if the purchase money of land is paid by one person, but the deed, through any aceident, mistake, frand, or other eircumstances contrary to the real intention of the parties, is taken in the name of another, the trust of the legal estate results to him who advanced the moner, ${ }^{11}$ and this circumstance formerly raised many questions in examinations of title. However, of late years, the operation of this rule has been greatly restricted by statute, and many of the questions which formerly perplexed examiner and comsel are now laid at rest. The statute has not abolished trusts arising or resulting by implication of law, but in a majority of instances has declared the legal title to be rested in the alience named in the deed, subject to the claims of creditors of the person paying the consideration, in whose favor a trust for the amount of their clains results, but even such trust can not be established to defent or prejudice the title of a purehaser for a valuable consideration and without notice of such trust. ${ }^{2}$

Wherever the foregoing law obtains, and it is now very general, but little diffieulty will be experienced from this elass of undisclosed trusts, and until their efficiency has heen declared by a court of competent jurisdiction they can form no

11 Case $v$. Codding, 38 Cal. 191; Frederick v. Haas, 5 Nev. 389; Fleming $v$. McHale, 47 Ill. 282; Dryden $v$. Hanway, 31 Md. 254; Mallory v. Mallory, 5 Bush (Ky.), 464; Johnson $r$. Qnarles. 46 Mo. 423; Nixon's Appeal, $63 \mathrm{~Pa}$. St. 279: Campbell v. Campbell, 21 Mich. 438; Harvey $v$. Ledbetter, 48 Miss. 95.
12 See R. S. Wis., Chap. 96; Gen. Stat. Minn., Chap. 43 ; Comp. Laws Mich. $\$ 2637$; R. S. N. Y. $\$ 51$; consult Martin $v$. Martin, 5 Bush (Ky.), 47: Durfee $r$. Pavitt, 14 Minn. 424; Finher $r$. Forbes, 22 Mich. 454; Foote $v$. Bryant, $47 \mathrm{~N}$. Y. 544 . 
appreciable factor in making up the estimate of title. A negleet to state the comsideration of the eonveyanee or acknowledge its payment was formerly eonsidered evidence of a resulting trust in faror of the grantor or some other person paying same, but this, as has been seen, no longer prevails, and a failure to reeite the eonsideration will not materially affect the conveyanec though it may, in some localities, be evidence of a vendor's lien.

$\$$ 238. Re-records and Duplicates. Re-records and duplieates of instruments already shown in present or former examinations, if they disclose no variations, may be passed with the briefest notice. Such instruments only serve to ineumber the ehain, and should be kept ont of sight as far as possible.

The following is considered a sufficient notice:

Harry M. Pachiham, bachelor, $\left.\begin{array}{l}\text { The Illinois Central Rail- } \\ \text { road Company, its succes- } \\ \text { sors and assigns. }\end{array}\right\}$

corded Aug. 16, 1852, as Doc. 36,168, in Book 101, page 580, as appears by the Recorder's certificate appended to the record.

In case of duplicates, say:

Apparently a duplicute of lease recorded Sept. 5, 1SSQ, as Doc. 100,580, in Book 910, page 550 (and shown as No. 15 of this examination).

A re-record, of course, carries its own internal evidence, while duplicates ean only be classed as such by inference, yot

1.3 Here follows the various matters relating to registration, consideration, the grant, ete., as shown in previous examples. For brevity they are omitted in the form above given and the same course will be pursued for the remainder of the work. 
where there appars an exact correspondence of parties, dates, sulject-matter, as well as identity of languge, it is almost impossible that the exaniner shall cre in classing it as a duplicate. When the originals appear in the same examination, re-records and duplicates should, whenerer practicable, immediately follow such originals, in which event say:

Apparently a duplicate of the foregoing instrument.

When such original instruments do not form a portion of the examination, the re-recorts should not be inserted in the chain of title, but are best shown among the appendices, under the head of " Re-records," or "We also find."

\$ 289. Corrected Records. Tot infrequently instruments are incorrectly transcribed by the recording officer and the error of transcription only becomes manifest after an abstract of the record has been made. In such cases a correction of the record is usually had and a mention of such corrected record becomes necessary in the abstract. It is, of course, permissible for the examiner to correct the abstract to conform to the corrected record, but this means an erasure or mutilation of some kind, and if such correction is made after the abstract has left the examiner's hands a precedent of most doubtful character is establishcd. In such event, perhaps, it is bettor to add a marginal note showing the correction than to tamper with what has already been shown. If this shall be thonght desirable something like the following may be inserted after the erroneons item or placed opposite to it in the margin of the abstract.

Note- Sines the date of this examination the record of the foregoing deed has been corrected by the Recorder so that the description of the land therelyy conveyed now appears on such record as follous: [Here set out the corrected description or other matter.]

$$
\text { (Signed) Handy d. Company. }
$$

Chicago, June 1, 1903. Examiners. 


\section{CHAPTER XVI.}

SPECIAI CIASSES OF INDINIDUAL CONVEYANCES.

$\S 240$. Marriage settlements.

24l. Conveyances to husband and wife.

242. Conveyances between husband and wife.

243. Conveyances by married women.

244. Efrect of wife's conveyance.

245. Acknowledgment of deeds by married women.

246. Release of dower.

247. Joint tenancies and tenancies in common.

248. Partition deeds.

249. Partnership conveyances.

250. Corporate convesances.

251. Statute of mortmain.

252. Power of aequisition-User.

253. Municipal corporations.

254. Conveyances to corporations.
\$25.5. Conveyances by corporations.

256. Continued - Execution Acknowledgment.

25. Acts of othicers in excess of charter powers.

25s. Tiecord of seal.

259. Conveyances by incorporated religious societies.

260. Ileirs at law.

261. Post obit conveyances.

262 . Conveyances by delegated authority.

263. Powers of attorney.

264. Revocations.

265. Conveyances in trust.

266. Revocation of trust.

267. Declarations of trust.

268. Removal and substitution of trustees.

269. Resignation - Refusal to act-Successor.

$\S 240$. Marriage Settlements. It was at one time doubted whether any interest in either real or personal property could be settled to the exclnsive use of a married woman without the intervention of tnistees; but for many years direct conveyances and settlements have been protected in equity alike against the marital rights of the husband, as against his creditors. Nor is it at all material whether the settlement be made by a stranger or hy the husband himsef, for it is now universally held that a settlement by a hushand, on his wife, made by direct enveyane to her, will he enfored in the same manner, and under the same circumstances, that it would be 
if made by a stranger, or to a tinstee for her exclusive use. ${ }^{1}$

A marriage settlement usually conferred upon the wife only the use of the property during her life, or for a definite period, with a remainder in fee to her issue or other persons designated; but marriage settlements proper have fallen into gencral disuse, while the general abolition of uses and trusts, and removal of former disabilities, have placed conveyances for this purpose upon the same plane and subject to the same rules as other conveyances between individuals.

Conveyances, of whatever nature, intended as a settlement, should be shown quite fully, particularly the granting clause and habendum, together with any special matter by way of restriction, for the power of disposition may be restricted or enlarged by the terms of the settlement; and in construing these terms, the intention of the grantor, as apparent upon a fair construction of the instrument, must govern. ${ }^{2}$ If the iustrument contains any express or implied restrictions upon the power of disposition, either as to the mode of conveyance, or purpose for which it may be conveyed, she can convey it in no other manner and for no other purpose, while if it contains no limitation or restrictions, express or implied, she may convey it in the same mamner as her general estate. ${ }^{3}$

$\S 241$. Conveyances to Husband and Wife. Under the common law, a grant to a man and his wife does not constitute them either joint tenants or tenants in common, they being in legal contemplation but one person, and hence unable to take by moieties. Both would therefore be seized of the entirety; neither could dispose of any part of the estate without the assent of the other, and upon the death of either, the whole of the estate would remain in the smrrivor. This rule

1 Jones $v$. Clifton, 101 U. S. 225; Sims $r$. Rickets, 35 Ind. 192; Putnam $v$. Bicknell, 18 Wis. 35l; Burdens $v$. Amperse, 14 Mich. 91 : Wallingford $v$. Allen, 10 Pet. 594.

2 Young $v$. Young, 7 Coldw.
(Tenn.) 461; McChesney $v$. Brown's Heirs, 25 Gratt. (Va.) 393.

3 Young $v$. Young, 7 Coldw. (Temn.) 461; McClintic $v$. Ocheltree, $4 \mathrm{~W}$. Va. 249 ; Kimm $v$. Weippert, 46 Mo. 532 . 
has not been materially changed by statute and is accepted in a majority of the States. ${ }^{4}$

In such an estate there can be no partition, as neither spouse has any separate interest. ${ }^{5}$ Between them there is but one owner, and that is neither the one nor the other, but both together. The common law permitted the husband, for his own benefit, during their joint lives, to nse, possess and control the land and take all the profits thereof, and even to mortgage and convey an estate to continue during such joint lives, though he could make no disposition of the land that would prejudice the right of the wife in case she survired him; but later authorities hold that, from the peculiar nature of this estate, and from the legal relation of the parties, there must be unity of estate, unity of possession, unity of control, and unity in conveying and incumbering it; and it necessarily and logically results that it can not be seized and sold upon execution for the separate debts of either. ${ }^{6}$

In several of the States where the rule formerly prevailed, it has been held that the legal unity of husband and wife

4 Arnold v. Arnold, 30 Ind. 305; Hemingway $v$. Scales, 42 Miss. 1; Washburn $v$. Burns, 34 N. J. L. 18; McCurdy $\imath$. Canning, 64 Pa. St. 39; Fisher $v$. Provin, 25 Mich. 347; Garner $v$. Jones, 52 Mo. 68; Robinson $v$. Eagle, 29 Ark. 202; Marburg $v$. Cole, 49 Mrd. 402; Hulett $v$. Inlow, 57 Ind. 412; Bertles $r$. Nunan, 92 N. Y. 152; Meyers $v$. Reed, 17 Fed. Rep. 40.

5 In some of the Western States there is a peculiar system of property rights growing out of the marital relation, which, while it originated in the civil law has been borrowerl directly from the Spanish or Mexican law. This is known as the doctrine of community. The underlying principle of the community system is that whatever is acquired by the joint efforts of husband and wife shall be their common property; that the matrimonial relation in respect to the property acquired during it = existence is in fact a community, of which each spouse is a nember, equally contributing by his or her industry to its promerity, and posessing an equal riglit to succeed to he property after discolution in ase of one surviving the other. It extends to real as well as personal property, and inclules everything, acynired by either hushand or wife luning the marriacre exrept that which is acquired by gift, devive or descent.

6 Chambler r. Cheney. 3i Inul. 391: M.Duff $t$. Beanchamp, 50 Miss. 531; IIulett $v$. Inlow, 57 Ind. 412. 
has been broken by the "married women's" acts, and that they take only as tenants in eommon. ${ }^{\top}$ But estates which had vested prior to the acts in question are not affected, changed or modified by them. They remove no disabilities and confer no new rights in relation to such estates, which ean only be conveyed or incumbered by the joint act of both parties, while the survivor takes an absolute title to the whole in case of death, as heretofore. ${ }^{8}$

The legislation of the States, concerning the property rights of narried wonen, has been very uniforn, but the judicial construction of similar statutes has been variant and contradictory. In some instances, as has been observed, courts have decided that statutes naking joint grantees tenants in common, and giving to married women the sane rights in property as though they were sole, have effectually destroyed the common law mity of husband and wife, and made them substantially separate persons for all purposes; but in a majority of the States the declared efiect of these statutes has been confined to their express terms and they have been held to have no relation to or effect mpon real estates conveyed to husband and wife jointly, and that, notwithstanding those statutes, they still take as tenants by the entiretr. ${ }^{9}$

The granting clanse and habendum may serve in many instances to determine the nature of the estate granted, and it is advisable, in all cases where the deed purports to convey to lusband and wife, to set out sufficient of both elauses to fully disclose the nature of the grant. As a general rule, no special langrage is required to create an estate of entirety and where the deed does not specify the manner in which they are to hold the land a tenancy by entirety will be presumed. ${ }^{10}$ This conforms to the rule of the common law which provides

7 Hoffman $v$. Stigers, 28 Iowa, 302 ; Clark v. Clark, 56 N. H. 105; Cooper $v$. Cooper, 76 IH. 57 ; Walthall $v$. Goree, 36 Ala. 728.

8 Harrer $\ell$. Wallner, 80 Ill. 197.

9 Bertles $r$. Numan, 92 N. Y. 152; Bates $v$. Seeley, 46 Pa. St. 248;
Robinson v. Eagle, 29 Ark, 203; MeDuff $v$. Beauchamp, 50 Miss. 531. 10 Stelz $v$. Shreck, $128 \quad$ N. Y. 263; Phelps $v$. Simons, 159 Mass. 415; Morrison $v$. Seybold, 92 Ind. 298; Bramberry's Appeal, $156 \mathrm{~Pa}$. St. 628 . 
that in a conveyance to both sponses they will take as joint tenants or tenants in common only by express words, or words strongly implying such intention. ${ }^{11}$ Where the words of the grant clearly show that the intent was to create a tenancy in common effect will be given to it and they will so hold. ${ }^{12}$

\section{$\$ 242$. Conveyances Between Hushand and Wife. It} is now well settled that a conveyance by a husband to his wife, without the intervention of a third person or trustee, where suitable and meritorious, and not in frand of creditors, will bo upheld in equity, ${ }^{1:}$ while in those states where the legal identity of husband and wife is no longer recognized, such conveyanee may be good at law. ${ }^{14}$ Where the ancient doctrine still obtains, a deed from hnshand to wife, without the intervention of a trustee, is void at law; nor can a court of equity regard it as effectual to transfor the legal title. But where such deed is founded upon a good and sulficiont consideration, ${ }^{15}$ equity will enforce it according to the intention of the parties, where the sane can be done without prejudice to the rights of others. ${ }^{16}$

A voluntary converance, that is, a conveyance without consideration, is a fraud upon the creditns of the husband, even in the absence of fraudulent intent, and this is especially true when the conveyance leaves the husband insolvent. ${ }^{17}$ As a rule, conveyances of this class call for dose scrutiny, and fre-

11 Baker $v$. Stewart, 40 Kan. 442. 12 Miner $c$. Brown, 133 X. Y. 308; Thornburg $v$. Wiggins, 135 Ind.178. 13 Hunt $v$. Johnson, 44 N. Y. 27; Simmons $v$. Thomals, 43 Miss. 31 ; Sherman $v$. Hocland, 54 Ind. 578; Montz $r$. IIoffman, 35 IH. 553; Hockett $r$. Bailey. 86 IH. 76.

14 Booker 2 . Worrill, 5.5 ra. 33:3 ; Dickson 1. Ranual, 19 Kan. 212; Barclay r. Plant, 50 Ala. 509; Kaufman $r$. Whitney, 50 Miss. 103. 15. Not necestarily money: Wells v. Wells, 35 Miss. 664; Wilder $v$. Brooks, 10 Minn. 50; Sinls $v$. Tick- ets. 35 Ind. 181. Then the conveyance is made ats a provision for her, this will be sutlicient. for the duty of maintenance which a hus. bund owes to a wife is a good consideration for a voluntary conveyance resting title in her: Gill $b$. Wood, Armr, 81 111. 64; Kellogre $n$. Hale. 108 111. 164.

16 Huber r. lluber, 10 Ohio, 371 ; Brookbank $r$. Kernard, 4l Imi. 339; (ardell $r$. Rydere $35 \mathrm{Vt} .47$.

17 Watson v. liiskanire, 45 Iowa, 231. 
quently for inquiries in pais. Local statutes will go far to setthe many questions, yet there are numerons cases, even minder fivorable statutes, where a knowledge of the circumstances and situation of the partics must result in the rejection of the title so offered, whether the conveyance be to the wife direct, or through an intermediary, for it is a fundamental principle that the rights of creditors can not be infringed or defeated in this manner: ${ }^{18}$

$\$ 243$. Conveyances by Harried Women. Xo class of converances call for greater vigilance or closer scrutiny than those executed by married women. Though at present a progressive and liberal spirit is manifest in the enactments of the various State legislatures, tending to remove entirely all restraints and impediments from the free aequisition and alienation of real property by married women, yet such enactments are of rery recent origin, and furnish no rule for the construction of converances made prior to the time at. which they became effective. At common law, a maried woman conld make no disposition of her lands except by some matter of record, as a fine and reenery ${ }^{19}$ hence it follows that a conveyance of her separate property by a woman during her corerture would be void, unless specially authorized by statnte. ${ }^{2}$ Such statutes now exist, however, and confer upon married women a number of rights, which, being in derogation of common law principles, are strictly construed by the courts. In all cases a rigit and literal compliance with the statute is essential to rest title. The remoral of the common law disabilities was not accomplished at any one time, but extends over a series of rears, and an additional burden is thrown on examiner and commel by this fact. Different formalities were requisite at different periods, and thorongh knowledge of the changes in the law in this respect are indispensable to a correct and satisfactory examination.

By the common law, upon the marriage of a man with a 18 Aultman $r$. Obermeyer. 6 Neb. 260.

191 Blk. Com. 293; 2 Kent Com. 150.

20 Hoyt $r$. Swar, 53 Ill. 134. 
woman seized of an estate of inheritance, he became seized of the freehold jure uxoris during their joint lives, and if he had issue by her lworn alive, then for his own life absolutely; in which latter case, if he survived the wife, he was styled tenant by the curtesy. ${ }^{21}$ Subsequently, by statute, the hinsband was given this right of tenancy by the enrtesy, whether they had issne born or not. In most of the States tenancy by the curtesy is now abolished. A few remnants are still observable, however, and local law must be resorted to for the purpose of defining the husband's marital rights.

The first enactments looking toward the prwer of alienation by the wife provided that conveyances might be made by forns of deets ordinarily employed, but attended by many formalities, particularly in the matter of acknowledgment and authentication, it leing a vital principle always that the husband join in the eonveyance. Under these enactments the acknowledgment of the wife seems to have been the operative act to pass title and not the delirery of the deed. Subsequently the rigors of the early rules became relaxed, and, while the husband was still required to join in the execntion, the acknorledgment ceased to be the effective means to work the transfer of title, and the certificate thereof was placed on the same footing as that requirer for an mmarried woman. The greater part of the old formalities, in a majority of the States, are no longer requisite, the gradual and miform tendency of modern legislation being to facilitate the power of alienation by women of their separate estates, though it is still indispensable, in many jurisdictions, that the husband join with the wife in the execution of the deed. ${ }^{22}$

Legislation, in some of the more advancel States, has had the effect to destroy the common law unity of person in husband and wife, so far as that unity is represented by the lussland, and in its stearl a rule has been intrentued, analogmens to that of the ciril law, by which the wife is regarded ats a

\footnotetext{
21 ] BHk. Com. 126; 2 Kent Com. Hollman r. De Nye. 51 Ala. 95; 108. Hand $r$. Winn, 5e Mis. 78t; Arm22 Styles r. Probst, 69 Ill. 382; strong $v$. Ross, 20 N. J. Eq. 109.
} 
distinct person so far as her separate property, contracts, etc., are concerned, while her convesances may be made in the same manner, and with like effect, as if she were numarried. ${ }^{23}$ Under these laws no joinder is necessary, other than for the purpose of waiving homestear or other marital rights, and for all practical purposes of transfer of her separate property the husband and wife stand before the law as strangers. ${ }^{2+}$

The tenancy by the curtesy is also becoming obsolete or attaches only on the death of the wife, and then but to such lands as she died seized of, and of which she had made no final disposition by will. Where, howerer, the laws of a State give to the husband the same right of dower in the real estate of the wife that she has in his real cstate, the effect of a non-joinder of the husband in a deed of the wife's lands has the effect to preserve such dower interest, and hence the joinder becomes necessary to a properly executed deed. ${ }^{25}$

\section{$\$ 244$. Effect of Wifes Conveyance. When a married} woman joins with her husband, or otherwise properly executes a conveyance of lands, held ly her in her own right, which purports to conrey the entire estate therein, she is estopped from afterward setting up any title to such lands, whether it existed at the time of making such conreyance, or was subsequently acquired by her." ${ }^{26}$ So, too, the deed or other contract of a married woman respecting her separate property may be reformed for mistake the same as if she were sole. Where the deed is made upon a good consideration, defects may be remedied, and the deed specifically anforced in equity. ${ }^{27}$

$\$ 245$. Continned-Acknowledgment. The formalities attending the acknowledgment of married women's converances now differ in no material respect from other deeds, though formerly they involved no little circumlocution and ccremony. It was, and, in some ferr States, is ret, custom-

23 Price $r$. Osborn. 32 Wis. 34; Westlake $r$. Westlake. 34 Ohio St. 621 ; Tomlinson $r$. Mathers, $98 \mathrm{I} ! l$. 178.

24 Tomlinson v. Matthews, 98 Ill.
25 IIuston $r$. Seeley, 27 Iowa, 183.

2 ing $r$. Rea. 56 Ind. 1 .

27 Knox $r$. Brady, 74 Ill. 476; Shivers $r$. Simmons, 54 Miss, 520. 178 . 
ary to make a personal examination of the wife, apart from the husband, in which the contents and nature of the instrument must be made known to her, and upon such examination she is required to makr a "free and voluntary" acknowledgment withont "fear of compulsion," and to further state that she does not wish to retract; that she resigns her dower, waives her homestead riglits, etc., and, where such is the law, courts have usually exacted a strict and literal compliance, and material departures or onissions have been held to vitiate the converance as a means of passing the wife's interest in the property. ${ }^{2 S}$ The law long regarded the wife as under the control of the husband, and subject to his coereion. Hence, it was not expected that in his presence, and within his hearing, she would be likely to act contrary to his wishes, and therefore it reguired her to signify her wish or intention apart from him before the oficer taking the acknowledgment. The result of this separate examination is sometimes emborlied in a separate certificate, but the usual method is to state the facts in a separate clanse attached to or following the general statement of acknowledgmenit. In all cases the statement of essential facts must be clear and explieit.

- It will be seen from the foregoing that the date of execntion may be an important factor in determining the validity of a married woman's deed that during certain periods it will be valid only when the lmsband has joined in the execution and the certificate of acknowledgment shows a special method of authentication; that during certain other periods while the husband must still be joined ret the ackuowledgment mas be made as in other cases of transfer; and that in still other periods a married woman's deed is not distinguished from that of her husloand, requiring no joinder and no special method of acknowledgment. These various periods will be determined by local statutory law, and both examiner and comsel must be conversant therewitl.

2s Prible r. Hall, 13 Bush (Ky.), 61; Jomey r. Aramson, is Tex. 619; Wright $r$. Dufield. 59 Tenn.
218; Petition of biateman, 11 R. I. 585 ; Little 1. Donlge, 32 Ark. 453; Silliman $r$. Cummins, 13 Obio, 116. 
\$ 246. Pelcase of Dower. The right to dower is a legal right which ean not be harred, mless it has been relinquished in the manner prescribed by law, ${ }^{29}$ and this may be acconplished either by a joinder of the wife in a conveyance by the. husband, or by a separate deed of relinquishment. ${ }^{30}$

The release which a woman makes by joining with her husband operates against her only by estoppel and not by grant, ${ }^{31}$ and, in the absence of any express legislative requirement to the contrary, the release will be valid and effectual withont mention of her name, or of the dower, in the body of the deed. It being only an inchoate right, and not a present estate, no words of grant are necessary. ${ }^{32}$ Tor is it necessary that there should be a consideration moving to her, and though she might insist on a consideration inuring solely to herself as a condition of such release, yet, failing to exact this, her release will be gond if supported by an adequate consideration moving to the husband alone. ${ }^{33}$ Where a wife joins with her husband in a conveyance of his lands, which is properly executed by her, is effectual and operative against him, and is not superseded or set aside as against him or his grantee, her inchoate right of dower is thereby forever extingnished for all

29 Davis 2 . MeDonald, 42 Ga. 205. "A divorce from the bonds of matrimony," observes Nr. Washburn, "always defeats the right of dower, unless it be saved by the statute authorizing such divorce; for at common law, in order to entille a widow to dower, she must have been the wife of the humband at the time his decease": 1 Wash. Real. Prop., * 196. and see also Bish. Mar. \& Div., $\S 661$; 2 Black. Com. 1:30; 4 I Tent Com. 54; Whitsell $r$. Mills, 6 Ind. 229 ; McCraney $r$. McCraney, 5 Iowa, 232. A reasonable provision out of the husband's estate is usually given in lieu of lower. See "Chancery Proceedings," infra. In some States, however, where the ac- tion is brought by the wife, for the misconduct of the husband, her right of dower continues notwithstanding the divorce. This is the rule in Illinois and several other States.

30 Sykes $\tau$. Sykes, 49 Miss. 190; Shepard $v$. Howard, 2 N. H. 507 ; Thatcher $r$. Howland, 2 Met. 41.

31 Mallony $v$. Horan, 12 Abb. (N. Y.) Pr. N. S. 289 ; do. 49 N. Y. 111.

32 Johnson i. Montgomery, 51 Ill. 185; Frost $r$. Deering. 21 Me. 156; Sterns $v$. Swift, 8 Pick. 532, but compare MeFarland $v$. Febiger, 7 Ohio, 194.

33 Bailey v. Litten, 52 Ala. 282. 
purposes. $^{34}$ The conveyance, lowever, must be of the freehold or fee, ${ }^{35}$ and such as would destroy the seizin of the husband, while the right is of such a nature, when inchoate, that 'it can not be itself transferred by any of the instruments of conveyance in common use, ${ }^{36}$ and can be released only to the owner of the fee, or to some one in privity with the title by his corenants of warranty. ${ }^{37}$

The release is often accomplished by a separate instrument of relinquishment, but as this deed acts only by way of estoppel, no particular form of words is necessary, and any apt words indicating the intent will suffice. ${ }^{3 s}$ The abstract of such an instrument would consist mainly of its recitals, thus:

$\left.\begin{array}{c}\text { Clio S. Greene } \\ \text { to } \\ \text { James W. Penfold. }\end{array}\right\} \begin{aligned} & \text { Relcase of Dower. } \\ & \text { Dated Nov. 6, } 1851 . \\ & \text { Recorded Nov. 7, } 1851 . \\ & \text { Vol. "B," page 379. }\end{aligned}$

"For a valuable consideration," releases all right and claim of douer in and to a certain piece of land in the South-W'est fractional quarter of Section 19, Tou'n 2 North, Range 22, East-, described in a conveyance by "my husband," Patrick P. Greene, to said James W. Penfold, and recorded in Vol. "B," page 124.

Acknowledged Nov. 6, 1851.

Whenever practicable, let the deed of relinquishment immediately follow the husband's deed, irrespective of interrening conveyances, or if to a grantee of the husband's grantee, then immediately after his deed, the object being to keep the lower interest closely associated with the fee. This method of arrangement will be highly appreciated by counsel. 322.

34 Elmdorf $v$. Lockwood, 57 N. Y.

35 Sykes $r$. Sykes, 49 Miss. 190.

36 Marvin $v$. Smith, 46 N. Y. 571.

37 La Framboise $v$. Crow, $56 \mathrm{Ill}$.

197 ; lieed $v$. Ash, 30 Ark. 775.

20 as Gillilan $r$. Swift. 21 N. Y. Sup. Ct. 574 .

39 Deeds of this character are more properly "Surrenders" than "Tieleases," but this is the name they have acquired. 


\section{7 . Joint Tenancies and Tenancies in Common.}

Where several persons purdiase land, and advance the money in equal proportions, and take a conveyance to then and their heirs, this, at common law, is a joint tenancy; that is, a pur chase by them jointly of the chance of survivorship, which may happen to the one of them as well as to the other.

The doctrine of survivorship, however, is not in accordance with the genius of our instintions, ${ }^{40}$ and this incident of estates has been generally abolished in the United States, except in a few instances, while the extent of its operation has everywhere been very much restricted. Conveyances to two or more persons are now usually held to create a tenancy in common, unless the langnage used elearly and manifestly shows an intention to create a joint tenancy, in which event the intention may be given effect. But even where this is allowed a joint tenant, by deed, nay alienate his undivided interest and his grantee will hold as at tenant in conmon with the others.

Tenants in common are considered as solely and severally seized; they have several and distinct freeholds, and there is no privity of estate between them. ${ }^{41}$ They may convey and dispose of their undivided interests to a stranger and the same may be taken and sold on execntion, ${ }^{42}$ the purchaser simply taking the same position in relation to the co-tenants as was occupied by the grantor or judgment debtor; ${ }^{43}$ but one tenant in common, owning an undivided interest, can not convey to a stranger : certain portion of the tract in common, and put the purchaser in possession of the portion conveyed, ${ }^{44}$ unless the other tenants confirm the conveyance. ${ }^{45}$

$\$ 2+8$. Partition Deeds. Where property is owned by a number of persons in common, they may, by properly executed deeds, convey to each other in severalty specific por.

40 Burnett v. Pratt, 22 Pick. 557.

41 Burr 2 . Mueller, 65 Ill. 258.

42 Butler $v$. Roys, 25 Mich, 5.?.

$4:$ Fischer $v$. Eslaman, 69 Ill, 78.

44 Iattox $r$. Hightshue. 39 Ind. 95; Shepardson $v$. Rowland, 28 WVis.
108; Hartford, ete., Ore Co. $v$. Miller, 41 Conn. 112. Compare Barnhart $r$. Campbell, 50 Mo. 597.

45 Hart ford, etc., Ore Co. v. Miller, 41 Conn. 112. 
tions of what was formerly heli jointly, and where the course of title clearly shows the origin of their property rights and the proper measure of their title, the deeds so executed are evidences of title of the highest orter. This will be the case where land is held by partners, and all purchasers by deed or will in which they are specifically designated, but not always when the claim is by descent. In the latter event a propor proof of heirship is essential, and unless this appears the title is not marketable.

A partition deed is mutual, mless otherwise specified, the interchange of interests forming the consideration. In abstracting same, all the material recitals should be fully stated, and the method of division minutely deseribed. The ordinary corenants will not, as a rule, be fuund, but a mutual corenant of non-claim and warranty against their own aets, and those claiming under them, is usually inserted in their place. The deed shoud be signed and acknowledged by both parties to the transaction and is presumably interchangeably delivered. A deed possessing these and other requisites might be shown in the abstract as follows:

$\left.\begin{array}{c}\text { Andrew Barlow }{ }^{46} \\ \text { to and with } \\ \text { Charles Dalton. }\end{array}\right\} \begin{aligned} & \text { Partition Deed. } \\ & \text { Daled, etc. } \\ & * \text { * * * * }\end{aligned}$ *

Recites, that said partics are now seized in fee simple, as tenants in common of the following described real estale [describing same], and have ayreed to make a full, just, and equal partition and division bitween them, of and in the aforesaid tract, of and according to their respectice shares and inlerest therein, in manner following [describing same].

And said Andren Barlow gives, grants, allols, assignes, sets over, releases and confirms to said charles balion the scill first described piece or allobment of land, to hate amel lo hold * * * * in seremlly, as his full share linerin.

45 When the contse of tifle is

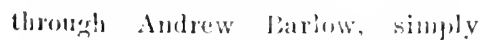
reverse the nanes. The next con-

veyance in this abstrate is suppored to be from Chates datton. 
And Charles Dalton gives, grants, etc. [describing his allotment].

And said Andrew Barlow covenants that said Charles Dalton shall frecly, etc., hold and enjoy said first described piece or allotment of land without molestation, interruption, or denial of him, said Andrew Barlow, or any person claiming by, through, or under him. (And said Charles Dalton covenants the same in regard to said second described piece or allotment of land.)

Signed and acknowledged by both parties August 1, $1 S S 1$.

$\S 249$. Partmership Conveyances. Lands held by several persons as partners, purchased by them with partnership funds and for partnership purposes, are regarded in a somewhat different light from lands held by an individnal, or even by tenants in eommon in their ordinary relation, and for certain purposes may be treated as personal property. Even though the title be taken in the individual name of one or both partners, the land will, in equity, be treated as personalty so far as is necessary to pay the debts of the partnership or adjust the rights of the partners. No other or different formalities are necessary in its acquisition than those observed in the ease of ordinary deeds of conveyance. Yet, though the conveyance to them is in form such as to make them tenants in common, still, in the absence of an express agreement, or of circumstances showing an intent that the estate conveyed shall be held for their separate use, it will be considered and treated in equity as vesting in them in their partnership capacity, and clothed with an implied trust that they hold it until the purposes for which it was purchased shall be accomplished, and that it shall be applied, if necessary, to the payment of the partnership debts.

Upon the dissolution of the partnership by the death of one of the partners, the surviror has an equitable lien upon such real estate for his indemnity against the debts of the firm, and for securing the balance that may be due to him from the deceased partner on settlement of the partnership accounts be- 
tween them, and the widow and heirs of such deceased partner have no beneficial interest in such real estate until the surviving partner is so indemnified. ${ }^{47}$ The legal title, it is true, is cast upon the heirs as in any other case of tenaney in common, but only becomes certain after all the debts of the firm are paid. ${ }^{48}$ As the widow and heirs can elaim only in the right of the husband and father, such derivative right in equity will extend no further in behalf of the wife and children than that of the partuer from whom it is derived. $A$ surviving partner, in a proper case, may sell the real estate of the firm, and though he can not convey the legal title which passed to the heir or devisee of the deceased partner, his salo will yet invest the purchaser with the equitable ownership of all the land and the right to compel a conreyance of the title from the heir or derisee in a court of equity. ${ }^{50}$

Conveyances of partnership realty should be exeeuted by each and all of the partners in the same manner as deeds by tenants in common, and it seems that a deed executed by one partner only in the name of the firm will convey only the undivided portion of the estate owned by such partner, ${ }^{51}$ or rather only a contingent right to such part after the debts aro paid, while the authorities are unanimous in declaring that a firm name, as "Jno. Smith \& Co.," is not a proper legal designation either of grantor or grantee, and is effective in either case only for or against the persons specifically named. ${ }^{52}$

472 Sugd. V. and P. 427 (Perkins' notes) ; Dyer $v$. C'lark, 5 Met. 562 ; Cobble $v$. Tomlinson, 50 Ind. 550.

48 Collins $v$. Warren, 29 Miss. 236; Holland $v$. Fuller, I3 Ind. 195; Shearer $v$. Shearer, 9s Mass. 111.

49 Burnside $v$. Merrick, 4 Met. 537 .

50 Dupuy $v$. Leavenworth, 17 Cal. 262 ; Shanks $v$. Klein, I04 U. S. 18.

51 Dillon $r$. Brown, 11 Gray, 179. Nor will it render the other partpers liable on the covenants: Hobson $x$. Porter, 2 Col. T. 28.
52 Arthur $v$. Webster, 22 Mo. 378; Winter $v$. Stock, 29 Cal. 407; Gossett $r$. Kent, 19 Ark. 607; Barnett $v$. Lachman, 12 Nev. 361. A sealed instrument (deed or other specialty), executed ly one partner in the name of the firm, may be treated as the deed of all the partners, upon proof that prior to the exeention the others had authorized him to execute the instrument, and after execution, with full knowledge, acquiesced in what he had done: Gib son v. Warden, 34 Wall. (U. S.) 244; Cady v. Shepard, 11 Pick. 
\$ 250. Comporate Conveyances. There are three classes of comporations roognizel by on laws: Public municipal corporations, corporations tochnically private, but of a quasi puldic character, as raiboads, etc., and corporations strictly private, all of whom, melir general or special conditions, have the ponver to arquire, hold, and transmit the title to land. Though regarded in law as persons for eertain purposes, they are not ontitled to the privileges of citizens, ${ }^{53}$ as gruaranteed by the Federal Constitution, neither in the State of their creation, nor in other States which they may enter for the purpose of lusiness. Their right to aeguire and transmit property is a statutory one in the home State, and in a foreign State is based upon the comity between the States. In the latter case it is a voluntary act of erace of the sovereign power, ${ }^{54}$ and is inarlunicsible when contrary to its policy or prejudicial to its interests. 55

1 corporation has only such powers as its charter gives it, either expressly, or as incident to its existence, and in determining whether a given act is within the power of a corporation, it is necessary to consider, first, whether the act falls within the powers expressly enmmerated in the charter or defined by law; and second, whether it is necessary to the exercise of one of the enumerated powers, ${ }^{56}$ and these apply both

(Mass.) 400; Peine $t$. Weber, 47 11l. 45; the dificulties attending such proof will be readily seen, however, and while by no means insurmountable they are of such a nature as to make it almost imperative on counsel to demand that the title be assured hy a better deed.

53 Although a corporation is not a citizen within the several provisions of the Constitution. yet where rights of action are to be enforeed by or against a corporation, it will be considerer as a citizen of the State where it was created: Railway Co. v. Whitton, 13 Wall. 270. This, however, applies more particularly to controversies in the Federal Courts.

54 Ducat $r$. Chicago, 48 Ill. 172; Ins. Co. $v$. Commonwealth, 5 Bush (Ky.), 68; State v. Fondick, 21 La. Ann. 484 .

55 Carroll $Ґ$. East St. Louis, 67 III. 568.

5 i Vamkall $v$. Dock Co., 40 Cal. 83; Pullan v. R. R. Co., 4 Biss. 35; Weckler $r$. Bank, 42 Mrd. 581 ; Matthews $v$. Skinner, 62 Mo. 329 . In determining whether a corporation mu make a particular contraet, it must be consirlered whether its charter, or some statute binding upon it, forlids or permits it to 
to the acquisition and transtir of real property. ${ }^{57}$ Land which a corporation can not hold in its own name it can not hold in the name of another, and when a corporation can not lould the legal title to land, it can not take a benefieial interest in it. 58

It would seem, therefore, that the organic act, or some portion thereof, should supplement every conveyance purporting to pass title to a eorporation as constituting one of the strongest assurances of the ralidity of subsequent conveyances, ${ }^{59}$ but in practice this is soldom done, though the authority to make a deed frequently constitutes one of the recitals in converances from corporations. As corporations are now almost universally organized under general laws, which define their powers in this respect, ${ }^{60}$ the matter presents fewer intricacies than formerly, yet as a rule, whenever the title under examination passes through a corporation, and the deeds furnish no internal evidence to demonstrate their ralidity, a requisition should be made by the examining counsel for such information as, in his opinion, may be necessary to show same.

make such a contract; and, if the charter and valid statutory law are silent upon the subject, whether the power to make such a contract. may not be implied on the part of the corporation as directly or incidentally necessary to enable it to fulfill the purpose of its existence, or whether the contract is entirely foreign to that purpose: Weckler $v$. Bank, 42 Md. 581; Watson $r$. Water Co., 36 N. J. L. 195.

57 Franco-Texan Land Co. v. MeCormick, 8j Tex. 416.

58 Coleman $r$. R. R. Co., 49 Cal. 517.

59 At the present time corporations are organized under general laws which define their powers and capacities. Hence, in the ease of modern corporations no difficulty will usually be experienced in determining questions of eapacity. The suggestion of the text applies more particularls to corporations organized during the period when special legislation of this kind was permitted. In the ease of domestic corporations the published volumes of private and loeal laws will supply the desired information. In case of foreign corporations a requisition for further information will often become necesary.

60 The filing of articles of incorporation in one of the county offices and with the Secretary of State is now the usual manner of organizing corporations. The law and the articles so filed, taken togetler, are considered in the nature of a grant from the State, and constitute the 
$\S$ 251. Statutes of Mortmain. The common law right of corporations to take and hold real estate has been restrained in England from an early day, by a series of laws called statutes of mortmain, which were passed to repress the grasping spirit of the clureh which, it was claimed, was absorbing in perpetuity the best lands in the kingdom. ${ }^{61}$ "They were called statutes of mortmain," observes an eminent writer, "because designed to prevent the holding of lands by the dead clutch of ecclesiastical corporations, which in early times were composed of members dead in law, and in whose possession property was forever dead and unproductive to the fondal superior and the public." 62 This system of restraint, though originally confined to religious corporations was subsequently extended to civil or lay eorporations.

The English statutes of mortmain, though they have been held in some of the States to be the law, so far as applicable to present political conditions, have not been re-enacted in this country; yet the policy has been retained and is manifest in the general and special enactments of every State. To prevent monopolies, and to confine the action of incorporated companies strictly within their proper sphere, the acts incorporating them almost invariably limit not only the amount of property they shall hold, but frequently preseribe in what it shall consist, the purposes for which it shall alone be purchased and held, and the mode in which it shall be applied to effect those purposes. Special legislation for corporations, in most of the States, has been abolished, and companies are incorporated under general laws of uniform application, but the policy above ontlined is still vigoronsly maintained.

\$ 252. Power of Acquisition-User. There is a broad distinction between the power of acquisition of property and the use to which it is to be applied, and the effect of

charter of the company: Abbott $v$. Smelting Co., 4 Neb. 416; Mining Co. $r$. Herkimer, 46 Ind. 142; Whetstone $r$. Ottawa University, 13 Kan. 320 ; Hunt $v$. Bridge Co., 11 Kan.
412; State $v$. Leffingwell, $54 \mathrm{Mo}$ 458.

611 Black Com. 479.

62 Ang. \& Ames on Corp., § 148;

3 Co. Lit. 2 b.; 1 Black Com. 479. 
the distinction upon the rights of third persons is equally marked. Where the charter of a corporation, or the general Iaw under which it is organized, prohibits the purchase of lands for any purpose, a deed to it would be an utter nullity, as its capacity to take is determined by the instrument or act which gave it existence; ${ }^{\text {e3 }}$ but, having the power to purehase and take, though for a specific purpose only, it becomes fully invested with title by a deed properly executed, even though the property be acquired and used for a purpose forbicken by the organic act. ${ }^{64}$ As a rule, deeds to and from corporations are effective to convey the title to the lands therein rescribed, and titles so derived can not be impeached collaterally, nor their validity be questioned by third persons, on the ground that the transaction was beyond the corporate power; for where a corporation exceeds its powers, the remedy is by a direct action in the name of the State, ${ }^{65}$ who alone can interfere. ${ }^{66}$ Parties dealing with corporations are chargeable, however, with notice of the limitations imposed by the charter upon their powers. ${ }^{67}$

\section{§ 253. Hunicipal Corporations. Municipal corpora-} tions are creatures of the statute, and can exereise only such powers as are expressly conferred, or such as arise by implication from general powers granted. Where the charter empowers a municipal corporation to buy and hold real property,

63 Leazure $v$. Hillegas, $7 \mathrm{~S}$. \& $\mathrm{R}$. (Pa.) 319. Tet whether real estate has been acquired in excess of the corporate powers to take and hold can not be made a question by any party, except the State, who alone must assert her policy in that regard: Alexander $v$. Tolleston Club, 110 Ill. 65; Baker $v$. Neff, 73 Ind. 68.

64 Hough $n$. Land Co., 73 Ill. 23. 65 Smith $v$. Sheeley, 12 Wall. 358 ; Kelly $v$. Transportation Co., 3 Oreg. 189; Conn., atc., Ins. Co. $v$. Sunith, 117 Mo. 261. The only exception to the rule which prohibits attack by private suitors on eomveyances or other unauthorized acts of a eorporation is where such attach is authorized by express legislative permision. See, Martindale $v$. R. R. Co., 60 Mo. 508; Bank v. Mathew's, 98 U. S. 621.

60 DeCamp v. Doblins, 29 N. $\int$. Eq. 36; Hayward v. Davidwon, 41 Ind. 214. The doctrine of ultra vires is gemerally applifel only to such contracts as remain wholly executory: Thompson v. Lambart, 44 lowa, 239.

6. Franklin ('o. $v$. Lewistom Inat. for Savings, 68 Ne. 43. 
it must lo molerstood to be purchases made in the ordinary way, and for corporate purposes only; and a grant to purchase for particular purposes would seem to be a limitation on the puwer of such corporations, and to exchde, by necessary implication, all purchases for mere speculation and profit. "Power to purchase for speenlative purposes," says Scott, J., " is not among the usual powers bestowed on municipal corlorations, nor does such power arise, by implieation, from any of the ordinary powers conferred on such corporations." 68

Municipal corporations, under a general grant of power to buy and hold land, may purchase, within the corporate limits, such property as may be necessary for corporate purposes, and may even buy and hold land beyond the corporate limits, for the location of cemeteries, pest houses, drainage, ete. ${ }^{69}$ but in the absence of any enabling statute, can not become the purchaser of lands or lots at a tax sale, and on compliance with the statute in that regard obtain a deed that will invest such corporations with the title to the property. ${ }^{i 0}$

Deeds by a municipal corporation stand upon a somewhat different footing from private corporations generally, and for their proper proof it is necessary that the authority for their execution should also appear. ${ }^{71}$ This authorization will usually take the form of a resolution by the municipal legislature. The resolution shonld always appear in the abstract in connection with the deed made pursuant thereto. Practical examples will be given further on.

\section{\$25t. Conveyances to Corporations. By common} law, and in the absence of statutory prohibitions, corporations aggregate, ${ }^{i 2}$ in whaterer manmer created, can take, like nat-

68 City of Champaign $r$. Harmon, 98 Ill. 491; and see 2 Dill. Mun. Corp. § 433.

692 Dill. Mun. Corp., § 435. The general rule is that municipal corporations can not purchase or hold real estate beyond their territorial limits. unless this power is conferred by the legislature: 2 Dill.
Mun. Corp. $\S 435$; and see Denton $r$. Jackion, 2 Johns. Ch. 336; Chambers $v$. St. Louis. 29 Mo. 543. 70 City of Champaign $v$. Harmon, 98 11l. 491.

i1 Ward v. Lumber Co., 70 Wis. 445 .

i2 Corporations sole. though eomparatively common in England, are 
ural persons, by erey methol of conveyance known to the law. No particular worls of swant are necessary, other than those in common uze in conveyances to natural persons, thomgh it is usual to insert, as a word of limitation, the term "snceessors." The worl is not necessary, howerer, to conrey a fee, independent of the statute which provides for a fee, for, admitting that such a grant is strictly only a life estate, get as a corporation, nuless of limited duration, never dies, such estate for life is perpetual, or an equiralent to a fee simple, and therefore the law allows it to be one. it

As between the parties, where the corporation is anthorized by its chartrr or the law under which it is organizerl, to purchase land, receive converances thereof, and hold title to the same, but is prohibited from purchasing and holding for any other than a prescribed purpose, the question of the ralidity of the title convered can not be inquired into. The title rests in the corporation by a deed duly executed, and the question as to whether the corporation has exceeded its power can be raised only by the State or by a stockholder. ${ }^{75}$ A distinction must, however, be observed between the power of aequisition and the use to which the land is to be applied, but, as a general rule, a proper and legitimate purpose is always presumed on the part of a corporation in aceepting a conveyance of land. ${ }^{\circ}$

§ 255. Conveyances by Corporations. All pricate corporations have an incidental right to alien or dispose of their lands, without limitation as to objects, mless restrained by the act of incorporaton, or by statute; and the power to nortgage,

seldom created in the United States. The general laws for the organization of corporations all provicle for a number of corporators. But, umder former laws instances of sole corporations will be fommd. Thus, "The Catholie Tisliop of Chivaco" is a corporation solo by virtue of a sperial ar.t of Jregiclature."

$73 \mathrm{Am}$. Bible Society $r$. Sherwood, 4 Abb. (. Y.) App. 227; Ang. \& Ames on Corp. 140 . it Ang. \& Ames on Corp. 141; 2 Blk. Com. 109; Overseers l. Sears, 22 Pick. 122; Congrenational Society r. Stark, 34 Vt. 243.

75 1Iongh r. Lind Co., 73 Ill. 23; Smith $r$. Sluelry, 12 Wall. 358; baker r. Nefl, 73 Inl. 69; Kolly $r$. Transportation Co., 3 Orese. 189.

7 (i) Life Ins. Co. $v$. Smith, 117 Mo. 261 . 
when not expressyy given or denied, will be regarded as an incilcnt to the power to acquire and hold land, and to make contracts conecrning same. ${ }^{i 7}$ In general, they convey their land in the same manner as individuals, the laws relating to the transfer. of property being equally applicable to both, ${ }^{\text {is }}$ and the only features that particularly distinguish this class of conveyances from individual deeds are in the execution and acknowledgment.

The orderly parts of the deed follow closely the ordinary deeds in common use, the full name of the corporation appearing in the premises as the grantor, while the body of the deed frequently contains a recital showing the inducement of the instrument and the authority for its issuance. The exceution, in most of the States, is regulated by express statute which provides for a specifie method of signing and sealing and sometimes for acknowledgment as well. The scal is usually indispensable to a perfect execution and its absence is a defect that calls for notice. "A corporation," says Blackstone, "being an invisible body, can not manifest its intentions ly any personal act or discourse; it therefore acts and speaks by its common seal. For, though the particular members may express their prirate consents to : yy act, by worls or signing their names, yet this does not bind the corporation; it is the fixing of the scal, and that only, which mites the several assents of the individuals who compose the community, and makes one joint assent of the whole." is This is now true, however, only in a very limited sense, as corporations do contract by oficers and agents without the use of the scal, but in the conveyance of land the rule is still maintained, and the deed of a corporation without the corporate seal is inadmissible in evidence unless the authority of the officers exceuting it is shown. A mere recital of such authority in the deed is not sufficient for this purpose. ${ }^{8 t}$ The scal mnst be the common seal of the body, either originally or by adoption, and must he affixed by competent authority. ${ }^{81}$

77 Agrienitural Society $r$. Paddock, 80 111. 263.

7s Ang. \& Ames on Corp. § 193.
791 Bl. Com. 475.

so Gashwiler $v$. Willis, 33 Cal. 11. s1 Jackson $v$. Campbell, 5 Wend. 
Whatever light the instrument sheds upon itself by way of recital or otherwise should always be stated, either literally or with little deviation from the original, the literal transcriptions being indicated by quotation marks. Here follows an example of an abstract of a simple deed by a corporation:

Quitclaim deed.

South Park Commissioners, Dated Aug. 1, 1880.

a public corporation exist- Piccorded 1ug. 10, $18 S 0$.

ing under and by virtue of Book 120, page 540 .

the lau's of Illinois,

to

William Thomas.

Doc. $12 S, 2 S S$.

Consideration $\$ 100.00$.

Converys and quitclaims all interest said corporation acquired. or derived uniler, through, or by virtue of a certain ta.r sale deed to said corporation by the County Clerli of Cook County, Illinois, dated June 1, 1879, and recorded in Book 85 of Records, page 640, in and to the following described real estate, situated in said Cook County, to wit: [Here follows the description.] Said interest acquired being a tax claim covering the 1st, 2d, $3 d, 4$ th, 5th, 6th, rth and Sth installments of the South Park: Special Assessment.

"In witness whereof, said corporation hath caused this indenture to be signed by its President and attested by its Secretary, and its official seal to be hereto affixed."

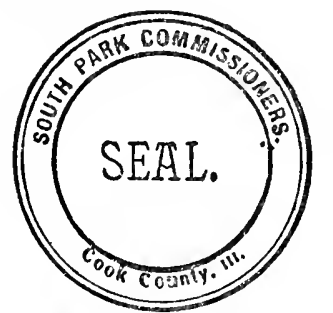

Signed:

$$
\text { "J. R. WALSII, President. }
$$
Attest:

"II. W. IIARMON, Secretary."

Lcknowledyed by said President and Secrelary as the free and voluntary aet of said Soulh Park Commissioners.

Certificate of acknowledgment dated A ug. 1, 1880.

672. The seal is itself prima facie evidence that it was aflixed by proper anthority: Solomon's Lodge $v$. Montmallin, 58 Ga. 5.17; Bank $r$. Kortright, 22 Wend. 348; Reed $v$. Bradley, 17 Ill. 321 ; Flint $v$. Clinton Co., 12 N. II. 434. 


\section{256. Continned - Execntion - Acknowledgment.}

In the preceling example, it will be observed that the execution and accompanying recitals are quoted, and this practice is recommented as being eonducive of greater certainty, and as presenting an answer to every question that can arise. The mode of execution of corporate conveyances is usually prescribed by statute, and ordinarily consists of the signature of the president or corresponding officer who subseribes as such officer, and the aftixing of the corporate seal. In addition to this, even when not required by statnte, it is customary for the secretary or person having the enstody of the seal to attest the same under his hand. Whatever may be the law, a full exemplification of the execution will present all the questions that can ariso under it. The seal, when shown of record, should be copied or describerl, and its absence specifically noted as a scrious defect. It does not seem, howerer, that it is necessary that the record should contain a fac simile of the corporate seal. ${ }^{82}$

The seal of a corporation, when affixed to any deed or contract by proper anthority, ${ }^{\mathrm{s}: 3}$ is not distinguishable in its legal effect from that of an intividual, and renders the instrument a specialty. ${ }^{84}$ It is the highest evidence of assent, and was formerly the only recuisite necessary to bind the corporation. In some of the States, the deed munst be signed with the name as well as sealed with the seal of the corporation. ${ }^{85}$

Where the execution conforms to the law of the State where the land comveyed is situate, no questions will probably arise.

s2 See, Anthony $v$. Bank. 93 Ill. 225 .

83 When the deed is shown to liave been duly execnted by one having authority, proof that the seal affixed is the corporate seal is unnecessary; Phillips $r$. Coffue, 17 Ill. 154.

84 Clark $r$. Manf. Co. of Benton, 15 Wend. 256; Benoist r. Carondelet. 8 Mo. 250. In the alsence of the common seal, or of proofs of facts whence the authority of the officers of a corporation to execute a conveyance may be inferred, such anthority an only be established ly resolution of the directors or trustces entered in the proper book of the corporation: Southern Cal. Colony Assoc. $x$. Bustamente, 52 Cal. 192.

s5 lsham $v$. Bennington Iron Co., 19 Yt. 251. 
Where it does not so conform, recourse wust be had by comsel, in the absence of other evidences of conformity, to the law of the State where the conveyance was executed, or where the "home office" is located. Appended matter, showing authority, conformity, etc., should as a rule, be fully presented. Where several officer's sign, an ackmowlergment by one only in behalf of the corporation is snfficient." But, in any case, the persons appearing must acknowledge as officers and not as individuals; failing in this the acknowledgment will be fatally defective. $^{8 \tau}$

In the absence of statutory provisions to the contrary, where a deed, purporting to be the deed of the corporation, is signed by its ofticers, as such officers, and has the corporate seal affixed, it is admissible in evidence as a deed of the corporation, and is itself presumptive evidence of the regular and duly anthorized execution of same. ${ }^{s s}$ The following is a good example of an abstract of execution, acknowledgment, and appendant matter:

"In witness whereof the said Union Mutual Life Insurance Company hath caused its Corporate seat to be hereunto afficed. and these presents to be subscribed by John E. De Witt, its President, duly authorized by vote of the Finance Committee of the Board of Director's of said Corporation, ${ }^{s 0}$ a certificate of which is hereto attached," etc.

86 Merrill $v$. Montgomery, 25 Mich. 73. "The officer of the corporation intrusted with its conmon seal, and who subscribes his name to the deed as the evidence that he is the person who has affixed the common seal to the same, stands also in the character of a subseribing witness to the exeeution of the deed by the corporation; and may be examined by the officer taking the proof to prove that the seal affixed by him is the common seal of the corporation, whose deed the conveyance or instrument to which it is aftixed purports to be." Willard's Conveyancing, 393; Lovett $r$. Steam Mill Association, 6 Paicre. 60 ; Johnson $v$. Bush, 3 Barb. C'h. 207.

87 Bernhart $v$. Brown, 122 N. C. 587 .

s. Miners' Diteh Co. $v$. Zellerbarh, 37 Cal. 543; Sizwyer r. Cox, 6.3 111. 130 ; Solomon's Letegre v. Montmallin, 58 (xa. 517 .

89 A purchaver of land from a corporation, being a stranger to the (orporation, is not houmd to know that there is a by-law of the com. 


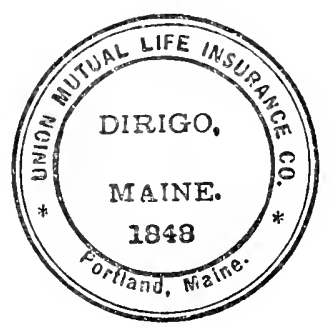

Signed:

" CNION MUTUAL LIFE INSURANCE COMPANY,

"By JOHN E. De WITT,"

President."

Ackinowledged by said President as his free and voluntary act and deed, and as the act and deed of said Company.

Certificate of acknowledgment dated August 10, 1883.

\section{APPENDED IS}

Extract from Article 9 of the By-Laus of the Union Mutual Life Insurance Company:

"The Finance Committee may authorize the foreclosure of mortgages in any manner provided by the laws of the State or country in which the mortgage property is situated and may direct the sale of any real estate held by the Company, or in trust for the Company; and when they shall direct any such sale of property hetd by the Company, the President, and in his absence the Tice President, is authorized to execute the proper instrument of conveyance."

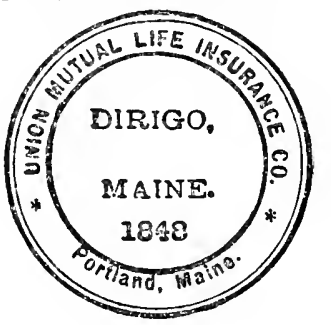

pany requiring an order of the bourd of directors to authorize a sale of land owned by the company. The rule is the same where a purchaser receives a bond from a corporation for a decd for land purchascd, and he will be entitled to
'Attest:

JAMES SIMMONS,

Secretary.

the deed according to the provisions of the bond, notwithstanding there was no order of the board of directors anthorizing the sale: Wait $v$. Smith, 92 Ill. 385.

90 It is presumed, when the common seal of a corporation is affixed 
At a meeting of the Finunce Commitlee of the Board of Directors of the C'nion. Wutual Life Insurance Company, held. on August 10, 1893, the foregoing Deed uas approved, and the President directed to exceute, acknowledge and deliver the same.

Attest:

$$
\text { JAUES STMMONS, }
$$
Secretary of the Finance Committee.

As a general rule the president of a corporation has power to bind it, within the scope of its powers, and as its rules and by-laws are not usually open to public inspection, particularly where the home office is in a distant State, such rules and by-laws ean have no appreciable effect upon persons having no knowledge of their existence; and notwithstanding such oflieer may have no power to make contracts or conveyances under the private rules and regulations of the corporation, yet, as to strangers, withont notice, it will be estopped to leny the power of its officers to perform the specifie acts."1 As a matter of safety, however, where no authority specifically appears from the instrument itself or matter appended thereto, a requisition should be made for further information.

\section{$\S 257$. Acts of Offeers in Excess of charter Powers.} The observations of the foregring section sugest another thought before leaving this branch of om subject. It must always be borne in mind, in construing deets of the character now under consideration, that a corporation is not vested with the capacities of a natural person, but only such as its charter confers, ${ }^{92}$ and that acts done in excess of the power so conferred are void, in the sense that they can have no effect to divest the eorporation of any right in or to property belonging to it. ${ }^{33}$ Every person attempting to contract with a corjuria-

to an instrument together with the signatures of the proper officers, thit such officers did not excred their authority: Kancas $r$. R. R. ro., 77 Mo. 185; Mullanphy Savings Bank $v$. Schott, 135 Ill. 655.
91 Life Ins. Co. $r$. White, 106 Ill. 67.

92 Davis r. R. R. (O., 131 Mass. 259.

9.3 Martin r. R. R. ('o., 8 Fla. 870; Franco-Texan land Co. $v$. HcCormick, 85 Tex. 416 . 
tion must, at his peril, take notice of the legal limits of its capacity and of the powers conferred upon it by its charter. ${ }^{94}$ If the officers of a corporation have no power under the charter to make conveyances, or, having such power, can only conrey for special purposes, a deed showing such excess of power would not be binding on the corporation and all persons claiming through or under such deed would be affected with notice of every fact therein recited. ${ }^{95}$

But, if a corporation has power to make conveyances for a stated purpose, and its officers execute a deed reciting compliance with its charter powers, then, notwithstanding the recital may be false, a person ignorant of its falsity would probably take as an innocent purchaser and be protected. In such a case, as the conveyance would be within the apparent power of the agents of the corporation the person receiving such deed, or one claiming under him, would be entitled to rely upon the express, or even the implied, representation that the facts existed which empowered them to execute the deed. ${ }^{96}$

$\$$ 258. Record of Seal. In all the examples given in this chapter, the seals have been shown as they were appended to the original instruments, but not infrequently the defects of the record will render this impossible. Where the scal has not been recorded, but only alluded to, the suggestion, as made upon the record, should be shown as it appears, thus:

Seal is recorded, "Corporate Seal."

Or should the record merely disclose a scrawl, then the serawl may be shown with accompanying words, if any. In recording an instrument purporting to be cxecuted by a corporation, in the absence of statutory requirements to the contrary, the corporate seal, if attached thereto, may, it seems, be represented

94 Elevator Co. $r$. R. R. Co., 85 Tenn. 703.

95 Jemison $v$. Bank, 122 N. Y. 135: Franco-Texan Land Co. v. McCormick, 85 Tex. 416. In this case the corporation had power to sell its lands for cash. It did not sell for cash but exchanged them for personal property, notes and bonds, which fact was recited in the deed. $H e l d$, that the deed was void upon its face.

96 Franco-Texan Land Co. $v$. McCormick, 85 Tex. 416. 
by a sranl, a fac simile of the seal or device not being absolutely necessing.y

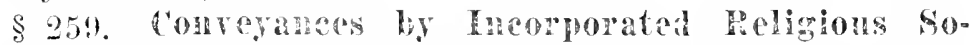

cieties. Tho chass of corporate conveyances to which allusion has been made in the preceling laragraphs are those execnted by public corporations or private corporations organized for business purposes. There remains, howerer, another class of private corporations which ocenpy, so far as regards their legal corporate existence, a peculiar position in commercial circles, and these are incorporated religions and kindred socicties not organized for pecmiary gain. The legal title to the property held by these societies in their corporate capracity is usually vested in trustees, and conveyances by such socicties are effected through the media of these trustres. Nore than ordinary care should be observed in abstracting such conveyances, and a number of tho incidents that do not call for cxplicit mention in other deeds, must, in this class of instruments, be set out in full. The method of converance, if pointed out or preseribed by the statute, is of the essence of the deed, and where the abstract does not disclose a statutory compliance, it should be sent back to the examiner for further investigation.

The sufticiency of a deed of this kind und lie statute of Illinois - and the same requisites are essential in all other States whose statutes have been examined - requires that the individual names of the trustees should be inserted as grantors, with the addition of words descriptive of the character in which they act. The granting clanse should wimess that the said grantors, as trustees of, for, and by the direction of, the society for which they purport to act, for the consideration, do grant, bargain, otc. The attestation clanse should he, that the said first parties, as such trustees, "have hereunto sct thrir" hands and seals," or their official style should be added to their signatures, and the instrunent should be acknowledged by the individuals in their proper character as trusters. ${ }^{2}$

$\$ 260$. Ioirs at Maw. The unsatisfaretory charater of

97 Illinois, ete., R. R. $v$. Johnson, 40 III. 35.
9 S Lombard $r$. Sinai Congregation, 64 III. $47 \%$. 
conveyances purporting to be made by the heirs at law of a deceased person has already been shown. The recital in a deed that the parties making it are the heirs at law of a former owner is no evidence of the fact recited, exeept as against the parties to the deed and their privies. Where the abstract furnishes no information, other than that contained in the deed, to prove the character of the parties, death of the ancestor, etc., a requisition should always be made by counsel for further information, which, unless a probate is had, usually consists of affidarits in support of the facts, made by persons who are supposed to be cognizant of them. ${ }^{99}$

On the other hand, grave questions may arise from eonveyances by third persons made in. derogation of the rights of heirs. Particnlarly will this be the ease where said rights consist only of equities. Matters of this kind may not be disclosed by the abstract, yet will readily appear by inquiries in pais. For this reason comnsel shonld always direct the attention of clients to the actual ocenpation of the land and the rights of the persons in possession, if any. The possession of land by a person at the time of his death is prima facie evidence of ornership at the time, and a subsequent purchaser of the legal title will be conchusively presumed to know that whatever rights such deceased person had in the lant, not disposed of by will, ${ }^{1}$ and of an inheritable character, devolved on his heirs, and his possession being construttive notice of his rights at the time of his death, it becomes the duty of such purchaser to make all necessary inquiries to ascertain the extent of the interest of such heirs. ${ }^{2}$

$\$ 261$. Post Obit Conveyances. The conveyance by an heir apparent of his expectancy in land owned by his living

99 Yahoola, ete., Mining Co. $v$. Irby, 40 Ga. 479. For a precedent of an alfidavit of this kind see chap. 30.

1 See "Descents:" infra.

2 The above rule was applied in a case where a person holding a bond for a deed died, and his widow upon payment of the sum due on the laml, procured the legal title to be made to her, and then conveyed same to a third person, who had notice of the equitable title of the heirs. McVey $v$. McQuality, 97 111. 93. 
ancestor, which would drsecnd to him if he survired his ancestor, and the latter should die intestate owning the same, is a conveyance of a mere naked possibility not coupled with an interest and passes no estate or interest in the land. Such a title can not operate to defeat the grantor's own title afterward acquired hy descent, except liy way of estoppel, and, if the deed was without warranty, such grantor is not precluded from asserting an after-acquired title. ${ }^{3}$ But where a converance of this character is made with covenants of warranty, it will operate to pass the title by estopnel if the land descends to the heir. ${ }^{4}$

\$ 262. Conveyances by Delegated Anthority. Every deed executed by virtue and in pursuance of a power should bear upon its face a recital of authority, but deeds purporting to be the direct act of the grantor though performed by an attorney in fact are sufficiently formal if the execution and authentication affirmatively show the fact. It is therefore recommended that the description of the parties grantor should, in all cases of delegated authority, be taken from the execution and not from the premises, which as a rule, does not, and as a matter of correct form, should not, show the vicarious act. The recital of acknowledgment should also be drawn to show the substitution of persons. Aside from these two points the abstract of a deed executed by an attorney in fact differs in no material respect from one exeented by the grantor in personam. The points mentioned may be shown in this manner:

$\left.\begin{array}{c}\text { John Sinith, by William Strong, } \\ \text { his attorney in fact, } \\ \text { to }\end{array}\right\} \begin{aligned} & \text { Wamanty Deed. } \\ & \text { Dated, etc. }\end{aligned}$

3 Hart $v$. Gregrs. 32 Ohio St. 502; Boynton v. Ilubbare, 7 Mass. 112. In this case a covenont was made by an heir to conrey, on the death of his ancestor, if he should survive him, a certain undivided part of what should come to him by deserent, and same was hold to be void at law as well as in equity.

+ liomenthal v. Maylingli, 33 Ohio St. 1.58; Bohon r. Bohon, $78 \mathrm{Ky}$. 408. 
Achoutedged I une 1. 1S52, by William Strong, as the act and deed of said dohn smith.

If desired, however, the alsstract of the decd may be made in the uswal mamer, the caption reciting the name of the grantor as found in the premises. In such case the execution naty be shown as follows:

Said grantor signs and aclinoulcdges by William Strong, his attorney in fact.

Erroneous or imperfect execution or acknowledgment must be indieated in the manner already pointed out. The instrument is properly and legally excented if it hears the name (signature) and seal of the grantor, showing the procurement of the attorney and purporting to be the act of the principal; but in making the acknowledgment, the attorney, being the person who actually executes the instrument, must acknowledge it; yet this he does as and for his principal.

As to what constitutes a proper signing there is some conflict of authority, the earlier cases holding it to be immaterial whether the attorney sign " $A$, attomey for $B$, or " $B$, by his attorney $\mathrm{A}, " 5$ on the theory that no particular form of words is necessary to bind the principal, provided the agency of the attorney appears from the deed itself. ${ }^{6}$ It is now well established, however, that a conveyance made by an attorney must be in the name of the principal, and purport to be execnted by him, ${ }^{\top}$ and where the agent assumes either to grant or to execute, as where lo signs and seals, although describing his office, the deed will be roid as to the principal. ${ }^{8}$ It has also

5 Jomes $r$. Carter, 4 IIen. \& $\mathrm{I}$. 184; Montgomery r. Dorion, $7 \mathrm{~N}$. II. 475; Wilke; r. Back, 2 East, 142 .

6. Magill $r$. Hinstale, 6 Conn. 464; Worrall v. Ximm, l Seld. 229.

T Pensonnean $r$. Blonkley. 14 Ill. 15; Elwell 1 . Shaw, 16 Mrst. 42; Thurmin $r$. Cameron, 24 Weud. (N. Y.) on: Stintheli $v$. Little, 1 Me. 231; Hale $v$. Woods, $10 \mathrm{~N}$.
II. 470. Less strictness is required where the instrument is not under seal, it hoing sufhcient, in such case, if the intent to bind the principal appears in any part of the instrument: Townsend $r$. IInbbard, 4 Hill (N. Y.). 351.

s Fowler $r$. Shearer, 7 Mass. 14; State r. Jenninga, $10 \mathrm{Ark}$ 423; McDomald r. Bear River Co., 13 Cal. 235 ; and this, even though in the 
been held that signing the principal's name, but making no, mention of the attorney, is not at ralid execution. ${ }^{9}$ It would seem, therefore, that in all eonverances by attorneys in fact, both the name of the principal and of the attorney must substantially appear in the execution of the deed, showing not only that the grant and seal are those of the principal, but by whon these acts are done; ${ }^{10}$ and where there are two grantors, and one of them acts as the attomey in fact of the other, he must subseribe his name twiee, once as attorney in fact for the other, and once for himself. One signature and a second seal is not equal to a second sulsscription. ${ }^{11}$

It is not necessary, however, that any particular form of words should be used to render the instrmuent ralid and binding upon the principal, provided it shows upon its face that it was intended to be exeented as the deed of the prineipal, and that the seal affixed is his seal and not that of the attorney; and it has been held, that where a deed is executed for several parties, it is not neessary to affix a separate and distinet seal for each signature if it appears that the seal affixed was intended to be adopted as the seal of each of the parties. ${ }^{22}$

$\S 263$. Powers of Attorney. Inmediately following the abstract of every deed purporting to have been made by the procurement of an attorney in fact, should appear the warrant or power which anthorized the atet; for an unathorized deed would be void for all purposes, and the proof of this power ean only be shown by an instrument exeented with all the formalities necessary to a valid deed of conveyance. ${ }^{3}$ The instrument usually recites the scope of the attorney's powers, yet

body of the instrument it is stated that it is the agreement of the principal by his attorney, and that the principal covenants, ete., while in the textimonium clause it is allegred that 1 . 1). (the agent), as the attorney of the principal, has set his hand and seal: Townend $r$. Corning, 2:3 Wincl. 4:5.

9 Wood $v$. Goodridge, 6 Cush, 117.
10 See 3 Wash. Real Prop., *573, and cases eited.

11 Meagher $v$. Thompson, 49 Cal. 189.

12 Townsend $r$. Inubhard, $4 \mathrm{Hill}$ (N. Y.), 351 .

1: Fire Ins. (o) $v$. Doll, 35 Md. 89: Wateon r. Sherman. 84 H1. 263; (larl: $r$. Gaham, (6 What. (I. S.) 577 ; Videall $e$. Gritlin, 21 Cal. 389. 
even where it is defieient in some partieular, others, which are necessary to the proper exercise of the powers expressly enumerated, will be implied as incidental thereto; as, where a power is expressly given to sell or lease the property of the principal, a power to contract to sell, as well as to convey and transfer, will be implied. ${ }^{14}$ The nsual rule, however, is to construe instruments of this lind strictly; hence, a power to "sell and convey," will not be extended by interpretation to include a power to mortgage, or otherwise to dispose of the property than by a sale and conveyance. ${ }^{15}$

The right of revocation is, as a rulc, always reserved, but this is a right incident to the power given, and a principal may always revoke the authority of his agent at his mere pleasure without a reservation of such express right, or even though the power may be expressly declared to be irrevocable. ${ }^{16}$ The only exceptions to this rule are when the authority or power is coupled with an interest or where it is given for a valuable consideration, or where it is part of a security, in all of which cases it is irrevocable, whether so expressed or not. ${ }^{17}$

As before remarked, powers of attorney must be strictly construed, yet the rule does not require a construction that will defeat the manifest intention of the parties, and where such intention fairly appear's from the language used, it must prevail, ${ }^{18}$ but the authority can not be extended beyond that which is clearly given in terms, or which is necessary and proper for carrying the anthority given into full execution. ${ }^{19}$ In this respect there is a marked difference as compared with powers

14 Hemstreet v. Burdick, 90 Ill. 444.

15 Minnesota, ete., Co. v. MeCrossen, 110 Wis. 316 ; Colesburg $v$. Dart, 61 Ga. 620; Hawxhurst $v$. Rathgeb, 119 Cal. 531.

16 Walker $v$. Denison, $\mathrm{S} 6$ Ill. 142; Brown v. Pforr, 38 Cal. 550.

17 Walker $r$. Denison, 86 Ill. 142; Gilhert v. Holmes, 64 Ill. 54S; Brown $v$. Pforr, 38 Cal. 550.
18 Hemstreet $v$. Burdick, 90 Ill. 444.

19 Pool $\imath$. Potter, 63 Ill. 533. Hoyt $r$. Jaques, 129 Mass. 256 ; Gilbert $r$. How, 45 Minn. 121. Thus, a power of attorney jointly exeented by husband and wife for the sale of all their property, and in which the words, "we" "ours," ete., are exclusively used, has been held insufficient to authorize a sale of 
of appointment created by deeds and wills, and powers introduced in eomnection with nses.

The formal requisites to be closervel, apart from such as are incident to all sealed instruments, are the constituent words, which are "make, constitute and appoint;" the powers delegated; the reservation of the right of revocation, and the power" of substitution, if any is given. ${ }^{29}$ The recital of the power always calls for minuteness in transcription, and when coupled with an interest or created upon a valualsle consideration, it should bo rendered with literal fidelity. The arrangement of the synopsis is much the same as other grants. An example is appended:

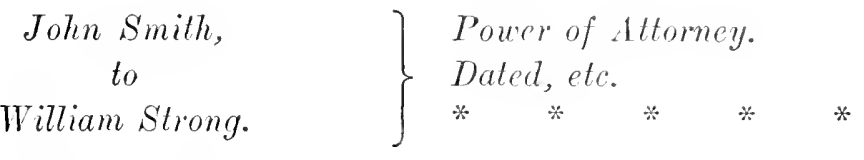

First party makes, constitutes and appoints second party his true and lawful attorney, for him and in his name, place and stead, to [here follows the special purpose of the power, literally rendered].

Full power of substitution and revocation.

Acknouledged, etc.

An unexecuted power, if still sulsisting, should, as a rule, be set out in full, though many examiners show such instruments only by way of note. This latter method may lie resorted to with propriety only in a fow instances, and unless there has been an implied revocation, as where the constituent

the individual property of either, or at least in the absence of proof of the non-existence of joint proprrty: Dodge $v$. Hopkins, 14 Wis. 6.30 .

20) Where the authority of the attorney is to execute decds of conveyance the power, as a rule, cannot be delegated. Where it relates to other mattors it is offer pore mitted to be exereisod ly purams whom the attorney may alphint or smbstitute for himself and to sureh frersons the attormey mer allowet the same or more limbilon powers as are given to him liy the primeinal. If the laters antain no penors of substitution this camot be done. 
has afterwarl male conveyance himself, or where there has been an expiration by limitation, or some other circumstance of like charater, snch a course is not reemmended. The following will serve to illustrate the method:

Note.-In Bool: 20, page 168, we find recorded a power of attomey from Thomas J. Walsh to Austin Bierbower, authorizing him to scll and comvey the North East quarter of Section 13, aforesaid (and other property), but as no action (appearing of record) has been had under said power (as regards the premises in question) we do not show it herein.

$\S 26 !$. Pevocations. The recall of a power or authority conferred, or the vacating of an instrument previonsly made, is called a revocation. ${ }^{21}$ A power of attorney may be reroked in a rariety of ways; as by the death of the principal, which operates as a revocation of erery power memipl it wh an interest; ${ }^{22}$ the marriage of the principal, the power having been given while he was a single man; ${ }^{23}$ an adjudication in bankruptey; or a conveyance by the principal of the subject-matter of the power before the agrint has had an opportmity to dispose of it." ${ }^{-4}$ But the giving of a second power to another agent, without specially revoling the first, would not act as a revocation, and if either power is executed, both will be exhansted. ${ }^{25}$ in the foregoing instances the revocation occurs by operation of law. The prineipal may revoke by a special instrument of reveation, which, when recorded with the power, will operate as mintructive notice of such fact. An mexercised power, followed by revocation, sheds no light on the title, and may, with propriety, be disregarded, but if it should be deemed desirable to show same, a brief mention among the appendices would seem to be all that is required. Should the

212 Bon. Law Dict, 477.

22 Blayton v. Nlerrett, 52 Miss. 353; Davis $r$. Savings Bank, $46 \mathrm{Vt}$. 728.

23 Henderson $v$. Ford, 46 Tex. 627 .

24 Walker 2 . Denison, 86 Ill. 142. 25 Cushman $v$. Glover, 11 ill. 600. 
examiner desire to slow the transaction in regular course it should be treated much in the same mamner as a satistied mortgage, that is, the puwer shonld be exhibited in brief terms in its proper place and the revocation shonde immeliately follow. This would be a suficient reference to the revocation:

$\left.\begin{array}{l}\text { John Smith } \\ \text { to } \\ \text { William Strong. }\end{array}\right\} \begin{aligned} & \text { Perocation. } \\ & \text { Duted. etc. } \\ & *\end{aligned}$ * * * * * *

Sets forth the excention of the pouer of attomey shown as No. 10, ante, and combermands and revolies same, and all power and anthority thereby given to said William Strong.

Achnowledged, etc.

It is important that sufficient evidence should always bo provided as to the contimnance of a power at the time of its exercise. An unrevoked power duly recoredel fumblied sullicient evidences as far as it goes, lont muless the abstract also discloses the fact that the principal was living at such time, or had not krom subjected to the disability of bankmptey or other distualifying canse, prudence wonld snepest that an inquiry in pais he maric to ascertain such facts. If the examiner is personally rognizant of the fact that a domor wi a power of attomey was alive at the time of the execution of the power he may, if so disposer, testify to this fact. This mav be accomplished by a wote as follows:

Note.- To my kirowledge, Johu. Smith, the granior named in the foregoing deed, was alice on lugust 1, 10tr.

This conse is purely optional with the examiner, but it will often be nit griat sprice to commel.

\$295. Conveyanees in Trast. Trust deeds wele finmerly of very common occurrence, hint are now rasely mulesed, save in a fow states where mortgages are mado in that form. They wepe nisd to convey the beneficial interest to jersens who were incapable of holding the legal title, or in whom it was 
not desirable to have the legal title rest. With the gradual disuse of nses and trusts in some States, and their smmary abolition in others, conveyances of this claracter have beeome infrequent, while no estate or interest, legal or equitable, will rest in the trustee muler the statutes of some of the States, but the beneficiary takes the entire legal estate of the same quality and duration, and subject to the same conditions as his benefieial interest. ${ }^{26}$

The character of the instrument, as well as its effect, may be readily determined by inspection; if it imposes on the trustee active duties with respect to the trint estate, such as to sell and convert into money, or to leace the same and collect the rents, pay taxes, etce, and to pay the ret proceeds to the beneficiary, it creates an active trust which the statute does not execute, ${ }^{27}$ but if there is simply a eonverance to the trustec for the use of, or uron a trust for, another, and nothing more is said, the statute immediately transfers the legal ostate to the nse, and no trust is created, although express words of trust are used.

26 Witham $v$. Brooner, 63 Ill. $3+4$; Roth $r$. Michalis, 125 Id. 325. This applies more particularly to "dry" or passive trusts. Express trusts are still generally permitted to be created for the following purposes:

1. To all lands for the benefit of creditors.

2. To sell, mortgage, or lease lands for the benefit of legatees, or for the purpose of satisfying any charge thereon.

3. To receive the rents and profits of lands and apply them to the use of any person during the life of such person, or for any shorter term, subject to the rules prescribed by the statute fixing the quantity and duration of estates.

4. To receive the rents and profits of lands and to aceumulate the same for the benefit of any married woman, or for any of the purposes and within the limits of the statute preseribing the nature and quality of the estates.

5. For the beneficial interests of any person or persons, when such trust is fully expressed and rearly defined upon the face of the instrument creating it. subject to the limitations, as to the time and the exceptions thereto, relating to literary and charitable corporations, preseribed by the statute.

Trust resulting from implication of law are always reeognized, but the doctrine has been very much cireumscribed, as described in the preceding chapter.

$2 \pi$ Kirkland $\varepsilon$. Cox, 94 Ill. 400; Kellogg $v$. Hale, 108 Ill. 164. 
When converanes in trust are allowed, the nature, quality and extent of the trust should be very explicitly stated; while in States where only a few enmmerated express trusts are recognized, avery part of the instrument necessary to bring it within one of the classes named in the statute must be shown. The trust is ordinarily sufficiontly dischoed by the recitals of the habentum, but where there is a power of appointment, and certain reservations for varions purposes, a very full synopsis of every part of the deed will be absolutely necessary for a proper understanding of it. In the latter case there should be shown the special matter of indncenent as recited in the premises; the grant; the halsendun ; the reservation, explicitly rendered; the enumeration of the trusts and powers, and the power of appointment, or successor in trust, if named.

No particular form of words is requisite to create a trust, the intent only being regarded by courts of equity, ${ }^{2 s}$ yet the habendum usually makes a formal reeital after the preliminary words " to have and to hold," etc., by continning, "in trust, nevertheless," or sone similar expression. These words, however, are not essential and trusts must, in all cases, be construed according to the intention of the parties as gathered from the entire instrmment." ${ }^{29}$ Thus, when a gift is expressed to be for the "nse and benefit" of another, or " to the end " that the donee sliall apply it to certain purposes, this will be sufficient to raise a trust in such donce. ${ }^{30}$

Where a trust is intended by a converance, but fails entirely, so that the grantee takes no estate in the land under the conveyance, it may nevertheless create in him a valid power in trust, ${ }^{31}$ the legal title remaining in the grantor. ${ }^{32}$ Where the deed creates a valid trust, the entire estate vests in the trustee, sulject only to the execution of the trust, excent as otherwise

28 Fisher $r$. Firld, I0 Jolns. 494. 29 Kier v. Venor, 6i; Pa. St. 326;

Guion $r$. I'ickett, 42 Misis. 77.

30. Randolph $x$. Land Co., 104 Ala. 355.
31 Fellows r. Hecrmans, 4 Lans. (N. Y.) 280.

82 This is now the general statutory doctrine. 
provided; and where the deed gives a power of sale to the trustee at the request and for the benefit of the beneficiary under the deed, no power of revocation heing reserved, no estate in the premises is left in the grantor which is capable of being transferred. ${ }^{33}$ Where the legal title is rested in a trustee, nothing short of reconreyance can place the same hack in the grantor or his heirs, but under certain ciremstanees such reconreyance will be presumed without direet proof of the fact. ${ }^{34}$ Trust estates are subject to the same rules as legal estates in every case, dower exeepted. ${ }^{35}$

$\$ 266$. Revocation of Trust. It is competent, in some cases, for the settler of a trust to reserve a right to revoke the same, and such reservation is not inconsistent with a ralid trust. The reserved power to revole does not operate to destroy the trust, which remains absolnte and efrective until the right is exercised, and if it is not exercised during the lifetime of the grantor the trust remains as though there had never been a provision for revocation. ${ }^{36}$. Where an instrument of this character is found, and the trust is mexeented, the reservation should be copied in full.

\$ 267. Declaration of Trust. To establish an express trust, the evidence must all be in writing, and suficient to show that there is a trust, and what it is, ${ }^{3}$ ' but where land has been conveyed by a deed absolute in form, if desiened simply for a holding in trust, the grantee may make a ralid admission of the trust in a separate instrument. ${ }^{3 s}$ Such instruments are known as "declarations of truet," and, nules recuired by statute, need not be by deed, but any writing sulneribed by the

33 Marvin $r$. Smith, 46 N. Y. 571 ; Leonard r. Dianond, 31 Md. 536. 34 Kirkland $x$. Cox, 94 Ill. 400 ; reversing 81 Ill. $11: 80$ 1ll. $6 \overline{6}$.

35 Danfortls $v$. Lowry, 3 Haywood (X. C.) 68 .

36 Lines $r$. Lines, 112 Pa. St. 149 ; Van Cott $r$. Prentice, 104 N. Y. 45; Nichols $r$. Emery, 109 Cal, 32:3.

a 7 Cook $t$. Barr, 14 N. Y. 150; Steere $r$. Stcere, 5 Johns. Ch. 355;
1 Green. Cruise, 335. But this does not apply to reanlting trist, which may be estabithed by parol: Faris $r$ Dum, I Bush (Ky.), 276; MeGinity r. Mckinity, 63 Pa. St. 38.

38 Elliott $r$. Armstrong, 2 Blackf. 19S: Melanuie r. Partlow, 5311 . 340 ; Cook $r$. Barr. 44 N. Y. 156; Fast $r$. Alcherson, 98 1ll. 496; or by the pleadings in a ehancery suit: Ibil. 
trustee will be suficient if it contain the requisite evidence. ${ }^{39}$ Although it is not essential that the writing by which the trust is manifested and proren shomld $h_{0}$ in ans particular form, it is customary for the trustee to declare same in a formal document, reciting the matter of inducement, declaring the nature of the trust estate, and frequently corenanting against his own acts, and for conveyance to the beneficiary. Whatever may be the form of the instrument, the nature and quality of the trust declared, and the terms and conditions upon which it is hold, should sufficiently appear to show the full intention of lie parties as manifested by the instrument. An illustration is herewith given:

$\left.\begin{array}{c}\text { Andrew Baxter, } \\ \text { Trustee, } \\ \text { to } \\ \text { om it may concern: }\end{array}\right\}$

Declaration of Trust. Dated, etc. $\because * * *$ Recites, that Charles Denton. by deed bearing even date hereuith, in consideration of $\$ 1,500.00$, conveyed to said first party in fee simple the following deseribed lands, to wil: [describing anme] as by said deed will more fully appear. And that said fint party has " this day" executed and delivered to said Charles Denton a mortgage upon said premises, as collateral security for the myment of his bond for the payment. of $\$ 1.000 .00$ [stating the terms] being part purchase money expressed in said deed.

Therefore, said first party, makes linown. and declares, that said premises so conceyed to him, he now holds. and will continue to hold, in trust caly. for the use and benefit of cieorge

39 Cook r. Barr. 44 N. Y. 156. By the Eng!ish statute of 29 Charles II, Chap. 3, $\S 7$, it was enacted "that all declarations or creations of trust or confidence of iny lands, temenents or hereditaments, shall be manifesterl or prowen by some writing signed by the party who is by law cnablerl to declare such trust, or by his list will in writing. or else they shan be utterly void and of none effect." This statute provider, not for the creation of trumts, lut for proving them, and is the baris of Ameriman statutes on the same subject. Though a trust of lands can not be entablinhed by parol. yet if the trustee execute the trust, he is bound by the act. 
Zeigler, son and heir at law of IIenry Zeigler, deceased, and that he has no beneficial interest thercin, except what may arise by legal or equitable implication from the circumstances attending the cxecution of said mortgage.

Said first party further admits that the residue of the consideration money expressed in said deed to him, to wit: the sim of $\$ 500.00$, was paid by Thilliam Zeigler, for the benefit of said George Zeigler.

Ind said first party covcnants to and with said William Zeigler and George Zeigler, that he will convey said premises by "good and sufficient" deed, to said George Zeigler, or his assigns, as he or they may direct, whenever and as soon as said mortgage shall have been paid off and discharged, or otherwise fully secured to said first party, and that free, clear and discharged from all and every incumbrance therein by said first party.

Tirst party further covenants against his oun acts.

$\$ 268$. Removal or Substitution of Trustees. Wherc a trustee is deat, the trust heing still alive and unexecuted, a comrt of equity will cary it out if necessary, through its own oflecrs and agents, ${ }^{40}$ and may appoint a new trustee, ${ }^{41}$ and it scens that in some States, even where the trust deed contains a power of appointment, in the event of the death of the trustee withont executing the trust, the cestui que trust can not amoint a new trustee, but the exercise of this right devolves exchusively on a court of chancery. ${ }^{42}$ A trustee may always be renoved in the discretion of the court upon proper cause shown. ${ }^{43}$

40 Batesville Institute $x$. Fauffman, 18 Wall. 120. It is a rule in equity, that a trust shall never fail for want of a trustee: Buchan $v$. Hart, 31 Tex. 647.

41 Curtis r. Smith, 60 Barb. 9; Hunter v. Vaughan, 24 Gratt. (Va.) 400.

42 Gnion $r$. Pickett, 42 Miss. 77. As a general rule, a court of chan- cery has jurisdiction to control the exercise of the power of appointment when vested in an individual so far, at least, as to prevent an abuse of discretion: Bailey $v$. Bailey, 2 Del. Ch. 95.

43 Att'y-Gen. v. Garrison, 101 Mass. 223; Ketchum v. R. R. Co., 2 Woods, 532; Scott $v$. Rand, 118 Mass. 215. 


\section{\$ 269. Resignation - Refusal to Act - Successor. A} trustee can not divest himsclf of the obligation to perform the duties of his trust without an order of court, or the consent of all the cestuis que trust, ${ }^{44}$ and where he refuses to act, equity will compel him to do so, or appoint a suitable person in his place. ${ }^{45}$ It is customary, howerer, in some classes of trust deeds, to appoint a successor in trust, in the event that the trustee becomes disabled or refuses to act, and where a deed contains an appointment of this kind it is alwavs well to show it. If the trust is, in fact, executed by the successor, the original appointment must be shown. This will often occur in cases of trust deeds in the nature of mortgages.

44 Thatcher $v$. Candee, 4 Abb. 45 Sargent $r$. Howe, 21 Ill. I48; App. Dec. (N. Y.) 387; Cruger $r$. Wilson $r$. Spring, 64 Ill. 14. Halliday, 11 Paige (N. Y.) 314. 


\section{CHAPTER XVII.}

OFFICIAI, CONVEYANCES.

\$ 270. Defined and distinguished.

271. Offieial deeds generally.

272. Recitals.

273. Covenants.

274. Sherifl's deed - On exeeution.

275. Continued - Acknowledg. ment.

276. Continued - Operation, effect.

27\%. Continuer - Imperfect description.

2-8. Statutory sheriff's deeds.

279. Sheriff's ded - Under decree.

2So. Masters', commissioner', and referees' deeds.

281. Trustees.
$\S$ 28:. Transfers of the legal estate by trustees.

283. Power of sale and trust of sale distinguished.

284. Trustees' deeds.

285. Mortgrgees' deeds.

286. Executor's and administra. tors.

287. Executors' deeds.

288. Administrators' deeds.

299. Administrator with will annexed.

290. Guardians' deeds.

291. Trustees ean not become purchisers.

292. Continued - Qualifications of the rule.

$\$ 250$. Defined and Distinguished. Official deeds comprise all those forms of converance wherein the maker acts by virtue of an office and not in his individual or personal capacity. They cover a wide portion of the field of conveyancing and assume a variety of shapes, but may be reduced to two general classes, viz. those male in a fiduciary capacity, as the deeds of trustees, executors, etc.; and those made in a ministerial cliaracter, as the deeds of sheriffs, commissioners, masters, ete. ${ }^{1}$ The rules for construing deeds are much the same, whether the deed be made by a party in his own right, or by a fiduciary or officer of the court. ${ }^{2}$

1 For a further discussion of the subjects of this chapter, the reader is referred to the chapters, "Exe"ution and Jullicial Siles," "Chan- cery Proceedings," “ Judgments and Decrees" and "Probate Proreedings and Descents."

2 White $r$. Luning, 93 U. S. 515. 


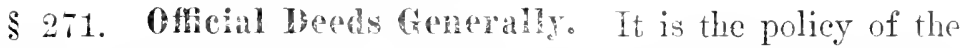
law to invest the sheriff, mater in chancery, administrator, or other officer making sales of real estate in a purely ministerial capacity, with only a nore naked power to sell such title as the debtor, deceased person, ete, lad, without warranty, or any tems, except those imposed by law. Hence purchasers at such sales assume the risk of the title, as well as the validity of the proceedings mider which the sale is male. ${ }^{3}$ The power to sell lands, however conferred, must, as a rule, be strictly pursued, otherwise the sale will be void and no title will pass," and a deed which shows on its face an excess of authority in the officer executing it, will not be sufficient to sustain the title of one claiming under it. ${ }^{5}$ Much detail will frequently be required in the abstract of an instrument of this character, which should show sulstantially all the material parts of the deed, including the recitals necessary to a full compliance with the law, even though the instrument may scem at times to be unreasonably long. I judicious condensation, where the full spirit of the original is retained, may be observed to good purpose, and the labor of examiner and counsel be thereby perceptibly lightened, but, in a matter of this kind, it is better to err by inserting too monch than too little.

$\$ 272$. Recitals. It is customary, and in many cases necessary, to show all the material recitals in oflicial deeds, notwithstanding that such recitals are regarded only as matters of inducement; "but where the form of a deed is prescribed by statute they become substance ${ }^{\top}$ and nunst always be shown

3 Bishop v. $0^{\circ}$ Commor, 69 IH. 431. 4 King $v$. Whiton, 15 Wiz. 68t; White $v$. Moses, 21 ('al. 44.

5 G. B. \& M. C. Co. r. Groat, 24 Wis. 210; French $r$. Edwards, 13 Wall. 50t. The deed in this ease was by a sheriti unler a julement. for laxes. Thes deed recited the sale of the property to the lighest bicher, when lue was andhorized by tive statute only to sell tles smollent quantity of the property which any one would take and pay the judgment and costs, and was held roid on its firce.

6 Leland $r$. Wilion, 34 Tex. 79;

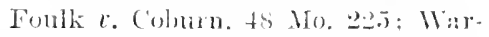
ner $r$. Sharp, sis hos sig: Jones $r$.

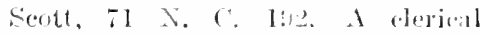
error in the repitils is not to be remorkel in equity: stow $r$ : itcele, 45117.328.

7 Alkins $\checkmark$ Kimman, 20 Wend. $24 ! \%$ 
or indicated in some manner. The main reason why such recitals should be shown, arises from the fact that they are usually regarded as evidence against the grantee and those claiming uuder him, ${ }^{8}$ and as to such parties are conclusive. ${ }^{9}$ The recitals are further regarded as presumptive evidence of the facts stated, ${ }^{10}$ and will prevail until the contrary is shown. These remarks, however, have referenee more to ministerial officers than to fidneiaries. The recitals in the deeds of the latter are material to show a due execution of the powers given.

$\$ 273$. Covenants. There are no implied covenants in official deeds, ${ }^{11}$ but where express covenants are inserted they have been held to bind the officer personally. ${ }^{12}$ Sometimes the deed will contain what is known as the "trustee covenant," which is to the effect that the vendor has done no act to encumber the estate. If express covenants of any kind are made they should be shown in the abstract.

\section{§ 274. Sherifi's Deed-0n Execution. A sheriff's} deed made in pursuanee of a sale on execution must be to the person to whom the certificate of purchase was issued or to his assignee, and if the deed is made to another, though it recites that he is the assignee of the certificate, it is a nullity if, in faet, the certificate was not assigned. ${ }^{13}$ It would seem, therefore, that in case of an assignment the certificate thereof should affirmatively appear of record or its absence be noted as a substantial defeet. ${ }^{14}$

To establish a title to land under a sheriff's sale on execution all that is necessary to be shown as a general rule, is a

8 French $v$. Edwards, 13 Wall. 506 ; Fisk $v$. Frores, 43 Tex. 340; Lamar $r$. Turner, 48 Ga. 329.

9 Durette $r$. Briggs, 47 Mo. 356 ; Pringle $v$. Dunn, 37 Wis. 449 ; Robertson $r$. Guerin, 50 Tex. $31 \%$.

10 Chase $v$. Whiting, 30 Wis. 544.

11 Webster $r$. Conley, 49 11l. 13.

12 Prouty $v$. Mather, 49 Vt. 415; Sumner $v$. Williams, S Mass. 162; Mitchell $v$. Haven, 4 Conn. 455; Aven $x$. Beckom, 11 Ga. 1; Crad- dock $i$. Stewart's adm'r, 6 Ala. 77; Magee $v$. Mellon, 23 Miss. 586.

13 Carpenter $v$. Sherfy, $71 \mathrm{Ill}$. 427 ; compare Bowman v. Davis, 39 Iowa, 398.

14 Where there has been an assignment of the certificate of sale the recital in the sheriff's deed of such certificate and assignment is evidence of their existence, and after the execution of the deed such certificate and assignments thereof cease to be 
valid judgment, or, as has been held, a julgment by a court of competent jurisdiction, no matter if it le erroneous on its face; ${ }^{15}$ execution duly issued; ${ }^{16}$ and a sheriff's deed. ${ }^{17}$ But in all cases the judement is the forndation of the title, ${ }^{1 \mathrm{~s}}$ and proof of such judgment is indispensable to its ralidity. ${ }^{19}$ As the sheriff is only the executor of a naked power it is necessary that his deed should show substantial anpliance with the terms creating the power as well as its proper execution, yet the recitals of a sherift's deed, as a general rule, are to be regarded only as inducement, ${ }^{20}$ and where the deed substantially complies with the statutory requirements, it is not invalidated by ambiguous recitals or omissions which do not mislead. ${ }^{21}$

It is said that the statute requiring recitals in a sheriff's deed was not intended to make deeds void which do not contain them, but was only intended to make the recitals evidence of the facts recited; and when such recitals are full, they dispense with the necessity of introducing the judgment and execution in evidence. So far as such a statute requires recitals beyond what are necessary to show the authority of the officer to sell, it is merely directory, ${ }^{22}$ and where the deed discloses sufficient to show the authority to sell, even though the particular judgment and execution be not recited, so long as it appears to be by virtue of a judgment and execution, the sale and conveyance will be valid, if, at the time of such sale, the sheriff had in his hands a ralid execution. ${ }^{23}$ Defects of

essential muniments of title (Gardner $v$. Eberhart, s: Ill. 316), yet, as a precautionary measure, it is always well to display these facts in the abstract.

15 Mayo v. Foley, 40 Cal. 2s1; and see Den $r$. Taylor, 16 N. J. L. 532.

16 Fischer v. Eslaman, 68 Hll. 78; Den $v$. Despreaux, 12 N. J. L. 182. 17 Riddle $v$. Bu*h, 27 Tex. 675; Hughes $v$. Watt, 26 Ark. 228; Splahn v. Gillespie, 48 Ind. 397 ; Lenox $r$. Clark, 52 Mo. 115. 18 Atkins $v$. Himman, 2 Gilm.
(III.) 437; Leland $v$. Wilson, 34 Tex. 79; Todd $v$. Philhour, $24 \mathrm{~N}$. J. L. 796 .

19 Carbine $x$. Morris, 92 Ill. 555. 20 Leland $v$. Wilson, 34 Tex. 79. 21 Allen $v$. Sales, 56 Mo. 28; Jones $r$. Scott, 71 N. C. 192; Loomis $r$. Riley, 24 Ill. 307; K'eith v. Keith, 104 11l. 397.

22 Clark $v$. Sawyer, 48 Cal. 133; Jordan $r$. Bradshaw, 17 Ark. 106; IJolman v. Gill, 107 1Il. 467. 23 Jones 1 . Seott, 71 N. C. 192; Clark $v$. Sawyer, 48 Cal. 133; Perkins $v$. Dibble, 10 Ohio 443. 
form are leniently regarded, and the instances are very rare, observes hil. Fropman, "in which a deed. issued in pursuance of an execution or chancery sale, is void for errors, defects, or mistakes in form." 24

Whrre a deed alone is rolied upon it must show upon its face the ofticer's authority as woll as all other essential requiremeints of a valid sale, ${ }^{25}$ but it may always be aided by the reimm on the execution, ${ }^{2 ;}$ and where the judgment and exe cuíion are hoth shown omissions in the deed are generally immaterial, provided the deficisncy is supplied by the writ and return. 27

\$275. Continued-Achnowleagment. Lnlike voluntary conreyances betwoen indiriluals, it is essential to the validity of a sherity's deet, for land sold by him under an exemution, that it shonld have been lewally acknowledged. It is trme that a sheriff', deed gives the reudor an inceptive interest in the land, but he has no right to enter, and no claim upon the properte, as againat the former owner, until after the deed is acknowledged. The property is conveyed against the will of the jutgment debtor; the converance is not his act, but the act of the law; and the law, when acknowledgment is requisite, must be strict? complied with. ${ }^{28}$ Where the acknowledgment is defective the deed is not aided by recork. ${ }^{29}$ Proof of offeial character is rarely necesary, however, for the law rerognizes such oficers as sheriff's and deputy sheriffs, and instruments executed by them in the course of their official duties are usually sufficient in themsclves to prove that

24 Freeman, Toid Jul. Sales, § 45. The deed, howerer, must be what it purports to be, hence a deed lacking a seal conveys no title: Iinsdale $r$. Thornton, 74 K. C. 167; Kruse $r$. Wilson, 79 111. 233.

25 Hill $r$. Reynolds, 93 Me. 25.

26) Melsh $t$. Joy, 13 Pick. (Miass.) 477: Stinson $r$. Ross, 51 Me. 55t.

27 Hayward $v$. Cain, 110 Mass. 2s Rșan r. Carr, 49 Mo. 483: Alams $r$. Buchanan, 49) lio. 64. Dint see contra, Stephenson $v$. Thom:on, 13 Ill. 186. where it is held that the deed may be proved ly other evidence, and though unacknowledged it is still valid.

29 Samuels $v$. Shelton, 48 Mo. 444 .

273. 
they were the officers, in fact and in law, which by their acts they pofess to brest

s. deed is prima facie cridence that the grantee holds all the title and interest in the land that was held by the judgment debtor at the time of the rendition of the judgment, and operates back, by relation, to the date of such rendition so as to extinguish all rights and equities in and to the premises derived from the judgment debtor in the meantime. ${ }^{31}$ And not only the entire interest of the judgment debtor passes by the deed, but also such covenants of title as run with the land. ${ }^{32}$ If made to a bona fide purchaser, and regular in itself, it is effectual as a conveyance, and can not be impeached in any collateral proceeding for mere irregularity, in any of the proceedings, judgment, execution or return. ${ }^{33}$

It will operate against the judgment debtor by estoppel, and he will be precluded from setting up an outstanding title to avoid the sale by the sheriff, or to deny the title thereby acquired by the purchaser. ${ }^{34}$ As an exception to this rule, it has been held, that if, after the sale, the judgment debtor abandons the land, and afterward returns to it, and is sned in ejectment, he may show an outstanding title, provided he also shows that he has taken possession and holds under it, and the same rule applies to a purchaser holding under the judgment debtor or defendant in execution. ${ }^{35}$

30 Ochoa $v$. Miller, 59 Tex. 460.

31 Shields $v$. Miller, 9 Kan. 390 ; White $v$. Davis, 50 Ho. 333; Ferguson $v$. Miles, 3 Gilın. (Ill.) 358; Miller $v$. Wilson, 32 Md. 297 ; Kirk $r$. Vanberg, 34 Ill. 440.

32 Whiting $v$. ButIer, 29 Mich. 122 ; White $v$. Whitney, 3 Met. 81 ; Leport $r$. Todd, 32 N. J. L. 124.

3: Lanclets $x$. Brant, 10 How. 371 ; Draper $v$. Bryson, 17 Mo. 71 ; Maurior $v$. Coon, 16 Wis. 46 .).

34 Matney $v$. Graham, 59 Mo. 190; Reid $v$. Heasley, 2 B. Mon.
(Ky.) 254; Jackson v. Bush, 10 Johns. 223; Jackson $v$. Hagaman, 1 Wend. 502; Gould $v$. Hendrickson, 6 Ill. 599. But see Kenyon $v$. Quinn, 4I Cal.325, where it is held, that a statutory provision to the effect that a conveyanee of land in fee simple shall convey the legal estate afterward aequired by the grantee, has no application to a sheriff's deed made under execution sale.

35 Gould $v$. Hendrickson, $96 \mathrm{Ill}$. 599. 
The recording of a sheriff's deel operates as constructive notice only to those who hold or clain under the judgment defendant; strangers, and those claining under an independent or hostile title, are not affected thereby. ${ }^{36}$

\$ 27\%. Continued-Imperfect Description. The only remedy for a false description in a sheriff's deed is to obtain a new deed in the court whence the process issued. Equity will not aid the imperfect execution of a statutory power. ${ }^{37}$ It follows, therefore, that if the description fails to show with certainty what property was in fact sold, or if in order to ascertain such fact it becomes necessary to institute an extraneous inquiry, the deed is roid ${ }^{38}$ and no title will pass thereunder. Where the deed has been lost before registration, the officer may, it seems, exeeute a substitute. ${ }^{39}$

\$278. Statutory Sheriff's Deeds. To overcome the consequence of mis-recitals, prevent collateral impeachment, and give the full desired effect of conveyances by the sheriff, the legislatures of a majority of the States have prescribed certain forms of official deeds and declared their legal effect. As in case of statutory forms of deeds between individuals, these instruments contemplate but little verbiage, the statute supplying what was formerly obtained by long and technical recitals. Only cnough matter of inducement is given to identify the judgment, exceution, and sale, and to show the authority of the officer, while the granting portion is confined to the fewest legal essentials. The deed, in itself, is little else than an abstract, and contains scarcely anything that must not also be shown in presenting a synopsis of it. The example which follows is an abstract of the form now in use in Illinois,

36 Gardner v. Jaques, 42 Iowa, 577.

37 Ware $v$. Johnson, 55 Mo. 500. But where a sheriff executed a deed at the proper time, but omitted to affix a seal or serawl thereto, the successor of the sheriff execnted another deed in proper form, and it was beld that this subsequent deed would relate back to the date of the first one: Kruse $v$. Wilson, iy III. 233.

38 Evans $v$. Ashley, 8 Mo. 177; Jackson $v$. Delancey, 13 Johns. (N. Y.) 536 ; Cunningham $v$. McCollim, 98 Ind. 38 .

39 McMillan v. Edwards, $75 \mathrm{~N}$. C. 81 . 
but which, so far as the observation of the writer has gone, differs but slightly from those now employed in other States.

\section{Seth Hanchett, Sheriff of $]$ Sheriff's Decd. \\ Cook County, Ill., \\ to \\ Williain B. Denton. Duted, etc.}

Recites that whereas, A. B. did, at the May term of the Circuit Court of Cook County, 1SSO, recover a judgment against C. D. for the sum of $\$ 100.00,4 "$ and costs of suit, upon which an execution was issued dated June 2, 1550, directed to said sheriff to execute, by virtue of whirh the suid sheriff levied upon the premises ${ }^{* 1}$ hereinafter described; and the time and place of the sale thereof having been duly adeertised according to law, the same were struck off and sold to William B. Denton, he being the highest and best bidder therefor.

Therefore, said sheriff, in consideration of the premises, conveys to said second party the following described parcel of land [describing the same].

Acknowledgment.

The legal effect of this brief deed, as declared by statute, is to convey to the grantec therein named, all the title, estate, and interest of the person against whom the exeention was issued, of every nature and kind, in and to the lands thereby conveyed, but implies no covenants on the part of the officer executing same. It is further prima facie evidence that the

40 A statutory provision which prescribes the form of a sheriff's deed, so far as it requires the amount of the judgment to be inserted in the deed, is merely directory. It is sufficient if it clearly appears, that the deed is marle by the officer in his official capacity, and in consummation of the legal proceedings upon which it is founded, with such references to the proceedings themselves that they may be realily found and illentified: Holman $v$. Gill, 107 Ill. 467.

41 This word, althongh erroneously employed, is the one enenerally prescribed by statute, and, when sucle is the case, should be slown in the alstrart as fommd in the deer. It is only anotlor illustration of the rareless and bungling manner in whicls lowal terms and phrases are sometimes employed by the law-makers. 
provisions of law in relation to the sale of the property for which it is giren were complied with; and in case of the loss or destrumion of the record of the judgment, or of the execution or lery thereon, is prima facie evidence of the recovery and existence of the judgment, and of the issuing and lery of the execution as therein recited. ${ }^{42}$

$\$ 279$. Sheriff's Deed-Under Decree. Though a master, commissioner or referee is the medium through which a court of chancery ordinarily executes its decrees, the duty not infrequently devolves upon the sheriff either by virtne of his office or through special appointment. While acting under a decree he oceupies the same position as a commissioner, and is but a ministerial officer of the court, to whom he must make reports of his acts and by whom they must be confirmed before conveyances can be lawfully made. ${ }^{43}$ His deed, like a master's, recites his authority, details his acts, and takes effect as a conveyance in the same manner. ${ }^{44}$

$\$ 280$. Masters', Commissioners' and Referces' Deeds. The conreyances of a master in chancery, commissioner, or referee, differ in no material respect from those of a sheriff acting under a decree, the power exereised being the same in each instance, and the principles which govern the one operating with equal force upon the others. Like the conveyances of the sheriff, their deeds are without warranty, or any terms except those imposed by law, and they convey only such titles as the defendant possessed. The recitals of this class of deeds are usually long and verbose and should be judicionsly condensed by the examiner to show all that is material in as few words as possible. The special formal parts are those which relate to the title and authority of the officer, and the recitals showing a due compliance with the decree. In the abstract the deed immediately follows the court proceedings and certificate of sale, and may be shown briefly, as follows:

42 R. S. IIl. 1874, Ch. 77.

43 Taylor $v$. Gilpin, 3 Met. (Ky.) 544; Hunting $v$. Walker, 33 Md. 60.
44 See the remarks relative to deeds of other ministerial officers, and the chapter on "Execution and Judicial Sales." 
Henry H. Bishop, as Master in Chancery of the cirenit Court of the Thited Stales for the Northern District of Illinois,

to

Silas Wegg, Jr.

Doc, 194.85\%.
Master's Deed.

Jated June 10, 1881.

liecorded, July 1:, 1881.

Book 410, parge 65.

Sets forth that in pusuance of a decree cntered March 13, 1S\$1, by said Court in a certain case then pending therein wherein John Doe was

Complainant, and Richard Roe, Defendant, the said Maste' duly advertised, according to law, the lands and tenements hereinafter described, for sale at public anction to the highest and best bidder, for cash, at two o'clock P. M., on Monday, June 1, 1880, at the north door of the U. S. Custom IIouse and Post Office, in the City of Chieago, Cook County. Illinois. That at the time and place so as aforesnid appointed for said sale, the said Master attended to make the same, and offered said premises for sale at pullic auction, to the highest and best bidder, for cash, and thereupon Silas Wegg. Jr., offered and bid therefor \$125.00, and that being the highest and best bid offered, said Master accordingly struch off and sold to said Silas Wegg, Jr., for said sum of money, the said premises, and did thereupon sign, seal and detiver to said silas Wegg, Jr., the usual Master's Certificate therefor, and that said premises have not been redeemed from said sale. Now, therefore, in consideration of the premises conveys; [Tere follows the description of the property.]

Certificate of acknowledgment dated June 10, 1881.

$\S 281$. Trustees. A trustee is defined as a person in whom some estate, interest, or power in or affecting property of any description is vester for the benefit of another, ${ }^{45}$ and though the name is technically applied to a particular class, it also, to a certain extent, comprises executors, arlministrattors, guarlians, assignees, etc. Where the legal titlo of a trus-

452 Bou. Law Dict. (j)6. 
tee is created by the owner of the property, the right of the trustee to enforee it will be recognized everywhere; but where such title is derived solely from some act of the law, the effect of that act is confined to the territorial jurisdiction over which the law extends. ${ }^{45}$ Upon the death of a trustee, the legal title to the estate devolves upon his heir at law; and the heir takes the same estate, and is subject to exactly the same duties and responsibilities as his ancestor. ${ }^{4 \tau}$

But in ease of more than one trustee, the rule would be different, for by the common law, and usually by the statute as well, the estate of trutees is held in joint tenancy, and hence, upon the death of one of several trustees nothing passes to the heir or personal representatives, but the whole estate devolves upon the survivors. ${ }^{48}$

Being founded on personal confidence, it necessarily results that a trustee can not delegate his trust to others, ${ }^{49}$ neither can he profit by his trust estate ${ }^{50}$ nor become a purchaser at any sale thereof by him, ${ }^{51}$ while the power under which he acts must in all eases be strictly pursued to render such acts valid. ${ }^{52}$

A joint power of sale must be executed by all, provided all

46 Curtis $r$. Smith, 6 Blackf. (Ind.) $53 \pi$.

47 Watkins $\tau$. Specht, 7 Coldw. (Teun.) 585: Mc.Iullen $r$. Lank, 4 Houst. (Del.) 648. By foree of the statute the trust sometimes rests in some tribumal in the county in which the trust property is situated, which, upon the application of some person interested in the trust, forthwith appoints a successor to the deceased trustee, whereupon the trust vests in the newly appointed trustee: Collier $r$. Blake. 14 Kan. 250.

48 Golder $v$. Brewster. $105 \mathrm{Ills}$. 419.

49 Grover $v$. Hale, 107 Ill. 638 . But where the trustee conveys the legal title to one having knowl. edge of the trust, or where such other person in any manner acquires the legal estate with such knowledge, he holds the property suliject to the trust and may be compelled in equity to execute it: Rran $r$. Doyle, 31 Iowa, 53 ; Smith $\imath$. Walser, 49 Mo. 250.

5o Faucett $r$. Fancett, I Bush (K巨.), 511.

51 Terwelliger $v$. Brown, $44 \mathrm{~N}$. Y. 237. This is the universally accepted doctrine. but is subject to some qualifications, the law not exacting the same rigid degree of strictness in all the States. Clark r. Clark, 65 N. C. 655, and see "Trustees as Purchasers," infra.

52 Huntt $v$. Townshend, 31 Md. $330^{\circ}$. 
are living and in condition to act, ${ }^{53}$ unless the instrument creating the trust provides otherwise, ${ }^{54}$ for the interest held by several trustees is an entirety, and can only pass as a whole; hence all the trustees living, having an interest in the property, must join in the conveyance, otherwice it will be wholly inoperative. $^{55}$ But in case of the death of one or more of the trustees, the survivor or survivors will hold the trusts and may execute the powers. ${ }^{5}$ A deed by the survivors, representing the entire title, will be good, even though they are authorized to fill the vacancy, as it is only where the terms of the power ereating the trust imperatively require the vacancy to be filled, that the acts of the survivors will be invalid. ${ }^{57}$

The questions suggested by the foregoing statements are many, and will readily present themselves to counsel upon the examination of an abstract. To satisfactorily solve them the grant of power must be exhibited in the chain, or, if made prior to the commencement of the search, a requisition for its production must be made, that it may satisfactorily appear, from actual inspection, that the proceedings of the trustees have been regular and in conformity to the terms of the instrument creating the trust.

\section{\$ 2S2. Transfers of the Legal Estate loy Trustees.} The doctrine of the obligation of purchasers to observe the proper application of the purchase money, in cases of sales by trustees and other fiduciaries, was formerly very intricate, abounding in many technicalities and subtilties; but these, in a large measure, have been swept away by special statutes in England, while in the United States the old English doetrine has rarely been administered except in cases of fraud in which the purchaser was a participant. The general rule now is, and for years past has been, that a purchaser who in 349.

53 Learned $v$. Welton, 40 Cal.

54 Gould $v$. Nather, 104 Mass. 283.

55 Golder $v$. Brewster, $105 \mathrm{Ill}$.
419 ; Brennan $v$. Willson, $i l \mathrm{~N} . \mathrm{Y}$. 502 .

56 Lane $v$. Dehenham, 11 Hare, 188.

57 Golder v. Brewster, 105 III. 419 . 
good faith pars the purdace nusicy to a person authorized to sell, is not bound to look to its application; and there is no difference in this popeet istween lands charged in the hands of a derisee with the paynent of debts, and lands devised to a trustee to be sold for that purpose. ${ }^{\text {is }}$

" The present well-established rule of law in regard to trust cstates is," says Mr. Redficld, "59 "that when the trustee holds the trust estate for the purpose of sale and conversion into money, or with a power of sale and conversion, any one who in good faith accepts such transfer upon adequate compensation, will aecuire a valid title. But if the trustee has no power of sale the purchaser will acquire no title unless he show that the purchase noney has been applied to the purposes of the trust. It is this which marks the true distinction between the cases, where the purchaser is bound to see to the application of the purchase noney and where he is not. For if the trustee has no power of sale, any transfer by him will be wholly inoperative and the trust will attach to the trust property in the hands of the rendee the same as in the hands of the trustee, until it appears that the money paid by the rendee, to the full ralue of the trust property, has been applied to the purposes of the trust." 6 on

\section{$\$ 253$. Power of Gale and Trust of Sale Distinguished.} In the execution of testmentary trusts questions of title are frequently raised on the construction of the authority under which the trustee eifected the sale, but the same questions may sometines arise under deads of trust. "The more common case of trust with porer of sale," observes Mr. Redfield, ${ }^{61}$ "is where the testator devises his estates, together with all his personalty, directing tilat the latter be first applied in the payment of debts and legacies; and in default of it proving suffi-

os Cryder's Appeal, 11 Pa. St.

Z2; Champlin $x$. Iraight, 10 Paige (X. Y.), 275; Vhite $r$. Carpenter, $\approx$ Paige (X. Y.), 217; Garmer $v$. Gardner, 3 Mason (C. Ct.), 17s, and sce Warvelle on Vendors. 55.3 .
593 Redf. on Wills (3d Ed.), 620 .

60 And see, Hughes $v$. Tabb, is

Y.. 325: T:mier $r$. Hoyle, $95 \mathrm{Mo}$.

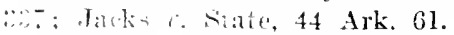

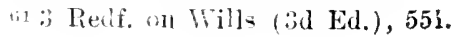


cient, that the real estates be sold by the trustees, either generally, in their discretion. or in some order named in the will." In such ease, the learned author contends that it would be the duty of the trustees to assure thenselves that a deficiency in the personalty has really occurred hefore they can properly proceed to sell real estate, and distinguishes between a trust and power of sale in this manner: "A power of sale, in the event of the personal estate proving insufficient to pay debts or legacies, or both, is a power depending upon a condition precedent, and will not attach mless the enndition ocenr; and a sale under such a pown, when the condition had not in fact occurred, will, of conrse, convey no title. It is, therefore, in a case of this kind essential, that all persons interested in the purchase and in acquiring a good title, should ase sure themselves that the power has really attacherl. In snch a case the receipt of the money by the appointee will hare no effect upon the passing of the title, and will commit no one to its application or repayment exeept the person receiving it. But in the case of a trust for sale under a will, the title having passed to the truster, the title will pass upon any such sale as rests upon an apparent occurrence of the emergencies justifying a sale; and the payment of the money by the purchaser to the trustee, and his receipt for same, will exonerate the purchaser from all responsibility." 62

The exercise of trusts and powers is now very generally controlled by statute. $\Lambda$ trust not allowed by the statute is wholly invalid and no estate vests in the trustees; but a trust directing or anthorizing the performance of any act, which may be lawfully performed under a power, will still be valid as a power in trust, ${ }^{63}$ subject to the provisions of the statute in relation to pewers. Where the trust given does not purport to ho a trust of sale, but simply a power in trust, a deed make by the executor under it, will convey title to the purehatere, and

f23 Redf. on Wills (3d Ed.), $52^{2}$, citins Walker $v$. Smallwood, 366.

Amb. (Eng. Ch.), 676. 
this, notwithstanding the fact that the land in question is devised absolutely by the will.64

\$ 284. Trustees' Deeds. Titles derived through trustees' deeds require close scrutiny, for where a deed of trust minutely and particularly prescribes the ciremetances under which, and the mamner in which, the trustees shall have authority to sell the trust property, they have 110 power or authority to dispose of such property under any other circumstances or in any other manner. ${ }^{65}$ Fiduciaries and trustees, if they exceed or violate their authority, are responsible, though no bad faith prompted their acts; and those who deal with them on the faith of the trust estate, must be aware that they exercise only limited and delegated powers, and are bound, at their peril, to take notice of such powers and sce to it that they confine themselves within their scope. ${ }^{66}$

A trustec having once accepted the trust in any manner, a purehaser can not safely dispense with his concurrence in a sale of the trust estate, notwithstanding he may have attempted to disclaim, and although he may have released his estate to his co-trustees. All the trustees, in case of several, must unite in a disposal of the trust property, and a deed by two, while a third is living, is not valid. The trustees take as joint tenants, and must all unite in the excention of the trust, and especially in a deed of lands.

A trustee can not delegate any duty, unless the power to delegate is expressly given, which involves the exercise of any discretion or judgment. Nere mechanical or ministerial duties may be performed by other's. The particular medium of advertisement, the manner of conducting the sale, the best method of offering the property, the question of postponement of the sale, and the sale itself, are matters regarding which,

64 Crittenden $r$. Fairchild, $41 \mathrm{~N}$. Y. 289. In this case it was held that such power was not inconcistent with the devise, but the estate vested in the devisces, subject to the exccution of the power.
6.) Huntt $v$. Townshend, 31 Md. 336.

fif Owen $v$. Reed, 27 Ark. 122; Ternon $v$. Board of Police, 47 Miss. 181; Ventres v. Cobb, 105 Ill. 33. 
when they are not prescriled by the instrument under which he acts, special trist and confidence are reposed in the trustee; and they can not be delegated to an agent. ${ }^{67}$ All these duties are usually matters of recital in the trustee's deed, and it is advisable that they be shown in the abstract substantially as there stated.

Where the trust deed forms a portion of the examination, the trusts and conditions shoulel fully appear in the abstract of that document, and reference to them will be sufficient in preparing the synopsis of the truster's leed. Shonld the trust deed not be included in the exannination the conditions as recited in the deed may be given, or a note sulstantially embodying them may be appended, as per the example shown. Ifore is an example of a trustee's deed made on foreclosure and in pursuance of a power of sale:

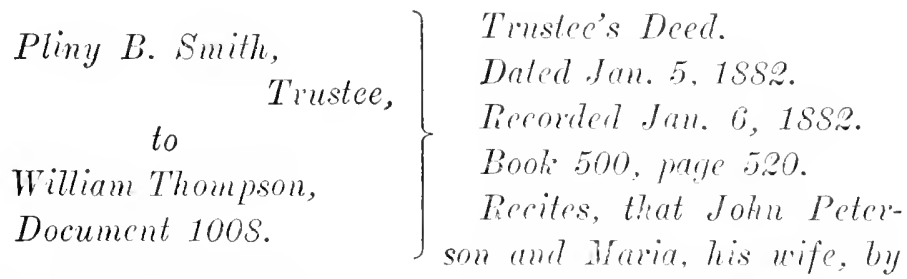
a Tiust Deed, dated May 1, 1880, and recoeded May U', 1850. in book 410, page 512, conveyed to Pliny R. Smith, as Tinstee, all the lands hereinafter described, to secure the paymont. of \$1,000, to IIram Jones. in one year from Way 1, 1580 , evidenced by said Peterson's one promissory note of eren dute with said Trust Deed.

Also sets forth the power of sale in said Trust Deed contained. ${ }^{68}$

And default having been made in the payment of snid note. and It iram Jones, the legal holder thereot, having aphlied to first party, as such Trustee, to canse the sail tunds herein te-

6 B Bales v. Perry, 51 Mo. 449; Grover $r$. Hale, $10 \%$ III. 03s.

68 The power of sale may be set oit here as directerl. but if the trust dreed has already been ex$2: 3$ hibited in the ehain, this of anrse. wonle be unnersitary, and the simphe recital shown in the text wial le suffirient. 
scribed to be sold for the purposes mentioned in, and in accordance with the provisions of said Trust Deed, ${ }^{69}$ first party on. Dee. 5, 1SS1, cansed a due notice to be pubtished in the Legal daiser. a newspaper published (printed) in the City of Thicago, Cook County, Illinois, that said lands hereinafter described would, on Jan. 5, 1SS2, at one o'clock P. M., be sold at public auction, at the North door of the Court IIonse," in the City of Chicago, Ills.. to the highest bidder for cash. by virtue of the power and authority in him vested by said Trust Deed; which said notice was (printed) published for thirty days in said paper, commencing on Dec. 5, 18S1, and ending on Jan. 4. 1SS2, the date of the first paper containing the same, being Dec. 5, 1SS1, and of the last of Jan. 4, 1SS2. And said lands having been, by said first party, on Jan. 5, 1SS2, at one o'clock: P. M., in the manner prescribed in and by said Trust Deed, and at the place last aforesaid, in pursuance of suid notire, offered for sale at public anction, to the highest bidder for cash, and second party having been the highest bidder therefor, and having bid for the tract hereinafter named, $\$ 1,050$, he was duly declared the purchaser thereof.

Nou, therefore, in consideration of the sum so bid, grants, bargains, sells, aliens, remises, releases and confirms the following described land in Chicago, Cook County, Illinois, to wil: [IIere set ont the description of the property conveyed.]

Together, with all and singular, the tenements, hereditaments, and appurtenances thereunto belonging, as the same

69 This is an important recital and should always be set out. Where a trust deed gives the trustee the power to advertise and sell the mort raged premises on default of paynent, when so requested by the holder of the indebtedness, and the trustee, without being so requested. alvertises the property for sale. his act will be unauthorized under the power, and the silie may be aroided and set aside as made in violation of its terms: Equitable Trust Co. $v$. Fisher, 106 III. 189.

70 A power to sell "at the north door of the court house," may be well executed, if the builuing has meantime been destroyed by fire, by a sale at the ruins of the north door. The meaning of the phrase consists in identifying a place of sale, not in the identity of the door: Waller $v$. Arnold, 71 IIl. 350. 
are described and converyet in and by the said Trust Deed: and also, all the estate, right, litle, interest, properly, claim, and demand whatsonere. hoth in lan amd arnity, of the said John Peterson and wife, as well as of the said first party, of. in, and to the above described promises, with the appurtemances, as fully to all inients and purposes, as first party hath power and aulhority to grant, sell, and coneey the same by vintue of the said Trust Deed.

Ackgt., duted Jan. 5, 18S?.

Should no trust deed be shown in the examination, append the power of sale under which the trustee's deed is given, as follows:

Note. - The Trust Deed from John Peterson and wife to Pliny B. Similh, dated Hay 1, 18S0, and recorded Way 2, 1S80, as Doc. 252, in book 410 of Records, paye 512, movides in trust, that in case of default in the payment of said note, or any part thereof, according to the lenor and cffect of said note, then, on application of the leyal holder of said note, to sell and dispose of the said premises, and all the right, title, benefit and equity of redemption of said first parly, their heirs and assigns therein, at public anction, at the North door of the Court Honse, in Chicago. Illinois, or on said premises, as may be specified in the notice of such sale, for the highest and best price the sume will bring in cash, at least thirly days' public notice having been previously given of the lime aida piace of such sale, by adrertisement in one of the daily or weelily neuspapers at that lime published in said C'ity of Chicago; and to make, execute and deliver to the purchaser or purchasers at such sale, good and sufficient deed or decds of conceyance for the premises sold, * * * * which sale or sales so made shall be a perpetnal bar, both in law and in ermily, against the said first parly, their heirs and assigns, and all other persons claiming the premises aforesaid, or any part thereof, by, from, through, or under said first party, or any of them. 
Seeond maly, with or without readrertising, is hereby authorivert and cmpowered to postpone or atjourn said sale from time to time at his discretion, and atso to sell suid premises entire, witholet dirision or in perests, as he may thinh best.

in rase of a breach of any of the covenants or agreements herein. by first paxty. said premises shall be subject to sale and comeyane, on request of the legal holder of said note, in litie mamer and with the same cffect as if the said indebtedness had matmed.

First party covenants and agrees that in case of a sale and comeyance, as aforesaid, of said premises. the deed and deeds of convemance made in pursuance of such sale shall be prima facie eriance of the due compliane with and performance of the terms, conditions and requirements of this deed of trust, by second party or his successor in lrust aforesaid, in adrertising and mating such sale and conveyance, to the extent of the recitals contained in such deed or decats.

Where a trustee's leed, made upon a sale under a ralid deed of trust, shows that sueh sale was eonducted in strict conformity with the power contained in the trust deed, and the purchaser lus lad no notice of any irregularities in the sale, his title will be protected, as respects such irregularities, if any there were, as that of an imnocent purchaser: "1 but the payment of the debt" secured by a deed of trust defeats the pwer of sale, and a purchaser at such sale must see to it that tho srantor in the trust deed is in default, and that some prat of the deht is due and mpaid. ${ }^{2}$

$\$ 25 . \%$. Montgagees' Deeds. Hortgagees recels, made in pursuance of a power of sale, differ in no important particular from eonveyances by trustees, the mortgagee being, for the purposes of the converance, an executor of an express trust. IIe is held to the same striet rules that regulate the conduct of other trustees, and can not exceed the express powers under

11 Hosmer $v$. Campbell, 98 Ill. 72 Ventres $v$. Cobb, 105 Ill. 33. 572 ; Montague $r$. Dawes, 14 Alien (Mass.), 369. 
which he acts. I mortgagee may sell the equity of redemp. tion of the mortgagor and such interest as is conreyed to him by the mortgage under which he sells, but he can not sell the equity of redemption by itself; nor can he sell an undirided portion of his interest in the land included in the mortgage. A proper execution of the porrer of sale requires him to sell all he is entitled to under it, ${ }^{i 3}$ and for the same reason he has no right to sell a greater interest than the mortgage gives him or authorizes him to sell. A violation of these rules will render the sale invalid. ${ }^{i t}$

The recitals of a mortgagee's deed are material to its validity, as tending to show a due execution of the power and compliance with the conditions of the trust, ${ }^{75}$ and should be shown in the abstract in the same manner as indicated in case of trustees' deeds. ${ }^{i 6}$ The original purchaser at a sale by a mortgagee, under a power of sale contained in the mortgage, is chargeable with notice of defects and irregularities attending the sale, and can not evade their effect, ${ }^{i T}$ but it would seem that as to remote purchasers, the sale is only voidable on proof of actual knowledge of such defects acquired before the consideration has been paid. is It has been hehl, however, that a properly executed deed reciting strict conformity, the purchaser having no actual knowledge or notice of any irregularity and taking such deed upon the strength of the assurances therein contained, will protect the title of such purchaser. ${ }^{79}$

$\S 256$. Executors and Administrators. The real estate

73 Fowle $v$. Merrill, 10 Allen, 350; Torrey $r$. Cook, 116 Mass. 163.

74 Donoliue $r$. Chase, 130 Mass. $13 \pi$.

75 Giblons $v$. Hoag, 95 Ill. 45.

76 Where a deed for land soli under a power in a mortgage, reciting correctly all the facts showing a right to nake the sale, is recordal in apt tine, the recoid thereof wiil affect all persoms thereafter claiming under the mortgagee with constructive notice that there had been a ralid sale under the power, although the deed may he defeetively executed so as not to pass the legal title: Gibbons $r$. Hoag, 95 III. 572 .

77 Hamilton $v$. Lubukee, 51 Ill. 11.5. But see Hosmer $v$. Campbell, (1) Ill. 572 .

is Grover $v$. llale, 107 1ll. 638.

i9 llosmer $v$. Camplell, 98 ill. 572. 
of a deceased person is frequently conreyed through the media of what are known as " persomal representatives," consisting of excentor's, or persons specifically designated for that purpose by the decedent, and administrators, who act by virtue of an appointment under the law. ${ }^{\text {so }}$ An exeentor may sell and eonrey lands held in special trust without the intervention of a court, but not such lands as are sold in due course of administration to pay decedent's debts, while an administrator can do no act affecting lands without the special order of a court. In case of sales by either officer no title passes mutil the execution and delivery of a deed,, 1 and without such title as the deed convers, the purchaser can not maintain or defend ejectment against or by the heir. ${ }^{82}$

\$ 287. Executors Deens. I testamentary executor stands in the place of and represents his testator. He derives his power primarily from the will, and in this respect differs somewhat from an administrator, whose sole power is derived from the law and the directions of the court. ${ }^{83}$ When acting moler a naked testamentary appointment, his powers are co-extensive with those of an administrator, and he is bound by the same rules, and subject to the same restrictions. But the excentor may also be a truster, ${ }^{84}$ and, when acting as such, the scope of his powers is measured and limited by the will which appoints him. The distinction therefore, must ever be kept in view of the powers and dutics of an excentor, as sueh, and those which may devolve upon him as trustee, and not as executrix. ${ }^{\mathrm{x}}$ Ender his testamentary anthority, he may sell land, and otherwise excente the trusts and exercise the powers

so "Legal" or "Personal representative" in the eommonly accepted sense, means administrator or executor. But this is not the on!y definition. It may mean heirs, next of kin, or desemdints: Warnoke $x$. Lembea. 71 111. 91.

$81 \mathrm{~A}$ properly comlucterl sale, after confirmation vests the equitable title in the purchaser. s2 Doe r. Hardy, 52 Ala. 291; Gridley $r$. Phillip, 5 Kan. 34 .

s3 Walker $v$. Craig. 18 Ill. 16. Tan Wickle $r$. Calyin, 23 La. Ann. 205; Gilkey $r$. llamilton, 22 Nich. 283.

S. Pitts v. Singleton. 44 Ala. 26:3.

so Warfield v, Brand, 13 Bush $(\mathrm{Ky}), \pi ;$;hite $v$. Clover, $59 \mathrm{IH}$. 462. 
enumerated and conferred in the will, subject to the general regulations of the statute, and free from the control or intervention of a court. ${ }^{86}$ But where authority is not expressly given, or where, during the administration, he performs the ordinary offices of an excentor, as where land is sold to pay the debts of decedent, no express power leeing given, he must first ol,tain authority or license from the probate court, and his sale must be reported to and confirmod hy such court, before a deed can lawfully issue to the purchaser.

An executor's deed, therofore, will be govemed by the law relating to trustees or administrators, according as he may convey in the one or the other capacity, and the reader is referred to the remarks on those classes of deeds respectively. ${ }^{87}$ In either case, the authority of the deed must precede it; in the one case the will, showing the power of sale or trust, and the manner, if stated, in which the power must be exereised or the trust executed, and in the other, the license, report of sale and confirmation, while a synopsis of the probate of the will must be shown in both instances. As in all other cases of fiduciary conveyances, the deed itself must show substantial compliance with the requirements of the will and of the law, and be in other respects regular.

An executor's deed, under power, should alwars expressly state that it is made in execution of such power, and where the executor also possesses individual interests in the land conveyed and his deed does not purport to be in pursuance of his delegated authority or in execution of the power with which he is invested, it will be insufficient to pass the interest of the testator. ${ }^{88}$

$\S 288$. Administrators Deeds. An administrator is re-

s6 Burkingham $r$. Wesson, 54 Miss. 526; Whitman $r$. Fisher, 74 11l. 147: Cronise $v$. Hardt, $47 \mathrm{Mr}$. 43.3 ; Jolks $v$. Barrett, 52 Miss. 315 ; Inghes $v$. Washington, 72 Ill. 84. But the power must be explicit; general words do not confer power to sell lands: Skinner v. Wood, 76 N. C. 109.

87 See ".Judicial and Execution Sales," and the chapter on Trstamentary Conveyanees.

ss Cohen r. ITemingway, 71 Miss. 22; Davenport $r$ Young, 16 Ill. 548 . 
garded as an executive offices of the court, while he also occu. pies the relation of trustce to the estate, its creditors and distributees. ${ }^{89}$ Although he may not jossess as much power as an exccutor, the latter deriving his authority from the testator and the law, and the administrator from the law only, ${ }^{90}$ he yet possesses the necessary power to sell property, negotiate securities, and to settle and pay debts, ${ }^{91}$ but always under the order and direetion of the court. He takes neither an estate, title, nor interest in the lands of his intestate, ${ }^{92}$ but a mere naked porrer to sell for specific purposes. ${ }^{93}$ He takes the land as he finds it, ${ }^{94}$ and haring no interest therein, can maintain no action to perfeet the title or relieve it of any burden, ${ }^{95}$ and must sell it as he finds it. ${ }^{96}$

In administrator's deed derives its primary validity from the order of the conrt directing the sale of the land in question, and this order, together with a srmopsis of the preliminary proceedings which induced it, and the report of sale and confirmation, should precede the deed in erery instance. ${ }^{97}$ The power to sell is a personal trust, which ean not be delegated, ${ }^{98}$ and the sale being a fiduciary act based upon statute, must show affimatively a strict compliance with the law. ${ }^{90}$ In addition

89 Wingate $x$. Pool, 25 111. 118 ; State $r$. Neagher, 44 Mo. 350. There remarks will alio alply to some phases of the oflice of executor. See foregroing section.

90 Gilkey $r$. Hamilton, 22 Mich. 283.

91 Walker $r$. Craig, 15 Ill. 116. Real estate cannot be sold by an administrator unless the personal estate is insufficient to pay the liabilities; and, ordinarily, only so much should be sold as is neces. sary for that purpose: Newcomer $v$. Tallace, 30 Ind. 216; Foley $v$. MeDonald, 46 Mís. 238.

s2 Pran $r$. Duncan. 88 Ill. 144; Stuart $r$. Allen, 16 Cal. 473.

93 smith $v$. McConnel, 17 Ill.
135; Floyd $r$. Herring, 64 N. C. 409.

$9+$ Cridley $r$. Watson, 53 Ill. 186.

95 LeMoyne $v$. Quimby, $70 \mathrm{Ill}$. 399 ; Ryan $r$. Duncan, ss Ill. 146. 96 Martin $r$. Beasley, 49 Ind. 280. 97 See Probate Proceedings, infra. ss Chambers $r$. Jones, 72 Ill. 275; Grilley $r$ Philips, 5 Kan. 349.

99 Fell $\therefore$ Yomng, 633 111. 106; Lockwood r. Sturderant. 6 Conn. 3s6; Corwin $t$. Merritt, 3 Barb. 341. An administrator's deed for land is not adnisible as evidence without proof that the maker was administrator: Lry $v$. Houston, s6 Tex. 260. 
to the report of sale, a substantial account of same is also incorporated into the deed, and this, together with all other material recitals tending to show a finl compliance with the decretal order and statutory requirements shonld be stated with reasonable detail in the abstract. A form is here appended for further illustration:

Nathaniel M. Jones, as administrator of the estate of John R. Thompson, deceased, late of Cook County, Ills., to

James McHen'y Doc. 125.416 .
Administrator's Deed.

Dated July 15, 1852.

Recorded Aug. 4, 1882.

Book 119, Page 410.

Sets forth. that the Probate Court. of Cook County, Illinois, at a regular term thereot, on May 10, 1882, in a certain cause, brought un-

der the statute, whercin said Nathaniel H. Jones, as Administrator of the estate of said Jolen R. Thompson, deceased, was plaintiff, and George R. Thompson and Hary E. Thompson, were defendants, did, by order duly entered, empower and direct said Nathaniel H. Jones, as such Idministrator, to sell at public vendue the real estate of said John R. Thompson, deceased, hereinafter described, for the purpose of paying the just claims against his estate.

That in pursuance of said decretal order, said first party, as such administrator, having given due public notice of the intended sale by causing a notice of the terms, time and place of such sale, together with a deseription of the real estate to be sold, to be previously postcd for four wecks, at four of the most public places in the county where such real estate was sold, and also, to be published for four successive weelis prior to said sale, in the Chicago Legal Nen's, a nemspuper metished. in said Cook County. the rounty where such irat cstate nass sold, agreeably to the order and directions of satit Probale court, and in accordance with the slatute in such retsess mede. and provided, did, on Jume 15, 18s8. pursument to the order. and notice aforesaid, sell at public vendue the real estate of 
said Jolm R. Thompson, deceased, in said order deseribed, to James MeIlenry, he being the highest bidder therefor.

That first party made and fited in the office of the elerk of said Probate Court a complete report of his proceedings and sale under said order, and said Probate Court having carefully cxamined the same on July 10, 1SS2, finding the same correct, did approve and confirm the same, and ordered said Nathaniel M. Jones, as such administrator, to execute, achnowtedge and deliver a dech of said real estate to second party. on his complying with the terms of said sale, ${ }^{1}$ and that second party has in all things complied with the terms of said sale on his part to be performed.

Now, therefore, first party, in consideration of the premises and $\$ 100.00$, grants, bargaims and sells land in Cook County, Ill., to wit: [Here follows the description of the land according to the deed.]

Together with all and singular the hereditaments and appurtenances thereunder belonging, and all the estate, right, title: interest, claim. and demand whatsocrer, at law or in equity, which said John R. Thompson. deceased, had at the time of his death, in and to said premises.

To have and to hold the same unto seeond party, his heirs and assigns forever, as fully and effectually, to all intents and murposes in law, as sceond party might, could or ought, to sell and convey the same, by virtue of said decretal order.

Certificate of asknomledgment, dated July 15, 1882.

The doctrine of eaveat emptor applies to all sales by the administrator, ${ }^{2}$ and the purchaser, who is presumed to have inade all necessary inquiries, takes the title at his peril, ${ }^{3}$ and subject to all liens, except those for the parment of which the land is sold. ${ }^{4}$ The purchaser has no right to the land until

1 One who produces an administrator's deed as evidence of his title, must show that its execution was authorized. LaPlante $v$. Lee, 83 Ind. 155.
2 MeConnell $r$. Smith, 39 Ill. 279.

3 Bishop $v$. O'Connor, 69 Ill. 431.

4 Henderson $v$. Whitinger, 56 Ind. I31. 
the sale has been confinued," hut where the sale has been made under a proper order of the court, and reported to and confirmed by such conrt, it conveys title eren though the proceedings be irregular. ${ }^{*}$

\$ 289. Administrator with Wrill Amexed. An administrator with the will amexed wempies much the same position as an executor and may exereise many of the excentor's powers. ${ }^{\top}$ He aets under the will and, as a rule, any power given to the executor, which is not in the nature of a personal trust, that is, where the power given belongs to the oftice of executor and not to the person, may be exercised by an administrator with the will annexed. ${ }^{8}$ Where the will creates a personal trust which the exccutor alone could excente without the intervention of a court, the trust will not pass to the administrator with the will amnexed, and sales thereunder of real property of the testator by the administrator will be withont anthority and void. ${ }^{9}$ Where the will gives to an executor therein named powers and duties to be performed which do not ordinarily come within the scope of an executor's functions, ${ }^{10}$ or where land is devised to him to be sold, ${ }^{11}$ an administrator with the will annexed has no power, without the aid of a court, to sell the lands so devised or directed to be sold, or to execute the special powers given to the executor. ${ }^{12}$

5 Mason $r$. Osgood, 64 N. C. 467 ; Rawlings $v$. Bailey, 15 Ill. 178; Ury $v$. Houston, 36 Tex. 260.

6 Thorn $x$. Ingram, 2.5 Ark. 52; Myer $v$. McDougal, 47 Hll. 27 . Compare Chase $r$. Rinss, 30 Wis. 267.

7 An administrator cum testamento annero is appointed on the following ocrasions: I. Where no execrutor is appointed by the will. 2. Whare an execntor is appointed but dies before the testator. :3. Where from any canse the execultor bromes incompetent, disqualified or renouneses the oflice. 4. Where the executor dies before the completion of administration; in this latter case the alministrator is also alministrator de bonis non.

8 Auderson $r$. MeGowan, 45 Ala. 462: Preseott $r$. Morse, 64 Me. 422: Belcher $r$. Branch, 11 R. I. 2:26.

9 Anderson $r$. MeGowan, 4.) Ala. 280: Dumning $r$. Oeean Nat. Bank, 61 N. Y. 497 ; Ross $v$. Barclay, 18 Pa. St. 179 .

10 Ingle $x$. Jomes, 9 Wiall. 486.

11 Nicoll $r$. Sontt, 99 111. 55!); Domming $r$. Ocean Nat. Bank, fil N. Y. 497: (ijlehriut r. Lioa, !) l'ilige, titi.

12 Sinch trustis frepunently devolve upon a trustee whom the court may 
\$ 290. Guardians" Deds. Guardians ${ }^{13}$ and conscrvator's ${ }^{1+}$ frequently make conveyances of the real estate of their wards, either to pay debts, or for the support and cducation of the ward, or for the purpose of inverting the proceeds; and such conrcyances, if attended by all the statutory requisites, are effectual to convey all the tille which the wart may hare possessed at the tine of the sale. ${ }^{15}$ Sales of this kind are made under the direction of the probate comt upon petition loy the glartian stating the necessary juriedictional facts, ${ }^{16}$ and after notice of such application, in the manner proviled ly law. ${ }^{17}$ Such sales must be further reported to and confirmed by the conpt granting the lieense, ${ }^{18}$ but the title of the warl will not be divested until a deed has been ordered and actually execrited. ${ }^{19}$

The deed should therefore be preceded in the abstract by. brief recitals of the antecelent steps or references to all jurisdietional facts. These would consist of an als anet of the letter of guardianship, but uot necessarily of the prininary matters of indrecment, as a letter of guardianship is in the nature of a certificate or commision, and, in the absone of any statu-

appoint for that purpose: Farwell r. Jacobs, 4 Mass. 634 .

13 The common law recognized four kinds of guardians, to wit: in chivalry, by nature, in socage, and by nurture. The distinctions do not. and never have existed in the United States. The statutory guardianship is the only kind which figures in land titles.

$1+$ The estate, and frequently the person as well, of persons non compos mentis, is often confiled to the care of a statutory guardian generally called a conservator or committee.

15 Kisenor $r$. Lindsay, 33 La. An. 1211: Mulford $r$ Beveridge, is Ill. 445: Fitzgibbon $v$ Lake, 29 Ill. 165.

16 The petition is of paramount necessity, and, it seems that wiillout such a petition the count gets no jurioniction to grant a liecnse to sell: Myder $r$ Flander, 30 Mieh. 336.

17 The notice is jurisdictional, and a sale withont giving the statutory notice has been held absolutely void: Rankin $v$ Miller, 43 Iowa, 11; Kennerly $v$ Gaines, 51 Miss. 625 . If, however, the notice is defective merely, the jurirdiction is saved: Lyon $v$ Vannatta, 3j Iowa, 521 .

1s Confirmation is essential to the validity of the sale. Penple $r$. Circuit Juige, 19 Xich. 296: White $\imath$. Clawson, 79 Ind. 1ss; Chapin $v$. Curtenius, 15 Ill. 427.

19 Doe $r$. Jackson, 51 Ala. 514. 
tory provision iequiring it, it is not essential to its validity as evidence of the appointment that it shonld recite the node and particular's of cmanation, while all reasonable presumptions must be induged in favor of its having bern regularly issurel and after lawful proceedings; ${ }^{20}$ a briof smupsis of the petiticn and notice, or at least references to thome iustrmments; a syiopsis of the decree or lieente of sale; an l ieference to the guardian's revort of sale, and order of continuation.

\$ 291. Trustees Can rot Pecome Purcassers. It is a settled principle of equity, liat no peroon who is placed in a situation of trust or confidence with respect to the subject of the sale can le a purelaser of the property on his own accomnt. The principle is not confined to a particular class of persons, such as grardians, trustees, ete., but is a rule of universal application to all persons coning within its principle, which is, that no party can be adnitted to purchase an interest, where he has a duty to perform that is inconsistent with the character of purchaser. The reason of the rule is, not because they might not, in many instances, malie fair and honest disposition of it to themsrlves, but because the probalility is so great that they would frequently do otherwise, withont dangre of detcetion, that the law considers it batter poliey to prohibit such purciases cutiply than to assume then to be valid excopt where they an be proved to be framdulent.

"The rule ior'idaling conflict between interest and duty is no respectir of persons. It imputes constructive fraud, becance the temptation to actual frand and the facility of enncealing it are so great. And it imputes it to all alike, who oome within its scope, howerer much or howerer little open to suspicion of actual frand." 21

The principles which prohibit the trustee from becoming a

20 Burrowe r. Bailey. $34 \mathrm{Mi} \cdot \mathrm{h} .64$. The procefoinges by al guarritian to sell his wallis lontis atre statutory, and a naterial deriation from the repuirenents of the statule is, in general, jarielietional.
21 Ryan, C. J., in Cook $r$. Berlin Mill Co., 49 Wis., 43:3; Story's Eq., $\$$ :in; (irumley r. Webs, 44 Mo. 444; Blamvelt i. Ackinnam, $20 \mathrm{~N}$. J. Eq. 141; R. R. (o. r. R. R. Co., 19 Giralt. (Va.) 5!2; Borrum $v$. 
purchaser extends to all sales of the trust property whether made by the trustee himself, muler his powers as trustee, or under an adverse proceding. As a general trustee of the subject-matter, it is his duty to make it bring as much as possible at any sale that may take place, and therefore he camnot put himself in a situation where it becomes his interest that the property should bring the least sum. ${ }^{-2}$

$\$ 292$. Continued - Qualineations of the Rule. The foregoing, thongh stating the generally received doctrine, is yet subject to qualification. While the rules as stated still apply in all their pristine vigor to a large class of fiduciary relations, to certain others their effect has been greatly modified: Thus, a purchase of land by an executor, at his own sale, directly or indirectly, is not ordinarily roid, but only voidable at the option of the heirs or beneficiaries scasonably expressed. ${ }^{23}$ it clear and mexpivocal attimance of the sale, which must be bona fide, mas conchde the beneficiary, if under no disability and in full knowledge of the facts, and the aceeptance of proceeds by the beneficiars would, in general, amount to an affirmanee. ${ }^{24}$

All snch sales, howerer, are riewed by the courts with a jealous eye and set aside for slight cause, and titles derived through or under them are questionable at best. If re-enforced by a quitelaim or confirmation by the heirs or beneficiaries, they become less obnoxions, ${ }^{25}$ yet even then they are far from perfect, as the unsatisfied rights of creditors may raise equities sufticient to racate and annual the deed.

Sicheneck. 41 N. Y. 182; Roberts $r$. Poberts, 65 N. C. 27; MeGowan $x$. Mclowan, 48 Miss. 553: Goodwin $r$. Goodwin. 48 Ind. 584; Sheldon $r$. Rice, 30 Mich. 296.

2. Martin $r$. Wyneoop, 12 Ind. 266 .

23 Frazer $r$. Lee, 42 Ala. 25 ; Smith v. Granbery, 39 Ga. 381: Williams $r$. Rhodes, 81 Ill. 571: Fromeberger $r$. Lewis, $70 \mathrm{~N}$. C.
4.56; Dodge $r$. Stevens, 94 N. Y. 209 .

24 Boerum 2 . Schenck, 41 N. Y. 182: Brantly $r$. Cheeler, 42 Ga. 209: Scott $r$. Manil, 33 Tex. 721 .

25 Where one recciving title from a trustee is chargeable with notice of the disability of his grantor, it is essential, in most cases, that some affirmation of the sale be obtained from the beneficiary. 


\section{CILAPTEI XTIII.}

\section{ASSIGNMENTS, INSOLYENCY AND BANKRUPTCY.}

\$293. Assignments generally.

294. Voluntary assigmment

295. Vialidity of assignments.

296. Formal requisites.

297. Title of assignee.

298. Construction and effect.

299. Confiict of laws - Foreign al-.inments.

300. Insolvency.

301. Bankruptcy,
$\S 302$. Jurisdiction and practice. 303. Classification - Procedure. 304. Nature and effect of bankruptey.

305. Procedure.

306. Bankruptcy proceedings.

307. The assignment.

305. The assignee's deed.

309. Discharge in bankruptey.

\$ 29:. Assignments Generally. An assignment, as defined by Burrill, " " is a transfer or setting over of property, or of some right or interest therein, from one person to another; the term denoting not only the act of transfer, but also the instrument by which it is effected." When applied to real estate it indicates a transfer of the entire interest of the assignor in the transferred property, but in popular use is restricted to the conreyance of an estate for life or years. The term is also used to distinguish a peculiar class of converances resorted to by persons who find themselves in embarrassed cireunstances, or who are unable to satisfy the full demands of their creditors. In this sense assigmments are classed as voluntary, or such as are made ly the free act and deed of the assignor; and involuntary or statutory, or such as are made under compulsion of law and in the furtherance of statutes of bankiruptey or insolvency. In all cases they imply a trust and the interrention of a truster, ${ }^{2}$ and conveyances made directly to the beneficiaries, though for the same purpose, are not technically assignmente,

1 Pirri!! on Aasignments.

2 rowlea r. Rickett, 1 Inwa, 382; Dirkson $r$. Rawson, in Olin St. 21s; Prock r. Morrill, 26 Vt. 696.
3 Beach $r$. Beston, 47 II]. 521; Keen $v$. Preston, 24 Twl, 395; Johmsun $v$. MaGraw, 11 Iowa, 151 ; Grif(in r. Roger, 38 Pa. 382. 
and ane mulp the provisions regulating ordinary deeds of transfor and sale.

s.:4. Foluntary Assignments. The power to make an assigmment for the benefit of cretitors is not derived from any statutury anactmont. Every debter, whether solvent or innolvent, posesses, independent of statutory grant, the right to make any disposition of his property which dees not interfere with the rights of others; in oftrer words, to make any honest disposition of his property that he pleases. The right of assignment is clearly within the absolute dominion which the law empowers every man to exereise over his own. Statutory prorisions concerning assignments are to be found in all the States, yet such statutes do not confer the right, but merely regulate its exereise, subjecting it, as in other transers of property, to entain restretions and limitations which experienee has demonstrated to be wise and just; but it is still the assignor's volmutary act, and not the act of the law.

So, alwe the purer of the assignee is fixed by the instrument of ascument, which at once the gnide and measure of his duty. Peymul that, or cutsile of its tems, le is potrerless and without anther:ty. Mo distributes the proceds and disposes of the estate placed in his care according to the dictation and under the sole midanee of the assignment, and the statutory provisions merely rewlate and guard his exercise of an authority derived from the will of the assignor. In all things the assignee is the icpresentative of the assignor, and must be governed by the express terms of his trust. ${ }^{4}$

As a general rule, in the alsence of special statutory restrictions, a debtor in failing circunstances, acting in good faith, may lawfully prefer one creditor, even to the total exclusion of all the other.." and may also, in like good faith, in a reasonable manner, no his property by mortgage, pledge or otherwiso in raising money to pay such ereditor. ${ }^{6}$

4 In re Lewis, 81 N. Y. 421 ; Pillobury $r$. Kingon, 31 N. J. Fq. 639: Bink $r$. Willis, 7 W. Va. 81 . 5 Temilinon r. Matthews, 98 Ill.
178: Thomas $r$. Goodwin, 12 Mass. 149.

s Cuendet $v$. Lahmer, 16 Kan. 527. 
\$ 295. Validity of Assignments. In all cases where conveyances are made for the ostensible purpose of securing an equal distribution among creditors, of the property of the debtor, the validity of the converance dopends upon the intention of the debtor. If the intention be to hinder and delay creditors in the enforcement of their drmands against snch debtor, rather than to secure an equitable distribution of the property among creditors, and for their benefit, the conreyance is fraudulent and void. It is not the offect of such conreyances that determines their validity, for every such conreyance in effect hinders and delays creditors. It is the intention that controls, and that intention can not be better determined than from the language of the deed of convesance, although it may be established by extraneons exidence. ${ }^{7}$

A full narration of the recitals and conditions of the trust seems desirable in all cases of recent conveyance, as, where it appears from the face of the deed, that the motive for making it was to present a sacrifice of the property; or if there be reserved to the assignor any benefit or advantage ont of the property conveyed, the intention as well as legal effect would be to hinder and delay creditors and the converance would be void. ${ }^{8}$ The consideration expressed is a matter of minor importance, the true consideration being the agreement of the assignee to perform the trusts imposed upon him by the assignment; and that, in contemplation of law, constitutes a full and completè consideration. ${ }^{9}$

§ 296. Formal Requisites. Though roluntary assignments are founded on common right, yet, to prevent frand by the setting up of fietitions transfers claimed to have been made for the benefit of creditors, they must be attended with the prescribed legal formalities of the State where nade. or where

7 German Ins. Bank $v$. Nunes, 14 Reporter, 2or; Mackie $t$. Cairns, 5 Cow. (X. Y.) 5tz; Ifenderson $t$. Downing, 24 Miss. 106.

8 Gardner $v$. Com. Nat. Bank, 95 111. 298; Vernon $v$. Morton, 8 Din: 24
(Ky.). 263; Phelps r. Curtis, 80 Ill. 113 ; Kayser $r$. Heavenrid, 5 Kan. 324; Lockhart $r$. Wyilt, 10 Ala. 231; Tieed $r$. Pelletier, 2. $11 \%$. 173.

9 Thomas $r$. Clark, 6.5 Mr. 296 ; Gates $t$. Labeaume, 19 Mo. 17. 
the property to be affected is situated; and unless executed in confonity with such laws, are inoperative and roirl. By the instrument the debtor's property must be nnconditionally and without restriction transferred to the assignee, with a general anthority to him to receive, hold, and dispose of it for the equal benefit of all the creditor's, or in the order of preference, if any, provided for. ${ }^{10}$

The assignment should be executed with the same solemnities that characterize ordinary deeds for the conveyance of land, and be duly acknowledged before an authorized officer. ${ }^{11}$ Defects of this nature should be noted by the examiner with the same serupulous care as in other conveyances between individuals.

No particular form of instrument is needed to constitute an assignment, and any ralid transfer, intelligibly indieating the trusts, will suffice. ${ }^{12}$ It is neual to set out the real estate conreyed, either in the body of the deed or a schedule thereto annexed, yet such is its force as a comverance, that, when made only in general terms, it will transfer all the property which the assignor then owns, eithre in possession or expectaney, and the omission to specifically describe property in the inventory would not prevent the title thereto from passing to the assignee. ${ }^{3}$ If the instrument mentions speeific property, without a clause of general conveyance, or even makes special exceptions, it will not, for that reasom, be void, as the title to such withheld property may still be pursued by ereditors, their remedies being neither hindered nor delayed, ${ }^{1+}$ and so long as there is no reservation of some part of, or some right or interest in, the property actually conveyed, the assignment will be valid.

10 MeIntire $r$. Benson, 20 Hll. 500. In some States preferenees are not permitted. Consult loeal statutes.

11 Britton $v$. Lorentz, $45 \mathrm{~N}$. Y. 51.

12 Norton $v$. Kearney, 10 Wis. 443.
13 Roseboom $r$. Mosher, 2 Denio (X. Y.), 61.

14 Knight $v$. Waterman, $36 \mathrm{~Pa}$. St. 25s; Ingraham $r$. Grigg, 21 Miss. 22: Bates $r$. Ableman, 13 Wis. 664: Carpenter $v$. Underwood, 19 N. Y. 520. 
The statutory requirements relate mainly to the acceptance of the trust by the assignee, filing of bond, notice to creditors, ete., and in these repocts a literal compliance is usually necessary. The abstract should show a full synopsis of the proceedings; the operative parts of the instrument of transfer, ineluding the trusts; and such portions of the inventory or schedule as cover the real estate in que-tion.

$\S 297$. Title of Assignee. It is a nsual requirement on the part of the assignec, that before taking possession of the assigned estate, he shall, within a stiprulated time after the filing of the inventory, execute and file, in the proper office, a bond conditioned for the faithful performance of his duties; and it has been held that the absolute title to the property assigned does not pass until this bond is filed. In the interval between the filing of the assignment and the filing of the bond, the inchoate or conditional title rests under the protection of the court, which has jurisdiction over the property but not over the assignee; and a failure to file the bond, within the prescribed time, is, it is said, equiralent to a dechination of trust which terminates all right in the property which the assignee may have acquired by the filing of the assignment. ${ }^{15}$ Where, however, there has been a formal aceptance of the trust the transfer is complete and irrevocable, and the title to the property rests in the assignee for the benefit of the creditors. ${ }^{16}$

An assignee is not regarded as a purchiser for value, and has none of the equitios of such purchaser. He stands entirely on his naked legal title and this he can aequire only by an observance of the methods prescribed by law. The filing of the bond in such ease, unles expressly mate so by statute, is not a condition precedent to the resting of the estate, nor will the failure to give the statutrory security within the time linisted invalidate the transfere or restore the title of the alsigned property to the assigner. In the avent of the failure to fike a bond, as required by law, the atsignere, thomgh insested wilh title,

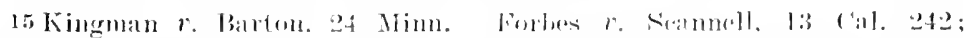
29.5. Jimwn r. (hamberlain, !) Fla. 4(it;

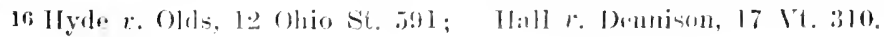


has no power or authority to dispose of the property for the purposes of the trust, which would then be a dry trust merely to take possession and hold until he should become qualified and empowered to dispose of it; but having accepted, he can only be relieved of the trust and divested of the estate by the order of a court of competent jurisdiction. ${ }^{1 \tau}$

\$ 295. Construction and Emect. An assignment for the benefit of ereditors, conveying property to trustees with power to sell and to apply the proceeds in payment of debts, is an absolute conveyance, by which both the legal and the equitable estate is divested ont of the grantor and vested in the assignee, sulject to the nses and trusts in favor of the ereditors. ${ }^{18}$ "An assigmment," says Burrill, ${ }^{19}$ "is more than a sceurity for the payment of debts; it is an absolute appropriation of the property to their payment. It does not ereate a lien in favor of creditors upon property which, in equity, is still regarded as the assignor's, but it passes both the legal and equitable title to the property absolutely beyond the control of the assignor. 'There remains, therefore, no equity of redemption in the property, and the trust which results to the assignor in the unentployed balance does not indicate such an equity." The title in the hands of the assignee is relieved of none of its burdens, but remains subject to all existing liens and equities. ${ }^{20}$

\section{$\S$ 299. Conflict of Laws - Foreign Assiguments.} Deeds of assigmment are governed by the same general rules as other conveyances, and when execnted in one State but including or operating upon lands in another, their validity and effect, as instruments of conveyance of such lands, must be determined by the laws of the latter State. ${ }^{21}$ They have no extra-

17 Brennan $v$. Willson, $71 \mathrm{~N}$. Y. 502 ; Thrasher $v$. Bently, 59 N. Y. 619 .

1s Dwight $v$. Overton, 32 Tex. 390 ; Tan Kenren $r$. MeLaughlin, 21 N. J. Eq. 163; Briggs r. Davis, 21 N. Y. 574 .

19 Burrill on Assignments, 12; and see, Briggs $r$. Davis, 21 N. Y. 57т; Hofiman $r$. Mackall, 5 Onio St. 124; Turner $v$. Natkins, 31 Ark. $4: 7 \%$.

20 Williams $v$. Winsor, 12 R. I. 9. 21 Story, Conflict of Laws, $\$ 364$; Cutler $x$. Davenport, 1 Pick. 81; Loving $x$. Paire, 106 Iowa, 282; Gardner v. Com. Nat. Bank of Providence, 95 Ill. 298. 
territorial force, yot, on principles of comity, an assignment valid in the State where it is made, and where the assignor resides, will generally be permitted to operate on the assets of such assignor in cach of the other States. ${ }^{22}$

$\$ 300$. Insolvency. A special procedure is provided in most of the States for the distribution of the estate and effects of insolvent debtors, and their subsequent discharge from the debts thus satisfied. Such proceedings have the same general effect, within the jurisdiction of the State, as proceedings under the national bankrupt law, and to which they bear a strong analogy. During the continuance of the bankrupt law their operation is suspended, and owing to this and the infrequency with which the remedy has been used, but few instances will occur where conveyances have been made under same. The examples which follow, of abstraets of proceedings under the national bankrupt laws, will serve as illustrations of the method of showing State insolvency matters whenever they may occur. The validity of titles so derived is a matter of local law and construction.

$\$$ 301. Bankrupter. At the date of this writing a national bankrupt law, passed in 1898, is in force, under which many transfers have been made. Numerous transfers under the operation of past laws will also be found of record. Proceedings by virtue of the act of $18+1$ require but slight notice, the rights of all parties thereunder having become permanently established by the efhuxion of time. Proceedings and conveyances under the act of 1867 should be shown in greater detail, yet even here only a brief synopsis seems necessary. The operation and effect of the law of 1898 being recent and continuous, more attention to details will be required.

\$ 302. Jurisdiction and Practice. By the bankrupt act of $1567,,^{23}$ the District Courts of the United States were given original and exchusive jurisdiction and power over all "acts, matters, and things to be done under and by virtue of the bankruptcy," and were authorized, by summary proceedings, to ad- 
minister all the relief which a cont of equity conld administer

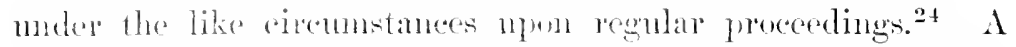
levisury juristiction was further conferred mpon the federal cirenit conte, but all juitiate procedings were confined to the distriet compts, which, when sitting as compts of bankruptey, were legarded as separate conrts, exereising powers and a jurisdiction distinct from their powers as district courts as originally constituted. ${ }^{25}$ Such courts were permitted to exercise extrateritorial juristiction in collecting the estate and adjusting the claims of the cretitors of the bankrupt, but in all matter's of controversy tonching the rights of the assignee under the assignment, when the suljicets in dispute were of a local nature, the rights of partics conlit only be determined by actions in local conrts. ${ }^{26}$ The art of 1898 also gives juristiction of proceedings in lankruptey to the District Court, but the proechure differs in many respeets from that observed under former laws.

$\$ 30 \%$. Classification. Banknuptey is either voluntary, when precipitated by the debtor's own act; or involuntary, when produced by the action of the creditors, the effect upon the property of the bankrupt being the same in either case. In both instances, it is initiated by the filing of a petition, and consumated hy adjudication. When, after adjudication and before any assignment has been made, a composition is effected and the bankrupt discharged, there scems no good reason why the abstract should be encumbered by details which are inmaterial to the title, and such proceedings may be safely omitted. ${ }^{2}$ -

24 Matter of Wallace, Deatly, 433; Newman 1\% Fisher, 37 Md. 254; Voorhees 1: Frislie. 25 Mich. 476.

25 Norris' Case, 1 Alb. (U. S. 514.

26 Whitridge r. Taylor, 66 N. C. 273.

27 This is on the principle that the natter possesses no more force than a satisfied judgment, which is neither a lien nor a clond upon the title. lut only a clog mon the examiner's eforts when shown in an abstract. Many examiners prefer, however, to bu iefly allude to the filing of the petition and discharge, at the lankrupt, during this period, has no power of disposition over his ufferts; the adjudieation being to demive him of the power, while the discharge lestores same. 
$\$$ 304. Sature and Effect of Bankruptey. A person adjudicated a bankrupt is deened a bankrupt from the day on which he files his petition, and, from the moment the petition is filed, so far as his property is concerned, he is considered as civilly dead. During the interval existing between the filing of the petition and the appointment of a trustee, ${ }^{28}$ a condition of things exists not unlike that before the appointment of an arministrator in the case of a person dying intestate, no one being authorized to dispose of or assign his assets. ${ }^{2}$ Under the law of 1867 a voluntary bankrupt was intrusted with the care of his estate before an assignee was chosen, as a sort of trustee, and in involuntary proceedings a warrant issned to the U. S. marshal, who, as the mersenger of the court, took possession prorisionally of all the bankrupt's property. ${ }^{30}$ Under the law of 1898 a receiver may be appointed to hold the bankrupt's property pending an adjudication, or, in involuntary cases, a warrant may issue to the marshal as heretofore.

$\$ 305$. Procedure. It is assmed that both examiner and counsel are familiar with the general procedure of the bankruptey court, and this chapter is prepared on that hypothesis. It may be well, however, to briefly direct the attention of the reader to the changes of method which are noticeable in the present law when compared with the former practice. Under the law of $186 \pi$ the proceedings were conducted under the direction and supervision of an ofticer called "Register in Bankruptey," and whenever it became necessary to administer the bankrupt's estate a formal transfer of his property was made by the Register to an officer called an "Assignce." In virtne of the authority thus conferred the assignee took possession of the property, and, if necessary, sold it to satisfy the bankrupt's debts.

28 Under the law of 1867 an assignment was made, the asignes occupying much the same position as a trustee under the present litw. 29 Johnston $v$. Gej:riter, 26 Ark.
30 In re Muller, Deady. 513; In re Ifarthill, 4 Ben. 448; Williams $r$. Nerritt, 103 Mass. 184; In re Carow, 41 How. Pr. (N. Y.) 112. 44. 
Under the law of 1898, after an adjudication of bankruptey has been entered ly the connt, the matter is scut to an officer ealled a "Referee," who thereafter conducts the proceedings. In the event that the creditors shall so desire a "Trustee" is appointed to take the debtor's property and convert it into money. Upon his appointment and qualifieation the Trustee becomes invested, by operation of law, with all of the bankrupt's titles and rights of ownership, except statutory exemptions, as they exister at the date of the adjudication. Whenever, in the comse of the proceding, the lands of the bankrupt are sold the title thereto is conveyed to the purchaser by the trustee.

\$ 306. Bankuptey proceedings - How Shown. As in chancery procedings, only a brief outline of the procedure of the bankruptey cont can well be shown in the abstract, which in cases of this nature is rather an inclex than a transcript. Sufficient, however, should be given to show the apparent regularity of the proceedings, and the degree of detail may be regulated by the wishes of the client. After confirmation, a sale by the assignee or trustce stands in the same relative position, with respect to irregularities, etc., in anterior proceedings, as other sales in chancery, and such anterior proceedings require no greater elaboration. With such changes as may be necessary to suit the exigencies of particular cases, the following will afford a sufficient example. This proceeding, it will be observed, is under the law of 1867 .

$\left.\begin{array}{c}\text { In the matter of the estate } \\ \text { of Andrew Smith, } \\ \text { Bankrupt. }\end{array}\right\} \begin{aligned} & \text { U. S. District Court, } \\ & \text { Northern District of Illinois. } \\ & \text { Case No. 1,000. } \\ & \text { Petition filed Nov. 10, } 1868 .^{31} \\ & \text { Schedule of assets and lia- } \\ & \text { bilities mentions, [here set }\end{aligned}$ out so much of the real estate deseribed as is covered by the

31 An assignment in bankruptey relates to the commencement of tie proceeding, and the title of the assignee becomes vested as of that date. International Bank $v$. Sherman, 101 U. S. 403. 
caption of the alsstract; or, if not mentioned, say: does not mention property in question.] Adjudication entered Tor. 10, 1868. ${ }^{32}$ Robert E. Jentins appointed assignee Nou. 16, 1868.

Petition of said assignee, fited Dec. 1. 1SGS, praying leave to sell assets of said estate at public auction, ctr.

Order entered, Dec. D, 1S68, authorizing said assignee to sell assets as prayed for in said petition, after giving three weeks' public notice by publication, elc., and ten days' notice by mail to creditors.

Assignee's report of sale, with proof of publication and notice of sale attached, filcd February 1, 1S69, showing sales of [here set out the description of property sold if corered by the search; or, if only one piece is named in schedule, or, if all the property named in schedule is sold to one person, say: the lands described in schedule of assets and above set forth] to Alexander Hamilton for \$10,000.

Assignee's report of sale approved and sale confirmed Febmary $10,1869$.

The subsequent proceedings, relative to the discluarge of the bankrupt are immaterial, as he has now been divested of all title to the land in question; but should the exaniner desire to add a symmetrical close to his smonsis of the action of the bankruptcy court, he may add:

Petition for discharge filed Warch 1, 1869.

Register's final report filed March 10, 1869.

Discharge entered and issued Hay 1, 1869.

\$ 307. The Assignment. The synopis given in the last section is taken from the rolls of the district comrt, and shows

32 In case there should have been a composition and subsequent discharge, the notes of same may, in the examiner's discretion, be entered inmediately following. Inasnuch as such proceedings shed no light on the title they are not inserted in the form above given.
They would consint of the dates, sevorally, of the entering and filing of the petition for compusition meeting: the Pirerister's repurt of componition, ame doeles coldirming same; the liegister's repert of compliance and firal discharge. 
the general conrse of the procectings under the law of $\mathbf{1 8 6 7 .}$ The formal instrument, howerer, by which the assignee aciniret the logal title, was an assignment by the Register, which was duly recorded as a title dieed in the registry of deels of the county wherein the land was situate, and in the abstract it may be shown as follows:

Homer N. Hibbard, one of the Registers in Bankruptcy of the District Court of the $U$. S. for the Northern District of Illinois,

\section{to}

Robert E. Jentins, assignee of Andreu Smith, Bankrupt.
Assignment.

Dated Nor. 16, 1868.

Pecorded Nor. 17, 1868.

Book 691, page 625.

Conveys and assigns all the estate. real and personal, of said Andrew Smith, bankrupt, including all the property, of whatever kind, of which he was possessed, or in which he was interested or entitled to have, on

Nor. 10, 186s, with all his decds, books and papers relating thereto, excepting surh property as is exempted from the operation of this assignment by the provisions of Sec. 5045, of title 61, Bankruptcy. of the Revised Statutes of the United States. ${ }^{33}$

In trust, for the uses and purposes, with the powers, and subject to the ronditions and limitations set forth in said act.

This presents substantially the contents of the assignment, and conveys all the information necessary to be shown in the

$\therefore:$ It should be remembered that only the property actually owned by the bankrupt passes by this as-igmment, and hence where such lankrupt possesses the legal title only, but no beneficial interest, the title does not rest in the assignee and can not be conveyed by him (Thodes $v$. Blackiston, 106 Mass. 334 ) : and the mere fact that the assignee inventories certain land as belonging to the estate of the bankrupt, and sells and conveys same under order of court, does not operate as an adjudication that the land was the property of the bankrupt au the time of the filing of the petition, but only that whatever of title the bankrupt then had is conveyed to the purchaser: Wilkins $v$. Tourtellott, 28 Kan. 825. 
abstract, hut showint the examiner so desire he may sot forth the instrument in ereater detail.

$\$ 308$. Ansignees or Trustee's Deed. In order to present the srnop-is of bankrupter proceedings in a connected manner, and as it should appear in the abstract, it is deened adrisable to give the asignee's decd in this place rather than where it more properly belongs, in the chapter deroted to oficial conveyanes. These dect-, like other conrerances by trustees, are usually long and prolix, and considerable discrimination must be exercised in preparing the abridgment, in order to present everrthing that ean shed light in the transaction and ret aroid burdening the abstract with unnecesary particular or useles rerbiage. The folluwing form, prepared from a long and technical deed, will serre wexplain the meaning of these renarks and illustrate the methods described:

Robert E. Jenkins. Assignee in Bankruptey of the Estate and Effects of $A$ ndreu Smith, Bankrupt. to

Alexander Hamitton.
Assignee's Deed. ${ }^{34}$

Dated - eb. 10, 1860 .

Recorded Feb. 12, 1869.

Bouk 100, page 200 .

Scts forth that, in acrordance with the provisions of the Rerised statutes of the Cnited States, Title "Bankiruptey:" a petition was filed in the District Court of the Cnited states for the Torthem District of Illinois, on Mou. 10, 1s6s. by said Andrew Smith. and on Nov. 16, 1S68, said Andrex Smith was duly adjudged and declared bankrupt; and on Nor. 16, 1S68, said Pobert E. Jenkins was duly appointed assignec of the estate and effects of said bankrupt by H. X. Hibbard. one of the Registers in Bankruptcy of said Court. which said appointment was thereafter

34 Thi - is an ahridgement of a deed under the law of 1867. Tnder the law of 1841 a deed containing a cops of the decres of hankruitcy and of the appointment of the assignee, needs no other recitals and will be good. if in other respects suticient. the same $a=$ a deel made bs the bankrunt lefore the adjudication; Rșer $*$ Rush. 102 Ill. 338. 
duly approved and confirmed by said Court, and on Nov. 16, 1S6s, suid liegister conveyed and assigned to said Jenkins, as sueh assignce, all the estate, real and personal, of said bankrujt, induding all the property of whatsoever hind, of which said bankmpt we possessed, or in which he was interested, or which he was entitled to have on Nov. 10, 1869 (excepting only such property as is excepted by the 504.th section of said Rerised Stututes).

That suid bankrupt, Andrew Smith, appear's to have been, on said last mentioned a ale, possesscal of or cutitled to an interest in real estale and property hercinafter mentioned. And said assignce having fist given notice, by publicution once a ween, for the consccutive weeks, pursuant thereto, on Feb. 1, 1869 , offered for sale, and sold said real estate and property at public auction, and at said sale, second party was the highest bidder, and became the purclaser thereof for $\$ 10,000.00$; which sale was, on Feb. 10, 1869, approved and confirmed by said Court, and said Conrt did, on the day and year last named, order and direct said assignce to execute and deliver to said second party a deed for the real estate so sold, conveying the same to him, in accordance with the terms of said sale.

Nou, therefore, in consideration of the premises, and $\$ 10$,000.00 , remises, reteases, sells, conveys and quitclaims, all the right, title, interest, cstate, claim and demand of said bankrupt. which he had on Non. 10, 1Sgs, and of said Robert E. Jentins, as assignee aforesaid, $i n$ and to the following described real cstate, to wit: [Ilere set out the description of the property conreyed, employing the langnage of the deed], with all the improvements, rights, privileges and appurtenances thereto belonging, but subject to all umpaid taxes and tax liens, and to all liens and incumbrances, unless expressly excepted, released or discharged by the orders of said Court, concerning said sale, and subjert to all the terms and conditions of said sale.

Certificate of acknowledgment, dated Fcb. 10, 1869. 
The foregoing will sore to suggest the treatment of a trustee's deel mobre the law of 1598, and the manner in which its recitals should be shown.

The title convered by the assignee or trustee is no better than that held by the bankrupt, and the purnhas takes it charged with all the equities to which it was subject in his hands, ${ }^{35}$ and burdened with all liens, by morkgage or judgment, which existed against him at the time of the adjulication.

\$ 309. Diseharge in Mankustry. The effect of an adjudication in barkmptey being to deprive the person arijulged a bankrupt of his power to take or convey property while resting under such sentence, it is propere that his restoration to civil rights shomld also be shown whenerer the abstract discloses him in the character of a grantor or grantee after such

s5 Walker $r$. Milier, 11 Ala. 1067 ; Stow $v$. Farrood, 20 Ill. 497; Hardin $v$. Osborne, 94 Ill. $5 \pi 1$. In this case, the court held that an assig. nee in bankruptey does not take the title to the property of the bankrupt as an inmeent purchaser without notice, free from latent equities, ete., but as a nere rolunteer, standing in the shoes of the bankrupt, as respects the title, and having no greater rights in that regard than the bankrupt himself could assert. The bankrupt had, prior to the time he was adjurlged a bankrupt, conveyed lairl, bit the deed remained uneerided, and the court held, that no title would pasi to the aswignee as against the purchaser holling under the prior unrecorded deed. "sippose," said Walker, C. J., "the debts had been paid without the sale of the land, does any ons suppose the bankrupt could have held it against his former grantee, whether or not his grantee hisd recorrlext his desels? Where the jurchatser had paid his money, and received the convey- ance. his equities are surely equal to that of other creerlitors. His deed operated to envey to him the title, and the creditors have advaneed nothing to procure a lien on the land, and the appointment only operated as a transer of whatever interest the bankrupt held for the benefit of his creditors." But the learned judge further observes: "If, however, in such a case the assignee were to sell and convey the land to an innoeent purchiser without notice, an? he were to place his deed on record bifore that of the prior purehaser, a different case would he presented." In the case of Holbrook $v$. Dickenson, $50 \mathrm{Ill}$. 497 , where the assignee hat sold the land under a similar state of facts, it was held that the prior pruelaser eould not sed up or show his unrecorded deei to cefeat the title of the assigner's grantee, and this is the venemily received doctrine resulting form the prian construction of the recoreline acts. And see Bank r. Stone, SO Ky. 100; Wilkins r. Tomlelot, as Kr. 285. 
arljullication. This may be arcomplished by a simple note of the fart. Where a composition has been effected, such note would be given in connection with a brief reference to the petition and proceclings in the bankruptey court. Where the debtor's property has passed from him to the assignee, or where a trustee has been appointed, and the subject of the examination consists of property in which the bankrupt has acquired an interest since the date of such assigmment or appointment, the fact of discharge may be shown as an independent circumstance, its legal import being merely to show the removal of disability; thus,

\begin{tabular}{|c|c|}
\hline & In the U. S. District Court, \\
\hline In the matter of the & Torthem District of Illinois. \\
\hline $\begin{array}{c}\text { In the matter of the } \\
\text { banlimptey }\end{array}$ & $\begin{array}{l}\text { Case } 10 . \text { s.s.'. } \\
\text { Toluntary Petition. }\end{array}$ \\
\hline of & Filed December 19, $18 \% 7$. \\
\hline James L. Sherman. & $\begin{array}{l}\text { Discharge cntered and issued } \\
\text { to said Banlirupt, February } 2 S \text {, } \\
18 \text { ig. }\end{array}$ \\
\hline
\end{tabular}

The general effect of a discharge in bankruptey is to free the hankrupt from all liability with respect to debts proved against his estate, as well as all debts founded on contracts made by him which might have been so proved. 


\section{CHAPTER XIX.}

\section{AGREEMENTS FOR CONVEYANCE.}

$\S 310$. Land contracts.

311. Relation of parties under land contracts.

312. Efrect and operation.

313. Nature and requisites.

314. As affected by recording acts.

315. Construction of land contracts.
§316. Formal parts.

:17. Assimment of the contract. 31s. Performance - Sufficiency of deed and title.

319. Forfeited contracts.

320. Bond for deed.

321. Agreement for conreyance by will.

\$ 310. Land Contracts. Land contracts, or agreements to deed, are of frequent occurrence on the records, and occasionally bonds for the same purpose will be found, though these latter are now practically obsolete. Shonld the contract be exceutory its contents should be set forth with considerable minnteness, particularly such parts as relate to the parties, the subject-matter, and the conditions of conveyance. If, on the contrary, the contract has been consummated by deed, a passing allusion to it, as part of the chain of title, will be sufficient. Where the subsequent deeds do not show a substantial compliance, a full synopsis may become material, althongh the contract has been executed, and the examiner should, as a precautionary measure, first satisfy himself on this point before abstracting the instrument. In cxecuted contracts, however, this is not of rital importance, for acceptance of a deed ordinarily merges any provisions of the contract of sale which are different from the deed. ${ }^{1}$

1 Davenport $v$. Whister, 46 Iowa, 287; Bull $r$. Willard, 9 Barl,. 64l; Jones $r$. Wood, 16 l'a. 25. This is the areepord doctrins. yet it is subjuct to large qualification. The actual contract as shown by the agreenent, will still be competent. where through fratul, inaluertence or mistake, a different deed has lern delivered; Snell $r$ Insurance 


\section{\$ 311. Relation of Parties Under Land Contracts.} The relation subsisting between the parties to an ordinary contract for the conveyance of laud upon the future payment of the purchase money, is analogous to that of equitable mortgagor and mortgagee, the vendor lolding the legal title as security for the umpaid purchase money, which security is essentially a mortgage interest. The vendee las an equity of redemption, and the vendor a correlative right of foreclosure upon default in the payments. ${ }^{2}$ In this, as in other eases, the mortgage is the incident, the debt the principal, and the vendor las no further interest except to the extent of the security the mortgage affords for his delot. ${ }^{3}$

S 312. Fifect and oreration of the Contract. The effect of a valid contract for the conveyance of land, is to rest in the vendee the equitable estate in the land, leaving the legal title in the vendor as a mere lien or security for the unpaid purchase money. ${ }^{4}$ The vemhr, in such case, is simply a trustee lraving an interest in the proeceds but not in the land, and this interest, upon his decease, would pass to his personal representatives and not to his heirs. The heirs would, it is true, take the legal title by descent, hut only as it was rested in the ancestor, which was as a mere security for the debt.

Co., 98 U. S. 85, and cases cited. Where there has been, by mutual mistake, a failure to emboly in the deed the actual agreement of the parties as evidened by the prior written agreement, and the meaning of the prior agreement is deme, and nothing has occurred betwen the parties after it was signed and delivered to vary its terms, except the mere faet of the delivery of the deed. and the deed not eflecting what boh parties intonies by t'e actual contract which they had made, a comrt of equity will intrer. fere and reform the deed so riven in arortance with the origin:l and minifast intention: Elliot $r$.
Sarkett, 108 U. S. 132. It would seem, therefore, that in case of discrepancy or repurgancy the agreement should be fully abstracted or at least sufficient thereof given to show the repugnancy.

2 Church r. Snith, 29 Wis. 492; Bufton $r$. Schroyer, 5 Wis. 598; King r. Ruckman, 21 N. J. Eq. 599: Baldwin r. Pool, 74 ill. 97; Fitzhugh r. Maxwell, 34 Mich. 138; Dew $r$. Dellinger, $5 . \mathrm{N}$. C. 300.

3 Strickland $r$. Firk, 51 Miss. 795.

4 liced $r$. Lukens, 44 Pa. 200; Cary $r$. Whitney, 48 Me. 516; MilIf $\mathrm{r} r$, Corey, 15 Iowa, 166. 
The debt being due to the amininistrators or exeentors of the vendor, and the lien being eonsidered as held by the heirs in trust, and simply as a pledge or security for its payment, on payment of the debt the heirs would be compellable in equity to execute the trust by the converance of the title, while the purchase money would go to the personal representatives." The equity is a proper subject of derise ly the rendee, or, in the event of his dying intestate will descend to his heirs the same as other realty, and in them is rested the equity of redemption.

\$ 313. Nature and Requisites. The statute of frauds, substantially re-enacted in all the States, provides that no action shall be brought to charge any perwon upon any contract for the sale of lands, unless such contract or some note or memorandum thereof shall be in writing, and signed br the party to be charged therewith, or some other person thereunto by him lawfully authorized, and where there is no exception contained in the statute the courts will not create any. ${ }^{6}$ No special form is required as an evidence of such contract, and courts seem inelined to allow a ride latitude in this particular. ${ }^{\top}$ The statute permits the menorandum to be signed by the vendor or his agent, yet it seems that if made by an agent it should still be in the principal's name. If the terms of the contract, the consideration, the sulject-matter of the sale, ete., are stated with reasonable certainty, the memorandum is suffieient. Form is not important, nor need it be under seal, ${ }^{9}$ the one indispensable requisite being, that it be in writing and signed by the rendor or his agent; ${ }^{10}$ and the power

5 Gerard's Tit. to Real Est. 472 ; Johnson $r$. Corbett, 11 Paige, 265; Noore $r$. Burrows, 34 Barb. 173. The agreement to deed, above referred to, is very different from the contract of purcluace or conditions of sale, under the English srstem of conveyanciag. The former contemplates a sale already male, the latter a site to be male. i Hairston $r$. Jandon, 42 Misi. 880.

7 Benis r. Berker. 1 Kan. 226;

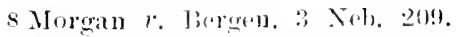

9 Mose r. Mkinome 4t Cal. i;

Ruttenberg $r$. Miliı, 47 Cal. 213.

10 Ilaydock $r$. Stow, 40 N. I. 363. 
to the agent, unless provided otherwise by statute, may be given orally. ${ }^{11}$

It is, however, a familiar rule in this branch of the law, that a contract which equity will specifically enforce, must be cortain in its terms, and the certainty required has reference both to the description of the property and the estate to be convered. Uncertainty as to either, not capable of being remored by extrinsic evidence, will invalidate the contract. ${ }^{12}$ Less particularity is required, however, than in case of actual comreyanees of the same land, and, as a rule, any description of the property will be suffieient provided it be such as to enable : surveyor to locate the land. ${ }^{13}$ Every contract which gives no means of identifying the boundaries of the land sold, ${ }^{14}$ which furnishes no information regarding the terms of the contract, ${ }^{\mathbf{1 5}}$ or which by faulty or imperfect description renders the location of the property uncertain, ${ }^{16}$ will be incapable of specific enforcement.

\$ 314. As Affected by the Recording Acts. Interests in land acquired through contracts of purehase fall within the protection of the recording acts. Therefore, although another may be interested as a part owner of land sold by contract, if the record fails to show that interest, and shows the entire title in the vendor, the purchaser from the apparent owner of record, withont notice of the real facts, will hold the title, and so of his assignee. ${ }^{17}$

$\$ 315$. Construction of Land contracts. A contract for the sale of land is, for most purposes, regarded in equity as

11 Ruttenberg $r$. Main, 47 Cal. 213: Ncllhorter $v$. McMahan, 10 Paige, 386.

12 Whelan $r$ Sullivan, 102 Mass. 204: Peters $r$. Phillips, 19 Tex. 74.

13 White $r$. Hermann, 51 Ill. 243.

14 Whelan $r$. Sullivan, 102 Mass. 204; Holmes $r$. Evans, $4 \mathrm{~s}$ Miss. 247 .

15 MrGuire $r$. Stevens, $42^{\circ}$ Miss. 724. The writing relied upon to es- tablish such a contract need not describe either the consideration or the lands which are the subject of the sale, otherwise than by a reference therein to some extrinsic fac' or instrument by means of which the consideration and the land can be known with sufficient certainty: Washburn $v$. Fletcher, 42 Wis. 152. 16 Gigos $v$. Cochran, 54 Ind. 593. 17 Allen $v$. Woodruff, 96 Ill. 11. 
if already specin̈caliy executed. ${ }^{18}$ When consisting of two instruments they will be construed together and effect given as of one entire instrument. ${ }^{19}$ Time, unless specificaliy male of the essence of thr contract, will not be construed to the disadvantage of the vendec, and a contract which uses the ordinary trme to express the time for the payment of the purchase money, without any express intention that such time is material, does not make it so. ${ }^{20}$

S 316. Formal Parts. The examiner will note the usual incidents of dates, parties, property, ete, as in other instruments, and in addition, the nethods of transfer and conditions and stipulations annexed to the contract, if any. Though usmally executed by both parties, this is not a requisite, and an executory contract is ralid and binding and can be as effectively enforced by the rendee, if signed by the rendor alone. $^{21}$ It is advisalle, however, particularly where the contract contains mutual covenants or stipulations, to note a divergency in this respect. The folloming is submitted as a synopsis of the salient features of an ordinary executory contract:

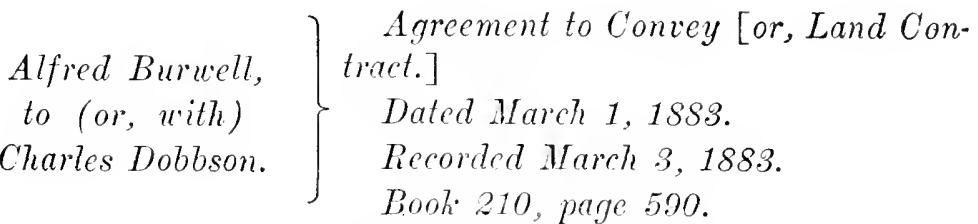

First party, on payment of $\$ 500.00$, agrees to convey to second party by good and sufficient warranty deed, the following described land situated in the town of Mount Pleasant, Racine County. Wis., described as [here set out the description] free from all lions and incumbrances, except [here set out incumbrance recitals, if any].

Second party, in consideration of the foregoing, agrees to

18 King $r$. Ruckman, $21 \mathrm{~N}$. J. Eq. 599.

19 Beman $v$. Green, 1 Duer (N. Y.), $: 382$.
20 Reed $r$. Jones, 8 Wis. 392.

21 Vassauli $v$. Edwards, 43 Cal. 458; Ewins $\iota$. Gordon, 49 N. H. 444. 
pay said sum of $\$ 500.00$ in manner following, to wit, etc.; [state the terms briefly].

Time to be the very essence of the contract.

Further mutually agreed that said second party shall have no right to the possession of said premises as purchaser, until after full payment of purchase money. and that he takes same as tenant from said first party until the last payment has been made.

E.recuted by both parties and acknowledged by them March 1, 1SS3.

\$ 317. Assignment of the contract. In the assignment of an execntory contract for the sale of land, there is no implied covenant, on the part of the assignor, of title to the land in the vendor; all that can be implied is a warranty that the assignor owned the contract and had the right to assign it, and that the signatures thereto are genuine. ${ }^{22}$ Such assignments are usually very bricf and informal, and consist of a bare recital of the fact of assigmment. Whether appended to the original or made by a separate instrument, they should be attended by the same solemnities relative to execution, etc., as were necessary in case of the original, and shonld be shown in the abstract as a separate link in the chain. The effect of an assigmment is to convey to the assignee all the interest of the assignor therein, and it entitles him to demand and receive a deed of conveyance from the vendor or his heirs upon payment of the purchase money dne thereon. He takes it subject to all the equities existing against his assignor, and is entitled to all the beneficial incidents. ${ }^{23}$

The delivery of a contract for the purchase of land by the purchaser to one to indemnify him against loss by becoming a guarantor for the purchaser, withont any written assignment thereof, constiutes an equitable mortgage, and a subsequent

22 Thomas $v$. Bartow, 48 N. Y. N. Y. 42; Gerard's Titles, 475; 193.

Reeves $\imath$. Kimball, 40 N. Y. 299;

23 Tompkins $r$. Seely, 29 Barb. Parmly $v$. Buckley, 103 Ill. 115.

212; Cromwell v. Fire Ins. Co., 44 
written assignment to another who has no interest in the same, and where no words of converance are used, would be inoperative. ${ }^{24} A$ written assigmment of a deed or contract for the conveyance of land is not necessary to the creation of an equitable mortgage, and the only effect of such written assignment is, that when the instrument and assignment are recorded, they will afford constunctive notice of the mortgagee's rights, and also be evidence of the fact of assigmment in case of a dispute. ${ }^{25}$ The doctrine of equitable mortgages by deposit of titie deeds does not at present meet with much faror in this country, howerer, and strict proof of notice is generally required from the equitable mortgagee to bar the rights of subsequent purchasers or incmubancers, ${ }^{26}$ while in several States the doetrine does not prevail at all. ${ }^{2 \pi}$

$\S 315$. Performance - Sufficiency of Deed and Title. A familiar form of expression used by conveyancers in drafting instruments of the character under consideration, in relation to the deed to be given, is, "good and sufficient," thongh not infrequently the contract expressly calls for a warranty deed. The term "good and sufficient deed," etc., has been the subject of much litigation and productive of a large amomt of judicial reasoning, both as regards the form of the instrument and the title conveyed thereby. In this, as in most other much litigated questions, a complete hamony of opinion has not prevailed, but it would scen to be the preponderating doctrine, that a covenant to give a good and sufficient conveyance of land is satisfied by a quitclaim deed, ${ }^{2 s}$ ret with respect to

24 Allen $r$. Woodruff, 96 Ill. 11; and sce Stury Ex. Tur. \$ 1020; 2 Wash. Real Prop. 82; Mandeville $v$. Welch, 5 Wheat. $27 \%$.

25 Chase $r$. Peck, 21 N. Y. 584; Jarvis $r$. Dutcher, 16 W1s. 307; Allen $v$. Woodrufi, 96 [1]. 11; Hall v. MeDuff, 2t Me. 311; Mounce $r$. Beyers, 16 ria. 469.

26 Bicknell $v$. Licknell. $34 \mathrm{Vt}$. 498 ; Story Eq. Jur. \$ 1020.

27 Bowers 2 . Oyster, 3 Pa. 239;
Van Meter $r$. MfFadden, 8 B. Mon. (ix.) 435; Strauss Appeal. 49 Pa. St. 358.

28 Kile $r$. Kavanagh. 103 Miss. 356 ; Thayer $r$. Torrey, 37 N. J. L. 339 ; Contra, Watkins $x$. Rogers, 21 Ark. 298. That parties have male a written agrerment for a sale, without provirling for any warranty, indiates that they did not intend there should be any warranty; and if the conveyance made is only of 
the title, such a eonveyanee can only be performed by a deed which conveys the entire estate, ${ }^{29}$ and vests in the purchaser an indefeasille title. ${ }^{30}$ A contract to execnte a good and sufficient warranly deed entities the purchaser to a waranty deed of the land free from all incumbrances. ${ }^{31}$

In cvery contract for the sale of lands, whatever may be the language in which it is conched, there is an implied undertaking to make a marketable title, mless such an obligation is expressly excluded by the terms of the argreement, ${ }^{22}$ and, in the alsence of any stipulation as to the lind of eonreyance, the presmimition is that the rendor undertook to make such a converance as will render the sale effectual. ${ }^{33}$ Special attention is directed to these nutters in this comnection, from the fact that it is at this period of the transaction that an attorney is usually called to pass mon the merits of the proffered title. Whatever may be the medinm of transfer, a searching investigation shomid be given to the title, which, if perfect in the person proposing same, renders the vehicle of conveyance of minor importance; hut an offer to make a quitclaim deed, which conveys only the rendor's interest, is not a compliance with an agreement to make title in a ease where the chain of title upon the public records is defective or broken, or the land is burdened with liens and incumbranees. ${ }^{34}$ In exerutory contracts the purchaser is never bound to accept a doubtful title. ${ }^{35}$

the right, title and interest of the vendor, he ean not be held liable for defeets of title, excopt on the ground of frand or conceilment: Johnston $\tau$. Mendenhail, 9 WV. Va. 112.

29 T: ft $v$ Kescel, Wis. 273.

30 Deleran $v$. Dnienn, 49 N. Y. 485; Daris $v$. Menderon, $17 \mathrm{ris}$ 10.5; Parker $r$. Parmilee, 20 John. 1.30 .

:1 Davidan v. Van Pelt, 15 Wis. 341; Burwell v. Jackson, 5 Seld. (N. Y.) 536 .
32 Holland r. Holmes, 14 Fla. 390; Hill $r$. Ressegien, 17 Barb. 162. Compare, Tobnston $i$. Mendenhall, 9 W. Va. 112.

3: Hofinan v. Felt, 39 Cal. 109; lut consult Fitch $v$. Willard, 73111. 92.

34 Holland $r$. Jolmes, 14 Fla. 390.

35 Delevan $r$. Dnmean, 49 N. Y. 485 ; Roberts $v$. Bassett, 10.5 Mass. 407 . 
Whenever the contrat callis for a specific title or methor of conveyance, the rendor must convey as specified; 3 s thus, where a purchaser has contracted for a title of record, he can not be compelled to take a title depending upon adverse pussession under the statute of linitations, ${ }^{3 i}$ althongh it may be perfectly good. ${ }^{3 s}$ But where the vendor of land assumes no responsibility as to his title, and is to make only a quitelaim or special warranty deed, but is to furnish a satisfactory abstract of title, the purchaser, for a reasonable objection to the title, may elect whether he will accept a eonveyance or rescind the sale, provided such election is made with no unnecessary delay. ${ }^{39}$ If he clects to take it muler a milateral contract, any delay on his part will be regarded with especial strictness, the fact of objection in such case not justifying great delay in performance, and it has been held, under similar circumstances, that if other written evilenes furnished in connection with the abstract, show a marketable title, this will be sufficient, although the abstract of itself does not. ${ }^{40}$

$\$ 319$. Forfeited contracts. Agreements for conveyance which do not contemplate an immediate sale are mainly resorted to by two classes; the one, where, by reason of financial inability, no immediate consummation of the contract of sale can be effected; the other, where parties desire to control the disposition of property for a limited time while araiting other developments. In each case forfeitures often occur, sometimes evidenced by foreclosure proceedings, but more frequently by an express or implied declaration of forfeiture.

Much stress is often placed by counsel upon the fact of unfulfilled contracts of sale appearing in the chain of title, and objections of a serious nature are frequently founded upon them, yet, as a rule, they are formidable only in appearance. Where a contract for the sale of land provides that if the pur-

36j Scott $r$. Simpson, 11 Heisk. (Tenn.) 310 .

3т Delevan $\boldsymbol{t}$. Duncan, $4 \mathrm{~N}$. Y. 485; Tomlin $v$. McChord, 5 Marsh. (Ky.) 138.
3. Page $e$. Greely, 7.5 111. 400. 39 Fitch $r$. Willard, 73 Ill. 92. 40 Welch $x$. Dutton, 79 Ill. 465. 
chaser fails to perform any of his corenants the rendor or his assigns shall have the right to declare the contract null and void, a subseguent sale by such vendor to another party for a valuable consideration, after the time fixed for performance, is, in effect, a declaration of forfeiture of the purchasers' contract. ${ }^{41}$

Subsequent purchasers of land, in the absence of express notice of latent equities in others than their grantors, can only be affected by such legal consequences as may be fairly drawn from the record itself; and when the record shows that the clain of prior purchaser has been eut off and defeated by a sale or foreclosure, or by a forteiture of his contract, such subsequent purchasers will have a right to rely on what is thus disclosed. ${ }^{42}$ An unfulfilled contract of recent date, lowwerer, should always be closely scrutinized and the fact of forfeiture clearly established, for it must be remembered that a vendor in such a contract can do no aet in derogation of his rendee's title when such vendee is not in default. Therefore, should the vendor convey to other's while such contract is still subsisting, all persons who elaim any interest in the land, with notice of the contract, will be held to perform such contract to the same extent that the original vendor would be bound if he had retained the title. ${ }^{43}$

$\$ 320$. Bond for a Deed. Bonds for the conveyance of land or interests therein, though formerly much in rogue, have now fallen into disuse, and when shown are usually in the earlier links of the chain. As in the case of land contracts, when followed by deed only a brief notice is required, while if the condition remains unfulfilled a greater degree of detail is necessary. The usual formal requisites of this class of obligations are equally necessary to bonds for title, and in addition, as it provides for a transfer of land, the essentials necessary to

41 Streeper $r$. Williams, $48 \mathrm{~Pa}$. St. 4.50; Grey $r$. Tubbs. 43 Cal. 364 ; Cummings $v$. Rogers, 36 Minn. $31 \%$
42 See Warren $r$. lichmond. 53 Ill. 54; Warder $v$. Cornell, 105 Ill. 169.

43 Tate $r$. Pensacola, Etc. Co., 37 Fla. 439. 
entitle it to record and to afford constructive notice, as acknowledgment and the like; an example is here given:

James Thompson

to

Thomas Witson. $\quad \begin{aligned} & \text { Tol. "B" of Deeds, page } 252 . \\ & \text { In the penalty of } \$ 1,000.00 .\end{aligned}$

Conditioned for the comeyance, by "good and sufficient" deed, of land in Kenosha County, W'is., described as the south half of the southeast quarter of Section ten. Town one north, Range twenty-three, east of the 4 th principal meridian, on payment of $\$ 500.00$.

A kinowledged July 1, 1SS2.

Special provisions, if material, should be shown as they oceur. A bond to convey land upon payment of the stipulated price is evidence of a mutual agreement of the obligee to purchase and of the obligor to sell. The agreement of one party is a consideration for that of the other, and it is immaterial that the obligation of the one party is secured by bond, and that of the other is not thus secured. ${ }^{44}$ It will be understond that the foregoing remarks lave reference only to the right of a vendee to compel performance by the vendor. If relief is sought against the rendee then he must sign the instrument before he can be charged.

\$ 321. Agreements for Conveyances by Will. Agreements to convey need not provide for the delivery of a deed, for an agreement to devise property by will may be subjecter to a specific performance by a court of equity, after the keath of the granting party, with the same effect as a contract to convey while living. It has been said by Wriltimmen, 4 .: "There can be no doubt but that a pereon may make a ralid agreement, binding himself legally to make a particular disper-

44 Fwins r. Ciordon, 49 N. II. 444. The rule is the same in case of agreements to convey signed by vendor only. Sere Vassault $v$. Edwarls, 4:; Cal. 4.58. 
sition of his property by last will and testament. The law permits a man to dispnse of his own property at his pleasure; and no good reason can be assigned why he may not make a legal agreement to dispes of his property to a particular individual, or for a particular purpose, as well by will as by conreyance, to be made at some specified future period, or upon the happening of some specified future erent. It may be unwise for a man to embarrass himself as to the final disposition of his property, but he is the disposer by law of his fortune, and the sole and best judge as to the manner and time of disposing of it. A court of equity will decree the specific performance of such an agreement upon the reeognized principles by which it is governed in the exereise of this branch of its jurisdiction." 45

45. Johnson $r$. Hubbell, 5 Am. Law Reg. 17t; Stephens $t$. Reynolds, 6 N. Y. 458; Wright $t$. Tinsles, 30
Miss. 389; Mundorf $v$. Howard, 4 Md. 459 . 


\section{CIIAPTER XX.}

LEASES.

§ 322. Nature and requisites.

323. Formal ports.

324. Covenants and conditions.
\$ 325. Implied covenants. 326 . Agricultural lank. 327. Assignment of lease.

$\$ 322$. Nature and Requisites. A lease is a contract for the possession and profits of land and tenements on the one side, and a recompense of rent or other income on the other; or it is a conveyance to a person for life or vears, or at will, in consideration of such rent. ${ }^{1}$ The estate or interest conveyed by a lease is personal in its nature, whaterer may be the duration of the term, and falling below the character and dignity of a freehold, it is regarded as a chattel interest. and is gorerned and descendible in the same manner. ${ }^{2}$ When made in writing, as it generally mot be if the term exceeds one year in duration, a lease is usually mutually signed in duplicate and interchangeably delivered by the parties, ${ }^{3}$ but if only signed br the lessor, its aceeptance by the lessee raises a piomise on his part to pay the rent reserved and faithfully obserce all the stipulations and conditions which the lease shows were to be observed or performed by him. ${ }^{4}$

Whether an instrument shall be considered a lease, or only an agreement for one. depends on the intention of the parties, as collected from the whole instrument, and the law will rather do violence to the words than break throngh the intent of the

1 Jackson $r$. Itarsen, ; Cow. 326; 2 Bl. Com. 217.

22 Kent Com. 342; Goodwin $r$. Goodwin, 33 Conn. 314 .

: The copy delivered to the tenant is called the original lease, the one to the landlord the counierpart, but for all practical purposes both are regarded as original: Dudley $r$. Sumner, 5 Mass. 438; Taylor's Landlord and Tonant, 106 (6th Ed.).

4 Pike $v$. Brown, 7 Cush. 134. 
parties by construing such an instrument as a lease, when the intent was uanifestly otherwise. ${ }^{\overline{5}}$

The proper definition of a lease enbraces only such instruments of conveyance as transfer to the lessec a less estate than is pessesod by the lessor, thus leaving a reversion in him, ${ }^{6}$ and this in the sense in which the term is now enployed, yet formerly it was not uncommon to grant land in fee, reserving an ammal rent charge, notwithstanding there was no reversion, and the covenant to pay such rent ran with the land, as well as the eondition of forfeiture and re-entry for its non-payment. ${ }^{\top}$

$\$ 323$. Formal Parts. Where a lease is found upon the records which has expired by its own limitation, it raises a vexed question among examiners as to whether it should be shown or passed without notice. It can in no way affect the title; it is not a charge or incumbrance, nor is it even a cloud. It may with propriety be disregarded mnless followed by a subsequent renewal, but should the examiner deem it expedient to note it, as being included in and covered by his certificate of search, a rery brief statement by way of appendix wonld seem fully sufficient. When for a short or almost expired term, being a cliarge upen the fec, it may be shown briefly, but when for a long term of years it shonkl be shown ully and succiuctly. When for niusty-nine years, or renewable forever, it has much of the dignity and many of the attributes of a conveyance of the fee and requires corresponding treatment. When shown fully, the examiner will observe the names of parties as in case of deeds; the dates; the description; the term; the rent reserved; the general and special covenants; the conditions and restrictions, and the special agreements, if any. The execution and authentication should comply with the statute.

Whenever a lease is of sufficient importance to show in extenso the entire instrument should be carcfully perused and

5 Jackson $r$. Delacroix, 2 Wend. 433.

6 Willard's Conveyancing, 425.

$\tau$ Van Rensselær $v$. Hass, 5
Smith, 6s: 2 Sugd. Vend. 725, Perkins' Ed. 177; Jackson $v$. Allen, 3 Cow. 220 . 
the covenants and conditions critically observed. The aid of an experienced conveyancer is frequently dispensed with in preparing instruments of this character, printed forms are generally employed, and, when they are not obtainable, copies are made from books of forms or from old instruments. In this way covenants are created without being well understood, and which often astonish the parties to be bound when occasion arises which calls for the performance of them.

The dates are important in leases, much more so than in absolute conveyances, and frequently are of controlling efficacy in determining the duration of the term. The words of limitation of the term will also be carefully noted, as also the words of forfeiture and ceaser. The proper words to be used in creating a limitation upon a term granted are, "while," "as long as," "during," and "until." s The words of grant are, "demise, lease and let," or "to farm let," but these words, as in case of deeds, have lost much of their original technical efficacy, and any other words which show the intention will do as well. ${ }^{9}$

The matter of execution, as sealing, acknowledgment, ete., is statutory, but as a rule neither of the afore-mentioned formalities are necessary. An example is appended:

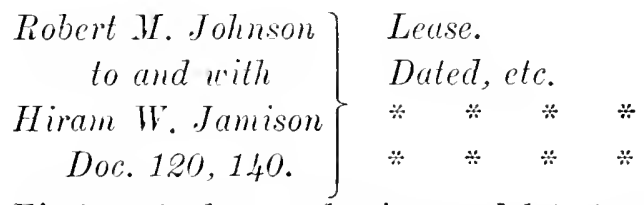

First party leases, demises and lets to second party the following described real estate in Cook County, Ills., to wit: [describe the property.]

To hold for the term of ten yents from the day of the date hereof; [or, a specific late, if inserted], at the ammal rental of $\$ 500.00$ payalile semi-annually.

s Vannatta $v$. Brewer, 32 N. J. Taylor's Landlord and Tenant, 114 Eq. 268. (6th Ed.).

o Hallett r. Wylie, 3 .Johns. 44*; 
Suid second party covenants: for the payment of the rent reserved; for the payment of all taxes and assessments levied on said premises during the term aforesaid; against waste, against sub-leasing, cte.

Said first party corenants: for quiet enjoyment; for the rencual of the term hereby demised at the expiration thereof for the same time and upon the same terms as this indenture, etc.

Prorides, that in ease said second party shall neglect, or fail to perform and observe any or either of before-mentioned covenants on his part to be performed, the term hereby demised is to cease and determine, and that first party may cnter and repossess said premises, without further notice or demand and expel suid second party (and those claiming under him) wilhout prejudice.

Provides further, that in case the premises shall be destroyed by fire or other maroidable casuatty, that the term hereby demised shall cease (or, that the rent be suspended, etc).

Signed and sealed by both parties.

Acknowledgment.

In many instances it will be necessary to set out the covenants and conditions with greater precision than in the cxample, particularly in cases of ground leases for long terms and where the land demised has been highly improved with permanent buildings by the tenant. In cases of leases for lives, more detail will be necessary in describing the term, and the provisions looking toward forfeiture.

$\$ 324$. Covenants and fonditions. Owing to the ignorance generally prevailing of the legal effects of corenants in leases and other instruments, which are often executed without any particular inspection or knowlerlge of their contents, people are often surprised into contracts which neither party intended when the instrment was excuted." The words "yielding and paying," etc, constitute a covenant for the pay-

10 Phillips $v$. Stevens, 16 Mass. 239. 
ment of rent, ${ }^{11}$ which runs with the land, and formerly, if not qualified by any exception or condition, bound the tenant to pay rent luring the continnaice of the term, notwithstanding the buildings on the prenises were destroyed by fire during the tenancy. ${ }^{2}$ Coverants for rebuluing, repairing, etc, run with tise land and are obligatory upon both parties and their assignus, ${ }^{13}$ according as either of the parties are bound. The covenant to pay for any buildings, ereeted by the tenant, at the expiration of the term, rums with the land and inures to the benefit of the assignee. ${ }^{14}$ The corenant for renewal is one of the most important to be noticed by the examiner, and like those just mentioned is incident to the land. ${ }^{15}$ A covenant to renew implies the same term and rent, but not the same covenants, ${ }^{16}$ and is satisfied, even though providing for renewal under the same eovenants contained in the original lease, by a renewal omitting the covenant to renew. ${ }^{17}$ A covenant for indefinite renewals at the option of the lessee is, in effect, the creation of a perpetuity, and therefore against the policy of the law. ${ }^{18}$ The burden of the payment of taxes and assessments is frequently assmed by the tenant, particularly in long terms, but whotier assmed by lessor or lessee it runs with the land, and binds the respective assigns. ${ }^{19}$

11 De Lancy r. Ganong, 5 Selt. 9. 12 Hallett $r$. Wlic, 3 Johnt. 44. 13 Alen $r$. Culuer, 3 Denio, 284.

14 Limenti $l$. Anderson, 6 Cow. 302; Van Ransseliar $v$. Pennimar, 6 Viend. 569 .

15 Sutherland $r$. Goodnow, 108111. 528.

16 Rutgers r. Hunter, ti . Johns. ('b. 218. The covenant for renewa) may be especially enforced, providol blas aplication be made within a reasomable timo after the eviantion of the former lease. and the owner of the reversion or fee will bo compelled to excrute a new lease. Banks $D$. Haskie, 45 Md. 209 .
1 с Carr r. Ellison, 20 Wend. 17. A covenant to renew whieh does not state the terms or length of time of such renewal, has been lech void for uncertainty: Laird $i$. Boyle, 2 Wis. 431.

18 brush $t$. Beccher, 110 Mim.

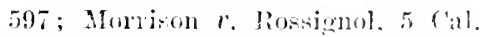
64. A lease renewable forever is an English exotir which neres serms to have thriver in olir suil. In most of the States such laties are invaliu.

19) Pow r. Kealluy, 2 comst. 394; Oswald r. Gilfert, 11 Johns. 443. 
The covenants of leases are usually protected by a condition aroiding the cutate and working a furfeiture in case of breach, and this condition, which is of the essence of the lease, must always be noticed at such length as its importanee seems to demand.

It is not uncommon for the landlord to give the tenant, by an agreenent in his lease, an option to purchase the demised prenises, and whenever such agreements are inserted they should be displayed in the abstract.

\$ 325. Implied Covenants. It is a fundamental principle that the law will always imply covenants against paramount title, and against surelu acts of the landlord as destroy the beneficial enjoyment of the premises. ${ }^{20}$

\$ 326. Agricultural Lands. To avoid perpetuities, as well as the ereation of large manorial estates, a majority of the States have, either by a coustitutional provision or an express statitory cmactment, prohibited the lease or grant of agricultural lan! for a longer period than twelve or fifteen years, and leases made in contravention of this prohibition, in which there is reserved any rent on service of any kind, are declared to he void. The louses or grants contemplated by the law, are such as are heh hy the tenant upon a rescrvation of an annual or preriolieal rent or service, to be paid as a compensation for the nse of the estate granted. It is still competent to make a grant for life, or lives, upon a good consideration to be paid for the state, which consideration may be payable at once, or by in-talments, or in services, so that it be not by way of rent. To bring it within the law there must be a reservation of rent or service. ${ }^{21}$ This may secm a subtle distinction, but it is one which the courts have made and which they strenuonsly en-

so streeter $r$. Streeter, $43 \mathrm{Ill}$. 155; Boreel $v$. Lawton, 90 N. Y. 293. Hamilton $v$. Wright, $28 \mathrm{Mn}$. 199 ; Plater $x$. Cumningham, 21 Cal. 233: This results from the principle of law, that every grant earries with it an implied understanding on the part of the grantor that the grant is intended to be beneficial, and that, so far as he is enncerned. he will do no act to interrupt the free and peaceable enjoyment of the thing granted. See Dexter $v$. Manley, 4 Cush. (Mass.) 24.

21 Parsell $v$. Stryker, 41 N. Y. 480. 
force. A reserration is defined as a keeping aside, or proriding, as when a man lets, or parts with his land, but reserves, or provides himself a reut or income out of it for his livelihood; and a rent is said to be a sum of moner, or other consideration, issuing yearly out of lands and tenements. It must be profit, but it is not necessary that it shonld be money. The profit must be certain, and it must also issue yearly. ${ }^{22}$

$\S 32 \pi$. Assignment of Lease. To constitute an assignment of a leasehold interest, the assignee must take precisely the same estate in the whole or in a part of the leased premises which his assignor had therein. The must not only take for the whole of the unexpired term, but he must take the whole estate, or in other words, the whole term; ${ }^{23}$ for the word "term" does not merely signify the time specified in the lease, but also the estate and interest that passes by the lease; for the term may expire during the continuance of the time, as by surrender, forfeiture, and the like. ${ }^{24}$

The grant of an interest which may possibly endure to the end of the term, is not necessarily a grant of all the estate in the term. Whether the converance be in the form of a lease or an assignment, if it provides new conditions with a right of entry, or new causes of forfeiture are created, then the tenant. holds by a different tenure and a new leasehold interest arises, which can not be treated as an assigmment or a continuation to him of the original term. Then an estate is convered to be held by the grantee upon a condition subeequent, there is loft in the grantor a contingent reversionary interest; ${ }^{25}$ and where by the terms of an instrument which purports to be an under lease, there is left in the lessor a contingent reversionary interest, to be availed of by an entry for breach of condition, which restores the sub-lessor to his former interest in the preminos,

22 Stephens $v$. Reynolds, 6 N. Y. 458 ; 2 lik. Com. 41.

23 Van Ransselar $r$. Gallup, 5 Denio, 454. The purchaser under a mortgage of all the estate of a les- see, is an assignee: Kearney r. Post, 1 Sandf. 105.

242 Plack ('om. 144.

25 Austin r. Cambrilgeport Parish, 21 Pick. 215; Brattle siquare Church $\%$. Grant, 3 Gray, 147. 
the sub-lessee takes an inferior and different estate fiom that which he would aequire by an assigmment of the remainder of the original term; that is to say, an interest which may be terminated by forfeiture, on new and independent ground, long before the expiration of the original term. If the smallest reversionary interest is retained, the tenant takes as sub-lessee, and not as assignee. ${ }^{26}$

26 Dunlap v. Bullard, 131 Mass. 161; MeNeil v. Kendall, 128 Mass. 245. 


\section{CHAPTER XXI.}

MISCELLANEOCS EVIDENCE AFFECTING TITLE.

$\S 328$. General remarks.

$3 \approx 9$. Irregular instruments.

330. Municipal ordinances.

331. Executive approval of Ordinances.

332. Operation and eflect of ordinances.

333. Municipal resolution.

334. Offieial certificates.
\$325. Incororeal lerelitaments. 336. Easements and servitudes. 337. Party wall agreements.

338. Letters.

330. Andarits.

340. Continued - General requisites.

841. Lnecorded instruments.

\$ 328. General hemarks. In this chapter it is proposed biefly to notice a variety of instruments which are not sns"rible of clawifeation in olier divisims of the work, but which have a direct beang mon the quetion of titte, and must be included in all properly prepared abetracte, whenever they appear upon the recurds duing the period covered by the search. Of this nature are afldarits, muicipal ordinances, letters, ete, all of which are proper, and, under certain conditions, competent evidence, in sulpent of the facts so presented.

\$329. Irregular Instruments. This is the name applied by examiners, to all deeds and instruments in which the subject-matter -is not suffieiently identified to permit them to be posted in the tract indices. They include "blanket" "onveyances, that is, all instrmuents of conveyance in which the property is mentioned only in general terms and not specifically; letters of attomey giving only a genoral power; releases, confirmations, ote., which deseribe no property but allucle to other instruments for identification; afficlavits of farts not directly resmected with land, but which incidentally affect or implicate title; and all other instruments and documents which 
do not upon their face indicate the particular parcel of land they affect.

In compiling the abstract these matters should receire careful attention, and not only should all independent instruments which generally affect the title be shown but also appendices to instruments conveying other lands, where such appendices hare ans appreciable bearing upon the property in question. The following will serve to illustrate:

Appended to Document 34r,614, in book 10S6, page 631, recorded sept. 13, $18 S 1$ is the following:

$\left.\begin{array}{c}\text { Affidarit } \\ \text { by } \\ \text { Thos. J. Walsh. }\end{array}\right\} \begin{aligned} & \text { Subscribed and surn to Oct. Q3, } \\ & 1 S 80 \text {. } \\ & \text { That he was a bachelor until July, } \\ & 1 S 36 .\end{aligned}$

\$ 330. Municipal ordinances. A city council is a miniature legislature, anthorized to legislate for a locality, and its ordinances, within the power intrusted, have all the force of laws passed by the legislature. It is restricted, however, to such matters as are not at variance with the general laws of the State, and are reasonable and adapted to, or proper for, the purposes of the corporation. Ordinances must be consistent with public legislative policy, and must not contravene common right. These are general principles universally recognized. ${ }^{1}$

Without entering into a discussion of the nature, requisites and ralidity of ordinances, which as a rule, must be determined by reference to the organic act or charter of the municipality, it may be stated generally, that such ordinances must be arlopted by the proper body, and be published in the manner provided by law, ${ }^{2}$ the practical operation of an ordinance dating from its passage and publication. When so passed and published

1 Jong $r$. Shelby County, 12 Reporter, 285: Maxwell r. Jonesboro. 11 Ireisk. (Tenn.) 257: Williams $r$. Augusta, 4 Ga. 509; Mount Pleasant $r$. Breese, 11 Iowa. 399.
21 Dil. Municipal Corp. 376; Barnett $r$. Newark. 29 IIl. 62: Conboy $x$. Iowa City, 2 Iowa, 90. 
they aff rd constructive notice to all persons bumm to take notice of them. ${ }^{3}$

The only occasion the examiner will have to show the acts of municipal Jurlies, will te in relation to the opening or vacating of stroets and alleys, with an oreasional conveyances of muncipal property, which should be prefaced by a synopsis of the ordinane or pesolution anthorizing sane. Being in the nature of public laws no record is repuired in the registry of deeds, though this may bo acomplishod by the individual, and reconse must nsually be had to the corporate records. The abstract slould show: the dates repectively of passage and publication, and, when reconted, tho date of record; the subjectmatter, briefly stated; and the attentation, if any is reguired. The following will nore fully illustrate the subject:

\section{Tacation}
The Village of Jeflerson.
Ordinane. No. 1,000. 1dopted siept. $6,18 \pi 3$. Recorded Sept. 15, 19\%3. Book is of plats, page 13.

Recites, that whereas, a petition has been duly filed with the Board of Trustees of the Tillage of Jefferson, signed by Thos. Wilson and Lillie M. C. Wilson, representing that they are the owners of Blocks it and $: \%$ in Torrood Part, and praying said board to order a vacation of all that part of Washington Strcet lying between said Blocks, commencing at Indiana Street and ruming to Eastern Lenue.

And whereas, salisfactory evidenee having been filed by said petitioners of due notice of said applieation. and no objections appearing, therefore it is,

Ordained by the President and Board of Trustees of the Village of Jefferson, that all that part of Washington street, in Norwood Park, which lies between Blocks roj and ry, beginning on Indiana Strect and running through to Eastern Avenue, be and same hereby is vacated.

Published Sept. \%, $18 \%$.

3 Palmyra v. Morton, 25 Mo. 593; Buffalo v. Webster, 10 Wend. 99. 
Note.- Appended to the record of the foregoing is a certificate by it. is Daris, " Tillage clerli," that same is a true cony of the original ordinance.

Not infrequently a discriptive note setting forth the material facts will be sullicient to impart all necesary information. Whenever this method can be adtantageously employed its use is recommended, in orrer that the abstract may not be modened by mimportant details. This plan will be found to produce eminently satisfactory results in eases where certain acts are required to follow the ordinance before it becomes effective, and in such cases a full resume of the supplementary aets should be emborlied in the note. The following example will more fully explain the method:

Notw- From document To. Sins of the municipal year 1894, of the files of the proceetings of the Common Council of the C'ity of C'hicago, on file in the office of the City clerk of said city, it appears that an ordinance was passed by said Council on May 12. 1895, for the vacttion of the East 135 feet of allcy in. Block 6, Jones' Subdirision of the Tortheast quarter of Scetion $r$, Toun. 39 North, Range 10 East of the 3 A Principal Meridiun. but with a proviso that same should not talie effect until a new alley 18 feet in width should have been opened from North to South through the South 1ro feet of said Block, the East line thereof to be 135 fect West of Blank street, in accordance with map attacked to said ordinance; that said alley should be opened and plat of same placed of record within 30 days from passage of ordinance, othermise same to be of no effeet.

The new alley referred to in the foregring note would properly be shown as a subdivision of the block in question and the minutes of survey and plat womld immediately follow.

It will often happen that it may be deemed mnecessary or 
inexpedient to set forth the ter'ms of an ordinance, or the cxaminer may be directed to show same briefly with a reference to the record for particulars. Thus, take the case of a transfer of territory from one municipality to another. In such event the action of both municipalities should be shown, yet this may be accomplished brictly, in most cases, by simple notes, as for example:

Note.- There was recorded on A pril 22, 1857, in Book 2047 at page so6, as Doc. 819,864 , an ordinance for the annexation of the territory of the Tillage of Jefferson, known as Section 36, Town. 40 North, Range 13 East of the 3 d Principal Meridian, to the C'ity of Chicago. Approved and ratified at the general election held Tuesday, April 1, $185 \%$.

Also, Recorded May 25, 1887, as Doc. 833,477, in Book 2047 at page $3 S S$, is an ordinance for the annexation to the City of Chicago of the teritory embraced within the limits of Sertion 36. Town. 40 North, Range 13 East of the 3 d Prineipal Meridian, with the map of said annexed territory attached.

For particulars reference is made to the records.

Where the event is ancient and no questions have been raised respecting it, or where all questions growing out of it are settled, this brief mention will be sufficient to impart all the information necessary. On the other hand, if the event is recent a more ample exhibition of the instruments should, perhaps, be made. Matters of this kind, however, do not reach the title to the land and their significanee, at best, is only political. The principal olject of their insertion in the abstract is to alpraise the person perusing it of the proper locatim of the property.

\$391. Expcutive approval of Ordinances. In many eases the signature or expressed approval of the Mayor, or some corresponding officer, is required to give validity to an ordi- 
nance, and when the sulmission thereof to the executive of the mmicipality is made necessary ly charter or general laws, a noncompliance will be fatal to the ordinance. ${ }^{4}$ In sueh cases the fact of submission and approval should be noted as a material part of the abstract of the ordinanee.

$\$ 332$. Operation and Effect of Ordinances. It does not seem that a mmicipal corporation, more than an individual, can convey the title to real estate in any other manner than by a duly exeented deed," and where a conreyance has been attempted by ordinance no title has been held to pass, while sueh an ordinance has further been held to be so defective as a conveyance as not to give color of title in support of an

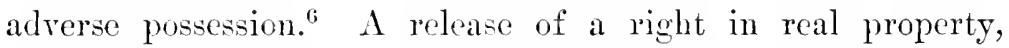
by ordinance and not by deed, will, it seems, be enforced in equity, when within the scope of the corporate power, and upon consideration, ${ }^{7}$ while the legal effect of a vacation of a public street or arenne, is to revest the title of the land embraced within its limits, in the original owner or person who dedieated same. ${ }^{\mathrm{s}}$

\$ 333. Municipal Resolutions. A resolution is an order of the council or governing board, of a special and temporary character, ${ }^{9}$ but, as a general rule, has the same effect as an ordinance, as both are legislative acts. ${ }^{10}$ Where any matter is eommitted to the decision of the comneil by the eharter, which is silent as to the mode, the decision may be evidenced by a resolution, and need not necessarily be by an ordinance, ${ }^{11}$ hence it is customary in sales of the municipal real estate, to authorize the sale and transfer of same by a resolution which

4 Babbidge $r$. Astoria, 25 Oreg. 417.

5 Dill. Mun. Corp. $\S 451$, and see, Cofran $\iota$. Cofran, 5 N. H. 458 ; Ang. \& Ames Corp. § 193.

6 Beaufort $r$. Duncan, 1 Jones $\mathbf{L}$. (N. C.) 239 .

7 Grant $v$. Davenport, 18 Ia. 179.
8 Hyde Park $r$. Borden, 94 Ill. 26 ; Gebhart $v$. Reeves, 75 Hll. 301. a Blanchard $v$. Bissell, 11 Ohio St. 96 .

10 Sower $r$. Plitadelphia, $35 \mathrm{~Pa}$ St. 231: Gas Co. v. San Francisco, 6 Cal. 190.

11 State v. Jersey City, 3 Dutch. (N. J.) 493. 
also directs the method of conregance and nominates the persons who are to execute the deed. ${ }^{12}$

It would seem to be the presailing doctrine that municipal converances of real property which upon their faces are regnlar, carry with them the presumption of a due and proper execution in pursuance of law: ${ }^{13}$ " hence." cheertes Mr. Dilion, "it is unnecesary for the grantee ur part claiming under it to produce the special resolution or ordinance authorizing its execution." 14 This may be true for the ordinary purposes of conreyancing, but can not be regarded as a safe rule in the preparation of an abstract. which should not ruly disclose sufficient of the deed to show a regular execution upon its face, but also the authority in pursuance of which it was made, that counsel mar know from inspection and comparison that it was duly esecuted. ${ }^{15}$ it leing the duty of counsel, so far as may be, to reduce presumptions to certainties, and whenerer an abstract is presented, showing a municipal deed but no order or resolution in support of it, a requisition should be made for the eridence of the authorits under which it was executed. In actions for the trial of disputed land titles, where a deed relied upon is the act of a muicipal corporation the authority for its execution must generally be put in eridence, ${ }^{15 a}$ and it would seem that conn-el exanining title shonld insist upon the same proof.

12 If the charter or con-tituent act of the corporation prescribes a particular mode in which the corporate property shall be disposed of, that mode must be pursued: ? Dill. on Mun. Corr. $\$ 47$. and see McCracken $r$. San Franci-co. 16 Cal. 591; Grojan $r$. San Francisen. 19 Cal. 590, where it wa= held that where municipal officers. under the authorits of a roid ordinance. had made sales of corporate real sitate. no title passed. the ordinance and sales not having been in conformity to the charter which prescribed a rule for such cases.

1.: Tamion $\because$ Foriana. $13 \mathrm{Mo}$ 565: Flint $r$. Clinton Countr. 12 $\mathrm{X}$. H. 43. See Hart 2 . Stone. 30 Conn. 94.

14 Dill. Mun. Corp. $\$ 450$.

15 Conrayances of rea? premierts ly the oficer $=\hat{f}$ a munivipal corforation moll the mals hy virtue of a sperial authority for that purnoze: Merrill r. Furlank, 23 Me. $53 \mathrm{s.}$

15 . Ward t. Lumber Co.. 70 Wis. 445 . 
\$ 334. Oficial Certificates. Certificates of officers having the legal eustody or supervision of records, ete, as well as of ministerial officers in the performance of some legal duty, are of frequent occurrence. Usually they are appended to some kind of documentary evidence to which they have speeial relation, but they may be used as affirmative and independent proof of matters within the certifying officer's jurisdiction. Instances are afforded by the ecrtifieates of levs, attachment, ete., made by officers executing the process of courts and which afford internal evidence of the matters therein recited.

Aside from the certificates of officers, and others, reeiting their own acts in connection with some partienlar proceeding in the line of their official duty, there is a elass of official eustodians who certify from the records, books, files, ete, committed to their care, and to whose certificates, under their official seal, if they have any, the statute in some cases and comity in others, attaches a certain degree of evidentiary value.

When a public officer is required or authorized by law to make a certificate or affidavit, touching an act performed by lim, or to a fact ascertained by him in the course of his official duty, and to file or deposit it in a public office, such certificate or affidavit when so filed or deposited is received as presumptive evidence of the facts therein stated, unless its effect is deelared by some special provision of law. Under this head come certifieates of sale by masters in chancery and of levy and attachment by sheriffs, examples of which will be found further on.

Certificates annexed to other documents for the purpose of proof or verification do not, as a rule, require nor should they receive extended notice, but when standing alone, and as affirmative evidence of some particular fact, they acquire a certain dignity that ealls for commensurate treatment. When these certificates, for instance, allude to facts which appear from the hooks, files and records of the officers of State in regard to the transfer of land by or to the government, Federal or State, or by the State to individuals, the original evidence of which is not accessible, or has been destroyed or lost, they become 
of the highest impontance and should be shown in detail. As, per example:

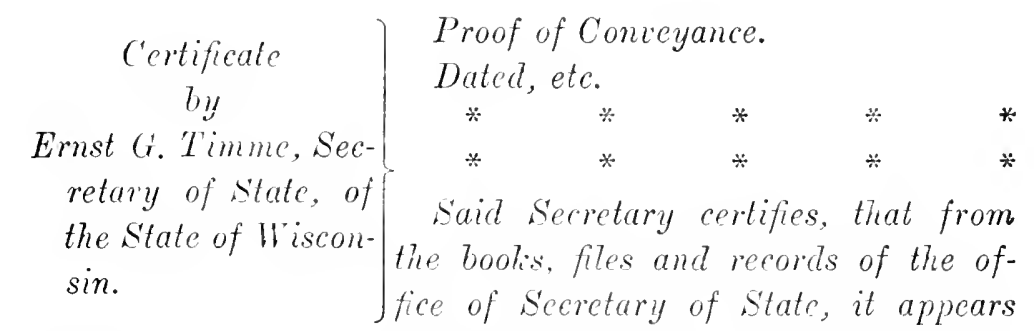
that on the 10th day of June, 1850, the following deseribed real estate. situated in the State of Wisconsin, vir.: [set out deseription] was duly transferred by the Cnited States to the State of Wisconsin, and that on the 15th day of July, 1852, the above described real estate was duly transferred by the State of Wisconsin to William Jones.

Signed by said Secretary and the great (or lesser) seal of the State of Wrisconsin affixed.

Where eertifieates are appendant merels, the degree of notice must be determined by the eharacter of the principal matter; as, if in the foregoing case a tranceript of books, files, ete., had been made, the eertifieate wonld simply have been by way of verification, and the examiner might have shown this by a formal abstract of the instrument as above, or he might with equal propriety mention it in this manner:

Certificate by Ernst G. Timme, Sccretary of State, that the "annexed and foregoing" is a true and correct transcript of all books, files, records, certificates and other written or documentary evidenre of title. on file or of record in his office, relating to or appertaining to the title to the lands described in the foregoing transeript, and of the whole thereof, appended.

\$ 335. Incopporeal Hereditaments. In an English work on titles this suljeret would occupy no inconsislerable space, while in the compilation and examination of English 
abstracts it plays a eonspicuous part, yet in the United States the term is seldom used, while the number of strietly ineorporeal hereditaments is very small. ${ }^{16}$ In this country they are usmally such things as come within the definitions and general doetrines of easements and servitudes.

\$ 386. Easements and Servitudes. An easement is technically mderstood to be raised or created by a grant, but may be reserved in a conveyance as effectually as by a grant by deed. Separate instruments are rarely employed to ereate easements, but oceasionally grants of rights of way will be found as well as instruments granting riparian rights, and in all cases, where such instruments are matters of reeord, purchasers of the land afiected thereby will take the premises subject to whatever rights they may eonfer upon others and burlened with the stipnlated service. ${ }^{1 i}$ Where an easement is appurtenant or aprendant to an estate in fee in lands, or in gross to the periom of the grantec for life or for years, it is incapable of alienation or conveyance in fee. ${ }^{18}$ When in gross, it is purely personal to the holder, and ean not be assigned, nor will it pass by descent ${ }^{19}$ when appurtenant, it is attached to the land as an incident and passes with it, whether the land be conveyed for a term of rears, for life, or in fee. ${ }^{20}$ Being incident to the land, it can not be separated from or transferred independent of the land to which it inheres. ${ }^{21}$ Where an easement is created by a separate instrment, as a grant of a right

16 The principal incorporeal hereditaments according to the common law; are: Adrowsons and next presentations, tithes, manors, franchises, offices, commons, rights of way, of light, wood, water, rents and annuities: Lee on Abstracts, ${ }^{*} 117$; 2 Black, Com. 21.

17 Turpin r. R. R. Co., 105 Ill. 11. 1s Wash. Easements. 10; Hiwle r. Knecht. 99 Ill. 496 .

19 Smiles $r$. Hastings, $22 \mathrm{X}$. Y. 217; Kœlle $v$. Knecht, 99 III. 496.
2 See "Easements and Servitudes." supra, p. 21.

21 Wash. Easements, 10; Kolle $r$. Knecht, 99 Ill. 496. "They are in the nature of covenants running with the land," says the court in Garrison $r$. Rudd, 19 IH. 55s, "and like them, must respect the thing granted or demised, and must concern the land or estate conveyed. They pasi bs a conveyance of the land, under the term 'appurtenances,' without being expressly named." 
of way, the esschtial toms should be fully stated in the ahotract and, for this mriowe, the better way is to employ the exact language of the deerl.

\$ 337. Party Wall Agrecments. In populous localities party wall agreements are of frecuent oceurrence, and, though not technically converanees of land, their legal effect is to give to each of the partics an easement on the other's land which becones appurtenant to their several estates and passes to their respective assignees by any mode of converance that may be effectual to transfer the land iteelf. While the authorities are not altogether harmonions with respect to the legal effect of corenants and agreements proriding for the construction of party walls between adjacent proprictors, the decided weight of authority fully estahlishes the propositions above stated, and an agreement under the hands and seals of the parties, containing mutual corenants and stipulations made binding on their respective heirs and assigns, will, when duly delivered and acted upon, create cross-easements in the respective owners of the adjacent lots with which the covenants in the agreement will rum, so as to bind all pereons succeeding to the estates to which such easements are appurtenant. ${ }^{22}$ Purchasers from such parties take with constructive, if not actual, notice of the agreement, and are presumed to have assmmed the burdens as well as the benefits which are incident to it. ${ }^{.3}$ "We concede," says Mulkey, J., "the general doctrine, that where the relation of landlord and tenant does not exist, only such covenants as are beneficial to the estate will rm with the land; but we do not regard the doctrine as applicable to cases where adjacent proprietors have so contracted as to create mutual easements mon each other's estates, and entered into covenants with respect to the same. The new relation

22 Hart $r$ L L yon, 90 N. Y. 6633 ; Thompson v. Curtis, 28 Iowa, 229; Standish $v$. Lawrence, 111 Mass. IIl.

29. Poclie $r$. [1] man. 104 II!. 11; Main $v$. Cumston, 98 Mass. 317;
Dorsey $r$. R. R. Co., 58 Ill. 65; Rindge r. Baker. 57 N. Y. 209 ; Rouers $r$. Sinsheimer, in N. Y. 646; IIart, $r$. Ixom, 90 N. Y. 6633 ; 'Thompson $\ell$. Curtis, as Jowa, 229?. 
thus created being of an intimate character, involving reciprocal duties with respect to each other's estates, may be regarded as an equiralent for the absence of tenure, so as to give effect to all covenants without regard to whether they are benefieial or onerous." 24 The abstract should disclose all the material facts. An example is appended:

$\left.\begin{array}{c}\text { Hiram Thompson } \\ \text { with } \\ \text { Jared B. Lalie. }\end{array}\right\} \begin{aligned} & \text { Party Wall Agreement. } \\ & \text { Dated, etc. } \\ & * * * * * * \\ & \text { Pecites, that first party is }\end{aligned}$

the ouner of the following described land [deseribing same] and that second party is the ouner of certain land adjoining same described as [describing sane] and that said first party proposes to crect on his said land a brich: building, and is desirous of haing the wall betwecn the two above described lots built onc-half on cach of of said lots for their mutual benefit, and that sceond party has assented to same, on condition that he shall have the right of using the said wall as hercinafter expressed.

And said parties corcnant and agree to and with each other as follows:

Said second party agrees that if first party shall build at any time a partition wall, he may erect and maintain onehalf of same on his, second party's land [state conditions if any] and way cuter on same with worlinen and materials; and further aygres that whenerer he shall mate use of same, he, or his heirs and assigns, will pay to said first party onehalf of the uhole cost of said parition wall.

Saic first party agrecs that sccond pariy. his heirs and assigns, may use said partition wall for the benefit of any building he may hercafter erect or place on his said land, provided he does not cut into said wall beyond his own half thereof, and pays the price stipulated above.

24 Roche $r$. Ullman, 104 Iil. 11. 
Signed by both parlies, and acknowledged by them August $1,18 \% 9$.

\$ 338. Letters. For a large variely of matters relating to interests in land, and sales and conreyances of such interest., which by law are not reguired to Je under seal or attested by any solemnity, epistolary corresundence, notes and memoranda, are competent evidence. This is partienlarly the case in regard to trusts, agreements ankl conclitions of sale, and sometimes in supplying missing information relative to descents, ete. Hence, it is not uncommon to tind lotters of record relating to or concerning interests in land. A contract for the sale of land made by letter correspondence between the parties is valid and will be enforced, if the consideration to be paid, and the time of parment, and description of the property appear sufficiently certain to enable a court to make a deeree. 25 Where a person aequires title to land in trust for another, and writes him a letter showing cleary that he holds the same in trust, this will be sufficient to manifest the trust as required by the statute of frauds: ${ }^{\circ}$ The abstract of a letter consists of little else than its recitals.

$\$ 339$. Aficiarits. In abstracting the proceedings of courts, in matters relating to title, affidarits will occasionally be met with, but as a rule they are of such a nature that their contents are immaterial to the examination and they may be disposed of in a single line and frequently passed without notice. There is, however, another class of affidavits, resorted to by conveyancers under a choice of difficulties, which frequently figure on the records and in the abstract. These are the ex parte sworn statements of individuals respecting some question raised by the examination, usually relating to deaths, marriages, births, ete., conceming which no other or better evidence can be found. Family records are not universal, now cren where, as is the enstom of many of the Statrs, a recorrl of

25 Nenfille $r$. Slewart, 1 Hill, 166 ; Wirth $v$. Lawrence, 1 Paige, 26 Moore $"$. Pickett, 62 Ill. 158. 434. 
births, deaths and marriages is kent by proper officers, can the requisite information be always obtained. When such is the case resort must be had to the next best and most available testimony, which is usmally supplied by the aftidavit of some person setting forth his knowledge of the matters under inquiry. Such an instrument, it is true, possesses no legal validity, and not being marle under the sanction of a court, or in any legal proceeding, is not strictly evilence for any purpose, ${ }^{27}$ yet being usually all that can be adduced, it has been, as it were, by eommon eonsent of the profession, arlopted as evidence in the examination of titles and the testimony taken as corroborative of general reputation, concurrent possession, ete. ${ }^{28}$ Such affidarits, though possessing no legal effieacy, should yet be attended with the same solemnities and formalities that are required in affidavits for use in court.

Ordinarily where an affidarit is required, and the statute does not designate the particular officer before whom the aet may be performed, it may be made before any officer having general authority under the statute to administer and eertify oaths. ${ }^{29}$ No legal rules can apply to affidavits of this nature, except inferentially, but, so far as the same may apply, they shonkl be eonstrued by the same standard as atidavits in legal proceedings. ${ }^{30}$ The eontents of an affidavit may be shown in this manner:

$\left.\begin{array}{c}\text { Affidavit } \\ \text { Wy }\end{array}\right\} \begin{aligned} & \text { Sulliam O. Jones. } \\ & \text { Aug. 4, 1S93. and sworn to } \\ & \text { Recorded Aug. S, 1883. } \\ & \text { Book 119, page 220. } \\ & \text { Venue, Cook Counly, Ills. }\end{aligned}$

Recites that, affiant was well acquainted with Robert Simpson, the identical person named as yrantor in a decd from

27 Quinn v. Rawson, 5 Ill. Apl. 130.

25 Lee on Abstracts, 215; Taylor on Titles, 136.
29 Dunn $r$. Ketchum, 38 Cal. 93; Wood $r$. Pank, 9 Cow. 194.

8) An afinlavit is simply a declaration on oath, in writing, sworn 
Robert Simpson to Halter Scott, dated June 1, 18\%9, and recorded June 2, 1859, in Book 52, page 521 of the recorils of Cook County, Ills, as document 2,110 , and that at the date of said deed said Robert Simpson, to the linowledge of affiant, was an uninarried man.

Jurat by "William Black, Notary Public." No Notarial seal of record. No other designation of offecer.

\section{$\S 340$. Continued - General Requisites-Sufficiency.}

It is usual, though not necessary, for the affiant to subseribe the affidavit, but, in the absence of positive requirements, an affidarit which appears by jurat and signature of an officer thereto to have been duly sworn to, is sutficient. ${ }^{31}$ On the other hand, if the officer fails to sign the jurat the affidarit is invalid. ${ }^{32}$ An afindarit relied upon as eridence of facts must allege the facts positivels. Arerring them to exist "as aftiant believes" proves nothing. ${ }^{33}$ The renue is generally regarded as a material fact in all affidarits, yet conts have exhibited great leniency in this particular and it has been held, that notwithstanding the instrument is without venue ret if it is subscribed by an officer duly empowered to administer and certify oaths, it will be presumed that the oath was taken only in the comnty where the ofiricer was authorized to act. ${ }^{34}$

$\$ 341$. Unrecorded Evilence. 1 loose and dangerous habit prevails with many examiners, of incorporating in their examinations evidences of facts not disclosed by the records. This is often the case with respect to affidavits, relrases, etc, the examiner usually putting such mrecorded matter in the shape of a note, and stating: "Mr. Blank las this day exhibited to us an affidarit by Wm. Parsons, of Providence, R. I.,

to by a party before some person who has authority under the law to administer oaths, and need not be in any particular form: Ifarris $r$ Juster, 80 Ill. 307.

31 Turpin $v$. Road ('o., 48 Ind. 45 ; Cappock $v$. Smith, 54 Miss. 640.

27
32 Morris $r$. State, 2 'Tex. Apr. 502 .

33 Thomsen $r$. Ilirginlotham, 18 Kan. 42; Mimpley r. Medrath, Ta I11. 591.

34 Hertig $v$. People, 159 Ill. 237. 
wherein he states that John Jones was a bachelor and that he died at Providence, R. I., ummarried," ete. But this is the mildest form, for, in an abstrat now before the writer, made by a responsible firm, is the full abstract of an instrument inserted at the request of their elient, and which they state in a fort-note, is "not recorded in Blank Comnty, Ills." Under no consideration should this ever be done except in the solitary case of titles emanating from the government. Where the examiner possesses reliable data, procured from the only authentic sources, the general land offices of the government, statutes, ete., this is not only permissible but should be done as a matter of comrse. In all other eases, if the client deems his evidence of sufficient importance to be inserted in the abstract, it should first be filed for record in the offices of registration where it will be properly covered by the examiner's certificate of seareh. 


\section{CHAPTER XXII.}

\section{MORTGAGES.}

$\S 342$. Nature of mortgages.

343. Different kinds of mortgages.

344. The equity of redemption.

345. Rights of mortgagor.

346. Miortgages as affected by estoppel.

347. Merger.

348. Equitable mortgages.

349. Vendor's liens.

350. Mortgages proper.

35l. Statutory forms.

352. Uncertainty or error of deseription.

353. Covenants in mortgages.

354. Effect of special covenants.

355. Special stipulations and conditions.

356. Effeet of informality.

357. Purchase money mort gages.

358. Mortgage of the homestead.
\$ 359. Mortgage of after-acquired property.

360. Record of mortgages.

361. Notice imputed from possession.

362. Re-records.

363. Trust deeds.

364. Power of sile.

365. Assigument.

366. Operation and effect of assignment.s.

367 . Formal requisites of assignments.

368. Release and satisfaction.

369. Form and requisites of release.

370. Release by trustees.

371. Marginal discharge.

372. Foreclosure.

373. Proof of title under foreclosure.

\$ 3 12 . Nature of Mortgages. A mortgage, as defined by Chancellor Kent, is a conveyance of an estate by way of plerlge for the security of a debt, to become void on the payment of it. ${ }^{1}$ The tern "mortgage" has a technical signification in law, and whon used in legal procentings as descriptive of a writion instrument, must be taken and construed accorrling to its fechuiral legal import. An equity of redemption is an cisential ingrer-

14 Kent rom. 136; Marvin $v$. face purports to be grivell to secelure

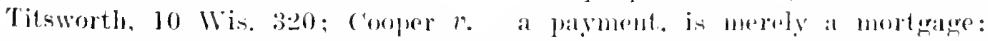
Whitney, 3 Hlill, 95. Any ind ru- cowles v. Marble, 37 Mich. 1.5. ment of conveyane that on its 
dient and is always implied, even though no defeasance is expressed in the instrument itself. ${ }^{2}$

1 mortgage, in form, purports to convey a present legal estate to the mortgagee, liable to be defeated only by performance of stipulated conditions, and so it was long held that the legal effect of the instrument was to vest title in the mortgagee, subject only to the expressed condition or proviso, ${ }^{3}$ and the mortgagor's right to regain his estate, after condition broken, which was by application to a court of chancery, was called "the equity of redemption." The modern doctrine is, however, that a mortgage is but a lien on land, by way of security for the debt, the legal title remaining in the mortgagor, subject only to the lien of the mortgage, and that the "equity of redemption" is a legal right." The right of a mortgagee to hold the mortgaged premises as sccurity for his debt is not an estate in land and passes only by an ascignment of the debt. ${ }^{5}$

$\S 313$. Difierent Kinds of Mortgages. Conveyances for the security of a debt or the protection of creditors, may be divided into three classes. The first includes mortgages properly so called, being converances from debtor to creditor, ex-

2 Walton r. Cody, 1 Wis. 420 ; Peugh $r$. Davis, 96 U. S. 332; Wing $r$. Cooper, 37 Vt. 169; Pearss $r$. Ford, 108 Ill. 16. "Once a mortgage, always a mortgage," is a univernal rule in equity, and no agreement in a mortgage to change it into an absolute conveyance upon any condition or event whatever, will be allowed to prevail: Clark $v$. Henry, 2 Cow. 324.

3 Croft v. Bunster, 9 Wis. 503; Drayton $r$. Marshall, 1 Rice's Eq. (S. C.) 373 ; Stewart $v$. Barrow, $i$ Bush (Ky.), 368. This doctrine still prevails in a few States, and in a modified form in others; as, after condition broken or default, the legal title is held to pass to the mortgagee: Johnson $r$. Houston, 47 Mo. 227; Fuller $v$. Eddy, 49 Vt. Il.
4 Vason $r$. Ball, 56 Ga. 268; Wing $r$. Cooper, 37 Vt. 169; Fletcher $v$. Holmes, 32 Ind. 497; Carpenter $r$. Sowell, 42 Miss. 28; Woods $v$. Hildebrand. 46 Mo. 284; Astor $v$. Hoyt, 5 Wend. 602. This was originally the equitable doctrine, established to prevent the hardships springing by the rules of law from a failure in the strict performance of the conditions attached to the conveyance, and to give effect to the just intent of the parties in contracts of this description, but has gradually been adopted by the courts of law.

5 Mack $r$. Wetzlar, 39 Cal. 247. This would secm to be generally true even in those States which regard a mortgage as a substantive form of conveyance. 
pressed to be by way of a pledge or security for the payment of an indebtedness, or for the indemnification of the grantee against a particular loss, and containing a clanse of defeasance upon the performance of the stipulated conditions. To this division also belongs that class of mortgage securities technically known as "Trust Deeds," wherein the debts are specified and the creditors naned or described, but because of their large number, or to allow greater freedom in the transfer of the eridences of the indebtedness, or from other circumstances making a conveyance directly to them less convenient, the deed is made to a mortgagee who combines the office of trustee, the ereditors standing in the position of cestuis que trust."

The second division consists of conveyances which are absolute in form, but being intended as seeurity for debt only, courts of equity will give effect to the intention of the parties whaterer may be the form of the converance, and treat the transaction as a mortgage, except as against the rights of bona fide purchaser's or other intervening equities. ${ }^{\top}$ These are known as "equitable mortgages," and being usually dependent on undisclosed intention, are to be treated and considered in the abstract only according to their manifest lecal import.

The third division contemplates all deeds of trust or assignments for the parment of creditors generally, the mortgagee in such case representing the rights of the mortgagor only. ${ }^{9}$ Mortgages may assume a rariety of shapes and their identity become almost concealed, but the fact of security is always sufficient to furnish an indication of their true character."

6 Hurley $r$. Futes, 6 Koh. 386 ; Turner $r$. Watkins. 31 Ark. 4.29. A trust deed executed to secure a debt does not ve:t in the trustee the legal title to the land. which can only be taken away from the grantor ly froreclosure or otluer lewal poreses in sulustintial aceord with the deed: lngle $r$. C'ulbertsn, 4:3 Iowa, 26.5.

7 Sweet $r$. Mitchell, 15 Wis. 6itl;
French $r$. Burns, 35 Corn. 359: Shays $r$. Norton, 48 Ill. 100.

8 Bank $v$. Lamahan, 45 W1. 396.

9 Spackman $r$. Ott, 6.j Pr. St. 131.

in $A$ penal bord to reconvey lamels hats heen held to be a mortegage: Reyuolds r. Sente. Brayt. (V1.) 75. So of a deed with a bond for reconseyance: Wing 1 . Cooper, 37 Vt. 199; but otherwise upon 
\$ 344. The Equity of Redemption. The estate remaining in the mortgagor is popmlarly, but erroneonsly, called an "equity of redemption," retaining the name it had when the legal estate was rested in the mortcagee, and the right to redeem existed only in eqnity. Althongh a misnomer, it does not mislead. The term is conrenient and its meaning well muderstood. The legal estate remains in the mortgagor and is sulject to dower and curtesy; the lien of judgments; may be sold on execution; and may be the subject of mortgage and sale, the same as any other estate in lands, while the mortgagee has but a lien upon the land as a security for his debt, and the same is not liable to his debts, nor subject to any of the incidents of an estate in lands. ${ }^{11}$ The mortgagor retains and is possessed of an cstate in the land in virtue of his former and original right, and there is no change of ownership. So far as the entire estate is concerned, there is but one title and this is shared between the mortgagor and mortgagee, the one being the general owner and the other having a lien which, upon a foreclosme of the right to redeem, may ripen into an absolute title, their respective parts, when united, constituting one title. ${ }^{12}$ The possession of the mortgaged premises in no

facts stated: Rich $r$. Doane, $35 \mathrm{rt}$. 12.5. Su also of a deed with a stipulation that title shall not vest mit the purchase money is paid: Pugh $r$. Tinlt, 27 Miss. 461. And generally any converance expressed to be to secure a payment: Cowles $t$. Marble, 37 Mich. 158; Bearss r. Forrl, 108 Ill. 16; Parke $\iota$. Hall, 2 Piek. (Mass.) 211.

11 Odell $r$. Nontross, $68 \mathrm{~N} . \mathrm{Y}$. 499; 2 Wash. Roul Prop. 152: Gorham $r$. Arnolel, 22 Mich. 217; White $r$. Rittenneyer, 30 Iowa, 268. This is the goneral doctrine, ret in some States it is still held that, aftor the expiration of the law day, the mortgagor or one oceupying his position, is considered as tenant at snfferance of the mortgagee, and liable to be evicted withont notice to quit. The mortgagee, in such case, has a right of entry which he may peaceally assert without notrce and without action; or he may. with or withont notice to quit, bring ejectment, and may recover possession of the land and dimages for nse and recupation after motice to quit, and if no notice, then after the service of the writ, and this either againt the notingor or his assignee: Mason r. (Any a6 Vt. 311 ; Collame $r$. Langlon, 29 Vt. $\mathbf{3 2}$; Welsh $r$. Phillips, 54 Ala. 89.

12 Odell $r$. Nontross, $6 \mathrm{~S}$ N. Y. 499 . 
way affeets the riglt of the one to redeem or the other to foreclosure. ${ }^{13}$

A party taking a mortgage on land pending a bill to foreclose a prior mortgage or lien, will be bound by the decree and sale made in the pending suit the sane as if made a party to the bill to foreclose, and will be bound to redeem from such sale within the period allowed by law. If he fails to do so his equity of redemption will he barred, ${ }^{14}$ and his rights under his mortgage will be extinguished and lost.

$\$ 345$. Rights of Mortgagor. The mortgagor, possessing the legal as well as the equitalle title, may perform any valid act relative to the property, and make any contract with refence to the title, subject to the lien of the mortgage, but he can, it seems, do no aet which shall be prejudicial to his mortgagee's interests or essentially change the legal character of the land. IIence, no dedication to public use of portions of a pareel of land, made ly the general owner after giving a mortgage upon it, can affect the lien of the mortgage, and a purchaser at a sale on foreclosure will take title free of the dedication. ${ }^{15}$

$\S 346$. Mortgages as Affected by Estoppel. It is a well settled prineiple of law, that if one who has no title to lands nevertheless makes a deed of converance, with warranty, and afterward himself purchases and receives the title, the same will vest immediately in his grante, who will hold the land in virtue of his deed with warranty, as against such grantor, by estoppel. In such ease the estoppel is held to bind the land, and create an interest in it. The grantor, being at the same time the warrantor of the title which he has assumed the right to convey, will not be heard to set up a title in limself against his own prior grant, nor to say that he had not the title at the late of the conveyance, or that it did not pass to his grantee in virtue of his deed. ${ }^{\mathbf{1 6}}$ 228.

13 Parsons v. Nogggle, 23 Minn.

14 Pratt v. Pratt, 96 Ill. 184.

15 Hague $v$. West Hoboken, $23 \mathrm{~N}$.
J. Eq. 354; Walker r. Summers, 9 W. Va. 533.

16 Teft $v$. Munson, 57 N. Y. 97 ;

Work r. Wellend, 13 N. H. 389; 
The doctrine is equally well settled that the estoppel binds not only the parties, but all priries, whether of blood, law, or estate ${ }^{17}$ and in such ease, the title is treated as having been previonsly rested in the grantor, and as having passed immediately upon the execution of his deed, by way of estoppel. So where a party makes a mortgage with express or implied warranty of title, he thereby becomes estopped from disputing that, at the date of the mortgage, he had the title and conveyed it; and this estoppel applies equally to all persons to whom such party may make subsequent conveyances, by deed, after he has obtained a title. Snch subsequent grantees are estopped from denying that the original srantor had title to the land at the date of the mortgige, and he must, therefore, for every purpose as against his grantees, be treated as having had the title at that date. ${ }^{18}$ Nor does this doctrine at all militate against the rule, that the record of a conveyance made by one having no title is a mullity, and constructive notice to is one.

When a mortgage is in the statutory form it is equivalent to one containing all the usnal covenants of title, and subsequently aequired titles inme to the benefit of the mortgagee. ${ }^{19}$

$\$ 347$. Merger. One of the most perplexing incidents of title that can come to the notice of the examiner in comeetion with mortgages, is that which forms the caption to this section, and as it is impossible, in the brief limits of this work, to enter into any extended diseussion of the subjcet, only passing reference can be made to it. The doctrine, as formulated by the carlier decisions, is that whenever a greater and a less estate unite in the same person, without any intermediate estate, the lesser is merged, ${ }^{20}$ and where the legal and equitable estates meet and unite in the same person withont an intervening interest ontstanding in a third person, the equi-

Jackson r. Bull, 1 Johns. Cas. 81; White $r$. Patten, 24 Pick. 324; Pike r. Galvin, 29 Me. 183.

17 Teft $r$. Munson, 57 N. Y. 97.

1 ऽ Teft $r$. Munson, 57 N. Y. 97 ; Wlite $\varepsilon$. Patten, 24 Pick. 324;
Ehler $r$. Derby, as Ill. 22s; R. \& M. R. R. Co. $r$. Trust Co., 49 Ill. $32,1$. 19 Elder $r$. Derly. 98 Ill. 228. 21. Jackson $r$. Roberts, 1 Wend. 478; James $v$. Morey, 2 Cow. 246. 
table is merged in the legal estate, the latter alone subsisting. Thus, a conveyance by the mortgagor to the mortgagee extinguishes the mortgage. ${ }^{21}$

Later decisions have greatly modified this rule and it is now held, that where taro estates meet as alove described, a merger does not necessarily follow, bnt will depend upon the intent and interest of the parties, and where it beemes necessary to advance the ends of justice, the two estates will he kept separate; thus, a deed from a morteagre to a mortergee, intended as additional security only, and not as a satifiaction of the mortgage, will not merge the mortgace in the sreater estate so as to give priority to another mortace which is a second lien. ${ }^{22}$ So, also in the absence of a special aprement to that effect, the taking of a new mortwace, from the same party and on the same property, will not merge or extinguish a prim one. $^{23}$ The rule, as first stated, thongh inflexible at law, is in equity controlled by the express or implied intention of the party in whom the interests or estates unite, and the mortgage interest will in equity be held to have meraed the fee, or otherwise, according to the actual or presumed intention of the mortgagee. ${ }^{24}$

With respect to merger no gencral rule can be laid down, for the question will depend in each case npon the interests and intent of the parties, and the denands of justice and efuitr.25 The most rigid investigation must be made by counsel wherever

21 Jackson $r$. Devitt, 6 C'ow. 310. 22 Huebseh $r$. Schnell, sl HJ. 281. 2:3 Cluristian $t$. Newberry, 61 Mo. 446.

24 Aiken $v$. R. R. Co., 37 Wis. 469; Morgan 2 . Hammet, 34 Wis. 512; Powell $x$. Smith, 30 Mich. 451; Waterloo Bank $r$. Elmore, 5: Iowa, 511 ; Tower 2 . Divine, 37 Mirl. 413.

as Franklyn $r$. Hayward, 6l How. Jr. (N. Y.) 43. Where a mortegager salls the moreracel premises, subject to the mortguge, and a thirl party, having purchased the nort- gage, afterward, throngh mene conveyances, obtains tille to the land, Je thereby heoonses rested with the estates of looth mortangor and morterace: the owmen of the morlgane having arduind tles poimay fund for its paryon nt, whish is of value efplal to the bertent

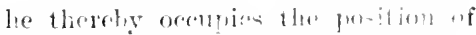

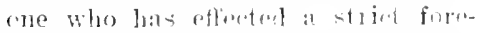

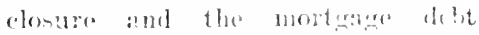
nutat be reererded as patid: Lilly $r$. Palmer, 5l Ill. 331. 
an apparent merger occurs in the title, as the record does not impart notice of nerger, or of any other fact which depends alone on the intention of the parties, or other extrinsic evidence, and if any one takes a converance upon the assumption that a former mortgage to his grantor has been merged in a subsequent converance of the fee, he does so at his peril. ${ }^{26}$

\$ 345. Equitable Mortgages. It is an established doctrine that a court of equity will treat a deed absolute in form, as a mortgage when it is exeented as security for a loan of money, for the conrt looks berond the terms of the instrument to the real transaction, and when that is shown to be one of security, and not of sale, it will give effect to the actual contract of the parties. ${ }^{27}$ Such a deed carries with it all the incidents of a mortgage, and the rights and obligations of the parties to the instrument are the same as if it had been subject to a defeasance expressed in the body thereof, or executed simultaneonsy with it. ${ }^{2 s}$ It is a further established doctrine that an equity of redemption is inseparably comnected with a mortgage; that is to say, so long as the instrmment is one of security the borrower has in a count of equity a right to redeem the property upon payment of the loan, and this right can not be waived or abandoned by any stipulation of the parties made at the time, even if embodied in the mortgage. This is a doetrine from which a court of equity never deriates. "Its maintenance is deened cssential to the protection of the debtor, who, under pressing necessitics, will often submit to ruinous conditions, expecting or hoping to be able to repay the loan

2s: Or. \& Wash. Trust Co. r. Shaw. 5 Sawyer (C. Ct.), 336.

27 Peugh $r$. Davis, 96 C. S. 332: Filein $r$. NeNamara, 54 Miss. 90 ; Carr $r$. Carr, 52 N. Y. 251 ; Shays $r$. Norton, 48 1ll. 100; Turner $r$. Kerr, 44 Mo. 429; Moore $r$. Wade, 8 Kan. 380 ; Kerr $r$. Agard, 24 Wis. 378. The rule that parol proof is atmissible to show that a conveyance of real estate, absolute upon its face, was intended to be a mortcage or security merely, is recognized and applied for the reason, that such evilence is received not to contradict an instrument of writing. but to prove an equity superior to $\mathrm{it}$ : Saunders $r$. Stewart, 7 Nev. 200; Wilcox $r$. Bates, 26 Wis. 465.

2s Odell $r$. Montrose, 68 N. Y. 499 . 
at its maturity and thus prevent the conditions from being enforced and the property sacrificed." 29

In view of these statements how is counsel to determine, on perusal of the abstract, what are and what are not mortgages, if all the instruments aprear ahoolute on their face? There is but one answer to the question. He ean not. The legal import of an absolute conveyance is that it carries the fee, ${ }^{30}$ and any contradiction of its apparent effect must arise from extrinsic evidence. This latter counsel can not know, nor is he expected to have such knowledge. The record rarely furnishes any clue to the true character of this class of conveyances, the facts governing their equitable nature resting entirely in parol, hence questions of this kind can scldom arise in the preparation of alstraets and only incidentally in passing upon titles. The examiner can judge of the lexul sufficiency and effeet of instruments only as they are presented on the record. ${ }^{31}$ Subsequent purchasers for value, withont notice, will be protected by the record, and where one in lossession of land, under a conreyance absolute on its face, sells the same, his grantee, withont notice that his vendor's deed was but a mortgage, will hold the property free from any equity of redemption ${ }^{32}$ and even thongh a court of equity afterward decides that the conveyance was in fact a mortgage, and that the

29 Field, J., in l'eugh $r$. Daris, 96 U. S. 332 ; Clark $r$. Henry, 2 Cow. 324 ; and see Walton $r$. Cody, 1 Wis. 420; Bearss $r$. Ford, 109 Ill. 16 .

30 A conveyance of the lemal title to secure the payment of money differs from a statutory nortgage in that the logal title passes to the grantre, the grantor rescrving the right in equity to rodecon. This right, however, may become barred by the statute of limitations, and when so barred that an artion for affirmative rolief ean not be maintained thereon. it sin not be interposed as a defense to an action liy the srantee to recover possession of the properts: lichardi $r$. Crawforl, 50 Iowa, 494. Sce, Elwards ง. Trumbull, 50 Pa. St. 509; Shaw $r$. Niltshire, 6.5 Me. 49.5. This re sult always follows if the instrument be recordid in the recomel of deets and mot of mertgages: brown r. Dean, 3 Wenl. (N. Y.) ogs.

31 It is the sootlest poling of the law to erive security to, am confidenee in, titles to the lambed estates of the eomtly whirh appear of rerord to les anod: MeVey $v$. MrQuality. 97 111. 9:3.

:2zenkins $v$. Tioscmburer, 105 Ill. 157 . 
mortgagor is entitled to his equity of redemption, yet the titio to the property will not be disturbed, but judgment in personam will be given against the mortgagee for the amount equitably due by him to the mortgagor. ${ }^{33}$

Where a lien on land is expressly reserved in the deed conveying such land, which is duly recorded, a clear equitable mortgage is ereated of which every one is bound to take notiee; ${ }^{34}$ but something more than a mere rescrvation of a right to purehase, or covenant to reconvey, must be shown in order to convert a deed absolute on its face into a mortgage. ${ }^{35}$ There is no positive rule that a covenant to reconvey shall be regarded, either in law or equity, as a defeasance. The owner of lands may be willing to sell at the price agreed upon, and the purehaser may also be willing to give the vendor the right to repurchase, upon specified terms. Such a contract is not opposed to publie policy, nor is it in any sense illegal. ${ }^{36}$

Equitable mortgages arising from the deposit of title deeds are not generally reognized, ${ }^{37}$ and the common-law doctrine respecting pledges of this lind ean not be said to prevail in this eountry.

$\$ 349$. Vendor's Lisus. It has long been settled that the ventor of real property, notwithstanding he has conveyed the legal title, has a lien on snch property for the unpaid purchase

33 Bangher $v$. Merryman, $32 \mathrm{Md}$. 186: Jackson $r$. MeChesney, 7 Cow. 360 ; Grimstone $v$. Carter, 3 Paige, 421.

34 Davis $r$. Hamilton, 50 Miss. 213 ; Armentront's Exr. $v$ Gibbons, 30 Gratt. (Va.) 652; Dingley $r$. Bank, 57 Cal. 467; as where a deed contains a stipulation that no title shall vest until the purcliase money has been paid (Pugh $v$. Ilolt, 27 Miss. 461; Austin $v$. Downer, $25 \mathrm{Vt}$. 5.59 , or that the deed shall be $a b$ solute on the payment of certain notes, but in default thereof to be void (Bank $r$. Drummond, 5 Mass.
$321)$. So if it be for the performance of any other duty, such as maintenance of the grantor during life, ete.: Lanfair $v$. Lanfair, 18 Pjek. (Mass.) 299.

35 But see Peterson $r$. Clark, 15 Johns. (N. Y.) 205.

36 Ianford $v$. Blessing, So Ill. 1SS; Henly $v$. Hotaling, 41 Cal. 22; Glover $v$. Payn, 19 Wend. 518.

37 Probasco $r$. Johnson, 2 Disney (Ohio), 96. The registry of a mortgage is a sulstitute for the deposit of the title deeds: Johnson $v$. Stagg; 2 Joluns. 510. 
money while it remains in the hands of the vendee, or volunteers or purchasers with notice. This, howerer, applies mainly to inplied liens, for where there is a distinct reserration of lien unon the face of the dend, it has been held to constitute a specific charge upon the land as ralid and effectual as a deed of trust or mortegage, ${ }^{3 s}$ and, fnither, that the lien being set forth in the rery tirst link of the rendee's claim of title, purehasers from him have just as much notice of it as they would have had of a lien on the land by mortgage or trust deed."39 "Indeed," sars Staples, J., " it may be a question whether a reserved lien is not of a higher nature than a mere nortgage security. In many eases the mortgage is treated as a mere incident to the debt, whereas the lien reserved is an express charge inherent in its nature upon the land which, in quity, is the natural primary fund for its payment." to

\$ 850. Nortgages Proper. A mortgage may be made by an absolute convefance with a defeasance back, but this form has never been in general use in the Enited States, and is now obsclete. The elass of conveyanees to which this name is technically applied consists of an instrument in form purporting to convey a present estate to the mortgagee, liable to be defeated by the performance of stipulated conditions, and is always between the principals to the transaction. Where the mortgage remains a valid and subsisting lien, it is advisable to narrate its essential terms quite fully, and when followed by forechosure, if other than by suit in chancer's, to relate with minuteness of detail the power of sale and other provisions, by anthority of which the forerhoure was made. Where the mortgage has been fully paid, satisfied and discharged, there exists no good reacon why it shonll appear at all, any mere than a judgment which has been satisfied; wet it is the mniweral custom of abstract makers to show, in the regular course of title, both the mortgage and its subseqnent assignments, if any,

\& Armentront's Ex'rs r. Ciiblons, 30 (ratt. (Ya. 632): Carpenter $v$. Mitwell, is! IJ!. 120.

39 Patton r. Iloge, 22 Gratt.
(Va.) 443; Ilines r. Porkins, 2 Ileisk. (Tem.) :39.

4" Coles $r$. Withers, 33 Gratt. (Va.) 186. 
and the discharge. Questions may sometimes arise that render an abstract of satisfied liens convenient or material, yet, as a sule, only the briefest outline should be presented, sufincient, in fact, to show the transaction and no more, that confusion may not result from the mingling of satisfied and unsatisfied liens. An unsatisfied, unforeclosed mortgage may be suffiiently presented as follows:

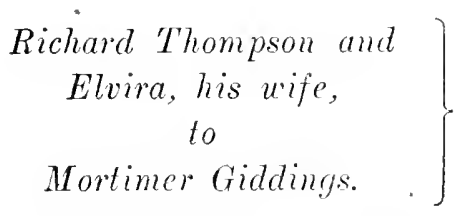

Mortgage.

Dated May 1, $1 S S O$.

Recorded May $2,18 S 0$.

Book 590, pg. 253.

To secure the payment of $\$ 500.00$ in one year from the date hereof, with interest at six per cent. per ammin, evidenced by said Richard Thompson's one promissory note of even date herewith. ${ }^{41}$

Conveys land in Brown County, Ills., described as lot one, in block one, of the Tillage of C'herry Tale, being part of the northeast quarter of section ten, town one noxth, of range five east of the third Principal Meridian.

Power of sale given on default after thirty days' notice. ${ }^{42}$ Homestead rights waiced.

Acknowledged May 1, $1 S 80$.

The above sufficiently designates the character and effect of an ordinary mortgage between individuals before default or foreclosure, or if followed by foreclosure in equity. When foreclosed by advertisement, if the mortgagee's deed is shown

41 It is the universal custom to witness the obligation of parment hy a bond or promisiory note, the mortgage simply stipulating that if the money be paid by the day named. the mortgage as well as the obligation shall be void; but it may often happen that no separate obligation is taken, and the absence of a bond or other express obliga- tion to pay the money will not make the instrument any less effectual as a mortgage, provided, of conrse, that the mortgagor had the money.

42 When followed by foreclosure under the power, set out the terms thereof fully. See the example of foreclosure of trust deed. 
in the same cxamination, instead of the reference to the power of sale above given, sut out the entire clause and accompanying conditions. When a foreclosure by advertisement and sale follows a mortgage shown in a former examination, or one appearing prior to the commencement of the search, a note, embodying the power of sale, should be appended to the abstract of the mortgagee's dect, in the same mamner as the example given of a trustee's deed, to which the reader is referred. Where the mortgage is given by a corporation, married woman, person under guardianship or other disability, a greater degree of detail is of course requirel, and all special matter, relating to eapacity, power to act, character of parties, etc., should be shown as in cases of absolute converance by deed. So, also, unusual clauses, conditions, stipulations or covenants, teuding to shed light on the transaction, or to linit or define the nature of the lien or security given, must in like manner be specifically shown. The example given in this section is to be considered rather as a suggestion than as a form, as are many other examples in this book, and whenerer any of the above mentioned incidents eccur they shonld find appropriate mention.

A mortgage, after julicial foreclowre, although in some sense merged in the decree, remains a mmiment of title which passes to the purchaser at the mortgage sale, to be looked to, not only for the purpose of ascertaining the time at which the mortgage lien attached, but also, in the absence of express directions in the decree limiting the estate to be sold, the quantity and quality of the estate conveyed by way of mortgage. ${ }^{43}$

$\$ 351$. Statutory Forms. As in case of absolute deeds, statutory forms for mortgages are now prescribed in many States, but, like such deeds, from their meagerness of detail, have not come into very general use in many localities. The statutory words of converance and pledge are "mortgage and warrant" and in all alstracts of such mortegages the operative words should be inserted as they appear in the original. The word "mortgages" is sufficient, muler the statute, to create a

43 Vallejo Land Assoc. r. Viera, 48 Cal. 572. 
mortgage in fee, while the addition of the words "and warrants" carries the legal import and effect of full covenants of seizin, right to convey, freedom from incumbrances, quiet enjorment and general warranty.

\$ 352. Uncertainty or Error of Beserintion. The obscrvations heretofore made ${ }^{44}$ in regard to unecrtain or erroneous descriptions in deeds are all applicable to mortgages, for the policy of the law requires that they give defnite information, not only as to the debt sccured, but as to the property mortgaged as well. ${ }^{45}$ Material omissions, or even misdescription, will not invalidate the instrument, where other adequate elements of identification exist, ${ }^{46}$ but purchasers without notice will be bound only by the description furnished by the mortgage. ${ }^{4}$

It is a rule of general observance that a mortgage, to be effective, mut in sone way describe and ilentify the indebtchness it is intended to sceure. Literal accuracy in describing the debt is not required, but the description must be correct as far as it goes and must be full enough to define the obligation with reascualle certainty, or, it must direct attention to other soures where correct information concerning the debt may be obtaincd. In every event it must be of such a character as nct to mind or leceive, either as to the nature of the debt or its ammnt. ${ }^{4 s}$ If the mortgage is given to secure an ascertrincl debt, then the amount of the debt should be stated; if it is intended to secure a debt not ascertained such data should be furnished respecting the debt as wonkl put any one interested in the inquiry upon the track leading to the discovery. If it is given to secure an existing or future liability, the foumdation of such liability should be set forth. ${ }^{49}$

44 See "Errors, Omissions and Defects." page 182 .

45 Herman $v$. Deming, 44 Com. 124; Simmons $t$. Fuller. 17 Minn. 4S5; Galaway $r$. Malchou, 5 Neb. 285; Murpliy $v$. Hendricks, 57 Ind. 593.

46 Slater $v$. Breese, 36 Mich. 77 ; Boon $r$. Pierpont, 28 N. J. Eq. 7. 4i Disque $r$. Wright, 49 Iowa, 538; Simmons $v$. Fuller, 17 Minn. 485.

4 New $r$. Sailors. 114 Ind. 407; Pettibone $r$. Griswold, 4 Conn. 15s; Bullock $\imath$. Battenlousen, 108 Ill. 36: Curtis v. Flyun, 46 Ark. 70.

49 Bullack $v$. Battenhousen, 108 Ill. 36 . 
\$ 353. Corenants in Hortgages. As mortgages are now drawn personal covenants are not usually inserted, but whenerer they are inserted they have the same operation as in deeds of bargain and sale. A brief allusion to the covenants of a mortgage may be profitably made, and where the words of grant which imply corenants are employed, and no express covenants are inserted in the instrument, such words should always be stated as in case of deeds. The words "grant, bargain and sell" are sufficient to create an estoppel, and any subsequent interest the mortgagrer may aeguire in and to the mortgaged premises will pass by the mortgage or any sale that may be made pursuant to its terms. ${ }^{50}$

It is a rule, howerer, in ordinary cases of foreclosure, that the title ordered to be sold is only the title which was held by the mortgagor at the date of the mortgare, ${ }^{51}$ and when a mortgage containing no corenant of warranty has been foreclosed, and the relation of mortgagor and mortgagee lias been extinguished by a sale of the mortgaged lands, the former is under no duty to protect the title of the purchaser, nor is he precluded from subsequently acquiring and claiming under an outstanding and paramount title." "The purchaser is presumed to know the conditions of the title which he purchases," says Andrews, J., "and if it is defective his bid is regulated in view of such defect. If the premises bring enough to satisfy the mortgage debt it would be inequitable to allow him to claim an interest subsequently acquired by the mortgagor, and which he did not purchase and was no part of the consideration of the sale. If there is a deficiency, that becomes a personal charge against the party bound to pay the debt, in favor of the creditor. Different considerations wonld apply when the montgage contained covenants of warranty. In that ease the "unsideration paid would represent the value of the land as warranted, and the mortgagor would be estopped from setting up

5 ( Gibbons $x$. Hoag, 95 Ill. 45; Teft $v$. Munson, 57 N. Y. 97 .

$\therefore$ Kreichbaum $v$. Melton, 49 Cal. 51 .

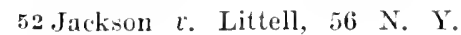
108. 
an after acquired title, against which he covenanted in the mort trage." 53

S3.5. Efect of Special Covenants. In addition to the ordinary covenants of title and warranty, a series of special covenants are found in mortgages which do not, as a rule, directly affect title. These corenants are sometimes annexed to conditions and stipulations, but may be separate from them and from the subject to which the stipulations allude. Of this nature is the covenant to keep the mortgaged property insured for the benefit of the mortgagee. Such a covenant creates a specific equitable lien upon the insurance moner, which is ralid as against the creditors of the mortgagor. The mortgage being recorded, the covenant acts upon the insurance as soon as affected, runs with the land, and furnishes notice to third persoms; and no subsequent assignment or other act ean affect the rights of the mortgagee. It is not necessury that the policies bo assigned, nor that the mortgagee select the companies, and any acts of the mortgagor without the consent of the mortgagee will not defeat the effect of the eovenant. ${ }^{54}$

\$ 355. Special Stipulations and Conditions. Many mortgagees insist npon a number of special stipulations and conditions in mortgages accepted by them, and frequently they are of such a nature that they can not be consistently passed by the examiner without notice.

The stipulation for insurance for the mortgagce's benefit, being intended to afford security supplementary to and connected with the mortgage, and to keep the mortgaged property itself so far intact as a means of security as to perpetuate the safety of the mortgagee's interest in ease the buillings should burn, is in equity a sort of adjunct to the mortgage, and is biuding on the mortgagor and all others who may sneced to his rights with notice. ${ }^{55}$

53 Jackson $v$. Littell, 56 N. Y. 108. And see, Vallejo Land Assoc. r. Viera, 48 Cal. 572.

$\therefore$ In Re Sands' Ale Brewing Co., 3 Biss. 175. In this matter, the question was raised by the assignee in bankruptry of the mortgagor.

55 Niller $x$. Aldrich. 31 Mich. 408. A failure in this respect eonstitutes such a default as will justify the 
The stipulation that in case of a defant in the parnent of interest the frincipal shall inmediately becone lue and payable, and that the mortgagne may immediately proceed to forcelose, is an essential part of the contract and may be enforced, ${ }^{56}$ and the same rule applies to the similar stipulation relative to the nom-payment of taxes. ${ }^{57}$

A provision that the mortgagee, upon defanlt, shall be entitled to tho immediate possession of the premises is generally regarded as valid, and of this provision subsequent purehasers and incumbraneers are chared with notice. ${ }^{58}$

A stipulation, whereby the mortgage assumes and agrees to pay a prior mortgage on the premixes, does not inpose upon the mortgagee a personal liability for the prior mortgage debt, which ean be enforeed against him by the prior mortgagee, for the stipulation in such eases is mot a promise made by the mortgagee to the nortgagor for the benefit of the prior mortgagee, but is a promise for the benefit of the mortgagor only; it is to proteet his property by artvancing money to pay his debt. ${ }^{59}$ In this respect it differs from a sinilar stipulation contained in an absolute conveyance.

All stipulations which are essential parts of the contract, or whieh tend to induce foreclosine before the axpresed time of the maturity of the debt, particularly when the mortgage contains a power of sale by adrertisement, should be stated or definitely alluded to.

$\S 356$. Erfect of Informality in Mortgages. Mortgages, or eonveyances ly way of security in the nature of mortgages, are seldom roid for informality mless the informality or omission goes to the groundwork of the instrument, and at

mortgagee in selling under the power in the mortgage: Walker $v$. Cockey, 38 M!l. 75.

56 Gulden $r$. O'Pyme, 7 Phil. (Pa.) 03; Ma]rom r. Allon, 49 N. Y. 448; Mryer r. Cirmber, 19 Kan. 16.7; Cook r. Clark, 68 N. Y. 179. 57 Stancifts $i$. Norton, 11 Kan.
58 Felino r. Lumber Co., (it Nob. 335 ; and see, Friuk r. Talioy, !9 Cal. 214.

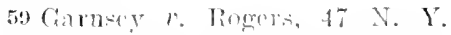
233. The same rula applies to a elore alsolute on its face, but, in fact, intended as a morteginge. 218. 
mortgage or trust deed, otherwise complete but lacking in some formal particular, though it may be denied legal effect, will ret be enforced in equity as an equitable mortgage, and this protection will extend to the assignee as well as to the original mortgagee. ${ }^{60}$ The rule has been held to apply in case of a trust leed which omitted the name of the trustee; ${ }^{61}$ and to a mortgage which did not purport to be sealed; ${ }^{62}$ and where the seal had been omitted; ${ }^{63}$ where the instrument was imperfectly witnessed, as where there was but one witness, and the statute required two; ${ }^{64}$ to imperfectly acknowledged instruments; ${ }^{65}$ and even to the want of an acknowledgment. ${ }^{66}$ Whenever a mortgage is sufficient as between the parties it will affect all third persons who have actual knowledge or notice of its existence, ${ }^{6 \tau}$ and purchasers with such notice will take subject to the equities created by such defective mortgage. ${ }^{68}$

\section{\$ 35t. Purchase Money Mortgages. A mortgage ex-} pressed to be for the whole or a part of the purchase money of the mortgaged property should be so described in the abstract, as such mortgages stand upon a somewhat different footing from other conveyances by way of security. The peculiar qualities of a purchase money mortgage are derived from statutes, under which it becomes a lien upon the entire estate of the mortgagor in the land, freed from any contingent elaim of the wife, whether she be a party to the mortgage or not; ${ }^{69}$ neither will she be a necessary party to a suit for foreclosure of a purchase money mortgage, in the execution of which she

60 McQuie $r$. Peay, 58 Mo. 56; McClurg $t$. Phillips, 49 Mo. 31. 61 Mequie $r$. Peay, 58 Mí. 56. 62 .Tones $r$. Brewer, 58 Me. 210. 63 Harrington $r$. Fortner. $5 \mathrm{~s}$ Mo. 468; Van Riswick $r$. Goodhne, 50 Mid. 57 .

64 Gardner r. Monre. 5l Ga. 268; Samborn r. Robinson, 54 X. II. 239. 65 Ira-kill r. Sevier, 25 Ark. 152; Zeigler $r$. Intughes, 55 Ill. 288.
66 Blaek $v$. Gregg, 5s Mo. 565.

$6 \pi$ Gardner $v$. Moore, 51 Ga. 268;

Sanborn $v$. Robinson, 54 N. H. 239 ;

Wilson $v$. Reuter, 29 Iowa, 176.

68 Gardner $v$. Moore. 51 Ga. 268.

69 Fletwer $v$. Holmes, 32 Ind. 497 ; Amphlet $r$. Hibbard, 29 Mieh. 298; Thompson $v$. Lyman. 28 Wis. 266 . 
Inad not joined, if such suit be brought in the lifetime of the husband. ${ }^{\text {to }}$

So, too, a purchase money mortgage, executed contemqoraneously with the deed of purchase, will take precedence over the lien of a prior julgment against the mortgagor. ${ }^{71}$

The fact in itself is important, but it may be stated in very brief terms, which is usually done by a parenthetical elause in comnection with the recital of the inclebtedness; thus:

To secure the payment of $\$ 4,000.00$ (part purchase money) evidenced by four notes, etc.

The same fact may, if so desired, be stated more fully, by a distinct allusion to the purchase money clause in the body of the instrument, in this mamer:

This mortgage is given (it is stated) to secure the payment of (a portion of) the unpaid purchase moncy for said above described premises.

$\S 358$. Mortgages of the Homestead. The jealous care with which the law guards the homestead is never more fully exemplified than in the safeguards and restraints which it has placed upon all attempts to ineumber it; and in all convesances of property, whether by deed or mortgage, the character of the premises, considered in relation to its use and oceupancy, is an inquiry never to be omitted. In some States no valid mortgage of the homestead can be effected; ${ }^{72}$ in a majority of the others such mortgage is effectual, only when there has been a speeial release and waiver of the homestead right ; ${ }^{73}$ while in all the States, the free and voluntary assent of the

70 Fletcher $v$. Holmes, 32 Ind. 497.

71 Stewart $v$. Smitl, 36 Minn. 82; Cake's Appeal, 23 Pa. St. 186.

¿2 Van Wickle $v$. Lankly, 29 La. Ann. 330; and see Moughon $v$.
Masterson, 59 Ga. 835; Campbell $v$. Elliott, 52 Tex. 151.

73 Trustees r. Beale, 9S Ill. 248; Browning v. Harriss, 99 11l. 456; Balkum v. Wood, 58 1 la. 642. 
wife, the morteagor being a married man, is a condition precedent to the vesting of the lien. ${ }^{7}$ Where the statute prescribes formalities relative to acknowledgment, such formalities become matter's of substance, and their due observance is in all rates necessary; is but where no particular node is preseribed, any joint action, properly acknowledged, will probably satisfy the requirement of the voluntary signature and assent of the wife. ${ }^{76}$ Where the statute requires an express waiver, this may be shown brietly, in all properly executed mortgages, by a simple recital of the fact; as,

\section{Homestead rights waived,}

while the absence of any words indicative of such intention may, with proprietry be also noted.

The only expeption to the rules above stated is, when the mortgage is given to secure all or a portion of the unpaid purchase money, and in such case they all yield to the superior equity of the vendor's lien. ${ }^{i t}$ In examinations of title an inquiry in pais is alwars raised by mortgages purporting to be exeented by the husband only, as well as when the joint action of husband and wife is shown, but unacempanied by any expression indicative of release or waiver of homestead, when such expressed waiver is a statutory essential, mless the mortgage in terms purports to be a security for the purchase price.

\$ 359. Mortgage of After-acquired Property. As to the effect of deeds and mortgages of property to which the grantor or mortgagor has no present legal title, and which con-

74 Long $x$. Mostyn, 65 Ala. 543; Anderson r. Culbert, 55 lowa, 233; Grittin $r$. Proctor, 14 Bush (Ky.), 571 ; Sherrid $r$. Southwick, 43 Mich. 515; Chambers $r$. Cox, 23 Kan. 393.

75 Mash $v$. Russell, 1 Lea (Temm.), 543; Balkum r. Nood. 58 Ala. 642: Warner $r$. Crosby, 89 Ill. 320. The fact that the deed recites a waiver does not help a defective acknowl- edoment: Best $r$. Gholson, 89 IIl. 465.

76 Forsyth $v$. Preer, 62 Ala. 443. Local statutes must decide these matters; the laws and decisions of other States shed but little light on questions of this character.

7 Fleteher $r$. Holnes, 32 Ind. 497 ; Amphlet $r$. Hibberd, 29 Mich. 298; Thompson v. Lynan, 28 Wis. 266. 
tain no covenants or other words creating an estoppel, there seems to be much diversity of judicial opinion, though the anthorities are in the main harmonions in declaring equitalue interests and estates to be proper subjects of conveyance by mortgage. is The question frequently arises in regard to mortgages of incipient or inchoate rights under the United States land laws, and such mortgages have usually been upheld by the State courts, particularly when the transaction was shown to be one of good faith, ${ }^{79}$ and, when congress has imposed no positive restrictions, the right is usually accorded to one rightfully in possession of the soil to make any ralid contract conceming the title to same predicated upon the hypothesis that he may thereafter lawfully acquire it. ${ }^{\text {s" }}$ So, too, where a railroad company marle a mortgage on the property "then belonging to or thereafter to he accuired" by said company, with covenants for further reasonable and necessary conveyances as to subsequently acquired property, it was held that the mortgage becane a valid lien upon any interest in real as well as personal estate subsequently aequired by the company for the use of its road, even superior to a rendor's lien for the purchase money of the lands. ${ }^{81}$

Courts of equity will enforce specific execution of contracts, and give relief in numerons cases of agreements relating to lands and things in action, or to contingent interests or expectancies, upon the maxim that equity considers that done, which, being agreed to be done, ought to be done, ${ }^{82}$ and in furtherance of this principle, where no rule of law is infringed, and the rights of third persons are not prejudiced, will, in

7s Bank of Greensboro $r$. Clapp, 76 N. C. 482.

79 Woodlury $v$. Dorman, lo Ninn. 338; Wallace $v$. Wilson, $30 \mathrm{Mo}$. 335; Clark $r$. Baker, 14 Cal. 615; lieasoner $r$. Markley, 25 Kan. 635. 307.

80 Lamb) r. Davenport, is Wall.

81 Pierce $r$. Milwaukee, etc.. R.
R. Co., 24 Wis. 551 ; and see Morrill v. Noyes, 50 Me. 458. Such mortgages from an exception to the general rule that property not in existence an not be conseyed. 82 villers $v$. Lester, 48 Misis. 5l3; Stevens r. R. R. ('o., 45 Hlow. (N. Y. Pr.) 104. 
proper cases, give effect to mortgages of subsequently acquired property. 83

$\$ 360$. Record of Mortgages. Mortgages eome within the provisions of the recording acts, and impart notice in like manner as deeds. ${ }^{\text {st }}$ They are governed in this respect by the sane general rules as affect other eonreyances, while in several States they are further regulated in regard to priority, ete., by special laws. The registry of a mortgage is notice only to the extent of the sum specified in the record, ${ }^{85}$ and of the property therein described, ${ }^{86}$ and intending purehascrs are only chargeable with notice of such facts as the record discloses, and not of undisclosed intent. ${ }^{s i}$

If a mortgage is given to secme an ascertained debt, the amount of the debt should be stated; and if it is intended to secure a debt not aseertained, such lata slould be given respecting it as will put any one interested in the inquiry upon the track leading to a discovery. If it is given to secure an existing or a future liability, the foundation of such liability should be set forth. Without this, a subsequent bona fide purchaser, with no actual linowledge or notice of the facts, is not chargealle with notice of the amount secured. ${ }^{\text {ss }}$

As between two mortgages, the first recorded is the prior

s3 Beall $r$. White, 94 C. S. 382 ; Rice $v$. Kelso, 57 lowa, 115.

s+ Juhnson $r$. Stage, 2 Johns. 510 ; Rice $r$. Dewey, 54 Larb. (N. У.) 455; Hickmill $r$. Perrin, 6 (oldw. (Tenn.) 135; Shamnon $v$. IIall, 72 Ill. 354; Tan tken $v$. Glesson, 34 Mich. 477.

s 5 Ceekman $r$. Frost, 18 Johns. 544: Nortl r. Belden, 13 Conn, 376. Even though there has been a mistake in reeorling: Bullock $r$. Fattenhousen, 108 111. 28; Lowry $r$. Davis, 69 lnd. 5s9. But it would seem that the reeorder would be liable in danages to any one who might suffer from the error: Lowry $\imath$. Daris, 69 Ind. 589 . so Simmons $r$. Fuller, 17 Minn. 485; Galway $r$. Malchou, 5 Neb. 285 ; White $r$. MeGarry, 2 Flip. (C. Ct.) 572 .

si Disque $v$. Wright, 49 Iowa, 538; Galway $v$. Malchou, 5 Neb. 285; Herman v. Deming, 44 Conn. $1: 4$.

ss So held where the reeord merely stated that the grantor had on the same date as the mortgage made his promissory note, payable, ete., without giving the amount: Bullock $v$. Battenhousen, I08 Ill. 28; Hart $v$. Chalker, 14 Conn. 77. But see North $v$. Knowlton, 23 Fed. Rep. 163, where en semble a contrary doetrine is indieated. 
lien, ${ }^{89}$ and where a mortgage and a deed of conveyance of the same property are made at the same time, the mortgage, if recorded first, will take precedence of the deed..$^{0}$

The rights of the mortgagee are fixed when he places his mortgage on record, and the subsequent destruction of the record, will not, it seems, extinguish or destroy the notice afforded by registration, nor injuriously affect the rights of the mortgagee, ${ }^{91}$ while as between the original parties, ${ }^{92}$ and their heirs, ${ }^{93}$ the mortgage will still be valid and effective although unrecorded.

$\S 361$. Notice Imparted from Possession. If the real owner of property allows it to stand recorded in the name of another, by a title translative of property, he puts it in the power of that other to create a valid mortgage on it; ${ }^{94}$ yet one who takes a mortgage from the record owner of lands, which are in the notorious and exchusive possession of another, is bound to inquire as to the claims or interest of the person so in possession, and is chargeable with whatever he might have learned by reasonable inquiry, notwithstanding he has searched the records and found no deed. ${ }^{95}$ Hence, it is always well for counsel, in framing an opinion of title, to specifically call attention to the rights of persons in possession if other than the record owner.

\$ 362. Re-records. A re-record of a mortgage is treated the same as a re-record of a deed; bare mention is sufficier t provided the two records show a literal conformity, otherwise they are to be regarded as independent instrments. Re-records of mortgages, like re-records of deeds, are frequently made

89 Ripley $r$. Harriy, 3 Piss. 199: Odd Fellows Sav. Bank $x$. Banton, 46 Cal. 603; Van Aken $v$. Gleason, 34 Mich. 477. 282.

90 Odgen $r$. Walkers, 12 Kan.

91 Shannon $v$. IJall, 72 Ill. 354. 197.
9. Mctaughlin $r$. Thmsen, s5 Pa. St. seit.

94 Jinnter $r$. Dukner, 29 La. Ann. Go4: Shepard $t$. Shepard, : 26 Mich. $17: \%$

9. School Dintriet $r$. Tuylur, 19 Kan. 287 : and sessell v. Thayer, 39 Mich. 467. 
to correct errors of the former record, and in every instance the two should be carefully compared.

When it satisfactorily appears that the instrument under consideration is a re-record it should be placed immediately after the abstract of the first record, whenever such a course is practicable, and may be shown somewhat as follows:

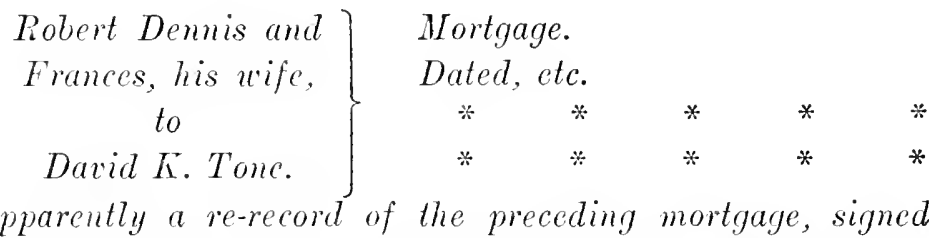
by both Demis and wife, with an additional certificate of acknowledgment of both, dated June 2, 1898 .

$\$ 363$. Trust Deeds. Trust deeds in the nature of a mortgage were once in very common use, but the changes produced by the abolition of the common law doctrine of uses and trusts and the limitation of powers, have now confined them to a few States, and even in those States, under the influence of recent legislation, mortgages are to some extent taking their place. In general effect a trust deed of the character now under consideration is the same as a mortgage, and like a mortgage is, in equity, a mere security for the payment of money, or for the performance of certain undertakings by the grantor. It is simply an incident to the debt which it secures, and upon which it depends. ${ }^{96}$

The same general principles are applicable to this class of conreyances as to other deeds intended only as security, and the chicf feature which distinguishes them from mortgages is, that here the conveyance is not made to the creditor direct, but to a trustee who holds a naked trust for the benefit of the legal holder of the evidence of the indebtedness, which, if negotiable, passes from hand to hand as other commercial paper, the incident of the lien following the note to the hands 96 Life Ins. Co. $v$. White, 106 Ill. 67. 
of the last indorsee, who, on default, may call upon the trustee to execute the trust according to its terms.

The grantor in a trust deed, in declaring the trust, may moll and give it any shape he chooses, and he may provide for the appointment of a suceessor or successors to the trustee upon such terms as he may choose to impose, but when imposed the terms must be pursued, to render the acts of the suceessor ralid. It is alone by the foree of the powers delegated by the deed that the trustee can perform any act with reference to the trust property, and in exeenting those powers he must strictly pursue them, or his acts will be roid. ${ }^{97}$

An unexecuted trust, if still an existing lien, is treated in the same manner as mortgages under like conditions. The abstract should show the trustee; the successor in trust, if any is appointed; the cestui que trust if naned; ${ }^{95}$ and a general deseription of the indebtedness as in case of ordinary mortgages. An illustration is herewith given:

$\left.\begin{array}{rl}\text { James Johnson } \\ \text { to } \\ \text { Americus B. Melville, } \\ \text { Trustee. }\end{array}\right\} \begin{aligned} & \text { Trust Deed. } \\ & \text { Dated June 1, 1852. } \\ & \text { Recorded June 5, 1882. } \\ & \text { Pook 129. Page 510. } \\ & \text { To secure the payment of } \$ 1,000\end{aligned}$ and interest thereon at eight per cent. per annum, in two years from the date hereof, evidenced by said first party's one certain promissory note, bearing even date herewith, and payable to the order of George W. Smith (or, payable to his oun order and by him endorsed).

Conveys land, etc. [here set out the deseription of the property convered] in trust and upon the conditions therein specified and enumerated.

Power of sale given on default after thirty days' notiee.

97 Equitable Trust C'o. $r$. Fisher, 106 Ill. 189; Ellis $x$. R. lR. Co., 107 Mass. 12.

as It is now a very general practice to make the notes payable to the maker's own order and after he has endorsed them they then pass by mere delivery. In surb atse the fact should be noticed in the abstract. 
IIomestead rights waived.

Wonroe A. Fullicrson, successor in trust. Achouledged June 1, 1S82.

If followed by foreclosure in pursuance of the power, and the trustee's deed appears in the same examination, insert the power of sale in full as fouml in the instrument, inmediately after the description of the property, thus:

In trust, nevertheless, that in case of defuult in the payment of the note secured hereby, or any part thereof, according to the tenor and cffect of said note, or in case of waste or nonpayment of taxes or assessinents, or neglect to procure or renew insurance as hereinajter protided, or in case of the breach of any of the coendints or agreements herein mentioned, then it shall be lauful for the said party of the second part or his suecessor in lrust, on application of the legal holder of said promissoing note (or cither of them), to enter upon, possess, hold and enjoy the abore granted premises, and cither with or without such cntry to sell and dispose of said premises, and all right, title. bencfit and equity of redemption of said party of the first part, his heirs and assigns therein, at mulic auction, at the front door of the court house in Chicago, Illinois, or on said premises, or any part thereof, as may be specified in the notice of such sale, for the highest and best price the same will bring in eash, thirty days previons notice of such sale having been given by publication once in each weeli, for four successive weeks, in the Chicago Legal Tews, or in any nerspaper at that time publishad in said city of Chicago, and to make, execute and deliver to the purchascr or purchasers at such sale, good and sufficient deed or deeds of conveyance for the premises sold. * * * * Which sale or sales so made shall be a perpetual bur, both in lave and equity, against the said party of the first part, his heirs and assigns and all other persons claiming the premises aforesaid, or an! part thereof, by. from, through or inder said party of the first part (or any of them).

Second party, with or without re-advertising, is hereby au- 
thorized and eimpowered to postpone or adjoum said sale fiom time to time at his discretion; and also to sell the said premises, entire, without division, or in parcels, as he may prefer or thint. best.

It is agreed that in case of default in any of said payments of principal or interest, according to the tenor and effect of said note, or any part thereof, or of a breach of any of the covenants or agreements herein, by the party of the first part. his executors, administrators or assigns, then, and in that case, the whole of said principal sum hereby sceured, and the interest thereon to the time of sale, may at once, at the option (without notice thercof to said party of the first part, his heirs, assigns or legal representatives) of the legal holder thereof, become due and payale, and the said premises be sold in the manner and with the same effect, as if the said indebtedness had matured.

First party covenants that in case of a sale and conveyance. as aforesaid, of said premises, any deed or deeds of conveyance made in pursuance of such sale shall be prima facie evidence of the due compliance with and performance of the terms, conditions and requirements of this deed of trust, by second party, or his successor in trust aforesaid, in adecrtising and mating such sale and conveyance, to the extent of the recitals contained in such deed or deeds.

$\S 364$. Power of Sale. The power of sale contained in a deed of trust or mortgage must be strictly pursued, ${ }^{9 !}$ and the utmost fairness must be observed in its execution; but such strictness and literal compliance should not be exacted at would destroy the power. ${ }^{1}$ Where title is clainmil through a trustee or mortgagee acting under a bower, a rasonable de459.

99 Cranston $r$. Crane, 97 Mass.

1 Walter $c$. Arnold, 71 Ill. 3.50. Parties to a mortgage may, by stipnlation, regulate the tornes of a power of sale of the premises by the nortgingee; and the rourts will not interfere ta control the right, in the absemere of framl, or of some statutory remitations on the subject: Ellioft $t$. Wim, ti N. Y. 71 . 
gree of detail is neecsary in the abstract, which should show suficient of the proceedings as evidenced by the trustee's ar mortgagee's deed, to indicate a substantial compliance with every essential requisite. When permitted by statute, the sale of a mortgaged estate, made in pursuance of a valid power giren by the owner, vests in the purchaser an estate in fee, free from the original condition and from any right of redemption, ${ }^{2}$ and the power, being coupled with an interest, is irrevocable, and hence nuay be exercised even after the death of the mortgagor:

Though one who mudertakes to exceute a power is bound to a strict compliance therewith, as well as the observance of good faith ${ }^{4}$ and a snitable regard for his principal, yet a dereliction in this respect will not usually affect a purehaser in good faith, who, being a stranger to his proceedings and finding them all correct in form, takes the property; ${ }^{5}$ yet as the payment of the debt seeured by the trust deed or mortgage defeats the power of sale, a purchaser at a sale made under such power must see to it that the grantor in the deed or mortgage is in default, and that some part of the debt is due and umpaid. ${ }^{6}$

The omission of the power from a trust deed or mortgage merely limits the mode of foreclosure to bill in equity, ${ }^{7}$ while its insertion does not oust the jurisdiction of a court of equity, nor preclude a party from resorting to that tribunal. It is comulative only. ${ }^{\circ}$ In its general nature it is a power coupled with an interest, is irrevocable, appendant to the land, and

2 Kinsley 2 : Ames, 2 Met. 29.

3 Berger $r$. Pronett, 1 Cáne's Cas.

(N. Y.) 1. Loeal statutes may, however, serve to modify the statement of the text.

4 If a sale is made by a mortgagee under a power in a mortgage, not in good faith, lut in fact for him. self, to whom the purchaser conveys, the sale is not roill. hut only voidable in equity, and it may be set aside while the title remains in the mortgagee, but not after transfer to a bona fice purchaser: Gibbons r. I10ag, 95 I1l. 45.

5 Montague $r$. Dawes, 14 Allen, 369.

6 Ventres $r$. Cobb, I05 Hll. 33.

т Cowles v. Marble, 37 Nieh. 158.

s MeAllister $v$. Plant, 54 Miss. 106. 
passes by an assignment of the mortgage and secured debt; 9 it is not impaired by the death of the mortgagor, nor by lapse of time, if not unreasonable, in closing the sale made under it; and covers the equity of redemption, nent only of a husband, but also that of his wife surviving him. ${ }^{10}$

At the present time power of sale nortgages are infrequent and in many States no foreclosure is permitted except in equity. But even in these States many examples of this species of security will be found upon the recurds and in the past history of titles, and when so found should be treated as above indicated.

§365. Assignment. The interest of a mortgagee, whether regarded as a lien or an estate, is assignable in law by a proper instrument purporting to conver the same, while the assignment of the notes secured by the mortgage operates in equity as an ascignment of the mortgage itself. ${ }^{11}$ In the latter case, the assignment of the debt carries with it the security for the debt, and ordinarily whoeser oms the debt is likewise the owner of the mortgage. ${ }^{2}$ Assignments of mortgages, however, are usually made by an instrument in writing and under

9 MeGuire $r$. Van Pelt, 55 Ala. 244; Strother $v$. Law, 5t III. 413 ; Hyde $t$. Warren, 46 Miss. 13; Brown $\boldsymbol{v}$. Delaney, 22 Minn. 349.

10 Strother $r$. Law, 54 Ill. 413.

11 Holmes $r$. McGinty, 44 Miss. 94; Moore $r$. Cornell, $6 \mathrm{~s}$ Penn. St. 322 ; Plake r. Williams, 3 N. H. 39 : Croft $v$. Bunster, $9 \mathrm{Wis}$. 503 ; Potter $v$. Stevens. 40 Mo. 229. In assignment in law is not recognized in some States.

12 Kurtz $r$. Sponable, 6 Kan. 395; Nelson v. Ferris, 30 Mich. 497; Preston $*$. Morris Case \& Co., 42 Iowa, 549; Mulford r. Poterson, 85 N. J. L. 129; Conner $r$. Banks, 18 1]a. 42; liell $r$ Simpson. 75 Mo. 485. Where a party is so related to a mortgage that be is not per. sonally liable upon it, but is obliged to pay it to save his estate, and he does pay it, the parment will be presumed to be made for that pur. pose, and in such case no assignment of the mortgage to the person paying it, nor proof of an intention on his part to keep it alive. is necessary to give him the benefit of it: Walkel $r$. King, 44 Vt. (ii)l: and in like manner a party paying a decree of foreclosire lexomes invested with the rights of the mortgagee and the ascience in repuity of the morterage: althourh in this aste the morterace is in fact paid. yod equity will requise it to subsist until every party who owes a duty uncler the morterge shall have distharerel jt: IVlealar r. Willarel, t.t Vi. 6to. 
seal, whick, when recorded, affords constructive notice of the rights of the assignee to all persons, as against any subsequent acts of the nortgagee affecting the mortgage, and protects as well against an manthorized discharge as against a subsequent assigmment by the mortgagee. ${ }^{13}$

The law does not, as a rule, require the assignment to be recorded, as essential to its validity, nor is it necessary for the purposes of foreclosure; and assignments are excepted from the operation of the recording laws of many of the States. With respect to the necessity of resistration for priority of title, the same general rule prevails between different assignees of a mortgage as between grantees in ordinary deeds, ${ }^{14}$ and a release by the mortgagee, no assignment appearing of recort, will effectually divest the lien, notwithstanding an assigmment las in fact been made. ${ }^{15}$

In a few States, a mortgage is not assignable, either by the statute or by the common law; the assignment of the note carries the mortage with it, but only in equity, and trust deeds given as security for a loan, being regarded in the nature of mortgages. stand upon the same footing as regards assignabilitr. ${ }^{16}$

\section{\$ 369. Operation and Efreet of Assignments. Though} there are not wanting authoritative decisions to the contrary, yet the heter and more generally received doctrine seems to be, that an assignment of a mortgage is to be regarded only as the tranefor of a mere chose in action, and not an interest in lands, the debt being considered as the principal and tho

13 Vise $r$. Judson, 82 X. Y. 32 ; Stein r. Sullivan, 31 N. J. Eq. 409 ; Torrey $r$ Deavitt, 53 Vt. 331.

14 Wilcy $r$. Williamson, 68 Me. 71: Trust Co. 2 . Slaw, 5 Sawyer (C. Ct.), 380; Neclure r. Burris, 16 lowa, 5.1; Torrey $r$. Deavit1, 53 Vt. 331; Bacon v. Van Schoonhover, ST N. Y. 446.

1: Vitobell $r$. Bumbam, it lie.
308. Bank $\ell$. Auderson. It Iowa, 541, Johnson $r$. Carnenter, 7 Minn. 176 ; Union College $r$. Whecler, 61 N. Y. 88; Ballwin $r$. Sager, 70 111. 505; Ayers $v$. Lays, 69 Ind. 452; Swartz 2 . Leist, 13 Olio St. 419.

1s Olis r. Cummings. 31 Ill. 188; Walker $r$. Dement, 42 Iil. 272; Baily r. Suith. 14 Ohio St. 396. 
land, or security, only the incident; ${ }^{17}$ and that the assignee takes it charged with the notice which his assignor had of prior incumbrances, and subject not only to any latent erpuities that exist in faror of the mortgagor, but also subject to equities in favor of third persons. ${ }^{18}$

\$ 367. Formal Revuisites of Assignments. Thongh the earlier decisions hold that the interest of a mortgagee nay be transferred or conveyed by the same forms of deals by which the owner of the legal estate can eomver it, ${ }^{19}$ the current of later cases promounces a contrary doctrine. The mortgagee's interest, being a mere rlattel, is inserarable from the debt it is given to secure, ${ }^{2 n}$ and, not constituting an estate or interest in the land, will not pass by any comverance thereof. Hence a deed of all the grantor's "estate, title and interest" in the mortgaged prenises, 21 or a converance of all his " lands, tenements and lereditaments," 22 will not operate as an assignment of a mortgage; and generally, any conveyance or attempted conveyance of the mortagee's interest before foreclosure, not accompanied by a transfer of the debt secured, is a nullity. ${ }^{23}$

17 Delano $v$. Bennett, 90 HII. 533; IIitcheock $v$. Merrick, 18 Wis. 357; Paige v. Chapman, 58 N. II. 333; Pennett $v$. Saloman, 6 Cal. 134 .

1s Sims $v$. Hammont, 33 Iowa, .68; Mason v. Ainsworth, is Jll., 163; Sehofer $v$. Jicilly, $50 \mathrm{~N}$. Y. 6I; Crane $v$. Turner, 67 N. Y. 437; Coffin v. Taylor, 16 11l. 4.7; Olds $v$. Cummings, $31 \mathrm{Jl}$. 18s. The text states the general rule but the statute, in some States, has changed this rule so as to cut off latent r quities.

19 Weleh v. Priest, \& Allen (Mass.), 165; Cutler $v$. Darenport, 1 Jink. 81. And see commor $v$. Whitunore, 62 Me. 186; Strwart $r$. Barrow, 7 Bnsh (Ky.), 368. But this is when the lingal estate passes to the mortgagee.

20 Mack $l$. Wetzler, 39 Cal. 247;

Seakler $r$. Delf, 25 Kan. 159; Trim $r$ Marsh, 54 X. Y. 509.

21 Swan $r$. Yaple, 8.) Iowa, 248 ; Runyan $r$ Mexsercan, 11 Johne.

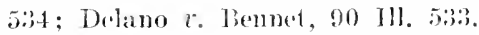
22 Mark v. Wrtzlar, 39 cal. 247. 2:3 Delano $r$. linumett, 90 Ill. 5:3:?; Swan $r$. Yalle, 3 lowa, 24s: Tulum. son $v$. Corlect, 29 Ind. 59) F Ellison r. Danith, 11 N. 11. 2-T. lint if the mortgatger is in pessesenton under Jis norlgage his converanede, while

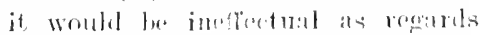
the title, might yod be sulfirient to

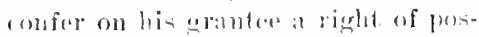
scosion. Welsh r. Philips, 5. Ala. 309. 
The interest owned by the mortgagee has reference solely to the mortgage debt, and any instrument which describes the parties and the indebtedness, and sufficiently identifies the mortgage, will be effective as an assigmment without referenee to the mortgaged property, while the instrument, in form, should purport to be a transfer of the mortgage itself and of the delst thereby secured, and not of the land pledged for the payment of such debt. ${ }^{24}$

$\$ 368$. Release and Satisfaction. Where no release or satisfaction of a mortgage appears of record, the law will presume a payment of the debt it was given to sceure, where the mortgage has failed to exercise his right of foreclosure for the priod of twenty years ${ }^{25}$ after the maturity of the debt, and the mortgage will cease to be a lien after the expiration of that period. ${ }^{25}$ The mortgage may also be satisfied by foreclosure, but the term "satisfaction" as ordinarily used, refers to a specific acknowledgment of payment of the debt and discharge of the lien, evideneed by sone written instrument. Though the terms "release" and "satisfaction" are nsed interrhangeably, there is yet a distinction between thenl. A satisfaction implics a payment of the debt, and ipso facto an ex-

24 When the mortgage is regarded as a mere incident to the debt this would be sufficient, but more, perhaps, would be required in States where the mortgagee holds the legal title and estate. In such States an amignment of the mortgage, in terms which does not profess to act upon the land, would not pass the mortgaree's estate in the land, but only the security it affords to the holder of the debt: Williams $v$. Teachey, 8.5 N. C. 402 .

25 Goolwin $\imath$. Baldwin, 59 Ala. 127 ; Lawence $v$. Ball, $14 \mathrm{~N}$. Y. 477: Enory $r$. Keighan, 88 Ill. 482; Howland $v$ Shurtleff, 2 Met. (Mass.) 26. The presumption is disputable, however: Cheever $v$.
Perley, 11 Allen (Mass.), 588. Delaney $v$. Brunette, 62 Wis. 615 .

20 This follows as a result of the statute of limitations. Sue also Blackwell $v$. Barnett, 52 Tex. 326; Whitney $v$. French, $25 \mathrm{Vt}$. 663; Pollock $v$. Maison, 41 Ill. 516; Locke $v$. Caldwell, 91 Ill. 417 ; and consult 4 Kent's Com. 189; Jackson $v$. Wood, 12 Johns, 242. In some States a shorter limitation period is provided. Thus, in Illinois, the lien ceases at the expiration of ten years after maturity. But even in these States, as between the parties, the lien may be extended by payments until the expiration of the full limitation period. 
tinguishment of the lien, whereas a release or discharge may relicre the land from the burden of the debt without in the least impairing its legal efficacy as a personal claim against the debtor. $^{2 \tau}$

\$ 369. Form and Requisites of Release. The general requisites of a release of mortgage differ somewhat, according to the light in which it is to lee regarded. Where the mortgage retains its common law character of a conveyance of the legal estate, a deed under seal with apt words of convesance will be necessary to revest the title of the mortgagor, which may be effected by a deed of release and quit-claim; ${ }^{28}$ but where it is regarded only as a lien or security, any instrument showing an intention to relieve the land from the burden, or acknowledging payment or satisfaction of the debt secured by the mortgage, will be sufficient to divest the lien and restore the land to its original condition. ${ }^{29}$ The latter instrument is that now generally used, and, as a rule, it is required by statute to be executed by the mortgagee or his assignee, and acknowledged or proved in the manner provided by law to entitle conveyances to record, and must specify that such mortgage has been paid, or otherwise satisfied or diseharged. No other formalities seem necessary, and such certificate, popularly known as a "satisfaction piece," has the same effect as the old deed of release. In a few States, a modified form of a release deed is still preserved, though its operation and effect is almost identical with the certificate of payment, or" "satisfaction piece" of the other States. It is customare, but not necessary, to describe the property, and, except in case of partial releases, such description has no other effect than to give greater certainty to the instrument in the identification of the land. A release or satisfaction immerliately follows the mortgage it affects, and may be shown in brief terms. ${ }^{30}$ Thus:

27 Adington r. IIefner, 81 Ill. 341.

28 Waters $v$. Jones, 20 Iowa, 363; Allard $v$. Lane, 18 Me. 9; Perkins $r$. Pitts, 11 Mass. 125; and see 2 Jones on Mortgages (21 Erl.), $\S 972$ et seq.
29) Headley r. Faundry, 41 Barb. 279; Thornton r. Irwin, 43 Alo. 153; Lueas r. IIarris, 20 III. 165.

34 A sati-firetion piece is a ronrevinee within the meaning of the recorling acts, and one who buys 


$$
\left.\begin{array}{c}
\text { Millard F. Riggle } \\
\text { to } \\
\text { James Enright. }
\end{array}\right\} \begin{aligned}
& \text { Release. } \\
& \text { Dated, etc. } \\
& * * * * * * * * * 00, \text { etc. }^{31} \\
& \text { Consideration, } \$ 1.00
\end{aligned}
$$

Releases all right, title, interest, ste, acquired by mortgage, creculed by second party to first party, bearing date A pril 1, 1850, and recorded A pril 2, 1880, in book 306 of liecords, page 59\%, to the premises therein described (describing same) or, to the premises therein described as follows, etc. [Where the release is partial; to so much of the premises therein as is described as follows:]

Acknowledgment.

This is an abstract of the release deed in use in Illinois. A satisfaction or certificate of parment will require only slightly different treatment.

$\$ 370$. Release by Trustee. Where by a trust deed, duly recorded, land is conveyed to trustees in fee, and they are anthorized to execute a release to the grantor upon payment of the indebtedness thereby secured, a release before payment would be a breach of their trust and would be unarailing in equity to any one who had knowledge of the breach. ${ }^{32}$ But, being rested with the legal title the same would pass by their deed of release to the releasee, ${ }^{33}$ and a second conveyance by him to one having no knowledge of such breach, the records, or a conveyancer's abstract thereof, showing the land to be unincumbered, would rest the legal title in such grantee, or

or adrances money to be secured by mortgage on the premises is a bona fide purchaser within the provisions of said acts: Bacon $r$. Van Schoonhoven, 87 N. Y. 446 . It takes the place of a release: Ibid., and see Merchant $r$. Woods, 27 Minn. 396.

31 The original clause usually recites "and other good and valuable considerations." This alludes to the payment of the mortgage debt. It is unnecessary to set out the clause; " $\$ 1.00$, etc.," sufficiently indicates its nature.

32 Ins. Co. $r$. Eldredge, 102 U. S. 545 .

33 Taylor $v$. King, 6 Munf. (Va.) 358; Den $v$. Trantman, 7 Ired. (N. C.) 155 . 
if made by way of pledge, wontd entitle the indebtedness thereby secured to priority of payment. ${ }^{3+}$

This is a subject, howerer, upon which there is not an entire unanimity of judicial opinion. Of eourse, if the trustee releases the trust deed before payment of the money which it was given to seenre, in contrarention of lis trust, such release, as between the immediate partics, as well as all others who have notice of the facts, will be void and the lien will be unaffected thereby, as the rights of the cestui que trust are superior to those of any person chargeable with notice that the trust deed was released in violation of its terms. There are cases whieh seem to hold that an unanthorized release is void as to all persons, even subsequent purchasers in good faith, ${ }^{35}$ but the better rule, and that which is sustained by the rolume of authority, is that the public reeords import verity; that being maintained for the purpose of furnishing evidenee of title a purchascr may rely thereon and will be proteeted by what is there shown, mless he has notice, or is in some way chargeable with notice of some titlc or claim ineonsistent therewith. ${ }^{36}$ It has further been held, that the mere fact that a trust deed is released of reeord prior to the time of the maturity of the indebtedness thereby secured, is not a cireumstance to exeite inquiry on the part of an intending purchaser. ${ }^{37}$

But, in any event, a far greater degree of care must be observed in passing the release of a trustee than of a mortgagee, and purchasers are chargeable with notice of all the recitals of the trust deed. They are bound to observe the limited power of the trustec to release the pledged property; the time the notes for which it was given have to rmu, and the terms whieh anthorize a reconveyanee; and where a rolease is marke

34 Williams $r$. Jarksols, 107 U. S. 478; Barbour r. Scottish-Imerican Mltg. Co., 102 111. 121.

35 See, Mcllyerson $v$. liollins, 107 N. Y. 316.

36 Day $v$. Brenton, 102 Jowa, 482;
Lennartz $v$. QuaJity, 191 III. 174. : ד Livermore b. Maxwell, 87 lowa, 705; Lennart\% v. Quilty, 191 Ill. 174; But sere, Mrephorom re lios. line, $107 \mathrm{~N}$. Y. :3l6; Atkinson $v$. Greaves, 70 Miss. 45. 
before the maturity of the notes, they being negotiable, a prident comisel should insist npon their production or of satisfactory evidence showing that they have been surrendered or paid. Another feature is presented where the trust has becn placed in two trustees, and comsel in making examinations should be eareful to see that both trustees have united in the release, for no point is better established than that the release of lands by one of two joint trustees is not, in itself, sufficient to discharge the land from the lien of the mortgage.

Not infrequently releases are exceuted by the successor in trust, the trustee having died or become disqualified. Where provision is made the refor in the trust deed such a release is valid and effectual upon the happening of the contingency. If the trust deed is hown in the examination the power of the accessor should be inserted in the abstract. If the trust deed is not shown, as where the relcase is exhibited in a continuation, or if the power of the snecessor is not given in the abstract of the trust deet as it appears in the former examination, a note embodying the essential facts should be appended to the abstract of the release. The following will serve as a snggestion :

Note.-The Trust Deed from Thomas Smith to James Brown, recorcled Oct. 30. 1891, as Doc. 15605, in Book 50 of Records, at pege 301, provides that in case of the death, resignution, removal from C'oole county. Illinois, or olher inability to act of said grantee. then Olney $B$. Stuart is thereby appointed and made successor in trust threin with like power and authority as is vested in said grantee.

\$371. Narginal Discharge. A release or discharge made by entry upon the margin of the recost of the mortgage or other instrument, is in common use in all the States, and when made by the owner of the mortgage, with whatever formalitics may be prescribed hy law, is as effectual in divesting the lien of record as a formal and separate satisfaction piece 
or release. ${ }^{38}$ It will be understood, however, that the authority of the person so undertaking to make the discharge must affirmatively appear of record, for a marginal entry of satisfaction by a stranger, without anthority, is void, although he claims to be the assignee of the mortgage and owner of the indebtedness, ${ }^{39}$ and where a person purporting to be the "assignee of said mortgage" assmmes to discharge same, but no assignment appear's of record, this constitutes a radical defect in the title ${ }^{40}$ which should be remedied before it is accepted. A marginal release or satisfaction should inmediately follow the mortgage it affects, and being brief itself the abstract is correspondingly so, consisting principally of a recital of the release; thus,

On the margin of the record of the foregoing is:

$\left.\begin{array}{c}\text { Thomas Smith } \\ \text { (Assignee) } \\ \text { to } \\ \text { William Jones. }\end{array}\right\} \begin{aligned} & \text { Satisfaction of Mortgage. } \\ & \text { Dated June 21, 1SS3. } \\ & \text { Recites that "within" mortgage } \\ & \text { has been fully paid, satisfied and dis- } \\ & \text { charged. }\end{aligned}$

Not witnessed. ${ }^{42}$

When a mortgage or deed of trust is duly recorded, the person whose property is incumbered thereby is entitled upon fully paying and satisfying the delot, to secure which such mortgage or trust deed was given, to have satisfaction of the same entered upon the margin of the record. And a mortgagee or trustee who fails or refuses, when duly requested, to

38 A purchaser finding a mortgage satisfied of record by a marginal entry, and upon the faith of which, withont actual notice of a mistake, pays the purchase price, will take the title eloar of the mortgage, althongh it turns ont that the entry was a mistake which would le rectificl as between the parties: Ayers $x$. IIays, 60 Ind. 452.
39 De Laureal $r$. Kemper, 9 Mo. App. 7 .

4" Torrey r. Deavitt, 53 Vt. 331.

41 When such is the ase.

42 Narginal releaces must, as a rule, be winesced by the recorder or oflicer having eharige of the reeorils. 
enter up such satiffaction or to execute a deed of release, is liable in damages to the party aggrieved. ${ }^{43}$

It will sometimes happen that the rclease is made, not by the mortgagee, but by some person acting for him, as an attorney in fact; or it may be that the mortgagce has died and the release is by his personal representative. In either event the authority should in some mamner appear. A note, in many instances, will be sufficient, and when the release is made, say by an executor, the essential facts of authority may be shown in this manner:

Note.-The Probate records of Cook County, Illinois, show that William Dinsmore died Oct. 19, 1895, leaving a last will and testament in and by which he appointed. Charles E. Pope executor thereof; that said will was duly proved and admitted to record and Letters Testamentary thercon were issued to said Charles E. Pope, on Oct. 29, 1895.

§ 372. Foreclosure. Foreclosures by entry and possession, or strict foreclosures, are now rarely pursued or allowed in a majority of the States, while in many they are positively prohibited. They are regarded by courts as scvere remedies, inasmuch as they transfer the absolute title withont sale, and sometimes without notice, no matter what the value of the premises. In like manner foreclosures by advertisement and sale, so called, are now gencrally discountenanced even where allowed, and resort is usually had to a court of equity to perfect a title acquired through this channel. In foreclosure by advertisement the mortgagee's or trustce's decd recites the proceedings, while forechosures in equity are shown by a summary of the procesdings, decree and report of sale.

\$ 87: Troof of Title under Foreclosure. To sustain a title mulcr foreclosure it would be necessary to show: the

43 Verges $v$. Giboney, 47 Mo. 171; Y.), 648. This is the general statuSherwood $r$. Wilson; 2 Sweeny (N. tory doctrine. 
mortgage; the judgment roll; the decree; the sale; and the officer's deed. The abstract, therefore, should disclose in a connected and orderly manner the essontial features of each of the steps and proceedings above enmmerated, and whenever practicable, in the order here given. The mortgage need not be minutely described, nor is it necessary that the power of sale be shown. ${ }^{44}$ General references are sufficient. The judgment roll must show the regularity of the proceedings and the jurisdiction of the court both as to the sulnject-matter and the parties. Final and interlocutory decrees must show every material point passed upon. The sale is critrucen hy the officer's certificate of sale, report and confirmation. The deed follows as a part of all that has preceded it, and the whole constitutes but one transaction. Each of the several separate features are integral and neeessary parts.

44 This feature derives most of its foreclosure by adrertisement under importance where there has been a the power. 


\title{
CHAPTER XXIII.
}

\author{
WILIS.
}

§ 374. Generally considered.

375. Nuncupative wills.

376. Nature of testamentary titles.

37.. Definitions.

378. Operation and effect of devises.

379. Validity of devises.

380. Testamentary capacity.

381. Construction of wills.

381a. Errors of description.

382. Tiepugnancy.

383. Descent or purchase.

384. Words of grant.

385. Words of purchase and limitation.

386. The rule in Shelly's case.

387. Interpretation of partieular words and phrases.

388. Words which pass real estate.

389. Limitations and remainders.

390. Devise to a class.

391. Gifts of the income of realty.

392. Derise with power of disposition.

393. Indeterminate devise.

391. Devise on condition precodent.
§ 395. Conditional devise - marriage.

396. Contingent remainders.

397. Contingent reversion.

398. Devise to married woman.

399. Devises to executors in trust.

400. Bequest to devisee by deseription.

401. Precatory trusts.

402. Perpetuities.

403. Lapsed devise.

40\%. Devises for the payment of debts.

405. Charges on lands devised.

406. Equitable conversion.

407. Resichary clause.

408. Codieils.

409. Revocation.

410. Formal requisites.

411. Abstract of wilis.

412. Method of arrangement.

413. Practical examples.

414. Probate of wills.

415. Effect of probate.

416. Foreign probate.

417. Abstract of probate proceedings.

\$ 37t. Cunerally Considered. The subject of testamentary conveyaness can only be treated briefly and in outline. They oceur in every title of long standing, and present a greater variety of phases and give rise to more questions in construction than any other species of convevance. They have 
been the subject of much legislation, and of a vast number of inharmonions, conflicting and sometincs contradictory decisions. As muniments of title they should be of equal dignity with deeds, after proper probate and arministration; but the subtleties which have been incorporated into the laws governing their construction have rendered them less so, except in cases of direct, absolute and nuincumbered gifts. In the following paragraphs an attempt has been made to briefly enumerate a few of the leading characteristics of this class of conveyances, and to point out, in a general way, some of the questions that arise in examination of titles acquired by way of testamentary gift. This las been done in a suggestive, rather than an exhanstive manner, for the narrow limits of our book will pernit of none other, and what follows is intended merely as clues or reminders to stimulate the examiner, and direct his attention to matters that otherwise night have escaped his observation.

\$ 375. Nunenuative Wills. Oral declarations of a tectirmentary character made in extremis are arailable only in the disposition of personal property, and hence are not considered in the examination of titles. ${ }^{1}$

\$ 376. Nature of Testamentary hithes. One who takes under a will is regarded as a purehaser equally with him who takes under a deed, but the estate and title in the hands of a devisec, while as full and anple as thongh deriver by deed, does not always possess that indefeasible character which attaches to it in the latter case. An inmeent purchaser ly leed takes the title maffectod by latent equities, and the undisclosed rights of third perons, but the devisec acopuires on? the title of the testator as it existed at the time of his drath, with all its infunities and imperfections, and suljoet to all equitios and liens in farog of strangers. Such title, though

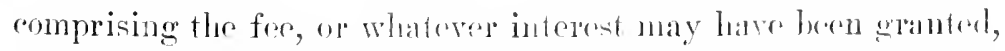

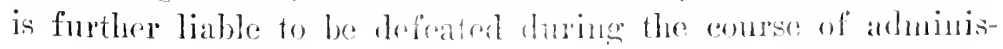

1 Lewis $r$. Aylott, 45 Trx. 190; Campbell v. Campbell, 22 I Mich. 438.

Smithdeal $v$. Smith, 64 N. C. 52 ; 
tration by a sale by the exeeutor in satisfaction of the debts of the decedent; ${ }^{2}$ or by the very instrument of its conveyance, when legacies thereby given are expressly charged upon the realty and there exists a deficiency of personal assets; ${ }^{3}$ or where the devise is conched in ambiguous or uncertain language requiring a judicial construction. The two former contingeneies can arise only prior to final settlement in the due course of administration; the latter at any time before the bar of the statute has intervened.

The title to land devised rests in the devisee immediately upon the death of the testator; and such devisee is entitled to the immediate possession of the land, and to hold the same until, when necessary, it is subjected by the executor to the payment of debts. ${ }^{4}$

\$ 377. Definitions. "Derise" is the generic term employed to denote a gift of real property by a person's last will and testament, and is distinguished from "legacy," which applies only to personalty. By analogy, the person to whom the gift is made is called a devisee, and the testator is frequently spoken of as the devisor. The term "bequest" is of indiscriminate application and includes both "devise" and "legacy." 5

$\$ 37$. operation and Effect of Devises. It is a rule of the common law that a will operates only upon lands owned by the testator at the time such will was made, and the title to which he retained to the time of his decease. This rule has been very generally changed by statute, which substitutes therefor a more reasonable rule to the effect, that every will that shall be made by a testator in express terms, of all his real

2 Hill $v$. Treat, 67 Me. 501; Vansyckle $v$. Richardson, 13 Ill. 171.

3 Wood $v$. Sampson, 25 Gratt. (Va.) 845; Lewis $v$. Darling, 16 How. 1. A devisee who takes an estate under a will assumes the payment of legacies imposed upon him by the terms of the will, and equity will regard him as a trustee and entertain a bill to compel him to perform his trust: Mahar $v$. O'Hara, 4 Gilm. (Ill.) 424; Burch $v$. Burch, 52 Ind. 136.

4 Hall $v$. Hall, 47 Ala. 290 ; Hamilton $v$. Porter, 63 Pa. St. 332.

5 Dow $v$. Dow, 36 Me. 211 ; Ladd v. Harrey, I Fost. (N. H.) 514 ; Lallerstedt $v$. Jennings, 23 Ga. 571 . 
estate, or in any other terms denoting his intent to devise all his property, shall be construed to pass all the estate which he was entitled to derise at the time of his death." It is the application of this rule which gives to the residuary clause much of its present importance. Intention, however, is, after all, the true test of a will, and where the intention is manifest, the will speaks from the time intended by the testator, " eren though before his death. ${ }^{\mathrm{s}}$

$\$ 379$. Validity of Devises. The several States possess inherent power to define the temure of real property within their respective limits; to prescribe the mode of its acquisition and transfer, the rules of its descent, and the extent to which a testamentary disposition of it may be exereised by its owners as well as the persons or classes of persons who may take under such disposition. ${ }^{9}$ Resort must therefore be had to the statute to determine the validity of all bequests, and, where that describes or enumerates the persons or classes who may take, a devise to persons or classes not therein specified will, it seems, be roid. ${ }^{10}$ Where a derise is roid by the rules of law, the land descends to the heirs at law of the testator. ${ }^{11}$

$\$ 380$. Testamentary Capacity. Erery work on wills is largely deroted to the subject of testamentary capacity. This is a subject, however, that will rarely be presented in exam-

6 Canfield $r$. Bostwick, 21 Conn. 550: Peters $r$. Spillman, 18 Ill. 373 ; Haley $v$. Gatewood, it Tex. 281; but though it is a general rule, that a will is held to speak from the death of the testator, it is otherwise where the language used repeals the presumption, taking into consideration the entire instrument: Uprike $r$. Tompkins, 100 Ill. 406. TGold r. Jurl-on. 21 C'onn. 616; Dunlap r. Dunlap. 74 Me. 402.

8 Plitliphnrg $v$. Burch, $37 \mathrm{~N}$.

J. Eq. $48 \%$.

9 United States $v$. Fox, 94 U. S.
(4 Otto) 315 ; Kerr $v$. Dougherty, 7 X. Y. 327 .

10 Thus, by a statute of New York, a devise of lands in that State can only be made to natural persons, and to such corporations as are created under the laws of the State and are authori\%d to take by devise: a deviop, therefore, of lands in that State to the grovernment of the Eniterl Stites was held voirl: [nited States r. Fox, 94 U. S. 315.

11 I) forl r. Deford, 30 Mh. 16s;

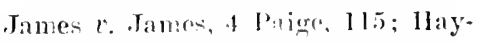
den $v$. Strughton, 5 Pirk. 528. 
inations of title, otherwise than as it incidentally appears in the proceedings relative to prohate. The right of testamentary disposition is controlled by statute, but is given generally to all persons of full (legal) age, being of somd mind and memory, and extends to all species of property and to every right, title and interest therein. Alienage and coverture, formerly constituted common law or statutory disabilities, but a gradnal remoral of restraints on alienation has virtually or expressly abolished such disalilities in the Cnited States. Infants and persons of insufficient mind are about the only persons upon whom any restrictions are now placed. The facts of legal age and a sound and disposing mind ${ }^{12}$ are matters of primary investigation and proof in all probates of wills, and the questions thus presented and presumably satisfactorily answered at the ontset, are not again raised during the examination.

$\$$ ss1. Construction of Wills. Tpon the ground that wills are often made in haste, and hy inexperienced persons, a devise is not construed strietly and teehnically, like a deed, but liberally, and according to the intent of the testator, and such intent may be gathered, in case of doubt, not from detached clanses, but from the whole will, so that every word may have its effect, if possible. ${ }^{13}$ On the other hand, there is a certain degree of strictness in the construction of wills that is almost wholly wanting in the ease of deeds, and while conts may look beyond the written words ret extrinsic evidence is never admissible to alter, detract from or add to what is there set down.

It is a cardinal rule in the eonstruction of wills, that a testator is always presumed to use the words in which he ex-

12 To be of solund and disposing mind. the law simn!y requires that the tectator be able to manage his own afrairs, and to know intelligently what disposition he is making of then: Harvey $v$. Sullen's Heirs, 56 Mo. 372.
13 Welch $r$. Truse. 49 Cal. 507; Butley $v$. Trestis. 69 III. 594; Lytle

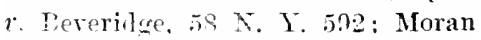
v. Dillehar. 8 Buth. 434; Bergan $v$. Cahill. 55 Ill. 160. 
presses himself, according to their strict and primary acceptation, unless from the context it appears that he has used them in a different sense; in which case the sense in which he thus appears to have used them will be the sense in which they are to be construed, ${ }^{14}$ and technical words are presumed to be used in their legal senze, unless there is a plain intent to the contrary. ${ }^{15}$ The general intent will prevail over expressions indicating a different particular intent, ${ }^{16}$ though every expressed particular intent must be carried out when it can be, ${ }^{17}$ and when a will is susceptible of a two-fold construction, one of which avoids and the other upholds it, the latter must be adopted. ${ }^{1 s}$ The general rule, however, that wills are to be construed accorling to the intention of the testator, must be understood as the intention of the testator as expressed in the will; and this must be judged of exclusively by the words of the instrument, as applied to the subject-matter and the surrounding cireumstances, ${ }^{19}$ and not from extrinsic matter or evidence aliunde. ${ }^{20}$

These are the fundamental principles that govern the con-

14 Luec $\%$. Dunham, 69 N. Y. 36: Edrards $\tau$. Pibb, 43 Ha. 66i6: Mead v. Jemnings, 46 , Mo. 91: Feltman v. Baits, 8 Bush (5y.). 115. Words nay be con-ilered in an order other than that in which they are placed, if the intent of the tes. tator is better served thus: Fury's Appeal, 102 Pa. St. 207.

15 Butler r. Insetis, fos Ill. 504; Franee's Estate, 75 Pa. St. 2:0: DeFay $r$. Irving, 5 Den. 6-60.

16 Pell $v$. Humphrey, \& V. Ta. I; Parles r. Palks, 9 Paire, 107: Sehott's Estate. 78 Pa. St. 40: Watson r. Binckmond, 50 Miss. 15.

1 Tell $\bullet$. Ilumplurey, $8 \mathrm{~W}$. Va. 1: Lepage $r$. Metanara, 5 Iowa, 124. 1s Masen r. Jomer. 2 liath. 229.

19 Bell r. Thumphrey, 8 W. Va. 1; Whecer $\imath$. Ifartshorn, 10 Wis. 83;
Blanchard $थ$. Maynard, 103 I!l. 60. 2 Metlister 1 . Butterfiold, 31 Ind. 2.); Prownfield $r$. Wilson, 78 111. $40 \tau$; Caldwell $\longleftarrow$. Caldwell, 7 Bush (Ky), 515; Sherwood $r$. Sherwod, 4.5 Wis. $35 \%$. It is true that the condition of the testator at the time of exceution, the state of his property, his family and the like, may be shown in order to throw light upon his intention, ret as the writing is the only outwaid and visible expression of his moming, no other words. as a rele. cen bo added to or substituted for those used. Frunt 1. White. 24 Ter. titis; Hackie r. Story, 03 U. S. 589: Alererombie $r$. Aherrombie, 27 Al: 489: IIerrick $r$. Storer, 5 Wend. (N. S.) 580. See, however. the sacceeding section on "repugnaney." 
struction of wills, and to then little can be added that is of general application. The donor of property by testamentary. disposition has an almost mulimited scope within which to exercise his judgment or to gratify his eaprice, and while multitudes of wills are daily presented for construction it is seldom that we find any two of them exactly similar. Unlike deeds of conveyance in this respect, they are as multiform and distinct in their structure, phraseology and purposes as are the mental operations, motives and feelings of the difierent testators. The intention must in all cases be sought for and if possible ascertained; and this intention, when it is not in conHict with the settled policy of law, will always be respeeted and allowed to operate. ${ }^{11}$ Any construction which will result in partial intestacy is to be avoided, unless the language of the will compels it. ${ }^{22}$

The questions of construction more frequently presented in the examination of titles, arise throngh the failure of the testator to make a full and explicit disclosure of the method of dieposition. The rnle is fundamental, in such cases, that the deficioncies camnot be supplied, nor the inacenracies corrected by extrinsic critence, and so strict are the courts in applying this rule that they will not permit the terms of the will to be altered eren where the trestator has, by mistake, misdescribed lands, by substituting those which can clearly be proved, he intruded to devise. ${ }^{23}$ This is in pursuance of the old and well known principle that extrinsic cridlence cannot be received to change or vary a solemnly executed instrument. Yet the rule is subject to some qualification in the case of erroneous descrip-

21 Douglass 2 . Bhackford, $7 \mathrm{Md}$. 22; Summit v. Yount, 109 ind. 506.

22 Vernon $r$. Vernon, 53 N. Y. 351 ; Cate $v$. Cranor, 30 Ind. 292. The state of the law at the time of the execution of a will often affords material assistance in arriying at the intention of the testator, when it would otherwise he doubtful, but the rights of parties taking under the will are always to be determined by the law as it existed at the time the will took efrect: Carpenter $v$. Browning, 98 Ill. 282.

23 See, Kurtz $v$. Hlibner, $55 \mathrm{Ill}$. 514 ; Starkweather $v$. Bible Society, 72 Ill. 50. The text states the general rule, but this seems to have been disputed in some States. 
tions where by striking out a word or phrase shown to be false a partial intestacy may be avoided.

$\$ 381 \mathrm{a}$ Errors of Description. Not infrequently, through inadvertence or mistake, a testator will derise lands which he does not own and omit to di-pose of lands which he does own, thereby creating a partial intestacy. Thus, the devise may be of Lot $A$, a tract which the testator did not own, either at the time of making the will or at his death. It may be that he did own Lot $B$, and that this fact is known to counsel. Here, then, we have what is known as a latent anbiguity and the questions which it raises are very perplexing. The general rule is, that, howerer many errors there may be in the terms of description employed in a will, whether of the devisee or the subject-matter of the devise, the gift will not be aroided if, after rejecting the errors or false words, enough remains to show with reasonable certainty what was intended by the testator. IIence, a derise of land by a description partly false, as where a wrong section number is given, may yet be effective if what remains, after rejecting the false, will serve to identify the particular tract which was intended. ${ }^{24}$

But this rule is for the guidance and direction of courts in the construction of wills. A court, in a proper case, may strike out false or ambiguous words, and may then read the will with the false words eliminated therefrom. Comsel, however, in the examination of a title, has no such privilege. IIis own knowledge of the actual facts may serve to inlicate a course to be pursued in order to prerfect title, but he camnot himself construe the will, nor should he attempt to apply the ruke, however certain he may be that the rights of the parties will be determined by it. In a case such as we are now considering counsel ean do no more than point ont the latent defect and suggest a remedy that will serve to cure it.

The strong tendency of morlern decisions is to aroid eren

24 See, Pate $v$. Bushong, 161 Ind. 116; Stewart $v$. Stewart, 96 lowa 533 ; Whitcounb v. Rodman, $1.56 \mathrm{lll}$. (j)0. 
partial intestacy, and while extrinsic oridence may not be resented to for the prrpose of changing or varving the words of a will, yet it is now well settled that when a latent ambiguity is disclosed by extrinsic evidence it mav be removed by extrinsic evidence. 25

\$ 38\%. Repuguancy. It is a well established rule, that where two or more provisions in a will are clearly repugnant or irreconcilable, the last should prevail, ${ }^{26}$ as being indicative of the testator's latest wish $;^{2 \pi}$ yet it is a rule that is only applied in cases of absolute necessity, as where the provisions are totally inconsistent with each other, and the real intention of the testator is incapable of determination. ${ }^{2 s} \mathrm{~A}$ prior provision, however, will never be disturbed, further than is absolutely necessary to give effect to a subsequent one, ${ }^{29}$ nor will the expression of a particular intent be sufficient to orercome the manifest general intent. ${ }^{30}$ Thus, where the first clause absolutely disposes of all testator's property, a subsequent clanse providing for the distribution of a fund which would or might at some future time accrue to his estate would not affect the antecedent general disposition, for in such case, no residuum being contemplated, there could be no residuary legatees. ${ }^{31}$ Similarly, where there is a devise of an unlimited power of disposition of an estate in such manner as the devise

25 Whiteman $r$. Whiteman, 152 Ind. 263: Patch $r$. White, $117 \mathrm{U}$. S. 210 ; Decker $v$. Decker, 121 Ill. 341 ; Mcrrick $r$. Merrick, 37 Ohio St. 126 .

26 Hamlin $r$. Express Co.. 107 Ill. 443; Fulton $v$. Hill, 41 Ga. 554; Bradstreet $r$. Clarke, 12 Wend. (N. Y.) 602; Van Nostrand $r$. Moore, 52 N. Y. 12; Evans $v$. Hudson, 6 Ind. 293 ; Miller $v$. Flournoy, 26 Ala. 724 ; Pickering v. Langdon, 22 Me. 430.

2 i liountree $r$. Talbot, 89 1ll. 246. 2 C Corenhoven $r$. Shuler, 2 Paige (X. Y.), 122; Oxley $r$. Lane. $35 \mathrm{~N}$. I. 340 ; Newbold $x$. Boone, $52 \mathrm{~Pa}$.
St. $16 \overline{\text {; }}$; Bartlett $v$. King, 12 Mass. 5.2; Thrasher $r$. Ingram, 32 Ala. 645 ; Siceloff $r$. Reciman, 26 Ind. 251.

29 Taggart $r$. Murray, $53 \mathrm{~K}$. Y. 233; Kenzie $v$. Roleson, 28 Ark. 102; Parker $r$. Parker, 13 Ohio St. 95: Stickle's Appeal, $29 \mathrm{~Pa}$. St. 234. 30 Hamlin $v$. Express Co., 107 Ill. 413; Bell $v$. Humphres, $\mathrm{S}$ W. Ta. 1: Cook $v$. Holmes, 11 Mass. 528 ; Pickering $v$. Langdon. 22 Me. 413; Schott's Estate, is Pa. St. 40; Watson $x$. Plackwood, 50 Miss. 15; Miller $x$. Flournoy, 26 Ala. 724.

31 Henning $r$. Varner, 34 Md. 102. 
may think proper, a limitation orer is inoperative and roid. by reaton of its repunnancy to the principal devise. ${ }^{32}$

Ender the application of the rule that a will should be so construed as to effectuate the intention of the testator as far as possible, express wolds must sometines vield to the otherwise manifest intention, and words will even be adderl whers it is absolutely necessary to awoid absurdity or give effect to such manifest intention.33

\$ 3s3. Toid Devise - Descent or Purchase. It was a maxin of the commum law that title by desecnt was a worthier or better title than one acening by purchase, and occasionally some belated American cont annonnces the same doctrine. ${ }^{3 t}$ As a consequence of this doctrine a mle was formulated that a devise giving exactly the same estate in quantity and quality as the derisee would take by descent if the devisee had not been made, is void, and the title so acquired is held by descent and not by purchase. This rule, it rould secm, still obtains in a few States. 35

This was one of the subtletios of the medieval lawren and grew out of the lesal notions inwolvel in old fenlal system. Ender that system there was but one leir, and that, nswally, was the oldest or ouly son. In case there were several daughters and no son the legal fiction was preservel mel the all took as one heir. There were a mminer of reasons that might be assigned for such a rule at the carly day in which it was promulgated, ${ }^{36}$ but these reasons never had any force in this coun-

32 Ilamlin $r$. Exprese Co., 147 Ill. 443. Although the limitation oier might, under some circumatinces, become effecive shond the doner of the powe: fain to expren it.

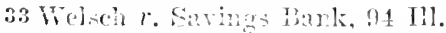
191; Wright $r$. Dum, in Whost. 204; Bartlett $r$. Ning, 12 Mros. jä;

liuston $r$. liuston, 2 D.11. 214. 34 Kollett r. Sliepard, l:3 111. $13: 2$. $\therefore$ Sthers r. Clatk, lst lll. 186; Biedler r. Biedler, 87 Vis. 300.
: In England title by descent was furored by the courts, firt. becance land in the hands of the liceir at law by dencent was charereahle with the payment of the ara-

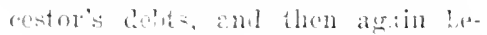
rase it farosul the right of acherat won the faibure of heirs on the part of tha ancentor from whom the

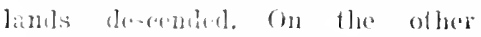
hamel, land actuired by purchase was mot liable for debts. and upon 
try while the rule itself has been abolished in England by statute.

Where one devises property to his heirs it is but fair to presume that he intended they should take the property under the will, and in furtherance of this principle the rule first stated has been set aside in a majority of the American States, and the devisees in such cases held to take by purchase and not by descent. ${ }^{37}$ Where, however, gifts to heirs at law are made to them simpliciter, the persons to take and the proportions of their respective shares must be determined by the statutes of descent and distribution. ${ }^{38}$

$\S 35 t$. Words of Grant. $\Lambda$ s in deeds so in wills, there must be apt words of grant or conveyance or words indicative of testamentary intent, but any form of expression will be sufficient to pass title, provided the intent is manifest. "Give," "derise," or "bequeath" are the words commonly in use, and all or either will be sufficient to pass real estate, though the technical word for this purpose in a properly drawn will is "devise." 39 Words of advice, desire, recommendation, etc., are not ordinarily sufficient, ${ }^{40}$ althongh, in some cases, they may be sufficient to raise trusts. ${ }^{41}$

$\$ 385$. Words of Purchase and Limitation. In pre-

the death of the owner, it descended first to the heirs on the paternal side, and upon failure of sueh heirs, then to the heirs on the part of the mother. Title by descent was considered the worthier title and where the will gave to a devisee the same estate in quantity and quality which he would have taken as heir at law, he was adjudged to take not uncler the will, but by descent or operation of law. Domnelly $r$. Turner, 60 Md. 81.

s7 Gilpin $r$. Hollingsworth, 3 Mr. 190. When heirs take by purehase they do not take as heir's, but as a. class of persons to whom ly that means the testator has selected to devise his property, and as they take in their own right, the distribution is to be made per capita and not per stirpes: Camplell v. Wiggins, 1 Rice's $\mathrm{Ch}$. (S. C.) 10 ; and see Robinson $r$. Le Grand, 65 Ala. 111.

s. Riehards $v$. Miller, 62 Ill. 417. 39 Acceptanee of a levise where it is beneficial to the devisee and attended with no charge or risk, is always presumed: Brown $r$. Thorndike, 15 Pick. 388.

40 Gilbert $r$. Chapin, 19 Conn. 342; Bolm $x$. Barret's Ex'r, 79 Ky. 378.

41 See "Precatory Trusts" infra. 
paring the synopsis of wills, the attention of the examiner is particularly directed to what are known as the words of "purchase" and "linitation." These are the words used in connection with gifts" to specifie persons, and show, as in case of deeds, the mature or quality of the estate conveyed. They consist of such words as "heirs," "heirs of the body," "issue," ete, and accordingly as the word is used may be either a word of purchase or of linitation. Sufficient of the context must be given to show the sense in which the word is employed and to permit a proper construction. The word "issue" presents the largest number of questions and has been productive of an almost innumeralle number of decisions. As a word of linitation it is collective, and signifies all the descendants in all generations; but as a word of purchase it denotes a particular person or class of persons to take muler the devise. The term may be employed in either manner, as will best effectuate the testator's intention, and is the most flexible word that can be used. ${ }^{42}$ Courts more readily interpret the word "issue" as the synonym for "children," and as a mere description of the person or persons to take, than they do the worls "heirs" or "heirs of the body." 43

The usual and ordinary words for conveying a fee simple in wills as well as in deeds, are "heirs," or "heirs and assigns forever;" but a devise to a man "forever," or to one "and his assigns forever," or to one in "fee simple," will pass an estate of inheritance to the devisee, notwithstanding the omission of the legal words of inheritance, ${ }^{44}$ while the

42 Timanus 2 . Dugan, 46 Mrl. 402 ; Daniel $v$. Whartenlyv, 17 Wail. 639. Words in the introductory or otler parts of a will indicating an intention of the testator to di-pose of his whole estate, although not conclnsive that ho intends to pass a fee, always favor such construction: Geyer $r$. Wontzel, 68 Pa. St. 84; Fearing $v$. Swift, 97 Mass. 413.

43 In England the word "issue" is a word of limitation and not of purchase, unless the contrary clearly appears: $2 \mathrm{Jarm}$. on Wills, 328.

44 Coke Tit. 9 b; 2 Black. Com. 10s; Nepers r. Antroson, 1 Sirobh. Eq. (S. C.) 344; Timamm r. Dulgan, 46 Nlel. 402; Tatum r. MeClellan, 50 Miss. 1; Wotter $r$. Walker, 62 Ga. 142; Fdwards v. Barnard, 84 Pa. St. 184. 
statute, in a majority of the States, will compensate for the defieiency and give to the derisee an extate in fee, nome other being mentioned. ${ }^{45}$

Question:, as to whether a devisee takes the fee or a lesser cstate, occur most frequently where the testator in his anxiety to make his gift effective makes several bequests in the alternative, or linits one estate npon another, and are usually to be decided by the application of the rule in Shelly's case as modifind by local law. No rule of general application can be formulated, and from a review of the reported cases on thus subject one can well appreciate the remark of a learned writer, that, "the liberality of the law in construing wills has opened the flood-gates of legal chaos." "4 It wonld seem, however, that whenerer the intention of the testator can be ascertained it will overcome all technical pules, $^{4 \pi}$ and this intention turns, mot upom the quantity of interest giren to the first taker or person specified, but upon the nature of the estate intended to be given to the "heir." 4 s

\& 386. The Rule in Shelly"s Case. Though entailed estates are no longer permitted, the rule in Shelly's ease still

45 Leiter $r$. Sheppard, 85 Ill. 243 ; MaConnell $r$. Snitl, 2:3 111. 617; Mirfitt $t$. Jessop, 94 III. 158. The statute very generally enacted throughout the Lnion provides, substantially, that every estate in lands which sliall be grantel, conveyed or devised, although other words heretofore nevenary to transfer an estate of inheritance le not added. shall be leemed a foe simple estate of inheritance, if a less estate be not limited by express words, or do not appear to have been granted. conveyed or deviced by construetion or operation of law.

46 O'Hara on Wills, 27, and see Clark r. Eoorman's Exrs, is Wall. 493.

47 Goodrich $v$. Lambert, $10 \mathrm{Comm}$.
44.9; Baker $v$. Scott, 62 Ill. 90 ; Butler $r$. Huestis, 68 111. 601. The decisions of the local courts will furnith the best muide for construing estates under wills, as, between the States, diametrically opposed views will frequently be met with on the sanie admitted facts.

4s Baker $r$. Scott, 62 IIl. 90; 4 Kent. Com. 221. The rule in Shelly's case, that $i s$, the technical application of the words "heir" and "heir." is not now received in all it original rigor. from the fact that it often operates to defeat the tes. tator's intention. and in many States it is ragurded of no especial foree except as an aid to coustruetirn and intention: Blake $r$. Stone, s. Yt. 45.5 
has a modifien force, and is often inroked in the eonstruetim of devises to determine the operation of the will and settle conflicting clains. This rules provides that, where the ancestor takrs an estate of frechold, and in the same gift or converance, an estate is linited, either mediately or immediately to his heirs, either in fee or in tail, the term "heirs" is a word of limitation and not of purchase, ${ }^{49}$ and when applied to wills is ordinarily confined to cases in which the remainder is linited in terms to the "heirs" and not to "children " or "issue." 50 When invoked, as a rule, it is not a real exception to the fundamental doctrine that the intention of the testator must guide in interpreting a will; it merely sacrifices a particular intent to a general intent. It does not interpret a will, but takes effect when the interpretation has been ascertained. ${ }^{51}$

\section{$\S 387$. Interpretation of Particular Words and}

Phrases. Though the testator is presumed to use teehnical

49 Baker $v$. Scott, 62 Ill. 90 ; Estate of Utz, 43 Cal. 200.

50 Akers 1 . Akers, 23 N. J. Eq. 26 ; Estate of Ltz, 43 Cal. 200. But see, Haley $r$. Boston, 108 Mass. 576. The word "children" in its usual sense is a word of purchase and not of limitation, and is always to be so regarded unless the testator has unmistakably used it otherwise: Stump r. Jorran, 54 Md. 631; 2 Wash. Real Prop. (fth Ed.) 603. While not infrequently the word "heirs," or even the words "heirs and assigns forever" are held not to operate as words of limitation because correrted or explained by words whirh follow and which are irreconcilable with the notion of descent: Shres's Case, 4.3 MIl. 39.9.

51 Yarnall's Appeal, 70 P'enr. St. 335. Greater latitule, however, is given in the construction of wills than in that of deeds, and courts will look to the whole will. Thus, the rule as stated in the text, while of general controlling efficaey in detus, where it may usually be safely appied, is subject to a wide latitude in wills, and while in some States it may be rigilly onforced, in the majority, when explanatory words are found in the will showing the intention of the testator that the words "heirs," or "leirs of the body" are employed to show that sueli persons shall take under the devise as a description ef perons, they will be treated as worls of purchase and not of limitation: Putler $r$. Huestis, 6s Ill, 594. When such appears to be the testator's intention "heirs" have been construed to mian "children." 
words according to their technical meaning, ${ }^{52}$ this can hardly be areerted at a rule, or shonld it be so asserted, it must be taken subect to that other all powernl rule that the intention of the testator must prevail. ${ }^{53}$ The construetion of words in a will is much less technical than that of the same words in a deed, for though in deeds efiect will always be given to the true intention of the parties, ${ }^{5 t}$ yet the words employed goveru such intention, while in a will the intention, in one sense, governs the words. ${ }^{55}$ The nze of the word "descend," does not operate to work a descent in the logal, strict sense of the term, as inheritance is only through operation of law; its employment, therefore, unless some other meaning is apparent, is to be taken as indicating the desire of the testator that his property shall follow the same chamnel into which the law would direct it. ${ }^{56}$ "Chiklren " is generally taken in its primary and strict signification, and does not include grandchildren, ${ }^{57}$ unless there is smmething in the context to show that the testator intended to inchule grandchildren, or unless such construction is necessary to render the provicions of the will operative. ${ }^{58}$ "Issue " means heirs of the boly. 59 "Heirs," as a rule, means statutory heirs, of every kind and degree, ${ }^{60}$ but under certain circumstances may be confined to children. ${ }^{61}$ The words "next of kin" limit the derise to blood relations, and do not

52 France's Estate, 75 Penn. St. 220 .

53 Smyth $r$. Tilylor, 21 Ill. 296 : Helser $r$. Harrin, 42 IIl. 425; Meade $r$. Jennings, 46 Mo. 91; Robertion $r$. Johnson, 24 Fa. 102.

54 Peckham $v$. Haddoek, $36 \mathrm{Ill}$. 38; Churchill $r$. Reamcr, $s$ Bush (Ky.). 256 .

55 Edwards $v$. Bibb, 43 Ala. 666: Brownfield $r$. Wilson. 78 Ill, 467 .

56 Demett $r$. Dennett, 40 N. H. 498.

5 t Hopson $r$. Commonwealth. etc., 7 Bush (Ky.), 644; Noffat $v$. Carrow, 7 Paige, 32s; Gernet $v$. Lynn,
31 Penn. St. 94: Cummings $v$. Plummer. 94 Ind. 403.

58 Feit $r$. Vanata, 21 N. J. Eq. 84; Houghton $r$. Kendall, $\tau$ Allen (Mass.). 72. The words " children forever" in a devise, when eonstrued with the context, were held to be words of inheritance, and to have been used in the sense of heirs. See Moran r. Dillehay, 8 Bush (Ky.), 434.

59 Kleppner $v$. Laverty, 70 Penn. St. 70 .

60 Richards $v$. Miller, 62 Ill. 417. 61 Butler $v$. Huestis. 68 Ill. 594. Where the context shows that the 
include husband or wife, ${ }^{62}$ unless accompanied by other words clearly manifesting a purpose to extend their signification. ${ }^{63}$ The term "relatives" contains no elements of legal certainty. ${ }^{64}$

There are, however, no arbitrary or mbending rules in the construetion of the words of a will. No two wills are in all respects alike. Where the same precise form of expression oeeurs as may have been the subject of some former adjudication, maffected by any indication of a different intention in other parts of the instrument, the conts, with a view to certainty and stability of titles, will follow the preedent; yet, the cardinal canon still holds good, that the intention of the testator of each will separately is to be gathered from its own four comers, ${ }^{\text {f5 }}$ and where the intention satisfactorily appears it should prevail over any artificial rule of construction. ${ }^{66}$

$\S 38 s$. Words Which Pass Real Estate. Sometimes wills contain no specifie allusions to land, or particular bequests may be made in general terms, and in such cases grave questions of construction may arise when real estate is claimed under them. The liberality of courts is nowhere more manifest than in the solution of these questions. The words " property" and "estate" when used in a general sense, are always held sufficient to embrace all the testatur's property, real as well as personal, ${ }^{6 \tau}$ but when coupled with directions applicable only to personalty, they will not have this effect, nor where

testator used the words "heirs" in the sense of children, it will be so construed: Harerstick's Appeal, 103 Pa. St. 394; Hinton v. Milburn, 23 V. Va. 166.

62 Townsend $v$. Radeliffe, 44 Ill. 446; Murdock $v$. Ward, 67 N. Y. 387; Tillman $v$. Daris, 95 N. Y. 17. 430 .

63 Haraden $v$. Larrabee, 113 Mass.

64 Handley $v$. Wriglitson, $60 \mathrm{Md}$. 198.

65 Provenchere's Appeal, 67 Penn. St. 463 .
66 Kiennedy $v$. Kennedy, $105 \mathrm{Ill}$. 350 ; Suydam $v$. Thayer, 94 Mo. 49.

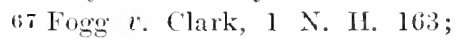
Jackion $r$. Honsel, 17 Johns, 281; Wheaton $v$. Andress, 23 Wend. 452; IIunt $r$. Hunt, 4 Gray (Mass.), 190; Korn v. Cutler, 206 Comm. 4; Momroe $r$ Jones, 8 R. I. 526. Tlis is directly contrary to the earlior and more technical rule, which confined these words cutirely to pere sonalty unless there was something in the context to show that the testator intended a nore enlarged meaning. 
subsequent particulars cleariy indicate that the testator had only personalty in contemplation. ${ }^{\text {is }}$ The word "effects," though saroring strongly of personalty ${ }^{69}$ may, when the context clearly shows the intention, as when used in connection with the word "real," to be sufficient to pass land. "11 "Goods," aceording to its natural, grammatical, and ordinary meaning, does not include lands. General usage has given it a meaning as consisting of personalty only, and this is its primary legal signification. $^{i 2}$ The context may sometimes enlarge this meaning, and where it satisfactorily appears that the testator intended to use the word in a different and more comprehensive sense, so as to cmbrace real estate, courts will give effect to that intent. The phrase, "all my worldly goods," if used without speeific enumeration, may reasonably be supposed to embrace lands, and in some instances has been so eonstrued; lut if attempt is made at designation the restrieted meaning implied from such designation will prevail. ${ }^{\text {3 }}$

The question will frequently occur in constructions of the bequest of the residum, and courts seem inclined to favor any construetion which will aroid even a partial intestacy. ${ }^{i t}$

Yet while no particnlar words are necessary to pass real estate, enough must appear to evidence the intention to conrey, and words ean not be supplied to meet the deficieney, even though they may have been omitted by what might seem to be palpable error, ${ }^{75}$ and where specific mention is made of

68 Smith $v$. Hutchinson, 51 Mo. 83.

69 Indeed, this term when used in a will, is generally construed to refer to personalty only, unless there is everything in the context to require a more extended applicution.

i) As, "all my effects, real and jrisonal."

i 1 Paige $v$. Foust, 89 N. C. 447.

72 Farish $v$. Cook, 78 Mo. 212.

$73 \mathrm{As}$ where testator bequeaths "all my wordly goods, consisting of," etc., the enumeration describing only personalty; real estate not specifically mentioned or otherwise referred to will not pass.

$i+$ Vernon $v$. Vernon, $53 \mathrm{~N}$. Y. 351 ; Cate $v$. Cranor, 30 Ind. 292; Damon $v$. Biblen, 135 Mass. 458.

$75 \mathrm{As}$ where testator, after making certain bequests and devises, gave "all the rest of my estatepersonal" to his four sons, and in a codicil stated that he had disposed of his "estate, real and personal," to said sons, and revoked 
certain property, other property not alluded to or covered by general terens wiil not pass.is

\$ 389. Limitations and Remainders. A large part of the litigation arising out of tostumentary conveyances is occasioned by questions relative to the construction of limitations and remainders. The subject has been incidentally discussed in several of the preceding paragraphs, and in addition to what has been there said, but little can be stated without entering into the matter at greater length than the exigencies of this chapter will permit. Local statutes are very effective in the settlement of such questions, so far as the ralidity of the remainder limited is concerned, as well as the persons who take, when particular words are accorded a statutory definition.

All works of purchase, as "children," it "issne," ete, ereate remainders according to their import, while "heirs" when construed as a word of purchase, designates not only the persons who are to take, but also the manner and proportions in which they take. ${ }^{\text {s }}$ The utmost liberality is displayed in the reported decisions construing remainders, and the circumstance that the first taker has it in his power to dispose of the whole estate and thus defeat a limitation over, is not of iteelf conclusive that the expectant estate is roid, when a contrary intention appears from the will. ${ }^{i 9}$ The intention of the testator must, in all cases, be carried out when such intention can be ascertained from the language employed by the will, and in no case can the intention thus ascertained be defeated by a technical construction of the language so employed. ${ }^{80}$

the share left to a certain son, held, that the court could not supply the words "real and" before "personal" in the will, and that testator died intestate as to his real estate, except a portion by another clause specifieally devicerl. Graham $v$. Graham. 2:3 Y. V: \$6.

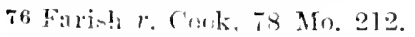

77 Beacroft $r$. Sitrown, 67 Ill. 28. is Rand $t$. Sanger, 115 Mass. 124. The rules of deseent in such rase are presumed to be the intended gruide.

70 Torry r. Wigrins, 2 Lans. (N. Y.) 272; Burleigh $x$. Clough, 52 N. I. 267. Compare Clark $i$. Tennison, 3:3 Md. 85.

s) Terry $\iota$. Wiggins, 2 Lans (N. Y.), 272 . 
Limitations to survirors have produced a vast amount of litigation, but the questions arising under such a derise may now be considered as well settled, and the general rule seems to be that the word "survivor" is to be taken in its natural and litcral import, unless the context plainly indicates a different intention, and should not be construed as equivalent to the word "other." s1 Where the courts have given the word "survivor" the force of "other," it has been done to avoid some consequence which it was very eertain the testator could not have intended. ${ }^{\mathrm{s}}$

$\$ 390$. Devise to a Class. It is a rule of the common law that a derise to a class of persons takes effect in faror of those who constitute the class at the death of the testator, that being the time when the will first speaks. But this rule has been greatly modified in many States, so that when an estate is dederised to the children or other relatives of the testator, the lineal descemlants of a devisee, who dies before the testator, take the share of their ancestor. ${ }^{s 3}$ In the absence of such a statute, howerer, the common law prerails and only those who are living at the time the derise takes effect are entitled to participate. Those who die before the gift beeomes effeetive are not regarded as ever having belonged to the class, and the whole estate inures to the surrivors.

$\$$ 391. Gift of the Income of Realty. It is well settled that a gift of the ineome of land or of the "rents and profits," or "benefits" is, in effect, a gift of the land itself. st Those to whom the testator has given the income for life will take a life estate, and those to whom he has given the perpetual income will take a fee simple estate. ${ }^{85}$ Such gift, however, to

S1 This is the construction which now obtains both in England and the United States: 2 Jar. on Wills, $648 ; 2$ Redf. on Wills. *37.2.

sa Leeming $r$. Sheratt, 2 Hare (Eng.), 14; 2 Jar. on Wills. 658; Consult Passmore's Appeal, $23 \mathrm{~Pa}$. St. 381; Moore $v$. Lyons, 25 Wend.
119; Martin r. Kirby, 11 Gratt. (Va.) 67 .

s3 Jamieson $x$. Hay. 46 Mo. 546 ; Smiley r. Bailes, 59 Barb. 80 ; Rudolph $r$. Rudolph, 207 Ill. 266.

st Johnson $r$. Johnson, 92 Tenn. 559.

s5 Reed $v$. Reed, 9 Mass. 372; But- 
aceomplish this purpose must be without qualification or restriction, and, in order to deternine whether there is such qualification or rectriction, recourse must be had to the whole will, with the view of ancertaining the sense in which the terms were used by the tostator. When it appears from other parts of the will that the fee is otherwise disposed of, such terms can not be helil to econvey the fee. ${ }^{\mathrm{si}}$

$\$ 392$. Devise with Power of Disposition. There an estate is given to a person generally or indefinitely, with a power of disposition, it carries the fee, mless the testator gives to the first taker an estate for life only, and annexes a power of disposition of the reversion. In that case, the express limitation for life will control the operation of the power, and prevent it from enlarging the estate to a fee. This is the doctrine laid down by Kont. ${ }^{s i}$ and the English writers,s and substantially followed by later Anerican deeisions. ${ }^{\text {9 }}$ The question often arises where life estates are created by implication, as where the testator devises property generally, without a specification of the quantity of interest, and adds some power of disposition with a remainder or limitation over. In such case, where an absolute power of disposition is amnexed to the gift, a limitation orer is of no effect, ${ }^{\text {on }}$ but where the power of disposal is not an ahsolute power, but a qualified one, conditioned upon some certain event or purpose, and there is a remainder or devise over, the words last need restrict and

terfield $v$. Haskins, 33 Me. 392: Earl $v$. Rowe, 35 Ne. 414; Collier $v$. Grimsey, 80 Ohio St. 17; Drusidow $v$. Wilde, 63 Pa. St. 170; Morgan $v$. Pope, 7 Coldw. (Tenn.) $5+1$.

sij Collier $v$. Grimsey, 36 Ohio St. 17 ; Morgan $v$. Pope, 7 Coldw. (Tenn.) 541 .

874 Kent Com. $* 535$.

ss Cruise Dig. iit. \$ 38, c, $13, \S 5$; Jar. on Wills (Higelow), *s73.

89 Ramsdell $r$. Rimsrlell, 2l Mr. 288 ; Jomes $v$. Bacon, 68 Me. 34;
Smith r. Bell, 6 Pet. 68: Gifford 1". Choate, 100 Mass. 346; Burleigh $v$. Clough, 52 N. II. 207; Jackson $r$. Robbins, 16 Johnc, 5:5; Ayer $r$. Ayer, 128 Mass. 575; Downey $r$. Borden, 36 X. J. L. 460 ; Benker $r$. Jacohy, 36 Iowa, 273: Hamlin $r$. Express Co., 107 111. 443.

fo Rand $r$. Neir, 47 Iowa, 607;

Scigwald $r$. Seigwald, 37 Ill. 4:30; Roseboom $r$. Roseboon, 81 N. Y. 356. 
linit the rolds first used, and reduce what was apparently an cotate in fee to an estate for life only. ${ }^{91}$

Where there is a derise for life, in cxpress terms, a power of disposal amnexed can not cnlarge it to a foe; 92 nor is it oppesed to any rule of law to create a life cstate with a power to sell and convey, and limit a remainder after its temination.": To satisty the doubts that must natmally anise in construing devises of this charncter, it is necesory that the entire clause relating to the devise be substantially, and in many cases literally, set forth, and, as the construction will often be influenced by other parts of the instrument, a conresponding treatment will be recuired of all such poitions as lirectly or indirectly concern the particular derise moler consideration.

A converance by a devisee for life, but with an absolute power of disposal of the reversinn, will vost in the grantee of such devisee an sistate in fore, while in ease the power has not been exercised, the land, on the death of such devisee, goes to the hars of the devisor." An important distinction will, however, be obsorved hetween an absolute and unconditional power of disposal in the discretion of the derisce and a power restrieting the disposition hoth as to time and man. ner. Tho devise of an cstate for life, with authority in the devisee to dispose of the laml by last will and testament, does not convey absoluto ownership, ${ }^{96}$ nor would the further fact that the will devising same charged the parment of the debts

91 Stuart $l$. Walker, 72 Me. lis; Merrill i. Enery, 10 Pick. 512; Jar. on With (Bigelow), "s.9. A derise with power of disposition, although providing for an ultimate remainler of what reinains undisposed of at the death of the first taker, will vest a fee, or a right to convey in fee: Lyon $t$. Mirsh, 116 Mass. 232.

92 Hamlin $v$. Express Co., $107 \mathrm{Ill}$ 443.

93 Ward v. Amory, 4 Curis, 425; Jar. on Wills (Bigelow), *873;
Welsele $r$. Sarings Bank, 94 Ill. 191; Jassey 1 . White, 28 Ga. 295; Downey r. Eorden, 36 X. J. L. 460. A different rule prevails in some States: See Hazel $i$. Hagan, $4 i$ Mo. $27 \%$.

$9+$ Fumk $c$. Figgieston, 92 I11. 515; Harel l. Hagan. 47 No. 277; Levy r. Gribiths, 65 N. C. 236 ; Lyon $v$. Marsh, 116 Mass. 232.

95 Faiman r. Teul. 14 111. 244.

9; Bryant r. Christian, 58 Mo. 98; and see Terry $v$. IViggins, 2 Lans. (N. Y.) 272 . 
on the devise be sufficient to enlarge the life estate to a fre simple. ${ }^{9 t}$ The right of testanntary dismosition is a more power, and though the authorities are mot atogether larmonious as to the right of the devisere to exercise such power by decl, it wonkd yot seem that a warranty deen in fee simple, executed by the dreviser, whicll made no leference to the will by which the power of disposition was given, and contained no evidence of an intuntion to exwote the joricre convers only the life estate of the derisee. ${ }^{98}$ 'The question seems to turn upon the fact of intention in the done of the powne to excente it, and when there are co-existing interests, one within and the other withont the power, it would seen that the intention to execute the power, whether by doed or will, must he apparent and elear, hut that intention, howerer manifested, whether directly or indirectly, positively or hy juct implication, will, when established, rendor a converance by the devisee valid and operative. $^{99}$ To state of facts, in an examination of title, presents graver questions, or questions more rifticult of solution.

97 Dunning $r$. Tan Dreen, 47 Ind. 423; Jassey $r$. White, 28 (4a. 295 ; Jar. on Wills (Bigelow), *8;?.

98 Dunning $t$. Van Dusen, 47 Ind. 423; Funk $x$. Eggleston, 92 111. 515. It may be laid down as a general rule, that in all cases where by the terins of the will there has been an express linitation of an estate to the first taker for life, and a limitation over, any general expressions apparently giving the tenant for life an unlinited power over the estate, but which do not in express terms do so, must be regarded as referring to the life interest only. and, therefore, as limited by such interest: Welseh $v$. Bellville Sargs. Bark, 94 Ill. 191.

99 Funk r. Fagleston, 92 Ill. 515. In this ease, the subject of a devise for life with power of disposition, iz very exlaustively treated in a larned and able opinion by baker, J. The fundamental minciple dedueible from the English deeisions is that there should be a certain areertainment of the intention of the donce of the power to act $m$ der the power. Three taskes of cases arose in which it was demonstrated to an absolute nomal eertainty there was an intention to execute the power, and these were, (1.) when there was a refernce to the power; or (2.) to the subject or property covered by the power: or (3.) when the instrument wol:]d be inoperative withont the aid of the power. The eases ranging themselves in one or the otluer of these three elasses, it was jullicially anmounces in some of the eases that thero could be no exeeution of a power unless the rase fell in one or the other of 
\$ 39:. Indeterminate Derise. Owing to the liberal construction now accorded to wills as well as sweeping statutory enactments relative to the limitation of estates, fewer questions will now arise in regard to the quantity or duration of estates than formerly. Wills drawn by the testator, or holographic wills, frequently fail to express clearly such testator's intentions, and as they are usually copied from the ever ready "form book" and adapted to his wants, they not infrequently fail to expressly define the nature or extent of the estate he seeks to conrey. A devise indeterminate in its terms and with-

these three chasses. See Sir Edward Clere's case, 6 Coke, 17 ; Standen $r$. Standen, 2 Ves. Jr. 589. But in furtherance of the general rule that the intention of the testator (in rase of disposition by will) is the pole star to guide in the inter. pretation, the English rule, which requires the existence of one of the three elements above enumerated. is made altogether suborlinate and secondary in its character, and if circumstances arise that indicate clearly the intention of the donee to work by the power, the artificial rule, predieated upon former experience, must give way, and the primary and fundamental rule, wich requires only that the intention must be clear and manifest, will prevail. "The main point," says Mr. Justice Story (Blagge $v$. Miles, 1 Story, 427), $\cdots$ is to arrive at the intention and object of the donee of the power in the instrument of execution, and that heing once ascertilined. effect is riven to it accordingly. If the donce intends to exroute, and the mode be in other respects unexeeptionable, that intention, however manifesteil. will make the exeention valid and orerative." But the intention must be clear and apparent, so that the transaction is not fairly susceptible of any other interpretation. If it be doubtful, under all the circumstances, then the doubt will prevent it from being deemed an execution of the power: Blagge $v$. Miles, 1 Story, 427; Dunning $v$. Van Dusen. 47 Ind. 423. Kent says, with reference to the exeeution of powers: "The power may be executed without reciting it, or even referring to it. provided the act shows that the donce had in view the subject of the power." The general rule of construetion. both as to deeds and wills, is that, if there be an interest and a power existing together in the same percon orer the same subjeet, and an aet be done without particular reference to the power, it will be applied to the interest, and not to the pouter. 4 Fent, Comm. (12th Ed.) p. 334; 2 Wash. Real Prop. *325, § 33. The subject of the creention of powers is exhaustire! y examined in Blagge $v$. Miles, 1 story, 427. The following caces are alon in point: Jones $r$. Woud, 11 i P. St. 25: Towles $r$. Fisher. TT X. C. 49: Pruwsick $v$. Crossign, is Ma. 
out words of limitation, which, standing alone and unaided by statute, would create only an estate for life, will generally be enlarged to a fee by the imposition of a charge upon the person of the devisee, or on the quantum of the interest devised to him $;^{1}$ but not if the lands are merely devised subject to a charge. Where the charge is on the estate, and there are no words of limitation, the derisee takes an estate for life only, ${ }^{3}$ but where the charge is on the person of the devisee in respeet of the estate in his hands, he talies a fee by implication. ${ }^{4}$ If the charge be on the person of the devisee, the amount is mimportant if the sim is to be paid absolutely. ${ }^{5}$ But this, it will be understoml, applies only to indefinite devises. Where the estate is given for life in express terms, and some other determinate astate is expressy given or arises by necessary implication from the language of the derise over, the rule is inoperative to enlarge such an estate to a fee. ${ }^{6}$

\$ 394. Derise on Contition Precelest. This frequently oceurs where land is given on condition that the devisee pay certain legacies, or perform certain acts, ete, and performance of the condition is essential to the vesting of the estate. ${ }^{7}$ Trhere the conditions are limited as to tine, and are not performed within that time, the devise does not take errect, s but becomes inoperative and void. I devise upon condition, therefore, frequently raises an incuiry in pais upon the examination of a

1 Tracy $r$. Kilborn, 3 Cush. (Mass.) 55j; Baker $x$. Brilige, 12 Pick. 27; Barheydt $t$. Barheydt, 20 Wend. 576 .

2 Hawkins on Wills, 134.

3 Fox $v$. Phielps, 17 Wend. 393. By force of the statute a general devise will pass all the testator's estate, including the fee, unless a contrary intent fairly aprears.

4 Jackion $r$. Bull, 10 Johns. 149; Funk $v$. Eagleston, 92 Ill. 515; Merritt $v$. Brantly, 8 Fla. 226 ; Cook $r$. IIolmes, 11 Mass. 528; Wait $v$. Eelling. 24 Pick. 129.
5 Colliers' Cane, 6 Rep. 16; 2 Jarm. on Wills, Iil; Jackson $r$. Merrill. 6 Johne. Isf: Darleyit $r$. Barleydt, 20 Viend. 5\%6; Jackson $r$. Ilaris, 12 Wenl. $8:$.

G Jarm. on Wihs, 17.; Groves $r$. Cox, 49 N. J. L. 49.

7 Nevius r. Gonley, 5 1ll. ano. A court of manery will nerer rect an estate when, by reasen of a condition preculent, it will not vest in law: Id.

s Nevins $r$. Hourley, 97 lll. 3.ti (2d hearing); Den $r$. Lessenger, 33 N. J. L. 490 , 
title proffered by the devisee, and before passing or accepting same, a requisition should be made for further information relative to the due performance of the condition.

$\$ 395$. Conditional Devise - Marriage. Estates for life are frequently devised to surviving husbands or wives, subject to a defeasance in the event of a second marriage, and oecasionally unmarried people are made the objects of such testamentary bounty so long as they may remain single. A title involving such an estate, whether offered by the life tenant or remainderman, demands and should receive the closest scrutiny.

The rule is well settled, both in England and this country, that conditions in general restraint of marriage, whether of man or woman, are void in law, being against public poliey. ${ }^{9}$ But this rule does not extend to special restraints, such as against marriage with a particular person, or before attaining a reasonable age, or without consent. Nor is it ever extended to

9 It appears from the early English cases that this doctrine was borrowed by the English ecelesiastical courts from the Roman civil law, which declared absolutely roid all conditions in wills restraining marriage, whether precedent or subsequent, whether thexe was any gift over or not. But the courts of equity found themselves greatly embarrassed between their anxiety on the one hand to follow the ecclesiastieal courts, and their desire on the other to give more heed to the plain intention and wish of the testator as manifested by the whole will. Thereupon the process of distinguishing commencel for the purpose of preventing obvious hardships arising from the application of that technical rule to particular cases. Is a result there has been ingrafted upon the doetrine a multitude of curious refinements and subtle distinctions respecting real and personal estate, conditions and limitations, conditions precedent and conditions subsequent, gifts with and withont valid limitations over, and the application of the rule to widows and other persons. Indeed it may be sail of the decisions upon the subject that " the more we read, unless we are very careful to distinguish, the more we shall be confounded." The whole subject as to what conditions in restraint of marriage shall be regarded as valicl and what as roid wonld seem to be involved in great uncertainty and confusion both in England and in this country. These is clearly discernible however, through all the decisions of later times, an anxiety on the part of the judges to limit as much as possible the rule adopted from the civil law. 
the case of a second marriage of a woman; but in all such cases the special restraint ly condition is allowed to take effect, and the derise over will be good on breach of condition. A condition, therefore, that a widow shall not marrer, is by all the authorities held not to be nnlawful. ${ }^{1 "}$ In the decided cases a distinction is taken between those where the restraint is made to operate as a condition precelent, and those where it is expressed to take effect as a condition subsequent, and the decisions have generally been made to turn upon the question, whether there be a gift or deriee orer or not. But if the devise be to a person until he or she shall marry, and upon such marriage then orer, this is a good linitation as distingnished from condition; as in such case there is nothing to carry the interest beyond the marriage. There can be no doubt, therefore, that marriage may be mate the gromel of a limitation of estate, either ceasing or commencing, and this, whether the devisee be man or woman, or other than husband and wife. ${ }^{11}$

§ 396. Contingent Remainders. Under derises similar to those mentioned in the preceding paragraph, many questions will arise relative to the devise over, which, according as the phraseology used, will be either a rested or contingent remainder. These questions are of great importance. The examiner should, therefore, exereise the greatest care in transcribing all devises of this character, and for greater certainty it is recommended that they be presented with little or no abbreriation. The essence of the contingent remainder is, that it is limited to take effect on an event or condition that may nerer happen or be performed, or which may not happen or be performed until after the detemination of the precerling particnlar estate. ${ }^{2}$ Thus where a devise orer operates at the death $1 \mathrm{I}^{\circ}$ marriage of the first devisee to such of testator's chiliten as shall then be living, this would give a contingent remininder

10 Bostick r. Blades, 59 Md. 231 ; Clark r. Tennison, 33 Md. 85; Litthe r. Giles, $25 \mathrm{Neb}$. 313; Knight $v$. Mahoney, 152 Mass. 523.
11 Bostirk r. Blarlesi, 59 Md. 231 ; Arthur r. Cole, ofi N14. 100); Brown v. Brown. 41 ×. Y. .07.

12 Bou. Law Dict. 435. 
to the children living when such contingeney of death or marriage happened. The elildren of the testator who may have died after the testator and prior to the happening of the contingency would take no estate, nor wonld their heirs, ${ }^{13}$ and the fact that the words "to them, their heirs," etc., followed the mention of the children would not affect the result, for such words do not describe the devises but only the quantity of their estate, and merely show the estate taken by the previous words to be fee. ${ }^{14}$

$\$ 39 \pi$. Contingent Reversion. A contingent reversion, so called, may be created either by deed or will, but more frequently oceurs moler the latter. It is not strictly a reversion, however, but rather a possibility of reinvesture in the grantor or his heirs, and occurs where a converance is made to one for life or years with a contingent remainder. Thus, in case of a devise to an unmarried woman, and to tho "heirs of her body" or "children;" here the devisee named would talse a life estate only, while a contingent remainder is created in favor of her speeified heirs, who, when born, would take the fee. The will in such ease, effectually divests the heirs of the testator of all estate bat a contingent reversion, ${ }^{15}$ dependent upon the devisee's dying withont issue. ${ }^{16}$

$\$ 398$. Devise to Married Woman. In a former chap$\operatorname{ter}^{1 \tau}$ the subject of conveyances to married women was quite

13 Olney r. Hall. 21 Pick. 311; Emmison v. Whitclsey, 55 Mo. 254.

14 Thompsoll $r$. Ludington, 104 Mass. 193.

15 Strictly speaking there is no such a tining as a contingent reversion. What is really meant by that phrase is a possibility of reverter, but in practice the term has acquired a currency in the manner indicated in the text and is constantly so used both by courts and writers.

16 Frazer $t$. Supervisors Peoria Co., 74 Ill. 282; 2 Bl. Com. 164;
Elair $r$. Vanblareum, 71 Ill. 290. This reversionary interest may itself be the subject of device: Austin $v$. Cambridgeport, 21 Pick. 215; and will pass uncier a residuary clause: Stcel $r$. Cook, 1 Met. 281; and the right to same mity be asserted by the heirs of such residuary derisce after his death: Clapp $v$. Stoughton, 10 Pick. 462. This doctrine, howerer, does not coincide with the common law rules relative to nakerl possibilitics. i $\tau$ See Chap. XVI. 
fully discussed and the general principles there laid down will apply with equal foree to a devise by will. The general rule of construction, in the absence of statutory provisions to the contrary, is, that in order to exclude the marital rights of the husband from ataching to property coming to the wife during coverture, or belonging to her at the time of marriage, an intention on the part of the testator to vest in the wife a scparate estate onght to appear from the terms or provisions of the will so clearly as to be beyond the reach of reasonable controversy. ${ }^{18}$ This is accomplished, in most cases, by the insertion of technical worls, as "sole and separate ise," or other words of similar import, while the same end may be attained by provisions excluding the marital rights of the husband, or by giving to the wife powers concerning the estate inconsistent with the disabilities of coverture. ${ }^{9}$ The statute, however, is a potent factor in solving questions of this character. In a majority of the States the common law disabilities of coverture have ceased to exist, and in those States the foregoing remarks have no application.

$\$ 399$. Devises to Executors in Trust. It is a rule in equity; that the language employed in derises in trust must be such as to show that the object is certain and well defined, and that the beneficiaries be either named, or capable of easy ascertainment within the rules of law which are applicable to such cases; and further, that the trusts shall be of such a nature that a court can direct their execution; failing in this the property will fall into the resilue of the estate. ${ }^{21}$

Devises in trust are frequently made to executors to promote some educational, charitable or religious purpose, the beneficiary being an institution devoted to the furtherance of those

is Schouler Don Rel. (2d Ed.) 189; 2 Perry on Trlists, $\$ 617$; Mill on Trustees, 611.

19 Vail $r$. Vail, 49 conn. 52. The statutes now in force in wo-t of the States will allord all the protedion that was formerly sought to be at- tained by testamentary provisions. 20 Holnes $r$. Mead, 52 N. Y. 332; Powell on Devises, 41s; Darlingr $r$. logers, 22 Wend. 494; 2 Sitory Eq. Jir. \& 979; Wheeler $r$. Sunith, 9 How. (L. S.) 5.5. 
objects, thongh it is not nncommon to make beneficial devises to individuals in the same mamner. It is usual, though not necessary, to specifically name or describe the intended beneficiarien, and numerous anthorities sustain devises to executors or trustees which confer npon them authority to divide the trust estate among such persons as they may select from certain classes which are designated, and anong such children or relatives, who are intended to be provided for, as they may deem proper. ${ }^{21}$

Where the devise is too indefinite to give certainty, or the trust is such that a court ean not execute, resort is usually had to a court of chancery for a construction of the will, and where, as a result, the devised property falls back into the residuum, such procecdings locene a noessary link in the elrain of the title to such particular property. $A$ devise in trust for such object of bencrolence and liberality as the trustee, in his discretion, shall approve, would have the effect last mentioned. ${ }^{22}$ So, also, would a power of appointment to one to give or devise property "among such benevolent, religions, or eharitable institutions as he may think proper," ${ }^{23}$ be rague and indefinite. A power of disposition, to such members of a speeified branch of a family as the trustee might consider most deserving, has bern held void, for the same reason. ${ }^{24}$ A direction to give a fund in "private charity" is too indefinite, ${ }^{25}$ or to give what they might chouse," but when the beneficiaries are capable of identiuication, althongh not named, the trust will yet be valid, and a tectator may commit to competent persons the power to designate who of certain persons shall participate in a

21 Power $r$. rasidy, 79 N. Y. 602; Bull $r$. Bull, 8 Conn. 49; Norris $x$. Thomprons Fxrs, 19 N. J. Eq. 307; McLonghlin $v$. McLoughlin, :30 Barb. 458.

22 Morice $r$. Dishop of Durham, 10 Ves. (Eng.) 5:2.
23 Norris $r$. Thompson's Exrs., 19 N. J. Eq. 307.

24 Stubbs $r$. Sargon, $3 \mathrm{Myl}$ \& Cr. (Eng. Ch.) 507.

250mmanny $r$. Butcher, 1 T. \& R. (Eng. Ch.) 260 .

20 Weturere v. Parker, 52 N. Y. 450 . 
specified portion of his estatr, and in what proportions the property shall be divided. ${ }^{27}$

\$ 400. Gift to Devisee by Description. The observations of the last section are in a measure applicable to direct gifts, for a devisee, whether a corporation or a natural person, may be designated by description, as well as by name. ${ }^{28}$ It is only necessary that the deseriftion of the devisee be by words that are sufficient to denote the person meant by the testator, and to, distinguish him fron all other persons. ${ }^{29}$ In such cases, however, a judicial construction will be necessary in order to fully perfect the title of the imperfectly designated devisee, and the decree rendered upon such construction, together with the will, forms the basis of the devisee's claim of title. Devises to corporations are particularly sulject to the rule above stated, as the testator, throngh inadrertence, ignorance, or mistake, frequently fails to insert the strictly legal name of the corporation. Parol evidence is alwars admissible to remove latent ambiguities, and where there is no person or corporation in existence precisely answering to the name or description in the will, parol evidence may be giren to ascertain who was intended by the testator. "A corporation," says Allen, J., "may be designated by its corporate name, by the name by which it is usually or popularly called and known, by a name by which it was known and called by the testator, or by any name or description by which it can be distinguished from every other corporation; and when any but the corporate name is used, the ciremmstances to enable the court to apply the name or description to a particular corporation and identify it as the body intended, and to distinguish it from all

$2 \pi$ Williams $v$. Williams, 4 Seld. (N. Y.) 548; Owens $r$. Miss. Soc.. 14 X. Y. $386 ; 2$ Redf. on Wills, 779 ; White $r$. Fisk, 22 Conn. 31 ; Lefevre $x$. Iefevre, 59 N. Y. 434. 28 Leferre $v$. Lefevre, $59 \mathrm{~N}$. $\mathrm{Y}$.
29 Button r. Am. Traet Soe' $\mathbf{2 3}$ Vt. 336: Medllister $r$. MeAllister, 46 Vt. 272 ; Minot $r$. Curtis, 7 Mass. 441 ; Holmes $r$. Mead, $52 \mathrm{~N} . \mathrm{Y}$. 332 ; Gardner $v$. Heyer, 2 Paige, 11. 434 . 
others and bring it within the terms of the will, mas, in all cases, be proved by parol." "3"

$\$$ 401. Precatory Trusts. Precatory trusts grow out of words of entreaty, wish, expectation, request, or recommendation frequently employed in wills, and the authorities, both English and American, are, in the main, harmonions in declaring that a trust will be created by sueh words as "hope," "wish," "request," ete., if they be not so modified by the context as to amount to no more than mere suggestions to be acted on or not according to the caprice of the immediate derisee, or negatived by other expressions incicating a contrary intention. But, to effeet this result, both the subject and object mist be certain. ${ }^{31}$ An absolute gift to one person, accompanied with a request to appropriate a partienlar sum to another person, ereates in the immediate devisee a trusteeship, to the extent of such sum, nor does the absolute gift contravene either an express or implied trust annexed to the gift, as it is a common thing to inrest the legal title and trusteeship in the same person who is to receive the benefit in the event of a failn"e of the trust. It is equally well settled, howerer, that a mere direetion by a testator, that a derisce shall pay a legacr, does not thereby ereate a charge on the land; to accomplish this there must be express words, or necssary implication from the whole will, that such was the intention. ${ }^{32}$

There has been a tendency manifested by some eourts to restriet the applieation of this rule, or to qualify it, and, in some instances, to reject it altogether, and to adopt, as more reasonable, the presumption that words precatory in form are meant to imply a diseretion in the donce, and should be so construed unless elearly shown to be used in an imperative

30 Leferre $r$. Leferre, $59 \mathrm{~N}$. Y. 421 ; St. Luke's Home $r$. Asso'n for Inligent Females, 52 N. Y. 191.

s1 Pohon $v$. Barret's Ex'r, $79 \mathrm{Ky}$. 79: IIill on Trustees, 92; Perry on Tru-ts, 4; Gilbert $v$. Chapin, 19 Conn. 342.
32 Cables Apneal, 9 Reporter, 57; Lunton $r$. Lupton, 2 Joluns Ch. 614; Chapin $r$. Gilbert, 19 Conn. 342; Pennock's Estate, 20 Penn. St. 268; Walter's Apreal. 9.; Penn. St. 305; Taylor $v$. Dodd, 58 N. I. 335 ; Read $v$. Cather, 18 W. Va. 263. 
sense from other parts of the will; ${ }^{33}$ but the weight of autbority sustains the principles first stated, and precatory words are generally held to be creative of trusts, when the contrary does not appear from the context or by necessary implication. ${ }^{34}$

$\$$ 402. Perpetuities. Attempts are frequently made in wills, though seldom in deeds, to create what the law regards as perpetnities, and this occurs whenever there is a suspension of the power of alienation for a longer period than a life or lives in being at the ereation of the estate, ${ }^{35}$ or of such lives in being and twenty-one years and nine months at the farthest, ${ }^{36}$ the rule varying somewhat in dificent States. In construing dispositions of property with reference to the statute against perpetuities, the rule is settled that any limitation is void as in violation of the statute, by which the suspension of the power of alienation will not neecsarily, under all possible circumstances, terminate within the prescriber perind. It is not enough that it may terminate; it must, and if by any possibility, the resting of the estate may be postponer beyond the statutory period, the limitation will be roid..3i In all cases, where the limitation is roid as being too remote, the will should be construed as if no such clanse were in it, and the first taker will hold his estate dischared from the limitation over. ${ }^{38}$

$\$$ 403. Lapsed Devise. When a derisee named in a will dies during the lifetime of the testator, the devise is said to lapse; that is, it does not go to the heirs of such deceased devisee, but falls back into the estate of the trotatm. The rule, though frequently acknowledger to be productive of great hardship, and to be often contrary to the intention of the testator, is too firmly established to be questioned. It is reegrded

33 Pennock's Case, 20 Pa. St. 272.

34 Reed's Adn'r $r$. Reed, 30 Ind. 313; Warner $\imath$. Bates, 98 Mass. 274. 35 Schettler $r$. Smith, 41 N. Y. 328 ; Knox $v$. Jones, 47 N. Y. 389. 36 Stephens $v$. Evans, 30 Ind. 39; see 1 Jar. on Wills, 226.
$3 \pi$ Schettler $r$. Smith, 41 N. Y.

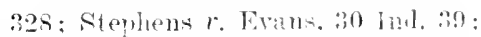

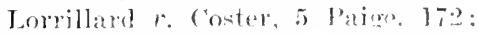
Hawley $c$. Northamptom. \& Mass. 3. 3s Wood $r$. Grifin, 46 N. II. 2:34; Anderson $v$. Grable, 1 Ark. 136. 
as a rule of necessity, and merely amomnts to this: That if there be no derisee, there is in effect no devise. ${ }^{39}$ The statute, in some States, has slightly modified this rule, particularly where the devise is to children, but in the absence of such statutes the rule seems to be inflexible.

\section{$\S 404$. Devises for the Payment of Debts. Land de-} rised to trustees for the parment of debts and legacies is usually regarded in equity as money, ${ }^{40}$ lnt the heir at law has a resulting trust in such land, after the debts and legaeies are paid, and may restrain the trustee from selling more than is necessary to pay such debts and legacies; or, he may pay them himself, and have conveyance of that portion of the land not sold in the first case, and the whole in the latter, which property will, in either ease, be land and not money. ${ }^{41}$ Equity will extend the same privilege to the resiluary legatee. ${ }^{42}$

A mere charge upon land stands upon a different footing, and the executor possesses no pover to sell or dispose of the land in such ease exeept by license or direction of the probate eomrt. ${ }^{43}$ The land in the hands of the derisee is burdened by the charge, ${ }^{44}$ and should he renomnce the derise such land will descend to the heir at law subject to the eharge; ${ }^{45}$ but the executor haring no status as a trustee, talies no interest in same, and no power can be implied from the mere charge of the debts and legacies mon the lands devised. ${ }^{46}$

$\$$ 405. Charges on Lands Devised. Real estate is not, as of comrse, charged with the payment of legacies. It is never so charged unless the testator mtended it should be, and that intention must be either expressly declared, or fairly and satisfactorily inferred from the langnage and dispositions of the will. ${ }^{47}$ Mere directions to pay debts and legacies are not suf-

39 Davis' Heir's $r$. Taul, 6 Dana, 52.

40 Craig $v$. Leslie, 3 Wheat. 463 ; Story Eq. § 552; Dill r. Wisner. 88 N. Y. 153.

41 Craig $v$. Leslie, 3 Wheat, 463. 42 Craig $t$. Leslie, 3 Wheat. 463.
43 Dill $r$. Wisner, 88 N. Y. 153.

44 Gridley $v$. Cridley, 24 N. Y. 130 ; Harris $v$. Fly, 7 Paige, 421.

45 Birdsall $v$. Hewlett, 1 Paige, 32 .

46 In re Fox, 52 N. Y. 530.

47 Okeson's Appeal, 59 Pa. St. 99; 
ficient to ereate a charge., ${ }^{4 s}$ but where the testator devises his real estate, after the payment of delots and legacies, or with a direction that debts and legaeies shall be first paid, then the real estate is chargen with the payment of them and they become liens upon the land. ${ }^{49}$ If the derisee accepts the devise, he becones personally liable for the legacies, ${ }^{5 t}$ which still remain, however, a charge upon the land. ${ }^{51}$ When the same sentence or clanse by which land is derised imposes on the derisee the duty of paying an annuits, and no other fund is provided out of which the parment is to be made, the annuity is a charge mpon the land; ${ }^{52}$ and in like manner, where a testator, without ereating an express trust to lay legacies, makes a general residuary disposition of hiv whole estate, blending the realty and personalty together in one fund, the real estate is constructively charged with the legacies. ${ }^{53}$

In every instante, therefore, where legacies are direetly or constructively charges or liens upon the realty, satisfactory assurance must be given that the legacies have heen paid or the lien released before the title is accepted by a purchaser from the devisee. Frequently these facts will appear from the executor's final report, and in the abstract of this docmment, in connection with the probate proceedings, statements of this kind should always be shown.

Kirkpatrick $r$. Chestnut, 5 S. C. 216; Lupton r. Lupton. 2 Johns. C'h. 614; Cable's Appeal, 9l Pa. St. 327. Legacies are prinarily payable out of the personal estate.

48 Taylor $r$. Dolk, 53 X. Y. 335 ; Walter's Appeal, 45 Pa. St. 305.

49 Lupton r. Lupton, 2 Jolns. Ch. 614; Wood r. Sampion, 25 Gratt. (Va.) 845 .

50) Birdsall r. Hewlett, 1 Paige. 33; Burch r. Burch, 52 Ind. 136.

51 "It seems to be well settled," says Mr. Reulfield, "that where lands are held by subequent bona fide purchasers for value, but who are obliged to trace title through a devise, wherebr a charge is created upon the land for the payment of legacies. such purchasers will be constructively afiected with notice of such charge, and equity will enforce it upon the land in their hands:" 2 Redf. on Wills, " 210 . riting Harris $r$. Fly. 7 Paice, 421; Wallington r. Taylor, Sixtur. 314; and sce Liston $r$. Fallowin, 3 lred. Eq. (N. r.) 120 .

52 Nerrill $r$. Mink forl, 65 Me. 11 s.

5.) Lewis r. Douling, lfi lfow. 1; Nichols $r$. Postlethwaite, Dall. 131; llill on Trustree, s60); Gallagher's Appeal, ts Par. St. l21. 
In this connection an important distinction should be noted, with regard to the estate possessed by the devise, between such legacies as constitute a personal charge upon the devisee, and such as are expressly charged upon the estate. Where an estate is devised subject to the payment of legacies, if the legacies are made a personal charge upon the devise, an aceptance of the devise operates to make such legacies a personal liability of the devisee, while he will take the estate devised as a purchaser in fee; but if the legacies are charged upon the cstate derised, the derisee does not take as a purchaser for raine, but as a beneficial devisce. ${ }^{54}$

$\$$ t06. Equitable Conversion. It is a fundanental principle in equity, long established and miversally recognized, that where a testator directs that lis real property be conrerted into money on or before a given time, it becomes, for practical purposes, money, and will be treated as personalty from the moment of his death. In such case, therefore, the heir takes no interest in the land, which is held by the executor as other personal property, and can make no conveyance of same that will defeat or impair the rights of a purchaser from tho executor. Yet to effect this change the intention of the testator must appear by unequivocal declaration. ${ }^{55}$ There must be an imperative and mmistakable direction to sell, and if the power to sell, or the sale itself is coupled with terms or dependent upon a contingency, there is no conversion until the terms have been complied with or the contingency has happened, ${ }^{56}$ and, as courts are always averse to sanctioning a change in the quality of an estate, if there be any doubt as to the intention of the testator the original character of the property will be retained. ${ }^{57}$ The policy of the law favors the resting of estates and the provisions of a will should always be construed as creating a rested estate if possible. ${ }^{58}$

$5+$ Funk $r$. Eggleston, 92 Ill. 515. 55 Ducker $r$. Burnham, 146 Ill. 9. $5 \mathrm{ti}$ See, Estate of Machemer, 140 Pa. St. 544 .
57 Orrick $r$. Boehm, 49 Md. 104;

Peter $v$. Veberly, 10 Pet. (U. S.) 533.

5 s Scofield $v$. Olcott, 120 Ill. 362 . 
$\S 40 \%$. The Residuary Clause. In a majority of wills there is inserted at the close a general devise of everything that the testator has not suceeded in disposing of in former parts of the will, which is called the residnary elause. This portion of the instument slonkl, as a rule, be eopied cutire, as it is often of vital importance in deternining questions of title under lapsed devises and of fixing the ownersip of tants not specifically granted or alluded to elsewhere in the instrument. Where the language of a residuary danse has sufieient scope and extent, evineing the intent of the testator to take up and earry into the residnary estate all of his estate remaining at his death undisposed of for any reason, the residnary clanse will reenive and pass a lapsed legacy and devise, ${ }^{59}$ as well as such as may fail for want of use of proper language to create the same, or to designate the devisee. ${ }^{60}$ But when the residuary elause loes not by its own terms take in a lapsed legacy or derise, so as to disclose the intent of the testator to pass the linped estate into the residue, the rule is different. ${ }^{61}$ Poil and illegal legacies or devises come unter the rule first above stated, ${ }^{62}$ and generally, mules a contrary intention is manifested, the residnum will take and pass everything of the nature abre indicated. ${ }^{63}$

A different rule, however, applies to the residue itself, for if a gift of the residue, or any part of it fuils, whether by lapse, illegality, or revocation, to the extent that it fails, the will is inoperative, and the suljeet of the gift passes to tloe heirs or next of lin aceording to the statute of descents. ${ }^{64}$

59 Youngs $v$. Youmes, 45 N. Y. 254; Patterson 2 . Swallow, $8 \mathrm{Mr}$. (Pa.) 490: Ilillic r. Tillis, 16 IIm (N. Y.) 76. Loeal statutes will sometimes materially aflert the doctrine stated in the text. 97.

(i) Lovering $r$. Allen. 129 Mass.

(1) Yard r. Murry, 86 Pal. St. 113. (:2 Burnct r. Burnet, 30 N. J. Eq. 50.5. A dintindion is madre in some States between legaries and levises.
The leguey falling into the resilumo; the lapsed derise descending to the heirs: See Orrick v. Borlum. 49 Nh. 2.

is: 'Tlayer r. Wollingron, 9 Allan (Mass.), 2S3. The residuary clatu:e will cary the estate devised in : ramse whirh the tretator hes res voker by strikine it ont of lis will.

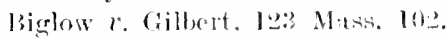

i4 Burnet r. Bmrnet, 30 N. J. Eq. 595. 
$\$ 40$. Collicils. 1 codicil is defined as some addition to, or qualification of, a last will and testament. ${ }^{65}$ Where it is in irreconcilable conflict with the will, it must prevail as a revocation, since it is the last expression of the testator's intent in the disposition of his property. ${ }^{6}{ }^{6}$ Usually, howerer, a colicil imports not a rerocation, but an addition to, or explanation, or alteration of the will, in reference to some particular, and assumes that in all other particulars it is to be in full force and effect. ${ }^{6 i}$ The authorities fully establish the proposition that a codicil which does not in terms revoke a clanse in the will, bnt modifies it in some of its features entirely consistent with the retention of its other provisions, will be allowed to have that partial effect, and the clanse thus changed will remain as the embodiment and expression of the testator's intent, while if duly exeented with all the formalities required by law, it will operate to confirm and republish the rest of the will, ${ }^{6 s}$ unless the testator declares that he does not intend that it shall have that effect. ${ }^{69}$

It will thus be secn that the codicil plays a most important part both in the disposition of the property and in the matter of validating that which has preceled it, and which, by reason of defective excention or other circumstance, has become in-

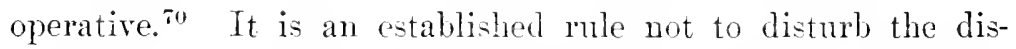
positions of the will further than is absolutely necessary to give effect to the codicil, ${ }^{i 1}$ and the intent of the testator is always sought to give effect to both instruments when they can operate in perfect harmony. ${ }^{22}$ But where the absolute and unqualified gift in the codicil is incompatible with the disposition of the land made in the will, and must hare a re-

155 Bou. Law Dict. 285.

66 Hallyburton $r$. Carson, $86 \mathrm{x}$. C. 290 .

67 Tretmore $v$. Parker, 52 N. Y. 450 .

6s O'Hara on Wills. 6; Brown $r$. Clark. 77 N. Y. 369; Tan Cortlandt r. Kip, I Hill, 590; Nooers $r$.
White, 6 . Johns. C'h. 375; 1 Jarm. on Wills, is.

es Tan Cortlandt r. Kip, I Hill, 590 .

(1) See Wms. on Cxcentors, 97; 1 Jarm. on Tills, 78 .

¿1 Tarm. on Wills, 343, note.

a. Hallyburton $r$. Carson, $86 \mathrm{~N}$. C. 290 . 
roking efficaey or be itself nugatory, the will must yield to tho codicil. ${ }^{73}$ A corlicil depending upon the body of the will for interpretation or execution can not be established as an independent will, when the will itself has heen revoked. ${ }^{7 t}$

$\$$ 409. Revocation. The question of revocation will arise during the examination of a title, if at all, only by implication. A proper probate disposes of all questions of this kind and establishes the will. But facts anl circumstances may be disclosed which ereate legal inferences and when such is the ease the duty of the examiner is to fully investigate and solve any question that may be so presented. A change of condition or domestic relation after the making of a will and which involves new or different moral duties, will generally raise a presumption of change of intention on the part of the testator. $^{75}$ Henee, the marriage of a feme sole; birth of issue; and divores. under certain conditions, may all tend to create this presumption.

$\$ 410$. Formal Requisites. There are a number of indispensable requisites to a valid will, which, though of the highest importance gemerally, do not require more than passing montion in this work. These requisites do not relate to form, but go to the very subtance of the instrument. They relate mainly to the testamentary capacity of the testator as dependent on soundness of mind, ete, and to his surromdings and the effect of frand, duress, molne infuence, and the like. All of these questions, however important ther may be, do not arise in the examination of a title derived through or under. a will, for they are all supposed to have heen duly investigated during the probate and satisfactorily answeres befor the will was permitted to become operative as a converanow.

With respect to the strictly formal parts a rery simple aml untechnical document will be sustained als a will, where the writing relied on has been executrd in conformity to the stat-

7.) Wainwright $v$. Tuekerman, 120 Mass. 232: Vaughan $v$. Bunch, 53 Miss. 513. it Youre $v$. Forman, 5 Jiuth (Ky.) : ::37.

754 Kent's Com. 521 ; 2 Greenl. Exid. § 684. 
ute, and shows upon its face a dcelaration by the testator that it is his will." The essence of a will is, that it is a disposition to take effect at death, ${ }^{i r}$ and the rorm of the instrmment, therefore, is immaterial if its substance is testamentary. ${ }^{\text {is }}$ The statute usually requires the paper to be signed by the testator, but the signature may be original or by adoption, ${ }^{i 2}$ and, as a rule, it nust be attested by two or more subseribing witnesses, who, at the testator's request, atix their signatures in his presence. ${ }^{80} \quad$ As the execution and publication are also matiers of strict proof in the probate comrt they may be presumed to have been in conformity to law after the will has been duly presented and admitted in such court. Shonld, however, the examiner observe palpable defects of form they shonld be presented in the abstract that proper inquiries may be founded on them.

\$ 411. Alsitract of Wils. An eminent English conveyancer ${ }^{\text {s1 }}$ once said, that he could scarecly admit of a will being abstracted at all, and strongly recommended that it be copicd instearl, in order that counsel might have an opportumity of junging by the context as well as by the particular wortis of the revise or bequest. ${ }^{2}$ The reason assigned by the Englin converancer is a gool one, ${ }^{83}$ yet in preparing the abstract of a with it is not nsually necessary that the entire in-

it 3 Wan. Tieal Prop. *681; Turner $r$. Scott, 11 Pa. St. 120; Burlington Lniversity $r$. Barrett. 22 Iowa, 60; Wall $t$. Wall. 30 Mise. 91. Althowgh an instrunent be in the form of a deol, and called such, still if its purpose be testamentary, and it is only to le consummated liy the death of the maker, eflect will be given to it as a will and not as a deed: Gillham v. Mustin, 42 Ala. 36.5.

it Not after death, as the looks frequently state.

is Wilson's Ex'rs $v$. Van Leer, 103 Pa. St. 600 .
79 A mark has been held a good signature even when the statute uses the word subscribcd: Van Honswyck $r$. Wiese, 44 Barb. 494; Jackson r. Jackion, 39 N. Y. 153.

so Consult Hopper's Will, 1 Tuck. (N. I. Sur.) 378; Lawrence's Will, Id. 243 ; Holloway $\imath$. Galloway, 51 111. 159 .

81 Mr. Barton.

sa Moore on Abst. 39.

83 This observation derives additional force from the fuct that, formerly real estate wills were not proved in England. 
strument should appear, but only such parts as have special or general reference to the property in question. Modern wills in many instances, and ancient wills uniformly, contain a preamble dedicating the testators' souls to Goul, expressing the soundness of their minds, the health or debility of their bodies, and other particulars of no special importance and which have no necessary connection with or relation to the subject of the examination, and may in all cases be safely omitted. The bequests and gifts of personalty are always omitted, exeept where a legacy constitutes a charge upon the land, in whieh ease it becones material. Derises of realty, other than the subject of the examination, may be advantageously omitted, but the residuary clanse, though couched in general terms, should, as a rule, be inserted.

The language employed by the will, aside from the strictly formal parts, should be elosely if not literally followed, as well in respect to the property devised as the particular estate therein granted. The essential features of a modern will consist of the parties, testator, legatees and derisees; the legaeies which are a charge on land; the speeifie devises; the trusts and powers; the appointment of executors; the residuary clause; and the exeention and attestation. ${ }^{84}$ In drawing the synopsis the general form of presenting eonveyanees by deed is followed as elosely as may be; the particular words employed in creating the estates derised are given, and all in-

8t Mr. Preston says (with reference to the method of abstracting wills) the points to be attended to are to show to whom the lands are devised; the words used in description of the lands; the words of limitation by which the estate is devised, the power, if any, in pursuance of which the devise is made: the words of modifieation, or of severance of the tenaney, if there he any; the words of qualification which may abridge or defeat the estate; the uses and trusts, if any are reated; the conditions, or conditional himitations by way of executory devise, or otherwine. annexed to the devise or appointment; the eharges imposed on the devisee; the indemnity, if any. against seeing to the application of the purchase money, or mortgage money: such powers, if ans, as are material to the title; and when leasehold lands are the subject of the title, the appointment of executors:" Prest. on Abst. 180. 
artifieial expressions rendered with literal exactness. Imperfect designation of persons or property, and manifest omissions, errors and irregularities, are noted in the same manner as in ease of deeds. The execution, if regular, may be passed without notice, as the proof of probate constitutes proof of the due and proper execution and publieation of the will, yet where the execution is manifestly erroneous, or not in complianee with law, it is recommended that same be shown as fully as in case of defeetive execution by deed, and be supplemented by the special proof offered on the hearing before the probate court.

$\$$ 412. Method of Arrangement. There are two methods of showing abstracts of wills: one, in ease of reeord as a conveyance, as an independent eircumstance, the same as other instruments of conveyance, and forming a separate link in the chain; the other, in connection with the proeeedings had in the probate court relative to the proof of the will and the administration of the estate. Either method may be adopted as will best serve the examiner's purpose, but it is believed the former method possesses advantages orer the latter, and is that whieh should be adopted whenever the will has been recorded as directed by law. In the event of the first named method being used, the proof addueed before the probate court, or a summary thereof, should also be appended, such proof being required by statute to be recorded with the will. The proceedings relative to the settlement of the estate then follow as a separate showing. When the latter method is employed, a digest of the will should be inserted at the beginning of the synopsis of the proceedings. When eonveyances have been made by heirs or devisees prior to probate or record, the chronological arrangement should follow the dates of execution, rather than of proof or record, except in the case of post obit eonveyances.

$\S$ 413. Practical Examples. Following this will be found a practical example of an abstract of a will and proof of probate. The will selecterl is of the most simple form, and no attempt has been made to illustrate special clauses, though 
an exanple of these oceurs in the form given in connection with the abstract of probate proceedings. The proof of probate is that now in use in liveomin, Minnesota and other western States, and will serve to indiate the method of showing these matters even where the record of proof is different:

$$
\begin{aligned}
& \text { ] Dated Oct. 10, } 1850 \text {. } \\
& \text { Last Will and Testament Armitled to Probate, May } \\
& \text { of } 1,1583 \text {. } \\
& \text { Thomas W. Watson. }\} \text { Treorded Iuty 1, } 1853 . \\
& \begin{array}{l}
\text { deceasert. Booli } 100 \text {, paye } 550 . \\
\text { Directs, that all just debts, }
\end{array}
\end{aligned}
$$

including funeral expenses and cipenses of atministration, be paid by his executor. s6

Gives and bequeaths to his wife. Amie Watson, one thousand dollars annually, to be paid, ete., [set out such legacies as constitute a charge on the land] together with sundry other bequests and legacies.

Derises and bequeaths to his son, George Watson, ete., [set out the specific derises].

Gives, devises and bequeaths all the residue and remainder of his estate to, ete., [set out the residuary brquests].

Appoints John. Williams his executor, ete., [note the trusts and powers, if any].

Add facts of execution. ${ }^{87}$

85 If desired, the ordinary caption of a deed may be uned; a:- - to the nature of the instrument being indicated by its name in the margin. The method emplosed in the example is, however, the better way.

86 "The direction of payments of debts and funeral expenses," observes Mr. Redfield, “is now merm formal, exept that as it may sometimes aid in the construction of a will, by showing that the subjert of the tesiator's dolits was hronght dietinetly to his mincle at the time of executing his will:" I Rodf. on
Wills, *6rt. The direction of a testator to his executors to pay his debts does not give to them a power of sale for that purpose. or vest them with any authority for their parment, other than the law itself creates, by expresty charying all the property of a deceshent with the gayment of his debt-, whether he die testate or interate. Will of Fox. 5.2 X. Y. 530; Harrie r. Domerlas, 64 Ill. Alif: Carlington $r$. Mamning's Heirs. 13 Ala. (ill.

sithe eximiner will notice whether any of the witnesses are 
If the proof of the will is appended, as is usually the case, this would doubtless be sufficient to show testator's death, but, if desired, a note embodying such information may be appended, thus:

Note.-By the records and files in the offec of the County Court of Kenosha County, Wis., it appears that Thomas W. Watson died on or about A pril $28,18 S 3$; that letters testamentary were granted to John Williams, May 1, 18S3.

Where a codicil is appended it should be abstracted as a separate instrument and its terms fully set forth, particularly when it tends to revoke any provision of the will, or alters the prior disposition of the real estate of the decedent. In such case say:

Appended to the foregoing is,

and then, as in case of the original, follow in the margin with,

Codicil to the last will and testament, etc.,

giving the date and substance of the codicil. With all wills filed for record as conveyances the law requires the "proof of probate" to be also filed. Such proof is generally in the shape of a certificate by the judge or clerk of the probate court, and a synopsis of same should immediately follow; thus,

named in the will as devisees or legatees, and in case of a correspondenee of names show the same. As a rule, any person taking any benefit under a will is excluded from being a witness to same, or else the provision in their favor is rendered void. 
Appended is:

$\left.\begin{array}{c}\text { Certificate } \\ \text { by } \\ \begin{array}{c}\text { Edward Martin, } \\ \text { County, Wis. }\end{array}\end{array}\right\} \begin{aligned} & \text { Proof of will. } \\ & \text { Dated July 1, } 1983 . \\ & \text { Pecites that on the 15th day of } \\ & \text { County, His., pursuant to notice }\end{aligned}$

duly given as required by law, Filliam Jachson and James Smith, subscribing witnesses to the last will and testament of Thomas W. Wratson, late of the County of Kenosha, dec'd, which is "hereto annexed," were produced, sworn and examined (and the said will being contested, and other witnesses as well for the contestant as for the proponent of said will, having been produced, swom and examined), ${ }^{8 s}$ and proofs having been heard before said court, and the court having thereupon found that said instrument was in all things duly executed as his last will and teslament by said Thomas IV. Watson, on the 10th day of October, 18SO; that he was then of full age, and of sound mind, and that said instrument was duly subscribed and attested (in his presence). ${ }^{89}$

Thereupon suid instrument being duly proved,90 was by said court duly allowed, and probate thereof granted as and for the last will and testament of said Thomas W. Watson, dec'd.

Signed by said Judge, and the seal of the Kenosha County Court afficed. laws.

88 This of course depends on local

s9 Where a will is properly signed by the testator and two or more attesting witnesses, both of whom testify that they were present, and saw the testator sign the will in their presence, or that the testator acknowledged same, and that they believe he was of sound mind and memory at the time of executing it, this, in the absence of any proof

of fraud, compulsion, or other improper conduct, is sufficient to make out a primu facie case and entitle the will to probate. Heirs of Critz $v$. Pierce, 106 Ill. 167.

90 The certificate of probate of a will need not set out in detail the evidence upon which the will was proved. If conclusions of law are stated, it is sufficient: Mosley $v$. Wingo, 7 Lea (Tenn.), 145. 
$\$$ 11. Probate of Wills. Probate of a will has been defined as, the prowt, before an officer authorized by law, that an instrument offered to be proved or recorded is the last will and testament of the deceased person whose testamentary act it is alleged to be. ${ }^{91}$ It is the antientication of the instrument, and that which gives to it its legal effect and validity as a conveyance, and nothing, says Lord Kenyon, " ${ }^{22}$ "but the probate or letters of alministration with the will annexed, are legal eridence of the will," language which has been repeated and approved by the Supreme Court of the United States. $^{93}$ A will, therefore, which has not been admitted to probate, though admissible perhaps in connection with proof of adverse possession, is not evidence of title in a court of law, ${ }^{94}$ nor would it afford constructive notice if recorded.

$\$ 415$. Effeet of Probate. The probate of a will, if decreed by a court of competent jurisdiction, establishes the facts: (1) that the instrument in question is the last will of the testator and that it was duly executed and published with all solemnities required by law; (2) that the testator at the time of executing the instrument, was of sound and disposing mind and memory, capable of understanding the act he was doing, and the relation in which he stood to the object of his bounty, and to the persons to whom the law would have giren his property if he had lied intestate; (3) that the instrument was executed without fear, fraud or undue influence by which his own intentions were controlled and supplanted by those of another' (t) that he executed the instrument animo testandi, with an understanding and purpose that it should be his last will and testament; 95 and $(5)$ it is presumptive evidence of the death of the person whose will it purports to

91 Bou. Law Dict. 378; Pet1it $r$. Black, 13 Neb. 142.

92 Rex $r$. Inhab. of Neatherseal, 4 T. R. (Eng.) 258.

93 Armstrong $r$. Lear. 12 Wheat. 175 .

94 Willamette, etc., Co. $r$. Gordon, 6 Oreg. 175; Wood $v$. Mat. thews. 53 Ala. 1; Pitts $v$. Melser, 7.2 1nu. 4ti9) Shumway $r$. Holbrook, 1 Pick. 114: Ochoa $r$. Niller, 59 Tex. 460): Pettit $r$. Black, 13 Neb. 14.2.

95 Barker $r$. Comins, 110 Mass. 47. 
establish.96; Such decree is generally regarded as in the nature of a judgment in rem, ${ }^{97}$ and in the absence of statutory provisions, is conchnsive as against all the world, as to the validity of the will,9s and affirms the title of the benefieiary under it from the time of the testator's death, relating back so as to make valid whatever has been previously done, which, under the will, after probate, the beneficiary could lawfully have done. ${ }^{99}$

But, though probate establishes the sufficiency of the will, and confirms the claims of those holding under it so far as to make it evidence of title, it does not determine the title to the property, nor establish the validity of any devise given by it, the will having no greater effect after probate than other legal conveyances. ${ }^{1}$

$\S$ 416. Foreign Probate. In order to entitle a devisee of lands under a will probated in a foreign jurisdiction, to deduce legal title to same in the courts of the State where the land is located, it is frequently necessary that the will be also probated in the local courts. This matter is governed by statute which generally provides that the copy of the will presented must be accompanied by a certificate of the foreign probate and duly authenticated, these together constituting the one instrument or subject-matter to be acted upon under the statute; and all are, as a rule, essential to authorize the probate court to exercise jurisdietion. ${ }^{2}$ Whenever this ancillary probate is resorted to it is generally allowed as a matter of course and withont inquiring into the validity of the will or

96 Carroll $v$. Carroll, 6 Thomp. \& C. (N. Y.) 294; Belden $t$. Meeker, 47 N. Y. 307.

9 ז Hall $v$. Hall, 47 Ala. 290 ; (rippen $v$ Dexter, 13 (Gray (Mass.). 330 ; State $v$. MeGlynn, 20 Cal. 233.

98 Brock $x$. Frimk, o Alit. 85; Janes $r$. Williams, 31 Ark. 175; Tucker $r$. Whitcliead, 58 Miss. 762 . In re Williams, I Lea (Tenn.), 529; Orr $v$. O'Brien, 55 Tex, 149 .
99 Stuphen $v$. Ellis, 35 Mich. 446; Allaire v. Allaire, 37 N. J. L. 312 ; Dublin $v$. Chadbourn, 16 Mass. 433.

1 Fallon $r$. Chidester, 46 Iowa, 588; Greenwood $v$. Murray, 26 Minn. 250; Ware $v$. Wisner, 4 MaCrary (C. C.t.), 66.

2 Pope $v$. Cutler, 34 Mich. 150; Ward $v$. Oates, 43 Ala. 515. 
the sufficiency of the proofs upon which the court granting the original probate acted, provided sneh original probate was granted by a court of competent jurisdiction and is properly authenticated. ${ }^{3}$

But even where ancillary probate is not required to establish a foreign will it may yet be essential to perfeet title in the devisces. Thus, a creditor of a decedent is not required to go into a foreign jurisdiction to prove lis claim. If such decedent leaves land in the State of the creditor's domicile it will be affected by the statutory lien of the debt and may be sold in satisfaction thereof. Hence, it may often become necessary or expedient to probate a forcign will for the sole purpose of extinguishing ereditors liens, and where the property under examination is raluable this course can never be safely omitted mnless the statute has run against possible debts. In any event an attorney examining title should note the absence of ancillary probate of a foreign will and found such objections upon the fact as he may deem proper.

$\S 417$. Abstract of Probate Proceedings. It is estimated that about once in every twenty-fice years all the real property in the country passes under the supervision of the probate courts, and whether the estimate be based on correct or incorrect data, it is certain that there are but few titles of twenty-five years' duration that do not show testamentary eonreyances or descents. The records and proceedings of these courts, therefore, have a direet and important bearing on every title of long standing, and are among the mmiments that go to give stability and security to the possession of the party asserting such title.

The ordinary proeeedings of county and probate courts which have a direct influence upon land titles are: the probate of wills and issuance of letters testamentary and of administration; the inventory and collection of the effects of

3 Brock 2 . Frank, 51 Ala. 89 ; Apperson $r$. Bolton, 29 Ark. 418; Newman $v$. Willetts, 52 Ill. 98; Russell. v. Hart, 87 N. Y. 19; Markwell v. Thorne, 28 Wis. 548. 
deceased persons; the proof of payment of debts and legacies; the assignment of dower and homesteads; the sale of lands by executors and administrators; the allowanee, distribution and partition of the estates of deceased pers̀ons; and incidentally of proceedings relative to gnardians and wards, adoption, ete. Sometimes the peculiar exigencies of the case may inelude all of the different matters just enumerated; again the desired end may be attained with a showing of but one or two. So, too, it will sometimes be necessary that a very full exemplification must be given of the matters presented and the action had thereon, while under other eircumstanees only a brief mention will be required. The matter will therefore rest, in a large measure, in the discretion of the examiner.

Upon the probate of wills, the abstract of the proceedings should show: the proof of the will; ${ }^{4}$ the acceptance or remumciation of the trust by the executor; the issuance of letters testamentary, ${ }^{5}$ and qualification of the executor; the inventory of real estate; the proof, allowance and payment of claims. This much is indispensable, but other steps and proceedings may often be profitably shown. The degree of detail to be observed must be gorerned in most respects by the judgment of the examiner in the absence of instructions from the elient. A summary is presented by way of illustration, and which, perhaps, is full enough for ordinary cases:

4 A transcript of the record of probate of a will devising lands, made before a proper tribunal, is competent evidence of title in an action of ejectment, if the record contains the proofs taken before the court, as required by the statute; and, if the proofs contained in the record show that the will was executed with all the formalities required by statute, the probate will be prima facie evicience, and will of itself be sufficient to establish title, if not overcome by counter proof: Allaire $r$. Allaire, $37 \mathrm{~N}$. J. L. 312.

5 The issuance of letters presumptively establishes the fact of deatll: Carroll $v$. Carroll, 6 Thomp. \& C. (N. Y.) 294: Holnes $i$. Johnson, 42 Pa. St. 159; Pick $r$. Strong, 36 Minn. 303. 
In the matter of the estate Hilliam II. $\left.\begin{array}{l}\text { Black, } \\ \text { deceased. }\end{array}\right\}$
C'ounty Court, Kane count!y. In Probate.

Case No. 3, in Box $153 .^{6}$ Will of William H. Black. Dated May 2, $187 \%$. Filed Octover 13, 1880.

Proven and admitted to record, January 28, 1881.

Recorded in Vol. 2, page $3 S 3$.

Said testator disposes of his estate as follows:

Directs the payment of all his just debts and funeral expenses.

Devises to his executor (or his successor) his "home place," consisting of house and barn, and about two acres of land on the west side of Park Place, and running through to Tenth street, and lying between Forrest avenue and Grinnell street, in the city of Elgin, Kane county, Ills., in trust, to lease same or to sell same and apply income and proceeds for the use and comfort of his wife, Anna Black, during her natural life, and for the support and education of his son, Walter Black, and at the death of said wife, if undisposed of, to be transferred and conveyed to his son, Walter Black, if then living, or to his issue, if any, if he be not living, or to testator's heirs at law, if his said son shall be then dead, leaving no issue.

Gives and devises to his nephew, John Black, son of his brother, James Black, ete.

If it is desired to set out the entire will, which will seldom be necessary, the devises and bequests will follow here in narrative form. As the inquiry will rarely cover more than one specific tract, the particular devise which has reference to such tract is shown in detail, and general reference made to all others; as,

Devises to various other persons, certain real estate not now in question (or, not covered by this examination).

6 This has reference to the depository of all the papers in the case. 
Unless there are legacies which are charged upon the land, the personal bequests nay be disregarded except the residuary clause which next follows:

Gives, derises and bequeathe all the rest and residue of his property, real and personal, including lapsed legacies and devises, unto his son. Walter Blact, subject to the payment of the following annuilies, to wil:

To his mother, etc., [set out the annuities].

Appoints his brother, James Black, sole executor and trustee, and in case of his death, declinution, resignation or inability to act, directs that Clarence D. Perry ast in his place, waiving security, and giving his executor full power to sell any part or parts of the real estate herein devised to his son Walter, at public or private sale, and to give good and sufficient deeds thereof to the purchaser or purchasers so that they shall not be answerable for the application of the purchase money, and in case of such sales the proceeds, after paying debts, legacies and anmuities, to go to his son Walter as part of the residue of his said estate.

Three witnesses.

Renunciation of James Black of his appointment as executor and trustee, filed January 2S, 1881.

Petition of Clarence D. Perry for proof of will and letters testamentary, filed Jamary $29,18 S 1$.

Said petition represents that William II. Black died testate May 27, 1SS0, leaving him surviving Anna Black, his widow, and Walter Black, his son, his only heir at law.

Sworn to Nov. 26, 1SS0,

Letters testamentary to Clarence D. Perry, issued, dated Jan'y 31, 18S1. Reconded in Vol. 2, pg. 273.

Bond in sum of $\$ 80,000.00$, security waired, filed and approved Jan'y 31, 18s1. Recorded in Vol. 2, pg.

Warrant to appraisers issued, dated Jamuny 31 , 1981.

A ppraisers' report filed and ajproved Jume S. 1SS1, shows no property belonging to said estate subject to aprmaisement. 
Appraiscment of widow's award filed and approved June 8, 1881. Total value, \$2,800.00.

Iincentory filed and approved June 8, 18S1. Recorded in Tol. 10, l'y. G2r.

Ifritions real esiate as follows:

Lots 19 and 21 ), Block 1, etc.

Proof of mubiration and posting of notices for adjudication filed July 12, 1SS1, approved in open court July 1S, 1881.

Adjudication ordered July 1S, $18 S 1$.

Sundry claims fited and allowed amounting to the sum of $\$ 5,042.30$.

Continue in this manner, showing all important steps, until final settlement and discharge of executor. The synopsis sinonld close with an abstract of the final order showing payment of the widow's award and of all proved debts. 


\section{CHAPTER XXIV. \\ LIENS, CHARGES, AND INCEAIBRANCES.}

§ 418. Liens generally.

419. How created.

420. Operation and effect.

421. Method of arrangement.

422. Mortgages.

423. Dower.

424. Judgments and executions.

425. Judicial and execution sales.

426. Lis pendens and attachment.

627. Decedent's debts.

428. Taxes.
$\S 429$. Municipal liens.

430. Othicial bonds.

431. Leases.

432. Vendor's liens.

433. Mechanic's liens.

434. Continuel - Priority.

435. Estate to which the lien attaches.

436. Limitation of lien.

437. Asignability.

438. Foreclosure.

$\S$ 418. Liens Generally. A lien is defined as a hold or charge which one person has upon the property of another as a security for some debt or charge, ${ }^{1}$ and in its broad sense would cover all burdens, charges or incumbrances placed on land, inchuding mortgages, judgments, taxes, etc., as well as common law and statutory liens, and liens arising by implication of law. In its more restricted signification it is used to denote certain preferred or privileged claims given by statute or arising by implication of law, and indicates a mere right to hold the property until the clain has been satisied. Even in this latter sense, as it is now employed in eonverancing and the compilation of abstracts, its popnlar meaning contines it to certain classes enumerated by statute; as the lien of nochanies and material men, attachment, lis pendens, ete., and liens arising by operation of law, as decedent's debts, purchase money liens, etc.

Liens are also classified as legal and equitable. The latter,

12 Bou. Law Dict. 47 
being generally unknown to the world, and frequently operating injurionsly on the rights of ereditors and purehasers, are never enforced except in cases where the right is clearly and distinctly made ont." The so-ealled "sendor"s lien" is a conspicuous example of this class.

$\$$ 419. How created. Liens upon lands are created by the statute, to secure the parment of taxes, and other public debts; to protect estates raised out of or incident to the marriage relation; to effectuate the judgments of courts by allowing the land of the defendant to be taken in execution, as well as to anticipate such judgments by way of attachment and lis pendens; to secure the payment of debts of deceased persons, and to seenre the wages of laborers and mechanics. They are also created by the direct act of the parties, as by leases, mortgages, etc, and arise in a number of cases by operation or implication of law, as to secure umpaid purehase money, ete., these latter being known as equitable liens. Intending purchasers are chargealle with notice of all statutory liens, the provisions of the statute having been substantially complied with, but will take the land, where the sale is male in good faith and for value, freed from the burden of equitable liens of which they had no notice.

$\S$ 120. Operation and Effect. Unlike a conveyance, a lien, howerer created, confers no estate in, or title to, the property to which it attaches, and mar be discharged at any time before foreclosure by the payment of the sum, or performance of the obligation, for which the property is held.

\$ 421. Method of Arrangement. Liens, charges and incumbrances of erery lind, with but one exception, are shown, not in the regular course of title, but in appendices to same, and, for better convenience, under classified lieads. The exception is in ease of mortgages, which, following the custom which prevailed when such instrments were conveyances of the legal estate, are shown in regular chronologieal order in

2 Conover $r$. Warren, 1 Gilm. (Ill.) 498; see Walker $v$. Matthews, 58 Ill. 196. 
the chain. This arrangement posecses many arrantages ower any other, the chief one being to preserve the symmetry of the title, which enables comsel to obtain a cluarer view thereof than conld possibly be obtained if the liens and charges were inserted in the chain in their order of time. An analysis of the abstract should always be prepared in wery long examination, and the effect of liens, considered with reference to the fee, can more easily be deternined by this arrangement on the compilation of such analysis than if the were allowed to interfere with the primary questions raisod by the actual conveyances. These points will be more fully demonstrated in treating of "Opinions of Title."

$\S 422$. Mortgages. The ancient doctrine, by which mortgages were regarded as conveyances of the legal estate, no longer obtains in the Lnited States, or at least but in a rery modified form, while in a majority of the States they are regarded simply as liens on land to secure the pasment of indebtedness." Considered simply as liens, ther might, before default or foreclosure, with propriety, be shown with other liens, and it is the custom of some examiners to follow this method of arrangement; after default and foreclosure they hecome essentially muniments of title, and must appear in the chain in regular chronological sequence. Mortgages followed by satisfaction are but dead matter, and when forming part of the chain are positive hindrances in passing the title; such mortgages might be shown in appendices under the head of "satisfied liens," the main object being simply to show a proper" and legal release.

$\S 423$. Dower. The inchoate right of dower, during the lifetime of the husband, is at least a cloud upon the title in the hands of the husband's alienee, which, in the event of his death before that of the wife, develops into a positive charger

3 See Chap XXI, Odell $r$. Montross, 68 X. Y. 499; Gorham $r$. Arnold, 22 Mich. 247; White $r$. Rittenmeyer, 30 Iowa, 268; Vason $r$. Ball, 56 ra. 268; Fletcher $v$.
Inolues, 2: Ind. 497: Carpenter $r$. lowen, 42 Miss. 2s; Wouls r. Ilitdebrand, 46 Mo. 284t Actor r. Hoyt, 5 Whend. 602; Parsons 19. Noggle, 23 Minn. 328. 
upon the lanu.* In the first event it is hardly a lien, while in the latter it is more than a lien, but in both instances it will appear only inferentially, and can not be shown afirmatively in the abstract.

\$ 124. Judgments and Executions. Judgments, from the time of their rendition, and executions. from the period of issuance or lers, create statutory liens, which necessitate a full exposition in the abstract. The subject is reserved for ample treatment in a subsequent chapter.

$\$$ 125. Indicial and Execution Sales. The purchaser of lands sold on execution acquires by his purchase no more than a lien upon the lands for the amount of his bid, and interest during the period, if any, allowed for redemption. Ho does not obtain the legal title: and if the lands are subject to a mortgage, he does not become the owner of the equity of redemption until after the expiration of the period allowed for redemption from the execution sale. ${ }^{5}$

\& 426. Lis Pendens and Attachment. A pending suit involving title conrers notice to intending purchasers, and charges the land, in whosesoever hands it may be, with the consequences of whatever decree may be made, while an attachment reserves the land to satisfy any jurgment that may lo rendered in the snit and creates a lien in favor of such judgment in adrance of its rendition. The attachment is a lien from the time of the lery. but in the ease of land this means the filing of the certificate in the office of the recorder of deeds. ${ }^{7}$

$\$ 427$. Decedent's Dehts. The dehts of a deceased person are a lien upon the lands of such decedent in the hands of his heirs or devisces, and the lien eontinus until paid or barred by the statute. If the heir aliens the lands, the alienee

* An incloate right of dower ontsanding $i-$ a lefect in the tille, and an incmunance unon the estate: Wright $r$. Founer (6 Win. 127.

5 Vouphan r. Ely, 4 Barb. 159;
Farmers Bank of Sinatoga $v$. MerGant, 13 Huw. (X. Y.) 10.

G Martin $r$. Drrden, 1 Gilm. (Ill.) $18 \%$.

TJall $r$. Gomld, 79 I!l. 16. 
holds them subject to this lin'n, and his title may be defeated by a subsequent sale by the arministrator. ${ }^{8}$

$\$ 428$. Taxes. The lien of the State for taxes attaches to all lands subject to taxation on some day stated, usually the first day of May of each year, ant every person owning land, on that day is liable for the taxes due thereon for the year." They take priority of all other liens under the principles applicable to the prerogatives of sovereigntr. ${ }^{10}$ The subject will be discussed further on.

\$ 429. Municipal Liens. Liens may be created upon the lands of individuals and corporations by ordinances of cities for municipal expenses; lighting, cleaning or repairing streets; public improvements, ete. All questions relative to the effect of municipal ordinances considered as liens, are local and statutory.

$\S 430$. Official Bonds. A peculiar class of licns arises in many States from offieial bonds, which are declared to be liens on all the real estate held jointly or severally by the officers giving same, and their sureties, from the time of filing the bonds until sueh offieers shall have been honorably discharged from their trusts. These bonds are most frecpnently required from collectors of taxes, and it would seem, that where any of the parties vendors named in the abstract, during the period in which an action may be brought on an official bond, have held this position, or have been a surety for any such officer, an examination should be made for liens of this nature. As the bonds are required to be filed or recorted in some of the designated public offies of the county, the files or records should be regularly inspected as often as oceasion may recquire, and references oltanined to the information thereby disclosed. The indiees to the information thus obtained may comsist of special volumes, but a better way is to post same in the "ir-

s Vansyckle r. Richardson, 13 Ill. 171 ; Hill $v$. Treat, 67 Ne. 501 ; and see Rosenthal $v$. Renick, 44 Ill. 202.

9 Almy $v$. Hunt, 48 Ill. 45. The date of the commencement of the 33 lien has reference to the day on which the aitizen is comperlyed to list his lanel for taxation.

t" Dunlap) r. (abllatin Co., 15111. 7 ; Dennis 1 . Mannard, 15 11. 47. 
regular" index where the names of the bounden individuals will always be found when compiling the chain. Usually where a bond has the effect of a lien, the principal and his sureties are entitled to have a discharge entered whenever the operation of the bond has ceased, and where the obligation is discharged, by proper entries, it may be disregarded in making up the abstract. Where the bond is apparently a subsisting lien, it must be shown in the same mamner as other liens. In abstracting these bonds, the general form already given may be followed, the essential particulars being the parties, penalty and condition of the obligation, which should be fully stated. ${ }^{11}$ It lias been held that the statutory lien created by giving an official bond does not in any way affect the homestead of the person giving same, ${ }^{12}$ but with this exception, it attaches to all the real estate then owned by the obligor or his sureties, and also, as in the case of a judgment, to all after acquired lands. ${ }^{13}$

$\$$ 431. Leases. A subsisting lease is rather in the nature of a charge or incumbrance on the fee than a lien. It confers a right of possession, according to its import, to the exclusion of the owner of the fee or reversion. Considered in this light and it can be viewed in no other, it does not properly come within the chain of title, but is appended to it, and should be shown in the abstract after the course of title has been traced. When exhibited in its proper order of time as a part of the chain it may, perhaps, be more readily considered with respect to its effect on subsequent conveyances, but it is the experience of the writer that correct estimates of title are more easily and correctly arrived at by keeping the fee disassociated from all minor estates. The better plan, therefore, seems to be to show leases among the appendices. Should the term extend over a long period of time, with numerous assignments

11 As to the nature. effect and construction of official bonds, considererl in their relation to real estate, ennsult Richeson $v$. Crawford, 9. III. 165; and Crawford $v$. Richesoil, 101 Ill. 351.
12 Trustees of School $r$. Hovey, 94 Ill. 394.

13 Crawford $\imath$. Richeson, 101 Ill. 351. 
or transfers of any interest less than the term, tie leasehold should be traced in a separate chain, with proper subleading's indicating the purport of the search.

\$ 432. Vendor's Liens. Where there is an express reservation made in a deed of the lien of the vendor, this is equivalent to a mortgage taken for the purchase noney contemporaneously with the deed. In fact the purchaser is practically in the same condition as if he had receivel a deed and given a mortgage for the purchase money, and he has the right to redeem. ${ }^{14}$

But in addition to this form there is a recognized lien of the vendor for umpaid purchase money which is not based upon contract; nor is it an equitable mortgage or resulting trust, but an equity which is raised and administered by the courts, who enforce or deny it as the merits of each particular case may seem to demand. It is never allowed to override or take priority of equities or rights of third persons, which have attached in ignorance of such rendor's equity, and is not in this respect like a mortgage, or any other lien created by express contract, or even by statute. ${ }^{15}$ Under the application of this doctrine a purchaser is not, in equity, the owner adversely to the lien of his vendor, but is treated as a trustee for him until the purchase money is paid. The vendor's lien exists against such purchaser, and against voluntecrs and purchasers under him with notice of his having an equitable title only, ${ }^{16}$ or with notice of the vendor's equitable lien. ${ }^{17} \mathrm{~A}$ vendor's lien, of the character now under consideration, is personal in its nature ${ }^{\mathbf{1 8}}$ and is raised by construction of equity

14 King $v$. Y. M. Assn., l Woods, 386 ; Smith $v$. Rowland, 13 Kan. 245; Carpenter $v$. Mitchell, 54 Ill. 126.

15 Allen $v$. Loring, 34 Iowa, 499 ; Swan $v$. Benson, 31 Ark, 728 ; Moody $v$. Fislar, 55 Ind. 592; Moshier $v$. Meek, so Ill. 79.

10 Walton $v$. IIargroves, 42 Miss. 18; Bureh v. Carter, 44 Ala. 115;
Swan $r$. Benson, 31 Aik. 728; Harshbarger $v$. Foreman, SI IIl. 364; Madden $l$. Barnes, 45 Wis. 135.

17 Graves $r$. Coutani, 31 N. J. Eq. 763 ; Wilson v. Lỵm, 51 IHl. 166.

18. Jones $v$. Joss, 27 Ark. 518 ; Bowlin r. Pearson, 4 Baxter (Tenn.), 341. 
in favor of the vendor only. ${ }^{19}$ It is not a matter of sale and can not be assigned, even by express language, with the note taken for the purchase money, ${ }^{\circ}$ and an assignment of the notes will, as a rule, extinguish the lien, ${ }^{21}$ as will also the taking of a distinct and independent security. ${ }^{22}$

Inasmuch as a vendor's lien, as just described, is secret, nnknown to the world, and often productive of harm, it will not be extended beyond the requirements of the settled prin(iples of equity, and such liens are not encouraged by the courts. $^{23}$ It is not apparent on perusal of the ahstract, and will not affect a purchaser for value and withont notice.

$\S$ 439. Mechanic's Liens. A mechanic's lien is the ereature of statute, and depends for its validity solely upon the act creating it. The act itself is an imnoration upon the common law affecting property and rights of property, as it authorizes land to be incmmbered without or against the consent of the owner, and without a resort to legal process or judicial action. Such an act ean not be extended in its operation and effect beyond the fair and reasonalite import of the words used, and whover asserts the lim must bring himself within its terms, and the lien must be shown, not only to have been regular and valid in its inception, but to be a continuing and existing lien muder the statute. ${ }^{2+}$ The design of the law is to protect the mechanic, laborer, and material man to the extent of services performed or materials furnished. The lien is absolnte to the extent of the owner's interest in the land atfected, and can not be divested by a sale or transfer of same

19 Lindsey $x$. Bates, 42 Miss. 397 ; Small $r$. Stagg, 95 Ill. 39.

20 Hect $v$. Spears, 27 Ark. 229; Markoe $v$. Andras, $6 \tau$ Ill. 34 . But see contra, Bill $r$. Mason, 42 Iowa, 330.

21 Pillow $v$. Helm, 7 Baxter (Tenn.), 545; Hightower $v$. Rigsby, 56 Ala. 126 ; Bonnell $v$. Holt, 89 Ill. 71.

22 Anderson $v$. Donnell, 66 Ind.
150 ; Stuart $v$. Harrison, 52 Iowa, 511 ; Neal $v$. Speigle, 33 Ark. 63; Stevens $v$. Rainwater, 4 Mo. App. 292; Cowl $r$. Varnum, 37 Ill. 181. 23 Cowl $r$. Varnum, 37 Ill. 181, Doolittle $r$. Jenkins, 55 Ill. 400. 24 Mushlitt $v$. Silverman, $50 \mathrm{~N}$. Y. 360 ; Dinkins $v$. Bowers, 49 Miss. 219; Rothgerber $v$. Dupy, 64 Ill. 452. 
after the commonement of performance of the eontract. ${ }^{25}$ For this latter reason it is always well to call the attention of prospective purchasers to the fact of possible liens not shown of record. A suggestion of this kind will be found in the remarks on opinions of title.

$\$ 484$. Continued - Priority. Being rependent on the statute for their force and extent, no gencral rule can be asserted in regard to the priority of mechanic's liens. They usually take precedence of mortgates given after the commencement of the work, but as lretween mechanies there ean be no priority. ${ }^{6}$ Where, howerer, a mortgage or other lien takes effect after the emmmencencent of one or more mechanic's liens, but before the commencement of others, the latter must be postponed to the mortgage lien. ${ }^{2}$ is between a lien upon an equitable interest and one upon a full legal title, the latter, though subsequent in time, may be preferred to the former, if the holder thereof be an innocent holder withont notice. ${ }^{2 s}$ Mechanies and laborers asserting a lien mpon real property for their work, and claiming priority over mortgagees and others who have aequired interests in the property, must furnish strict proof of all that is essential to the lien, ${ }^{29}$ but of what these essentials consist, local law must decile. In abstracting the petition, notice, or other preliminary measure, the examiner will consult the statute and observe that all its material requirements are complied with.

\& 435. Estate to Which the Rien Attaches. To render the lien effective, and afford protection to the artificer in every possible case, it is permitted by statute to attach to an estate in fee, for life, for years, or any other estate, or any right of redemption or other interest which sueh owner may have in

2.) Mehan $r$. Williams, 2 Daly (N. Y.), 367; Dumkles r. Crane, 103 Mass. 470; Thielmat $r$. ('arr, 75 I11. 385.

26 In re lfoyt, 3 Piss. 436; Thiclman v. Carr, 75 Ill. 385; Powler
Co. $r$. Loomis, 2 Disney (Ohio), 544.

27 Powder (n. r. Tommia, \& Disnay (Ohio), 544; Williams r. Clatpman. 17 111. 42:3.

28. Jomes r. 1apham, 15 Kinns. 540. 29 Davis $r$. Alrord, 94 U. \$. 545. 
the land at the time of making the contract, and whatever right or estate such owner laal at that time may be sold in satisfaction of the lien." But the lien affects only the title of the person contracting,: and where such person possesses only an crpuity, the legal title is not impaired.32 It can not extend to affect or impair the right of dower ${ }^{33}$ nor the estate or title of an infant; ${ }^{34}$ nor the title to the fee or reversion, when the contracting party is only a tenant for life or years; ${ }^{35}$ nor the property of a third party in the temporary use of another ${ }^{36}$ nor the separate property of a married woman, where the contract is made without her knowledge ; 3 nor will it extend against the property of the State. ${ }^{38}$ The lien extends to the property of a decedent, and may be enforced against the land in posscssion of the heir, but, it seems, can not be made a personal liability against them. ${ }^{39}$

$\$$ 436. Timitation of Kiem. $T_{t}$ is difficult to formulate a statutory rule that shall be of general application, and particularly iu so technical a matter as mechanie's liens. In many States they are subject to constant legislative tinkering and continual change, with the result that even the judicial decisions of such States are umreliable guides.

30 Kirlder r. Aholtz. 36 Til. 478; Donaldson $r$. Holmes, 2? Ill. Sis.

:1 Hickox $r$. Greenwood. 94111. 266.

:2 Mr.Carty 1 . Carter, 49 I11. 53; Hickox $r$. Fireentool, 94 Ill, 2fo: Craig r. Swinerton, 15 N. Y. Sun. Ct. 144; IIayes r. Pessenden, 106 Mass. 228; Mallahan $r$. Iferbert, 11 Abr. (N. Y.) Pr. (N. S.) 3פ6; Knapp $v$. Brown, 45 N. Y. 207. 33 Grove $r$. Cather, 23 IIl. Cist. s4 Mecartlyy $r$. Carter, 49 Ill. 53. 35 Knapp r. Brown. 45 N. Y. 207; NeCarty $v$. Carter, 49 Ill. 53: Fran(is $r$. Sayles, 101 Mass. 435; and this eren though the lessee is bound to make improvements and leave them on the premises at the expiration of the term: Knapp $v$ Srown, 45 N. Y. 207. :6 Tracy r. Rogers, 69 Ill. 662; Thaxter $r$. Williams. I4 Pick, 49.

3 Thomery $v$. Rohrmayer, 40 Conn. 558. Otherwice where such maried woman had personal knowledge of the work, or grave directions encerning it: Collins $e$. Megraw, 47 No. 495: or the materials were furnished at her request, or had her approval: Greenleaf $r$. Pabee, so n1. 520.

ss Thomas $r$. Industrial University, 71 111. 310; Pipley r. Gage Co., 3 Neb. 397; Panola Co. Sup. r. Gillen, 59 Miss. 198.

39 McGrew $b$. Macarty, 78 Ind. 496. 
To lien is given in any of the States unless steps are taken to secure and perfect it within a specified period, usually six months or one year from the time of the last charge for performance of work or furnishing of materials, and in some States there is a special limitation with respeet to the commenement of the work; as, when the contract is expressed, no lien is created if the time stipulated for the completion of the work is beyond three rear's from the commencement thereof, or the time of payment heyond one year from the time stipulated for such completion. Where the contract is implien, no lien is given unless the work shall have been done or the materials furnished within one year from the commencement of the work or delivery of materials. The petition for the enforcement of this lien must state everything necessary to show a due compliance with the statute, ${ }^{40}$ and such parts as specifically relate to the demand; the contract upon which it is founded; the dates of performance; the amomnt due; and the specifie property which is sought to be incumbered, together with other material facts in relation thereto, must be shown carefully and in detail, that counsel may see from inspection whether all of the conditions neeessary to create the lien are shown to exist and all statutory requisites have been complied with. Unless the petition shows on its face a contract within the statute, no lien will result. ${ }^{41}$

§ 437. Assignability. The lien given by the statutes is, in general, a personal right given to the mechanic, material man or laborer for his own protection, and the right can not be assigned or transferred to another, ${ }^{42}$ unless the assignment is made for the benefit of the assignor, and to be held as his

46 Mushlitt $r$. Silverman, $50 \mathrm{~N}$. Y. 360; Dinkins $r$. Bowers, 49 Miss. 219 ; linthgerber $v$. Dupy, 64111. 452; Davis r. Alvord, 94 U. S. 545 ; Valentine $r$. Rawson, 57 Iowa, 179; Conroy $v$. Perry, of Kansas, 472; Ringer r. IInover, 28 Minn. 401. 41 NeClurken $v$. Logan, 2:3 Ill.
79; lowley $r$. James, 31 111. 298; Valentine 2 . Rawson, 57 Inwa, 179: and see Hammond v. Wella, 45 Mich. 11; Treusch $r$. Shryock, 5i) Mil. 330 .

42 Caldwell $r$. Laminer, 10 Wis. 332; Pearsons $r$. Tincker, $36 \mathrm{Mr}$. 384. 
agent, so that the lien may be preserved. ${ }^{43}$ In some States the lien, while not assignable, will pass as an incident to the debt. ${ }^{44}$ $\$ 438$. Foreclosure of Lien. The lien given by statute is not snsceptible of immediate enforeement, but must be prosecuted by action of an equitable nature, and where the lien is finally satisfied by sale under a decree, all the intermediate steps should be snceinctly stated so as to show a complete divesture of title under the statute. In many of the States a right of redemption does not follow a sale under a decree to satisfy a meehanie's lien, and as the proceedings, in this respect, are of a summary nature, it is essential that in all such instances more than ordinary care be taken in preparing the synopsis.

13 Rollin $r$. Cross, 45 N. Y. 766 . ferent rule, but the text states the Local statutes may introdnce a dif- general doctrine.

44 Brown $r$. Smith, 55 Iowa, 31 . 


\section{CHAPTER XXY.}

IIS PENDENS ANI, ATTACHMENT.

$\S 439$. Doctrine of lis pendens.

440. Requisites of lis pendens.

441. Effect of dismissal.

442. Notice lis pendens.
\$443. P'roperty drawn incidentally in question.

44. Attachment.

445. Formal requisites of attachuents.

$\S 439$. Doctrine of Lis Pendens. It is a rule in equity, long established and acted on, that a purchase of property actually in litigation, or, as the technical phrase runs, a purchase pendente lite, although for a valuable consideration and without any actual notice, affects the purchaser in the sane manner as if he had such notice, and he will accordingly be bound by the judgment or decree rendered in the snit. "This rule is said to rest," observes Earl, C., " upon the presumption that every man is attentive to what passes in the courts of justice of the State or sovereignty where he resides, and to be founded on public policy; for otherwise alienations and transfers of title made during the pendency of a suit might defeat its whole purpose, and there would be no end to litigation." 1 "A suit in chancery," says Depere, J.," "duly prosecuted in good faith, and followed by a decree, is constructive notice to every person who acquires from a defendant pendente lite, an interest in the subject-matter of the litigation, of the legal and equitable rights of the plaintiff as charged in the bill and established by the decree. This effect of a successful lifigation in subordinating the title of a purchaser pending a litigation,

1 Leitch $r$. Wells, 48 N. Y. 585; Story's Eq. .Jur. § 405; Jackson $v$. Andrews, 7 Wend. 152; Hayden $r$. Bucklin, 9 Paige, 572; Green $r$. Slater, 4 Johns Ch. 38; Hopkins :38. r. MeLaren, 4 Cow. nigt; Miller $r$. Sherry, 2 Wall. (T.S.) 2:? T: Jackson r. Warren, 32 III, 331.

2 Green v. Slayter, 4 Johns. Ch. 3.5. 
to the rights of the plaintiff as established in the suit, is not derived from legislation. It is a doctrine of courts of equity of ancient origin and rests not upon the principles of the court with regard to notice, but on the ground that it is necessary to the administration of justice that the decision of the court in a suit shonld be binding not only on the litigant parties, but also upon those who acquire the title from them during the pendency of the suit. Such a purchaser need not be made a party, and will be bound by the decree which shall be made." 3

The doctrine of lis pendens applies only where a third person attempts to intrude into a controversy by accuiring an interest in the sibject-matter of the litigation, and the reason of the rule is, that if a transfer of interest pending a snit were to be allowed to affect the proceedings, there would be no end to litigation; for as soon as a new party was brought in, he might transfer to another, and render it necessary to bring that other before the court, so that a suit might be interminable. ${ }^{4}$ It will be muterstood, however, that the rule, that a party purehasing pendente lite is to be regarded as a purehaser with notice, subject to all the equities of the person under whom he elaims, and bund by the decree that may be rendered against the person from whom he derives title, applies only to cases in which such purchaser derives title from one of the parties litigant. If he claims adversely to both parties by title paramount, the proceelings to which he is neither party nor privy can not bind him. ${ }^{5}$

\$ 440. Requisites of Lis Pendens. In applying the doctrine of lis pendens three facts are always necessary for its maintenance. The property involved must be of such a character as to be sulject to the rule; the court must have jurisdiction, both of the parties and the subject-matter of the suit,

3 Haughwout r. Murphy, 7 C. E. Green (N. J.), 531 ; 2 Story's Eq. Jur., § 908; Murry r. Lyburn, 2 Johns. Ch. 444; Dickson r. Todd, 43 Ill. 405; Alwood $r$. Mansfield, 59 Ill. 496 .
4 Murry v. Lyburn, 2 .Johns. Ch. 444.

5 Allen $v$. Morris, 34 N. J. L. 159 ; Searlett $v$ Gorham. 28 IIl. 319; Herrington $v$. Herrington, 27 Mo. 560: Parsons $v$. Hoyt, 44 Iowa, 154. 
or thing in controwers: and the thing, on property inrolved, must be sufficiently described. ${ }^{6}$ That is, the property must be so pointed out in the proceedings as to warn the public that they intermeddle at their peril; and anyone roading the bill must be able to learn thereby what property is intended to be made the subject of the iitigation. ${ }^{\top}$

$\S 441$. Eifect of Dismissal. Where a suit at law is dismissed, or the plaintiff suffers a non-suit, or, if in chancery, the bill is dismissed for want of prosecntion, or for any other eause not reaching the merits, although in all such cases a new action can be bronght, snch action will not, it scens, affect a purchaser during the pendency of the first suit; and where at suit is dismissed and afterward reinstated, the doctrine of $l$ is pendens is not applicable to one who purchases after the dismissal and before the revival of the suit.s

$\$ 442$. Notice of his Pendens. This common law rule of requiring purchasers, at their peril, to take notice of the pendency of suits in courts of justice for the recovery of the property they are about to purchase, although it is rally inpossible that they should actually know that such suits have been commenced, has always been considered a hard rile, and is by no means a farorite with the courts. ${ }^{9}$ It has always been considered a very harsh rule in its application to bona fide purchasers for value, and has onl 5 been tolerated by learned judges from a supposed necessity.

In the absence of statutory provisions to the contrary, the bill or complaint is itself a sufficient notice to the world, so as to defeat the transfer of property ly the defendant, marle subsequent to its filing; ${ }^{10}$ but in a large mumber of the States, particularly where the X. I. code has been followed, a material

(; Norris $r$. Hle, 152 Ill. 190: Leavell $v$. Poore. $91 \mathrm{Kr}$. 322l.

7 Miller $r$. Sherry, 2 Wall ( C.S.) 237; Badger $r$. Daniel, 77 N. C. 251; Brown $r$. Guodwin. $75 \mathrm{~N}$. Y. 409.

s Herrington $r$. McCollum, $73 \mathrm{Ill}$
9 Hayden $r$. Bucklin, 9 Paigt, 572.

1" Parkin-on $r$. Trenstale. 3 Scam (111.) 367; Vanyant r. Vanzant. 23 Ill. 536; Davis r. Life Ine. Co., 84 111. 508.

476. 
change has been made in this rigorous rule, which provides that the pendency of a snit shall not be notice to a stranger until a notice of lis pendens has been filed in the office of the recorder of deeds, or clerk's office, of the county where the land is situated, and that as to one having no actnal notice, he mas, in good faith, and for a valuable consideration, acquire a valid title until such notice is filed. ${ }^{11}$ The lis pendens in this ease would take effect as constructive notice in the same manner as attachments.

Where the suit is pending, and before the bill or complaint has been filed, the notice lis pendens will best be shown by way of appendix, the same as attachments, but, where the abstract gires a synopsis of the proceediugs then had, its orderly arrangement would be to precede the symopsis. After decree it appear's only as an unimportant incident and is merely alluded to in making the chain. The form and substance of the notice, as well as the validity and effect of same, are matters of local practice and construction, but the following will serve as an example in abstracting:

\section{Circuit Court for Kenosha County.}

$\left.\begin{array}{c}\text { John Doe } \\ \text { agst. } \\ \text { Richard Roe. }\end{array}\right\} \begin{aligned} & \text { Totice Lis Pendens. } \\ & \text { Dated March 1, 1SS.3. } \\ & \text { Recorded Harch 2, 18S3. } \\ & \text { Tol. 25, page 500. }\end{aligned}$

Recites that an action entitled as above, has been commenced in the above named court, and is now pending therein, on complaint of above named plaintiff ayainst above named defendant, for [here set out the object of the action as stated; as, "the foreclosure of a mortgage, dated June 10, 1SSO. executed by said Richard Roe to said John Doe, and recorded in volume 10, page S5, and conveying the following described lands, to wit:" here set out the description as stated].

11 see N. Y. Code, $\S 132$. This section has been very generally re- enacted in all States having a code practice. 
The practical purpose of a notice of pendency of suit is to restrain strangers from acquiring interests in the subject-matter of the litigation during the progress of the suit. It is practically without effect as to persons whose rights existed prior to the filing, nor does it protect the plaintiff in the suit against pro-existing equities. ${ }^{12}$

\section{$\$ 4+3$. Property Drawn Incilentaly in question.} Where the rule of lis pendens in its original form is still retained, the authorities are generally unanimons in declaring it to apply only, first, where the litigation is about some specific thing which must be necessarily affected by the termination of the snit; and, secondly, where the specific property is pointed out by the proceedings in such a manner as to warn the whole world that they nextlle with it at their own peril. ${ }^{3}$

Under the application of these principles, it has been held by an almost invariable miformity in the decisions on the subject, that the rule does not apply to proceerlings in suits which are in personam. ${ }^{14}$ But the principle inolved nuar be inroked in those suits which, while in form in personam are, in fact, suits in rem. Thus, the question arises frequently in suits for dironce in which the wife seeks to have a certain sulwistence secured to her out of the estate of hor husband, and while the general prayer is not sufficient to subject the property of the husband to the application of the rule, it yet soms that where specific property is incrilentally drawn in question, either by recitals of the bill ar orders of the court, such a tis pendens is created as will bind a purchaser pendente lite. ${ }^{5}$

$\$ 4+$. Attachment. The office of an attachment is simply to secure to a creditor the property which a dolotur has at the time the writ is levied so that it may be seized and sold in

12 Baker $r$. Bartlett, 18 Mont. 446; Warnock $r$. Harlow, 96 Cal. 298; Parks $c$. Jackson, 11 Wend. (N. Y.) 442.

1.3 Freeman on Judg't. 196; Green v. Slayter, 4 .Johns. Ch. 38; Miller r. Sherre, 2 Wall. (C'. S.) 237; Norris r. He, 152 111. 100.

141 Story Eq. Jr.. \$ 19f, Nmond $r$. Almond, 4 Rathd. biti2; Brightman

r. Brightman, I R. I. 11 !.

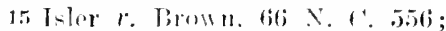

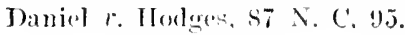


satisfaction of the debt, after judgment and cxeention shall have been obtained. ${ }^{16}$ It ereates no estate in faror of the person at whose instance the writ issued, ${ }^{17}$ and does not ehange or alter the estate of the defendant debtor. ${ }^{18}$ It places no impediment on the power of alienation, ${ }^{19}$ nor will it affect prior bona fide liens that may have been plaeed upon the land." ate, however, a lien, which nothing but the dissolution of the attachment can destroy, ${ }^{21}$ and every person into whrse hands the property mas subsequently come, takes it charged with this lien, and subject to all the rights of the attaching creditor to have the property seized and sold on execution for the satisfaction of his debt. ${ }^{22}$ An attachment can operate only upon the right of the debtor existing at the time the wit was levied and no interest subsequently aequired by the debtor can in any manner be affeeted by the return thereof, prorided he was without title at the time the attachment was made. ${ }^{23}$ Being in derogation of the common law, an attachment is dependent entirely upon the statute for its ralidity and effect, and must conform to statutory requirements in all essential particulars. ${ }^{24}$

\section{$\$$ 44. Formal Requisites of Attachment. Though} the remedy by attachment is purely statutory, and while there exists in many partioulars a wide dissimilarity between the attachment acts of the sereral States, there is ret a marked uniformity in the general steps that must be pursued to render it available, and its effect in all the States is nearly identical. The suit is instituted by the filing of a statutory affidavit, whereupon a writ is issued. This is followed by a lery, which,

1 G Crocker $l$. Pierce, 31 Me. 17.

17 Goddard $r$. Perkins, 9 N. H. 485; Foulks $r$. Pegg. 6 Ner. 136.

1 s Digelow $v$. Wilson, 1 Pick. 485; Blake $r$. Shaw, 7 Mass. 50J; Merrick $r$. Hutt, 15 Ark. 331.

19 Warner $r$. Everett, 7 B. Mon. (Kr.) 262.

20 Husbands $r$. Jones, 9 Bush (Ky.) 218.
21 Smith $r$. Bralstreet, 16 Pick. 264: Hamnahs $r$. Felt, 15 Iowa, 141.

22 Randolpin $r$. Carlton, 8 Ala. 606 .

23 Crocker r. Pierce, 31 Me. 177. 24 Mary $r$. Baker, 15 Ill. S9; Haywood $r$. Collins. 60 Ill. 328. 
in the case of land, must, of necussity, be a paper lery. The lery is initiated by an endorsenent of the fact mon the writ, and perfected by the return thereof, while notice is afforded by the filing of a cortificate of lery with the recorder of deeds. Until such certificate has been filed the attachment does not become effective as to third perons without notice. ${ }^{25}$

In preparing the abstract the certificate of levy would probably be all that is required to furnish a notice lis pendens, but in practice it is customary also to show a brief synopsis of the conrt proceedings, and this is the better method, as counsel not infrequently desires same as a reference or index, as well as to see that the formal steps have been properly taken. Neither in this, nor in other cases where court procedings are shown, is it enstomary to give more than brief references, or statements of steps taken, and where greater detail is desired it is obtained ly a transcript of the record and papers, or by personal inspection of the files. An abstract entry of an attachment showing the court proceedings and sheriff's certificate of lery is appended and will illustrate the method just described:

\section{Licns and Lis Pendens. ${ }^{26}$}

\section{In Superior Count of Cook County, Ills.}

$\left.\begin{array}{c}\text { William R. Smith } \\ \text { vs. } \\ \text { John Sarage. , }\end{array}\right\} \begin{aligned} & \text { C'ase No. SO,92S. } \\ & \text { Utachment. } \\ & \text { Affidarit and bond fited, and writ } \\ & \text { issued Way } 23,1881 .\end{aligned}$

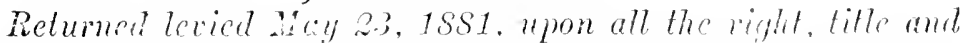
interest of above-named defendant in and to the followim! described real sotale, to wit: [ITere set ont the pownty as returned.]

No personal service. Notice by pubtication. (C'anse pemting.)

25 firoves $r$. Whiber, 72 111. 606. 26 This is the sub-head under which matters of the kind mow under conederation sombl be shown. 
$\left.\begin{array}{c}\text { John Salage } \\ \text { William } R . \text { Smith. }\end{array}\right\} \begin{aligned} & \text { Certificate of levy. } \\ & \text { liecorded May } 26,1881 . \\ & \text { Book 500, page } 210 .\end{aligned}$

O. L. Mann, Sheriff of C'ook County, Ill. (by Deputy), cer-

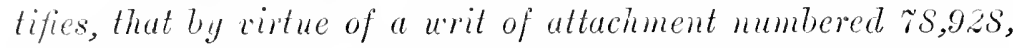
to him directed from the Superior C'ourt of Cook C'ounty, Ill., in favor of William R. Smith, plaintiff, and against John satage, defendant, dated May $2.3,1881$, he did on "this" 3.3d day of May, 18\$1, levy on the right, title and interest of said defendant in and to the following described real estate, to wit: [Here follows the description.]

Where the action is duly prosecuted and is followed by judguent, recution and sale, the attachment may be indicated only by references to the issue, levy and return of the writ, and filing of certiticate, the validity of the sale depending upon the judgment and execution; but where, as in the above example, no persomal service has been had, and the notice is constructive merely, the notice, proof of publication, and other acts necesiney to confer jurisdiction must appear. The only oliget of the entries as above is to show the fact of a lien. Where the attaciment has been dissolved or the action discontinued, a continuation of the abstract should disclose those facts so as to show the remoral of the lien. 


\section{CHAPTER XETT.}

JUDGMENTS AND DECREES.

$\S 446$. Defined and distinguished.

447. Operation and effect of judgments.

448. Lien of judgments.

449. Territorial extent of lien.

450. Duration of lien.

451. Priority.

452. After-acquired property.

453. Docketing.

454. Formal requisites of judgments.

455. Antecedent proceedings.

456. Judgments against a deceased person.

457. Judgments against infants.

455. Exemptions.

459. Satisfaction and discharge.
$\S 460$. Decrees, elassified and distinguished.

461. Operation and effeet of derrees.

462. Decrees rendered on eonstructive notice.

463. Lien of decrees.

464. Formal requisites of deerees.

465. Abstract of deerees.

466. Errors and defects.

467. Continued - Middle name.

46s. Continued - Initials.

469. Operation and effeet of probate deerees.

470. Foreign judgments and deerees.

\section{$\S 446$. Judgments and Decrees - Defined and Distin-}

guished. Any distinction between judgments and decrees is rather fanciful than real, since all adjudications by a court of competent jurisdiction are essentially judgments, get in practice the term "decree" is used to distinguish the determinations and orders of a court of equity, while the term judgment is generally employed to denote the adjudications of a law tribunal. Judgments are usually for damages, and provide for a definite recovery in money; decres contemplate some method of affirmative relief or operate in some specific way in answer to the prayer of the complaint.

In examinations of title, judgments in personam are important only as they serve to incumber the land of the jurlgment debtor with a statutory lien, and when the lien has been extinguished, either by lanse of time or satisfaction of the 
judgment, they become of no importance whaterer and are wholly disregarded. Decrees, on the other hand, operating directly upon the land, are of controlling and continuing efficacy. They become a part of the general course of title, and through whatever mutations it may afterwards pass they always remain essential links of the chain. ${ }^{1}$

$\$ 447$. Operation and Effect of Judgments. It is a general rule, that a judgment by a court having jurisdiction over the parties and the sulject-matter, rendered directly upon the point in question, is conclusive as between such parties and in relation to such point, ${ }^{2}$ and there is no essential difference between the effect of a decree in equity, and that of a judgment at law to bar a subsequent suit. ${ }^{3}$ But such adjudication is conclusive only for the purposes for which it was made, and does not conclude matters collaterally introduced or recited. ${ }^{4}$

It is, however, in regard to their effect on the lands of the judgment debtor, by reason of the lien given by the statute, that they become at all important in examinations of title; and in pursuing such examinations whaterer other operation or effect they may have is comparatively of no significance. This, of course, has reference only to judgments in personam, and not to judgments in legal actions which operate in rem. ${ }^{5}$

$\S 448$. Lien of Judgments. Judgment liens on real es-

1 The Codes of Procedure, adopted in many of the States, do not recog. nize the distinction made in the above paragraph. Under these coles all final determinaíuns of the rights of the parties in the action are classed as judgments, without reference to the subject-matter, or the character of the relief granted. In these codes the word " lecree" is not used, but the term "judgment" is substituted in its place, as regards actions both of an equitable and a legal nature. In practice, however, both by the bench and bar, the term is used and in the scuse above indicated.

2 Geary $v$. Simmons, 39 Cal. 224; Spencer $r$. Deanth, 13 Vt. 9s: Gates $r$. Preston. 41 X. Y. 113; Finney $v$. Boyll, $26 \mathrm{Wis} .360$; Russell r. Place, 94 C. S. 606.

a Foster $r$. The Richard Busteed, 100 Mass. 409.

4 Fish $r$. Lightner, 44 Mo. 268; Land $r$. Fieirn, 52 Miss. 341 ; Eastman $r$. Porter. 14 Wis. 39.

5 As julgments in ejectment, which. while they may purport to confer only the right of nossession are yet anciusive as to title. 
tate are wholly statutory. The lien attaches and becomes effertive only ly force of the statute, and only in the mode, at the time, and upon the conditions and limitations imposed by it. It receives no vigor or even ait from the common law, to which it was unknown. At common law, the judgment creditor conld have satisfaction only ont of the goods and chattels and present profits of the lands of the debtor, but under the statnte it is the pulicy of the law to make all of a man's property, real as well as personal, liable for the parment of his debts, both during his life and after his deatl, exeept in cases of specified statutory exemptions: and a converance of land by a judgment debtor, for a valuable consideration, after a judgment has become a lien theren, and pending an appeal, will not defeat the lien of the judgment. In such ease the grantee takes title subject to the lien, and a sale and deed made on excution under such judgment will pass title, unaffected by the converance."

Where the abstract shows a judgment duly rendered against any of the parties in interest from which an appeal has been taken, notwithstanding that a bond has been given, such judgment should be noted as a defeet of title. The appeal does not racate the judgnent nor destror its lien. Its only effect is to operate as a stay of proceding for enforcement during the pendency of the appeal, ${ }^{\top}$ and in case the judgment is affirmed it has practically the same force and effect as though no appeal had been taken. ${ }^{8}$

In general, personal property must first be taken upon legal process, and it is a miversal rule that this is the primary fund for payment of debts, after the deatin of the debtor."

A judgment lien on land constitutes no property in the land itself, ${ }^{10}$ for the lien is but an inedelent, not the ofigect of the judgment, and the jurlgment creditor is not entitled to any advantage which his delotor had not. ${ }^{11}$ Snch iirn is subject

6 Dobhins $r$ Wil-en. 107 111. 17.

7 Oakes $r$. Willioms, 107 111. 154.

8 Walker $r$. Dnanc, 108 111. $2: 06$.

9 Mitrhell $r$. Wood, 47 Mis. 231 :

Whitney $r$. Whitney. 14 Man. 58.
11. School Di-t. $x$. Werner, 4:; Iowa, 643: Conrad r. Ins. Co., l Pet. 3.8.

11 liped't Appual, 13 lemm. St. 475. 
to all equities which existed against the land, in favor of third persons, at the time of the recovery of the judgment, and with a failure or extinguishment of the debtor's title the lien entirely ceases and is lost. ${ }^{2}$

The statute usually provides that the judgment shall be a lien on the "real estate" or "lands and tenements" of the debtor for a specified period, but is sometimes coupled with conditions relative to the issuance of execution, etc., the observance of which is necessary to perfect the lien. The terms "real estate" or "lands and tenements," as used in this connection, are of very broad signification, and have been held to include remainders and reversions rested under legal titles, as well as legal estates in possession, ${ }^{13}$ but do not embrace mere equities ${ }^{14}$ or inchoate rights; nor does a judgment against a firm create a lien upon the individual property of the partners, ${ }^{15}$ although if they are all made defendants they will all be severally liable, and all the incidents of a judgment will attach to their several estates. ${ }^{16}$

$\$ 449$. Territorial Extent of Lien. The lien of a judgment rendered by a State court attaches only to the land of the debtor sitnate within the county for which the court is held, or in which a transcript has been regularly docketed, and a certificate covering only the county courts of record is all that is necessary to fully apprise intending purchasers of the condition of the title so far as same may be affected by the adjudications of the State courts. ${ }^{17}$

12 Hydraulic Co $r$. Loughry. 72 Ind. 56:; McBane $v$. Wilson, 12 Reporter. 325; Frazer r. Thatcher, 49 Tex. 26. A judgment recovered against a person after he is adjudged bankrupt, will not be lien upon the lauds of the hankrupt: Burgett r. Paxtor, 99 Ill. 28s.

13 Lawrence $r$. Belger, 31 Ohio St. 175: Ducker $r$. Burnham, $146 \mathrm{Ill}$. 9.

$1+$ Dixon $r$, Dixon. 81 \%. C. 323 ;
Powell $v$. Knox, 16 Ala. 364. This doctrine, however, is not universal, and though the prevailing one yet in several of the States it is denied: see Lathrop $r$. Brown, 23 Iowa, 40; Jackson $r$. Williams, 10 Ohio. 69; Wallace $r$. Nonroe, 22 11l. App. 602 .

15 Stadler r. Allen. 44 Iowa, 198. 16 Starry $r$. Johnson, 32 Ind. 438. 17 Taker $r$. Chandler. 5l Ind. S5. The lien of a judgment of the Su- 
It was long held that judgments rendered in the Federal courts lave the same lien on the lands of the debtor within the district that is given to the judgments of the State courts within the limits of their respective territorial jurisdictions, ${ }^{1 \mathrm{~s}}$ and therefore, in the compilation of abstracts it was quite as essential that the Federal courts of the district should be covered by the search, as the county conits. But this rule has been greatly modified of late years. In the year 1888 by an act of Congress it was provider that judgments of Federal courts shall be liens "to the same extent and under the same conditions only as if such judgments and decrees had been rendered by a court of general jurisdiction of such State," and this act, it is contended, places judgments of the Federal courts on the same basis as judgments of the State courts with respect to their effect as liens. Accordingly it has been held that where a State statute restricts the territorial lien of a judgment to the county in which it was rendered, and to counties in which a transcript is filed, such statute, since the passage of the law of $18 s 8$, prevents the lien of a Federal judgment from becoming operative throughout the entire district and subjects it to the restrictions of the State law. ${ }^{19}$

A judgment, whether of State or Federal courts, is not a specific lien upon any particular land of the judgment debtor, but extends generally upon all his proprietary holdings, subject to prior liens, legal or equitable. ${ }^{20}$

preme Court is co-extensive with the territorial linits of the State: Durham $v$. Heaton, 28 11l. 264.

$1 \mathrm{~s}$ Sellers $r$. Corwin, 5 Ohio, 398 ; Shrew $r$. Jones, 2 McLean, 78 ; Massingill $r$. Downs, 7 How. 760 ; Brown $r$. Pierce, $\rightarrow$ Wall, 205; Branch $r$. Lowrey, 31 Tex. 96.

19 See, Blair $x$. O-trancler, 109 Iowa, 204; 47 L. R. A. 469. The constitutional power of ('ongress to make a judgment of a Federal court a lien on the debtor's property, and fix the duration and territorial ex- tent of the lien, is declared in Dart mouth Sav. Bank r. Bates, 44 Fed. Rep. 546, and other cases sustain the doctrine. But it liats alway's been the policy of Congress to conform such liens, ats well as the processes of the Federal courts, to those of the State comrts.

2" Rodgers $r$. Punner, $45 \mathrm{~N}$. Y. 379. Judgment lions being purely legal, shonle they fail at law, can not he extemded in eopuity: Donglasa $r$. llouston, 6 Hammond (Ohio), 162. 
$\$ 450$. Duration of hien. The lien of judgments upon real estate is regulated by statute, and the general rule is, that the lien continu's for ten years ${ }^{21}$ from the rendition of the judgnent, and no longer, except that in a few enumerated (ases where a party is restrained from enforcing his judgment by appcal, injunction, ete, the time so consumed is exchuled from the computation. I purchaser from a judgment defendant, after the expiration of ten years from the rendition of the judgment, or such other period of limitation as the statute may prescribe, takes the land discharged from the lien of same, unless it has been preserved by some of the exceptions whitained in the statute. ${ }^{22}$ Ordinarily a search for judgments covering a period of ten years is sufficient, and it is not customary for the examiner to certify judgments for a longer time. Unless specially excepted, neither injunction, appeal, nor other eause will hare the effect to prolong the lien beyond the statutory periorl, as against a purchaser from the jurgment debtor. ${ }^{23}$

There is some uncertainty with respect to the territorial extent of judgments rendered in the [nited States courts. Prior to the act of 1888 it was the invariable rule that a judgment rendered in the Federal courts has the same lien on the lands of the debtor within the district that is given to a judgment

21 In some States for a shorter period. Thus, in Illinois for only seven years.

22 Applegate 1 . Flwards, 4.j Ind. 329 ; Gridley $r$. Wation, 53 Ill. 186. The limitation periol in some States is less than ten years: thrs, in lllinois. the time is soven years. In nost instances, howerer. the period is fixed at ten years, as stated in ine text.

23 Tucker $*$ Shade, 25 Ohio St. $\therefore$.) The lien of a judgment is a "inibied right, given by law, and …다. lie taken away by law: Inonston r. Foncton, 67 Ind. 276 , an! when the law is repealed unon
Which the lien depends, the lien is destroped by the repeal: Ray $u$. Thompson, 43 Ala. 434. A familiar form of statutory expression is, that the judgment shall cease to be a lien or incumbrance on any real estate, as amainst purchasers in good faikh, subsequent incumbraneers, etc., lnt within the meaning of such an act, all purchasers are to be con-idered as purchasers in good faith, cxcent those who purchase with an ccunl frawlulent intent, and mere nuike of tha prior jutgment, either scual or ronstructive, will not render the purchase mala fide: Little r. IIarey, 9 Wend. 157. 
of a State conrt within the limits of its territorial juristiction $;^{2 \frac{1}{2}}$ but, however this may be, there is no meertainty with respect to its termination for it is provided that "judgments and decrees rendered in a Enited States cirenit or district court, within any State, shall ecuse to be liens on real estate or chattels real, in the same manner and at like periods as judgments and decrees of the comts of such State cease, by law, to be liens thereon." 25

\$ 151. Priority. It has been held, that neither judgment creditors nor purchasers at sherift's sale, deriving rights by operation of law, are regarded as purchasers for a valuable consideration, but as mere volnntecrs in contemplation of a comrt of equity, and that the general lien of a judgment creditor upon the lands of his debtor is subject to all equities which existed against such lands, in faror of third persons, at the time of the recovery of the judgment. $2 \tau$ Generally this is true, yet, mder the statute, as it exists in a majority of the States, the lien of a docketed judgment, lawfully obtained at the suit of any party asuinst the person in whose name the title to such land appears of record, will have priority over an unrecorded mortgage, or deel. ${ }^{2 s}$ These statutes protect judgment creditors as bona fide purchasers for a valuable consideration whose liens arise while the record title appears in the judgment debtor, although in fact he may have conveyed the property.

As between judgment ereditors there is no general rule respecting priority, the matter heing usually regulated by statute. Judgments rendered at lhe same term of comt, or on the same day in vacation, or linarily lave no priority over each other, but this is lyy no means a miform observance, and it has been

24 Scllers $\%$. Corwin, 5 OHio, 398 ;

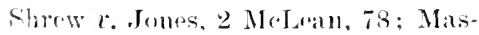
sircill r. Downe, 7 How. 7 (60).

25 IT. S. Ler. Stat., \$ 967 ; see Meyers r. Tyon, 1:3 Batchf. 2.12.

sis Davis $v$. Hamilton, 50 Miss. 312.
27 Hydraulir Co, v. Loughry, 72 Ind. 56:; Apperson r. Burgutt, 33 Ark. 328.

2s Jash $r$. Ilardick, 5 Dillon, 505: Wood r. Young, 38 fown, 102: Miss. Valley ('o. r. R. R. C'o., 58 Miss. 846 ; Cinitean $r$. Wisely, 47 III. 433. 
held, that when several judgments are rendered at the same term of court, but on different days, such judgments do not relate to the first day of the term and become effective as of that date, but are liens on the real estate of the judgment debtor only from the dates at which they are respectively entered or docketed, and take priority accordingly. ${ }^{29}$ As a rule the law does not regard fractions of a day and all acts done upon the same day are to be taken as done at the same time. Yet, where it is necessary to justice, and can be done, this rule will be made to yield to the exigencies of the particular case. Thus, where the hour itself may become material; as where a lien attaches upon the doing of an act, or in behalf of the party who asserts it or seeks to fasten same on property, the fraction of a lay may be considered in detemining a question of priority. In the matter of apparently concurrent judgments this latter doctrine has frequently been applied and the preference given to the one first entered. ${ }^{30}$ As before remarked, however, the application of this doctrine is largely a matter of statutory direction and construction.

When lands are incumbered simultaneous with their acquisition, the incumbrance being to secure the unpaid purchase money, the authorities are uniform in declaring that such incumbrance will take priority over the lien of a judgment already docketed. "The reason for this is readily found," observes Freeman, "when we remember that it is a universally recognized principle of law that no judgment lien can be a charge upon any greater interest than the defendant owns. A purchaser who has paid only a portion of the sum contracted to be paid, has no title which is not liable to be subjected to the lien of the vendor for unpaid purchase money. A judgment against such a vendee must, therefore, be subordinate as a lien to that held by the vendor; and for this purpose, it is perfectly immaterial whether the claim is put in the shape

29 Anderson $r$. Tuck, 33 Md. 225.

30 Mitchell $v$. Schoonover, 16 Oreg. 211; Coal Co. $v$. Barber, 47 Kan. 29; Lang $v$. Phillips, 27 Ala.
311 ; Murfree $v$. Carmack, 4 Yerg. (Tenn.) 270 .

31 Curtis v. Root, 20 Ill. 53; Roane $v$. Baker, 120 Ill. 308. 
of a vendor's lien, or of a mortgage to secure the parment of purehase money." 32

$\$ 45 \%$. After-acquired Property. It is a well established doctrine, that the lien of a judgment attaches to and binds land, the title to which is subsequently acquired by the judgment debtor, and, where the statute is silent on the subject, this rule has been generally received and acted upon throughout the United States. ${ }^{33}$ The lien does not take effeet by relation as of the date of the judgment, but attaches to such after-aequired property only from the time it is aequired by the judgment debtor, and the liens of all judgments in existence when the debtor obtains the property attach alike. ${ }^{34}$

$\S 453$. Docketing. The general rule seems to be, that before a judgment can become a lien it nust be regularly docketed. That is, be entered of record in such books as the statute requires to be kept. This, it is said, is the only proof of a judgment and hence essential to its validitr. ${ }^{35}$ In some instances it has even been held that the reeord is not eomplete until an entry has been made in the index, ${ }^{36}$ and that an omission in this particular is fatal to the lien. On the other hand, some of the cases hold that docketing is not an essential of the efficacy of a judgment nor a condition precedent to issuing execution thereon, but is a nernasy condition for the purposes of a lien. ${ }^{3 i}$ Others have gome so far as to declare that the lien of a judgment is not lost by the failure of a clerk to enter the rendition in the docket, althongh the land affected by such judgment lien may have passed into the hands of a bona fide holder withont notice. ${ }^{38}$

32 See contra, Ryner $r$. Frank, 105 Ill. 326. 560.

33 Thulemeyer $v$. Jones, 37 Tex.

34 Coyce $v$. Stovall, 50 Miss. 396 ;

Babcock $v$. Jones, 15 Kan. 296;

Wales $v$. Bogue, 31 I11. 464.

35 Callanan $r$. Votruba, 104 Iowa, 672; Davis $v$. Steeps, 97 Wis. 472 ;

Rockwood $v$. Davenport, 37 Minn.
533. But see, Durant $v$. Comegrs,

2 Idaho, so9.

36 . Etna Ins. Co. r. Insser, 77 Iowa, 381; Crouse 2 . Murphy, 140 P'ir. St. 33.j.

:7 Bernhardt r. I3rown, 122 X. C. 587 .

38. Johnson $i$, Schloesser, 146 Ind. 509. 
It will be seen, therefore, that the authorities are not in accord upon this subject, and that local law and usage is the only safe guide.

$\S 154$. Formal Requisites of Jugments. No set form of words is necessary to be employed in reudering judgments, ${ }^{39}$ provided they are certain and find the sum for which they are rendered, but failing in this, they are fatally defective. ${ }^{40}$ The certainty required has reference both to the parties and the recovery, for the judgment is regarded as a mit and nust comprehend all the parties then before the court, while the recovery must be eertain and specific in the anount with nothing left to implication; thus a judgment for " four hundred and sixty-one and 53-100 damages" is not for a certain definite sum of money, and is therefore a mullity, ${ }^{41}$ and where only numerals are nsed without some mark or word indicating for what they stand, the judgment is insufficient. ${ }^{42}$ Otherwise, to constitute a judgment record valid upon its face so that it may he enforced by action, nothing more need appear by it than that the court had jurisdiction of the subject-matter of the action and of the parties, and that a judgment was in fact rendered. ${ }^{43}$ It is customary, as well as proper, in making the entry, to set out the names of the parties against whom the judgment is rendered, but it seems that a judgment against "said defendants," the title of the cause being stated, is suffi-

39 Guild v. Hall, 91 Ill. 223; Church v. Crossman, 41 Iowa, 373. $40 \mathrm{Ry}$. Co. $v$. Chicago, 53 Ill. 80 ; Carpenter $v$. Sherfy, 71 Ill. 427 ; Lirette $v$. Carrane, 27 La. Ann. 298: Randolph $v$. Metcali, 6 Coldw. (Tenm.) 400.

41 Carpenter $v$. Sherfy, 71 Ill. 427.

42 Lawrence $v$. Fast, 20 I1l. 338; Avery $r$. Babcock, 35 Ill. 175.

4. Maxwell $v$. Stewart, 22 Wall. ment is not rendered, so as to be a lien from the time of its " rendition," until it has been entered upon the record, notwithstanding an entry or direction for entry has been signed by the judge and endorsed by the clerk as "filed." Callanan v. Vatruba, 104 lowa, 672; Rockwood $v$. Davenport, 3 ? Minn. 533. But see, Durant $v$. Comegys, 2 Idaho, 809; Johnson $x$. Schloesser, 146 Ind. 509 .

77. It has been held that a judg. 
cient. ${ }^{44}$ And, generally, an obecure judgment entry may be constrned with reference to the pleadings and reeord. ${ }^{45}$

In the abstract it is the general practice to give the name of the formm, together with the case number or some other inclex for the purpose of reference; the full title of the ease, and a statement of the faret of judgment, together with the amomt for which it was rendered. A srnopsis of the judgment is rarely giren, nor is it at all necessary, yet the examiner should always carefully rear the judgment roll for errors of form or substance; as the omission of partics, imperfect recitals of recorery, ete. Where the judgment becomes dormant unless followed by execution it becomes necessary to show the issuance and return of the execution, provided such facts appear of record. I minute of judgments in personam may be made in this manner:

\section{Judgments.}

In the Superior Court of Cook County, Ill.

$\left.\begin{array}{c}\text { Henry W. Newman } \\ \text { vs. } \\ \text { William. Jasper. }\end{array}\right\} \begin{aligned} & \text { Case No. 53,166. } \\ & \text { Assumpsit. } \\ & \text { Fee Booli } 85, \text { page } 585 . \\ & \text { Judgment rendered against de- } \\ & \text { fendant, Dec. } 9,18 \% 4, \text { for } \$ 634 .- \\ & 9 \Omega .\end{aligned}$

Execution No. 2:,993 issued, dated Dec. 9, 18\%4, returned no part satisfied.

Any arditional matter that may seem material, as, the issuance of alias or pluries executions; reniscion or satisfaction of any part of the judgment, etce, ming be shown after this point, with such detail as may be necessary, thus:

44 Bank of Athens $v$. Garland, 109 Mich. 515.

45 Sce, Fowler $v$. Doyle, 16 Iowa,
534 ; MeCartrey $r$. Kittrell, 55 Miss. 2.53; Smith $r$. Chenault, 48 Tex. 455. 
Dec. 18. 18\%4, Plaintiff remits \$103.61.

Dec. 20, 18\%4, Execution (alias) issucd and returned satisfied for $\$ 100.00$.

Where the lien of the judgment is independent of execution the note of the issuance of same is immaterial, except as it may tend to show a reduction or partial satisfaction; but, in many of the States, when execution is not issued on a judgment within one rear from the time of its rendition, the lien thereafter ceases and is lost. ${ }^{46}$ Executions may also become operative as liens from the time they are delivered to the sheriff, or other proper officer, to be executed, when issned during the statutory period, even though the general lien of the judgment has been lost by laches. ${ }^{4}$ Wherever the rule last stated prevails the issnance of execution becomes almost as important as the rendition of the judgment, and in abstracting the judgment, careful search must also be made for executions, and should none appear of record it would seem that such fact slould be affirmatively stated rather than left to inference. There can be no donbt that this conrse wonld frequently sare inquiries by comsel and greatly expedite his labors. In continuations, where the former examination shows a judgunent upon which no execution appears to have issued prior to the date of such examination, the subsequent steps, if any, should appear in the continuation, either by re-exhibiting the judgment and resulting proceedings, or by setting forth the substance of such proceedings in a note. ${ }^{48}$

$\$$ 45. Antecedent Proceedings. It is not customary, in abstracting a judgment, to show anything more than the mere fact of rendition in the manner heretofore indicated. But in making the search the entire judgment roll shonld be perused by the examiner for possible defects. While the law implies a presumption of regularity, and of all jurisdictional

\footnotetext{
289.

46, See, Kirby $r$. Runals, $140 \mathrm{Ill}$.

47 These provisions, howerer, have

reference more to personalty than to realty.

to See also, "Satisfaction and Discharge," infra.
} 
facts in cases where the record is silent, ${ }^{49}$ yet where the record states what was done this presumption does not apple." Thus, it will be presumed, in the alsence of anything to the contrary, that a personal service of process was had upon the dofendant. But if the record shows something different, as that the service was by publication, the legal presumption cannot be permitted to aid the record. I familiar example is furnished in the case of a deficieney judgment on forechosure. If the record aftirmatively discloses that the service was hy publication, particularly if the defendant was a non-resident of the State, such a judgment would be roid and no lien wonld be created. ${ }^{51}$

Again, a personal judgment must as a rule, be preceded by a personal service of summons to appear and answer the plaintiff's demand. It will often happen, howerer, that the defendant was not served with procens, but voluntarily appeared in the ease by attorney. It is always presumed in favor of a judgment based on the appearance of an attomer, that the attorney was duly anthorized for such purpose, eren where there is an appearance without service, ${ }^{52}$ and in a collateral proceeding this presumption is conclusive. ${ }^{53}$ If the attorney was without authority the judgment will be set asile on motion or may be enjoined in equitr, but, until some move of this kind is made, the courts, from reasons of public policy, will hold the appearance goorl and the proceedings valirl. Still, it would seem to be the better plan, where a judgment is rendered without service and on appearance of attorney only, to show these facts in the abstract.

$\$ 456$. Judgment Against a Deceased Person. It is a rule of the common law, and one generally observed in all

49 Galpin $x$. Page, 18 Wall. (U. S.) 350 .

50 Hahn $v$. Kelly, 34 (al. 391.

51 Latta $v$. Tutton. 122 ('al. 273) and see, Griflith r. Inarvester ('o.. 92 Iowa. 634; Willamette, ete. Co. $\boldsymbol{c}$. Fendrix, 28 Oreg. 485.
52 Arnold $r$. Nye, 23 Mich. 2S6; Ferguen $r$. Crawforl, $70 \mathrm{~N}$. Y. 253.

5:3 Williams $r$. Tohnson, 112 N. C. 424. 
the States, that a judgment against a deceased person is void, and the fact that service may have been obtained, or the suit commenred before the death of the party, in tho absence of any statutory provision on the subject, does not affect the operation of the rule. ${ }^{54}$

It has been held in a large number of cases, however, that where a court has once aequired juriscliction of the parties and the subject-matter of an action, a judgment rendered against a party after lis death is not void, if the death has not been suggested upon the record, hut only roidalble, and this doetrine seems to have been aroptes in a numler of States. It is conceded that the rendition, of such judgment is erroneous, and hence subject to be set asike or vacated on motion timely made. ${ }^{55}$

The subject possesses a further interest for the examiner of titles in arses where a joint judgment has been rendered against several persons, one of whom, at the time of such rendition, is dead. The authorities are not in full aceord as to the effect of such judgment, but the better rule would seem to be that it shoukl be regarded as a mit with respect to all of the defendants and hence void as to all, or, at least, subject to collateral attack. ${ }^{56}$

$\$ 457$. Julgments $\mathrm{gainst}$ Infants. The general status of infants has heretofore been referred to and the dangers attendant upon the state pointed out. It may be said, however, that while the statute nsually provides that infant parties must be represented by guarlian, either general or ad litem,

54 Burke r. Stokely, 6.5 N. C.569; Life Assoe. of America r. Fissett, 102 111. 315; Weis $r$. Aaron, 75 Miss. 138. Where the julgment was recovered prior to defendant's death it may be revived and enforced against his estate by sci fa: Brown $t$. Parker, 15 Ill. 307. While if execution had been issued and leried during the lifetine of such defendant, a sale after his death will be valid without any nutice to his legal representatives on revivor by scire facias.

5.i Sce, Hayes r. Shaw, 20 Minn. 405 ; Yaple r. Titus, 41 Pa. St. 203 ; Jennings $r$. Sinuson, 12 Neb. 565; Coleman $r$. Medmulty, 16 Mo. 177; Ried r. Ilomes, 127 Mass. 326.

56 Claflin $r$. Denne, 129 Ill. 24l; Weis $r$. Aaron, 75 Miss. 128 . 
yet a judgment rendered against an infant for whom no graidian has been appointed is not, for that reason, roid. If he in fact appeared in the action, and an anpearance by attorney will be presumed to have been authorizod, the judgment will be merely voidable at his instance scasonably expressed.57 If he desires to vacate snch julgment he must move for sam promptly on coming of age. An mexeused delay will bar his right. 58

$\S 458$. Cxemptions. The homestearl acts of the different States have created an exception to the general rule which subjects the lands of the debtor to the lien of judgments recovered against him, and an exemption from levy and forced sale is mate of certain lants which shall be oceupied by the debtor as a homestead. This exemption consists either of a specific allotment of land retemined by fixed bountaries, or of an estate of limited duration, measured by a detinite money value and withont reference to the ruantity of land ocempied. The lien of the judgment does not affect such homestead, either in the possession of the judgment dohtor or his grantes. ${ }^{59}$ The only exception to this rule, where any exeeption is pemitted, is where the debt, for which the judgment was rendered, is a liability inemred for the purchase or improvement of the land. ${ }^{60}$

$\S$ 459. Satisfaction and Discharge. Judgments may be discharged by an entry upon the record; by a formal release or satisfaction filed in the case; ${ }^{61}$ or by a return of the execution fully satisfied. The partienlar method employed is of little moment to the examiner and only noticed hy him in case of a continuation, where the former examination shows a subsisting unsatisfied judgment. Even in this instaues it is not absolutely neeessary that it be notieed in the abstract, as his

57 Childs $v$. Lanterman, 103 Cal. 387; Kemp v. Cork, 18 Md. 130; Colm $v$. Baer, 134 Ind. 375.

5s Ri-mmenger $r$. Murphy, 42 Minn. 84.

50 Green v. Marks, 25 111. 221.
60 Bush v. Scott, 70 111. 5et.

61 The satiofartion piece, llough filed, is not a record, but a meres warrint to the rerk to enter satisfaction on the roll: Lowns r. Rem. sen, 7 Wend. (N. Y.) 35. 
certificate to the effect that there are no judgments unsatisfied of record would be sufficient to show the discontinuance of the lien, yet it is recommented as the better practice, that, where the former examination shows unsatisfied judgments, but which subsequent to the date of such examination and prior to that of the continuation have been discharged or satisfied, and which if unsatisfied would still be a lien, such satisfaction or discharge should affirmatively appear. A simple note will in most cases be all that is required, thus:

Note.- In case No. 40,075 in the Superior Court of Cook County (Smith $v$. Jones), judgment was rendered against the defendant, on October 10, 18\%2, for $\$ 250.00$ and costs, which was satisficd of record December 1, 1S\%Q, by plaintiff's attorney.

To this simple statement may be alded the mention of any other matter which may seem material, as:

Execution No. 18,189 issued thereon dated October 11, 1872, is not returned.

\$ 460. Deerees Classified and Distinguished. Decrees are classified as interlocutory and final, the former being one which only partially disposes of the subject-matter, or of a particular portion thereof, learing something still to be done; the latter, disposing of the whole subject, deciding all questions in controversy, ascertaining the rights of all the parties, and awarding the costs. ${ }^{62}$ The fact that something remains to $b$ : done to carry out or enforce the decree does not render it any the less final, ${ }^{63}$ but the true test seems to be, that no further necessity exists for bringing the canse again before the court. ${ }^{6 t}$

62 Taylor $r$. Reed, 4 Paige, 561; Mills $r$. Hoag, 7 Paige, 18 ; Kane $r$. Whittick, 8 Wend. 2:4.

63 To aroid the confusion incilent to the use of the word julgment, in two senses, one as interlocu- tory, and the other as final, the colles designate the former as orders, and do not recomize such a thing as an interlocutory judgment.

64 Mills $v$. Hoag, 7 Paige, 18; 
$\S$ 461. Operation and Efrect of Decrees. I formal decree operates differently from a judgment, but its effect is the same, and the same general rules apply with equal force to either. As res adjudicata it is eonclusive upon the question actually presented or directly involverl, ${ }^{65}$ though not num collateral issnes, ${ }^{66}$ and embraces not only the questions aetually contested and determined, but also all those which night have been if they had been reasonably presented. ${ }^{67}$ It is binding on parties and privies and inports such absolute verity that it ean not be attacked collaterally on aceount of mere irregularities in the proceedings by one not a party in interest, ${ }^{6.5}$ nor ean defects therein be set up br a stranger to the record, for the purpose of defeating a claim of right to land based thereon. ${ }^{69}$ It is evillence of itself to sustain a converance. made under it, ${ }^{70}$ but where it does not in terms direst the title

Butler $r$. Lee, 33 How. 25l. An interlocutory decree is properly a decree pronounced for the purnose of ascertanning matter of law or fact preparatory to a final decree. Therefore, when it happens that some material circumstance or fact necessary to be made known to the court is either not stated in the pleadings, or is so imperiectly ascertained by them that a court is unable to determine finally between the parties; and therefore, a reference to. or an inquiry before a master, or a trial of farts before a jury becomes necessary, the decree entered for that purpose is an interlocutory decree. The court, in the meantime. suspends its final decree. until by the master's report, or verdict of the jury, it is enabled to decide finally: 1 Barb. Ch. Prac. * 326; Seaton on Decrees, 2; 1 Harr. Ch. Prac. 420.

65.5 Geary $v$. Simmons. 39 Cal. 224 ; Camnon $r$. Brame, 45 Ala. 262; Foster $r$. The Richard Busteed, 100
Mass 409: Peopler. Bri-lin, so IH. 423; State $r$. Ramsburg, $43 \mathrm{Md}$. 325. When a judgment or decree is rendered by consent, or as the result of a compromise, it can not be admitted as res adjuricata: Wadhams $r$. Gay .73 111. 415. And slach decree would only bind the parties con-enting. and would not affect the rights of others not made parties to the suit, hut who should have been: Dibrell $r$. Carlisle, 51 Miss. 785.

6if Land $r$. Keirn, 52 Miss. 341: Eastman $r$. Porter, 14 Wis. 3!; Finh $r$. Lightner, 44 Mn, 268.

is Petersine r. Thomas. 28 Ohio St. sog: Puten $r$. Fpooner. 4.5 trel. 489; Imugerorl's, Appeal, 41 coner. 222: Talbot $r$. Todd, 5 Dama, 193.

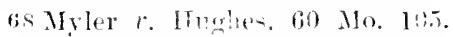
69 Lathron, $r$. American Emir. Co., 41 lown 54: : Peitit r. Cooper, 9 Lea (Temn.), 21.

7o Greblin $r$ Davis. $2 A$ K. Marsh. (Kyo) 17: Dunklin r. Wils(m), 64 Ala. 162. 
of the defendant, but merely directs the execution of a deed, until such exeeution, the legal title remains in the defendant. ${ }^{i 1}$ A reversal of the decree does not divest the title of a purchaser thereunder in good faith, ${ }^{72}$ who is a stranger to the record, but all rights acquired by parties to the suit as purchasers of the land under the deeree, fall with the reversal. ${ }^{i 3}$ A decree upon a matter not involved by the cause, nor in issue by the pleadings, is coram non judice and void, ${ }^{7+}$ and will be treated as a nullity, even in a collateral proceeding. ${ }^{75}$

\section{$\S 462$. Decrees Rendered on Constructive Notice.}

The remarks of the last section must be understood to apply more particularly to decrees which have been rendered upon a full hearing of the case and with all the parties properly before the court. Where, however, there has been no personal service upon the defendants, and such persons are before the court only construetively by a substituted service, somewhat different rules prevail. The law will not hastily preclude a person's rights when he has had no opportmity to be heard; hence, a decree entered in such a case does not become final and conclusive until some time has elapsed during which the defendants may come forward and urge any matter they may have in extemuation or defense. The time allowed for this purpose as well as the method by which such defendants are let in, are matters of local statutory regulation, bnt the principle is of general observance, that all persons acquiring rights under such decree, before it becomes final and conchnsive, are equally affected with notice of its conditional character; and all interests so acquired, whether for a valuable consideration or otherwise, are entirely dependent upon the confirmation of the deeree, which, if vacated, renders all proceedings moler it

71 Peak v. Ligon, 10 Yerg. 569; Powell v. Rogers, 105 IHl. 318. (Tenn.) 469.

72 Taylor $v$ Boyd, 3 Hammond (Ohio). 353; Lambert $v$. Livingston, 131 Ill. 161.

$i+$ Meredith $v$. Little, 6 Lea (Tenn.), 517.

75 Monday $v$, Vail, 34 N. J. L.

73 Fishback $v$. Weaver, 34 Ark. 418. 
a mere nullity, and of this all persons dealing with the land must take notice ${ }^{76}$

In this connection the attention of the examiner is directerl to the antecedent procedings and the character of the process by which the defendant is lnought within the jurisclietion of the court. Where a decree is hased on a constructive service everything essential to juristiction must appear. 'The defendant must be properly named or identified. In other words, he must have notice, and if the fact of no notice aftirmatively appears upon the face of the rroceedings the julgnent is void and open to collateral attack. Thus, a notice to - Sinith, without other description an identification will mot suffice to bring John Smith into court, nor will a judgment rendered against him have any hinding effect. ${ }^{i t}$

$\S 463$. Lien of Decrees. Decrees, equally with judgments, ereate liens upon the lands of the losing party. This follows as an incident where there is a nondy decree in personam, ${ }^{78}$ while, by statute, where a becree is pronounced requiring a party to perform some act other than the payment of money, it may be marle a lien upon the property of such party until he shall perform the acts mentioned in the decree. $^{79}$ In the first instance the lien has the same force and effect, and is subject to the same limitations and restrictions as judgments at law. ${ }^{80}$

$\S 464$. Formal Requisites of Decrees. Unlike judgments in personam, which are ordinarily shown only by a brief reference, decrees and judgments in rem, or which affect or implicate title, are copied almost verbatim, or at least set forth with little condensation. The formal parts of de-

76 Southern Bank 1 . Ifmmphreys, 47 III. 227.

77 Clark $c$. IIillis, 194 Incl. 421; Thompson $r$. MeCorkle, 136 Ind. 484.

78 Karnes $r$. Ifarper, 48 III. 597; Yaekle $v$. Wightman, 10:3 Ill. I69. No personal decree can le rendered in equity against defenclants not per- sonally before the emort: as to such defendants the bill must be dimmissed without prejulice: Virden $r$. Needles, 98 Ill. 366.

9 Kirby r. Runals. 140 IIl. 289. so Karnes 2 . JIarpere, 48 Ill. 527; Eames $i$. Germania Turnverein, it IIl. 56 . 
erees are, the caption and title of the eause; the reeitals; and the ordering or mandatory clanse. I fourth part, called the declaratory clause, is sometimes added. ${ }^{\text {11 }}$ The strictly formal parts which relate to the caption, etc., may in some cases be abbreriated, partienlarly when the decree is shown in regular order as a part of the synopsis of the proceedings of the comrt which pronounced it, but when the alstract is marle from a certified copy recorded with the rocorder of deeds, it is arlvisable to show these parts also. The eaption shows the court; term, day, ete., on which the decree was rendered; the name of the presiding judge or chancellor' and the title of the eanse. The recitals are now very meager and refer briefly and generally to the hearing, pleadings and proofs, and to the fact of their having been duly considered by the enurt. Formerly it was eustomary to set out at great length the pleadings, evidence, ete., but this practice, by reason of its expense and inconvenience, has been discontinned, and the indurement of the recitals reduced to a bare mention, ${ }^{82}$ although in some States the evidence still is, or may be, preserved in some instances in this manner. ${ }^{83}$ The recitals being brief, should be shown in full. ${ }^{s+}$ The ordering or mandatory clanse is the vital part of the decree, and must always, with the exception of the part referring to the costs, be copied verbatim. This part contains the specific directions of the eourt with reference to the subject-matter before it, and provides for the final disposition of the rights of the litigants. All decrees must be

s1 When this is used it inmediately precedes the ordering part, and consists of a declaration of the rights of the parties. It is not necessary, however, and its omission will not invalidate the decree.

82 Dousman $r$. Hooe, 3 Wis. 466.

83 Cooley $v$. Scarlett, 38 Ill. 316 ; Walker $v$. Carg, 53 Ill. 470.

84 Though formerly a stricter rule prevailed, every reasonable presumption is now indulged in favor of the jurisdiction of a court of general jurisdiction, and its find- ings in decrees are heid to be prima facie evidence of the existence of jurisolictional fucts, while the recitals frequently have the further effect to cure defects of service, etc. For this reason the recitals should be fully stated. See Turner $r$. Jenkins, 79 Ill. 228 ; Rivard $v$. Garlner. 39 Ill. 125; Prettyman $r$. Baruard, 37 Ill. 105; Haworth $r$. Hnling, 87 Ill. 23; Bèlden $r$. Meeker, 2 Lans. (N. Y.) 470 . 
founded on, and in conformity with, the allegations and proofs; and can nut be based upon a fact not put in issue by the pleat-

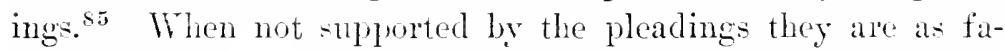
tally defective as though not sustained by the verdict of findings. ${ }^{s i}$

Where a decree directly affects land, as in case of foreclosure or other action in rem, it is of vital importance that the description be accurate and certain. The rules of conveyancing, which permit reference to extrinsic facts to aid the intention of the partics, have no application to descriptions found in judicial decrees, or deeds of conveyance founded upon them, nor can the assistance of equity be invoked to reform such descriptions. ${ }^{\text {st }}$ Hence, if the decree and resulting deed are so defective that it can not be ascertained by inspection, or from data which they furnish, what property was in fact sold, or, if in order to ascertain the intention of the ofticer selling it becomes necessary to institnte an extraneous inquiry, the proceeding will be roid for uncertainty. ${ }^{s s}$

$\S 465$. Abstract of Decrees. From what has been said it will be perceived that an abstract of a decree, unless it preserves the evidence, can consist of little else than a copy of such decree. The recitals may permit of some condensation, and the mandatory parts that refer to the costs are also susceptible of the same treatment. The rerbiage of the caption may also be condensed and parts thereof onitted, thus:

$\left.\begin{array}{c}\text { Alexander Stewart } \\ \text { vs. } \\ \text { Charles Dalton. }\end{array}\right\} \begin{aligned} & \text { Circuit Court Cook County. } \\ & \text { June Term, 1883. } \\ & \text { In Chancery. } \\ & \text { Reciles, that this cause having come } \\ & \text { on to be heard upon the pleadings }\end{aligned}$

8. I Barb. ('h. Prac. * 339; Carneal $r$. Bank, 10 Wheat. 181; Maunday $r$. Vail, 34 N. J. I. 418.

8f Bachman $v$. Sepulverla, 39 Cal. 688; Marshman $v$. Conklin, 21 N. J.
Eq. 546; Parsley v. Nicholson, 65 N. ('. 207 .

sт Jewis $v$. Owen. 64 Ind. 446. ss Evans $v$. Ashley, 8 Me. 177; Bowen $t$. Wickersham, 124 Ind. 404. 
argued by counset, and the court having duly considered the same, and being fully adrisea in the premises; ${ }^{89}$

Doth order, adjudye and decree, that the said deed of conveyanes from William Jones and wife to the defendant. Charles Dallon, bcaring dale Jamury 4, 1SS2, of the lands described as follows, to wit: [set ont description] and recorded in the recorder's office of C'ooli ('ounty, 1hl., as Doc. 199,242, be, and the same is herrby set aside and declared null and void, as against the complainant, his heirs and assigns, as a cloud upon the title of the complainunt; and that the defendant, Charles Dalton, do deliver up the suid deed to be canceled by the elerk of this comrt."

Further ordered, that defendunt pay costs of this suit, to be taxed, and that execution issue therefor. ${ }^{91}$

$\$ 466$. Frrors and Deferts. Errors and defects in judgments or decrees require, when apparent, appropriate mention. But the defects that are noticeable are mainly confined to matters of practice, form, ete, and vital defects, from their very nature, are frequently undiscernible. Thus, a judgment against an individual as a defendant, by a name which is not his in contemplation of law, can. not ordinarily be enforced against him,, 2 and certainly is not constructive notice of a lien upon his land. ${ }^{93}$ It has in some instances been held,

sa Recitals in a decree of a court of inferior jurialiction of the facts necessary to give jurisuliction are prima facie evidence of such facts, subject to be contradicteil, but sufficient per se to mplsold the pro. ceeding if uncontradicted: Pelden $r$. Necker, 2 Lane. (X. Y.) 470.

so Equity will generally compel an instrument to he delivered up, for eancellation. where it has heen derlared inoperative, and may possibly do harm if allowed to remain in defendant's hands: Keemle $r$. Conrad, 12 Phila (Pa.) 524. A de- cree anceling a deed may direct the clerk to enter the fact on the margin of the record of such anceled deed: Jonew 1 . Porter, 59 Misi. 628.

21 This is equivilent to a money judgment and reates a statutory lien on the defendant 's lands.

32 Farnham r. Hildreth. 32 Barb. 27-: Thomas $r$. Deney, 57 Iowa, 58.

9: Thomas $r$. Desney, 57 Iowa, 5s; Grundien $r$. Reid, 107 Ill. 304. Thus, a julgment against Mrs. J. B. Smith, is not constructive notice that it is a lien on land owned. by 
that a judgment in an action in which the defendant is named in all the proceedings therein by a different name from that of a particular existing individual, will be of no arail against the latter, even if entered up against him by his real name, although process was in fact served upon him, when the name of the defendant in such process was not his; ${ }^{94}$ because, unless he actually appeared in the action, no juriscliction over him was obtained therein by the service of such process. ${ }^{95}$ But the weight of anthority would seem to indieate that if the proess is served on the party intended to be served, though by a wrong name, and he fails to appear and plead the misnomer in abatement and suffers jurlgment to be obtained against him, he is concluded, and in all future litigation may be comnected with the suit or julgment by proper averments. ${ }^{95}$

In compiling an abstract, lowever, the two matters just noted would not be treated alike. In the former case, the name of the judgment debtor not being the same as the party whose title is under emsideration, the judgment might with safety and propriety be disregarded: as where the name of the land owner is "Freeman" Jones, and that of the judgment debtor "Herman" Jones. ${ }^{9 i}$ But in the latter, though the judgment debtor was sued by a wrong name, yet inasmuch as judgment was entered against him by his true name, such judgment must substantially appear. together with so much of the procedings, including the proeess and return, as will show the repugnaney or invalidity, and the opinion of title should specifically pass upon the facts thus exhibited.

Mary Smit!, notwithstanding that she is the wife of J. B. Smith; Bankers, etc. Co. $r$. Blair, 99 Va. 606.

94 Bates $r$. State Bank, 7 Ark. 394. In this case service was returned as had upon Asher B. Bates and jurgment was rendered against Ashley B. Bates.

95 Iloulton $v$. De Maearty, 6 Rob.
(X. Y.) 470: Ford $r$. Doyle, 37 Cal. 346.

9r, Sce Bloomfield R. R. Co. r. Burgess, 82 Ind. 83: National Bank $r$. Jaggers, 31 Md. 38; Walsh $r$. Kirkpatrick. 30 Cal. 202: Foshier $r$. Narver. 24 Oreg. 441.

9 F Furnham r. Hildreth, 32 Barb. 277: Thomas r. Deeney, 57 lowit, 58; Kennedy $v$. Merriam, 70 lll. 228. 
$\S 467$. Continued-Middle Names. A more perplexing question arises in case of correct Christian and surnames, but wrong middle names or initials. The anthorities are all agreed that the law requires and recognizes but one Christian name, and that the omission or insertion of middle names or initials is immaterial, ${ }^{98}$ yet in many instances the middle name is the only clue by which judgment debtors can be identified. In populous localities it is not always expedient to show all the judgments appearing against a particular name. Say the person whose title is under consideration is named John R. Smith, and the record discloses judgments against "John Smith," and John Smith with middle initials other than "R," now what course must be pursued in view of the propositions last presented? To insure absolute certainty, every judgment that comes within the rule must be shown, and this in many cases would be impracticable, for to exhaust the possibilities as to John Smith might require hundreds of searches. In the absence of positive instructions, therefore, when questions of doubt arise, the examiner usnally looks only for judgments against the particular name under consideration, and in his certificate expressly states that no search has been made for the other names. ${ }^{99}$

While this practice is sometimes condemned it is yet in consonance with the general tendency of the courts in construing docket entries and enforeing judgments. It is now a common statutory requirement that the judgment docket shall set forth the name at length of each judgment debtor. Hence, if the true name of the judgment debtor is "John R. Smith" but judgment is docketed against him as "John Smith," while the judgment might be effective as between the parties it would be of no effect as against a purchaser. ${ }^{1}$ In the cases

9s Thompson r. Lee, 21 Ill. 242; Bletch $r$. Johnson, 40 Ill. 116; Allison $r$. Thomas, 72 Cal, 562; Choen $r$. State, 52 Ind. 347 , in this ease it is sail the middle name is mere surplusagre.
99 This matter is further considered in the chapter deroted to "Opinions of Title."

1 Terry $r$. Sisson, 125 Mass. 560 ; Dutton $v$. Simmons, 65 Me. 583; Hutchinson's Appeal, $92 \mathrm{~Pa}$. St. 
which support this doctrine it is held that the midlle name rir initial is an essential part of the name and that the omisinin of such middle name or initial, or the substitution of others than the true one, is a misdescription of the person, the tendency of which is to deceive intending purchasers. The object of the statute is that the locket shall, of itsclf, fumish reasonably satisfactory evidence as to whether a judgnent exists against the person shown by the records to own the land which prospective purchasers seek to aequire. In order to make the judgment lien effeetive as constrnctive notice to subsequent purchasers the true name shonkl be shown and if the index fails to make this disclosure, and the purchaser has no actual knowledge of the identity of the judgment debtor, he should take the land freed from the lien..2

$\S 468$. Continued - Initials - Irem sonans. The same perplexity arises where only initials are employed, an incorrect yet nevertheless common practice. A judenment docketed against "A. Jones" has been held sufficient notice of a judgment against "Abel Jones," where the defendant uniformly wrote his name by his initials and there was no other "A. Jones" in the county. ${ }^{3}$

Again, the examiner, and counsel as well, must deal with the discordant doctrine of idem sonans. Thus, a judgnent against John "Bobb" was in one instance permitted to operate as a lien on land owned by John " Bubb," 4 and one against Henry "Hackman" was in another case allowed to partiripate against the property of IIenry "Heckman." 5 It is said in

186; Ridgeway's Appeal, $15 \mathrm{~Pa}$. St. 177.

2 Crouse $v$. Murphy, 140 Pa. St. 335. The docket entry of a judgment against Edward Davis was beld not to constitute constructive notice of a lien on the land of either E. A. Davis or Elward $A$. Dalvis. See, Davis $r$. Steeps, 87 Wis. 472 ; and see, Johnson $r$. Hess, 126 Ind. 298.
3. Jones Estate, 27 Pa. St. 336; Hart $c$. Lindsey, 17 N. II. 233.

4 Meyer r. Fegaly, 39 Pa. St. 429. 5 Bergman's Aprent. se l'il. St. 123. The names "Welel" and "Welsh" are idrm senens. Donuhoe-Kelly Bankine ('o. $r$. South. Pac. Co., las C:1l. 18:3: so une the names Watkine and Wadkins, he-

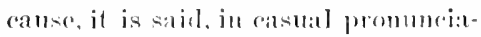
tion there is scarcely any difference 
support of these precedents that identity of sound is a surer designation of the names of persons than identity of orthography, and that in ascertaining identity of sound the prevailing usage in pronunciation in the loeality will prevail. It is also contended that persons searehing the judgment docket for liens ought to know the different forms in which the same name may be spelled, and to make their searches aceordingly; unless indeed where a spelling is so entirely musual that persons can not be expected to think of it. ${ }^{6}$

It is, however, the duty of a judgmen't ereditor to see that his judgment is properly entered, and in such a manner as to furnish to the eye of purehasers and subsequent incumbrancers, that record notice which the law contemplates, ${ }^{7}$ therefore, while slight rariations not materially changing the sound may be permitted to stand under the rule of idem sonans, total departures in initial letters, misleading the seareher and failing to furnish him with proper elues, ean not be allowed. As where the judgment debtor is named "Yoest," but the judgment is docketed "Joest," notwithstanding that the foreign pronmeiation of the name is the same using either initial, yet the eye is misled, and the law does not impose upon any one who searches, the duty of inquiring whether some other letters may not spell the name of the debtor in another language. ${ }^{8}$ So, too, a material ehange in the spelling, although preserving to a large extent the original sound of a name, is fatal to the lien as against one having no notice. Thus, the names "Hesser" and "Hesse" are so dissimilar that one searehing for incmbrances against the former would not be

in the sounds. Bennett $v$. State, 62 Ark. 516. See Lyon r. Kain, 36 IIl. 368, where Emonds. Emmens, and Emmons, were all held to have practically the same sound and hence to be within the rule. On the other hand. it has been held, that Hyde and Hite, do not come within the rule, State $r$. Williams, 68 Ark. 2+1. And that purehasers from W.
H. Furman are not eharged notice of incumbrances by $\mathrm{W}$. H. Freeman, Howe $r$. Thayer. 49 Iowa, 154.

6. See Meyer $r$. Fegal:' 39 Pa. St. 429.

7Hutchinson's Appeal. 92 Pa. St. 186.

8 Heil's Appeal, 40 Pa. St. 453. But see Kirtz $v$. Behrensmeyer, 125 Ill. 141. 
charged with notice of a judgment against the latter, nor put upon inquiry. ${ }^{9}$

But while it is undonbtedly true, that the law of notice by record is addressed to the cye and not to the ear, and that record notice is principally a matter of sight and not of somed, yet, it is held, it is abre all a matter for the comsideration of the mind, and if the record of a name spelled in one way should directly suggest to the ordinary mind that it is also commonly spelled another way, the seareher should be charged with whatever the record nay show in some other spelling, particularly under the same initial letter. Hence, a judgment against "Seibert" was held to be notice to purchasers of property owned by "Sibert." 10 It will be seen, therefore, that the subject is one of dowlot and uncertainty, and beeanse of this an additional burden of eare and diligenee is cast upon both examiner and counsel.

$\S 469$. Operation and Eifect of Probate Decrees. $\Lambda$ decree of a probate court acting within the sphere of its jurisdietion, is conclusive upon all those to whom the right of appeal is given, ${ }^{11}$ when such right is mexereiserl, and as to all matters which appear from the recort to have been adjudieated upon; ${ }^{12}$ and all such decrees, where the comrt has jurisdiction of the subject-matter, will be presmmed to have been made upon proper notice and formal proceedings, even though such proceedings do not appear of record. ${ }^{13}$

Orders of sale made by probate courts are a class of decrees to which the attention of the examiner is particularly directed. These orders are escential parts of the title and call for severe scrutiny. It has been held that an order of compt. for the sale of land must in itself be sufficient without refer-

9 Etna Ins. Co. $r$. Hesser, 77 Iowa, 381 ; and roe Bates $x$. Bank. 7 Ark. 394; Anthony r. Taylor, 68 Tex. 403 . 438.
11 Lawence $r$. Engleshy. $24 \mathrm{Vt}$. 42.

12 Rix r. suith. s Vt. 3.6ti.

13 Sparlawk r. linell, a Vt. 4? ; Pollock r. linif. 4:3 Misis. 140. but ses Martin r. Williams. 4'2 Miss. 210. 
ence to extraneous matters, ${ }^{14}$ and where the description is insufficient the sale will be invalid. ${ }^{15}$

$\S 470$. Foreign Judgments and Decrees. The courts of a country have no extraterritorial jurisdiction, hence, they can not, by judgment or decree, afiect title to land situated in a foreign country. It is true, that courts of equity may, and do, entertain bills for the specific performance of contracts respecting lands situate in a foreign conntry, if the parties are resident within the territorial jurisdiction of the court, but, in such cases, the court can not bind the land itself by any decree it may make; it can only bind the conscience of the party in regard to the land, and enforce him, by process against his person, to perform his agreement.

$1+$ A decree need not set out the evidence on which it is founded but should find the allegations of the petition to be proved, and, generally, it will be presumed that the evi- dence warranted the decree. Bree $v$. Bree, 51 111. 367 .

15 Crosby $r$. Dowd, 61 Cal. 557; Hill $r$. Wall, 66 Cal. 130. 


\title{
CILAPTER XXVII.
}

\author{
JUDCIAL AND EXECUTION SALES.
}

$\S 471$. Defined and di-tinguislred.

472. Fxecution sales-Validity and effect.

473. Title under execution sales.

4it. When the title rests.

475. The writ.

476. The lery.

477. Notice of sale.

478. Proof of publication.

479. Execution sabes as affected by deatih.

480. Exemption.

481. Dower rights.

482. Julicial sales-Validity and effect.
$\$ 433$. Title under judicial sales. 4s4. Rights of purchasers.

455. Comprling purchaser to acrept title.

486. Order of confirmation.

457. Effect of confirmation.

458. Certificate of sale.

459. A-rignment of certificate.

490. Proof of title under judicial and execution sales.

491. Continued - Presumptions.

492. Probate sales.

493. Nature and requisites of probate sales.

494. Abstract of probate sales.

\section{§ 4โ1. Judicial and Execution Sales- Defned and}

Distinguished. No inconsiderable portion of the real property of the comntry changes hands every year thromgh the media of execution and judicial sales, meaning by such terms, all sales and transfers of property mate in pursuance of the orders, julgments or decrees of courts, or sales made to obtain satisfaction of such orders, judgunents or decrees. The term "judicial sale" is properly applied only to sales made in conformity to an order or decree directing same, and refuiring a subsequent confirmation or approval by the conrt." "Execution sales," though based upon a judgment, are marle under

1 Mr. Freeman classes judicial sales as: (1) those made in chancery; (2) those nade by executors, administrators and guardians, when acting by virtue of authority derived from orders of sale ulutained in judicial proceedings: and (2) all other cases where property is sold under an order or decereo of comet designating such properey, an.l ainthorizing its sale: Freeman Void. Jud. Sales, 15 
the statute, for the recovery of a specific sum of money in satisfaction of the judgment. "The chief differences between execution and judicial sales," says Freeman, "are these: the former are based on a general judgment for so much money, the latter on an order to sell specific property; the former are conducted by an offices of the law in pursuance of the directions of a statute; the latter are made by the agent of a court in pursuance of the directions of the court; in the former the sheriff is the vendor, in the latter, the court; in the former the sale is nsually complete when the property is struck off to the highest bidder; in the latter it must be reported to and approved by the court." 2

Sales made under an execution must conform, in all respects, with the mles which the law lays down for the protection of the debtor. If not so made, they may be held irregular and void. But sales made under the decree of a court are, to a considerable extent, under the discretionary control of the court, which often sets them aside, although no error or irregularity has been committed, merely for the sake of an advance in the price; or which may, if satisfied that no injustice has been done, disregard inregularities in the conduct of the sale, and confirm the action of the master or other officer making same. $^{3}$ An erroneous or voidable judgment or deeree stands good until reversed; and a stranger who purchases property sold under such judgment or decree will generally be protected in his purchase. ${ }^{4}$

$\S$ 172. Execution Sales - Valinity and Effect. It is a familiar principle that statutory proceedings to divest title to land must be strictly pursued; and that a substantial departure from the requirements of the statute renders the proceedings void. ${ }^{5}$ As a rule, the sheriff is presumed to have done his

2 Freeman on Void Jud. Sales, 14.

3 Lasell $v$, Powell, 7 Coldw. (Tenn.) 277 .

4 South Fork Canal Co. r. Ciordon, 2 Abb. (U. S.) 479 ; McAusland $v$ Pundt, 1 Neb. 211; Storm $v$. Smith, 43 Niss. 497: Garrett $v$. Lynch, 45 Ala. 204; Sinnett $v$. Cralle, $4 \mathrm{~W}$. Ta. 600.

5 Stillwell $\ell$. Swarthaut, 81 N. Y. 109 ; Havens $v$. Sherman, 42 Barb. 
duty in making a sale, and to have complied with all the requirements of law." But this rule does not apply where the fact that the sale was in riolation of the statute, is apparent on the face of the record through which the title is claimed, ${ }^{7}$ although the validity of a purchaser's title will not be affected by the failure of the officer to make a seizure in the mode, or by the steps, preseribed by the statute, when such failure consists of mere irregularities. ${ }^{s}$ Ilis power to soll comes from the judgment and execution, and is not to be measured by his proceedings under the writ. ${ }^{9}$ Greater strictness is required in conducting the sale, the details of which are regulated by express statutory provisions in all the States, and non-compliance in this particular, as by offering land in gross instead of in parcels, ete., will be sufficient to vitiate the proceeding, and the sale may be set aside, even as against a stranger who has bonght the property and paid the price. ${ }^{10}$

One whe buys at execution sale is not an innocent purchaser in the full meaning of the term, but takes the estate subject to all equities existing against it at the time of the purchase, and is chargealle with notice of all defects in the exccution debtor's title, together with the value of the property and of its situation, and of the legal rules bearing upon the.

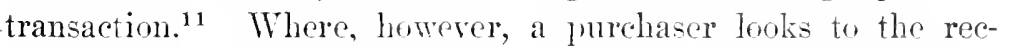
ord and finds there a sulsisting judgment, and buys in good faith, pays the price and receives a deed, he takes a title which is valid until the sale is set aside and the purchase money refunded. ${ }^{12}$

The doctrine of carcat emptor applies to every purchaser at

636; Surgi $r$. C'olmer, 22 La. Ann. 20.

6 Leonard $r$. Sparks, 117 Mo. 103 ;

Hogue $r$. Corbit, 1.\%6 IH, 540.

7 Piel $r$. Brayer, 30 Ind. 392.

8 Wood $r$. Morehouse, 1 Tans. (N. Y.) 405; Stewart $v$. Pettigrew, 28 Ark. 372 ; Curd $r$. Lackland, 49 Mo. 451 .

9 Blood v. Light, 38 Cal. 649.
10 Vass $r$. Jolinson, 41 Ind. 19; Browne $r$. ferrea. jl (al. sis; Morris $r$. Rober. 73 111. 46. C'ompare Eaton $x$. Ryatl, s Nel. 47.

11 Richardon r. Wirken, it N. C. 278; Allen $r$. Mrelizueluey, 31 Ark. 252; Dontis r. Robey, 73 111. 432.

120 wen $r$. Niviatata, 41 Tex. 517; Wing $v$. Dodge, so I11, 564. 
a sheriff's sale. He buys at his peril, and succeeds only to the right and title which the defendant in execution had at the time the judgment was rendered against hinı. ${ }^{13}$ The selling officer has no power to warrant the title and the purchaser is presumed to have made all proper examinations and to know what he is acquiring. ${ }^{14}$ The judgment is, of course, the foundation for the title, and the purchaser must see to it that at the time of the sale snch judgment is subsisting and unsatisficd, for, however innocent he may be, he can acquire no title when the power which confers the same has ceased to exist. ${ }^{15}$

§ 473. Title under Execntion Sale. A purchaser at an execution sale succeds to all the rights which the judgment debtor had, ${ }^{16}$ and takes the same title possessed by him with all its imperfections and infirmities. ${ }^{1 \overline{ }}$ It is the policy of the law, however, to uphold and protect such titles, and thongh the dead purports to convey only "the right, title and interest" which the judgment debtor possessed or had in the land at date of the jurlgment, yet the purchaser under such a deed will take the entire chtate as against prior unrecorded deeds or equities of which he had no notice. ${ }^{18}$ The title so acquired may be sold and conveyed, even pending an appeal, ${ }^{19}$ and the reversal of the judgment for error, where the court had

13 Millej r. Wilson, 32 Md. 297; Walke $r$. Nurly, 65 N. C. 599 ; Fro.t $r$. Bank, T0 N. Y. 553; Barron $r$. Nullin, 21 Minn. 371 ; Holmes $\iota$. Shaver, 78 111. 578; MeCartney $r$. King, 25 Ala. 681.

14 Atwood $\iota$. Wright, 29 Ala. 346: Bassett $x$. Lockurd, 60 Ill. 164 ; Hensley $1:$ Bakes, 10 Mo. Ist.

15 Wood $v$. Calvin, 2 Hill (N. Y.) 560 ; Jackson $r$. Anderson, 4 Tend. (N. Y.) $4 \pi 4$; King $v$. Goodwin, 16 Mia:r. 63.

14i Morgan v. Bonse, 53 Mo. 219; Williams $v$. Amory, 16 Mass. 186.

17 Ilicks $t$. Skinner, $i 1$ N. C. 539 ; Cameron $v$. Logan, 8 lowa,
434; Bassett $\imath$. Lockard, 60111. 164.

18 ITarplam $r$. Little, 59 Ill. 509.

19 The issue of an exeeution on a judgment, pending an appeal, is irregular, but not void, and a sale of land under such an exeention is subject to be set aside, on motion made in proper time by the defendant, whose land has been sold; but no one except the defendant in the execution can question the sale for irregularity, however gross, and if not so set aside, the sale wull pass the defendant's interest in the land: Shirk $v$. Gravel Road Co., 110111. 661. 
jurisdiction of the subject-matter and the parties, ${ }^{20}$ will not materially affect the purchaser's rights, for it is a settled principle of the common law, coeval with its existence, that the defenuant shall have restitution of the purchase money, and the purchaser shall hold the property sold, except where the plaintiff in the judgment becones purchaser, and still holds the title. ${ }^{21}$ In this latter erent the title acquired under such judgment is divested by the reversal. ${ }^{22}$

$\$ 47$. When Title Vests. In all cases where a redemption is permitted, the legal estate of the judgment debtor is not divested by the sale until after the period allowed for redemption, nor even then, mless the sale has been consummated by a deed from the sheriff. Intil the exeention of such deed the title of the purchaser is inchoate, for by the simple act of purchase he acquires no legal estate in the land. but only a right to an estate which may be perfected by conveyance. $^{23}$ Prior to the sheriff's deed, the debtor is entitled to the possession and profits of the land, while the equity held by the purchaser is a lien upon the land for the amount of his bid and interest. ${ }^{24}$

$\S 475$. The Writ. It is a cardinal rule that the execution must conform substantially to the judgment, or the sale will be void; ${ }^{25}$ yet it is not enstomary to more than allude to this instrument in the abstract of an execution sale, mless special instructions are given otherwise. Its date, number and import are usually noticed, and in case of a renditioni exponas a brief allusion to the lands specifically descrilherl. Nor will a more extended notice, in most cases, be necessary, as the

20 Feaster $v$. Fleming, 56 Ill. 457 ; Hobson $v$. Ewan, 62 Ill. 146.

21 Fergus $r$. Woodworth, 44 Ill. 374; Mansfield $r$. Hoagland, $46 \mathrm{Ill}$. 359. In this event the sale is usually void under special statutes: see Hutehens $r$. Doe, 3 Ind. 52s; but compare Gossom $\imath$. Donaldson, 18 B. Mon. (Ky.) 230.

22 Powell v. Rogers, 105 Ill. 318.
23 Smitlı $r$. Colvin, 17 Barb. 1.57; Evertson $r$. Sawrer, 2 Wend. 507 ; Bowman $x$. The people, s. 111. 246; and see Rucker $r$. Decker, 49 Ill. $37 \%$.

24 Vaughn $r$ Ely. 4 Parb. 159.

25 Crittenden $x$. Leitensingrer, 35 Mก. 239; Hightower 2 . Handlin. 27 Ark. 20) Jastings $v$. Johnson, 1 Ner. 612 . 
purport and effect of the writ are generally recited in other of the proceedings muler it. Where an execution is not signed by the officer authorized to issue it, ${ }^{26}$ or where there is an insufficient teste, as where the seal of the court is omitted, ${ }^{27}$ or where there is a want of correspondence with the judgment, such defects should be shown, as a valid execution is one of the integral links in the chain of title, but mere clerical variance will not invalidate, ${ }^{28}$ nor afford spomd for collateral impeachment. $^{29}$ An execution issued and levied in the name of deceased plaintiffs, or against deceased defendants, will be void in some States, but may be effectual in others, provided certain statutory provisions are complied with. ${ }^{30}$

$\$ 476$. The Levy. A levy of lands is made by an indorsement thereof upon the writ, there being no such thing as seizure of the property. The sheriff, when levying on real estate, does not disturb the possession of the debtor nor even his right of possession, and this constitutes the chief distinction between a levy on real estate and on personal property." The decisions as to what constitutes a valid lery are generally harmonions in declaring that the land nust be described with sufficient certainty to enable it to be identified withont other evidence, ${ }^{32}$ but if defective in this respect it will be cured by a correct deed. ${ }^{33}$ In an abstract of the sale it is regarded as a minor detail, which may be briefly noticed in the return of the execution, but the certificate and deed supply in better

26 Rawles $v$. Jackson, 104 Ga. 593; Wooters $r$. Foseph, 137 Hll. 113.

$2 \tau$ This has been held a fatal defeet which will invalidate the deed: Ins. Co. $v$. Hallock, 6 Wall. 556; Davis r. Ran*om, 26 Ill. 100; Weaver $r$. Peasley. 163 Ill. 251 ; Gordon $v$. Bodwell, 59 Kan. 51 ; but see, contra. Corwith $r$. Bank, 18 Wis. 560.

$2 s$ Wheaton $r$. Sexton. 4 Whert. 503; Jackson r. Spink, 59 Ill. 404;
Riddle r. Bush, 27 Tex. 675; Woodley $r$. Gilliam, (i7 N. C. 237.

29 Butler $r$. Haynes, 3 N. H. 21. 36) Hildreth $r$. Thompson. 16 Mass. 191; Meck $x$. Punker, 33 lowa, 169; Bowen $r$. Bonner, 45 Miss. 10.

31 Dement $r$. Thompson, $80 \mathrm{Ky}$. 255.

32 Chadbourne v. Mason, 48 Me. 389: Gault $r$. Woodbridge, 4 MeLe:in, 3:9.

33 Hopping $r$. Burnam, 2- Greene (Ia.), 39 . 
shape the neessiary information concerning it. "And," ob serves Arr. In rer,; "though the purehaser relies on the judgment, execution, the lory and the deed, yet when the purchaser at sheriff"s sale shows an authorized execution and deed, a correct levy and notice is presumed. A judgment, execution and decel from the sheriff are sufficient to support the title of a purchaser without proof of a levy, though the return be incorrect, or there be no returu.": :5

$\$ 47 \pi$. Notice of Sale. It is a gencral statutory provision that land shall not ho sold by virture of any execution except at public sale, now wulese the time and place of bolding such sale shall haw bern previonsty given by preseribed methods. These methods gencrally ansitt in putting up written or printed notices of sale and ly advertisement thereof in some newspaper, which notices must describe the parties, property, terms, cte, and this applies as well to judicial as to execution sales. $^{36}$ This notice it is well to briefly abstract, showing only the legal requirements in a connected narrative form, and when proof of publication is appented, show this as well. The proof of publication is afforded by the publisher's affidavit or ecrtificate of wame. The statutes requiring notice of sale are said to be directory merely, and failure to give such notice will not avoil the sale so as to defeat the title of an innocent purchaser not himsolf in fault; ${ }^{37}$ lience, a passing allusion sufficient to show. its purport, seems all that is necessary in regard to the notice. ${ }^{3 s}$ In the general symopsis of sale it may be mentioned in this manner:

34 Rorer Jud. and Ex. Sales, 292, citing Brooks $v$. Rooney, 11 Ga. 423; Hoppling $r$. Burmum, 2 freene, 39 ; Evans r. Davis, 3 B. Mon. 344; Mcentive $r$. Duslann. 7 Ired. L. 151; Jarkson r. Jomme. 5 Cow. 260; Phillips r. Coffue, 17 111. 1,it.

:3 Levy on antarelument is governed by different primejples, and a return or entificate filed $j$ of rital importanes in preareving the linen:
See Lis Pendens and Attachments.

sti Olcolt r. Robinson, zo Barb. 148.

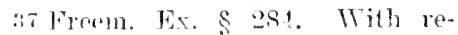
garl to prohate sales a more strict rule serms to prevait and notice is

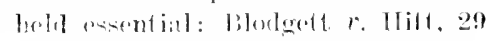
Mis. 169: Nonntume r. Purdy, 11 Nime. 381.

:s Deferetive notice does not ren. 
Printed copy of notice of sale, gives title of court ana cause, describes the said premises, ${ }^{39}$ and fixes on Sept. $\%, 18 S 1,{ }^{40}$ at 11 o'clock a. $\mathrm{m} .{ }^{41}$ at the east door of the Court House, ${ }^{42} \mathrm{Ch}$ cago, Ill., and for cash, as the time, place and terms of said sale.

$\$ 478$. Proof of Publication. Appended to the notice of sale will usually be found an attidavit or certifieate by the publisher of a newspaper, to the effect that the notice was duly published according to law, and this affidarit or certifieate it is well to show in brief terms. Its material points may be noted as follows:

Appended to the foregoing is,

$\left.\begin{array}{c}\text { Affidavit } \\ \text { by } \\ \text { Myra Braduell, President } \\ \text { of the Chicago Legal } \\ \text { News Co. }\end{array}\right\} \begin{aligned} & \begin{array}{l}\text { Subscribed and sworn to, June } \\ 1,18 S 3 . \\ \text { Pccites, that a notice "of } \\ \text { which the annexed printed slip is } \\ \text { a true copy," was duly published } \\ \text { in the Chicago Legal News, a }\end{array} \\ & \text { weekly newspaper of general circulation, printed and published } \\ & \text { in Cook County, Ill., for the period of three successive }\end{aligned}$

der the sale void, or even voidable unless the purchaser has notice of the irregularity. Purchasers in good faith can not be affected by such non-compliance with the statute: Osgood $v$. Blacknore, 59 Ill. 261; Watt $r$. McGalliard, 67 I11. 513.

$39 \mathrm{~A}$ minute description is not necessary provided what is given is correct and sufficiently identifies the property to enable the public to understand, by the exercise of ordinary intelligence, what is to be sold: Sterens $r$. Bond, 44 Mil. 506 ; Collier $r$. Vason, 12 Ga. 440; Allen $r$. Cole, 9 X. .J, Eq. 286.

40 The date of sale is material and destroys the validity of the notice if of such a character as to mislead the public: Fenner $v$. Tucker, 6 R. I. 551.

41 If the notice does not name the exact hour at which the sale is to be held, it should name the hours between which it will take place, which will be sufficient if the hours named belong to the business hours of the day: Cox $r$. Halsted, 2 N. J. Eq. 311; Burr r. Borden, 61 Ill. 388. A failure to state some time renders the notice insufficient: Trustees $r$. Snell, 19 Ill. 156.

42 The designation of a place of sale is an essential requisite of the notice, without which it is in law 
weeks; ${ }^{43}$ that the date of the first publication was Ian. 6, 1593: ${ }^{44}$ that the date of the last publication was Jan. 20, $1883 .^{45}$

A certificate of publication under the statute is sufficient if it shows a substantial compliance therewith, but the essential requisites must appear' such aftidarit or certificate may properly be likened to the return of an ofticer, and like such return should show all jurisdictional facts.

A defect in the certificate of publication, in not stating the first and last days of the publication, has been held to be cured by a recital in the decree that "it appearing to the court that notice according to law was given," etc., the presumption being that the conrt receired other evidence than the certificate, of the date of the publication. ${ }^{46}$ It must be observed further, that the certificate or aftidarit of publication can only be made by the publisher or his anthorized agent, ${ }^{4 i}$ and a certificate signed "John Wentworth, publisher, br Reed," has been held insufficient. ${ }^{48}$ In this instance the certificate did not purport to be given by the publisher, but by another person who used

no notice whatever: Bottineau $r$. Ins. Co., 31 Minn. 125; Blodgett $v$. Hitt, 29 Wis. 169.

43 The number of times. or period of time, the notice was published, and the date of the first and last issues containing same, are indispensable to its validity: Beygeh $r$. Chicago, 6.5 Ill. 189.

44 It may be well to observe that the date of publication aoes not fall on Sunday as this would in. validate the notice: Smith $r$. Wil$\operatorname{cox}, 24$ N. Y. 353; Scammon $r$. Chicago, 40 Ill. 146; Shaw $r$. Williams. 87 Ind. 158.

45 It wonld seem that the statute is satisfied if there are three different insertions in as many weckly issues before sale, althorgh twenty- one dars do not clapse from first insertion to day of sale, Pearson $v$. Bradley, 48 Ill. 250. Where this fact appears, however. counsel should notice it in his opinion, if the statute requires twenty days' notice.

46 Moore $r$. Teil, 39 Ill. 256 . The foregoing example, though inserted in conuection with execution sales, is that also employed in all decretal sales as well, either in chancery or in probate, and must be shown in the same manner in expositions of such sales.

47 This matter is statutory: usually the proof of publication must be made hy the "printer or publisher."

4s Fox $\imath$. Turtle, 55 Ill. 377. 
the publisher's nane but failed to show his own authority. Where a newspaper is published by a tirm or by a corporation, a certificate by one of the partners, or by an officer of the corporation, when such certiticate shows the official connection of the person making it with the newspaper, will usually be sufficient. ${ }^{49}$

\$ 79. Execution Sale as Affected by Death. The death of a plaintiff after judgment and before execution issued is of comparatively little moment in respect to title, as his personal representatives may sue out execution in the name of such deceased plaintiff, or in their official eapacity, as the statute may direct. $^{50}$ If the lefendant dies after judgment, the plaintiff may sne out execution in the mode prescribed by statute, or, if permissible, proceed by the common law scire facias. But, in the event of the death of either party prior to exeeution, to render valid a sale under the judgment it should be revived by scire facias, or an execution must be sued out in the mode prescribed by statute, which usually provides for the filing or recording, in the court in which the judgment exists, of the letters testamentary or of administration, after which execution may issue and proceedings be had thereon, in the name of the executor or administrator. ${ }^{51}$

49 Fox $r$. Turtle, 5.5 1ll. 37. It would seem to be the rule in some States, that when the affidarit of publication is defective, an amended affidarit may be filed according to the truth of the case: Bunce $r$. Reed, 16 Barb. 347 .

50 It is a familiar provision of the statute that liens ereated by law do not abate by reason of the death of any plaintiff or plaintffs, but that same shall survive in faror of the executor or arlministrator. whose duty it shall be to lave the jurlgment enforcerl Durham $r$. Heaton. 28 Ill. 264 .

51 Scammon $v$. Swartout, $35 \mathrm{Ill}$.
320: Brown r. Parker. 15 Ill. 307. In this case a sheriff's deed was relied on for title. The execution under which the sale was made was not issued until several years after the death of the judgment erelitor. without first reviring the judgment in faror of the persomal representative. or recorling in comt his letters of administration, and was also $i$-wed in the name of the deceased plaintifi, and not in the name of his personal representative. Held, that the execution. and all proceedings under it, were absolutely roid. 
$\$$ fing. Hxemplioms. Though all the real estate of a judgment dobtor may be primarily liable to seizure and sale on execution, a statutory right has been given to him in erery State, to relieve a portion of same from this burden, but the exeroise of this right is largely dependent on intention. When, therrofere title is claimed, or songht to be addueed through the medinm of an excention sale, and the abstract furnishes no information, it wonlel seem that an inquiry should be made coneerning the status of the land with reference to the statutory right of exemption. The debtor' is not always obliged to assert his right at the time of the levy, neither will a subsequent sale impair same, and the question, when such a state of facts may exist moler the statnte, becomes of controlling inportance. A sale of the homestate muder execution being inoperative, the purchaser thereat takes 100 title. ${ }^{52}$

$\S$ 481. Dower rights. It must always be borne in mind, while making searches of the character now under consideration, that a sale made in pursuance of a judgment affects only the title of the parties to the suit. To the great majority of judgments at law the wives of the defendants are not made parties, and it necessarily follows, in such a ease, that an execution sale of the luusband'r land toes not extinguish the wife's right of dower. ${ }^{53}$ Therefore, whenever title is derived through a sale of this kind, and the records fail to disclose anything respecting the domestic condition of the judgrnent debtor, an inquiry is raised and a requisition for further information should be made.

\section{$\S$ 482. Judicial Sales - Validity and Effect. $A$ sale} of land under a decree, must be made in the manner and on the terms preseribed in such decree; ${ }^{54}$ and a confirmation by the court of the report of the officer, can not, it seems, cure the invalidity of a sale not so made. ${ }^{55}$ But a sale will not be disturbet unless the party suing ean show an injury re-

52 Conklin $r$. Foster. 57 Ill. 104. 380; Augustine $r$. Doud, 1 111. App.

53 Butler $r$. Fitzgerald, 43 Neb.

192; Dayton $r$. Corser, 51 Mim. 406 ; Ficklin $r$. Rixey, 89 Va, 832. 588.

55 Bethel $r$ Bethel, 6 Bush (Ky.) , 65: but this will only apply

54 Langsdale $v$. Mills, 32 Ind. 
sulting to him therefrom, ${ }^{56}$ as well as an interest in the subjectmatter, ${ }^{57}$ while it is always the policy of the law to uphold judicial sales, and to protect the rights of purchasers under them; ${ }^{58}$ and although the judgment or decree may be reversed, yet all rights acquired at a julicial sale while the decree or judgment was in force, and which it authorized, will be protected. It is sufficient for the buyer to know that the court had jurisdiction and exercised it, and that the order on the faith of which he purchased was made, and anthorized the sale, ${ }^{59}$ for where the court has jurisdiction of the parties, and of the subject-matter of the litigation, no matter how erroneously it may thereafter proceed, within the bounds of its jurisdiction, its decree will be conclusive until rerersed or annulled in some dircet proceeding, ${ }^{60}$ and the title to property acquired at a sale under such decree, by a stranger to the record, will be upheld, although the decree itself may afterward be reversed for manifest error. ${ }^{61}$

On the other hand it must be remembered that the rule of careat emptor applies to all juclicial sales, ${ }^{62}$ and one who purchases thereat must, for his own protection, always exercise that reasonable caution and vigilance which the rule exacts. It is of the utmost importance, therefore, that in the examination of a title depending on a juchicial sale every essential step of

to gross departures; mere irregularity is generally cured ly confirmation: Williamson $r$. Berry, s How. 546 ; Koehler $r$. Ball, 2 Kan. 160. Void sales, whether execution or $\mathrm{jn}$ dicial, are classed by Mr. Freeman, as (1) those which are void because the court had no authority to enter the judgment or order of sale: (2) those which, though based on a valid judgment or order of sale, are invalid from some vice in the subsequent proceedings: Freeman Void Jud. Sales, 15.

56 Matter of Gilmer, 21 La. Ann
57 Nixon $v$. Cobleigh, 52 Ill. 387.

58 Dorsey $v$. Kendall, 8 Bush (Ky.), 294; Allman v. Taylor, 101 Ill. 185 ; Norton $r$. Reardon, 67 Kas. 302.

59 Gray $r$. Brignardello, 1 Wall. 627 ; Fergus $v$. Woodworth, $44 \mathrm{Ill}$. 374.

60 Norton $v$. Reardon, 67 Kas. 302; Noland $x$. Barrett, $122 \mathrm{Mo}$ 181; Bland $r$. Muneaster, 24 Miss. 62.

61 Allman v. Taylor, 101 Ill. 185. 62 Holmes $v$. Shaver, 78 Ill. 578 . 589. 
the transaction should be carefully scrutinized and the facts of juristiction established.

\section{$\S 483$. Title under Judicial Sale. The title acquired} under a sale by order of the cont differs in no material respect from that obtained where the sheriff is the vendor. The purchaser is entitled to the interest of all the parties to the suit, and to the interest of those who have purchased pendente lite from any of the parties. ${ }^{63}$ But he acquires no new rights, nor does the fact that the court is regarderl as the rendor ${ }^{154}$ confer upon him any superior equities. A court does not insure the title to real property sold under its decrees, ${ }^{65}$ and the purchaser buys, presumably, with full knowledge of all clefects aud preexistent liens. ${ }^{66}$ The is charged with notice of all facts disclosed by the record which affect the rights of others in the property sold, ${ }^{67}$ and he is bound to examine the title or purchase at his peril. If he buys without an examination and obtains no title, he must, as a general rule, suffer the loss arising from his neglect, unless fraud or mistake has entered into the trancaction. ${ }^{68}$ Prior to confirmation he has no independent rights, but is regarded as a mere proposer ; ${ }^{69}$ after confirmation his rights become vested, and the sale will not be set aside except for frand, mistake, surprise, or other cause for which equity would give relief if the sale had been made by the parties in interest instead of by the court. ${ }^{70}$ Teither will the title of an innocent purchaser, a stranger to the record, be affected by the subsequent

63 Harryman $v$. Starr, 56 Mrl. 63. 64 In all sales made under the anthority of a decree in equity, the court is the vendor, and the commissioner making the sale is the mere agent of the court. The decree is the warrant of authority to sell: Parrat $r$. Neligh, $7 \mathrm{~N}$ ch. 546 ; Thompson $v$. Craighead, 32 Ark. 291.

65 Gunton $v$. Zantzinger, 3 MacArthur (D. C.), 262.
66 Housley $r$. Lindway, 10 Heisk. (Temn.) 651; Gurnn $r$. McCauley, 32 Ark. 97; Capehart $l$. Dowery, 10 W. Ta. 130; Watoon r. Hoy, 28 Gratt. ( $\mathrm{Ya}$.) 698.

67 Williamson $r$. Jones, $43 \mathrm{~W}$. Va. 562 ; Meacham $r$. Stefele, 93 111. 135. Bs Tilley r. Bridges, 105 m. 336. 6o State $r$. Roame Nar. Co., 86 N. C. 408.

70 Berlin $r$. Melhorn, 75 Va. 639. 
reversal of the decree for irregularity; ${ }^{\top 1}$ but where the purchaser was an original plaintiff in the suit, or an assignee of the judgment or decree, he acquires only a defeasible title, which may be defeated by a subsequent reversal, and the same rule obtains whether the reversal is based on an amendable defect or one that is incurable. ${ }^{2}$

$\$$ 48t. Rights of Purchaser. A purchaser at a judicial sale has a right to presume that it is conducted according to the provisions of law, ${ }^{73}$ and proceedings in court, in a matter in which it has jurisdiction, will be presumed to be regular. Ifence, a purchaser, at a sale made by order of such court, is not bound to look further back than the judgment or decree, and the legal effect it may have on the title which is the subject if inquiry. ${ }^{74}$ Such judgment is a complete protection to a purchaser under it, ${ }^{75}$ except as to matters which reach the jurisdiction of the court. Neither is he bound, in any case, to see to the application of the purchase money, for this is under the control of the court; and however unwise the disposition may be, his title will not be affected by it. ${ }^{76}$

$\$$ 485. Compelling Purchaser to take Title. A sale made by order of a court of equity is, until final ratification, an executory contract, open to objection, and not to be enforced if the enforcement would be inequitable and against good conscience. $^{77}$ A purchaser can not be compelled to accept a doubtful title. $\Lambda$ title is doubtful when its condition invites litigation. When doubts are raised by extrinsic eircumstances, which neither the purchaser nor the court can satisfactorily investigate, for want of means to do so, the court will refuse to

71 Sutton $v$. Schonwald, 86 N. C. 198; Barlow $v$. Stanford, $82 \mathrm{Ill}$. 298 .

72 McDonald $v$. Life Ins. Co., 65 Ala. 358; Fishback $v$. Weaver, 34 Ark. 569; MeLagan v. Brown, 11 I11. 519.

7:3 Browning $v$. Howard, 19 Mich. 323.

74 Fleming v. Johnson, 26 Ark.
421 ; Dugan v. Follett, 100 I1l. 581; Allman v. Taylor, 101 Ill. 185.

75 Ilening $v$. Punnett, 4 Daly (N. Y.), 543 .

i6 Knotts $v$. Stcarns, 91 U. S. 638.

i Hunting $v$. Walter, 33 Md. 60 ; Ormsby $v$. Terry, 6 Bush (Ky.), 553 ; Mullins $v$. Aiken, 2 Heisk. (Tenn.) 535. 
impose snch title on the purehaser. When the means of incuiry are offered, and the result is satisfactory, perfommes will be enforced. is But all objections must be made before the sale is confirmed, ${ }^{79}$ for after confirmation no reliof will be sranted to the purchaser upou the gromend of defect of title; ${ }^{80}$ he can not have a rebate of price on discovering liens unknown to him before confirmation, ${ }^{81}$ and even thongh the title he may procure from the eomrt may he worthlese, he can not be relieved from payment of the price. ${ }^{82}$ A purchaser can not, after confirmation, set up, as a ground of redicf against his purchase, facts known to him before it was completed; ${ }^{3} 3$ and one who buys without inquiry or examination will not be relieved becanse of a misapprehension as to the legal effect of the decree for sale and the character and extent of the title he will aequire; such mistake being a mistake of law, and due to the carelessness of the purchaser himself. ${ }^{84}$

$\S 486$. Order of Confirmation. After the sale, and before the execution of a conveyance, in all cases of judicial sales, and sometimes of excention sales as well, ${ }^{\mathrm{s}}$ a return or report of sale must first be made to the court which ordered the same, which upon examination approves and confirms the action of

is Kostenboder $v$. Spotts, 80 Pa. St. 430; Monaghan $v$. Small, 6 Rich. (S. C.) 177; Gralıam $\iota$. Bleakie, 2 Daly (N. I.), 55 .

79 Long $v$. Weller, 29 Gratt. (Va.) 347 .

80 Farmers' Bank $v$. Peter, 13 Bush (Ky.), 591. But the general rule, that objections, by purchasers, to judicial sales, for defects of title, must be made before the sale is confirmed by the court, and that objections afterward come too late, does not apply to the equity of a purchaser arising from after discovered mistakes, fraul, or other like matter: Watson $v$. Hoy, 28 Gratt. (Va.) 698. liut if mistake is relied on it must be the mistake of both parties: Long $v$. Weller, 29 Gratt. (Va.) 347. And see Berlin $\bullet$. MelJorn, $75 \mathrm{Vir}$. 639.

s1 Farmers Bank $v$. Peter, 13 Bush (Ky.), 591; Curtis 2 . Root, 28 I11. 367 .

sa Capehart $x$. Dowery, $10 \mathrm{WV}$. Va. 130, and see Dills $r$. Jasper, 33 Il]. 263.

s.3 Spence $r$. Armour, 9 Ileisk. (Tenn.) 167.

s4 IIayes 2 . Stiger, $29 \mathrm{~N}$. J. Eq. 196 ; Morris $r$. Ilogle, 37 1]l. 150: Johnson r. 13aker, 3s 11l. 98.

s5 Confiruation of execution sales is not neressury at common law, but is sometimes rendered so by statute. 
the officer who made the sale. ${ }^{\text {so }}$ Until this has been done the sale is incomplete, and confers no rights on the purchaser. ${ }^{87}$ In judicial sales a confirmation is rendered necessary from the fact that the court, and not the officer making the sale, is the vendor, and confimation is regarded as the final consent; but even where there has been no confirmation, if a deed has been made and delivered, and there has been a possession and holding thereunder, time mar, if sufficiently long, operate to confirm and ratify the sale, and perfect the title of the purchaser. ${ }^{88}$

Where an abstract of judicial proceedings culminating in a sale and conveyance, is shown, the order of confirmation is material, and if wanting, the apparent defect should be noted by counsel and proper inquiries made regarding same.

$\S 48 \%$. Ereet of Confirmation. An order confirming a sale of land, made by a court having jurisdiction of the parties and the subject-matter, is a final and conclusive determination of all matters passed upon or which might have been passed upon had they been presented by way of objection. It binds all of the parties and their privies and forever precludes any attack upon the sale except for fraud, mistake, surprise, or some other circumstance for which equity would give relief if the sale had been made by the parties in interest instead of by the court. $^{89}$ So, too, as the order of confirmation is practically

86 A sale of land under a decree will not be approved by a court if fraud or misconduct on the part of any of the parfies to the sale is slown. Barling $r$. Peters, 134 Ill. 609 .

st Busey r. Hardin, 2 B. Mon. (Ky.) 407; Bank v. Humplireys, 47 111. 227; Williamson r. Berry, 8 How. 547: Thorn r. Inglam, 25 Ark. 52; Valle $v$. Flemins, 19 Mo. 454; Hunting $v$. Walter, 33 Md. 60. Approving the sale makes the officer's act that of the court, and where, upon such approval, he is ordered to make a deed, no order confirming the deed is necessary: McHany $v$. Schenk, 89 111. 357.

ss Gowan $r$. Jones, 18 Miss. 164; Rorer on Jud. and Ex. Sales, 57. In such an event, however, the deed would he regarded only as color of title in connection with adverse possession.

so Kineaid $r$. Tutt, 88 Ky. 392; Perlin r. Melhorn, 75 Va. 639; Brown r. Gilmor. S Mr. 322; Speck r. Pullman Co., 121 Ill. 33; Willis v. Nicholson, 24 La. Amm. 545. 
a final judgment it has the effect of euring all irregularition in the procecelings leading up to the sale. ${ }^{90}$

But, while the order of confirmation cures all irregularitics in the mode of making the sale it adds nothing to the anthority of the oflicer who made it. If the sale was without anthority, the ratification of it by the eomrt must be considered as having been given inadvertently, ${ }^{91}$ or, if given deliberately and on a full examination of the facts, must still be regarded as an unanthorized procecding. ${ }^{92}$ So, too, where the court has exceeded its jurisdiction in ordering the sale, a confirmation would have no effect, for the sale being roid, there was no subject-matter. upon which the order of confirmation could act. If the court had no jurisdiction to order the sale, it had none to confirn it, for where there is no power to render a judgment or to make an order, there can be none to confirm or execute it. ${ }^{93}$ But where these questions do not arise it is presumptive cridence that the sale was regularly and properly marle, and questions arising under it ean not le presented collaterally. ${ }^{94}$

$\S 485$. Certificate of Sale. Where a contract for the sale of land is executory on both sides, it is necessary that it should be evidenced by a memorandum in writing, signed by the vendor, and sheriff's sales form no exception to the gencral rule. ${ }^{55}$ The usual method is to exccute a certificate of sale. If no certificate or deed is given to the purchaser, and no memorandum of the sale is made on striking off the property, it has been held that the sale can not be enforced, even though the purchase money is paid, and the sheriff afterward nukes due return of

90 Thorn 1 . Ingram, 25 Ark. 53; O'Brien r. Gaslin, 20 Neh. 347; Koehler $r$. Pall, 2 Kan. 172; Hotchkiss $v$. Cutting, 14 Mimn. 537; Conover $v$. Musgriove, 68 Ill. 58.

91 Wills $r$. Chandler, 1 Mccrary (C. Ct.), 276. IIirkenbotham $v$. Blackledge, 54 Ill. 316.

92 Shriver's Lessee r. Lynn, 2 How. 60, and see Jacobus r. Smith, 14 III. 359.
93 Townsend $r$. Tallant, ::: Cal. 54; Hawkins r. Hawkins, 29 Ind. 70; Bethel $r$. Bethel, 6 Push (ky.), 65.

94 Crowell $v$. Johnson, $2 \mathrm{Neb}$. 146; Mathew $c$. Elly, 4 Orem. 2.25; Waton r. White, is Wis. 517. Sperk r. Pullman (4a., las lll. 3\%. 95 Puckle $r$ B Burlonur, 48 Ind. 274; Evans r. Ashley, \& Mo. 177. 
the alc. ${ }^{96}$ But this is an extreme view. The sheriff, in making sales, acts as the legal agont and representative of the plaintiff and defentant in the judgment, and of the acepted bidder at the execution ale, and he has the right to hind all the parties by his memorandmu. This, it seems, he may do by his return on the execution; ${ }^{97}$ his roturn of the facts attenling the purchase, made at the time of the sale, taking the case ont of the statute of frauds, ${ }^{n s}$ and binding all parties by an enforeeable executory contract. It is no part of the office of a sheriff's return, however, to show what land is sold on excention, the province of a return being to show the satisfaction or part satisfaction of the julgment, or failure to make satisfaction thereof, and the particulars of the sale, subject-matter, consideration, purchase, ete, are lest shown by the certificate of purchase or by the recitals in the sherifr's deed. ${ }^{99}$

Deeds do not isaue immediately upon execution sales, and, in many eases, judieial sales as well, hut a reasonable time is allowed duning which the judgment debtor may redeem the property upon parment of the judgment, costs, charges, etc., and a certificate stating the facts is issned to the purchaser at the time of the sale. ${ }^{1}$ A duplicate of this certificate is recorded by the officer in the registry of dcets, and the certificate, duplicate, or record of same, is, by law, make evidence of the facts therein stated. In case of redemption, as provided by law, a certificate

96 Gostiarl $r$. Ferguson, it Ind. 519: but see Sanborn r. Chamberlin, 101 Mars. 409.

97 Warehnise Co, $r$. Terrill, 13 Bush (Ky.), 463; Sabhorn $r$. Chamberlin, 101 Mass. 409; Remington $r$. Linthicum, it Pet. 92.

98 it is a prevaling ribe however, that after confirmation julicial sales are not within the st itute of framls; Bozza r. Rowe, 301 Ill. 198 ; Fire Ins. C'n, r. Lembis, 11 Paige, 491; Steward r, Gorvin, ?1 Mo. 36; Hutton r. Williams, 35
Ala. 503. And in some States they are held to be not within the statute at all: Fulton $r$. Noore, 25 Pa. St. 468: Halleck r. Guy, 9 Cal. Isl.

99 Gardner $r$. Eberhart, 82 111. 310.

1 The logal effect of the certificate is to evidence the lien of the purrhaser upou the lamls, for the amount of his bid and interest, during the proved allowed for rearmption: Vaurhn r. Ely. 4 Barb. 156. and see Evertson $r$. Sawyer, 2 Wend. 507 . 
of redemption is issued and recerderl in like manner. The crestificate of sale made by the sheriff is sufficiently shown as follows.

\begin{tabular}{|c|c|}
\hline $\begin{array}{l}\text { Seth IIanchett, sheriff } \\
\text { of C'ook Co.. Ills., } \\
\text { to } \\
\text { Hiram Simith. }\end{array}$ & 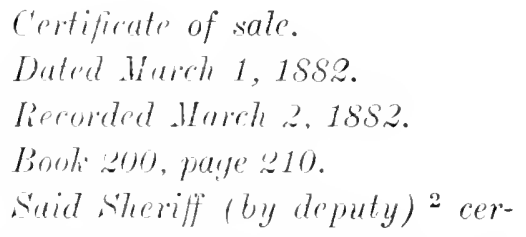 \\
\hline
\end{tabular}
tifies that by virtue of a certain (alias, pluries. ete.) writ of execution to him directed from the superior Court of Cook C'ounty. issued on a judgment renderd at the November Term. 1881, of said court, in favor of Witliam Thompsom. plaintiff, against Thomas Jones, defendant, for \$1,000.00 and costs, dated Febre-

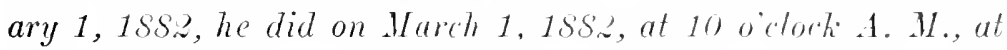
the front door of the court house in the city of Chirago (the time and place aforesaid having been duty advertised according to law), sell at public vendue all right, title and interest of said defendant in and to [here set out the description as found in the certificate] to II iram simith for $1,0.35 .00$, snid sum boing the highest and best bid offered for said trart or lot of land. the same having been first offered in separate trarts or lots without receiving any bid or bids therefor or for any part thereof, and the purchaser will be entitled to a deed of the premises so sold on Mareh 1, 1SS3, unless the same shall be redeemed as provided by law.

As has been seen, where lands are sold by orler of court, although the sheriff is a proper person to make the sale, the cont' has discretionary power to appoint a commissioner. master in chancery, or other officer of the court, or any fit and proper person to make it. Sales marle by a commiscioner or master, muler the direction of a court of chancery, lo not stand in all respeets on a footing with sales made by the sheriff under an exention. The latter are made under the naked authority of the writ, 
the former under the direct supervision of the court. ${ }^{3}$ Judieial sales are nsually intrusted to a master, who also executes the deed, and on such sale a certificate issues to the purchaser in like mamner as in sales on execution. The following abstract presents the salient features of a master's certificate:

\begin{tabular}{|c|c|}
\hline & \\
\hline Edward A. Dicker & Cer \\
\hline Master in Chan & $3,18 S O$ \\
\hline ery of the Circuit & $\begin{array}{l}\text { Rerorded May 3, } 1880 \text {. } \\
\text { Book } 210 \text {, page } 500 .\end{array}$ \\
\hline $\begin{array}{l}\text { Court of Cook } \\
\text { C'ounty, Ili., }\end{array}$ & $\begin{array}{l}\text { Said master certifics that in pursu- } \\
\text { ance of a decree 'ntered June 15,18\%9, }\end{array}$ \\
\hline $\begin{array}{l}\text { to } \\
\text { William Jackson. } \\
\text { Doc. } 10,02 S \text {. }\end{array}$ & $\begin{array}{l}\text { by said court in the cause in chancery } \\
\text { cutitled [here set ont the title of the } \\
\text { cause] he duly advertised according to }\end{array}$ \\
\hline
\end{tabular}
law the lands hereinafter described to be sold at public auction to the highest and best bidder for cash at 10 o clock A. M., on May 3. 1S80, at the front door of the court house, in the city of Chicago, Ill.

That at the time and place, so aforesaid, appointed for said sale, he attended to wake the sume and offered and exposed said lands for sule at public auction to the highest and best bidder for cash. Whereupon William Jackson offered and bid therefor $\$ 1,000.00$, and that being the highest and best bid therefor, he accordingly structi off and sold to said bidder for said sum the said lands which are situated in Cook County. Illinois, and described as follows, to wit: [here deseribe the property]. He further certifies that said William. Jackson, his legal representatives or assigns, will be entitled to a deed of said premises on May 3, 1SS1, unless the same shall be redeemed according to law.

The certificate of sale confers on the holder no title $1:$ interest in the land, especially where the time for redemption has

3 Meetze $r$. Padgett, 1 S. C. 127; Lasell $r$. Powell, 7 Coldw. (Tenn.) $27 \%$ 
not expired, ${ }^{4}$ and the possession of the defendant in execution can not be disturbed until his title has been tranterered by the officer's deed." Ifter the exreution of a deed the criticate of sale ceases to be an essential mmiment of title. ${ }^{6}$

\$ 489. Assignment of certifieate. A eertificate given at a judicial or execution sale is usually asignable by indorsement, and the assignee is entitled to the benefits, in every respect, to which the original purchaser was entitled therefrom. On the other land, it is subject in his hands to all defenses that could have been made against it in the hands of the assignor, such assignee standing in the shoes of the original purchaser. But such purchaser does not take the land itself by his birl; he has only an incipient interest that may or may not ripen into an absolute estate; and as a party can not asign that which he hath not, so such purchaser, not haring the legal title to the property, of course can not assign it. It wonld seem, therefore, that the assignee can not le regarded as an innocent purchaser, nor entitled to protection as such, until he is elothed with a legal title by a sheriff's deed. ${ }^{\top}$

Where the original purchaser dies before the issuance of a deed, in the absence of an express derise, his executors will succeed to no rights in the land, and have no right to demand a deed, but the sheriff's deed should be made to the deceased purchaser's heirs at law. ${ }^{\mathrm{s}}$

\section{$\S 490$. Proof of Title Under Judicial and Execution}

Sales. Where a person attempts to arail himself of a clecree, as an adjudication upon the subject-matter, or as a link in his chain of title, founded on a judicial sale under the decree. he is required to prodnce the judgment roll, so that, among other things, the court may determine, on an inspection of the untire roll, whether the court which rendered the decree had jurisdic-

4 Huftalin $v$. Misner, 70 Ill. 55.

5 Hays $v$. Russell, 70 Ill. 669.

6 Gardner $v$. Eberhart, 82 Ill. 316.

$\tau$ Roberts $v$. Clelland, 82 Ill. 538;

Reynolds $v$. Harris, 14 Cal. 667 , and see Messerschmidt $\quad l$. alicr, 2.2 Minn. 81.

8 Potts r. Davenport, 79 111. 455; Swink $v$. Thompson, 31 Mo, 336. 
tion "f the subject-matter." It is true, the purehaser may rest, in support of his title, upon the judgment or decree, and the deed theremder, but he must produce a valid judgment or deeree, and the well established rule is, that the method of proving such judgment w decree to be valid is by the prodnetion of the roll, on an inspection of which it may be determined whether the court had the necessary jurisdiction of the parties and of the subject-matter. ${ }^{10}$ In analogy, therefore, to the presentation of the judgment roll, a synopsis of the papers and proceedings in the cause should always form a preliminary statement to the abstract of the officer's deed, and this should be sufficiently full and explicit to enable counsel to pass with judicial discrimination mpon the merits of the title as affected by the proceedings. In all proceedings in equity, where the suits are wholly or partially in rem, this is always done, but in legal actions, or where the proceeding is in personam, a different rule is generally observed. Tho reason for this is apparent, in that personal actions afiect the land only collaterally and by reason of the statutory lien of the judgment, hence, cxaminers have not deemed it necessary to show the rarious steps which led up to the judgment, but have contented themselves with a simple showing of the fact that judgment was rendered. Tet if the conrt failed to obtain jurisdiction of the person of the jurlgment debtor, and has erroneonsly proceeded to hear the proofs and renter judgment when no sufficient steps had been first taken to bring the parties properly before it, any sale made in satisfaction of such judgment would be roid and confer no title on the purchaser. ${ }^{11}$ These are extreme cases, yet they have occurred, and similar cases may again occur, and it wonld seem, therefore, that in actions in personam, followed by judgment,

9 See "Actions and Proceedings," infra.

10 Harper $r$. Rowe, 53 Cal. $233 ; 1$ Greenl. Ev. \$511; 2 Phil. Ev. 138; Vail $r$. Iglehart, 69 Ill. 33:.

11 Nibee $r$. Ward. 8 Mass. 79 ; Miller $x$. Ilaudy, 40 Ill. 448. In this case, there was a sale under exeeution: the judgment was afterward declared void for want of proof of service, and the sale declared a nullity; amd see Johnson $x$. Baker, 38 Ill. 98: hut compare Fitch v. Boyer, 51 Tex. 336. 
execution and deed, sufficient should be shown to enable counsel to see that the partics were properly before the court. In any event, the examiner should inspect the judgnent roll as well as the doeket, and if, from such inspection, palpable errors are manifest they shomld be properly noterl.

\$ 491. Continued-Presumptions. It is true, howerer, as a general proposition, that a domestic juclonent of a court of general jurisdiction, upon a subject-nutter within the ordinary scope of its powers and procoedings, is entitled to such absolute rerity, that, in a collateral action, even where the record is silent as to notice, the prosmption, when not contradieted by the record itself, that the conrt had juriadiction of the person also, is so conclusive that eridence aliumde will not be admitted to contradict it. ${ }^{2}$ It is probably on the strength of this doctrine that examiners have been aceustomed to show only the fact of julgment, and not the prelininary steps attending it, assuming the julgment to be ralid: and attorneys have passed upon the facts so presented in view of the oft-repeated principle, that all that a purchaser must show to sustain his title, is a valid judgment, execution, and a sheriff's deed. $^{13}$ If the court had jurisdiction of the subject-matter, and the proper partics were before it, and its proceedings were regular, and the sale was properly conlucted, then the title of an innocent purchaser will not be disturbed, and he may rest secure upon the assurances of his deed. These are the great essentials to a perfect title, and all that a purchaser must show to satisfactorily prove it.

A purchaser is not hound to go through all the proceedings,

12 Fitch $r$. Boyer, 51 Tex. 336; Guilford $\imath$. Love, 49 Tex. 715; Grifin $t$. Page, 18 Wall. 3.50; Wahn $v$. Kelly, 34 Cal. 391; Freeman on Judg'ts, §124; 2 Am. Lead. Cas. 736.

1. Coffee $v$. Silvan, 15 Tex. 362; Hugles $v$. Watt, 26 Ark. 228; Lennox $v$. Clarke, 5z Mo. 115; Silahn $v$. Gillespie, 48 Ind. 397 ; Mayo $v$.
Foley, 40 Carl. 2.8. The ammon law presmuption in favor of the jurisciation and regularity of the proceelings of comts of record or general juristiction, had its origin in the faret that, at common law, no judgment could be wiven against a defomdant molil he had appeared in the artion: Nefl $r$. Ponnoyer, 3 Sawyer, 274. 
and to lonk into all the ciremmstances, and see that the judgment or decree is right in all its parts. He has the right to presume that the court has taken the necessary steps to inrestigate the rights of the parties, and upon such investigation has properly rendered a judgment or decreed a sale. He will not be affected by any imperfection in the frame of the bill if it contain sufficient matter to show the propriety of the decree, and the propriety of the decree must be attested, and its validity determined by the then existing eiremmstances. ${ }^{14}$

$\$ 492$. Probate Sales. "Probate sales," says Mr. Freenan, "we are sorry to say, are generally viewed with extreme suspicion. Though absolutely essential to the administration of justice, and forming a portion of almost every chain of title, they are too often subjected to tests far more tring than those applied to other judicial sales. Nere irregularities of proceeding have, even after the proceedings had been formally approved by the court, often resulted in the orerthrow of the purchiser's title. In fact, in some courts, the spirit manifested toward probate sales has been scareely less hostile than that which has made tax sales the most precarious of all the methods of acquiring title." 15 Possibly the learned author has taken a tow extreme view of the matter, thongh it must be conceded that by reason of the many jurisdictional facts and circmmstanees which environ sales of this elaracter, titles derived thereunder are not always as stable as those derived under sales in equity, or even by execution. ${ }^{16}$ The jurisdiction of probate

14 Zirkle $r$. Mccue, $26^{\circ}$ Grait. (Va.) 517 .

15 Freeman Void Jud. Sales, 44.

16 While the decrees of a probate court, upon matters within its juriscliction are as final and conchusive as the julgments of any other court (Balker r. Barker, 14 Wis. 181: Cumminge r. Commines, 123 Mats. 271; Darton $r$. Mintzer. 22 Minn. 3933) and its reererds import alenlute rerity (Wond r. Mrrick, 16 Jlinn. 494; Tiblitits $r$. Tilton, 24
X. II. 124), yet, owing to the peculiarly connected character of its proceedings, and the interdependence of all its acti, as well as the further fact that its practice is neither in accordance with established common law nor chancery precedents, and hence not reviewable in the light afforded by such precedents, they are not merely voidable if want of jurisliction appears, but absolutely void (Sumner $r$. Parker, 7 Mass. 79 ; Smith v. Rice, 11 Mass. 
courts to order the sale of lands of a decedent is statutory and linited, and nunt appear fom the record, but, while no intendments will be narle in its faror, the tendeney is to rispegarel mere irregularities, ermes of forn and other matters not directly affecting jurisdiction, and all presumptions in this respect are in faror of the sale and of the ralidity of the title based on such proceedings. ${ }^{17}$

Probate courts are inrested by law with a general jurisdiction in cases where real estate is to be sold for the paynent of the debts of decedents, and where a comrt ordering a sale has jurisdiction of the subject-matter and of the proper partics, even if the proceedings are irregular and erroneons, the decree and sale moder it can not be assailod in a collateral proceding, ${ }^{\text {s }}$ nor can the purehaser for that reason avoid the sale. ${ }^{19}$ Tntil reversed, the decree confers power to sell and pass the title, howerer erroneons it may be. ${ }^{21}$ To class of public sales are better entitled to a just degree of protection than those of administrators. 21

But while this represents the prevailing sentiment it must set be renembered that the administrator, as such, has no interest in or power over the land belonging to lis intestate at his death; nor has the probate court any jurisdiction orer it for any purpose whatever, but only a simple porrer to order its sale. This power is derived wholls from special legislative grant and its exercise is restricted to the lappening of particular contingencies. There contingencies are jurisdictional

507 ), and an unwarianted step at the outset will sullice to vitiate all sulsoruent proceeding- Thus, if the nrinal appointment of the administrator is voil, all the subsequent procecoling- are void: Gilly's Prob. Prac. 12: Frederick r. Pacquette. $19 \mathrm{Wi}$ - 541.

17 Reynolde r. Selmide, 20 Wis. 374; Moler r. Tuli], fo Mis. 60; Woods $r$. Mlontere 17 Micle. 22:8: Mornow $r$. Wefel. 4 lowa. $7 \%$; King $v$. Kent's IIrirs, 29 Ma. 54:2 : Mollitt r. Moffitt, 69 Mll. 641: Maurr $v$. Parri-h, 26 Ohio St. 636; liowen $r$. Bonel, 80 Ill. 351.

1s Nichols $x$. Milchel, 70 Ill. g.5s; Wing $r$. Dorlge, 80 Ill. 5tit: Dayton

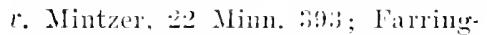
ton r. Wiksm, on Wis. 3sis: Falkner r. Guile, 10 Wis. 5ti3.

19) Wing r. Dorlge, so lll. sfit.

2u Wing $r$. Dolges, so lll. seft;

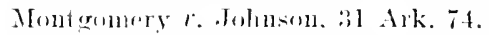

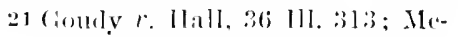
Cowan r. Foster, 3:; Tex. 241. 
and should all aprear aftirmatively. They consist, mainly, of the fact of insolvency of peremal estate, ${ }^{2}$ as shom by the administrator's report; notice to persons interested, and a finding of the fact of insulicieney of personal assots. The reeord must show on its face these jurisdictional facts. ${ }^{23}$

It must further be borne in mind, that the foundation of all title derived through an administrator is the fact of the death of the intestate. This must alwars afinmatively appear-directly and positively. Administrations are sometimes granted on presumptions, but every one acts at his peril in dealing with an adninistrator who has been appointed upon a mere presumption that his supposed intestate is dead; and all persons are conchively presmed to know, if the supposed intestate should subsequently turn up alive, that the grant of administration, and all acts done unler it, would be absolutely roid. ${ }^{24}$

\section{$\S$ 493. Nature and Reduisites of Probate Sales. Sales} in probate, thongh marle in comection with, and as a part of the regular administration and ecttlement of the decedent's estate, are ret to be regarded as special and independent proceedings. Such proceedings are regularly inangurated by the filing of a petition, stating the necessary jurisdictional facts, and praving for license to sell, and it is this petition, and the recital of the statutory requisites, which gives to the court its

20 The lien of a eveditor in probate is dificrent from all other liens now lond in this. What it ran never he cinforen witil the persumal extate of the decedent las been exhausted. Garrin r. Stewayt. 50 111. 2.?.

2.: lioot $x$. MeFerrin, 37 Minn. 17 . $2+$ suringer $r$. Shaventer. $118 \mathrm{X}$. c. A3: Nolia $l$. Simmons. 45 ris. 2.34: Thomas r. loople, 10 T 111. 517. The toxt ot ates the oll and well estallis? in mie and the one which obtrine rencally thromghout the Cnitert states. But of late years we nay fin sme departures lierefrom in a few States where it is held that where the fact of death has been presented to and decided by a court of competent jurisdiction the adjudication becomes conchusive of the fict. horrever erroneous such adjudication mas be, until set aside in a diret proceeding (Porter r. Purdy, 29 X. Y. 106) and that litles aequired under snch atgurlication wili remain intact. rotwithstanting the, smpposed decedent returns alive. See Srott $r$. Mroterl. j Mash. 303. The leading are on this point is Roderigas $r$. Erat River Savings Inatitution. 63 ×. Y. 46 ?. but compare the same rase in $76 \mathrm{~N}$. Y. 316 . 
jurisdiction to take congnizance of the matter ant make subequent orders in relation to same. ${ }^{25}$ The proceeding is in the nature of an action, of which the petition is the comnencement, and the order of sale the judgment, the whole forming a new, separate and independent proceeding, depending for its validity upon the suftieiency of the facts stated in the petition. ${ }^{26}$ All the necessiry features common to erpuitable actions, both as respects the subject-matter and the praties, must be present and affimatively appor, and as the action is alversary in its character, and in derogation of the rights of the devisees and heirs, all the parties laving an interest in the property, defendant as well as plaintiff, must be regularly hought before the court. $^{27}$ The filing of the petition will give the comrt jurisdiction of the snbject-matter, ${ }^{2 \times}$ lut juristiction must also be obtained over the persons of the heirs and derisees in the manner prescribed by law, as well as of the subject-matter, or its order will be void. ${ }^{29}$ Hence, the proceedings must show issuance and service of citations, or appearance in the action, and a due observance of the rights of minors and others under disability, for whom special guardians must be appointed, should they

25 Pryor 1. Downey, 50 Cal. 339: Hall v. Chapman, 35 Ala. 553 ; Jackson $v$. Robinson, 4 Wend. 436 ; Ethell $r$. Nichols, 1 Idaho (X.S.), 74I. Moffitt $r$. Mothitt, 69 111. 641. 26 The necessity for a sale is not a matter for the administrator or executor to determine, but is a conclusion which the eourt must draw from facts stated, and the petition must fumish materials for the judgment: Pryor $v$. Downey, 50 Cal. 298; Fihell v. Nichols, 1 Idaho (N. S.), 74 I.

2 T Morris $v$. Ifogle, 37 Ill. 150; Hoard $v$. Hoard, 41 Ala. 590; Guy $v$. Pierson, 21 Ind. 18; Fiske $v$. Kel logg, 3 Oreg. 503. This is contrary to the doctrine stated in Grignon's Lessee $v$. Astor, 2 Ilow. (U. S.) 319, which for many rears was arcepted in this conntry, and is founded on better reason and more correct principles. In that case it was held, that the proceeding is in rem and not adversary, and that the administrator represents the land.

as Grapson r. Wetlle, 63 Mo. 523; Bolsforl r. O'Commor, 57 111. 79. The text states the rule as usually understoorl, of course, jurjsdiction in the cont prononneiug a decree of sale does not rest mon the petition nor the arerments of pleadings but lupon the existenee of substantive fatch.

an Fiske r. Kinloger, :) Oreer. 50:3; Clark r. Thompinam, 47 Hll. 25; 1srael $v$. Arthur, 7 Col. 8. 
have no guardians, or if liaving guardians they fail to appear. ${ }^{30}$ The method of citation is statutory, but, as a rule, contemplates a general notice by publication and a personal serrice on all persons interested, if within the juriscliction of the court, and if the proofs show an insufficient service or publication, the subsequent proceedings are fatally defective. ${ }^{31}$

$\S 494$. Abstract of Probate Sales. Sales by an executor or administrator may be shown in comnection with the settlement of the decedent's estate, or as independent exhibits. Where a former abstract shows the death of the decedent, probate of his estate, etc., and a sale of all or a portion of the land of such decedent oecurs during a subsequent examination or continuation, no necessity exists for re-exhibiting the probate proceedings, and the abstract of the sale commences with the filing of the petition. Where the examination is original, sufficient of the action of the probate court numst be given to show the facts of deatl, applieation for probate, appointment of administrator, and proof of heirship, in case of intestate estates; and of probate of will, letters testamentary and devisees, in case of testate rstates. Examples of probate of wills will be found in the chapter on wills, and of the probate of intestate estates in the chapter on descents; a probate sale in either case would be shown somewhat as follows, making due allowance for the ninor differences which must appear between testacy and intestacy:

30 Fiske $v$. Kellogg, 3 Oreg. 503. The omission to make the guardian of the minor heirs or devisees a larty, can not be taken adrantage of in a collateral proceeding: Harris $v$. Lester, 80 Ill. 307.
31 Blodget $v$. Hitt, 29 Wis. 169 ; Molır $v$. Tulip, $40 \mathrm{Wis} 66$; Sibley $v$. Waffle, 16 N. Y. 180 ; Botsford $v$. O'Connor, 57 111. 72. 


\section{Probate Court of C'ook C'ounty. Int.}

\section{Probute Sulc.}

Samuel M. IIenderson, administrator of the Estate of Nathan Adams, deceased,

$v s$.

Charles TI. Adams, Henry S. Llams, Mary E. Adams, widom of Ninthan Adams, and Thomas R. Smith.
Prtition of Sammel M. II enderson, administrator aforesaid, filed Juty 6, 1851 .

liepresents (among other things) that the personal estate of decensed is insuffecient to pry claims ayduinst selid estute in the sum of site(30.00, besides the cost of admimistration. ${ }^{32}$ That deceased dical havimeg a derim and tille to the fortlouing deseribed real estate: [describing the same.] That sairl deceased loft surtiling Wary $E$. Alams, his widow. having a dower interest in his real estate; and Charles W. Adums, and IIenry S. Adums, his chithen, his only heirs at law. That Ilemry s. Adums is a minor and has no guardian. That Lot 2., Block 14, [etc..] is now occupied by and in the possession of Thomas $R$. smith.

Prays that a guardian ad litem may be appointed for said minor heir, and that the Court will order and divert said petitioner to sell the said real estate or so much as niay be neessiary to pay said deficiency.

Surom to July $6,18 S 1$.

Summons issued, dated July 6, 1SS1, to all of said defendants, retumate on the $3 d$ Monday of July, $18 S 1$.

Summons returned indorsed as follows: ${ }^{33}$ [In a necessary case set out the return.]

32 This is the vital part of the petition, for a sale of land to pay debts is never allowed until the personal property has been exhausted; this statement is therefore a jurisdictional fact: Foley $r$. MeDonald, 46 Miss. 238; Diversy $v$. Johnson, 93 Ill. 547.

33: The return of proeess in every action furnishes the proof of juris- diction over the person, and in all eases of defanlt or mon-aplestune of any of the parties the nuthol of service is invariably io b... shown

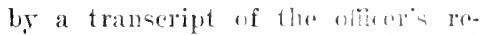
turn. Conteses partion arr lomplot

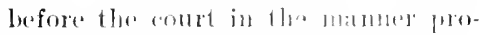

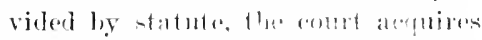
no jurisdiction orer tlement Domlin $r$ Ilettinger, 57 III. 348 . Where all 
Order entered July 25, 1SS1, appointing Charles Anderson guardian ad litem for said minor defendant.

Answer by said defendants and said minor defendant by his guardian ad litem, and reply thercto, filed July 25, 1SS1. ${ }^{34}$ [Note default, if any].

Decree cntered July 25,1581 . (Record 2 of decrees, page 49.) [Set out the decree or the substance of same].

Administrator's report of sale filed sept. 2.S, 1851.35

Represents, that in pursuance of a decree, etc., [set out the substance of the report]. Sillorn to, sept. 19, 1881.

Attached to the report of sule and filed therewith, is proof of publication and posting notices of sale.

Printed copy of notice of sule gires title, etc. ${ }^{36}$

Administrator's report of sale annored and sale confirmed, Sept. 22, 1581.

parties have appeared this beromes of minor importance. and a brief statement of the fact of service without discloing the methou is sufficient.

34 If the court has aequired juriscliction of the subject-matter by the filing of a petition, and of the persons of infint defendants by the publication of netice. a fatilure to appoint a gruardian ad litem, or his failure to answer. will not defeat the jurisdiction: Gage $r$. Schroeder, 73 Ill. 44.

35 It is not usual to abstract the report of sale, but where the record is silent on vital points or no evidence appears of statutory essentialc, as, of ponting notices of sale, or other necessary incidents, statenents under oath in a report of sale have been held sutficient in collateral proceedings: Woods $r$. Monroe, 17 Mich. 2989. In slich arses the recitals of the rejort become necessary to show validity. and should find appropriate mention.

si: See $\$ 477$ for abstract of notice of sale. 


\title{
CHAPTER XXVIIT.
}

\author{
ACTIONA ANI IROAEEIINGS.
}

\$495. Chancery procedings.

496. Anthority and jurndietion of chancery colerts.

497. Authority and juriscliction of probate courts.

498. Actions and proceedings to be noticed.

499. Huriadiction the great essential.

500. Notice afforded hy ehancery records.

501. Process.

502. Formalities of a summons.

503. Scrvice.

504. Proof of serviec.

505. Adlidarit and order of publieation.

506. Appearance without process.
307. Master's and referee's reports.

509. Verdicts.

500. Abstract of chancery procredings.

510. Injunctions.

511. Ejecturent.

5lo. Quia timet.

513. Partition.

514. Sperific performance.

5li. liedemption.

516. Forectosire.

517. Dower.

518. Diroure.

519. Tisht of eminent domain.

500. Procerlinge for condemmation.

531. Construction of wills.

$\$$ 495. Chancery Proceedings. In the compilation of abstracts the general nane of " Chancery Proceedings" has been given by examiners to all classes of actions that operate directly upon the land and culminate in judgments in rem. And while it is undonbtedly true that the proper tribumals for the trial of land titles are the common law courts, and that equitable jurisdiction is only invoked when the law is inarlecplate to give relief, yet the common law actions respecting land have to a great exteut been abolished, or supersoled by statutory remedies of the same nature but based upon equitable prinoiphes."

1 The State of New York. in 1848, State, whereby the then existing pascerl an art " $t$, simplify and forms of artions and pleatings in abridge the practice, pleadings and ammon law atses were abolished; procecelings" of the comrts of that the distinction between legal and 
Th many States no separate chancery jurisdiction exists and the law courts are anthorized to exercise chancery powers and administer aquitalble relief in all cases brought before them, and to adjust the claims of the parties litigant according as the right may aplear without refreme to the techniral rules applying to either jurisdiction. ${ }^{2}$ The common law actions resperting title, in such contrts, are regarded rather as equitable than legal proceedings, and rquitable defenses are pormitted, while the judgment of the court adapts itself to equitalle methals in disposing of the rights of the parties. ${ }^{3}$ This chapter will be deroted to a general review of all legal actions respecting land which partake of an equitable nature and to such actions as are strictly within the equity jurisdiction.

\section{\$ 496. Authority and Jurisdiction of chancery}

courts. The primary object of courts of equity, is, to supply defects in the adninistration of justice in the ordinary courts, assuning the power of enforcing the principles upon which the ordinary courts decide, when the powers of those courts or

equitable remedies abrogated; and a uniform course of proceeding, in all cases, was established. The State of Ohio some years later folIowed the example of New York, and the codes thus formulated by these two states, have been made the basis of the procedure of a number of other States. In some States the ancient practice is still retained, but in a greatly modified form, and the distinction between legal and equitable remedies preserved, though both remedies are administered in the same court.

2 Troost $x$. Daris, 31 Inl. 34 . When the legal title alone is in question it needs no support from equities, but stands impregnable in its own strength and is presumed to embrace all rquites. Proof of equities becomes important when the legal title is defective, or when it is proposed to assail it: Shaw $r$. Chambers, 48 Mich, 35.5.

3 The corles of procedure which abolish all distinction botween legal and equitable remedien, enteavor to blend them into one system, combining, or profesing to combine, the principles peculiar to each, but though the only form of a suit recognized by them is that known as the "civil action," the established principles pertaining to each branch of the law are still intact and of binding force and effieacy. The only true difference between the new and old systems is in the practical application of those principles: Rubens r. Joel. 3 Kern. 4ss; Scovill r. Griffith, ב Kern, 515; Rozierz 2 Van Dam, 16 Towa, 175. See Neyers $r$. Rasback, 4 How. (N. Y.) 83; Giles r. Lyon, 4 Cont. (N. Y.) 600 . 


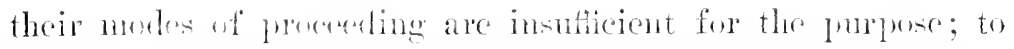
provent these principles, when enfored by the ondinary aourts, from beomine, antratry to the purpose of their original ostablishment, instrumente of injustice; and to decille on princiuldes of muiversil justice, when the interforenere of a conet of junlicature is menestry to prevent a wome, and the positive law in silent. Comets of equity also administer to the emels of justice by renovine inperlinents to the fair deeision of a puestion in other conts, by providing for the safety of property in lispute pending a litigation," by restrainiug the assertion of donbtful rights in a manner productive of irreparable clamage,"

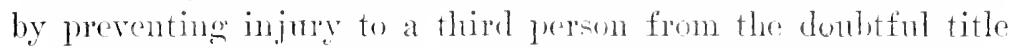
of others, and hy putting a bund to rexations and oploresive litigation, and preventing munecesary multiplicity of suits; ${ }^{8}$ and without penomeding any judgument on the subjoct, by compelling a discovery which may enable other courts to wive their judgnent; and hy preserving testimony, when in danger of hoing lost, before the matter to which it relates can the mane thre subject of judicial investigation. In one way and another the exereise of this juristiction often aftects the tith to lanel.

s 497. Inthority and durisdietion of Probate conds. The probate courts of the [nited States are conrts of special and limited juristiction, deriving all their anthority fon the statute. $^{10}$ But while the scope of their juristiction is restrieter they can in no proper sense be regarded as inferiol tribunals, as is sometimes asserted, and their judgments, within the spluere of their authority, are not distinguishable from the dropruinations of ofher courts. They possess original and frequently exclusive juristiction in all matters pertaining to the sottlement

4 Whitncy r. Roberts, 22 Ill. 381; Long $r$. liarker, sis Ill. 4:31 ; Bennett $r$. Nidhols, 12 Mieh. 22- Mears $r$. llowarth, 34 Misd. 19.

5 Menntyrer. Storey, so Ill. 127.

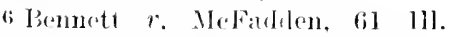

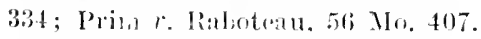
isentt r. Moore, 3 Scann. (III.) 306.
S Srott $r$. Moore, :3 Sram. (Ill.) 300: Tmp. Firn Ins. Co. r. Cumming. S1 11l. 2ati; Peatty r. Dixull, sic cal. 619); Thire tre. M. IR. ('o. r. Mapor, ol(...54 N. I. 1.59.

9 Mit. I'l. 3; I smith's ('hatr. Prac. ".

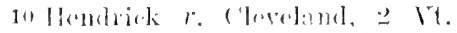

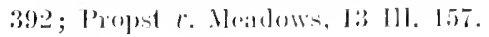


of estates of dreeased persons, ${ }^{11}$ which jurisdiction contimues so long as there is any occasion for its exereice, and until there has leen a foll and complete settlement and distribution. ${ }^{12}$ They aloo posioss, so far as may be necessary, a portion of the equitable powers exereised by a cont of chancery, and are not eonfined to the technieal mules of common law in opposition to established chancery principles. ${ }^{1+}$ They are ordinarily courts of record upon the aduinistration of estates, or other matters over which they poseses a general jurisdiction, and as liberal intendments are, or should be, made in their favor, as are extended to the procedings of the eirenit compt. ${ }^{15}$ Their jurisdietion in no State rxtends to controversies respecting the title to land, lint the peculiar nature of the matters entrusted to their charge makes their julgments and decrees of controlling eftieacy in the decision of questions relative to title, which may arise in other courts.

\section{$\$$ 498. Actions and Procedings to be Foticed. The} actions and proceeding that call for special notice on the part of the examiner, are such as relate to the recovery of specific real property, or the possession thereof, callert ejectment; ${ }^{16}$

11 A court of chancery may. in the exercise of its general jurindiction take upon itself the alministration of estates, and thus, in a particular ase, supersede the jurisdiction of the probate conrt: Freeland $r$. Dazey, 25 Ill. 294; but the interference of a court of chamery in the settlement of estates is usually confined within the narrowest limits, and has gone upon the ground nerely of atiling the jurisdietion of the probate court in those points only wherein its funetions and lowers are inadequate to the purposes of perfect justice, retaining its ancillary jurisdiction to the same extent over matters in the probate court, which it has over those in the common law counts: Adams $x$. Adams, 22 Vt. 50; Heustis $r$. Johnson, st Ill. 61 . 12 Keeler $r$. Keterer, 39 $V^{t} .550$.

13 Bennett $r$. Whitman, 22 Ill. 48: Appeal of Sehaeflner, 41 Wis. 260; Prooks $r$. Chappel, 34 Wis. 405.

14 Robinson $r$. Sirift, 3 Vt. 283.

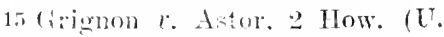
S.) 319; Propst r. Heatows, 13 Ill. 15; Moreland $t$. Lawrenee, 23 Minn. 8t; Barker $r$. Barker, 14 Wis. 131: Ustrom r. Curtis, I Cush. 160 .

16 Ejectront is a common law remely, but the statutory action substituted in many States is equitable in its nature, and in at least one State the action is a substitute for a bill in equity. 
actions and procerdings for partition: ${ }^{17}$ forcelosure of lions 18 and mortgages; bills to quiet title; actions brought to enforee the specific pertormance of land contracts; proceedings under the right of eminent domain; suits for dower; and incidentally such bilk, actions, or proceedings as from their nature may operate as lis pendens. All the procecdings specially enumeratod, whother pending or closed ly leree, shonld be carefully scrutinized and stated in the abstract with a reasonable degree of detail. The decree entered in these matters, when followed by deed, is the foundation for such deed, and of equal dignity with it, while the anterior proceedings go to establish the validity of the decree. In addition to those matters of exclusive cognizance in the eireuit court, the examiner will also show all proceedings in the comnty (probate) conrts that incidentally affect title, hy reason of the relation of the parties to the subject-matter. In this way matters relating to adoption, guardianship, etr.. will frequently appear, as well as assignments of dower, homestearls, ete.

\& 499. In of all decrees, as well as sales and conveyances which may rosult from them, lepends on the jurisdiction of the court, ${ }^{19}$ and this has roference both to the parties and the subject-matter. Both of these particulars must satisfactorily aplear in the abstract, and are shown in the one ease by a statement of tho roturn of the summons, the mothod of service being also given where greater certainty is desired, and in the other by a synusis of the bill, answer, and other pleading-. The decree in all instances must conform to the process and allewations, i. e., to the parties in the action and the matter reciterl in the pleadings. ${ }^{20}$ It will therefore he seen that a correct rendering ot

17 Partition is aloo a comnon law action: Hopkins $r$. Mediey, $97 \mathrm{Ill}$. 40.2: lut partakes of many apuitable qualities. and equity has jurisliction als woll as law conts: Hew r. Vois, 52 11!. 472.

1s. 1 suit to enforee a mechanic's lien, allhough statutory, is substan- tially a chanery precesing. and is governed ly the dhanesy prodtare:

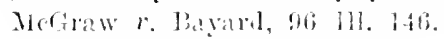

19 Weidersum $r$. Xammam, 63

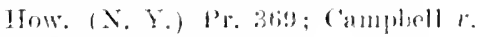
Nocillan. 41 111. 45.

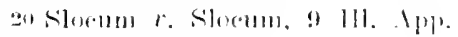
418. Thus, one reter wan unt be 
the commencement of the action; statement of facts constituting the subject-matter; and a full presentation of the adjudication made thereon, are the only matters of prime consideration on the part of the examiner, and when these sereral matters show apparent regularity and a just correspondence in all their parts, correct and satisfactory opinions may be predicated upon them, even thongh minor details may have been neglected, and positive error is shown by the record.

Where it appears from the whole record that the court had no jurisdiction orer the person or subject-matter the judgment is roid. By jurisdiction is meant the right to adjudicate concerning the subject-matter, ${ }^{21}$ and by subject-natter is meant "the nature of the canse of action and of the relief sought." 22 $A$ court may be said to have juristiction of the subject-matter of a suit when it has the riglit to determine the issne between the parties or grant the relief prayed. The issue is determined from the pleadinge. When the court has cognizance of the matter as it appear's from the pleadings, and has the parties loffore it, then the jutgment or decree which is authorized by the pleadings, howerer erroneous, irregular or informal it mar be, is ralid nutil set aside or reversed on appeal. ${ }^{23}$

500. Totice Afrorted by Chancery Records. It is a fomlanontal rule in equity that purchasers are directly affocted by every matter or circumstance concerning the title to the property they take, which athimatively appears from the plodings or acees of comts of competent jurisdiction, in actions relating to such property, whether such purchasers have actual notice or not. ${ }^{24}$ It is the application of this rule which

alleged and another proved: Neredith $r$. Little, 6 Lea (Tem.). 52I; Parkhurst $r$. Race, 100 1ll. 207.

21 Munday $r$. Vail, 34 N. J. L. 429.

22 Cooper $r$. Reynolde, I0 Wall (U. S.) 316.

23 Hope $r$. Blair, J05 Mo. 85; Tancaster $r$. Wilson, 27 Gratt. (Va.) 624 .
24 Leitch $r$. Wells, 48 N. Y. 585; Jackson $\ell$. Warren, 32 Ill. 33I; Hersey $r$. Turbett, 27 Pa. St. 418; Blanchard $r$. Ware, 37 Iowa, 305 ; Hunt $r$. Haven, 52 N. H. 162. The same rule has been frequently applied in actions at law: See, Jackson $r$. Tuttle, a Cow. ( . Y.) 233; Howard $r$. Kennedy. 4 Ala. 592; Bennett $r$. Williams, 5 Ohio, 461 . 
renders necessary a searehing investigation of the court rolls whenever real property is sold, for every man is presumed to be cognizant of what transpires in the courts of justice, and the law will eharge him with aetual notice of whatever there oceurs, which affects the merits of the title he would take. ${ }^{25}$ This rule, which has always been considered a hard one, ${ }^{26}$ is not a favorite with the courts, who are crer inelined to limit its application, and it wll not be extended to embrace collateral matters, or matters not specifically mentioned in the bill or decree. $^{2 \pi}$ "In the investigation of titles," says Mulkey, J., "purchasers look for decrees and judgments against those who appear of record to have been owner's, and when it is ascertained that a particular decree or julgment does not affect the title which is the object of inquiry, it is believed not to be customary to look further; and to hold that purehasers are affected with constructive notice of every fact relating to the purchased estate that may happen to appear in some of the files of a ease, and not elsewhere, would, in our judgment, be carrying the doctrine of constructive notice to a dangerous extent. The establishment of such a rule would have a direet tendeney to msettle titles, for no one conld know of a certainty when he was getting a good title, without examining the files in every case in the county where the land lay, and this wonld be wholly impracticable. We hold, therefore, purehasers are not bound to look beyond the judgment or decree, and the legal effect it may have on the title which is the subject of inquiry." 28

$\S 501$. Process. Equity suits are commenced by the filing of a bill or petition in the office of the elerk of the court in

25 Leiteh $t$. Wells, 48 N. Y. 585; Fissler's Appeal, 75 Pa. St. 48:3 Loomis $v$. Riley, 24 111. 307. 572 .

25 Hayden $v$. Bucklin, y Paige,

27 Dugan v. Follett, 100 1]l. 581.

28 Dugan v. Follett, 100 Ill. 581. This rule is in consonance with the general doctrine that one buying land, of which the record tithe is in the srantor, is not hommd ly egaities stated in derels unemmerted with the rhain of title, and of which he is not informed. Sre Odle v. Odle, 73 Mo. 289. 
which the action is lrought, which bill contains a statement of the facts constituting the complainant's claim, and a prayer for such relief as he may deem limself entitled to. Upon the filing of this bill or petition process issues to compel the appearance of the defendants. This is the ancient chancery procedure, and process issued before the filing of a bill, or service made prior thereto, is a nullity. ${ }^{29}$ The codes substitute a new procerture, by which the issuance of summons is made, in ordinary cases, the commencement of the action, ${ }^{30}$ but the law governing the service of process is substantially the same, and the court in either case derives its jurisdiction only from a full and technical compliance with the statute. 1 discussion of practice is foreign to the purposes of this work, and in speaking of these matters reference can only be made to the commonly aceepted principles which are recognized by all courts and are applicable to all systems of practice, trusting that the points given will suggest other's depending upon local rules and decisions. The proces of a court has vitality, and may be enforced, anywhere within its jurialiction, but bevond that it is of no effect. Hence, a service ontside of its jurisdiction confers no rights over the pereon of the defendint. ${ }^{31}$

$\$ 502$. Formalities of a Summons. It is not neeessary in the abstract of court records to set out minutely all the papers and files, and as a rule the practical purposes of the abstract can be accomplished by references and partial statements. The summons, however, is rital, and unless there has been an appearance, the formal requisites are juriselictional. ${ }^{32}$ When the summons, as under the old chancery practice, issues out of the erourt where the bill has been filed, it must be with proper

29 Story's Eq. Pl. § 7 ; Barton's Suit in Eq., 39 ; Hodgen $v$. Guttery, 58 11l. 431.

$3 n$ This is the procedure of the New York cole and all systems hased thereon. This is also the procelure in legal actions at common law.

31 lsett $r$. Stuart, $80 \mathrm{Ill} .404$. In some of the States the statute provides for actual peronal service without the State. and pernits the notice threby given to supersede the neeesity of publication.

:2 Orendorff $t$. Stanberry, 20111. 89: Niller $r$. Handy, 40 Ill. 448 ; Garland r. Britton, 1.2 111. 292: Resemer $r$. The People. 1.5 IIl. 4:98 
Venue, ${ }^{38}$ for a defendant has a riglet to know when and where he is required to apprear, and when the writ fails to furnish such information, it is void.:4 It must rum in the name of the

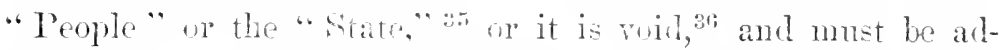
dressed to the sheriff of the connts in which the defendant resides if he loe a resirlent of the State. ${ }^{37}$ It nust correctly describe the parties to the suit, ${ }^{3 *}$ and, when required by statute, the cause for which it is lorought," and must be made retumable to a particular term. ${ }^{40}$ When issuing from a court it must be tested in the name of the clerk ${ }^{41}$ or presiding judge, ${ }^{42}$ and must bear teste of the day on which it is ismed.t3

by some of the codes, the summons may be issued by an attorney of the court, and need not be signed by the clerk or judge, but must be subscribed by the attorney who causes same to issue. ${ }^{4}$ When regarded as the direct mandate of the court,

33 Orendorff $r$. Stanberr, $20 \mathrm{Ill}$. 89. And this rule has not been changed by the codes: Blanchard $r$. Strait, \& How. (X. Y.) st. The force and efiect of a reme in a judicial writing is to inclicate the county wherein the comt in acting: Van Dusen $t$. People, is 111. 645 .

34 Orendorff $r$. Stanberry, 20111. 89. A cole summons requiring the defendant to serve a copy of his answer upon "the subscribrr." the plaintifl"s attorney, at a place designated, is snficiently certain under the corle, and confers jurisdiction: Hotchkiss r. Cutting. 14 Minu. 537.

35 C'urry $r$. Himman, 11 111. 420. The style is generally ronstitutional. 96.

36 Ferris r. Crow, 5 Gilm, (Ill.)

si A summont i-sued by the derk of one conntr, aldhesousl to the

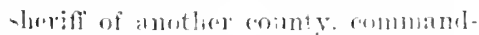
ing him to smmmon a chefomlinnt in his county to appear at Lincoln, in saill county is roid: Gill $r$. Hoblit. 2:3 111. 473, and see Kennedy r. People, 15 Ill. 41s. The X. Y. code summons is aldressed simply to the defendant.

:S Fichardion $r$. Thompion, $4 \mathrm{I}$ Iil. 202; Rogers r. Green, 33 Tex. c6l.

39 McDermill r. Rukell, 4l 111. 489: King $r$. Blood. 41 Cal. 314.

4i) A summons returnable to the wrong term confers no juridiction on the court to render a judgment in the artion: Culver $r$. Phelps, 130 I1!. 217.

41 Yorton $r$. Dow. 5 Gilm. 459; Costly $r$. Driver, 4.5 Ala, 2:39; Milson $r$. Owen, $\left.\frac{1}{x} \mathrm{~d}\right]_{\mathrm{il}}$. 451.

42 Brown r. Parker. 15 Ill. 307; Howerter $r$. kelly. 23 Mirh. $\$ 33$. 43 Brown r. Parker, 1.5 Ill. $30 \pi$.

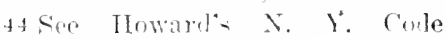
(1s.is), 16:2. Thie in the methot in mont of the Stateis which employ the X. Y. ende.

15 Jorsemer 1. People. 1.5 111. 439; yorrian r. Silverbmen, 133 111. 5.j). 
a seal is indispensable to its validity, ${ }^{45}$ but under the code system this is munecessary. ${ }^{46}$

\$ 503. Service. To bind a person by a judicial sentence he must be a party to the proceeding, and must have either actual or constructive notice thereof, ${ }^{47}$ or enter his appearance. ${ }^{48}$ These matters are jurisdictional, and where the service of the sunnmons is insufficient to confer jurisdiction, the judgnent or deeree as to the defendants is a mullity, ${ }^{49}$ and open to attack in all collateral proceedings. ${ }^{50}$ The retmrn of the officer serving the process must show strict compliance with the statute, before the court can obtain jurisdiction of the person, ${ }^{51}$ and this has reference both to the time, the manner, and the person on whom the service was made. 52

When personal service can not be made, by reason of the absence of the defendant, or because he can not be fouml, a substituted service is prescribed by statute, but in making this service, as well as in ease of constructive service by publication, the requirements of the statute must all be strictly complied with, and this must affirmatively appear on the record. ${ }^{53}$ Service, or eonstructive notice, by publication, was only obtainable formerly on the return of process non est inventus, and such is still the rule in some States, but ordinarily, where an affidavit of non-residence has been filed a constructive service by advertisement may be obtained. ${ }^{54}$

46 For a brief period a U. S. liev. stamp was required on all process, but this law was repealed March 2, 1867 ; see 14 U. S. Stat. at Lairge, 475 .

4 i Borders $r$. Nurphy, is 111. 81; Easterly $r$. Goodwin, 35 Comn. 273. 4 s Barker $r$. Ins. Co., 24 Wis. 630.

49 Botsford $v$. O'Conner, 57 Ill. 72.

50 Haywood $v$. Collins, 60 Ill. 328.

51 Cost r. Rose, 17 11l. 276; Par dom $t$. Dwire, 2:3 Ill. 572; People $r$. Bernal, 43 Cal. 385.
52 Botsford $v$. O'Conner, $57 \mathrm{Ill}$. 72 ; Hochlander $v$. Hochlander, 73 Ill. 618; Mack $v$. Brown, $73 \mathrm{Ill}$. 295; Rankin $v$. Dulaney, 43 Miss. $19 \overline{7}$; York $r$ Crawford, 42 Miss. 508 ; Hendley $r$. Baccus, 32 Tex. 328 ; Vandiver $v$. Roberts, $4 \mathrm{~W}$. Va. 493; Melvin $v$. Clark, 45 Ala. 285.

5.3 Boyland $v$. Boyland, $18 \mathrm{Jll}$. 551; Miller $r$. Mills, 29 Ill. 431; Wells r. Stumph, 88 Ill. 56; Williams $r$. Downes, 30 Tex. 51 ; Brownfield r. Dyer, 7 Bush (Ky.), 505 ; Mullins $v$. Sparks, 43 Miss. 129.

$5+$ Millett 1. Pease, 31 11l. 377; 
In all cases of constructive serrice the statute must lio strictly pursued, and as the aftidavit of nom-residence contitutes the basis of an order of pullication, whenever snch order is required, it is escential that such affidavit should appear of record, and, as a matter of conrse, be properly exhibited in the abstract in comnection with the order of publication, ${ }^{56}$ notice, and publisher's proof of publication.

It is now generally enncederl that the State possesses the power to provide for the adjudication of land titles within its linits, as against non-residents who are brought into court only by publication, and decrees based on snch constructive service are as valid and effectual as if rendered with the parties actnally appearing. ${ }^{5 i}$

$\$$ 504. Proof of Service. The service of a summons is ordinarily proved by the return of the sheriff or other person serving it, ${ }^{5 s}$ or ly the admission of the person so served, ${ }^{59}$ but in all cases where the record shows an appearance of the defendant, this becomes a matter of minor importance, for a general appearance is an admission on the part of the defendant that he has been regularly brought into court, and subjects him to

Tibbs $r$ Allen, 27 Il], 119: Coons $v$. Throckmorton, 25 Ark. 60.

55 Bardsley $r$. Hines, 33 lowa, 157; Merrill $r$ Montgomery, 25 Mich. 73; Brrne $r$. Roberts, 31 Iowa, 319: Coons $v$. Throckmorton, 25 Ark. 60; Millett $v$. Pease, 31 H1. 377 . In this ease, while holding the affidavit to be the basis of the order, it is yet held, that where the reeord shows a notice by publication, which recites the fact that an affidavit was duly filed, but does not appear of recold, the court will presume that the affidavit was duly filed ; and see Tompkins $r$. Wiltberger. 55 Ill. 38.).

56 A rule of rourt providing for publication on filing an aflidavit of non-residence may take the place of a formal order in each case. It will not be necessary to show the rule in the abstract.

5 T Perkins r. Nakeham, S6 Cal. 580: MeLaughtin $v$. McCrors, 55 Ark. 442; Adams $v$. Cowles, 95 Mo. 501 .

58 No person can execute a process in his own favor: Snydacker $r$. Brown, 51 Ill. 357. The return of a process server, if other than an officer, must be under oath.

59 An admission of service is not very satisfactory as cridence. The romet takes jurlieial notice of the sirmatures of its oflioers hut is uot prommend to know the signature of a party defendint, who has not appreated: lifelificld $r$. Burwell, 5 Jlow. (X. Y.) :34l. 
the juristiotion thereof." In such rases it wonld seem that a passing reference to the issuance and service of summons would be sulticient, thongh many attomeys require a synopsis or forll transeription of the officer's return, particularly in the ase of infants, lunatios, and persons muler disability, when the apporanes is hy guadian. But where a plaintiff molertakes to ohtain a judgnent or decior acainst a defendant, withont any appearance by the latter, oithor in person or by attorney, he is repuined at his peri] to bring such defendant within the jurisdiction of the tribural in whole he is suing, or his proceedings will be set asile as inregular, anel totally defective and void. ${ }^{61}$ In the case of joint dofendants this mattor is particularly important, for, althomgh the plaintiff nay generally proced against the defendants served, no valid julgment can be rendred against those not sorved, except that service upon one momber of a firm has, in some instanees, been held to give the compt juriscliction orer all the members in an action brought against the firm. ${ }^{62}$

Whenever, therefore, the record shows no appearance it is alvisable that all matters relating to service be set ont minutely and in detail. In case of personal service, show the retmm Jriefly, but alwars displar enongh to show the jurisdictional essentials; who were served, when, where, ete. In case of sub-

bu Dix $r$, Palmer, 5 How. (N. Y.) 2333 ; Webh $r$. Mott, o How. (N. Y.) 439 ; Barker $\ell$. Ins (o., 24 Wis. 630; Bustancte $\ell$ Bescler, 43 Miss. 17:2; Bowin $\ell$. Sutherlin, 44 Ala. 2is: Liles r. Woods, is Tex. 416; Abbot $r$. Semple, 2.5 Ill. 107.

(i1 Williams $r$, Valkenlurg, ]fi How. (N. Y.) 14t; Robert $r$. Stowers, 7 Bush (Ky.), 295: Grantern $r$. Rowecierranee, 27 Wis. 488. A distinction is sometimes made betwern a total wint of servies of prowens. and a defective servien, as to their effoct in judicial procene? ings. Tn the one ane a jutgment or decree is lield to be corm non judice and roid. In the other, the defective service gives the defendant actual notice of the proceedings against him, and the judgment or decree, although erroneous, is ralid until reversed loy a direct proceeding in an appellate jurisulietion; and its validity can not be collaterally called in quention: Harrington $r$. Wollord, 4 li Miss. 31.

1;2 Anderson $r$. Arnette, 27 La. Ann. 237. Yot servime upon an alleged partner, the fact of partnerthin not lieing etablished, does not comfer juristiction upon another :?! : d partner: Nixon $\iota$. Downey, 4..2 lowa, 78. 
stituted servior. show the return rutire; that is, a literal transcription. If the service is effected by notice and publication, show a synopris of the notice and proof of publication.";3 The advertiscurent in the lattre case performs the same office as process, $^{64}$ and it is not enongh that the decree recites that the defendant has been duly scrved, or that he has been regularly notitied; the record should show process or notice duly served or publishod and a decree pro confesso is rendered erroneous and invalid when these particulars are wanting. ${ }^{65}$

A decree renderen mpon the constructire notice afforded by publication is not regarded in many States as final or conclusive upon the subject presented for considerable time after its rendition, and is liable to be vacated, in the interests of justice, where application is made in apt time, and of these facts purehasers or others dealing with the title to land are lonnd to take notice. ${ }^{6}$

$\$ 505$. Affidavit and Order of Publication. The statute authorizing construetive service hy pullication, in ease of nonresident or absent parties, roquires celain facts to be presented by aftidarit to the cont in which the action is pending, whereupon, if such presentation is satisfactory to the conrt, an order is made for the publication of the summons or notice to appear, which not only preseribes the period but designates the paper in which the publioation is to le matle, while if the residenes of the defendant be known such order further provides for an additional notice throm the mail. The service is deemed

6:3 Proof of the publiation of the summons for" "six successive weeks" has been held insufficient to show a publication "once each weck" for the period named: Sce Godfrey $v$. Valentine, 39 Mim. 336.

et Randall r. Songer, 16 Jll. 27; Church $r$. Furniss, tit N. C. 6i.s. 65) Seddick $r$. State Bank, 27 111. 145. This doetrine has beril somewhat modified by later derisions, and every reasonable presumption will be indulged in favor of the jurisdiction of a court whose deejees recite due process and service and such recitals are generally held to be prima facie evillence of the juristictional facts: Turner $r$. Jenkins, 79 111. 228; Tompkins $r$. Wiltberger, 50 Iil. 335. Mere derical omissions, pro:ided sullicient is shown to confer jurisdiction, are usually of little consecpuene': ("arter $r$. liodewold, 108 111. 3is.

isi Southern Bank $x$. Ihumphreys, 47 11l. $2: 27$. 
complete at the expiration of the time prescribed by the order of publication, and the proof is afforded by the affidavit or certificate of the printer, and an affidarit of deposit in the postoffice, if such deposit has been made. ${ }^{6 t}$

These preliminaries, though often overlooked when compiling an abstract, are as important as any step in the action and upon their due performance the validity of the subsequent proceedings rests. It is not sufficient to show merely the affidarit of publication, for, although that fact is an important ingredient of the service, it is comparatively of no force or effect unless connected with the preliminary steps which occasioned it. Publication of a summons in a newspaper is not service of the summons, nor is an aftidarit of such publication proof of serrice. To be of any arail the publication must have been made in a paper designated by the order of the court or judge and for the period prescribed by such order. ${ }^{6 s}$ The terms of such order must, therefore, be comnected with the affidarit, or the proof will amount to nothing. ${ }^{69}$ Is the printer is not supposed to know anything of the order, and is not called upon even to refer to it in his affidarit, it becomes necessary in making up the abstract to include the substance of the affidarit of non-residence and the order of the court made upon it, otherwise it will disclose no proof of service. Where publication is made pursuant to a gencral rule of court, while the service must comply with the requirements of the rule, it is not necessary to set out the rule itself.

$\$$ 506. Appearance Without Process. A party may enter lis appearance in a pending action without service of summons, and such appearance, voluntarily made, either in person or by attorney, binds him with respect to any judgment or decree that may be rendered in the case.

67 This matter is statutory and varies with locality.

is This is often provided for by a general rule of court which stands for a special order in the particular case. Of course, the publication must comply with the rule; usu. ally, however, the publication may be made in any " secular newspaper of general circulation."

69 Galpin $r$. Page, 3 Sawyer (C. Ct.), 93. 
Where, however, the appearance is by attorney and withunt service of process, this is a faet that should be noted, for while all of the presumptions are in favor of a judgment basal on such an appearance, " yet, if the appearance was in fact nuauthorized the judgment may be vacated on motion or its enforcement enjoined. ${ }^{71}$

$\S 507$. Master's and Referee's Reports. Frequently during the progress of a cause a reference is made to a master or referee to ascertain some partieular fact, or for a trial of the whole issue, and the manner in which the master or referee presents his opinion and the result of his inquiries to the court, is either by a certificate or report. A certificate is a simple notification of a fact, or of an opinion, or a conclusion; reports are the results of his inquiries with his findings or conclusions, and opinions thereon. ${ }^{i 2}$ References are more frequently made to state an account, or for other matters arising out of commercial transactions, but oceasionally referenees of title are made, and these will sometimes require notice in making up a synopsis of chancery proceedings. All reports, upon which are founded decrees or decretal orders, require confirmation. Judicial sales are frequently conducted by a master or commissioner, and a circumstantial report of such sale must be rendered to and confirmed by the court ordering same, and though it is not usual to abstract this report, where the decree and deeds are shown, some allusion must be made to it.

$\S 508$. Verdicts. The original chancery practice did not contemplate the intervention of a jury, but all facts were found by the court. ${ }^{i 3}$ Issues were sometimes made up and submitted to a jury, and such is still the general practice, though under the codes all questions of fact in litigated cases, whether the aetion is legal or equitable, may be, and usually

70 Corbitt $v, \quad$ Timmerman, 95 Mich. 581; Williams v. Johnson, 112 N. C. 424.

71 Winters $v$. Mears, 25 Neb. 241.

72 Smith's Ch. Prac. * 161; 2
Barb. Ch. Prale. *54t; 2 Dan. Ch. Prae. 934.

is Oral examinations were not formerly permitted 
are, the subject of jury trials. The verdict of a jury on an issue which a court of equity has directed them to try is advisory merely, ${ }^{74}$ and is not conclusive on the court, ${ }^{75}$ who may reverse the verdict and render a decree opposed to the findings of the jury. ${ }^{i t}$ As a material fact, however, when acted upon by the court, the verdict should be appropriately noticed, which can ordinarily be accomplished by a statement of the issue presented and the finding made thereon. In legal actions for the trial of title to land the verdict or finding of the jury is always important and must be shown.

\section{\$ 509. Abstract of Chancery Procepdings. In prepar-} ing minutes of equitable actions involving title much nice liscrimination is necessary in order that the abstract may show a perfect resume of the procecdings and all the material points presented, and yet not become unwieldy or burdensome. The name of the court in which the action is prosecuted; the title of the cause; case number, and date of commencement of the action come first, and in the order indicated. Then follows a brief statement of the material parts of the bill, avoiding all repetition and surplusage. The subsequent steps next follow in ehronological sequence down to the final determination or decree which is usually shown in full. The examples given in this section and other parts of this chapter will fully serve to illustrate the matter. Where the case is still undetermined

T4 Quinby $t$. Conlan, 104 U. S. 420 ; lusling $c$. Rusling, 35 N. T. Eq. 120; McGan $r$. O'Yeil, 5 Col. 58. It would seem that this principle has not been materially changed by the code, although the forms of action have been, and that the verdict is only in aid of the court, and does not have the same effect as a verdict at law. See Stanley $x$. Risse, 49 Wis. 219 . In some forms of equitable actions the verdict, when issues are sent to a jury, has the same binding eflect as a verdict at law. This, however, is always the result of special legislation and is in derogation of the common-law powers of a chancery court.

75 Rusling $v$. Rusling, 35 N. J. Eq. 120; Marshall $v$. Marshall, 18 W. Va. 395 ; Stanley $r$. Risse, 49 Wis. 219 ; Contra, Marvin $r$. Dutcher, 26 Minn. 391.

76 Ivy $r$. Clawson, 14 S. C. 267; Wakefield $t$. Bonton, 55 Cal. 109; Smith r. Richardson, 5 Utah, 424; Swegle $r$. Wells. 7 Or. 222; Gladsen $v$. Whaley, 9 S. C. 147 ; Austin $v$. Bainter, 50 Ill. 308. 


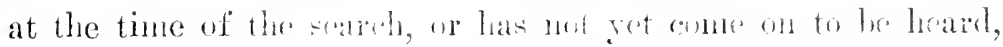

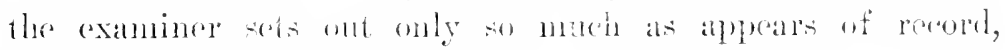
and indicates the condition of the canse by adding the word "pending," thus:

In the Circuit Court of Cook County, Illinois.

William strafer.

vs.

Henry Brown.
C'ase No. 12,2,510.

In Chancery.

Bill filed July 16, 18\%4, sets forth that on or about June 12, 18\%4, complainant entered into a contract with said defendant to convey to him all his right, tille and interest in and to certain property in Wcllenry Co., Ills., and that said defendant agreed to convey to him all his right, tille and interest in and to Lot 30, in Block 3, in Lowman's Subdicision of part of the East half, of South East quarter, of North East quarter of Sec. 6, Town 39 North, Range 14, East of 3d P. M., Cook County, Ills.

Prays, that said defendant be adjudged to specifically perform the said contract, and to convey to complainant the said premises, and to fumish an Alstract of Title to said property showing clear and perfect title to same, and that defendant be compelled to pay to complainant the damage he has sustained by his refusal to perform said contract, etc.

\section{(Pending.)}

A continuation should take up this case at this point, and show all subsequent proceedings, thus:

In the Circuit Court of Cook County, Illinois.

$\left.\begin{array}{l}\text { Henry Brown. } \\ \text { vs. }\end{array}\right\} \begin{aligned} & \text { (ase No. 12,510. } \\ & \text { In Chancery. } \\ & \text { The following proceedings have } \\ & \text { been had in this canse since July }\end{aligned}$

18, 187\%. (Chancery record 4.2, page 1\%.) 
Aug. 1S, 18\%4, suit dismissed at complainant's costs for want of prosecution. ${ }^{i \pi}$ (C'osts paid.)

Where more direct reference to a former examination is demed desirable the following form may be used in a continnation :

In Circuit Court of Cook County, Ills. Case 12,510.

William Shafer Continuing No. S of an exami. i's.

Menry Brown. nation made by us [or by any other person] dated July 18 , 15\%4, (and hereto attached.)

Aug. 1S. 1974. dismissed at complainant's costs and judgment. Exccution No. 2.415 issued, dated Dec. 1.18\%4.

The further examples given in this chapter of special proceedings in the different chancery actions, will, it is believed, furnish sufficient data for any exigeney that may arise, while the examiner will have no difficulty in adapting them to details or differences of practice in his own State. ${ }^{\text {is }}$

$\$ 510$. Injunctions. An injunction is a writ, commanding or restraining the commission of some act, to serve the purposes of equity and good conscience. In the endless variety of cases where a plaintiff is entitled to equitable relief, if that relief consists in restraining the commission or continuance of some act of the defendant's, a court of equity will administer it by neans of the writ of injunction.

Injunctions are rarely shown in abstracts of title, and when shown have reference usually to transitory matters which affect the title only incidentally, being connected rather with the use

77 An order or decree dismissing a suit for want of prosecution, is like a non-suit at law, and is not a bar to a subsequent suit for the same matter: Porter $r$ Vaughan, is In connection with this chapter the reader is referred to the chapter of this work entitled "Exe. cution and Judicial Sales." 
and ocenpation of the laud, than with any matter which goves to the title. 'Trumoralry injunclioms restraming the sale of land pending litigation is will sometimes be found, as well as writs restraining lle action of public ofticers, who, muler a claim of right, are proceding illegally to impair the rights or injure the property of individuals or corporations, so as also, to prevent a multiplicity of snits. Injunctions are granted upon motion in pursuance of the statute and are nsmally auxiliary to some logal procerding then commeneed or pending, and may be shown, when material to the title, either in connection with such pending suits, or as independent exhibits. An injunction which has been dissolved does not call for notice. Perpetual injunctions, when relating to matters which directly concern title, become permanent numiments, and, of course, must be regularly shom in connection with the "ujoined matter. This will be the case in respect to rights of ray appurtenast to laud; ${ }^{s}$ or of deeds declared to be void, when attempted to bo used as evidence of title; 82 and of judgments which have becone invalidated for any leason. s: A perpetual injunction to quiet title will sometimes lie when there has been no trial at law; as when the party having possession is disturbed, but not so dispossessed as to make it the subject of an action at law. ${ }^{84}$

79 Camp $x$. Bates, 11 C'onn. 5l; Sidener $v$. White, 46 Ind. 5ss; Felrle $v$. Turner, 77 Ind. 530 (reversing, 34 Ind. 300). An injunetion is a preventive remedy and can not be invoked to commind a party to undo what he has done or restrain lim from doing an act which he is alleged to bave abeady done: Wangelin $r$. Goe, 50 Ill. 459 .

80 Smith v. Pangs, 15 Ill. 399; MeIntyre $v$. MeIntyre, 80 IIl. 127; Keam $\bullet$ Ash, 27 N. J. Eł. 5T. The writ is often employed in disputes between the rivic anthoritios and individuals relative to riglits of way, oceupation of streets, ete: Pettibone $r$. Hamilton, $40 \mathrm{Wis}$ 402; Knox $v$. Police Jury of Baton Rouge, $27 \mathrm{La}$. An. 204.

s1 Truehart $v$. Price, 2 Munf. (Va.) 488.

82 Buslinell $v$. Itarford, 4 Johns. Ch. 302.

83 Kruson $v$. Krusom, 1 Bibb (Ky.), 184; Brinkerloff r. Lansing, 4 Johus. (h. 69) (xairity r. Russell, 40 Comn. 450; Dalton le Lamburth, 9 Ner. 192.

84 Trustees of Lonisville $l$. Gray, 1 Litt. (Ky.) 148. The writ of injunction, as a provisional remedy, has been abolishoul by the codes. 
5 511. Ejectment. The action of ejectment is said to have originated at some period uncertain between the years 1327 and $137 \%$, and was at first a mere action of trespass to recover damages from an intruler who had usurped possession. $^{85}$ A new feature, not contrmplated by the original writ, was soon introduced, ${ }^{\mathrm{s}}$ for the purpose of enabling the plaintiff to reeover the term as well. It was originally brought only by a lessee, to recover poss sion of the lands from which he had been ousted, and in its strictly technical sense is still an action for the recovery of the possession of real estate, but in practice it is more generally used, both in England and the Cnited States, to determine the title to lands, ${ }^{87}$ to which possession attaches itself as an essential atiribute. Under the statute it possesses little of its original features, ${ }^{8 s}$ while its general scope has been so extended that it is competent to determine almost every question that can arise in conflicting titles. It is now regarded as a legal remedy, ${ }^{80}$ to be prosecuted only by the real parties in interest, ${ }^{90}$ having the legal title to the land, ${ }^{91}$ and can be bronght only against the person in possession of the premises, if they are ocenpiet, ${ }^{92}$ or against a person claiming title, ete, when the prenises are racant and unocenpied. It is used, not only to determine the title of parties claiming from the same souree, as well as to settle enflicting adverse titles derived from independent sources, but also by purehasers

which substitute a statutory remedy by order; lut the nature of the remedy has not bcen changed.

85 Warrelle on Ejectment 4 . Et seq.

se Supposed to be about the year 1455.

si Guyer r. Wookey, 18 111. 536. ss As originally administered it depended upon a series of legal fictions and feigned issues: 3 Black. Com. 200.

sa Gillett r. Neganza. 13 Mis. 472 ; Cuyer $l$. Wookey, 18 Ill. 536 ; Joy $r$. Berdell, 25 Ill. 537.
90 Hanson $r$. Armstrong, 22 Ill. 442; Thomp:on $r$. Schuyler, 2 Gilm. (111.) 271 .

91 Allen $r$. Smith, 6 Blaekf. (Ind.) 525; Norton 1 . Greene, 2 Neb. 441.

92 Persons in possession merely, as servants $a^{\circ}$ employes of the party claiming alversely, are not oecupants within the meaning of the law: Chiniquy $v$. Catholic Bishop, $\$ 1$ 1ll. 148. 


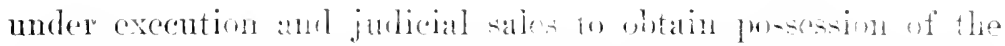
property purdased and extinguish the ocenpring dainant's rights.

At common law a julgment or droper in ejectment is not regarded as conchure in repeet to the quastion of title, but as a recosery of the possession without prejulice to the right, as it may afterward aphear, even between the sane parties. ${ }^{93}$ but wherever the emmun law form of the artion is abolished, and same is prosecuted by the real parties in interest, in their own nanes, the jullement is an estoppel and a valid bal to any subsequent action, muless such privilege is expressly given by statute. ${ }^{94}$ Where a recorery is had against the occupant, the judgment hinds not only him, but all persons in privity of estate or possession with hinn, ${ }^{95}$ and conchules then from again litigating the sane title, ${ }^{93}$ but is not necesarily a bar to a subsequent suit, or to defenses set up in a subsequent suit, unless the titles and defenses are precisely the same as in the first suit. ${ }^{9 \pi}$

Nor does a judgment in ejectment transfer to the succesful party the title of the adrerse party, but, if presented in the proper manner, whenever such adverse title is dratrn in issue, it shuts out all proof of same, and its effect bears a closer resemblance to an extinguishment, than a transer of the adverse title. The judgment awards the possession to the prevailing party, because he had the title at the commencement of the action, and because the losing party had no title, or not such a title as would authorize him to withlold the possession; but it neither directly nor indirectly transfers the title. ${ }^{95}$ Inasmuch as the judgment is conclusive on the riglits of the parties to the subject-matter of the action and all persons claining by,

93 Mitcbell $\iota$. Tirbertson, 15 Ala. 412; Holmes $v$. Caromdolet, 38 Mo. 551 ; Smith 1 . Sherwood, 4 Conn. 276 ; Atkins $r$. Horde, 1 Burr. 114. 94 Freem. on Julgets. \& 299 ; Camplell r. Hall. 16 N. Y. 575; and soe Clarlisule $r$. Stanchificld, 57 Mo. 573. In mont of the States a defeated party may liave a second trial as of riglit.

95 Hanson $v$. Armstrong, 22 Ill. 442; Roderers $v$. Bell, 5.3 (ia. !); State r. Orwig, 3.t Iowal. 112. 94: Anumeti r. Cantro. 4! Cal. 325). 97 Foxirr r. Fans. 51 Mo. 39. 98 Mahoney r. Midelleton, 41 Cal. 
through or under them by title accruing after the commencement of the action, 99 the abstract should fully show the points presenterl, their relation to the land, and the final disposition made, which may all be easily accomplished by a full synopsis of the pleadings, the verdict, ${ }^{1}$ and the judgment or decree.

\$ 512. Quia Timet. This is an anticipatory remedy to quiet the title to lands, ${ }^{2}$ and, unlike ejectment, is brought only by the person in possession of the land, or one claiming to be the owner when the lands are unimproved or unoceupied. ${ }^{3}$ It is an ancient chancery remedy, but in most of the States is now a statutory action, resorted to for the purpose of quieting the title or the remoral of a cloud, ${ }^{4}$ and equity is inroked to reach persons out of possession, who can not be compelled to defend their right at law. ${ }^{5}$

The decree, mnless otherwise provided by statute, is not properly a judgment in $\mathrm{rem}$, establishing title to the land, but operates in personam only, by restraining the defendant from asserting his claim, or by directing him to perform some duty, as to deliver up his deed to be canceled, or to exceute a relcase, etc."

The possession which confers jurisdiction in such cases must have been acquired in a lawful way, ${ }^{7}$ though the complainant is not bound to show a perfect title as against all the world, ${ }^{8}$

99 Sheridan $v$. Andrews, 3 Lans. (N. Y.) 129 ; Amesti r. Castro, 49 Cal. 325.

1 Where the rerdict fails to specify any estate, juigment can not be rendered on it: Long $r$. Limn, 71 111. 152; hut a finding that the plaintiff is the owner of the land is sufficiently explicit as to the plaintiff's title: Haddock v. Ifaddork, 22 H1l. 384 ; when tried by the court the finding and judgment must be for the premises described in the pleadings and the character of the estate recovered must be stated: Harding $v$. Strong, 42111. 1 \&8. a Frequently denominated a bill of peace.

3 Gould $v$. Sternberg, $105 \mathrm{Ill}$. 488; Hardin $v$. Jones, 86 Ill. 313.

4 Itardin $v$. Jones, 86 11l. 313; Collins $v$. Collins, 19 Ohio. St. 468.

5 Barron $r$. Robbins, 23 Mich. 42; Alton Ins. Co. $v$. Buckmaster, 13 H1l. 201.

G Massie $v$. Watts, 6 Cranch (U. S.) 148; Vandever $r$. Freeman, 20 Tex. 334. Such deerees are conclusive on parties and privies: Buckmaster $r$. Rycler, 12 Tll. 207.

7 Ilardin $r$. Jones, 86 1ll. 313.

8 Rucker $r$. Dooley, 49 Ill. 377; 
as is the case of one seeking to recorer prossion, and the title asserted must be the legal title, ${ }^{9}$ or at least the complainant must be the real onner." in equitalle claimant, who is not in possession, can not invoke the aid of a court to quiet his title and remove the cloud cast upon it by oflucr claimants. ${ }^{11}$

Where elouds or obscurations of any hind are found $n_{j}$ ) examination, and no other or nore convenient method can be employed to remove them, it is the duty of counsel to recommend a bill to quiet title, and for nearly every species of colorable interference with the legal titie this furnishes a most efficient remedy. There is in sume States a special statutory action to establish and confirm title where recorts have been destroyed. The general featmes of these artions resemble the action to quiet title above described but the scope and legal effect is broader. ${ }^{2}$

§ 513. Partition. Originally, partition could only be enforced between co-parceners, but by statute in England at an early das compulsory partition was allowed between joint tenants and tenants in common. The right, as exercised there and in this country as well, is given only to one laving an actual or constructive possession of the lands sought to be partitioned. Hence, unless the statute expresty provides otherwise, the right is peculiar to these having a prosent estate, which carries with it the riglt of possesion, and necessarily excludes remainder-men and reversioners, who lave simply an estate to vest in possession in futuro. ${ }^{3}$ It wounl seem, however, that remainder-men or reversioners in fee may have

Schroeder $v$. Gurney, 17 N. Y. Sup. Ct. 413.

9 San Diego $v$. Allison, 46 Cal. 162; O'Brien v. Creig. 10 Kan. 202; Fonda $r$. Sage, 48 N. Y. 173.

10 Carlisle $v$. Tindall, 19 Miss. 229 ; Lee $v$. Ruggles, 62 Ill. 427 ; Eiden $\imath$. Eiden, 41 Wis. 460.

11 Iferrington $v$. Williams, 31 Tex. 448.
12 Of this ra-s is the so-called "Burnt Recort tet" of Hlinmi-. which enables parties to establinit title against all persons, eren though unknown. who may have or claim interests in the land.

1.) Sullivan $r$. Snllivan, t6 N. Y. 37 ; Spight $r$. Waldenn, 51 Jiris. 356 ; Scarborough $v$. Smith, is Kan. 399. 
partition among themselves subject to the mexpired precedent particular estate. ${ }^{14}$

Partitions occur in many titles of long standing, particularly in agricultural lands and large tracts, and as the interests of minor heirs and others under disability are frequently involved, the proceedings should show affirmatively a full statutory compliance. The procedure is substantially the same in all the States, ${ }^{5}$ making due allowances for minor differences of practice, and incolves a presentation of the case to a court of competent jurisdiction; a decree defining the interests of the parties; the appointment of a master or commissioners to execute the decree and make partition, or to inquire into the expediency of same or susceptibility of the property to partition; the report of the commissioners; and confirmation or final decree. All of the foregoing steps are essential, and form regular links in the chain of title.

It is customary under the old chancery practice to decree a mutual interchange of deeds, but statutory power is now generally given to confirm title in the parties in cases of partition, without this formality. ${ }^{16}$ The decree is prima facie evidence of title in faror of each of the parties to the particular tract adjudged to him, ${ }^{17}$ and conclusive against all the parties before the court, and their privies. ${ }^{18}$ The decree under the statute may be final and conclusive as eridence between the parties without the interchange of deeds, either by the partics or commissioners, as it ascertains all the rights involved, and leaves nothing to be done but to carry it into effect. It does not. however, vest in either of the co-tenants any new or additional title in respect of the respective parcels set off to each, but

14 Scoville $v$. Hilliard, 48 Ill. 453.

15 Under the statute the action for partition of lands in a suit at law in some of the States, and not in equity. and is a substitute for the old common law action of par- tition: Hopkins 1 . Medley, 97 Ill. 402.

16 Smith $x$. Crawford, 81 Ill. 296. 17 Word $r$. Douthett, 44 Tex. 365.

18 Wright $r$. Marsh, 2 r. Greene, 94; Allie $r$. Schnitz, 17 Nis. 169; Smith $r$. Craw ford, S1 11l, 296. 
simply severs the mity of possession theletofore existing. 19 The title by which each holds his divided share after partition, is the same as that by which his nndivided interes was held prior thereto. ${ }^{20}$

Where title is deduced throngle a decree of partition in a suit between the heirs of a decoand omner, the aljudiration, where the court has jurisdiction, fincling who are the bars at law of the deceased owner, is prima facie evidence of who were the heirs and owners of the land whose interests were allotted or decreed to be sold; and in an action of ejectment brought by a grantee of one of the partics, or a purchaser at the sale against a stranger to the partition suit, the plaintiff is not bound to produce evidence of heirship ontside of such decree, in the absence of proof to the contrary. The doctrine that julgments and decrees are evidence only in suits between parties and privies has no application, it wonld seem, in such a case. ${ }^{21}$ The synopsis which follows will serve to fairly indicate the method of showing a partition, and will also serve as a precedent for other chancery actions:

In Circuit Court of Cook County, Illinois.

Robert E. Jones,

is.

Edward C. Walker.

Thomas Cannon, Sarah

C. Newhouse, a minor,

and James IV. Neuhouse, her guardian and next friend.
C'ase No. $39,3 \% 9$.

In Chancery.

Bill fited Oct. 24, 1891.

Represents that complainant. and defendant Edward ('. Walker, are the owners earti of an undivided one half as tenants in common of Lot so, stohool Tinstees' Subativision of the North part of Section 16, Toun 39 North, Riunge 13. rast of sil I'. M., being now subdicided into sixleen lots and linoun. as Secrist's Subdirision of said Lot 80.22

19) Wade $v$. Deray, 50 Cal. 376. 96.
20 Carter $v$. Day, 59 Ohio St. 109.

$22 \mathrm{~A}$ bill in equity for partition 
That defendants, Sarah C. Neuhouse, a minor, and Thomas Cannon, have or claim to have, some interest in or licn upon said premises. ${ }^{23}$

Prays for a partition and dirision of said premises according to the rights and interests of the parties in severaliy, if same can be done without manifest prejudice to the owners thereof, or if the partition can not be made without such manifest prejudice, that a sale thereof be made according to lau, and that the proceeds of such sale be distributed among the parties respectively entitled thereto. ${ }^{24}$

Chancery summons, (to Cook county) issued, dated Oct. 24, 1SS1, to all said defendants, retwmable Bd Monday of Nor., $18 S 1$, and duly served upon all said parties. ${ }^{25}$

Answer of defendant Edward C. Waller (and replication thereto) filed Dec. $8,18 S 1$.

Default of defendants, Thomas Cannon. James Tr. Tewhouse, guardian and next friend, talien and entered Dec. S,

need not make any formal deraignment of title but must state the complainant's own title and the title of the defendants so that it may appear that they hold the land as cotenants. It should aloo show the undivided proportion belonging to eacli, and that they are entitled to a partition.

23 To entitle a party to partition it is not enough for him to show prima fucie title in himself; he must also make persons holding adverse titles parties to the action or show that they are not under disability and that their title is completely barred: Ross $\imath$. Cobb. 48 Ill. 111.

$2:$ The law contemplates two modes of proceeling in order to procure a division of real estate held in joint tenaney or in eommon: (1) $\mathrm{By}$ a partition of the premises without sale; and (2) where a partition ean not he conveniently made, by a sale of the property.

25 Very frequently com el desires to know the manner of service, partienlarly where prerons nuler clisability are interested, and in sueh cise the alb-tract at this point should disclose such method by a eopy or summary of the returns of the officers. Where all the parties enter an appearance the method above given is sulficient. lont when there has heen defanlt, it is escential to a correct opinion that the method of service upon the non-ap. pearing parties be shown, and this ean only be done by a cony of the return. Stating that defendant was "personally served" is not sufficient, as a very slight omission will frequently vitiate the return and prevent jurisdiction from attaching. 
18S1, (chancery record 42, po. 19S) for want of plea, answer or demurer to bill. and Lomis II unt appointed guardina ad litem for satid minor defendant, Sarah A. Newhouse.

Cause refered to $\mathrm{H}^{\circ}$. Fenimore Cooper, Master in C'hancery, Dec. 8 , 1SS1, to talie proofs, ete.

Answer of said minor defendant by her guardian ad litem, filed Dec. 8, 1881.

Master's inport, submitting proofs and extibits, filed Feb. 20, 1SS2.

Said master mports that the matevial facts acered in the bill hare beon fully proted. and said complainant is entitled to the relief prayed for in said bill.

Decree entered, Fet. 20 , 1882 (Chancery Record 42, page 406.)

[Here should follow the decree or every matcrial part thereof. $\left.{ }^{26}\right]$

Where the decree is interlocutory only, the subsequent proceedings, as the appointment and report of commissioners, offers and aceptances of parties, together with the final decree and confimation should follow in rogular order. What has been given will serve to fully illustrate the nethod in which subsequent steps may be slown.

Where a partition occurs in the history of a title counsel should carefully note that all persons shown to have any interest are properly joined in the snit as parties. For this pripose reference shonld alwars be made to the pront of heirship, made in the probite of the ancestor's estate, where the title is derived through descent, and the names of the heirs companderl with those in the partition suit. If minors are interested the procectings will brs void as to them nuless they are anade partics and persomally sepred with proeess. ${ }^{27}$

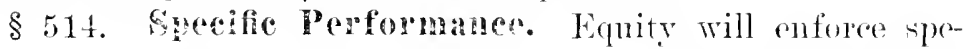

26 See "Juldrments and Decrees" for a precelent of a decree.

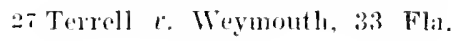
25.5. 
cifie performance of agreements relating to lands; ${ }^{28}$ compel conveyance of land purchased, ${ }^{29}$ either by the vendor or his heirs; ${ }^{30}$ or where specific performance can not be enforced, will give other adequate relief. ${ }^{31}$ The essential conditions of such contracts are: That they be made by competent parties, willingly entered into; ${ }^{32}$ that the terms are certain and well defined; ${ }^{33}$ be foumded upon suficient consideration; ${ }^{34}$ and the party seeking its performance must fulfill his obligations under it. $^{35}$ The contract must further be lawful in its character, ${ }^{36}$ and such as a conrt can enforce. ${ }^{3 \tau}$ As this matter occurs most frequently, in connection with title, in action: growing ont of agreements to deed, it is advisable, that, in case performance lias been decreed and consmmiated, a rather full synopsis be given of all the material parts of the pleatings; master's report, if there has been a reference; and of the final decree. If performance has been denied, and the contract or agreement is of record, the same, together with a brief notice of the action, may be shown as a special appendix.

In addition to actions in the Cirenit Court, it is provided in some States that when any deceased person was bound by a contract in writing to conrey any real estate a specific performance by the personal representatives of such deceased person may be decreed in the probate conrt, in all cases where the deceased, if living, might be compelled to execute such conveyance. The jurisiliction in this event is obtained by petition setting forth the jurisdictional facts, and of notice duly given in accordance with the statute. The petition,

2s Kerfoot i. Breckenridge, si 111. 205 .

2! Narling $r$. Marling, $94 \mathrm{~W}$. Va. 79.

30 Bennett $r$. Waller, 23 III. 97.

31 Wookwarl $r$. Harris, 2 Barb. 439; Oliver $r$. Croswell. 42 Ill. 41.

32 Johnson $r$. Dodge, 17 Ill. 433;

Taylor e. Merrill, sj 111. ie.

33 Shmeling $r$. Friesel, 45 Wis. 357 ; Colson $r$. Thompson, 2 Wheat.
336: Figos $v$. Cochriu, 54 Ind. 593.

$3 \pm$ Cheney $r$. Cook, 7 Vis. 413 ; Smith $r$. Wood. 12 Wis. 382.

$35 \mathrm{X}$. W. Iron ('o. r. Mead, 21 II is. 474; Ishmeal $r$. Parker, I3 Ill. 321.

3e Mclurken r. Dotrich, $33 \mathrm{Ill}$. 249: Honker $t$. De Palos, 28 Ohio St. 251 .

3 T McClellan $v$. Darrah, 50 Ill. 249 . 
motice, proof of service and decree, should preceds or smphlement the anhninistrator's or executor's deed whenever it is shown in the abstract.:"s

\$ 515. Rodemption. Bills to redeem, though formerly of common oecurrence, are now rarely employed, from the fact that the fundamental law concerning mortgages has been radically changed, and the necessity of equitable interference to restore the mortgagor's rights no longer exists save in a few instauces. After the law day has passed the status of the mortgagor's title is substantially the same as it was before, and mit forcelosed by legal methods the right to redeem by simple payment is mimpaired. Such, at least, is the recognized law in a majority of the American States. But when a deed, though in fact given as secmity only, is absolute on its face, and purports to cunvey an absolute estate in fee, the mortgagor, to assert his right of redemption and become reinvested with his former title, must still make application to a court of equity by a bill to redeem, or such other similar remedy as the statute has provided. In like manner, if a mortgagee, having entered for condition broken, ${ }^{39}$ refuses to relinquish possession of the mortgaged lands after payment, or tender of payment, of the money dne on the mortgage, the only remedy of the mortgagor, in States where the ancient doctrine still obtains, in order to regain the estate, is by a bill to redeem. ${ }^{40}$ Ordinarily, howerer, this latter end is attained by a direet proceeding to have the mortgage canceled. The bill, in some form, together with its attendant deeree, will oceasionally

38 By statutory provision in many States a certified copy of the order or decree directing the execution of the eonreyance, is required to be recorled in the registry of deeds of the county in which the land is situate, and such ceetified copy is made evidence of the correctness of the proceedings, and of the anthority of the executor or administrator to make the conveyance, while the conveyance itself is made eflectual to pass the estate contracted, as fully as if the contracting party limself were still living and then executed same: R. S. Wis. ('h. 167; Mimn. (ien. Stat. Ch. 58.

39 This is still permitted in a few States, see Chalp. XXIl.

40 Parsons v. Wells, 17 Mass. 419; sherman $v$. Abbott, 18 Pick. 448. 
occur, partieularly in case of equitable mortgages, and as its effect upon title is very marked, it must be fully set forth.

$\S 516$. Foreclosire. Probably no elass of legal proceedings so often figures in examinations of title as aetions bronght to foreclose and enforee liens, and particularly is this true in the matter of the foreclosure of mortgages. A foreclosure in equity, aeeording to aneient legal theory, is a proceeding by which the mortgagor's right of redemption in the mortgaged premises is barred or closed forever, and oceurs when the mortgagor has forfeited his estate by non-payment of the money due on the mortgage at the time appointed, but still retains the equity of redemption. ${ }^{41}$ In such case the mortgagee may call upon the mortgagor, in a court of equity, to redeem his estate presently, or, in default thereof, be forever elosed or barred from any right of redemption.

Two general methods of foreclosure are recognized in equity, ${ }^{42}$ one, ealled striet foreelosure, whereby the mortgagee is adjudged the absolute owner of the property; and the other, by a sale of the property under the direction of and by an officer of the court, in which case the proceeds are applied to the discharge of incumbrances, aecording to their priority, and the balanee, if any, paid orer to the mortgagor. Striet foreelosure has always been regarded as a harsh remedy, and is not permitted in most of the States, nor is the title thus aequired as safe as when made by the ordinary foreclosure by sale.

The title derived under a foreclosed mortgage is evidenced by the mortgage itself; the proceedings and decree in foreelosure; the eertificate of sale, report, and confirmation; and finally by the selling officer's deed, all together composing one transaction. Much care should be exercised in preparing a synopsis of the proceedings, espeeially in regard to parties,

411 Bou. Law. Dict. 599. A court of equity will never decree a foreclosure until the period limited for payment has expired: Harwhaw $v$. Mckesson, 66 N. C. 266.
42 There is also a method of foreclosure at law, by means of a proceeding by scire facias, but which, from its inadequate nature, is seldom resorted to. 
and counsel, in passing title, shonld see that all persems who might legally assert any rights in relation to the mortgaged premises have been regularly bronght in and jupenly barred or their rights adjusted. This will inchute not only the mortgagors, but subsequent mortgagees, judgment creditors, lim holders, and all other persons possensing legal rights or expities accruing subsequent to the lien asserted ly the mortgage. ${ }^{43}$ Where the foreclosure is recent, and particularly when the title under investigation is that offered at the foreclosure sale, the decree and antecedent proceedings should be set out very fully.

\$ 517. Dower. The interest which a triciow possesses in the lands of her deceased lusband in right of dower nay, at common law, be assigned to her in severalty by the heir, withont the order of a conrt and withont a deed, for the assignment in such case is not regarded as a conveyance of title, but only the ascertainment of an interest which is a continuation of the estate of the husband, and which is held of him by appointment of law; ${ }^{44}$ the only effect of the assigment being to distinguish the land to which it attaches from the rest of the husband's estate. But should the heir neglect or refuse, within a reasonable time after the death of a hm-hand, to lay off and assign to the widow such portion of the land as she may be entitled to use and oceupy, or when the particular part can not be agreed upon, or when the right is disputed, recomse may be had to equity to determine the rights and apportion the interests of the parties. In some States an ejectment suit at law may be resorted to by the widow.

Where the right is undisputed, dower may be assigned by the probate court, as an incident to the settlement of the linsband's estate, and the award in such case should substantially appear in the synopsis of probate proceedings, or as an intcrpendent exhibit.

Where the right is disputed the probute cont, as a rule, lats

4.3 Hinson v. Adrian, 86 N. C. 61 ; Mabury $v$. Ruiz, 58 Cal. 11.
44 Farnsworth $r$ Cole, 12 Wis. $405 ; 4$ licnt. Com. 62. 
no jurisdiction, while in many States if the heir or ther person shall not, within some specified period after the death of the husband, ${ }^{45}$ satisfictorily set orer and assign to the surviring wife dower in and to all lands whereof by law she is or may be dowable, snch surviving wife may, in the first instance, sue for and reeover the same by petition in equity, against the heir or any other person claming right or possession of said estate. In either case the interposition of commissioners is contemplated, and the report of the commissioners, together with the approval of the cont, are necessary parts of the abstract of the proceedings. Where an allowance is made in lieu of dower a statement must be made of that fact, particularly when by decree the assessment of such allowance is made a lien upon the heir's land.

518. Divorce. The lissolution of the marriage contract, though formerly a power exereised by the legislature, is now very generally reglegated to conts of equity, and as a rule, such courts have exclusive original jurisdiction. Lntil decree has actually been entered, the legal relations of the parties continue to subsist, even where the marriage is utterly roid for preexistent canses, and such decree, to be effective, mast further be mate during the lifetime of both parties. ${ }^{46}$

At common law, a disorce was only granted for pre-existent canse, and hat the effect of bastartizing the issue. Lnder the statute divores are granted for canses arising subsequent, as well as prior, to the marriage, and do not affeet the legitimacy of the children of the marriage, except, perhaps, when the divorce is granted on the gromeds of a prior matriage. ${ }^{4}$

Pending the determination of the cause the holand mar be enjoined from disposing of his property in order to defeat any allowance of alimony, ${ }^{\text {s }}$ but such injunction is never made per-

4.5 There hubband and wife are equally dowable in the lands of the other, these remarks will apply to both sexes.

46 Reryes Dom. Riel. 204: 1 4i Conanlt local statutes for the effeet of divorce.

4s Vanzant $v$. Vanzant, 23 Ill. 536; Gray $r$. Gray, 6.5 Ga. 193.

Black. Com. 440. 
petual on granting the dreree. ${ }^{49}$ The allowanes of alimony may, howerer, be enforeed by a sale of the hushand's roal estate, and by the decree tho parment of same is frepuently makle a specific lien mpon his property. When alimony or maintenance is made to berome due liy installments, and a sale is made to meot such installments, the title will pass subject to the lien of installments not then due nuleas the comet shall, at the tinue, direct otherwise. ${ }^{50}$ Whan proporty is hold by one party which equitalily belongs to the other, the comt may compel enveyance thereof to be made, and sometimes, in case of a community of interest, a partition is necessary. ${ }^{5}$ Lands in fee may be deereed in satistaction of alimsmy or the count may assign as such the nse for life of part of the humbund's estate. ${ }^{53}$ It is not enstomary, howerer, to disturb the husband's real estate, but a definite money allowance is made instead; "indeed," says Dickey, J., "the cases are rere rape whene the fee in lands held by the husband should ever be remired to be transferred to the wife, muless she las sonie special conity in that particular land, arising from the purchase haring been made with her money, or from some other catuse substantially placing the husband in the position as to that property orpivalent to that of a trustee holding in his name for the wife, or in a position in its nature equitably equivalent thereto. In such cases, though the form of the deeree may be that of aljusting the question of alimony, the substance is more in the nature of the enforcement of a trust." 54

With respect to the effect upon lands of a decree for alimony payable in gross, the rule does not seem to be woll settlex. The

49 Errismann $r$. Errismamn, 25 Ill. 136; Keating $r$. Keating. 48 11l. 242. Insteal of the injunction, the decree makes the alimony a lien upon his land, and he may be compelled to secure the lien further by mortgage.

5o All these matters are the sull. ject of express statutory regulation. Consult local statutes.
51 Stewartson r. Stewartson, 15 Ill. 145.

52 Wheoler r. Whower, ls 111. 39.

5. Koating r. Konting, 4s 111. 241; Jollifr r. Jollifl. : 23 1ll. 52.

nit Wilson v. Wilson, 102 111. 297 . 
volume of authority, however, holds that such a decree will operate as a lien upon the lands of the husband located in the comty where the decree is rentered or docketed, and may be enforced by execution levied upen such lands either in the hands of the divored huband or his grantee, where they have been conveyed atter the rendition of the recree. ${ }^{55}$

55 In Chase $r$. Chase, 105 Mass. 3S., it was held that a jradgnent fir alinomy in the ase of a cirorce " rinculo, or from bed and board, riptics a delst of record in faror of the wife, and that she is entitled, ats a cresitor, to inpeach a convevance made ly him with intent to defraul her. It is sail by the Supreme court of the I'nited States in Parber $x$. Barber, 21 Ifow. 582, that when the count, haviug jurisdirtion of her suit, allows the wife, from her husband's means, by way of alimony, a suitable maintenance and support. "it becomes a judicial deht of reentd against the hmshand, and is as much a debt of record, watil the douree has heen recalled, is any other judgment for money is." And see, to the same effect. Wetmore $r$. Wetmore, 149 N. Y. 520. In Frakes $r$. Brown, 2 Blackf. (Int.) 295, the wife obtained a livorce, and a judgment for the sum of $\$ 550$ as alimony. By virtue of a fieri facias issued upon this judgment, the land in question was sold, and the complainant was the purchaser. In a bill in ehancery the complainant prayed that a conveyance of the land made by the husband to the defendant might be set aside as fraudulent and void. In the opinion, Plackford, J., says: "Tt is said that real estate is not liable on a decree for a divorce and alimony. The answer to this is that liere is a judgment against the husband for a certain smm of money, rendere? by a court having jurisdiction of the canse, and that every jndment of this kind, is by statute, a lien on real estate. It is not for this court to look beyond the judgment in the cave before us. It must be considered as having the same effect as all other judgments for the payment of money, whilst it stands mreversed and remains unsati-ficl." The statute by which judgments became lieus on real estate was the general enactment: "Judgments in the Circuit Courts are herriy made liens on the real estate of the defendant or defendants, from the day of the rendition thereof, in the comty where such judgment may be rendered." Rev. Laws Ind. 1824, 192. In Keyes $v$. Seanlan, 63 Wis. 345, the complaint set ont that the plaintiff reeovered a judgment for divoree against her husbant, and that the sim of $\$ 300$ alimony, and cost of suit, were adjudged in her faror. Section 2367 of the Amnotated Statntes of Wisconsin provides that, upon the failure to pay the alimony adjudged to the wife, "the eourt may enforce the parment thereof by execution or otherwise, as in other cases." In construing this langnage, the court say: "There are very satisfaetory reasons for saying that the divoree judgment stood upon the same footing as ordinary money 


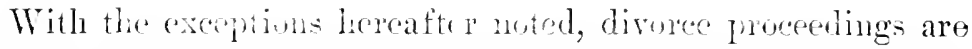
seldon shom in ahstracts of titic, save as they may incmuber land by the lien fir abiangy, and then only in brief and general terms. I lisore has another important effect on titles. howerer, "ristidered in repect to dower. It is a doctrine, buth of the common law and of the statute, that the discolntion of the marrige relation, ipso facto restopes the parties, legally ats well as socially, to the same relative position they occupied prior to eutering into same. One of the incilents, therefore, is loss of the dwwer right of the wife, ${ }^{5-}$ and to show a full and complete expesition of title an apprepniate mention of a divoree seems necentary in all cases where the question of dower would properly arise. This may be accomplished by a brief reference to the case as follows:

\section{Circuit Court, Cook County.}

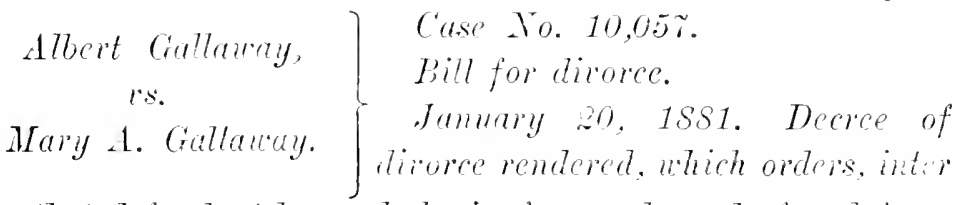
alia, that defendant be, and she is, forever barred of and from all right and cluim of dower in and to the lands and tenements of sail compleinant.

C'osts paid.

A decree of divoren, however, has no retroactive effect except as specially provided for by statute, and therefore a wife's richt of dower which had rested prior to a decee is not tinerely divested unles the statute so specifically declares. ${ }^{54}$

There is another effect produced by diroree which preperly

judgments, and became a lien mon the real estate of the debtor. liable to exerution, as soon as docketerl."

57 Purdick $r$ Brigras, 11 Wis. 126; Rice $r$. Lumley, 10 Ohio St. sog; Given r. Marr, 27 Me. 212 ; Miltmore $r$. Miltnore, 40 Pa. St. 13!. In sonec Sitates dower is pre- served where the dorece in renered? in fotror of the wife for the misconduct of the humand. Coisulit loral atatutes.

5s Tan Cleaf $r$. Purns, $118 \mathrm{~N}$. Y. 549 ; and we, llt $r$. Banloblzer, 39 Minn. 311. 
finds mention in a work of this character. As has been shown a conveyance to husband and wife, in most of the States, produces what is known as an estate by entirety, that is, an estate sinilar to a joint tenancy. ${ }^{50}$ It is held that this estate is destroyed by divoree, the legal unity of the parties being broken, and that the former spouses become tenants in (mminen. ${ }^{\text {fo }}$

In many cases where a divorce is pending, prudence would suggest that a brief allusion be made to it, yet the commencement and pendeney of such action, where the bill merely sets forth the defendant's lands as affecting the amount of alimony to be allowed, and neither ascerts nor seeks any right in respect to them, affords no notice lis pondens sufficient to affect the rights of purchasers from such defendant. Where, however, the bill sets up some specific clain of right in the lands, or where any part of them are asked to be assigned for alimony, or any other right is asserted in respect to them or any other relief asked in regard to them, it would sem that the doctrine of lis pendens will apply; and any one who purehases such property during the pendeney of the action will be bound by the jurgment subsequently remdered therein. ${ }^{61}$

\$ 519. The Right of Eninent Domain. The general subject of eminent domain has been alluded to in a former part of this book, but may be adrantageously referred to at this place in comnection with its practical application to the alienation of land. The right of eminent domain is defined to be the ultimate right of the sorereign power to appropriate not only the puhlic property, but the private properts of all persons within the territorial sovercignty, to public purposes, ${ }^{62}$ and thongh the exercise of the right usually affects only the use and enjoyment of the land and not the fee, ${ }^{63}$ it is, in effect, a per-

59 Consult, § 241 supra.

bo Steltz $v$. Shreek, 128 N. Y. 263 ; and see, Harrer $v$. Wallner 80 ill. 197; Lash $r$. Lash, 58 Ind. 526 .

61 Sapp r. Wightman. 103 Ill.
150; Wilkinson r. Elliott, 43 Kan. 590.

62 Vattel's Law of Nations, b. 1, ch. 20 ; Charles River Bridge $v$. Warren Bridge, 11 Pet. 611.

f.: R. R. $r$. Burkett, 42 Ala. 83; 
pertual right of usere almote expal in dignity to the fore and in some Shates it contromplates a transfor of the fee itselfo" This

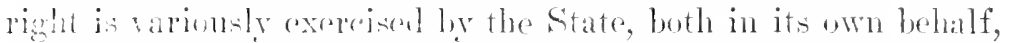
as for the alduistion of land for state institutions or improsements, roake, cantals ancl other works of a strictly public char-

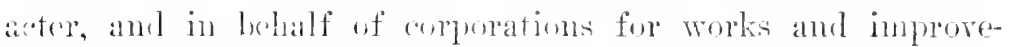
ments of a quesi piblie character, but it is a fundamental principle that any lands of the smlject, for whaterer purpose required, s!all not la taken or damaged for pullic use, without just combrasation. Whem land is taken moder this right and in fere, it is fored from all contingent interests, liens and equities, including inchuate rights of dower, judement liens, etc.

In the examination of titles questions growing ont of the exercise of this right are often presented where there has been an abandmunent of the lands approputiated, on a diverwion from the original purpose. Condennations are also slown incidentally, as where rights of way arre accunired orer tracts which forme the sulpject of an examination.

\$ 520. Procedings for Condemuation. Prorision is made in every state for the condemnation of land, and the compensation to be paid for or in repeet of the property songht to be alprepriated or damaged, when no agreenent can be effected hy the parties interested; or in case the owner of the property is incapalle of consenting; or his name or residence is unknown; or le is a nom-resident of the state.

The general procedure is very miform, though the instrun mentalities need are not alike in all the States. The procedings generally contenplate an investigation by a jury, and an assessment and award, which, when regularly accomplished and confirmed, hat the effect of divesting the title of the former owner and clothing the corporation with such title as the law

Hatrh r. R. R., 18 Ohio, 92; Morris r. Schallsville, e Bush (Ky.), $6 i 1$.

1.4 Nimll r. R. R. Co., 2 Kern. 1.21: People r. Mauran. 5 Den. 389; Heyward r. Mayor of N. Y., 3
Seld. 214; Troy r. R. R. Co., 4: Vt. 265 ; Challis v. R. I. Co., 16 kan. 117.

65 Moore r. Mltermen, ete. $t$ Sand. 45fi; affimend, 4 Sel. 110; Watson r. R. R., $47 \mathrm{~N}$ Y. 157. 
imports. This is effected by a petition addressed to a court of compctent jurisdiction, or to a jutge thereof, either in term time or vacation, setting forth, by reference, the authority in the premises of the party secking to talie or damage the property so required; the purpose for which said property is songht to be taken or damaged; a description of the property; the names of all persons interested therein as appearing of record, if known, or if not known stating the fact, and if the proceedings seck to affect the property of persons under guardianship the guardians, or conservators of persons having conservator, must also be made parties defendant, and if married women their husbands must be made parties. Persons interested whose names are unknown may be made parties by the description of the unknown owners; the latter fact being prosented by affidavit. Notice is given to the parties interested by personal or substituted service, and a hearing is had either before the jurge to whom the petition was addressed, or comnisioners appointed hy him, and when heard by the judge a jury may be impancled to ascertain the damages. The record in the matter stonlel substantially appear in the abstract, and must be sufticiently full to disclose all jurisdictional facts and that the puwer has been excreised according to the direction of law. When the procedings are conducted by eommissioners a repurt is mank to the court granting the authority, and this "whert subtantially cmbodies all that is neeessury to show comi) lete divesture, while the court roll, when such proceedings are minchetel prinarily before a conrt, or on apueal, will also serve the same end.

If the proceedings are regular in form the synopsis may be considerably condensed, and when such proceedings are displayed only incilentally, for the purpose of explaining the situation of the land and not to show the title of the condemned tracts, this comrse is recommended. In such ease brief references to the petition, the appearance of partics, the verdict and the judgment of the court, are all that will be necessary. Thus: 


\section{In the County Court of Cook County.}

\section{Central Railuay Com- pany \\ $v s$.}

James Thompson.
Ca.se. 1.509.

Petition, filed July 1, 1903, for the condemmation of the South 100 feet fof the North West quarter of Setion 10, Toun 39 North, Range 1.3 East of the 3d Principal Meridian, for the purposes of a railroad.

A ppectrance of defendant entered Aug. 4, 1903.

Case heard Oct. 15, 1903 (Lau Rec. 12, pg. 25). Terdict rendered wherein the jury funds that the petitioner do take from the owner the following property, to-w it: a strip of land 100 feet in width over and across the South side, etc. [set ont the finding].

Ordered, by the court, that petitioner have judgment of condemnation herein, and that upon the payment by it to the County Treasurer of said county, of the sum aforesaid, that said Central Railway Company do enter into possession of the said land and hold the same for the purposes provided by law.

It will frequently be advisable to show condemnation proceedings where land is taken for the opening or widening of streets, and the result is a change in the shape or dimensions of platted lands. Where provision is also mate for an assessment of benefits as well as compensation for damage, it will become necessary to show the essential features of the proceeding and the extent of the lien thereby occasioned. Brief general recitals will, however, be sufficient. As per example:

\section{In Superior Court of Cook Co.}

City of Chicago

vs.

Unknown Owners.

\section{Case, No. 79,050.}

Petition filed June. $2.1906, \mathrm{rep}$ resents that on March 28.1901 ; the City Council of said Cily passesed

an ordinance providing that Fairmonnd Aveme be opened and widened from West 2Sth Slreet to Wilson Avemue, by con- 
demning therefor the East 161/2 feet of Lots 10, 11, 12 and 13, in Block 4 of 11 hite de Blach's subdivision of the W. $1 / 2$ of N. E. 1/4 of Sec. 16, T. 24, N. R. 12, and other property.

Attached to petition is a eopy of said otdinance, duly verified, wherein it is provided that said improvement be made by special assessment to be levied upon the property benefited.

Prays that the just compensation to be made for property taken or damaged be ascertained by a jury.

Feb. 14, 1907, (Law Rec. 4.5, pg. 276) Terdict, where in the jury find the just compensation to be paid to the ouners of the East 161\% feet of said Lots to be \$5.00 for each lot.

Judyment on the verdict for said respective sums.

Assessment roll filed June 10, 1907, wherein Lots 10, 11, 12 and 13 are each assessed the sum of $\$ 125.00$.

July 1, 1907, (Lau Rec. 45. pg. 4SS) Assessment confirmed.

\$ 521 . Construction of Wills. The validity of a will may be contested in equity as well as before the probate court, ${ }^{66}$ yet this is scldom done, except on appeal, and the aid of a court of equity is usually invoked only to pass upon and construe indefinite and mucertain passages, or to direct the executor in the execution of indeterminate or insufficiently expressed trusts. Where any doulot arises as to the proper construction of a will, or as to the rights of parties thereunder, resort is usually had to a court of equity for a construction and decree for distribution, and the decree so made, so far as it relates to land, either directly or by just inplication, becomes an essential mmiment of title, equal in importance to the will itself, and of which, as an expression of the testator's intention, it forms an integral part.

66. Duncan $r$. Duncan, 23 111. 264; Flinn r. Owen, 68 111. 111. 


\section{CIIAPTER XXIX.}

TAXES AND TAX TITLES.

§522. Definition - Nature of tax- \$5:31. Tax sales-Tax payer as ing power.

523. Subjects of taxation. purchaser.

52. Lien of taxes.

532. Tights of purchasers.

5:3:3. Tiedermption.

534. Certificate of sale.

5:5.5. Tax dereds.

526. Nature of tax titles.

s:ice. Continuerl.

5.3. Formal parts.

53. E. Elfect of deed as evidence.

539. Tax deed - Possession Limitation.

529. Sale of non-payment.

530. Forfeitures.

5:40. Tax abstracts.

511. Special Assesiments.

\section{\$ 522. Definition - Nature and Scope of the Taxing}

Power. By the concurrent opinion of lawyers, judges, lexicographers, and political economists, as well as by the gmeral and popular mderstanding, taxes are burdens or elarese inposed by the legislative power, upon persons or property, to raise money for public purposes or to accomplish some governmental end. ${ }^{2}$ This power is vested wholly in the lecristature, though municipalities may exereice it by a special delegation of authority, and is merestrieted exeept when it is apposed to some provision of the Foderal or State constintion. ${ }^{2}$ It extends to every trate wrecupation, to erery object of industry,

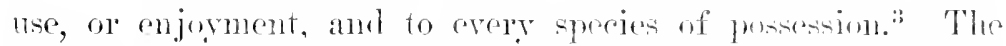
right of taxation has for its foundation the minciple that the

1 Ilanson $r$. Vernom, 27 Ioma, 28; Mitrlull r. Williams. 27 Tul. fi:; Backw. Tax Tit. 1.

2 Pouple $r$ Marsha\}, 1 Cilm.

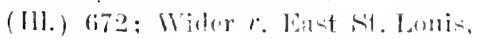

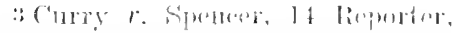

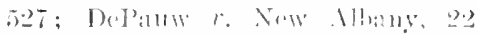

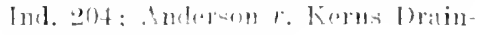
iner Co., 1.t lall. 19?. 5.) 111. 13:3. 
citizen shall contribute to the support of the government which protects his person and property, in just proportion to the value of the property protected; ${ }^{4}$ and equality, so far as is practicable, is its distinguishing characteristic. ${ }^{5}$ While it is scarcely possible to attain absolute equality in all cases, or benefits commensurate with the burden of taxes imposed, yet the principle upon which the approximation to equality is to be maintained must be preserved inviolate in this, that all property subject to taxation shall be uniformly assessed, according to value; a rule applicable to all taxation, whether for general, local or special purposes. ${ }^{6}$

The legislature, as we have seen, is the sole source and repository of the taxing power; on the other hand, the counties and other municipal divisions are mere auxiliaries of the government, established simply for the more effective administration of justice, and the power of taxation, as confided to them, is a delegated trust, and is to be strictly construed. They act, not by virtue of inherent power, but as mere agencies of the State, ${ }^{7}$ the whole theory of our system of taxation being based upon the idea that it is prepared by the representatives of the people, upon due deliberation and reflection, and when thus prepared for State purposes, it may be safely applied by the counties and other local agencies of the commonwealth.

$\S 523$. Subjects of Taxation. Primarily all property is subject to a just proportion of the burdens of taxation in return for the protection which the State affords, but the legislature may grant an exemption to certain classes, and such grant may

+ Dunleith $v$. Reynolds, 53 IIl. 45; In re Van Antwerp, 56 N. Y. 265.

5 Sherlock $r$. Village of Winnetkil, 60 Ill. 530; Holl rook $v$. Dickinson, 46 1ll. 2S5; Weeks v. Milwaukee, 10 Wis. 242; AttorneyGeneral $r$. Plankroad Co., 11 Wis. 3.).

r. Peay r. Little Rock, 82 Ark. 31 ; Chieago $t$. Larned, $3 t$ Ill. 253;
MeCormack $r$. Patchin, 53 Mo. 33; Weeks $v$. Milwaukee, 10 Wis. 242; People $v$. Bradley, 39 Ill. 1:00; Ottawa $v$. Spencer, 40 Ill. 211; Attorney-General $r$. Plankroad Co., 11 Wis. 35; Scens $v$. Racine, 10 Wis. 271.

TR. R. Co. v. Wasbington County. 30 Gratt. (Va.) 47]; E. S. r. New Orleans, 98 U. S. (s Otto) $38 \mathrm{I}$. 
be in the nature of a contract and therefore invinable. But such grant must be expressed in clear and mmistakable language, and can not be aided by presmmption or inference, ${ }^{8}$ while all langrage creating an exemption is to be strictly constrined. ${ }^{9}$

\$52. Lien of Taxes. The lien for taxes attaches to all land subject to taxation, amnually, upon some day stated, the time being different in nearly every State, and continues until the tax is paicl. ${ }^{10}$ Where, for instance, the lien attaches on the first day of May, and the property is conveyed subsequent to that date, it is incumbered by the lien, and unless a special exception is made in the deed the vendor is liable upon his covenants for the payment of the tax. It is also a statutory provision in many States, that taxes assessed on personal property of the same owner become a lien on his real estatc. ${ }^{11}$

Many examiners make no search for information concerning current taxes, yet this is one of the things of which intending purchasers should be apprised. Taxes are dne and payable at a stated time each year and when the date of the search is after this time, and before that fixed for the sale of lands for taxes, an examination should be made to ascertain the fact of payment or non-payment. The result may be embodied in a brief note among the appendices, as follows:

\section{Note.- It does not appear from the collector's warrant that} the taxes for the year 1903 , levied on the property described in the caption [or whatever piece may be delinquent] have been paid.

A general statement that the examiner finds no unpaid taxes may be embodied in the final certificate but, if desired, the fact

8 Minot $v$, R. R. Co., 18 Wall. 206; Butler's Appeal, 73 Pa. St. 448 ; R. R. Co. $v$. Maguire, 49 Mo. 490 .

g Commissioners $r$ Drackenridge, 12 Kan. 114; Nanf. Co. $r$. Fast
Sarrinaw, 19 Mich. 259; Methodist Church r. Chicago, 26 1ll. 482.

10 Binkert $v$. Wabash liy. Co., 98 Ill. 20.5.

11 Union Trust Co., $v$. Webar. nf; I11. 346 . 
of payment may be shown attimmatively by a note similar to the foregoing, and whenerer the title is complicated by adverse chims or interests it is always well to show who paid the tax. Thus:

Note-- On the collector's books for the year 1903 the general tares levied on the lund described in the caption hereto, are marked as haring been paid May 14. 1904, by Thomas Brown.

\$ 5.5. Tax Titles. A tax title is a purely technical, as contradistinguished from a meritorions title, and depends for its validity upon a strict compliance with all the requirements of law. ${ }^{12}$ To presumption can be raised to cure radical defects in the proceedings, and the proof of regularity devolves on the person asserting the title. ${ }^{3}$. If the lind claimed nnder such a title was subject to taxation, and the proceedings under the law have been regular, and the owner has failed to redeem within the time limited by law, then the whole legal and equitable estate is rested in the purchaser, and a new and perfect title is established. ${ }^{14}$ This results from the paramount authority of the State to lery the tax and coerce its parment by subjecting the property to sale, ret owing to the complexity of the pro-

12 Altes r. 11 inkkler. 26 Ill. 26.5: Whitmore r. Larmenl. 60 Ne. 276 : Charles $r$. Wargh. 35 Ill. 315: Hewes $x$. Reis, 40 ('al. 225: Rivers $r$. Thompisoll, 13 Ala. 633 .

13 Oliver $r$. Robinum. 58 Ala. 46. 14 Atkins r. Hinman. 2 Crilm. (IIl.) 43i: Smitl $r$. Messer, $17 \mathrm{X}$. II. 420; Dunlap $r$. Fallatin Co.. 15 Ili. 7 ; Jarris r. Peck, 19 Wis. 74: Cram r. Cotting, 22 Iowa, 411. The following primiples, or rules. for testing the valielity of tax titles. appear to he fairly deducible from the reported cases: (1) Where the statute mnder which the sale is made directs a thing to be done. or prescribes the form, time, and manner of loing anything, such thing must be done. and in the form. time and nanner prescribed, or the title is invalid; and in this re-pect the statute must be strictlr, if not literalls. complied with: (?) but in determining what is required to he done. the statute must receive a reaconable construction: and where no particular form or manner of loing a thing is pointer out, any mode which effects the object with reasonalule certinty is sufficient: Hall. I.. in Chandler $v$. Spear. 22 Vt. $38 \mathrm{~s}$. 
cedure enployed, and the careless, bungling or ignorant manner in which it is often noed, as well as the many grave questions which nay arise eren on perfect service, a tax title is regarded as among the poorest evidences of the ownership of land, and is always taken with suppicion and riewed with jealousy.

Though the end to be attained by the sale of the land, to wit, the satisfaction of the lery, is the same in every State, yet no two States scem to pursue exactly the same methods in arriving at this end, but whatever be the methods employed, there must at least be a valid judgment or corresponding feature; a valid precept authorizing the sheriff, auditor, or other officer to make the sale; ${ }^{15}$ and a proper conveyance of the land from such officer or other authorized person. These are essential to the prima facie validity of the title, and none of them can be dispensed with. ${ }^{10}$ The basis of the title is, of course, a legal tax, and no title passes by a deed when the whole or any part of the tax on which it is founded was illegal. ${ }^{17} \quad \Lambda$ sale of land for taxes frees it in the hands of the purchaser from all liens or liabilities for taxes of previous years; ${ }^{18}$ divests all prior liens and incumbrances; ${ }^{19}$ bars the inchoate right of dower; ${ }^{20}$ and vests in such purchaser a new, original, and unimpeachable title in fee simple. ${ }^{21}$ Such, at least, is the accepted doctrine in a majority of the States, though there are some in which it may not prevail. ${ }^{22}$

15 The preeept, though not technically process within the constitutional provision requiring all process to run in the name of the people, performs the office of an exeention, and is the authority under which the officer sells: Eagan $v$. Conmelly, 107 Ill. 458.

if ITolhrook $r$. Dickinson, $46 \mathrm{Ill}$. 285.

17 Dogan r. Grifin, 51 Miss. 782; MrLaughlin $r$. Thompson, $5.5 \mathrm{Hll}$. 219.

18 Bowman $r$. Thompson, 36 Iowa, 505; Preston v. Van Cordor,
3I Iowa, 250; Knox $v$. Leidgen, 23 Wis. 292.

19 Dunlap 2 . Gallatin Co., 15111. 7 ; Cram v. Cotting, 22 Iowa, 411.

20 Jones $r$. Devore, 8 Ohio. St. 430. Local statutes may morlify or change the doctrines stated in the text.

21 Turner $r$. Smith, 14 Wall. 553; Osterberg $r$. Union Trust Co., 9 Chi. Leg. News, 1.56; Schaeffer v. People, (i) 111.179 .

22 The statute usnally provides for a fee simple: It is lowd in several States, however, that the 


\section{\$ 526. Nature of Tax Tities-Dependent or Inde-}

pendent. A tax title, thongh bearing some resemblance to titles derived under judicial and execution sales, differs in this, that the latter are strictly derivative titles, and dependent not only on the legality of the procedure of transfer, but upon the acts of former owners. A tax title, on the eontrary, from its very nature, has nothing to do with the previous chain of title, nor does it, in any way, connect itself with it. The person asserting it need go no further than his tax deed, and the former title can neither assist nor prejudice him. The sale operates upon the land and not upon the title by which it had theretofore been held. It matters not how many different interests may have been connected with such title, for if the sale has been regularly made, the land, accompanied by a new and exclusive legal title, goes to the purchaser. No covenant rumning with the land, nor warranty, or other incident to the title as it formerly stood, passes to the purehaser, but he takes it by a new, independent and paramount grant, which extinguishes the old title and all the equities deepudent upon it. ${ }^{23}$

The statute usually pronounces the new title thus acquired a fee, but this would legally follow, even though the statute were silent, where no other estate is reserved in the deed. It must be understood, howerer, that the clanse of the statute which provides that a conveyance resulting from a sale shall vest in the grantee an "absolute estate in fee simple" does not mean that such estate shall rest in the grantee, notwithstanding the fact that the law has not been complied with in making the sale, but refers merely to the quantity of the estate conveyed as distinguished from a lesser estate. ${ }^{24}$

grantee of a tax deed takes only the title and estate of the former owner. See Sheaf $v$. Wait, $30 \mathrm{Vt}$. 735.

23 Neiswanger $v$. Gwynne, 13 Ohio, 74; do. 15 Ohio, 367; Ross $v$. Barland, 1 Pet. 664; Blackwood $v$. Van Vliet, 30 Mich. 120. See Blackw. on Tax Titles for a very elaborate discussion, p. ${ }^{*} 535$ et seq.

24 Stceple $v$. Downing, 60 Ind. 478. As the statute provides the title to be passed, it also, as a rule, states how that title shall be given in regard to prior lieus and incumbrances, and sometimes makes the sale subject thereto. Consult local 


\section{\$ 527. Proceedings Incident to Taxation. Where a} statute requires a series of acts to be performed before the owners of property are properly chargeable with the tax, such acts are conditions precedent to the exereise of the power, and all the requirements of the statute must be eomplied with or the tax will be invalid. ${ }^{25}$ These proceedings relate to the valuation, assessment, listing, returns, ete, and do not, as a rule, properly come within the scope of the examiner's duties. They are not usually shown in the abstract, unless there has been a special direction, and when required are nsnally made the subject of a separate and special examination. When a tax deed is relied upon as the foundation of title, all the antecedent steps become material, and should be shown, but this is the only instance in which it is done. Mere irregularities, not going to the groundwork of the tax, do not vitiate such procedings, ${ }^{26}$ and are cured by special statutes of limitation which exist in all the States. ${ }^{27}$ The subject is too vast to open, even in a general way, and the reader must be referred to techical works on the subject.

$\$ 528$. Description of Land-Assessors' Plats. Where lands are listed or assessed for taxation they must ordinarily be deseribed by reference to the govermment surveys, or, if divided into lots, then by reference to anthenticaterl plats. The subject of private subdivision has already been considered in other parts of the work, but there also exists in many, perhaps all, of the States, a method of oflicial subdivision for the more convenient and accurate purposes of taxation. The power to make these subdivisions is usually delegated to the assessor but is exercised, as a rule, only when land can not be otherwise described than by noting the metes and bounds. The statute is usually very explicit in regard to assessors' plats and subdi-

statutes for the efrect of tax deeds and the quantity and quality of the estate conveyed.

25 Hewes $r$. Reis, 10 Cal. 22.5; Rivers n. Thompoon, 43 Ala. 639; Abbott $v$. Doling, 49 Mo. 302.
26 R. R. Co. $r$. Morris, 7 Kan. 210: Greene r. Lunt, 58 Mr.518; Parker r. Sextoll, 29 lowa, 421; Thateber 4. People, 79 TH. 597.

27 Sec Thomas $v$. Stickle, 32 lowa, 71 . 
visions, and every material requirement must be complied with to give validity to the plat or any assessment of any of the divisions thereof. The attention of the examiner is therefore ealled to these plats whenever they appear in the abstraet, and the facts of conformity and sufficiency of deseription shonld be satisfactorily shown. Both the exact loeation and quantity must be manifest, and the plat will usually be fatally insuffieient so far as the subdivision of the tract for the purpose of description of its parcels for taxation is eoncerned, if wanting in these particulars. ${ }^{28}$

5.9. Sale for Non-payment. Taxation is regulated by statute, but the right is inherent in the govermment, and while summary remedies are given ly law, yet taxes when assessed become a personal debt, to be collected by any of the legal methods ineident thereto, should the gorernment choose to resort to such a remedy. ${ }^{29}$ Usually, however, the payment of a tax is enforeed by a sale of the land upon which it has been imposed. The methods employed are too various to attempt special mention, every State providing a special procedure for this purpose, and the subject ean only be treated generally. A tax is not an ordinary debt, however; it takes precedence of all other demands, and is a charge upon the property; withont reference to the matter of ownership. It grows out of the perpetual lien which the State, by rirtue of its sovereignty, has upon all taxable lands within its limits, and the property may be seized and sold, although there may be prior liens or incumbranees upon it, and payment enforeed to the exclusion of all other creditors. ${ }^{30}$ Whatever be the methods employed, the proceedings are summary in their nature and the requirements of law must be strietly pursued or the whole transaction will be void. ${ }^{31}$ When special proceedings are authorized by statute,

2s See People $v$. Reat, $107 \mathrm{nll}$ 581.

29 Mayor of .Toneshoro $r$. Mckee,

2 Yerg. (Tenn.) 167; Dunlap $v$. Gallatin Co., 15 Ill. 7 ; Binkert $v$. Riy. Co., 98 Ill. 205.
30 Reinhart $x$. Schnyler, 2 Gilm. (Ill.) 473 ; Dunlap $r$. Gallatin Co., 15 IIl. 7.

31 Charles $v$. Waugh, 35 Ill. 315; Cahoon $r$. Coe, 57 N. H. 556; Clarke $v$. Rowan, 53 Ala. 401; People $v$. 
by which the estate of ono man may be divested and transforod to another, the owner has a right to insist mpon a strict performance of all the material loppirements of the statute, espe-

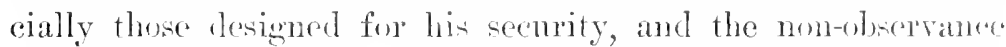
of which may operate to his prejudice. ${ }^{32}$ It is not the poliey of the law to derrive the citizen of lis property hy sals marle on accomt of the government thromeh its offieers, who have no interest in the matter, withont putting him wholly in fault in not complying with his oblisations. ${ }^{33}$

A symopsis of the special proceding culminating in the sale is of the highest importance whomerer the salo is relied upon as the foundation of title, but in ortinary cxaminations tax sales are shown rather in the nature of incmubrances on the title or charges upon the land, and it is custrmary to show only the fact, leaving the question of ralidity to be decided by other and special scarches. For this purpose tax sales, when still subject to redemption or not comsummated ly deed, are shown after the chain and under a classificd hear, the abstract consisting only of a brief mention of the date of sale and tax for which the sale is made, with reference to the official record; a hrief description of the premises sold; and the name of the person to whom the critificate issned. Forfeitures to the State are treated the same as tax sales. The following will indicate the method:

\section{T'ax Sales.}

Sale commencing Sept 18, 1SSO, for special assessments of the City of Chicago.

liecord $3 \%$, parge 58 .

Lot 5, in East half of Block. D4, Canal Trustees' Subdivision of Hest half, and West half of Novth East quatere

Biggins, 96 Ill. 481: Abbott $r$. Doling. 49 No. 302 .

32 Marsh r. Chestnert, 14 Ill. 223;

Holbrook $r$. Dickinson, 46 III. 285.

33. Rivers r. Thompsom, 4:3 Ala.

633. The lien of taxes is purely legal in its edarater, the creature of the statute, not arixing upon

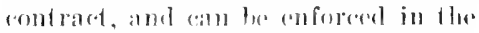
mole provided by the law of its creation, and in no oflere mamer: I'eople v. Bigrind, 96 111. 481. 
of Section 17, Town 39 North, Range 14, East. Sold Oct. 15, 1880, (Warrant No. 4,382, for macadamizing, ctc., W. Jackson Strcet) to Asahel Gage for $\$ \$ .40$.

Sale commencing Aug. 2, 1S\%5, for State and County taxes of 1874 .

Record 20, page 201 .

Lots 1.3 and 14 in Block 10, of Rockivell's Addition to Brocliton. Sold Sept. 25, 1875, for State and County tares, $18 \% 4$, to 1 sahel Gage, for $\$ 51.95$.

Where there are forfuitures as well as sales these are shown in much the same mamer.

$\$$ as: Forfeitures. The class of forfeitures to which this section allures, is based nyon the principle, "that every owner of lands hold his estate upon the implied condition that he will furnish a list of his taxalle estate, and promptly pay his share of the common burdens assessed against the entire community; and if he omits to comply with the condition, and his estate is offered at public vendue, and no purchaser can be found for it, the title is transferred from the owner to the State, the latter being, always ready to bid for the land, when no other bidder appears." 34 The term "forfeit" is not always used, but the effect in every State, where the property passes to the State in default of purchasers, is a forfeiture. A forfeiture operates to divest the title of the original owner, though ample time is ahways allowed for redemption, and purchasers of forfeited lauds, where the law has been strictly complied with, will acquire a valid title from the State.

A note of forfeiture is sufficiently expressed as follows:

Forfeiture.

Sale commencing Sept. 13, 1S80, for State and County taxes of 1879 .

Record 23, page 205.

Lot 5, of Block 10, in Williams' Subdivision of the North East quarter of Section 16. Toun 29 North, Range 34 Blackw. Tax. Tit. ${ }^{*} 460$; See Clery $v$. Himman, 11 Ill. 430. 
14 Eust, of the cid I'. M., Whs forfeited to the State of Illinois, Ort 15, 1830, for the non-payment of state und county taces of 15i\%. Imount, 55.00.

\section{\$581. Tax Gales - Trex Payer as Purchaser. A repy} erroneous opinion has sained curpency in many localities that a purchase by one owning, or interested in, the land sold for taxes strengthens a title previons a anpired, and henee it is not uncommon to find tax deeds to persons already possessing legal interests in the property. Such deeds, however, are nere nullities, for it is a proposition beyond dispute that one whose duty it is to pay a tax can not be a purchaser of property ofiered for sale for the purpose of collecting it. ${ }^{3 \pi}$ The parment of the money, in sueh ease, will be regarded only as a parment of the tax, and not as a purchase of the property; ${ }^{36}$ and the deed, at best, would eridence nothing more than that the tax on which it was founded was satisfied, the lien of the State discharged, and the estate restored from the sale, but no new title would be created or transferred by it. ${ }^{3 i}$

Nor does this principle apply only where there is a direct legal obligation. The party against whom a tax is assesed is directly liable for the tax, as is also a purchaser, ${ }^{38}$ or lessee, ${ }^{39}$ who has contracted to pay same, and in these cases, where there is a direct legal obligation, there can be no question about the duty. But other parties may accuire an interest in real estate who are not directly responsible for the taxes, and who enter

35 Douglas $v$. Dangerfieid, 10 Ohio, 152; Busch $r$. Huton, 755 Ill. 343 ; Barton $x$. Moss, 33 ill. 50 ; Dum $x$. Snell, it Me. 22: Christy $x$. Fisher, 58 Cal. 256; Williamson $v$. Russell, 1S W. Va., 612; Cooley on Taxation, 346; Blackw. on Tax Tit. 400.

36 Baily $i$. Doolittle, 24 Ill. 577; Ballame \%. Forsythe. 13 How. (U. S.) 18; Rlaney $r$. Elliott, 14 Ill. 456; Middleton Bank v. Bacharach,
46 Comm. 513: Johnston r. Smith, i0 Ala. 108.

$3 \tau$ Gould $r$. Day, 4 Uito (U. S.) 40.5. A tax deed, lowever, is al. ways color of title and where possesion is taken unier it and such posassion is crintinme for the statutory lesiod of initation a title may be preslicated upon it.

3 s Fitzgerald $v$. Spain, 30 Ark. 334.

39 Wagroner $r$. McLulughliu, 33 Ark 201 . 
into no contract in resect to thon, yet may be so situated that it is their duty to gar them. For infance, a purchaser of the property or of the enuity of redemption subject to a tax lien may be emplelled to pay the taxes in order to protect his own title. Such a party can not ordinarily be a purchaser of a tax title. So, too, a mortgagee is muler no legal obigation to pay the taxes, and get lie nay be compelled to pay them in order to protect his mortgage. Althorgh there mat be cases which hold that under certain circumstances he ma purchase a tax title, get the gencral rule is that he can not; ${ }^{40}$ for the reason that it is not ncessary for him to do so. He may pay the tax and the anomnt paid will be arlded to his debt, and he will hold the whole property as security therefor. In such a case it is unnecessary to complicate the legal title with a tax deed, and the law will not allow it to be done. Nor does it rary the case in principle if the person paying the tax owns less than the whole equity. Whether his interest be worth much or little, whether he owns the whole or a part, can make no difference. In either case if his interest is worth protecting he will pay the tax, and in neither care can he purehase a tax title. All such persons are incapable of purchasing at a tax sale, and deeds to them convey ino title. ${ }^{11}$

\$ 532. Rights of Purchasers. A purehaser at tax sale is not affected by any natter pertaining to title not connected with the tax procedings, nor is he charged with notice of any facts extraneous thereto. I sale for taxes is not subject to the rule that one who purchases during the pendeney of a suit is held hound by the decree that may be made therein, ${ }^{42}$ for the lis mendens onle relates to and afoets roluntary alienations by the defendant pending the action. It has nothing to do with

40 Williams $r$. Townsent, $31 \mathrm{~N}$. Y. 411 ; Sturderant $r$. Mather, 20 Wis. 576 .

41 Middleton Sav. Bank r. Bacharach, 46 Comn. 513; Jacks r. Dyer, 31 Ark. 34 Ponsession under a decel which ronveys no intervest will not disqualify the grantee to pur- chase the property whon sold for taxes. So one who holds a quitdaim deed to property previously conveyed may purchase same at tax sale: Comtis $r$. Smith, 42 lowa, 6in.

42 Wright $x$. Walker, 30 Ark. 44. 
parties asserting rights inderendent of and adrerse to that of the defondant, and where one ateruires title under a sale for taxes he is not bound loy the forecelosure of a mortgage given by a former owner of the land, and his title will prevail against that of the purehaser at the forechosure sale. ${ }^{4: 3}$ It is a cardinal rule, however, that a purchaser at a tax sale comes strictly and rigidly within the rule of eneat emptor, ${ }^{4+}$ but this has reference to the methods by which he accpuires title, and not to autecedent matters.

\$ 533. Redemption. The subject of redomption from tax sales bears a strong analogy to the satisfaction and discharge of judgments, and raises nuany of the sane questions in regand to the method of treatunent in the abstract. It is not the nsual custom of examiners to make special mention of a rectemption, as the certificate of the abstract is presuned to be a sufficient statement of the condition of the title at its date. But in riew of the current of authority, which ever inclines to limit the examiner's liability to the actual oceurences during the period covered by his search, irrespective of subsisting but previousty contracted liens, it would seem a far more satisfactory practice, and one tending to greater certainty in arriving at conchsions or passing opinions, to show the extinguishment of any and every lien which former examinations may have disclused, except, perhaps, where this has been effected by the statute of limitations.

From two to three years is the period ordinarily allowed in which the owner or interested party may discharge the obligation imposed by the levy of the tax and relieve the land from its burden. During this period the purchaser has a coutingent interest, which, after the day for redemption has pastorl, may ripen into an absolute title. This contingeney may he lefrated by payment, and when such is the case, it will often lwoonce as proper a matter for special mention as a release or diselarem

43 Jecker $\%$. Howard, 6 Thomp. \& C. (N. Y.) 603: 4 Uun (N. Y.). 359. This is sometimes denied.
Soe Smithr r. Idwis, 2 Wrat Via. 39. 44 Hamilton vo Valiant, 30 Md. 139. 
of a mortgage. Where the sale and redemption both oecur during the period inchuled and covered by the dates of the examination the whole transaction may with propricty be wholly disregarded, since it only amounts to a payment of the tax; but where a former examination discloses a sale, and a continuation is made during the redemption period, the lien in the meantime having been extinguished, such fact should affirmatively appear, and should the abstract be silent in this particular, a requisition for further information should be made by counsel before passing the title. Many exaniners show redemptions by a marginal note on the original abstract of the tax sale, and most attorneys prefer this method as it effectually disposes of the question the moment it is raised.

\$ 531. Certificate of Sale. Certificates of sale are rarely recorded, though they undoubtedly vest in the purchaser an equitable interest in the land which entitles him to be clothed with the legal title at any time after the period of redemption has expired, and before his right has been barred by the statute of limitation. ${ }^{45}$ The right to record such certificates, and assignments thereof ${ }^{46}$ when such assigmments are duly sealed, attested by witnesses, and acknowledged in conformity to law, is often given by statute, and when recorded in the proper eounty they have the same efiect as other records therein. When found upon the records they are shown, if prior to deed, as a lien or charge nom the land and after the course of title has been exhibited; when followed by deed they are briefly noted in comnection with that instrument. A symopsis of a certificate of sale simply recites the facts stated therein. The form will vary as the certificate may be made in pursuance of a judgment, as in Illinois; or by the county treasurer under the law, without judgment, as in Wisconsin. An example of the latter form is given. The reader is referred to illustrations of sheriff's certificates in other parts of the work.

45 Blackw, on Tax Titles, *372. 46 The aswignce of a tax certificate bolis it sulject to all the infirnities by which it would have been affected in the hands of the tax purchaser: Light $r$. West. 42 Iowa, 138: Besore $r$. Dosh, 43 Iowa, 211. 


\section{Hugh McDermott, County} Treasurer of Kenosha County, Wis., to

William Goffe.
Tax C'ertificate.

Dated, ete.

* $* * \quad *$

$\because \quad * \quad * \quad *$

Suid Treasurer certifies that he Bid. at public anetion,

pursuant to notire given as by lave required. on May 1, 185.;, sell to William Goffe, (or the county of Kenosha.) the following deseribed real estate [describing same] for s.5.50, being the amount due for taxes, interest and charges on suid lands for the year 1SSQ, and that said Witliam Goffe (or assigns) witl be entitled to a deed of stime in three years from date, untess sooner redeemed according to late.

\$535. Tax Deeds. Neither the legal nor the equitable title to lands sold for non-parnent of taxes vests in the purchaser until the exeention and delivery of a tax deed. ${ }^{4}$ This deed does not operate ipso facto to transfer the title of the owner as in ordinary deeds between individuale, but is the last act of a series of proceedings upon the regularity of which it depends for its character and effect. It is not title in itself, nor. unless aided by statute, even evidence of it. Its recitals bind no one, and it creates no estoppel upm the former owner. ${ }^{\text {ts }}$ The mere production of the deed, in the absenee of statutory aid, creates no presumption in its favor until all the anterior proceedings prescribed by law have been aftimatively shown to have been complied with, when it becomes enclutive evirlence of title according to its extent aut purport. The forconom dortrine, which long obtained in this comutry, is hased upon the policy that it is better that the purchase thum loe the small amount of his bid rather than the owner shomld forfeit a ralnable estate, where the proceedings show irregularity or illegal-

47 Stephens $v$. Holmes, 26 Ark. 48 ; Ius. Co. $r$. Scales, 27 Wis. 640); Jineket v. Gilmore, 15 Minn. 245;

Lake $r$. Gray, 35 lowa, 44. 4h Blarkw. on Tax Titles. * 364 : Jackson $r$. Esty, 7 Wend. 148. 
ity, ${ }^{49}$ and the burden of proring title under tax deeds has been thrown upon him who asserts such title. ${ }^{50}$

\$ 536. Continued - Statutory Modifications. Though the rule of the common law, that he who affirms the existence of a material fact must prove it, was for many years applied to sales for taxes in all its mbending rigidity, until the astuteness of judicial refinement had rendered almost inoperative all legislation providing for snch sales, a marked change is now apparent in many States. Stringent legislation has endeavored to comteract the tendency of judicial refinement, by declaring the operation and effect of tax deeds, and such conveyances in a majority of the States, when formal and duly executed, are now taken as prima facie or presumptive evidence of the regularity of all procedings, from the listing or valuation of the land up to the issuance of the deeds. A few States have gone so far as to declare such deeds conclusive evidence of every matter or fact required by law to make a ralid sale and rest title in the purchaser, except the facts of exemption, payment, and redemption, and as to the non-existence of those facts it is made prima facie evidence. ${ }^{51}$ This doctrine, however, has been expressly repuliated by the courts as an uneonstitutional confiscation of property, and the rule has been amounced that the legislature can make a tax deed conclusive evidence of the regularity of prior proceedings only as to non-essentials or matters of routine which rest in mere expediency. ${ }^{52}$ But the owner of property can not be preeluded from showing the invalidity of a tax deed thereto by proving the omission of any act essential to the due asscsinent of the same, the lery of a tax thereon, and the sale thereof on that account. As to the performance of these

49 Blackw. on Tax Titles, *68; Demning $\ell$. Smith, 3 Johns. Ch. 344; Jackion $t$. Morse, 18 Johns. 442.

50 Lyon $t$. Hunt, 11 Ala. 295; Keane $r$. Cannomoran, 21 Cal. 291.

51 See riwyne $r$. Neiswanger, 18 Ohio, 400; Allen $r$. Armstrong, 16 Iowa, 508 .
52 Acts which need not have been required in the first place - as the affidavit of the sherifl to the delinquent list-aud which the legislature may by a curative act excuse when omitted: Marx $v$. Hawthorn, 12 Saw. (C. Ct.) 374. 
acts, and the farts necescary to constitute them, the deed can only be made primu fucie evidene. ${ }^{53}$

It would seem to be well settled, however, that the legi-lature has the power to make a tax deed mima farie evidence of material facts upon which the right to sell and consey kepents, and when this has been done it has the effect to entirely change the burden of proof, reliering the purchaser therefrom and imposing it upon the jerson who attempts to eontrovert the deed ${ }^{5+}$ but to have this effecet the deed numst be regular on its face ${ }^{55}$ and display an apparent conformity to law. Whenerer it is shown that any essential particular in the anterior proceedings has been irregular, the authoritics are quite harmonious in deelaring its prima faric eharacter to be lost. ${ }^{5 i}$ and when the prima facie character, as established by statute, is orerthromn, the common law principles stated in the preceding section, at once attach, and the person ascerting the title must prove by satisfactory evidence the regularity of the proceetings. ${ }^{5-}$ The law declaring a tax deed prima facie eridence of title, does not dispense with the statutory requirements which precede the sale, but only shifts the burden of proof from the party elaiming under the deed to the party impeacling it. ${ }^{5 s}$

\$ 537. Formal Parts. The form and substance of tax deeds are usually prescribed by statute, in which case a strict conformity is required or the deed will be roid, ${ }^{59}$ though if de-

53 Allen $r$. Armstrong. 16 Iowa, 508 ; MacCready $r$. Sexton, 29 Iowa, 356; Paley $r$. Guinm, 76 Ho. 263: Callanan r. Hurley, 93 U. S. 387 ; Steeple $x$. Dowing, (6.5 Insl. 501.

54 Biscoe $r$. Coulter, 18 Ark. 423; O'Grady $r$. Barnishel, 23 Cal. 225; Watson $r$. Atwood, 2.5 Conn. 313; Millikan $r$. Patterson. 91 Ind. 515: Clark $r$. Conner, 28 Iowa, 311; Hart $v$. Smith, 44 Wis. 213; Lacey $\imath$. Davis, 4 Mich. 140; Washnngton $r$. Hasp, 43 Kan. 324; Taylor $r$. Wright, 121 111. 4.5.

55 Taylor $r$. R. R. Co.. 4.5 Minn.
67; Merriam $r$. Doves, 25 Neb. 618.

56) Sibley r. Smith, 2 Mich. 486; Graves $t$. Bruen, 11 Ill. 431 ; Turney $r$. Yomman, 16 Ohio. 24: Rayburn r. Kuhl, 10 Iowa, 92; Thompson $l$. Ware, 43 Iowa, 45.5.

5) IInrd $r$. Brimer, 3 Wash. 1.

ns Williams $r$. Kirtland, 13 Wiall. 306 .

50 Chandler r. Spear. 22 Vt. $38 s$; Inardman $r$. lonurne, 201 lowa, 134; Kroger $r$ Knoh, 220 11 is. 4:99. The form in suld rase beomes substance, and munt los strictly pur- 
feetive a new deed will usually issue to the person entitled, ${ }^{60}$ and the deed will not be aroided for slight irregularities or variances from the statutory form. ${ }^{61}$ The ordinary incidents of deeds attach to conveyances of land sold for taxes and in most respects they stand upon the same footing as deeds between individuals. ${ }^{62}$ To attempt an enmeration of the special distinctive features, however, wonld be to refer to the statutes of erery State in the Cnion, and not alone to one but to many, as few suljects have been so harassed hy legislative tinkering, both as to the methods of procedure and its evidence, as the sale of land for taxes. But inasmuch as the deed does not derive its validity from its capacity as an independent conveyance to transfer the estate described in it, but from the existence of a power and compliance with prescribed conditions, it should show upon its face a proper exercise of the power in pursuance of which it purports to have been executed. ${ }^{63}$ This rule is of uniform operation everywhere. All the recitals provided by law, which go to show full compliance, are necessary and integral parts, and the failure to reeite any one of the prerequisites to a valid sale will raise a presumption that the onitted requirement was not complied with. ${ }^{64}$ The execution and authentication are purely matters of local statutory regulation.

sued; Atkins v. Kimman, 20 Wend. 249.

60 Finly $v$. Brown, 22 Towa, 538; Woodman $r$. Clapp, 21 Wis. 350.

61 Bowman $r$. Coekerill, 6 Kan. 311.

62 Blakely $v$. Bestor, 13 Ill. 708. The construction of a tax deed in respect to the deseription of the land eonveyed must be the same as if such description were used in a deed between private individuals. The doetrine of striet construction, as applied to the execution of naked statutory powers, has no applieation in such ease: Blakely v. Bestor, 13 Ill. 70 . 63 Blackw. Tax Tit. *368; Jack- son $r$. Roberts, 11 Wend. 425; Tolman $r$. Emerson, 4 Pick. 160.

64 Long $r$. Burnett, 13 lowa, 29; Lain $r$. Cook, 15 Wi.. 446; Large $r$ Fisher, 49 Mo. 307. A ministerial offieer, in making a return or recital as to how he executed a power, must set ont the facts and the manner in which he performed the acts, and let the court determine whether they comply with or are in accordanee with the law. The sale of property for taxes is an es parte proeeeding. The officer acts at his own peril, and must perform every prerequisite required by statute bofore the title of a citizen to his property 
The later formos of tax deeds prescriled by statute are very short and (onerise, and the recitals confined to a few material points, while their legal reffect and operation is expresely defined as in case of deeds between individnals after statutery forms. The execution of the dreed is contided to the amuty clerk, or other offie re having the enstody of the tax recorts. A statutory deen as prearibed in Illinois and many of the Western States may be shown in the abstiact, as follows:

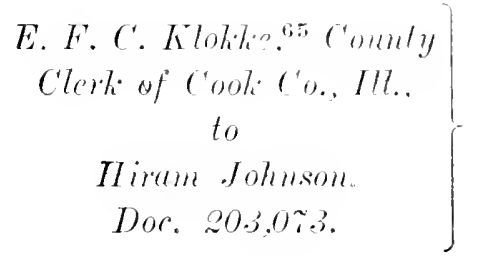

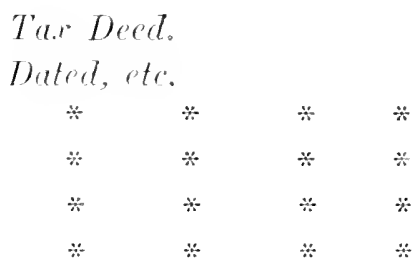

Recites, thint at a publie sate of real estate for non-payment of taxes, wade in the cominty aforesaid on Oct. 12, 18\%t; the following deseribed reat extate was sold, to-uit: [describing same] and some not hacing been redeemed from said sale. and it appearing that the holder of the certificate of purchase has complied with the lau necessary to entitle him to a decd of said real estate:

Therefore, said county clerti. in consideration of the premises and by virtue of the statute, grants and comeys to said second party the real estate hereinbefore described. subject to any iredemption provided by law.

Signed by said clerk, and the seal of the County Court affixed.

Aclinouledgment.

can be taken from him. The deai must show aflimatively that the law has been amplied with in all particulars: Simuleck r. Allen, 4? Mo. 178; Ablott $r$. Doling, 4! Mo. 302 ; Annan r. Baker. 4! $X$ H. l6i.
65) Where the county is the

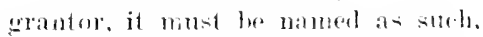
while the frocurement of the rounty rerk may he shown in the exrention. 
Inasmuch as the deed is statutory and can only be in one form, a shorter mothod is sometimes arlonted, which, after the caption and formal parts relating to dates and record, would read somewhat in this mamer:

Conveys (with other property) Lot 56, in Block 2, in Canal Trustees' Subdivision of the south east quarter of Section 57 , T. 39, N. R. 14 E. of 3ll I'. H., Cook Co., Ills., sold Oct. 12, $18 \% 6$, reciting sale of same for non-payment of taxes.

\$ 538. Effect of Deed as Evidence. The form last considered, and which will not vary materially from that now in general use where a statntory form is prescribed, is very meager in recitals. Its effect as evidence is dependent on the statute, which has made it mima faric evidenee, in all controversies and suits in relation to the right of the purchaser, or those claiming under him, to the property thereby conveyed, of the following facts: That the propelty envered was suljeet to taxation at the time the same was assessed, and hat lieen listed and assessed in the time and mamer required by law; that the taxes or assessments were not paid at any time before the sale; that the property had not been redeemed from the sale at the date of the deed; that it was adrertised for sale in the manner and for the length of time required by law; that it was sold for taxes or special assesments, as stated in the deol: that the grantee in the deed was the purchaser or assigne of the pmrchaser; that the sale was condncted in the mamer required by law. ${ }^{66}$

In addition, any judgment ${ }^{67}$ for the sale of real estate for delinquent taxes estops all parties from raising any abjections thereto or to a tax title hased thereon, which existen at or before the rendition of such judgment, and conld have henn presented

wit R. S. 1ll. 1874, Chap. 120; R. S. Wis. 1878. Chap, 50, and see R. S. Ind. 1876, chap. 123.

Gi No application for julgment is required in many States, but the county treasuren, or some other designated officer, is given power to sell lands returned as delinquent after notice has been given 
as a defense to the application for such judgnent in the court wherein the same was rendered, and as to all such questions the judgment itself is declared to be conclusive evidence of its regularity and validity in all collateral procectings, except in cases where the tax or assessment has been paid, or the property was not liable to the tax or assessment.

The efiect of statutes sinilar to the foregoing and of such statutes as have been enacted to quiet tax titles and secure the property conveyed by tax deeds, has been to give stability to such deeds and remove the chances of reinvesture in the original owner. Fet eron in the face of snch statutes the courts still cling to the former doctrines in this respect and critically inspect tax ileeds when offered in support of title, ${ }^{\text {is }}$ and where a deed is void upon its face, as when there is a want of power on the part of the officer, or where there is included in the amomt of the sale that for which the land could not be sold, and which is entirely mauthorized, it has been held not to divest the orner of his title to the land, even thongh the special limitation of the statute has rum in favor of such deed. ${ }^{69}$ In respect to the description of the land conveyed, a tax deed is gorerned by the same rules of construction as other deeds. ${ }^{\text {" }}$

In this connection the attention of comnsel is directed to a practice often obscrvable where spirited bidding attend tax sales. In some States it is provided that the ofticer conducting the sale shall sell so much of the land as a purchaser is willing to bid the amount of the tax upon. This has resulter in sales of infinitesimal portions and it is not uncommon to meet with tax deeds of the east vigintillionth of a tract. These deeds are practically nullities, and do mot eren cast a doud noon the title. The portion of the lot which such a deed purports to

6s A statute whieh makes a tax deed conclusive evillenre. is in derogation of the common law and must be strictly ronstrued: Gavin $r$. Shuman, 23 Ind. 323 ; and see Beekman $r$. Pigham, l Selel. (N. Y.) 366; MaCready $r$. Sexton, 39
Iowa, 356; Cooley on Tixation, 3.)6; Blitekw. on Tax Til. 7!).

fig Anman r. Jaker, 4! N. H. I6I ;

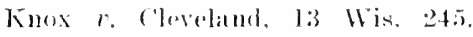
lult sce Datlon $r$, Lulats, 63 III. 337.

70 Blakely v. Bestor, 1:3 III. 708. 
convey can neither be formd nor identified and is not susceptible of a possession of any kind. Hence, as the land deseribed has no practical existence the deed which purports to eonvey it really conveys nothing. Such a deed has been held void on its face. ${ }^{i 1}$

In a majority of the States application for a tax deed must be made within a stated time, usually one year after the expiration of the redemption period. In the event that the deed shall not be taken ont and recorded within the time allowed therefor both the certiticate and the sale upon which it is based becomes void. ${ }^{2}$ It would seem, therefore, that where a deed is found upon record after the time so allowed, it may safely be disregarded in making an opinion of title, the invalidity being apparent on its face. But if the holder of the certifieate has been prevented from obtaining a deed within the prescribed period, either by injunction or refusal of the proper officers to issue sane, and these facts are recited in a deed afterward issued, then the time during which he has been so prevented may be excluded from the computation. ${ }^{73}$

§ 539. Tax Deed-Possession - Limitation. Radical defeets in tax sules and resulting conveyances may be remedied in many of the States, by compliance with curative statutes which provide, that where purchasers mite possession and payment of taxes for a definite period to the tax deed an unimpeachable title inures to such purchaser; and this, even though on its face the deed shows that the sale was irregular, if there is nothing to charge the purchaser with actual bad faith. ${ }^{i 4}$ Good faith is always presumed until the contrary is made to appear, and is imported by the deed itself. ${ }^{55}$ Where the holder of the tax title has becone entitled to the protection of the statute, all questions as to the regularity of the

71 Petty $r$. Beers, 224 Ill. 129.

72 Gage $v$ Reid. 118 Ill. 35;

Fuller $r$. Shedd, 161 Ill. 496.

7.3 These matters are statutory.

Consult local statutes.

7+ Dalton $v$. Lueas, 63 Ill. 337.

Compare Bowman $v$. Wettig, 39 111. 416 ; and see Geekie $v$. Kirby Carpenter Co., 9 Reporter, 37. 279 .

i5 Diekenson $v$. Breeden, $30 \mathrm{Ill}$. 
tax proceedings are set at lest, exeept, perhaps, these which oomcern the power anel juriediction of the taxing ofliceses or the liability of the land to taxation. The tax deed then heremenes antchusive evidonce that tho taxes wore joprely levied, and that all the requirenents of law were emmplied with. "is Pint whore a deed discloses on its face that it is illeral, and has ]yen "xeented in violation of law, a statute of limitation "an mot be brought in to aid its ralidity ${ }^{77}$ Tho constitutionality of special statutes providing for a shorter period than that provirlexl in the general statute of limitations has beren the sulijert of much debate, and is not yet a settred question; but there can be no doubt that a defective deed, thomeln invaliel as a convervance, will yet be admissille as color of title, and when followed by actual adrerse pussession will sot the statute in opulation. is

\$ 540. Tax Alostracts. Whenerer a tax doral is pelied on as a foundation of title which is independent of and atrerse to all other titles, particularly that of the proson who was last seized of the fee, a full exposition of the method by which the right was acquired is an essential preliminary to denumstrate the validity of all suceceding conveyances. The tax deed, nnaided by statute, is not sufficiont to demonstrats title, though it may be prima facie evidence of such, lut the prior steps must be shown and all the requisites necessary to a complete am perfect title momer the statute must be fully and sucoinctly stater. ${ }^{79}$ An abstract of a tax title may consist of a smopsis of the purceedings from the listing or assessment to the sale and issnance of deed, with all the material matters copied in full; or if so directed, a narrative statement of what was dome, tho times, manner, place, ete.; but all sufficiently explieit to enable comn-

76 Knox $r$. Cleveland, 13 Wis. 7313 ; Chapman $x$. Templaton. an Mo. 245. 463; Washburn $r$. Conten. 17 Minn.

77 Shoat $v$. Walker, 6 Kan. 65. 361; Wing 1. Hall. 44 VI. 11 S. In this case the law under which the deed was issued had been repealed prior to such issue: Compare Dalton $v$. Lucas, 63 Ill. 337.

78 Dillingham $v$. Brown, 38 Ala.

7a Mr. Blackwoll in his work on Tax Titles rives semene very valuablo forms for an ahetriot of this chatracter. So liarkw. on 'Tax Tit. Appendix. 
sel to see that every material step has been talien, and that in a proper and legal manner.

$\S 541$. Special Assessments. In addition to the ordinary charges annually imposed by the State, and which are usually designated as taxes, the examiner must also search for what are generally termed "assessments." An assessment, as distinguished from other forms of taxation, means a special or local imposition upon property in the immediate vicinity of municipal improvements which is uecessary to pay for such improvements, and is laid with reference to the special benefit which the property is supposed to have derived therefrom. ${ }^{80} \mathrm{~A}$ properly prepared abstract shonld show all confirmed special assessments against the property under investigation which remain unpaid at the date of the certificate. The statement may be brief but should comprise such data as will fully acquaint counsel with all necessary particulars and readily enable any person interested to refer to the original sources of information. Assessments are shown as appendiees in connection with statements of mpraid taxes and tax sales. The following will be a sufficient mention:

Special Assessments.

Assessment, Doc. 24.206, warrant 24.712, for a plank sidewalk: on Rilge Aveme, confirmed Feb. 15, 1900, was laid on Lot 1\%, Block: 5, aforesaid.

Amount of assessment, $\$ 15.00$.

Sometimes the entire smm of an assessment is divided into fractional parts and the payment extender over a series of vears. When such is the case the fact should be noticed and the installments paid and unpaid shonld find appropriate mention.

so Hale v. Kenosha, 29 Wis. 599. In many respects the system is vicious and unjust, being an attempt to compel individuals to pay for public improvements, but it srems to be too firmly established to be questioned at this time. 


\section{CIIAPTER XXX.}

\section{DESCENTS.}

\$ 542. Title by descent.

543. Nature, operation and incidents of the title.

544. Inheritance as dependent on seizin.

545. Heirship, its rights and privileges.

546. The line of suceession.

547. Generul rule of descents.

548. The right of representation.

549. Preferences.

550. Who may take by descent - aliens.

551. Continued-Adoptive heirs.

552. Ancestral cstates - Half blood.

553. Surviving consorts.

554. Coparceners.

555. What descends.

556. How affected by ancestral rovenants.
\$57. Lialility for ancestral covenants.

5.5. Creditor's liens.

5.59. Equitable conversion.

560. Proof of heirship.

501. Pronf of adoption.

56:2. Proof of a death.

563. Continued - Official regis. tration.

561. Continued - Probate of death.

505. Pronf of birth anr legitimacy.

566. Presumption of legitimaer.

567 . Validity of descents.

568. Abstraet of descents.

569. Continued - Probate proredings.

570. Settlement without administration.

571. Escheat.

\$ 542. Title by Descent. The best known but least understood title to land is that which the law raises for the heir upon the death of the ancestor. ${ }^{1}$ It is ealled title by descent, and though for practimal purposes it is regarded as a new title springing from the death of the anerstor, and when asserterl must be so proved, yet in reality it is but a continuation of the ancestor's title, which the law casts upom the heir at the moment of the ancestor's death. ${ }^{2}$ The heir is recalded in law

1 'The torm "ancestor," when meed with reference to the descent of real property, embrares all pore sons, collaterals as well as lineads, through whom an inheritance is derived: Wheeler r. Intterbuck, 52 N. Y. 67.

2 Hopkins r. Mec:ann, 19 111. 113 ; Minthall r. liose, 86 ill. 374. 
as a legal appointee to receive the title, ${ }^{3}$ and this appointment he ean neither disclaim nor avoid. ${ }^{4}$ Whenever the death of any person is shown, mitil rebutted, the presumption is that he died intestate, ${ }^{5}$ and that his heirs take his estate muder the laws of descent. ${ }^{6}$ Posthmmons children take in all respects as though they had been born in the life-time of the intestate. ${ }^{7}$

548. Nature, epreration and Incidents of the Title. The title of an heir is not so mueh an acquisition as a succescion. The death of the ancestor does not create a title, but rather comfinms in the heir that which was previonsly inchoate, uncertain and defeasible. "An estate of inheritance under" the feulal law," says Mr. Bingham, " existed only in the contract between the lord, for himself and his heir's on the one side, and the rassal, for himself and his heirs on the other. The one contracted that the other might have the possession and ocsupation of certain lands, usually npon the condition of rendering in return therefor certain rents and services, which the latter agreed to pay and perform. The heirs of each party were expressly named, and regarded, in the eyes of the law, as parties to the contract; and, when the original parties died, the heirs became the real and acting partics to the contract; and so parties continued to snceed each other from one generation to another, so long as there were heirs capable of becoming parties. This eontract right of possession of the lands constitnted what is known in the law as an estate of inheritance, or an estate in fee; and the succession of one person on the death of another, is what, in more recent times, is said to be the acquisition of title by descent."

3 Coke Lit. 191.

4 Wms. Real Prop. 75; 2 Black. Com. 201; 3 Wash. Real Prop. 6; Moore $r$. Chandler, 59 Ill. 466.

5 The word "intestate" properly signifies a person who died without leaving a will; but where it is used with respect to particular property. it signifies a person who died without effectually disposing of that property by will, whether he left will or not.

6 Lyon $v$. Kain, 36 I11. 362 . In all cases of intestacy the lex rei sitre governs the descent: Lingen $\iota$. Lingen, 45 Ala. 410.

7 Smith $v$. McConnell, 17 Ill. 135; Sansbery $r$. McElroy, 6 Bush (Ky.) 440.

s Ping. on Descents, 2; and see Watk. on Descents, 65. 
The rules governing the method of descent and the clases of heirs who shall take, as well as the order in which they shall take, have been many times changed; the nature of the s-tate has been enlarged; the right of alienation during life and linherison after death has been giren to the ancestor; the exiate. may also he diverted from the heir to satisfy the anco-tur' debts; ret the fumlamental principle of inleritance lials lomained practically unchanged. The contract on the part of the State as evidenced by the original grant still is, that the grantee and his heirs may hold, possess and enjoy the land, and on the death of the ancestor the heir suceeds to his rights in virtue of the original agreement, as strictly as thongh the right or power of alienation did not exist. The estate held he this title possesses none of the attributes of the ancient fendal estate, howerer, but is entire in the ancestor and his heirs, with no reversion or other feutal incilent. ${ }^{9}$ While the State may still exereise the right of escheat ret this, nuder modern statutes, is in no proper sense a reversion.

$\$ 5 ! 4$. Inheritance as Dependent upon Seizin. It waz a primal rule of the common law that no peron could inherit real estate, unless he was heir to the person list seized. Tnder the application of this rule it was not sufficient to be heir to the persom who last had the right to the land, but not the actual seizin. This rule grew ont of the fental doctrine, which re'puired the heir to be of the blood of the first purchaser, and the seizin of the last possessor was regarded a presumptive evidence of this fact. ${ }^{10}$ The rule was subject to some exception in England. In this comtry it has never heen adopted in a majority of the States, while in the others it has been expressy abrogated, and every possible right or title whirh the anesstor may have had in land, whether accompanies by al'tual seizin or possession, or not, is rendered transmissible by inheritance, with the exception of estates for vears, which are rewatrod as chattels, and estates for his own life. ${ }^{11}$ The wowl "seizin "

9 Ilaynes r. Jomrn. 42 Vt. 686; Wallace $r$. IIarmatad, it Pa. St. 423.

10 Co. Tit. 11: 11:1tk. an Wrie. (i.).

11 Kent ('om. 3ss; Jakkinn $v$. 
is now equivalent to "ownership," and though the term is still retained both in the statutes and the language of the courts, its legal significance does not extend further than above stated, and is in no way dependent upon possession. Every right or interest, legal or equitable, to which the intestate was in any manner entitled at his decease, except estates which come within the definition of chattels real, are valid subjects of descent.

\section{$\$ 545$. Heirship-Its Rights and Privileges. The} title of an heir is held in his own right, ${ }^{2}$ suljeet only to the payment of the debts of the ancestor, ${ }^{13}$ or the fulfillnent of his covenants, ${ }^{14}$ and though he may afterward be divested by the decree of the probate court and sale by the administrator, yet until such contingency he is the owner. and entitled to all rents, profits or other beneficial incidents flowing from the land. ${ }^{15}$ Subject to the lien of the creditors, he mar make any disposition of the land he may choose, and after due probate and administration, together with an extinguishment of the ancestor's debts, the title becomes perfect in him or his assigns. ${ }^{16} \mathrm{He}$ is favored by the law, and his inheritance is never defeated except by the clearest proof of intention on the part of the ancestor, and although he is expressly exchurled by the terms of a will, yet unless some valid and effectual disposition of the land is made to some other person, it descends to him by operation of law, and in case of an invalid or insufficient devise, he takes in preference to the residnary devisee. ${ }^{17}$

$\$ 546$. The Line of Succession. The law invests the heir with the title of the ancestor, but it also designates who is to be that heir, and in this respect is rigid, arbitrary and

Hendricks, 3 John. Cas. 214; Bates $r$ Selraeder. 13 John. $260: 3$ Watk. (Ohio) 333; Nillians $v$. Amory, 14 Mass. 20.

12 Wallbridge $r$. Day. 31 Ill. 379.

13 Foltz $r$ Pronse. 17 Ill. 487; Cockerel r. Coleman. 55 Ala. 583. 14 Miller $r$. Eledsoe. 6l Mo. 96. 15 Foltz $r$. Prouse. 17 Ill. 487.
This old pule hals been infringed in some States by permitting the administrator to tali: the rents and profits peuding the final settlement of the ance-tor's estate.

1; Tansckle $r$. Richardson, $1 ;$ 111. 171; Austin $r$. Bailes, $37 \mathrm{Vt}$. 219.

17 Haxton $r$. Corse, I Parb. Ch. 506 ; Rosevelt 2 . Fulton, 7 Cow. 71. 


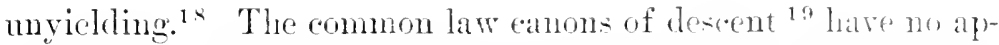
plication in the Enited States, but rules have been sstablished in every state that regulate the line of sucession and declare who, mudor cortain conditions, shall be the heir. Succession in the Enited States, as in Fingland, follows the line of consangninity," exrept where the smoving hnshand or wife is allowed a participation as a successor, and a person, to successfully establish his claim of title, must bring 'himself within one of the elasses presaribud by the statute, as well as show that no nearer degrees of kindrod exist which by statute would defeat the claim which he asserts.

S5t. General Rules of Descent. While there is a sad lack of liammony in the statutes of descent of the different States, which not only prevents the formulation of a positive rule but also any intelligent method of gemeral treatment, it may yet he said that fire well defined prineiples relative to the succession are discernible. The descent in accordance with these principles is as follows: Real estate of an intestate descends (1) to his lineal descendants, except where a surviring consort is allowed to participate: (2) to his father, ravied in some cases by a participation of brothers and sisters: (3) to his mother, raried as before by collateral participation: (4) to his collateral relatives: and $(\tilde{5})$ to the State by escheat. These fire elenentary principles are covered by a network of condi-

is Tyler $\iota$. Reynolds, 5:; Iniva, $1+6$.

19 There were seven common law ranons of dereent to the effect: 1 , that inheritance should always de. scend lineally. and nerer aseend lineally; 2 , that males are always preferred to females; 3 , of two or more niales in equal legree, the elrlest only should inherit, but fomales all together; 4, that lineal deserendants in infinitum, of any person dereased, slowald represent their ancestor; 5 , on falure of lineal descendantr, the inheritance should dexrent to the collateral relations, being of the blood of the first purchaser. subject to the three preceding rules: 6 , the collateral lieir of the person last seized mu-t be his next collateral kin-man of the whole blool; 7 , in anllatera! inheritances, the male stork should be preferred to the female, nulese where the lande hasl, in filct, the scencled from a fonnale: 2 likak. com. $2018,231$.

20 Sec Table of Consanguinity, § 31 of this work. 
tions and provisos, differing more or less in every State, and the application of these conditions governs the descent, and directs it into some one of the chamnels above emmerated. In all cases not provided for by the statute, the inheritance descends according to the course of the common law.

$\S 548$. The Right of Representation. This is the right of the lineal descendants to take the portion which their ancestor wonld have taken, and is called inheritance per stirpes. It is a statutory right, and by reason of the diversity of the statutes of the different States, no positive rule can be stated. Generally, if one of several children shall have died before the ancestor, the heirs of such child will take the portion which would have descended to it if it had survived the ancestor, ${ }^{21}$ and the same rules apply for determining who are the heirs of such child, as in any uther case of descent. In a few States, whero an intestate leaves grandehildren only, they all take per capita, or in their own right, ${ }^{22}$ but as a rule of more general observance, the lineal decendints pepresent only their ancestor. ${ }^{23}$

$\$ 5+9$. Preferences. By the common law camons of descont, males were preferred before females, the eldest male taking in preforence to others of equal degree, and females chually, while in collateral inheritance the male stocks were always preferred to the female, except where, in fact, the lands had herended from a female. This has all been abolished by the statittes of decent which provided in all cases for equal participation anong the members of a class, and the right of primogeniture, if it ever existed in this country, is now unknown.

5 550. Who May Take By Descent - Aliens. There is a mass of eurious and obsolete learning in the books, relative to persons capable of succeding to an inheritance, for the law

21 Dodge $r$. Beeler, 12 Kan. 524; Crump $r$. Faueett, 70 N. C. 345.

22 Cox $r$. Cox, 44 Ind. $36 \mathrm{~s}$; Esbleman's Appeal, $74 \mathrm{~Pa}$. St. 42 . Compare Harris Estate, $74 \mathrm{~Pa}$. St. 452.

23 This is somewhat in accordince with the fourth canon of inleritance at common law, only by the applieation of that rule, descendants of a person deceased $i_{n}$ infinitum represented their ancestor, and only when the representation failed were the lineal descendants of the intestate's next of kin permitted to come in. 
formerly guarded the landed estates of the comntry with jealums care, and ruthlessly excluded from a successiom thereto all peresons who owed fealty to another sovereign. Inheritan wats long confined to citizens of the Enited States, aml aliens were expressly declared incapable of taking lands by deconte or other mere operation of law, and hecanse an alien onull have no inheritable blood throngh which title conld be dedued, a citizen was precluded from asserting a title so terived. In ease of the death of an alien owning lands, or of a citizen without other than alien heirs, the lands of such persons escheated to the State. ${ }^{24}$ Private laws were often passed to enable individuals to receive and transmit title, and the effect of such laws was to invest the person mentioned with inheritable blood and to enable him to alien or devise his property and to transmit by descent in all respects the same as a citizen of native birth, ${ }^{25}$ but not to remove the barrier against alien heirs. All of this grew out of the timidity of the islander, and was a part of our inheritance of the English common law.

At present a few relics of the narrow, insular ideas of the common law may still be found, but in many States where the doetrine formerly prevailed, it has been swept away by the liberal policy of later years and in other States it never har a recognition. In a few States, while the right of inheritance is not denied to an alien, it is ret restricted by limitations of time, value and quantity, but, generally, for all practical purposes, so far as respects the acquisition and descent of land, the alien and the citizen stand upon an equal footing. ${ }^{26}$

In the examination of titles an inquire into the questions just noted is sometimes material and necessarry, and if, from a view of the facts shown, or of answers to inquiries in pais, it appears that title is deduced through an alien, at a time when

24 Craig $v$. Radford, 3 Theat. 363 ; Doe $v$. Governeur, 11 Wheat. 352; Jackson $v$. Green, 7 Wend. 333 ; Levy $r$. Levy, 6 Pet. 102. This extended as well to the estates of dower and rurtesy: Mick $r$. Mick, 10 Wend. 859.

25 Parish 6 . Ward, 29 Barl, 328. 26 See Meromville $r$. Howell, 17 Fed. Riep. 104. 
aliens were incapable of transmitting by lescent, ${ }^{27}$ evidence of other matters, sufticient in law to support the title of the present claimant, should be required before accepting same. The laws of the States remoring the disabilities of alienage and granting or withholding the privileges of citizenship, are not usually retroactive, nor do they possess any extraterritorial effect, and the domicile of the ancestor at the time of his death does not affect the application of the lex rei site, for no State can preseribe qualifications of citizenship, to be exereised in another State, in opposition to its local laws and poliey, and even the clause of the Federal constitution declaring that the citizens of each State are entitled to all the privileges and imnumities of citizens in the sereral States, is not suffieient to overcome the rule. ${ }^{28}$

\$ 551. Continued - Adoptive Heirs. The rights growing out of adoption present a series of somewhat similar views. This act, being in derogation of the common law and of natural right, confers upon the heir by adoption rights which can only by asserted strictly within the law, and particularly is this the case when title is elaimed in States other than that under whose laws the heirship was effected. The rights of inheritance acquired by an adopted heir in one State can be recognized and upheld in another State only so far as they are not inconsistent with the law of descent of such latter State, and his inheritable capacity must be measured by the laws of the State where the land is situate, and not by that of his late ancestor's domicile, or the State conferring inheritable likod. ${ }^{29}$

\$ 5.5. Ancestral Estates - Half Blood. A marked provision may be observed in the statutes of deseent of many States in relation to ancestral estates and the exclusion of all persons

27 Sporadie attempts to revive the har against alien heirs and to restriet alien ownership will be foumd in the legislation of many States. The effect of such legislation must be determined by loeal laws and statutory construction.
28 Gerard's Titles, 89 ; Corfield $u$. Corgell, 4 Wash. (C. Ct.) 371 ; Keegan $v$. Geraghty, 101 Ill. 26.

29 Consult Ross r. Ross, 129 Mass. 24:; Sewal $r$. Roberts. 115 Mass. 262; Keegan v. Geraghty, 101 III. 26 . 
who do not partake of the hlowel of such ancestor. The clanse in question provides in substaner that in calse an inlereitanos comes to an intestate ly desent, dovise or gift of one uf his aneestors, all thoce not of the blood of such anceston shall ber excluded from such inheritance, and the rule obiersen by the courts is general, that only persons of ancestral hloos ran inherit ancestral estates: ${ }^{\circ 0}$ The current of later decisions, hormever, is miform in declaring that the mle has reference to the immediate ancestor from whom the intestate recoivel the inheritance, and not from a remote ancestor who was the original somee of title. 31

\$ 553. Surviving Consorts. Thubands and wives are in no sense of the word next of kin to the other, ${ }^{32}$ but inamneh as heirship is peculiarly a creation of the legislature, it has the power to make a surviving hus band or wife, as well as a child, an heir, and this has been directly or indirectly aceomplished in a number of the States. ${ }^{33}$ But further, the right of dower has been radically changed in a few States, so that instead of the use, during life, of a portion of the husbanl's estate, the fee to a specific quantity rests absolutely in the widow upon his death, and thongh it will require no small amome of astute reasoning to discover wherein such procedure dnes not constitute a descent, yet the comrts of such States, in view of the fact that the statute declares that she shall be "entitled," ete, have decided that the wilow does not take by deseent, as an heir, but by virtue of her marriage relation, as a widow. ${ }^{34}$ Further provision for a surriving consort is made in sme States where

30 Campleell r. Ware, 27 Ark, 65; Wheeler r. C'lutterbuck, 52 N. I. 67; Perkins $r$. Simmonds. 28 Wis. 90.

31 Buckingham $r$. Jaeques, 37 Con. 402; Curren r. 'liylur. 1!) Ohio, 36; Cramer's Appeal, 4: Wis. 167 ; Ryan $r$. Ancluews, al Mich. 2.29; Whoeler $r$. ('Iutterluck, 52 $\mathrm{N}$. Y. 6 i7.

32 Townsend r. Rarleliffe, 41111. 446; Tillman $r$. Daris, !. N. Y. 17.
The term " next of kin" refers only to relatives by blood. She slowson r. Iynch, 43 Parh. (X. I.) 147; Inaralen $x$. Iarrabee, 1l:; Mass. 430 ; Joxluces appeal, lo6 Pa. St. 216.

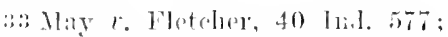

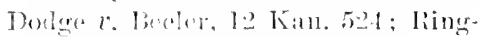
lomer re kearer, 4! 111. 470.

st Pramom r. May, 43 lad. 92;

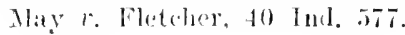


the deceased spouse leares no children, or no kindred of any kind, and in such erent the survivor takes strictly as an heir. ${ }^{35}$

$\S 554$. Corparceners. Persons to whom estate of in heritance descends jointly, and by whom it is held as an entire estate, are called coparceners. ${ }^{36}$ Formerly in England the term included all persons, and such is its legal signification in America, but its present use in England is confined to females. ${ }^{37}$ The distinction between coparcenary and tenancy in common, is virtually abolished in the Lnited States, and the general rules relative to tenants in common have the same application whether the common property be derived by deseent or by purchase.

\$5.5. What Descends. Everything comprised in the term "lands," or "lands, tenements and hereditaments," descends according to law to the heirs, and these terms include every estate, interest and right, legal and equitable, whether in possession or expectancy, vested or contingent, except such matters as may be determined or extinguished by the death of the intestate, leases for years, and estates for the life of another. ${ }^{3 s}$

\section{$\$ 550$. How Affected by Ancestral Covenants. Heirs} are not bound by the corenants of their ancestors, further than the real estate descended to them and the amount of their distributive shares of their ancestor's personal estate, ${ }^{39}$ but where the ancestor conveyed with warranty, land to which he had no title, or in which he had only an inferior or limited estate, his heirs must make the warranty good if they have assets by descent equal to the value of the land. ${ }^{40}$

\$5 5. Liability for Ancestral Debts. An heir is under no legal liability to discharge the debts of his ancestor from whom he takes real estate, except where the personal estate of

35 See. York r. York, 39 I11. 52.2. 361 Bon. Law Dict. 363; 2 Black. Com. 187.

374 Kent Com. $462 ; 2$ Bor. Inst. ก. 1781 .

3. The statute usually defines the subject of inheritance. but the above is the substance of the statute as generally enicted.

3a Holder $r$. Mount, 2 Marsh. (Ky.) 189.

fil Miller $r$. Bledsoe, 61 Mo. 96. 
such ancestor is insufficient to pay sane, ${ }^{41}$ and "reditors, in the first instance, must resort to the personal representatives before sceking satisfaction of the heirs. ${ }^{2}$ After having areepted the succession, they becone personally liable for the debts of the ancestor, ${ }^{+3}$ but only to the extent of what descends to them finom such ancestor. ${ }^{44}$

\$5.5. Creditors Miens. Fren though a title loy descent may be perfect in the person asserting same, it is yot liable to be defeated hy a sale made in satisfartion of the ancestor's debts, and no security can be predicated for it until the loar of the statute has intervened. In case of umprohated estates the full period of limitation must have expired before a purchaser can feel reasonably certain as to the stability of his title, and where there is no statute - as is generally the case - interposing any limitation of time within which the lien of creditors on the lands of a decedent must be enforced, difficult and cmbarrassing questions are presented, for which no absolute rule of solution can be given. The questions that naturally arise are; will the delay and laches of the creditor destroy his lien and right to pursue the land in the liands of the grantee of the heir, holding under a converance duly recorded, and if so, what period of time must elapse? Cortainly the lien can not be perpetual, and it would seen, by analogy to the liens of judgnents and the limitation for entry upon land, that the statutory period provided in those eases should bar such lien, and this has been the view taken by the courts in several instances when such ques-

41 McLean $r$. McBean, $74 \mathrm{Ill}$. 134; Woodfin $v$. Anderson, 2 Tenn. Ch. 331. Though cu-tomary, it is not aecurate to say that lands descending to heirs are charged with the delsts of the ancestor. The lands are liable only to be charged with the payurent of debts upon a deficiency of personal assets; and this right may be lost by delay: l'isloge $r$. $0^{\circ}$ Conner, 69 1ll. 421.

12 Mix $r$. French, 10 Ileisk. (Tenn.) $37 \%$.

43 Succession of Bougere, 28 La.
Ann. 743. The debts chargeable upon lands desurnded are those contracted by the decedent owner, not those incurred by his representatives in the cource of alministration: Allen r. Puole, 54 Misis. 323; Porterfield $r$. Taliaferro, 9 Lea (Tenn.), 2.42.

4t Pageon r. Ilalduck, 8 lise. (C. (t.) 293; William; r. Ewing, 31 Ark. 2ug: Branger to Luey, s. 11 . 9); Cutright $r$. Stanford, s] 111. 240. 
tions have been prosented. ${ }^{45}$ The question, however, is still one of great dombt and nucertainty. The conclusion above stated seems in every way just and cquitable and in consonaner with established legal rules, ret it appears to have been adopted in but few states. The preponderance of anthority leares the matter open and indefinite. It is agreed that an order to sell lands should be prorured within a roasonable time, but what is a reasonable time is gencrally left to the discretion of the rourts to be detemined upon consideration of all the circmmstances of each particular case. ${ }^{46}$

In case of probated estates, a shorter period is required. The limit of the time when application can be made by ereditors to sell the lands of the decedent, is varionsly fixed at from one to four years from the granting of letters of administration. During this period the land remains subject to sale, in case of a deficiency of personal assets, not only in the hands of the heirs, but of erery subsequent purchaser, ${ }^{47}$ and the title made at snch sale will he paramomnt to all titles made by or thromgh the heirs. ${ }^{4 s}$ There is no prohibition to the alienation of the land before the expiration of the prescribed perior. for the heir may sell and conver at any time after the reath of the ancestor, but if he should conver before the expiration of that period, the lands pass subject to the power of the probate

45 McCoy $r$. Morrow, 18 H11. 519; Fitzgerald $r$. Glaney, 49 [11. 46.5; Furlong $x$. lidey, 103 Ill, 638. The policy of the law is, repose and security of titles and estates again dormant clains. and further, to afford notice of liens against linds througl the public records. and to disfaror those liens of which it has provided no pullic notice.

46 llatel r. Kelly, 63 X. H. 29; Gunlyy r. Brown, 86 Mo. 253; Mays $x$. Rogers, 37 Ark. 155; Liddel $r$. MeVirkar, 11 N. J. L. 44 ; Hergusen $r$. Scott, 49 Miss, 500.

47 Hyde $\tau$. Tanner, 1 Barb. 79 :
Hill r. Treat. 67 Me. 501: MeCoy $r$. Miorrow, 18 11l. 519.

48 Meyer $r$. McDougal, 47 I11. 278. The same is equally true of derisees: Hyde $r$. Tamner, 1 Barb. 79 . But where the arelitor proceeds directly again-t the heir, if the real estate has leen sold by such heir in good faith, it would seem that it can not be sold under a judencont again.t him; but the creflitor must satisfy his judgment ont of other property of the heir to the extent of the value of the land so aliened: Vansyekle $r$. Richardson. 13 Ill. 171. 
rourt to order a sale for the pavment of debts, which is a kind uf statuteng lien rumbing with the land. Aftre the expiration af the statumere period, the power of the probate comet ceases: the land is dischared from the hen; and the hroir may sell, and bonn fide purchasor will take the estate, freed and dischareed finu the debts. ${ }^{49}$

The forcgoing is based upon decisions made in pursuance of liral statutes, hut will probahly scre as a general exposition uf the law in all States so far as respects erectitors who fail to prosent or prove their claims.

559. Equitable conversion. The suceession of the heir may also be drfeated lyc what is known as equitable conversion, as where the ancestor had made a valid contract of sale but died before its consummation by deed. In such a case equity will intervene, on the familiar prineiples heretofore shown. In the crent just noted, the purchase money acerues to the exeentor or administrator, and not to the heirs, ${ }^{51}$ while on the contrary, if the ancestor had purchased land but received no converanee, the title subsequently acquired would inure to the heirs, even though the administrator paid the purcliase money.

$\$ 560$. Proof of Heirship. Title by inheritance or succession acerues only to the issue of lawful wedlock, ${ }^{52}$ and can be asserted only by the person or persons who ean bring them-

49 Collamore $v$. Wilder, 19 Kan. 67 ; Sevier $v$. Gordon, 29 La. Ann. 440 ; Hyde $v$. Tanner, l Barl. 79; Nowell $r$. Bragdon, 14 Me. 320; Aiken $v$. Morse, 104 Mass. $27 \%$. This is a matter of statutory regulation; consult local statutes.

50 See Chap. XVI11, Agreements for Conveyances.

51 The heirs in such a case would take the legal title by descent, hut only as trustees: Jolnson r. rorlett, 11 l'aige, 265: Moore r. Burrows, 34 Barb. 17s: Smith $x$. Smith,
55 11l. 204; Eaton r. Bryan. 18 Ill. 525.

52 It is a rule of construction that, prima facie the term "children" meaus lawful children, and the statute of descents, by which the property of an intestate is made to descend to and among the children and their descendants, has reference to lawful children only, and does not do away with the common law rule, which prevents illegitimate children from inheriting anything: Mlacklaws $v$. Milne. $8 *$ Ill. 505. 
selves within the line of succession provided by the statute. To successfully assert the title, therefore, it is neeessary for the heir to prove: (1) the death of the ancestor, and lawful seizin in him of the subject-matter of the title at the time of such decease; (2) the marriage of his parents; and (3) proof of his legitimacy or a lawful adoption. These three points satisfactorily established, the law will incest him with title to such portion of the ancestor's estates as, under the statute, he is entitled to take. To prove heirship in a collateral line, a party must show the descent of himself and the person last seized, from some common aneestor, and the extinction of all those lines of descent which would elaim before him. ${ }^{53}$

In contests concerning the succession, these matters are proved in a variety of ways, but mainly upon the established precedents of the common law, which will be discussed in succeeding paragraphs. The difficulties which may attend the judieial determination of (puestions of heirship, inchding the ascertaining who are entitled to succed to an intestate's real estate, do not seem to be provided for by statute in a majority of the States, though an attempt has been marle in some to provide means, by a proceding in probate, for obtaining presumptive evidence of the facts as to the persons who constitute the heirs at law of a deceased person. ${ }^{54}$ Ordinarily the meager proof offered by the administrator, upon the application for letters of administration, is the only record proof of heirship available in the compilation of an abstract, and thongh the decree or adjudication may find the persons mentioned in his petition the only heirs at law of the decedent, it is not conclusive on that point, and is done rather for the purpose of fixing the right of the person appointed to alminister, and for his guidance in the distribution

53 Emmerson $v$. White, $29 \mathrm{~N}$. H. 482 .

54 See, N. Y. Civ. Co. Proc. § 2654. This is done by petition describing the real estate: setting forth the facts upon which the jurisdiction of the court depends; the interest of the petitioners and other heirs: and praying for a decree establishing the rights of inherit. ance; but this proceeding does not affect the right or interest of a person not a party thereto. 
of the personalty, than to establish the clains of the heirs to the realty thromeh deseent.

\$ 501. Proof of Alloption. Where the lecir is surh by adoption and not by blond, it may be well, in proper (atces, to require further prof of heirship than is afforderl ly the fimling of the probate cont. This would be acomplished hy showing the decree of adoption. The right of aduption is not of common law origin but is borrowed from the eivil law, and, in every instance, is purely statutory. It is necesiary, therefore, that the facts essential to the exercise of this special jurisdiction should be shown hy the record, and to give a decree of adoption any force or effect the court pronouncing same must, as a rule, have acquired jurisdiction (1) orer the persm seeking to adopt the ehild; (2) over the child; and (3) orer the prarents of such child.55 In other words, the statute must in all cases be complied with; ${ }^{56}$ its terms and conditions must be fulfilled; and if the specified requisites ${ }^{5 \tau}$ are not performed, then the act is incomplete and the child can not inherit from the parent by adoption. ${ }^{58}$ Where the statute provides specifically the means whereby one sustaining no blood relation to an intestate may inherit his propertr, the rights of inhritance must be aequired in that manner, and can be acquired in no other way. ${ }^{59}$

$\$ 562$. Proof of Death. To establish the claim of the heir it is neeessary to prove the death of the ancestor, and, in the absence of proof, all the presmmptions are that an individual is still living. ${ }^{60}$ For certain purposes an absence of 204.

55 Ferguson $v$. Jones, 17 Oreg.

56 Tyler $v$. Reynolds, 53 Iowa, I46; Keegan $v$. Geraghty, $101 \mathrm{Ill}$. 26.

57 Usually the consent of the parents or surviving parent of the child is required, and if the child is over the age of consent, its own consent as well. Where these requisites are speeified they are vital.
5. Luppie 2 . Winans, 37 X. T. Eq. 245; Foster $v$. Waterman, 124 Mass. 592.

59 Shearer $r$. Weaver, 56 Iowa, 578.

Go Martinez r. Fives Succession. 32 La. Anm. 305; Moheimer $r$. Ussleman. 36 111. 232; Whiting $r$.

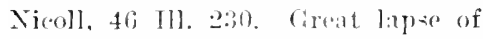
time will, of course, relut the prosumption, and in the interval of, 
seven years without tidings has been held to ereate a presumption of death, ${ }^{61}$ but this presumption is repelled by very slight facts and circumstances ${ }^{62}$ and comts have refused to entertain the presmonption after an interval of absence and silence of twenty soars, where the circumstances rendered it improbable that a party, if alive, would have communicated with her friends." "Scarcely any length of time," observes a Canadian writer", "will be sufficient to compel an umilling purchaser to take a title depending on snch a presumption of death, unless made with reference to the age of the party said to be deceased; and if the party whose death is asserted was, when last heard of, very young, the period must be that besond which human life does not commonly extend." Instances similar to that cited by the writer just quoted must, however, be of very rare occurence in the United States as other agencies, arising from taxation, arlversè possession, statute of limitations, etc., might,

say one hundred years, a party must be presumed to have died in the ordinary course of nature. The (ivil law, however, presumes a person living at one hundred years of age, and the common law does not sitop much short of this. See Watson $x$. Tindal, 24 Ga. 494.

(1) Whiting $v$. Nicoll, 46 Ill. 230 ; Dart. on Tend. 315; Hubback on Suc. (Eng.) 179; Newman $v$. Jenkins, 10 Pick. 155; Wambough $v$. Schenk, 1 Pa. 229; Darie $r$. Briggs, 97 U. S. 628; Adams $v$. Jones, 39 (ia. 479 .

62 Smith $v$. Smith, 49 Ala. 158; Brown $v$. Jewett, 18 N. H. 230. A failure to hear from an absent per. sou for seven years, who was known to have had a fixed place of residence abroad, would not be sufficient to raise a presumption of his death, unless due inquiry had been made at surh place without getting tidings from him. Wentworth $v$. Wentworth, 7I Me. 72.
63 Taylor on Titles, 65; Bowden $v$. Henderson, $2 \mathrm{Sm}$. \& G. (Eng.) 560. On the other hand one may be presumed to be dead before the expiration of the lapse of time requisite to establish the presumption in the case of absence without being heard from, if there is sufficient evidence, thougl circunstantial only, to fairly induce a belief in the fact that death has occurred: Boyd $v$. Ins. Co., 34 La. Ann. 848. The presumption varies somewhat aecording to the subject to which it is applied; this is strikingly illustrated in the case of second marriages, where more liberal intendments are permitted, than in case of succession and descent. See, Cooper $r$. Cooper, 86 Ind. 75; Williams Estate, 13 Phil. (Pa.) 325.

64 Taylor on Titles, 65; citing Lee on Abstracts, 467. And see, O'Gara r. Eisenlohr, 38 N. Y. 296; Watson $v$. Tindal. 24 Ga. 274; Sprig $\tau$. Moale, 28 Md. 497 . 


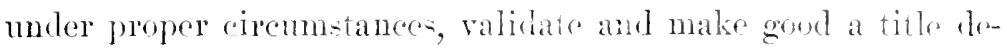
rived by sucossion eren thomgh dofective in itsolf and fommed upon insuttir.ient eridence of ancestral death.

The orlinary evidence of death in England eonsists of entries in parowial registers, or eertified copies of same, and declarations as to the identity of the parties; these registers, however, do not seem to be evidence of the time of death, and diselose the fact on $\}_{y}$ inforentially, as br showing that it must have oecurred before the late of burial, of which fact they seem to be evidence. ${ }^{65}$ Such evidence has, howerel, been receivel in the Cnited States," particularly in proving pedigrees, but is of doubtful character, mless aided by statute. To remedy the defects, inacenracies, omissions, ete., of parish registers, as well as to provide some tangible eridence of births, marriages and deaths, for the large class who would not be affected by such registers in a country where a complete disassociation of chureh and State is observed, many of the States have provided a special registration of such facts in the permanent archives of the counties.

Where the question arises in the examination of title, and no other or better evidence can be adduced, it is enstomary to procure the affidavits of eve witnesses who are conversant with the fact. Thus, the aftidarit of the attendind phrician, or the mndertaker, or a person who knew deecased in life and saw his remains in the coffin, are often resorted to in eases of diffieulty and to sustain conveyances br alleged heirs.

Granting of letters of administration is prima farie evidence of the death of the party upon whose estate they are issued, but the presumption thus raised is of the lowest elass;

65 Dart on V.\& P. * 176 .

66 Hyam $r$. Edwards, 1 Dall. (U. S.) 2; Duplessis $r$. Kennedy, 6 La. 231; Jackson 1 . Boneham, 15 Johns. (X. Y.) 226. The question was dereided in faror of such entries in an early ease in the Supreme Court of the United States, where entries of lurial in a church in Pliladelphia were held to be admisithe in a land controversy in Kentucky, tried in one of the conurts of the United States. It was there held, expressy. that they were competent testimony. Lewis $r$. Marshall, 5 Peet. ([.,S.) 470 . 
is weak and inconclusive, and may be rebutted by slight evidence. $^{6 i}$

Death, like any other fact, may be proved by circumstantial evidence; hence a sudden disappearance, particularly if coupled with an unsound mental or physical condition, ${ }^{6 \mathrm{~S}}$ or proof of a wreck of a ressel in which the ancestor was known to have taken passage, or any other circumstances from which the death of the person may be reasonably inferred, are all competent to show the fact in comnection with long and mnexplained absence. Where several lives are lost in the same disaster, there is no presumption from age or sex that either survived the other, nor is it presumed that all died at the same moment; but the fact of survivorfhip, like every other fact, must be proved by the party asserting it. ${ }^{69}$ In the absence of evidence from which the contrary may be inferred, all may be considered to have perished at the same monent; not because that fact is presumed, but, lecause frrm a failure of those asserting it to prove to the contrary, property rights must necessarily be settled on that theory. ${ }^{70}$ All cases involving the question of survivorship must be determined upon their own peculiar facts and circumstances

67 Tisdale $x$. Ins. Co., 26 Iowa, 170.

6s John IIaneock, ete, Co. $v$. Moore, 34 Mich. 41.

6o Newell r. Nichols, 75 N. Y. 7s; Coye r. Leach, 8 Met. (Mass.) 371.

70 This is the generally accepted doetrine in all the States which derive their systems of jurisprulence from the rommon law; under the civil law, however, there is no room for dispute on the subject, it being the invariable rule of the civilians that when a parent and his grown chitel perish together, the manner thorenf being unknown, the child shall be supposed to survive the parent. Aceording to the Roman law the presumptions were never in favor of contemporaneous death. If a father and his son perished in the same battle or shipwreck, the son above the age of puberty was presumed to lave survived his father: under that age to have predeceased him. This was upon the ilea that in the former case the son was usually stronger, in the latter ease weaker, lhan his father. So if persons perishing in the same disaster were all muler fifteen, the presumption of survivorship was with the elder: if all were over sixty, with the younger. Similarly the wife (being of the weaker sex), was presmmed to have yielded first to the common peril. 
whencver the evidenee is sufficient to support a finding of survivorship; in the alsenes of such evidence the question of survivorship nut necesarily be regarded as unaseertainabils.

\section{\$ 569. Continued-Oficial Registration. In States} where a srstem of ofticial registration prevails, all persms or societies solemnizing marriages; all phrsicians, or other professional persons, moler whose eare a birth shall oremr, or in case of no professional attendance, then the mother ; and all persons who shall be in attendance professionally at the time of the death of any person, are required to transmit to the recording officer of the comnty a statement under their hands of the facts attending snch marriage, birth or death, and a register of the facts so returned is kept by such oflicer. A transcript of such registry is further required to be transmitted semi-anmually to the Secretary of State to be by him preserved at the seat of government. ${ }^{\top 1}$ This record, when made and kept pursuant to law, is received as presumptive evidence of the marriage, birth or death so recorded. ${ }^{2}$ When no probate proceedings have been had, this method of proof, if arailable, should be resorted to for the purpose of showing the death of the ancestor, as well as the birth and legitimacy of the heir claimant. The facts of a death certificate may be stated in this manner :

$\left.\begin{array}{c}\text { Proof of Death } \\ \text { of } \\ \text { George Williams. } \\ \text { Doc. 200,110. }\end{array}\right\} \begin{aligned} & \text { Certificate by Wm. M. Farr, M. D. } \\ & \text { Dated Warch 10,1SS3. } \\ & \text { Recorded March 11, 18s.3. } \\ & \text { Death Register "d," page 20.SS. }\end{aligned}$
Certifies that George Williams, white, male, aged fifty-five

71 This matter is local and statutory. The statement above made is compiled from the rode of the State of Wisconsin. As affecting real estate by decent, it is a must wise and salutary measure and one that shoulel find immodiate aloption in all states in whicle it doeses mot now prevail. In some states the munieipal authorities are required to keep a resister of "vital statiotics," which, in some measure, will serve at an aid in serolling misting links in a chain of perligrem.

T2 State r. Wallanc, 9 N. I1. . Mlilford r. Woreseter, 7 Mass. 4s; Stater. Potter, 52 Vt. :33; Niles $t$. Spragate, 13 fow:1, 198. 
years, by occupation a carpenter, died Mar. S, 18S3, at the toun of Pleasant Prairie. Kenosha County, Wisconsin, of Bright's disease of the kidneys, and was Guried in the "German Roman Catholic Cometery."

That said decensed was born Mar. S. 1S2S.

That the name of the father of said deceased was Ifemry Williams, and of his mother Jane (Flym) Withiams, and that the name of said deceased's wife is Mary (Jones) Withiams. ${ }^{\text {is }}$

\section{\$ 564. Continued - Probate of Death. Before admin-} istration is granted upon the estate of airy person alleged to have died intestate, satisfactor proof is always repured to be made before the probate court to whom application for that purpose is malde, that the peron in whose estate letters of administration are requested, is dearl, and died intestate. This is accomplished by an aflidavit or verifed potition, made by the person applying for such letters, or l, some other eredible person, and forms the basis of all subequent proceedings in snch court. Oral testimony of the fact of death is aloo received on proof of will or heirship and in such eases a julicial finding of death is entered of record.

s 565. Proof of Rirth and Legitimacy. Certificates of the narriage of the parents and the baptism of the person proposed within a reasonalle time after the marriage, are admitted in England, and it would sem in Canada, as full and ample evidence of lesitimacy, withont any pron of the identity of the praties, ${ }^{7 t}$ and such eridence in a contest regarding the suecession would also be receival in the Tnited States, while for many purposes, in the absence of better evidence, general

is This serves to intentify the deceased with reasonable cortainty, and prechures the necescity of affidarits or declarations of identity.

it Taylor on Titles. 63: Hulbark on Sure (is). A rertificate of bretism is no evilence of the exact atye of a liny ; it is rood evidence of lis lectitinang. lut not of his age: Coy. Con. Ev. 281. And an cutry in a baptimal register is competent to prove only the fact ant date of hoptinn: Plackburn $r$ crawforls Losoes. 3 Wall. (U. S.1 175. 


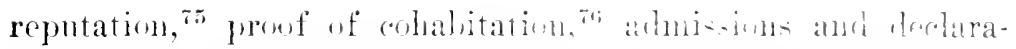

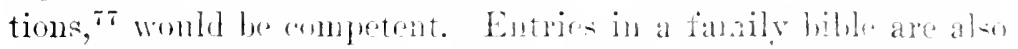

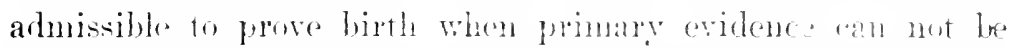

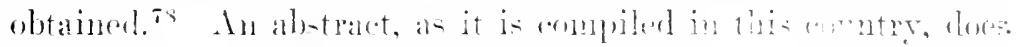

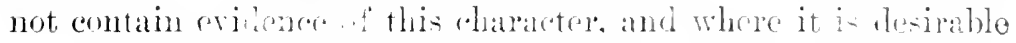
to obtain information rolative to heirship, and no deceen has been made in any mattro resperting sume, and no srotem of official registration of births and marriages exists, an infuriry in pais must be marle. Where otticial returns are marle and kept pursuant to law, sluch retume, or the recorel thereof, would fumish prima facie evidence of the desired facts, ${ }^{9}$ while the probate of the estate, including distribution, assignment of dower, ete., would also be evidence of the same character.

Except in cases of contested sucession the question of narrage does not become very material in the examination of a title. All intendments are in its farol and rery slight evidence will usually be sufficient to sustain the claim of an lieir where wothing appeas to opp it. If the estate has been probated nothing more than the proof of heirship taken therein will be required: if there has been no probate an aftidavit of pedigree should be furrished. Ab-olute facts are not essential to such an afidarit nor $i$ it necessary that the affiant should make a

75 Fenton $r$. Reed, 4 Johns, 52; Brice's Estate, 11 Phila. (Pa.) 98; IIarland $r$. Eastman, 107 111. 535. An affidavit by some person who was present and witnessed the marriage would be competent (Brewer $r$. State, 59 Ala. I01; State $r$. Williama, 20 Iowa, 98), or by the celebrant (State $r$. Goodrich, $14 \mathrm{~W}$. Va. 834), or by some member of the family that a marriage was reputed to have taken place: Waldron $r$. Tuttle, 4 N. H. 37l; Kelly r. MeGuire, 15 Ark. 555; Jackson $\imath$. Browner, 18 Johns. (N. Y.) 37.

is Clayton $r$. Wardell, $4 \mathrm{~N}$. Y. 230 ; State $r$. Armington, 25 Minn. 29. lroof of both reputation and coliabitation are sufficient evidence upon which to presume narriage, but proof of either alone is not sufficient: Commonwealth $r$. Stump, $53 \mathrm{~Pa}$. St. I32. Reputation is generally held to connist of the expressed opinions of persons who knew the parties.

ic Betsinger $r$. Chapman, $88 \mathrm{x}$. Y. 485: Proctor r. Bigelow, 38 Nich. 282: Ill. Land \& Loan Co.. $r$. Bomner, 75 111. 315.

is Camplocll r. Wilson, 33 Tex. 252: Hunt $r$. Chosen Friends, 64 Mich. 67 .

Tostate $r$. Potter. 52 Vt. 33; Niles $v$. Sprague, 1:3 Iowa, 198. 
statement from lis own knowledge. Common reputation, living together of the parents, and other corroborating circumstances will all tend to prove nuarriage. At common law no special form or solemnity is necessary to constitute a valicl marriage and where parties enter into the relation by mutual consent the legal results of marriage will follow. Such marriages have repeatelly been recognized in the United States ${ }^{80}$ and the assent may and will be presumed from the actions of the parties. Continnous matrimonial intercourse for a number of years will furnish grounds for the presumption of a valid marriage, ${ }^{81}$ and evidence of a legitimate descent. ${ }^{82}$

\section{\$ 506. Presumption of Legitimacy. It was formerly} the rule in England, as also in this country, that when a child was born in wedlock the presumption of legitamacy was conchsive. But recent years have greatly modified the old rule and now, while the presumption is not to be rebutted by circumstances which only create donbt and suspicion, it may yet be wholly removed by proper and sufficient evidence showing that the hushand was (1) incompetent; (2) ontirely absent, so as to have no intereourse or commmication of any kind with the

so Port $r$. Tort. 70 H1l. 486; Moister $r$. Hoore, gf $\mathrm{C}$. S. 76 ; Tutchins r. Kimmell, 31 Mich. 126...

si The rule may be succinctly stated as follows: Where it appears that the intercource between the parties was originally illicit, there being no impediment to marviage, it will he presumed that the intereonrse continued to he illicil; and where thrir subsequent relations appear to be clandestine. and are kept concealed from others who will nowesarily divorver that the relation is illicit, mless made to believe that the partios are married, the evidence is insufficient to prove marriage. Put whre such subsequent relations have all the aplearance of the marliage relation, and there is nothing apparently clandestine, and no dividol reputation, and the parties acknowlodge each other on all oceasions and nuler all circumstances as man and wife to the extent that married persons ordimarily do, a legal presumption of marriage is raised. Cross $v$. Cross, 55 Mich. 285: Williams $r$. Williams, 46 Nis. 464: Harbeck $r$. Harbeck, I0: N. Y. 711 ; Arnold $r$. Cheseblongle, 46 Fed. Red. 700.

s. K. P. R. R. Co. r. Miller, 2 Cal. 442; Askew $r$. Dupree, 30 Ga. 173; Duncan $r$. Duncan, 10 Ohio St. 181: Dyer r. Brennok, 66 Mo. 391. Tut see, Robertson $r$. State, 42 Ala. 509; Mangue r. Mangue. I Mass. 240; In re Thaley, 93 Pa. St. 36. 
mother; (3) entirely absent at the period during whieh the child must in the course of nature, have been begotten; or (1) only present under such eireumstances as afford clear and sati-factory proof that there was no sexual intercourse.

$\$ 567$. Validity of Descents. Titles depending up:n deseent are viewed by our English brethren with disfaror and ranked amongst the poorest that can be offered, or the weakest that can be asserted. Such titles are always to be riewed with jealousy, observe their leading writers, and if dependent upon several successive deseents are scarcely marketable. ${ }^{\mathrm{s}}$ In a limited sense this may also be true of title by descent in the United States, and purchasers would be justitied in refusing to take many titles that might be offered by parties claiming in this manner. This almost invariably follows in eases of unprobated estates, for no title can be more uncritain and insecure, and scarcely any length of time in the ahsence of other evidenee, would be sufficient to furnish a reasonable presumption of death and the exclusion of the rights of other heirs who might possess ralid elaims upon the property. ${ }^{\text {st }}$ Proof that certain persons are the only children who survive their father does not establish the fact that they are the only heirs, as he may have grandchildren by deceased children, ${ }^{\mathrm{s}}$ and henee it is neeessary, in some instanees, that additional information to that furnished by the proceedings in prolate, be also proenred to fully establish an asserted right. A properly taken proof of heirship in probate should, however, show the fact of decease of children prior to the death of the intestate and whether or not sueh ehildren died without iscue, but frequently this fact is not, found. ${ }^{86}$ The statute of limitations will furnish a strong re-

s3 Atkinson on Titles, 374; Hubback on Sue. (Eng.) 71 ; Taylor on Titles (Canarla), 61.

$84 \mathrm{~A}$ deceased person is always presumed to have left heirs: Pile $r$. McBratney, 15 Ill. 314.

85 Skinner $x$. Fulton, 39 Ill. 484. 86 From personal inquiries made by author it appears that in a majority of the probate courts of the
State of Ilinoti- no proof of heirship is reguired of her than that fur. nished by the statements of the petition for letters of administration, and that in molh courts it is not 'ustomary to make any judicial findings of heirship. Probably the sane conditions prevail in other Siates. 
enforeement to a doubtful title by deseent, and serve to effectually settle many of the questions that otherwise would render the titlo undesirable.

$\$ 568$. Abstract of Descents. Under the English system of abstracting, a descent is shown by a pedigree, supported by certificates of marriage, births and deaths, inserted in the order of their date. If the certificates can not be procured, which, from the loss or imperfect state of registers or other circumstances is sometimes the case, substitution is made of entries in the Inoval College of Arms, in family bibles or books, inscriptions on tomb stones, and the solemn declarations of family solicitors, tenants, workmen, and parties acquainted with circumstances and facts, as well as such evidence of the seizin of the different parties, shown by the pedigree to be entitled, as can be adduced; for which evidence old leases of the propcrty, land tax, and parochial assessments, are referred to. ${ }^{87}$ Pedigrees, or family histories, may be used to a very limited extent in the eastern States and are sometimes alluded to by writer's on conveyancing, but in the west they are practically unknown, while authentic information of the facts to which a pedigree relates is usually extremely difficult of ascertainment, and the sources as mentioned above would hardly be considered sufficiently certain by the average attorney. ${ }^{88}$

Family records, when shown to have been regularly compiled, are not without weight in the United States, and are frequently resorted to for proof of heirship in the administration of estates and trial of disputed land titles, but while they, with other evidence, will be received by courts to prove pedigree and establish rights of succession, they do not constitute such evidence, save

87 Noore on Abst. 44.

88 As a matter of curiosity, rather than for any real utility, the following abstract of an English pedigree is inserted. The object is to show title by descent in Thomas Noakes:

Ralpil Nonkes was the granlfather of Thomas Noakes, Esq., of Cliff Hall (the mortgagor), as will be seen by the subjoined pedigree (ex parte paterna) copied from one in his possession, and kept by his family. It is also shown by different entries found in the family registers, now likewise in his possession. The fact of his being the direct lineal heir of 
as they appear in court proceedings by way of recital, at in frequired in compiling an abstract, and exaniners as a rule do not, and as a matter of fact, should not, attempt to introduce them or any other matter strietly in pais. A judicial determination in an action brought by atrerse elaimants, or in a proceeding in rem to determine the rights and apportion the interests of the parties before the court, would be projer record evidence of deseent and right of succession, while the proceedings in probate are evidence of the same nature. These matter's therefore, must always be noted and appropriately exhibited, and with a very few exceptions will furnish sufficient data, and be sufficiently conelnsive of the facts of teath and heirship, to warrant the belief that the persons so found to be the heirs of the decedent are such heir's and the only ones entitled to participate in the distribution or share in the succession.

§ 569. Continned - Probate Proceedings. The usual and ordinary method of showing a descent in the [nited States is by an abstract of the settlement of decedent's estate. This should diselose the jurisdietion of the court, appointment of administrator, proof of heirship, and adjudication. This is suffieient to show the descent, but in order that the title of the heirs may not be obseured by latent defeets or creditors' liens,

said Ralph Noakes is also confirmed by entries at the Royal College of Arms.

And the following is a pedigree and entries referred to:

Ralph Nokes $=$ Ann Freke.

$$
\begin{aligned}
& \text { Richard }=\overbrace{\text { Sarah Hart. }} \text { An = John Brown. } \\
& \text { ob. ob. }
\end{aligned}
$$

\begin{tabular}{|c|c|}
\hline Thomas $=$ Oliva Jones. & $\begin{array}{r}\text { Susan = Jamen Old. Jane. } \\
\text { ol. xet. } 18\end{array}$ \\
\hline
\end{tabular}

Thomas $=$ Charlotte Smart.

Samuel, Eliza, Thonlas.

Thomas, and six other ehildren.

"Feb. 10, 1740] Richard, only son of Ralph Noakes, was born at Cliff Hall, at 3 in the morning."

"April 3, 1762] Thomas. only son of Richard, hom at clifl Hall on Turslay the 31 of April, 176.2. a1 12 o.lock at night."

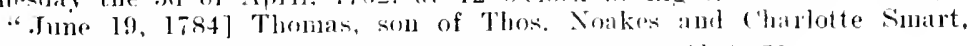
born at Cliff Iall, at 9 in the morning." - Noore on Abst. 59. 
the inventory, parment of claims, and final report and discharge of the administrator should also be shown. The degree of tetail is optional with the exaniner, provided the jurisdiction be made to appear and an apparent regularity is shown in all of the subsequent steps. The following is offered as a specimen of a very simple settlement:

\section{In Probate Court, Cook County, Ills.}

$\left.\begin{array}{c}\text { In the matter of the estate } \\ \text { of }\end{array}\right\} \begin{aligned} & \text { Descent. } \\ & \text { Case No. 2.000 in box } 135 . \\ & \text { Petition of Amna Hasticll for } \\ & \text { letters of administration, filed }\end{aligned}$ May 10, 1SS3. Fiecord 14, pg. 12.

Represents that Julia A. Mason died intestate, Aug 2, 1SS2, leaving property and effects in C'ook County. Ills., as follows, to wit: [describe the real estate] and leaving her surviving. ${ }^{89}$ Anna Haskell (wife of Charles IIaslicll) and Walter A Mason, her only heirs at lau.

Swom to May 10, $18 S 3$.

Letters of administration issued to 1 ma II askell, dated May 10,1583 .

Bond in sum of $\$ 6,400.00$ with suretics, filed and approved May $10,1 S S 3$.

II arrant to appraisers issued, dated May 10, $18 S 3$.

Proof of heirship entered May 10, 1883.

The court finds from the evidence moduced in open court, that Julia A. Mason died Aug. 2, 1SS2,90 leaving her surviving

89 This fact, if properly proved, will be sufficient to establish the heirship of the persons named (Russell $v$. Jackson, 22 Wend. (N. Y.) 275 ), but is not conclusive, nor does it prove that the persons named are the only heirs entitled to share in the succession, as the intestate may have had children who did not survive him, but who in turn may have left children entilled to a representation: Skinner $v$. Fulton, 39 Ill. 484.

go The proof of death is the foundation of title by descent or through the administrator; this must be conclusive, and, while the evidence need not be shown, the fact should be mide to appear as strongly as possible. See Thomas $v$. People, $107 \mathrm{Ill} .517$, for a learned and instructive opinion on grants 
IFalter A. Mason, her son, and Anna ITaskell (wife of Charles Ilaskell) her daughter, her only next of kin and heirs at lau. Proof of publication and posting of notices for adjudication filed June 1, 18S3, and approved July 16, 1889.

Adjudication ordered.July 16, 1883.

Proceed in this rorder showing sureeding steps in much the same manner as an abstract of a devise. This wonld include the proof and parment of claims, and the final order of distribution and discharge of the arministrator.

$\$ 570$. Settlement without Administration. It is competent for all the hoirs to an estate, if of age, to settle and pay the debts of the estate, and to make partition of the property among themselves, without any administration; and neither creditors nor debtors of the estate have a right to complain. ${ }^{91}$ If, in pursuing this course, they sell portions of the property and make proper application of the proceds to the parment of the debts, their acts are entitled to full faith and credit, as though they acted in the capacity of administrators or execrttors. ${ }^{92}$

Where deeds are found upon the records which purport to have been executed by the heirs at law of a party in whom title is shown to have been rested, and no administration appears to have been had upon the estate of such alleged ancestor, it is well to call attention to such latter fact by a brief note immediately following the heir's deed. Thus:

Note.-We find no evidence of administration in Cook County, Illinois, on the estate of William Black, nor probate of his will, if any.

It will frequently happen that the ancestor was a non-resident and that administration was had upon his estate at the place

of administration. male on presumptions and insufficient proof.

91 Taylor $x$. Phillips, 30 Vt. 23s;

Babbitt $v$. Bowen, 33 Vt. 43T; and see Brathear $r$. Connor, 29 La, Ann. 374 .

92 Morris $v$. Hallert, 36 Tex. 19. 
of his late domicile. When such is the fact an exemplification of such proceedings slonld be procured and filed in the registry of deeds of the comnty where the land in question is situate. This will be sufficient to show lescent, provided a finding of heirship appears, but in order to make an indefeasible title an ancillary administration should be had. The chief object of such ancillary arministration is to bar the claims of creditors, and if the proverty is valuable this step should always be taken.

S571. Escheat. The latest taker, under the statute of descents, is the State. But the State is not to be deemed an heir within the ordinary meaning of the term, and takes, not as an heir, but rather because there are no heirs. ${ }^{93}$ The right of the State is estahlished by a formal proceeding generally called "inquest of office," and where title is deduced through escheat this proceding nnet the shown. Instances of title derived in this manner are, however, very rare.

93 State $r$. Ames, 23 La. Anu. 69. 


\title{
CHAPTER XXXI.
}

\author{
ADVERSE TITIE.
}

$\$ 572$. Adrerse titles, generally considered.

573. Adverse conveyaness.

574. The character of adverse possession.

575. Color of title.

576. Adverse possession under rolor of title.

577. Construetive possession.

578. Adverse possession from user.

579. Naked possession without claim.

580. Tacking.
$\$$ 581. Possession as notice.

582. Whe may arquire adverse title.

583. Remainder-men.

584. Reversioners.

585. Tenants in common.

586. Persons under disability.

587. Marriel women.

588. Adrerse riglits as against the sitate.

589. Effect of arberse possession.

590. Proof to support title.

\section{\$ 572. Adverse Titles, Generally Considered. In ex-} aninations of title it is nut uncommon to find two, or even three, conflicting claims of title evilleneed by deeds or other matter of record, while inquiries in pais may further disclose claims of title and ownership founded upon actual oceupation and possession, under claims of right resting upon unrecorded deeds, undisclosed descents, or preseriptive user. In some cases the adverse titles have a common origin and all flow from the same source; in others they originate through tax sales, or by reason of independent conveyances from individuals. Sometimes the adverse titles are only seeming, being the results of mistakes in the dranghting of instruments of conveyance. The questions raised by these conflicting claims are numerous and sometimes diffienlt of solution, and are among the most perplexing incidents upon which counsel are obliged to pass.

$\$$ 573. Adverse Conveyances. Indor this head are grouped all conveyances emanating from independent sources and not connected with original grantor or forming a part of 
the regular course of titie. These conveyances may consist of tax deeds and resulting conveyances which have not been merged into the common ownership; an assertion of title by one having no record eridence; and deeds which by erroneous descriptions do not conrey the property intended, but cover other and entirely different parcels. It is the practice of examiners to arrange these deeds as an appendix to the chain, setting them out under the classified head, "adverse conveyances," and prefixing to them the statement, "we also find."

Where an alverse title appears of record, followed by mesne conveyances, and eventually merging into the original title, they constitute part of the chain and are shown in the regular course. In cases of this kind the better way is to trace the title from the original grantor to the person in whom a perfect and unembarrassed title is found; here stop and separate what follows by a broad dash, or, if desired, a prefatory note; then show the tax deed or other initial adverse conveyance and the conreyances resulting therefrom, until title is again found in the person proposed. Now separate the succeeding matter as before, and the next deed will commence, a remited and perfect chain. Isolated adverse conveyances, as has been stated, are frequently the result of error, and are often followed by curative deeds which demonstrate same. When the examiner can supply the necessary information an explanatory note should follow the adverse deed, thus:

Noтe.- We find recorded in Book 500, page 260, a deed between the same parties, and bearing same date as the foregoing, conveying property in the northeast quarter of Sec. 10,T. 2N., R. 2.3 E., and wherein it is recited that said deed is given to correct an error in the description of land conveyed by deed recorded in Book 490, page 359 (shown as No. 25 of this examination; or, shoun above).

The foregoing suggestion is considered the better way to treat adverse conreyances, particularly when it can not be demon- 
strated that the adverse conveyance is the result of arror and not the assertion of an independent title; yet examiner's of undoubted standing and ability have frequently deemed an explanatory note, without any exhibition of the adverse dect, sufficient for the purposes of the alsstract. Should the later method bo considered desirable, a statement sinilar to the following may be made:

\section{Adverse Conveyances.}

In Book 155, page 53\%, is recorded a deed from John II. Fellows and wife to Lorenzo Dow', purporting to convey lund described as: Beginning at the southeast corner south of the Indian Boundary Line of southeast quaster of section 35, Town 40, Range 13; thenee north on cast line of said quarter section 40 rods; thence west 160 rods; thence south 40 rods; thence east 160 rods, containing 40 acres; and in Book 49 of Mortgages, page 519, is recorded a mortgage from said Lorenzo Dou to James Parton, covering same premises; said mortgage is relensed on margin of record (as appears by our indices). Fellow's ouncd land in Section 35, Toun 41, Range 13, and we assume that said deeds by Fellows and Dow were intended to convey land there and not in Section 35, Town 40, Range 13, where he had no interest whatever.

The foregoing example is given to show the methods that can be and sometimes are employed, rather than as a precedent to be followed, for, although the conveyances are sufficiently identified to furnish actual notice of their character and import to all persons perusing the abstract, and possibly suflicient explanation is given to warrant the assmmption of the examiner, and, in the instanee under consideration, the examiner has suffiaiently discharged his duty to relieve himself of liability, yet the practice of showing positive transartions by notes, and of making assumptions without expressed anthority, is dangerous 
and often misleading, and calculated to involve the examiner in serious complications. Any and every converance, inembranee, lien or charge which directly or by just implication affects, impairs or clouds the title, if a matter of record, and within the dates comprising the period of the seareh, should be shown affirmatively and without expression of opinion as regards the legal effeet of the instruments, or the real or supposed intention of the parties, and if the examiner is also the counsel, let the abstract and the opinion be separate and distinet papers.

$\$$ 574. Adverse Possession. An adverse title need not depend on doementary evidence, but may rest wholly on occupation, or on oceupation coupled with other cireumstances. This, of course, the abstract will not show and the facts which constitute such title are ascertained by inquiries in pais.

It is a well established rule that a possession, to be adverse, must be so open, notorions and important as to give notice to parties interested that a claim of right is intended thereby; that the right of the true owner is invaded intentionally, and with a purpose to assert a claim of title adversely to his; and to furnish the basis of a sulstantial title, must extend in unbroken continuity over the period prescribed by the statute of limitations. ${ }^{1}$ This element of peaceful continuity is perhaps nore distinctly material in conferring title by adverse possession than any other, ${ }^{2}$ and is a consideration of primary importance in all examinations.

A statutory distinction is made in some States between a claim of title founded upon some written instrument or judgment, and an actual, continued occupation under claim of title,

1 Carrol r. Gillien, 33 Ga. 539: Beatty $r$. Mason. 30 Mrl. 409: Dixon $r$. Cook, 47 Miss. 220: Laramore $r$. Minish. 43 Ga. 282; Bowman $r$. Lee, 48 Mo. 335: Calhoun $r$. cook, 9 Pa. St. 226; Cahill r. Palmer, 4.5 N. Y. 484; Booth v. Small, 23 Iowa, $17 \%$.

2 Tyler Adv. Enj. 907; Groft $v$. Weckland, 34 Pa. 308; Williams $r$.
Wallace, $7 \mathrm{~s}$ N. C. 354; Shields $v$. Roberts, 64 Ga. 370. Possession of land onee established by material acts of visible, notorious ownership must be presumed to eontinue until open, notorious, adverse possession be proved to have been taken by another: Clements $v$. Lamkin, 34 Ark. 598. 
exclusive of any othor right. but not founded muse any writen

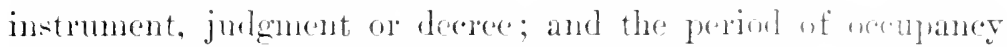
in the latter case must he continned moneh lonere! than in the former. Thus, in the first instaner, thr title may becone perfect and indefeasble at the end of ten years," while in the latter the period of legal memore must hare rum to warrant the yresumption of an orjeinal valid entry, and the losis or destruction of the numiments that establi-h the ocoupant s risht to the soil. The character of the poscesion, too, may he ratsly different under the tro clainss; as, in the first instanee, a jaltial ocentpancy only is required, such partial oceupance drawing to it comstructively the possession of all of the land mentioned in the instrument under which the claim is marle, while in the latter the adverse holding extend only to so much of the land as may

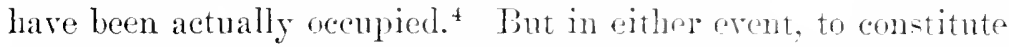
a bar to the assertion of the legal title, the posesin must be hostile," and not at mere trespass," and must also be vi-ible, continnous, notorions, $^{9}$ drefinite, ${ }^{10}$ and inconsistent with the claim of others," while the claim of right acompanying such possession must not have originated in fralld. ${ }^{2}$ Those are the

3 Limitation periods are wholly statutory. The text states the general rule but in some States a shorter period is prescribed. Thus. in Illinois possession under color of title with parment of taxes for seven years will create an estoppel available against all persons not under disability.

4 What acts are sutficient to constitute possesion are matters of loeal statutory regulation. but, as a rule, there mut le either cultivation or improrement; protection ly a substantial enclosure; and a une of the premises. if not enclosed, for the supply of fuet, or hushandry, or the ordinary use thereof by the oecupants in the same manner that lands similarly situated are used.
5Turnes $\bullet$. Chamberlain. 15 Ill. 271: Thompen r. Felton, 5t Cal. 547 .

(I) Ilumbert \& Trinity (h.. 24 Went. 5si; Cahill r. Palmer, t5 N. Y. 479.

T Irring $r$. Brownell. 11 Ill. 402. s Jackion $r$. Berner. ts 11I. 203.

a Mcclellan $r$. Kellowg. 17 Ill. 498: Dixon $r$. Conk. 47 Miks. 203.

10 Fugate $r$. Pieree 49 Mn, 4tl; Grule r. Mells. 34 Iowa, 148.

11 Ambrose $r$. Raley is 111. 506: Sparrow r. Hovey. $4 t$ Mich. 63.

12 Moody $r$. Mondy. lfi Ilun (N. Y.). 189: Jaramore r. Minish. 43 Ga. 282. Thro gurstion whetlser one who holds ly eolor of title lolds in goorl faith or bard, depends upon the purpose with which he 
universally recognized elements that must enter into every adverse holding, and unless they are present the settled principles of law require us to consider the true owner as constructively in possession of the land to which lie loolds the title. ${ }^{13}$

A clandestine entry or possession will never serve to set the statute in motion, for in order to bar the true owner from asserting his title, he must have actual or constructive notice of the instrument under which the adrerse claimant enters, or linowledge, or the nueans of knowledge of such ocenpation and claim of right, ${ }^{14}$ and the entry must be made and the possession continned under such eircmimstances as to enable sneh true owner, by the use of reasonable diligence to ascertain the fact of entry and the right and claim of the party maling it. ${ }^{15}$

Any substantial interruption of an adverse possesion, before the lapse of the period required to constitnte the statntory bar, will have the effect of restoring the seizin of the rightful owner of the land, and in order to set the statute in motion a new entry and disseizin will be necessary. It seems also, that the ruming of the statute may be interrupted if the possession ceases to be adverse, notwithstanding a possession in fact may still continne. ${ }^{16}$

$\S 575$. Color of Title. It is a general rule that where one enters upon land under a recorded deed, his entry and claim must be referred to that deed and measured by it. ${ }^{17}$

acquired the title relied on, and the reliance placed upon it. If the holder received it, knowing it to be worthless, or in frand of the owner's rights, it cannot be said to be held in good faith. Still, many things that may be sufficient to destroy the presumption of good faith may he insufficient to prevent the deed from being color of title. See Hardin $v$. Gonverneur, $69 \mathrm{Ill}$. 140; Hall $v$. Mooring, 27 La. Ann. 596.

12 Bliss r. Johnson, 94 N. Y. 235;
Doe r. Thompson, 5 Cow. (N. Y.) 371.

14 Fugate $r$. Pierce, 49 Mo. 441; Crispen $v$. Iannavan, 50 Mo. 536; Thompson $v$. Pioche, 44 Cal. 508; Nowlin $v$. Reynolds, 25 Gratt. (Va.) 137.

15 Soule $v$. Barlow, 49 Vt. 329; Brown $r$. Cockerell. 33 Ala. 151.

16 Stewart $v$. Stewart, 83 Wis. 364.

$1 \mathrm{i}$ Stevens $v$. Prooks, 24 Wis. 326; Crary $v$. Goodman, $22 \mathrm{~N}$. W. 170. 
Such deed, though void in fact, gives a "coloralule title" 18 to the purchason, and where it professes to conver the entire estate a claim and recupation under it creates an adreres possession as against all the world. ${ }^{19}$ What amounts to a color of title, is still an open and unsettled question, though munerous decisions defining its character exist in all the States as well as in the federal courts, and notwithstanding that in a few instances it has ben held that documentary evidenes is not required to support a claim under color of title, ${ }^{20}$ the weight of authority indicates that a written instrmuent is necessary, so far good in appearance as to be consistent with the idea of goud faith, and purporting on its face to convey a title. ${ }^{21}$ The definitions in the books, thongh witlely divergent in many particulars, yet agree in the main on these points.

A clain of heirship has becn held to enne within the term, the supposed inlicritance forming the "color," for says Gibson, J., "one entering ly a title depending on a void reed, would certainly be in by color of title, and it would be strange if another, entering under an erroneons belief that he is the legitimate heir of the perom last seized should be deemed otherwise." 22 I confusion, howerer, scems to exist, arising from the interchancealle use of the trims "color" and "clam" of title, which, as a matter of fact, may, and do, exist separate and independent of each other. To constitute the former, there must, as a rile, be a paper title, while the latter may exist wholly by parol. ${ }^{23}$ Possession under a claim of title, withont a deed or other written instrument, limits the person so asscrting his claim, to his actual enclosure or occupancy, ${ }^{24}$ but when

1s Edwerton r. Bird. 6 Wis. 527 : Brooks $r$. Truyn. 35 Jll. 394: Lindsay v. Fry, 2; Wi.. 460; Beverly $v$. Broke. a (a. 4t0; Hamilton $r$. Bogges, 6is lío. 233.

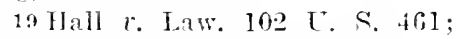

Bell r. Lungworth, 6 Ind. 273.

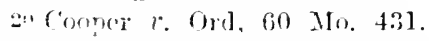

21 P.ker r. Sirn, 32 Mrd. 355:

Sruse $r$. IVilon, 79 III. 240; Stark r. Starr, 1 Sawyer, 20; Gittens $v$. Lowry, 15 Ga. 338. 22 ir (all $r$. Nicly, 3 Watts (Pa.) T.2: and see Cooper $r$. Ord, $60 \mathrm{M}$. 420; Trabont $r$. Daniels, 38 Iowa, lis.

2.) Hamilton $v$. Wriglit, 30 Inwa. 486; Clagrett 2 . Conlee, 16 Jowa. 487.

24 Jills n. IInbbard, 21 lil. 328. 
founded upon a claim and color of title, a constructive possession of the entire tract will follow the actual occupaner of any portion, ${ }^{25}$ provided the deed or other matter be of record. ${ }^{20}$

\section{\$576. Adverse Possession Cuter Color of Title. A} valid title is not required in order to enable a party to rely upon adverse possession under the statute of limitations, ${ }^{27}$ nor is it necessary that he shond trace title throngh a chain to any source. $^{28}$ A deer which purports to convey a complete title will be sufficient to give color of title, althongh the grantor may, in fact, have only the rights of a mortgagee, ${ }^{29}$ or lessee; ${ }^{30}$ or, if tho deed was issued on an erroneons or coid decree; ${ }^{31}$ or, in pursuance of a sale under an imperfectly executed trust; ${ }^{32}$ and generally, when followed ly a continuous and uninterrupted possession for the entire statutory period, it will constitute an adverse holding, effective for all purposes, howerer groundless the supposed title may be ${ }^{33}$ It is essential, however, that the lands elaimed be fully identified or described in the instrument, ${ }^{34}$ for mere ocempancy of land in virtue and under a claim of a grant. which does not embrace it, is not ardverse possession sufficiont to constitute an estoppel or effect a transfer

25 Brooks r. Bruyn, Is Ill. 539: Seott $x$. Elkins, 83 N. C. 424 ; Coleman $r$. Billings. 90 Ill. 577; Little $v$. Merquier, 2 Me. 176; Web $r$. Richardson, $42 \mathrm{Vt}$. 465 ; but if the true owner be in actual possession of any part of the lands. his eonstructive seizin extends to all not in fart occupied by the intruier: Hunnicut $v$. Peyton, 102 C. S. 333. 2f Tritt $r$. Roberts, 64 ra. 1.56. 27 Close $r$. Samm, 27 Iowa, 503; . Tarkion $r$. Woodruff. 1 Cow. 276; Flliott $r$. Pearle, 10 Pet. 412: Ford $r$ Wilson. 35 Mics. 504; Grant $r$. Fowler, 29 N. H. 104.

24 Rawson v. Fox, 55 111. 200. Compare Hedges $r$. Paulin, 5 Biss. $1 \%$.
29 Sterens $r$. Brooks, 24 Wis. 326. 30 Sands $r$. Hughes, 53 N. Y. 287.

31 Huls $r$. Bunten, 47 Ill. 396 ; Minkley $r$. Green, 52 M11. 223.

32 Gebhard $r$. Sattler, 40 Iowa, 153.

33 Ford $r$. Wilson, 35 Miss. 504; Grant $r$. Fowler, 39 X. H. 104; Tyler Adv. Enj.. 907: Davis r. Easly, 13 Ill. 192.

34 Lane $r$. Gould, 10 Barb. 254; Jackson $r$. Woodruff. 1 Cow, 276; Fugate $r$. Pierce, 49 Mo. 441 ; Grube $r$. Wells. 34 Iowa, 148; Brown $x$. Coble, 72 N. C. 391. 
of title,"s and the elaim must not be general, lnt sureific."3;

s 57\%. Constructive Possession. Where title is atsorted adrersely moler a claim of right, and by reason of acempancy and possession, it is a rule of universal application that tho extent of the elaim must be measmed by the instrunent muler which the claim is made." When such instrument purports to conver an estate in fee in specific lands, although actual owcupaney is only had of a portion of the premises described, the claminant is yet constructively in possession of the entive tract, ${ }^{38}$ his occupancy of a part being in contemplation of law the occupancy of erery portion, ${ }^{39}$ bnt there can be no constructive possession without the color of title ${ }^{40}$ afforded by some deed, instrmment or proceeding purporting to convey the whole and defining bomndaries, as well as actual possession of a part. ${ }^{41}$ Tor will constructive possession be sufticient to confer title to any portion of the tract in the adrerse seizin of another. ${ }^{42}$

§ 57s. Adverse Possession From Cser. An actual continned occupation of lands under a claim of title exchise of any other right, althongh not fomded on a written instrument, judgment or decree, is ret sufficient, if extending through the entire statutory period, to confer title to the portion so actually occupied. ${ }^{43}$ It is immaterial to support title thus claimed whether there be a deed ralid in form, or whether there be no deed, ${ }^{44}$ and the party in possession may even knew that his title is groundless, ${ }^{45}$ but there must be a claim of title; ${ }^{46}$ an

:5 Javerty $r$. Xoore, $33 \mathrm{x}$ I. 658; Farish $r$. Coon, 40 ('al. 33: Grube $r$. Wells, 34 Iowa, 148; Wood $r$. Banks, 14 X. II. 111.

36 Crary $r$. Goodman, 22 X. Y. 170 ; Hallas $r$. Bell. 53 Barb. 247: Pepper $r$. O'Dowd, 39 Wis. 538. 37 Washburn $r$. Cutter, 17 Mimn. 361 .

38 Constructive possession has been defined to be a possession in law, withont possesion in fart: Hodges r. Edly, 38 Vt. 32T; Wal. Inrn $r$. Anderson, 37 Miss. lis. 39 Brooks r. Bruyn, 18 111. 539; Crispen $v$. Hannavan, 50 Mo, 536.
4) Wells $r$. Tackson Manuf. Co., 48 N. H. 491.

41 Fingate $r$. Pierce, 49 Mo, 441.

42 Walsh $r$. llill, 41 ('al. 57 l: Jackonn $r$. Vemplyea, 6 Cow. $(X$. Y.) 677 .

43 Dills $r$. IIulbatri, 31 Ill. 320: Doe $r$. Elara, 11 Ali. 102.

4t liammesis $r$, Rannels, ne Mo. 108.

45 Bogralus $x$. Trinity (hurch, 4 Sand. ('h. (N. Y.) (a):3) Jakkon r. Wheat, 18 . Jollu- 40.

4; Humbert $r$. Trinity Clumeh, of Wend. 587; Rammels $v$. Rammels, 52 Mlo. 108. 
assertion of paramemnt right; ${ }^{4}$ and there must be actual occupancy measured ly a distinct, visible and marked possession. ${ }^{48}$ Pcrmissive user can never, by any lipse of time and even thongh continuous and exchnsive, ripen into a title to the fee, nor when the original entry was by consent of the owner, and no adverse claim of ownership has been asserted. ${ }^{49}$

\$ 579. Naked Possession without claim. "Squatters" or intruders upon lands acquire no rights by reason of their possession, as the gist of every alverse holding is, that it is accompanied by a claim of right, and a mere trespass can never ripen into a right, so as to set the statute in motion, no matter how long eontinued; ${ }^{50}$ nor will oceupation by mistake or ignorance suffice to constitute an aclverse holding, ${ }^{51}$ althongh upon this point there is much confusion in the anthorities. But an entry by one withont color of title, or claim of right, may subsexuently become adverse hy his acquiring and asserting a elaim of title; and the statute will begin to run from the time of such assertion. $^{52}$

\$580. Thoking. When several adverse claimants unite thrir several possessions into one continuous term, this is called "tacking." Where there are several successire adverse claimant, the last one mar tack the possession of his predecessors to his own, so as to make a continuous adverse holding for the

47 Howard $r$. Howard, 17 Barb. 25̃: Jackson $r$. Johnson, 5 Cow. 7: Bowman r. Lee, 48 Mo. 335.

48 Coming $r$. The Troy, etc., Factory, 44 N. I. 577; Fugate $v$. Pierce, 49 Mro. 441.

49 Indianapolis, ete., R. R. Co. $v$ Ross, 47 Ind. 25; Cooper r. MeBride, 4 Houst. (Del.) 461 ; Bedell $v$. Shaw, 59 i. Y. 46; Hudson $v$. Petney, 14 W. Va. 56l. Compare Ford $v$. Holnes, 61 Ga. 419.

50 Thompson $\%$ Pioche, 44 Cal. 508; Nowlin v. Reynolds, 25 Gratt. (Va.) I37. Nor can the successive possession of trespassers be connected to make the bar of the statute: Baker $v$. Hale, 6 Baxter (Tenn.), 46.

51 Thomas $r$. Babb, 45 Mo. 384; Farish $v$. Coon, 40 Cal. 33; Grube $v$. Wells, 34 Iowa, 148; Dow $v$. McKenney, 64 Me. 138. The text states the generally received doctrine but the cases, in many instances, make some fine distinctıons, and the authorities are not in full accord with respect to the rights acquired by one who encloses and occupies land by mistake. See Warvelle on Ejectment, $\S 440$, et seq. for a full discussion and collected cases.

52 Hamilton $v$. Wright, 30 Iowa, 480. 
statutory period, provided there is a privity of possession between such occupants. ${ }^{53}$ Such privity nay arise from a parol bargain and sale of the possession of the land, followed by delivery thereof, as well as by a formal convesance from one orecupant to the other. ${ }^{54}$ ictual possession by prior occupants claiming title, althougl having no color of title, will always arail a subsequent oceupant under color of title, claiming under such prior occupants, in making out a possessory title in himself. 55 The element of continuity must appear, however, and sereral successive but unconnected disseizins or adrerse possessions, though amounting in the aggregate to twenty years, or such other period as the statute may prescribe, can not be tacked together to make a continuous possession. ${ }^{56}$

$\S 581$. Possession as Notice. Possession, while it may not be "nine points of the law," always has been, and will doubtless ever continue to be, prima facie evidence of the highest estate in land, to wit, a seizin in fee, ${ }^{57}$ and when open, notorious and visible, it has always been regarded as affording constructive notice to others of the occupant's title and equities. $^{58}$ For this reason, counsel, in framing an opinion of title, should alwars direct the attention of his client to the rights of the person in possession, if any, or suggest that an inquiry in pais be made as to present occupancy.

§ 582. Who May Acquire Adverse Title. One who enters into possession of land in subordination to the title of

53 Shuffleton $v$. Nelson, 2 Sawyer (C. Ct.), 540; Haynes $v$. Boardman, 119 Mass. 414; Alexander $v$. Stewart, $50 \mathrm{Vt}$. 87; McNeeley $v$. Langan, 22 Ohio St. 37.

54 Shuffleton $v$. Nelson, 2 Sawrer (C. Ct.), 540; Kruse $v$. Wilson, 79 Ill. 233; Weber $v$. Anderson, $73 \mathrm{Ill}$. 439.

55 Day $v$. Wilder, 47 rt. 584. This has been held to be the ase of nne who held as heir of one who held adversely under mere claim of right: Teabout $v$. Daniels, 38 Iowa, 158.

56 Shuffleton $r$. Nelson, 2 Sawyer (C. Ct.), 540: Marsh v. Griffin, 53 Ga. 320; Pegues $v$. Warley, $14 \mathrm{~S}$. C. 180 .

5 r rulf R. R. Co. $r$. Owen, 8 Kan. 409.

5s liedten r. Miller, 95 Ill. 336 ; Pinney r. Fellows. 15 Tt. 525; Perkins $r$. Swank. 43 Miss. 349: Joppin $r$. Dotr. 25 Wis. 573; O'Rourke $r$. O'onmor, 39 Cal. 442. 
another is estopped from denying that title, while he holds actually or presumptively under it; this is a fundamental rule of universal observance. ${ }^{5 y}$ Yet a trustee may disavow and disclaim his trust; ${ }^{60}$ a tenant the title of his landlord, after the expiration or surrender of his lease $;^{61}$ a purchaser the title of his vendor, after the breach of his contract by the latter; and a tenant in common, the title of his co-tenant; and drive the respective owners and claimants to their action of ejectment within the period of the statute of limitations. In like manner one who has possession of land under an agreement to purchase, which contemplates a continuing right of possession while the contract is being perforned, and an absolute right of possession by virtue of its performance, may, on performance, deny the title of the vendor; and thereafter his possession will be adverse. ${ }^{62}$

A grantor remaining in possession wonld seem to be effectually estopped by the covenants of his deed, and such has been held to be the law, ${ }^{63}$ yet in a number of instances a grantor who conveys by quit-claim deed only; by remaining in possession of the property and asserting a hostile claim, has been permitter to acquire a title against his grantee by virtue of the statute of limitations; ${ }^{64}$ while some courts have even held that a grantor with warranty may, subsequent to the delivery of his grant, originate an adverse possession, and is not estopped from asserting the same by his covenant of warranty. ${ }^{65}$ In any event the possession of the vendor camnot be igmored even though he

59 Nilson $\because$. James, 79 N. C. 349 ; Clarke $r$. Clarke, 51 Ala. 498; Hatel $r$. Bullock, 57 N. H. 15.

60 Jamison $v$. Perry, 38 Iowa, 14. 61 Nellis $\imath$. Lathrop, 22 Wend. (N. Y.) 121; Mattis $x$. Robinson, 1 Neb. 5. Or by rescinding the loase and elaiming a new title: Weichselbaum $v$. Curlett, 20 Kan. 709 : as where the tenant purehased the property at tax sale.

62 Catlino $v$. Decker, 38 Conn. 2(i); Stark v. Starr, 1 Sawyer (C. (t.), 15. The executed contract then becomes a silke and not merely an agreement to purchase: Ridgeway $v$. Ifolliday, 59 Mo. 444.

cos Van keuren $r$. R. R. Co., 38 N. J. I. 165.

$6+$ Dorland $v$. Magilton, 47 Cal. 485.

65 Sherman $v$. Kane, $86 \mathrm{~N} . \mathrm{Y}$. 57. 
may have conveyed with warantr, and where lire rontinues to oecupy the premises all persons acpuiping tith from his

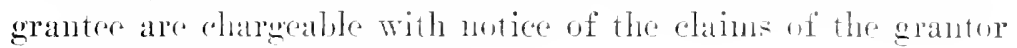
and of his equitable pighte. irs

$\$ 583$. Remainder-men. It is a well ostallinlerd principle that the statutes of linitation alu not romunenee to rum until the right of action or right ot entre arorues. It therefore does not commence to run acalinst a remainder-man mutil the termination of the precerlent estate, "when the derel reating such prior estate is of record, or the party in posseseion has notice of its existrnee. But when a party hats had the mintermpted and undisputed poseseion of land for the statutory period, and during that time has yad all taxes lesally assessed thereon, and has had neither actual nor constructive notice of a prior unrecorded conveyance creating a life estate with a remainder over to others, such possession and parment of taxes by him will be a bar to a recovery by such remainder-man, even though the full priod of the statute has not clapsed since the termination of the life estate, and notwithstanding the fact, that the party so asserting title is, by the terms of such undisclosed deed, made a tenant in common with such remainder-man. ${ }^{6 s}$

\$ 584. Reversioners. As against a reversoner there an be no adrerse possession. It can only exist against one entitled to possession. ${ }^{69}$

$\$ 585$. Tenants in Common. The general rule is, that the statute of limitations dues not rum as between terants in common, for the reason, in part, that the possession of one, in contemplation of law, is the possession of all," and this is

Go White $r$. White, s? III. 460); Ford r Marshall, 107 ill. 1:36.

67 Christie r. Gage. 71 N. Y. 189 : Dugian r. Follett, 100 111. 581; Fogal r. Perro, 10 Iins. (X. Y.) 100 ; Carpenter r. Denome ea Ohio Sit. 379; Gernet r. Lymn, :31 Pa. St. 94.

6s Dugan i. Follett, J00 Ill. 581.
69 clark r. 11upos, 13 Barb. 147;

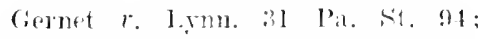

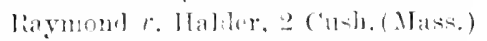

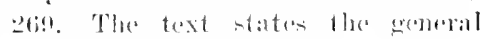
rulde but exeptionsl ares may at fimes militate angin-t it.

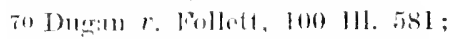
Ing. on Lim. \$ t22; Florence $v$. 
especially so when all the parties derive title through the same deed or conveyance. ${ }^{i 1}$ But if a tenant in common conveys the whole tract, by a deed which purports to inelude the entire estate, his grantee, if in possession, will hold adversely to the others, $^{i 2}$ while the possession of one of sereral tenants may become adverse, when his acts amount to an exclusion of his co-tenants. ${ }^{73}$

\$ 586. Persons under Disability. A special exception has been made by the statute in case of infants, insane persons, and persons imprisoned on a criminal charge for any period less than life, ${ }^{74}$ and their rights in land are not only protected during the period of disability, but for a certain period after the disability has ceased, or after the death of a person dying under disability. This period is usually fixed at ten years, but the statutes vary in this particular. It will be seen, therefore, that before any positive assurance can be entertained that a title has become perfect by adverse possession or prescriptive user, it must appear, not only that the property has been adversely held for the requisite time, but also that it has been held against some person against whom a preseriptive title can be aequired. ${ }^{75}$

But umless provided for in express terms this statutory exception does not have the effect of suspending the operation of the statute of limitations after it has legitimately commenced to r'm, and hence, if an adverse possession commence in the lifetime of an ancestor, it will continue to run against

Hopkins, 46 N. Y. 182; MeQuiddy $v$. Ware, 67 Mo. 74; Aquirre $v$. Alexander, 58 Cal. 21.

71 Dungan $v$. Follett, 100 Ill. 581. 72 Clapp $v$. Bromagham, 9 Cow. 530 ; Florence $v$. Hopkins, $46 \mathrm{~N}$. Y. 182; Rigg $r$. Fuller, 54 Ala. 14l; Faulke v. Bond, 41 N. J. L. 527.

73 Florence $v$. Hopkins, $46 \mathrm{~N}$. Y. 182. Though adverse possession and disseizin may not be in all particulars identical, their effect is the same for the purpose of terminating a tenancy in common: Millard $r$. MeMfullen, 68 N. Y. 345.

$7+$ Married women are sometimes incluted in this exception.

75 Melvin $r$. Whiting. 13 Pick. (Mass.) 188; Arbuckle $r$. Ward, 29 Vt. 55. 
the heir, notwithstanding any existing disalility on the part of the latter when the right acerues to him or her. ${ }^{i t}$

585. Married Women. In the abeener of evidenee to the contrary the presumption of law is, that the prssessinn of husband and wife in the joint recupancy of land as a home is the possession of the husbund, but this presumption may be rebutted by a showing that the woman took and held possession in her own right and so continued to hold chring the statutory period of limitation. If such is the case, her title, when once rested, canot be affected by any recorery in ejectment against the husband nor by any of his acts or declarations during the joint occupation. ${ }^{i \tau}$

\$58. Adverse Rights as Against the State. It is matter of common knowledge that statutes of limitation do not run against the State. That no laches can be imputed to the king, and that no time can bar his rights, was the maxim of the common law, and was founded on the principle of public policy, that, as he was occupied with the cares of gorernment he ought not to suffer from the negligence of his officers and servants. The principle is applicable to all governments which must necessarily act through numerous agents, and it is essential to a preservation of the interest and property of the public. ${ }^{79} \mathrm{It}$ is upon this principle that in this comtry the statutes of a State prescribing periods within which rights must be prosecuted are not held to embrace the State itself, ${ }^{80}$ unless it is expressly included, or the mischiefs to be remedied are of such a nature that it must necessarily be included. As legislation of a State can only apply to persons and things orer which the State has jurisdiction, the Cnited States are also necessarily excluded from the operation of such statutes. ${ }^{81}$ But the State may submit itself to the operation of the statute, in which

i6 Fleming $v$. Griswold. 3 Hill (N. Y.). 85; Jackson $r$. Moore, 13 Johns. (X. Y.) 513; Oates r. Berkworth. 112 Ala. 356 ; White $x$. Clawson, 79 Ind. 192.

it Collins $r$. Lyuch, $157 \mathrm{~Pa}$. St. 246.
79 Gibson $r$. Choutean, 13 Wall. 92.

su Gardiner $r$. Miller, 47 Cal. 570 .

s1 [nited States $v$. Hoar, 2 Mason. 31:; People $v$. Gilbert, 18 Johns. 228. 
event the same mle as to ouster and possession will obtain where the Stato is the owner as would apply in the case of private parties. 52

As adrerse possession cannot run against the govermment, it logically follows that the claim can not be asserted against a grantee of the gorelnment, and mere possession of government lands, thongls open, exclusive and minterupted for twenty rears, creates no impediment to it- recovery by the government, or hy one who within that period receires a converance from the government. ${ }^{\mathrm{s}}$

\section{s 5:). Effect of Arrerse Possession. When title to} land has been perfected by twenty rears' adverse possession and enjorment, it becomes equally as sirong as one obtained by crant, ${ }^{4}$ and creates in the person so asserting same, if otherwise mimpaired, a legal title to the fee which is effective for all purposes. s5 In many States, ten, seven or eren five years' mintermpted possession muler color of title, compled with acts of ownersip, pasment of taxes, etc., will, under the operation of the statute, cure defects in the instruments under which the entry was made, and bar all actions for the recorery of the land, thus seeming to the occupier an indefeasible title

-2 See, Schneider $r$. Hutchinson, 35 ()reg. 2.53; St. Panl r. Ry. Co.. 45 Minn. 390 ; Green $r$. Irving. 54 Mis- 450. Consult local statutes. s: Oakmith $r$. Johnon, 92 C. S. 343. But while it is true that mere lapse of time and continuance of possession withont pretense of title, or under pretense of a void title. can not he set up against the government, ret long possession is nevertheless a strong weapon of defense in the hands of one who cas show reatonable proof that the title of the govermment has becn parted with and has derolved on him: so hell, where a patent had been i-sued to one, of lands then in possession of auother, who claimed same by virtue of a selection by the State in lieu of section sisteen, but to prove which no primary evidence could be alduced. See Hedrick $r$. Hughes, 15 Wall. (T.S.) 123 .

st Sherman $r$. Kane, 86 N. Y. 57; Schmejiler r. Botsch, 90 Ill. 577; Bowen $r$. Preston, 4s Ind. 367. The presumption of a grant from adverse porsession continued for the statutoxy term. is not founded on any mobability of an actual grant, but is a positive rule established $\mathrm{f} \circ \mathrm{r}$ mirting titles: Melvin $r$. Wadde!l, 75 X. C. 361 .

s. Covington $v$. Stewart, 77 N. C. 148. 
in law, wo mater how lefeetire the title of the grantor, or

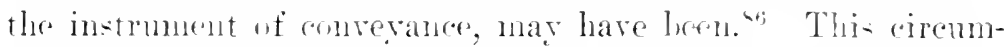
stance, in rases where no disability is shom to oxist, is often

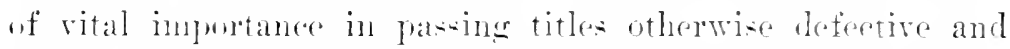

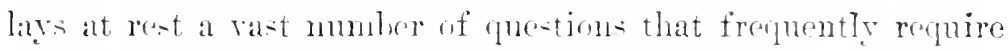
lomer and laborions investigation to properly solve. The statu-

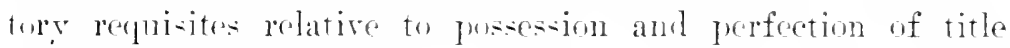
must he fully ascortained, howorer. eitler hy record evidence or otherwize before the has of the statute an be relied on.

\section{s.50. Proofs to Support Title hy d drerse Possession.}

Whon the title offered is adrerse in its character, comnsel should sock by inquiries in pais to dommotrato its validity before passing same. The highest and bust recoml frowf that condd be adduced wonld be the judgment of sone court of eompetent jurisdietion, either in an aretion of ejertment or a suit to quiet the title. I dead purporting to conver the title is next in order, while parment of taxes and the like still further tend to strengthen it. ${ }^{\text {si }}$ Many of the facts which wo to confirm an adverse title are not capable, lowerer, of aftirmative showing in an abstract, and evilence concerning them must, from the nature of the title, be disclosed aliunde. ${ }^{8 s}$

In an examination of title a mureh greater degree of strictness in the proof should be insisted upon than would be necessary to support a claim in a legal proceeding. In the latter case affirmative evidence is nsually all that is required. but in the former, inasmuch as there is no one to present negative evi-

se Ryan r. Kilpatick. 66 Ala. 332; Hunton $r$. Nichols, 55 Tex. 217: Stark r. Brown. 101 111. 395: Harris $r$. McGovern. 99 C. S. 161 ; Moingona Coal Co. $r$. Blair. 51 Iowa, 44i; Jones $r$. Patterion, 62 Ga. 527 .

si Paying taxes on land is not evilence of porsession, hut goes to show a rlaim of title: Paine $r$. Hutchins, 49 Vt. 314; Brown $r$. Rose. 48 Iowa. 231. But payment of taxes for a fixed period of years. coupled with possession and color of title. will by statute, in some States. mnfer a title commensurate with the deed under which entry was made.

ss Con-nlt Turner $r$. Hall, 60 Mo. 271: Howland $r$. Cemetery Asoce, 66 Parb. 366: Soule r. Barlow, 4s Vt. 132; Harnage $r$. Herry. 4; Tex. 567 ; Kerr $\ell$. Hitt. 75 111. 51. 
dence, counsel should require the person asserting the title to satisfactorily show that no evidence of this kind exists; as, that the claim is not liable to be lefeated by the infancy of heirs of the servient estate, or the lunacy or disability of parties who might, were it not for such disability, be able to establish a claim. 


\title{
CIIAPTER XXXII.
}

\author{
OPINIONS OF TITLE.
}

$\S 591$. Perusing the abstract.

502. Note taking.

593. Examination of the muniments.

594. Examination of deeds.

595. Examination of legal proceedings and jurgments.

596. Marginal notes and requisitions.

597. Continued.

598. Answers to requisitions.

599. Afldavits of pedigree.

600. Analysis of title.

601. Analytical chains.

602. Sketch maps.

603. Preservation of memoranda.

604. Passing the title.

605. What constitutes a valid title.

606. Flaws.
$\S 607$. Clonts upon title.

608 . Inquiries in pais.

609. Continued - Mechanics' liens.

610. Continued - Easements and Servitules.

611. Continued - Homesteads.

61:. Printed copies.

613. Framing opinions.

614. Opinions of title.

615. Continued-Certificates of title.

616. Opinions based upon the abstract.

617. Perspicuity of expression.

618. Oral opinions.

619. Liability for erroneous opinions.

620. Conclusion.

\$ 591. Perusing the Abstract. No specific rules can be laid down in regard to the perusal of an abstract by comnsel, as this is something that depends largely on the habits and professional methods of the individual. "The perusal should, if the length of the abstract will permit of it," says Sugden, ${ }^{1}$ "be finished at one sitting, althongh any difficult point of law, the whole bearing of which is not ascertained, may properly be reserved for further and separate consideration;" and this perhaps, will, to the majority of the profession, be found to be the method best calculated to produce satisfactory results. "It may sometimes be useful," says the same author, ${ }^{2}$ to 1 Sugd. on Vendors, 10.

\section{Ibid.}


glance over the abstract in the first place, in order to obtain a general view of the title, and experience will rapidly point ont when a subsequent part of the abstract may be looked into arrantageously before its proper turn; but, speaking generally an abstract should be perused but once, and that once effectually: The party should never pass on until he thoroughly conprehends what he has already read; the advancing in a difficult title, in order to comprehend what you have passed and do not understand, often leads to insurmountable difficulties." The experience of the writer would indicate that the remarks just quoted are not without merit, but the difference in the plan of compilation, as well as the effect of the instruments with reference to registration, notice, and other incidentals not common to the English abstract, renders necessary a somewhat different course from that pointed ont by Mr. Sugden.

The writer suggests, that whether the abstract be long or short, or whether the title be simple or complicated, a general perusal. in order to obtain a preliminary riew should first be made. This perusal is only to establish the fact of an apparent chain of title from its sonrce, the govermment, or from some person proposed in whom the title is assumed to have been rested. To assist in arriring at a correct estimate, an analysis of the abstract must always be made in intricate cases, and such a conrse will be found helpful in every case. Having established the fact of apparent title extending in unbroken sequence from the initial point to the person in whom it is last asserted, a critical review of every remore ${ }^{3}$ must then be made to determine its effect and validity, in much the same mamer, though not for the same purpose, as the English counsel examines the mmniments. All defects, whether of form or substance, are noted upon the analysis just mentioned, together with notes of discrepancies, objections and requisitions for further information. It wonld be mwise, however, to lay down

3 For want of a better name, each link in the chain. whether by deed, will, mortgage, lease, etc.. is called a "remove," and the removes are all numbered seriatim from the beginning, and referred to by number whenever occasion calls for reference. 
any unvarying rule for a matter of this kind. Mren's minds are not alike, and the mothous that insure the best results in the case of on', may be entirely inadequate in the case of another. The commel's persomal professional hahits will, after all, be the best gnide, lint slould he have no decided habits of professional thought or studr, it is beliered the comse indicated in this chapter will cuable him to form better opinions, and arrive at more satisfactury conclusions, than can be attained by any haphazard or molefined methods.

$\$$ 5!2. Note 'Taking. The real utility of note taking, as an aid to study or investigation in any pursuit, nust ever remain an open question, yet it can not be denied that in the examination of complicated titles the use of notos is, in a majority of cases, of undonbted benefit, as well in mrareling a tangled chain as in framing subsequent opinions. In the judgment of some writers, comsel will find it the best and surest method of arriving at a just conchsion, to trust to his view of the title on the face of the abstract itself, without incumbering himself with or relring upon notes, ${ }^{*}$ they being regarded as unnecessary details which often serve to distract the attention. ${ }^{5}$ Properly and methodically used, however, notes will nsualle be found an important aid, while in complicated cases they appear almost indispensable. Particnlarly is this true in making an

4 Sugd. on Vendors, $10 \quad(\mathrm{Am}$. Ed.).

5 The prejudice which exists among many distinguished members of the profession against the use of notes as an aid to study or investigation, refers more particularly to common-placing and abriclging, and though this was recommended by the earlier writers, notably Fulheck (1599), Sir Matthew Hale (16ss), and others of later periods, as Mr. Hoffman, in our own time and country, yet mokern writers like Mr. Warren, Mr. Bi-hop, etc.. strongly contemn the practice. Mr. Bishop says that if hr wisher "to renember a thing. the last method available is to commit it to paper. This is, with me, to put it ont of the jurisdiction of the memory." This prejulice, however, is mostly in regard to note-books as a means of assisting the memory, and the author last quoted admits the utility of notes taken by a lawger in looking up a question on which to advise a client, or references which will enable him, if litigation is afterward arried on, to go on with the ane withont a fresh search. Sie bish. First book of the Law, $\$ 423$. 
analysis of title, where the interest of every person connected with the title, or possessing any rights in the land, must be ascertained at every remove, and notwithstanding the fact that so high an authority as Mrr. Sugden condemns their use, the American counsel will find that in a majority of instances he must resort to them or run the risk of orerlooking some important matter in making up his final estimate of title and framing his opinion.

$\S 593$. Examination of the Muniments. In addition to the general survey of title from all the instruments and proceedings, each particular step must be examined technically and critically, and its own sufficiency or insufficiency passed upon. Under the English system this would consist of a comparison of the original instruments with the abstract, ${ }^{6}$ but this task under the American system, is supposed to have been satisfactorily performed by the abstract maker, and all that counsel is expected to do is to see that the instruments as they are presented are sufficient in form and substantially correct. This task is the most arduous part of the examination, for the sufficiency of erery instrument and proceding must not only be investigated with respect to itself but frequently with reference to numerous other instruments in the chain and sometimes in connection with matters not disclosed by the abstract.

Thus, a deed, by the donee of a power under a will to dispose of the property by last will and testament, he haring also the nse of the land for life, preaents two distinct phases. In the first place the instrument itself must be considered with reference to its formal parts; its date; registration; estate conveyed - a most rital point; execution, ete. Viewed only in this

6. The duty of a solicitor in exam. ining an abstract is thus summed up by Mr. Dart. He sars: "The object of the examination is to ascertain, 1st, that what has been ab-tracted is correetly abstraeted: endly. that what is omitted is Aearly immaterial: 3dly, that the documents are perfect as respects execution, attestation. indorsed receipts, registration, stamps, etc.; and 4thly, that there are no indorsed notices. nor any circumstances attending the mode of execution, attestation. ete., ete., calculated to excite suspicion." Dart on Vendors, 381. 
light it may be insuflicient an failing to diselose the intention of the donee to exerente the power, and though purporting to convey tha fee, conveys only the life estate of the grantor. ${ }^{7}$ In the second place, the deed nunst be eonstrued in comnection with the will granting the power, and its legal sufficiency considered in relation to such will, presuming that in form it is mimpeachable and fully diseluses the power and evinces the intention of the grantor to work under it. Now it is a vexerl question as to whether it is pessible for the donee of a power to make any disposition of the subject of the power save in the manner indieated in the instrument, granting same. ${ }^{8}$ In important question is here presented, therefore, and upon its solution depends the validity of the proffered title. The donor of the power intended that it should be executed by the will of the donee; he has attempted to execute it by deed." Here counsel must refer to the will and to the grant of the power therein, and the two must be earefully considered in relation to their effect upon the title. This is but an instance, but it is suffieient to illustrate the matter and to show the importance of this branch of the examination as well as the care and attention that must be bestowed upon it.

7 Dumning $x$. VanDusen, 47 Ind. 423 ; Jassey $r$. White, 28 Ga. 295 ; and see Funk $r$. Eggleston, 92 IIl. 515. In order to execute a power it is not absolutely essential that a deed should recite or even refer to the power, where it was manifestly the intention of the party to execute the power. But where the maker has an estate which will pass without executing the power, and the instrument is silent on that point, as in the case supposed, the law will presume that he intended to convey such eutate and no more: See, Pease $r$ Pilot Knol, Iron Co., 49 Mo. 124.

s See $\$ 392$ for a discussion of this subject.
9 The courts in England, and very generally in this country, have determined that when a power is to be executer hy will, the donor intended that it should remain under the contract of the donee "to the moment of his death." And the authorities are numerous, and uniform, in enunciating the principle that the donce ean not enlarge and amplify the seope of the power, but must be strictly controlled in its execution by the wardared intention of the clonor; and that a prower to be exeruted ly will ail not be exocuted by dered, and engity will not relieve if the attrompt is mate:

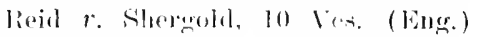
370 ; Wilks r. Burn: tio Mal. 64. 
594 Lxamination of Deeds. It is not proposed, nor is it necessary, to recapitulate all that has preceded relative to the formalities or leyal effect of instruments and proceedings offered in support of title, but it may be well, at this point, to briefly call the attention of counsel to the prominent features thereof as they are presented in the abstract. After a proper inception of title has been shown, or where sane las been satisfactorily established in some person at some definite period, either by assumption or investigation, the first duty of comsel is to see that the course of title is unintermpted from that person and perind. For this purpose he should observe the names of parties and dates of instruments down throngh the entire chain, and note all places where the chronological sepnence is broken or in inverse order. This, with a general view of each intmment, constitutes the preliminary survey. In analysis of the abstract, if it be long or the title complicated, must now be made, and the sufficieney and effect of crery remove noted therein. Again retmming to the first instrument lie shomld read the same carefully, observing the following points, which, for greater certainty, it is well to put interrogatively.

The parties: are they properly named and do they include all who by the initial matters are shown to possess title or interests? ${ }^{10}$ Hare they all executed the cleed, and is the execution correct in furn! Observe in this connection any apparent differences in the orthography of names as shown in prior or subsequent eonveyances, and in case such differences appear, make a requisition for further information disclosing identity. See that correct descriptio persone aceompanies the names as indicative of capacity, domestic relations, ete. Where one conveys alone, no clue being given as to his domestic status, an infuiry as to marriage can never be safely omitted. In

10 The legal effect of the matters mentioned in this section have all been discusied in other parts of the work and the anthorities relating thereto given. The reader is re- ferred to the virions heads, and sululivisions moler whirh they will reverally he found for extended discussions. 


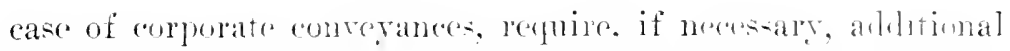
evidence relative to the powere of the anporation to receive, hold and convey, as woll as to show proper axecution. If the deed is the act of a municipality the resolution of authority must appear; if it does not a requisition for sane should be niade.

The estate: what estate purports to he convered! If the entire estate, observe by reference to prior eomperances what estate is held by the grantor, for he an conver no nure tham he possesses, whaterer be the form of words ued. Is it ineumbered by expresserl or latent liens? Ilas the right of dower, in a proper case, been relinquished! Ilave the humestand rights been waived? and if attempt has hern made in either case, las it been sucessfully accomplished? If the abstract fails to disclose these facts, make a requisition for further information.

The property: does the deseription correspond in essential parts to the caption of the abstract, or to the subject of the examination? Does it correspond with prior converances? Observe carefully for onissions and misclescription.

The covenants are not essential to title, and, being simply for the further assurance of the purchaser, may be dispegarded except when they become necessary to show an estoppel.

The conditions are important; observe in what mamer they may affect title by reason of non-performance or brearls. Do they disclose a possibility of divesture of title at sume futuro periol, or confer upon the grantor contingent reverionary rights of re-entry or forfeiture? Do they areate a comblitional limitation? If the deed itself is the result of prior aterement. does it substantially conform to such prior agreenent as shown? This inquiry is not always important, lnt nay locome so.

The dates: compare the dates respectively, of rxecution, alcknowledgment, and registration. Do they show a proper entrespondence? Compare these dates with those of prior and

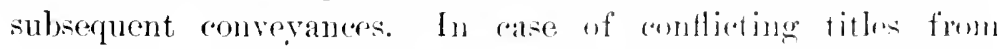
the same somper, this may berome very important in the solution of questions depending on priority. 


\section{\$ 595. Examination of Legal Proceedings and Judg-}

ments. So much has been said upon this subjeet in the preceding ehapters that little remains withont indulging in repetition, yet, as it has long been enstomary in nearly every part of the country to look solely to deeds as evidences of title, it is the desire of the writer to strongly impress upon the minds of examiner and counsel that all conveyances resulting from legal proceedings, aside from their prima facie quality, are valueless as evidenee without proof of eapacity in the grantor, and this can come only from the fact of jurisdietion in the court pronomeing the judgment or deeree. Should evidence of this fact be wanting, a requisition must be made for further information eoncerning same, and in no ease should a deed made in pursuance of a judicial sale be passed without full proof of its validity.

Where ofticial deeds of any kind are, by statute, made presumptive eridence of their own validity and of the validity and regularity of the anterior proceedings upon which they rest, and conmsel relying on the prima facic evidence thus presented dispenses with proof of prior regularity and jurisdiction, prudence, as well as fair dealing, would suggest that special reference to such facts be made in the opinion, that the elient and his assigns may know that the title passed is a prima facie title only, and has not been demonstrated.

In the prelininary measures to all execution and judicial sales comsel will first observe that the proceeding is apparently regular and formal; this is not rital, but may in some instances suggest an incuiry that requires answer. Next, he should observe, the parties: do the names in proeess, pleadings and judgment correspond? Has there been a personal appearance, or was the judgment taken on default? If the latter, dues the abstraet show a due and legal service of process, either personal or substituted? The subjeet-matter: do the pleadings disclose a cause of action within the jurisdietion of the conrt? The judgment or decree: is it regular in form, i. e., definite, certain, etc.? Doss it correspond with the process and pleading, $i$. e., parties and allegations? The sale: is it 
warranted by the prior procedings ! Is the selling ofthere clothed with proper authority! Was it amberend according to law ?

With respect to judgments in personam: olserve the lrames of defendants or judgment debtors; are they identical with those of the persons who now own the land, or who at some former period lave held title or possessed enuities capable of being reached by execution? Resolve any donbts that may arise by a requisition. Aftidarits of identity and disclaines are about the best arailable means for detemining this point. A certificate by plaintiff's attorney, when whe can be procured, will also serve to remove dubts concerning the islentity of persons bearing the same nane. Is the julgment still a subsisting lien! Was exceution issued within a rear from rendition? If donnant, has there been at revore! If against. a party in interest has it been appealed from? In appeal does not destroy the lien but may act as a supersedear. If it is a subsisting lien provision should be marle for its satiffaction before accepting title.

$\S 596$. Marginal Notes and Requisitions. It will be remembered that in England the abstract is compiled almost entirely from original documents, and that devions courses as well as intervals of title are supplemented and filled up by matter which to the American examiner wonld be entirely extraneous. So the English comuel, as he procects in the perusal, frequently ealls, in the margin, ${ }^{11}$ for evidence of facts which he supposes may be material and will rearlily be produced, and further notes such oljections to the vemilor's title as he thinks proper; all of which must he satisfactorily met and answered by the vendor and his solicitor. In a less degres, the same procedure may be followed by the Smerisan

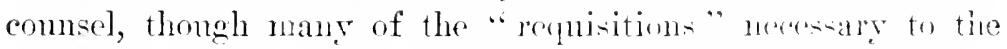
proper elucidation of an English title are unnewsily in the

11 The English abstract is frequently written upon a shert with fonc margins (so called), the outer left hand one being left clear fol' 45 the oberwation of examining

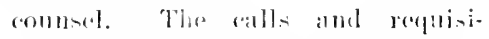
tions mate wh this matrgin thus become a part of the abstract. 
Cnited States by reason of our system of registration and its attendant doctrines of notice and estoppel. Where, however, an apparent descent occurs in the abstract, and a deed is shown purporting to be executed by the "heirs at law" of the person last seized, a call should be made for further inquiry or evidence tonching the legitimacy of the claim of title thus asserted. So, too, of a partition among heirs, by the mutual interehange of deeds, in which minor's rights mav be affected.

Frequently a death is suggested inferentially, as where a man and wife conver, and on subsequent revesture of title the man alone executes a deed. In the same way a marriage may be suggested, and in erery ease, where an indiridual cunvers with no words deseriptive of the person, inquiry should be marle in regard to marriage.

American abstracts are not male with a "margin," however, and the little strip on the left hand side of the sheet was not left to write or seriblle on, nor should the examining counsel use it for that purpose. If hy chance, or sheer perversity, he should do so, his writing should all be erased before the abstract leares his hands, that what he has written may not confuse others or be mistaken for the work of the abstract maker. Objections may be noted on his analysis, or preserved on separate sheets, and when required for use may be formally drafted and annexed to the abstract, or embodied in his opinion. Even in England, where the custom originated, it seems to loe generally discouraged by modern conreyancers and solicitors, as will be seen by the next paragraph.

\$ 597. Continuel. The American system of title abstracts, or at least that expounded in this work, does not contemplate the narginal divisions need in the compilation of English abstracts, and henee, the only margin is the narrow strip on the left hand side of an ordinarily ruled page of legal eap, which is often used for lead pencil memoranda, all of which should be erased before the abstract is returnet to the client. It would seem to be the present custom of English comsel to make their formal requisitions on a separate sheet of napre, which has heen divirled longitudinally by being folded down the middle. Upon the left half of this sheet, counsel, 
from the notes taken in the cource of perusing the abstract, draws his questions, inquiries, objections, etce, and delivers the same for answers. The vendor, or his solicitor, then peruses the requisitions, and proceeds to the reply to them on the right half of the sheet, the questions and answers being numbered in consecutive order, and the replies, so far as practicable, being written opposite to the requisitions. It is not thought that this is practiced to any consideralile extent in this country, or at least, if practiced, it has never been brought to the attention of the writer. In a modified form it might be found useful.

The method may be of advantage to American practitioners; therefore a form, taken from Ball's "Popular Conveyancer" (London, 1Si $;$ ), is given herewith.

\section{Brow to Toxes.}

Requisitions on Title and lieplies thereto.

\section{Requisitions.}

1. The lease of the ... day of $\ldots$, ls .., does not appear to have been registered. This should be done; the reference should be supplied.

2. The license to underlet given by... to ...., and dated the .... day of $\ldots$, ls ., must be delivered up on eompletion, and the vendor must obtain the requisite license for the present assigmment.

3. The assignment dated the .... day of ..., $18 \ldots$, and made between .... and .... purports to as. sign the term from 29th September. 1866, whereas the original term is from 29 th September, 1S63. How is this aeeounted for?

4. Is the vendor, or are his solicitors, aware of any charge or incumbrance, or other matter affecting the premises sold which is not disclosed by the abstract?

ANDREW ABBE,

Solicitor for Purehaser.

\section{Replies.}

1. This lease was registered. We can not give the reference. but it can readily be ascertained by the usual search. See claure-of eontract.

2. This will be done.

3. This is an error. The term is from 29th September, 1863, and the assignment referred to in the requisition is of the residue of the term.

4. No. It is presumed that the purchaser will make the usual searehes.

Charles \& Darwis,

Solicitors for the Vendor.

(Dated) 
It will be observed the axample just given is of requisitions and replies upon a leaschold title.

\$ 598. Answers to Requisitions. "A purchaser is entitled," observes an English writer," "to be furnished with evidence of facts material to the title, whether such facts are to be nued as positive or negative proofs, and the renctor is bound to answer, to the best of his knowledge, any relevant question upon the subject of the title, and to furnish such evidence as may be in his power; but the prrehaser must confine his questions to some particular defect, and not call for a general explanation of matters which he may consider require to be explained." 13 The foregoing remarks, though made in relation to the English laws on the subject of sales of real property, are not without some force in the United States, but, as a rule, and unless the agreenent for sale otherrise provides, the purchaser is entitled to a full disclosure of everything in any way material, and the cvidence should, so far as practicable, mable the purchaser to deduce a marketable title of recold. Where attidarits, or other instruments are furnished in answer to requisitions, such instrunents should be recorded, if aceepted, as they then constitute a part of the muniments of title. ${ }^{14}$ Statements not under oath or not attested by any solemnities are too unsatisfactory, even though reduced to writing, thongh sometimes from neessity, or moler a choice of difficulties, letters are admissible to supply information or furnish data for missing facts. Certificates, particularly when

12 Seaborne Vend. \& P. 175.

13 Greell v. Pulsford, 2 Beav. (Eng.) 70; Pearse $r$. Pearse, 1 Der:. \& S. (Eng.) 12. These matters are usually arranged beforehand by what is called the "Conditions of Sale," an insirument resemblingr what is known in this eountry as a "Contract for Sale," (not " Agreement to Deed") but much more cirementantial and explicit.

14 As suggested, in another place, after all inquiries have been made and requisitions supplied, the matter thus obtained, or such portions as are suseeptible, should be recorded, and a supplemental abstract of same made and appended to the original. This would make, so far as may be, a perfert and coherent itte, and is preferable to an opiuion showing all the defects, which must be remedied afterward. 
marle in the line of official duty, may be received. and fon many pmopeses they wonld be prima facie evidenee of the facts reeiterl.

$\$ 5$ 5.9. Mflidavits of Pedigres. Frequent alluwion hias been made in this work to titles asserted ly desent, in which no probate or othere court procesdings have bere hand and the unsubstantial and unsatisfactory nature of sueh titles has beren duly considered. As before remarked, it is customary for comed to call for additional evidenee in such cases as to the right of the party asserting title to make a deed, and this is usually supplied, in the absence of hetter testimne, by ex purte aftidavits of pedigree. Facts involved in a question of pedigree should, whenever practicable, be stated unw the persomal knowledge of the athiant, but may be established by profe of general reputation in the fanily, or even by proof of what deceased members of the family may have said. ${ }^{15}$ From the necessity of the case, hearsay cridenee of certain kinds is admissible in establishing matters of this character, because it is the best of which the nature of the ease admite, ${ }^{16}$ but such evidence is restricted to the declarations of dereased persons who were related by blool or marriage to the person from whom the descent is decheed. ${ }^{17}$

An affidarit of pedigree may be prepared in manner following:

\section{$\left.\begin{array}{l}\text { State of Illinois } \\ \text { County of Cool: }\end{array}\right\}$ ss.}

Thomas Jones, being first duly surorn, on oath says: That he was well acquainted with James Smilh in his lifetime; that said Janes Smith died at the C'ity of C'hirago, Ill., Jume 1. 1904. That said James Sinith wes married but onee and then

15 Harland $r$. Eastman, 107 Ill. 535): Fisenlord r. Clum, 126 N. Y. 5.5 .2$.

16 IIarland $v$. Fastman. $107 \mathrm{Ill}$. 53.); Blacklum r. Craw ford's Lessee, 3 Wall. (U. S.) 175.
17 Blacklum r. Craw ford's Iessoes. Wall. (I. S.) 17.5; Harland $r$. Walst. min, ]11 111. 5:35; 1 Greml. Evidenee. \$ 103; l Tayl. Ev. \$57t. 
to Sarah Williams; that three children were born of the marriage, to wil; Andren smith, a son, who dicd in the lifelime of said James Smith, unmarried and without issue; Thomas Smith, a son; and Sarah Smith, "daughter, now the wife of William Jackson. That at the time of his death said James Smith left him surviring his ridou, Sarah Smith, his son, Thomas Smith, and his daughter, Sarah Smith (Jachson), his only heirs at lan and nixt of lin. (Jurat.)

(Signed) Thomas Jones.

To the foregoing should be added suh facts as to counsel may scem material in the particular canc, but the recitals above stated are all that are csential to show a ralid descent to lineal heirs. Where the decedent was ummarried, and the descent is claimed by collateral heirs, more detail will be necessary. In such case the affidarit must show the death, marriage and issue of the common ancestor as well as the death, without issue, of any one who otherwise might have participated in the inheritance. The example above given will serve to indicate the manner of framing such an affidarit. Whenever the affiant is a member of the family, or i related, either by blood or affinity, to any of the partics, or where special circumstances have given him opportunities for knoviledge of a family history, it is always well to incorporate the face in the affidarit.

$\$ 600$. Analysis of Title. Every preon who has ever attempted to critically examine an abstract consisting of twenty removes, or more, must have experienced some difficulty in endeavoring, while grappling with a present puestion, to still keep in riew the past conree of title, or to apply it toward the solution of the question under consideration. I master mind, possibly, might he alle to successfully encompass the matter and from chaos bring order with no extemal aids. but to the arerage lawyer some ascistance is frequently indispensable, and this may be obtained by making, what mar be called an analysis of the title, as he proceeds in its perusal. This is accomplished by a chain, on which is noted the condition of the ownership of the land after every conveyance, and is a sort of 
halanee sheet whide shows the state of the title at every stager. for tracing minnte, variol, or munerons ownershipe, it can mot be well disprensed witl, and its use can frequently be advantageonsly smpplemented by skotch maps of the land itecalf.

It is lerliered that no better plan exists for preserving at every stage of the title the true interests of the parties, than by reducing them, at erery step, to a common deneminator. Shonld any of the parties in interest by inatreptenee, mistakr or design, eonver more than his or here repertive share, or intending to enurey all, shonld envey lese, the ormen, mistake or frand is instantly detected, and the confusion which necessarily must prevail in sulsequent ronverances, will not serve in the slightest to distract the attention of (a)m-el or set him trying to reconcile the irrecondilable by making six wo into four. As an illustration, take the case of a mannfacturing site in a city. In the conrse of business, many partners come and go. Some own large interests, some small. They trade anong themselses and purchase interests from each other. All the interests are undivided. The purdiasers lmy interests in the business, but incidentally they purchase orresponding interests in the real estate as well. It will take but a short time to thoronghly complicate such a title, as a demonstration will show. Suppose the abstract revealed substantially the following facts:

Nos. 1 to 5 show a conveyance from the government, and a regular investure of title with unbroken chain to $\mathrm{A}$. $\mathrm{B}$.

No. 6. A subdivision by A. B. (Now trace one lot.)

No. 7. A. B. to C. D., mulivided one half.

No. 8. C. D. to E. F., undivided one fourth.

No. 9. E. F. to G. II., undivided one eightll.

No. 10. A. B. to G. II., undivided one half.

No. 11. C. D., E. F. and G. II., a mortgage to O.

No. 12. C. D. to E. F., undivided one half of one half.

No. 13. C. D. to I. K., undivided one laalf of one half.

I. K., the last grantee, now desires to have lis title examined with the result slown in the following analysis. This analysis takes no mote of errors, lut is simply to separate and keep distinct the various ownerships: 


\section{ANALISIS OF TITLE.}

to

Lot 6, Bloch 4?, original Plat of the City of Kenosha, Wis., as shoun by the annexed abstract. The numbers correspond to the numbers of the remores as shou'n in the abstract.

The ormership of said lot after each of the conveyances mentioned in said abstract was as follous:

1 Numbers 1 to 5 show regulur incesture of title in A. B. to No. a a subdivision by him. Lot 6 being shown on 6) Mlat of such subdirision.

; t. $R . . \frac{1}{2}$ C. D., $\frac{1}{2}$

till. Sept. 1, 1858.

S A. B.. $\frac{1}{2}=\frac{2}{3}$

r. D.. $\frac{2}{4}=\frac{1}{4}$

E. $F ., \frac{1}{4}=\frac{1}{4}$

$9 \quad$ A. $B . . \frac{1}{2}=\frac{4}{5}$

C. I... $\frac{1}{2}=\frac{1}{2}$

E. $F ., \frac{1}{8}=\frac{i}{8}$

(i. $H ., \frac{1}{8}=\frac{1}{8}$

10 C. D.. $\frac{1}{4}=$

E. F., $\frac{1}{8}=$

G. $H ., \frac{1}{8}$ and $\frac{1}{2}=\frac{8}{8}$

$\{A l l$

If ay 10,1859 .

11 Mortyage.
1.2. $\quad$ F. F.. $\frac{1}{5}$ and $\frac{1}{4}=\frac{3}{8}$
i. $H . . . \frac{5}{8}=$
\} $\quad t l l$.
Aug. 2r, 18:9.
$13 \quad$ E. $F_{.} . \mathrm{s}_{\mathrm{s}}=\frac{3}{3}$
G. $H ., 5=5$
I. K.., $\frac{1}{4}=\frac{2}{3}$

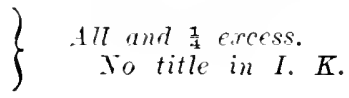
Jan. 9, 1860.

The foregoing illustration is necessarily brief and simple. In practice, much more difficult problems are presented, as where the abstract consists of from $f$ rty to fiftr remores, each one of fractional interests, and not in the easily understood parts shown in the example, but ci ninths, fifteenths, etc., until the chain presents one bewildering maze of civerse fractional interests. In no other war known to the writer can these mevenly halanced interests be hamonized and presented ir tancible shape than ly the method of reduction above indicuted. Counsel can then see at a glance the actual interest of 
every owner at exery stage of the title. He can tell if any have combered more than they posesesed, as wroll at whother

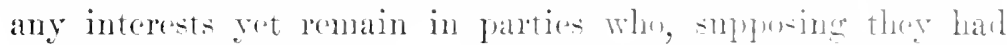

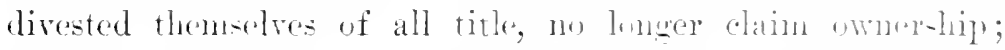
and the further fact, in whom the present title of the jorendi-es rests, and the extrut of the omership of eateh fereon.

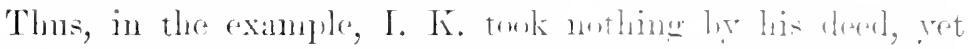

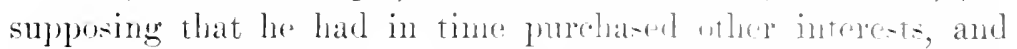
bonght and sold from and to others of the pronent partion, as woll as new parties who subsepuntly catne in, this -mplus

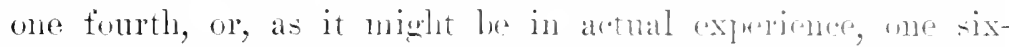

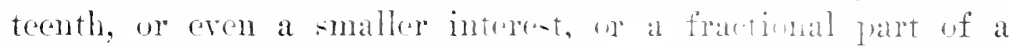

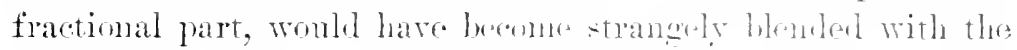

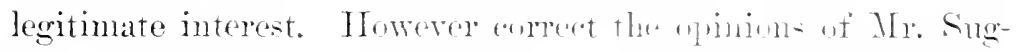
den in respect to note taking on the permial uf English abstracts, it must be alplarent that moter of sone kind can not be well dispensed with nuder the Amerioan ir-tren, and of all the devices to trace title, nome an complue in -implicity and thoroughness with the simple "analysis" atore presonted. ${ }^{1 s}$

\$ 601. Analytical Chains. Even whon the title is not

$18 \mathrm{Mr}$. Greenwood, an Engli:h writer on eonverancing, sars he "has found it a convenient course in perusing an abstract to take a sheet of paper with a double margin and insert the date of the deed in the left hand margin, and on the opposite side put such part of the deed as is neee sary to show the devolution of the title and any special clanses or stipulations, leaving the right hand margin for notes and queries. It may sometimes be convenient to keep the devolution of the legal and equitable estates separate. This will depend on the title; but it is alwars the best course in perming an ab-tract to show the desolution of the title to any attendant term of years on a separate sheet if paper. All this mas be done vely loriefly: it is only necesary to make a note in the margin opposite any particular clause or matter, in order that attention may he readily called to it afterward, as perlaph the next or a subsequent deed may have the effect of dispo-ing of the point: and should this be so. it i- a rrood plan to in-ert a note in the maruin of the andyri- muler the defect previon-ly noted, and thas many of the points it has been fomm men...ily to raise will the di-foust ot. and those not deared up will form the material for requi-itions on the title." cireenwools's Conveyancing (Gtll Fid.), 46. 
complicated by a multiplicity of small ownerships, if it be long drawn out, that is, extending over a long period of years and passing through many hands, some kind of chain is generally of material assistance in keeping the course of title prominently before the examiner, and prevents frequent recurrence to parts of the abstract that have already been passed over. This can be fairly accomplished by an analytic, or in one sense synthetic, chain, showing all the conveyances and their connection with each other. Whenever an adverse title intrudes, this chain will be a great help, both in keeping the titles separate and in showing their general conrse, and, if that event oceurs, their ultimate union. This chain may be prepared and used in connection with the analysis of title described in the last section, or it may be compiled on a separate sheet, and each used to supplement the other.

The chain may be constureted in any mammer that will best serve to aceomplish the desired purpose, but a very simple method is to make a geomrtrical diagran, the instruments being represented by quadrangles, and the connections and course of title by straight lines. This method has the merit of simplicity, and presents at a glance the general enm'se of title in a very elear and coneise manner. The quadrangles bear numbers with reference to the abstract, and may be further distingnisled by the names or initials of the parties and the dates of transfer. As a mechanical assistance in making this analysis a rubber stamp may be employed for marking the squares, the specific matter heing filled in with a pen.

A chain presenting few difficulties might be male somewhat in the following manner. In this example the dates are omitted, but, when this form of analysis is the only method employed, it is suggested that they be inserted.

$\$ 602$. Sketch Maps. The great aid derived from sketch maps has several times been alluded to during the progress of this work, and in all cases of "snarls" in the description of land, as well as in keeping counsel posted on the relative dimensions of the property convered at each successive remove, they are invaluable. Their aid is more frequently invoked in 
OPINIONS OF TITLE.

ANALTSASOF TITLE

to

Section 10, T. I N., R. 23, E.

ORIGINAL TITLE.

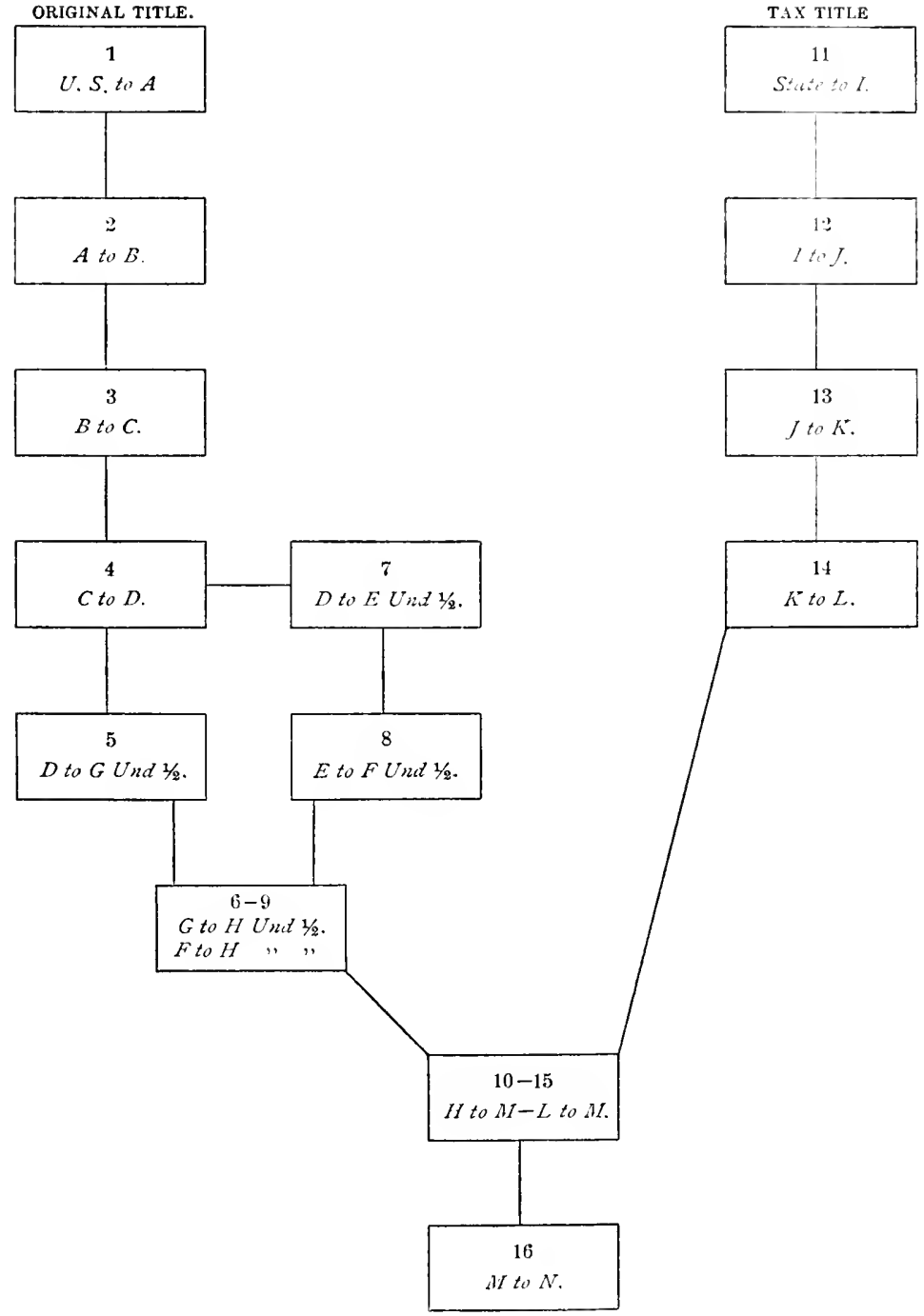


abstracts of what are popmlarly termed "agrienltural lands," or lands which are still referred to by the descriptions furnished by the government survers, but they will be found equally useful in tracing title to all land sold by metes and bounds, and which has nerer been the subjeet of formal subdivision into blocks and lots.

To snecessfully employ these maps, it is necessary that counsol should possess a little knowledge of surveying and understand the use of a protractor and a few other simple instruments. ${ }^{19}$ A tracing of the goremment survey will be foumd rery convenient in all examinations, and if comsel is unable to procure such tracing he should request the examiner to furnish a sketeh of the survey in conneetion with the abstract. In like manner, should he feel inadequate to the task of preparing sketches of the property, arrangements should be made with the examiner to furnish them. In no case should he dispense with their services unless he thoronghly understands the condition of the property both topographically and with reference to its superficial measurements, and in erery case where it can be done, the slietches should be marle br limself rather than by an assistant, as the work of figuring out the dimensions, tracing the coursos, and beating the monuments is of incalculable value in arriving at a proper conchusion and a thorongh mulerstanding of the "lay of the land."

The maps or sketches should be preserved with the analysis and ofler memoranda, or turned over to the client in connection therewith if such should be the understanding. In case they are given to the elient the particular tracts under eonsideration shmuld he colored or shaderl, to distinguish them from other parts of the map, and the limensions, whenerer practicable, should be marked on the lines or courses.

\section{$\$ 603$. Preservation of Memoranda. "It is desirable,"}

19 Mr. Curwen recommends only a semi-circular protractor, a pair of dividers, and a scale of equal parts. A scale divided into fiftieth parts of an inch he recommends as most convenient, on account of the accuracy with which. hy means of it, links. heing the humbledth parts of a chain, can be measured. See Curwen on Absts. 21. 
say- Mr. I.

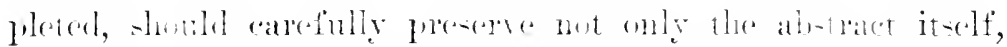

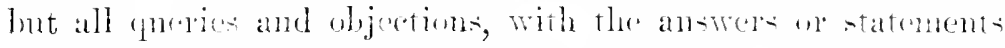

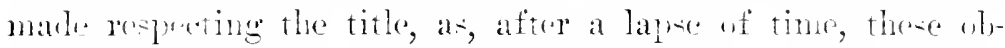
servations and answers may of themselves be of some weight in detemining futme questions." The palder will umlersand howerer, that an-wers and statements made in resmonse to queries and oljections, play a far more inportant part in the acceptance of English titles than they posibly conld in the natter of American titles. The statements are semed by solicitors or parties making thern, and are rowarded for certain purposes as a part of the abstract to which they are usually annexed.

Linder onr system the only memoranda that could be of naterial vahue to the purchaser would consist of the analysis of the abstract, or "f the title, and these, when properly and carefully maile, would undoubtedly bo a desirable acouisition and well worthy of preservation. They would not on! ye of areat assistance to the purchaser by cuabling him to pernse the abstract intelligibly at his leisure, but would also tend to materially reduce the expense of subsequent examinations. Lint, heing the private memronda of comsel, he would, of contse, be nuder no olibation to deliver his notes to the client, humever valualle they might be, as his opinion is all that is asked and presmmably all that is paid for. The methods by whel he arrived at such opinion, or the instrumentalitirs employed. are his own property to be given or withheld as he may see fit. The writer suggests, that in all cases ther he retained lig oomnsel, as not infrequently oceasions for their ronsultation will subsequently ocenr. In his own practice lie lat fomed it romvenient to keep a blank book in which has bean preserered his notes of examinations. On the loft himel pawe is platerd tho analyeis of the atstraet and on the opposite paes the objection:= querios and requistions for further information, towother will his note and obeervations. Whenerer questions hare afterward

20 Lee on $A b-t s,{ }^{*} 3$. 
arisen with respect to the opinion rendered on the title, the matters thus preservel have been found of very material assistance. Another adrantage will be found, in the aid such memoranda may afford in subsequent examinations of the same property or parts therenf.

$\$ 604$. Passing the Title. In examining a title, counsel is frequently compelled to atmit evidence which, although it may be satisfactory as a proof of the fact, yet wonld not be received in a court of justice: for example, affidarits as to facts disclosed inferentially, and to prove deaths, marriages, etc. Such afidarits, thongh inalmissible nuder the rules of evidence, are raluahle from the reason that they show that liring persons can at the time establish the facts therein recited. On the other hand, in receiving evidence admissible at law, counsel is compelled to sulmit the latter to a sererer test than it woukl be subject to upon an ordinary trial, for it is not a contest between two litigants which has the better title, but a calm consideration by a man in his chambers, whether the seller's title is a safe one against all the world. ${ }^{21}$

$\$ 605$. What Constitutes a Valid Title. In the absence of any stipulations to the contrary the vendor, in every contract of sale, impliedly undertakes to furnish to the purehaser a marketable title. ${ }^{22}$ It is for the purpose of determining this

21 Sugd. V. \& P. 16.

22 The remarks of an eminent English writer upon this subject may not be uninteresting. Mr. Lee says: "Under the term purchaser, the law generally includes, a mortgagce. and also a lessee, to the extent of their respeetive interests; to that extent they are purchasers; but the rules of law and the evidence of title, as they relate to a lessee, are very different from the rules and the evidence relating to a purchaser in the eommon acceptation of the term, as likewise to a mortgagee; but the title and eridence nsually required on behalf of a purchaser and a mortgagee are nearly similar. Some books indeed have stated that a purchaser, commonly so called, should require the strictest evidence of title, becance all his interest depends upon bis power of making out a strict title on a future sale; and that a mortgagee. seldom adraneing money to the full value of the estate, may well di-pense with the most complete evidence of title, as an imperfect title might probably feteh the amount of his advanees. Others say that, as a mortgagee an never gain anything beyond the amount of the monev lent, he 
quality in regard to the proffered title that wnmed is asked to investigate it prior to the consummation of the sale. "I am of the opinion that John Snith pescesed a good and valid title," ete, is a faniliar expresim in attorney's certifinates of opinion, and they are the controlling words that induce the jurchawer to acecpen the rendor's deed. Therefore the inquiry; what is a "good and ralid" title is pertinent in this eonnection. It may be briefly stated in answer, that the title disclosed should extend to show a full and perferet right to property and present possession vested in the remor. ${ }^{23}$ It must also cmllare the entire estate or intrasest sol,,${ }^{2+}$ and that free from the lien of all burdens, charese, or incumbrances, ${ }^{25}$ and should not only be free from litigation, ${ }^{26}$ but from palpable defects ${ }^{27}$ and grave donbts. ${ }^{28}$ It should consist of both the legal and the equitable titles, ${ }^{29}$ and be fairly derlucible of record. ${ }^{30}$ It may still be a valid title, even thongh charged with incumbrances, ${ }^{31}$ but in that event the opinion should discriminate and the title, if otherwise unimpaired, must be certified as " subject to the lien," ete., of the incumbrance. The terms of the contract of sale will, in many instances, determine the question of title when raised, but ordinarily, while a purchaser will not he compelled to accept a title palpably defective, he can not justify his refusal to accept by mere captious objections, nor is it sufficient for him, when the jurisdic-

ought to run no risk of losing that, not even the slightest: that a purchaser takes the esiate for better and for worse, and therefore, rather than reject a title for want of sufficient evidence, he may be sometimes arlvised to take it, and speculate for a rise in value." Lee on Ab. (Eng.) * 18 .

23 Delevan $r$, Duncan, 49 $\mathrm{N}$. $\mathrm{I}$. 49.5; Daris $r$. Henderson, 17 Wis. 105.

24 Taft $r$. Kesserl, 16 Wis. 273.

25 Roberts $r$. Balasett, 105 Mass. 407: Jones $r$. Garrlner, 10 Johns.
266: Davidson $x$. Tan Pelt, 15 Wis. 341 .

26 Speakman $r$. Forepaugh, $44 \mathrm{~Pa}$. St. 363.

27 Snith $r$ lioberton, 23 Ala. 312; Holland r. Holmes, 14 Fla. 390.

28 Gans $r$. Renshaw, 2 Barr (Pa.) $34 ;$ Scott $r$. Simpson. 11 Heisk. (Tenn.) 310.

29 Taft $r$. Kessel, ]6 Wis. 273.

so Murtin $r$. Juldl, sl Ill. 4ss.

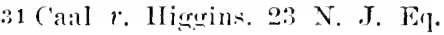
308. 
tion of a court is inroked to compel him to perform his contract, merely to raise a doubt.

I defect in a record title, will, muler most cireumstances, furnish a defense to a purchaser, particularly where it affects the valne of the property or wonld interfere with its sale, and thus render it unmarketable, ${ }^{32}$ but there is no inflexible rule, in the absence of stipulations to the contrary, that a rendor must furnish a perfect title of reord, and it has frequently been held that defects in the record or paper title may be remored by parol evidenee. ${ }^{33}$ There, however, the title depends upon a matter of fact which is not capable of satisfactory proof, or, if capable of that proof, yet is not so proved, the title is not markctable and the purchaser is not obliged to take it.

A title, to be valiul, need not necessarily be dedueible of record, for a prescriptive title may, under proper conditions, be as strong as a title by grant, ${ }^{34}$ yet snch titles, mnless there has been a continm nu holing for at least twenty years, are alwars liable to defoat from mulisclosed defects, and even after the repiration of such periol they may still be open to attack thromgh claims by minor heirs, or persons under disability.

Again, a valis title shomld, as is self-erident, be free from latent drfoets or taint of frand; yet this is something that, from its rey nature, must frequently pass undetected, even by the rexere of the greatest prudence. As a rule, howwer, where the lrgal title is rosted in the rendor, and there is nothing apparing from which purehasers can know that there has been any frand in his acquisition of the title, or any invalidity in any of the teeds in his chain of title, they will be protecterl in the purchase. ${ }^{35}$

S 600. Flaws. This tem mas be aptly used to deseribe an apparent gap or lireak in the chain, which, when ocenring, constitutes in many cases an insumountable impediment. A requisition munt in all cases be made for the missing links,

32 Shriver $r$. Shriver, $86 \mathrm{~N}$. Y. 576.

3. Hellreigel $r$. Manning, $97 \mathrm{~N}$.
$3+$ McNab r. Young, 81 Ill. 11. 35 Sherman $r$. Kane, 86 N. Y. 57.

Y. 56 . 
whether the intermption le partial, as where nus of several pertons shown to poseses a mity of interest fails to anurey ar entire, as where no privity of title is slown to exist betweren present and prast owners. Where the original title fails amel repuisitions for the purpere of showing comnertion ale re-

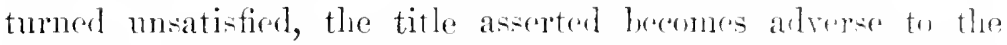
original title and necessary incuiries in pris mont be made to show a ralid title hy adverse pososion.

An apparent berak in the rhain often cocents in cave of descents, the estate of the intestate nerer having leeen settled in probate: and when the only heirs are marriel women, and a conveyance is subsequently made by theme, if no description of the person or capacity is given, the break, upon the reeord, will, of course, be absolute. When a grantee miler an unrecorded land contract has gone into possosion, but no deed has ever been made, the same state of facts exists in respect to conreyanees by him. Again, and these cases are by no means uncommon, simple or ignorant people frequently go into possession under deeds which they never canse to be recorded, and this apparently breaks the continuity of interest and title. Requisitions, in manr instances, will suffice to discover the missing evidence, but when they can not be fomml, possession and claim of title under the statute of limitations nust be relied on.

A serious defect of the character under consideration will frequently be found at the very initiation of the title, the abstract showing only the original entry at the govermment land office, supplemented, possibly, he the local record of the receiver's duplicate receipt. Now it is immaterial how long the premises may have remained in private occupanes nor through how many hands they may have passed; the title, in such a case, is simply an equity, for no limitation luns aguinst the government. Yet such defects are very coummom. From a very early day in the listory of the prblic land system, settlers and purchasers seem to have lreen strangely indifferent in the matter of securing posession of the gevermunt fatents for their lands, and in hundrecte of thomsands of instances thes foundation of title, as exhibited by local records, to lands pur- 
chased from the government, some of them of rast present value, is merely the duplicate receipt above alluded to. Probably this indifference has arisen chiefly from ignorance on the part of purchasers that a patent constitutes the only positive evidence of the transfer of title from the govermment to the individual, but whatever nay be the canse, the fact exists, ${ }^{36}$ and it should be the duty of every attorney examining a title to see that this rital link, showing the original derivation, is restored whenerer it is shown to be wanting. ${ }^{3 i}$

$\$ 607$. Clouls upon Title. In the examination of abstracts commel frequently finds minor defects, imperfect descriptions, invalid instruments, and abortive attempts at conreyance, which, while not reaching the merits of the title, nor yet, in many cases, casting any suspicion upon it, still tend in a measure to obscure it. These defects are known as "clonds upon the title," and it is the duty of comsel to detect and point out such defects that proper steps may be taken to remore them. The opinion should properly discriminate between deeds which are defective nercly, or which might be made the foundation of a valid title in comnection with other circumstances, and those which are absolutely void, for the legal effect of the two classes is not the same. As a general rule, a deed, lien, charge or incumbrance of any lind, to cast a shadow upon title, so as to give the owner relief in equity, must be one that is regular and valid upon its face, but is, in fact, irregular and void from circumstances which have to be proved by extrinsic evidence. $^{3 s}$ If the invalidity plainly appears on the face of the

36 It would seem from the report of the Commissioner of the General Land Othice for the year 1875 , that at that time there were remaining in the files of the general and local liand offices nearly two millions of uncalled for patents, covering, prolably, not less than $1,20,000,000$ acres, no small proportion of which were lands purchased of the government grore than a half century before, and lying in the older States of Ohio, Indiana, Ininois, ete.

$: 3$ The initial statements taken from the Government Tract Book will always furnish a clue to a break of this kind, and a certified 'opy of the patent can be obtained by any person showing himself to be entitled to it.

3. Murphy $v$. Mayor, ete., of Wilnuiugton, 6 lioust. (Del.) 108; crooke $r$. Andrews, 40 N. Y. 54i; 
instrmuent, ${ }^{39}$ or, although not apresent on the writing, if it is shown by any of the prelininaries which attend it, or in any of the links which ermuect it with the title, ${ }^{\prime \prime}$ so that no lapse of time nor change of circmustances can weaken the means of defense, such an instrunent does not, in a just sense, eren cast a cloml upun the title, or diminish the security of the owner of the land, ${ }^{41}$ for the rnle is well settled that such an instrument can work no mischief, and that no oceasion arises fur equitable interference for its remoral or cancellation. ${ }^{42}$

It is not recommended, however, that every matter appearing in the abstract, and shown thereby to be irregnlar and roid upon its face, be disregarded for that reason, for the legitinate provine of the opinion is to specitically show the legal effect of all instruments or proceedings that to the non-professional reader may seem suspicious, and, by pointing out such matters and showing their invalidity, to allay his fears and confirm his confidence in the title. It is for this very purpose, that intending purchasers seek the aid of comsel, and every donbt or question that may arise to the legal mind should find expression in the opinion. Many questions of this character, which formerly conld be summarily disposed of, now require a very different treatment, from the fact that in a large number of States the statute has made certain classes of deeds and conveyanees prima facie evidence of the facts therein recited, and not only of their own validity, but of every anterior proceding necessary to constitute such validity. Whenerer a deed is primary evidence of title and of regularity in the prior pro-

Sanxay $v$. Hunger, 42 Ind. 4t: Davidson $v$. Seegar, 15 Fla. 671. But see, Rigdon l. Shirk, 127 Ill. 411.

39 R. R. Co. $r$. Selmyler, 17 N. Y. 599 ; Sloan $r$. Sloan, 25 Fla. 5).

40 Fonda $r$. Sigge, 48 X. Y. 173; Griswold v. Fuller, 33 Mich. 26s; as where title in drebued thromgh a

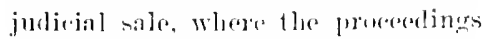
which were the basis of suchl sile, and upon which the validity of the atrore title depends, are shown to be roid for jurisdictional defects: Florence r. Paschal, 50 Mla. 28; Inatch $v$. City of Luffialo, $38 \mathrm{~N}$. Y. 276.

th R. R. Co. r. Simuyler, 17 N. Y. 599: Bowert $v$. ('ity of Elizabetli, 27 X. J. Eq. .tis.

12 Fond:a r. Sitge, 48 N. Y. 173; cohen r. Filated, 44 ('al. 29. 
ceedings, and can only be overcome by proof of certain facts dehors the deed, a clond is always created, ${ }^{43}$ for though the instrument is really void, it has an ostensible validity, and throws a doubt upon the title, and not only can be used for vexatious purposes, but is such a title that, if asserted by action and put in evidence, would drive the other party to the production of his own title in defense. ${ }^{44}$

$\S$ 608. Inquiries in Pais. Technically, when an attorney is called upon to pass the title to land under a given state of facts as presented by the abstract, he is not supposed or presumed to extend his investigations beyond what is directly or inferentially disclosed therein. The absence of requisite links in the chain of title calls for inquiries respecting same, but the existence of unrecorded evidence, or of equities not. apparent or fairly deducible, do not legitimately come within the province of an examining connsel.

It is, however, strongly recommended, that in addition to the inquiries and requisitions made during the perusal of the abstract, and which are raised by the disclosures therein made, a further inquiry be directed to the present jossession and occupation of the land under examination. ${ }^{45}$ A due observance of this suggestion will give greater stability to the opinion, and may in many cases prove a mild preventive of a bitter lawsuit. A long series of adjudicated cases confirm the doctrine that open and exchusive possession of land affords notice of the claim of the person so in possession, ${ }^{46}$ and a purchaser of land

43 Tilton $v$. R. R. Co., 3 Sawyer (C. Ct.), 22 .

44 Lick $r$ Ray, 43 Cal. 83.

45 The importanee of this inquiry ean not he over-estimated in cases where a long interval exists between the time of acquiring title and its divesture of record. In some cases seven years, and in nearly every ease twenty years, will be sufficient to bar an apparent title of record when adverse rights have been aequired; aud continuous possession is almost as essential a showing as unbroken continuity of record title. In fact, in an action of ejectment, which is nothing more than an action to try a disputed title, the fact of possession by the plaintiff or those under whom he claims is an essential part of the proof, and the mere production of a deed, without more, will not be sufficient to establish 1itle.

4 lirithard $r$. Brown, 4 N. H. 397 ; Redden $v$. Miller, 65 Ill. 336 ; 
at the time adversely held by another who does not inquire of the party in possession as to his title or right of occupancy, will not te considered a bona fide purchasce, notwithstanding he may have examined the registry of titles ${ }^{4 i}$ A purcha-er of land who exmines the records is protected ly them as far as they can protect him, hut lie necossarily takes the risk of having the actual state of the title correpond with that which appears of record. ${ }^{4}$ The registration laws are designed only to protect purchasers against latent equities; hence, unrecorded conveyances are void as against subecpuent purchasers without notice, and while in a few instances courts may be found lolding strongly against the doctrine of molnctive notice arising from possession merely, ${ }^{49}$ though admitting such to be competent for the consideration of a jury in ennection with direct evidence of actual notice, the rast preponderance of anthority sustains the principle that a purchaser from the record owner is bound to notice the possession of another, and takes subject to the right indieated by such possession. ${ }^{50}$

In any erent the safe course is to make the inquiry, for the law will not extend its protection to those who through negligence or inattention suffer an advantage to be taken of their credulity, nor will it afford relief to those who neglect to examine and by personal observation ascertain the knowledge of those facts of which they are presumably conversant. "It is not to be supposed," sars Richardson, C. J., "that any man who wishes to purchase land honestly, will buy it withont knowing what are the claims of a person who is in the open possession of it. It is reasonable, if men buy in such eases

Maghee $r$. Robinson, 98 Ill. 458;

Pinney $r$. Fellows, 15 Vt. 525: Hackett $v$. Callender, 32 vt. 97 . The rule is the same both at law and in equity: Griswold $r$. Smith, $10 \mathrm{Vt} .454$.

${ }_{47}$ Russell $v$. Sweezy, 22 Mich. 235; Warren $v$. Ricliniond, $53 \mathrm{Ill}$. 52.

48 Peck v. Clapp, 98 Pa. St. 581.
49 Pomeroy $r$. Stevens. 11 Met. 244: Glass $r$. IInrlbut, 102 Mass. 34; Clark r. Bowworth, 51 No. 529. 50 Pinney $r$. Fellows, 51 Vt. 52.5; Pusell r. Swerzy, 22.2 Mirh. 235; Redllen $r$. Miller. 9.j 1ll. 3:36; Perkins $r$ Swank, 43 Miss. 349; O'Rourke $r$. O'conner, :39 C'al. 44:; IJappin r. Doty, 25 IVis. 573: Edwards $v$. Thompson, 71 N. C. 177. 
without inquiry, that they should be presmmed to have known overything which they might have learned upon due inquiry," 51 "and one important evidence of title to an improved estate," continues Shepley, J., "is the possession of it. When one person purchases of another who is not in possession, he is put upon inquiry into the canse of such apparent defect of a perfect title." to When land is vacant or unoccupied, no presumption can arise against the legal or record title. ${ }^{53}$.

\$ 609. Continued - Mechanies" Liens. It has been held in a late case, ${ }^{54}$ that a party purehasing land on which buildings are in process of ereetion, having knowledge of the same, is bound to make inquiry as to the rights of parties furnishing materials or performing work thereon, and that such person is charged with constructive if not actual notice of their lien. Further, that a sale of property after the lien is fixed, to one cognizant of the fact, gives him no rights as against the lien. This is in consonance with the general doctrine on the subject of mechanies' liens, which provides that the lien shall take effect from the time of the commencement of the work, and that no sale or transfer thereafter is sufficient to divest it. ${ }^{55}$ It follows, therefore, that an inquiry respecting possille liens shonld always be made and that the attention of prospective purchasers should be directed thereto.

$\$$ 610. Continued - Easements and Servitudes. In addition to all the recommendations heretofore made, it is further suggested that an actual inspection of the premises be had for the express purpose of ascertaining whether there

51 Pritehard $v$. Prown, 4 N. H. 397 ; Russell $r$. Ransom. 76 Ill. 168. 52 Mattliews $r$. Demerritt, 22 Ne. 312 .

53 White v. Fuller, 38 Vt. 201; Thompson $r$. Burhans. 79 N. Y. 93; Weir $x$. Lumber Co., 186 Mo. 388.

54 Austin $r$. Wohler, 5 Bradw. (Ill. App.) 300. A mechanic may file his lien against the person who held the legal title when the work was commenced, and he is not bound to inquire further or take notice of any subsequent conveyances of the property: Fourth Are. Bap. Church r. Sehreiner. 88 Pa. St. 124.

55 Dunklee 19. Crane, 103 Mass. 470: Thielman $x$. Carr, 75 Ill. 385 ; Mehan $r$. Williams, 2 Daly (N. Y.), 367. 


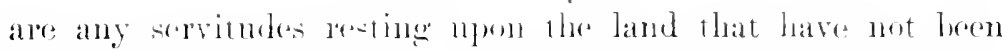
discloserl by the abstrant. This, at first blush, may seem an mnecesary and useless procoeding, yet thore are many conditions and cilcumstances that not only justify such a course, but render it an imperative duty. It is true that, as a rule, a claim for an rasount must be fomded upon a grant by leed, yet an easement may pass by inplication, when its existones is necessary to the cojomment of that which is expressly granted or leserved, upon the principle that where one grants anything to another, he therely grants him the means of enjoying it, whether expresied or not. ${ }^{56}$

This is well illustrated in the rule of the common law which provides that, where the owner of two heritages, or of one heritage of several parts, has arrangod and arlapted them so that one derives a benefit or adrantage from the other of a continuous and obvious character, and then sells one of them without making mention of these incidental adrantages or burdens of one in respect to the uther, there is, in the silence of the parties, an implied understanding and agreement that the adrantages and burdens, respectively, shall continue as before the separation of the title. ${ }^{5 i}$

But in order that an easement shonld pass by implication, under the grant of an estate, it must be obvions to any observer, while an apparent sign of servitude nust be impressed upon the servient estate: in other words, the marks of the burlen must be open and visible. ${ }^{5 s}$ Where these conditions exist, their effect upon the servient estate is frequently productive of results that the purchaser neither anticipated nor intended, but of which he might have been fully apprised had proper inquiry and cxamination been made prior to the acceptance of the title.

The foregoing renarks are particularly true with regard to city property or property in popmlous neighlorhoods, where

5e Janier $r$. Booth, 50 Miss, 410 ;

Pingree $v$. McDufTe, sf; N. II. 306;

Dillman $v$. Hoffman, $39 \mathrm{Mi}$. 559.

57 Morrison $r$. King, 62 Ill. 30:

Lampman $v$. Milks, 21 N. Y. 505;
Jones $r$, Jenkins, 34 Md. 1, and see Wash. Fanement, 58 .

5is Butterworth r. Crawford, 46 N. Y. 349 . 
buildings and improvements crowd and encroach upon each other, ofttimes disclosing, upon even a casual inspection, all the marks of servitude, and thereby charging the purchaser with notice of their existence. ${ }^{59}$ Where any doubts exist with respect to lines, courses or dimensions, a survey should be had to fix boundaries.

$\$$ 611. Continued-Homestead. It will be remembered that in several of the States the right of homestead is a special estate requiring a special release to divest, and in other' States, where it is regarded merely as a statutory right of exemption, certain furmalities are expressly necessary to a waiver. Where such laws obtain, and the deeds make no reference to the homestead, eren though the possession of the land is shown to be in the parties convering, a further inquiry should, it would seem, be made with respect to the character of the possession, and a special release or waiver of the homestead right should be obtained when such inquiry expressly or impliedly discloses a homestead occupancy. ${ }^{60}$

$\S 612$. Printed Copies. When large subdivisions are made for general sale to purchasers of small lots, it has now become customary to duplicate the original abstract to the

59 So held where the owner of lands divided the same east and west and erected a building on the north part, placing the south wall half on each side, with a flue projecting eight inches on the soutl lot, which was nsed to carry off the smoke from a furnace permanently attached in the building, the flue being necessary to the use of the furnace; the flue stood exposed to view with chimney thereon, and the owner sold the north portion of the lot to the center of the south wall, with the building thereon, to the plaintiff, and afterward sold the south half of the lot to the defendant, who contributed to the expense of the party wall, and the latter gave notice of an intention to close up the flue, whereupon the plaintiff filed his bill to enjoin the act: Ingals $r$. Plamondon, 75 Ill. 118.

60 Printed blank forms of conreyance generally contain a homestead waiver, and this is also a part of the form prescribed for statutory deeds, but where forms are draughted for special occasions the waiver is generally omitted when the lands, in fact, are not occupied as homesteads. In subsequent examinations this course irequently raises embarrassing questions and the better plan is to insert the waiver in all deeds regardless of the actual facts. 
entire tract by printed copies. This is done to aroil the expense of a separate search for each lot of the sublivision as well as a scrivener's copy of the original, and it is rained that such printed copies are far more reliable and tru-tworthy than where a written copy is made from the wrininal for every transfer. Where the work is performed (nuncententionsly and carefully this is probably true, yet the great majority of the profession have set their faces strongly against the use of printed copies and many lawyers rofusc to promonnce upon a title diselosed by them, unless the original is also prorlnced at the same time for comparison and inseretion. This strongly grounded prejudice arises from tha fiact that the temptation for the interpolation of foreign matter, or the suppression or expurgation of original matter is so great, that unscrupulous parties not infrequently do not hesitate to resort to such expedients to conceal the defects of imperfect title.

A printed cops, if made by an honorable and responsible person, who, at the close of such copy appends a certificate of verification, loses some of its objectionable features, ret this is but a poor protection, as the printer merely presents what he finds, and if foreign matter has been introduced into the original it will of conrse be reproduced in the duplicate. Nor does the fact that a comparion of such duplicate with the original has been marle by a notary, and of which fact a certificate under his hand and oflicial seal accmmpanies the copy, make the copy much, if any, more reliable. In both of these instances the opportunities for frand and imposition are present, while ignorance, carelessness, mistake and aceident may all conspire, where no bal faith exists, to render. such copy inaceurate and unreliable.

But as printed copies will continue to be nsed, and as in many instanees the cost of an original abstract would be equal to the price of the land, care should be olserved to see that every precaution has been taken to insme the reliability of sueh copy and prove its acenacy. This can, in a largere measure, be sucessfully acemplished hy a repilieation of the printed copy by the examiner who compiled the original, and 
it is recommended that, in every instance where a printed copy is offered in support of title, a comparison be first made by the examiner, and a certificate under his hand, that same is a true copy, be appended thereto. To insure further accuracy the examiner should write his name, or at least his initials, upon every page or sheet of the eopy, and if after all this, imposition is still practiced, counsel will at least have the satisfaction of knowing that the imposition was beyond his power to prevent and that he has fully performed his duty in the matter. ${ }^{61}$

A certificate of verification should fully identify the copy to which it is annexed by proper references to the original and should unmistakably state the primary fact of correctness. If any divergence from the original is shown this should be noted and if corrections are made in the copy these also should be indicated. The following will serve as an illustration:

The foregoing seventeen (17) pages (this included) is a true copy of the original examination of title except [here note differenees, if any, as; that sundry words abbreviated in the original are printed in full in this copy and sundry words written in full in the original are abbreviated in this copy] Corrections Nos. 1 to 40 inclusive, in red ink, made by $u s$.

IIandy \& Company.

\$ 613. Framing Opinions. After the abstract has been thoroughly perused, the inquiries answered, the requisitions satisfactorily supplied, and the relative rights of parties determined, counsel should proceed to formulate his opinion in a connected and orderly manner. This will include: first, a concise caption or title, similar to that which prefaces the abstract, deseribing the object and purport of the opinion. Then follows the result of his investigations, and here should be stated all the defects and irregularities which he may deem

61 For a more extended discussion as to what constitutes a merchant-

able abstract see Warvelle on Vendors, § 292, et seq. 
worthy of notice as affecting the title. Finally comes the formal opinion, which shomld bx as concise and terse at possible, and based upon the abstract and the defects or other matters noted in the stating part of the opinion. Should the exigencies of the case repuire it, or the client so direct, counsel may ard such directions or suggestions as to him may seem expedient in perfecting what the abstract shows to be an imperfect title, but it is suggested that the better way is to commmieate such information or directions together with any hypothetical opinions, by a separate rriting, and confine the opinion, which it is proposed to ammex to the abstract, solely to the state of the title which the abstract presents.

Another method, and one that is preferred by many lawyers, is to state the general opinion first and then to follow with a recital of the defects or imperfections of title which qualify the opinion. Either method will serve to apprise the client of the condition of the title.

$\S 614$. Opinions of Title. A formal opinion upon the merits of the proffered title does not seem to have been contemplated by the English writers on the subject of abstracts, nor by those American writers who hare herctofore ventured to touch upon the theme, and this feature is doubtless an outgrowth of "westem civilization." The queries, objections, requisitions, etc., of an Englisl examiner in a measure take the place of a formal opinion, as they tend to note and point ont defects and make suggestions whereby defects may be remedied and missing links supplied. Bnt, as abstracts are now prepared, a carefully framed opinion is an inseparable incident and a fitting climax of every examination.

There are two methods of framing opinions of title, both of which are in general use. The first, and most common, consists of statements based upon, and ammexed to, a formal abstract, and is made by connsel after a perusal thereof; the second, is where the examiner, after investigating the title, by personal examination of the records or of his own indices thereto, places the title in some individual named subject to whatever impaiments he may find of record. This lattor 
method is also known as "certifying the title." No chain or athrmative evidence is usually shom in such cases. Frequently such certificate is based upon a directed assmmption of title in a certain person at a certain date, and the examiner certifies from his examination of the records from such date. In the latter case, the certifier assumes the dual office of examiner and attorney, and in many cities, where no special class of examining conveyancers or abstract makers exists, ail abstracts and cxaminations are made in this manner. The plan has little to recommend and much to condemm it, and, in the opinion of the writer, more satisfactory results are obtainerl, at least in populous and active cities, by a thorongh disasociation of abstract maker and comsel. ${ }^{62}$ An opinion of title male in the mamner just described would be prepared somewhat in the following manner:

\section{OPINTON OF TITLE}

to

Lots 17 and 18, Block 3. Town of IIyde Park, Cook County, Ills.

By direction of William P. Smith, at whose request this opinion is given. ${ }^{63}$ it is assumed without examination, ${ }^{64}$ that

62 Possibly the writer's experience has tended to prejudice him in favor of a system with which he has long been familiar, but from what he has seen of "Certificates of Title," he is strongly inclined to condem their nse. Of late years and in some localities an effort has been male by law to abolish the old and well settled system of recording titles, by the introduction of the crude methods of some European countries. By this innovation. usually called the "Torrens System," a Certificate of Title is issued by on officer having the superintendence of a transfer register. The movement seems to be an effort on the part of brokers and real estate dealers to eliminate law and lawyers from transactions relating to land and to restore the old conditions of primitive simplicity in which lawrers and abstract makers are unknown.

63 This is a matter of protection to the examiner. It shows the privity of contract existing between elient and counsel, and prevents claims for damages being asserted by third parties, who may have purchased or adranced money on the assuranees of the certificate: See Bank $r$. Warl, 100 U. S. 195.

64 In every case where an assumption is made it should be so stated, 
on June 11, 15i0, the Trustees of the Toun of IIyde I'ark held the title to the fee of said Lots 18 and 18, free from incumbrance. From an examination of the records of Cook Commly, Ills., (or, of our Indexes to the Records, etc.) of Deeds, Jurlyments, and Tax Sales, make upon the abore stated assumption, we conclude that the title to the fee of said Lots is now vested in John F. Manson, subject to defects, if any, existing in the execution or achnouledgment of the following deed: (or; subject to the lien of the following mortgage, ete.)

Tere follows an abstract or smmury of the deerl, mortgage, lien, judgnent or other matter, which, in the opinion of the person certifying, imparirs or clouds the title of the individual named in the certificate. It nothing appears to impair the title, say:

Subject to no objection indicated by our books.

or,

Subject to no objection indicated by the public records.

After this, any special matter by way of qualification or explanation may be inserted which shomld be followed ly the date of the examination and the examiner's signature. In these certificates a wide option is left witl the examiner, and in this lies the ehief source of danger. He may regard or disregard all sich instrmments as he may see fit, passing not only on their formal sufficiency, hut their legal coffect as well, and that without displaying them, or displaying only such of them as, in his opinion, create liens or incumbrances upm the title.

Should the examiner desire to qualify his opinion, as is

while it is always advisable to state as well that same has been dome hy direction and often at whose direse tion. This is a direct and positive notice that the examination is imperfoct an rertain reengnized thenries of the law of eonveyalueiner and registration. 
frequently the case, this may be done by a statement substantially as follows:

This opinion is not to be construed as covering:

1st. Any matter or thing not noted on our indexes to records in C'ook County, Ill., of deeds, judgments, and tax sales, and especially unpaid tares and adverse possession.

and. Any other matter or thing, etc.

\section{§ 615. Continned-Certificates of Title. A striking} instance of the subject under discussion is furnished by a late Missouri ease, ${ }^{65}$ wherein the examiner compiled an abstract in which he eertified that, "as per the county reeords and the county index to said reeords," the title to the land in question was "good" on the day of the date of such abstract in one Daniel Cobb, " and that there was no incumbrance thereon, nor any lien thereon excepting for certain taxes therein specified." As a matter of fact a trust deed was then of record purporting to convey the subject-matter of the examination, but excented by one who at the time hat no record title, although he afterward aequired same, and this subsequently aequired title was that which the examiner had certified as "good" in Daniel Cobb, the second grantee. The examiner in this ease admitted that he was wholly ignorant of the existence of the prior deed, but attempted to justify upon the ground that a deed recorded before the grantor has any record title may be safely disregarded in examinations of title, under the system of registration and notice adopted in the Lnited States, and upon this point the ease turned in the appellate court. Upon a question of this character the examiner ean afford to take no chances. The law is so diffieult; the exceptions to its rules so numerous; the cases so many and so slightly distinguished, so often apparently conflicting, that the risk is too great, unless he is also willing to assume the liability that may attach to

65 Dodd $r$. Willians, 3 Yo. App. 278. Consult in this connection, Bank v. Ward, 100 U. S. 195. 
it. What constitutes a line or incombrance upene leal sate may in some instances be a difticult gurestion to drecile: " but

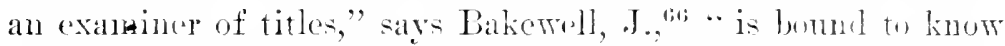
the state of the law on the sulijert, and, where there may he a reasonable doubt as to whether such or such a recomed instrument is a lien, if he rhoses to resutre the donbt he dues so at his own peril. $\%$ * $*$ If he does not chose to assume this liability he may easily aroid it by noting in his certificate erery question which arises upom the title as to which there can be the slightest doubt in the lecal minr, or by griving a list of deeds and incumbrances, and abstaining from expressing any opinion as to their lewal effect."

$\$$ 616. Opinions based Hou the Abstract. As a rule few lawyers desire to have anything to do with the compilation of the abstract, further than surh ineidentals as necessarily result from the inquiries, requisitions and objections made upon the title. The assumption of the dual character of examiner and comsel ran ralely be successully aceomplished, for an attorney competent to pass mpon the grave questions so often presented can harlly snare from his practice the time which must be consumed in the preparation and proper keeping of indices, nor, even when public indices are available, the time necessary for a proper search: while an examiner who makes a business of furnishing abstracts does not, and from the very circumstances of his briness ean not, devote the time necessary to keep up a theoretical knowledge of the law applicable to examinations of title, while he is entirely defieient in that fine legal acmen that eomes only from direct and personal experience in the every-day walls of a lawyer's life. The examiner, by constant practice, becomes rery expert in compilations, far more so tlan a lawyer making recasional searches can ever hope to he, but by constantly dirceting his attention only to requisites and refeets of form in instruments and proceedings which pass under his hands, and thomgh becoming, so far as relates to such matters, an authority, he

66 Dodd $r$. Williams, 3 Mo. App. 27s. 
yet loses sight of much of the legal effect of such instruments and proeedings, and for this reason, if nome other, should never attempt an opinion.

The opinion of "ommel is based, in the first instance, upon the presumption, necessarily entertainer, that the examiner has faithfully performed his work and that the abstract is a true reflex of the records, and of every matter and thing shown thereby that apparently affects, impairs or implicates the title under consideration. It may be confined to a bald statement of the title shown hy such abstract, with no comments or suggestions, or it may indicate the weakness of the title with reeommendations for strengthening same. But, inasmneh as the client frequently seeks professional aid quite as much for advice and assistance in perfecting a title, this matter will depend largely upon the elient's wishes.

In the event just indicated, the perusal and analysis will possibly suggest many inquiries, which, mless remedied before the opinion is rendered, must find adequate expression therein and where, upon a continuation, former opinions have suggested acts to be done, the contimuation should show compliance with such suggestions. Where the title is defective from any canse capable of easy remedy, as where missing deeds are found rpon inquiry, or satisfactory information is furnished in answer to requisitions, the sereral matters shonld be placed on record and a supplemental abstract made covering such special matter. Tpon the original and supplemental abstract the opinion may he rendered, and, if all doubts have been resolved thereby, such opinion wonld consist of little else than a statement that the fee of the premises rests in whoever is shown to be the owner, nunembered and nuembarrassed. More frequently, howerer, comsel prefer to recite the ohjectionable features, and qualify the opinion by referenee to such recitals, leaving the client to acept or reject the title, as his inclination may suggest, or take steps to perfect it in aceortance with the opinion. When such is the ease an opinion may be rendered somewhat after the following manner: 


\section{OPINIUN OF TITLE}

to

Lot 10, in Block 40, of Simpson's sutdivision of the N. E. qr. of Sec. 10, T. 12 N., R. 13 E., as diselosed by the annexed abstract, made by IIaddock, Talletle and Rickcords, and dated Aug. 15, 1853.

I have examined the amnexed abstract, consisting of twentythree numbers, relative to the title thereby disclosed to the premises above and in said abstract described, and find:

A defective deed, shoun as No. 10 from Thomas Jones and Olivia, his wife, to C'yrus B. Maxwell, in that saic Olivia failed to release her dower in the manner then (1S.2.2) prescribed by law.

A defective deed shoun as To. 18, from Benson IIardy to William J. II anson, in that the wife of said Mardy, she having been shou'n to be then and still living. failed to release her dower by joining in the execution of said deed.

A mortgage for \$500.00, show as No. 19, from William $J$. IIanson to Thomas Jackson, the indeutcdness thereby socured maturing Jan. 31, 1889.

$I$ further find:

No releases or waivers of the right of douer purporting to be made by Olivia Jones or the wife of Benson Hardy, shown by said abstract to be of record in this county.

No release or discharge of the morlgage above noted. And I am of the opinion:

That conveyance No. 10 creates no lien, cloul, or charge. upon the title, and that the defect noted is rured by the lapnese of time and the possession of the thercin mentioned grantors. assigns; it satisfactority appearing that Thomas Jones has been dead for more than twenty years.

That conveyance No. 18 discloses a contingent lim or slarye upon the title to the extent of the inchoule right of doure of the wife of Benson ILardy.

That the mortgage, No. 19, is a valid subsisting incumbranes. 


\section{I ain further of the opinion:}

That the title to the fee of said premises is now vested in William Springer, free from all liens, charges and incumbrances appearing of record, and shoun by said abstract, except those hereinabove expressly enumerated and described.

To perfect the title of said Springer, I would recommend:

$A$ deed of release from the wife of Benson Hardy.

A deed of release from Thomas Jackson, said mortgagee, or his assigns.

\section{(Signed)}

Date. ${ }^{6 i}$

\section{THOMAS W. BROWN.}

Counsel.

The foregoing crude outline will serve to suggest a form for the expression of opinions, and the general manner in which such opinions should exhibit the defects of the title. It is necessarily brief, and, for the better purposes of illustration, very simple, ret will indicate the method of treatement of more difficult and complicated matters.

A more encise and terse way of preparing an opinion would be to find the fact of title first and then show defects, if any. Should such a course be deemed desirable the certificate may be constructed after the following form:

I have examined the amnexed abstract, etc. and am of opinion, that the title to the fee of said Lot was on Aug. 15, $1883,{ }^{\text {is }}$ rested in one William Springer, sulject to the following liens and defects.

Then set out the impairments of title, with such recommendations as may be thought necessary or expedient.

Where the abstract consists of several continuations, made by the same or different examiners, it may be well to preface

67 This should be the same date as that appended to the certificate of the abstract, irrespective of the actual time at which the opinion was rendered.

6s The date of the certificate of the abstract. 
the opinion with a recital of the different cxaminations under consideration, thus:

I have examined what purports to be an eramination of title by Handy, Simmons of ('o., from the gowernmert to date of June 10, 18\%2.

A continuation [or, a certified ropy of continution] of same by Haddork, Coxe d. Co. to dale of 1 pril $20,1879$.

A continuation by Chirago Title and Trust Company to date of July 1, 1903, and find, ete.

If the alsstract itself, for any reasom, is not merchantable, ${ }^{69}$ it is better to apprise the dient of this defect before attempting to make a perusal, that proper steps may be taken to remedy the defect, but should the diont lee willing to aceept the abstract as furnished and direct an opinion thereon, prudence would suggest that commel specifically note this fact in his opinion, as for instance:

The continuation purporting to be made by Haddock, Coxe \& Co., under date of 1 prit $20,18 \% 9$, I consider unmerchantable, in that it appears to be a copy and not an original, and is without proper certificalion; but by direction of liobert Smith, Esq., for whom this opinion is made, I assume that it is a true copy, and this opinion is expressly subject to and qualified by undisclosed defects of title, if any, during the period covered by suid scarch.

It is customary, and quite proper, to add entain directions or suggestions as aids to the purchaser in making inciries in pais or with respect to matters not covered by the examinat-

69 This term has now come to be a recognized expression among lawyers, to denote an abstract compiled and certified hy a responsible person and which is accepted without question by the profession.
There are no rulus for determining the fated of merehantability and the matter rest larerely in general and sersleus of opinion. the resolut ioms of liar Associations, we. 
tion, and these suggestions may be shown by a note, just before the signature, in this manner:

Note.-The taxes for 1892 are now a lien. ${ }^{70}$

Satisfactory assurance should be furnished of the payment of taxes for the year $1891 .^{71}$

Attention is directed to the present occupation of the premises, if any, and the rights of the parties in possession.

For greater certainty many lawyers append to their opinions a statement of the matters not passed upon and to which the opinion is subject. Thus, they say:

This opinion is expressly sulject to:

1. Rights or claims of parties in possession not shoun of record.

2. Defects of title, if any, which may be disclosed by an accurate survey.

3. Possible rights of dower of the spouse of ouner.

4. Mechanic's liens not shown of record.

5. Special assessments, if any, which have not been confirmed.

6. Taxes for, etc.

$\S 617$. Perspicuity of Expression. In every case the language of an opinion should be elear and perspicuous. This is a prime requisite. Counsel oecasionally shirk a direct opinion by hypothetical statements as to what the title might be if certain matters could be shown; as, that the title "would be good in John Smith, provided," ete. This can not be regarded

70 This is a sort of reminder to the parties for the purpose of fixing conditions of sale and should always be inserted in opinions rendered after May 1, or whatever other day the statute may prescribe as the time of commencement of lien for the taxes of the year.
71 This should be inserted in opinion rendered after Dec. 1 , or whatever other day is fixed by law for the commencement of the payment of taxes for the past year. Should the abstract disclose payment the clause should, of course, be omitted. 
as a desirable method of expression. The issue should be net finirly.

So also, the use of qualifying adjectives in connection with title is very objectionable. Notwithstanding the fact that a court of equity sometimes hesitates to pronounce a title invalid that it yet will not force upon an unwilling purchaser, and hene pronomees it doubtful, there are no degrees of excellence in titles. ${ }^{22}$ At law all titles are valid or invalid. It is not in good form, therefore, to say that a "good" title is vested in any person, for this implies that there may be a "better," and, possibly, a "best," while a "bad" title is sintply no title. It is still worse to say, as is often done, that A B possesses "sulnstantially a good title," or, that the title is "substantially good" in a person named. As colloquial phrases such terms may, and do, have a definite meaning, but in formal written opinions they are ont of place. The title should be specifically foumd in whomsoever it is made to appear, and it must rest somewhere. If it is olscured, or insecure in the person named, state the facts and announce the legal cficet. There is no such thing in law or in fact as a doubtful title per se, although the claim of an individual to title may be the subject of doubt. The fee is always in existence; it is never in abeyance; it is nerer without an owner" it is never "goorl," "bad" or "doubtful." The evidences of the rights of ownership may be all or either, but the confusion of terms sometimes betrays counsel into expressions that he does not really mean. The term "marketable title" is employed by the

72 It is the specitic claim of title to which a court alludes when pissing upon its validity. In common parlance we spealk of good tilles, bad titles, and donibtful titles hut we mean the cliam of title and the evidence upon which it is foumberl, and not the title itself. An allodial title in fee is the highent type of ownership and estate, and this is always "good." A claim to this ownerslip and estate may be made liy several, bnt unless there is a common tenancy only one can possens it. The claim of the others we often denominate titles; a palpable misnoner; and in speaking of such claims we freguently saly his titlo is bad, etc., moming, however, the insufliciency of the evidence of his clainl. 
courts, and has acquired a definite legal meaning, yet there is nothing gained by its use in franning an opinion.

In a finding of title the estate should always be mentioned. While we are accustomed to speak of the title to land yet this is not strictly arcurate. It is the interest in land, or the estate, that is held by a title, not the land itself, and a properly framed opinion should indicate the nature and extent of the interest. To find that the title is rested in a person named is not enough; he mar have title, and a "good" title, and ret not haw the ultimate ownership. If the abstract discloses that the perom named is possessed of the fee this fact should be stated. If there are several nuited in ownership this fact should be stated and the character of the estate held by them, whether jointly or in eommon, should be amounced. If any lesser estate than the fee is shown, then, in most cases, the ornership of both the particular and the ultimate estates must be found.

$\S 615$. Oral Opinions. Questions as to the propriety or expediency of oral opinions in matters of title are solely for individual solution. It would seem that in so weighty a matter as the acceptance or rejection of a title, if an opinion is worth rendering, it is worth reducing to writing. It is, or should be, the result of careful and critical examination, and presumably, has eost comsel many hours of laborious investigation. Whether the questions presented be trivial or momentons, since the decision of the iscue is of importance to the intending purchaser, is it well to leave it to his unaided recollection? Whatever action connel may have taken, mless he preserves all his memoranda, the pressure of other matters soon drives from his mind, and when, afterward, the purchaser, who then entertains but an indistinet recollection of what was told him, applies to counsel for information on some particular point comnected therewith, counsel can remember nothing whatever about it. The opinion, in such a case, except as it may haw influened the sale at the time it was rendered, was practically nseless and the time ennsmed in its preparation, in one sense, wasted and lost. Again, the client may not have 
understoml the opinion as counsel promounced it, and a dispute arises between comnel and client as to the advice actually given; and thms coumsel is drawn into a controrersy, the most detestable in which it is possible for a lawyer to be engaged. All this can be avoided by reducing the opinion to writing. There it remains unclianged, with no chane for disputes or nuisconstructions; always available when needed; and frequently a stromg pillar in support of the title when it is again placed upon the market.

\$ 619. Liability for Erroneous Opinions. An attorney employed ly a purchaser of real property to investigate the title of the grantor prior to the purchase, impliedly contracts to exereise reasonable care and skill in the performance of the undertaking, and if he is negligent or fails to exercise such reasonable care and skill in the discharge of the stipulated service, he is responsible to his employer for the loss oceasioned by such neglert or want of care and skill. Like conditions and results also follow an emplorment to investigate and ascertain whether property offered is a safe or sufficient security for a loan of moner. ${ }^{73}$

The obligation imposed on the attorney does not require of him the possession of perfect legal knowledge or the highest degree of skill in relation to business of that character, nor that he will conduct it with the greatest degree of diligenee, eare and prudence, but simply that he shall possess the ordinary legal knowledge and skill common to members of the profession; and that, in the diseharge of the dutics he has assumed, he will be ordinarily and reasonably diligent, careful and prudent. ${ }^{i t}$ This is the ordinary milertaking of every attorney in every branch of legal emplorment, and while courts have ever been inclined to exercise lenieney in dealing with

73 Addison on Cont. (6th Ed.) 400 ; Dodd v. Williams, 3 Mo. App. 278; Dundee Mtg. Co. $r$. Hughes, 20 Fed. Rep. 39 ; Houseman $r$. Girard, ete., Ass'n. 81 Pa. St. 256; Watson $v$. Muirhead, $57 \mathrm{~Pa}$. St. $16 T$. it Wharton on Neg. 749: Shear. \& Red. on Neg. 211: Trells on Attys. 28.; ; Fambert r. Hart. 44 Cal. 543: Skillen r. Wallace, 36 Ind. 319 . 
questions of this character the rule has always been strictly enforced whenever the facts have been brought within its operation. Hence it follows, as a necessary sequence, that if the attorney fails to bring to the discharge of the duties assumed by him, the ordinary legal knowledge and skill possessed by members of the profession, or has failed to discharge the duties with ordinary and reasonable diligence, care and prudence, he will be guilty of negligence, and liable to the client for the damages he may have sustained by reason thereof. ${ }^{\mathbf{7 5}}$

In most of the cases where the question has been raised the errors charged have related mainly to the management of suits, and consisted in the non-observance of established forms and legal rules, ${ }^{76}$ and the damages were the direct result of the negligence of the attorney. The rule, however, is just as applicable to opinions or assurances of title and the attorney must be held to a strict accountability for acts of negligence. But if he acts in good faith, to the best of his skill, and with an ordinary degree of attention, he will not be responsible. ${ }^{77} \mathrm{He}$ is not liable for mere errors of judgment, nor for mistakes of law in matters where the law is not well settled. ${ }^{78}$ These are general principles of universal recognition.

In a case decided by a federal court in Oregon, it was held that where an attorney who is employed to examine the title of property offered as security for a loan, certifies that the security is a "good" one, he thereby warrants that the title shall not only be found "good" at the end of a contested litigation, but that it is free from any palpable grave doubts or serious questions as to its validity. ${ }^{79}$ The learned judge who 882.

75 Spangler $v$. Sellers, 5 Fed. Rep.

76 Spangler $v$. Brown, 26 Ohio St. 389 ; Gambert $v$. Hart, 44 Cal. 542; Skillen $r$. Wallace. 36 Ind. 319 ; Walker $v$. Goodman, $30 \mathrm{Ala} .482$.

77 Wilson $v$. Russ, 20 Me. 421.

78 Dodd $v$. Williams, 3 Mo. App. 278; Morrill $v$. Graham, 27 Tex. 646.
79 Page $v$. Trutch, 3 Cent. Law Jour. 559. There can be no doubt that, in a case similar to the above, it is understood by the client and intended by the attorney, that the title is all the learned judge claims it should be, but no authority can be found, so far as the investigation of the writer has extended, to sustain the statement that the attorney 
delivered the foregoing opinion does not, however, fortify it with any eitations of authority, and diligent search fails to reveal any; while in a later case, deciled in the same circuit, it was held that prima facie there is no element of guaranty involved in such employment; that the attomey only uncertakes to bring to the discharge of his duty reasonable skill and diligence, and does not warrant or guarantee the eorrectness of his work any more than a physician or mechanic does. ${ }^{80}$ It may be safely said, therefore, that the statement first above made does not present the true spinit of the law in relation to the facts stated, and that there is no implied agreement in the relation of counsel and client, or in the employment of the former by the latter, that the former will guarantee the soundness of his opinions, or that they will be ultimately sustained by a court of last resort.

A more strict rule is observed in case of examiners, or where the attorney professes to fumish information as well as pass opinions in eonnection therewith; and where one who proposes to make a specialty of examining titles in the course of his business gives a certificate that he has made examination and finds no incumbrance against certain property, he will be liable if the incumbrance is of record in such a way as to give constructive notice to every one interested and actual notice to every one looking for it in the proper way. ${ }^{81}$

It is a further rule, sustainerl by a long line of decisions, that an attorney is liable for the negligent performance of professional duties, arising from ignorance or want of eare, only to the person who employed him - that is, to one between whom and the attorney a contract of service existed. To insure a recovery for any injury arising from mere negligence, however gross, the rule seems to be imperative that there nunst exist between the one inflicting the injury and the one in-

uarrants the title, nor to cliarge him with any liability upon such a. warranty.

so Dnulea Mtg. Co. v. Hughes, 20 Fed. Riep. 39.
81 Dodd 2 . Willians, 3 Mo. Mpp. 278; Chase $v$. Hoiney, 70 111. 368; Clirk $r$. Marshall, 34 Mo. 429; Bank v. Ward, I00 U. S. 195. 
jured, some privity, by contraet or otherwise, by reason of which the former owes some dity to the latter, and the rule applies with full force to acts of an attorney in framing an opinion of title. A third party, therefore, who may have acted upon the opinion would be without remedy against the attorney unless something in the eircumstances of the ease should take it out of the general rule. ${ }^{s 2}$ Maliee, fraud, eollusion or other tortious act would be sufficient to create a responsibility without reference to any question of privity between the tort feasor and the injured party, but where these elements are wanting no reeovery ean be had by a third party, and a eontract between two persons will not be held to inure for the benefit of a third person from the mere faet that its breach, or the negligent diseharge of the duties involved in it, has resulted in injury to another. ${ }^{83}$

$\$ 620$. Conclusion. In bringing this book to a close the writer pereeives many imperfections in his work, and feels that in abler hands its treatment miglit have been far different. Yet he ventures to express the hope that to many it will furnish much desired information and be a practical help and guide. The methodical preparation of abstraets of title in the United States has not yet passed the experimental stage; English precedents fumish but little assistanee, being founded upon a system that never had any praetieal applieation in this eountry, and, by reason of the peeuliar genius of our institutions, never ean have. By slow degrees we are formulating a system essentially our own, and if this work, by precept or suggestion, shall be instrumental in assisting in this formation, in diseouraging false methods, and in affording a light on obseure points that shall aid the young and inexperieneed, the highest desire of the writer, in relation thereto, will be satisfied.

S2 Savings Bank v. Ward, 100 83 Buckley $v$. Gray, 110 Cal. 339.

U. S. 195; Buckley $v$. Gray, 110

Cal. 339 . 


\section{APPENDIX.}

NEW ENGLANL AESTRACTS.

A peculiar stestem of alstract making seems to prevail in the New England States, or cerfain of them. This system is apparently an offshoot from that now, we formerly, praticed by the English converancers, and resembles, in many respects, the English abstracts alluted to in the lowly of this work, particularly in "natrginal" divisions. It is not the same, howerer, as that expomided and illustrated by Len, Moore, and other late Fnglish writers, but is probably a variant of the same general stock. There, as in England, thongh one plan is to show everything rolating to the title of the estate under consideration, another, and the one apprarently in popular use, is to commenee with some early deed as the root of the title, and insert after it a list of the converances marle by the grantee to the point or time when the estate passes ont of him, and so continue with snecessive grantees until the present orner is reached. ${ }^{1}$

The instruments are verr fairly and fully abstracted, but the examiner indulges in a wealth of abbreviation muknown to any other part of the country. It is arranged very systematically, and, probably, to those who are in the hahit of examining such abstracts, enveniently. The name of the grantor, and the date from which his title is tracerl, is written at the top of the page and orer the columns or margins, which are then filled up as follows: The first contains tle lates, which inchuld the years of the indexes, and dates of exeention, acknowlerlesment and registration; the name of the offices taking the aceknowledgment, and the initials of ach grantor, where there are:

1 See appendix by M. H. Durgin, to Curtis" well known "American Conveyancer." (Boston, 1871.) 
more than one, to designate his separate conveyances. Tollowing this comes the book and page of the record in two narrow columns. In the next column are inserted the names of the grantees; consideration; notes of. dower and homestead; words of grant; eovenants; and mention of formal defects. In the last, or right hand column, are placed the descriptions; notes of incumbrances; conditions, recitals, ete. Is a further explanation an example is appended:

HIRAM W. SMITII, GRANTOR FROM 1822.

\begin{tabular}{|c|c|c|c|c|}
\hline $\begin{array}{l}1822 \text { to } 1835 . \\
1835-7 .\end{array}$ & 355 & 210 & $\begin{array}{l}\text { None. } \\
\text { Wm. Jackion. }\end{array}$ & $\begin{array}{l}\text { Mtg. } \$ 1,000,2 \text { rrs. (Descrip- } \\
\text { tion.) Nov. io, } 1837 . \text { Can- } \\
\text { reled on margin by Wm. } \\
\text { Tackson. }\end{array}$ \\
\hline $\begin{array}{l}1838-9 . \\
1839 . \\
\text { Nov. } 20 . \\
\text { “ } 21 . \\
\text { “ } 21 . \\
\text { Jno. Smith } \\
\text { J. P. }\end{array}$ & 493 & 121 & $\begin{array}{l}\text { None. } \\
\text { J. L. Woodnan } \\
\\
\$ \$ 5,000 . \\
\text { Enmma, rel. d. } \\
\text { g. g. b. s. \& conv. } \\
\text { Wty. free. }\end{array}$ & $\begin{array}{l}\text { A certain parcel of } 1 \text {. in Stan- } \\
\text { ford, on sly. sirle of liush St. } \\
\text { contg. } 15 \text { acs. m. or l. } \\
\text { Beg. at S. W. cor. on Rush St. } \\
\text { at ld. of O. S. Newell, the. } \\
\text { rung. N. E. by sd. st. as } \\
\text { fence now stands } 50 \text { rds. } 9 \\
\text { lks. to a stone standing by } \\
\text { ll. of J. Smith, the. rung. } \\
\text { N. } 90^{\circ} \text { E. } 15 \text { rds.. etr. } \\
\text { Reservg. privilege to pass, ete. }\end{array}$ \\
\hline
\end{tabular}

The next conreyance by J. L. Woodman wonld place his name at the head of the page as grantor, and the procedure would be the same until he finally parted with title. All the conveyances made by the grantor during the period in which he held title are noted, whether they include the premises in question or not, but if of other land, reference only is made to them, as "ld. in Charlestown;" nor is any mention made of defects, dates, etc.

ANALYSIS OF ABSTRACT.

Mr. Tee, in the appendix to his valuable work on abstracts, gives the following form of an analysis of an abstract, which may be of service to American practitioners by way of suggestion. 


\section{ANALYSIS OF ABSTRACT.}

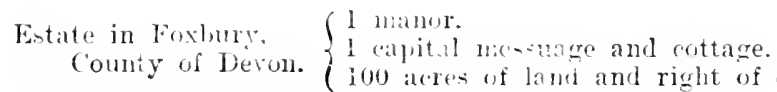

\begin{tabular}{|c|c|c|c|}
\hline Observations. & Date, Partics, l'arcels. & Uses, Trusts, Limitations, etc. & $\begin{array}{c}\text { Terms, Incum } \\
\text { brances. }\end{array}$ \\
\hline 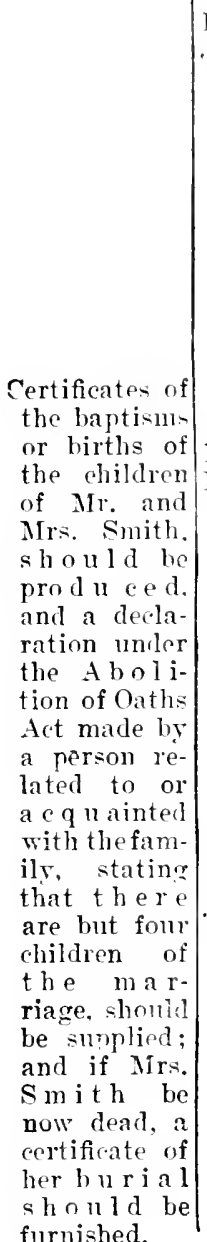 & 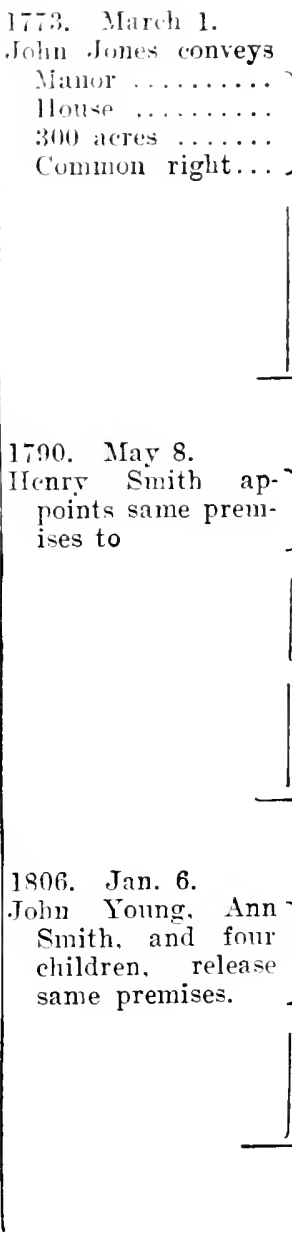 & $\begin{array}{l}\{ \\
\left\{\begin{array}{c}\text { C'se of II. Thompson } \\
\text { 1.000 years. } \\
\text { - of John Young in fee. } \\
\text { Trust for A. S. for } \\
\text { life. for H. Smith's } \\
\text { children in fee. }\end{array}\right.\end{array}$ & $\begin{array}{l}1000 \text { rears in } \\
\text { H. Thomp- } \\
\text { son to raise } \\
2.000 l \text {. for } \\
\text { portions. }\end{array}$ \\
\hline
\end{tabular}




\begin{tabular}{|c|c|c|c|}
\hline Observations. & Date, Parties, Parcels. & Uses, Trusts, Limitations, etc. & $\begin{array}{l}\text { Terms, In- } \\
\text { cumbrances. }\end{array}$ \\
\hline & $\begin{array}{l}\text { 1815. June } 18 . \\
\text { Proved } \\
\text { Richard Jenkins } \\
\text { wills- } \\
\text { Mlanor, house, cot- } \\
\text { tage, } 100 \text { acres and } \\
\text { common right. } \\
\\
\text { Note. - 200 acres } \\
\text { sold by Mr. Jenkin } \\
\text { during his life. }\end{array}$ & $\begin{array}{l}20 t i \text { July, } 1816 . \\
\text { to J. Morris and E. Simp- } \\
\text { son. } \\
\left\{\begin{array}{l}\text { Trut for testator's wife } \\
\text { for life, remainder. } \\
\text { in for testator's children }\end{array}\right.\end{array}$ & $\begin{array}{l}\text { 2,000l. paid off } \\
\text { Term of } 1,000 \\
\text { yea s. A s- } \\
\text { signed to Oli- } \\
\text { ver Pearson, } \\
\text { in trust to at- } \\
\text { tend for par- } \\
\text { ties entitled } \\
\text { under Jenkins' } \\
\text { will. }\end{array}$ \\
\hline
\end{tabular}

\section{L.AND MEASTRES.}

In the preparation, as well as in the examination of abstracts of title, numerous occasions will arise for the computation of areas, the measurement of lines and distances, and other matters calling for calculations based upon the different methods now or formerly in vogne for land parceling. To assist the practitioner by affording a rearly reference to the standard tables of land measurement, the following are inserted.

The measures of extension sanctioned by law in the United States, conform to the standard established by the English government, which is based upon the phenomenon of nature, that the force of gravity is constant at the same point of the earth's surface and consequently, that the length of a pendulum which oscillates a certain number of times, in a given period, is also constant. IIad this mnit been known before the adoption and use of a system of measures, it wonld have formed the natural unit for division, and been the natural base of the system of linear measure. But the foot and inch had long been used as units of linear measure; and henee, the length of the pendulum, the new and invariable standard, was expressed in terms of the known units, and found to be equal to 39.1393 inches. The new mit was therefore declared invariable - to contain 39.1393 equal parts, each of which was called an inch; 
12 of thees parts wore declared by act of Parliament to be a standard foot, and :3ti of them, an Imperial yerd. The Inperial yard and the standarel fort are marked upen a brass bar, at the trmperature of $1921 / 2$, and these are the linear measures fron which those in general nse in this country are taken.

TABLE OF IINEAR MEASLRE.

12 inches (in.)

3 fect

$5 \frac{1}{2}$ ydl, or 16 i $\frac{1}{2} \mathrm{ft}$. 40 rods.

8 furlongs, or $: 3: 0$ rd., make 1 font, marked ...........ft.

" I yard. " $" \ldots \ldots \ldots \ldots \ldots \ldots$.

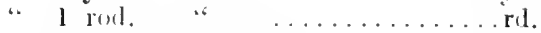

". l furlong, marked .........fur.

" 1 statute mile, " ..........

INIT KQTIVALENIS.

\begin{tabular}{|c|c|c|c|c|c|c|c|}
\hline & & & & & $\mathrm{ft}$. & & in. \\
\hline & & & $\mathrm{rd}$ & & 1 & $=$ & 12 \\
\hline & & rd. & $\mathrm{i}$ & $=$ & 3 & $=$ & 36 \\
\hline & fur. & $1=$ & $5 \frac{1}{2}$ & $=$ & $16 \frac{1}{2}$ & $=$ & 198 \\
\hline mi. & $\mathrm{l}=$ & $40=$ & $2 \cdot 20$ & $=$ & $660^{\circ}$ & $=$ & 7920 \\
\hline $1=$ & $8=$ & $320=$ & 1760 & $=$ & $5 \cdot 30$ & $=$ & 63360 \\
\hline
\end{tabular}

TABLE OF SQTARE MEASLRE.

144 square inches (sq. in.) make 1 square foot, marked.....sq. ft.

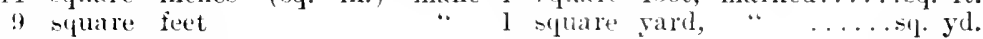

301 square yards " $\quad$ "square rod $\quad$ " $\ldots . . . .$. sq. rd.

40 square rods " $" 1$ rood, $\quad$ " .......R.

4 roods $\quad " \quad 1$ atere, $\quad \ldots \quad \ldots \ldots \ldots \ldots$.

640 acres $\quad " \quad$ l square mile, " $\ldots . .$. sq. mi.

UNIT EQUIVALENTS.

\begin{tabular}{|c|c|c|c|c|c|c|}
\hline & & & & & $\mathrm{sq} . \mathrm{ft}$ & sq. in. \\
\hline & & & & $\mathrm{sq} \cdot \mathrm{yd}$ & $1=$ & 144 \\
\hline & & & sq. rd. & $1=$ & $9=$ & 1296 \\
\hline & & R. & $1=$ & $30.1=$ & $27 \cdot 2 \frac{1}{4}=$ & 39204 \\
\hline & A. & $1=$ & $40=$ & $1210=$ & $10590=$ & 1.568160 \\
\hline q. $\mathrm{mi}$. & $1=$ & $4=$ & $160=$ & $4840=$ & $43560=$ & 6272640 \\
\hline$=$ & $640=$ & $2560=$ & $10 \cdot 2400=$ & $3097600=$ & $27878400=$ & 4014489600 \\
\hline
\end{tabular}

\section{SLRVEYOR'S MEASURE.}

In the primary division of the public lands, and usually in all subsequent subdivisions of considerable area, the measurements are made with what is called a Gmuter's chain, which consists of a metal chain fif feet long and composed of 100 links. The chain emploved by the goverument in the execution of the public surveys is, however, $66.06 \mathrm{in}$ lengtls. The object in adding six-lunndredthe of a foot to the 66 feet of the ordinary chain is to assure thereby that 66 feet will be set off 
upon the earth's surface without the application of a greater strain than about twenty pounds by the chainmen, thus providing for loss by vertical curvature of the chain, and at the same time avoiding the uncertain results attending the application of strains taxing its elasticity.

TABLE OF LINEAR MEASURE.

7.92 inches

25 links

4 rods, or 66 feet,

80 chains (in.) make 1 link $\ldots \ldots \ldots \ldots \ldots \ldots \ldots \ldots$

" $1 \operatorname{rod} \ldots \ldots \ldots \ldots \ldots \ldots \ldots, \ldots \ldots$.

" 1 chain $\ldots \ldots \ldots \ldots \ldots \ldots \ldots \ldots \ldots$ ch.

" 1 mile ...............mi.

UNIT EQUIVALENTS.

\begin{tabular}{|c|c|c|}
\hline & 1. & in. \\
\hline rd. & $1=$ & 7.92 \\
\hline $1=$ & $25=$ & 198 \\
\hline $4=$ & $100=$ & 792 \\
\hline $320=$ & $8000=$ & 63360 \\
\hline
\end{tabular}

In practice rods are now seliom used, distances being taken in chains and links. The foregoing table is used in measuring lines and distances. In the computation of areas or in ascertaining the contents of land, the following table is employed:

TALLE OF SQUARE MEASURE.

625 square links (sq. 1.)

16 poles

10 square chains

$6+10$ acres

make 1 pole,

P.

36 square miles ( $6 \mathrm{mi}$. square)

" 1 square chain,..........sq. ch.

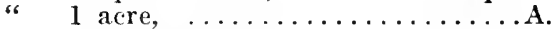

" 1 square mile, ........... mi.

1 square mile, $\ldots \ldots \ldots \ldots \ldots \ldots \ldots \ldots \ldots$. mi.

UNIT EQUIVALENTS.

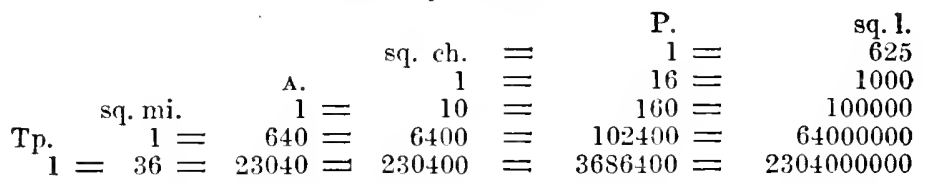

The contents of land are usually estimated in miles, acres, and hundredths.

As a further aid in arriving a correct understanding of the dimensions of divisions made according to the govermment surrey, a diagram of a quarter section of land is herewith appended, the distances being marked in feet, rods and chains. 


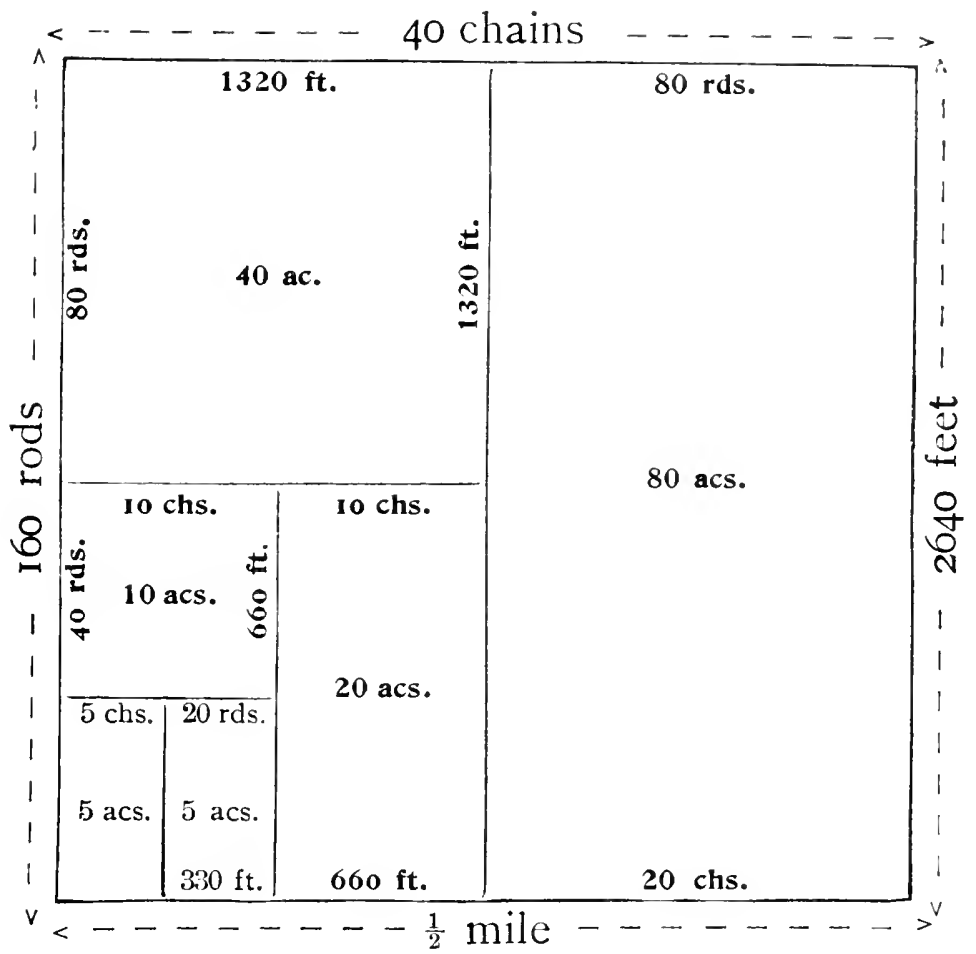

The government surveys of all principal base, meridian and township lines are made with an instrmment operating independently of the magnetic needle. The solar compass or some other means of equal utility must, of necessity, be used in such cases. But where the needle can be relied on the ordinary surveyor's compass is used in subdividing and meandering.

\section{SPANISH-FRENCII LAND MEASCRES.}

During the administration of the Spanish-French governors, in the province of Louisiana, the granting power of the royal domain was freely exercised, and the grants so marle lie at the foundation of many of the early titles in the States subsequently formed from that province. ${ }^{1 \text { a }}$

1a. The larger part of the south- present territory of the Inited ern and western portions of the States wit formerly under the 
The surveys of these grants are found in many places wrought in with our publie surveys, presenting, as it were, curious mosaic irregularities in striking contrast with the simple rectangular system adopted by the national government. They illnstrate, in a forcible manner, the peeuliar agrarian systems of the governments which preceded ns, in the diversified, irregular forms of grants, from urban in-lots, and outlots, rural tracts of inconsiderable dimensions, and from thenee inereasing in extent to 7,056 arpens or a league square, the "arpen" of Paris being the standard of prorineial measurement.

The following is a comparative statement adopted by the surveyor general's office at St. Louis, Mo., of the land measures of the United States, and the French measures formerly used in the province of Lonisiana:

dominion of Spain and France, and both governments made numerous grants and concessions both to conpanies and individuals. In 1803 the province of Iouisiana was ceded by France to the United States, though it was not until many years afterward that the boundaries of the province were definitely established.

The Louisiana Purchase was erected into two territories by act of Congress, March 26, 1804, one ealled the Territory of Orleans and the other the District of Louisiana. The Territory of Orleans, on April 30, 1812, became the State of Lonisiana.

The entire Louisiana purchase, being five times greater than the area of France, viz., 201,900 square miles, excepting certain grants made by French and Spanish authorities, and other legal exceptions, became pub. lic domain, subject to the survey, settlement and disposition laws of the United States when the same were extended over the several political divisions from time to time by separate acts of Congress. But all claims which had their origin in some form of concession from a foreign government before the acqusition of the territory by the United States are recognized and protected and after confirmation the titles to lands so acquired have much of the stability of titles derived from the United States.

The grants by the Spanish and French governors lie mainly within what are now the States of Louisiana, Missouri and Iowa. In the State of Louisiana alone there are upward of ten thousand confirmed private land claims. 


\begin{tabular}{|c|c|}
\hline Linear Measure. & Sinperficial Measure. \\
\hline 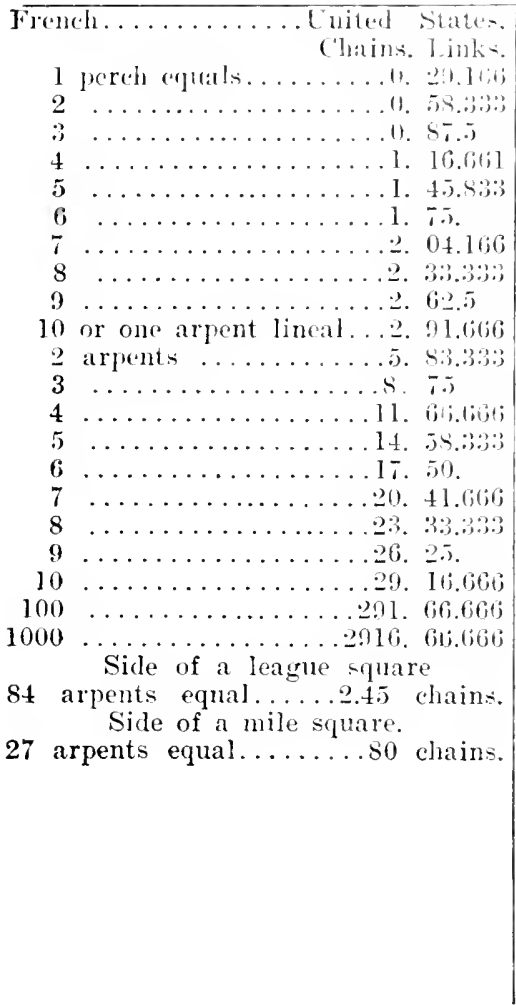 & 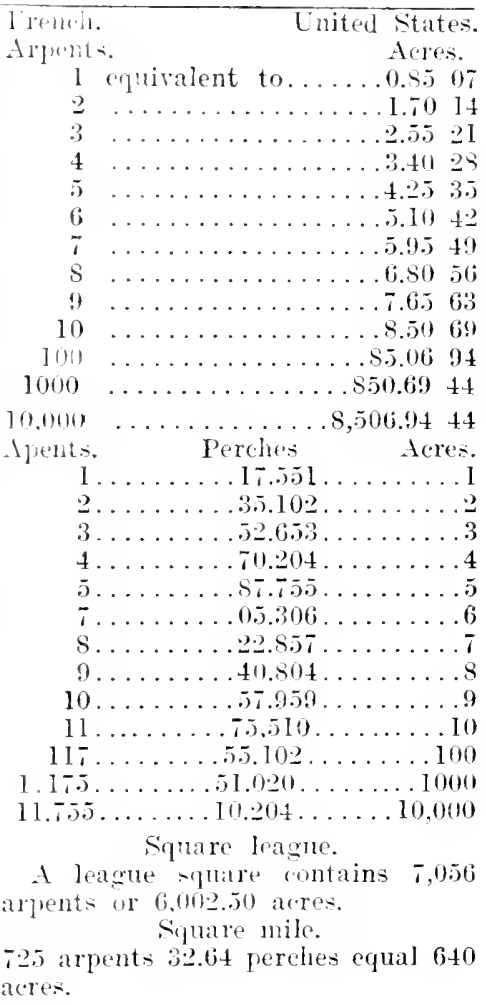 \\
\hline
\end{tabular}

\section{SPANISH-MEXICAN LAND MEASLRES.}

By the treaty of Guadalupe II ilalgo, ratified May 30, 184s, and the treaty commonly known as the Gadselen Purchase, ratified June 30, 18.5t, the Mexican Repullie coded to the Enited States the territory enbraced within the present limits of the States of California, Nevada and Itah, the tereitory of Mrizona, a part of the State of Colorade, and parts of the terit tories of New Mexion and Wroming. Seattered orer this dis

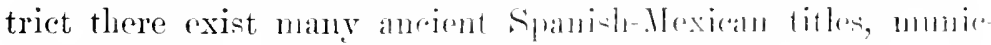

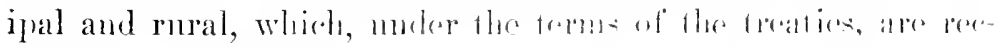

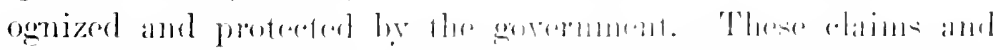
grants are for irregutar shaped tratts, illy defined, and boumded 
mainly by natural objects. They were made for agriculture, mining, stock-raising, and colonization, and in all sizes, from a village lot to a million-acre tract. Upon confirmation it is necessary to have these titles traced ont and fixed, by survey or re-survey, according to the peculiarities of the srstem of the government from which they originated, and incidentally they must frequently be referred to in subsequent conveyances and subdivisions.

The Surveyor General of California, in a report made-in 1851, states that all grants in California, made either by the Spanish government, or that of Nexico, refer to the "vara" of Mexico as the measure of length, and that by common consent, in California, that measure is considered as exactly equivalent to thirty-three American inches. ${ }^{2}$ It would scem that another length is given to the "vara" by Mr. Alexander, ${ }^{3}$ who states its length to be equal to $92.7+1$ of the American yard. In practice, however, the General Land Office has sanctioned the recognition, in California, of the Mexican vara as being equiralent to thirty-three American inches.

The following is a table of land measures adopted by the Mexican government: ${ }^{4}$

\begin{tabular}{|c|c|c|c|c|c|}
\hline Names of the measures. & $\begin{array}{l}\text { Figures of the } \\
\text { measures. }\end{array}$ & 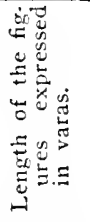 & 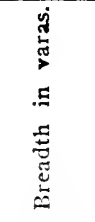 & 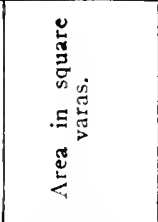 & 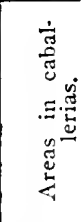 \\
\hline $\begin{array}{l}\text { Sitio de ganado moyer....... } \\
\text { Criadero de ganado moyer.. } \\
\text { Sitio de ganado menor....... } \\
\text { Criadero de ganado menor. } \\
\text { Caballeria de tierra......... }\end{array}$ & 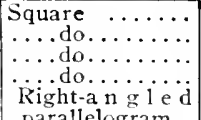 & $\begin{array}{l}5,000 \\
2,500 \\
3,3331 / 3 \\
1,6662 / 3 \\
1,104\end{array}$ & $\begin{array}{l}5,000 \\
2,500 \\
3,3321 / 3 \\
1,6662 \% 3 \\
552\end{array}$ & \begin{tabular}{|c|}
$25,000,000$ \\
$6,250,000$ \\
$11,111,111^{1} / 9$ \\
$2,777,777^{3} \%$ \\
609,408
\end{tabular} & $\begin{array}{r}41,023 \\
10,255 \\
18,232 \\
4,558 \\
1\end{array}$ \\
\hline 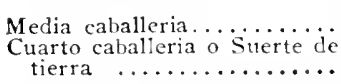 & Right-a n g l e d & 552 & 552 & 304,704 & $\begin{array}{l}1 / 2 \\
1 / 4\end{array}$ \\
\hline $\begin{array}{l}\text { Fenega de sembraduro de } \\
\text { maiz } \ldots \ldots \ldots \ldots \ldots \ldots \ldots \\
\text { Sala para casa } \ldots \ldots \ldots \ldots \ldots \\
\text { Fundo legal para nueblos } \ldots \ldots\end{array}$ & 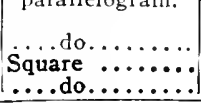 & $\begin{array}{r}376 \\
50 \\
1.200\end{array}$ & $\begin{array}{r}184 \\
50 \\
1,200\end{array}$ & $\begin{array}{r}56,784 \\
2,500 \\
1,440,000\end{array}$ & $\begin{array}{l}1 / 13 \\
0,004 \\
2,036\end{array}$ \\
\hline
\end{tabular}

2 Rep. Genl. Land Office, 1854.

3 Dictionary of Weights and Measures.

4 Translated from the "Orde. nanzas de Tierras y Agnas" by Galvan. Ed. 1884; and see Ex. Doc. No. 17, 1st Session, 31st Congress, House. 
The Mexican vara is the unit of all the measures of length, the pattern aud size of which are taken from the Castilian vara of the nurk of Burgos, and is the legal ratra noed in the Mexican republic. Fifty Mexican varas make a measure which is called cordel, which instrument is used in measuring lands.

The legal league contains 100 cordels, or 5,000 varas, which is found by multiplying by 100 the so varas eontained in a cordel. The league is divided into two halves and four quarters, this being the only division made of it. IIalf a league contains 2,500 varas, and a quarter of a leagne 1,250 raras. Anciently, the Mexican league was divided into three miles, the mile into a thousand paecs of Solomon, and one of these paces into fire-thirds of a Mexican rara; conseruently the league had 3,000 paces of Solomon. This division is recognized in legal affairs, but has been a very long time in disuse - the same as the pace of Solomon, which in those days was called rara, and was used for measuring lands. The mark was equivalent to two raras and seren-eights - that is, eight marks containing twenty-three varas - and was used for measuring lands.

The United States owned no public land in Texas. Upon its admission into the Cnion the titlo to the soil was retained by the State and its lands were disposed of under its own laws. The methods of land parceling followed, in most respects, those in rogie while the State was a part of the Mexican Republic. A table of land measures is appended. 


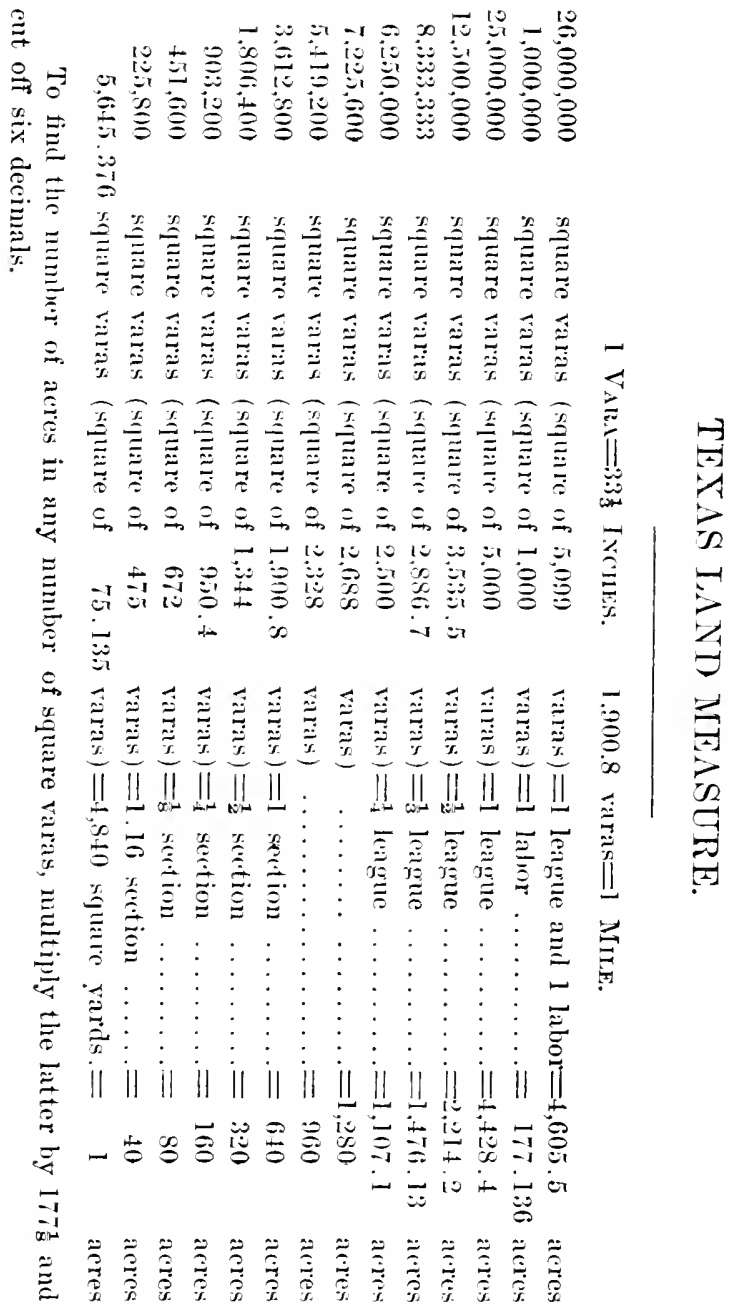

It will be observed that the Texan vara is slightly longer than the standard recognized in California and adopted by the General Land Office. 


\section{INDEX.}

[THE REFERENCES ARE TO SECTIONS.]

ABANDONMENT,

considered as a method of acquiring title, 52 .

of homesteall, defeats right of exemption, 22.

ABBREVIATIONS,

may be used to advantage, when, 101.

may destroy abstract as evidence, 66 .

ABORIGINAL TITLE,

of what consisting, 51 .

ABSENCE,

long and mexplained, when presumptive evidence of death, 562 .

ABSTRACTS,

definition of, 2.

origin and early use of, 3 .

essential matters to be shown in, 4 .

English method of compilation of, 5 .

American method of compilation of, 6 .

distinguished from examinations, 7 .

what constitutes to be merchantable, 7 .

liability for erroneous statements in, 9 .

duty of furnishing devolves on whom, 11.

become property of purchaser, when, 11 .

compiled from ofticial sources of information, 58, 76, 89, 90 .

from private indices, 67,74 .

formal parts of, 92 .

caption of, how expressed, 93.

arrangement of, 94 .

of instruments and proceedings shown, 95, 97, 98, 100 .

letter press copies of, 102 .

concluding certificate, 103.

of inceptive measures under U. S. land laws, 128.

of entries on govermment tract books, 129.

of receiver's duplicate receipt, 134, 135 .

of legislative grants, 137 .

of patents from United States, 149.

of subdivision by owner, 166 .

of vacation of subdivicion by owner, 169.

of deeds, parts to be shown, 172 . 
ABSTRACTS - Continued.

of corporate conveyances, 250.

of power of attorney, 263.

of declaration of trusts, 267.

of sheritr's deed, 274 .

of master's deed, 280.

of trustee's deed, 281 .

of administrator's deed, 286, 288.

of bankruptey proceedings, 293, 301.

of land contract, 316 .

of leases, 323 .

of vacation of plat, 330 .

of official certifieates, 334,445 .

of party wall agreement, 337 .

of affidavit, 329 .

of mortgage, 342,351 .

of wills, 413,417 .

of probate proceedings, 417.

of court proceedings, 501, 521.

of probate sales, 494.

of tax sale certificates, 534 .

of tax deed, 535 .

of tax title, how compiled, 540 .

of proof of death, 564 .

of deseent in probate, 568 .

of adverse titles, 573 .

methods of perusal of, 591 .

printed copies of, opinions concerning, 612.

analysis of, 600 .

methor of compiling in New England, Ap.

ABSTRACT BOOKS,

taxation of, 12.

exemption of from execution, 13.

ACCRETION AND RELICTION,

what constitutes, 46 .

title acquired by, nature of, 46,48 .

rule for measurement of lands acquired by, 46 .

distinguished from avulsion, 47.

ACKNOWLEDGMENT,

office and effect of, 196.

how shown in abstract, 196.

if defective, effect of, 209.

what constitutes defects of, 209, 210.

defects of, how noted in abstract, 210.

of wife's deed, formalities of, 245 .

of corporate conveyances, 256.

by attorney in fact, how shown, 262.

of sheriff's deed essential to validity, 275 . 


\section{ACTIONS,}

respecting title at law and in equity, 498.

for divoree, should be shown when, 518 .

ADMINLSTRATUR,

powers of, distinguished from executors, 286, 287, 288.

deeds by, how made, 283.

how shown in abstract, 288 .

with will annexed, powers of, 289.

ADMINISTRATION OF ESTATES,

how shown in abstract, 417,568 .

settlement without, eflect of, 570 .

ADOPTION,

defined, 33.

effect of in descent of estates, 33, 551.

proof of in case of succession, 33, 561.

ADVERSE CONVEYANCES,

how displayed in abstract, 573 .

ADTERSE POSSESSION,

character and effect of, 572, 5\%4, 576.

from user only, 578.

under color of title, 576 .

naked oceupancy without claim is not, 579 .

tacking of successive holdings b5, 580 .

constitutes notice, 581 .

can not be established against remainder-men, 583 .

or reversioners, 584 .

or persons under disability, $5 \$ 6$.

or the State, 588.

proofs to support title by, 590.

ADVERSE SEIZIN,

will not prevent valid converance of land, 233 .

ADVERSE TITLE,

general characteristics of, 572 .

how shown in abstract, 573 .

who may acquire, 582.

proofs to support, 590.

AFFIDAVTS,

of matters in pais, are required when, 339.

how shown in abstract, 329,339 .

general requisites and sufficiency of, $339,340$.

of pedigree, form of, 599 .

of nonresidence, when required, 505 .

of publication, 478 .

AFFINITY,

what is, and how governed, 32.

AFTER-ACQUIPED ESTATES,

when bound by lien of jurlgments, 448, 452.

effect of mortgages upon, 359 . 
AGREEMENTS,

for conveyance, general doctrines of, 310 .

for conveyance by deed, 312, 313.

for conveyance by will, 321 .

for deed, performance of, 318 .

for party wall, eflect of, 337 .

AGRICULTURAL LANDS,

what leases may be made of, 326 .

ALIENS,

maly take by descent, 550 .

may not make homestead entries, 127.

ALIENATION,

of land, what laws govern, 28 .

of the homestead only effectual when, $2 \mathbf{2}$.

ALIMONY,

requires notice when a lien on land, 518.

ALLEGIANCE,

does not relate to title or imply feudal obligation, Is.

A.IBIGLITY,

effect of and how treated, 200 .

in deeds, 186, 200, 205, 208.

in wills, $381,382,387$.

AMERICAN,

method of compiling abstract, 6 .

doctrines with respect to title, 18 .

Indian, title of, how extinguished, 5l.

ANALYSIS OF TITLE,

utility of in examination, 600 .

how constructed, 601 .

how made in England, Ap.

ANCESTOR,

who is to be considered, 542 .

covenants of, bind heir when, 545 .

debts of, aflect heir how, 545 .

death of, must be proved, 562 .

title of, descends to heir by operation of law, 543.

ANCESTRAL ESTATES,

by what rule distributed, 552.

ANCIENT DEEDS,

- what are, 198 .

require no proof of execution, 198.

APPEARANCE,

effect of in legal proceedings, 506 .

ARRANGEMENT,

of abstract. suggestions for, 94 .

ASSESSNENTS,

special, how shown in abstract, 541 . 
ASSESSORS" PLATS,

fol what purpose made and how shown, 528.

ASSLLELE,

of military warrants and land scrip, le0.

of land contrart, rights of, :317.

of lease, achuires what interest, $32 \overline{-}$.

of mortgage, rights of, 366 .

in biakruptey, deed of, 307 .

ASSIGNAENT,

as a mode of conveyance, 225 .

of military warrat, when permitted, 120.

for benetit of ereditors, 293 .

voluntary, how made, 294 .

construction and eflect of, 295, 298.

by register in bankruptey, 30 .

of agreements for conveyance, 317 .

of lease, how made, 327 .

of mortgage, eflect of, $365,366,367$.

of mechanic's lien, effect of, 437 .

of certificate of sale under execution, 489 .

ATTACHMENT,

general doctrine of, 444 .

formal requisites of, 445 .

how shown in abstract, 445 .

ATTESTATHON,

by subseribing witnesses to deeds, 195.

ATTORNEI,

power of, how shown, 263.

opinion of title by, 613,614 .

liability of for erroneous opinion, 619.

ATTORNEY IN FACT,

conveyance by, how made, 263.

how shown in abstraet, 263 .

purport and extent of powers of, $262,263$.

revocation of authority of, 264 .

substitution of, 264.

AVULSION,

what is, and by what laws governed, 47 .

\section{BANKRUPTCY,}

jurisdiction and practice in, $30 \mathrm{I}, 302$.

nature and effect of, 304 .

proceedings in, how shown in abstract, 306 .

register's assignment in, 307 .

deed of assignee in, $30 \mathrm{~s}$.

BIRTH, effect of discharge in, 309 .

of heir, affects tenant by curtesy, 23.

proof of, necessary to establish claim of heir, 565 . 
BONDS,

for eonveyance, how shown, 320 .

of officials are liens on land, when, 429 .

BOOKS,

abstract, how laid out and kept, 78 .

exemption of, from forced sale, 13.

BOUNDARIES,

of lands adjoining navigable waters, 48, 165.

by lines of the publie surveys, 163, 164, 186.

\section{CANONS OF DESCENT,}

of what consisting, $30,547$.

CAPTION,

of abstracts and examinations, 93 .

of opinions of title, 614,616 .

CAVEAT EMPTOR,

doctrine of applies to purchases at execution sale, 472 . and from administrator, 288.

\section{CERTIFICATES,}

official, by custodian of records, $72,334$.

appended to abstract by examiner, 103.

how shown in abstract, 334 .

of proof of will, 413.

of levy of attachment, 445 .

of publisher, notice of sale, 478 .

of sale by officer, liow shown, 488 .

of sale, assigmment of, 489 .

of publication of notice of sale, 478 .

of sale for non-payment of taxes, 534 .

of title, what are and otility of, 615 .

deaths, births and marriages, 563.

CHAIN OF TITLE,

preliminary sketch of, 91 .

analytical, on examination of abstract, 601 .

as arranged in abstract, 94 .

\section{CHANCERY COURTS,}

jurisdiction of, 496 .

proceedings of, how shown, 498.

notice afforded by records of, 500 .

CHANCERY PROCEEDINGS,

method of indexing, 85.

authority and jurisdiction of courts in, 496 .

requiring notice in abstract, 498.

jurisdiction the great essential in, 499.

notice afforded by record of, 500 .

how instituted and conducted, 501, 506.

now shown in abstract, 504, 509. 


\section{CHATTERS,}

of corporations, effect of on titles, 257 .

CHILDREN,

is word of purchase not limitation, 385, 389 .

construed as synonymous with issue, 387.

limitation of estate to, eflect of, 386 .

does not inchule grandehildren, 387.

CHURCH RECORDS, may be resorted to for evidence, 73 .

CLASS,

derise to, effect of, 423 .

CLASSIFICATION OF TITLE,

Blackstone's distinctions, 16 .

by courts of equity, 16.

CLOLDS UPON TITLE,

what are, and effect of, 607.

COLOR OF TITLE,

what constitutes, 26,575 .

entry under and adverse possession, 576 .

COMPILATION,

of abstract, English method, 5 .

American method, 6.

from what sources of information, $58,67,76,90$.

from official indices, what should be examined, 67 .

making the chain, 91 .

from private indices, 74 .

insertion of notes in, 98 .

abbreviation, when permissible, 101.

of initial statements, 93 .

of abstract books, 78 .

CONDEMNATION,

proceedings for, how shown, 520 .

CONDITIONS,

annexed to grants, effect of, 190.

will be invalid when, 190, 232 .

how shown in abstract. 232.

in mortgages, effect of, 355 .

devise upon, effect of, 394,395 .

CONFIRMATION,

nature and characteristies of, 50 .

as basis of title in foreign grants, 50 .

how shown in abstract, 132 .

as a morle of substantive enveyance, 226.

of judicial sales, effect of, 486,487 .

CONFLICT OF LATTS,

in alienation and descent, 28.

in matters of assignment and insolveney, 299. 
CONFISCATION,

nature and characteristies of, 56 .

CONGRESSIUNAL GRANTS,

nature and effect of, 138 .

construetion of. 13:9.

bow shown in abstract, 140 .

CONSANGUINITY,

defined, 31 .

computation of degrees of. 31 .

table of degrees of, according to the ciril law, 31 .

distinguished from aftinity, 32.

as affected by statutes of adoption, 33 .

CONSIDERATION,

as expressed in deeds, effect of, $179,180$.

CONSTRECTION,

of patents from $\mathrm{C}$. S... 15.5.

of deeds and other instruments, 186, 214.

CONSTRUCTIVE NOTIC'E,

general doctrines of, $6:$.

afforded by public records, $64,65$.

by records, rigidly construed, 65 .

distinguished from actual notice, 63.

not impaired by destruction of records, 66 .

judgments and deerees rendered upon, 462 .

CONSTRUCTIVE POSSESSION,

distinguished from actual, 577 .

of lands held adrersely, 57 .

CONTINGENT RENERSION,

under wills, how created, 397.

CONTINGENT REMAINDERS, under wills, how eonstrued, 389, 394, 396.

CONTRACTS FOR CONTEYANCE,

general remarks concerning, 310 .

relation of parties under, 311 .

effect and operation of, 312 .

nature and formal requisites of, 313 .

low affected hy recording acts, $3 \mathrm{I} 4$.

construction of, 315 .

low shown in abstract. 316 .

performanee of sufficiency of deed and title, $31 \mathrm{~s}$.

effect of assignmient of. 317 .

effect on title when forfeited, 319.

in form of hond, effect of, 320 .

by will, validity of, 321 .

CONTINUATIONS.

of abstracts, caption of. 93 .

CONTEYANCES,

by heirs, what facts jurislietional, 36 . 
CONTEYANCLA'-C Continued.

should be rejected, when, 36 .

by preemptioners before untry, 11:2, 113.

of homestead claim before maturity. 117.

by way of legislative grant, effect of $124,125,137,149$.

from the $\mathrm{U}$. S. govermment, 12.5.

from the state, 138, 15.5 .

between individuals, 212.

derived from the common law, 2.24.

of future interests and estates, 2:-29.

of special interests and qualified estates. 2:30.

restrictive or conditional in character, 23:2.

of lands held in adverse posiession of another, 233 .

in frand of ereditors, 234.

subjeet to incumbrance, 235 .

intended for marriage settlement, 240 .

to husband and wife, etfect, 241 .

between husband and wife, 242 .

by married wonen, 243,244 .

of lands held in common, 247 .

to elfect partition, 248 .

of partnership lands, 249.

by or to corporations, 250.255 .

post obit, effect of, 261.

by delegated authority, 262 .

in trust, for what purposes permitted. 265.

made in official character. 270.

by trustees of legal estate, 281, 283. 284.

by mortgagees, 285 .

by executors and administrators, 286 .

by guardians and conservators, 290 .

by way of voluntary assignment, 293 .

through bankruptey proeeedings, 306, 308 .

agreements for, nature and requisites, 313 .

by will, agreements for, 321 .

intended as security only, effect of, 345 .

by way of devise, 376 .

how affected by liens and incumbranees, 418.

by lis pendens and attachment, 439 .

by judgments and deerees, 449.

resulting from judieial and execution siles, $274,280$.

resulting from tax sales, 535, 539 .

of alverse interests and estates, $573,580$.

COPARCENERS,

who are, and by what rules governed, 5ist.

COPIES,

of abstract should be preserved by examiner, 102.

printed, of alsitracts, value of, 612. 


\section{CORPORATIONS,}

right of, to acquire, hold and transmit, 250, 252.

as affected by statutes of mortmain, 251.

conveyances by and to, 254,255 .

exectition of deeds by, 256 .

municipal, may hold land when, 253.

\section{COVENANTS,}

classified and distinguished, 191.

operation and effect of, 191.

defects of form or substance in, $20 \mathrm{~s}$.

operate by estoppel, when, 42.

not implied in official deeds, 273.

in leases, effect of, 324 .

implied in leases, what are, 325 .

in mortgages, effect of, 353, 354, 355 .

effect of, in party wall agreement, 337 .

of ancestor, atlect heir how, 557 .

\section{CREDITORS.}

assignment for benefit of, 293 .

liens of, on decedent's real estate, $557,558$.

CURTESY,

tenancy by in the United States, 23.

\section{DATES,}

of deed not essential, 177 .

of registration should be shown, 178 .

disparities of, how shown, 203.

DEATH,

proof of essential to rights of heir, 35 .

how shown in case of succession, 562 .

how shown in abstract, $562,563,568$.

as shown by proccedings in probate, 569 .

affects sale on execution how, 479 .

\section{DEBTS,}

are a charge on land, when, 557 .

of ancestor, liability of heir for paynent of, 557 .

of testator, liability of devisee for, 405 .

devises for payment of, when regarded as money, 406 .

DECLARATION OF TRUST,

how made and shown, 267.

\section{DECREES,}

defined and distinguished, 446, 460 .

operation and effect of, 461.

rendered on constructive notice, 462 .

lien of, 463 .

formal requisites of, 464.

how shown in alstract, 465.

errors and defects in, low treated, 466. 
DECREES - Continued.

rendered in foreign jurisdiction, 470.

in probate, effect of, 469.

DEDICATION,

consists of what, 49 .

at common law and under statute, 49.

by plat, effect of, 170 .

by deed, form and efrect of, 236 .

DEED,

title by, what is, 38 .

DEEDS,

operative parts of to be considered, 172.

names of parties in, $173,174,175$.

necessity and effect of consideration for, $179,180$.

special words of limitation, purchase, ete., 181, 182.

deseription of property in, 18\%, 186.

special recitals of, 187 .

exceptions, contitions, ete., 189, 190, 191.

facts of execution considered, 192.

delivery of, necessity for, 197 .

operation and effect of ancient deeds, 198.

stamps, necessity for and how shown, 199.

erroncous recitals in, how shown, 200, 203.

misdescription of property. 205, 207.

defective execution of, 209 .

classified and distinguished, 213.

how shown in abstract, $216,217$.

statutory forms of, 223.

common law forms of, 221.

of qualified estates, 230, 231.

by way of conveyance in future, 229.

restrictive and conditional clauses in, 190.

dedication by, 236.

particular elasses of, by indiriduals, 240.

to effect a partition, 248 .

of corporations, 250.

by heirs at law, effect of, 36, 260 .

by attorney in fact, 262.

by sheriff, on execution, 274 .

by master, commissioners, or referees, 280.

by trustees, 281 .

by mortgagees, 285 .

by executors and administrators, 286 .

by guardians and conservators, 290.

of voluntary assignment, 294.

by assignee in bankruptcy, 307, 308 .

agreement for, 313 .

of vacation of plat, 160 . 


\section{DEEDS - Continued.}

absolute, will be treated as mortgage, 348 .

of trust in nature of mortgage, 363 .

issued on tax sales, 535, 539.

shown adversely, 573.

DEED POLL,

defined and distinguished, 213.

\section{DEGREES,}

of consanguinity, how computed, 31 .

DELIVERY,

of U.S. patents, not essential, 151.

of deeds, is essential to transfer title, 197. presumption of from recording, 197 .

DESCENT,

title by, defined, 29, 542.

by what laws governed, $28,29,30,543,547$.

rules in the United States, 30, 547.

operation and incidents of title by, 543 .

who may take by, 546, 550 .

what property passes by, 555 .

how affected by ancestral covenants, 556 .

how affected by creditors' liens, 558 .

may be defeated by equitable conversion, 559 .

validity of, how established, 560 .

how shown in abstract, 564, 568 .

DESCRIPTION OF PROPERTY,

sufficiency and construction of, 183.

uncertainty and error in, how shown, 205.

DESERT LAND ACT, entries of public land under, 118.

DESTRUCTION OF RECORD, does not impair constructive notice of same, 66 .

DEVISE,

title by, what is, $39,376,377$.

operation and effect of, 378 .

rules of construction of, 381 .

affected how, by words of purchase and limitation, 385 .

rule in Shelly's case applied to, 386 .

of real estate, what words are necessary, 388 .

to a class, effect of, 390 .

with power of disposition, construction of, 392 .

of indeterminate character, how construed, 393.

on condition precedent, effect of, 394 .

with remainder over, 396 .

to married woman, 398 .

to executors in trust, 399 .

to beneficiary by description only, 400 .

with precatory words annexed, effect of, 401 . 
DEVISE - r'ontinued.

with suspension of power of alienation, 402 .

will lapse when, f(0):3.

for the payment of debts, 404 .

subject to payment of dobts, effect of, 405 .

will work equitable ronverwion, when, 406.

of the residum, eflect of, 407 .

of the income of realty, effect of, 391 .

DEVISEE,

takes by descent, when. 383.

nature of the title acquired by, 376 .

DISABILITY, persons under, exceptions in favor of, 586 .

DISCHAPGE,

in bankrupter, how shown, 309.

of mortgage, 368,371 .

of lien of judgments, 459 .

DISPOSAL OF PCBLIC LANDS, effected by what system, 106 .

by public sale, 107 .

by private entry, 108.

DIVISIONS,

of the public domain, 161 .

DIVORCE,

effect of on titles, 518 .

proceedings in, how shown in abstract, 518.

DOCUMENT NUMBER,

index of, how kept, 79 .

DONATION ENTRIES,

of public lands, how effected, 115.

DOWER,

definition of, 23,423 .

nature of estate conferred by, 23 .

how conveyed or barred, 23,246 .

right of, not affected by execution sale, when, 481 .

proceedings for, how shown in abstract, 517 .

DUPLICATES,

how shown in abstract, 238.

\section{EASEMENTS AND SERYITUDES,}

defined, distinguished, 25, 336.

how acquired or lost, 25.

distinguished from license, 25 .

when inquiries should be made with regard to, 610 .

EJECTMENT, effect of julgment in. 511.

EMINENT DOMAIN,

nature of the right, 53 . 
EMINENT DOMAIN - Continued.

character of title acquired by, 53, 54 .

actions in exercise of, 519 .

matters to be noticed in abstract of, 520 .

ENGLISH METHODS, of compiling abstract, 5 .

ENTAIL,

to what extent permitted, 182, 386.

ENTRY,

of public lands, 108.

nature of title conferred by, 109 .

what land subject to, 110 .

how shown in abstract, 129.

EQUITY,

of redemption, what is, 342,343 .

will treat deed as mortgage, when, 348 .

EQUITABLE CONVERSION,

what is, and how effected, 406.

may defeat succession of heir when, 599 .

EQUITABLE MORTGAGES,

general doctrines respecting, 348 .

deeds in form may be decreed, 348 .

ERROR,

liability of examiner for, 9 .

in deeds and other instruments, 200.

of description, in deeds, 205.

and mortgages, 352 .

in opinion, liability of counsel for, 619 .

ESCHEAT,

origin and former nature of, 55 .

nature of at present time, 55, 571 .

ESTATE,

distinguished from title, 14.

as affected by uses and trusts, 20 .

by exercise of powers, 21 .

of homestead, of what consisting, 22.

by entirety, how ereated, 241.

in common, how held, 247.

ESTATES,

under allodial titles, 19.

under existing laws, 19.

of dower and curtesy, 23.

for years, nature of, 24 .

ESSENTIALS,

of abstract of title, 4 .

ESTOPPEL,

defined and distinguished, 41.

elements of, 41 . 
ESTOPPEL - rontinued.

classification of, technical, 42.

equitable, 43.

does not affect sorureign power, 43.

applies to mortgages, 346 .

of a jurlginent, extends to what, 42.

by deed is raised in what manner, 43 .

EXAMINER,

necessary qualifications of, 8.

is liable for erroneous certificate, when, 9.

conditions necessary to fix liability of, 9 .

duty of, in expositions of title, 9.

EXAMINER'S NOTES, should be inserted when, 98, 218.

EXAMINATION,

of title, distinguished from abstract, 7 .

liability for error in, 9 .

of official indices and records, 67 .

of abstraet by counsel, 593, 594 .

EXCEPTIONS,

distinguished from reservations, 189.

how ereated and shown, 189.

EXECUTION,

of judgments, 475,476 .

sales under, effect of, $4 \pi 1$.

must conform to judgment, 475 .

levy of, how made and returned, 476 .

of deeds, formalities required, 192, 209.

of deed of corporation, 256.

of deed of attorney in fact, 263.

sale of abstract books under, 13.

EXECUTION SALES,

defined and distinguished, 471 .

validity and effect of, 472 .

purchaser at, takes subject to all equities, 472 .

title under, extends to what, 473 .

title vests under, when, 474 .

dependent on validity of writ, 475 .

as effeeted by levy, 476 .

notice of, how given, 477 .

affected how by death, 479 .

exemptions from, 480.

EXECUTION OF DEEDS,

consists of what, 192, 210 .

various parts of, how shown, 193, 210.

EXECUTORS AND ADMINISTRATORS,

nature of power held by, 286 .

deeds and conveyances by, 286, 287. 
EXECUTORS AND ADMIXISTRATORS - Continued. with will annexel, powers of, 289 .

devises to, in trust, 399.

EXEMPTION,

from the lien of judgments, 455 .

inquiry concerning, should be made when, 480 .

of abstract books from forced sale, 13.

EXPRESS TRLSTS,

for what purposes created, 20 .

EXTENT OF SEARCH,

in compiling abstraet of title, 90 .

FEE SIMPLE,

estate, signifies what, 19.

FIELD NOTES,

of govermment surveys, importance of, 77 .

FLAIIS,

in title, of what consisting and how remedied, 606 .

FORECLOSLRE,

of mortgage, general observations, 372,516 .

of mortgage, by advertisement, 373 .

proof of title under, 373 .

of mechanies' liens, 438 .

actions of, how shown in abstract, 516 .

FOREIGN PROBATE,

effect of, and how shown, 416.

FORFEITLRE,

defined and distinguished, 57.

for non-parment of taxes, how shown, 529.

FRAMING OPINIONS, general remarks upon, 604.

FRAUDLLENT CONTEYANCES,

considered with respect to abstracts thereof, 234 .

GENERIL LAND OFFICE,

records of, when recourse must be had to, 152 .

GOTERNMENT SURVEYS,

character and effect of, 77 .

GRADUATION ENTRIES, of public lands, how effeeted, 114.

GRANTS,

under swamp land act, 122.

in ail of education, 123.

in aid of internal improvements, 124.

in aid of railroads, 125 .

GUARDLANS,

deeds and convegances by, 290 . 
IIABENDLA,

of leeels, office of, 188.

HALA' BLOOD,

children of, participate equally, 552.

HEHRS,

who are, 30,547 .

conveyances by, effect of, $36,260,570$.

post obit conveyaners by, effect of, 261.

entitled to representation, when, 548 .

lialility of for ancestral dehts, 5.57 .

must establish death of ancestor, 562 .

must prove birth and legitimacy, 565 .

HEIRSHIP,

defined, 29.

rules groveruing, 30,547 .

proof of, how made, 34, 560 .

eflect of conveyances by virtue of, 36, 260,570.

rights and privileges of, 545 .

dependent on fact of death, 562 .

accrues only to litwful issue, 565 .

HIGHWAYS,

on the public lands, 126 .

HOMESTEAD,

right of in Lnited States, 22.

consists of what, 25.

entries, nnder U. S. land laws, 116.

mortgages of, how made, $35 \mathrm{~s}$.

exempt from lien of judgment, 458, 480.

when inquiries as to, should be made, 611 .

HOMESTEAD ENTRIES.

of public lands, nature of, 116 .

rights acquired by, 117 .

HUSBAND AND WIFE,

conveyances to, effect of, 241 .

conveyances between, 242 .

not heirs to each other, 553 .

\section{IMPLIED COVENANTS,}

in leases, what are, 325 .

from words of grant, what are, 181.

LNCEPTION OF TITLE, presentation of different measures of, 129.

INCOME OF PEALTY, gift of, passes land, 391.

INCLMBRANCE,

conveyances subject to, effect of, 235 .

when grantee becomes liable for, 235 . 


\section{INDENTURE,}

defined and distinguished, 213.

INDETERMINATE DEVISE, construction of, 393 .

\section{INDEXES,}

official, in public offices, 67 .

grantor and grantee, 68 .

plaintiff and defendant, 70 .

to public records, not a part of same, 68 .

importance of in abstract nuking, $6 \bar{i}, 74$.

inutility of "patent" forms of, 75 .

of government tract book, 76 .

of field notes of government surveys, 77 .

books of original entry, $i 8$.

of document numbers, 79 .

suggestions for form of entries in, 80 .

of tracts and parcels, 81 .

of irregular instruments, 82.

of tax sales and redemptions, 83 .

of judgments, 84, 85 .

of names, 86 .

method of laying out and keeping, 88 .

scale for paging, 88 .

\section{NFANTS,}

effect of judgments against, 457 .

INHERITANCE,

words of, in deeds, 182.

as affected by rule in Shelly's case, 182.

not dependent on seizin, 544 .

right of in case of adoption, 551, 561 .

\section{INJUNCTIONS,}

should be shown in abstract, when, 510 .

INQUIRIES IN PAIS,

to demonstrate adverse possession, 578, 581, 586.

to show fact of death, 562,599 .

to prove birth and marriage, 565, 599.

INSOLVENCY,

voluntary assignments and bankruptcy, 293.

\section{INSPECTION.}

of records, right of, 60 .

\section{INSTRLAIENTS,}

of conveyance, synopsis of, 95 .

fullness of narration of, 96 .

shown for reference, 97 .

references to original, 100 .

irregular, how sliown, 99.

nature of, how indicated in abstract, 176. 
INTERNAL RMPROVEMENT GRANTS,

for what purposes made, 124, 125.

nature of title conferred by, 124 .

how shown in abstract, 124.

INTESTATE,

property signifies what, 542 note.

INTRODUCTORY,

remarks concerning abstracts, 1 .

statements in abstract, 93, 129.

IRREGULAR INDEX, how compiled and used, 82 .

IRREGULAR INSTRUMENTS, method of compiling index for, 82 . how shown in abstract, 99, 329 .

ISLANDS, ownership of and rules for division, 46.

JOINT TENANCY,

deeds of land held by, 247.

JUDICIAL SALES,

defined and distinguished, 471 .

differ from execution, how, 471 .

validity and effect of, 472 .

title under, how construed, 473, 474.

rights of purchaser at, 484 .

purchaser may be compelled to take title under, when, 485 .

must be confirmed to pass title, 486,487 .

certificate of, how shown in abstract, 488 .

proof of title under, how made, 490.

JUDGMENTS,

defined and distinguished, 446 .

operation and effect of, 447.

extent and duration of lien of, 450 .

priority of, 451 .

lien of attaches to after-acquired property, 452 .

formal requisites of, 454 .

entry and docketing of, 453.

how shown in abstract, 454 .

satisfaction and discharge of, 459 .

against deceased person, effect of, 456 .

against infants, 457.

exemptions from lien of, 458.

errors and defects in, how treated, 466.

extra-territorial effect of, 449.

sales under, 471 .

JUDGMENT INDEX, of examiner, how compiled nnd used, 84. 


\section{LAND CLAIMS,} private, nature of title under, 126a.

LAND CONTRACTS, relation of parties under, 311 . operation and effect of, 312 . nature and requisites of, 313 . as affected by recording acts, 314 . construction of, 315 . how shown in abstract, 316 . assignment of, operation and effect, 317 . performance of, sufficiency of deed and title under, 318 . when forfeited, effect of, 319. in form of bond, effect of, 320 .

LAND GRANTS TO RAILROADS, how made, and title conferred by, 125 .

LAND MEASURES, tables of, in common use, Ap.

used in Spanish-French grants, Ap. used in Spanish-Mexican grants, Ap. used in Texas, Ap.

LAND SCRIP, for what issued and to whom, 121. location of public land under, 121.

LAYING OUT BOOKS, suggestions in regard to, 78 .

LEASES, nature and requisites of, 322 . formal requisites of, 323 .

how shown in abstract, 323 . effect of covenants and conditions in, 324 . covenants in are implied when, 325 . of agricultural lands, effect of, 326 . assignments of, 327 .

are a charge upon the fee, 431.

LEGAL MEMORY, periods of, how fixed, 45.

LEGISLATIVE GRANTS, nature and effect of, $13 \bar{i}, 138$. rules of construction relating to, 139 . formal requisites of, 140 . how shown in abstract, 140 .

\section{LETTERS,} or private correspondence may be shown in abstract, when, 338 . LETTER PRESS COPIES, of abstract, should be taken by examiner, 102.

\section{LIABILITY,} of examiner for erroneous search, 9. 
LIABLLITY - Continued.

of examiner, character of, 10.

of attorney for erroneous opinion, 619 .

LICLNSE,

distinguished from easement, 25 .

\section{LIENS,}

general doctrines of, 418 .

how created and exhibited, 419, 421.

created by official bonds, 430 .

by reservations in deeds, 4.3. .

in aid of mechanics, 433.

attach to what estate or intrrest, 435.

limitation of, 436 .

of taxes, attach when, 428.

of creditors may defeat snceession of heir, $55 \mathrm{~s}$.

of judgments and decrees, 449, 450 .

LIMITATION AND PRESCRIPTION,

doctrine of, 45 .

title founded upon, 45.

LIMITATION,

and purchase, words of, 192, 385 .

of estate, how created, 216,385 .

of liens of mechanies and others, 436 .

LMMITATION, WORDS OF,

employed in deeds, 18:, 216.

used in leases or creation of lesser estates, 323.

how affected by the rule in Shelly's case, 182.

LIS PENDENS,

general doctrine of, 439 .

filing of notice of, 74,442 .

how shown in abstract, 442 .

\section{M.AP,}

of township subdivision, $16 \mathrm{I}$.

of sectional subdivision, 163.

MARGINAL DISCHARGE,

of mortgage, effect of, 371 .

MARGINAI NOTES,

how employed in examination of abstract, 596 .

MARKETABLE TITLE, elements which constitute a, $604,605$.

MARRIAGE SETTLEMENTS, legal effect of, 240.

MARRIED WOMAN.

conveyances by, how marle, 243.

effect of conveyances by, 244 .

formal requisites of conveyances by, 245 .

release of dower by, 246 . 
MARRIED WOMAN - Continued.

abstract of release of dower by, 246 .

devise to, construction of, 398 .

may acquire title by adrerse possession, 587 .

MASTERS,

certificate of sale, how shown, 488 .

reports, how shown, 507 .

MASTERS' DEEDS,

operation and effect of, 280 .

how shown in abstract, $2 S 0$.

MEANDER LINES, how run and for what purpose, 165 .

MECHANICS' LIENS,

nature and effect of, 433 .

rules with respect to priority of, 434 .

attach to what estates, 435 .

limitation of, 436 .

foreclosure of, 438 .

should be detected by inquiries in pais, when, 609 .

MERGER,

general doctrine of, 347 .

MILITARY WARRANTS,

location of public lands under, 120.

MISDESCRIPTION,

of parties to deeds, 201, 202.

of lands in deeds, 20.5.

in official deeds, 277 .

MORTGAGES,

defined and distinguished, 342, 343.

rights of parties under, 344,345 .

as affected by estoppel, 346 .

doctrine of merger applied to, 347 .

deeds absolute may be decreed to be, when, 348 .

how shown in abstract, 350 .

statutory forms of, 351 .

erroneous description in. 352.

effect of covenants in, 353, 355 .

effect of informality in, 356 .

when for purchase money, effect of, 357.

of the homestead, how made, 358 .

of after-acquired property, 359 .

how affected by recording acts, 360 .

re-records of, how treated, 362 .

trust deeds in nature of, 363 .

power of sale in, how shown, 364.

sale under, by virtue of power, 364 .

assignment of, how made, 366 .

operation and effect of, 366 . 
MORTGAGES - Continued.

formal requisites of assignment of, 367 .

releases of, how made, 368 .

by tru-tee, 370 .

oll margin of record, 371 .

foreclosure of, how made, 372 .

proof of title under, 373 .

MORTMAN,

statutes of, how far recognized, 251.

MUNICIPAL ORDINANCES,

should be shown in abstract, when, 330 .

executive approval of, $3: 31$.

operation and effect of, 332 .

and resolutions, 333.

NAVIGABLE WATERS,

what are, 48.

incidents of land bounding upon, 46.

NEW ENGLAND ABSTRACTS, method of compilation of, Ap.

NON.CLAII,

deed of, what is, 222.

NOTARY,

must affix seal to official certificate, 210.

certificate of, when defective, 209 .

may not acknowledge deed to self, 210 .

NOTES,

by examiner, how inserted, 9s, 218.

NOTE-TAKING,

utility of, considered, Ap.

NOTICE,

general doctrines of, 61 .

constructive, effect of, $62,64,65$.

not effected by the destruction of record, 66 .

constructive, decree rendered upon, 462.

actual, effect of, 63 .

lis pendens, how shown in abstract, $74,442$.

of mechanic's lien, 433, 609 .

of sale, under execution, how shown, 477 .

afforded by chancery records, 500 .

of easement or servitule, 610 .

imparted by possession, 361, 581 .

NUNCUPATIVE IVILLS,

or oral declarations not sufficient to transfer real estate, 375 .

\section{OCCOPANCY,}

nature and extent of rights acquired by, 51 .

OFFICLAL, BONTS,

constitute a lien on land, when, 429. 


\section{OFFICIAL CERTIFICATES,}

may be shown in abstract, how, 334 .

OFFICIAL CONVEYANCES,

defined and distinguished, 270.

nature and effect of, 271 .

OFFICIAL AIDS TO SEARCH,

what are and how consulted, 67 .

OPINIONS OF TITLE,

general remarks concerning, 614 .

aids in rendering, 600,601 .

how framed, 613 .

clearness of expression essential in, 617 .

by oral communication, 618 .

erroneous, liability of counsel for, 619 。

ORAL OPINIONS, undesirability of, 618 .

ORDER,

for examination of title, form of, 103 note.

of publication for constructive service, 505 .

of confirmation, in judicial sales, 486,487 .

ORDINANCES,

of cities and towns, when necessary to be shown, 330 .

practical example of abstract of, 330 .

executive approval of, 331 .

operation and effect of, 332 .

ORIGIN,

of abstracts, speculations upon, 3.

ORIGINAL ENTRY.

in abstract books, how made, 78 .

suggestions as to form of, 78 .

long form method of, 80 .

\section{PARTIES,}

to deeds and other instruments, 173, 175.

names of, how displayed in abstract, 174, 175.

defects or errors respecting, how shown, 201.

to land contracts, relation of, 311 .

PARTITION,

effect and nature of, 248 .

deed of, how shown, 248.

proceedings for, how shown in abstract, 513.

PARISH RECOPDS,

are competent as evidence, 73 .

PARTNERS,

lands held by, how regarded, 249.

conveyances by, 249.

PARTY WALLS,

agreements for, effect of, 337 .

how shown in abstract, 337 . 


\section{PATENTS,}

detined and distinguished, 141.

formal requisites of, 156 .

operation and elfect of, $153,154$.

registration of-general land ofrice record, 152.

construction of, 155.

how shown in abstraci, 156.

from the state, eflect and construction of, 157 .

formal requisites of, 159 .

PATENT SYSTEMS,

for compiling abstracts, observations upon, 75 .

PERFORIIANCE,

of contract to convey, sufficiency of deed and title, 318.

PERPETUITIES,

attempts to create same void, 402 .

PERUSAL OF ABSTRACT,

general suggrestions for, 591 .

utility of notes as an aid to, 592 .

analytical chains used in, 601.

use of sketch maps, 602 .

preservation of memoranda employed in, 603.

inquiries in pais shonld be directed, when, 608 .

PEDIGREE,

to prove heirship, example of, 568 note.

affidavit of, 599 .

PLATS,

of public surveys, how made, 161, 163, 164.

of private survers and subdivisions, 166.

formal requisites of, 167 .

how shown in alstract, $16 \%$.

effect of registration of, 168 .

vacation and eancellation of, 169 .

dedication by, effect of, 170 .

by assessor in tax proceedings, 528 .

POSSESSION, notice imputed from, 361.

POST OBIT CONVEYANCES, effect of, 286 .

POIVERS,

definition of, 21.

obtain to what extent in United States, 21.

of disposition to bolder of life estate, 392 .

POWERS OF ATTORNEY,

general doctrine of, $262,263$.

how shown in abstract, 262.

revocation of, 264.

POWER OF SALE,

distinguished from trust of sale, 283 . 
POWER OF SALE - Continued.

in trust deeds, how exercised, 364 .

how slown in abstraet, 363 .

PRECATORY TRUSTS, what are and how created, 401.

PRE-EMPTION ENTRIES, of public lands, how effected, 111. nature of title conferred by, 112. what lands subject to, 111 . conveyances made before, effect of, 113. abstract of, from government tract book, 129.

PREFERENCES, among heirs, rules of, 549 .

PRESCRIPTION, is founded on what presumptions, 45, 572 . etlect of on title, 45, 572 .

limited by what fixed periods, 45 . and adverse possession, $572,580$.

PRESERVATION, of memoranda of counsel, 603.

PRESLAHTIONS, of heirship and legitimacy, 566 .

PRIMOGENITURE, right of, not recognized in United States, 549.

PRINTED COPLES, of abstracts, opinions conceruing, 612.

PRIVATE LAND CLALIS, what are, and how established, 126a.

PROBATE PROCEEDINGS, in respect to wills and testamentary papers, 411, 414, 417. of wills, how shown in abstract, 414.

in foreign jurisdiction, how shown, 416 .

operation and effect of decrees in, 497, 564, 568 .

in intestacy, how shown in abstract, 568.

to show death and heirship, 564, 569.

PROBATE SALES, validity and effect of, 492 .

nature and requisites of, 493 . how shown in abstract, 494.

PROCESS, office and formalities, 501, 502 .

service of, how made, 503 . proof of service of, how shown, 504. PROHIBITED CONVEYANCES,

former and present state of law respecting, 233 . PROOF,

of eonveyance by official certificate, 334 .

of title under foreclosure of mortgage, 373. 
PROOF - Continued.

of publication, notice of sale, 478 .

of title under judicial and execution sales, 490 .

of service of summons in legal actions, 504 .

of heirship, how eflected, 34, 560.

of death, 35 .

of birth and legitimaey, 565 .

of adoption, 561 .

to support title by adverse possession, 590 .

PUBLIC LANDS,

system of disposal of, 106, 107, 108.

public sales of, 107.

private entry of, 108.

subject to private, what are, 109, 110.

pre-emption entries of, 111, 112.

graduation entries of, 114 .

donation entries of, 115 .

entries of, under homestead laws, 116.

under desert land act, 118.

under tree claim aet, 119 .

location of by military warrant, 120 .

by U. S. land serip, 121.

selections of under swamp land grants, 122.

disposal of in aid of education, 123.

and internal improvements, 124, 125.

publie highways upon, 126.

private elaims of, $126 \mathrm{a}$.

who may acquire title to, 127.

inceptive title to, how shown in abstraet, 128.

town site entries upon, 133.

survey and division of under U. S. land laws, 161.

PUBLIC GRANT,

title by, what is, 40 .

synopsis of, in abstract, 125.

PUBLIC SURVEYS,

how executed and returned, 161.

PUBLICATION,

construetive serviee by, effect of, 503,504 .

of notice of sale under exeeution, 477,478 .

of summons, affidavit and order for, 505 .

PURCHASE,

title by, defined, 37 .

money, application of, 282.

PURCHASER,

may require to be furnished with abstract, when, 11 .

abstract becomes property of, when, 11 .

must see to application of purehase money, when, 282.

at official salc, as charged with notice of what defects, 472 . 


\section{PURCHASER - Continued.}

at execution sale, takes what title, 473.

trustee can not become, of trust estate, 291, 292.

tax payer can not be, at tax sale, 531 .

rights of, at tax sale, 532 .

\section{QUALIFICATIONS,}

of examiner of titles, 8.

QUIA TIMET,

action of, effect of on title, 512.

QUIT-CLA1M DEEDS,

legal import of, 219.

how shown in abstract, 220 .

effect of covenants in, 221.

\section{RAIL ROADS,}

grants made in aid of, 125.

RECEIVER'S RECEIPT,

issued at time of entry, 108.

does not constitute evidence of title, 134.

how shown in abstract, 134 .

\section{RECITALS,}

in deeds, how shown in abstract, 187.

effect of in official deeds, 272 .

in sheriff's deeds, when material, 274.

in tax deeds, 537 .

RECORDS,

consist of what, 58 .

depositories of, 59 .

right of inspection and copy of, 60 .

doctrine of notice imparted by, 61 .

afford constructive notice, when, 62 .

loss or destruction of, 66 .

when abstract may supply the place of, 66 .

as aids in real estate examinations, 67 .

of church or parish, effect of, 73 .

of United States land entries, where kept, 76 .

of government surveys, effect of, 77 .

of general land office, how made and kept, 152.

of mortgages, impart notice of what, 360 .

of chancery proceedings, 495, 498 .

corrected, how shown, 239.

RECTANGULAR SURVEYING, exposition of the system of, 164 .

\section{REDEMPTION,}

equity of, of what consisting, 344 .

bills for, how shown, 515.

from tax sale, how shown in abstract, 533 . 


\section{REGISTRATION,}

American doctrine of, 62,64 .

general rules regarding, 64,65 .

effect of not abrogated by destruction of record, 66 .

of patents from United States, 1.52.

of plats and subdivisions, effect of, 167, 168 .

of deeds, how noted in abstract, 178.

raises of presumption of delivery, when, 197.

of nortgages, effect of, 360 .

of death certificate when evidence of fact, 563 .

RELATION,

doctrine of, expounded, 44.

of parties under land contracts, 311 .

RELEASE,

as a substantive mode of conveyance, 225 .

of dower by wife, $23,246$.

of mortgage, form and requisites of, 368,369 .

how shown in abstract, 369 .

of mortgage by trustee, 370 .

of mortgage on margin of record, 371 .

\section{RELICTION,}

defined and distinguished, 46 .

title to land acquired by, $46,48$.

RELIEF ACTS,

how shown in abstract, 140 .

RELINQUISHMENT, considered as method of passing title, 52 .

\section{REMAINDER,}

definition of, 19.

estate in, will be raised when, 389,396 .

contingent, limitation of in wills, 394, 396.

REMAINDER-MAN, adverse possession will not lie against, 583 .

REMOVAL, and substitution of trustees, 268.

REPRESENTATION, right of, among heirs, 548.

\section{REPUGNANCY,}

in deeds, by what rule governed, 201, 209, 211.

in wills, how construed, 382.

REQUISITIONS FOR TITLE,

made by counsel on examination, 596 .

answers to, 598 .

of what consisting, 598 .

RE-RECORDS,

how shown in abstract, 238 .

of mortgage, how shown, 362. 
RESERVATION,

distinguished from exception, 189.

how created and shown, 189.

RESIDUARY DEVISEE, when charged with testator's debts, 405.

RESIGNATION, of trustee will not divest the trust, 269.

RESOLUTIONS, of municipal boards, should be shown when, 333 .

RESTRAINT OF MARRIAGE, imposed by will, validity of, 395 .

RESTRICTIONS, inserted in conveyances, effect of, 190, 232.

RESULTING TRUSTS, general doctrine of, 237 .

REVERSIONERS, adverse possession will not run against, 584 .

REVOCATION, of power of attorney, how made, 264 .

of trust, 266.

of wills, 409 .

RIPARIAN TITLES, nature and incidents of, 48 .

ROOT OF TITLE, of what consisting, 136.

RULES,

for division of land acquired by accretion, 46 . of descent, 30,547 .

for land measurement, Ap.

\section{SALES,}

of public lands, how made, 107.

in pursuance of judgments and decrees, 473,482 .

in probate, 492, 493 .

for non-payment of taxes, 529, 530 .

SATISFACTION,

of mortgage, distinguished from release, 368 .

form and requisites of, 369 .

how shown in abstract, 369,371 .

of liens and charges generally, 418.

of judgment, how shown, 459 .

SCALE,

for indexing abstract books, 87 .

of land measures in United States, Ap.

SCHOOL LANDS,

method of donation of, 123 .

grant of, how shown in abstract, 131 . 
SEALS,

effect of, when affixed to deeds, 194.

of notaries should attest acknowledgment, 196.

of corporations, 258.

SECTIONS,

of public land, how surveyed and subdivided, 162, 163, 164.

diagrams of, 163.

when made fractional, 163,165 .

SERVICE,

of process, how made and shown, 503, 504.

proof of, how made, 504, 505.

SHELLY'S CASE,

rule in, effect of, 182,386 .

SHERIFF'S DEED,

operation and effect of, 274 .

necessity of acknowledgment of, 275 .

may not be reformed in equity, 277.

statutory fornis of, 278 .

how shown in abstract, 278.

under decree, effect of, 279.

recitals in, when material, 274 .

SIGNATURE,

gives efficacy to conveyances, 193 .

how indicated in abstract, 193.

in execution of corporate deeds, 256.

to deed by attorney in fact, 262 .

SOURCES OF TITLE,

in England and the United States, 17, 18.

when search should extend to, 90, 129.

SPECIFIC PERFORMANCE,

actions for, when shown in abstract, 514.

STAMPS,

when required and how indicated, 199.

STATE LANDS,

by what title held, and how disposed of, 135 .

sales of, how shown in abstract, 135 .

formal requisites of patents for, 159 .

effect and construction of patents for, 157, 158.

adverse rights will not run against, 588 .

STATUTORY FORMS,

of decds and conveyances, 223 .

of sheriff's decd, 278.

of mortgage, effect of, 351 .

of tax deed, 535, 537.

SUBDIVISIONS,

of the public lands, how made, 161.

of section, 163 .

resubdivisions of, 166 . 
SUBDIVISIONS - continued.

effect of, in subsequent conveyances, 166.

formal requisites of, 167 .

how shown in abstract, 167 .

vacation and cancellation of, 169 .

by assessors for taxation, 523.

SUBSTITUTION,

of attorney in fact, when permitted, 263 note.

SUCCESSION,

line of, in descents, $30,547$.

rules of, according to civil law, 31 .

through adoption, requires what to be shown, 33,561 .

SUMMONS,

how shown in abstract, 501, 502 .

service of, how made, 503.

proof of service of, 504 .

service of by publication, how shown, 505 .

SURRENDER,

considered as form of conveyance, 227 .

how shown in abstract, 227.

SURVIVORSHIP,

in joint tenancies, doctrine of, 247 .

presumption of, in case of disaster, 562.

SURVIVING CONSORTS,

are not heirs of deceased, 553 .

SWAMP LAND GRANTS,

origin and history of, 122.

selection of public land under, 122.

SYNOPSIS,

of instruments, suggestions for, 95 .

TACKING,

of adverse claims, doctrine of, 580 .

TAX,

index, how laid out and kept, 83.

definition and nature of, 522 .

what property subject to, 523 .

lien of, attaches when, 428,524 .

sale for non-payment of, how effected, 529.

TAXATION,

subjects of the burdens of, 523 .

proceedings incident to, 527 .

of abstract books and indices, 12 .

TAX ABSTRACT,

raption of, 93.

should show what matters, 540.

TAX DEEDS,

validity and effect of, 535 . 
TAX DEEDS - continued.

formal requisites of, 537 .

how shown in abstract, 537.

effect of as evidence, 538 .

how aided by limitation and possession, 539 .

TAX INDEX,

of the examiner, how compiled and used, 83 .

TAX SALE,

how made and how shown, 529, 531.

tax payer as purchaser at, acquires no title, 531 .

rights of purchasers under, 532 .

redemption from, how shown, 533.

certificate of purchase of, 534 .

abstracts of, how compiled, 540 .

TAX TITLE,

nature and extent of, 525, 538 .

TECHNICAL ESTOPPEL, application of principles of, in examinations of title, 42 .

TECHNICAL PHRASES,

in deeds, effect of, 181, 182.

in wills, how construed, $385,387$.

TENANCIES,

for years, of what consisting, 24.

TENANTS IN COMMON,

nature of the estate held by, 247.

deeds by, to effect partition, 248 .

when partners will hold as, 249 .

statute of limitations does not run as between, 585 .

TESTAMENTARY TITLES,

character aud effect, 374 .

formal proof of, 414,416 .

TIDE WATERS,

common law of, not applicable in United States, 48.

TITLE,

distinguished from estate, 14.

methods of acquisition of, $14,15,37$.

how classified, 16 .

as affected by the doctrine of relation, 44 .

derived from what sources, 17.

nature of in the United States, 18, 29.

allodial, nature of estate held under, 19.

color of, what constitutes, 26.

evidences of, 27 .

how acquired and transferred, 28.

by purchase, defined, 37 .

by descent, how acquirerl, $28,29,542$.

by deed, 28,38 .

by devise, $28,39,376$. 


\section{TITLE - Continued.}

by public grant, 28,40 .

through estoppel, 41.

acquired through accretion or reliction, 46 .

to lands on navigable waters, incidents of, 46,48 .

derived through eminent domain, 53.

by dedication, 49 .

by escheat, 55 .

derived through confiscation, 56.

by prescription and limitation, 45 .

preliminary atages of, 104.

inceptive measures under U. S. land laws, 105.

nature of, conferred by private entry, 108, 109.

conferred by general laws, 111, 114, 115, 116, 118, 119.

to public lands, who may acquire, 127.

acquired by sheriff's deed, 274 .

of assignee in insolvency, 297, 307.

of purchaser at execution sale, 473 .

under execution sale, vests when, 474 .

under judicial sale, 483.

purchaser may be compelled to take, when, 485 .

proof of, under execution and judicial sales, 490 .

derived from tax sale, 525, 526 .

acquired by adverse possession, 572, 590 .

opinions of, how made, 613 .

analysis of, utility in examination, 600 .

validity of, in framing opinions, 604 .

flaws in, how detected and obviated, 606.

clouds upon, effect of, 607.

TOWNSHIP,

how surveyed and subdivided, 161.

diagram of, 161 .

TOWN SITE ENTRIES,

how made and for what purpose, 133.

how shown in abstract, 133.

TRACT BOOK,

of the government land office, 76 .

of the exaniner, how compiled, 81 .

TREE CLAIMS,

on public lands, how effected, 119.

\section{TRUSTS,}

general doctrine concerning, 20 .

resulting, generally considered, 237 .

for what purposes permitted, 20.

words which create, 293.

declaration of, how made and shown, 267.

created by will, $399,401$.

precatory, what are and how raised, 401. 


\section{TRUSTEES,}

how created, $265,281,399$.

declarations by, 267.

removal or substitution of, 268.

resignation or refusal to act of, 269 .

transfers of legal estate by, 282.

purchaser must see to application of purchase money by, when, 282, 283.

deeds and conveyances by, 281, 284.

may not purchase trust estate, 291, 292.

deeds by under power of sale, 283.

releases by, of mortgaged property, 370 .

in testamentary conveyances, 282, 399.

may not delegate trust powers, 281.

\section{TRUST DEEDS,}

character and effect of, 363 .

power of sale in, how shown, 364 .

in nature of mortgage, 363 .

how shown in abstract, 363 .

TRUST OF SALE,

distinguished from power of sale, 282.

\section{UNITED STATES,}

nature of title to land in, 18.

estates in land recognized by, 19 .

being the sovereign power, not affected by estoppel, 43 .

or limitation, except when, 43,45 .

system of disposal of lands of, 106 .

UNRECORDED EVIDENCE,

abstract does not contemplate, 341 .

USES AND TRUSTS,

nature of in United States, 20.

defined and distinguished, 20.

USER,

and possession will support claim of title when, 572,578 .

\section{VACATION,}

of plats and subdivision, 169 .

how shown in abstract, 169.

of streets and public roads, 330 .

VENDOR, not required to furnish abstract in absence of contract, 11 .

\section{VENDOR'S LIENS,}

must be disclosed to bind third parties, 423 .

\section{VERDICTS,}

should be noticed, when, 508 .

VOLUNTARY ASSIGNMENT, character and operation of, 293. 
VOLUNTARY ASSIGNAENT - Contimued. validity of, 295.

formal requisites of, 296 .

construction and effect of, 298.

conflict of laws relating to, 299.

VOWEL INDEX,

object and method of use, 86 .

WARRANTY,

covenant of, extends to what, 191, 216.

of title, in quit-claim deeds, effect of, 221 .

against acts of grantor only, effect of, 222 .

how construed in statutory forms, 223 .

implied from words of grant, 191, 216.

WARRANTY DEEDS,

legal import of, 216.

how shown in abstract, 217.

with limited covenant, 222 .

WIFE,

conveyances to, as marriage settlements, 240 .

conveyances to, and to husband, effect of, 241 .

conveyances to, from husband, 242.

conveyances by, to stranger, 243 .

release of dower by, 23,246 .

deed of, how acknowledged, 245 .

WILLS,

agreements for conveyances by, 321 .

general doctrines relating to, 374 .

construction and operation of, 378 .

when real estate will pass under, 388 .

limitations and remainders in, 389 .

contingent remainders created by, 396 .

language required to raise trusts in, 399.

precatory trusts in, how expressed, 401 .

residuary clause in, effect of, 407 .

codicils to, effect of, 408 .

formal requisites of, 410 .

abstract of, how made, 411 .

probate of, effect of, 414 .

construction of in equity, 531 .

WITNESSES,

to deeds, attestation of, how shown, 195.

WORDS,

importing technical character, 387 .

which pass real estate in wills, 388 .

WORDS OF GRANT,

what are, in deeds, 181.

and wills, 384 . 
INDEX.

WORDS OF PLRCHASE AND LIMITATION, of what consisting, 182.

in leanes, what are, 323.

in wills, grneral rules of, 385.

create remainders, when, 396,397 .

WRIT,

of attachment, how levied, 445.

of execution, levy and return of, 475,476 . 


\section{INDEX TO FORMS.}

\section{ABSTRACT,}

formal captions for, 93 .

general examination, 93 .

special examination, 93.

examination of tax title, 93.

formal conclusion of, 103.

ABSTRACT INDICES,

original entry, 78 .

document number index, 79 .

tract index, 81 .

irregular index, 82 .

judgment index, 84 .

tax index, 83.

scale for indexing, 87 .

ACKNOWLEDGMENT,

notes of, 196, 210.

of corporation deeds, 256.

AFFIDAVIT,

general form of, 329 .

of domestic condition, 329,339 .

of pedigree, 599 .

of matter in pais, 339.

of publication, 478 .

AGREEMENT,

for conveyance by deed, 316 .

for party wall, 337 .

ANALYSIS OF TITLE,

to show ownership, 600 .

to trace conrse, 601 .

English method, Ap.

ASSIGNMENT,

by register in bankruptcy, 307 .

ARRANGEMENT,

of abstract, chain of title, 94 .

ASSESSMENTS,

note of levy of, 541.

ATTACHMENT,

proceedings in, 445 .

certificate of, 445 . 


\section{BANKRUPTCY,}

petition, 306.

assignment, $30 \pi$.

assignee is deed, 308.

discharge, 309 .

BOND,

for deed, 320 .

CERTIFICATE,

of examination, 103.

of general land office record, 156.

of public officials, 334 .

of conformity, 210 .

of lery (attachment), 445 .

of sale (execution), 488.

of sale (judicial), 488.

official, 334 .

of proof of conveyance, 334 .

of death, 563 .

of proof of will, 413.

CHANCERY RECORDS,

gencral form, 509.

in special cases, 513.

in partition suits, 513 .

in condemnation suits, 520 .

notes of, divorce, 518 .

CONGRESSIONAL GRANTS,

act of Congress, reinstatement, 140 .

by way of confirmation, 140 .

CORPORATE CONTEYANCES,

corporation deed. 255.

special appended matter, 255 .

showing power to execute, 255 .

DECLARATION,

of vacation of plat, I69.

of trust, 267.

DECREE,

common form, 465.

DEEDS,

warranty, 217.

warranty, by attorney, 262 .

warrants. special, 222.

confirmation, 226 .

in futuro, 229.

surrender, common law, 227.

of special estates, 231.

partition, 248. 
DEEDS - Continued.

re-record of, 238.

duplicate, 238.

by corporation, 255.

by attorney in fact, 262 .

by sheriff, $27 \mathrm{~s}$.

by master, 280 .

by trustee, 284 .

by administrator, $28 \mathrm{~s}$.

by register in bankruptey, 307 .

by assignee in bankruptcy, 308 .

by county elerk (tax), 537.

of trust, 363 .

of relinquishment, 246 .

DISCHARGE,

in bankruptey, 309.

on margin of record, 371 .

of judgments, 459 .

INDEX,

of original entries, 78 .

of document number record, 79 .

of land tracts, 81.

of tax sales, 83 .

of judgments, 84 .

INITIAL STATEMENTS,

entry at government land office, 129.

donation by the United States, 130. .

cession of section sixteen, 131.

cession of lieu lands, 131.

receiver's receipt, 134 .

commissioner's receipt (State lands), 135.

\section{JUDGMENT,}

common form, 454.

note of satisfaction of, 459 .

LEASE,

for years, 323 .

re-record of, 283.

\section{LIS PENDENS,}

notice of, 442 .

\section{MASTERS,}

certificate of sale, 488 .

deed. 280.

MORTGAGES,

common form, 350 . 
MORTGAGLS- Comtimued.

to secure purchase money, 357.

re-record of, 362 .

trust deed, in nature of, 363.

power of sale in, 363.

release of, $36 \%$.

marginal discharge of, 371 .

NEW ENGLAND ABSTRACTS, sample, Ap.

NOTES,

of reference to original doruments, 100, 178, 201, 218.

of non-registration of instruments shown, 140 .

of referenes to other rexords, $263,370,371$.

of certiticate of magristracy, 210.

of convenant of non-claim, 222.

of ehancery records, 509 .

of adverse conveyances, 573

of probate of will, 413,417 .

of correction of record, 239.

of power of sale in other instrument, 284.

of reference to municipal records, 330 .

of non-payment of taxes, 524 .

of payment of taxes, 524.

NOTICE,

lis pendens, 442.

of sale, 477.

proof of publication of, 478 .

OFFICIAL CONVEYANCES,

sheriff's deed, $2 i 8$.

master's deed, 280.

trustee's deed, 284.

administrator's deed, 288.

assignee's deed, 308 .

county clerk's deed (tax), 537 .

ORDER,

for examination of title, 103.

ORDINANCE,

of municipality, 330 .

OPINION OF TITLE,

based on personal search, 614 .

based on the abstract, 616 .

\section{PATENTS,}

from the United States, 156.

PEDIGREE,

English form of, 568 .

affidavits of, 599 . 
POWER,

of attorney, 263.

of sale, 363 .

PROBATE,

of wills, 413,417 .

of estate, 569 .

sales, 494 .

PROCEEDINGS,

in bankruptcy, 306 .

in probate (will), 413, 417 .

in probate (sale), 494.

in probate (heirship), 569 .

in chancery, 509.

in partition, 513 .

in condemnation suits, 520 .

for divorce, 518 .

\section{RECEIPTS,}

of Receiver U. S. Land Office, 134.

of Commissioner State Lands, 135.

RELEASE,

of dower, 246.

of niortgage, 389 .

on margin, 371.

RE-RECORD,

of deeds, 283.

of lease, 283.

of mortgage, 362 .

REVOCATION,

of power of attorney, 264.

SALE,

notice of, 477 .

certificates of, 488 .

for taxes, 529,530 .

in bankruptcy, 307 .

SALES,

in probate, 494.

in chancery, 488 .

under execution, 488.

SCALE,

for indexing books, 87 .

SHERIFF'S,

certificate of sale, 488 .

leed, 278.

STAMPS,

method of showing, 199 . 
SC'BDIVISIOA,

minutes of plat, 167.

vacation of, it9.

SURREXDIR,

of life estate, 227.

\section{TAX SALES,}

general forms, 529.

forfeiture, 5:s0.

certificate of, 534 .

deeds resulting from, 537.

TRLST,

deciaration of, 267 .

reed in, 363.

VACATION,

of plat, 169 .

of street, 330.

IERIFICATION,

of copy of abstract, 612 .

\section{WILLS.}

conmon form, 413.

with special provisos, 413, 417.

proof of, 413.

probate of 413,417 .

note of proof of death, 413 .

51 






LAW MPRARY

UNIVERSIT'

LOS ANGELRS 
UC SOUTHERN REGIONAL LIBRARY FACILITY

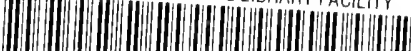

AA 0008514531 
